Oak Ridge Reservation

Annual Site

Environmental Report

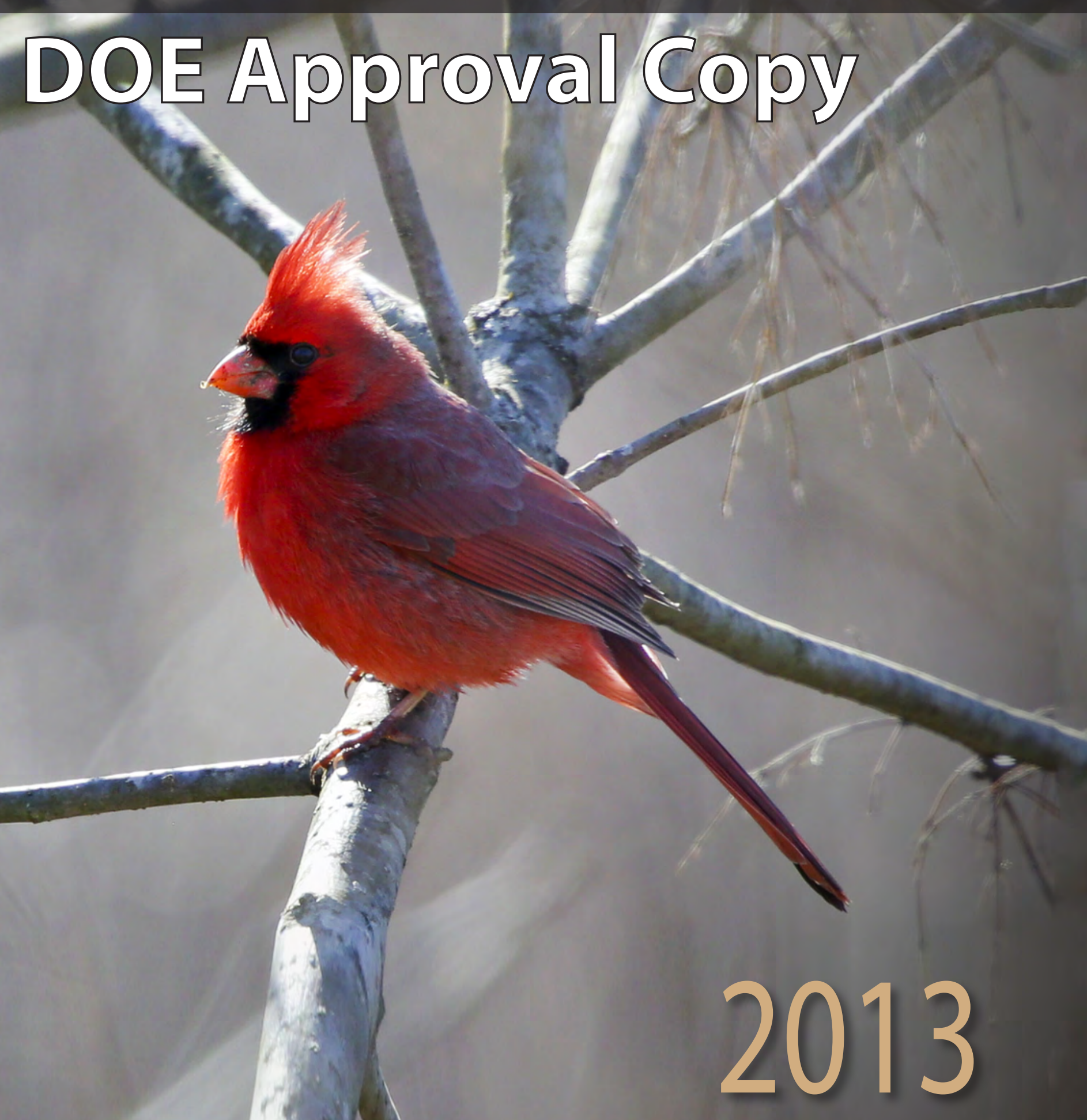


Oak Ridge Reservation

Annual Site

Environmental

Report 2013

Cover Image \& Design

Creative Media

Communications

Oak Ridge National Laboratory 


\title{
Oak Ridge Reservation Annual Site Environmental Report for 2013
}

\author{
on the World Wide Web \\ http://www.ornl.gov/sci/env_rpt/ \\ Project director \\ Joan Hughes \\ Project coordinator \\ Sharon Thompson \\ Department of Energy project manager and Oak Ridge Office coordinator \\ Katatra Vasquez \\ Technical coordinators \\ Joan Hughes \\ Oak Ridge National Laboratory \\ Editors \\ VJ Ewing, Wendy Hames \\ Mike Coffey \\ East Tennessee Technology Park \\ Graphic artists \\ Terry Bonine, Cindy Johnson
}

Wayne McMahon

Y-12 National Security Complex

Electronic publisher

Kathy Jones

August 2014 - APPROVAL COPY

Prepared by

Oak Ridge National Laboratory

P.O. Box 2008, Oak Ridge, TN 37831-2008

Managed by UT-Battelle, LLC,

for the Department of Energy under Contract DE-AC05-00OR22725

and by

the Y-12 National Security Complex

Oak Ridge, TN 37831-8169

Managed by B\&W Technical Services Y-12 L.L.C.

for the Department of Energy under Contract DE-AC05-00OR22800

and by

URS | CH2M Oak Ridge LLC

Managing and Safely Delivering the Department of Energy's Vision

for the East Tennessee Technology Park Mission

under Contract DE-SC-0004645 



\section{Contents}

Page

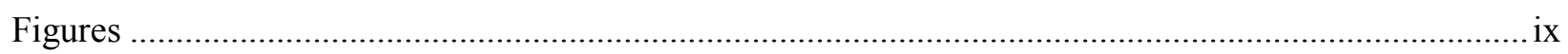

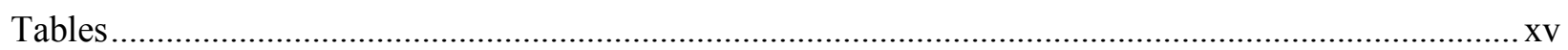

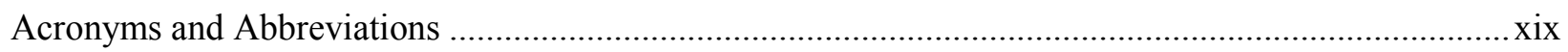

Units of Measure and Conversion Factors .........................................................................................x

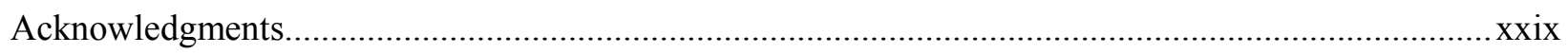

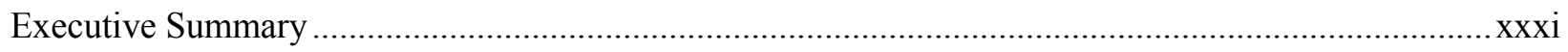

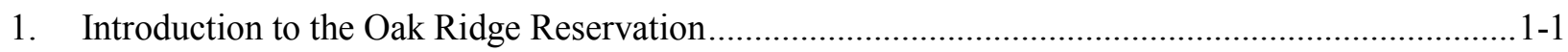

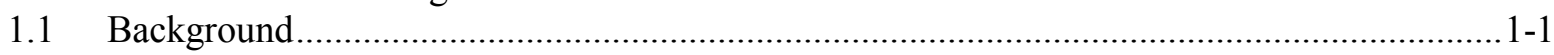

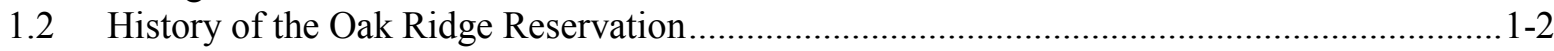

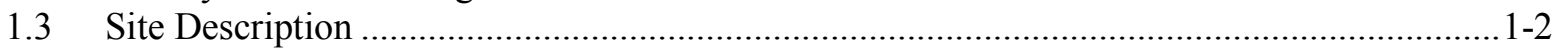

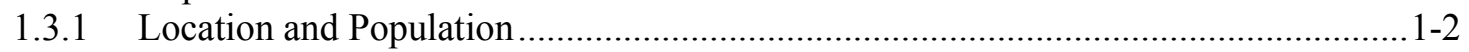

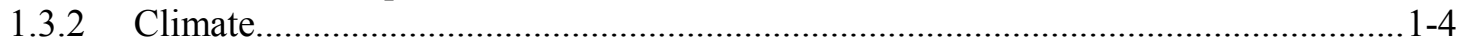

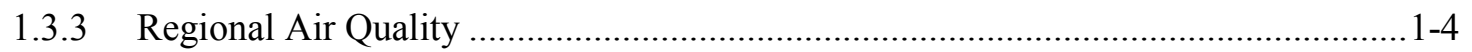

1.3.4 Surface Water ........................................................................................ $1-4$

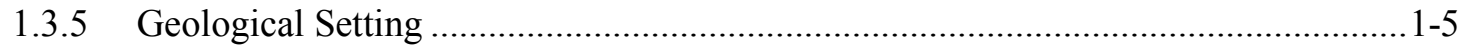

1.3.6 Natural, Cultural, and Historic Resources ............................................................ 1-6

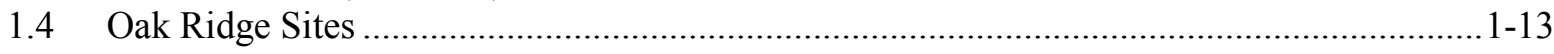

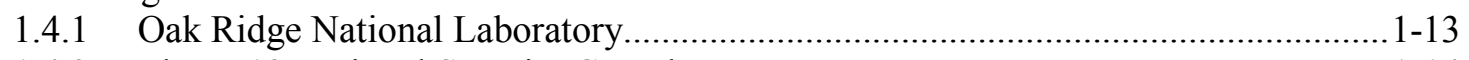

1.4.2 The Y-12 National Security Complex …....................................................... 1-14

1.4.3 East Tennessee Technology Park …................................................................ 1-15

1.4.4 Environmental Management Waste Management Facility...................................... 1-16

1.4.5 Oak Ridge Environmental Research Park ...........................................................1-16

1.4.6 Oak Ridge Institute for Science and Education ................................................. 1-17

1.4.7 The National Nuclear Security Administration Office of Secure

Transportation, Agent Operations Eastern Command .............................................1-17

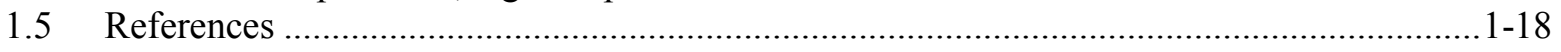

2. Compliance Summary and Community Involvement ....................................................... 2-1

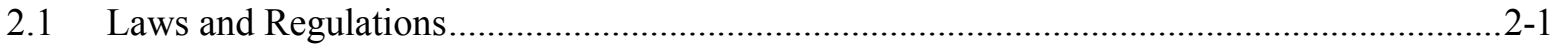

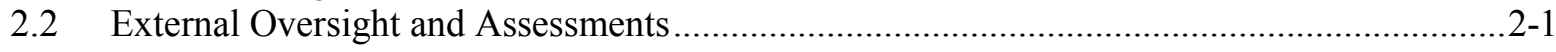

2.3 Reporting of Oak Ridge Reservation Spills and Releases ................................................. 2-7

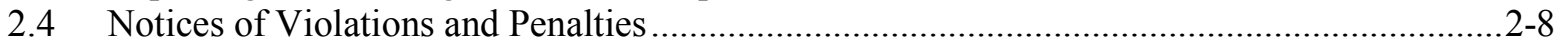

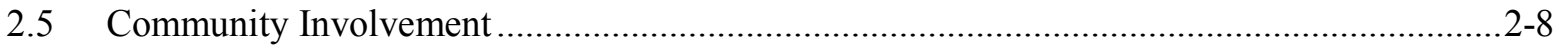

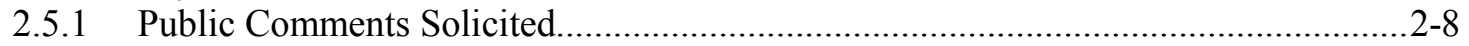

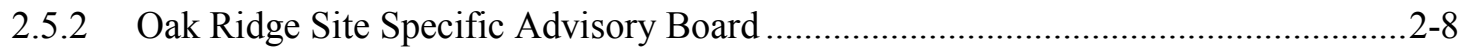

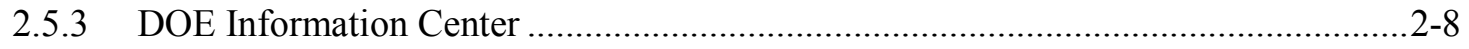

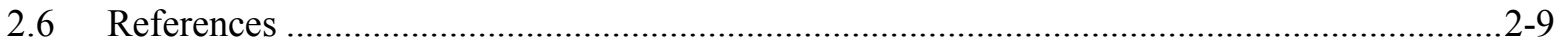

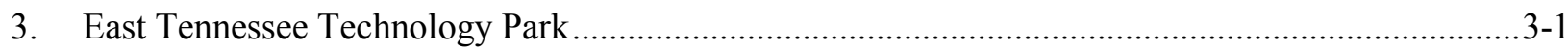

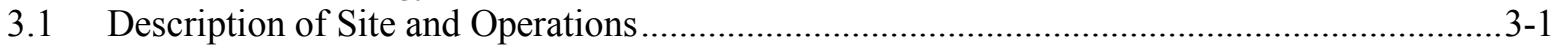

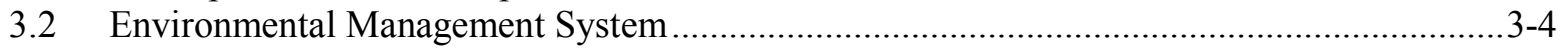




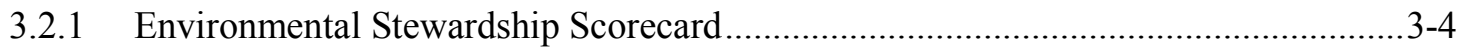

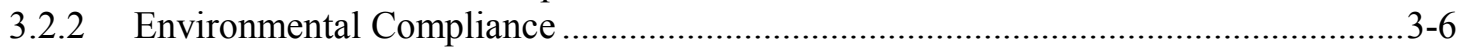

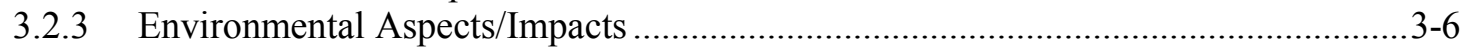

3.2.4 Environmental Performance Objectives and Targets .............................................

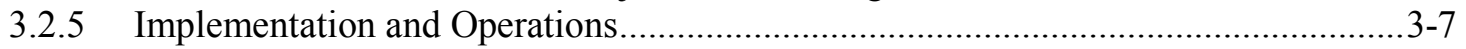

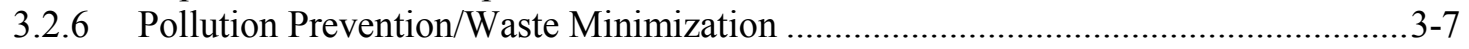

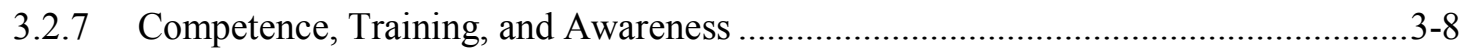

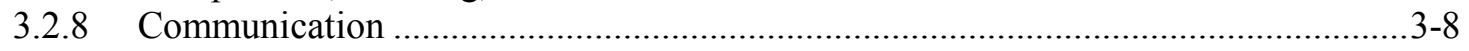

3.2.9 Benefits and Successes of Environmental Management System

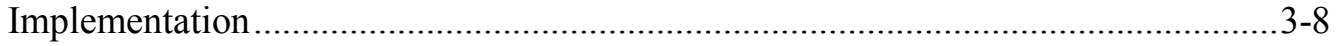

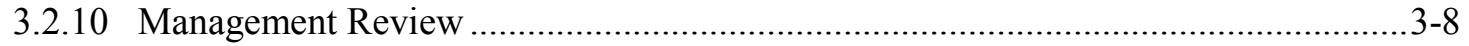

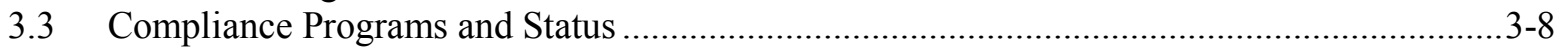

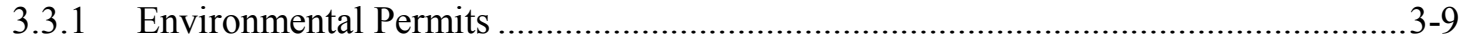

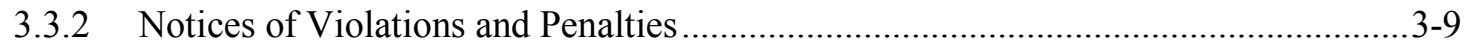

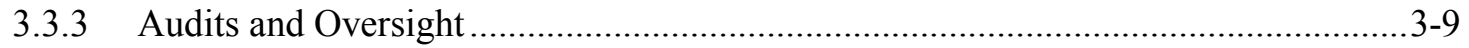

3.3.4 National Environmental Policy Act/National Historic Preservation Act ..................3-12

3.3.5 Clean Air Act Compliance Status .......................................................................... 3-13

3.3.6 Clean Water Act Compliance Status ...................................................................... $3-13$

3.3.7 National Pollutant Discharge Elimination System Permit Noncompliances.............3-14

3.3.8 Safe Drinking Water Act Compliance Status ............................................................. 3-14

3.3.9 Resource Conservation and Recovery Act Compliance Status ................................3-14

3.3.10 Resource Conservation and Recovery Act Underground Storage Tanks .................3-14

3.3.11 Comprehensive Environmental Response, Compensation, and Liability Act

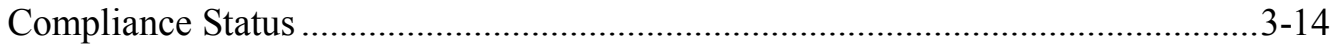

3.3.12 East Tennessee Technology Park RCRA-CERCLA Coordination ..........................3-14

3.3.13 Toxic Substances Control Act Compliance Status-Polychlorinated

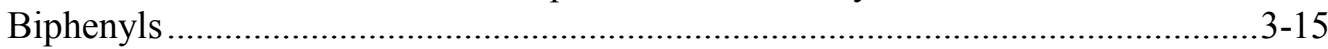

3.3.14 Emergency Planning and Community Right-to-Know Act Compliance Status ........3-15

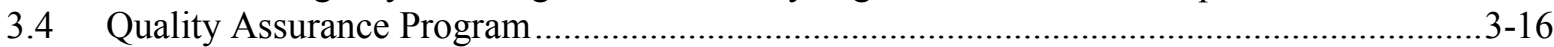

3.4.1 Integrated Assessment and Oversight Program ......................................................

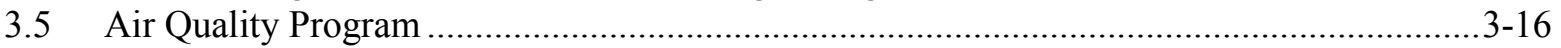

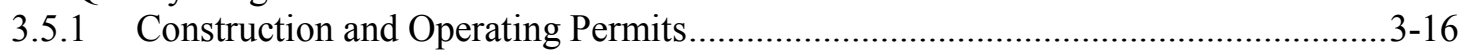

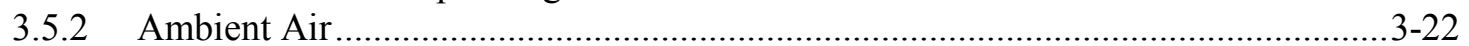

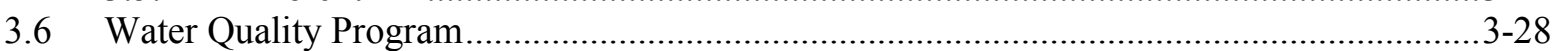

3.6.1 NPDES Permit Description—New NPDES Permit................................................ 3-28

3.6.2 East Tennessee Technology Park Storm Water Pollution Prevention Program ........3-28

3.6.3 Sampling for NPDES Permit Renewal Application ............................................ 3-28

3.6.4 Radiological Monitoring of Storm Water Discharges ...........................................3-29

3.6.5 Monitoring of Storm Water Runoff from East Tennessee Technology Park

Decontamination and Decommissioning/Remedial Action Activities ......................3-30

3.6.6 Investigation of Mercury at East Tennessee Technology Park..................................3-41

3.6.7 NPDES Monitoring at the Central Neutralization Facility Wastewater

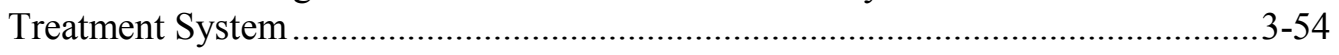

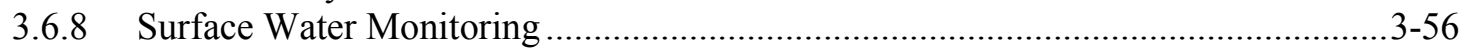

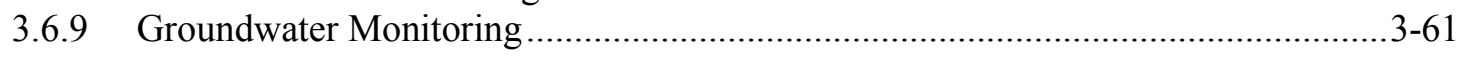

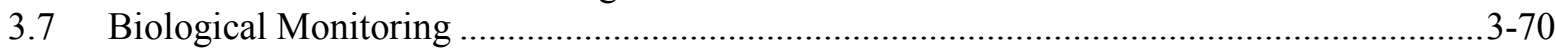

3.8 Environmental Management and Waste Management Activities.......................................3-82

3.8.1 Waste Management Activities ....................................................................... 3-82

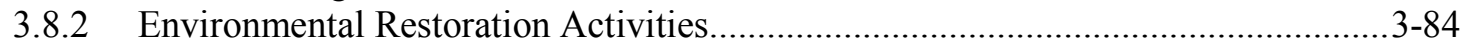

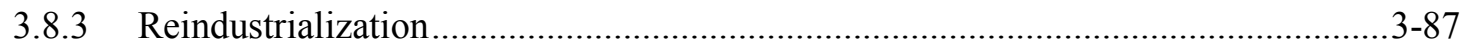

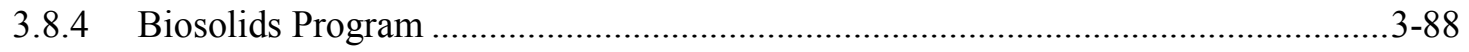

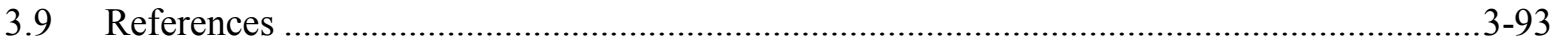




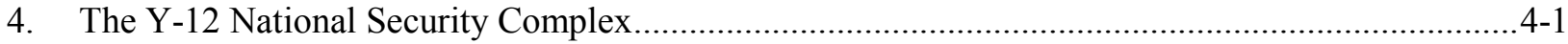

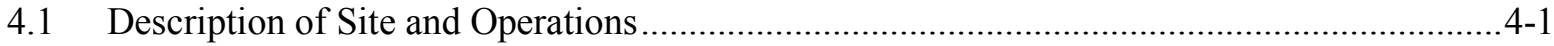

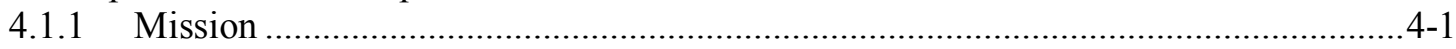

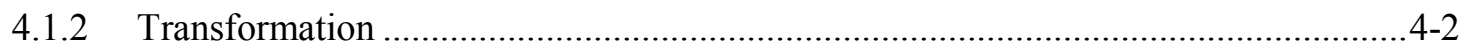

4.2 Environmental Management System ......................................................................... $4-3$

4.2.1 Integration with Integrated Safety Management System.....................................4-3

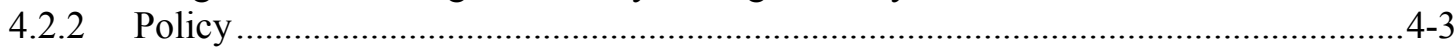

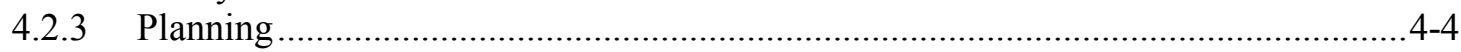

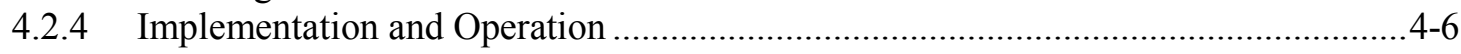

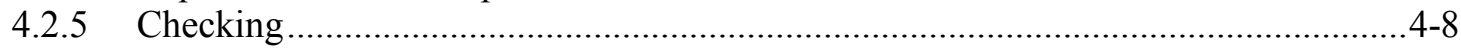

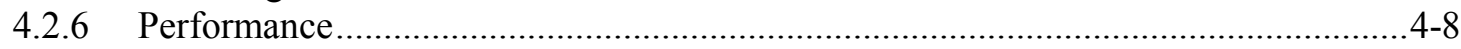

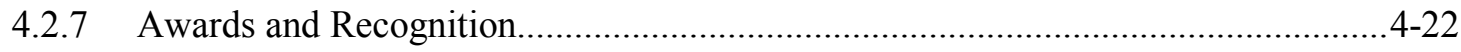

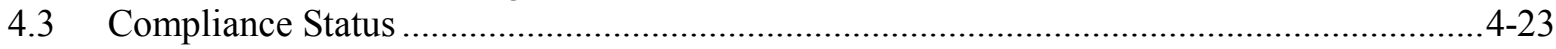

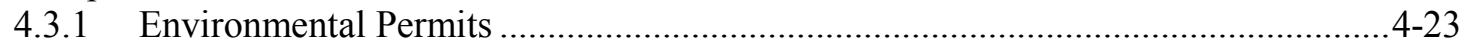

4.3.2 National Environmental Policy Act/National Historic Preservation Act .................4-23

4.3.3 Clean Air Act Compliance Status........................................................................ $4-26$

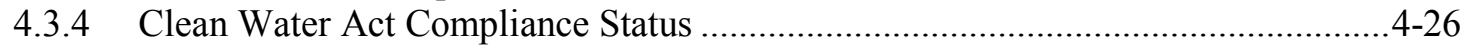

4.3.5 Safe Drinking Water Act Compliance Status .........................................................4-27

4.3.6 Resource Conservation and Recovery Act Compliance Status ................................4-27

4.3.7 Resource Conservation and Recovery Act-Comprehensive Environmental Response, Compensation, and Liability Act Coordination......................................4-29

4.3.8 Toxic Substances Control Act Compliance Status ................................................... 4-31

4.3.9 Emergency Planning and Community Right-to-Know Act Compliance Status ........4-31

4.3.10 Spill Prevention, Control, and Countermeasures..................................................4-32

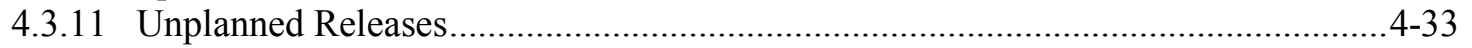

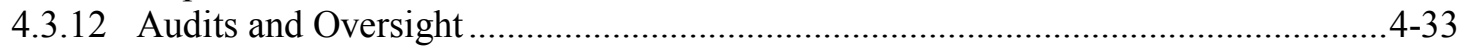

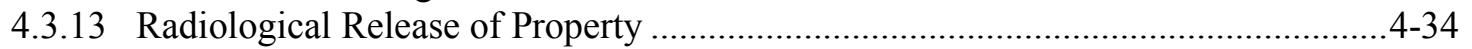

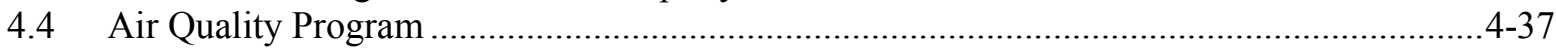

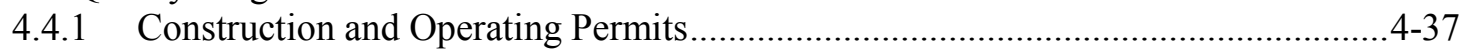

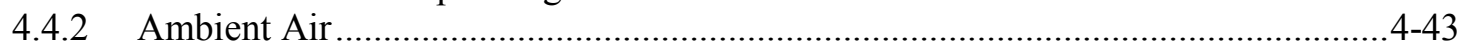

4.5 Water Quality Program........................................................................................... $4-48$

4.5.1 National Pollutant Discharge Elimination System Permit and Compliance

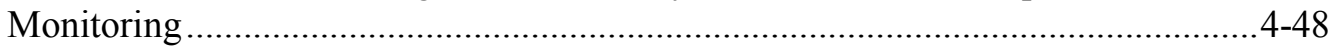

4.5.2 Mercury Removal from Storm Drain Catch Basins...............................................4-52

4.5.3 Radiological Monitoring Plan and Results ....................................................4-52

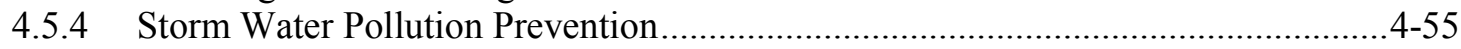

4.5.5 Flow Management (or Raw Water) .................................................................... 4-56

4.5.6 Y-12 Complex Ambient Surface Water Quality...................................................4-57

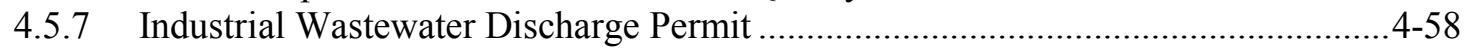

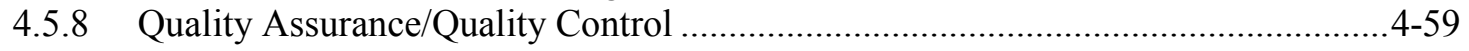

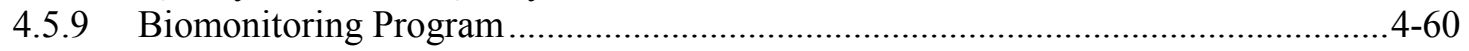

4.5.10 Biological Monitoring and Abatement Programs ................................................. 4-60

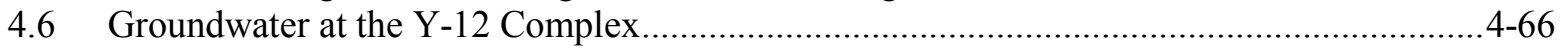

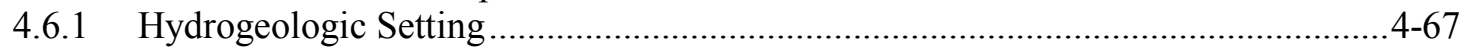

4.6.2 Well Installation and Plugging and Abandonment Activities ................................4-69

4.6.3 Calendar Year 2013 Groundwater Monitoring .....................................................4-69

4.6.4 Y-12 Complex Groundwater Quality ................................................................4-72

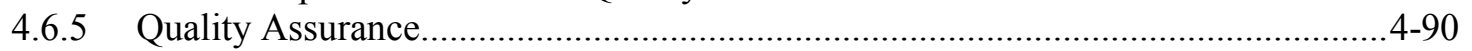

4.7 Quality Assurance Program ......................................................................................... $4-90$

4.8 Environmental Management and Waste Management Activities.........................................4-92

4.8.1 Mercury Remediation Strategy for Y-12, East Fork Poplar Creek...........................4-92

4.8.2 Mercury Reduction Project Work Continues...........................................................4-92 


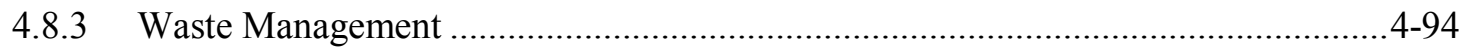

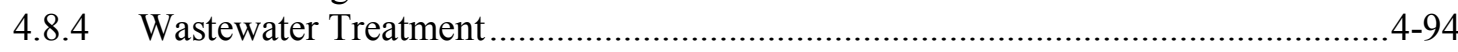

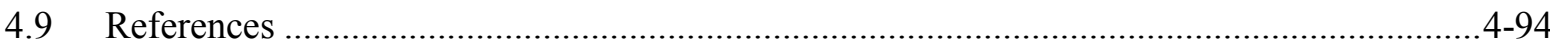

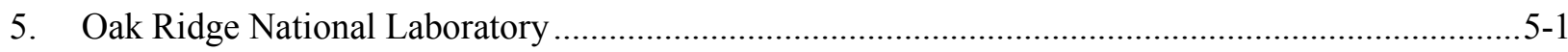

5.1 Description of Site, Mission, and Operations ............................................................... $5-1$

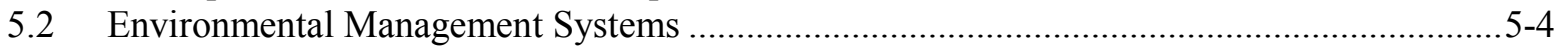

5.2.1 UT-Battelle Environmental Management System................................................5-4

5.2.2 Environmental Management System for the Transuranic Waste Processing

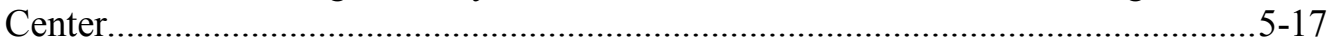

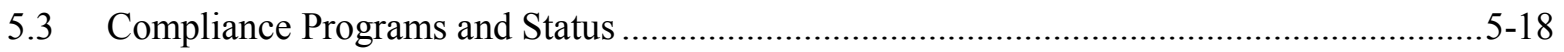

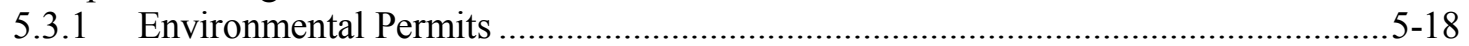

5.3.2 National Environmental Policy Act/National Historic Preservation Act ..................5-21

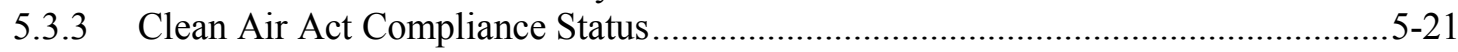

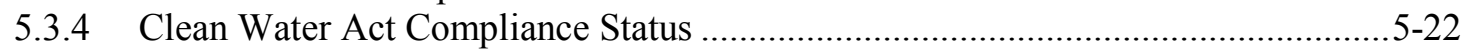

5.3.5 Safe Drinking Water Act Compliance Status ........................................................... 5-22

5.3.6 Resource Conservation and Recovery Act Compliance Status ................................5-22

5.3.7 Oak Ridge National Laboratory RCRA-CERCLA Coordination.............................5-24

5.3.8 Comprehensive Environmental Response, Compensation, and Liability Act

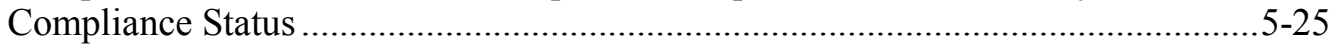

5.3.9 Toxic Substances Control Act Compliance Status ..................................................5-25

5.3.10 Emergency Planning and Community Right-to-Know Act Compliance Status ........5-26

5.3.11 US Department of Agriculture/Tennessee Department of Agriculture ....................5-27

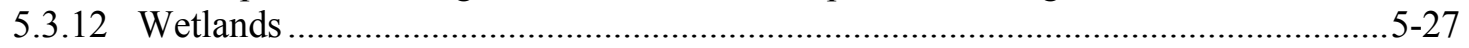

5.3.13 Radiological Clearance of Property at Oak Ridge National Laboratory ..................5-29

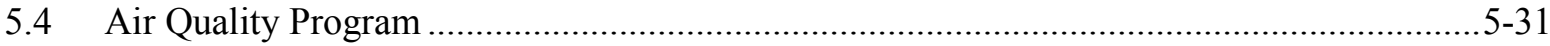

5.4.1 Construction and Operating Permits..................................................................... $5-31$

5.4.2 National Emission Standards for Hazardous Air Pollutants-Asbestos....................5-32

5.4.3 Oak Ridge National Laboratory Radiological Airborne Effluent Monitoring..........5-32

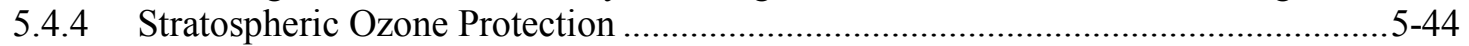

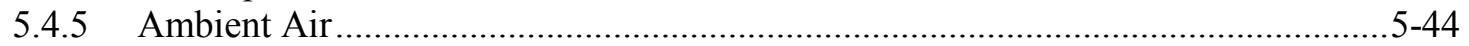

5.5 Oak Ridge National Laboratory Water Quality Program ..................................................5-46

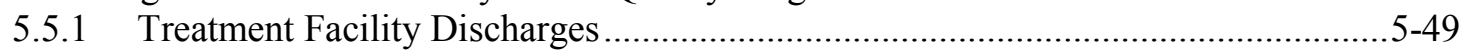

5.5.2 Residual Bromine and Chlorine Monitoring ..........................................................5-50

5.5.3 Cooling Tower Blowdown Whole Effluent Toxicity Monitoring .............................5-51

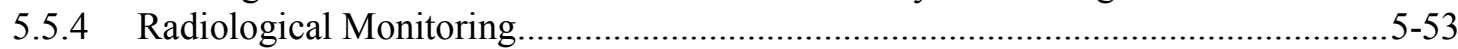

5.5.5 Mercury in the White Oak Creek Watershed..........................................................5-59

5.5.6 Storm Water Surveillances and Construction Activities ......................................5-62

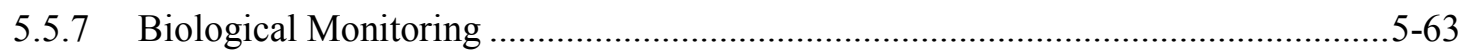

5.5.8 Polychlorinated Biphenyls in the White Oak Creek Watershed..............................5-71

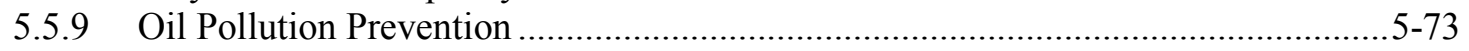

5.5.10 Surface Water Surveillance Monitoring ............................................................. 5-73

5.5.11 Carbon Fiber Technology Facility Waste Water Monitoring ................................5-75

5.6 Groundwater Monitoring Program .............................................................................. 5-76

5.6.1 DOE Office of Environmental Management Groundwater Monitoring ...................5-76

5.6.2 DOE Office of Science Groundwater Monitoring ................................................ 5-78

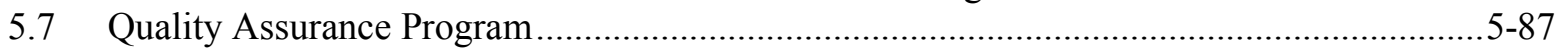

5.7.1 Work/Project Planning and Control................................................................ 5-87

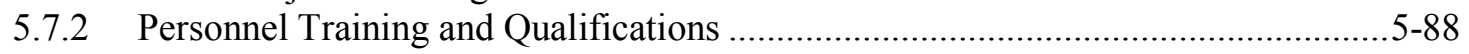

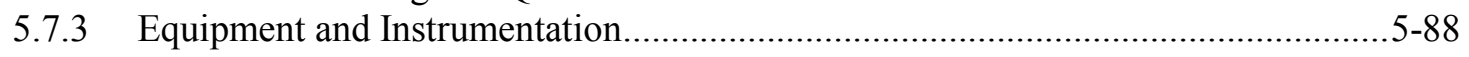

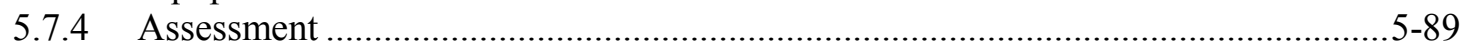

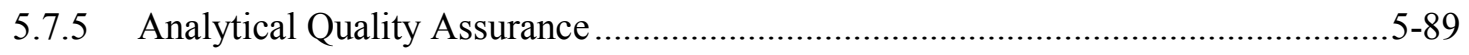




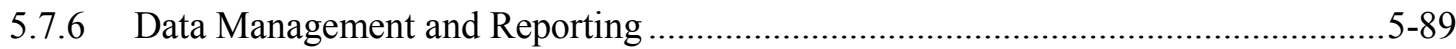

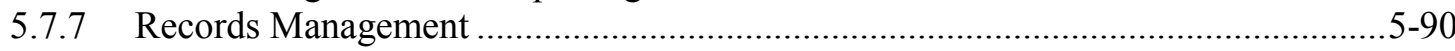

5.8 Environmental Management and Waste Management Activities at Oak Ridge National

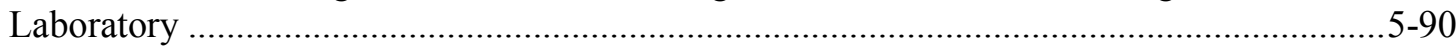

5.8.1 3026 Hot Cells Facility Downgraded and Maintained in Surveillance and

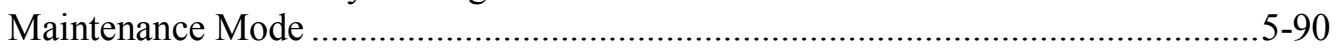

5.8.2 Bethel Valley Groundwater Monitoring ..............................................................

5.8.3 Off-Site Groundwater Monitoring ........................................................................

5.8.4 Upgrade of 4500 Area Gaseous Waste System .................................................... $5-91$

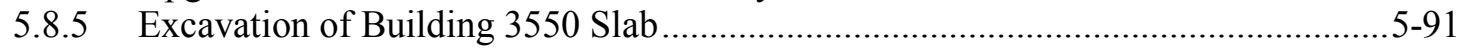

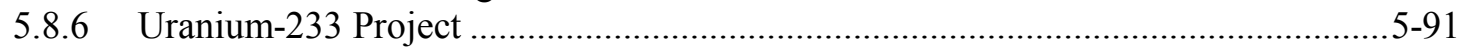

5.8.7 Building 3038 Waste Removal and Stabilization ..............................................5-92

5.8.8 Molten Salt Reactor Experiment Flush and Fuel Salt Removal ..............................5-92

5.8.9 Oak Ridge National Laboratory Waste Management............................................5-92

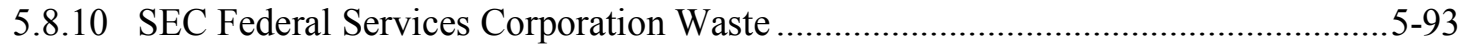

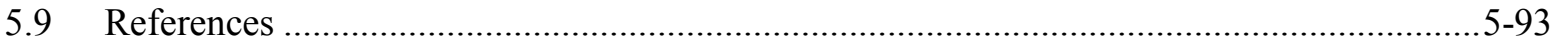

6. Oak Ridge Reservation Environmental Monitoring Program ................................................... 6-1

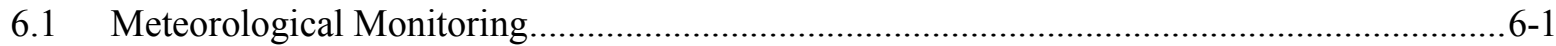

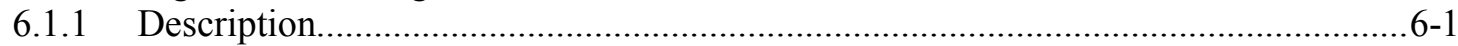

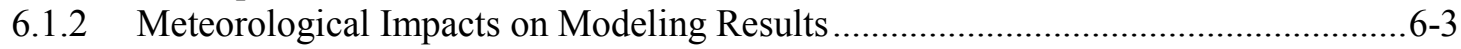

6.2 External Gamma Radiation Monitoring …........................................................................ 6-4

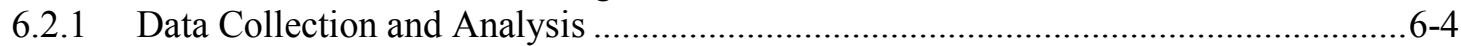

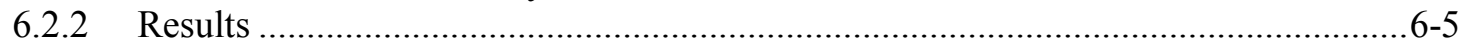

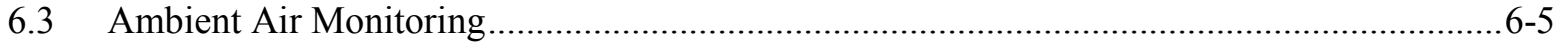

6.3.1 Oak Ridge Reservation Ambient Air Monitoring...................................................6-6

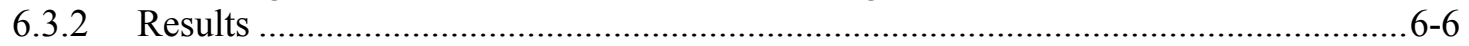

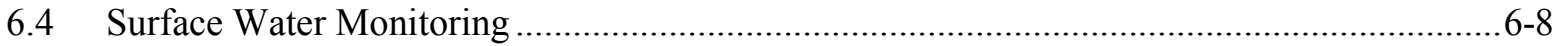

6.4.1 Oak Ridge Reservation Surface Water Monitoring ...............................................6-8

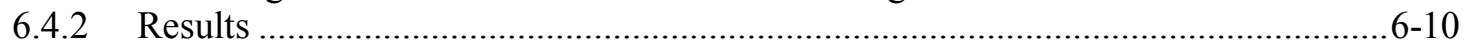

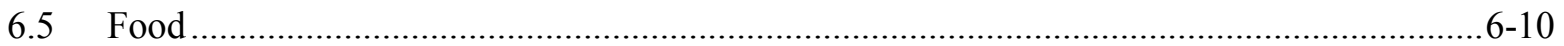

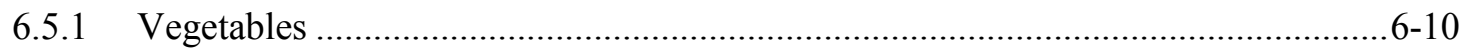

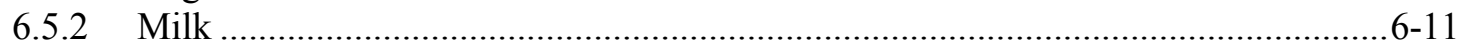

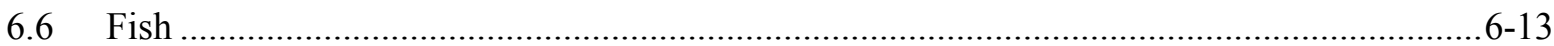

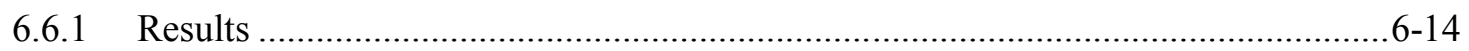

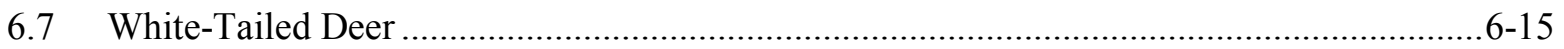

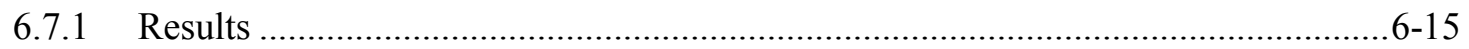

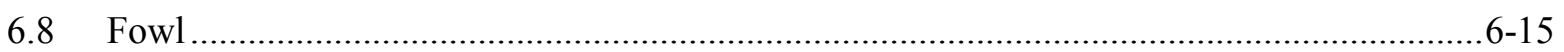

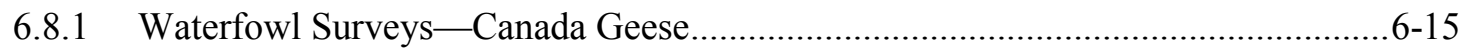

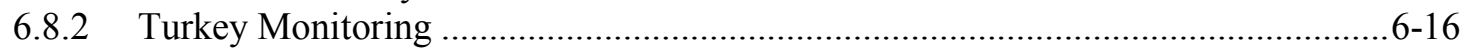

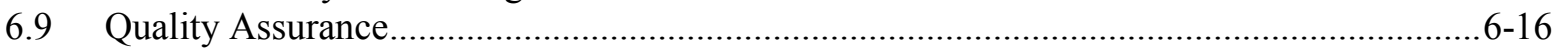

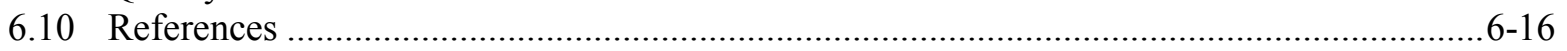

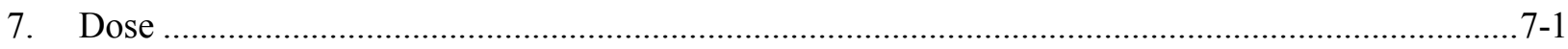

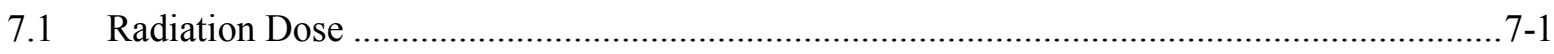

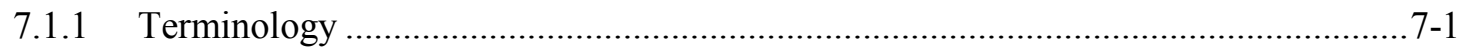

7.1.2 Methods of Evaluation..........................................................................

7.1.3 Current-Year Summary .........................................................................

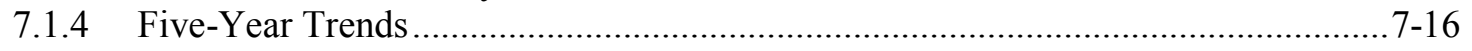

7.1.5 Potential Contributions from Non-DOE Sources .............................................. 7-17

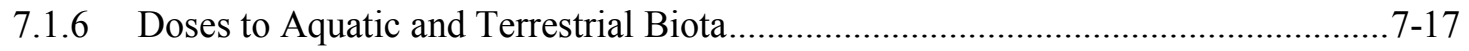

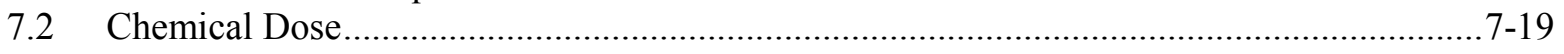




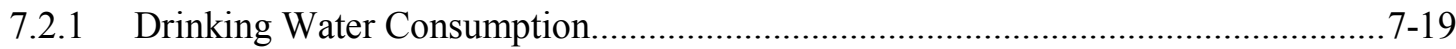

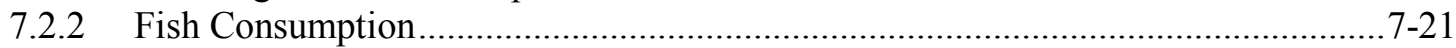

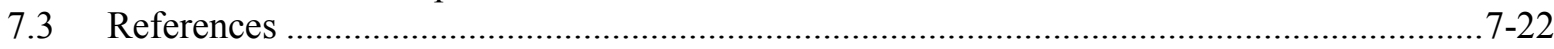

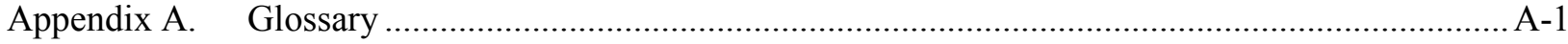

Appendix B. Climate Overview of the Oak Ridge Area .............................................................. B-1

Appendix C. Reference Standards and Data for Water ................................................................ C-1

Appendix D. National Pollutant Discharge Elimination System Noncompliance

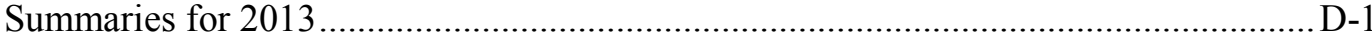

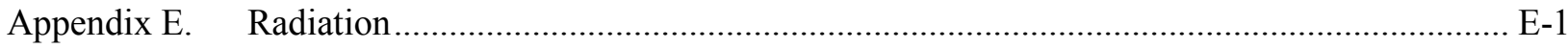

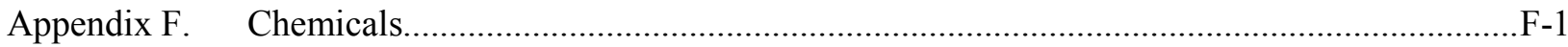




\section{Figures}

Figure

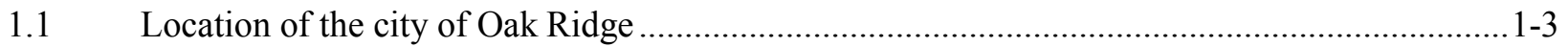

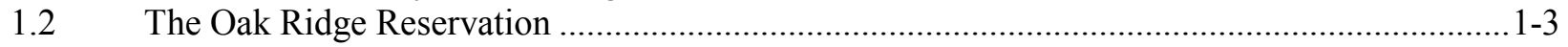

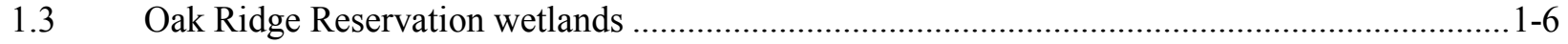

$1.4 \quad$ Bald eagle nest on the Oak Ridge Reservation ..................................................................1-10

1.5 Other interesting birds sighted on the Oak Ridge Reservation during 2013 .......................... 1-10

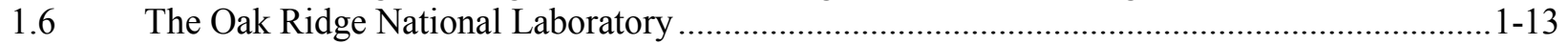

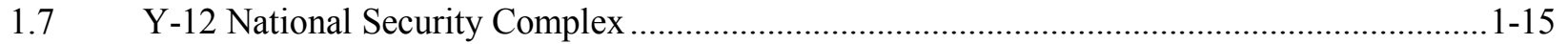

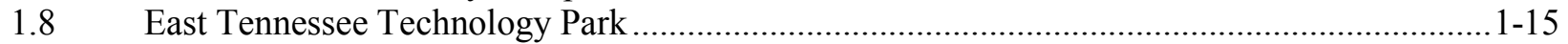

1.9 The Oak Ridge Environmental Research Park ................................................................. 1-17

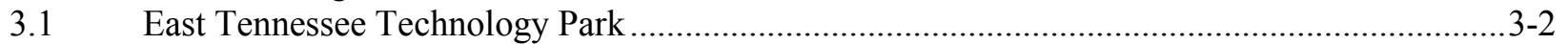

3.2 East Tennessee Technology Park before the start of decontamination and

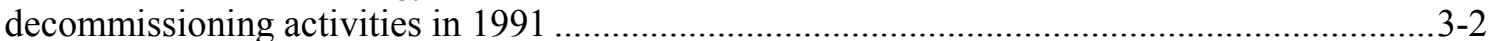

3.3 East Tennessee Technology Park in 2013 ...........................................................................3

3.4 Pollution prevention recycling activities related to solid waste reduction at East Tennessee Technology Park in FY 2013 ........................................................................

3.5 US Department of Energy headquarters sustainability award winners for 2012

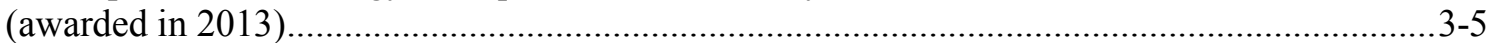

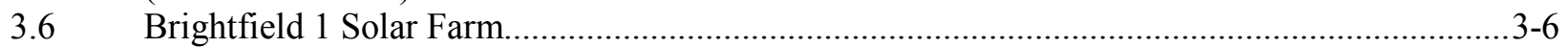

3.7 Truck carrying a waste shipment passing through an electronic tracking station .....................3-7

3.8 East Tennessee Technology Park National Pollutant Discharge Elimination System

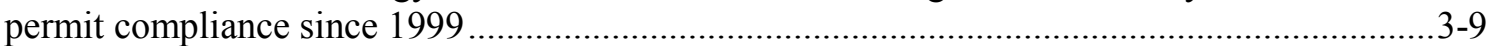

3.9 East Tennessee Technology Park total on-site ozone depleting substances (ODSs)

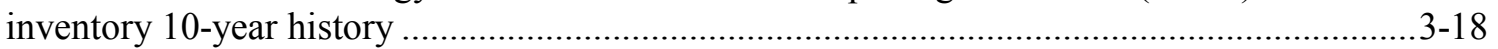

3.10 East Tennessee Technology Park ambient air station K11 radionuclide quarterly and rolling 12-month effective dose results from January 2009 through December 2013 ..............3-19

3.11 East Tennessee Technology Park tracking history for stationary source greenhouse

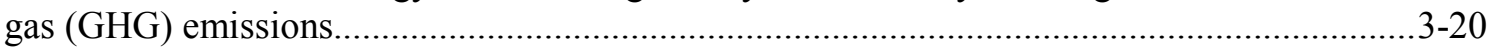

3.12 East Tennessee Technology Park greenhouse gas (GHG) emissions trend and targeted reduction commitment ................................................................................ $3-21$

3.13 CY 2013 East Tennessee Technology Park (ETTP) greenhouse gas (GHG) emissions distributed among the scopes defined in Executive Order 13514 ...........................................3-21

3.14 East Tennessee Technology Park ambient air monitoring station locations ............................3-23

3.15 East Tennessee Technology Park ambient air monitoring station........................................3-23

3.16 Ambient air monitoring results for arsenic from January 2009 through

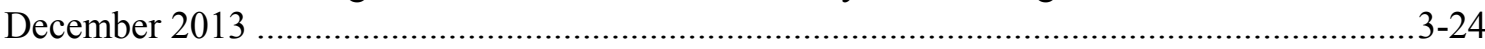

3.17 Ambient air monitoring results for beryllium from January 2009 through

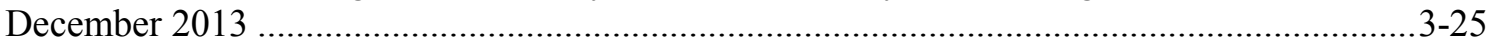

3.18 Ambient air monitoring results for cadmium from January 2009 through

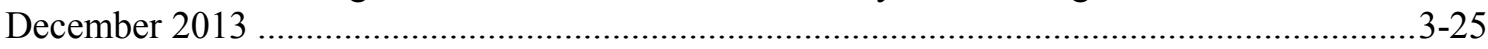

3.19 Ambient air monitoring results for chromium from January 2009 through

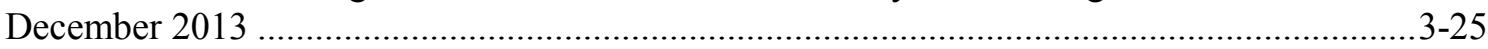

3.20 Ambient air monitoring results for lead from January 2009 through

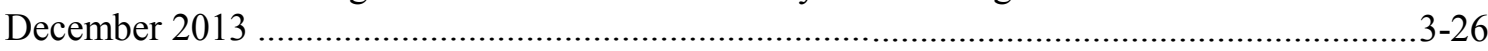

3.21 Ambient air monitoring results for uranium from January 2009 through December 2013 
3.22 East Tennessee Technology Park quarterly and rolling 12-month effective

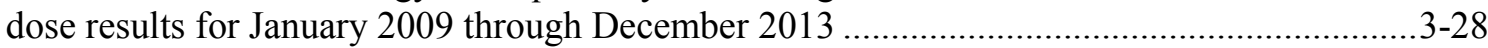

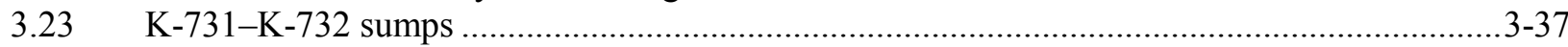

3.24 Hexavalent chromium discharges into Mitchell Branch ....................................................3-39

3.25 Total chromium sample results for the chromium collection system....................................3-40

3.26 Hexavalent chromium sample results for the chromium collection system..........................3-41

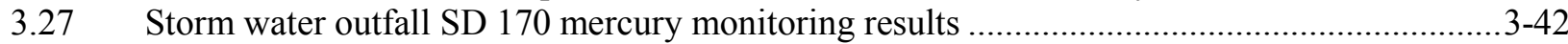

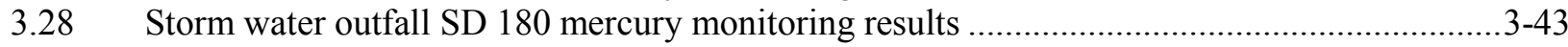

3.29 Storm water outfall SD 190 mercury monitoring results ................................................. 3-43

3.30 Storm water outfall SD 05A mercury monitoring results ....................................................4-44

3.31 Storm drain (SD) networks for SDs 170, 180, 190, 200, and 210 ..........................................

3.32 Sampling locations at the K-1203 Sewage Treatment Plant area...........................................

3.33 East Tennessee Technology Park Environmental Monitoring Program

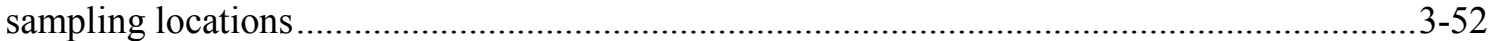

3.34 Mitchell Branch instream mercury sampling results, 2008-2013 .......................................3-53

$3.35 \quad$ K-1700 weir surface water mercury sampling results, 2008-2013 .....................................3-53

3.36 Central Neutralization Facility-K-1435 Wastewater Treatment System

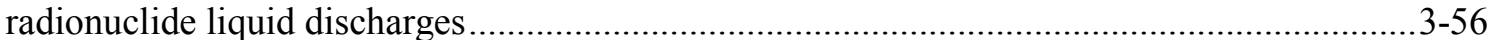

3.37 East Tennessee Technology Park Environmental Monitoring Program surface

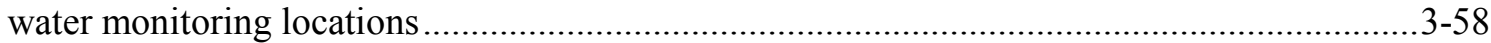

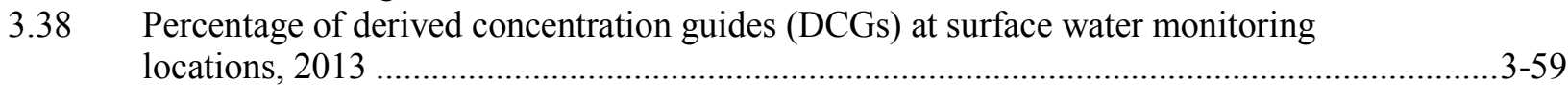

3.39 Trichloroethene concentrations in Mitchell Branch ................................................................5-59

$3.40 \quad$ 1,2-dichloroethene concentrations in Mitchell Branch .......................................................... $3-60$

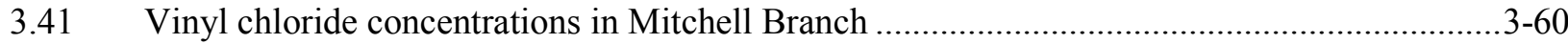

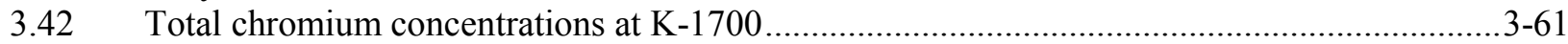

3.43 East Tennessee Technology Park exit pathway monitoring locations and associated volatile organic compound (VOC) concentration levels ............................................................. $3-62$

3.44 Volatile organic compound concentrations in groundwater at the

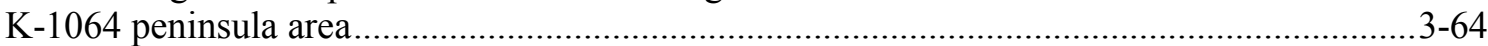

3.45 Chromium concentrations in groundwater in the $\mathrm{K}-31-\mathrm{K}-33$ area ........................................ $3-65$

3.46 Detected volatile organic compound concentrations in groundwater exit pathway

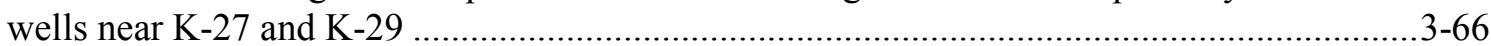

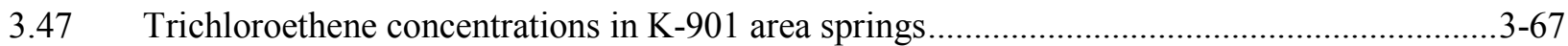

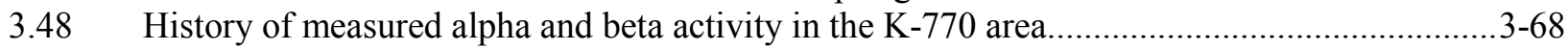

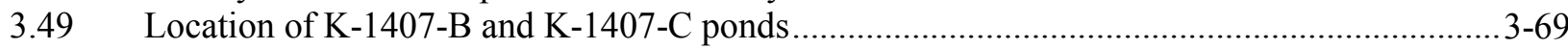

$3.50 \quad$ Water bodies at the East Tennessee Technology Park ......................................................... 3-71

3.51 Major storm water outfalls and biological monitoring locations on Mitchell Branch ..............3-72

$3.52 \quad$ Water flea (Ceriodaphnia dubia) ..................................................................................... 3-72

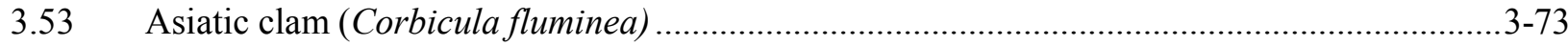

3.54 Fish bioaccumulation sampling at K-1007-P1 pond ..........................................................

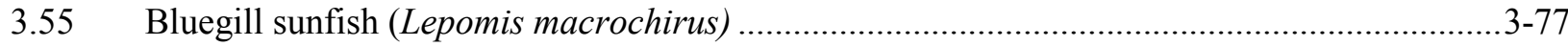

3.56 Mean taxonomic richness in Mitchell Branch, 1987-2013 …..............................................3-79

3.57 Benthic macroinvertebrate sampling using Tennessee Department of

Environment and Conservation protocols ......................................................................... 3-80

3.58 Temporal trends in biotic index and stream habitat index scores for Mitchell Branch,

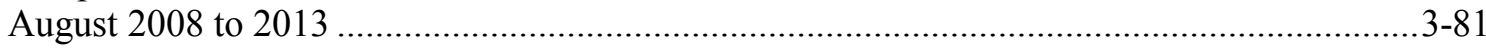

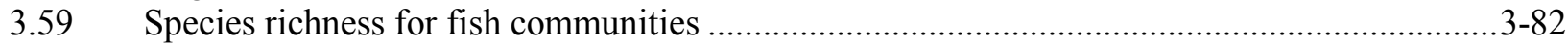

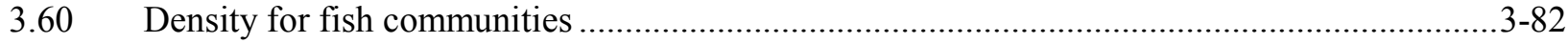

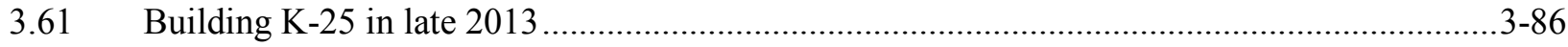

3.62 East Tennessee Technology Park reindustrialization status, 2013 ........................................ $3-88$

3.63 Biosolids application areas on the Oak Ridge Reservation.................................................... $3-89$ 
4.1 Gross square footage by age of mission-critical facilities at the Y-12 Complex ....................4-2

4.2 Uranium Processing Facility conceptual image ...................................................................

4.3 B\&W Y-12 environment, safety, and health policy .............................................................4-4

4.4 Y-12 hosts the Tennessee Green Star Partnership East Tennessee Workshop..........................4-7

4.5 Girls experience hands-on activities at various exhibits during the second "Introduce

a Girl to Engineering" day at the Y-12 National Security Complex .......................................4-7

4.6 Cost efficiencies from Y-12 Complex pollution prevention activities ....................................4-10

4.7 Y-12 Complex pollution prevention initiatives ...............................................................

4.8 Clean Sweep sustain area at the Y-12 National Security Complex.......................................4-11

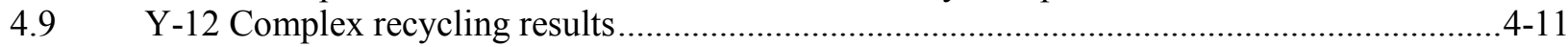

$4.10 \quad$ Y-12 has achieved a 34\% reduction in energy intensity compared to the

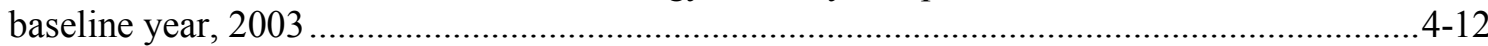

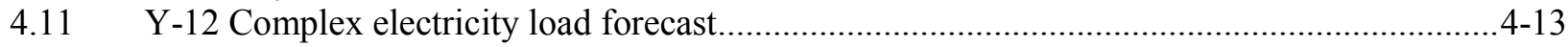

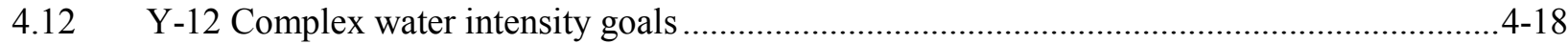

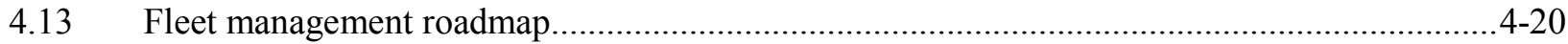

4.14 Faircloth skimmer at Sediment Basin 1 ..........................................................................22

4.15 Permeable pavement and native planting contributes to compliance with

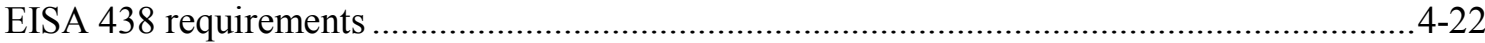

4.16 Y-12 National Security Complex path to elimination of inventory of legacy mixed waste as part of the Oak Ridge Reservation site treatment plan .............................................4-28

4.17 Hazardous waste generation, 2009-2013 ......................................................................... $4-29$

4.18 Total curies of uranium discharged from the Y-12 Complex to the

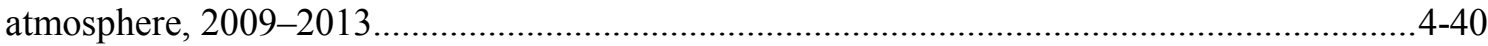

4.19 Total kilograms of uranium discharged from the Y-12 Complex to the atmosphere,

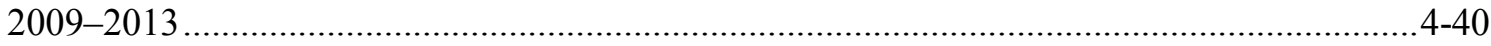

4.20 Locations of ambient air monitoring stations at the Y-12 Complex ...................................4-44

4.21 Temporal trends in mercury vapor concentration for the boundary monitoring stations, July 1986 to January 2013, and ambient air station 8, January 1994 to

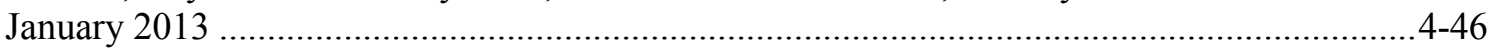

4.22 Major Y-12 Complex National Pollutant Discharge Elimination System (NPDES) outfalls and monitoring locations.....

4.23 Surface water and sanitary sewer radiological sampling locations at the Y-12

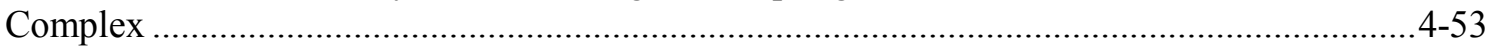

4.24 Five-year trend of Y-12 Complex releases of uranium to East Fork Poplar Creek..................4-55

4.25 Y-12 Complex storm water monitoring locations ..............................................................4-56

4.26 Surface Water Hydrological Information Support System (SWHISS)

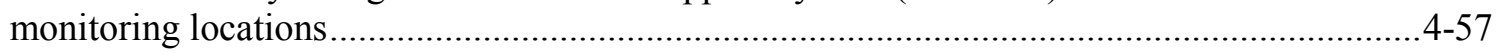

4.27 Locations of biological monitoring sites on East Fork Poplar Creek in relation to the Y-12 National Security Complex ................................................................. $4-61$

4.28 Locations of biological monitoring reference sites in relation to the Y-12 National Security Complex

4.29 Semiannual average mercury concentration in water from and muscle fillets of redbreast sunfish in East Fork Poplar Creek (EFPC) at EFPC kilometers 23.4 (water) and 24.4 (fish) through 2013.

4.30 Mean concentrations of polychlorinated biphenyls (PCBs) in rock bass muscle fillets in East Fork Poplar Creek (EFPC) at EFPC kilometer 23.4 through spring 2013 ..........4-64

4.31 Total taxonomic richness of the Ephemeroptera, Plecoptera, and Trichoptera of the benthic macroinvertebrate communities sampled in spring from East Fork Poplar Creek and two nearby reference streams, 1986-2013 
4.32 Comparison of mean sensitive species richness each year from 1985-2013 from four sites in East Fork Poplar Creek and a reference site ..............................................................4-66

4.33 Fish density (number of fish per square meter) for two sites in upper

East Fork Poplar Creek and a reference site from 1985-2013 ............................................4-66

4.34 Known or potential contaminant sources for which groundwater monitoring was performed at the Y-12 National Security Complex during CY 2013.

4.35 Hydrogeologic regimes at the Y-12 National Security Complex and the position of the Maynardville Limestone in Bear Creek Valley...............................................4-68

4.36 Cross section of a typical groundwater monitoring well .......................................................4-69

4.37 Location of Y-12 National Security Complex perimeter/exit pathway well, spring, and surface water monitoring stations ..................................................................... $4-71$

4.38 Groundwater monitoring well sampling at the Y-12 National Security Complex ...................4-72

4.39 Nitrate observed in groundwater at the Y-12 National Security Complex, 2013 ...................4-75

4.40 Y-12 groundwater and surface water monitoring stations where mercury has been

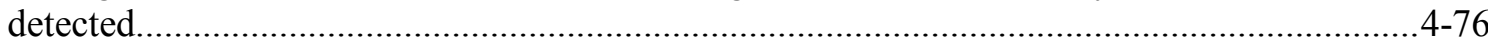

4.41 Summed volatile organic compounds observed in groundwater at the Y-12

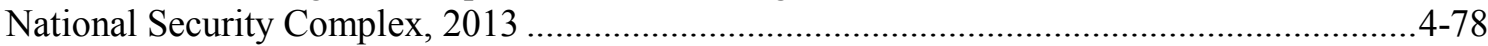

4.42 Gross alpha activity observed in groundwater at the Y-12 National Security

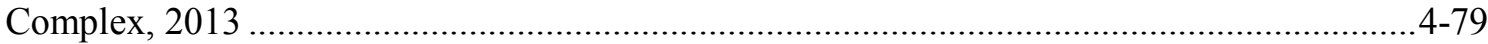

4.43 Gross beta activity observed in groundwater at the Y-12 National Security Complex, 2013 4-80

4.44 Decreasing summed volatile organic compounds (VOCs) observed in exit pathway well GW-722-17 near the New Hope Pond, 1997-2013 ....

4.45 Increasing levels of volatile organic compounds observed in groundwater at well GW-627, west and downgradient of the Bear Creek Burial Grounds, 1991-2013 ....

4.46 CY 2013 concentrations of selected contaminants in exit pathway monitoring wells GW-724 (a), GW-706 (b), and GW-683 (c) in the Bear Creek hydrogeologic regime

5.1 Location of Oak Ridge National Laboratory within the Oak Ridge Reservation and its relationship to other local US Department of Energy facilities.

5.2 Production of lower cost carbon fiber at the Carbon Fiber Technology Facility .......................5-3

5.3 The relationship between the UT-Battelle Environmental Management System and

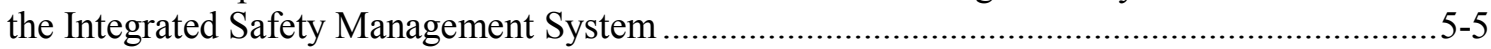

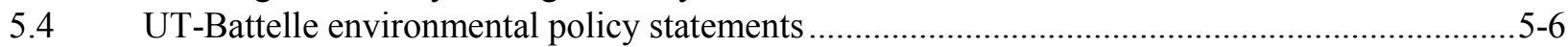

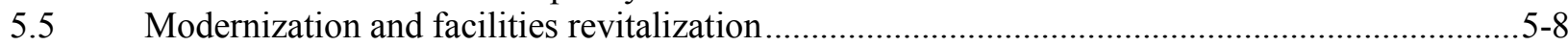

5.6 Summary of energy intensity reduction results and progress toward goal

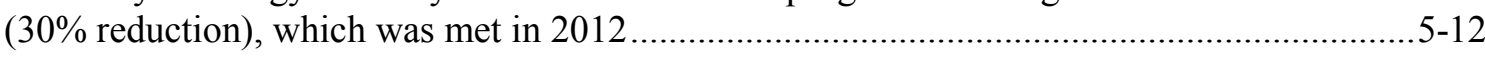

5.7 Oak Ridge National Laboratory building energy performance from FY 2001

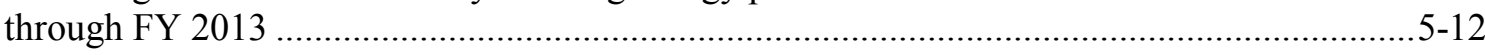

5.8 Oak Ridge National Laboratory's solar-assisted electric vehicle charging station ...................5-13

5.9 Oak Ridge National Laboratory water use intensity (WUI) FY 2007-FY 2020, including 2020 and incremental DOE goals.................................................................... $5-13$

5.10 Solid waste recycled at Oak Ridge National Laboratory as a result of recycling

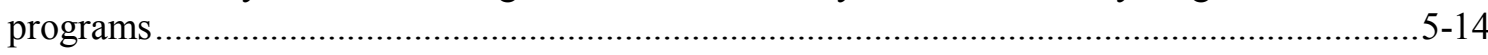

5.11 Chemical and Materials Sciences Building ..................................................................5-15

5.12 Locations of major radiological emission points at Oak Ridge National Laboratory ...............5-33

5.13 Total curies of tritium discharged from Oak Ridge National Laboratory to the

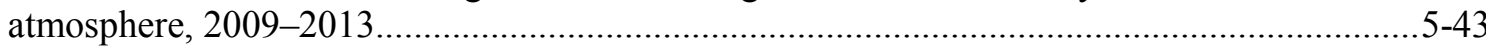

5.14 Total curies of ${ }^{131}$ I discharged from Oak Ridge National Laboratory to the

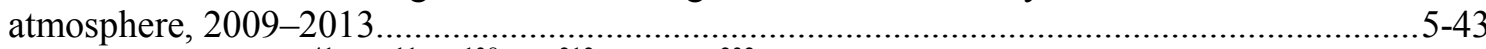

5.15 Total discharges of ${ }^{41} \mathrm{Ar},{ }^{11} \mathrm{C},{ }^{138} \mathrm{Cs},{ }^{212} \mathrm{~Pb}$, and ${ }^{232} \mathrm{Th}$ from Oak Ridge National Laboratory to the atmosphere, 2009-2013. 
5.16 Locations of ambient air monitoring stations at Oak Ridge National Laboratory ...................5-45

5.17 Diagram of the adaptive management framework with step-wise planning specific to the Oak Ridge National Laboratory Water Quality Protection Plan (WQPP) ...........................5-47

5.18 Application of stressor identification guidance to address mercury impairment in

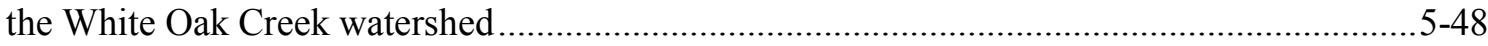

5.19 Oak Ridge National Laboratory surface water, National Pollutant Discharge Elimination System, and reference sampling locations.........................................................5-56

5.20 Outfalls at Oak Ridge National Laboratory with average radionuclide concentrations greater than $4 \%$ of the relevant derived concentration standards in 2013 ................................5-57

5.21 Cesium-137 discharges at White Oak Dam, 2009-2013 _....................................................5-57

5.22 Gross alpha discharges at White Oak Dam, 2009-2013 ................................................5-57

5.23 Gross beta discharges at White Oak Dam, 2009-2013 .................................................5-58

5.24 Total radioactive strontium discharges at White Oak Dam, 2009-2013 ...............................5-58

5.25 Tritium discharges at White Oak Dam, 2009-2013 …...................................................5-58

5.26 Annual flow volume at White Oak Dam, 2009-2013 …...................................................5-59

5.27 Total aqueous mercury concentrations at sites in White Oak Creek downstream from Oak Ridge National Laboratory, 1998-2013 ..............................................................5-60

5.28 Total mercury concentration and flux at selected Oak Ridge National Laboratory instream locations, 2009 through 2013 ...................................................................................... 5-61

5.29 Active construction sites and Oak Ridge National Laboratory Water Quality Protection Plan monitoring locations, 2013 ......................................................................... 5-62

5.30 Mean concentrations of mercury in muscle tissue of sunfish and bass from White Oak Creek and White Oak Lake, 1998-2013 ...............................................................5-64

5.31 Mean polychlorinated biphenyl (PCB) concentrations in fish fillets collected from the White Oak Creek watershed, 1998-2013 ........................................................................... 5-64

5.32 Temporal trends in Tennessee Department of Environment and Conservation Biotic Index Scores for White Oak Creek watershed, August 2006-August 2013 ............................5-66

5.33 Total taxonomic richness of the benthic macroinvertebrate community in First Creek, April sampling periods, 1987-2013

5.34 Total taxonomic richness of the benthic macroinvertebrate community in Fifth Creek,

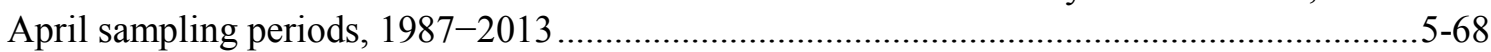

5.35 Total taxonomic richness of the benthic macroinvertebrate community in White Oak Creek, April sampling periods, 1987-2013

5.36 Total taxonomic richness of the benthic macroinvertebrate community in lower Melton Branch, April sampling periods, 1987-2013 ......................................................5-70

5.37 Fish species richness (number of species) in upper White Oak Creek and lower Melton Branch compared with two reference streams .......................................................5-71

5.38 Locations of monitoring points for First Creek source investigation.....................................5-72

5.39 Oak Ridge National Laboratory surface water sampling locations.....................................5-74

$5.40 \quad$ UT-Battelle exit pathway groundwater monitoring locations at Oak Ridge

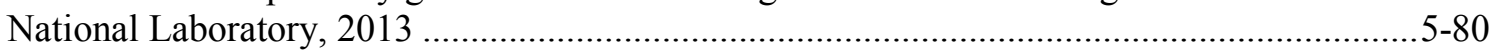

5.41 Groundwater monitoring locations at the Spallation Neutron Source, 2013 .........................5-85

5.42 Simple hydrograph of spring discharge vs. time after initiation of rainfall .............................5-85

5.43 A concrete berm being poured as part of the 3026 stabilization activities............................5-90

$5.44 \quad$ HEPA shield plug being removed from a filter pit.......................................................5-91

6.1 The Oak Ridge Reservation meteorological monitoring network, including SODARs (sonic detection and ranging wind profilers) ............................................................................6-3

6.2 External gamma radiation monitoring locations on the Oak Ridge Reservation. ......................6-4

6.3 Oak Ridge Reservation ambient air station ....................................................................6-5

6.4 Locations of Oak Ridge Reservation perimeter air monitoring stations ..................................6-6

6.5 Oak Ridge Reservation surface water surveillance sampling locations ....................................6-9 
6.6 Milk sampling locations in the vicinity of the Oak Ridge Reservation...................................6-12

6.7 Fish sampling locations for the Oak Ridge Reservation Surveillance Program......................6-13

7.1 Nuclides contributing to the effective dose at the Y-12 National Security Complex .................7-6

7.2 Nuclides contributing to effective dose at Oak Ridge National Laboratory .............................7-6

7.3 Nuclides contributing to effective dose at East Tennessee Technology Park ........................... 7-7 


\section{Tables}

Table

Page

1.1 Animal species of special concern reported on the Oak Ridge Reservation ............................1-7

1.2 Vascular plant species listed by state or federal agencies and sighted/reported on or near the Oak Ridge Reservation, 2013 ................................................................... 1-11

2.1 Applicable environmental laws/regulations and 2013 status ............................................2-2

2.2 Summary of regulatory environmental evaluations, audits, inspections, and

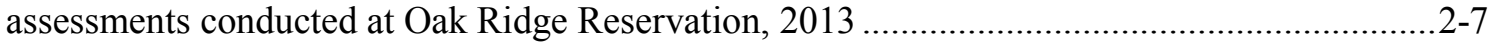

3.1 Radio Frequency Identification Transportation System sustainable results.............................3-8

3.2 East Tennessee Technology Park Environmental Permits, 2013 ..........................................3-10

3.3 Regulatory oversight, assessments, inspections, and site visits at

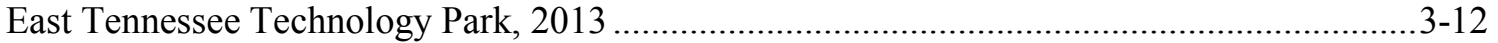

3.4 Total uranium in ambient air by inductively coupled plasma-mass spectrometer analysis at East Tennessee Technology Park, 2013 ..........................................3-26

3.5 Radionuclides in ambient air at East Tennessee Technology Park, January 2013

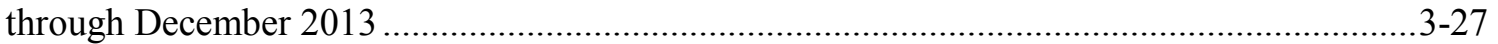

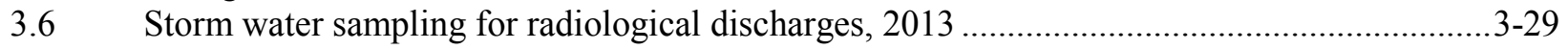

3.7 Analytical results over reference standards for radiological monitoring at East Tennessee Technology Park storm water outfalls/drains (SDs), 2013 .....................................3-30

3.8 Radionuclides released to surface waters from the East Tennessee Technology Park storm water system, 2013.

3.9 Analytical results for storm water outfalls SD 230 and SD 240 that exceeded the radiological field evaluation screening level or chemical reference standard, 2013.

3.10 Analytical results from follow-up sampling at storm water outfall SD 230, 2013.................3-31

3.11 Analytical results that exceed the field evaluation screening level values internally established at $4 \%$ of the DCG for the drainage areas associated with the

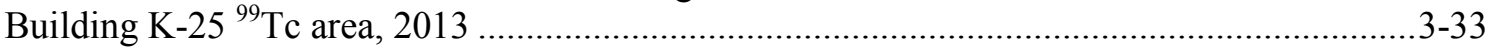

3.12 Surface water sampling to support remedial action activities at the K-1070-

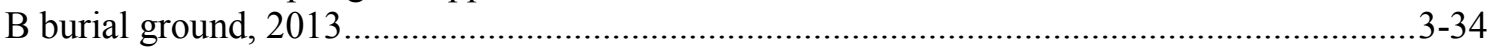

3.13 Analytical results over reference standards for K-1070-B burial ground

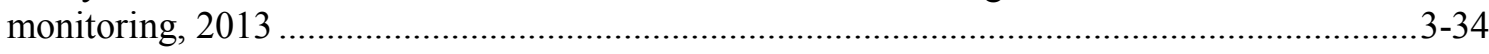

3.14 Sediment sampling to support remedial action activities at the K-770 Scrap

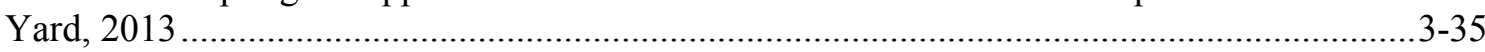

3.15 Analytical results for contaminants of concern in 724 holding pond

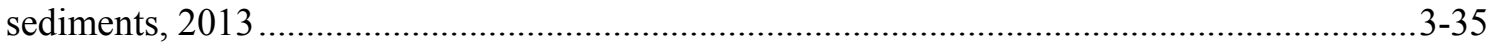

3.16 Analytical results over reference standards for water from the

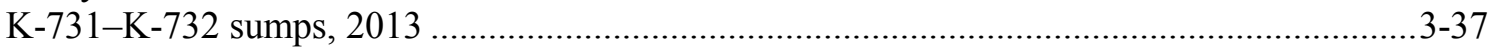

3.17 Analytical results for contaminants of concern in sediments from the K-732 switchyard oil-water separators, 2013 ................................................................. 3-38

3.18 Monitoring requirements-Mitchell Branch subwatershed total and

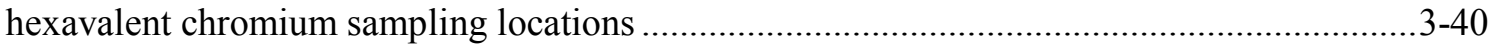

3.19 Quarterly National Pollutant Discharge Elimination System mercury monitoring results as reported for CY 2013 .

3.20 Mercury results from wet weather monitoring conducted in the drainage networks of the Mitchell Branch storm water outfalls in June 2013.

3.21 Mercury results from dry weather monitoring conducted in the drainage networks of the Mitchell Branch storm water outfalls in July 2013 
3.22 Mercury results from sediment sampling at select Mitchell Branch storm

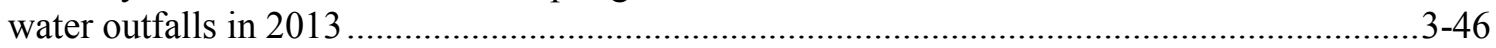

3.23 Mercury results from soil/sediment sampling conducted in the K-1203 Sewage

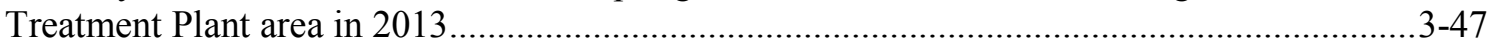

3.24 Mercury results of water sampling conducted in the K-1203 Sewage Treatment

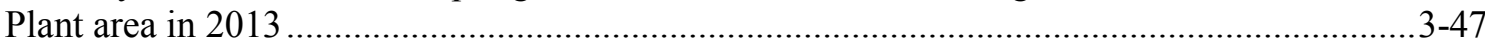

3.25 Mercury results from storm water sampling activities associated with decontamination and decommissioning activities at the $\mathrm{K}-25$ building.................................... 49

3.26 Mercury results from storm water sampling activities associated with the remedial action activities at the $\mathrm{K}-1070$-B burial ground

3.27 Mercury result from sediment sampling associated with the remedial action activities at the K-700 scrap yard area

3.28 Mercury result from water sampling associated with the remedial action

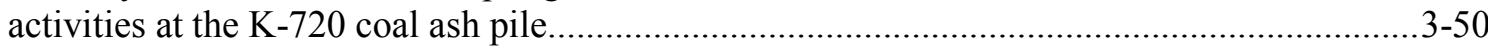

3.29 Mercury results from storm water monitoring conducted in CY 2013 .................................3-50

3.30 East Tennessee Technology Park Environmental Monitoring Program quarterly surface water mercury results for CY 2013

3.31 East Tennessee Technology Park Environmental Monitoring Program semiannual surface water mercury results for CY 2013.

3.32 Water Resources Restoration Program mercury sampling results for the K-1700 Weir in CY 2013.

3.33 National Pollutant Discharge Elimination System permit TN0074225 storm water outfall SD 001 monitoring requirements

3.34 Isotopic discharges from the Central Neutralization Facility Wastewater Treatment System, 2013

3.35 Volatile organic compounds detected in groundwater in the Mitchell Branch exit pathway

3.36 Toxicity test results for Mitchell Branch and associated storm water outfalls, 2013 (no-observed-effects concentrations)

3.37 Compiled data for polychlorinated biphenyl concentrations in caged Asiatic clams (Corbicula fluminea), 2009 to 2013.

3.38 Compiled data for mercury concentrations in caged Asiatic clams (Corbicula fluminea), 2010 to 2013

3.39 Polychlorinated biphenyl levels in fish samples at East Tennessee Technology Park, 2009 to 2013 $3-76$

3.40 Mercury levels in fish fillet and whole body samples at East Tennessee

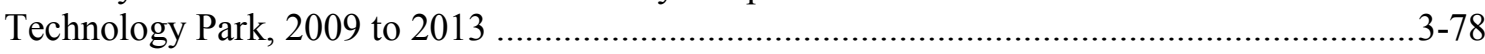

3.41 Biosolids applied on the Oak Ridge Reservation in CY 2013 by the City of Oak Ridge. $3-89$

3.42

3.43

3.44

3.45

3.46

3.47

3.48

3.49

3.50

3.51

4.1 Energy conservation measures included in Energy Savings Performance Contract

delivery order 3

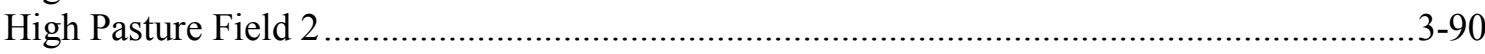

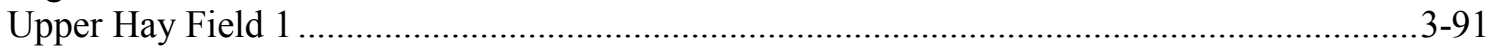

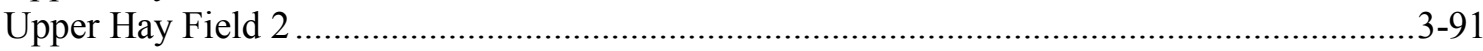

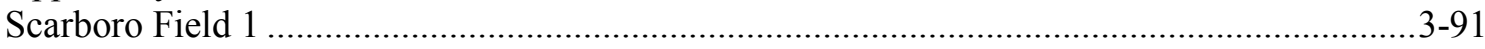

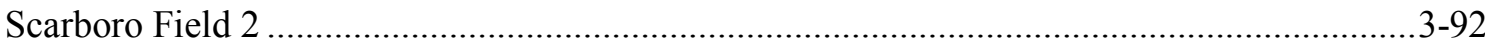

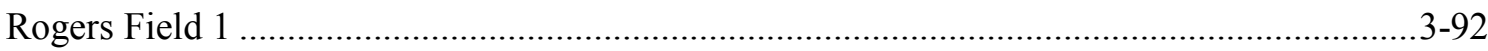

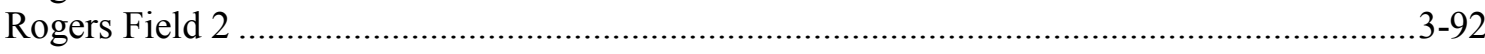

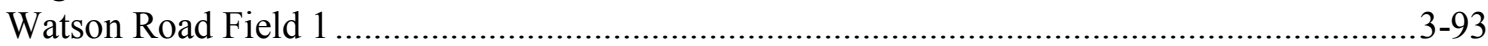

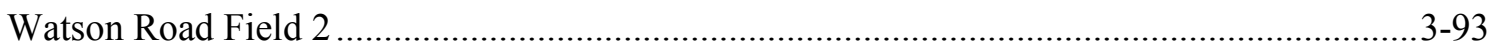

4.2 FY 2013 sustainability goals and status 
4.3 Summary of petroleum and alternative fuel use over an 8-year period.................................4-19

4.4 Y-12 National Security Complex greenhouse gas emissions summary .................................4-20

4.5 Y-12 National Security Complex environmental permits, 2013 ...........................................4-24

4.6 Y-12 National Security Complex Resource Conservation and Recovery Act postclosure status for former treatment, storage, and disposal units on the

Oak Ridge Reservation.

4.7 Emergency Planning and Community Right-to-Know Act Section 313 toxic chemical release and off-site transfer summary for the Y-12 National Security

Complex, 2012 and 2013.

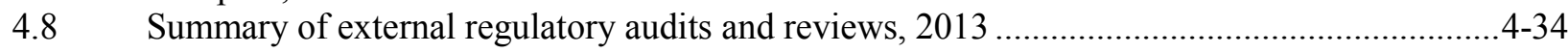

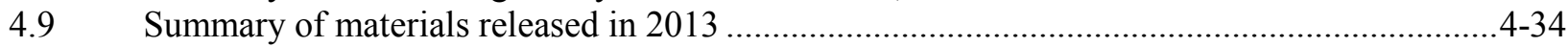

4.10 DOE O 458.1 preapproved authorized limits ...................................................................36

4.11 Actual versus allowable air emissions from the Y-12 Complex Steam Plant, 2013 ................4-38

4.12 Greenhouse gas emissions from Y-12 Complex stationary fuel combustion sources...............4-42

4.13 Summary of data for the Y-12 National Security Complex ambient air monitoring

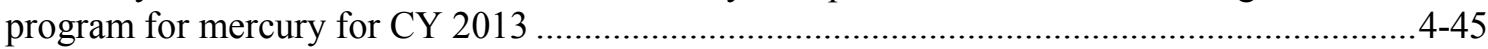

4.14 National Pollutant Discharge Elimination System compliance monitoring requirements and record for the Y-12 Complex, January through December 2013 .................4-50

4.15 Radiological parameters monitored at the Y-12 Complex, 2013 ........................................4-52

4.16 Summary of Y-12 Complex radiological monitoring plan sample requirements and

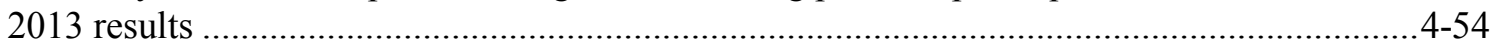

4.17 Release of uranium from the Y-12 Complex to the off-site environment as a liquid

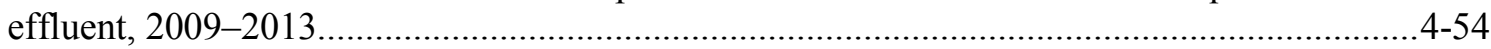

4.18 Y-12 Complex Discharge Point SS6, Sanitary Sewer Station 6, January through December 2013

4.19 Y-12 Complex Biomonitoring Program summary information for outfalls 200 and

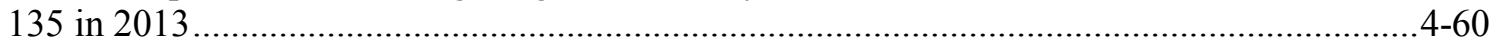

4.20 Summary groundwater monitoring at the Y-12 National Security Complex, 2013 ................4-70

4.21 Description of waste management units and underground storage tanks included in groundwater monitoring activities, upper East Fork Poplar Creek hydrogeologic regime, 2013

4.22 Description of waste management units included in calendar year 2013 groundwater monitoring activities, Bear Creek hydrogeologic regime................................................... $4-82$

4.23 Nitrate and uranium concentrations in Bear Creek ....................................................... $4-85$

4.24 Description of waste management units included in groundwater monitoring activities, Chestnut Ridge hydrogeologic regime, 2013 ......................................................4-88

5.1 Summary of UT-Battelle progress toward attainment of DOE sustainability goals,

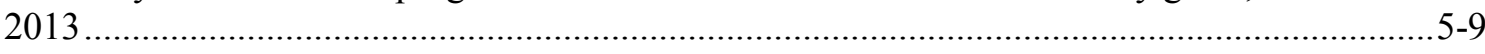

5.2 Summary of regulatory environmental audits, evaluations, inspections, and assessments conducted at Oak Ridge National Laboratory, 2013 .........................................5-18

5.3 Oak Ridge National Laboratory environmental permits, 2013 ........................................5-19

5.4 National Environmental Policy Act (NEPA) activities, 2013 ..............................................5-21

5.5 Oak Ridge National Laboratory Resource Conservation and Recovery Act

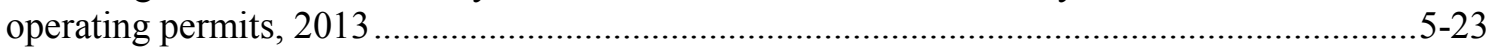

5.6 Main elements of the Emergency Planning and Community Right-to-Know Act...................5-26

5.7 Excess items requested for release and/or recycling, calendar year 2013 ..............................5-30

5.8 Radiological airborne emissions from all sources at Oak Ridge National

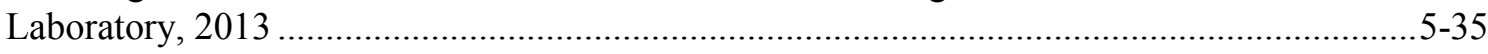

5.9 Radionuclide concentrations measured at Oak Ridge National Laboratory perimeter

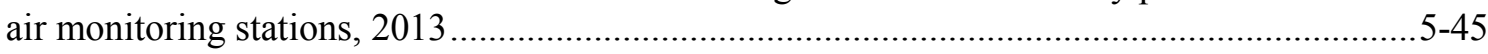

5.10 National Pollutant Discharge Elimination System compliance at Oak Ridge National Laboratory, 2013 
5.11 Outfalls exceeding total residual oxidant action level in 2013 ..........................................5-51

5.12 Summary results of chronic Ceriodaphnia dubia toxicity tests of Oak Ridge

National Laboratory cooling towers and outfalls conducted during September 2013 ..............5-52

5.13 Field parameters and results from laboratory analyses of blowdown from Oak Ridge

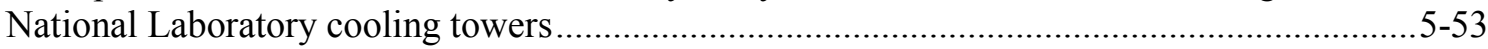

5.14 Radiological monitoring conducted under the Oak Ridge National Laboratory Water

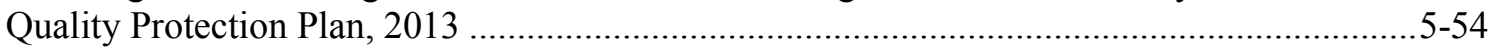

$5.15 \quad$ First Creek PCB source assessment, August 2013 ...........................................................5-73

5.16 Oak Ridge National Laboratory surface water sampling locations, frequencies, and

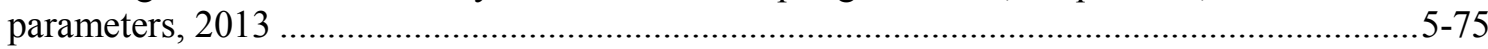

5.17 Industrial and Commercial User Waste Water Discharge Permit compliances at the Oak Ridge National Laboratory Carbon Fiber Technology Facility, 2013 ............................5-76

$5.18 \quad$ Scheduled 2013 exit pathway groundwater monitoring ......................................................5-81

5.192013 exit pathway groundwater monitoring - results of trend analyses for parameters exceeding reference standards ........................................................................... 5-82

5.202013 exit pathway groundwater monitoring results — detected radiological

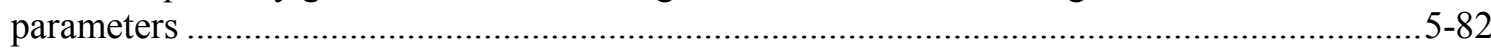

5.212013 exit pathway groundwater monitoring results — detected organic

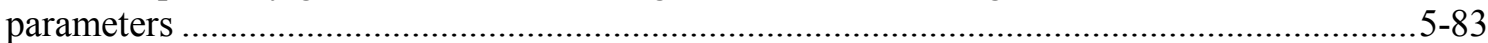

$5.22 \quad 2013$ Spallation Neutron Source monitoring program schedule .........................................5-86

5.23 Spallation Neutron Source groundwater monitoring results - tritium detections

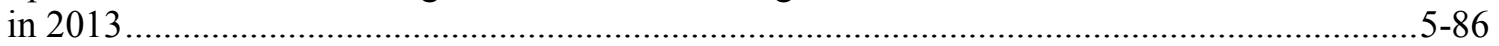

5.24 Spallation Neutron Source groundwater monitoring results — other radionuclide

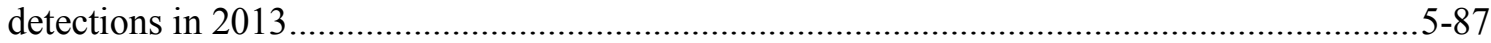

6.1 Oak Ridge Reservation meteorological towers ............................................................... 6-2

6.2 External gamma (exposure rate) averages for the Oak Ridge Reservation, 2013 ...................6-5

6.3 Average radionuclide concentrations at Oak Ridge Reservation perimeter air monitoring stations, 2013.

6.4 Oak Ridge Reservation surface water sampling locations, frequencies, and parameters, 2013

6.5 Concentrations of radionuclides detected in vegetables, 2013 ............................................6-11

6.6 Concentrations of radionuclides detected in raw milk, 2013 ...........................................6-12

6.7 Tissue concentrations in catfish and sunfish for mercury, detected PCBs, and

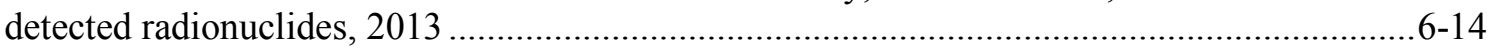

7.1 Emission point parameters and receptor locations used in the dose calculations.......................7-3

7.2 Meteorological towers and heights used to model atmospheric dispersion from source emissions.............................................................................................................

7.3 Calculated radiation doses to maximally exposed off-site individuals from

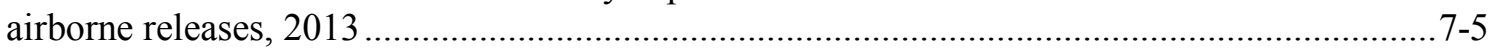

7.4 Calculated collective effective doses from airborne releases, 2013 ................................... 7-5

7.5 Hypothetical effective doses from living at the Oak Ridge Reservation and the East Tennessee Technology Park ambient-air monitoring stations, 2013 ............................ 7-7

7.6 Summary of annual maximum individual and collective effective doses (EDs)

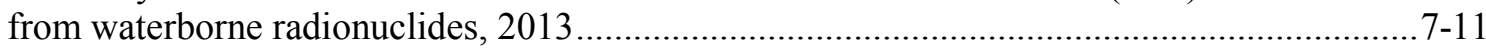

7.7 Summary of maximum estimated effective doses to an adult by exposure pathway ............... $7-16$

7.8 Trends in effective dose for selected pathways .................................................................... $7-17$

7.9 Chemical hazard quotients and estimated risks for drinking water, 2013 ..........................7-20

7.10 Chemical hazard quotients and estimated risks for carcinogens in fish, 2013 .....................7-21 


\section{Acronyms and Abbreviations}

\begin{tabular}{|c|c|}
\hline AAS & ambient air (monitoring) station \\
\hline $\mathrm{ABC}$ & aluminum beverage can (recycling) \\
\hline ACHP & Advisory Council on Historic Preservation \\
\hline $\mathrm{ACO}$ & Analytical Chemistry Organization (Y-12 Complex) \\
\hline $\mathrm{ACM}$ & asbestos-containing material \\
\hline AFV & alternative fuel vehicle \\
\hline AGL & above ground level \\
\hline ALARA & as low as reasonably achievable \\
\hline ANSI & American National Standards Institute \\
\hline ANSI/HPS & ANSI Health Physics Society (standard) \\
\hline $\mathrm{AOEC}$ & Agent Operations Eastern Command (NNSA OST) \\
\hline ARAP & Aquatic Resource Alteration Permit \\
\hline ARRA & American Recovery and Reinvestment Act \\
\hline ASER & Oak Ridge Reservation Annual Site Environmental Report \\
\hline AWQC & ambient water quality criterion \\
\hline B\&W Y-12 & Babcock \& Wilcox Technical Services Y-12, LLC \\
\hline BCG & biota concentration guide \\
\hline BMAP & Biological Monitoring and Abatement Program \\
\hline BRW & bedrock well \\
\hline C\&D & construction and demolition \\
\hline CAA & Clean Air Act \\
\hline CAP-88 & Clean Air Assessment Package (software) \\
\hline CAS & condition assessment survey \\
\hline CERCLA & Comprehensive Environmental Response, Compensation, and Liability Act \\
\hline CFR & Code of Federal Regulations \\
\hline CFTF & Carbon Fiber Technology Facility \\
\hline $\mathrm{CH}$ & contact-handled \\
\hline CMSB & Chemical and Materials Science Building \\
\hline CNF & Central Neutralization Facility \\
\hline $\mathrm{CO}_{2} \mathrm{e}$ & $\mathrm{CO}_{2}$ equivalent \\
\hline $\mathrm{COC}$ & contaminant of concern \\
\hline CPU & central processing unit (computer) \\
\hline CRK & Clinch River kilometer \\
\hline CROET & Community Reuse Organization of East Tennessee \\
\hline CRT & $\begin{array}{l}\text { cathode-ray tube (also display devices, especially computers, incorporating } \\
\text { cathode-ray tubes) }\end{array}$ \\
\hline CWA & Clean Water Act \\
\hline CWTS & Chromium Water Treatment System (ETTP) \\
\hline $\mathrm{CX}$ & categorical exclusion \\
\hline
\end{tabular}




\begin{tabular}{|c|c|}
\hline $\mathrm{CY}$ & calendar year \\
\hline D\&D & decontamination and decommissioning \\
\hline DAC & derived air concentration \\
\hline DCA & dichloroethane \\
\hline DCE & dichloroethene/dichloroethylene \\
\hline DCG & derived concentration guide \\
\hline DCS & derived concentration standard \\
\hline DNAPL & dense nonaqueous phase liquid \\
\hline DOE & US Department of Energy \\
\hline DOE ORO & DOE Oak Ridge Office \\
\hline DVD & digital video disc \\
\hline E85 & $\begin{array}{l}\text { Ethanol-fuel blend consisting of up to } 85 \% \text { ethanol and } 15 \% \text { gasoline or other } \\
\text { hydrocarbon }\end{array}$ \\
\hline EBSR & Environmental Baseline Survey Report \\
\hline EC\&P & Environmental Compliance and Protection \\
\hline ECD & Environmental Compliance Department (Y-12 Complex) \\
\hline $\mathrm{ECM}$ & energy conservation measure \\
\hline ED & effective dose \\
\hline EDTA & ethylenediaminetetraacetic acid \\
\hline EFK & East Fork Poplar Creek kilometer \\
\hline EFPC & East Fork Poplar Creek \\
\hline EISA & Energy Independence and Security Act \\
\hline EM & environmental management \\
\hline EMDF & Environmental Management Disposal Facility \\
\hline EMMIS & Environmental Monitoring Management Information System (Y-12 Complex) \\
\hline EMP & environmental monitoring program \\
\hline EMPO & Environmental Management Program Office (ORNL) \\
\hline EMS & Environmental Management System \\
\hline EMWMF & Environmental Management Waste Management Facility \\
\hline EO & executive order \\
\hline EPA & US Environmental Protection Agency \\
\hline EPCRA & Emergency Planning and Community Right-to-Know Act \\
\hline EPEAT & Electronic Product Environmental Assessment Tool \\
\hline EPT & Ephemeroptera, Plecoptera, and Trichoptera (taxa) \\
\hline EP\&WSD & Environmental Protection and Waste Services Division (UT-Battelle) \\
\hline $\mathrm{ES} \& \mathrm{H}$ & environment, safety, and health \\
\hline ESPC & Energy Savings Performance Contract \\
\hline ESS & Environmental Surveillance System (ORNL) \\
\hline ETTP & East Tennessee Technology Park \\
\hline EU & exposure unit \\
\hline FAST & Federal Automotive Statistical Tool \\
\hline FCK & First Creek kilometer \\
\hline
\end{tabular}




\begin{tabular}{|c|c|}
\hline FEC & Federal Electronics Challenge \\
\hline FFA & federal facility agreement \\
\hline FFCA & Federal Facilities Compliance Agreement \\
\hline FFK & Fifth Creek kilometer \\
\hline FY & fiscal year \\
\hline GET & General Employee Training \\
\hline GHG & greenhouse gas \\
\hline GI & green infrastructure \\
\hline GWPP & Groundwater Protection Program (Y-12) \\
\hline HAP & hazardous air pollutant \\
\hline $\mathrm{HCC}$ & Halcyon Commercialization Center \\
\hline HEPA & high-efficiency particulate air \\
\hline $\mathrm{HEU}$ & highly enriched uranium \\
\hline HFIR & High Flux Isotope Reactor \\
\hline HPSB & high-performance sustainable building \\
\hline HQ & hazard quotient \\
\hline HVAC & heating, ventilating, and air-conditioning \\
\hline $\mathrm{IC}_{25}$ & $\begin{array}{l}\text { inhibition concentration (the concentration of effluent that causes a } 25 \% \\
\text { reduction in survival, reproduction, and/or growth of monitored species) }\end{array}$ \\
\hline ICP-MS & inductively coupled plasma-mass spectrometer \\
\hline ID & identification (number) \\
\hline IDMS & Integrated Document Management System (UT-Battelle) \\
\hline ISMS & Integrated Safety Management System \\
\hline ISO & International Organization for Standardization \\
\hline Isotek & Isotek Systems LLC \\
\hline IWC & instream waste concentration \\
\hline LCD & liquid crystal display \\
\hline LEED & Leadership in Energy and Environmental Design \\
\hline LID & low impact development \\
\hline LIMS & Laboratory Information Management System (Y-12 Complex) \\
\hline LLW & low-level waste \\
\hline $\mathrm{M} \& \mathrm{E}$ & material and equipment \\
\hline M\&TE & measurement and test equipment \\
\hline MACT & Maximum Achievable Control Technology \\
\hline MARSAME & $\begin{array}{l}\text { Multi-Agency Radiation Survey and Assessment of Materials and Equipment } \\
\text { Manual }\end{array}$ \\
\hline MARSSIM & Multi-Agency Radiation Survey and Site Investigation Manual \\
\hline MBK & Mill Branch kilometer \\
\hline MCK & McCoy Branch kilometer \\
\hline MCL & maximum contaminant level \\
\hline
\end{tabular}




\begin{tabular}{|c|c|}
\hline MDA & minimum detectable activity \\
\hline MDF & Manufacturing Demonstration Facility \\
\hline MEI & maximally exposed individual \\
\hline MEK & Melton Branch kilometer \\
\hline MIK & Mitchell Branch kilometer \\
\hline MOA & memorandum of agreement \\
\hline MSRE & Molten Salt Reactor Experiment \\
\hline MT & meteorological tower (when directly followed by a numeral as in "MT2") \\
\hline NAAQS & National Ambient Air Quality Standards \\
\hline NEPA & National Environmental Policy Act \\
\hline NESHAPs & National Emission Standards for Hazardous Air Pollutants \\
\hline NHPA & National Historic Preservation Act \\
\hline NIST & National Institute of Standards and Technology \\
\hline NNSA & National Nuclear Security Administration \\
\hline NNSS & Nevada National Security Site \\
\hline NOV & notice of violation \\
\hline $\mathrm{NO}_{\mathrm{X}}$ & oxides of nitrogen \\
\hline NPDES & National Pollutant Discharge Elimination System \\
\hline NPL & National Priorities List (EPA) \\
\hline NPO & NNSA Production Office \\
\hline NRHP & National Register of Historic Places \\
\hline NSF-ISR & NSF International Strategic Registrations, Ltd. \\
\hline NSPS & New Source Performance Standard \\
\hline NTRC & National Transportation Research Center \\
\hline O\&M & operations and maintenance \\
\hline ODS & ozone-depleting substance \\
\hline OMP & operational monitoring plan \\
\hline ORAU & Oak Ridge Associated Universities \\
\hline OREIS & Oak Ridge Environmental Information System (ORNL) \\
\hline ORFRC & Oak Ridge Field Research Center \\
\hline ORGDP & Oak Ridge Gaseous Diffusion Plant \\
\hline ORISE & Oak Ridge Institute for Science and Education \\
\hline ORNL & Oak Ridge National Laboratory \\
\hline ORO & Oak Ridge Office \\
\hline ORPS & Occurrence Reporting and Processing System (Y-12 Complex) \\
\hline ORR & Oak Ridge Reservation \\
\hline ORRL & Oak Ridge Reservation Landfill \\
\hline ORSSAB & Oak Ridge Site Specific Advisory Board \\
\hline ORSTP & Oak Ridge Science and Technology Park \\
\hline OS & Office of Science (DOE) \\
\hline OST & Office of Secure Transportation (NNSA) \\
\hline
\end{tabular}




\begin{tabular}{|c|c|}
\hline PAM & perimeter air monitoring (station) \\
\hline PCB & polychlorinated biphenyl \\
\hline PCE & tetrachloroethene \\
\hline PEMS & Predictive Emissions Monitoring System \\
\hline PM & particulate matter \\
\hline $\mathrm{PM}_{10}$ & particulate matter with an aerodynamic diameter less than or equal to $10 \mu \mathrm{m}$ \\
\hline $\mathrm{PM}_{2.5}$ & $\begin{array}{l}\text { fine particulate matter with an aerodynamic diameter less than or equal to } \\
2.5 \mu \mathrm{m}\end{array}$ \\
\hline POTW & publicly owned treatment works \\
\hline PSD & Prevention of Significant Deterioration \\
\hline PSDT & Professional Site Design Team \\
\hline PWTC & Process Waste Treatment Complex \\
\hline QA & quality assurance \\
\hline QC & quality control \\
\hline RA & remedial action \\
\hline $\mathrm{R} \& \mathrm{D}$ & research and development \\
\hline Rad-NESHAPs & National Emission Standards for Hazardous Air Pollutants for Radionuclides \\
\hline RATA & relative accuracy test audit \\
\hline RCRA & Resource Conservation and Recovery Act \\
\hline RDR & remedial design report \\
\hline REDC & Radiochemical Engineering Development Center \\
\hline RESRAD & residual radioactivity \\
\hline RFITS & Radio Frequency Identification Transportation System \\
\hline RH & remote-handled \\
\hline RI & remedial investigation \\
\hline $\mathrm{RI} / \mathrm{FS}$ & remedial investigation/feasibility study \\
\hline RICE & reciprocating internal combustion engine \\
\hline RMP & risk management plan \\
\hline ROD & record of decision \\
\hline RQ & reportable quantity (CERCLA) \\
\hline RRSTP & Rarity Ridge Sewage Treatment Plant \\
\hline RSI & Restoration Services, Inc. \\
\hline RSO & radiation safety officer \\
\hline S\&M & surveillance and maintenance \\
\hline SAA & satellite accumulation area \\
\hline SAP & sampling and analysis plan \\
\hline SARA & Superfund Amendments and Reauthorization Act \\
\hline SBMS & Standards-Based Management System (UT-Battelle) \\
\hline $\mathrm{SCP}$ & standards and calibration program \\
\hline SD & storm drain \\
\hline SDWA & Safe Drinking Water Act \\
\hline SEC & SEC Federal Services Corporation \\
\hline
\end{tabular}




\begin{tabular}{|c|c|}
\hline SHPO & State Historic Preservation Office (Tennessee) \\
\hline SNAP & Significant New Alternatives Program (EPA) \\
\hline SNM & special nuclear material \\
\hline SNS & Spallation Neutron Source \\
\hline SODAR & sonic detection and ranging \\
\hline SPCC & spill prevention, control, and countermeasures (plan) \\
\hline SPMD & semipermeable membrane device \\
\hline SSP & site sustainability plan \\
\hline SSPP & Strategic Sustainability Performance Plan (DOE) \\
\hline STP & sewage treatment plant \\
\hline SVOC & semivolatile organic compound \\
\hline SWEIS & sitewide environmental impact statement \\
\hline SWHISS & Surface Water Hydrological Information Support System (Y-12 Complex) \\
\hline SWPP & Storm Water Pollution Prevention \\
\hline SWPPP & Storm Water Pollution Prevention Plan \\
\hline SWSA & solid waste storage area \\
\hline TCA & trichloroethane \\
\hline TCE & trichloroethene/trichloroethylene \\
\hline TDEC & Tennessee Department of Environment and Conservation \\
\hline TEMA & Tennessee Emergency Management Agency \\
\hline TGSP & Tennessee Green Star Partnership \\
\hline TMDL & Total Maximum Daily Load \\
\hline TOA & Tennessee Oversight Agreement \\
\hline TP3 & Tennessee Pollution Prevention Partnership \\
\hline TRI & toxic (chemical) release inventory \\
\hline TRO & total residual oxidant \\
\hline TRU & transuranic \\
\hline TSCA & Toxic Substances Control Act \\
\hline TVA & Tennessee Valley Authority \\
\hline TWA & time-weighted average \\
\hline TWPC & Transuranic Waste Processing Center \\
\hline TWRA & Tennessee Wildlife Resources Agency \\
\hline UCOR & URS | CH2M Oak Ridge LLC \\
\hline UMC & Unneeded Materials and Chemicals \\
\hline UMS & Utilities Management System (Y-12 Complex) \\
\hline UNW & unconsolidated well \\
\hline UPF & Uranium Processing Facility (Y-12 Complex) \\
\hline USACE & US Army Corps of Engineers \\
\hline USDA & US Department of Agriculture \\
\hline UST & underground storage tank \\
\hline UT & University of Tennessee \\
\hline UV & ultraviolet \\
\hline
\end{tabular}




$\begin{array}{ll}\text { WAI } & \text { Wastren Advantage, Inc. } \\ \text { WCK } & \text { WOC kilometer } \\ \text { WEMA } & \text { west end mercury-use area (Y-12) } \\ \text { WET } & \text { whole effluent toxicity } \\ \text { WIPP } & \text { Waste Isolation Pilot Plant } \\ \text { WOC } & \text { White Oak Creek } \\ \text { WOD } & \text { White Oak Dam } \\ \text { WQC } & \text { water quality criterion } \\ \text { WQPP } & \text { water quality protection plan } \\ \text { WRRP } & \text { Water Resources Restoration Program } \\ \text { Y-12/Y-12 Complex } & \text { Y-12 National Security Complex } \\ \text { ZPR } & \end{array}$





\section{Units of Measure and Conversion Factors*}

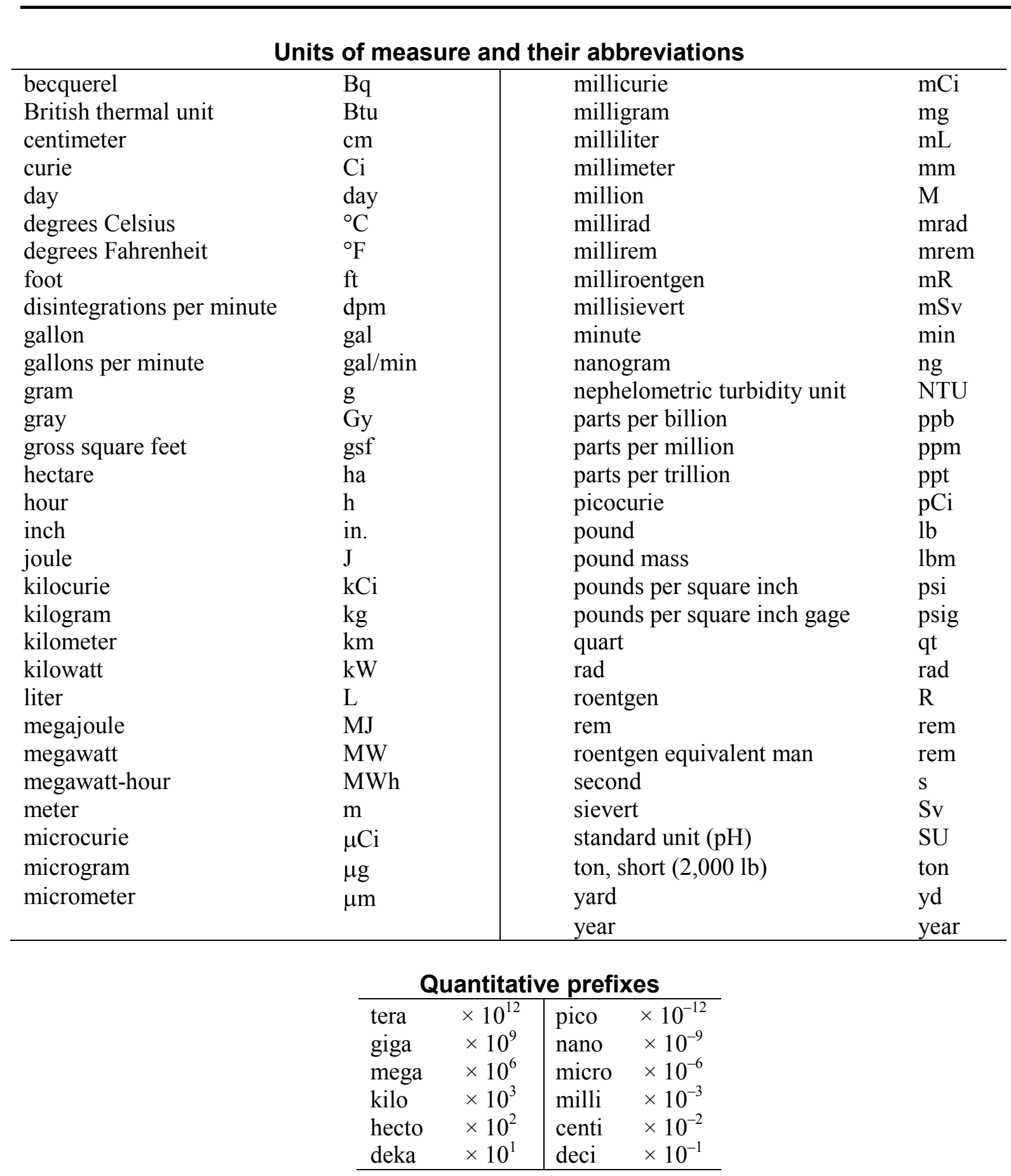

\footnotetext{
* Due to differing permit reporting requirements and instrument capabilities, various units of measurement are used in this report. The provided list of units of measure and conversion factors is intended to help readers convert numeric values presented here as needed for specific calculations and comparisons.
} 


\section{Unit conversions}

\begin{tabular}{|c|c|c|c|c|c|}
\hline Unit & Conversion & Equivalent & Unit & Conversion & Equivalent \\
\hline \multicolumn{6}{|c|}{ Length } \\
\hline in. & $\times 2.54$ & $\mathrm{~cm}$ & $\mathrm{~cm}$ & $\times 0.394$ & in. \\
\hline $\mathrm{ft}$ & $\times 0.305$ & $\mathrm{~m}$ & $\mathrm{~m}$ & $\times 3.28$ & $\mathrm{ft}$ \\
\hline mile & $\times 1.61$ & $\mathrm{~km}$ & $\mathrm{~km}$ & $\times 0.621$ & mile \\
\hline \multicolumn{6}{|c|}{ Area } \\
\hline acre & $\times 0.405$ & ha & ha & $\times 2.47$ & acre \\
\hline $\mathrm{ft}^{2}$ & $\times 0.093$ & $\mathrm{~m}^{2}$ & $\mathrm{~m}^{2}$ & $\times 10.764$ & $\mathrm{ft}^{2}$ \\
\hline mile $^{2}$ & $\times 2.59$ & $\mathrm{~km}^{2}$ & $\mathrm{~km}^{2}$ & $\times 0.386$ & mile $^{2}$ \\
\hline \multicolumn{6}{|c|}{ Volume } \\
\hline $\mathrm{ft}^{3}$ & $\times 0.028$ & $\mathrm{~m}^{3}$ & $\mathrm{~m}^{3}$ & $\times 35.31$ & $\mathrm{ft}^{3}$ \\
\hline qt (US liquid) & $\times 0.946$ & $\mathrm{~L}$ & $\mathrm{~L}$ & $\times 1.057$ & qt (US liquid) \\
\hline gal & $\times 3.7854118$ & $\mathrm{~L}$ & $\mathrm{~L}$ & $\times 0.264172051$ & gal \\
\hline \multicolumn{6}{|c|}{ Concentration } \\
\hline $\mathrm{ppb}$ & & & & & $\mathrm{ppb}$ \\
\hline ppm & $\times 1$ & $\mathrm{mg} / \mathrm{L}$ & $\mathrm{mg} / \mathrm{L}$ & $\times 1$ & ppm \\
\hline \multicolumn{6}{|c|}{ Weight } \\
\hline $\mathrm{lb}$ & $\times 0.4536$ & $\mathrm{~kg}$ & $\mathrm{~kg}$ & $\times 2.205$ & $\mathrm{lb}$ \\
\hline $\mathrm{lbm}$ & $\times 0.45356$ & $\mathrm{~kg}$ & $\mathrm{~kg}$ & $\times 2.2046226$ & $\mathrm{lbm}$ \\
\hline ton, short & $\times 907.1847$ & $\mathrm{~kg}$ & $\mathrm{~kg}$ & $\times 0.00110231131$ & ton, short \\
\hline \multicolumn{6}{|c|}{ Temperature } \\
\hline \multicolumn{6}{|c|}{ Activity } \\
\hline $\mathrm{Bq}$ & $\times 2.7 \times 10^{-11}$ & $\mathrm{Ci}$ & $\mathrm{Ci}$ & $\times 3.7 \times 10^{10}$ & $\mathrm{~Bq}$ \\
\hline $\mathrm{Bq}$ & $\times 27$ & $\mathrm{pCi}$ & $\mathrm{pCi}$ & $\times 0.037$ & $\mathrm{~Bq}$ \\
\hline $\mathrm{mSv}$ & $\times 100$ & mrem & mrem & $\times 0.01$ & $\mathrm{mSv}$ \\
\hline $\mathrm{Sv}$ & $\times 100$ & rem & rem & $\times 0.01$ & $\mathrm{~Sv}$ \\
\hline $\mathrm{nCi}$ & $\times 1,000$ & pCi & pCi & $\times 0.001$ & $\mathrm{nCi}$ \\
\hline $\mathrm{mCi} / \mathrm{km}^{2}$ & $\times 1$ & $\mathrm{nCi} / \mathrm{m}^{2}$ & $\mathrm{nCi} / \mathrm{m}^{2}$ & $\times 1$ & $\mathrm{mCi} / \mathrm{km}^{2}$ \\
\hline $\mathrm{dpm} / \mathrm{L}$ & $\times 0.45 \times 10^{9}$ & $\mu \mathrm{Ci} / \mathrm{cm}^{3}$ & $\mu \mathrm{Ci} / \mathrm{cm}^{3}$ & $\times 2.22 \times 10^{9}$ & $\mathrm{dpm} / \mathrm{L}$ \\
\hline $\mathrm{pCi} / \mathrm{L}$ & $\times 10^{-9}$ & $\mu \mathrm{Ci} / \mathrm{mL}$ & $\mu \mathrm{Ci} / \mathrm{mL}$ & $\times 10^{9}$ & $\mathrm{pCi} / \mathrm{L}$ \\
\hline $\mathrm{pCi} / \mathrm{m}^{3}$ & $\times 10^{-12}$ & $\mu \mathrm{Ci} / \mathrm{cm}^{3}$ & $\mu \mathrm{Ci} / \mathrm{cm}^{3}$ & $\times 10^{12}$ & $\mathrm{pCi} / \mathrm{m}^{3}$ \\
\hline
\end{tabular}




\section{Acknowledgments}

The ASER technical coordinators and project team wish to thank those who participated in the publication of the Oak Ridge Reservation Annual Site Environmental Report. Although we cannot name everyone involved in the environmental monitoring program, we would like to also thank and acknowledge those conducting sampling and analytical support.

DOE

Tracye Baber

Steve Cooke

ENVIRONMENTAL MANAGEMENT

Carrie Barber

Betsy Brucken

Kevin Crow

Christa Davis

Katie Davis

Howell Estes

Steve Foster

Glen Galen

Sherry Gibson

Stephen Goodpasture

Charles Justice

Richard Ketelle

Rodney Kingrea

Bruce McElhoe

Jeff Murphy

Tony Poole

Gill Salade

Cheryl Sayler

Roxianne Sherles

Adam Smith

Karen Whaley

Steven Wood
ORISE

Rac Cox

ORNL

Bill Biloski

Kevin Birdwell

Terry Bonine

Jason Case

Gary Chadwick-Isotek

Jim Eaton

Rich Franco

Neil Giffen

Wes Goddard

Scott Gregory

Julia Hancock

Trent Jett

Swati Kirpekar

Regis Loffman

Larry Long

Diane Maddox

Terry Mathews

Lori Muhs

Don Naab

Todd North

Anne Ostergaard

Mark Peterson

Kyle Rutherford

Ernest Ryan

Pat Scofield

Jeff Sickau

George Stephens

John Smith

Linda Smith

Sam Thomas-WAI

Charlie Valentine

\section{Y-12 COMPLEX}

Gary Beck

Ellen Boatner

Jeff Bruner

Terry Cothron

Laura Cunningham

Melanie Dillon

Jennifer Dixon

Stan Duke

Jan Jackson

Kim Hanzelka

Russ Harden

Gail Harp

Clarence Hill

William Hurst

Robert Johnson

Steve Jones

Ivy Lalonde

Cathy McCoy

Stacey McNamara

Carrie Miller

Jane Nations

Terry Nore

Aprell Patterson

Randy Redmond

Paula Roddy-Roche

Beth Schultz

Mark Shedden

Brad Skaggs

Johnny Skinner

Tim Tharp

Lenny Vaughan

Jeannette Widman

Mick Wiest

Rebekah Young 



\section{Executive Summary}

\section{Overview}

The US Department of Energy's (DOE's) Oak Ridge Reservation (ORR) is located in Roane and Anderson counties in east Tennessee, about $40 \mathrm{~km}$ ( 25 miles) from Knoxville. ORR is one of DOE's most unique and complex sites. It encompasses three major facilities and thousands of employees that perform every mission in the DOE portfolio-energy research, environmental restoration, national security, nuclear fuel supply, reindustrialization, science education, basic and applied research in areas important to US security, and technology transfer. ORR was established in the early 1940s as part of the Manhattan Project for the purposes of enriching uranium and pioneering methods for producing and separating plutonium. Today, scientists at the Oak Ridge National Laboratory (ORNL), DOE's largest multipurpose national laboratory, conduct world-leading research in advanced materials, alternative fuels, climate change, and supercomputing. The Y-12 National Security Complex (Y-12 Complex) is vital in maintaining the safety, security, and effectiveness of the US nuclear weapons stockpile and reducing the global threat posed by nuclear proliferation and terrorism. The East Tennessee Technology Park (ETTP), a former uranium enrichment complex, is being transitioned to a clean, revitalized industrial park.

DOE has established an Integrated Safety Management System (ISMS) to integrate safety into all aspects of work at its facilities. Safety, as defined in ISMS, encompasses protection of the public, the worker, and the environment and includes all safety, health, and environmental disciplines (i.e., radiation protection, fire protection, nuclear safety, environmental protection, waste management, and environmental management). Several contractors, including UT-Battelle, LLC; Babcock \& Wilcox Technical Services Y-12, LLC; URS | CH2M Oak Ridge LLC (UCOR); Wastren Advantage, Inc.; Oak Ridge Associated Universities; and Isotek Systems LLC, are responsible for carrying out the various DOE missions at the three major ORR facilities. These contractors manage and implement environmental protection programs through Environmental Management Systems (EMSs) that adhere to International Organization for Standardization (ISO) 14001: 2004, Environmental Management Systems, and are integrated with ISMS to provide unified strategies for managing resources. An EMS is a continuous cycle of planning, implementing, evaluating, and improving processes and actions undertaken to achieve environmental missions and goals. Routine, external (independent) audits of contractor-implemented EMSs on the reservation are typically conducted annually and, if applicable, a triennial recertification is also performed. Detailed information on contractor EMSs is provided in Chapters 3, 4, and 5.

DOE operations on ORR have the potential to release a variety of constituents into the environment via atmospheric, surface water, and groundwater pathways. Some of the constituents, such as particles from diesel engines, are common at many types of facilities, while others, such as radionuclides, are unique to specialized research and production activities like those on ORR. Any releases are highly regulated and carefully monitored. DOE is committed to enhancing environmental stewardship and managing the impacts its operations may have on the environment and encourages the public to participate in matters related to ORR's environmental impact on the community by soliciting citizens' input on matters of significant public interest and through various communications. DOE also provides public access to information on all its Oak Ridge environmental, safety, and health activities.

The Oak Ridge Reservation Annual Site Environmental Report (ASER) is prepared for DOE according to requirements of DOE O 231.1 B, Environment, Safety and Health Reporting. ASER includes data on the environmental performance of each of the major DOE ORR contractors and describes significant accomplishments in pollution prevention and sustainability programs that serve to reduce all types of waste and pollutant releases to the environment. An environmental report for ORR that provides consolidated data on overall reservation performance and status has been published annually since the mid-1970s. ASER is a key component of the DOE effort to keep the public informed about environmental conditions across DOE/National Nuclear Security Administration sites. The report is prepared for 
readability, and frequent reference to other sections, chapters, and reports is made throughout the report to avoid redundancy.

\section{Impacts}

DOE ORR operations in 2013 continued to result in minimal impact to the public and the environment. Permitted discharges to air and water were well below regulatory standards, and potential radiation doses to the public from activities on the reservation were significantly less than the 100 mrem standard established for DOE sites in DOE O 458.1, Radiation Protection of the Public and the Environment.

The maximum radiation dose that a hypothetical off-site individual could have received from DOE activities on ORR in 2013 was estimated to be $0.4 \mathrm{mrem}$ from air pathways, $2.2 \mathrm{mrem}$ from water pathways (drinking water, fish consumption, swimming, recreation, and other uses), and 2.2 mrem from consumption of wildlife harvested on ORR. This is about $5 \%$ of the DOE 100 mrem standard for all pathways and is significantly less than the 300 mrem annual average dose to people in the United States from natural or background radiation. The 2013 maximum hypothetical dose is consistent with those calculated for the previous 5 years (2008-2012), which have ranged from 3 to $5 \mathrm{mrem}$.

\section{Environmental Monitoring}

Extensive environmental monitoring is conducted across ORR each year. Site-specific environmental protection programs are carried out at ORNL, the Y-12 Complex, and ETTP, and ORR-wide environmental surveillance programs, which include locations and media on and off the reservation, are conducted to enhance and supplement data from site-specific efforts. In 2013, thousands of samples and measurements of air, water, direct radiation, vegetation, fish, and wildlife collected from across the reservation were analyzed for both radioactive and nonradioactive contaminants. Sample media, locations, frequencies, and parameters were selected based on environmental regulations and standards, public and environmental exposure pathways, public concerns, and measurement capabilities. Chapters 2 through 7 of this report provide detailed summaries of the environmental protection and surveillance programs on ORR. These extensive sampling and monitoring efforts demonstrate DOE's commitment to safety; protecting human health; complying with regulations, standards, DOE orders, and "as low as reasonably achievable" principles; reducing the risks associated with past, present, and future operations; and improving cost-effectiveness.

\section{Compliance with Environmental Regulations}

Federal, state, and local government agencies, including the US Environmental Protection Agency and the State of Tennessee, monitor ORR and enforce compliance with applicable environmental regulations. These agencies issue permits, review compliance reports, participate in joint monitoring programs, inspect facilities and operations, and/or oversee compliance with regulations. Compliance with environmental regulations and DOE orders related to environmental protection provides assurance that on-site processes do not impact the public or the environment adversely.

During 2013, there were only a few instances of noncompliance with regulations, permits, and DOE orders, which were promptly addressed to ensure that no adverse environmental or public health effects resulted. Noncompliances and notifications made to regulatory agencies during the year are summarized below, and detailed information is provided in Chapters $2-5$ of this report.

- A Tennessee Department of Environment and Conservation (TDEC) inspection at the Y-12 Complex identified three alleged violations related to an open satellite waste container, an unlabeled satellite waste container, and unlabeled used oil containers. These issues, which were addressed at the time of the inspection, were of an administrative nature with no potential for environmental insult. 
- A reportable fish kill caused by a potable water line break occurred at the Y-12 Complex in June 2013, and three fish kills, attributed to inadequate dechlorination of cooling water discharges, occurred at ORNL: on July 31, 2013; October 4, 2013; and October 6, 2013.

- There were no releases of hazardous substances exceeding Comprehensive Environmental Response, Compensation, and Liability Act reportable quantities.

Chapter 2 provides a detailed summary of ORR environmental compliance during 2013, and Chapters 3, 4, and 5 discuss each facility's compliance status for the year.

\section{Pollution Prevention and Site Sustainability}

Numerous pollution prevention and sustainability programs across ORR embody efforts to achieve enduring sustainability in facilities, operations, and organizational culture. These programs promote energy and water conservation, building efficiency, sustainable landscaping, green transportation, sustainable acquisition, and waste minimization, which in turn reduce life-cycle costs of programs and projects and reduce risks to the environment. During 2013, ORR contractors were recognized for excellence in pollution prevention and sustainability programs with multiple awards, which are described in Chapters 3, 4, and 5.

\section{Cleanup Operations in 2013}

ORR has played key roles in US defense and energy research. However, past waste disposal practices and unintentional releases have left land and facilities contaminated. These contaminants include radioactive elements, mercury, asbestos, PCBs, and industrial wastes. The DOE Environmental Management (EM) program is responsible for cleaning up these sites, and numerous cleanup projects are under way at the reservation's three main facilities.

In 2013, one of EM's greatest accomplishments in Oak Ridge was the finalization and issuance of the “Oak Ridge Environmental Management Program Plan." This document outlines DOE EM priorities and visions for the next decade and establishes eight goals that direct and focus future operations. Another notable 2013 achievement was the significant progress and success made on American Recovery and Reinvestment Act-funded work. The $\$ 755$ million received in Oak Ridge has provided opportunities to address projects at all sites that reduce risk and environmental liability. Finally, the largest decommissioning and demolition project in the history of the DOE EM program, the K-25 building at ETTP, continued in 2013 and is expected to be completed in 2014. 



\section{Introduction to the Oak Ridge Reservation}

The Oak Ridge Reservation (ORR) is a 13,560 ha $(33,508$-acre) federally owned site located in the counties of Anderson and Roane in eastern Tennessee. ORR is home to two major US Department of Energy (DOE) operating components, the Oak Ridge National Laboratory (ORNL) and the Y-12 National Security Complex (Y-12 Complex). A number of other facilities are located on ORR, including the East Tennessee Technology Park (ETTP), site of a former gaseous diffusion plant that is undergoing environmental cleanup and transition to a private sector business/industrial park; the Oak Ridge Institute for Science and Education (ORISE) South Campus, which includes training facilities, laboratories, and support facilities; a variety of smaller government-owned, contractor-operated facilities involved in environmental cleanup; and the government-owned, government-operated Agent Operations Eastern Command (AOEC) of the National Nuclear Security Administration (NNSA) Office of Secure Transportation (OST).

ORR was established in the early 1940s as part of the Manhattan Project for the purposes of enriching uranium and pioneering methods for producing and separating plutonium. ORR missions are continuing to evolve as it adapts to meet the changing basic and applied research and national security needs of the United States.

Due to differing permit reporting requirements and instrument capabilities, various units of measurement are used in this report. The list of units of measure and conversion factors provided on pages xxvii and xxviii is intended to help readers convert numeric values presented here as needed for specific calculations and comparisons.

\subsection{Background}

The Oak Ridge Reservation Annual Site Environmental Report (ASER) is prepared annually and presents summary environmental data to (1) characterize environmental performance, (2) summarize environmental occurrences reported during the year, (3) confirm compliance with environmental standards and requirements, and (4) highlight significant program activities. The report fulfills the requirement contained in DOE O 231.1B, Environment, Safety and Health Reporting, (DOE 2012) that an integrated annual site environmental report be prepared.

The results summarized in this report are based on data collected before and continuing through 2013. This report is not intended to, nor does it, present the results of all environmental monitoring associated with ORR. Data collected for other site and regulatory purposes, such as environmental restoration/remedial investigation reports, waste management characterization sampling data, and environmental permit compliance data, are presented in other documents that have been prepared in accordance with applicable DOE guidance and/or laws and are referenced here as appropriate. Appendix A contains a glossary of technical terms that may be useful for understanding the terminology used in this report.

Environmental monitoring on ORR consists primarily of two major activities: effluent monitoring and environmental surveillance. Effluent monitoring involves the collection and analysis of samples or measurements of liquid and gaseous effluents at the points of release to the environment; these measurements allow the quantification and official reporting of contaminant levels, assessment of public exposures to radiation and chemicals, and demonstration of compliance with applicable standards and permit requirements. Environmental surveillance consists of direct measurements and collection and analysis of samples taken from the site and its environs exclusive of effluents; these activities provide information on contaminant concentrations in air, water, groundwater, soil, foods, biota, and other media. Environmental surveillance data support determinations regarding environmental compliance and, when 
combined with data from effluent monitoring, support chemical and radiation dose and exposure assessments of the potential effects of ORR operations, if any, on the local environment.

\subsection{History of the Oak Ridge Reservation}

The ORR area was first occupied by Native Americans more than 10,000 years ago, and members of the Overhill Cherokee tribe still lived in the East Tennessee region when European settlers arrived in the late 1700s. These settlers lived on farms or in four small communities called Elza, Robertsville, Scarboro, and Wheat. All but Elza were founded shortly after the Revolutionary War. In the early 1940s about 1,000 families inhabited the area.

In 1942, the area that was to become ORR was selected for use in the Manhattan Project because the Clinch River provided ample supplies of water, nearby Knoxville was a good source of labor, and the Tennessee Valley Authority (TVA) could supply the huge amounts of electricity needed. About 3,000 residents received court orders to vacate within weeks the homes and farms that their families had occupied for generations. The site's wartime name was "Clinton Engineering Works."

The workers' city, named Oak Ridge, was established on the reservation's northern edge. The city grew to a population of 75,000 and was the fifth largest in Tennessee; however, it was not shown on any map. At the Y-12 Complex, south of the city, an electromagnetic separation method was used to separate

${ }^{235} \mathrm{U}$ from natural uranium. A gaseous diffusion plant, later known as K-25, was built on the reservation's western edge. Near the reservation's southwest corner, about $16 \mathrm{~km}$ (10 miles) from the Y-12 Complex, was a third facility, known as X-10 or Clinton Laboratories, where the Graphite Reactor was built. The X-10 facility was a pilot plant for the larger plutonium production facilities built at Hanford, Washington. Two years after World War II ended, Oak Ridge was shifted to civilian control, under the authority of the US Atomic Energy Commission. In 1959, the city was incorporated and a city manager and city council form of government was adopted by the community.

Since that time, the missions of the three major ORR installations have continued to evolve and operations have adapted to meet the changing defense, energy, and research needs of the United States. Their current missions, as well as the missions of several smaller DOE facilities/activities on ORR, are described in Sect. 1.4 of this document.

\subsection{Site Description}

\subsubsection{Location and Population}

ORR lies within the Great Valley of East Tennessee between the Cumberland and Great Smoky Mountains and is bordered by the Clinch River (Fig. 1.1). The Cumberland Mountains are $16 \mathrm{~km}$ (10 miles) to the northwest; the Great Smoky Mountains are $51 \mathrm{~km}$ (31.6 miles) to the southeast. ORR encompasses about 13,560 ha $(33,508$ acres) of mostly contiguous land owned by the federal government and under the management of DOE in Anderson and Roane counties (Fig. 1.2). The population of the 10 -county region surrounding ORR is about 961,000 , with less than $2 \%$ of its labor force employed on ORR. The population estimate for the official nine-county Knoxville Metropolitan Statistical Area is 848,350 . Other municipalities within about $30 \mathrm{~km}$ (18.6 miles) of the reservation include Oliver Springs, Clinton, Lake City, Lenoir City, Farragut, Kingston, and Harriman.

Knoxville, the major metropolitan area nearest Oak Ridge, is located about $40 \mathrm{~km}$ (25 miles) to the east and has a population of about 181,000. Except for the city of Oak Ridge, the land within $8 \mathrm{~km}$ ( 5 miles) of ORR is semirural and is used primarily for residences, small farms, and cattle pasture. Fishing, hunting, boating, water skiing, and swimming are popular recreational activities in the area. 


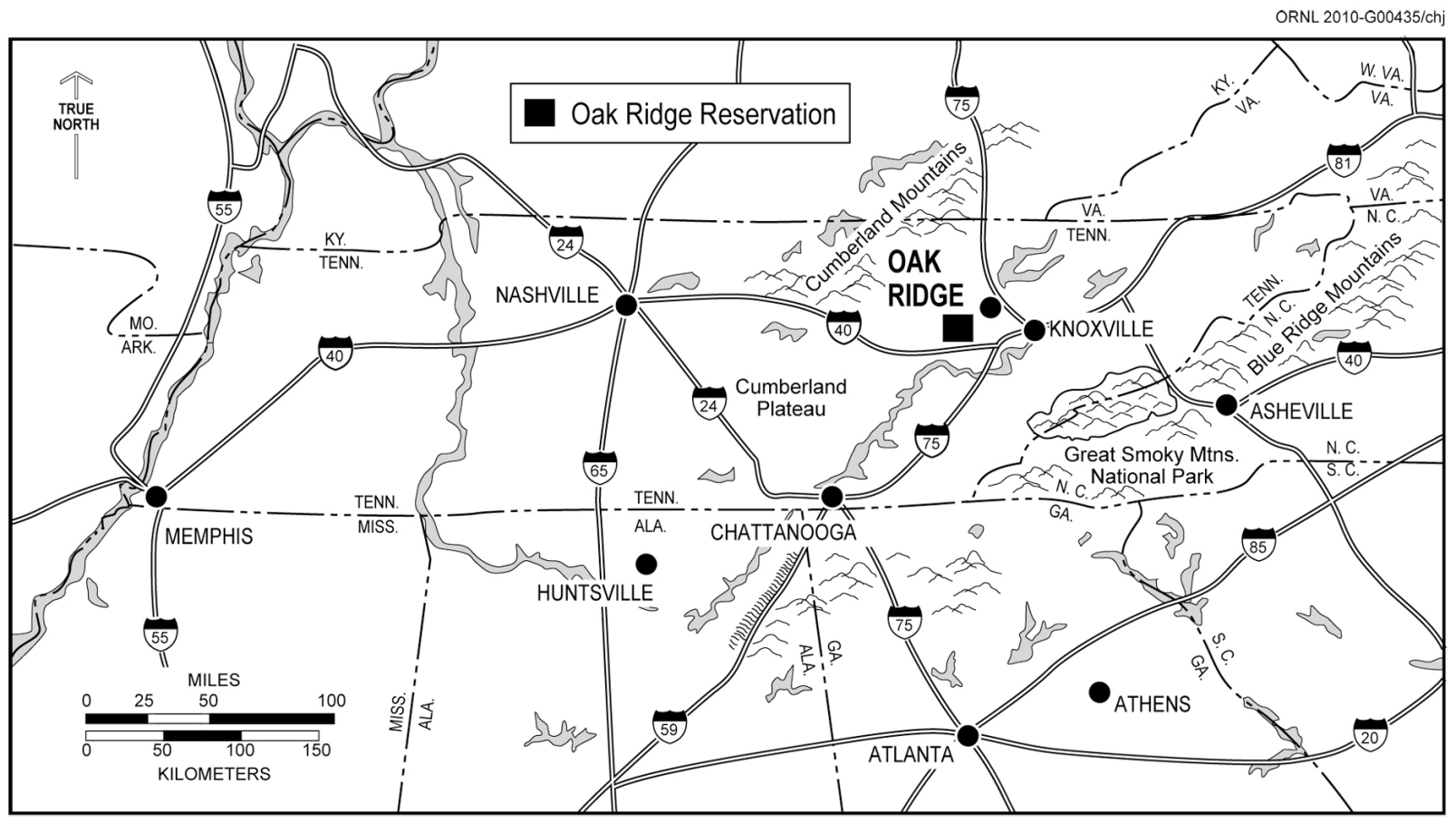

Fig. 1.1. Location of the city of Oak Ridge.

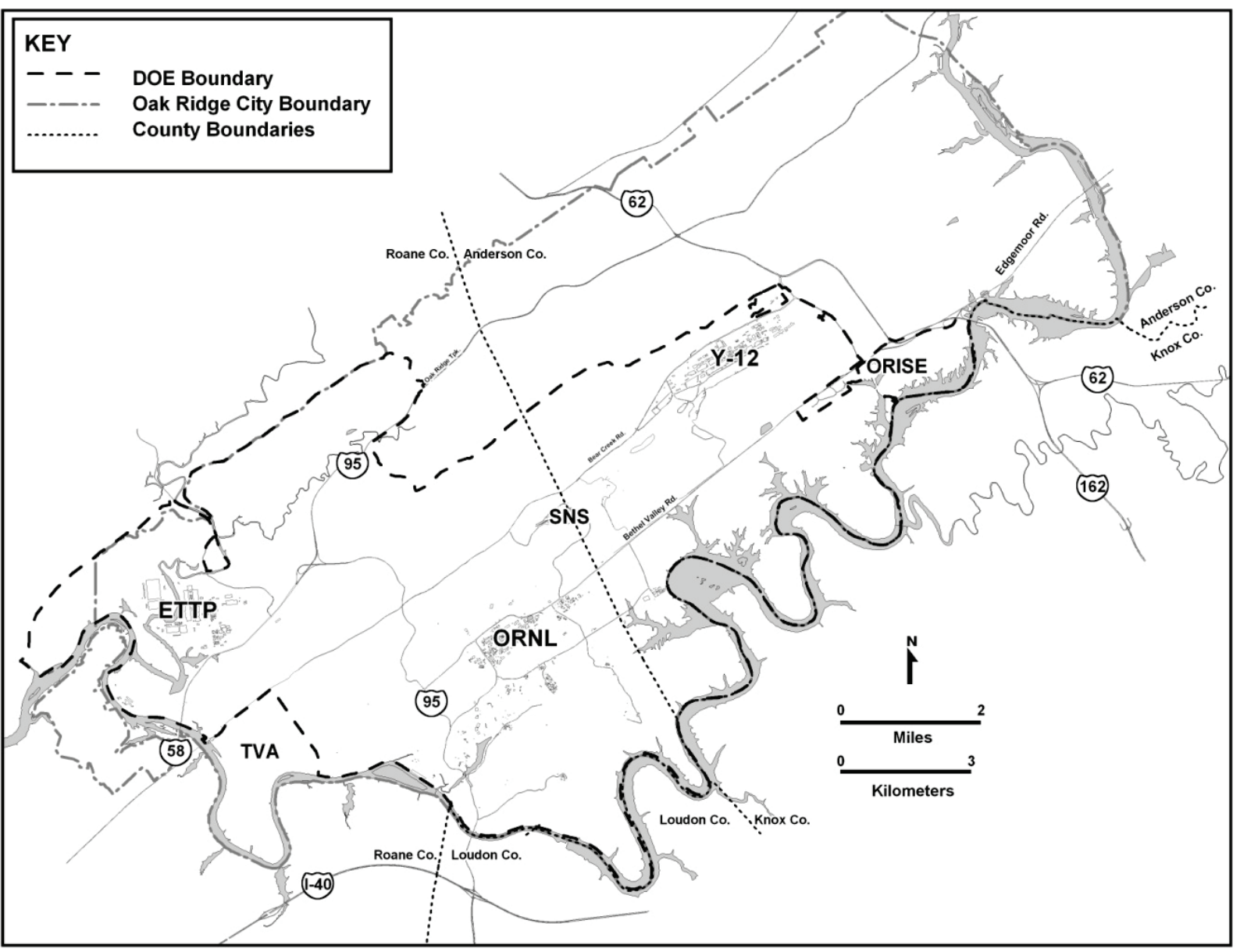

Fig. 1.2. The Oak Ridge Reservation. 


\subsubsection{Climate}

The climate of the Oak Ridge region may be broadly classified as humid subtropical and is characterized by significant temperature changes between summer and winter. The 30-year mean temperature for $1981-2010$ was $14.9^{\circ} \mathrm{C}\left(58.8^{\circ} \mathrm{F}\right)$. The average temperature for the Oak Ridge area during 2013 was $14.8^{\circ} \mathrm{C}\left(58.7^{\circ} \mathrm{F}\right)$. The coldest month is usually January, with temperatures averaging about $3.2^{\circ} \mathrm{C}\left(37.7^{\circ} \mathrm{F}\right)$. During 2013 , January temperatures were above normal at $5.6^{\circ} \mathrm{C}\left(42.0^{\circ} \mathrm{F}\right)$. July tends to be the warmest month, with average temperatures of $25.8^{\circ} \mathrm{C}\left(78.5^{\circ} \mathrm{F}\right)$. However during the $2000 \mathrm{~s}$, August temperatures were slightly warmer than July $\left[25.7^{\circ} \mathrm{C}\left(78.3^{\circ} \mathrm{F}\right)\right.$ vs. $\left.25.4^{\circ} \mathrm{C}\left(77.7^{\circ} \mathrm{F}\right)\right]$. July 2013 temperatures averaged $24.6^{\circ} \mathrm{C}\left(76.2^{\circ} \mathrm{F}\right)$, below the 30 -year average.

Average annual precipitation in the Oak Ridge area for the 30-year period from 1981 to 2010 was $1,293.5 \mathrm{~mm}$ (50.91 in.), including about $21.3 \mathrm{~cm}$ (8.4 in.) of snowfall annually (NOAA 2011). Total precipitation during 2013 [measured at the Oak Ridge National Weather Service meteorological tower (MT)] was 1,712 $\mathrm{mm}$ (67.37 in.), 32\% above the 30-year average. Total 2013 snowfall was $9.4 \mathrm{~cm}$ (3.7 in.), $60 \%$ below the 30 -year average. Monthly summaries of precipitation averages, extremes, and 2013 values are provided in Appendix B, Table B.1.

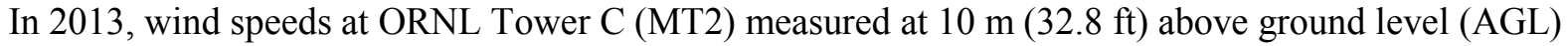
averaged $1.1 \mathrm{~m} / \mathrm{s}(2.5 \mathrm{mph})$. This value increased to about $2.9 \mathrm{~m} / \mathrm{s}(6.4 \mathrm{mph})$ for winds at $100 \mathrm{~m}$ (328 ft) AGL (about the height of local ridgetops). The local ridge-and-valley terrain reduces average wind speeds at valley bottoms, resulting in frequent periods of calm or near calm conditions, particularly during clear early morning hours in weak synoptic weather environments. Wind direction frequencies with respect to 2013 precipitation hours for the ORR towers may be reviewed at http://www.ornl.gov/adm/fo/lp/orrm/page 7.htm.

More detailed information on the climate of the Oak Ridge area is available in Oak Ridge Reservation Physical Characteristics and Natural Resources (Parr and Hughes 2006) and in Appendix B of this document. A detailed analysis of wind patterns for ORR was conducted from 2009 to 2011 and may be reviewed online at http://www.ornl.gov/ das/met/MT/KRB_ORNL.pdf (Birdwell 2011).

\subsubsection{Regional Air Quality}

The US Environmental Protection Agency (EPA) Office of Air Quality Planning and Standards has set National Ambient Air Quality Standards (NAAQS) for key principal pollutants, which are called "criteria" pollutants. These pollutants are sulfur dioxide $\left(\mathrm{SO}_{2}\right)$, carbon monoxide $(\mathrm{CO})$, carbon dioxide $\left(\mathrm{CO}_{2}\right)$, nitrogen dioxide $\left(\mathrm{NO}_{2}\right)$, lead $(\mathrm{Pb})$, ozone $\left(\mathrm{O}_{3}\right)$, particulate matter $(\mathrm{PM})$ with an aerodynamic diameter less than or equal to $10 \mu \mathrm{m}\left(\mathrm{PM}_{10}\right)$, and fine $\mathrm{PM}$ with an aerodynamic diameter less than or equal to $2.5 \mu \mathrm{m}\left(\mathrm{PM}_{2.5}\right)$. EPA evaluates NAAQS based on ambient (outdoor) levels of the criteria pollutants. Areas that satisfy NAAQS are classified as attainment areas, whereas areas that exceed NAAQS for a particular pollutant are classified as nonattainment areas for that pollutant.

ORR is located in Anderson and Roane counties. EPA has designated Anderson County as a basic nonattainment area for the 8-hour (h) $\mathrm{O}_{3}$ standard as part of the larger Knoxville $8 \mathrm{~h}$ basic $\mathrm{O}_{3}$ nonattainment area, which encompasses several counties. In addition, EPA has designated Anderson, Knox, and Blount counties as a nonattainment area for the $\mathrm{PM}_{2.5}$ air quality standard. EPA also designated the portion of Roane County surrounding the Kingston Steam Plant as a nonattainment area for $\mathrm{PM}_{2.5}$. The greater Knoxville and Oak Ridge area is classified as an NAAQS attainment area for all other criteria pollutants for which EPA has made attainment designations.

\subsubsection{Surface Water}

ORR lies within the Valley and Ridge Physiographic Province, which is composed of a series of drainage basins or troughs containing many small streams feeding the Clinch River. Surface water on ORR drains into a tributary or series of tributaries, streams, or creeks within different watersheds. Each of these watersheds drains into the Clinch River that, in turn, flows into the Tennessee River. 
The largest of the drainage basins is Poplar Creek, which receives drainage from a $352 \mathrm{~km}^{2}$ (136-mile ${ }^{2}$ area, including the northwestern sector of ORR. It flows from northeast to southwest, roughly through the center of ETTP, and discharges directly into the Clinch River.

East Fork Poplar Creek (EFPC), which discharges into Poplar Creek east of ETTP, originates within the Y-12 Complex and flows northeast along the south side of the Y-12 Complex. Bear Creek also originates within the Y-12 Complex but flows southwest. Bear Creek is mostly affected by storm water runoff, groundwater infiltration, and tributaries that drain former waste disposal sites in the Bear Creek Valley Burial Grounds Waste Management Area and the current Environmental Management Waste Management Facility (EMWMF).

Both the Bethel Valley and Melton Valley portions of ORNL are in the White Oak Creek drainage basin, which has an area of $16.5 \mathrm{~km}^{2}\left(6.4 \mathrm{mile}^{2}\right)$. White Oak Creek headwaters originate on Chestnut Ridge, north of ORNL, near the Spallation Neutron Source (SNS) site. At the ORNL site, the creek flows west along the southern boundary of the developed area and then flows southwesterly through a gap in Haw Ridge to the western portion of Melton Valley, where it forms a confluence with Melton Branch. The headwaters of Melton Branch originate in Melton Valley east of the High Flux Isotope Reactor (HFIR) complex. It has a drainage basin area of about $3.8 \mathrm{~km}^{2}\left(1.47 \mathrm{mile}^{2}\right)$. The waters of White Oak Creek enter White Oak Lake, which is an impoundment formed by White Oak Dam. Water flowing over White Oak Dam enters the Clinch River after passing through the White Oak Creek embayment area.

\subsubsection{Geological Setting}

ORR is located in the Tennessee portion of the Valley and Ridge Physiographic Province, which is part of the southern Appalachian fold-and-thrust belt. As a result of thrust faulting and differential erosion rates, a series of parallel valleys and ridges have formed that trend southwest-northeast.

Two geologic units on ORR, designated as the Knox Group and the Maynardville Limestone of the Upper Conasauga Group, consisting of dolostone and limestone, respectively, make up the most significant water-bearing hydrostratigraphic units in the Valley and Ridge Province (Zurawski 1978) and on ORR. Being composed of fairly soluble minerals, these bedrock formations are prone to dissolution as slightly acidic rainwater and percolating recharge water come in contact with the mineral surfaces. This dissolution increases fracture apertures and can form caverns and extensive solution conduit networks under some circumstances. This hydrostratigraphic unit is referred to locally as the "Knox Aquifer." A combination of fractures and solution conduits in the aquifer control flow over substantial areas, and large quantities of water may move long distances. Active groundwater flow can occur at substantial depths in the Knox Aquifer [91.5 to $122 \mathrm{~m}$ (300 to $400 \mathrm{ft}$ ) deep]. The Knox Aquifer is the primary source of groundwater for many streams (base flow), and most large springs on ORR receive discharge from the Knox Aquifer. Yields of some wells penetrating larger solution conduits are reported to exceed $3,784 \mathrm{~L} / \mathrm{min}(1,000 \mathrm{gal} / \mathrm{min})$. The high productivity of the Knox Aquifer is attributed to the combination of its abundant and sometimes large solution conduit systems and frequently thick overburden soils that promote recharge and storage of groundwater.

The remaining geologic units on ORR (the Rome Formation, the Conasauga Group below the Maynardville Limestone, and the Chickamauga Group) are composed predominantly of shales, siltstones, and sandstones with a subordinate and locally variable amount of carbonate bedrock. These formations are predominantly composed of insoluble minerals such as clays and quartz that were derived from ancient continental erosion. Groundwater occurs and moves through fractures in those bedrock units. Groundwater availability in such settings is dependent on the abundance and interconnectedness of fractures and the connection of fractures to sources of recharge such as alluvial soils along streams that can provide some sustained infiltration. The shale and sandstone formations are the poorest aquifers in the Valley and Ridge Province (Zurawski 1978). Well yields are generally low in the Rome, Conasauga, and Chickamauga bedrock formations except in very localized areas where carbonate beds may provide greater groundwater storage than adjacent clastic bedrock. Detailed information on ORR groundwater hydrology and flow is available in Oak Ridge Reservation Physical Characteristics and Natural Resources (Parr and Hughes 2006). 


\subsubsection{Natural, Cultural, and Historic Resources}

ORR contains a unique variety of natural, cultural, and historic resources. Ongoing efforts continue to focus on preserving the rich diversity of these resources.

\subsubsection{Wetlands}

About 243 ha (600 acres) of wetlands have been identified on ORR; most are classified as forested palustrine, scrub/shrub, and emergent wetlands. Wetlands occur across ORR at low elevations, primarily in riparian zones of headwater streams and receiving streams and in the Clinch River embayments (Fig. 1.3). Wetlands identified to date range in size from several square meters at small seeps and springs to about 10 ha (25 acres) at White Oak Lake. Surveys of wetland resources presented in Identification and Characterization of Wetlands in the Bear Creek Watershed (Rosensteel and Trettin 1993), Wetland Survey of the X-10 Bethel Valley and Melton Valley Groundwater Operable Units at Oak Ridge National Laboratory, Oak Ridge, Tennessee (Rosensteel 1996), and Wetland Survey of Selected Areas in the Oak Ridge Y-12 Plant Area of Responsibility, Oak Ridge, Tennessee (Rosensteel 1997) serve as references to support wetland assessments for upcoming projects and activities. In addition, wetland maps have been developed for selected areas of ORR in response to project-specific requirements. These are also consulted, and verified by site inspections, when appropriate.

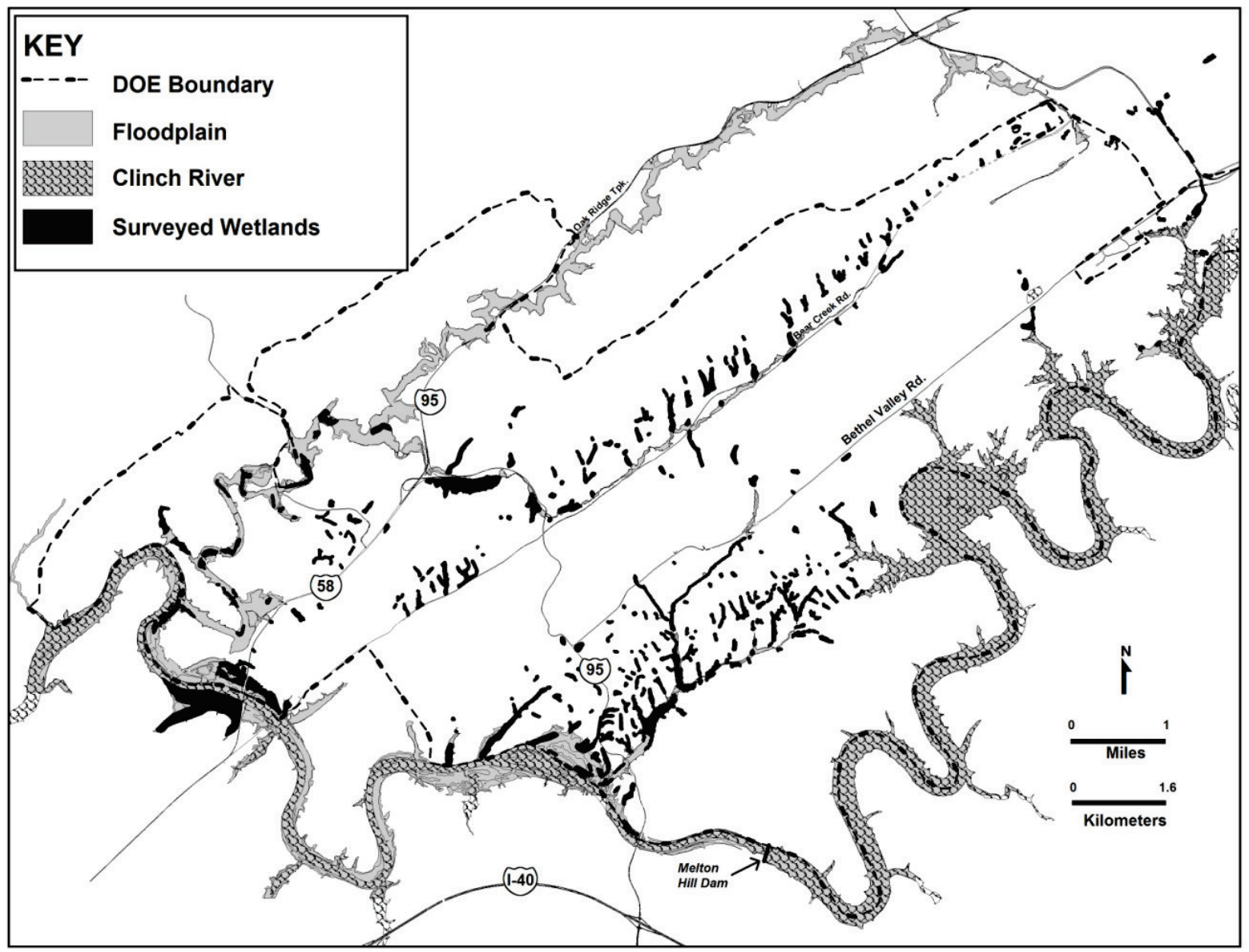

Fig. 1.3. Oak Ridge Reservation wetlands.

Monitoring restored or created mitigation sites for 5 years is a standard requirement of the Tennessee Department of Environment and Conservation's (TDEC's) wetland mitigation Aquatic Resource Alteration Permits (ARAPs) required by Section 401 of the Clean Water Act (CWA). 
In 2013, as part of the Uranium Processing Facility (UPF) project at the Y-12 Complex, work was begun on the Bear Creek Road by-pass phase II and a haul road extension project that modified wetlands on the north side of Bear Creek Road. The work was performed under an approved US Army Corps of Engineers (USACE) Section 404 permit. The wetland mitigation work performed under the permit will result in a more than $3: 1$ net increase in total wetland area when the multiyear project is complete.

\subsubsection{Wildlife/Endangered Species}

Animals listed as species of concern by state, federal, or international organizations and known to be present on the reservation (excluding the Clinch River bordering the reservation) are listed along with their status in Table 1.1. Some of these (e.g., anhinga) have been seen only once or a few times; others (e.g., sharp-shinned hawk, southeastern shrew) are comparatively common and widespread on the reservation.

Table 1.1. Animal species of special concern reported on the Oak Ridge Reservation ${ }^{a}$

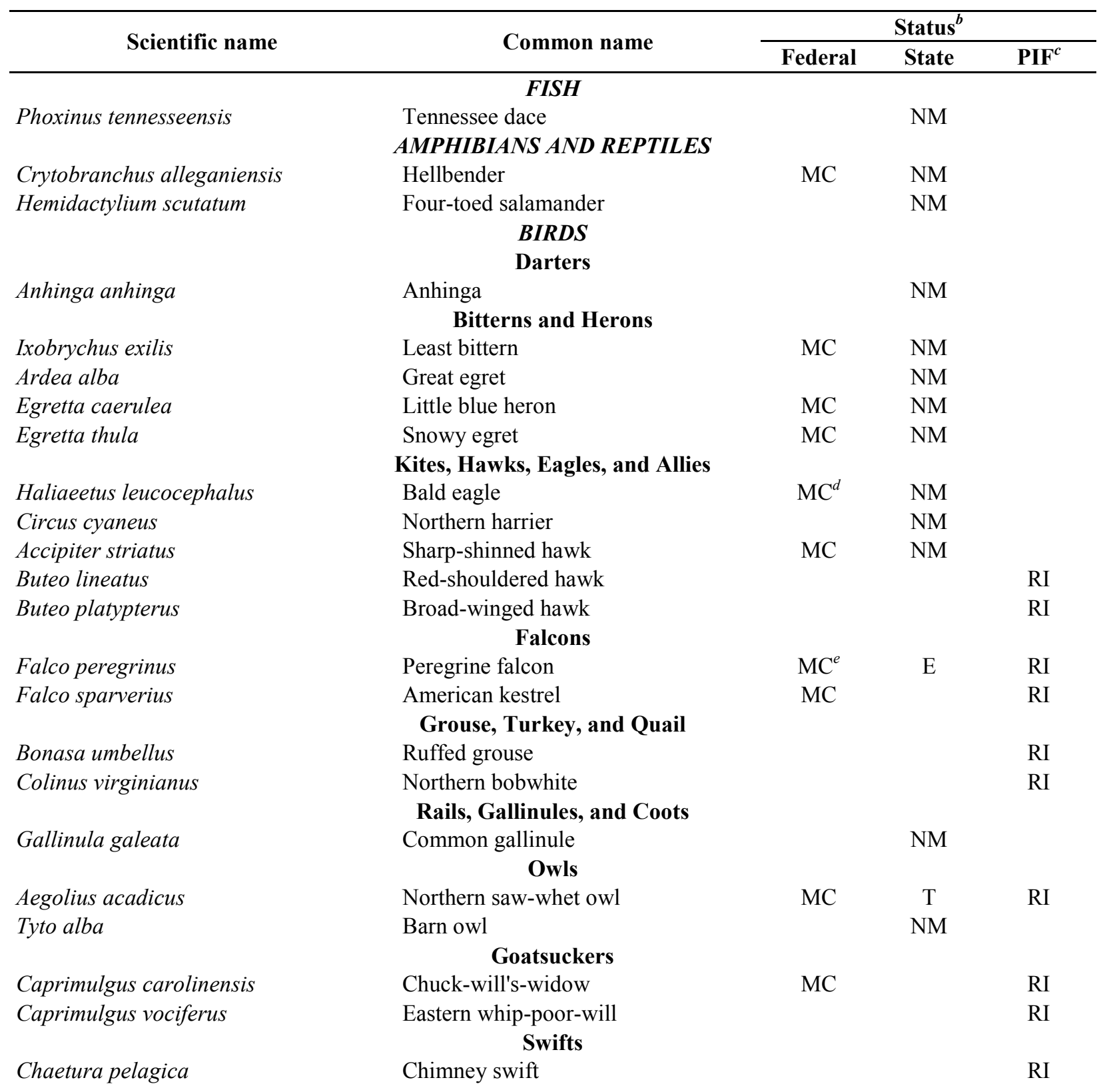


Table 1.1. (continued)

\begin{tabular}{|c|c|c|c|c|}
\hline \multirow{2}{*}{ Scientific name } & \multirow{2}{*}{ Common name } & \multicolumn{3}{|c|}{ Status $^{b}$} \\
\hline & & Federal & State & $\mathbf{P I F}^{c}$ \\
\hline \multicolumn{5}{|c|}{ Kingfishers } \\
\hline Megaceryle alcyon & Belted kingfisher & & & RI \\
\hline \multicolumn{5}{|c|}{ Woodpeckers } \\
\hline Melanerpes erythrocephalus & Red-headed woodpecker & $\mathrm{MC}$ & & RI \\
\hline Sphyrapicus varius & Yellow-bellied sapsucker & $\mathrm{MC}$ & NM & \\
\hline Picoides pubescens & Downy woodpecker & & & RI \\
\hline Colaptes auratus & Northern flicker & & & RI \\
\hline \multicolumn{5}{|c|}{ Tyrant Flycatchers } \\
\hline Contopus cooperi & Olive-sided flycatcher & $\mathrm{MC}$ & NM & RI \\
\hline Contopus virens & Eastern wood-pewee & & & RI \\
\hline Empidonax virescens & Acadian flycatcher & & & RI \\
\hline Empidonax trailii & Willow flycatcher & & & RI \\
\hline \multicolumn{5}{|c|}{ Swallows } \\
\hline Progne subis & Purple martin & & & RI \\
\hline Riparia riparia & Bank swallow & & & RI \\
\hline Hirundo rustica & Barn swallow & & & RI \\
\hline \multicolumn{5}{|c|}{ Titmice and Chickadees } \\
\hline Poecile atricapillus & Black-capped chickadee & $\mathrm{MC}$ & NM & \\
\hline Poecile carolinensis & Carolina chickadee & & & RI \\
\hline \multicolumn{5}{|c|}{ Nuthatches } \\
\hline Sitta pusilla & Brown-headed nuthatch & $\mathrm{MC}$ & & RI \\
\hline \multicolumn{5}{|c|}{ Wrens } \\
\hline Troglodytes troglodytes & Winter wren & & & RI \\
\hline Thryothorus ludovicianus & Carolina wren & & & RI \\
\hline \multicolumn{5}{|c|}{ Kinglets, Gnatcatchers, and Thrushes } \\
\hline Hylocichla mustelina & Wood thrush & MC & & RI \\
\hline & Thrashers and Mockingbirds & & & \\
\hline Toxostoma rufum & Brown thrasher & & & RI \\
\hline \multicolumn{5}{|c|}{ Waxwings } \\
\hline Bombycilla cedrorum & Cedar waxwing & & & RI \\
\hline \multicolumn{5}{|c|}{ Shrikes } \\
\hline Lanius ludovicianus & Loggerhead shrike & MC & NM & RI \\
\hline \multicolumn{5}{|c|}{ Vireos } \\
\hline Vireo flavifrons & Yellow-throated vireo & & & RI \\
\hline Vireo solitarius & Blue-headed vireo & & & RI \\
\hline Vireo griseus & White-eyed vireo & & & RI \\
\hline \multicolumn{5}{|c|}{ Wood Warblers } \\
\hline Vermivora chrysoptera & Golden-winged warbler & $\mathrm{MC}$ & NM & RI \\
\hline Vermivora cyanoptera & Blue-winged warbler & MC & & RI \\
\hline Setophaga cerulea & Cerulean warbler & MC & NM & RI \\
\hline Setophaga discolor & Prairie warbler & $\mathrm{MC}$ & & RI \\
\hline Setophaga dominica & Yellow-throated warbler & & & RI \\
\hline Mniotilta varia & Black-and-white warbler & & & RI \\
\hline Helmitheros vermivorum & Worm-eating warbler & $\mathrm{MC}$ & & RI \\
\hline Parkesia motacilla & Louisiana waterthrush & MC & & RI \\
\hline Protonotaria citrea & Prothonotary warbler & $\mathrm{MC}$ & & RI \\
\hline Geothlypis formosa & Kentucky warbler & $\mathrm{MC}$ & & RI \\
\hline Cardellina canadensis & Canada warbler & $\mathrm{MC}$ & & RI \\
\hline Setophaga citrina & Hooded warbler & & & RI \\
\hline
\end{tabular}


Table 1.1. (continued)

\begin{tabular}{|c|c|c|c|c|}
\hline \multirow{2}{*}{ Scientific name } & \multirow{2}{*}{ Common name } & \multicolumn{3}{|c|}{ Status $^{b}$} \\
\hline & & Federal & State & PIF $^{c}$ \\
\hline Icteria virens & Yellow-breasted chat & & & RI \\
\hline Setophaga pinus & Pine warbler & & & RI \\
\hline Cardellina pusilla & Wilson's warbler & & & RI \\
\hline Setophaga magnolia & Magnolia warbler & & & RI \\
\hline Setophaga fusca & Blackburnian warbler & & & RI \\
\hline Setophaga pennsylvanica & Chestnut-sided warbler & & & RI \\
\hline Setophaga virens & $\begin{array}{c}\text { Black-throated green warbler } \\
\text { Tanagers }\end{array}$ & & & RI \\
\hline Piranga olivacea & Scarlet tanager & & & RI \\
\hline Piranga rubra & Summer tanager & & & RI \\
\hline & Cardinals, Grosbeaks, and Allies & & & \\
\hline Passerina cyanea & $\begin{array}{l}\text { Indigo bunting } \\
\text { Towhees, Sparrows, and Allies }\end{array}$ & & & RI \\
\hline Pipilo erythrophthalmus & Eastern towhee & & & RI \\
\hline Spizella pusilla & Field sparrow & & & RI \\
\hline Ammodramus savannarum & Grasshopper sparrow & & & RI \\
\hline Pooecetes gramineus & Vesper sparrow & & NM & \\
\hline Ammodramus henslowii & Henslow's sparrow & $\mathrm{MC}$ & NM & RI \\
\hline Melospiza Georgiana & Swamp sparrow & & & RI \\
\hline & Blackbirds and Allies & & & \\
\hline Dolichonyx oryzivorus & Bobolink & & & RI \\
\hline Sturnella magna & Eastern meadowlark & & & RI \\
\hline Spinus tristis & $\begin{array}{l}\text { Finches and Allies } \\
\text { American goldfinch } \\
\text { MAMMALS }\end{array}$ & & & RI \\
\hline Myotis grisescens & Gray bat & $\mathrm{E}$ & E & \\
\hline Myotis sodalis & Indiana bat ${ }^{f}$ & $\mathrm{E}$ & $\mathrm{E}$ & \\
\hline Myotis septentrionalis & Northern long-eared bat & $\mathrm{PE}$ & & \\
\hline Sorex longirostris & Southeastern shrew & & NM & \\
\hline Sorex cinereus & Masked shrew & & NM & \\
\hline Zapus hudsonius & Meadow jumping mouse & & NM & \\
\hline
\end{tabular}

${ }^{a}$ Land and surface waters of the Oak Ridge Reservation (ORR) exclusive of the Clinch River, which borders ORR.

${ }^{b}$ Status codes

$\mathrm{E}=$ endangered

$\mathrm{T}=$ threatened

$\mathrm{PE}=$ proposed endangered

$\mathrm{MC}=$ of management concern

$\mathrm{NM}=$ in need of management

$\mathrm{RI}=$ regional importance

${ }^{c}$ Partners in Flight - an international organization devoted to conserving bird populations in the Western Hemisphere.

${ }^{d}$ The bald eagle was federally delisted effective August 8, 2007.

${ }^{e}$ The peregrine falcon was federally delisted effective August 25, 1999.

${ }^{f}$ Single specimen captured in mist net bordering the Clinch River, June 2013.

Birds, fish, and aquatic invertebrates are the most thoroughly surveyed animal groups on ORR. The only federally listed animal species that have been observed on ORR in recent years have both been bats. Gray bats were observed over water bordering ORR (the Clinch River) in 2003 and over a pond on ORR in 2004. Three gray bats were mist-netted outside a cave on ORR in 2006. Several gray bats and one Indiana bat were also captured in mist nets bordering the Clinch River in June-July 2013.Several state-listed bird species, such as the anhinga, olive-sided flycatcher, and little blue heron, are uncommon migrants or visitors to the 
reservation; however, the little blue heron is believed to be increasing in numbers. The cerulean warbler, listed by the state as in need of management, has been recorded during the breeding season; however, this species is not actually known to breed on the reservation. The bald eagle (Fig. 1.4), also listed by the state as in need of management, is increasingly seen at all times of the year. One nest was confirmed on the reservation in 2011, and the pair nested again in 2012 and 2013. A second bald eagle nest was discovered in 2013. Other species, such as the northern harrier, great egret, and yellow-bellied sapsucker, are migrants, winter residents, or casual visitors and are not known to nest on the reservation. The golden-winged warbler, listed by the state as "in need of management," has been sighted once on the reservation. Barn owls have been known to nest on the reservation in the past and are still occasionally seen on the reservation.

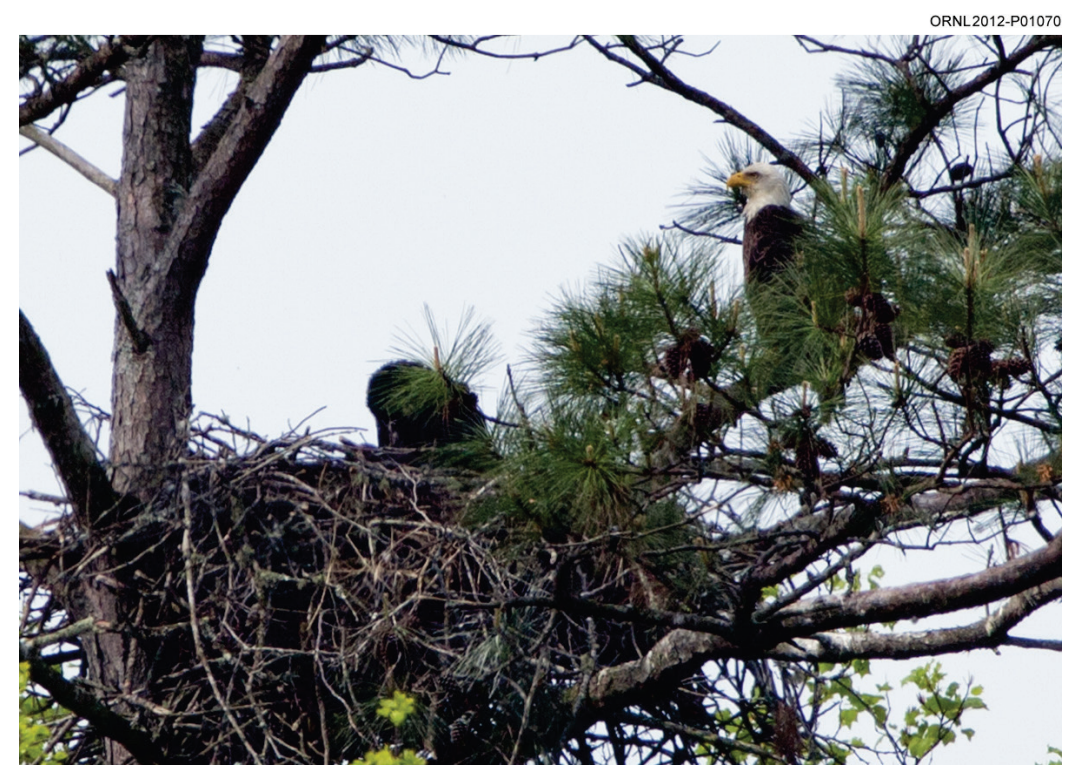

Fig. 1.4. Bald eagle nest on the Oak Ridge Reservation. [Source: Jason Richards, ORNL photographer.]

Some interesting birds uncommon for ORR were recorded in 2013. These included the sora and least bittern (Fig. 1.5). Both sightings were at the K1007 P1 Pond at ETTP, where high quality wildlife habitat has been established as a result of recent restoration efforts. The sora, seen as recently as December 2013, is considered to be a fairly common migrant through Tennessee, but it is not often seen on ORR. The least bittern, heard in July 2012 and then again in May and July of 2013, is an uncommon migrant and summer resident in Tennessee and is on the state "in need of management" list.

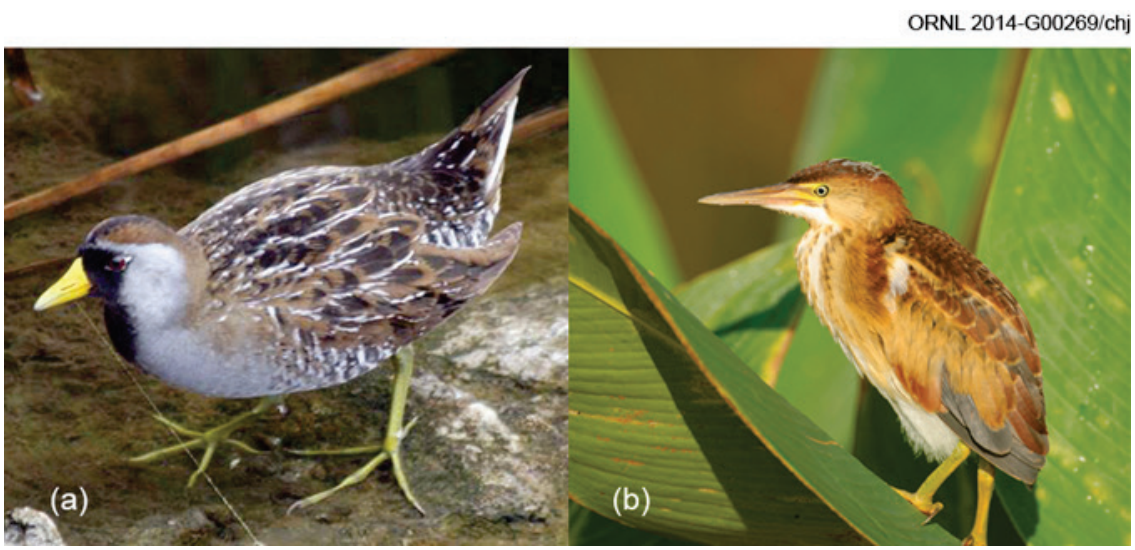

Fig. 1.5. Other interesting birds sighted on the Oak Ridge Reservation during 2013: (a) sora and (b) least bittern. [Source: Neil Giffen.] 
One species of fish, the spotfin chub (Erimonax monachus), which is listed as threatened by both the state and the federal government, has been sighted and collected in the city of Oak Ridge and may be present on ORR. The tangerine darter (Percina aurantiaca), a species listed by the state as "in need of management," has also been recorded in close proximity to ORR. The state-endangered lake sturgeon (Acipenser fulvescens) is known to inhabit the adjacent Clinch River. The Tennessee dace, listed by the state as being "in need of management," has been found in Bear Creek watershed, tributaries to lower East Fork watershed, and Ish Creek and may occur in some sections of Grassy Creek upstream of Scientific Ecology Group, Inc., and International Technology Corporation at Clinch River kilometer (CRK) 23 (e.g., south of west Bear Creek Road near Grassy Creek sampling point 1.9).

\subsubsection{Threatened and Endangered Plants}

Four species currently known to be on ORR, spreading false foxglove, Appalachian bugbane, tall larkspur, and butternut, have been under review for listing at the federal level and were listed under the formerly used "C2" candidate designation. These species are now informally referred to as "special concern" species by the US Fish and Wildlife Service. (Note: Appalachian bugbane is no longer listed by Tennessee and does not have official federal status; therefore, it does not appear in Table 1.2.)

Seventeen plant species occurring on ORR are listed by the state as endangered, threatened, or of special concern. An additional 10 threatened, endangered, or special concern species are known to occur in the area and although currently unconfirmed on ORR have the potential to be present (Table 1.2).

The Tennessee Heritage Program scientific advisory committee met in 2012 to revise the state's Rare Plant List. Those changes are now official. This has reduced the number of state-protected species on ORR by six. The protection of these six species on ORR was a factor in their delisting.

Table 1.2. Vascular plant species listed by state or federal agencies and sighted/reported on or near the Oak Ridge Reservation, 2013

\begin{tabular}{|c|c|c|c|}
\hline Species & Common name & Habitat on ORR & Status code ${ }^{a}$ \\
\hline \multicolumn{4}{|c|}{ Currently known to be or previously reported on ORR } \\
\hline Aureolaria patula & Spreading false foxglove & River bluff & FSC, S \\
\hline Berberis canadensis & American barberry & Rocky bluff & S \\
\hline Bolboschoenus fluviatilis & River bulrush & Wetland & $\mathrm{S}$ \\
\hline Delphinium exaltatum & Tall larkspur & Barrens and woodlands & FSC, E \\
\hline Diervilla lonicera & Northern bush-honeysuckle & Rocky River bluff & $\mathrm{T}$ \\
\hline Draba ramosissima & Branching whitlow-grass & Limestone cliff & $\mathrm{S}$ \\
\hline Elodea nuttallii & Nuttall waterweed & Pond, embayment & $\mathrm{S}$ \\
\hline Eupatorium godfreyanum & Godfrey's thoroughwort & Dry woods edge & $\mathrm{S}$ \\
\hline Fothergilla major & Mountain witch-alder & Woods & $\mathrm{T}$ \\
\hline Helianthus occidentalis & Naked-stem sunflower & Barrens & $\mathrm{S}$ \\
\hline Juglans cinerea & Butternut & Lake shore & $\mathrm{FSC}, \mathrm{T}$ \\
\hline Juncus brachycephalus & Small-head rush & Open wetland & $\mathrm{S}$ \\
\hline Liparis loeselii & Fen orchid & Forested wetland & $\mathrm{E}$ \\
\hline Panax quinquifolius & American ginseng & Rich woods & $\mathrm{S}-\mathrm{CE}$ \\
\hline Platanthera flava var. herbiola & Tuberculed rein-orchid & Forested wetland & $\mathrm{T}$ \\
\hline Spiranthes lucida & Shining ladies'-tresses & Boggy wetland & $\mathrm{T}$ \\
\hline Thuja occidentalis & Northern white cedar & Rocky river bluffs & $\mathrm{S}$ \\
\hline \multicolumn{4}{|c|}{ Rare plants that occur near and could be present on $O R R$} \\
\hline Agalinis auriculata & Earleaf false foxglove & Calcareous barren & FSC, E \\
\hline Allium burdickii or $A$. tricoccom ${ }^{b}$ & Ramps & Moist woods & $\mathrm{S}, \mathrm{CE}$ \\
\hline
\end{tabular}


Table 1.2. (continued)

\begin{tabular}{lllc}
\hline \multicolumn{1}{c}{ Species } & \multicolumn{1}{c}{ Common name } & \multicolumn{1}{c}{ Habitat on ORR } & Status code $^{a}$ \\
\hline Pseudognaphalium helleri & Heller's catfoot & Dry woodland edge & $\mathrm{S}$ \\
Lathyrus palustris & Marsh pea & Moist meadows & $\mathrm{S}$ \\
Liatris cylindracea & Slender blazing star & Calcareous barren & $\mathrm{E}$ \\
Lonicera dioica & Mountain honeysuckle & Rocky river bluff & $\mathrm{S}$ \\
Meehania cordata & Heartleaf meehania & Moist calcareous woods & $\mathrm{T}$ \\
Pedicularis lanceolata & Swamp lousewort & Calcareous wet meadow & $\mathrm{S}$ \\
Pycnanthemum torrei & Torrey's mountain-mint & Calcareous barren edge & $\mathrm{S}$ \\
Solidago ptarmicoides & Prairie goldenrod & Calcareous barren & $\mathrm{E}$ \\
\hline
\end{tabular}

${ }^{a}$ Status codes

$\mathrm{CE}=$ Status due to commercial exploitation.

$\mathrm{E}=$ Endangered in Tennessee.

FSC $=$ Federal Special Concern; formerly designated as C2. See Federal Register, February 28, 1996.

$\mathrm{S}=$ Special concern in Tennessee.

$\mathrm{T}=$ Threatened in Tennessee.

${ }^{b}$ Ramps have been reported near ORR, but there is not sufficient information to determine which of the two species is present or whether the occurrence may have been introduced by planting. Both species of ramps have the same state status.

Abbreviations

ORR $=$ Oak Ridge Reservation

\subsubsection{Historical and Cultural Resources}

Efforts continue to preserve ORR's rich prehistoric and historic cultural resources. The reservation contains more than 45 known prehistoric sites (primarily burial mounds and archeological evidence of former structures), more than 250 historic pre-World War II structures, 32 cemeteries, and several historically significant Manhattan Project-era structures. Seven historic ORR properties are individually listed in the National Register of Historic Places (NRHP):

- Freels Bend Cabin,

- Graphite Reactor,

- New Bethel Baptist Church and Cemetery,

- Oak Ridge Turnpike Checking Station,

- George Jones Memorial Baptist Church and Cemetery,

- Bear Creek (Scarboro) Road Checking Station, and

- Bethel Valley Road Checking Station.

Although not yet listed in the NRHP, an area known as the Wheat Community African Burial Grounds was dedicated in June 2000, and a memorial monument was erected.

The DOE Oak Ridge Office (ORO) cultural resource management plan (Souza et al. 2001) was developed to identify, assess, and document historic and cultural resources on ORR and establish a management strategy.

A memorandum of agreement (MOA) for the interpretation of historical properties at ETTP was signed in 2012 by DOE ORO, the State Historic Preservation Officer, the Advisory Council on Historic Preservation (ACHP), the City of Oak Ridge, and the East Tennessee Preservation Alliance. The MOA is being implemented through planning for a museum that will highlight the historic aspects of the ETTP and of the communities that were displaced during the construction of the site. Details are provided in Chapter 3, Section 3.3.4.

A sitewide programmatic agreement among DOE ORO, NNSA, Tennessee State Historic Preservation Office (SHPO), and ACHP concerning management of historical and cultural properties at the Y-12 Complex has been enforced since its approval on August 25, 2003. 
A sitewide programmatic agreement among DOE ORO, SHPO, and ACHP concerning management of historical and cultural properties at ORNL has been enforced since its approval on February, 23, 2005.

\subsection{Oak Ridge Sites}

\subsubsection{Oak Ridge National Laboratory}

ORNL is the largest science and energy national laboratory in the DOE system (Fig. 1.6). ORNL's scientific programs focus on materials, neutron science, energy, high-performance computing, systems biology, and national security. The laboratory is home to several of the world's top supercomputers and is a leading neutron science and nuclear energy research facility that includes SNS and HFIR. ORNL hosts a DOE leadership computing facility-home of the Titan supercomputer-one of DOE's nanoscience centers, the Center for Nanophase Materials Sciences; one of DOE's energy research centers, the BioEnergy Science Center; and a DOE innovation hub, the Consortium for Advanced Simulation of Light-Water Reactors. UT-Battelle also manages the US ITER project for DOE.

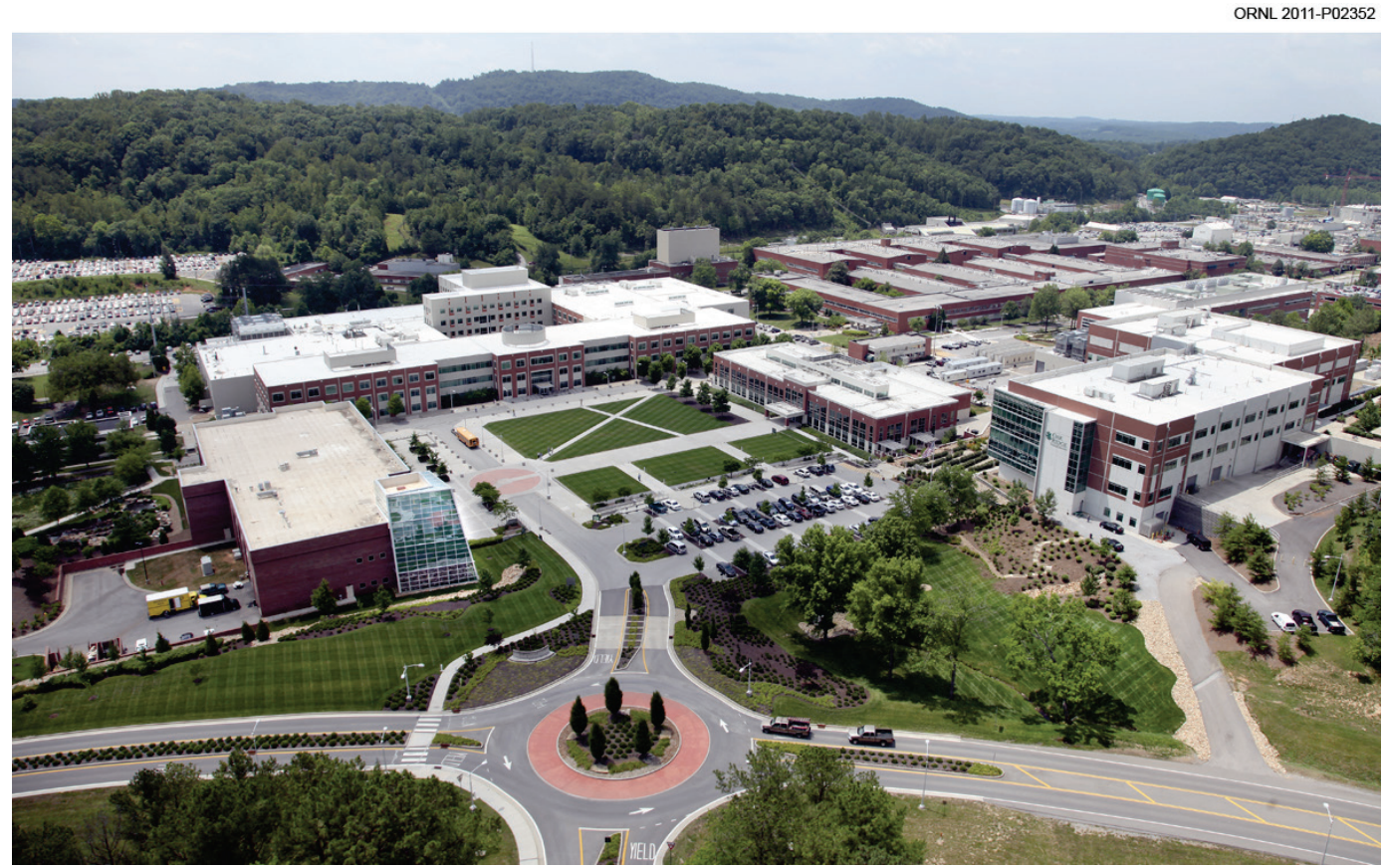

Fig. 1.6. The Oak Ridge National Laboratory.

Managed by UT-Battelle, LLC, a partnership of the University of Tennessee and Battelle Memorial Institute, ORNL was established in 1943 to support the Manhattan Project. From an early focus on chemical technology and reactor development, ORNL's research and development (R\&D) portfolio broadened to include programs supporting DOE missions in scientific discovery and innovation, clean energy, and nuclear security.

There are about 4,400 workers at ORNL and the annual budget exceeds $\$ 1.6$ billion. The laboratory's extensive capabilities for scientific discovery and innovation are applied to the delivery of mission outcomes for DOE and other sponsors.

The Transuranic Waste Processing Center (TWPC) is located on a tract of land about 10.5 ha (26 acres) in size in the Melton Valley area of ORNL about $120 \mathrm{ft}$ west of the existing Melton Valley Storage Tanks. TWPC is managed by Wastren Advantage, Inc. (WAI), for DOE. TWPC's mission is to receive transuranic (TRU) waste from ORNL for processing, treatment, repackaging, and shipment to designated facilities for final disposal. Processed TRU waste is shipped to the Waste Isolation Pilot Plant (WIPP) for disposal. Waste that is determined to be non-TRU (e.g., low-level radioactive waste, mixed low-level waste) is shipped to the Nevada National Security Site (NNSS) or another approved facility. 
Isotek Systems LLC (Isotek) manages activities at ORNL's Building 3019 complex for DOE and is responsible for activities associated with processing, down-blending, and packaging the DOE inventory of ${ }^{233} \mathrm{U}$ stored in the Building 3019 complex.

URS | CH2M Oak Ridge LLC (UCOR) is the DOE ORR "cleanup contractor." The scope of UCOR activities at ORNL includes long-term surveillance, maintenance, and management of inactive waste disposal sites, structures, and buildings such as former reactors and isotope production facilities. Other activities include groundwater monitoring, TRU waste storage, and operation of the liquid low-level and process waste systems and the off-gas collection and treatment system.

About 5 ha (12 acres) in the central portion of ORNL has been leased to Halcyon, LLC, a subsidiary of the Community Reuse Organization of East Tennessee (CROET), for development into the Oak Ridge Science and Technology Park (ORSTP). ORSTP provides space for private companies doing research at ORNL, partner universities, start-up companies built around ORNL technologies, and ORNL contractors to conduct business within a short distance of ORNL researchers and DOE user facilities such as SNS, the Center for Nanophase Materials Sciences, and HFIR. Construction of the first ORSTP facility, Pro2Serve's 115,000 $\mathrm{ft}^{2}$ National Security Engineering Center, was completed in 2009, and the company is now well-established in the building. In addition, the former Building 2033, also leased to Halcyon, LLC, is now known as the Halcyon Commercialization Center (HCC) and continues to attract tenants. HCC's largest tenant is Roane State Community College, which is offering job training classes on-site in the areas of carbon fiber manufacturing and solar energy technology. Other HCC tenants include a construction management firm and a carbon fiber manufacturer that is partnering with ORNL for materials research. There may be potential to expand ORSTP as more environmental cleanup in ORNL's central campus is completed.

As of the date of this report, no construction was occurring within ORSTP.

\subsubsection{The Y-12 National Security Complex}

The original Y-12 Complex was constructed as part of the World War II Manhattan Project and began operations in November 1943. The first site mission was the separation of ${ }^{235} \mathrm{U}$ from natural uranium by an electromagnetic separation process. At its peak in 1945, more than 22,000 workers were employed at the site.

Today, as part of the NNSA Nuclear Security Enterprise, the Y-12 Complex (Fig. 1.7) serves as the nation's only source of enriched uranium nuclear weapons components and provides enriched uranium for the US Navy. The Y-12 Complex is a leader in materials science and precision manufacturing and serves as the main storage facility for enriched uranium. The Y-12 Complex also supports efforts to reduce the risk of nuclear proliferation and performs complementary work for other government agencies. Since November 2000 Babcock \& Wilcox Technical Services Y-12, LLC (B\&W Y-12; formerly called BWXT Y-12), a partnership of Babcock and Wilcox Company and Bechtel National Inc., has served as the management and operations contractor for the Y-12 Complex. 


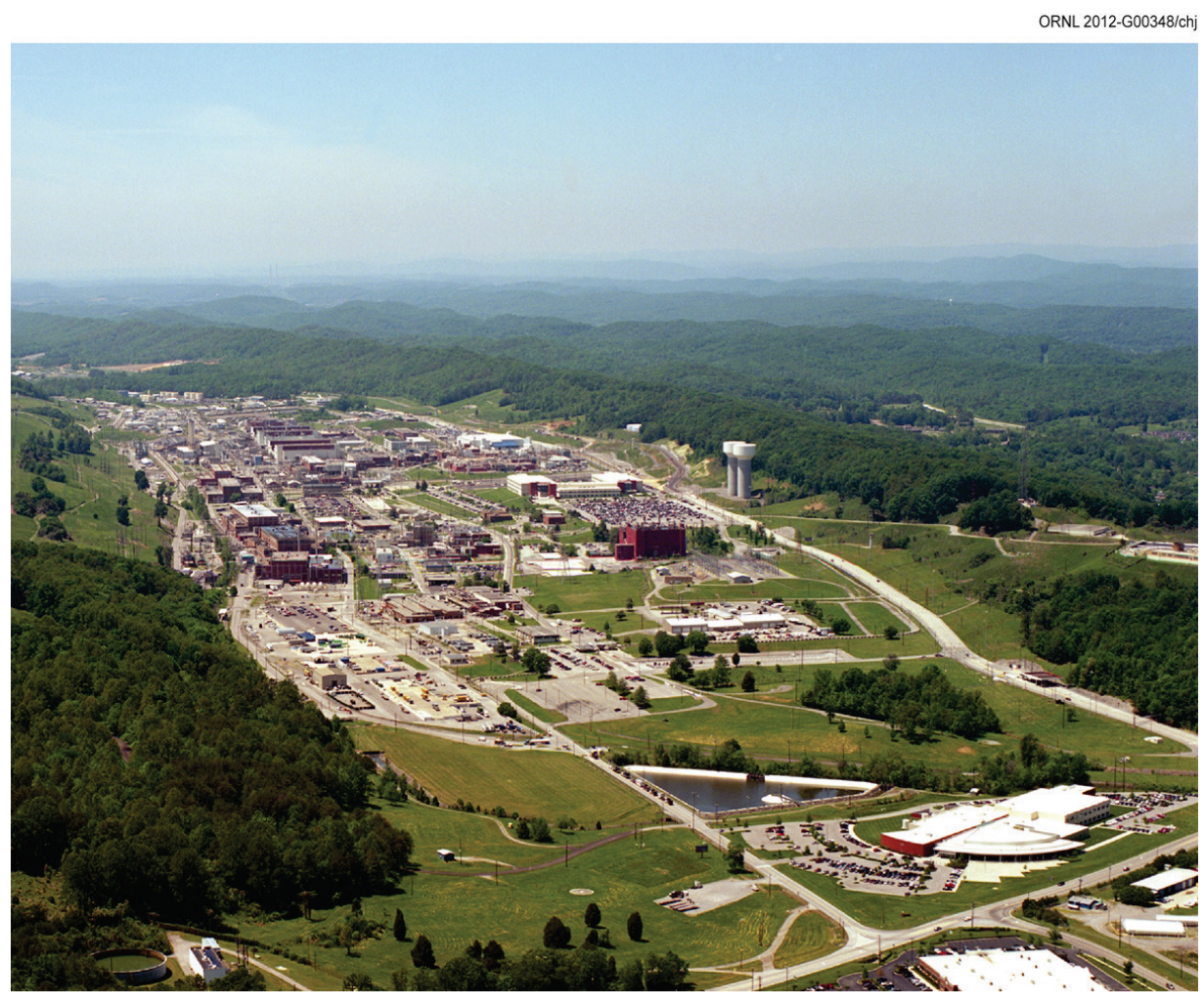

Fig. 1.7. Y-12 National Security Complex.

\subsubsection{East Tennessee Technology Park}

What is now known as ETTP (Fig. 1.8) was originally named the K-25 Site, where the nation's first gaseous diffusion plant for enriching uranium, as part of the Manhattan Project, was located.

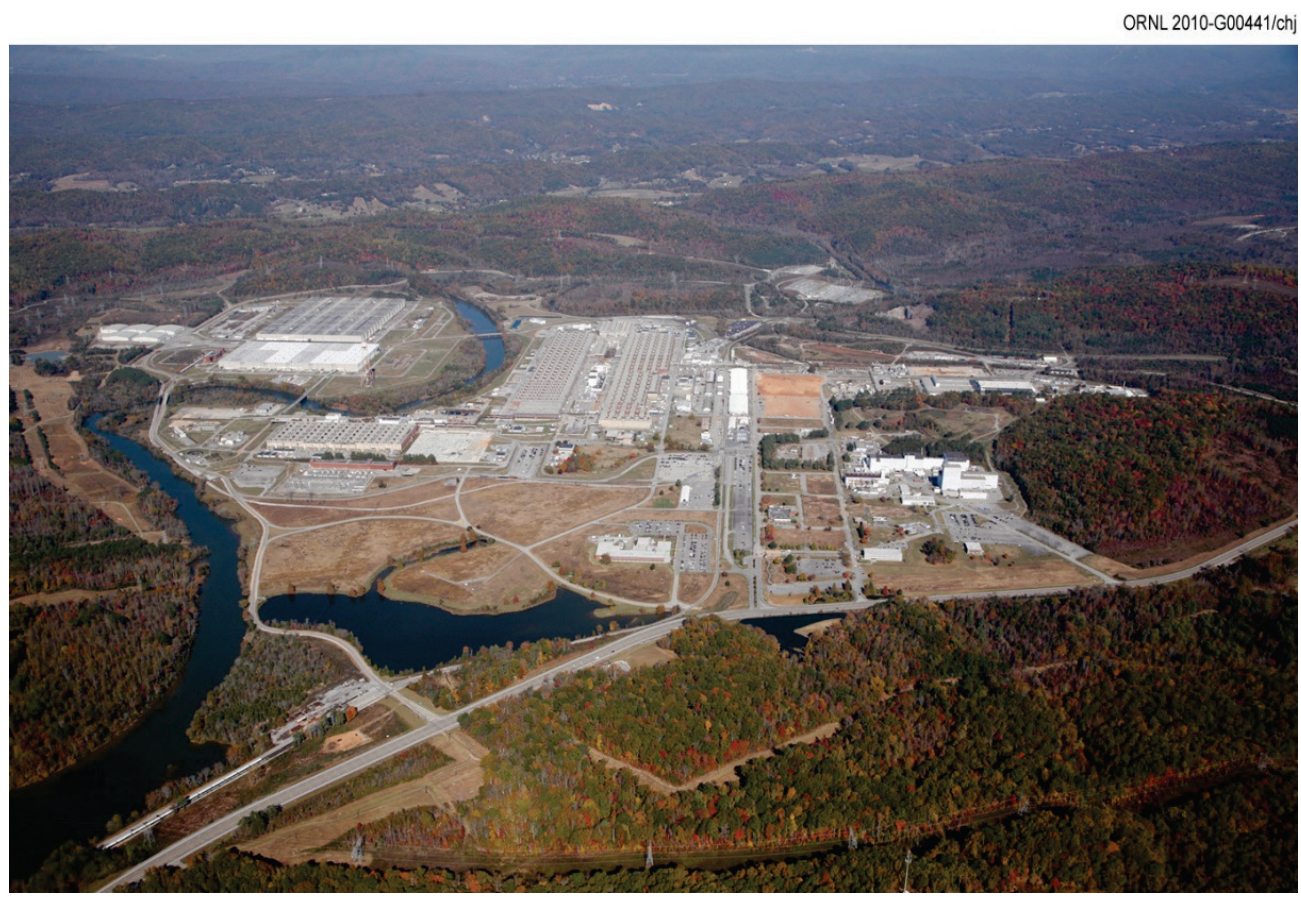

Fig. 1.8. East Tennessee Technology Park. 
In the postwar years, additional uranium enrichment facilities were built adjacent to K-25, forming a complex officially known as the Oak Ridge Gaseous Diffusion Plant. Uranium enrichment operations at the site ceased in 1987, and restoration and decontamination and decommissioning (D\&D) activities began soon after in preparation for ultimate conversion of the site to a private-sector industrial park to be called the Heritage Center. Reindustrialization of the site began in 1996 when it was renamed the East Tennessee Technology Park. Restoration of the environment, D\&D of facilities, disposition of wastes, and reindustrialization are the major activities at the site. During 2013, ETTP landlord contractor functions and the majority of the ETTP cleanup program actions were managed by UCOR.

\subsubsection{Environmental Management Waste Management Facility}

EMWMF is located in eastern Bear Creek Valley near the Y-12 Complex and is managed by UCOR. EMWMF was built for disposal of waste resulting from CERCLA cleanup actions on ORR. The original design was for the construction, operation, and closure of a projected 1.3 million $\mathrm{m}^{3}\left(1.7{\left.\text { million } \mathrm{yd}^{3}\right)}^{3}\right.$ disposal facility. The approved capacity was subsequently increased to 1.8 million $\mathrm{m}^{3}\left(2.4\right.$ million $\left.\mathrm{yd}^{3}\right)$ to maximize use of the footprint designated in a 1999 record of decision (ROD). The facility currently consists of six disposal cells.

EMWMF is an engineered landfill that accepts low-level, mixed low-level, and hazardous wastes from DOE ORR sites that meet specific waste acceptance criteria developed in accordance with agreements with state and federal regulators. Waste types that qualify for disposal include soil, dried sludge and sediment, solidified waste, stabilized waste, building debris, scrap equipment, and secondary waste such as personal protective equipment, all of which must meet land disposal restrictions. In addition to the solid waste disposal facility, EMWMF operates a leachate collection system. The leachate is treated at the ORNL Liquids and Gaseous Treatment Facility, which is operated by UCOR.

\subsubsection{Oak Ridge Environmental Research Park}

In 1980, DOE established the Oak Ridge Environmental Research Park (Fig. 1.9). The research park serves as an outdoor laboratory to evaluate the environmental consequences of energy use and development and the strategies to mitigate those effects. It contains large blocks of forest and diverse communities of vegetation that offer unparalleled resources for ecosystem-level and large-scale research. Major national and international collaborative research initiatives use it to address issues such as multiple stress interactions, biodiversity, sustainable development, tropospheric air quality, global climate change, innovative power conductors, solar radiation monitoring, ecological recovery, and monitoring and remediation.

Field sites at the research park provide maintenance and support facilities that permit sophisticated and well-instrumented environmental experiments. These facilities include elaborate monitoring systems that enable users to precisely and accurately measure environmental factors for extended periods of time. Because the park is under the jurisdiction of the federal government, public access is restricted and experimental sites and associated equipment are, therefore, not disturbed.

National recognition of the value of the research park has led to its use as a component of both regional- and continental-scale research projects. Various research park sites offer opportunities for aquatic and terrestrial ecosystem analyses of topics such as biogeochemical cycling of pollutants resulting from energy production, landscape alterations, ecosystem restoration, wetland mitigation, and forest and wildlife management. 


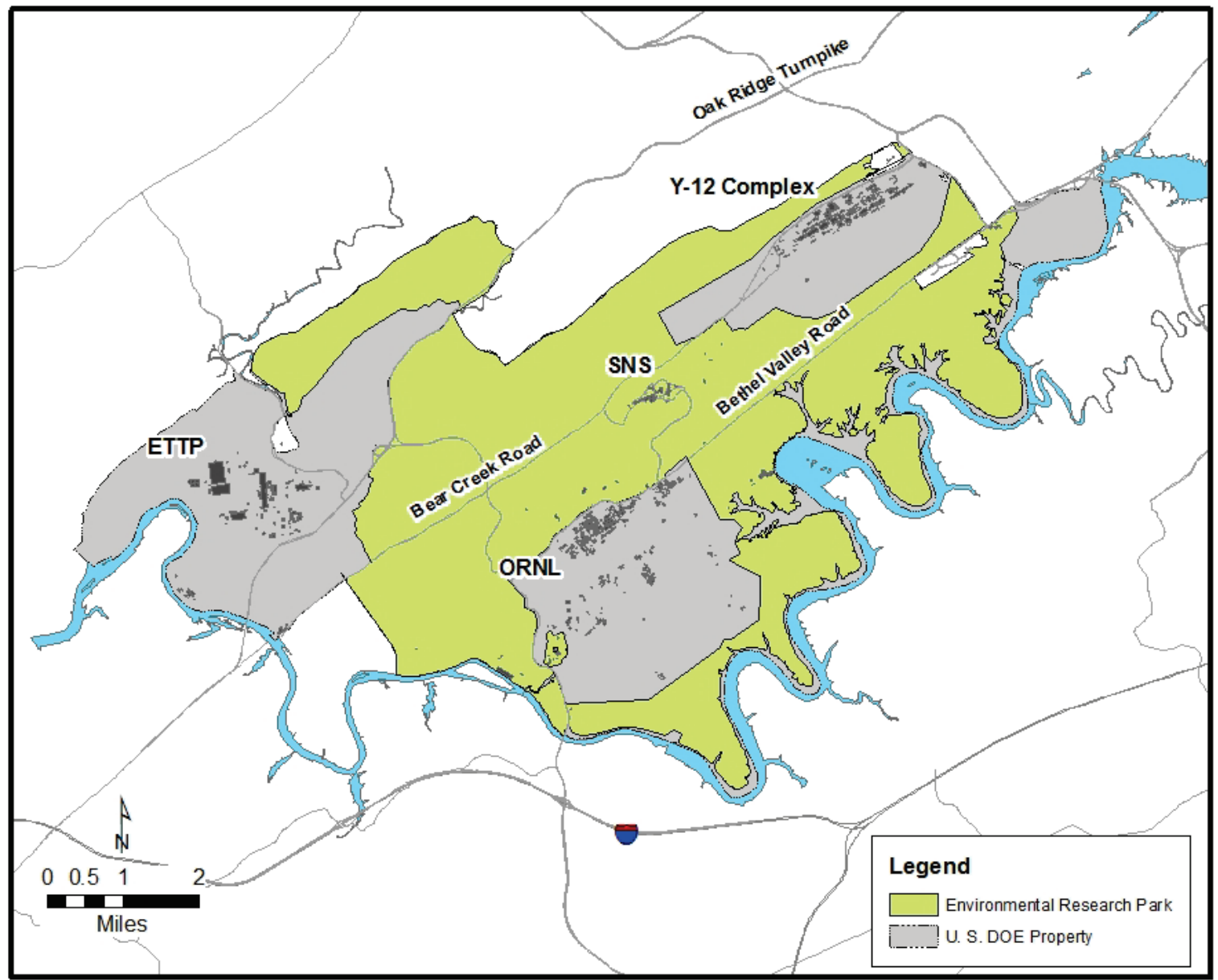

Fig. 1.9. The Oak Ridge Environmental Research Park.

\subsubsection{Oak Ridge Institute for Science and Education}

ORISE is a DOE institute managed by Oak Ridge Associated Universities (ORAU). ORISE addresses national needs in assessing and analyzing environmental and health effects of radiation, beryllium, and other hazardous materials; developing and operating medical and national security radiation emergency management and response capabilities; and managing education programs to help ensure a robust supply of scientists, engineers, and technicians to meet future science and technology needs. ORISE creates opportunities for collaboration through partnerships with other DOE facilities, federal agencies, academia, and industry in a manner consistent with DOE objectives and the ORISE mission.

ORISE is located on an area on the southeastern border of ORR that from the late 1940s to the mid1980s was part of an agricultural experiment station owned by the federal government and, until 1981, operated by the University of Tennessee. The site houses offices, laboratories, and storage areas for the ORISE program offices and support departments.

\subsubsection{The National Nuclear Security Administration Office of Secure Transportation, Agent Operations Eastern Command}

Since 1947, DOE and its predecessor agencies have moved nuclear weapons, weapons components, special nuclear materials (SNMs), and other important national security assets by commercial and government transportation modes. In the late 1960s, worldwide terrorism and acts of violence prompted a review of procedures for safeguarding these materials. As a result, a comprehensive new series of regulations and equipment was developed to enhance the safety and security of these materials in transit. Thus, modified and redesigned transport equipment was created to incorporate features that more 
effectively enhance self-protection and that deny unauthorized access to the materials. Also during this time, the use of commercial transportation systems was abandoned, and a totally federal operation was implemented. The organization within DOE NNSA responsible for this mission is OST.

The NNSA OST AOEC Secure Transportation Center and Training Facility is located on ORR. NNSA OST AOEC is situated on about 485 ha (1,198 acres) of ORR and operates under a user permit agreement with DOE ORO. NNSA OST AOEC implements its assigned mission transportation operations, maintains applicable fleet and escort vehicles, and continues extensive training activities for its federal agents.

\subsection{References}

Birdwell, Kevin Ray. 2011. Wind Regimes in Complex Terrain of the Great Valley of Eastern Tennessee. $\mathrm{PhD}$ dissertation, University of Tennessee, May 2011.

DOE. 2012. Environment, Safety and Health Reporting. DOE O 231.1B. Approved: 06-27-11. US Department of Energy, Washington, DC.

NOAA. 2011. Annual 2011 Local Climatological Data Report for Oak Ridge, Tennessee (Site KOQT). Published by the National Climatic Data Center, Asheville, North Carolina.

Parr, P. D., and J. F. Hughes. 2006. Oak Ridge Reservation Physical Characteristics and Natural Resources. ORNL/TM-2006/110, Oak Ridge National Laboratory, Oak Ridge, Tennessee.

Rosensteel, B. A. 1996. Wetland Survey of the X-10 Bethel Valley and Melton Valley Groundwater Operable Units at Oak Ridge National Laboratory, Oak Ridge, Tennessee. ORNL/ER-350, Oak Ridge National Laboratory, Oak Ridge, Tennessee.

Rosensteel, B. A. 1997. Wetland Survey of Selected Areas in the Oak Ridge Y-12 Plant Area of Responsibility, Oak Ridge, Tennessee. Y/ER-279, Y-12 Plant, Oak Ridge, Tennessee.

Rosensteel, Barbara A., and Carl C. Trettin. 1993. Identification and Characterization of Wetlands in the Bear Creek Watershed. Y/TS-1016, Oak Ridge National Laboratory, Oak Ridge, Tennessee.

Souza, Peter A., Glyn D. DuVall, and Melisa J. Hart. 2001. Cultural Resource Management Plan, DOE Oak Ridge Reservation, Anderson and Roane Counties, Tennessee. DOE/ORO/2085. US Department of Energy, Washington, DC.

Zurawski, A. 1978. Summary Appraisals of the Nation's Ground-Water Resources-Tennessee Region. US Geological Survey Professional Paper 813-L. 


\section{Compliance Summary and Community Involvement}

DOE operations on ORR are required to be in conformance with environmental standards established by a number of federal and state statutes and regulations, executive orders (EOs), DOE orders, contract-based standards, and compliance and settlement agreements. Principal among the regulating agencies are EPA and TDEC. These agencies issue permits, review compliance reports, participate in joint monitoring programs, inspect facilities and operations, and oversee compliance with applicable regulations.

When environmental concerns or problems are identified during routine operations or during ongoing self-assessments of compliance status, the issues are typically discussed with the regulatory agencies. The following sections summarize the major environmental statutes and 2013 status for DOE operations on ORR. Several facilities at ETTP and ORSTP sites have been leased to private entities over the past several years through the DOE Reindustrialization Program. The compliance status of these lessee operations is not discussed in this report.

Because of different permit reporting requirements and instrument capabilities, various units of measure are used in this report. The list of units of measure and conversion factors provided on pages xxvii and xxviii is intended to help readers convert numeric values presented in this document as needed for specific calculations and comparisons.

\subsection{Laws and Regulations}

Table 2.1 summarizes the principal environmental standards applicable to DOE activities on the reservation, the 2013 status, and references to the report sections that provide more detailed information.

\subsection{External Oversight and Assessments}

Inspections of ORR environmental activities by regulatory agencies were conducted during 2013 and are summarized in Table 2.2. This table does not include internal DOE or DOE contractor assessments, audits, or evaluations.

The State of Tennessee also conducts a program of independent monitoring and oversight of DOE activities on ORR through the Tennessee Oversight Agreement (TOA). TOA is a voluntary agreement between DOE and the State of Tennessee and is designed to assure the citizens of Tennessee that their health, safety, and environment are being protected through existing programs and substantial new commitments by DOE. More information on TOA and reporting of monitoring conducted under TOA is available at http://www.state.tn.us/environment/remediation_energy-oversight.shtml. 
Table 2.1. Applicable environmental laws/regulations and 2013 status

\begin{tabular}{|c|c|c|}
\hline Regulatory program description & 2013 status & Report sections \\
\hline $\begin{array}{l}\text { CAA and Tennessee environmental conservation } \\
\text { laws regulate the release of air pollutants through } \\
\text { permits and air quality limits. Emissions of } \\
\text { airborne radionuclides are regulated by EPA via } \\
\text { NESHAPs authorizations. Greenhouse gas } \\
\text { emissions inventory tracking and reporting are } \\
\text { regulated by EPA. }\end{array}$ & $\begin{array}{l}\text { In 2013, all activities on ORR were conducted in accordance with CAA } \\
\text { requirements. }\end{array}$ & $\begin{array}{l}3.3 .5 \\
4.3 .3 \\
5.3 .3\end{array}$ \\
\hline $\begin{array}{l}\text { CERCLA provides the regulatory framework for } \\
\text { remediation of releases of hazardous substances } \\
\text { and of inactive hazardous waste disposal sites. }\end{array}$ & $\begin{array}{l}\text { ORR has been on the EPA NPL since 1989. The ORR FFA, initiated in } 1992 \\
\text { among EPA, TDEC, and DOE, establishes the framework and schedule for } \\
\text { developing, implementing, and monitoring remedial actions on ORR. } \\
\text { No NOVs were issued for CERCLA-related ORR actions during } 2013 \text {. }\end{array}$ & $\begin{array}{l}3.3 .11 \\
4.3 .7 \\
5.3 .8\end{array}$ \\
\hline $\begin{array}{l}\text { CWA seeks to protect and improve surface water } \\
\text { quality by establishing standards and a system of } \\
\text { permits. Wastewater discharges are regulated by } \\
\text { NPDES permits issued by TDEC. }\end{array}$ & $\begin{array}{l}\text { Discharges to surface water at each of the three major ORR sites are governed by } \\
\text { NPDES permits. A compliance rate greater than } 99 \% \text { was achieved by all three } \\
\text { major ORR sites in 2013. Discharges to surface water at ETTP are governed by } \\
\text { NPDES permits. A compliance rate of } 100 \% \text { was achieved at ETTP in } 2013 \text {. }\end{array}$ & $\begin{array}{l}3.3 .6 \\
4.3 .4 \\
5.3 .4\end{array}$ \\
\hline $\begin{array}{l}\text { EISA } \S 438 \text { establishes requirements for federal } \\
\text { agencies to reduce storm water runoff from } \\
\text { development projects to protect water resources. }\end{array}$ & $\begin{array}{l}\text { To comply with EISA a variety of storm water management techniques, referred to as } \\
\text { GI or LID practices, have been implemented on ORR. The site sustainability plans } \\
\text { and associated reporting provide data on sustainability projects and support EISA } \\
\S 438 \text { compliance. }\end{array}$ & $\begin{array}{c}4.2 .6 .8 \\
5.2 \cdot 1.4 .2\end{array}$ \\
\hline $\begin{array}{l}\text { EPCRA, also referred to as SARA Title III, requires } \\
\text { reporting emergency planning information, hazardous } \\
\text { chemical inventories, and environmental releases of } \\
\text { certain toxic chemicals to federal, state, and local } \\
\text { authorities. }\end{array}$ & $\begin{array}{l}\text { In 2013, DOE facilities on ORR were operated in accordance with emergency } \\
\text { planning and reporting requirements. }\end{array}$ & $\begin{array}{l}3.3 .14 \\
4.3 .9 \\
5.3 .10\end{array}$ \\
\hline $\begin{array}{l}\text { NEPA requires consideration of how federal } \\
\text { actions may impact the environment and an examination } \\
\text { of alternatives to the actions. NEPA also requires that } \\
\text { decisions include public input and involvement through } \\
\text { scoping and review of NEPA documents. }\end{array}$ & $\begin{array}{l}\text { During 2013, DOE activities on ORR were conducted in accordance with NEPA } \\
\text { requirements. }\end{array}$ & $\begin{array}{l}3.3 .4 \\
4.3 .2 \\
5.3 .2\end{array}$ \\
\hline $\begin{array}{l}\text { NHPA provides protection for the nation's } \\
\text { historical resources by establishing a } \\
\text { comprehensive national historic preservation } \\
\text { policy. }\end{array}$ & $\begin{array}{l}\text { ORR has several facilities eligible for inclusion in the NRHP. Proposed activities } \\
\text { are reviewed to determine potential adverse effects on these properties, and } \\
\text { methods to avoid or minimize harm are identified. During 2013, activities on ORR } \\
\text { were in compliance with NHPA requirements. }\end{array}$ & $\begin{array}{l}3.3 .4 \\
4.3 .2 \\
5.3 .2\end{array}$ \\
\hline
\end{tabular}


Table 2.1. (continued)

\section{Regulatory program description}

\section{ORR Floodplain Management Programs}

are established to avoid, to the extent possible, adverse impacts associated with the occupancy and modification of floodplains and to avoid direct or indirect support of floodplain development wherever there is a practicable alternative.

\section{ORR Protection of Wetlands Programs are}

implemented to minimize the destruction, loss, or degradation of ORR wetlands and to preserve and enhance their beneficial value.

RCRA governs the generation, storage, handling, and disposal of hazardous wastes. RCRA also regulates USTs containing petroleum and hazardous substances, universal waste, and recyclable used oil.

SDWA establishes minimum drinking water standards and monitoring requirements.

TSCA regulates the manufacture, use, and distribution of all chemicals.

\section{3 status}

ORR floodplain management programs incorporate management and protection goals into planning, regulatory, and decision-making processes through each site's NEPA program. Goals include flood-loss reduction, minimization of the impact of floods, and restoration and preservation of ORR floodplains. Floodplain management on ORR is conducted in accordance with 10 CFR 1022 and EO 11988, Floodplain Management.

Protection of about 243 ha (600.5 acres) of ORR wetlands was implemented through each site's NEPA program, and surveys for the presence of wetlands are conducted on a project or program as-needed basis. Wetland protection on ORR is conducted in accordance with 10 CFR 1022 and EO 11990, Protection of Wetlands.

The Y-12 Complex, ORNL, and ETTP are defined as large-quantity generators of hazardous waste because each generates more than $1,000 \mathrm{~kg}$ of hazardous waste per month. Each site is also regulated as a handler of universal waste. In addition, several permits have been issued for hazardous waste management units on ORR. During 2013 a TDEC inspection at the Y-12 Complex identified three alleged violations related to an open satellite waste container, an unlabeled satellite waste container, and unlabeled used oil containers. The issues, which were administrative in nature with no potential for environmental insult, were immediately corrected. No other RCRA violations or concerns were cited for ORR in 2013.

The City of Oak Ridge supplies potable water to the facilities on ORR and meets all regulatory requirements for drinking water.

ORR facilities manage TSCA-regulated materials, including PCBs. The ORR PCB FFCA between EPA and DOE continues to provide a mechanism to address legacy PCB-use issues across ORR. The agreement specifically addresses the unauthorized use of $\mathrm{PCBs}$, storage and disposal of $\mathrm{PCB}$ waste, $\mathrm{PCB}$ spill cleanup and/or decontamination, $\mathrm{PCBs}$ mixed with radioactive materials, $\mathrm{PCB}$ research and development, and records and reporting requirements for ORR. EPA is updated annually on the status of DOE actions with regard to management and disposition of PCBs covered under the ORR PCB FFCA. In 2013, there were no TSCArelated NOVs issued for ORR activities.
Report sections

3.3 .4

4.3 .2

5.3 .2

1.3.6.1

4.3 .2

3.3 .9

4.3 .6

5.3 .7

3.3 .8

4.3.5

5.3 .5

3.3 .13

4.3 .8

5.3 .9 
Table 2.1. (continued)

\begin{tabular}{l} 
Regulatory program description \\
\hline Bald and Golden Eagle Protection Act (16 U.S.C. \\
$\mathbf{6 6 8 - 6 6 8 d )}$ protects bald and golden eagles by \\
prohibiting, except under certain specified conditions, \\
the taking or possession of and commerce in such \\
birds. The act imposes criminal and civil penalties for \\
any such actions.
\end{tabular}

Endangered Species Act prohibits activities that would jeopardize the continued existence of an endangered or threatened species or cause adverse modification to a critical habitat.

Migratory Bird Treaty Act protects migratory bird by governing the taking, killing, possession, transportation, and importation of such birds, including their eggs, parts, and nests and any product, manufactured or not, from such items.

DOE $O$ 231.1B, Environment, Safety and Health Reporting, ensures timely collection, reporting, analysis, and dissemination of information on environment, safety, and health issues.

DOE O 435.1, Change 1, Radioactive Waste Management, is implemented to ensure that all DOE radioactive waste is managed in a manner that protects workers, public health and safety, and the environment.

\section{DOE O 436.1, Department Sustainability, was} approved in May 2011 and cancels DOE O 450.1A, Environmental Protection Program, and DOE O 430.2B, Departmental Energy,

Renewable Energy and Transportation

Management. DOE O 436.1 requires SSPs that

identify a site's contributions toward meeting DOE's sustainability goals and an EMS that conforms to the ISO 14001:2004 standard.
Bald eagles are known to frequent ORR year-round. Currently there are two active 1.3.6.2

bald eagle nests on ORR that are protected in accordance with this act.

ORR is host to several plant and animal species that are categorized as endangered, threatened, or of special concern and that are protected in accordance with this act.

ORR is host to a diversity of migratory birds that are protected under this act.

The Oak Ridge Reservation Annual Site Environmental Report for 2013 summarizes ORR environmental activities during 2013 and characterizes environmental performance.

Waste certification programs that are protective of workers, the public, and the environment have been implemented for all activities on ORR to ensure compliance with this DOE order.

DOE contractors on ORR have developed SSPs and have implemented EMSs that are incorporated with the contractors' ISMSs to promote sound stewardship practices and to ensure compliance with this DOE order. 
Table 2.1. (continued)

\begin{tabular}{|c|c|c|}
\hline Regulatory program description & 2013 status & Report sections \\
\hline $\begin{array}{l}\text { DOE O 458.1, Radiation Protection of the Public } \\
\text { and the Environment, issued in June } 2011 \text {, canceled } \\
\text { DOE O } 5400.5 \text { and was established to protect } \\
\text { members of the public and the environment against } \\
\text { undue risk from radiation. This order established } \\
\text { standards and requirements for operations of DOE } \\
\text { and DOE contractors. }\end{array}$ & $\begin{array}{l}\text { In } 2013 \text { DOE O } 458.1 \text { was the primary contractual obligation for radiation protection } \\
\text { for UT-Battelle, LLC, and B\&W Y-12, and DOE O 5400.5 was the primary } \\
\text { contractual obligation for UCOR. A dose assessment, performed to ensure that the total } \\
\text { dose to members of the public from all DOE ORR pathways did not exceed the } \\
100 \text { mrem annual limit established by this order estimated the maximum } 2013 \text { dose to } \\
\text { a hypothetically exposed member of the public from all ORR sources could have been } \\
\text { about } 5 \text { mrem. Clearance of property from ORNL and the Y-12 Complex was } \\
\text { conducted in accordance with approved procedures that comply with DOE O } 458.1 \text {. }\end{array}$ & $\begin{array}{l}4.3 .11 \\
5.3 .13 \\
\text { Chap. } 7\end{array}$ \\
\hline $\begin{array}{l}\text { DOE O 5400.5, Radiation Protection, was established } \\
\text { to protect members of the public and the environment } \\
\text { against undue risk from radiation. This order established } \\
\text { standards and requirements for operations of DOE and } \\
\text { DOE contractors. This order has been substantially } \\
\text { canceled by DOE O } 458.1 \text { but remained a contractual } \\
\text { obligation for UCOR in } 2013 \text {. }\end{array}$ & $\begin{array}{l}\text { A dose assessment, performed to ensure that the total dose to members of the } \\
\text { public from all DOE ORR pathways did not exceed the } 100 \text { mrem annual limit } \\
\text { established by this order estimated the maximum } 2013 \text { dose to a hypothetically } \\
\text { exposed member of the public from all ORR sources could have been about } \\
5 \text { mrem. }\end{array}$ & Chap. 7 \\
\hline $\begin{array}{l}\text { EO 13186, Responsibilities of Federal Agencies to } \\
\text { Protect Migratory Birds, identifies the } \\
\text { responsibilities of federal agencies to promote the } \\
\text { conservation of migratory bird populations. }\end{array}$ & $\begin{array}{l}\text { An MOU was entered into by DOE and FWS that meets the requirements under } \\
\text { Section } 3 \text { of EO } 13186 . \text { ORR is host to a diversity of migratory birds that are } \\
\text { present either seasonally or year-round. This MOU strengthens migratory bird } \\
\text { conservation on ORR through enhanced collaboration between DOE and FWS. }\end{array}$ & 1.3.6.2 \\
\hline $\begin{array}{l}\text { EO 13423, Strengthening Federal Environmental, } \\
\text { Energy, and Transportation Management, } \\
\text { instructs federal agencies to conduct their } \\
\text { environmental, transportation, and energy-related } \\
\text { activities under the law in support of their } \\
\text { respective missions in an environmentally, } \\
\text { economically, and fiscally sound; integrated; } \\
\text { continuously improving; efficient; and sustainable } \\
\text { manner. } \\
\text { EO 13514, Federal Leadership in Environmental, } \\
\text { Energy, and Economic Performance, expands on } \\
\text { the energy reduction and environmental performance } \\
\text { requirements for federal agencies identified in } \\
\text { EO } 13423 \text { and establishes an integrated strategy } \\
\text { toward sustainability in the federal government to } \\
\text { make reduction of greenhouse gas emissions a } \\
\text { priority for federal agencies. }\end{array}$ & $\begin{array}{l}\text { In } 2013 \text { "site sustainability plans" addressed the requirements of EOs } 13423 \text { and } \\
13514 \text { and DOE's Strategic Sustainability Performance Plan. }{ }^{a} \text { Progress toward } \\
\text { achieving DOE sustainability goals is summarized in this report. ORR activities } \\
\text { complied with the planning and reporting requirements of these executive orders } \\
\text { in } 2013 \text {. }\end{array}$ & $\begin{array}{c}3.2 .3 \\
4.2 .6 .3 \\
5.2 .1 .4\end{array}$ \\
\hline
\end{tabular}




\section{Table 2.1. (continued)}

${ }^{a}$ DOE. 2013. 2013 Strategic Sustainability Performance Plan, Report to the White House Council on Environmental Quality and Office of Management and Budget. US Department of Energy, Washington, DC.

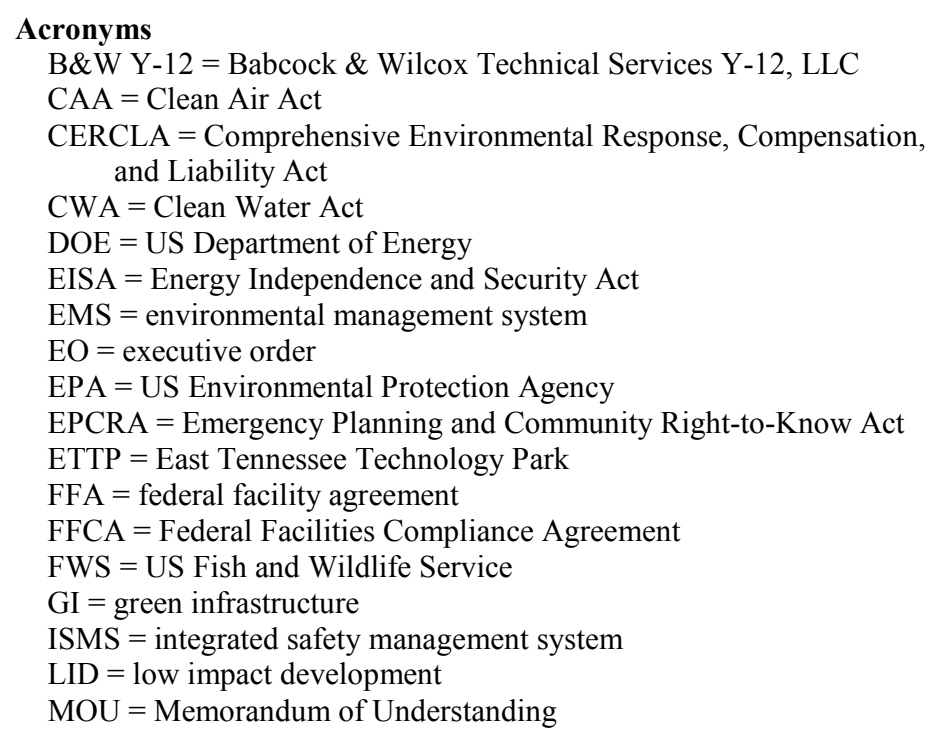

NEPA $=$ National Environmental Policy Act

NESHAPs = National Emission Standards for Hazardous Air Pollutants NHPA $=$ National Historic Preservation Act

$\mathrm{NOV}=$ notice of violation

NPDES $=$ National Pollutant Discharge Elimination System

$\mathrm{NPL}=$ National Priorities List

NRHP = National Register of Historic Places

ORNL $=$ Oak Ridge National Laboratory

ORR $=$ Oak Ridge Reservation

$\mathrm{PCB}=$ polychlorinated biphenyl

RCRA = Resource Conservation and Recovery Act

SARA $=$ Superfund Amendments and Reauthorization Act

SDWA $=$ Safe Drinking Water Act

$\mathrm{SSP}=$ site sustainability plan

TDEC $=$ Tennessee Department of Environment and Conservation

TSCA $=$ Toxic Substances Control Act

UCOR = URS | CH2M Oak Ridge LLC

UST $=$ underground storage tank

Y-12 Complex $=$ Y-12 National Security Complex 
Table 2.2. Summary of regulatory environmental evaluations, audits, inspections, and assessments conducted at Oak Ridge Reservation, 2013

\begin{tabular}{|c|c|c|c|}
\hline Date & Reviewer & Subject & Issues \\
\hline \multicolumn{4}{|c|}{$\begin{array}{c}O R N L \\
\text { (including UT-Battelle, LLC; UCOR; Isotek; and WAI activities) }\end{array}$} \\
\hline February 19 & City of Oak Ridge & CFTF Wastewater Inspection & 0 \\
\hline June $10-11$ & TDEC & Annual RCRA Inspection for ORNL & 0 \\
\hline August 6 & Knox County & Annual CAA Inspection for NTRC & 0 \\
\hline August 9 & TDEC & Annual CAA Inspection for ORNL and CFTF & 0 \\
\hline September $26-30$ & TDEC & NPDES Compliance Evaluation Inspection & 0 \\
\hline September 30 & City of Oak Ridge & CFTF Wastewater Inspection & 0 \\
\hline October 23 & TDEC & Annual TWPC CAA Inspection & 0 \\
\hline November $4-5$ & TDEC & Annual RCRA Inspection of ORNL at Y-12 Facilities & 0 \\
\hline \multicolumn{4}{|c|}{ ETTP } \\
\hline January 24 & TDEC & Inspection of ETTP USTs & 0 \\
\hline February $11-12$ & TDEC & Annual RCRA Inspection & 0 \\
\hline September 30 & TDEC-Knoxville & CNF NPDES Compliance Evaluation Inspection & 0 \\
\hline October 24 & EPA Region 4 & TSCA Incinerator-PCB Site Visit & 0 \\
\hline \multicolumn{4}{|c|}{ Y-12 Complex } \\
\hline March 14 & City of Oak Ridge & Semiannual Industrial Pretreatment Compliance Inspection & 0 \\
\hline June 19-20 & TDEC-Knoxville & Annual CAA Inspection & 0 \\
\hline August 7 & City of Oak Ridge & Semiannual Industrial Pretreatment Compliance Inspection & 0 \\
\hline November $4-5$ & TDEC & Annual RCRA Inspection & 3 \\
\hline
\end{tabular}

RCRA $=$ Resource Conservation and Recovery Act

TDEC $=$ Tennessee Department of Environment and Conservation

TSCA $=$ Toxic Substances Control Act

TWPC $=$ Transuranic Waste Processing Center

$\mathrm{UCOR}=\mathrm{URS} \mid \mathrm{CH} 2 \mathrm{M}$ Oak Ridge LLC

UST $=$ underground storage tank

WAI $=$ Wastren Advantage, Inc.

Y-12 Complex $=$ Y-12 National Security Complex

NTRC $=$ National Transportation Research Center

ORNL $=$ Oak Ridge National Laboratory

$\mathrm{PCB}=$ polychlorinated biphenyl

\subsection{Reporting of Oak Ridge Reservation Spills and Releases}

Comprehensive Environmental Response, Compensation, and Liability Act (CERCLA) hazardous substances are substances that are considered to be severely harmful to human health and the environment. Many are commonly used substances that are harmless in their normal uses but are quite dangerous when released. CERCLA establishes a corresponding reportable quantity (RQ) for each hazardous substance. Any hazardous substance release exceeding an RQ triggers reports to the National Response Center, ${ }^{*}$ the State Emergency Response Center, and community coordinators. Discharges of oil must be reported if they "cause a film or sheen upon or discoloration of the surface of the water or

\footnotetext{
*The National Response Center (http://www.nrc.uscg.mil/nrcback.html) is the sole federal point of contact for reporting oil, chemical, radiological, biological, and etiological releases into the environment anywhere in the United States and its territories.
} 
adjoining shorelines or cause a sludge or emulsion to be deposited beneath the surface of the water or upon adjoining shorelines" [40 CFR 110.3(b)].

During CY 2013 there were no releases of hazardous substances exceeding an RQ or observed oil sheens at the Y-12 Complex, ETTP, or ORNL.

There were three fish kills at ORNL in 2013. These occurred on July 31, 2013; October 4, 2013; and October 6, 2013, with the number of dead organisms from each event ranging from 5 to 74 fish and invertebrates. All three events were attributed to inadequate dechlorination of cooling water discharges. Mechanical and administrative improvements have been made to guard against future occurrences. There was also a reportable occurrence due to a potable water line break that occurred at the Y-12 Complex on June 8, 2013. Chlorinated water from the point of the break entered the storm drain system and resulted in a fish kill (see Section 4.5.1).

\subsection{Notices of Violations and Penalties}

TDEC conducted an annual RCRA inspection of operations at the Y-12 Complex on November 4-5, 2013. Three alleged violations were observed during the inspection. The three issues identified were an open satellite waste container, an unlabeled satellite waste container, and unlabeled used oil containers. All issues were immediately corrected and were verified to be corrected by the TDEC inspector. These issues were of an administrative nature, and there was no potential for environmental insult. No other NOVs, penalties, or consent orders were issued on the reservation during 2013.

\subsection{Community Involvement}

\subsubsection{Public Comments Solicited}

To keep the public informed of comment periods and other matters related to cleanup activities on ORR, DOE publishes a monthly newsletter, Public Involvement News (http://www.ucor.com/public_involvement_news.html). DOE also keeps the public informed by publishing notices in local newspapers and conducting public meetings. In addition, the ORNL National Pollutant Discharge Elimination System (NPDES) permit renewal draft was posted for public comment by TDEC on December 16, 2013.

\subsubsection{Oak Ridge Site Specific Advisory Board}

The Oak Ridge Site Specific Advisory Board (ORSSAB) is a federally appointed citizens' panel that provides independent advice and recommendations to the DOE Oak Ridge Environmental Management (EM) Program. The board was formed in 1995 and is composed of up to 22 members chosen to reflect the diversity of gender, race, occupation, views, and interests of persons living near the DOE ORR. Members are appointed by DOE and serve on a voluntary basis without compensation.

Information on recommendations the board has made since its establishment, minutes of board and committee meetings, and other information are available on the ORSSAB website at http://www.energy.gov/ORSSAB.

Videos of the first hour of recent board meetings are posted on YouTube at http://www.youtube.com/user/ORSSAB.

Additional information may be obtained by calling 865-241-4583, 865-241-4584, or 1-800-382-6938.

\subsubsection{DOE Information Center}

The DOE Information Center, located at 1 Science.Gov Way, Oak Ridge, Tennessee, is a one-stop information facility that maintains a collection of more than 40,000 documents describing environmental activities in Oak Ridge. The center is open Monday through Friday, 8 a.m. to 5 p.m. The DOE ORO website (www.oakridge.doe.gov) includes a "Public Activities" tab that links to a page with descriptions of DOE ORO program activities for the general public. The "Online Catalog" tab, under the "DOE Information Center" tab on the Public Activities page, can be used to search for DOE documents by 
author, title, date, and other fields. The "New Documents" tab provides links to recently published documents.

\subsubsection{Telephone Contacts}

- DOE Information Center: 865-241-4780; toll free 1-800-382-6938 (option 6)

- DOE Public Affairs Office: 865-576-0885

- DOE ORO Public Information Line: 1-800-382-6938

- ORSSAB: 865-241-4583, 865-241-4584, 1-800-382-6938

- TDEC, DOE Oversight Division: 865-481-0995

- $\quad$ EPA Region IV: 1-800-241-1754

- Agency for Toxic Substances and Disease Registry: 1-800-232-4636

\subsubsection{Internet Sites}

- DOE Main Website: http://www.energy.gov

- DOE ORO Home Page: http://www.oakridge.doe.gov

- DOE ORO EM Program: http://www.oakridge.doe.gov/external/Programs/ EnvironmentalManagement/tabid/42/Default.aspx

- ORSSAB: http://www.oakridge.doe.gov/em/ssab/default.htm

- ETTP: http://www.ettpreuse.com/default.htm

- Agency for Toxic Substances and Disease Registry: http://www.atsdr.cdc.gov

- EPA Region 4: http://www.epa.gov/region4

- TDEC: http://www.state.tn.us/environment/

- TDEC, DOE Oversight Division: http://www.tn.gov/environment/remediation_energyoversight.shtml

- DOE Information Center: http://www.oakridge.doe.gov/external/PublicActivities/InfoCenter/tabid/ 126/Default.aspx

- American Recovery and Reinvestment Act: http://www.recovery.gov and www.energy.gov/recovery

\subsection{References}

DOE. 2013. 2013 Strategic Sustainability Performance Plan, Report to the White House Council on Environmental Quality and Office of Management and Budget. US Department of Energy, Washington, DC. 



\section{East Tennessee Technology Park}

ETTP was originally built during World War II as part of the Manhattan Project. Known as the K-25 Site, its primary mission was to enrich uranium for use in atomic weapons. After the war, the mission was changed to include the enrichment of uranium for nuclear reactor fuel elements and recycling of uranium recovered from spent fuel, and the name was changed to the "Oak Ridge Gaseous Diffusion Plant." In the 1980s, a reduction in the demand for nuclear fuel resulted in the shutdown of the enrichment process, and production ceased. The emphasis of the mission then changed to environmental management and restoration operations, and the name was changed to the "East Tennessee Technology Park." Environmental management and remediation operations consist of operations such as waste management, the cleanup of outdoor storage and disposal areas, the demolition and/or cleanup of the facilities, land restoration, and environmental monitoring. Proper disposal of the huge quantities of waste that were generated over the course of production operations is also a major task. Beginning in the 1990s, reindustrialization (the conversion of underused government facilities for use by the private sector) also became a major mission at ETTP. Reindustrialization allows private industry to lease underused facilities, thus providing both jobs and a new use for facilities that otherwise would have to be demolished. State and federally mandated effluent monitoring and environmental surveillance at ETTP involve the collection and analysis of samples of air, water, soil, sediment, and vegetation from ETTP and the surrounding area. Monitoring results are used to assess exposures to members of the public and the environment, to assess the performance of treatment systems, to help identify areas of concern, to plan remediation efforts, and to evaluate the efficacy of remediation efforts. In 2013 , there was $100 \%$ compliance with permit standards for emissions/discharges from ETTP operations.

\subsection{Description of Site and Operations}

Construction of ETTP (Fig. 3.1), originally known as the K-25 Site, began in 1943 as part of the World War II Manhattan Project. The plant's original mission was the production of enriched uranium for nuclear weapons. Enrichment was initially carried out in the S-50 thermal diffusion process facility, which operated for 1 year, and the K-25 and K-27 gaseous diffusion process buildings. Later, the K-29, K-31, and K-33 buildings were built to increase the production capacity of the original facilities by raising the assay of the feed material entering K-27. Following the war years, the site became officially known as the "Oak Ridge Gaseous Diffusion Plant" (ORGDP).

After military production of highly enriched uranium was concluded in 1964, the two original process buildings were shut down. For the next 20 years, the plant's primary missions were the production of only low enriched uranium to be fabricated into fuel elements for nuclear reactors. Other missions during the latter part of this 20-year period included developing and testing the gas centrifuge method of uranium enrichment and laser isotope separation R\&D.

By 1985, the demand for enriched uranium had declined, and the gaseous diffusion cascades at ORGDP were placed in standby mode. That same year, the gas centrifuge program was canceled. The decision to permanently shut down the diffusion cascades was announced in late 1987, and actions necessary to implement that decision were initiated soon thereafter. Because of the termination of the original and primary missions, ORGDP was renamed the "Oak Ridge K-25 Site" in 1990. Figure 3.2 shows the ETTP site areas before the start of D\&D activities. In 1997, the K-25 Site was renamed the "East Tennessee Technology Park" to reflect its new mission. Fig. 3.3 shows the ETTP areas designated for D\&D activities through 2013. 


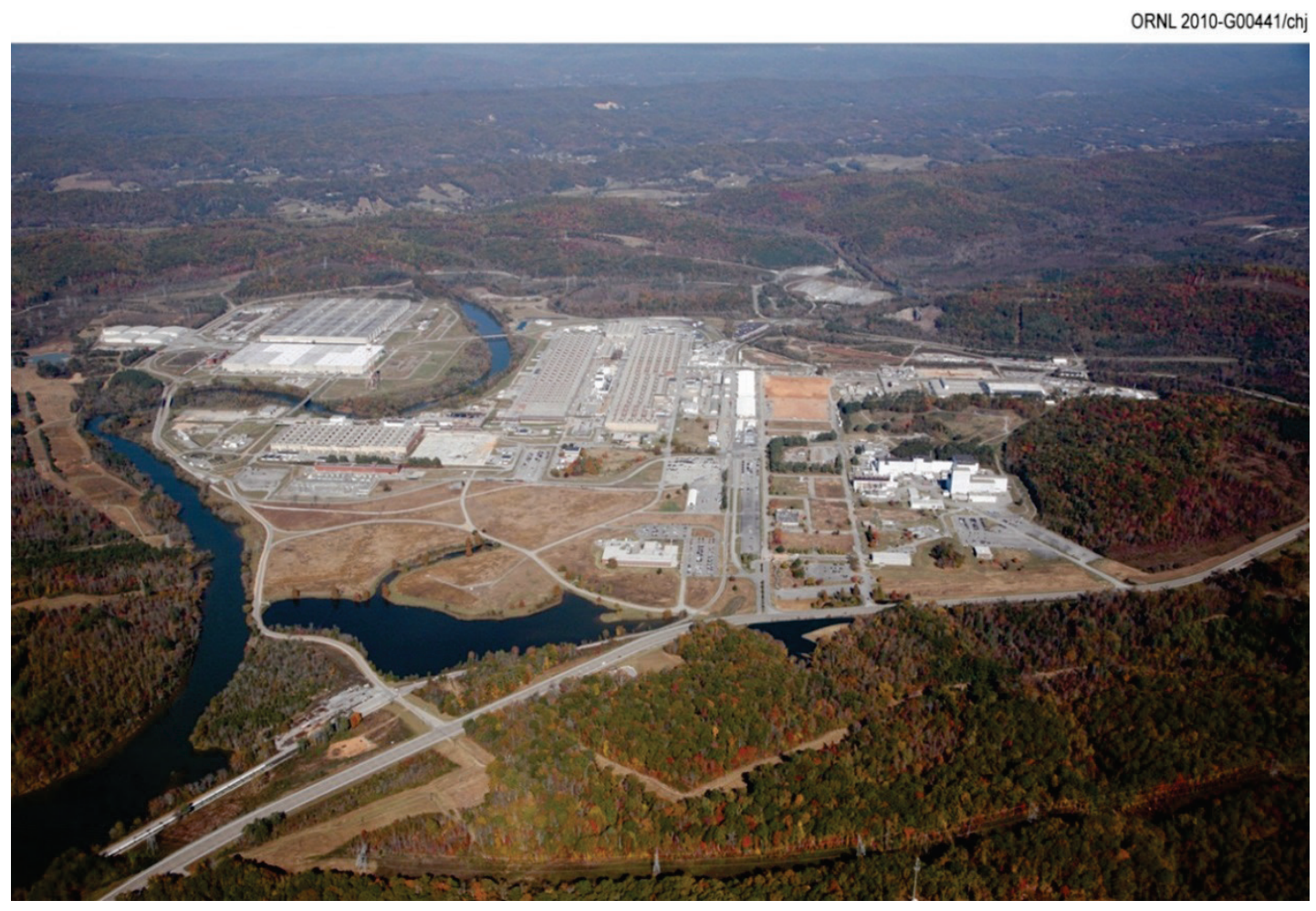

Fig. 3.1. East Tennessee Technology Park.

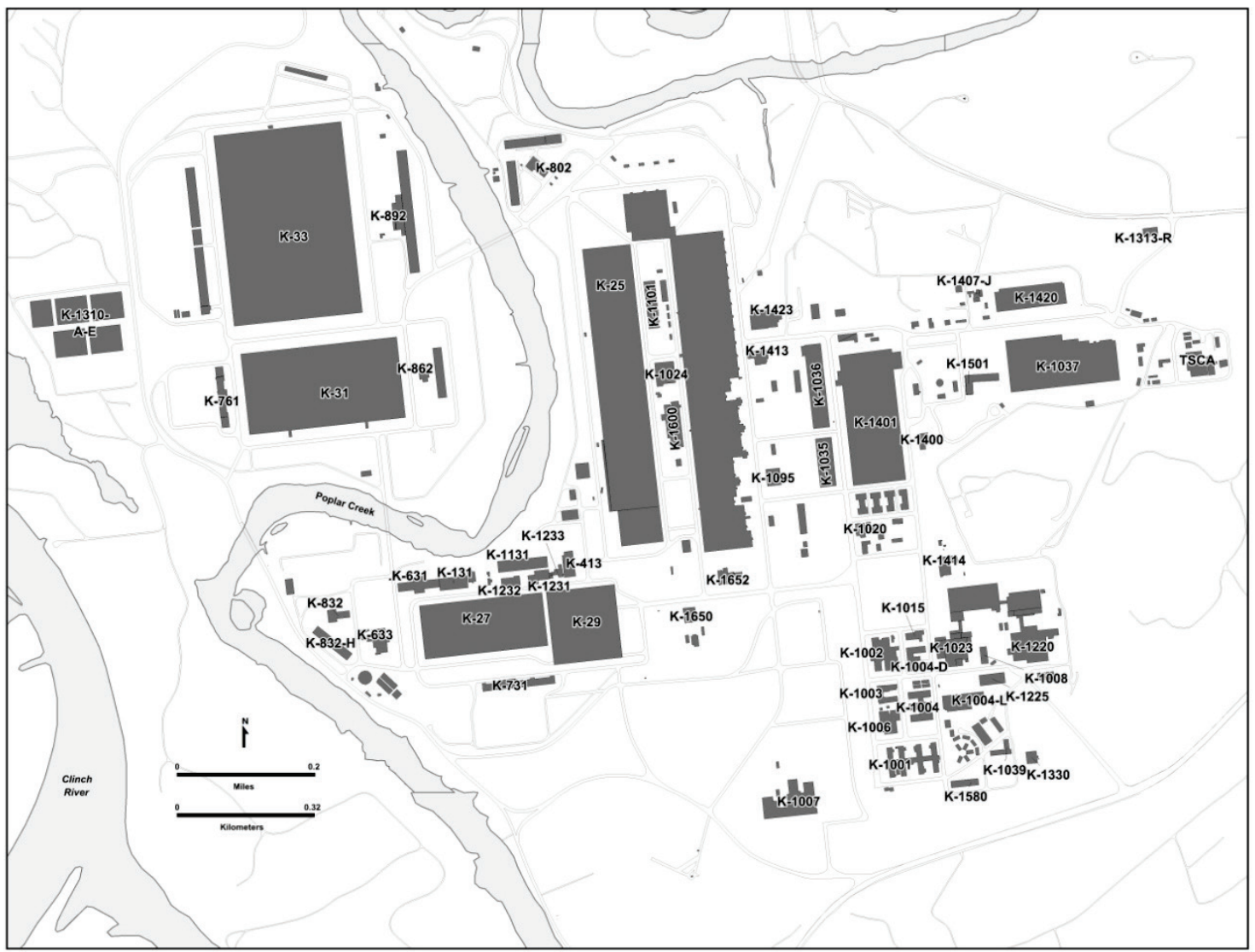

Fig. 3.2. East Tennessee Technology Park before the start of decontamination and decommissioning activities in 1991. 


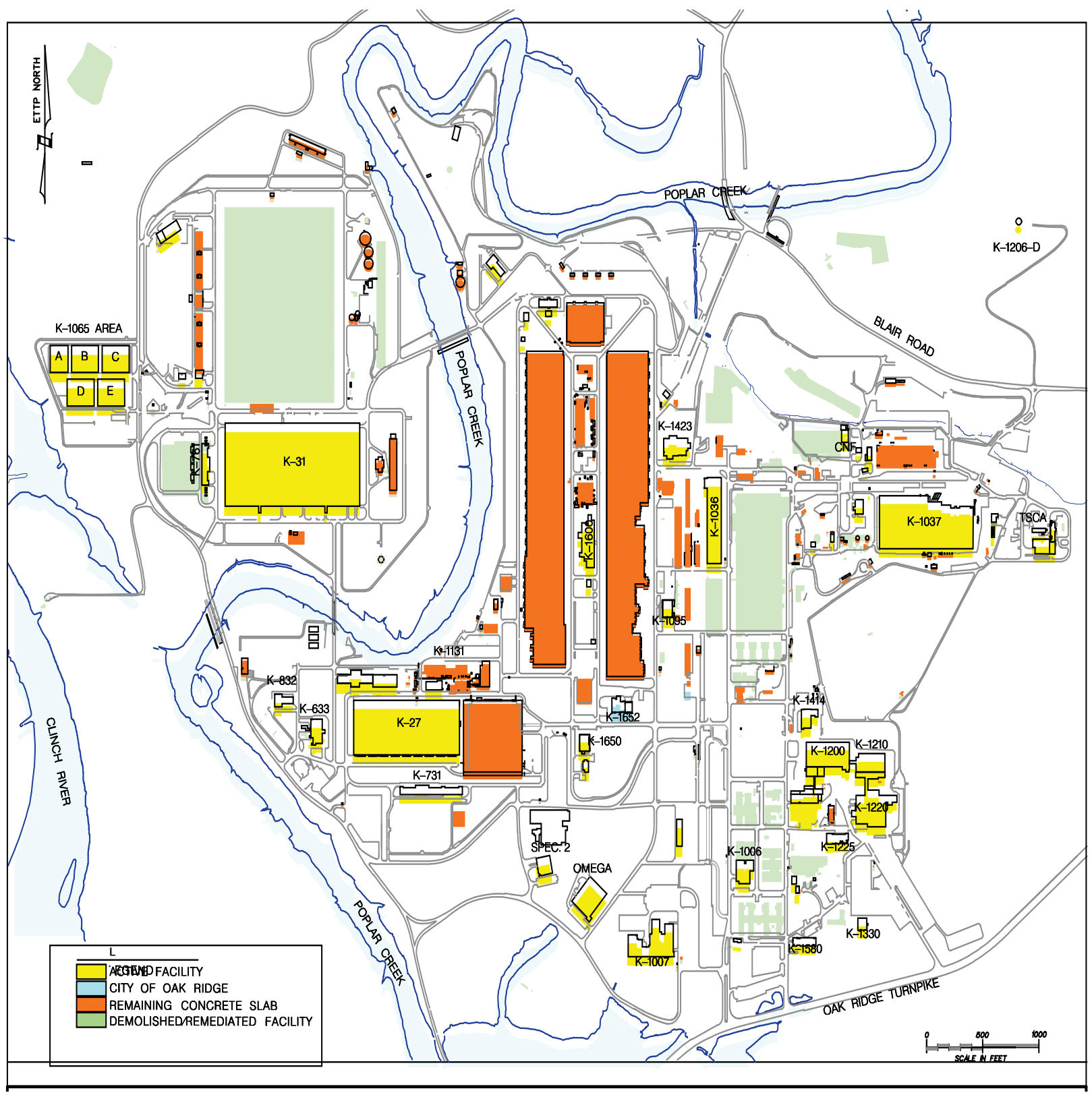

Fig. 3.3. East Tennessee Technology Park in 2013.

The ETTP mission is to reindustrialize and reuse site assets through leasing or transferring excess or underutilized land and facilities and through incorporating commercial industrial organizations as partners in the ongoing environmental restoration, D\&D, and waste treatment and disposal.

DOE's long-term goal for ETTP is to convert as much of the site as possible into a private business and industrial park. The site is undergoing environmental cleanup of its land as well as D\&D of most of its buildings. The reuse of key facilities through title transfer is part of the site's closure plan. The cleanup approach makes land and various types of buildings (e.g., office, manufacturing) suitable for private industrial use and for title transfer to CROET or other entities such as the City of Oak Ridge. The facilities may then be subleased or sold, with the goal of stimulating private industry and recruiting business to the area.

UCOR, the environmental management contractor for ETTP, supports DOE in the reindustrialization program as part of the continuing effort to transform ETTP into a private-sector industrial park. Unless otherwise noted, information on non-DOE entities located on the ETTP site is not provided in this document. 


\subsection{Environmental Management System}

The UCOR Environmental Management System (EMS) is integrated with the UCOR Integrated Safety Management System (ISMS). UCOR's EMS is based on a graded approach for a closure and remediation contract and reflects the elements and framework contained in International Organization for Standardization (ISO) standard 14001:2004 (ISO 14001:2004), Environmental management systemsRequirements with guidance for use. UCOR is committed to incorporating sound environmental management, protection, and sustainability practices in all work processes and activities that are part of the DOE EM program in Oak Ridge, Tennessee. UCOR's environmental policy states in part, "Our commitment to protect and sustain human, natural, and cultural resources is inherent in our mission to complete environmental cleanup safely with reduced risks to the public, workers, and the environment." To achieve this, UCOR's environmental policy adheres to the following principles.

- Management Commitment - Integrate responsible environmental practices into project operations.

- Environmental Compliance and Protection (EC\&P) - Comply with all environmental regulations and standards.

- Sustainable Environmental Stewardship-Minimize the effects of our operations on the environment through a combination of source reduction, recycling, and reuse; sound waste management practices; and pollution prevention.

- Partnership/Stakeholder Involvement-Maintain partnerships through effective two-way communications with our customer and other stakeholders.

\subsubsection{Environmental Stewardship Scorecard}

The Environmental Stewardship Scorecard is used to track and measure site-level EMS performance. During 2013, UCOR received "green scores" for EMS performance. As an example, Fig. 3.4 presents information on UCOR's pollution prevention recycling activities for 2013. UCOR recycles office and mixed paper, cardboard, phone books, newspapers, magazines, aluminum cans, antifreeze, engine oils, batteries (lead acid, universal waste, and alkaline), universal waste bulbs, plastic bottles, all types of \#1 and \#2 plastics, and surplus electronic assets such as computers (CPUs and laptops) and monitors (CRT and LCD). Other recycling opportunities include unique structural steel, stainless steel structural members, transformers, and electrical breakers. Figure 3.4 shows the pollution prevention recycling activities at ETTP related to solid waste reduction.

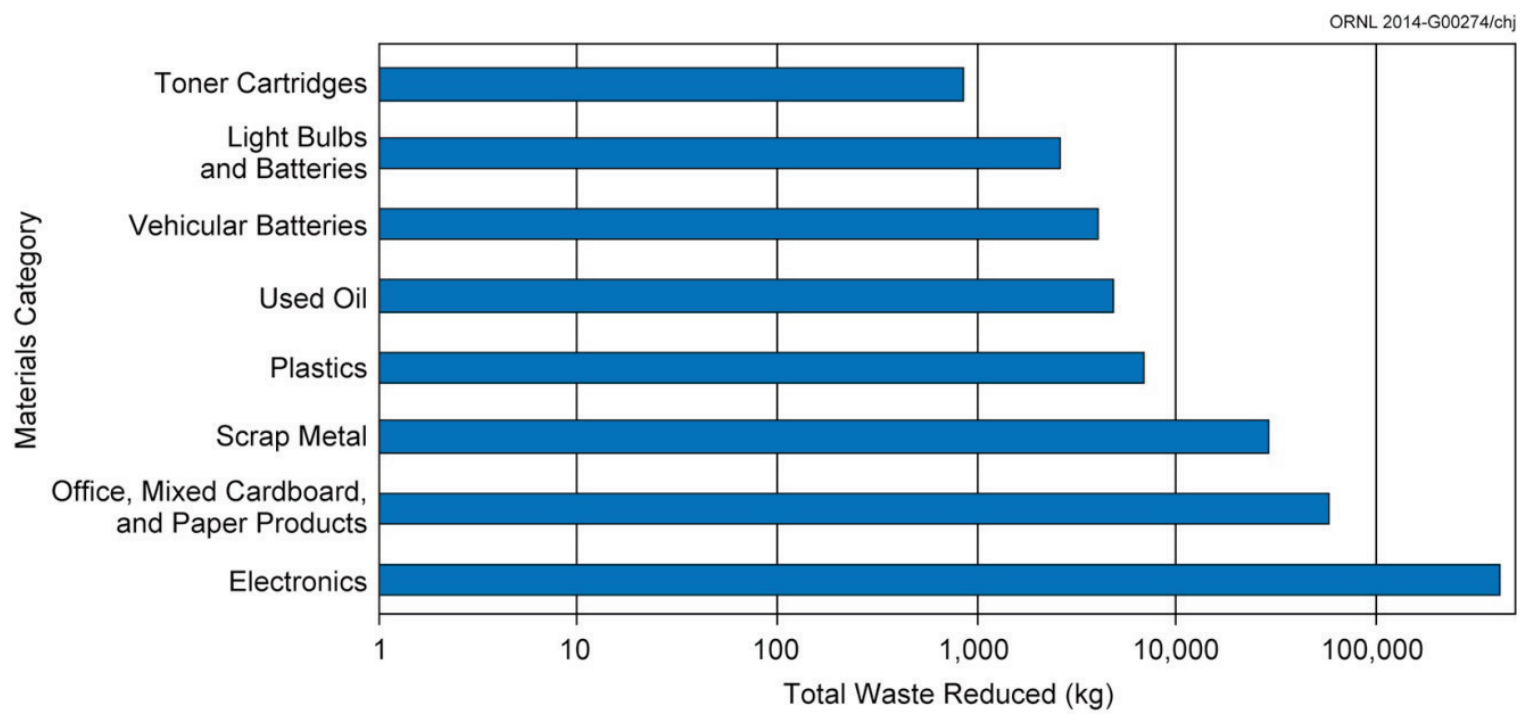

Fig. 3.4. Pollution prevention recycling activities related to solid waste reduction at East Tennessee Technology Park in FY 2013. 
UCOR's electronic stewardship is award winning. In 2013 EPA awarded ETTP its second Federal Electronics Challenge (FEC) Platinum-Level Award. [ETTP won its first FEC Platinum-Level Award in 2012 for its electronics assets management achievements, including the Radio Frequency Identification Transportation System (RFITS).] UCOR also received two out of only five DOE headquarters sustainability awards in 2013. One, in the category of Waste Reduction and Pollution Prevention, was for successfully diverting more than 8,000 metric tons of construction and demolition (C\&D) debris from projects at ETTP, ORNL, and Y-12 (Fig. 3.5). The other was an individual award in the category of Exceptional Service/Sustainability Champion for excellence in electronics stewardship.

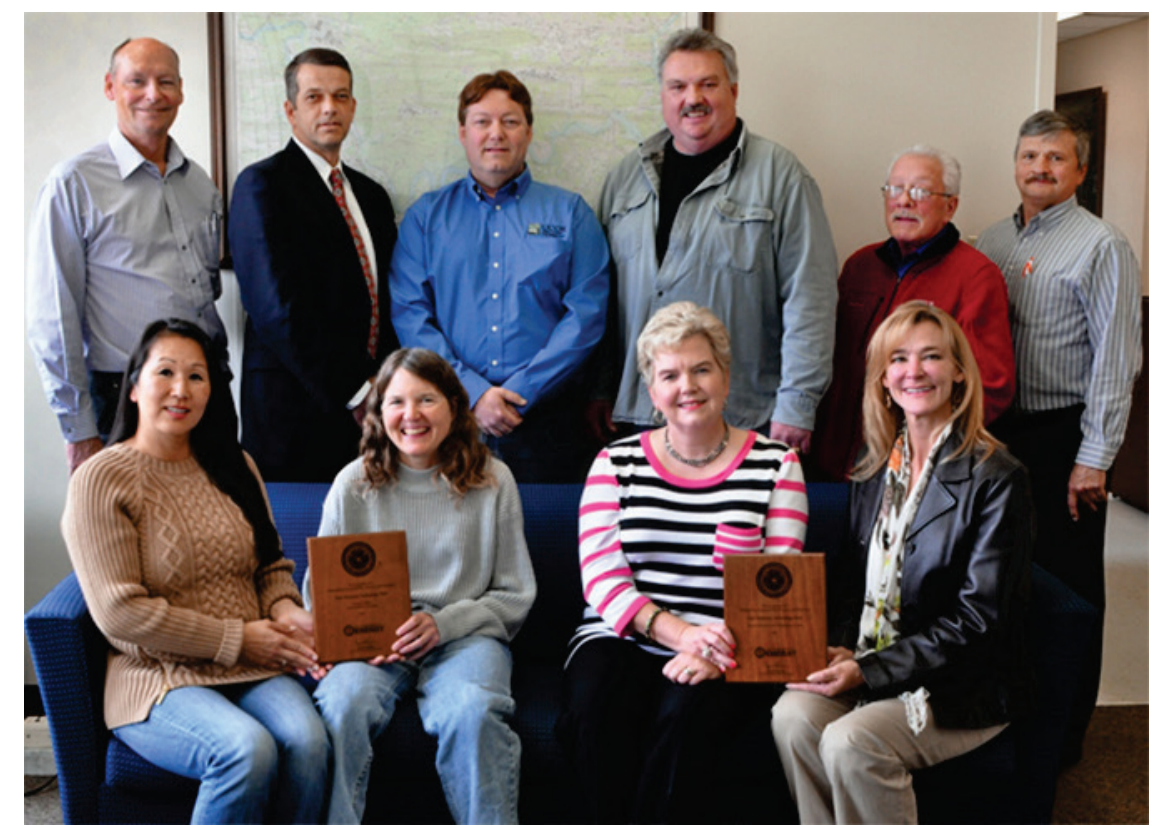

Fig. 3.5. US Department of Energy headquarters sustainability award winners for 2012 (awarded in 2013).

Additionally, UCOR internally recognized six projects for their pollution prevention/waste minimization accomplishments during the year, representing 42,000 $\mathrm{lb}$ of construction debris being diverted from landfills and a cost savings of $\$ 170,000$. In the area of alternative energy, Restoration Services, Inc. (RSI), in concert with UCOR, continued operation of ETTP's first solar farm on the east end of the plant property. Brightfield 1 (Fig. 3.6), as it is known, is a $200 \mathrm{~kW}$ solar array located at ETTP and built by RSI as part of the UCOR commitment to the revitalization of the former K-25 Site. The 0.405 ha (1-acre) tract was purchased from CROET. RSI self-financed the project, used solar panels manufactured in Tennessee, and partnered with other local small businesses for the installation. Power generated from Brightfield 1 is being sold to TVA through the City of Oak Ridge Electric Department using a TVA Generation Partners contract. The completed project was commissioned in April of 2012 and is part of RSI's brownfield to brightfield initiative that works to develop restricted use properties into solar farms. Brightfield 1 energy production in its first year was $110 \%$ more than projected, with no downtime due to maintenance issues. In CY 2013 Brightfield 1 produced 262,100 kWh of energy. UCOR also continued to use "green" products whenever possible and evaluated large quantity purchases for less toxic alternatives. In addition, UCOR maintained its extensive recycling program and benefitted the local community through donations of proceeds to local charities from its aluminum beverage can (ABC) recycling efforts. 


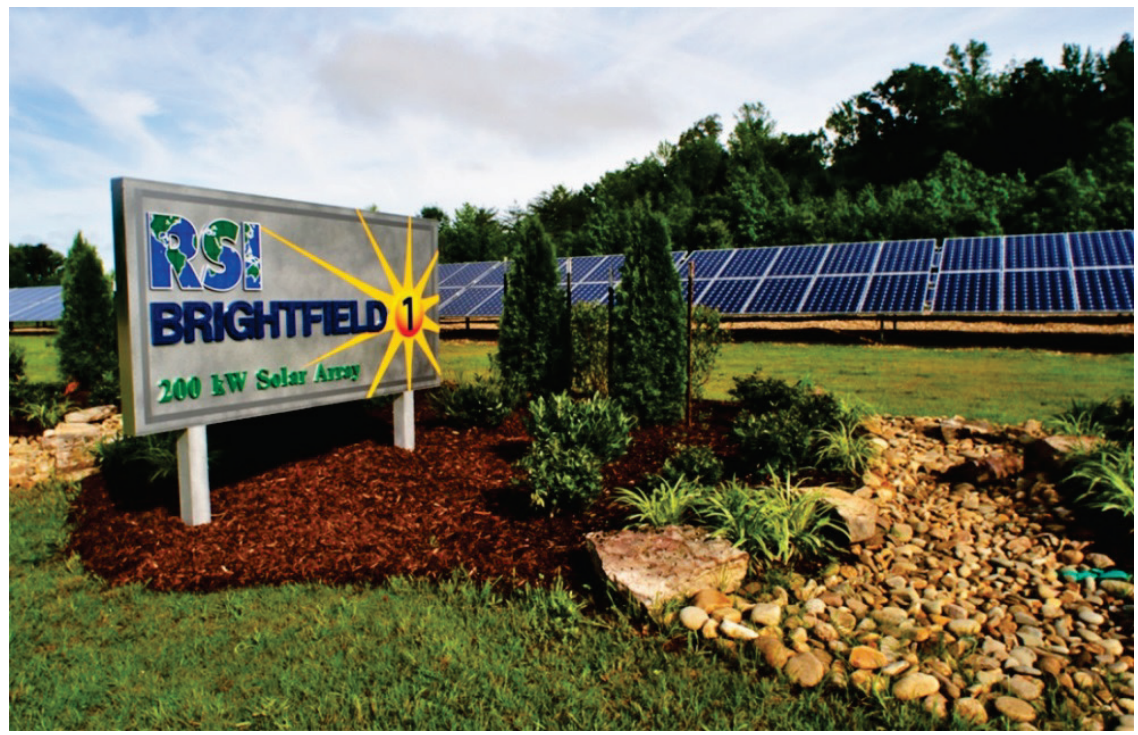

Fig. 3.6. Brightfield 1 Solar Farm.

\subsubsection{Environmental Compliance}

UCOR maintains various layers of oversight to ensure compliance with legal and other requirements. The methods of evaluation include independent assessments by outside parties, management assessments conducted by functional or project organizations, and routine field walkdowns conducted by a variety of functional and project personnel. Management and independent assessments are performed in accordance with Management Assessment, PROC-PQ-1420, and Independent Assessment, PROC-PQ-1401. Assessments are scheduled on the UCOR Assessments SharePoint Site in accordance with PROC-PQ-1420. Records are maintained for all formal assessments and audits. Issues identified in assessments are handled as required by ISO 14001, Section 4.5.3, "Nonconformity, Corrective Action, and Preventive Action" (ISO 2004).

\subsubsection{Environmental Aspects/Impacts}

Using a graded approach appropriate for EMS includes an environmental policy that provides a unified strategy for the management, conservation, and protection of natural resources; the control and attenuation of risks; and the establishment and attainment of all environment, safety, and health (ES\&H) goals. UCOR works continuously to improve EMS to reduce impacts from activities and associated effects on the environment (i.e., environmental aspects) and to communicate and reinforce this policy to its internal and external stakeholders.

\subsubsection{Environmental Performance Objectives and Targets}

UCOR conserves and protects environmental resources by incorporating environmental protection and the elements of an enabling EMS into the daily conduct of business; fostering a spirit of cooperation with federal, state, and local regulatory agencies; and using appropriate waste management, treatment, storage, and disposal methods. The environmental performance objectives are to achieve zero unpermitted discharges to the environment; comply with all conditions of environmental permits, laws, regulations, and DOE orders; integrate EMS and environmental considerations as part of ISMS; and, to the extent practicable, reduce waste generation, prevent pollution, maximize recycle and reuse potential, and encourage environmentally preferable procurement of materials with recycled and biobased content.

UCOR has established a set of core EMS objectives that remain relatively unchanged from year to year. These objectives are generally applicable to all operations and activities throughout UCOR's work scope. The core environmental objectives are based on complying with applicable legal requirements and 
sustainable environmental practices contained in DOE O 436.1, Departmental Sustainability (DOE 2011), and include the following:

- comply with all environmental regulations, permits, and regulatory agreements;

- reduce or eliminate the acquisition, use, storage, generation, and/or release of toxic, hazardous, and radioactive materials; waste; and greenhouse gas (GHG) emissions through acquisition of environmentally preferable products, conduct of operations, waste shipment, and pollution prevention and waste minimization practices; and

- reduce degradation and depletion of environmental resources through postconsumer material recycling; energy, fuel, and water conservation efforts; and use or promotion of renewable energy.

\subsubsection{Implementation and Operations}

UCOR protects the safety and health of workers and the public by identifying, analyzing, and mitigating aspects, hazards, and impacts from ETTP operations and by implementing sound work practices. All UCOR employees and subcontractors are held responsible for complying with all ES\&H requirements during all work activities and are expected to correct noncompliant conditions immediately. UCOR internal management assessments also provide a measure of how well EMS attributes are integrated into work activities through ISMS. UCOR has embodied its program for EC\&P of natural resources in a companywide environmental management and protection policy. The policy is UCOR's fundamental commitment to incorporating sound environmental management practices into all work processes and activities.

\subsubsection{Pollution Prevention/Waste Minimization}

UCOR's work control process requires that all waste-generating activities be evaluated for source reduction and that product substitution be used to produce a less toxic waste when possible. The reuse or recycling of building debris or other wastes generated is evaluated in all cases.

ETTP continues to operate its nationally recognized RFITS, an electronic waste management tracking system that uses paperless and otherwise enhanced transportation logistics to track and monitor onsite waste shipments to EMWMF. An electronic tracking station is shown in Fig. 3.7. The system eliminated errors associated with manual data entry, improved cycle times by 25 min per truck shipment (i.e., saving large quantities of fuel and paper that significantly reduces GHG emissions), improved

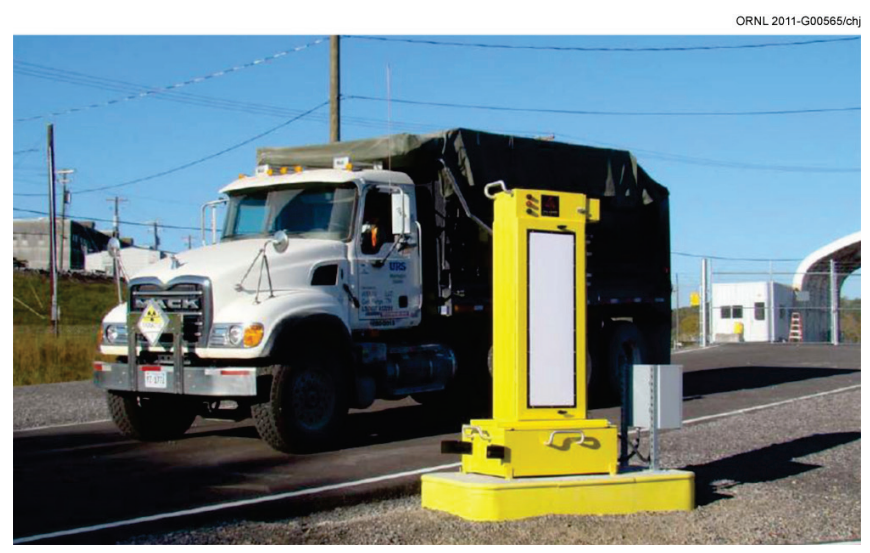

Fig. 3.7. Truck carrying a waste shipment passing through an electronic tracking station, part of the Radio Frequency Identification Transportation System en route to the Environmental Management Waste Management Facility.

performance of vehicle searches at truck stations when exiting controlled areas, and centralized logistics for all shipments to EMWMF. The overall project cost savings of \$15.6 million from using RFITS is shown in Table 3.1. 
Table 3.1. Radio Frequency Identification Transportation System sustainable results

\begin{tabular}{lc}
\hline \multicolumn{1}{c}{ Sustainable factor } & Results \\
\hline Diesel fuel use avoidance & $108,645 \mathrm{~L}$ \\
$\mathrm{NO}_{\mathrm{X}}$ and $\mathrm{CO}_{2}$ emissions avoidance & $5,039 \mathrm{~kg}$ and $287,845 \mathrm{~kg}$ \\
Paper and trees saved & 11 metric tons and 73 trees \\
\hline
\end{tabular}

\subsubsection{Competence, Training, and Awareness}

The UCOR training and qualification process ensures that needed skills for the workforce are identified and developed. The process also documents knowledge, experience, abilities, and competencies of the workforce for key positions requiring qualification. This process is described in PROC-TC-0702, Training Program. Completion and documentation of training, including required reading, are managed by the Local Education Administration Requirements Network.

\subsubsection{Communication}

UCOR communicates externally regarding environmental aspects through the UCOR public website, which includes a link to its environmental policy statement, POL-UCOR-007; a list of environmental aspects; and a link to the ISMS Description, PPD-EH-1400. A number of other documents and reports that address environmental aspects and cleanup progress are also published and made available to the public [e.g., ASER and the annual cleanup progress report (UCOR 2013)]. UCOR participates in a number of public meetings related to environmental activities at the site (e.g., ORSSAB meetings, permit review public meetings, and CERCLA decision document public meetings). Written communications from external parties are tracked using the weekly Open Action Report.

\subsubsection{Benefits and Successes of Environmental Management System Implementation}

UCOR uses EMS objectives and targets, an internal pollution prevention recognition program, environmentally preferable purchasing, work control processes, and a recycle program to meet sustainability and stewardship goals and requirements. The approach is outlined in UCOR's Pollution Prevention and Waste Minimization Program Plan for the East Tennessee Technology Park, Oak Ridge, Tennessee (UCOR 2013c). In 2012 the UCOR EMS program underwent the independent program verification required triennially by EO 13423 (CEQ 2007), which resulted in zero findings and five opportunities for improvement (mostly related to documentation). Further, the report noted several practices worthy of benchmarking. In 2013 UCOR conducted an internal management review of the EMS program that resulted in one finding and one observation, both of which were closed.

\subsubsection{Management Review}

Senior management review of EMS is performed at several layers and frequencies. A formal review/presentation with UCOR senior management that addresses the requirement elements contained in this section is conducted at least once per year. At least two of the senior managers are present for management reviews. The ISMS description is updated annually to address improvements and lessons learned and to update objectives and targets as necessary and signed by the UCOR president. The environmental policy is also reviewed during the management review annually and revised as necessary.

\subsection{Compliance Programs and Status}

During 2013, ETTP operations were conducted in compliance with contractual and regulatory environmental requirements, and there were no NPDES permit or Clean Air Act (CAA) noncompliances. 
Figure 3.8 shows the trend of NPDES compliance at ETTP since 1999. No notices of violation (NOVs) or penalties were issued to ETTP operations in 2012 or 2013. The following sections provide more detail on each compliance program and the related activities in 2013.

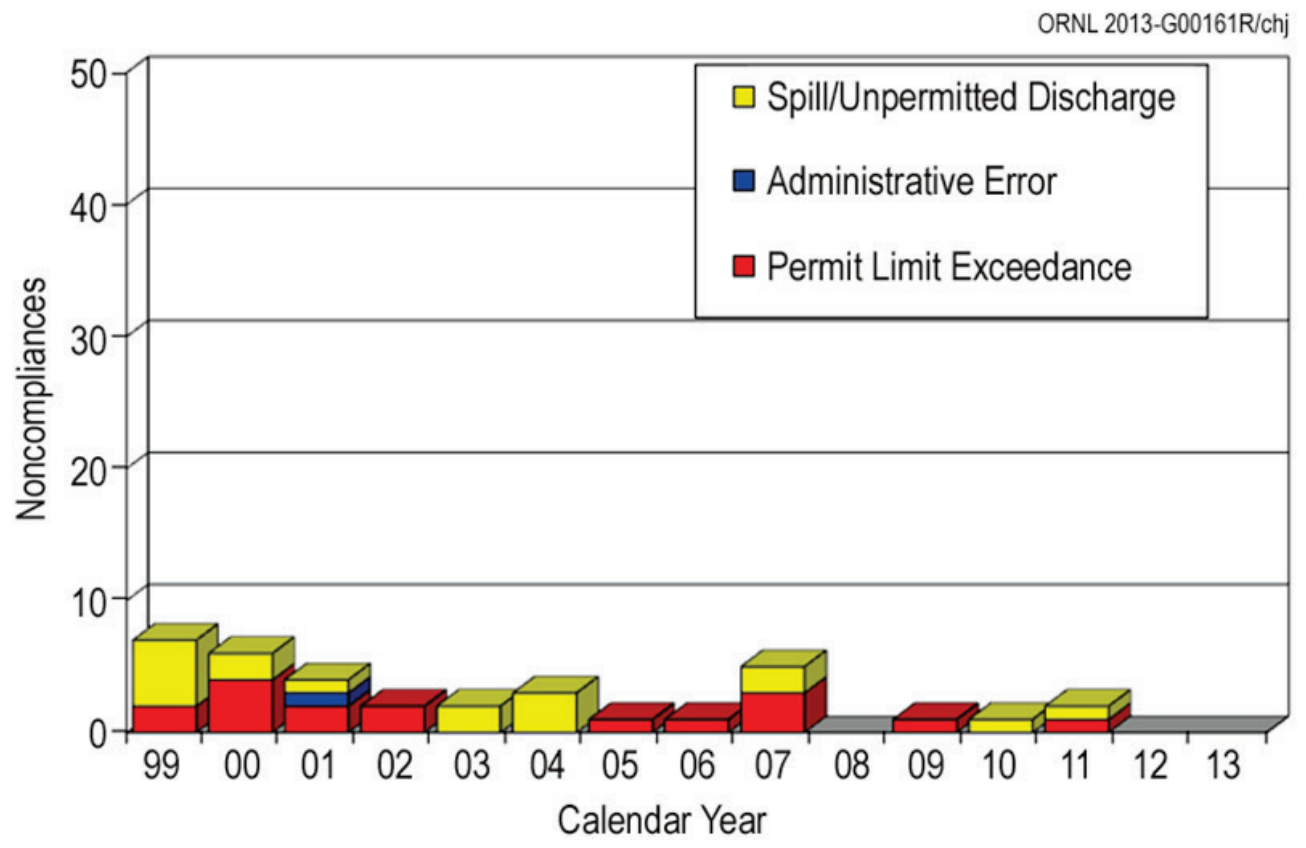

Fig. 3.8. East Tennessee Technology Park National Pollutant Discharge Elimination System permit compliance since 1999.

\subsubsection{Environmental Permits}

Table 3.2 contains a list of environmental permits that were in effect at ETTP in 2013.

\subsubsection{Notices of Violations and Penalties}

ETTP did not receive any NOVs or penalties from regulators in 2013.

\subsubsection{Audits and Oversight}

Table 3.3 presents a summary of environmental audits conducted at ETTP in 2013. 
Table 3.2. East Tennessee Technology Park Environmental Permits, 2013

\begin{tabular}{|c|c|c|c|c|c|c|c|}
\hline $\begin{array}{l}\text { Regulatory } \\
\text { driver }\end{array}$ & Permit title/description & Permit number & Issue date & Expiration date & Owner & Operator & $\begin{array}{l}\text { Responsible } \\
\text { contractor }\end{array}$ \\
\hline CAA & $\begin{array}{l}\text { State permit to construct or } \\
\text { modify an air contaminant } \\
\text { source-Internal combustion } \\
\text { engine-powered emergency } \\
\text { generators and fire water pump }\end{array}$ & $967220 \mathrm{P}$ & $08-22-2013$ & $08-23-2014$ & UCOR & $\mathrm{UCOR}$ & UCOR \\
\hline CWA & $\begin{array}{l}\text { NPDES permit for the Central } \\
\text { Neutralization Facility } \\
\text { Wastewater Treatment System }\end{array}$ & TN0074225 & $10-29-10$ & $\begin{array}{l}\text { Expired }^{a} \\
12-31-13\end{array}$ & UCOR & UCOR & UCOR \\
\hline CWA & $\begin{array}{l}\text { NPDES permit for storm water } \\
\text { discharges }\end{array}$ & TN0002950 & $02-26-10$ & $12-31-13^{b}$ & DOE & UCOR & UCOR \\
\hline CWA & $\begin{array}{l}\text { State operating permit-Waste } \\
\text { Transportation Project; Blair } \\
\text { Road and Portal } 6 \text { Sewage } \\
\text { Pump and Haul Permit }\end{array}$ & SOP-05068 & $08-19-11$ & $02-28-14$ & TOPS & TOPS & UCOR \\
\hline CWA & $\begin{array}{l}\text { State operating permit-- } \\
\text { K-1310-DF and K-1310-HG } \\
\text { Trailers }\end{array}$ & SOP-99033 & $04-30-10$ & $04-30-15$ & UCOR & UCOR & UCOR \\
\hline CWA & $\begin{array}{l}\text { State operating permit-- } \\
\text { K-1065 Facility; Trailer } \\
\text { K-1310-BS added in March } \\
2009\end{array}$ & SOP-01042 & $11-30-06$ & $\begin{array}{l}\text { Terminated } \\
5-31-11\end{array}$ & UCOR & UCOR & UCOR \\
\hline CWA & $\begin{array}{l}\text { Authorized/certified USTs at } \\
\text { K-1414 Garage }\end{array}$ & $\begin{array}{l}\text { Customer ID } \\
30166 \\
\text { Facility ID } \\
073008\end{array}$ & $03-20-89$ & Ongoing & DOE & UCOR & UCOR \\
\hline
\end{tabular}


Table 3.2. (continued)

\begin{tabular}{|c|c|c|c|c|c|c|c|}
\hline $\begin{array}{l}\text { Regulatory } \\
\text { driver }\end{array}$ & Permit title/description & Permit number & Issue date & Expiration date & Owner & Operator & $\begin{array}{l}\text { Responsible } \\
\text { contractor }\end{array}$ \\
\hline RCRA & $\begin{array}{l}\text { ETTP Container Storage and } \\
\text { Treatment Units }\end{array}$ & TNHW-117 & 09-30-04 & 09-30-14 & DOE & UCOR & UCOR \\
\hline RCRA & $\begin{array}{l}\text { Hazardous Waste Corrective } \\
\text { Action Document } \\
\text { (encompasses the entire ORR) }\end{array}$ & TNHW-121 & 09-28-04 & $09-28-14$ & DOE & $\mathrm{DOE} / \mathrm{All}{ }^{c}$ & $\mathrm{DOE} / \mathrm{All}{ }^{c}$ \\
\hline
\end{tabular}

${ }^{a}$ The Central Neutralization Facility ceased operation in 2013 and was permanently shut down. NPDES permit TN0074225 was allowed to expire.

${ }^{b}$ An NPDES permit renewal application has been submitted in a timely manner. In cases where permit renewal applications have been submitted to regulatory agencies in a timely manner, but a new permit has not been issued, permission is granted by regulators to continue operating under the terms of the existing but expired permit.

${ }^{c}$ DOE and all ORR co-operators of hazardous waste permits.

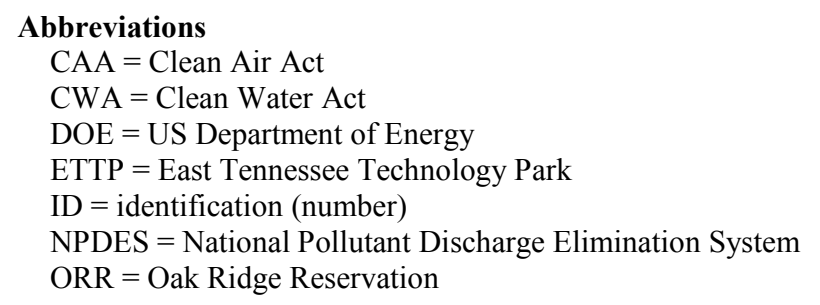

ischarge Elimination System

RCRA $=$ Resource Conservation and Recovery Act

SOP $=$ state operating permit

TOPS $=$ Transportation, Operations and Professional Services, Inc.

UCOR $=$ URS $\mid$ CH2M Oak Ridge LLC

UST $=$ underground storage tank 
Table 3.3. Regulatory oversight, assessments, inspections, and site visits at East Tennessee Technology Park, 2013

\begin{tabular}{lllc}
\hline \multicolumn{1}{c}{ Date } & \multicolumn{1}{c}{ Reviewer } & \multicolumn{1}{c}{ Subject } & Issues \\
\hline January 24 & TDEC & Inspection of ETTP USTs & 0 \\
February 11-12 & TDEC & Annual RCRA Compliance Inspection & 0 \\
September 30 & TDEC-Knoxville & CNF NPDES Compliance Evaluation Inspection & 0 \\
October 24 & EPA Region 4 & TSCA Incinerator -PCB Site Visit & 0 \\
\hline \multicolumn{4}{c}{ Abbreviations } \\
CNF = Central Neutralization Facility & RCRA = Resource Conservation and Recovery \\
EPA = US Environmental Protection Agency & Act \\
ETTP = East Tennessee Technology Park & TDEC = Tennessee Department of Environment \\
NPDES = National Pollutant Discharge & and Conservation \\
\multicolumn{2}{c}{ Elimination System } & TSCA = Toxic Substances Control Act \\
PCB = polychlorinated biphenyl & UST = underground storage tank &
\end{tabular}

\subsubsection{National Environmental Policy Act/National Historic Preservation Act}

The National Environmental Policy Act (NEPA) provides a means to evaluate the potential environmental impact of proposed federal activities and to examine alternatives to those actions. ETTP maintains compliance with NEPA through the use of site-level procedures and program descriptions that establish effective and responsive communications with program managers and project engineers to ensure NEPA is a key consideration in the formative stages of project planning. Many of the current operations at ETTP are conducted under CERCLA. NEPA reviews are part of the CERCLA planning process to ensure that NEPA values are incorporated into CERCLA projects and documentation.

During 2013, ETTP continued to operate under site-level, site-specific procedures that provide requirements for project reviews and NEPA compliance. These procedures call for a review of each proposed project, activity, or facility to determine the potential for impacts to the environment. To streamline the NEPA review and documentation process, DOE ORO has approved generic categorical exclusion (CX) determinations that cover certain proposed activities (i.e., maintenance activities, facilities upgrades, personnel safety enhancements). A CX is one of a category of actions defined in 40 CFR 1508.4 that does not individually or cumulatively have a significant effect on the human environment and for which neither an environmental assessment nor an environmental impact statement is normally required. UCOR activities on ORR are in full compliance with NEPA requirements, and procedures for implementing NEPA requirements have been fully developed and implemented. At ETTP, a checklist incorporating NEPA and EMS requirements has been developed as an aid for project planners. For routine, recurring activities, DOE generic CX determinations are used. During 2013, no new CX determinations for activities at ETTP were issued by DOE.

Compliance with the National Historic Preservation Act (NHPA) at ETTP is achieved and maintained in conjunction with NEPA compliance. The scope of proposed actions is reviewed in accordance with the ORR cultural resource management plan (Souza et al. 2001). At ETTP there were 135 facilities eligible for inclusion on the NRHP, as well as numerous facilities that were not eligible for inclusion on the NRHP. To date, more than 220 facilities have been demolished. Artifacts of historical and/or cultural significance are identified before demolition and are cataloged in a database to aid in historic interpretation of ETTP.

Consultation for the development of an MOA for D\&D of the K-25 and K-27 buildings started in 2001; the document, approved in 2003, required a third-party analysis of the preservation and interpretive strategies for those two buildings. In 2005 DOE, the Tennessee SHPO, and ACHP entered into an MOA that included the retention of the north end tower (also known as north wing, north end, north tower) of the K-25 building and Portal 4 (K-1028-45), among other features, as the "best and most cost-effective mitigation to permanently commemorate, interpret, and preserve the significance" of ETTP. Another series of consultation meetings ensued in 2009, and DOE advised that prohibitive costs and safety 
considerations precluded fulfillment of three stipulations in the 2005 MOA, including the preservation of the north end tower. The parties offered a wide array of potential mitigation measures and, in the absence of consensus on how best to commemorate Building K-25, DOE, SHPO, and ACHP entered into a bridge MOA until the parties could reach a final agreement. After completing an evaluation of the structural integrity of the K-25 building and interpretative approaches for the site, DOE distributed a preferred mitigation plan to the consulting parties in October 2011. The DOE final mitigation plan, addressing comments submitted by consulting parties in November 2011, permitted demolition of the entire K-25 building and called for, among other mitigation measures, the designation of a commemorative area around the building's perimeter from which future surface development would largely be restricted; the retention, if possible, of the entire concrete slab or the demarcation of the building's footprint; the construction of a viewing tower and of a structure for equipment display; and the development of a history center within the ETTP Fire Station. A final MOA was signed in August 2012 finalizing the aspects set forth in the mitigation plan. During 2013, a request for proposal was issued for a "Professional Design Team and Museum Professional" as specified in the MOA. Nine firms were prequalified, and the selection and award are expected in 2014. The procurement process for the K-25 "virtual museum" web design firm was also begun in 2013. This procurement and award should be completed in 2014.

\subsubsection{Clean Air Act Compliance Status}

CAA, passed in 1970 and amended in 1977 and 1990, forms the basis for the national air pollution control effort. This legislation establishes comprehensive federal and state regulations to limit air emissions and includes five major regulatory programs: the National Ambient Air Quality Standards, State Implementation Plans, New Source Performance Standards (NSPSs), Prevention of Significant Deterioration permitting programs, and National Emission Standards for Hazardous Air Pollutants (NESHAPs). Airborne discharges from DOE Oak Ridge facilities, both radioactive and nonradioactive, are subject to regulation by EPA and the TDEC Division of Air Pollution Control.

\subsubsection{Clean Water Act Compliance Status}

The objective of CWA is to restore, maintain, and protect the integrity of the nation's waters. This act serves as the basis for comprehensive federal and state programs to protect the waters from pollutants (see Appendix C for water reference standards). One of the strategies developed to achieve the goals of CWA was EPA establishment of limits on specific pollutants allowed to be discharged to US waters by municipal sewage treatment plants (STPs) and industrial facilities. EPA established the NPDES permitting program to regulate compliance with pollutant limitations. The program was designed to protect surface waters by limiting effluent discharges into streams, reservoirs, wetlands, and other surface waters. EPA has delegated authority for implementation and enforcement of the NPDES program to the State of Tennessee. In CY 2013, ETTP discharged to the waters of the state of Tennessee under two individual NPDES permits:

- NPDES permit TN0002950, which regulates storm water discharges, and

- NPDES permit TN0074225, which regulates industrial discharges from the Central Neutralization Facility (CNF).

In 2013, compliance with ETTP NPDES storm water permit TN0002950 was determined by more than 200 laboratory analyses, field measurements, and flow estimates. The NPDES permit compliance rate for all discharge points for 2013 was $100 \%$.

In 2013, compliance with the ETTP NPDES permit for industrial wastewater from CNF was determined by almost 1,000 laboratory analyses and field measurements. The CNF NPDES permit compliance rate for 2013 was $100 \%$ with no noncompliances. The CNF facility was permanently shut down in August 2013 and did not discharge in the months of September through December 2013. The CNF NPDES permit was allowed to expire on December 31, 2013. 


\subsubsection{National Pollutant Discharge Elimination System Permit Noncompliances}

During 2013 ETTP and UCOR operations were conducted in compliance with contractual and regulatory environmental requirements. There were no NPDES permit noncompliances in 2013.

\subsubsection{Safe Drinking Water Act Compliance Status}

The ETTP water distribution system is designated as a nontransient, noncommunity water system by TDEC's Division of Water Supply. Chapter 0400-45-01 of the Tennessee regulations for public water systems (TDEC 2012) sets limits for biological contaminants and for chemical activities and chemical contaminants. TDEC requires sampling for the following constituents for compliance with state and federal regulations:

- chlorine residual levels,

- bacteriological (total coliform),

- lead and copper, and

- disinfectant by-products (trihalomethanes and haloacetic acids).

The City of Oak Ridge supplies potable water to the ETTP water distribution system. The water treatment plant, located on ORR, southwest of ETTP, is owned and operated by the City of Oak Ridge.

\subsubsection{Resource Conservation and Recovery Act Compliance Status}

ETTP is regulated as a large-quantity generator of hazardous waste because the facility generates more than $1,000 \mathrm{~kg}$ of hazardous waste per month. This amount includes hazardous waste generated under permitted activities (including repackaging or treatment residuals). At the end of 2013, ETTP had three generator accumulation areas for hazardous or mixed waste.

In addition, ETTP is permitted to store and treat hazardous and mixed waste under Resource Conservation and Recovery Act (RCRA) Part B Permit TNHW-117. Hazardous waste may be treated and stored at permitted locations in Building K-1423 and at the K-1065 complex. This hazardous waste permit will be expiring in September 2014, and activities have commenced to prepare the permit renewal application for submission to TDEC at least 180 days before the permit expiration date.

There were no RCRA generator or permitted noncompliances in 2013.

\subsubsection{Resource Conservation and Recovery Act Underground Storage Tanks}

Underground storage tanks (USTs) containing petroleum and hazardous substances are regulated under RCRA Subtitle I (40 CFR 280). EPA granted TDEC authority to regulate USTs containing petroleum under TDEC Rule 0400-18-01 Underground Storage Tank Programs; however, EPA still regulates hazardous-substance USTs.

\subsubsection{Comprehensive Environmental Response, Compensation, and Liability Act Compliance Status}

CERCLA, also known as Superfund, was passed in 1980 and was amended in 1986 by the Superfund Amendments and Reauthorization Act (SARA). Under CERCLA, a site is investigated and remediated if it poses significant risk to health or the environment. The EPA National Priorities List (NPL) is a comprehensive list of sites and facilities that have been found to pose a sufficient threat to human health and/or the environment to warrant cleanup under CERCLA. ORR is on the NPL.

\subsubsection{East Tennessee Technology Park RCRA-CERCLA Coordination}

The ORR federal facility agreement (FFA; DOE 1994) is intended to coordinate the corrective action processes of RCRA required under the Hazardous and Solid Waste Amendments permit with CERCLA response actions. 


\subsubsection{Toxic Substances Control Act Compliance Status-Polychlorinated Biphenyls}

On April 3, 1990, DOE notified EPA headquarters (as required by 40 CFR 761.205) that ETTP is a generator with on-site storage, a transporter, and an approved disposer of PCB wastes.

PCB waste generation, transportation, disposal, and storage at ETTP are regulated under EPA ID number TN0890090004. In 2013, ETTP operated 10 PCB waste storage areas in ETTP generator buildings, and when longer term storage of PCB/radioactive wastes was necessary, RCRA-permitted storage buildings were used. The continued use of authorized PCBs in electrical systems and/or equipment (e.g., transformers, capacitors, rectifiers) is regulated at ETTP. At this time, no PCBcontaminated electrical equipment is in service at ETTP. Most Toxic Substances Control Act(TSCA)-regulated equipment at ETTP has been disposed of. However, some ETTP facilities continue to use or store nonelectrical PCB-contaminated equipment for future reuse.

Because of the age of many ETTP facilities and the varied uses for PCBs in gaskets, grease, building materials, and equipment, DOE self-disclosed unauthorized use of PCBs to EPA in the late 1980s. As a result, the DOE ORO and EPA Region 4 consummated a major compliance agreement known as the Oak Ridge Reservation Polychlorinated Biphenyl Federal Facilities Compliance Agreement (DOE 2012), which became effective December 16, 1996, and was last revised on May 23, 2012. The agreement specifically addresses the unauthorized use of PCBs in ventilation ducts and gaskets, lubricants, hydraulic systems, heat transfer systems, and other unauthorized uses; storage for disposal; disposal; cleanup and/or decontamination of PCBs and PCB items including PCBs mixed with radioactive materials; and ORR records and reporting requirements. A major focus of the agreement is the disposal of PCB waste. As a result of that agreement, DOE and UCOR continue to notify EPA when additional unauthorized uses of PCBs, such as PCBs in paint, adhesives, electrical wiring, or floor tile, are identified at ETTP.

ETTP was home to the TSCA Incinerator. On December 2, 2009, the TSCA Incinerator ceased operations as a waste incinerator and transitioned to a facility closure and decommissioning mode. The RCRA and PCB closure certification report for the TSCA Incinerator RCRA Permitted Unit areas was submitted to EPA and TDEC on June 10, 2011. A Closure Certification Letter was issued by EPA Region 4 on June 14, 2012, and by TDEC on September 21, 2012. The PCB Institutional Control walkdown inspection was completed in July 2012. During 2012, the primary focus at the TSCA Incinerator was completing the decontamination of the Permit-by-Rule components of the TSCA Incinerator facility for RCRA and TSCA closure actions. The decontamination steps were completed in 2012, and the Permit-by-Rule components of the facility are no longer active.

During 2012, a postclosure TSCA Incinerator PCB Institutional Control Plan that requires monthly inspections of the facility was implemented and will remain in effect as agreed upon in the closure certification while the facility is in a surveillance and maintenance (S\&M) mode pending demolition.

\subsubsection{Emergency Planning and Community Right-to-Know Act Compliance Status}

The Emergency Planning and Community Right-to-Know Act (EPCRA) and Title III of SARA require that facilities report inventories and releases of hazardous and toxic chemicals that exceed threshold planning quantities. The reports are submitted to the local emergency planning committee and the state emergency response commission and the local fire department. ETTP complied with these requirements in 2013 through the submittal of reports under EPCRA Sections 302, 303, 311, and 312. ETTP had no releases of extremely hazardous substances, as defined by EPCRA, in 2013.

\subsubsection{Chemical Inventories (EPCRA Section 312)}

Inventories, locations, and associated hazards of hazardous and extremely hazardous chemicals were submitted in an annual report to state and local emergency responders as required by EPCRA Section 312. Of the ORR chemicals identified for 2013, nine were located at ETTP. These chemicals were nickel metal, lead metal (includes large lead acid batteries), sodium metal, diesel fuel, sulfuric acid 
(includes large lead acid batteries), Chemical Specialties Ultrapoles, creosote-treated wood, unleaded gasoline, and Sakrete Type S or N mortar mix.

\subsubsection{Toxic Chemical Release Reporting (EPCRA Section 313)}

Section 313 requires facilities to complete and submit a toxic chemical release inventory (TRI) form (Form R) annually. Form R must be submitted for each TRI chemical that is manufactured, processed, or otherwise used in quantities above the applicable threshold quantity. A Form $\mathrm{R}$ for each chemical must be submitted by July 1 of each year. DOE electronically submits annual TRI reports to EPA on or before July 1 of each year. The reports address releases of certain toxic chemicals to air, water, and land and waste management, recycling, and pollution prevention activities. Threshold determinations and reports for each of the ORR facilities are made separately. Operations involving TRI chemicals were compared with regulatory thresholds to determine which chemicals exceeded the reporting thresholds based on amounts manufactured, processed, or otherwise used at each facility. After threshold determinations were made, releases and off-site transfers were calculated for each chemical that exceeded the threshold quantity. In 2013, the only chemicals that met the reporting requirements were diisocyanates associated with foaming activity to stabilize deposits in pipes undergoing remediation actions.

\subsection{Quality Assurance Program}

\subsubsection{Integrated Assessment and Oversight Program}

Quality assurance (QA) program implementation and procedural and subcontract compliance are verified through the UCOR Integrated Assessment and Oversight Program. The program identifies the processes for planning, conducting, and coordinating assessment and oversight of UCOR activities, including both self-performed and subcontracted activities, resulting in an integrated assessment and oversight process. The program is composed of three key elements: (1) external assessments conducted by organizations external to UCOR, (2) independent assessments conducted by teams independently of the project/function being assessed, and (3) management assessments and surveillances conducted as selfassessments and surveillances by the organization or on behalf of the organization manager.

Self-assessments are performed by the organization/function with primary responsibility for the work, process, or system being assessed. Organizations and functions within the company plan and schedule self-assessments. Self-assessments encompass both formal and informal assessments. The formal selfassessments include management assessments and surveillances and subcontractor oversight. Informal self-assessments include weekly inspections and routine walkthroughs conducted by subcontractor coordinators, ES\&H and QA representatives, quality engineers, and line managers.

Conditions adverse to quality identified from internal and external assessments are documented, causal analyses are performed, and corrective actions are developed and tracked to closure. Analyses are conducted periodically to identify trends for management action. Senior management evaluates data from those processes to identify opportunities for improvement.

\subsection{Air Quality Program}

The State of Tennessee has been relegated authority by EPA to convey the clean air requirements that are applicable to ETTP operations. New projects are governed by construction and operating permit regulatory requirements. The owner or operator of air pollutant emitting sources is responsible for ensuring full compliance with any issued permit or other generally applicable CAA requirement. During 2013, ETTP DOE EM operations were under UCOR responsibility for regulatory compliance

\subsubsection{Construction and Operating Permits}

During 2013, UCOR ETTP operations became subject to amended CAA regulations and permitting under TDEC Air Pollution Control Rules. The regulations were specific to stationary fossil-fueled reciprocating internal combustion engines (RICEs) for emergency use. UCOR has responsibility for five 
RICE units subject to permitting and therefore prepared and submitted permit applications. TDEC issued a Permit to Construct or Modify (967220P) with an effective date of August 22, 2013. The permit covers compliance demonstration requirements for four emergency generators and one fire water pump system. Compliance for all units is demonstrated by following specified maintenance schedules, limiting hours of operations for nonemergencies to $100 \mathrm{~h}$ /year, and record keeping. Regulations exempt any operating hours of these units during unscheduled (emergency) power outages. All other ETTP operations that do emit low levels of air pollutants have been classified as insignificant under TDEC rules. Any planned stationary sources that may emit air pollutants are evaluated and compared against applicable pollutant emission limits to document this classification and pursue permitting if required under TDEC regulations.

\subsubsection{Generally Applicable Permit Requirements}

ETTP is subject to a number of generally applicable requirements that involve management and control. Asbestos, ozone-depleting substances (ODSs), and fugitive particulate emissions are specific examples.

\subsection{Control of Asbestos}

ETTP's asbestos management program ensures all activities involving demolitions and all other actions impacting asbestos-containing materials (ACMs) are fully compliant with 40 CFR 61, Subpart M. This includes using approved engineering controls and work practices, inspections, and monitoring for proper removal and waste disposal of ACMs. ETTP has numerous buildings and equipment that contain ACMs. Major demolition activities during 2013 involved the abatement of significant quantities of ACMs that were subject to the requirements of 40 CFR 61, Subpart M. Most demolition and ACM abatement activities are governed under CERCLA. Under this act, notifications of asbestos demolition or renovations as specified in 40 CFR 61.145(b) are incorporated into CERCLA document regulatory notifications. All other non-CERCLA planned demolition or renovation activities were individually reviewed for applicability of the TDEC notification requirements of the rule. During 2013, no individual non-CERCLA ETTP activity required a notification submittal. The rule also requires an annual notification for all nonscheduled minor asbestos renovations if the accumulated total amount of regulated or potentially regulated asbestos exceeds stipulated thresholds. For 2013 the total ETTP projected nonscheduled amounts were below thresholds that would require the submittal of an annual notification to TDEC. No releases of reportable quantities of ACMs occurred at ETTP during 2013.

\subsection{Stratospheric Ozone Protection}

The management of ODSs at ETTP is subject to regulations in 40 CFR Part 82, Subpart F, Recycling and Emissions Reduction; these regulations require preparation of documentation to establish that actions necessary to reduce emissions of Class I and Class II refrigerants to the lowest achievable level have been observed during maintenance activities at ETTP. The applicable actions include, but may not be limited to, the service, maintenance, repair, and disposal of appliances containing Class I and Class II refrigerants, including motor vehicle air-conditioners. In addition, the regulations apply to refrigerant reclamation activities, appliance owners, manufacturers of appliances, and recycling and recovery equipment. Figure 3.9 illustrates the historical on-site ODS inventory at ETTP. 


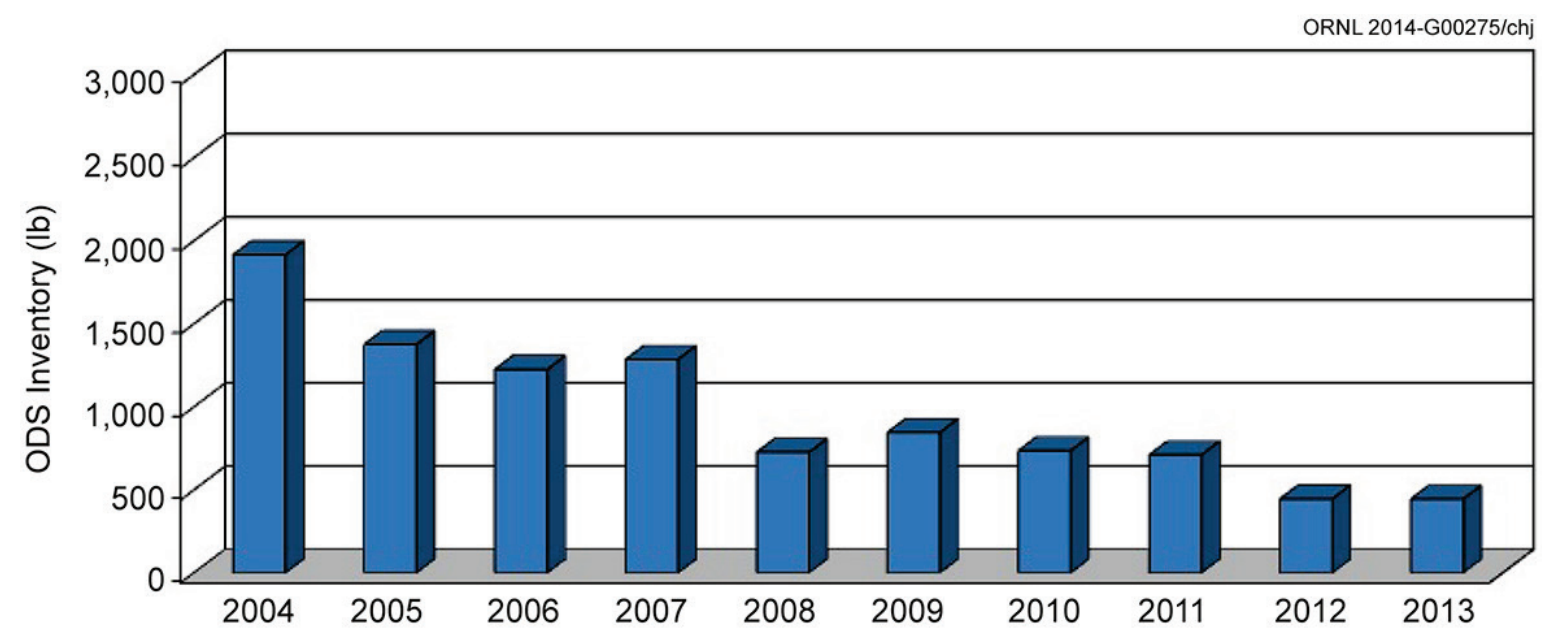

Fig. 3.9. East Tennessee Technology Park total on-site ozone depleting substances (ODSs) inventory 10-year history.

\subsection{Fugitive Particulate Emissions}

ETTP has been the location of major building demolition activities and waste debris transportation with the potential for release of fugitive dust. All planned and ongoing activities include the use of dust control measures to minimize the release of visible fugitive dust beyond the project perimeter. This includes the use of specialized demolition equipment and water misters. Gravel roads in and around ETTP that are under DOE control are wetted as needed to minimize airborne dusts caused by vehicle traffic.

\subsubsection{Radionuclide National Emission Standards for Hazardous Air Pollutants}

Radionuclide airborne emissions from ETTP are regulated under 40 CFR 61, National Emission Standards for Hazardous Air Pollutants: Department of Energy Facilities (Rad-NESHAPs). Characterization of the impact on public health of radionuclides released to the atmosphere from ETTP operations was accomplished by conservatively estimating the dose to the maximally exposed member of the public. The dose calculations were performed using the Clean Air Assessment Package (CAP-88) computer codes, which were developed under EPA sponsorship for use in demonstrating compliance with the $10 \mathrm{mrem} /$ year effective dose (ED) Rad-NESHAPs for the entire DOE ORR. Source emissions used to calculate the dose are determined using EPA-approved methods that can range from continuous in-stack sampling systems and ambient air sampling to conservative estimations based on process and waste characteristics. Continuous in-stack sampling systems are required for radionuclide-emitting sources that have a potential dose impact of not less than 0.1 mrem per year to any off-site member of the public. ETTP Rad-NESHAPs sources - the K-1407 CNF Volatile Organic Compound (VOC) Air Stripper; K-1407 Chromium Water Treatment System (CWTS) VOC Air Stripper; K-2527-BR Grouting Facility; and K-2500-H Segmentation Shops A, B, C, and D-are considered minor based on emissions evaluations using EPA-approved calculation methods. A minor Rad-NESHAPs source is defined as having a potential dose impact on the public not in excess of $0.1 \mathrm{mrem} /$ year. Figure 3.10 provides a historical dose trend on the most impacted on-site member of the public. The results are based on actual ambient air sampling in a location conservatively representative to the on-site location. 


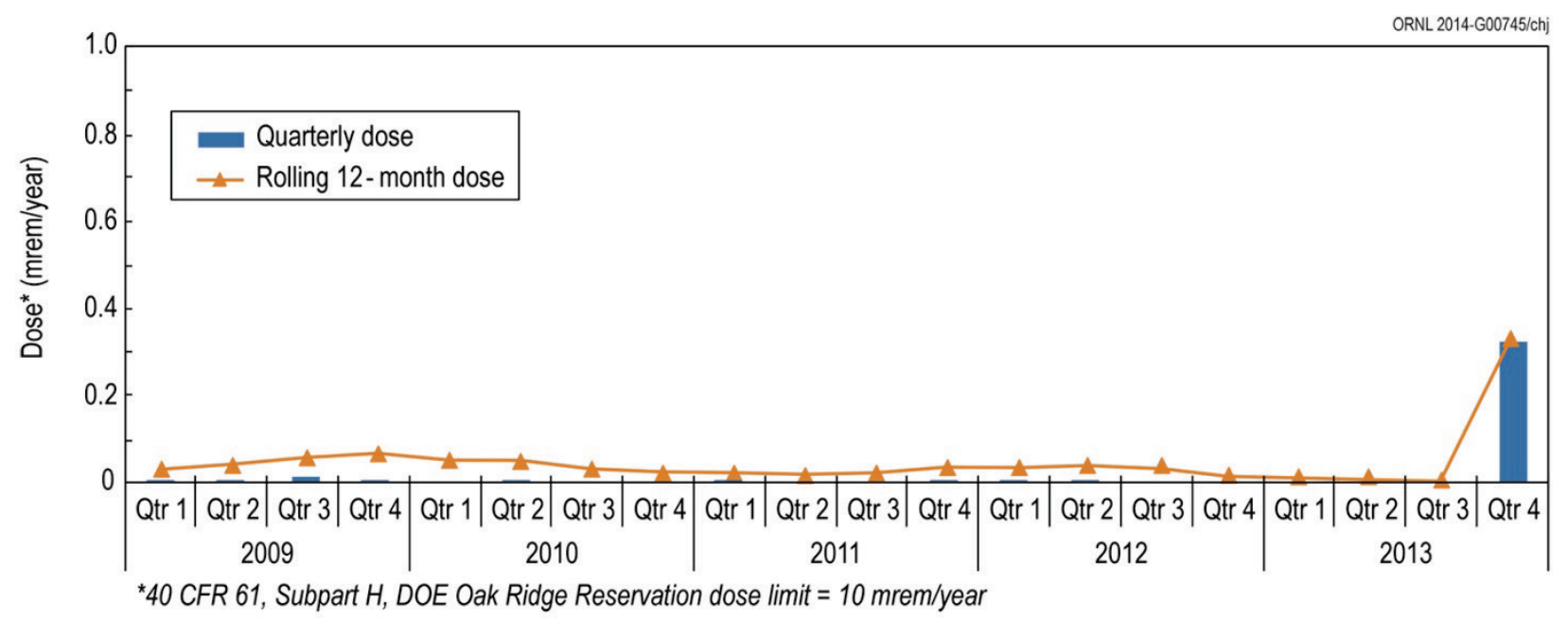

Fig. 3.10. East Tennessee Technology Park ambient air station K11 radionuclide quarterly and rolling 12-month effective dose results from January 2009 through December 2013.

Historically, the annual dose impact at ETTP ambient air sampling locations has been based on quarterly composites prepared from weekly samples. A comparison of ETTP results with data provided by TDEC using a colocated sampler at K11 indicated a reasonable correlation between the two data sets for the first three quarters of 2013 for both ${ }^{99} \mathrm{Tc}$ and the uranium isotopes. The uranium isotope results also correlated well for the fourth quarter. However, the ETTP fourth quarter K11 ${ }^{99} \mathrm{Tc}$ composite results did not show a good correlation with the TDEC results. The TDEC ${ }^{99} \mathrm{Tc}$ results were significantly higher. Both data sets indicated a significant increase in ambient air concentrations of ${ }^{99} \mathrm{Tc}$ at K11 during the fourth quarter, and both data sets yield dose modeling results well below the annual effective dose limit of $10 \mathrm{mrem}$. Because of this difference, biweekly composite samples of ETTP archived filter remnants were prepared and submitted for ${ }^{99} \mathrm{Tc}$ analysis. The biweekly time periods were very similar to those used by TDEC. The ambient air concentrations of ${ }^{99} \mathrm{Tc}$ based on the results of the ETTP biweekly composite samples were very consistent with the TDEC biweekly composite sample results.

A follow-up investigation of the original ETTP fourth quarter composite ${ }^{99} \mathrm{Tc}$ laboratory results identified an issue with a spike recovery percentage that was around $18 \%$ as compared to a more typical expectation of $100 \%$ recovery. The spike recovery for the ETTP biweekly fourth quarter laboratory results was within acceptable limits. Due to data quality concerns with potentially underreporting the ${ }^{99} \mathrm{Tc}$ dose contributions from the fourth quarter ${ }^{99} \mathrm{Tc}$ composite result, the ETTP biweekly ${ }^{99} \mathrm{Tc}$ results were used to represent the air concentrations at the K11 station for the fourth quarter of CY 2013. Follow-up corrective action discussions with the commercial laboratory conducting the ${ }^{99} \mathrm{Tc}$ analyses are ongoing.

Figure 3.10 provides the historical dose impact at K11 up through 2013. This sampling location is representative of the most impacted on-site member of the public from both point and fugitive airborne radionuclide emissions. The annual dose impact of about $0.3 \mathrm{mrem}$ during the fourth quarter of 2013 is very significant compared to previous results. This impact represents only $3 \%$ of the annual limit of 10 mrem to any on-site or off-site member of the public. (Refer to Section 3.5.2 for additional sampling data and discussions of station $\mathrm{K} 2, \mathrm{~K} 6$, and $\mathrm{K} 11$ results.)

\subsubsection{Quality Assurance}

QA activities for the Rad-NESHAPs program are documented in the Quality Assurance Program Plan for Compliance with Radionuclide National Emission Standards for Hazardous Air Pollutants (UCOR 2012d). The plan satisfies the QA requirements in 40 CFR 61, Method 114, for ensuring that the radionuclide air emission measurements from ETTP are representative of known levels of precision and accuracy and that administrative controls are in place to ensure prompt response when emission measurements indicate an increase over normal radionuclide emissions. The requirements are also 
referenced in TDEC regulation 1200-3-11-08. The plan ensures the quality of ETTP radionuclide emission measurement data from continuous samplers and minor radionuclide release points. Only EPA preapproved methods are referenced through the Rad-NESHAP Compliance Plan on the Oak Ridge Reservation (DOE 2005).

\subsubsection{Greenhouse Gas Emissions}

The EPA mandatory GHG reporting rule was enacted September 30, 2009, under 40 CFR Part 98.2. According to the rule, in general, the stationary source emissions threshold for reporting is 25,000 metric tons or more of $\mathrm{GHG}$ emissions per year, reported as $\mathrm{CO}_{2}$ equivalents $\left(\mathrm{CO}_{2} \mathrm{e}\right)$ per year. The rule defines GHGs as

- carbon dioxide $\left(\mathrm{CO}_{2}\right)$,

- methane $\left(\mathrm{CH}_{4}\right)$,

- $\quad$ nitrous oxide $\left(\mathrm{N}_{2} \mathrm{O}\right)$,

- hydrofluorocarbons,

- perfluorocarbons, and

- $\quad$ sulfur hexafluoride $\left(\mathrm{SF}_{6}\right)$.

A 2013 review was performed of ETTP processes and equipment categorically identified under 40 CFR 98.2 whose emissions must be included as part of a facility annual GHG report starting with the calendar year 2010 reporting period. Based on total GHG emissions from all ETTP stationary sources during 2013, ETTP did not exceed the annual threshold limit and therefore was not subject to mandatory annual reporting under the GHG rule during this performance period. The total GHG emissions for any continuous 12-month period beginning with calendar year 2008 have not exceeded 12,390 metric tons. The decrease in stationary source emissions is due to the permanent cessation of waste processing at the TSCA Incinerator in 2009 and ongoing facility demolitions. The remaining sources are predominantly small comfort heating systems, hot water systems, and power generators. Figure 3.11 shows the historical trend of ETTP total GHG stationary emissions including contributions from the TSCA Incinerator. For the 2013 calendar year period, GHG emissions totaled only 201 metric tons.

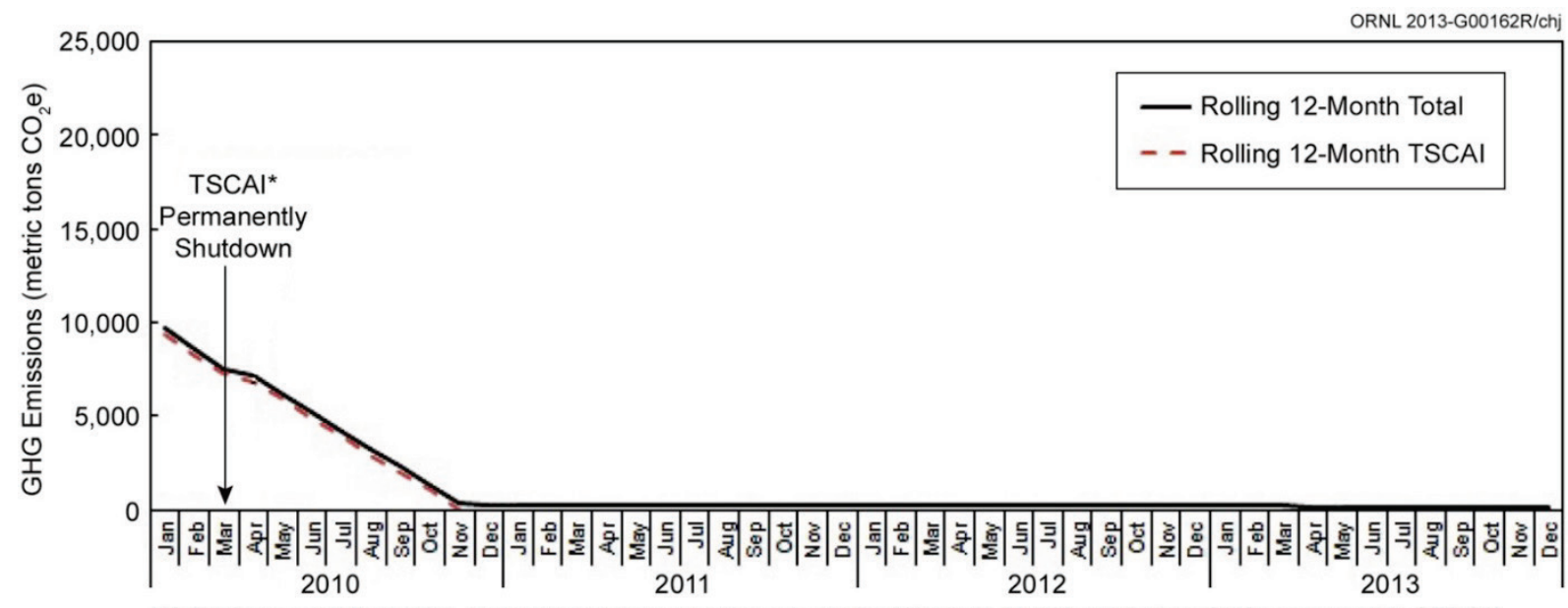

US Environmental Protection Agency mandatory reporting rule applicability limit: 25,000 metric tons GHGs per year (40 CFR 98). *Toxic Substances Control Act incinerator

Fig. 3.11. East Tennessee Technology Park tracking history for stationary source greenhouse gas (GHG) emissions [in $\mathrm{CO}_{2}$ equivalents $\left(\mathrm{CO}_{2} \mathrm{e}\right)$ ] (rolling 12-month totals).

EO 13514, Federal Leadership in Environmental, Energy, and Economic Performance, was signed by President Obama on October 5, 2009. The purpose of this order is to establish policies for federal facilities that will increase energy efficiency; measure, report, and reduce GHG emissions from direct and indirect activities; conserve and protect water resources through efficiency, reuse, and storm water 
management; eliminate waste; recycle; and prevent pollution at all such facilities. While the order deals with a number of environmental media, only it's applicability to GHGs is considered here. The executive order defines three distinct scopes for purposes of reporting. Scope 1 is essentially direct GHG emissions from sources that are owned or controlled by a federal agency; Scope 2 encompasses GHG emissions resulting from the generation of electricity, heat, or steam, including energy purchased by a federal agency; and Scope 3 involves GHG emissions from sources not owned or directly controlled by a federal agency but related to agency activities such as vendor supply chains, delivery services, and employee business travel and commuting.

Figure 3.12 displays the trend toward meeting the 28\% total Scopes 1 and 2 GHG emissions reduction target by FY 2020 as stated in the DOE Strategic Sustainability Performance Plan (SSPP; DOE 2013). FY 2013 emissions totaled 16,065 metric tons $\mathrm{CO}_{2} \mathrm{e}$ as compared to the target level of 31,847 metric tons $\mathrm{CO}_{2} \mathrm{e}$, which shows a $64 \%$ reduction to date as compared to the 2008 baseline year level of 44,232 metric tons.

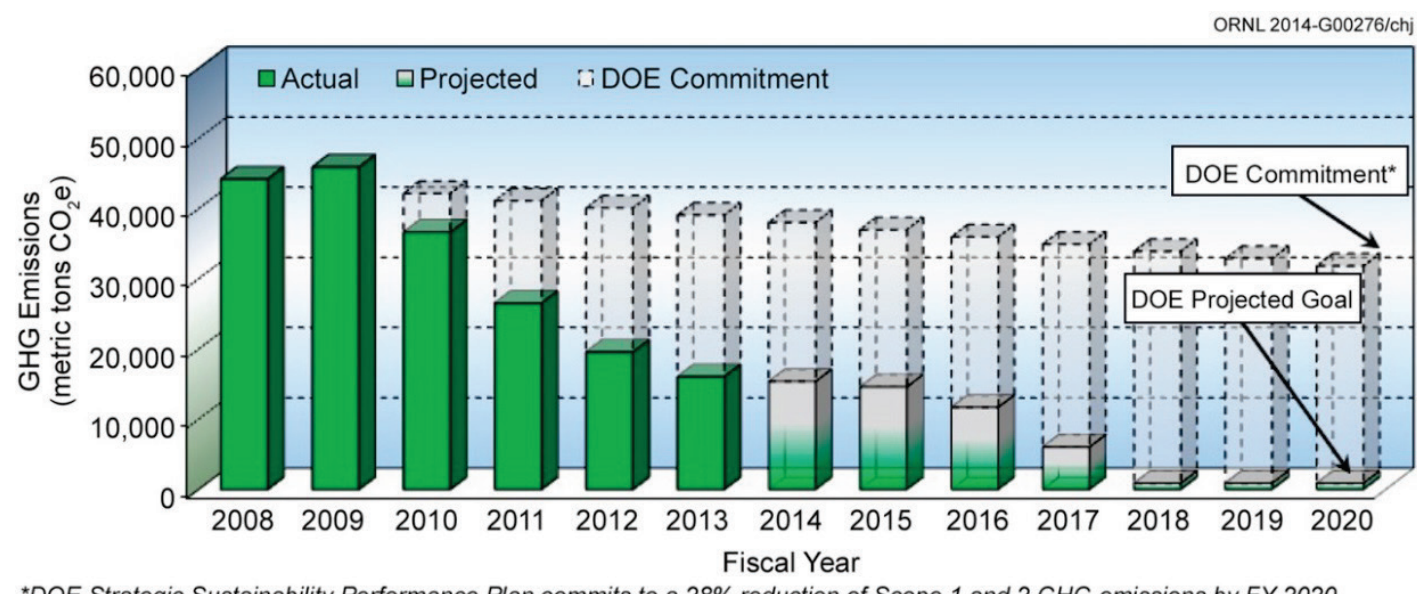

${ }^{*}$ DOE Strategic Sustainability Performance Plan commits to a 28\% reduction of Scope 1 and 2 GHG emissions by FY 2020.

Fig. 3.12. East Tennessee Technology Park greenhouse gas (GHG) emissions trend and targeted reduction commitment [both in $\mathrm{CO}_{2}$ equivalents $\left(\mathrm{CO}_{2} \mathrm{e}\right)$ ].

Figure 3.13 shows the relative distribution of ETTP FY 2013 GHG emissions for Scopes 1, 2, and 3. Total GHG emissions continue to decline as demolition and remediation efforts continue at ETTP. Much of the reduction is the result of lower combustion of fuels on the site (stationary and mobile sources), a drop in the consumption of electricity, and a smaller workforce.

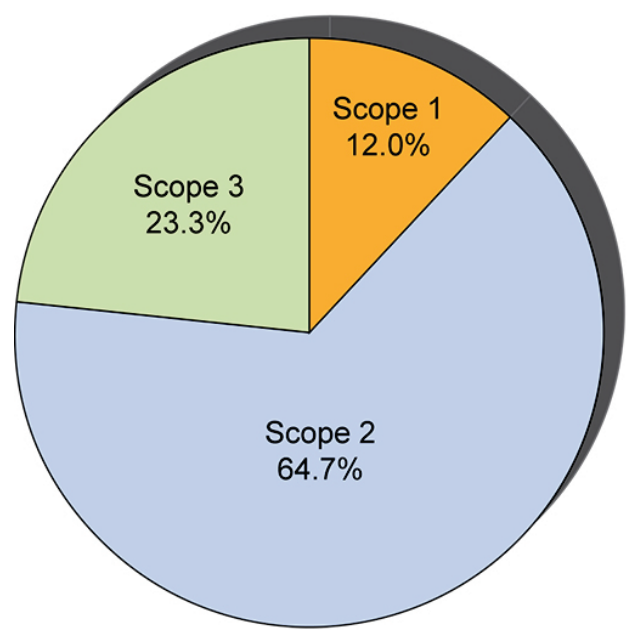

ORNL 2014-G00277/chj

Fig. 3.13. CY 2013 East Tennessee Technology Park (ETTP) greenhouse gas (GHG) emissions distributed among the scopes defined in Executive Order 13514. 


\subsubsection{Source-Specific Criteria Pollutants}

ETTP operations up until July 1, 2011, included only one functioning stationary source with permit restrictions for any form of criteria air pollutant emissions: the CNF VOC air stripper. This permit was surrendered following an updated potential to emit review that identified air pollutant emissions to be below any regulatory requirement for permitting. During December, 2011, the new CWTS began operations. This unit is equipped with an air stripper to remove VOCs from the effluent stream. All process data records and the calculated potential maximum VOC emission rates for the CNF and CWTS air strippers were well below levels that would require permitting. The calculated maximum VOC annual emissions for CNF and CWTS were only 6.5E-03 ton/year and 9.1E-03 ton/year, respectively, as compared to an emission limit of 5 ton/year. The annual potential emissions for these facilities would be well below the 5 ton/year limit assuming both operated at the maximum hourly emission rates continuously for the entire year. All other stationary sources were evaluated and determined to have emissions levels below the levels that require permitting.

New regulations became effective during 2013 that required UCOR to obtain permits for existing and new stationary RICEs used for emergency purposes at ETTP. To demonstrate compliance with requirements to assure allowable emission levels are not exceeded, prescribed maintenance routines must be followed and hours of nonemergency operations must be limited. The permit became effective on August 22, 2013. From the effective date through the end of 2013 none of the five permitted RICE units exceeded the $100 \mathrm{~h} /$ year limit for nonemergency operations. The highest operating time was incurred by the RICE emergency generator located at K-1007. The total hours recorded on this unit from the effective date of the permit was only 11.9. This time also includes operating during a plant wide power outage lasting $3.3 \mathrm{~h}$. (The $3.3 \mathrm{~h}$ were categorized as an emergency event and not considered against the $100 \mathrm{~h}$ annual limit.) For the whole 2013 period, this same unit had the most operating hours; however, the total 2013 run time, $33.3 \mathrm{~h}$, was well within regulatory limit of $100 \mathrm{~h}$.

ETTP operations released airborne pollutants from a variety of minor pollutant-emitting sources such as stacks, vents, and fugitive and diffuse activities. All stacks and vents are evaluated following approved methods to establish their low emissions potential. This is done to document the verification of their minor source permit exempt status under all applicable state and federal regulations.

\subsubsection{Hazardous Air Pollutants (Nonradionuclide)}

Unplanned releases of hazardous air pollutants (HAPs) are regulated through the risk management planning regulations under 40 CFR 68. To ensure compliance, periodic inventory reviews of ETTP operations were performed that used monthly data obtained through the EPCRA Section 311 reporting program. This program applies to any facility at which a hazardous chemical is present in an amount exceeding a specified threshold. A comparison of the EPCRA 311 monthly Hazardous Materials Information System chemical inventories at ETTP with the risk management plan (RMP) threshold quantities listed in 40 CFR 68.130 was conducted. This is an ongoing action that documents the potential applicability for maintaining and distributing an RMP and ensures threshold quantities are not exceeded.

ETTP personnel have determined that there are no processes or facilities containing inventories of chemicals in quantities exceeding thresholds specified in rules pursuant to CAA, Title III, Sect. 112(r), "Prevention of Accidental Releases." The results of this review indicated that all RMP-listed chemicals were less than $1 \%$ of their specific trigger threshold. Therefore, activities at ETTP are not subject to the rule. Procedures are in place to continually review new processes, process changes, or activities with the rule thresholds.

\subsubsection{Ambient Air}

Compliance of fugitive and diffuse sources is demonstrated based on environmental measurements. The ETTP Ambient Air Quality Monitoring Program is designed to provide environmental measurements to accomplish the following:

- track long-term trends of airborne concentration levels of selected air contaminant species, 
- measure the highest concentrations of the selected air contaminant species that occur in the vicinity of ETTP operations, and

- evaluate the impact of air contaminant emissions from ETTP operations on ambient air quality.

The sampling stations in the ETTP area are designated as base, supplemental, or ORR perimeter air monitoring (PAM) stations. Figure 3.14 shows the locations of all ambient air (monitoring) stations (AASs) in and around ETTP that were active during the 2013 reporting period. The base program consists of two locations using high-volume ambient air samplers. Supplemental locations are typically temporary, project-specific stations that use samplers specific to a type of potential emission. Samplers typically include high-volume systems, depending on the source emission evaluation of the project. All base, supplemental, and PAM samplers operate continuously with exposed filters collected weekly.

The radiological monitoring results for samples collected at the two ETTP area PAM stations were provided by UT-Battelle staff and are included in the ETTP network for

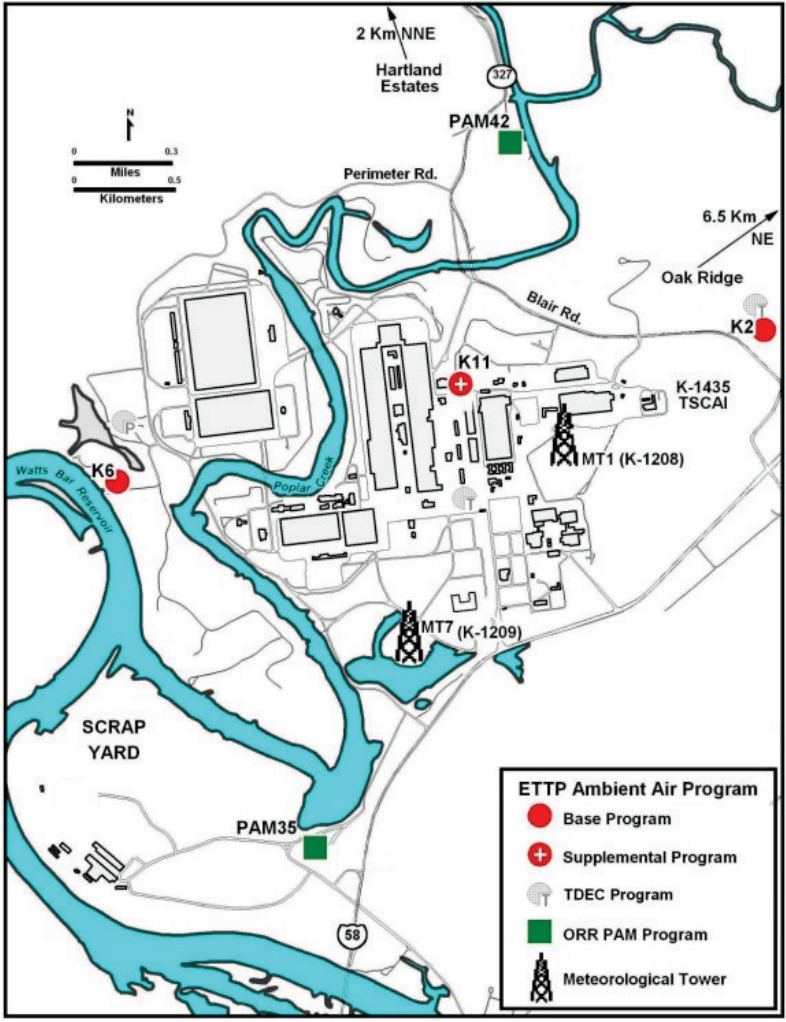

Fig. 3.14. East Tennessee Technology Park ambient air monitoring station locations. comparative purposes. Figure 3.14 shows the location of all AASs that were active during the 2013 reporting period. Figure 3.15 shows an example of a typical ETTP air monitoring station.

The analytical parameters were chosen with regard to existing and proposed regulations and with respect to activities at ETTP. Supplemental station K11 is located to demonstrate compliance with radiological emissions from demolition and remediation activities dose impact to on-site members of the

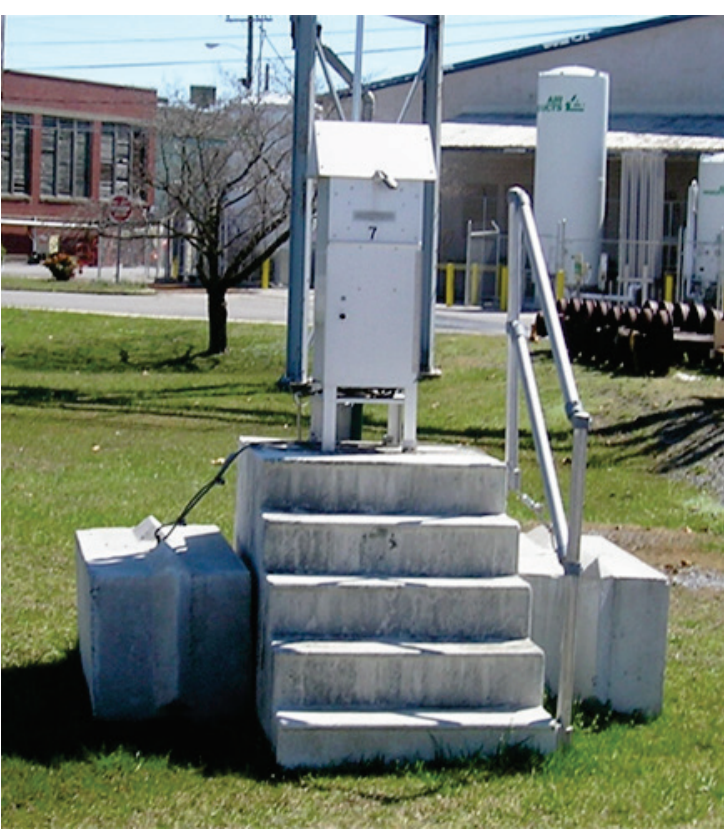

Fig. 3.15. East Tennessee Technology Park ambient air monitoring station. public. Changes in emissions from ETTP will warrant periodic reevaluation of the parameters being sampled. Ongoing ETTP reindustrialization efforts also introduce new locations for members of the public that may require adding or relocating monitoring site locations. To ensure understanding of the potential impact on the public and to establish any required emissions monitoring and emission controls, a survey of all on-site tenants is reviewed every 6 months.

All base and supplemental stations collect continuous samples for radiological and selected metals analyses. Inorganic analytical techniques were used to test samples for the following nonradiological pollutants: $\mathrm{As}, \mathrm{Be}, \mathrm{Cd}, \mathrm{Cr}, \mathrm{Pb}$, and total uranium. Radiological analyses of samples from the ETTP stations test for the isotopes ${ }^{237} \mathrm{~Np},{ }^{238} \mathrm{Pu},{ }^{239} \mathrm{Pu},{ }^{99} \mathrm{Tc}$, ${ }^{234} \mathrm{U},{ }^{235} \mathrm{U}$, and ${ }^{238} \mathrm{U}$; ORR station sampling results for ${ }^{234} \mathrm{U},{ }^{235} \mathrm{U}$, and ${ }^{238} \mathrm{U}$ provided by UT-B are included with ETTP results.

Figures 3.16 through 3.20 illustrate the ambient air concentrations of $\mathrm{As}, \mathrm{Be}, \mathrm{Cd}, \mathrm{Cr}$, and $\mathrm{Pb}$ for the 
past 5 years based on quarterly composites of weekly continuous samples. All samples were analyzed by the inductively coupled plasma-mass spectrometer (ICP-MS) analytical technique. The results are compared with applicable air quality standards for each pollutant. The annualized levels of $\mathrm{As}, \mathrm{Be}, \mathrm{Cd}$, and $\mathrm{Pb}$ were well below the indicated annual standards. With the exception of chromium and lead results for station K11, 2013 annual averages were all generally similar to the data trends during 2012 at all sampling stations. Station K11 is in close proximity to major demolition and remediation activities on the site and showed slightly higher annual chromium and lead ambient air concentrations compared to the other sampling locations. Also, the K11 sampling results for chromium and lead historically have been more variable than those for the other stations. Stations K2 and K6 are representative of ambient air conditions at the ETTP boundary, with very similar measurement results. Variations in chromium data during 2013 follow historical trends that have been coincidental to the ETTP demolition activities that have included rubblizing large amounts of concrete. All chromium results are compared to the more conservative hexavalent chromium annual risk-specific dose standard. The large variation in lead concentration levels is coincidental to a large increase in diesel-powered motor vehicles and equipment used in the area of station K11.

Following the permanent shutdown of the TSCA Incinerator, no on-site operation remained that could emit $\mathrm{As}, \mathrm{Be}$, and $\mathrm{Cd}$ at any measureable level. After several years of analyzing for these pollutants, the trends of pollutant concentrations were observed to be coincidental to background levels found in the ambient air. For these reasons, analyses for $\mathrm{As}, \mathrm{Be}$, and $\mathrm{Cd}$ were discontinued at the end of the third quarter of 2014. Total uranium analyses by ICP-MS were also discontinued as redundant to the isotopic analyses that are still being performed on all samples. Chromium and lead analyses are continuing due to on-site activities that have the potential to emit measureable levels of these pollutants into the ambient air.

Total uranium was measured as a quarterly composite of continuous weekly samples from stations K2, K6, and K11 during 2013. The total uranium mass for each sample was determined by ICP-MS. Station K9 was discontinued during 2011, but K9 results are included in the historical trend information. Uranium concentration measurements for all sites are presented in Table 3.4. Figure 3.21 illustrates the air concentrations of uranium for the past 5 years based on quarterly composites of weekly continuous samples. The highest 12 -month average result $\left(2.19 \mathrm{E}-05 \mu \mathrm{g} / \mathrm{m}^{3}\right)$ was measured at station $\mathrm{K} 6$. The highest result for the previous year was at K11 $\left(5.44 \mathrm{E}-05 \mu \mathrm{g} / \mathrm{m}^{3}\right)$.

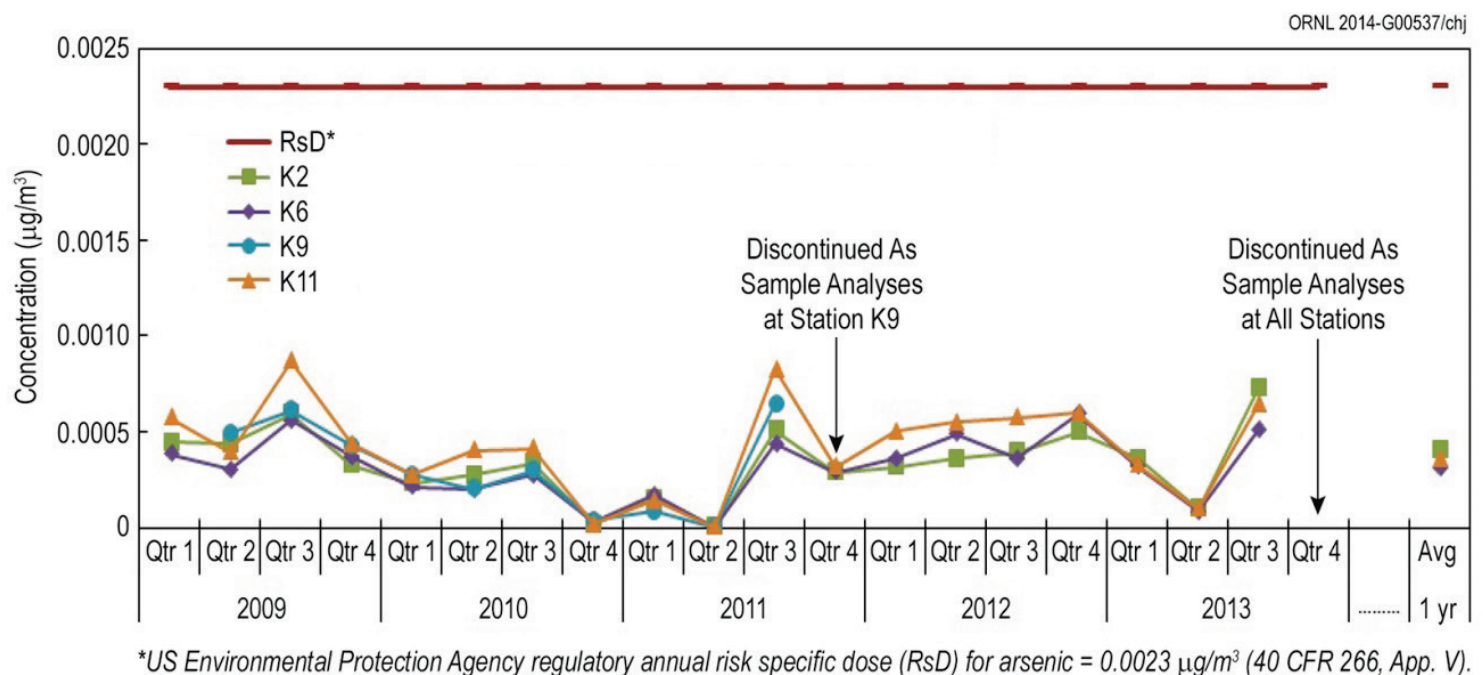

Fig. 3.16. Ambient air monitoring results for arsenic from January 2009 through December 2013. 


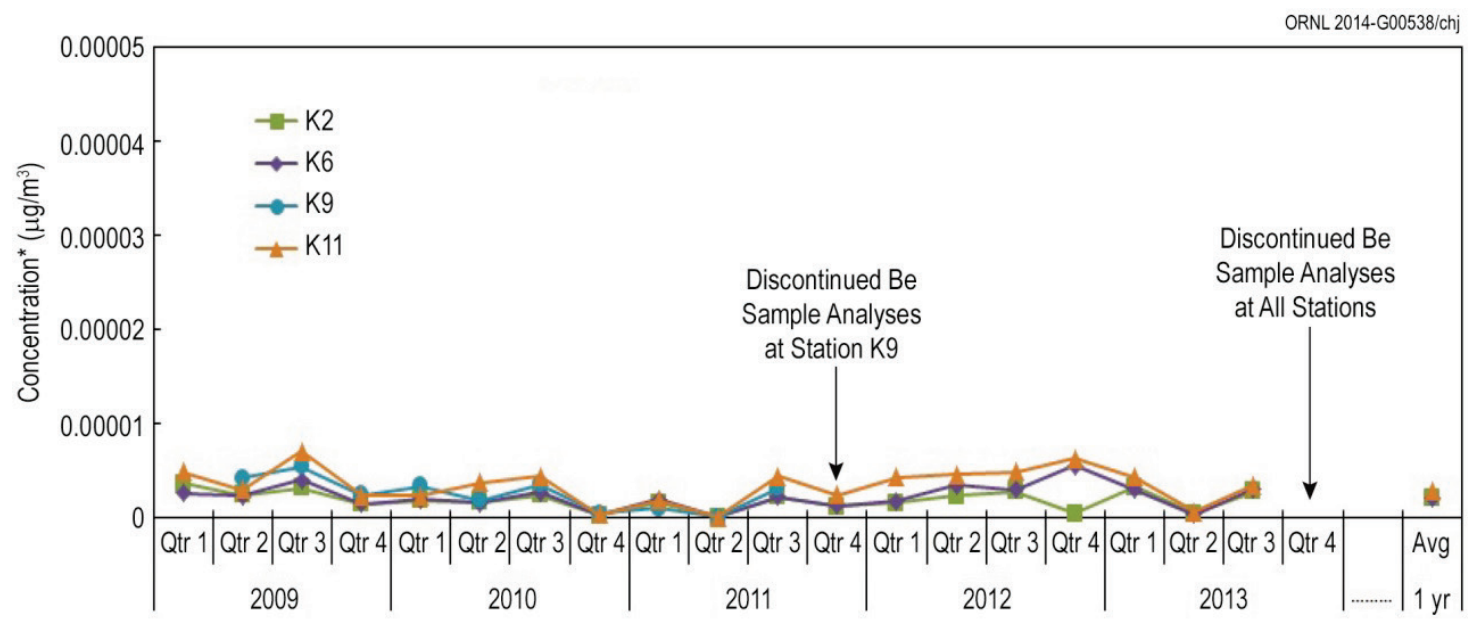

*US Environmental Protection Agency regulatory annual risk specific dose (RsD) for beryllium $=0.0042 \mu \mathrm{g} / \mathrm{m}^{3}$ (40 CFR 266, App. V).

Fig. 3.17. Ambient air monitoring results for beryllium from January 2009 through December 2013.

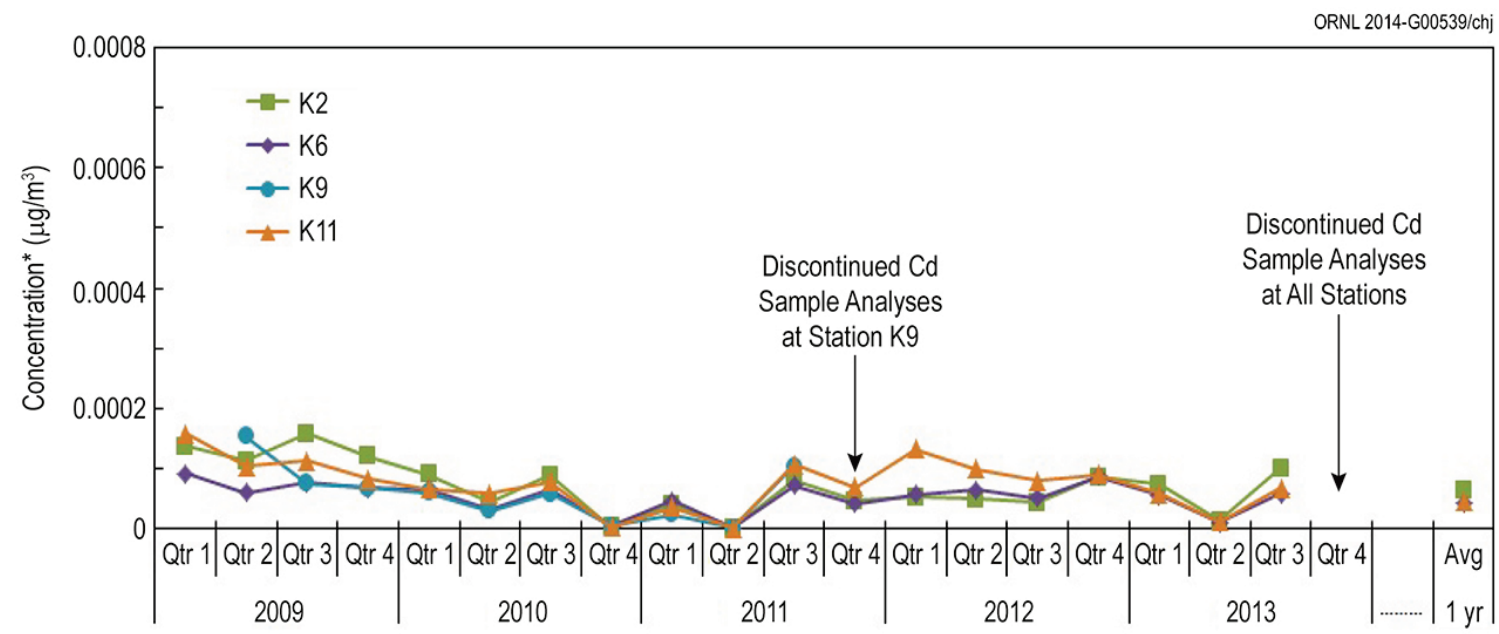

*US Environmental Protection Agency regulatory annual risk specific dose (RsD) for cadmium $=0.0056 \mu \mathrm{g} / \mathrm{m}^{3}$ (40 CFR 266, App. V).

Fig. 3.18. Ambient air monitoring results for cadmium from January 2009 through December 2013.

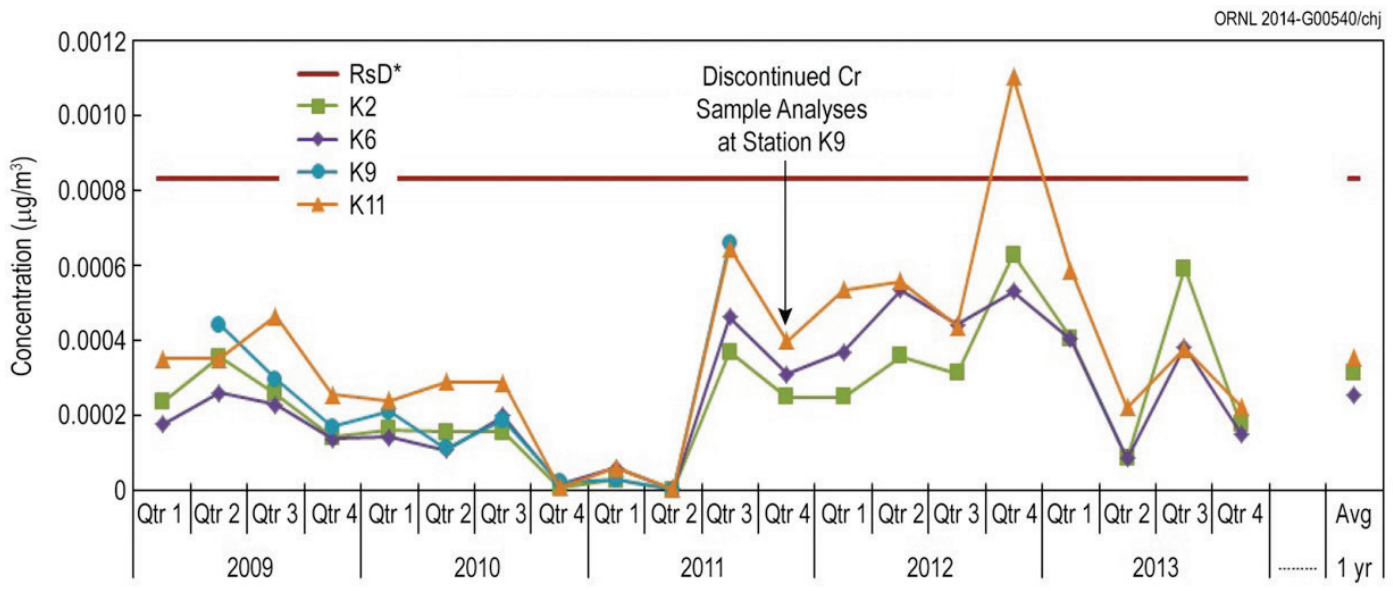

*US Environmental Protection Agency regulatory annual risk specific dose (RsD) for hexavalenet chromium $=0.00083 \mu \mathrm{g} / \mathrm{m}^{3}$ (40 CFR 266, App. V).

Fig. 3.19. Ambient air monitoring results for chromium from January 2009 through December 2013. 


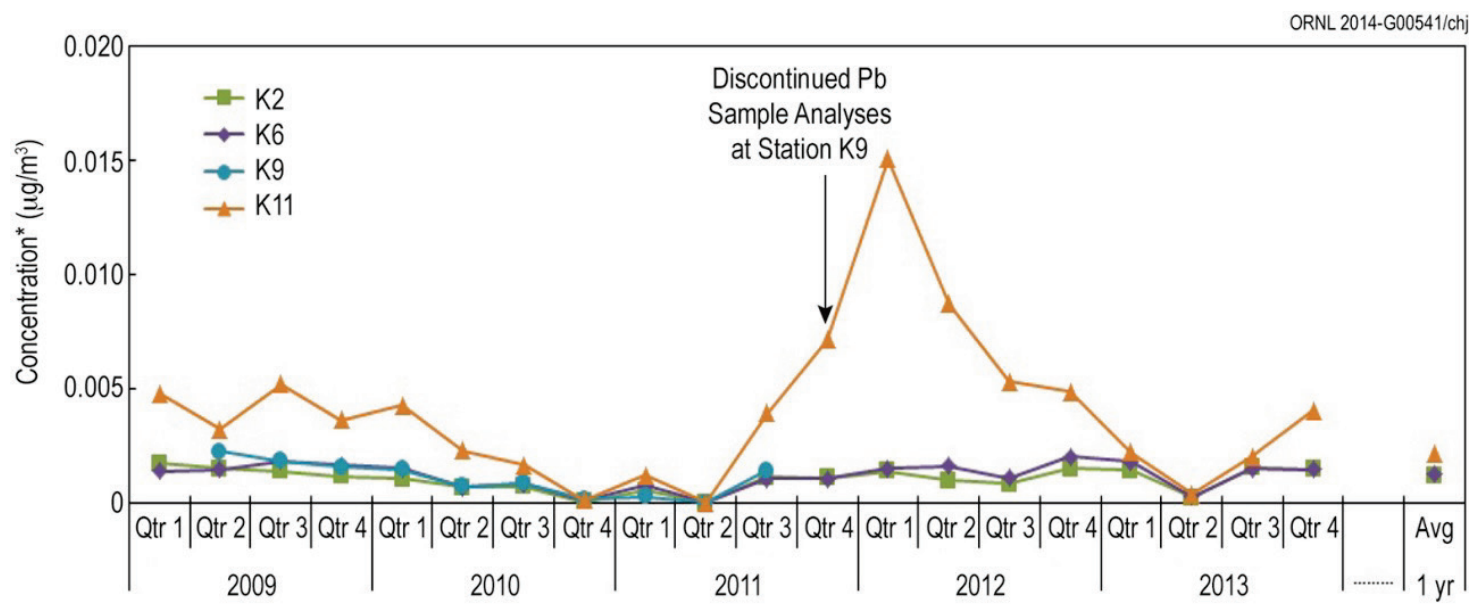

National Ambient Air Quality Standard for lead $=0.15 \mu \mathrm{g} / \mathrm{m}^{3}$ per quarter beginning October 2008.

Fig. 3.20. Ambient air monitoring results for lead from January 2009 through December 2013.

Table 3.4. Total uranium in ambient air by inductively coupled plasma-mass spectrometer analysis at East Tennessee Technology Park, 2013

\begin{tabular}{|c|c|c|c|c|c|c|c|}
\hline \multirow{3}{*}{ Station } & \multirow{3}{*}{$\begin{array}{c}\text { Number of } \\
\text { samples }\end{array}$} & \multicolumn{4}{|c|}{ Concentration $^{a}$} & \multirow{2}{*}{\multicolumn{2}{|c|}{$\begin{array}{c}\text { Percentage of derived } \\
\text { concentration guide }\end{array}$}} \\
\hline & & \multicolumn{2}{|c|}{$\left(\mu \mathrm{g} / \mathrm{m}^{3}\right)$} & \multicolumn{2}{|c|}{$(\mu \mathrm{Ci} / \mathrm{mL})$} & & \\
\hline & & Average & Maximum $^{\mathrm{c}}$ & Average & Maximum & Average & Maximum \\
\hline $\mathrm{K} 2$ & 3 & $7.45 \mathrm{E}-06$ & $1.28 \mathrm{E}-05$ & $4.96 \mathrm{E}-18$ & $8.56 \mathrm{E}-18$ & $<0.01$ & 0.01 \\
\hline K6 & 3 & 2.19E-05 & $5.68 \mathrm{E}-05$ & $1.46 \mathrm{E}-17$ & $3.79 \mathrm{E}-17$ & 0.01 & 0.04 \\
\hline K11 & 3 & $1.68 \mathrm{E}-05$ & $3.18 \mathrm{E}-05$ & $1.12 \mathrm{E}-17$ & $2.12 \mathrm{E}-17$ & 0.01 & 0.02 \\
\hline ETTP total & 9 & $1.54 \mathrm{E}-05$ & & $1.02 \mathrm{E}-17$ & & 0.02 & \\
\hline
\end{tabular}

${ }^{a}$ Mass-to-curie concentration conversions conservatively assume a natural uranium assay of $0.717 \%{ }^{235} \mathrm{U}$.

${ }^{b}$ The DOE O 5400.5 derived concentration guide (DOE 1990) for naturally occurring uranium is an annual concentration of $1.03 \mathrm{E}-13 \mu \mathrm{Ci} / \mathrm{mL}$ used as a more conservative conversion than the DOE O 458.1 derived concentration standard (DOE 2011a) values for uranium isotopes.

${ }^{c}$ Maximum individual sample analysis result with dose calculations conservatively assuming the value to be an annual concentration.

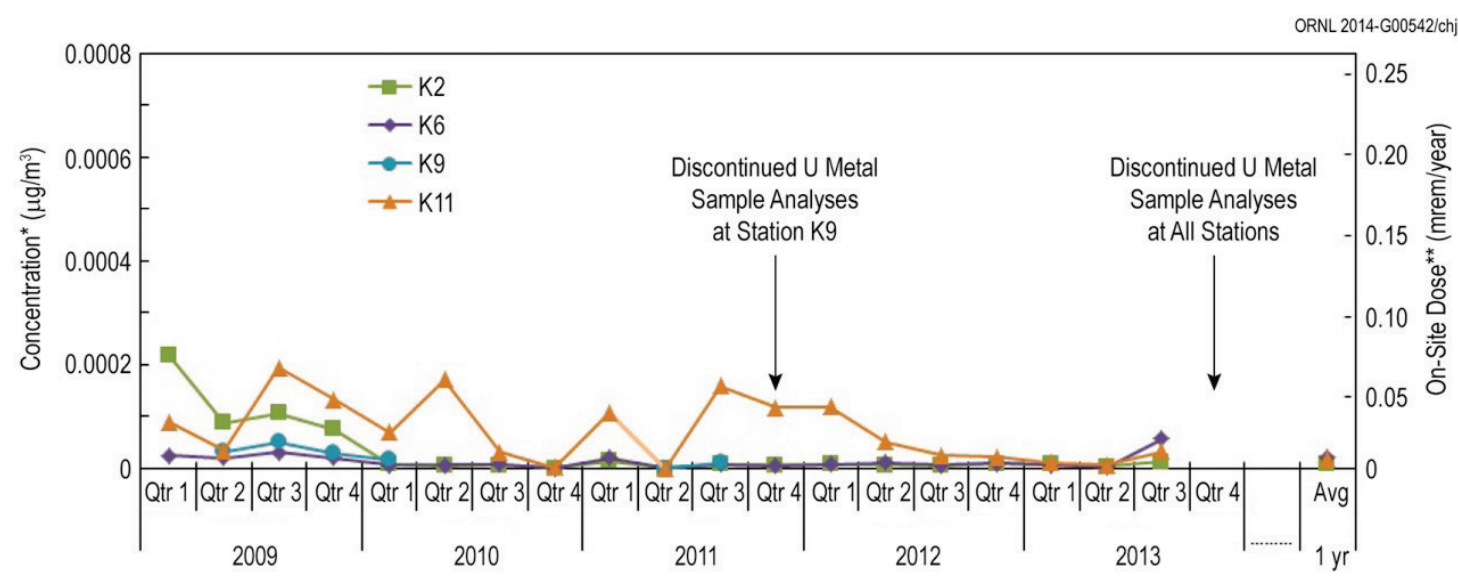

40 CFR 61. Subpart $H$, dose limit for uranium $=10$ mrem per year.

${ }^{*}$ DOE 05400.5 derived concentration guide for natural uranium resulting in $100 \mathrm{mrem} / \mathrm{year}$ dose is $1.03 \mathrm{E}-13 \mu \mathrm{Cl} / \mathrm{m}^{3}=0.15 \mu \mathrm{g} / \mathrm{m}^{3}$.

**US Environmental Protection Agency approved Oak Ridge Resenvation on-site business receptor dose assumes a 50\% annual occupancy.

Fig. 3.21. Ambient air monitoring results for uranium from January 2009 through December 2013. 
Quarterly radiochemical analyses are performed on composite samples collected at all stations. The selected isotopes of interest were ${ }^{237} \mathrm{~Np},{ }^{238} \mathrm{Pu},{ }^{239} \mathrm{Pu},{ }^{99} \mathrm{Tc}$, and isotopic uranium $\left({ }^{234} \mathrm{U},{ }^{235} \mathrm{U}\right.$, and $\left.{ }^{238} \mathrm{U}\right)$. The sampling results for ambient air concentration, dose impact, and percent of the total dose for each radionuclide at each of the three stations are presented in Table 3.5 for the 2013 reporting period. The highest potential dose impact for an individual working on the site in the vicinity of Station K11 was about 0.33 mrem as compared to the annual limit of $10 \mathrm{mrem}$. The on-site location of Station K11 is in close proximity to major demolition and remediation activities that impacted radiologically contaminated materials. The added contribution by ${ }^{99} \mathrm{Tc}$ was also concurrent with the demolition of the section of the K-25 building most contaminated with this isotope. Historically, the primary isotopic dose contributor has been ${ }^{234} \mathrm{U}$. However, during the fourth quarter of 2013 the percent dose impact from ${ }^{99} \mathrm{Tc}$ was significant at all three stations, as indicated in Table 3.5.

Table 3.5. Radionuclides in ambient air at East Tennessee Technology Park, January 2013 through December 2013

\begin{tabular}{|c|c|c|c|c|c|c|c|c|}
\hline \multirow{2}{*}{ Station } & \multicolumn{8}{|c|}{ Concentration $(\mu \mathrm{Ci} / \mathrm{mL})$} \\
\hline & ${ }^{237} \mathrm{~Np}$ & ${ }^{238} \mathrm{Pu}$ & ${ }^{239} \mathrm{Pu}$ & ${ }^{99} \mathrm{Tc}$ & ${ }^{234} \mathbf{U}$ & ${ }^{235} \mathrm{U}$ & ${ }^{238} \mathbf{U}$ & Total \\
\hline $\mathrm{K} 2$ & ND & ND & ND & $2.70 \mathrm{E}-15$ & $2.85 \mathrm{E}-17$ & $1.15 \mathrm{E}-18$ & $5.37 \mathrm{E}-18$ & $2.74 \mathrm{E}-15$ \\
\hline K6 & ND & ND & $1.37 \mathrm{E}-18$ & $4.43 \mathrm{E}-15$ & $3.11 \mathrm{E}-17$ & ND & $2.42 \mathrm{E}-18$ & $4.46 \mathrm{E}-15$ \\
\hline K11 & ND & ND & ND & $2.06 \mathrm{E}-14$ & $1.62 \mathrm{E}-16$ & $6.28 \mathrm{E}-18$ & $2.89 \mathrm{E}-17$ & $2.08 \mathrm{E}-14$ \\
\hline \multirow{2}{*}{ Station } & \multicolumn{8}{|c|}{40 CFR 61, Effective Dose ${ }^{a}$ (mrem/year) } \\
\hline & ${ }^{237} \mathrm{~Np}$ & ${ }^{238} \mathrm{Pu}$ & ${ }^{239} \mathrm{Pu}$ & ${ }^{99} \mathrm{Tc}$ & ${ }^{234} \mathbf{U}$ & ${ }^{235} \mathrm{U}$ & ${ }^{238} \mathbf{U}$ & Total \\
\hline $\mathrm{K} 2$ & ND & ND & ND & 0.08 & $<0.01$ & $<0.01$ & $<0.01$ & 0.09 \\
\hline K6 & ND & ND & $<0.01$ & $<0.01$ & $<0.01$ & $\mathrm{ND}$ & $<0.01$ & 0.14 \\
\hline K11 & ND & ND & ND & 0.31 & 0.02 & $<0.01$ & $<0.01$ & 0.33 \\
\hline \multirow{2}{*}{ Station } & \multicolumn{8}{|c|}{ Percent of Total Dose } \\
\hline & ${ }^{237} \mathbf{N p}$ & ${ }^{238} \mathrm{Pu}$ & ${ }^{239} \mathrm{Pu}$ & ${ }^{99} \mathrm{Tc}$ & ${ }^{234} \mathbf{U}$ & ${ }^{235} \mathbf{U}$ & ${ }^{238} \mathrm{U}$ & Total \\
\hline $\mathrm{K} 2$ & ND & ND & ND & 95.4 & 3.9 & 0.1 & 0.6 & 100 \\
\hline K6 & ND & ND & 1.5 & 95.7 & 2.6 & ND & 0.2 & 100 \\
\hline K11 & ND & ND & ND & 91.6 & 7.1 & 0.2 & 1.1 & 100 \\
\hline
\end{tabular}

${ }^{a} 40$ CFR 61, subpart H, effective dose limit $=10 \mathrm{mrem} /$ year.

$\mathrm{ND}=$ Not detected.

Figure 3.22 shows the dose impact at each AAS that operated over the 5-year period from 2009 through 2013. Stations K2 and K6 are positioned near the ETTP fence line and conservatively represent a dose impact on an off-site residential member of the public. Station K11 is representative of the most impacted on-site member of the public. Each data point represents the accumulated dose over the previous four quarterly sampling results. All 2013 fourth quarter dose results show an increase. Dose results at K2 and K6 increased to a lesser degree due to being at a more distant sampling location from all possible point and fugitive sources of airborne releases of radionuclides. All data show potential exposures are well below the 10 mrem annual dose limit. 


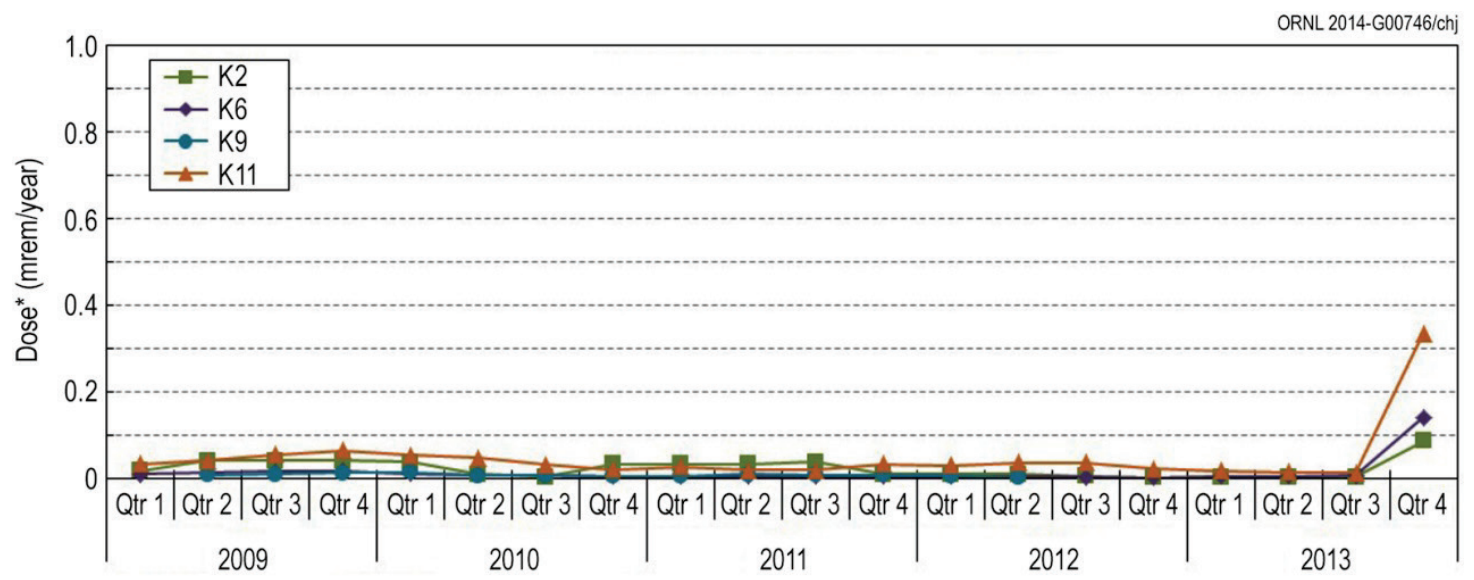

*40 CFR 61, Subpart H DOE Oak Ridge Reservation dose limit = 10 mrem per year.

Fig. 3.22. East Tennessee Technology Park quarterly and rolling 12-month effective dose results for January 2009 through December 2013.

\subsection{Water Quality Program}

\subsubsection{NPDES Permit Description-New NPDES Permit}

Currently there are 108 NPDES-permitted storm water outfalls at ETTP. As part of the current NPDES permit, these storm water outfalls are listed in two groups based on the types of flows being discharged through the outfalls. A total of 32 storm water outfalls are sampled as being representative of these groups.

\subsubsection{East Tennessee Technology Park Storm Water Pollution Prevention Program}

The current ETTP NPDES permit includes a requirement to review and update, if necessary, the Storm Water Pollution Prevention (SWPP) Plan (SWPPP) at least annually. This requirement is met by publishing the ETTP SWPP Program Annual Update Report, which includes monitoring results, site inspection summaries, and other information for each fiscal year. Additionally, the SWPP Program baseline document serves as a reference document for implementing and conducting the required elements of the ETTP SWPPP. This document will continue to be used as part of the ETTP SWPP Program specified in the current ETTP NPDES permit. The baseline document is reviewed annually and updated as necessary.

\subsubsection{Sampling for NPDES Permit Renewal Application}

The ETTP NPDES permit renewal application was submitted to TDEC on June 20, 2013. In 2013, a portion of the SWPP Program was directed toward the collection of analytical data and field readings that were required to complete the EPA $2 \mathrm{E}$ and $2 \mathrm{~F}$ forms that were submitted as part of the NPDES permit renewal application. Data collected in CY 2013 for the EPA 2F forms included field readings at storm water outfalls SD 382 and SD 660.

The sample collection requirements for each parameter are specified by the respective analytical method. Parameters that are designated to be collected as composite samples were collected by use of automatic samplers. If a composite sample could not be collected with automatic samplers due to location, volume, or time constraints, the sample was collected as a series of manual grab samples and then composited for analysis. Parameters designated to be collected by manual grab only were not collected by automatic compositor under any circumstances; however, other parameters that are designated simply as grab samples may have been collected either manually or with automatic samplers configured for grab sampling. 
All storm water samples were collected from discharges resulting from a storm event greater than $0.1 \mathrm{in}$. in $24 \mathrm{~h}$ or less and which occurred at least $72 \mathrm{~h}$ after a discharge from any previous rainfall greater than 0.1 in. in $24 \mathrm{~h}$.

None of the results from the sampling effort conducted in CY 2013 for completion of the ETTP NPDES permit application exceeded reference standards.

Several modifications to the current NPDES permit were suggested as part of the new NPDES permit application, including the following.

- Removal of 17 storm water outfalls that meet the removal criteria published in the NPDES permit rationale, section III.B.1.4, reducing the total number of outfalls covered by the NPDES permit to 91.

- Elimination of outfall SD 340 as a representative location because the inlet pipes to this outfall were grouted closed as part of the remediation of the K-25 building area and this outfall no longer produces a flow.

- Removal of the mercury sampling requirement for outfall SD 170 because mercury results for SD 170 and associated catch basins have been well below the ambient water quality criterion (AWQC) of $51 \mathrm{ng} / \mathrm{L}$ since July 2009.

\subsubsection{Radiological Monitoring of Storm Water Discharges}

As part of the SWPP Program, radiological monitoring of storm water discharges is routinely conducted to determine compliance with applicable dose standards. The "as low as reasonably achievable" (ALARA) process is applied to minimize potential exposures to the public. Sampling for gross alpha and gross beta radioactivity, as well as specific radionuclides, is conducted as part of the SWPP Program sampling efforts. In CY 2013 new radiological sampling results were obtained for eight storm water outfalls as part of the periodic radiological sampling effort. Table 3.6 shows the storm water outfalls sampled during CY 2013, and Table 3.7 lists the parameters that exceeded their respective reference standards. In addition, in CY 2013 radiological sampling was conducted as part of the SWPP Program during the demolition of the K-25 building (refer to Section 3.6.5.2).

Table 3.6. Storm water sampling for radiological discharges, 2013

\begin{tabular}{|c|c|c|c|c|}
\hline $\begin{array}{l}\text { Storm water } \\
\text { outfall }\end{array}$ & $\begin{array}{l}\text { Gross alpha/beta } \\
\text { (composite sample) }\end{array}$ & $\begin{array}{c}\text { Transuranics }^{a} \\
\text { (composite sample) }\end{array}$ & $\begin{array}{c}\text { Isotopic } \mathrm{U} \\
\text { (composite sample) }\end{array}$ & $\begin{array}{c}{ }^{99} \mathrm{Tc} \\
\text { (composite sample) }\end{array}$ \\
\hline SD 100 & $\mathrm{X}$ & $\mathrm{X}$ & $\mathrm{X}$ & $\mathrm{X}$ \\
\hline SD 124 & $\mathrm{X}$ & $\mathrm{X}$ & $\mathrm{X}$ & $\mathrm{X}$ \\
\hline SD 292 & $\mathrm{X}$ & $\mathrm{X}$ & $\mathrm{X}$ & $\mathrm{X}$ \\
\hline SD $724^{b}$ & $\mathrm{X}$ & $\mathrm{X}$ & $\mathrm{X}$ & $\mathrm{X}$ \\
\hline $\mathrm{SD} 730^{\mathrm{b}}$ & $\mathrm{X}$ & $\mathrm{X}$ & $\mathrm{X}$ & $\mathrm{X}$ \\
\hline SD $740^{b}$ & $\mathrm{X}$ & $\mathrm{X}$ & $\mathrm{X}$ & $\mathrm{X}$ \\
\hline $\mathrm{SD} 750^{\mathrm{b}}$ & $\mathrm{X}$ & $\mathrm{X}$ & $\mathrm{X}$ & $\mathrm{X}$ \\
\hline SD $760^{b}$ & $\mathrm{X}$ & $\mathrm{X}$ & $\mathrm{X}$ & $\mathrm{X}$ \\
\hline
\end{tabular}

${ }^{a}$ Includes ${ }^{237} \mathrm{~Np},{ }^{238} \mathrm{Pu}$, and ${ }^{239,240} \mathrm{Pu}$.

${ }^{b}$ Sampling at this storm drain was conducted after closure was completed at the K-770 Scrap Yard. The results were used for both decontamination and decommissioning and remedial action support and for the calculation of radionuclide discharges from East Tennessee Technology Park. 
Table 3.7. Analytical results over reference standards for radiological monitoring at East Tennessee Technology Park storm water outfalls/drains (SDs), 2013

(Reference standard: $15 \mathrm{pCi} / \mathrm{L}^{a}$ )

\begin{tabular}{cc}
\hline Sampling location & Gross alpha $(\mathbf{p C i} / \mathbf{L})$ \\
\hline SD 292 & 27.7 \\
SD 724 & 41.9 \\
SD 730 & 28 \\
\hline
\end{tabular}

${ }^{a}$ This reference standard is shown in Table 3 of the East Tennessee Technology

Park Storm Water Pollution Prevention Program Sampling and Analysis Plan (UCOR 2013b).

These analytical results are used with radiological results for other storm water outfalls from other years, along with calculated flows based on rain events in 2013, to estimate the total discharge of each radionuclide from ETTP via the storm water discharge system. Table 3.8 shows the total radionuclides released to surface waters from the ETTP storm water system.

Table 3.8. Radionuclides released to surface waters from the East Tennessee Technology Park storm water system, 2013

\begin{tabular}{cc}
\hline Radionuclide & Amount (Ci) \\
\hline${ }^{99} \mathrm{Tc}$ & $2.6 \mathrm{E}+00$ \\
${ }^{234} \mathrm{U}$ & $1.0 \mathrm{E}-02$ \\
${ }^{235} \mathrm{U}$ & $4.2 \mathrm{E}-04$ \\
${ }^{238} \mathrm{U}$ & $4.4 \mathrm{E}-03$ \\
\hline
\end{tabular}

$1 \mathrm{Ci}=3.7 \mathrm{E}+10 \mathrm{~Bq}$.

\subsubsection{Monitoring of Storm Water Runoff from East Tennessee Technology Park Decontamination and Decommissioning/Remedial Action Activities}

Demolition of the K-25 building was initiated in 2008. Demolition of the west wing was completed in 2010 , and the north tower was demolished in 2013. Initial demolition activities for the east wing of the K-25 building began in 2011 and were completed in the summer of 2013 (with the exception of the south portion of the east wing). The D\&D of the final section of the K-25 building, the south portion of the east wing, began in the summer of 2013 and was completed in December 2013. Removal of building debris from the demolition area and disposition of the material will be completed in early 2014.

To closely monitor the storm water runoff from the K-25 building demolition activities, sampling was performed at regular intervals during the demolition process for each portion of the building. Initial sampling was performed to provide baseline data for conditions present before demolition began. Additional periodic monitoring was performed following the start-up of demolition. When required, modifications to storm water controls were made based on the results of this sampling effort.

\subsubsection{Decontamination and Decommissioning of the North Tower of Building K-25-Follow-Up Sampling}

Sampling was performed at storm water outfalls SD 230 and SD 240 to provide information on the quality of the storm water runoff from Building K-25 during demolition. Table 3.9 shows the results that exceeded the applicable reference standards for this sampling activity. 
Table 3.9. Analytical results for storm water outfalls SD 230 and SD 240 that exceeded the radiological field evaluation screening level or chemical reference standard, 2013

\begin{tabular}{cccc|cccc}
\hline $\begin{array}{c}\text { Sampling } \\
\text { location }\end{array}$ & $\begin{array}{c}\text { Gross alpha } \\
(\mathrm{pCi} / \mathrm{L})\end{array}$ & $\begin{array}{c}{ }^{233,234} \mathrm{U} \\
(\mathrm{pCi} / \mathrm{L})\end{array}$ & $\begin{array}{c}{ }^{235,236} \mathrm{U} \\
(\mathrm{pCi} / \mathrm{L})\end{array}$ & $\begin{array}{c}\text { Lead } \\
(\boldsymbol{\mu g} / \mathrm{L})\end{array}$ & $\begin{array}{c}\text { Mercury } \\
(\mathrm{ng} / \mathrm{L})\end{array}$ & $\begin{array}{c}\text { PCB-1254 } \\
(\boldsymbol{\mu g} / \mathbf{L})\end{array}$ & $\begin{array}{c}\text { PCB-1260 } \\
(\mu \mathrm{g} / \mathrm{L})\end{array}$ \\
\hline $\begin{array}{c}\text { Reference } \\
\text { standard }^{a}\end{array}$ & $\mathbf{1 5}$ & $\mathbf{2 0}$ & $\mathbf{2 0}$ & $\mathbf{2 . 5}$ & $\mathbf{5 1}$ & $\mathbf{0 . 0 0 0 6 4}$ & $\mathbf{0 . 0 0 0 6 4}$ \\
$\begin{array}{c}\text { SD 230 } \\
\text { SD 240 }\end{array}$ & 335 & 361 & 21.8 & & & & \\
\hline
\end{tabular}

${ }^{a}$ These reference standards are shown in Table 3 of the East Tennessee Technology Park Storm Water Pollution Prevention Program Sampling and Analysis Plan (UCOR 2013b). For this analysis, specific radionuclides were compared to 4\% of the derived concentration guide for that radionuclide in water, as listed in DOE O 5400.5, Chapter 3 (DOE 1990), as a field evaluation screening level.

$\mathrm{SD}=$ storm water outfall/storm drain.

After investigation, it was determined that demolition activities at the K-25 building may not have been the source of the mercury or PCBs identified in discharges from storm water outfall SD 240. The likely sources of the mercury and PCBs in discharges from SD 240 are historic operations conducted in the SD 240 drainage area.

Several possible sources for the elevated radiological results observed at storm water outfall SD 230 were also investigated. The most likely source of the elevated radiological results was determined to be a white substance within a small concrete settling basin/oil-water separator upstream of SD 230; the sediment and white material were removed and disposed.

In May 2013, sampling was conducted at SD 230 to determine whether the removal of the white material resulted in a reduction in the concentrations of radiological contaminants. The results of this sampling effort are shown in Table 3.10. As shown, the removal of the white material from the SD 230 drainage network has reduced the elevated radiological concentrations.

Table 3.10. Analytical results from follow-up sampling at storm water outfall SD 230, 2013

\begin{tabular}{ccc}
\hline $\begin{array}{c}\text { Gross alpha } \\
(\mathbf{p C i} / \mathbf{L})\end{array}$ & $\begin{array}{c}{ }^{233,234} \mathbf{U} \\
(\mathbf{p C i} / \mathbf{L})\end{array}$ & $\begin{array}{c}{ }^{235,236} \mathbf{U} \\
(\mathbf{p C i} / \mathbf{L})\end{array}$ \\
\hline 28.1 & 21.3 & 0.894 \\
\hline
\end{tabular}

\subsubsection{Decontamination and Decommissioning of the Technetium-Contaminated Portion of Building K-25}

Demolition on the southern section of the east wing of Building K-25 was begun in July 2013 and was completed in December 2013. The removal of the debris from the demolition activities will be completed in 2014. The southern section of the east wing of Building K-25 was contaminated with ${ }^{99} \mathrm{Tc}$, a slow-decaying radioactive isotope. The greatest concern in regard to storm water was the rain and dust control water that fell directly onto the debris pile during and after the demolition. Storm water controls were designed and implemented to prevent the transport of radiological and chemical contaminants, sediments, and other particulates away from the demolition area.

On May 28, 2013, surface water sampling was performed at the K-1007-P1 pond weir as part of the ETTP Environmental Monitoring Program (EMP). Analytical data from these samples indicated a gross beta radiation level of $57.1 \mathrm{pCi} / \mathrm{L}$, which exceeds the field evaluation screening level of $50 \mathrm{pCi} / \mathrm{L}$ (Table 3.11). The field evaluation screening level is a value that has been established internally for the beta parameter as a measurement that is roughly comparable to $4 \%$ of the DOE O 5400.5 annual derived concentration guide (DCG). The ${ }^{99} \mathrm{Tc}$ level in this sample was $113 \mathrm{pCi} / \mathrm{L}$, which is slightly elevated when compared to historic sampling results for ${ }^{99} \mathrm{Tc}$ at this location but well below the DCG value of 
$100,000 \mathrm{pCi} / \mathrm{L}$. In an effort to identify the source of the elevated gross beta radiation, sampling was performed at storm water outfall SD 490 on June 25, 2013. The gross beta radiation level in the sample from SD 490 was $645 \mathrm{pCi} / \mathrm{L}$ and the ${ }^{99} \mathrm{Tc}$ level was $1,460 \mathrm{pCi} / \mathrm{L}$.

The likely source for the elevated gross beta radiation and ${ }^{99} \mathrm{Tc}$ values in comparison to historical trends was determined to be the demolition preparation activities being conducted at the southern section of the east wing of the K-25 building. At the time of the June 25, 2013, sampling, intrusive work was under way that involved the removal of process gas system components contaminated with ${ }^{99} \mathrm{Tc}$ in the purge cascade units (K-311-1, K-310-3, and K-310-2). Due to the poor structural condition of the roof in this area, precipitation was infiltrating the building and the runoff was transporting ${ }^{99} \mathrm{Tc}$ to storm water catch basins in the SD 490 network. In response, a berm was installed around the demolition area to minimize storm water runoff. The removal of the process gas system components was performed in accordance with ALARA principles and radiological work permit controls to minimize the spread of contamination.

Additional sampling that was performed during the remainder of the demolition activities conducted at the south end of the east wing of the K-25 building confirmed that all discharge values were below annual DCG reference standards. The results from this monitoring that exceeded the field evaluation screening levels are shown in Table 3.11. As a result of this monitoring, elevated levels of ${ }^{99} \mathrm{Tc}$ were identified on several occasions at storm water outfalls SD 210 and SD 490, which are the primary ETTP storm water outfalls that transport drainage from the east wing of the K-25 building. In addition, investigative sampling performed in catch basins in the SD 490 drainage system showed elevated levels of ${ }^{99} \mathrm{Tc}$. In all cases the individual ${ }^{99} \mathrm{Tc}$ results were below the annual DCG standards for radionuclide discharges.

On December 5, 2013, water was observed flowing from three electrical duct system manholes at the southwest corner of the Portal 4 parking area. The Portal 4 parking area is located south and downgradient from the K-25 building demolition. The water surfacing from the manholes in the Portal 4 area then flowed across the paved parking area and into a nearby storm water catch basin. The water was then discharged to the K-1007-P1 pond via storm water outfall SD 490.This flow from the duct system manholes occurred after a significant amount of rainfall.

Discharges from the electrical duct system manholes in the Portal 4 parking area were routinely noted after heavy rainfall events. Preliminary radiological surveys indicated fixed contamination (attached to asphalt pavement and concrete surrounding the manholes) in the parking lot at the water discharge area. Supplemental water sampling within the electrical duct system indicated the presence of elevated levels of ${ }^{99} \mathrm{Tc}$. Access to the parking area where water was discharging was restricted after the discovery of the elevated ${ }^{99}$ Tc levels.

The electrical duct system manholes in the Portal 4 parking area are part of an underground electrical duct network that once carried electrical power lines from the former powerhouse area to portions of ETTP. A large portion of the electrical duct network downgradient from Portal 4 was filled with grout in CY 2010; however, the placement of grout into this system was stopped immediately downgradient of the Portal 4 parking area manholes where the water discharge was observed. This portion of the duct system remained susceptible to inflow from groundwater and storm water.

It is estimated that ${ }^{99} \mathrm{Tc}$ contaminated storm water from the demolition of the southeastern portion of the K-25 building probably entered the electrical duct system from seepage through cracks or breaks in the concrete slab structure of the building and infiltrated the electrical network system that runs adjacent to the demolition field. The duct system eventually filled with water and then overflowed during heavy rainfall events.

Although the storm drain discharges were below the annual DCG reference standards, in January 2014, thirty eight electrical duct bank system manholes were filled with grout to maintain discharge levels at storm water outfall SD 490 to levels that were ALARA. This corrective action eliminated the discharges from the electrical duct system into the storm drain system. 
Table 3.11. Analytical results that exceed the field evaluation

screening level values internally established at $4 \%$ of the $D_{C G}{ }^{a}$

for the drainage areas associated with the Building K-25 ${ }^{99} \mathrm{Tc}$ area, 2013

\begin{tabular}{|c|c|c|c|}
\hline \multirow[b]{2}{*}{ Sampling location } & \multicolumn{3}{|c|}{ Parameter } \\
\hline & $\begin{array}{c}\text { Gross alpha } \\
\text { (pCi/L) }\end{array}$ & $\begin{array}{c}\text { Gross beta } \\
\text { (pCi/L) }\end{array}$ & $\begin{array}{c}{ }^{99} \mathrm{Tc} \\
(\mathrm{pCi} / \mathrm{L})\end{array}$ \\
\hline Reference standard & $15^{b}$ & $50^{b}$ & $4,000^{c}$ \\
\hline \multicolumn{4}{|l|}{ OUTFALL SD 210} \\
\hline \multicolumn{4}{|l|}{$9 / 21 / 2013$} \\
\hline $11 / 18 / 2013$ & & 57.9 & \\
\hline \multicolumn{4}{|l|}{$11 / 26 / 2013$} \\
\hline \multicolumn{4}{|l|}{$12 / 09 / 2013$} \\
\hline $12 / 23 / 2013$ & & 116 & \\
\hline $12 / 30 / 2013$ & & 86.3 & \\
\hline \multicolumn{4}{|l|}{ OUTFALL SD 490} \\
\hline \multicolumn{4}{|l|}{$9 / 21 / 2013$} \\
\hline $11 / 18 / 2013$ & & 6,510 & 10,600 \\
\hline $11 / 26 / 2013$ & & 835 & \\
\hline $12 / 09 / 2013$ & & 36,200 & 56,900 \\
\hline $12 / 23 / 2013$ & & 39,700 & 59,200 \\
\hline $12 / 30 / 2013$ & & 27,500 & 57,400 \\
\hline \multicolumn{4}{|l|}{ K-1007-B } \\
\hline $12 / 09 / 2013$ & & 802 & \\
\hline $12 / 23 / 2013$ & 23.9 & 765 & \\
\hline $12 / 30 / 2013$ & & 1,510 & \\
\hline
\end{tabular}

\footnotetext{
${ }^{a}$ The analytical results for specific radionuclides were compared to $4 \%$ of the derived concentration guide (DCG), as listed in DOE O 5400.5, Chapter 3, as a screening level for that radionuclide in water.

${ }^{b}$ Reference standard source: Title 40 Code of Federal Regulations Part 141.

${ }^{c}$ Reference standard source: DCG.
}

\subsubsection{Remedial Actions at the K-1070-B Burial Ground-Follow-Up Sampling}

Remediation of the K-1070-B burial ground was completed in FY 2012. In May 2013, follow-up sampling was performed at manhole 8002 (downgradient of the K-1070-B remediation area), manhole 8017 (upgradient of the K-1070-B burial ground remediation area), and storm water outfall SD 190 to determine the impacts of the remediation activities. Manholes 8002 and 8017 both carry flow that ultimately discharges to Mitchell Branch via SD 190. Samples from these three locations were collected as part of the same sampling event. Table 3.12 shows the analytical parameters that were sampled at each of these locations, and Table 3.13 shows the analytical results from this sampling effort that exceeded reference standards.

The Record of Decision for Soil, Buried Waste, and Subsurface Structure Actions in Zone 2, which was submitted in 2005, includes remedial actions (RAs) for unrestricted industrial use to a depth of $10 \mathrm{ft}$ and for sources of groundwater contamination. Zone 2 was divided into 44 exposure units (EUs) for planning and evaluation purposes. The K-1070-B burial ground is located in EU30. The PCCR for EU Z2-30 in Zone 2 (K-1070-B Burial Ground) (DOE/OR/01-2521\&D1) was submitted to the regulators on September 23, 2012. Additional evaluation of surface water and groundwater will be conducted in accordance with this report. In addition, land use controls will be implemented in this location to prevent exposure to residual contamination and to prevent residential use in the area. 
Table 3.12. Surface water sampling to support remedial action activities at the K-1070-B burial ground, 2013

\begin{tabular}{|c|c|c|c|c|c|c|}
\hline RA or D\&D activity & $\begin{array}{l}\text { Sampling } \\
\text { location }\end{array}$ & $\begin{array}{c}\text { Gross } \\
\text { alpha/beta }\end{array}$ & $\begin{array}{l}\text { Isotopic } \mathbf{U}, \\
{ }^{99} \mathrm{Te}, \\
\text { transuranics }\end{array}$ & PCBs & $\begin{array}{l}\text { Metals }{ }^{a} / \\
\text { Mercury }\end{array}$ & VOCs \\
\hline \multirow{3}{*}{$\begin{array}{l}\text { K-1070-B Burial } \\
\text { Ground }\end{array}$} & $\begin{array}{l}\text { MH } 8002 \\
\text { (drains to } \\
\text { SD 190) }\end{array}$ & $X$ & $\mathrm{X}$ & $\mathrm{X}$ & $\mathrm{X}$ & $\mathrm{X}$ \\
\hline & $\begin{array}{l}\text { MH } 8017 \\
\text { (drains to } \\
\text { SD 190) }\end{array}$ & $\mathrm{X}$ & $\mathrm{X}$ & $\mathrm{X}$ & $\mathrm{X}$ & $\mathrm{X}$ \\
\hline & SD 190 & $X$ & $X$ & $\mathrm{X}$ & $X$ & $\mathrm{X}$ \\
\hline
\end{tabular}

${ }^{a}$ Metals analysis includes Al, Ag, As, Ba, Be, B, Ca, Cd, Co, Cr, Cu, Fe, K, Mg, Mn, Na, Ni, Pb, Sb, Se, Tl, V, and Zn. Analysis for transuranics includes ${ }^{237} \mathrm{~Np},{ }^{238} \mathrm{Pu}$, and ${ }^{239,240} \mathrm{Pu}$.

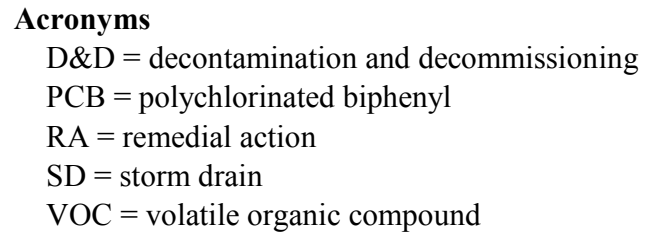

Table 3.13. Analytical results over reference standards for K-1070-B burial ground monitoring, 2013

\begin{tabular}{cccccc}
\hline $\begin{array}{c}\text { Sampling } \\
\text { location }\end{array}$ & $\begin{array}{c}\text { Copper } \\
(\mu \mathrm{g} / \mathrm{L})\end{array}$ & $\begin{array}{c}\text { Selenium } \\
(\mu \mathrm{g} / \mathrm{L})\end{array}$ & $\begin{array}{c}\text { Mercury } \\
(\mathbf{n g} / \mathrm{L})\end{array}$ & $\begin{array}{c}\text { PCB-1254 } \\
(\boldsymbol{\mu g} / \mathrm{L})\end{array}$ & $\begin{array}{c}\text { PCB-1260 } \\
(\boldsymbol{\mu g} / \mathrm{L})\end{array}$ \\
\hline $\begin{array}{c}\text { Reference } \\
\text { Standard }\end{array}$ & $\mathbf{9 . 0}$ & $\mathbf{5}$ & $\mathbf{5 1}$ & $\mathbf{0 . 0 0 0 6 4}$ & $\mathbf{0 . 0 0 0 6 4}$ \\
Manhole 8002 & 15.8 & & & 0.0553 & \\
Manhole 8017 & & 12.9 & 126 & 0.0933 & 0.0587 \\
SD 190 & & & 75.4 & 0.0681 & \\
\hline
\end{tabular}

\footnotetext{
${ }^{a}$ These reference standards are shown in Table 3 of the East Tennessee Technology Park Storm Water Pollution Prevention Program Sampling and Analysis Plan (UCOR 2013b).

Acronyms

$\mathrm{PCB}=$ polychlorinated biphenyl

$\mathrm{SD}=$ storm drain
}

\subsubsection{Remedial Actions at the K-770 Scrap Yard Area-Follow-Up Sampling}

Closure activities at the K-770 Scrap Yard have been completed; however, further project activities are currently pending based on additional directions from DOE. All of the large pieces of scrap metal in the yard have been removed and disposed. A radiological survey of the scrap yard was conducted to identify areas where residual radiological contamination was present. Soil was removed from these areas of radiological contamination. In addition, smaller pieces of scrap metal that were not identified during previous activities have been removed. Soil from several areas in the scrap yard where asbestos had been located have been removed and disposed; however, areas of the scrap yard are still contaminated with asbestos.

Sampling of the storm water runoff from the K-770 Scrap Yard area was conducted in CY 2013 to determine the effect of the remediation of the scrap yard on storm water quality. Radiological monitoring 
of the storm water outfalls in this area was completed at SDs 724, 730, 740, 750, and 760. The sampling results that exceeded radiological field evaluation screening levels or chemical reference standards are presented in Tables 3.7 and 3.9. These results were used for both D\&D and RA support and for the calculation of radionuclide discharges from ETTP.

A fairly large area of the K-770 Scrap Yard drains to a holding pond located on the north side of the scrap yard. Water that collects in this holding pond discharges to the Clinch River through storm water outfall SD 724. Due to inadequate erosion and sediment controls during the time the scrap yard was in use, a large amount of sediment has collected in this holding pond. Based on the operational history of the K-770 Scrap Yard, the sediment may contain radiological, heavy metals, and other types of contamination. Sediment sampling was performed in the holding pond in CY 2013 to identify the types and quantities of contaminants that might be present. Table 3.14 shows the parameters that were sampled as part of this investigation. Notable results from the sampling of the 724 holding pond sediments are presented in Table 3.15.

Table 3.14. Sediment sampling to support remedial action activities at the K-770 Scrap Yard, 2013

\begin{tabular}{cccccc}
\hline RA or D\&D activity & $\begin{array}{c}\text { Sampling } \\
\text { location }\end{array}$ & $\begin{array}{c}\text { Gross } \\
\text { alpha/beta }\end{array}$ & $\begin{array}{c}\text { Isotopic U, }{ }^{99} \text { Tc, } \\
\text { transuranics }^{a}\end{array}$ & PCBs & $\begin{array}{c}\text { Metals }{ }^{a} / \\
\text { Mercury }^{-}\end{array}$ \\
\hline K-770 scrap yard & $\begin{array}{c}\text { Holding pond } \\
\text { upstream of } \\
\text { SD 724 }\end{array}$ & $\mathrm{X}$ & $\mathrm{X}$ & $\mathrm{X}$ & $\mathrm{X}$ \\
\hline
\end{tabular}

${ }^{a}$ Metals analysis included Al, Ag, As, Ba, Be, B, Ca, Cd, Co, Cr, Cu, Fe, K, Mg, Mn, Na, Ni, Pb, Sb, Se, Tl, V, and Zn. Analysis for transuranics included ${ }^{237} \mathrm{~Np},{ }^{238} \mathrm{Pu}$, and ${ }^{239,240} \mathrm{Pu}$.

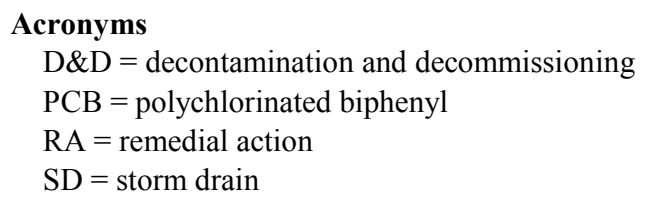

Table 3.15. Analytical results for contaminants of concern in 724 holding pond sediments, 2013

\begin{tabular}{|c|c|c|c|c|c|c|c|c|c|c|}
\hline $\begin{array}{l}\text { Sampling } \\
\text { location }\end{array}$ & $\begin{array}{c}\mathbf{P b} \\
(\mu \mathrm{g} / \mathrm{g})\end{array}$ & $\underset{(\mu \mathrm{g} / \mathrm{g})}{\mathbf{C d}}$ & $\begin{array}{c}\mathrm{Cu} \\
(\mu \mathrm{g} / \mathrm{g})\end{array}$ & $\begin{array}{c}\mathrm{Zn} \\
(\mu \mathrm{g} / \mathrm{g})\end{array}$ & $\begin{array}{c}\text { As } \\
(\mu \mathrm{g} / \mathrm{g})\end{array}$ & $\underset{\text { (ng/g) }}{\mathbf{H g}}$ & $\begin{array}{c}\text { PCB-1242 } \\
(\mu \mathrm{g} / \mathrm{g})\end{array}$ & $\begin{array}{c}\text { PCB-1254 } \\
(\mu \mathrm{g} / \mathrm{g})\end{array}$ & $\begin{array}{c}\text { PCB-1260 } \\
(\mu \mathrm{g} / \mathrm{g})\end{array}$ & $\begin{array}{l}\text { Gross alpha } \\
\quad \text { (pCi/g) }\end{array}$ \\
\hline $\begin{array}{l}724 \\
\text { holding } \\
\text { pond }\end{array}$ & 26.1 & 0.283 & 16.1 & 135 & 26.8 & 124.7 & 0.11 & 0.0429 & 0.0146 & 33.6 \\
\hline
\end{tabular}

Acronyms

$\mathrm{PCB}=$ polychlorinated biphenyl

Storm water outfall SD 724 and the 724 holding pond discharge to the K-770 embayment on the Clinch River. The Action Memorandum for the Ponds at the East Tennessee Technology Park, Oak Ridge, Tennessee: K-1007-P Holding Ponds, K-901-A Holding Pond, K-720 Slough, and K-770 Embayment (DOE 2007) states that no further action will be taken at the K-770 embayment. Land use controls will be implemented to restrict the use of and access to this area. Once it has been established that the area is safe for unrestricted industrial use, controls such as property record restrictions, property record notices, zoning notices, excavation permits, and less significant surveillance patrols will be used.

\subsubsection{Monitoring at the K-731 Switch House-K-732 Switchyard Area}

The K-731 switch house building and the K-732 switchyard were constructed in 1945 to serve the K-27 and K-29 cascades. After these operations shut down, these facilities served as the primary power 
center for ETTP until 2011, when the responsibility for supplying electrical power to the site was assumed by the City of Oak Ridge and the switchyard was shut down.

Several sumps are located in the K-731-K-732 area. These sumps accumulate storm water during wet weather conditions. Figure 3.23 shows the locations of these sumps. Two sumps are located in the basement of K-731. Sump S-053 discharges to sump S-054. Sump S-054 discharges to storm water outfall SD 430. An additional five sumps (sumps S-055, S-056, S-057, S-058, and S-059) are located in the K732 switchyard. Sump S-055 collects water from valve vault 2 in the K-731 switchyard. Sump S-056 collects water from valve vault 3 in the K-731 switchyard. Sump S-057 collects water from synchronous condenser 101. Sump S-058 collects water from synchronous condenser 102. Sump S-059 collects water from synchronous condenser 103. All of these sumps discharge to storm water outfall SD 440. A portion of the south side of the switchyard discharges to SD 440 as well. This discharge to SD 440 includes surface runoff from paved sections of the switchyard area as well as infiltration through the gravel portion of the switchyard area. The K-731-K-732 sumps and the drainage system from this area to SDs 430 and 440 are shown in Fig. 3.23.

Water samples were collected from each of the sumps in the K-731-K-732 area during CY 2013. Results from these samples that exceeded reference standards are shown in Table 3.16.

All of the sumps located in the K-732 switchyard area were completely flooded. It is possible that the sumps in these locations may no longer be operational and that water continues to collect in the sumps without being discharged to the storm drain system.

In addition, storm water outfalls SD 430 and SD 440 were also sampled to determine the effects the discharges from the sumps in the K-731-K-732 area might be having on the quality of the discharge from the outfalls. No detectable PCBs or VOCs were found in samples collected from these locations.

Oil-water separators K-897-J and K-897-K provide containment for any oil or other types of spills that might occur in the K-731 switch house-K-732 switchyard area. Oil-water separator K-897-J is part of the storm water outfall SD 430 drainage system. Oil-water separator K-897-K is part of the SD 440 drainage system. Sediment samples were collected from oil-water separators K-897-J and K-897-K. This sampling was done to identify any contaminants present due to historical settling of sediments in the oilwater separator. Samples were collected for analysis for metals and PCBs as part of this effort. Sediment samples were collected in accordance with applicable EPA and sampling subcontractor procedures. Sediment samples were collected during a dry period when flow into the oil-water separator was low and any suspended materials present in the oil-water separator had settled out. Table 3.17 shows notable results from the K-732 area sampling effort.

The cleanup of the soils in the switchyard will be conducted as part of the CERCLA Zone 2 ROD. There are still several potential transformers and oil circuit breakers that contain regulated levels of PCB oils. In addition, five aboveground storage tanks currently store oils that were once used in the electrical equipment during the historic operation of the K-732 switchyard. Three of these tanks hold oils with less than 50 ppm PCBs. 


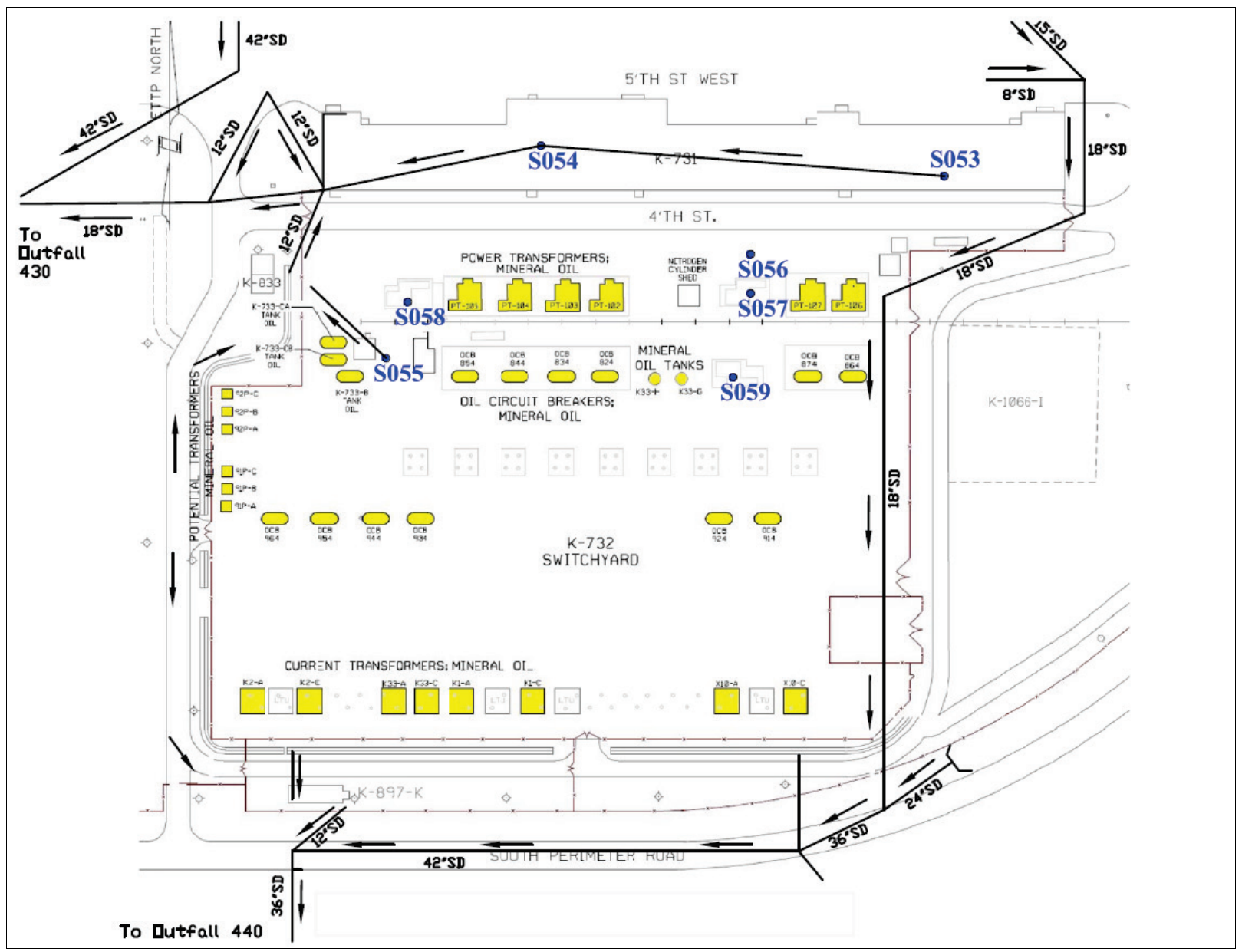

Fig. 3.23. K-731-K-732 sumps.

Table 3.16. Analytical results over reference standards for water from the K-731-K-732 sumps, 2013

(Reference Standard: $0.00064 \mu \mathrm{g} / \mathrm{L}^{\mathrm{a}}$ )

\begin{tabular}{cc}
\hline Sampling location & $\begin{array}{c}\text { PCB-1254 } \\
(\boldsymbol{\mu g} / \mathbf{L})\end{array}$ \\
\hline S-057 & 0.489 \\
S-058 & 1.57 \\
S-059 & 14.6 \\
\hline
\end{tabular}

${ }^{a}$ This reference standard is shown in Table 3 of the East Tennessee Technology Park Storm Water Pollution Prevention Program Sampling and Analysis Plan (UCOR 2013b).

$\mathrm{PCB}=$ polychlorinated biphenyl 
Table 3.17. Analytical results for contaminants of concern in sediments from the K732 switchyard oil-water separators, 2013

\begin{tabular}{cccccccccc}
\hline $\begin{array}{c}\text { Sampling } \\
\text { location }\end{array}$ & $\begin{array}{c}\mathbf{P b} \\
(\boldsymbol{\mu \mathrm { g }} / \mathbf{g})\end{array}$ & $\begin{array}{c}\mathbf{C d} \\
(\boldsymbol{\mu g} / \mathbf{g})\end{array}$ & $\begin{array}{c}\mathbf{C r} \\
(\boldsymbol{\mu g} / \mathbf{g})\end{array}$ & $\begin{array}{c}\mathbf{C u} \\
(\boldsymbol{\mu} \mathbf{g} / \mathbf{g})\end{array}$ & $\begin{array}{c}\mathbf{Z n} \\
(\boldsymbol{\mu} \mathrm{g} / \mathbf{g})\end{array}$ & $\begin{array}{c}\text { As } \\
(\boldsymbol{\mu g} / \mathbf{g})\end{array}$ & $\begin{array}{c}\mathbf{N i} \\
(\boldsymbol{\mu g} / \mathbf{g})\end{array}$ & $\begin{array}{c}\text { PCB-1254 } \\
(\boldsymbol{\mu g} / \mathbf{g})\end{array}$ & $\begin{array}{c}\text { PCB-1260 } \\
(\boldsymbol{\mu g} / \mathbf{g})\end{array}$ \\
\hline $\mathrm{K}-897-\mathrm{J}$ & 591 & 8.21 & 119 & 222 & 1750 & 10.9 & 149 & 0.314 & 0.264 \\
$\mathrm{~K}-897-\mathrm{K}$ & 57.8 & 1.74 & 41.4 & 91.3 & 1030 & 12.8 & 47.6 & $\mathrm{BDL}$ & $\mathrm{BDL}$ \\
\hline
\end{tabular}

Acronyms

$\mathrm{BDL}=$ below detection limit

$\mathrm{PCB}=$ polychlorinated biphenyl

\subsubsection{Sampling of Legacy Chromium Groundwater Plume Discharge}

During FY 2007, hexavalent chromium was detected in surface water in Mitchell Branch at levels exceeding the applicable AWQC of $0.011 \mathrm{mg} / \mathrm{L}$ for the protection of fish and aquatic life. At Mitchell Branch kilometers (MIKs) 0.71 and 0.79, locations in Mitchell Branch immediately downstream from the storm water outfall SD 170 discharge point, hexavalent chromium levels were measured at levels as high as $0.78 \mathrm{mg} / \mathrm{L}$. The source of the discharge was determined to be groundwater infiltration into the SD 170 piping as well as seep flows through the SD headwall. Figure 3.24 shows the locations where hexavalent chromium releases to Mitchell Branch were identified.

Because hexavalent chromium has not been used in process operations at ETTP for more than 30 years, the release of hexavalent chromium into Mitchell Branch is a legacy problem and not an ongoing, current operations issue. Therefore, DOE in coordination with EPA and TDEC determined that the appropriate response to this release was a CERCLA time-critical removal action. A Removal Action Report for the Reduction of Hexavalent Chromium Releases into Mitchell Branch at the East Tennessee Technology Park, Oak Ridge, Tennessee (DOE 2008) for the time-critical removal action was issued in July 2008. Subsequently a non-time-critical Action Memorandum for the Long-Term Reduction of Hexavalent Chromium Releases into Mitchell Branch at the East Tennessee Technology Park, Oak Ridge, Tennessee (DOE 2010) was issued, which led to the construction of CWTS.

Construction of CWTS was initiated in the spring of 2011 with final process installation completed in 2012. CWTS treats chromium- and hexavalent-chromium-contaminated groundwater pumped from a groundwater plume near storm water outfall SD 170 in accordance with the non-time-critical action memorandum mentioned previously (DOE 2010). During 2013, the chromium collection system wells operated during $100 \%$ of the days with only short duration periods where collection system pumping volumes were limited due to treatment facility operational constraints. The total volume of wastewater that was treated in CY 2013 was about 5.6 million gal.

High levels of calcium and magnesium in the groundwater plume continued to create scale buildup on the facility pumps, valves, and piping during CY 2013. This has been an operational issue from the start of the pump-and-treat operations. During CY 2013, CWTS operational changes were implemented to help address the scale buildup issues by installing the One-Flow Anti-Scaling System upstream of the air stripper in February 2013. The additional equipment in the treatment train seemed to reduce the rate of the scale buildup, but there was still a need for numerous pump replacements and repairs for both the air stripper and day tank pumps during the past year.

Pump scale buildup was the cause of a treatment system bypass that occurred in late August 2013 for a period of about $60 \mathrm{~h}$. The volume of plume water that bypassed treatment for a direct discharge into the Clinch River was about 27,640 gal. On October 1, 2013, a second bypass began that consisted of about 22,000 gal and lasted about $46 \mathrm{~h}$. These bypasses are authorized in accordance with the terms of the non-time-critical CERCLA action memorandum (DOE 2010) but require that notifications be provided to the CERCLA regulatory parties for a bypass that lasts longer than $4 \mathrm{~h}$. The notifications provided information on the causes of the events, volume of water bypassed, most recent quarterly sampling results, and points where the treatment unit pumps were repaired. There were no AWQCs exceedances in 
the Clinch River as a result of these discharges. Facility modifications are being evaluated to determine whether cost-effective changes could be implemented to decrease the water scaling pump and valve maintenance issues.
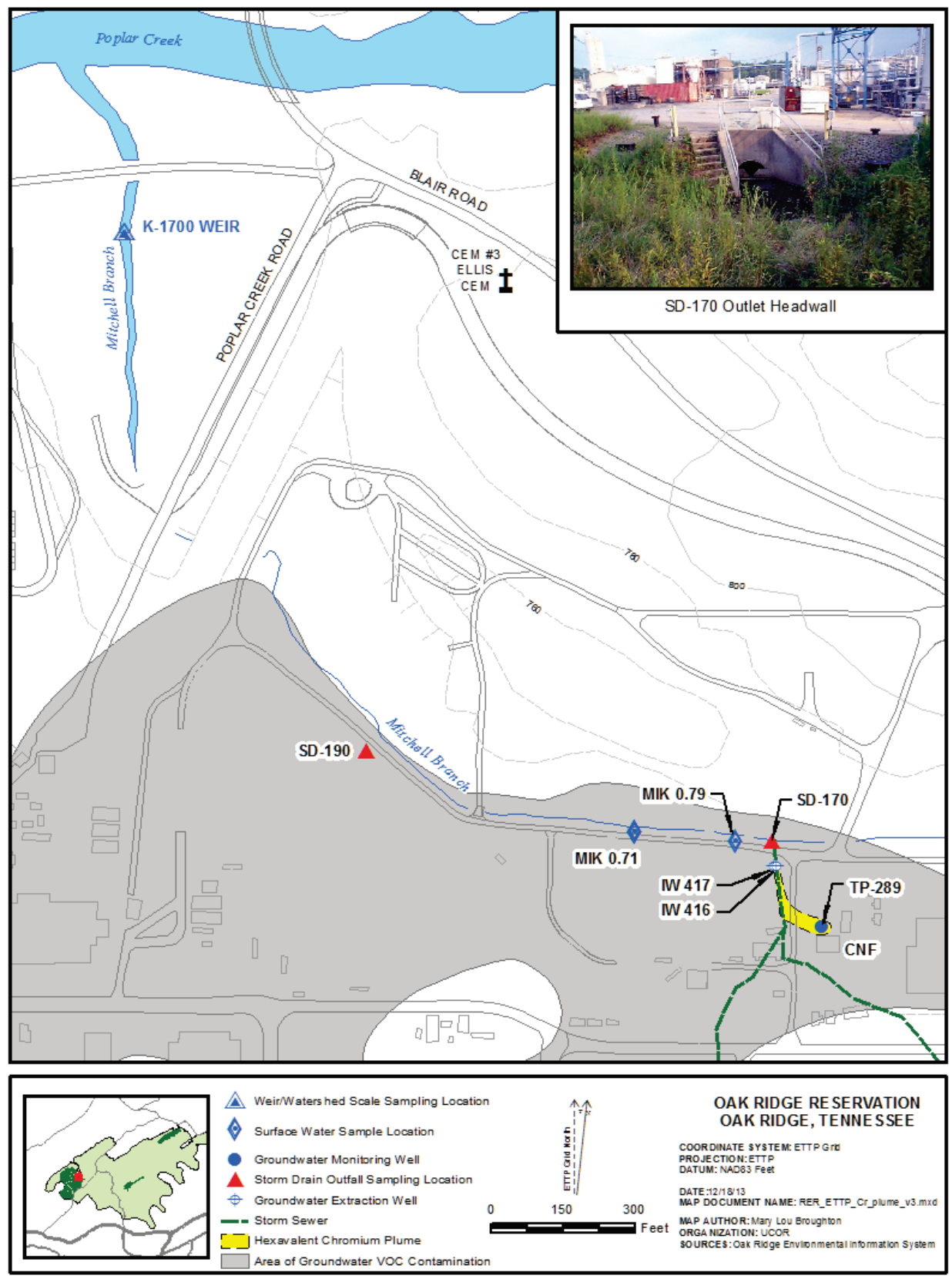

Fig. 3.24. Hexavalent chromium discharges into Mitchell Branch.

$(\mathrm{CEM}=$ cemetery, $\mathrm{CNF}=$ Central Neutralization Facility, IW = extraction well, $\mathrm{MIK}=$ Mitchell Branch kilometer, $\mathrm{SD}=$ storm drain, $\mathrm{TP}=$ piezometer, and $\mathrm{VOC}=$ volatile organic compound.)

To monitor both the continued effectiveness of the collection system and the effectiveness of CWTS, periodic monitoring was performed in CY 2013. Samples were collected at monitoring well-289, the chromium collection system wells, SD 170, and MIK 0.79. Samples collected at monitoring well 289 (TP-289) directly monitor the concentrations of chromium in the contaminated groundwater plume. Samples collected from the chromium collection system wells monitor the chromium in the water 
recovered by the groundwater collection system. Samples collected at SD 170 monitor the concentrations of the chromium and hexavalent chromium plume being discharged directly to Mitchell Branch. Samples at MIK 0.79 are collected to allow monitoring of chromium and hexavalent chromium concentrations in Mitchell Branch. Requirements for this sampling effort are listed in Table 3.18. Figures 3.25 and 3.26 are graphs of the analytical data from this sampling effort.

The analytical data indicate that chromium levels may fluctuate slightly at TP-289 and the chromium collection system wells but are relatively consistent over the long term. Chromium values at storm water outfall SD 170 and MIK 0.79 have much more variability. This is most likely due to the greater variability in flow rates at these two locations.

Table 3.18. Monitoring requirements-Mitchell Branch subwatershed total and hexavalent chromium sampling locations

\begin{tabular}{lccc}
\hline \multicolumn{1}{c}{ Location } & Parameter & $\begin{array}{c}\text { Measurement } \\
\text { frequency }\end{array}$ & $\begin{array}{c}\text { Sample } \\
\text { type }\end{array}$ \\
\hline MIK 0.79 & Total chromium & $1 /$ quarter & $\mathrm{Grab}$ \\
MIK 0.79 & Hexavalent chromium & $1 /$ quarter & $\mathrm{Grab}$ \\
Storm drain 170 & Total chromium & $1 /$ quarter & $\mathrm{Grab}$ \\
Storm drain 170 & Hexavalent chromium & $1 /$ quarter & $\mathrm{Grab}$ \\
Monitoring well 289 (TP-289) & Total chromium & $1 /$ quarter & $\mathrm{Grab}$ \\
TP-289 & Hexavalent chromium & $1 /$ quarter & Grab \\
Cr collection system wells & Total chromium & $1 /$ quarter & Grab \\
Cr collection system wells & Hexavalent chromium & $1 /$ quarter & Grab \\
\hline
\end{tabular}

NOTE: Total chromium and hexavalent chromium will be collected during varying weather conditions (for example, samples will be collected during wet weather conditions one quarter and during dry weather conditions the following quarter).

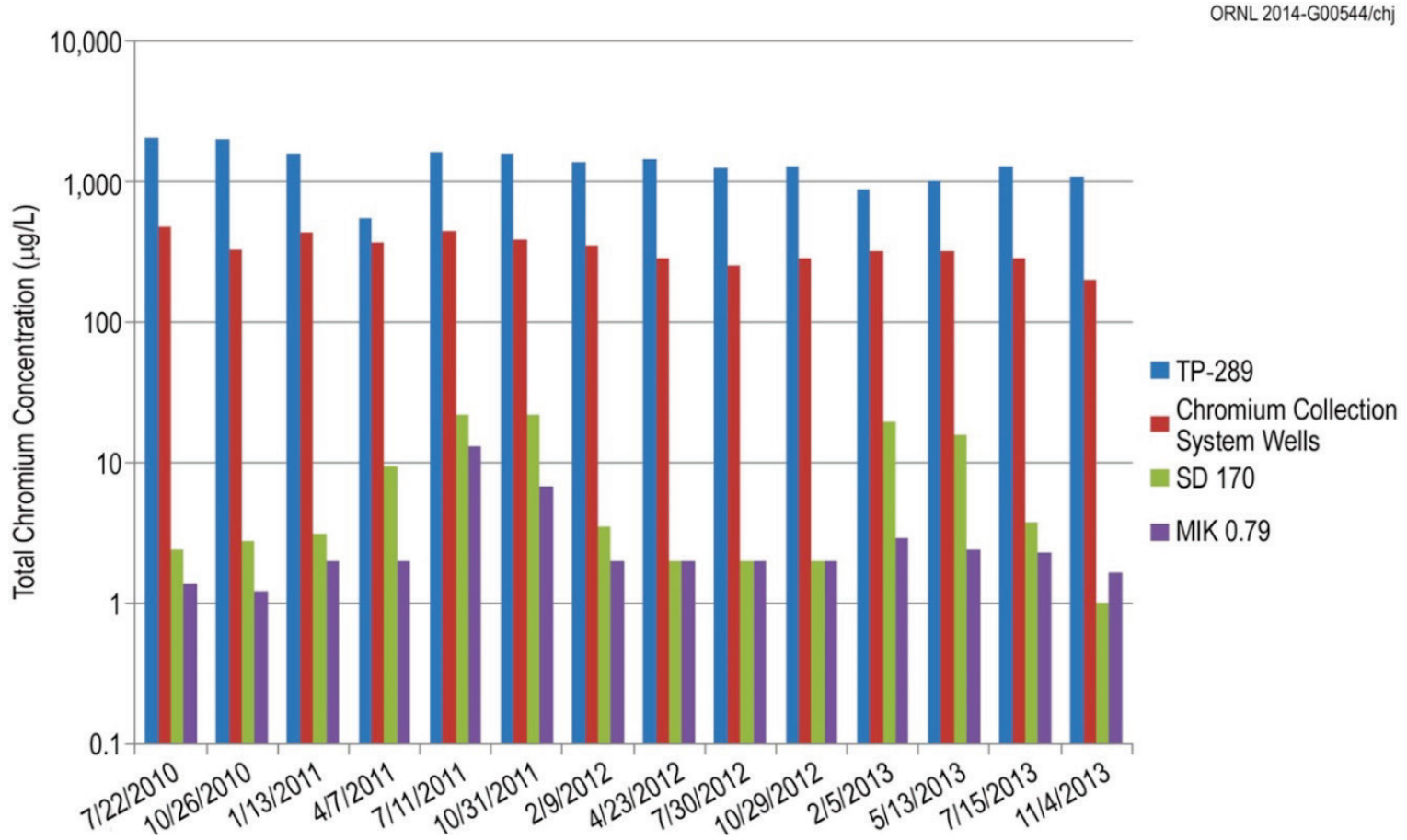

Fig. 3.25. Total chromium sample results for the chromium collection system.

( TP = piezometer, $\mathrm{SD}=$ storm drain, and $\mathrm{MIK}=$ Mitchell Branch kilometer.) 


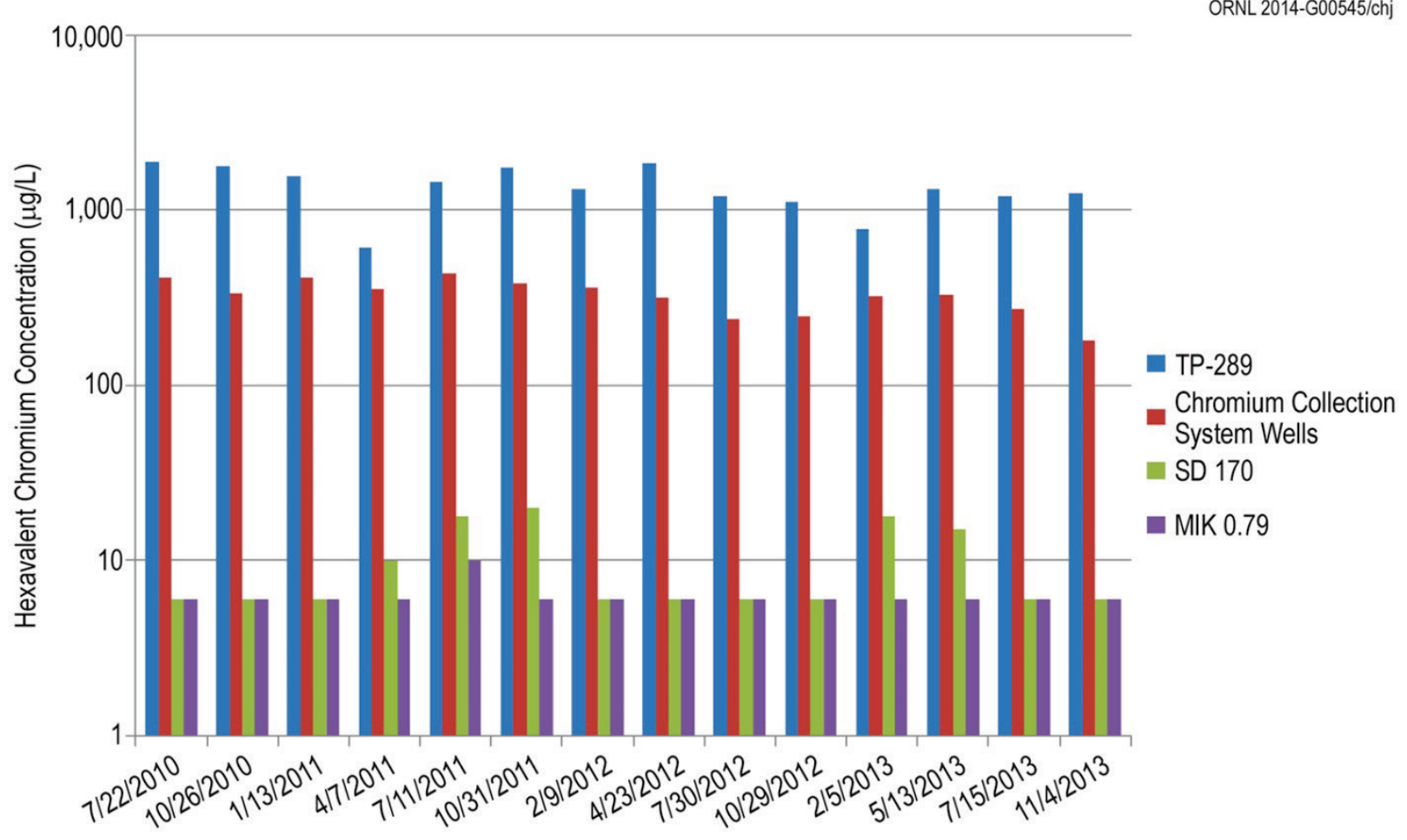

Fig. 3.26. Hexavalent chromium sample results for the chromium collection system. ( $\mathrm{TP}=$ piezometer, $\mathrm{SD}=$ storm drain, and MIK = Mitchell Branch kilometer. $)$

\subsubsection{Investigation of Mercury at East Tennessee Technology Park}

\subsubsection{History of Mercury Use at ETTP}

Mercury activities at ETTP included use, handling, and recovery operations. Mercury use and handling were common in such equipment as manometers, switches, mass spectrometers, mercury diffusion pumps, mercury traps, and laboratory operations. Process buildings contained many of these manometers, thermometers, and switches. Large quantities of mercury-bearing wastes from the on-site gaseous diffusion plant operations and support buildings, ORNL, and Y-12 were processed and stored at ETTP. Mercury from soils and spill cleanups were processed on-site as well.

\subsubsection{Current NPDES Requirements for Mercury Monitoring}

The current NPDES permit requires quarterly mercury sampling to be performed at storm water outfalls SD 170, SD 180, SD 190, and SD 05A. These four locations were selected because the permit application information indicated that mercury levels at these outfalls exceeded the AWQC level of 51 $\mathrm{ng} / \mathrm{L}$. SDs 170, 180, and 190 collect storm water from large areas on the north side of ETTP and discharge to Mitchell Branch. SD 05A, which is located on the east side of ETTP, is the discharge point for the former STP drainage basin into Poplar Creek. The quarterly mercury monitoring results as reported to TDEC are shown in Table 3.19.

Mercury results for SD 170 have been well below AWQCs since July 2009. SDs 180 and 190 appear to be the primary sources of mercury discharges into Mitchell Branch. Both the SD 180 network and the SD 190 network drain areas with historical mercury processes. Potential sources of mercury in the SD 180 drainage system are from the former K-1401, K-1301, and K-1303 building areas and from the K$1407-B$ pond area. Potential sources of mercury in the SD 190 drainage system are from the former K1035, K-1401, and K-1413 building areas. 
Table 3.19. Quarterly National Pollutant Discharge Elimination System mercury monitoring results as reported for CY 2013

\begin{tabular}{ccccc}
\hline $\begin{array}{c}\text { Sampling } \\
\text { location }\end{array}$ & $\begin{array}{c}\text { First quarter } \\
\text { (ng/L) }\end{array}$ & $\begin{array}{c}\text { Second quarter } \\
(\mathbf{n g} / \mathbf{L})\end{array}$ & $\begin{array}{c}\text { Third quarter } \\
(\mathbf{n g} / \mathbf{L})\end{array}$ & $\begin{array}{c}\text { Fourth quarter } \\
(\mathbf{n g} / \mathbf{L})\end{array}$ \\
\hline SD 170 & 5.32 & 4.6 & 9.3 & 2.75 \\
SD 180 & 92.8 & $34.5^{a}$ & $39.9^{b}$ & 100 \\
SD 190 & 279 & $203^{c}$ & $164^{d}$ & 38.5 \\
SD 05A & 130 & 690 & 351 & 223 \\
\hline
\end{tabular}

${ }^{a}$ An unfiltered mercury result of $30.7 \mathrm{ng} / \mathrm{L}$ and a filtered mercury result of $19.6 \mathrm{ng} / \mathrm{L}$ were considered for this reporting period.

${ }^{b}$ An unfiltered mercury result of $24.1 \mathrm{ng} / \mathrm{L}$ and a filtered mercury result of $9.22 \mathrm{ng} / \mathrm{L}$ were considered for this reporting period.

${ }^{c}$ Unfiltered mercury results of 75.4 and $65.7 \mathrm{ng} / \mathrm{L}$ and a filtered mercury result of $27.3 \mathrm{ng} / \mathrm{L}$ were considered for this reporting period.

${ }^{d}$ An unfiltered mercury result of $119 \mathrm{ng} / \mathrm{L}$ and a filtered mercury result of $34.1 \mathrm{ng} / \mathrm{L}$ were considered for this reporting period.

The storm water outfall SD 05A compliance sampling point is the K-1203-10 sump. This sump was the discharge point for the former STP overflow during its years of operation. The STP was piped to the K-1203-10 sump to allow discharge of treated effluent by the lift pumps in the event high water in Poplar Creek prevented gravity discharge. Operations at the STP ceased in 2008. The K-1203-10 sump also serves as a collection sump for storm water. Currently, the K-1203-10 sump receives water influent from storm water flow as well as flow through the existing out of service STP piping. Potential sources of mercury in the discharge from SD 05A are currently under investigation.

Results for SDs 170, 180, 190, and 05A are shown in Figs. 3.27 through 3.30. Samples collected for compliance with the current NPDES permit were collected as manual grab samples.

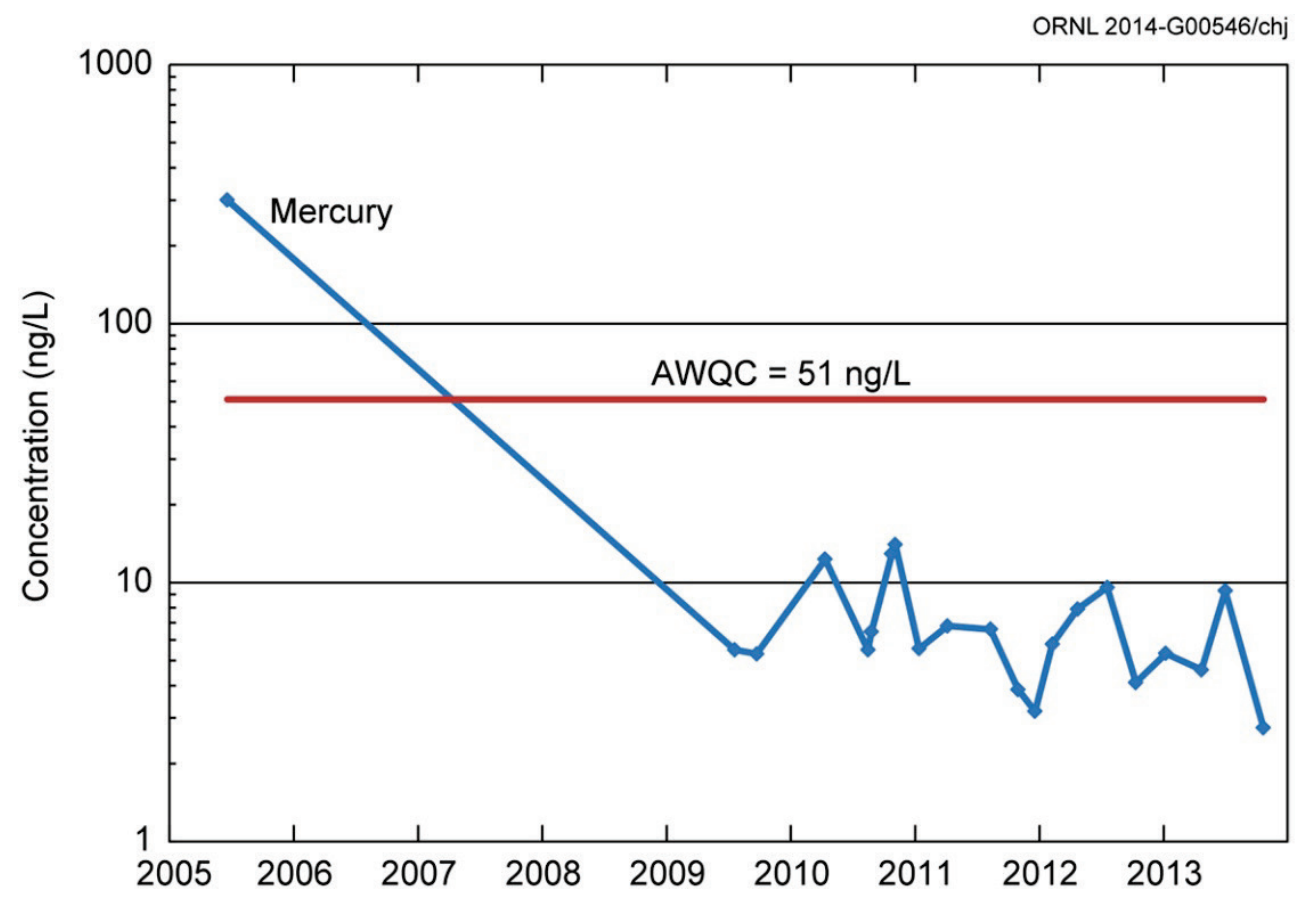

Fig. 3.27. Storm water outfall SD 170 mercury monitoring results.

(AWQC $=$ ambient water quality criterion. $)$ 


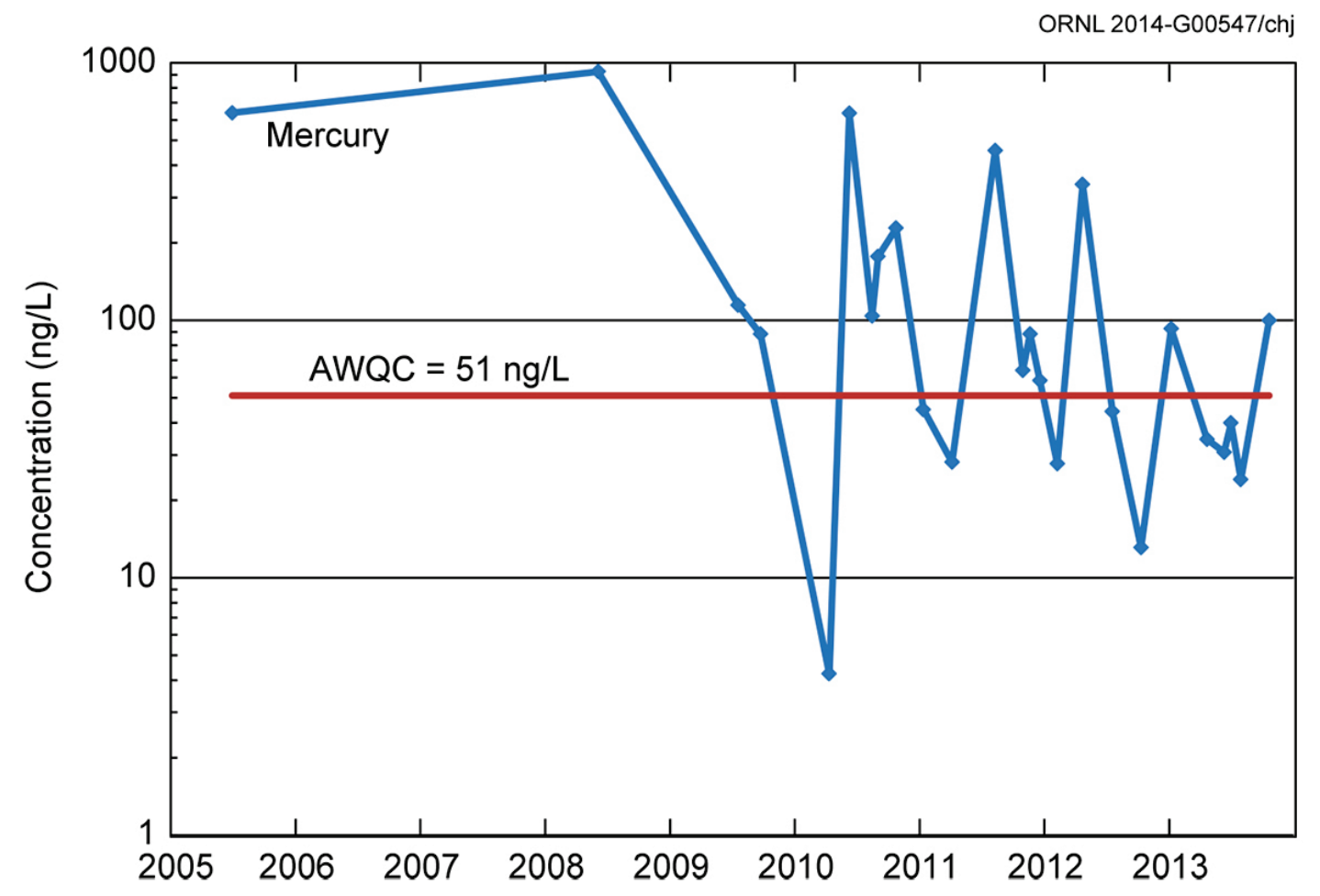

Fig. 3.28. Storm water outfall SD 180 mercury monitoring results. $(A W Q C=$ ambient water quality criterion.)

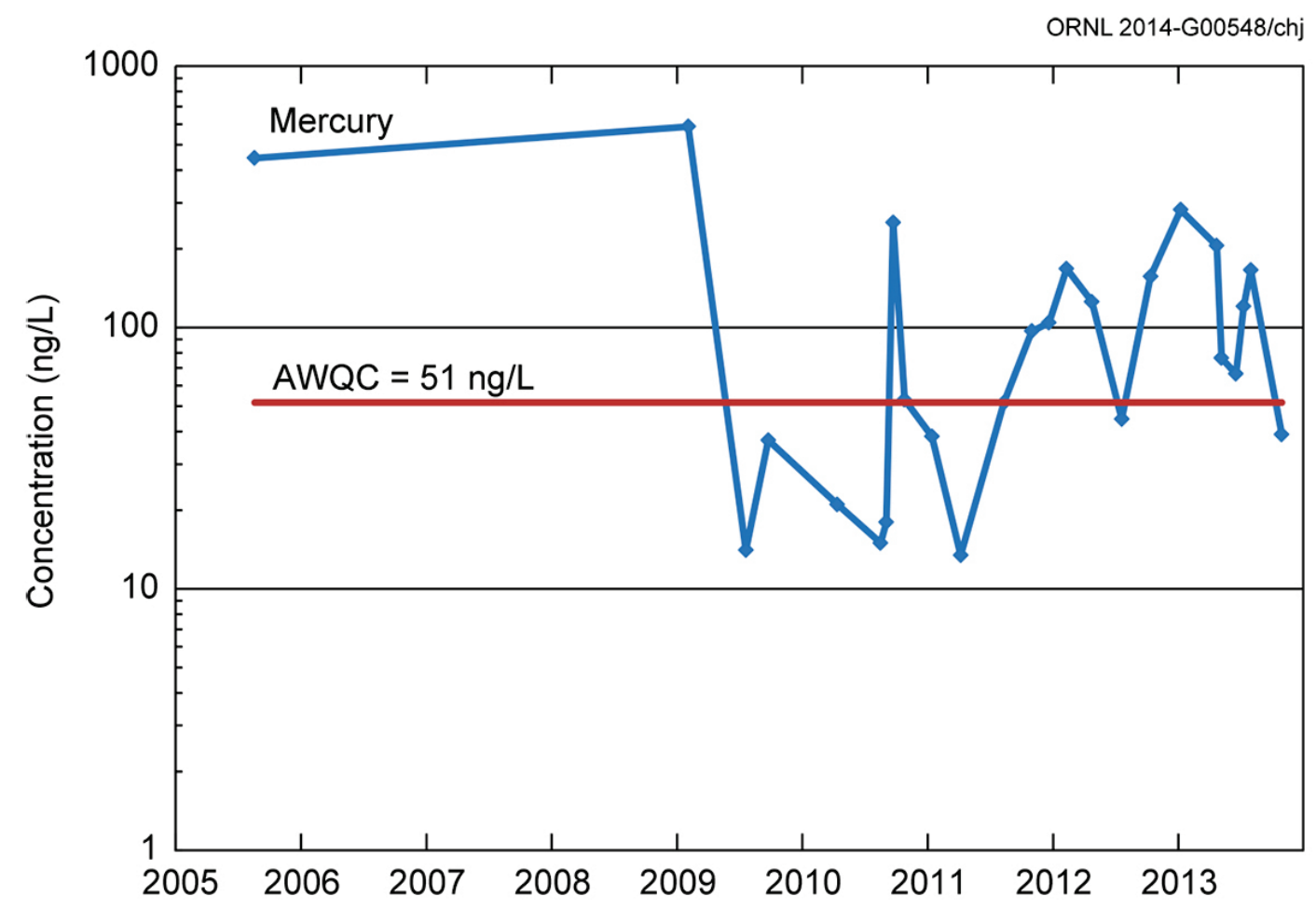

Fig. 3.29. Storm water outfall SD 190 mercury monitoring results. (AWQC $=$ ambient water quality criterion.) 


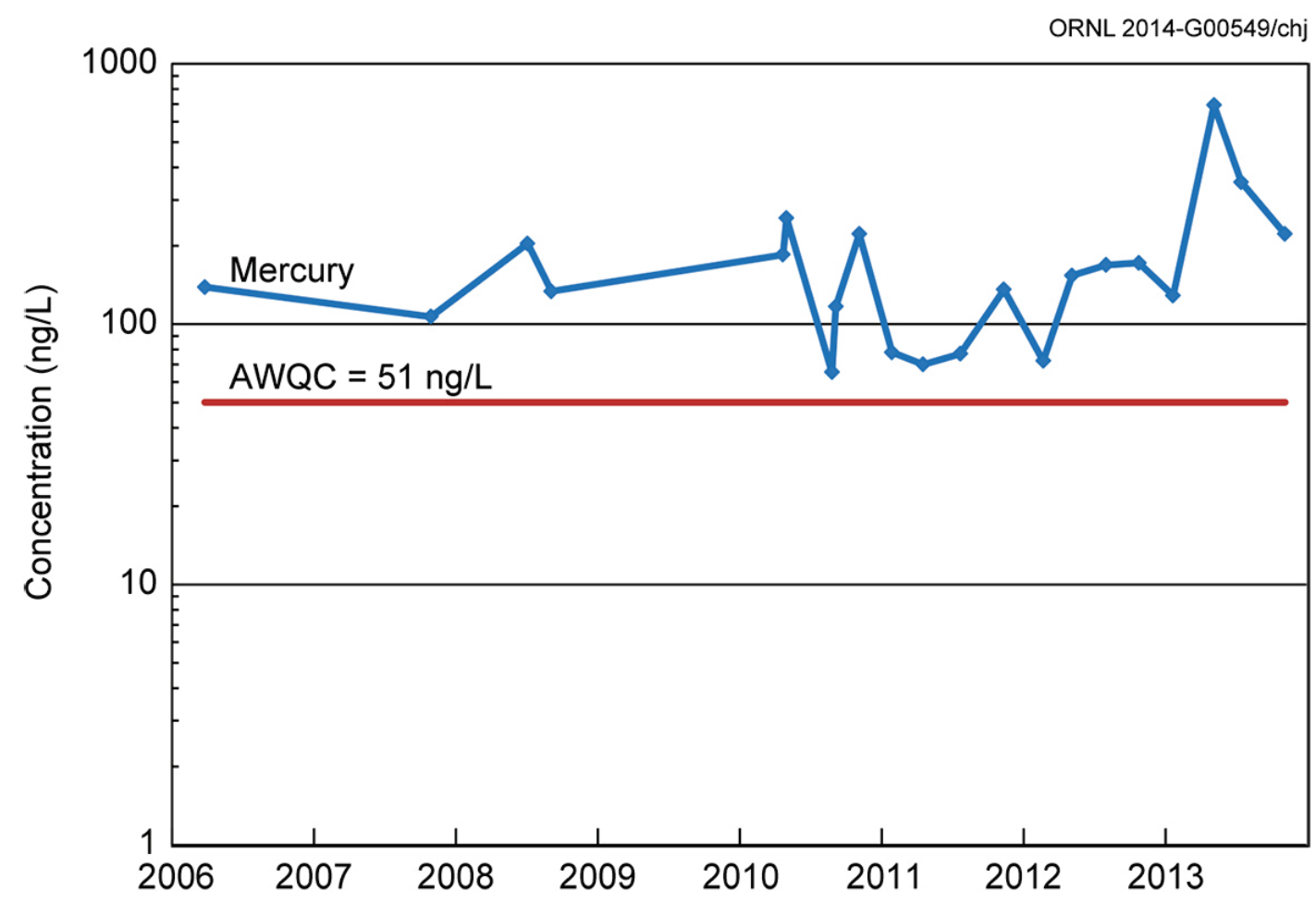

Fig. 3.30. Storm water outfall SD 05A mercury monitoring results. (AWQC $=$ ambient water quality criterion.)

\subsubsection{Additional Mercury Monitoring Activities}

In an effort to obtain analytical data to identify how the discharges from the storm water outfalls might be affecting the water quality of Mitchell Branch, Poplar Creek, and associated waterways, mercury sampling has been performed at numerous storm water outfalls where mercury activities may have occurred within their watersheds. To identify specific areas of mercury contamination, sampling was performed in the storm water outfall networks in the Mitchell Branch subwatershed. Filtered and unfiltered samples were collected during wet weather in June 2013 and during dry weather in July 2013.

Wet weather samples were collected from flows resulting from a storm event greater than $0.1 \mathrm{in}$. in magnitude within $24 \mathrm{~h}$ that occurred at least $72 \mathrm{~h}$ after any previous storm event of $0.1 \mathrm{in}$. or more within $24 \mathrm{~h}$. If an intermittent rainfall occurred over a period of $24 \mathrm{~h}$ and did not equal or exceed $0.1 \mathrm{in}$., it was not considered to be a storm event, and the $72 \mathrm{~h}$ delay until the next rainfall that could potentially be sampled was not in effect. Dry weather samples were collected at least $72 \mathrm{~h}$ after a storm event of $0.1 \mathrm{in}$. or more. All dry weather samples were collected by the manual grab sampling technique.

Mercury water samples were collected from the following locations in the storm water outfall SD 180 drainage network: SD 180 and manholes 8131, 13002, and 13141. Mercury water samples were collected from the following locations in the SD 190 drainage network: SD 190 and manholes 8002, 8017, 13037, 13048, and 13074. Mercury water samples were collected from the following locations in the SD 200 drainage network: SD 200 and manhole 3014. Finally, mercury samples were collected from the following locations in the SD 210 drainage network: SD 210 and manhole 3010. Table 3.20 shows the results of the wet weather mercury monitoring, and Table 3.21 shows the results of the dry weather mercury monitoring.

In addition, mercury sediment samples were collected from SDs 180, 190, and 210. Table 3.22 shows the mercury sediment sample results. Figure 3.31 shows the networks and sampling locations. 
Table 3.20. Mercury results from wet weather monitoring conducted in the drainage networks of the Mitchell Branch storm water outfalls in June 2013

\begin{tabular}{ccc}
\hline Sampling location & Unfiltered Hg (ng/L) & Filtered Hg (ng/L) \\
\hline SD 180 & 30.7 & 19.6 \\
MH 8131 & 3.94 & 3.06 \\
MH 13002 & 5.5 & 1.93 \\
MH 13141 & 0.571 & $<0.5$ \\
SD 190 & $\mathbf{6 5 . 7}$ & 27.3 \\
MH 8002 & $\mathbf{1 4 6}$ & 20.5 \\
MH 8017 & $\mathbf{3 5 3}$ & $\mathbf{3 3 9}$ \\
MH 13074 & $\mathbf{3 6 6}$ & $\mathbf{1 7 8}$ \\
MH 13037 & $\mathbf{1 1 3 0}$ & $\mathbf{4 9 5}$ \\
MH 13048 & 7.42 & 6.82 \\
SD 200 & 3.55 & 3.01 \\
MH 3014 & 3.27 & 2.44 \\
SD 210 & 13.5 & 9 \\
MH 3010 & 30.1 & 18 \\
\hline
\end{tabular}

$\mathrm{MH}=$ manhole, $\mathrm{SD}=$ storm drain

Bold $=$ above ambient water quality criterion of $51 \mathrm{ng} / \mathrm{L}$.

Table 3.21. Mercury results from dry weather monitoring conducted in the drainage networks of the Mitchell Branch storm water outfalls in July 2013

\begin{tabular}{ccc}
\hline Sampling location & Unfiltered Hg (ng/L) & Filtered Hg (ng/L) \\
\hline SD 180 & 24.1 & 9.22 \\
MH 8131 & 3.51 & 4.89 \\
MH 13002 & 2.21 & 1.51 \\
MH 13141 & $<0.5$ & $<0.5$ \\
SD 190 & $\mathbf{1 6 4}$ & 34.1 \\
MH 8002 & $\mathbf{2 1 3}$ & 38.6 \\
MH 8017 & $\mathbf{3 4 5 0}$ & $\mathbf{6 7 8}$ \\
MH 13074 & $\mathbf{7 0 8}$ & $\mathbf{6 1 0}$ \\
MH 13037 & $\mathbf{7 9 3}$ & $\mathbf{6 2 8}$ \\
MH 13048 & 31.8 & 12.3 \\
SD 200 & NS & NS \\
MH 3014 & NS & NS \\
SD 210 & NS & NS \\
MH 3010 & NS
\end{tabular}


Table 3.22. Mercury results from sediment sampling at select Mitchell Branch storm water outfalls in 2013

\begin{tabular}{ccc}
\hline Sampling location & Date & Result (ng/g) \\
\hline SD 180 & $9 / 9 / 2013$ & $1,006.8$ \\
SD 190 & $9 / 9 / 2013$ & $17,183.4$ \\
SD 210 & $9 / 9 / 2013$ & 337.2 \\
\hline
\end{tabular}

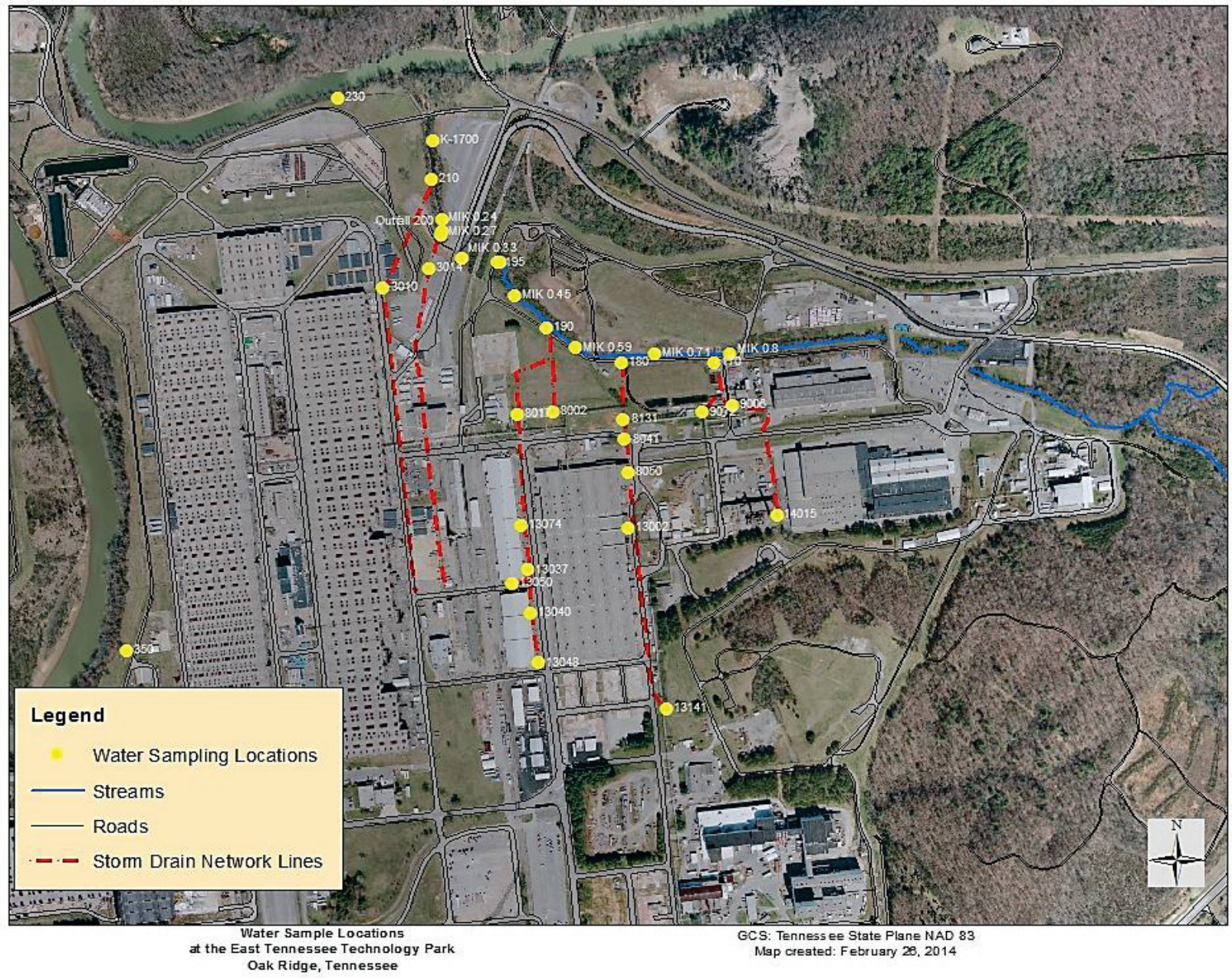

Fig. 3.31. Storm drain (SD) networks for SDs 170, 180, 190, 200, and 210.

\subsubsection{K-1203 Sewage Treatment Plant}

The mercury investigation at the K-1203 STP continues. The K-1203 STP was previously used to treat and process all sanitary sewage waste from ETTP. The plant was shut down on May 29, 2008, as a result of the transition of sewage treatment for ETTP to the City of Oak Ridge. The City of Oak Ridge expanded the Rarity Ridge STP (RRSTP) to include capacity to treat the waste from ETTP, and CROET constructed a new ETTP lift station and force main to RRSTP. Table 3.23 shows the mercury results from soil and sediment sampling conducted at the K-1203 STP area. Table 3.24 shows the mercury results from water sampling conducted at the K-1203 STP area. Figure 3.32 shows the sampling locations. 
Table 3.23. Mercury results from soil/sediment sampling conducted in the K-1203 Sewage Treatment Plant area in 2013

\begin{tabular}{lcc}
\hline \multicolumn{1}{c}{ Sampling location } & Date & Result (ng/g) \\
\hline K-1203-2 Imhoff tank-west & $4 / 23 / 2013$ & $40,684.7$ \\
K-1203-2 Imhoff tank-east & $4 / 23 / 2013$ & $5,053.1$ \\
K-1203-8 chlorine contact basin & $4 / 23 / 2013$ & $153,773.1$ \\
Storm drain 05A-A & $4 / 18 / 2013$ & 260.6 \\
Storm drain 05A-C & $4 / 18 / 2013$ & 997.8 \\
K-1203-10 sump & $4 / 18 / 2013$ & $6,570.1$ \\
\hline
\end{tabular}

Table 3.24. Mercury results of water sampling conducted in the K-1203 Sewage Treatment Plant area in 2013

\begin{tabular}{lcc}
\hline \multicolumn{1}{c}{ Sampling location } & Date & Result (ng/L) \\
\hline K-1203 clarifier & $4 / 29 / 2013$ & 82.6 \\
K-1203-2 Imhoff tank-west & $4 / 8 / 2013$ & 0.937 \\
K-1203-2 Imhoff tank-east & $4 / 8 / 2013$ & 1.72 \\
K-1203-2 Imhoff tank-west & $9 / 23 / 2013$ & 0.777 \\
K-1203-2 Imhoff tank-east & $9 / 23 / 2013$ & 0.902 \\
K-1203 SB manhole 2 & $9 / 21 / 2013$ & 89.1 \\
K-1203-12 sump & $9 / 21 / 2013$ & 27.2 \\
K-1203-14 comminutor & $9 / 21 / 2013$ & 78.7 \\
K-1203 aeration basin & $9 / 23 / 2013$ & 172 \\
K-1203 inner clarifier & $9 / 23 / 2013$ & 4.11 \\
K-1203 sludge holding basin & $9 / 23 / 2013$ & 4.48 \\
K-1203 effluent channel & $9 / 23 / 2013$ & 4.53 \\
Storm drain 05A-JCT & $4 / 8 / 2013$ & 73.1 \\
Storm drain 05A-JCT & $4 / 29 / 2013$ & 55.6 \\
Storm drain 05A-JCT & $5 / 6 / 2013$ & 80.3 \\
Manhole 1 & $4 / 8 / 2013$ & 35.5 \\
Manhole 1 & $5 / 6 / 2013$ & 8.79 \\
Manhole 171 & $4 / 8 / 2013$ & 21.1 \\
Manhole 171 & $5 / 6 / 2013$ & 17.1 \\
Manhole 173 & $5 / 6 / 2013$ & 27.4 \\
Manhole 275 & $4 / 8 / 2013$ & 1,860 \\
Manhole 275 & $5 / 6 / 2013$ & 5.4 \\
Manhole 276 & $4 / 8 / 2013$ & 350 \\
Manhole 276 & $5 / 6 / 2013$ & 5.5 \\
Manhole 278 & $4 / 8 / 2013$ & 56.8 \\
Manhole 278 & $5 / 6 / 2013$ & 3.98 \\
Storm drain 05A-A & $4 / 29 / 2013$ & 6.97 \\
Storm drain 05A-B & $4 / 8 / 2013$ & 11.7 \\
Storm drain 05A-B & $4 / 29 / 2013$ & 20.1 \\
Storm drain 05A-D & $4 / 8 / 2013$ & 32.1 \\
Storm drain 05A-D & $4 / 29 / 2013$ & 51.5 \\
Storm drain 05A-E & $4 / 29 / 2013$ & 14.3 \\
\hline
\end{tabular}




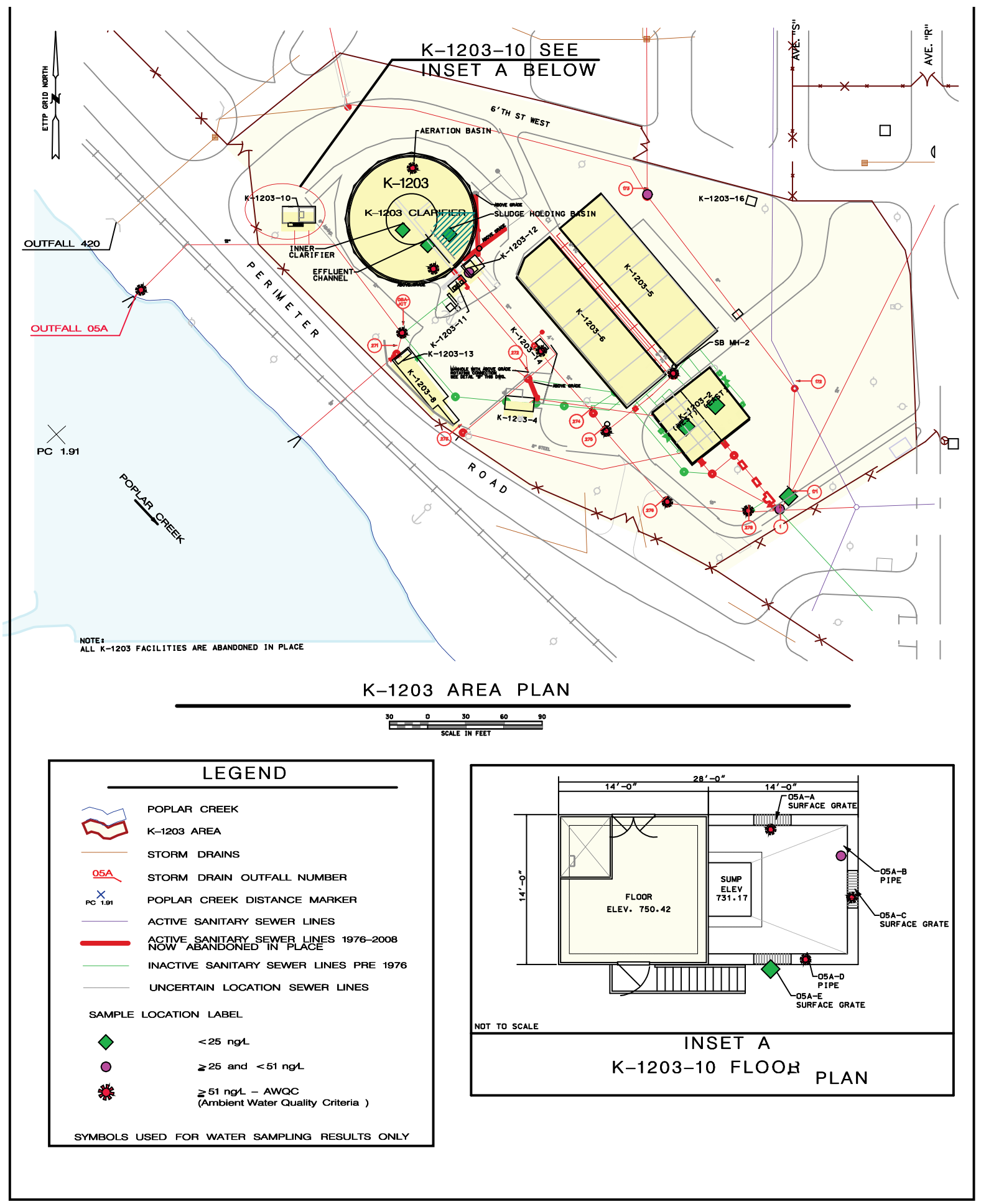

Fig. 3.32. Sampling locations at the K-1203 Sewage Treatment Plant area. 


\subsubsection{Decontamination and Decommissioning of the Technetium-99- Contaminated Portion of the East Wing of Building K-25}

RA and D\&D activities have continued across the site. In 2013, storm water outfalls affected by the demolition cleanup of the last section of the K-25 building were monitored for ${ }^{99} \mathrm{Tc}$, mercury, and other contaminants. Table 3.25 shows the results of the mercury monitoring at outfalls SD 210 and SD 490 and manholes 17006 and 18102 .

Table 3.25. Mercury results from storm water sampling activities associated with decontamination and decommissioning activities at the $\mathrm{K}-25$ building

\begin{tabular}{ccccc}
\hline Date & $\begin{array}{c}\text { Storm drain 210 } \\
\text { Hg results } \\
\text { (ng/L) }\end{array}$ & $\begin{array}{c}\text { Storm drain 490 } \\
\text { Hg results } \\
(\mathbf{n g} / \mathbf{L})\end{array}$ & $\begin{array}{c}\text { Manhole 18102 } \\
\text { Hg results } \\
\text { (ng/L) }\end{array}$ & $\begin{array}{c}\text { Manhole 17006 } \\
\text { Hg results } \\
\text { (ng/L) }\end{array}$ \\
\hline $9 / 21 / 2013$ & 12.4 & 7.77 & 7.44 & 10.7 \\
$11 / 18 / 2013$ & 7.46 & 8.92 & 15.4 & 8.9 \\
$11 / 26 / 2013$ & 16.6 & 8.31 & 8.37 & 7.09 \\
$12 / 9 / 2013$ & 8.62 & 6.4 & 8.02 & 8.01 \\
$12 / 23 / 2013$ & $\mathrm{NA}^{a}$ & 6.1 & 6.23 & 9.59 \\
$12 / 30 / 2013$ & $\mathrm{NA}^{a}$ & 4.83 & 5.54 & 11.1 \\
\hline
\end{tabular}

${ }^{a}$ Samples were not collected for mercury analysis at this location on this date during the sampling period.

\subsubsection{Remedial Actions at the K-1070-B Burial Ground}

Remedial efforts at the K-1070-B burial ground were completed during FY 2012. Additional storm water sampling was performed in this area during 2013 in an effort to determine the impacts of the cleanup activities. Sampling was performed at manholes 8002 and 8017 (upgradient of the K-1070-B burial ground) and at SD 190 (downgradient of the K-1070-B burial ground). Samples were collected in CY 2013 for a suite of analytes, including mercury. Table 3.26 shows the mercury results from this sampling effort.

Table 3.26. Mercury results from storm water sampling activities associated with the remedial action activities at the K-1070-B burial ground

\begin{tabular}{ccc}
\hline Sampling location & Date & Result (ng/L) \\
\hline Storm drain 190 & $5 / 6 / 2013$ & 75.4 \\
Manhole 8002 & $5 / 6 / 2013$ & 36.7 \\
Manhole 8017 & $5 / 6 / 2013$ & 126 \\
\hline
\end{tabular}

\subsubsection{Remedial Actions at the K-770 Scrap Yard Area}

Closure activities at the K-770 scrap yard have been completed, and all of the large pieces of scrap metal in the yard have been removed and disposed. Much of the scrap yard drains to a holding pond on the north side of the scrap yard. Water that collects in this holding pond discharges to the Clinch River through storm water outfall SD 724. Sediment sampling was performed in the holding pond for a suite of analytes, including mercury. Table 3.27 shows the mercury result from this sampling effort. 
Table 3.27. Mercury result from sediment sampling associated with the remedial action activities at the K-700 scrap yard area

\begin{tabular}{ccc}
\hline Sampling location & Date & Result (ng/g) \\
\hline 724 holding pond & $4 / 16 / 2013$ & 124.7 \\
\hline
\end{tabular}

\subsubsection{Remedial Actions at the K-720 Coal Ash Pile}

Runoff and leachate from the $\mathrm{K}-720$ coal ash pile resulted in occasional low $\mathrm{pH}$ readings at storm water outfall SD 992 for several years. In addition, elevated levels of metals that are often found in coal, including arsenic and selenium, have been detected in storm water samples from the area. Investigative efforts performed as part of the ETTP SWPP Program demonstrated that the major source of concern for the low $\mathrm{pH}$ values measured at SD 992 was the channel that receives drainage from the coal ash sluice pond. This channel also receives drainage from a portion of the coal ash pond that was not completely covered with soil during the RAs that were conducted in the mid-1990s.

In an attempt to remediate the area near the ash sluice pond drainage channel and raise the $\mathrm{pH}$ of the flow in the channel, a series of actions were taken. Uncovered ash that had been pushed into the drainage channel during previous remedial activities was removed and placed onto a flat area of the coal ash pile. Rip-rap was placed along the area of the drainage channel where the ash had been removed. The area where the ash had been placed, as well as other areas where coal ash was exposed, was covered with clay to prevent infiltration of storm water into the ash. The clay layer was then covered with topsoil to provide a suitable medium for vegetation to grow back on the surface of the ash pile. The area was then seeded and covered with straw.

To collect additional information on the effectiveness of the RAs taken in the K-720 coal ash pile area, additional monitoring was conducted as part of the FY 2014 SWPP Program. Table 3.28 shows the results of this monitoring activity.

Table 3.28. Mercury result from water sampling associated with the remedial action activities at the $\mathrm{K}-720$ coal ash pile

\begin{tabular}{ccc}
\hline Sampling location & Date & Result (ng/L) \\
\hline Storm drain 992 & $11 / 26 / 2013$ & 12.5 \\
\hline
\end{tabular}

\subsubsection{Storm Water Outfall Sampling}

The mercury investigation scope was broadened to encompass areas that have not been investigated before, have not been sampled recently, and/or warrant additional investigation due to operational history. Table 3.29 lists these mercury storm water sampling results by storm water outfall. These outfalls were selected for sampling because they drain areas where mercury may have been used as part of past site operations or because recent mercury analytical results are not available for them.

Table 3.29. Mercury results from storm water monitoring conducted in CY 2013

\begin{tabular}{ccc}
\hline $\begin{array}{c}\text { Storm water } \\
\text { outfall }\end{array}$ & $\begin{array}{c}\text { January } \\
(\mathbf{n g} / \mathbf{L})\end{array}$ & $\begin{array}{c}\text { March } \\
(\mathbf{n g} / \mathbf{L})\end{array}$ \\
\hline SD 220 & & 12.3 \\
SD 530 & 13.2 & \\
SD 590 & 24.9 & \\
\hline
\end{tabular}




\subsubsection{Environmental Monitoring Program}

As part of the EMP, mercury samples are collected at select surface water locations throughout ETTP. These mercury results are reported as part of the EMP as well as incorporated into the sitewide mercury investigation. The quarterly EMP sample results are shown in Table 3.30, and the semiannual EMP sample results are shown in Table 3.31. Figure 3.33 shows the EMP sampling locations. For additional information on the EMP, please refer to the surface water monitoring section (Section 3.6.8).

Table 3.30. East Tennessee Technology Park Environmental Monitoring Program quarterly surface water mercury results for CY 2013

\begin{tabular}{lcccc}
\hline $\begin{array}{c}\text { Mitchell Branch } \\
\text { location }\end{array}$ & $\begin{array}{c}\text { First quarter } \\
(\mathbf{n g} / \mathbf{L})\end{array}$ & $\begin{array}{c}\text { Second quarter } \\
(\mathbf{n g} / \mathbf{L})\end{array}$ & $\begin{array}{c}\text { Third quarter } \\
(\mathbf{n g} / \mathbf{L})\end{array}$ & $\begin{array}{c}\text { Fourth quarter } \\
(\mathbf{n g} / \mathbf{L})\end{array}$ \\
\hline K-1700 weir & 26.65 & $\mathbf{1 1 5 . 9}$ & 36.8 & 29.15 \\
MIK 0.45 & 14.2 & 3.8 & 13.6 & 4.64 \\
MIK 0.59 & 8.6 & 2.9 & 4.2 & 2.83 \\
MIK 0.71 & 2.0 & 1.6 & 2.4 & 1.52 \\
MIK 0.82 & 1.6 & 1.3 & 1.7 & Not Sampled \\
MIK 1.4 & 1.8 & 1.4 & 2.1 & $0.5(\mathrm{U})$ \\
\hline
\end{tabular}

Bold indicates results above Tennessee water quality criteria.

MIK values represent distance in Mitchell Branch from the downstream confluence with Poplar Creek.

Abbreviations

MIK = Mitchell Branch kilometer

$\mathrm{U}=$ Nondetect result

Table 3.31. East Tennessee Technology Park Environmental Monitoring Program semiannual surface water mercury results for CY 2013

\begin{tabular}{ccc}
\hline Sampling location & $\begin{array}{c}\text { January-June } \\
\text { (ng/L) }\end{array}$ & $\begin{array}{c}\text { July-December } \\
\text { (ng/L) }\end{array}$ \\
\hline K-1007B & 2.4 & 4.61 \\
K-702-A & 21.5 & 33.8 \\
K-901-A & 2.2 & 4.94 \\
K-1710 & $\mathbf{8 1 . 8}$ & 47.9 \\
K-716 & $\mathbf{7 7 . 1}$ & 15.1 \\
CRK 16 & 12.3 & 6.41 \\
CRK 23 & 1.7 & 0.587 \\
\hline
\end{tabular}

Bold indicates results above Tennessee water quality criteria.

CRK $=$ Clinch River kilometer 


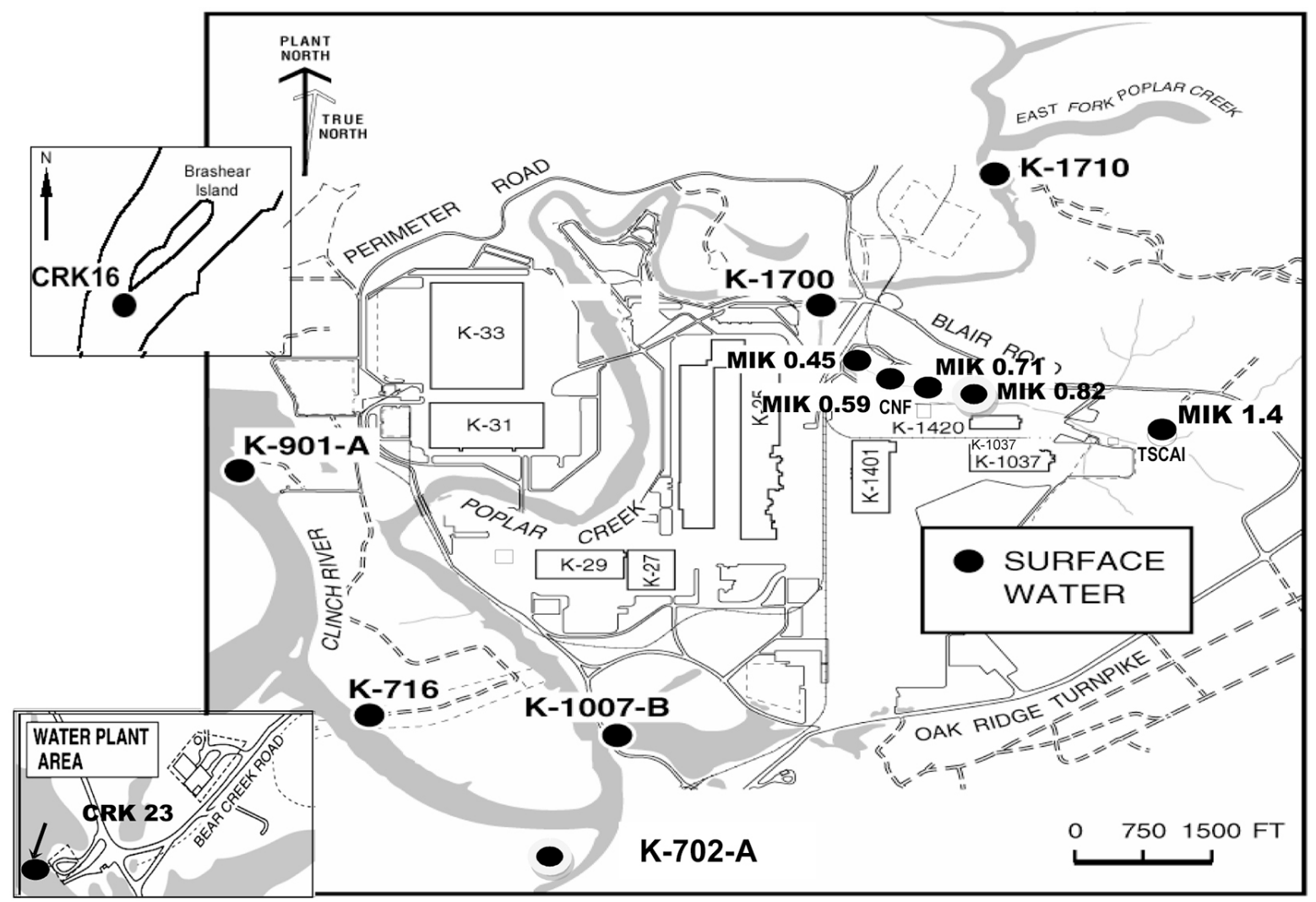

Fig. 3.33. East Tennessee Technology Park Environmental Monitoring Program sampling locations.

\subsubsection{Additional Mitchell Branch Instream Sampling}

Figure 3.34 shows that Mitchell Branch instream mercury concentrations for the period 2008-2013 increase significantly moving downstream toward the K-1700 weir. Figure 3.35 shows the historic mercury concentrations measured from routine surface water sampling at the K-1700 weir. At the K-1700 weir there was a significant increase in mercury concentrations from December 2009 to March 2010. Near this time frame several activities were under way with the potential to influence the mercury concentrations at the K-1700 weir such as the D\&D activity at Building K-25, the remediation of the K-1070-B burial ground, and the D\&D activity at Buildings K-1035 and K-1401. Figure 3.35 combines mercury sampling data from the Water Resources Restoration Program (WRRP) sampling events with results from EMP monitoring. Table 3.32 summarizes the WRRP mercury data for CY 2013.

In 2013, fish and caged clams from various locations at ETTP were analyzed for mercury. For details of this study, please see Section 3.7.

For information regarding the monitoring of mercury in the groundwater at ETTP, please see Sections 3.6.8 and 3.6.9.

Further monitoring for mercury has been proposed for 2014 for Mitchell Branch, the former K-1203 STP, and other locations as part of the NPDES permit compliance sampling program, SWPP Program, ETTP EMP, groundwater program, and Biological Monitoring and Abatement Program (BMAP). Historical documents continue to be researched and future monitoring proposed as part of the ongoing mercury investigation. 


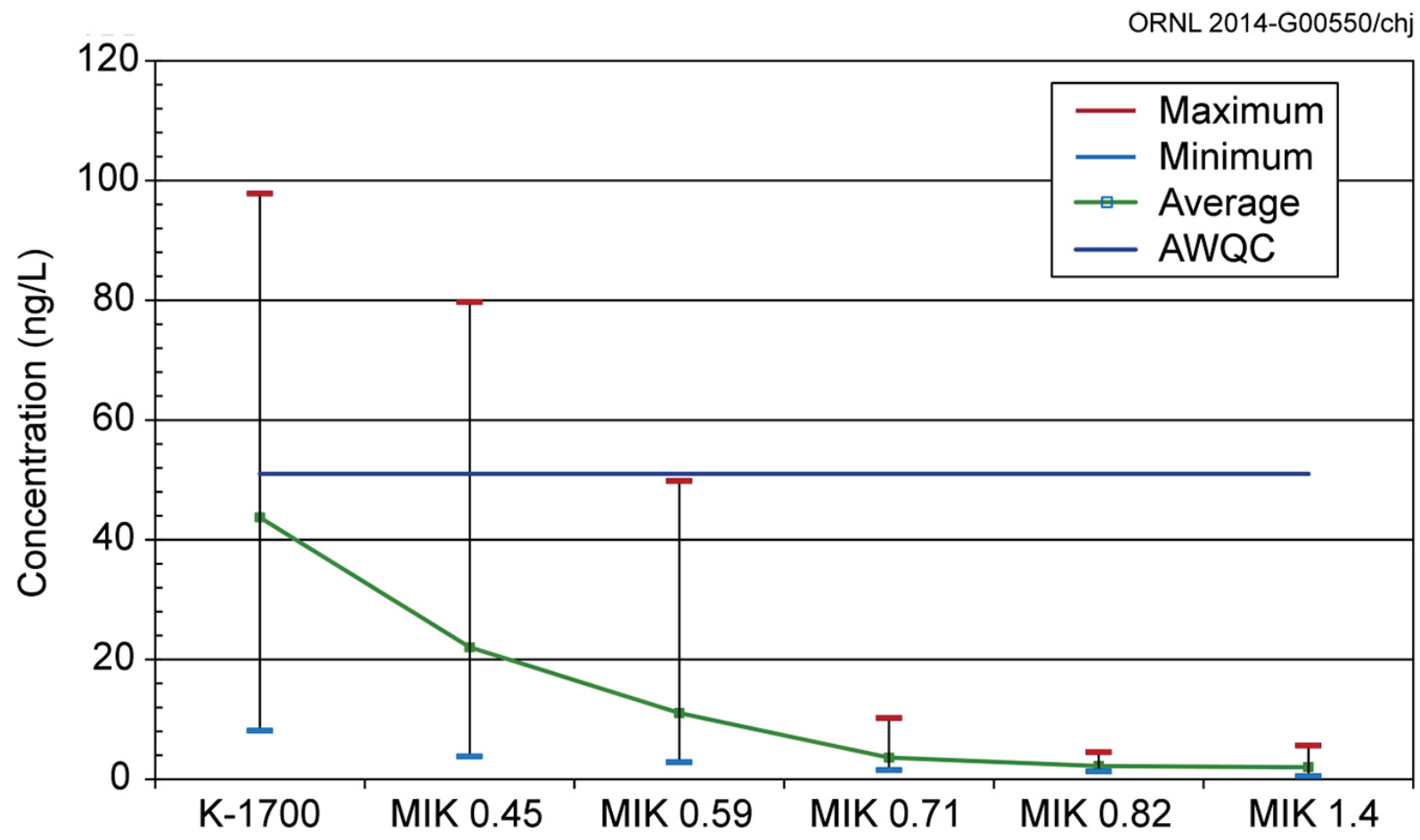

Fig. 3.34. Mitchell Branch instream mercury sampling results, 2008-2013. (AWQC $=$ ambient water quality criterion, MIK = Mitchell Branch kilometer.)

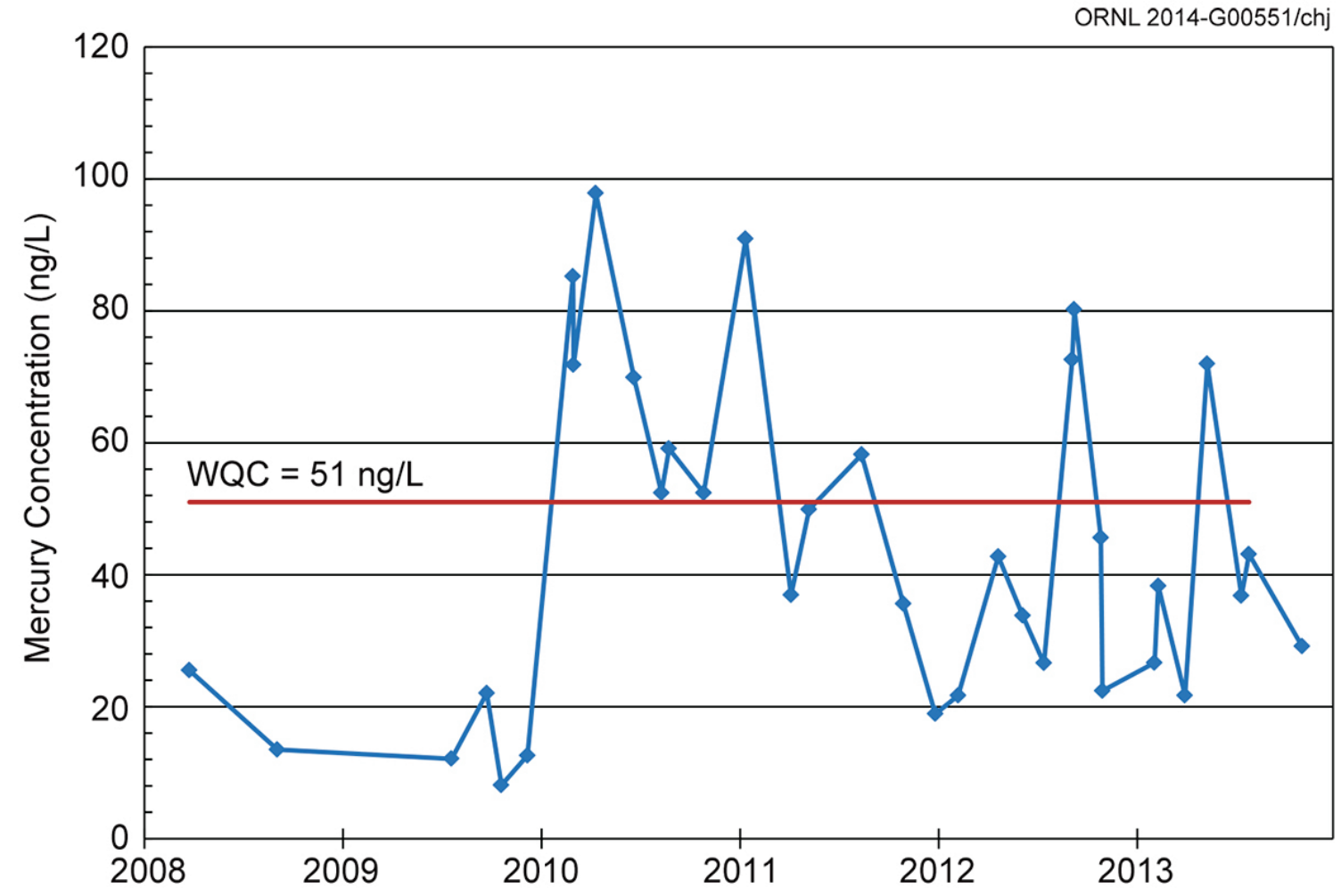

Fig. 3.35. K-1700 weir surface water mercury sampling results, 2008-2013. (WQC = water quality criterion.) 
Table 3.32. Water Resources Restoration Program mercury sampling results for the K-1700 Weir in CY 2013

\begin{tabular}{ccc}
\hline Date & $\begin{array}{c}\text { Hg result } \\
\text { (ng/L) }\end{array}$ & Field filtered \\
\hline $2 / 12 / 2013$ & 38.3 & No \\
$4 / 2 / 2013$ & 21.7 & No \\
$5 / 13 / 2013$ & 28 & No \\
$5 / 13 / 2013$ & 7.5 & Yes \\
$7 / 29 / 2013$ & 43.1 & No \\
\hline
\end{tabular}

\subsubsection{NPDES Monitoring at the Central Neutralization Facility Wastewater Treatment System}

Wastewater from CNF is discharged through storm water outfall SD 001 into the Clinch River. Nonradiological monitoring of CNF effluent was conducted according to the requirements of NPDES permit TN0074225. Monitoring requirements, frequencies, and sample types required under the permit changed during 2010 with the reissuance of the permit on December 1, 2010. During the permit renewal process, CNF was reclassified from the "Metal Finishing" category into the "Centralized Wastewater Treatment" category by the permit writer. This change in point source category was mainly responsible for the change in parameters between the previous permit and the renewed permit. The requirements for the 2010 permit are listed in Table 3.33.

As of December 15, 2012, CNF no longer accepted any external wastewater for treatment. CNF continued to discharge until August 22, 2013, when the final discharge from CNF occurred. Closure actions at CNF in 2013 included removal of the air stripper, pressure filters, and carbon adsorption units; sludge removal from and cleaning of the clarifier, sumps, dikes, and settling basins; backfill of sumps with flowable fill; and painting of some internal tank walls to fix radiation in place. Actions were completed to decommission $\mathrm{CNF}$ and ready it for demolition and remediation. RCRA clean closure information was submitted to TDEC and EPA in CERCLA phased construction completion reports on November 15, 2013. NPDES permit TN0074225 was allowed to expire on December 31, 2013.

Radiological sampling of effluent from CNF was conducted weekly according to the requirements of NPDES permit TN0074225. The weekly samples were then composited into a single monthly sample. Table 3.34 lists the total discharges in 2013 by isotope. The radiological results were compared with the DCG values from DOE O 5400.5 (DOE 1990). The rolling average sum of the fractions of the DCGs must be kept below 1.0. In practice, the effluent results rolling average sum of fractions of the DCGs from CNF were well below 1.0 until 2007, as indicated in Fig. 3.36. Figure 3.36 also shows the rolling 12-month average through August 2013. Monitoring results for 2013 showed a continuing decrease in the rolling 12-month average of the sum of the fractions of the DCGs from a high of 0.16 in January 2013 to 0.10 in August 2013.

Although uranium isotopes constitute a greater mass of radionuclides discharged from $\mathrm{CNF},{ }^{99} \mathrm{Tc}$ accounts for the greatest activity due to its much higher specific activity. Transuranic isotopes constitute a small fraction of the total in the rolling 12-month average of the sum of the fractions of the DCGs. 
Table 3.33. National Pollutant Discharge Elimination System permit TN0074225 storm water outfall SD 001 monitoring requirements

\begin{tabular}{|c|c|c|}
\hline Parameter & Measurement frequency & Sample type \\
\hline Flow & Continuous & Recorder \\
\hline $\mathrm{pH}$ & Continuous & Recorder \\
\hline${ }^{137} \mathrm{Cs}$ & 1/month & Monthly composite \\
\hline${ }^{234} \mathrm{U}$ & $1 /$ month & Monthly composite \\
\hline${ }^{235} \mathrm{U}$ & $1 /$ month & Monthly composite \\
\hline${ }^{236} \mathrm{U}$ & $1 /$ month & Monthly composite \\
\hline${ }^{237} \mathrm{~Np}$ & $1 /$ month & Monthly composite \\
\hline${ }^{238} \mathrm{Pu}$ & $1 /$ month & Monthly composite \\
\hline${ }^{238} \mathrm{U}$ & $1 /$ month & Monthly composite \\
\hline${ }^{239} \mathrm{Pu}$ & $1 /$ month & Monthly composite \\
\hline${ }^{99} \mathrm{Tc}$ & $1 /$ month & Monthly composite \\
\hline COD & $1 /$ month & $24 \mathrm{~h}$ composite \\
\hline Gross alpha radioactivity & $1 /$ month & Monthly composite \\
\hline Gross beta radioactivity & $1 /$ month & Monthly composite \\
\hline Oil and grease & $1 /$ month & Grab \\
\hline Other radionuclides contained in wastewater ${ }^{a}$ & $1 /$ month & Monthly composite \\
\hline Total uranium & $1 /$ month & Monthly composite \\
\hline 2-4-6-trichlorophenol & 1/quarter & $24 \mathrm{~h}$ composite \\
\hline Acetone & 1/quarter & Grab \\
\hline Acetophenone & 1/quarter & 24 h composite \\
\hline ICP metals ${ }^{b}$ & 1/quarter & $24 \mathrm{~h}$ composite \\
\hline Methyl ethyl ketone (2-Butanone) & 1/quarter & Grab \\
\hline o-Cresol (2-methyl phenol) & 1/quarter & 24 h composite \\
\hline p-Cresol (4-methyl phenol) & 1/quarter & $24 \mathrm{~h}$ composite \\
\hline Phenol & 1/quarter & 24 h composite \\
\hline Pyridine & 1/quarter & 24 h composite \\
\hline Trichloroethylene & 1/quarter & Grab \\
\hline TSS & 1/quarter & $24 \mathrm{~h}$ composite \\
\hline BOD & 1/year & $24 \mathrm{~h}$ composite \\
\hline Chloroform & $1 /$ year & Grab \\
\hline Methylmercury & $1 /$ year & Grab \\
\hline Total mercury & 1/year & 24 h composite \\
\hline PCBs & 1/year & $24 \mathrm{~h}$ composite \\
\hline
\end{tabular}

${ }^{a}$ No other radionuclides are currently being analyzed each month.

${ }^{b} \mathrm{ICP}$ metals shall include, at a minimum, $\mathrm{Sb}, \mathrm{As}, \mathrm{Cd}, \mathrm{Cr}, \mathrm{Co}, \mathrm{Cu}, \mathrm{Pb}, \mathrm{Ni}, \mathrm{Ag}, \mathrm{Sn}, \mathrm{Ti}, \mathrm{V}$, and $\mathrm{Zn}$ per the permit and $\mathrm{Al}, \mathrm{Ba}, \mathrm{Be}, \mathrm{B}, \mathrm{Ca}, \mathrm{Fe}, \mathrm{Mg}, \mathrm{Mn}, \mathrm{Mo}, \mathrm{K}, \mathrm{Se}, \mathrm{Si}, \mathrm{Na}$, and $\mathrm{Tl}$.

\footnotetext{
Abbreviations

BOD $=$ biochemical oxygen demand

$\mathrm{COD}=$ chemical oxygen demand

ICP = inductively coupled plasma

$\mathrm{PCB}=$ polychlorinated biphenyl

TSS $=$ total suspended solids
} 
Table 3.34. Isotopic discharges from the Central Neutralization Facility Wastewater Treatment System, 2013

\begin{tabular}{cccc}
\hline Isotope & $\begin{array}{c}\text { Discharge } \\
(\mathbf{C i})\end{array}$ & Isotope & $\begin{array}{c}\text { Discharge } \\
(\mathbf{C i})\end{array}$ \\
\hline${ }^{137} \mathrm{Cs}$ & $1.1 \mathrm{E}-6$ & ${ }^{233 / 234} \mathrm{U}$ & $3.6 \mathrm{E}-5$ \\
${ }^{237} \mathrm{~Np}$ & $1.8 \mathrm{E}-7$ & ${ }^{235} \mathrm{U}$ & $3.5 \mathrm{E}-6$ \\
${ }^{238} \mathrm{Pu}$ & $2.4 \mathrm{E}-7$ & ${ }^{236} \mathrm{U}$ & $3.5 \mathrm{E}-6$ \\
${ }^{239,240} \mathrm{Pu}$ & $2.6 \mathrm{E}-7$ & ${ }^{238} \mathrm{U}$ & $4.2 \mathrm{E}-5$ \\
${ }^{99} \mathrm{Tc}$ & $1.2 \mathrm{E}-3$ & & \\
\hline
\end{tabular}

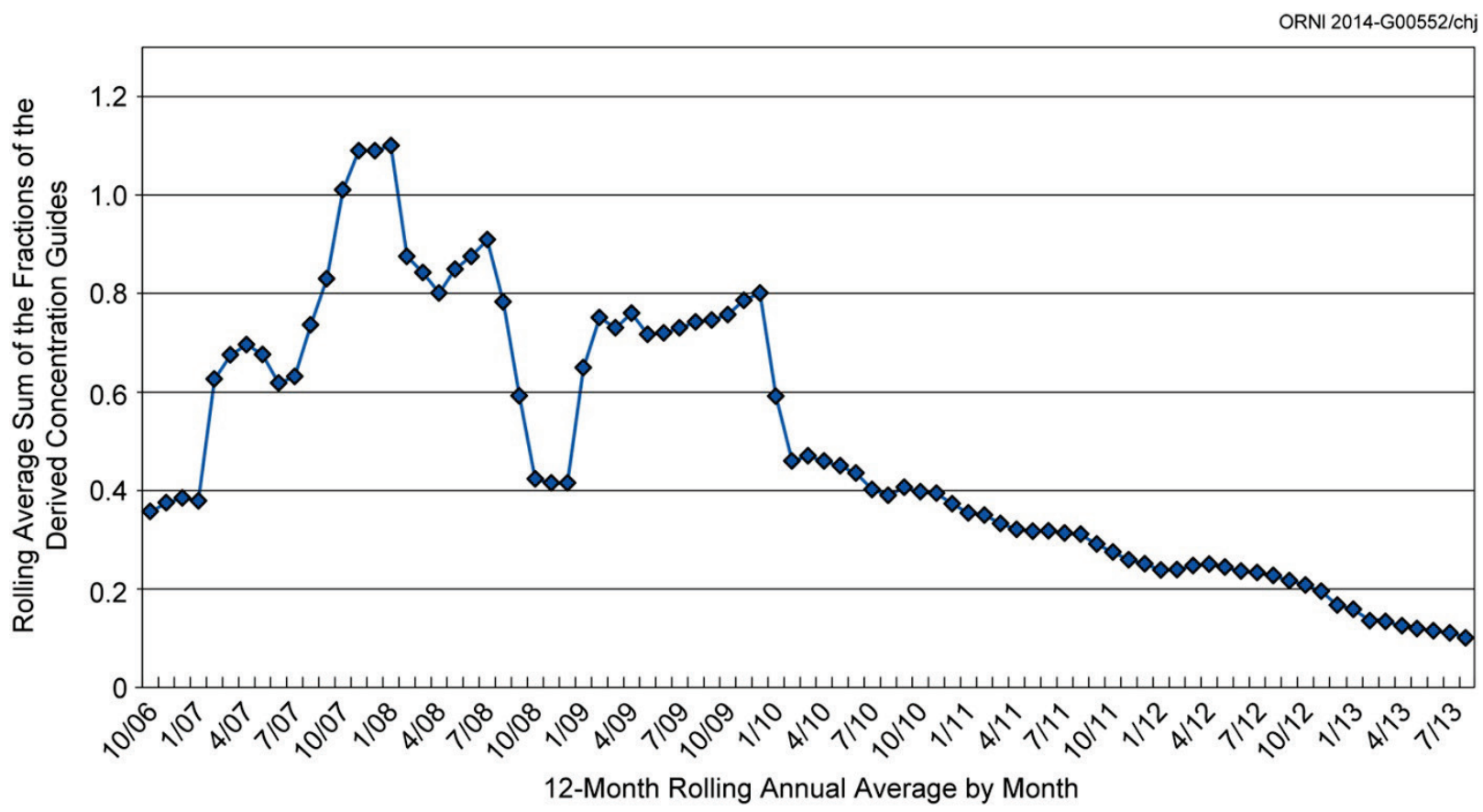

Fig. 3.36. Central Neutralization Facility-K-1435 Wastewater Treatment System radionuclide liquid discharges.

\subsubsection{Surface Water Monitoring}

During 2013, ETTP EMP personnel conducted environmental surveillance activities at 13 surface water locations (Fig. 3.37) to monitor groundwater and storm water runoff (K-1700, K-1007-B, and K-901-A) or ambient stream conditions (CRKs 16 and 23; K-1710; K-716; K-702-A slough; and MIKs $0.45,0.59,0.71,0.8$, and 1.4). Monitoring at MIK 0.8 ceased in July 2013. Depending on the location, samples were collected and analyzed quarterly for radionuclides (K-1700 and MIKs $0.45,0.59$, $0.71,0.8$, and 1.4) or semiannually (remainder of locations). Results of radiological monitoring were compared with the DCGs. Radiological data are reported as fractions of DCGs for reported radionuclides. If the sum of DCG fractions for a location exceeds $100 \%$ for the year, a source investigation is required. Sources exceeding DCG requirements would need an analysis of the best available technology to reduce the sum of the fractions of the radionuclide concentrations to their respective DCGs to less than $100 \%$. Comparisons with DCGs are updated regularly to maintain an annual average. The monitoring results at the majority of locations were less than $1 \%$ of the allowable DCG (Fig. 3.38). The exceptions were K-1700 and three locations on Mitchell Branch, as indicated by the sums of the fractions of the DCGs for these locations: K-1700-1.8\%, MIK 0.45-1.8\%, MIK 0.59-1.7\%, and MIK 0.71-1.5\%. 
The percentage of the DCGs at K-1700 (1.8\%) was greater than the percentage of the 2012 monitoring results $(1.0 \%)$. The percentage of the DCGs at MIK 0.45, MIK 0.59, and MIK 0.71 also increased slightly from the 2012 results.

Depending on the monitoring location, water samples may be analyzed for $\mathrm{pH}$, selected metals, and VOCs. In 2013, results for most of these parameters were well within the appropriate Tennessee state water quality criteria (WQCs).

Exceptions were exceedances for mercury at K-716, K-1700, and K-1710; for zinc at MIK 0.59; and for lead at K-716 and K-1710 (the Poplar Creek monitoring locations) and a failure to meet the minimum level for dissolved oxygen at K-716 and K-1710. The elevated levels of lead in Poplar Creek are within the range of historical results at these locations but are an order of magnitude greater than what has been seen at the same locations in the last several years. Due to the wide drainage area and the diversity of operations in the Poplar Creek drainage basin and the fact that levels of lead are elevated upstream as well as downstream of ETTP, it is difficult to determine the source. The cause of the elevated zinc levels at MIK 0.59 is unknown but appears to be an anomaly as levels of zinc in samples collected both upstream and downstream of MIK 0.59 were within normal ranges, and subsequent sample results were also well within the WQC.

The WQC for dissolved oxygen in streams and ponds is a minimum level of $5 \mathrm{mg} / \mathrm{L}$. On three occasions during the 2013 monitoring dissolved oxygen levels at several of the surface water monitoring locations fell below this level. The lowest levels $(4.4 \mathrm{mg} / \mathrm{L}$ and $4.5 \mathrm{mg} / \mathrm{L})$ were measured at $\mathrm{K}-716$ and $\mathrm{K}-1710$, respectively, in June. Levels at K-1700 were also measured at less than $5 \mathrm{mg} / \mathrm{L}$ at one point during 2013 (4.7 mg/L in November). No obvious signs of distress (e.g., dead fish) were observed to be associated with any of these measurements in 2013. Low levels of dissolved oxygen are not uncommon in area streams and are usually associated with higher temperatures (and the associated elevated levels of biological activity) and low rainfall and stream flow. Late summer and fall of 2013 had very low rainfall.

The WQC for mercury is $0.051 \mu \mathrm{g} / \mathrm{L}$. On three occasions in 2013 levels of mercury were measured above this level. In May, levels of mercury in the sample from K-1700 (in Mitchell Branch) were measured at $0.12 \mu \mathrm{g} / \mathrm{L}$. In June, water collected from K-716 and K-1710 contained levels of mercury of 0.077 and $0.082 \mu \mathrm{g} / \mathrm{L}$, respectively. Both of these locations are in Poplar Creek, with $\mathrm{K}-716$ being the monitoring location downstream of most of the ETTP influence and K-1701 being the monitoring location upstream of most of the ETTP influence. It should be noted that both locations are within the reach of Poplar Creek that occasionally experiences reverse flow, so the difference between the two locations is not as well defined as might be expected. For details, please see the discussion of the sitewide mercury investigation given in Section 3.6.6.

Figures 3.39 and 3.40 illustrate the concentrations of TCE (trichloroethene/trichloroethylene) and total 1,2-DCE (dichloroethene, cis-1,2-dichloroethylene, trans 1,2-dichloroethylene) from the K-1700 weir (which is used to monitor Mitchell Branch), the only surface water monitoring location where VOCs are regularly detected. Concentrations of TCE and total 1,2-DCE are below the Tennessee WQCs for recreation, organisms only ( $300 \mu \mathrm{g} / \mathrm{L}$ for TCE and 10,000 $\mu \mathrm{g} / \mathrm{L}$ for trans 1,2-DCE), which are appropriate standards for Mitchell Branch. Moreover, the standards for 1,2-DCE apply only to the "trans" form of 1,2-DCE; almost all of the 1,2-DCE is in the cis-isomer. In addition, vinyl chloride has sometimes been detected in Mitchell Branch water (Fig. 3.41). VOCs have been detected in groundwater in the vicinity of Mitchell Branch and in building sumps discharging into storm water outfalls that discharge into the stream; however, storm drain network monitoring generally has not detected these compounds in the storm water discharges. When detected, the concentrations are lower than in the stream. Therefore, it appears that the primary source of these compounds is contaminated groundwater. 


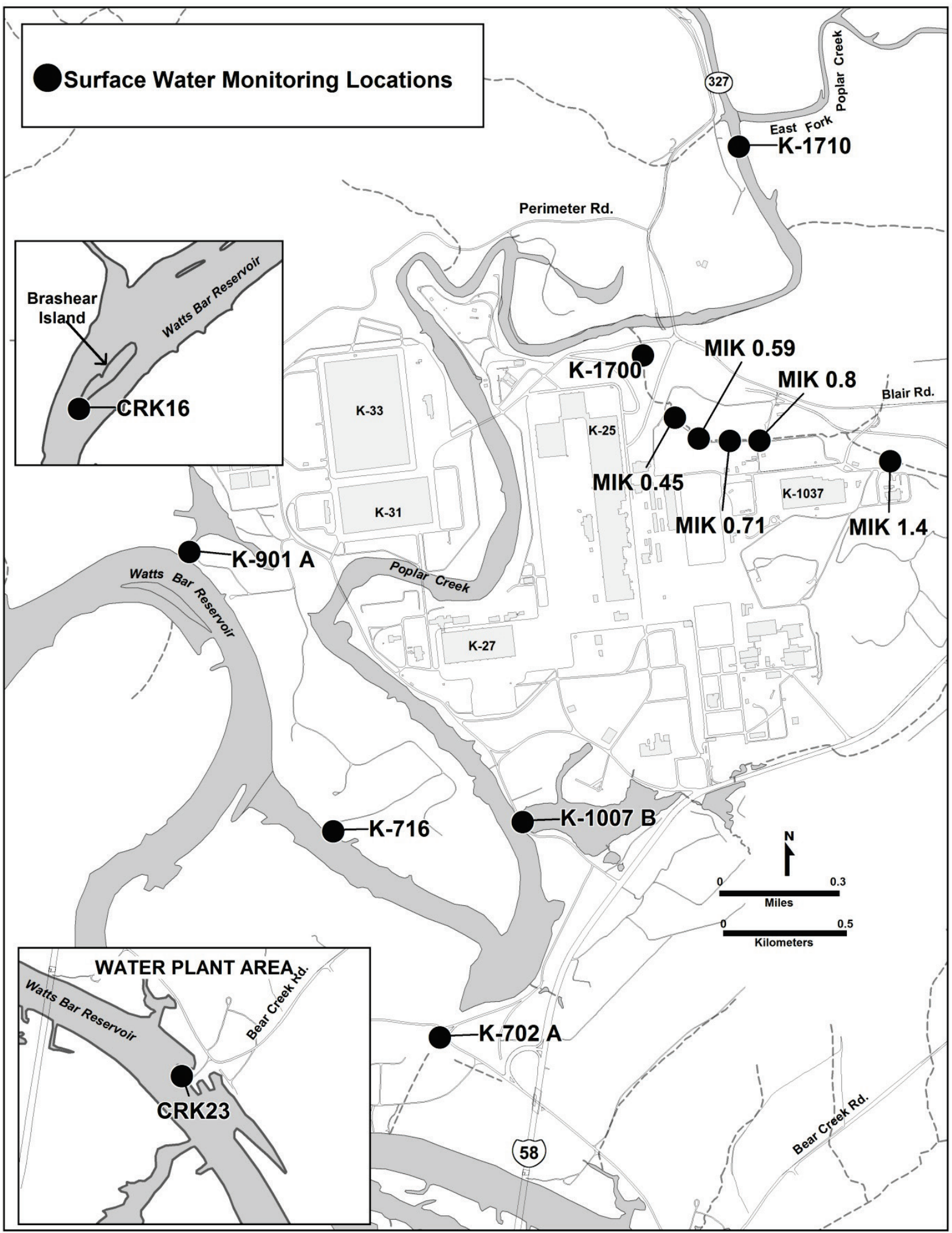

Fig. 3.37. East Tennessee Technology Park Environmental Monitoring Program surface water monitoring locations. 


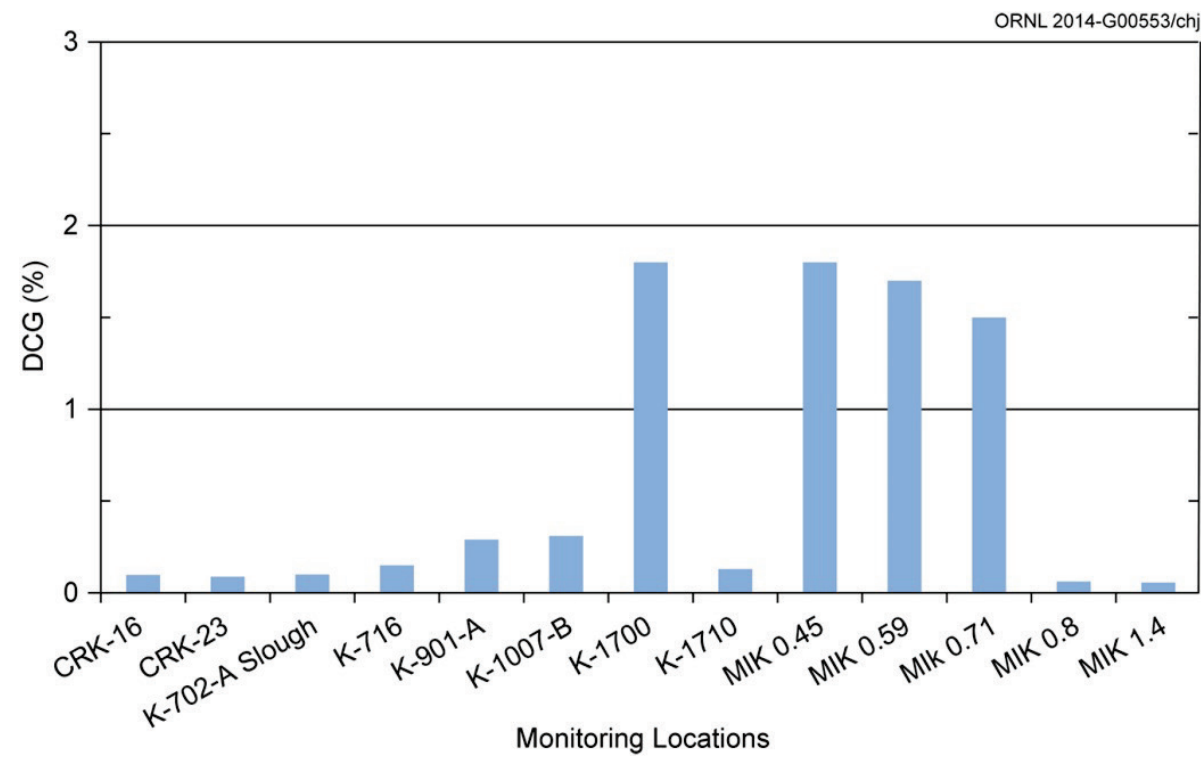

Fig. 3.38. Percentage of derived concentration guides (DCGs) at surface water monitoring locations, 2013. (CRK = Clinch River kilometer; MIK = Mitchell Branch kilometer.)

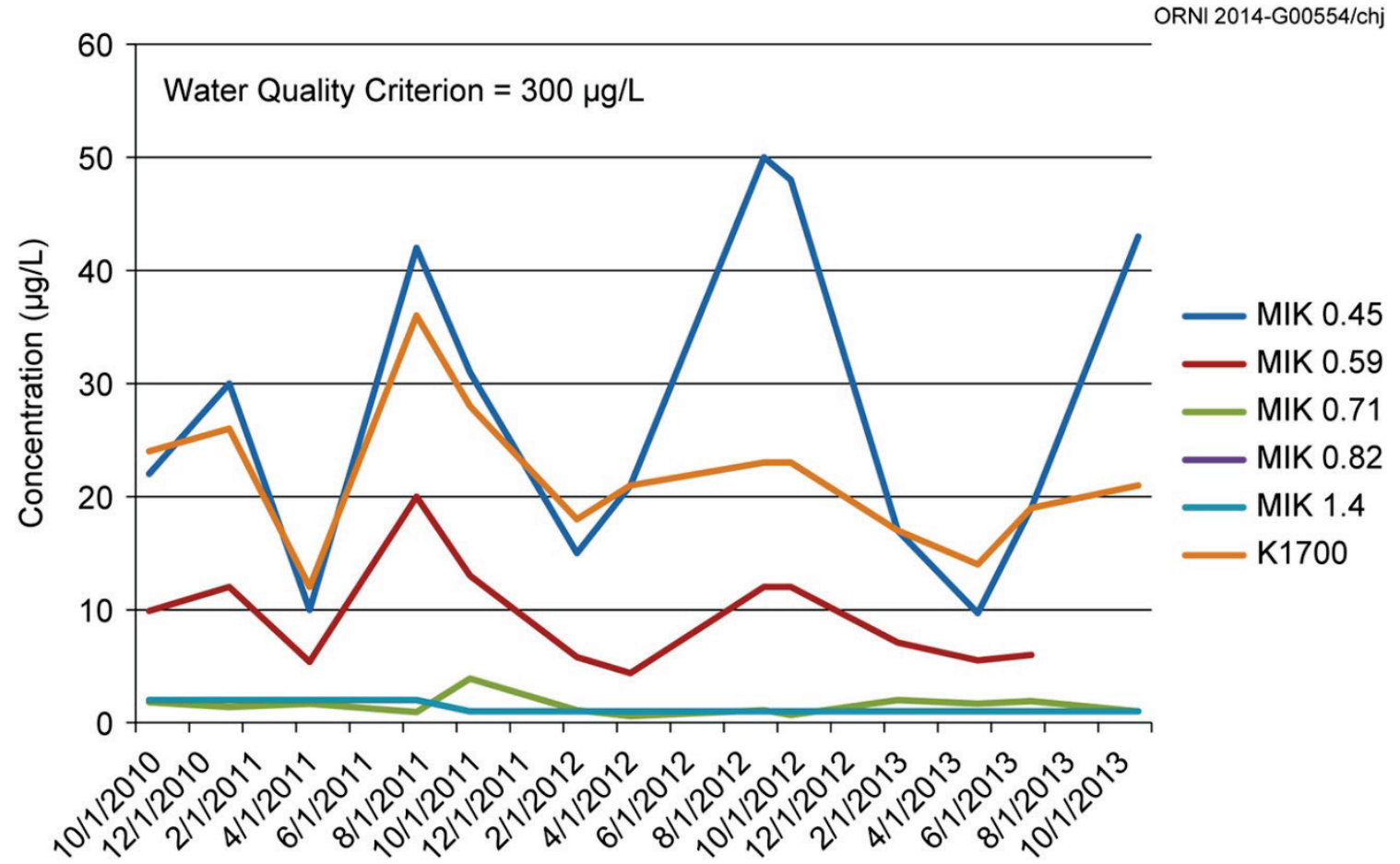

Fig. 3.39. Trichloroethene concentrations in Mitchell Branch. (MIK $=$ Mitchell Branch kilometer.) 


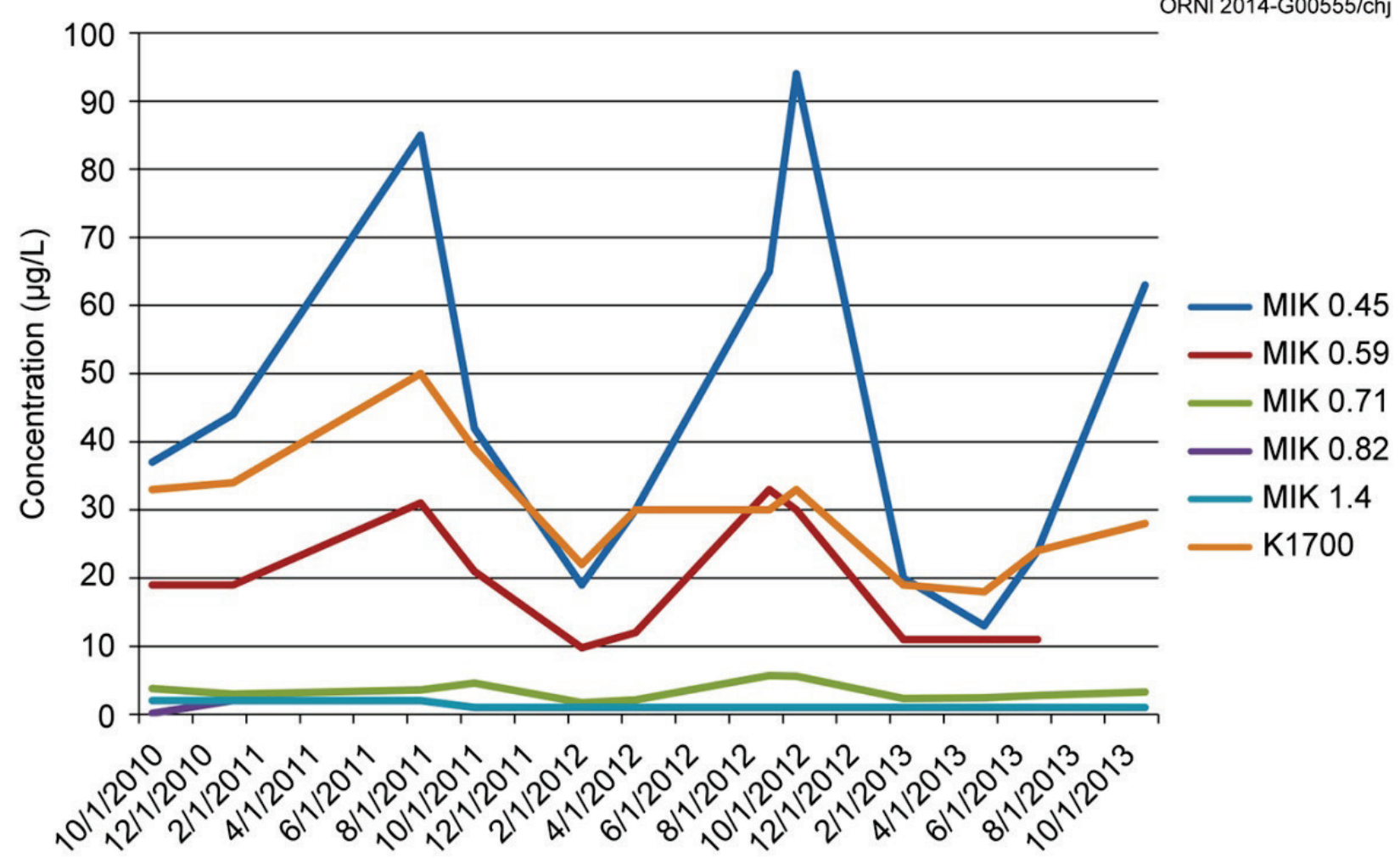

Fig. 3.40. 1,2-dichloroethene concentrations in Mitchell Branch. (MIK = Mitchell Branch kilometer.)

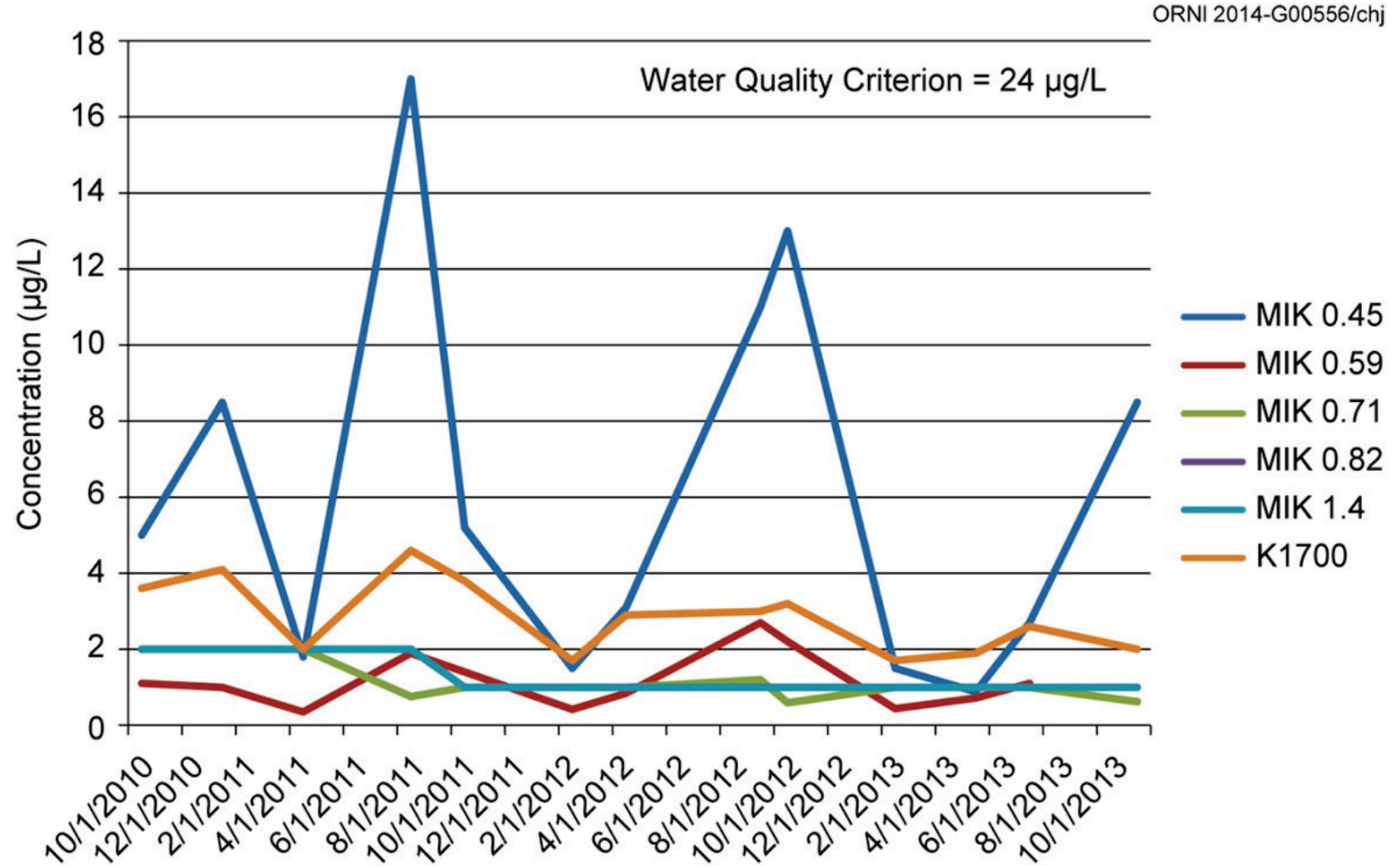

Fig. 3.41. Vinyl chloride concentrations in Mitchell Branch. (MIK = Mitchell Branch kilometer.) 
Surface water has been routinely sampled by DOE contractors and TDEC for several years as part of EMPs. The DOE contractor surface water sampling program is conducted in accordance with DOE order surveillance program guidance. In data collected as part of the DOE contractor's sampling effort, dry weather levels of total chromium over the past 10 years (Fig. 3.42) have been shown to be generally less than $10 \mu \mathrm{g} / \mathrm{L}$ or, in some instances, at nondetectable levels. Results from routine surface water monitoring conducted in fall 2006 showed a significant increase in the total chromium level in Mitchell Branch, but it was still below the WQC for total chromium. Sampling performed in the spring of 2007 by DOE contractors and TDEC indicated that chromium levels had increased above the levels found in the fall 2006 sampling. A chromium collection system using two extraction wells and pumps was installed to pump water from the vicinity of storm water outfall SD 170 for treatment at CNF. Since this system was installed, chromium levels in Mitchell Branch have dropped dramatically, with levels of total chromium being routinely measured at less than $3 \mu \mathrm{g} / \mathrm{L}$.

Samples from Mitchell Branch locations are also analyzed for hexavalent chromium. In 2013, hexavalent chromium levels in Mitchell Branch were all below the detection limit of $6 \mu \mathrm{g} / \mathrm{L}$.

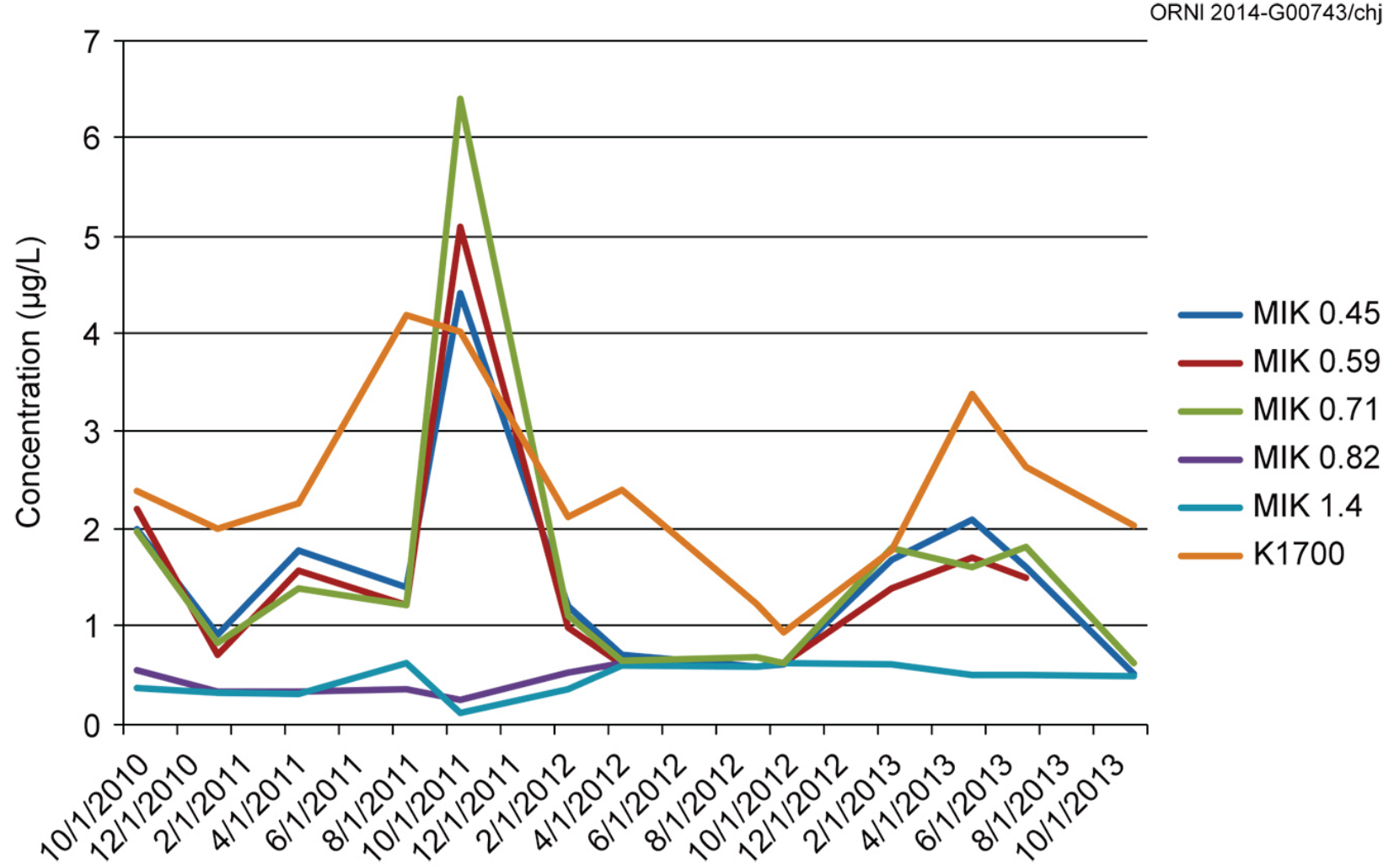

Fig. 3.42. Total chromium concentrations at $\mathrm{K}-\mathbf{1 7 0 0}$. [The water quality criterion for $\mathrm{Cr}(\mathrm{III})$, which is hardness dependent, is $74 \mu \mathrm{g} / \mathrm{L}$, based on a hardness of $100 \mathrm{mg} / \mathrm{L}$. The water quality criterion for $\mathrm{Cr}(\mathrm{IV})$ is $11 \mu \mathrm{g} / \mathrm{L}$. (MIK = Mitchell Branch kilometer.)]

\subsubsection{Groundwater Monitoring}

\subsubsection{East Tennessee Technology Park Groundwater Monitoring at Major Site Contaminant Plumes}

Extensive groundwater monitoring at the ETTP site has identified VOCs as the most significant groundwater contaminant on the site. To analyze the groundwater contaminant issues at ETTP, the remedial investigation/feasibility study (RI/FS) subdivided the site into several distinct areas-the Mitchell Branch watershed, K-1004 and K-1200 areas, K-27-K-29 area, and K-901 area (Fig. 3.43). The groundwater in each of these areas has significant VOC contamination. The principal chlorinated 
hydrocarbon chemicals that were used at ETTP were tetrachloroethene (PCE), TCE, and 1,1-dichloroethane (1,1-DCA).

Figure 3.43 shows the distribution and generalized concentrations of the primary chlorinated hydrocarbon chemicals and their transformation products. Several plume source areas are identified within the regions of the highest VOC concentrations. In these areas, the primary chlorinated hydrocarbons have been present for decades and mature contaminant plumes have evolved. The degree of transformation, or degradation, of the primary chlorinated hydrocarbon compounds is highly variable across the site. In the vicinity of the K-1070-C-K1070-D source, a high degree of degradation has occurred, although a strong source of contamination still remains in the vicinity of the "G-Pit" where about 9,000 gal of chlorinated hydrocarbon liquids were disposed in an unlined pit. Other areas where transformation is significant include the K-1401 acid line leak site and the K-1407-B pond area. Transformation processes are weak or inconsistent at the K-1004 and K-1200 areas, K-1035, K-1413, and the K-1070-A burial ground, and little transformation of TCE is observed in the K-27-K-29 source and plume area.

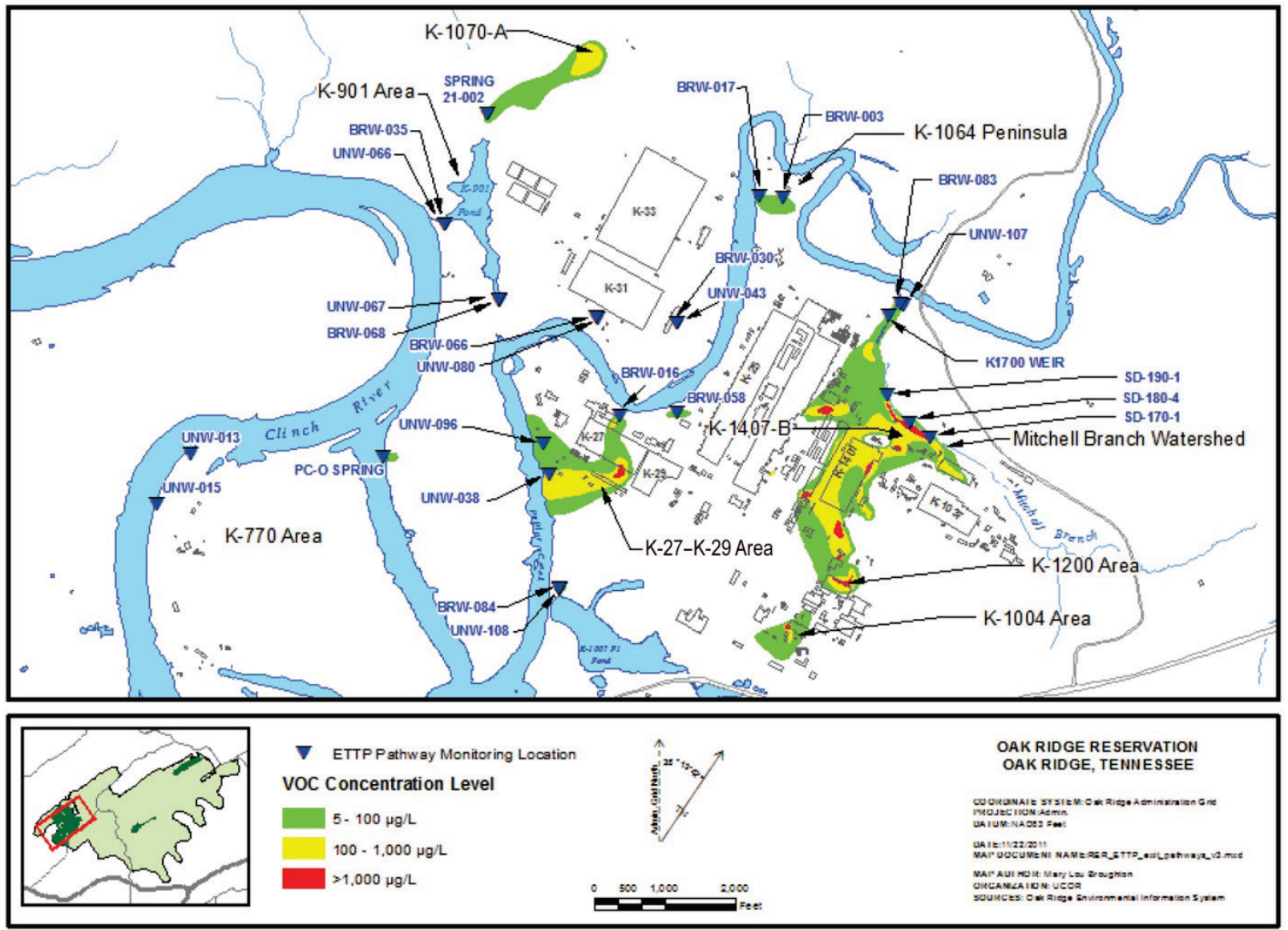

Fig. 3.43. East Tennessee Technology Park exit pathway monitoring locations and associated volatile organic compound (VOC) concentration levels. $(B R W=$ bedrock well, $S D=$ storm drain, and UNW = unconsolidated well.)

\subsubsection{Exit Pathway Monitoring}

Groundwater exit pathway monitoring sites are shown in Fig. 3.43. Groundwater monitoring results for the exit pathways are discussed below starting with the Mitchell Branch exit pathway and then progressing in a counterclockwise fashion.

The Mitchell Branch exit pathway is monitored using surface water data from the K-1700 Weir on Mitchell Branch and two wells: bedrock well 83 (BRW-083) and unconsolidated well 107 (UNW107). BRW-083 and UNW-107, both located near the mouth of Mitchell Branch (Fig. 3.43), have been 
monitored since 1994. Table 3.35 shows the history and concentrations of VOCs detected in the groundwater. Detection of VOCs in groundwater near the mouth of Mitchell Branch is considered an indication of the migration of the Mitchell Branch VOC plume complex. The intermittent detection of VOCs in this exit pathway is thought to be a reflection of variations in groundwater flowpaths that can fluctuate with seasonal hydraulic head conditions, which are strongly affected by rainfall. No chlorinated VOCs were detected in BRW-083 or UNW-107 during FY 2013.

Table 3.35. Volatile organic compounds detected in groundwater in the Mitchell Branch exit pathway ${ }^{a, b}$

\begin{tabular}{|c|c|c|c|c|c|}
\hline Well & Date & $\begin{array}{c}\text { cis-1,2- } \\
\text { Dichloroethene }\end{array}$ & Tetrachloroethene & Trichloroethene & Vinyl chloride \\
\hline \multirow[t]{14}{*}{ BRW-083 } & $8 / 29 / 2002$ & ND & 5 & 28 & ND \\
\hline & $3 / 16 / 2004$ & 0.69 & 2.2 & 9.9 & ND \\
\hline & $8 / 26 / 2004$ & 2 & 4.7 & 20 & ND \\
\hline & $3 / 14 / 2007$ & 5 & 9 & 28 & ND \\
\hline & $3 / 20 / 2008$ & ND & ND & ND & ND \\
\hline & $8 / 21 / 2008$ & ND & ND & ND & ND \\
\hline & $3 / 12 / 2009$ & ND & ND & $1.31 \mathrm{~J}$ & ND \\
\hline & $8 / 3 / 2009$ & ND & 2.66 & 14.2 & ND \\
\hline & $3 / 3 / 2010$ & ND & ND & ND & ND \\
\hline & $8 / 30 / 2010$ & 3.6 & 5.1 & 18 & ND \\
\hline & $3 / 15 / 2011$ & 2.8 & 6.7 & 22 & ND \\
\hline & $8 / 10 / 2011$ & ND & ND & ND & ND \\
\hline & $3 / 1 / 2012$ & ND & ND & ND & ND \\
\hline & $8 / 16 / 2012$ & ND & ND & ND & ND \\
\hline \multirow[t]{15}{*}{ UNW-107 } & 8/3/1998 & ND & ND & 3 & ND \\
\hline & $8 / 26 / 2004$ & 4.7 & ND & 3.6 & ND \\
\hline & $8 / 21 / 2006$ & 3.4 & 14 & 2 & 1.2 \\
\hline & $3 / 13 / 2007$ & 25 & $2 \mathrm{~J}$ & 23 & $2^{c}$ \\
\hline & $8 / 21 / 2007$ & 17 & ND & 30 & $0.3 \mathrm{~J}$ \\
\hline & $3 / 5 / 2008$ & ND & ND & ND & ND \\
\hline & $8 / 18 / 2008$ & ND & ND & ND & ND \\
\hline & $3 / 12 / 2009$ & ND & ND & ND & ND \\
\hline & $7 / 30 / 2009$ & ND & ND & ND & ND \\
\hline & $3 / 4 / 2010$ & ND & ND & ND & ND \\
\hline & $7 / 28 / 2010$ & ND & ND & ND & ND \\
\hline & $3 / 16 / 2011$ & ND & ND & ND & ND \\
\hline & $8 / 11 / 2011$ & ND & ND & ND & ND \\
\hline & $3 / 20 / 2012$ & ND & ND & ND & ND \\
\hline & $9 / 12 / 2012$ & ND & ND & ND & ND \\
\hline
\end{tabular}

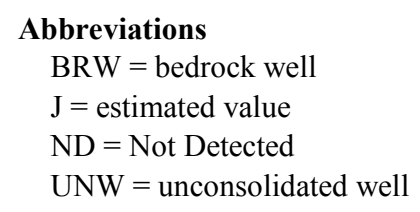

${ }^{a}$ All concentrations in micrograms per liter $(\mu \mathrm{g} / \mathrm{L})$.

${ }^{b}$ Bold table entries exceed Safe Drinking Water Act maximum contaminant level screening values (tetrachloroethene and trichloroethene $=5 \mu \mathrm{g} / \mathrm{L}$, cis-1,2- dichloroethene $=70 \mu \mathrm{g} / \mathrm{L}$, vinyl chloride $=2 \mu \mathrm{g} / \mathrm{L}$ ).

${ }^{c}$ Detection occurred in a field replicate. Constituent not detected in regular sample. 
BRW-003 and BRW-017 (Fig. 3.43) monitor groundwater at the K-1064 peninsula burn area. Figure 3.44 shows the history of VOC concentrations in groundwater from these wells from FY 1994 through FY 2013. TCE concentrations have declined in both wells over that time period. TCE was present at concentrations less than the maximum contaminant level (MCL) during FY 2013 at BRW-017 and was not detected in either sample from well BRW-003. 1,1,1-trichloroethane (TCA) also declined to undetectable concentrations in BRW-003. Cis-1,2-DCE was detected at concentrations much less than its MCL in both semiannual samples in BRW-017.

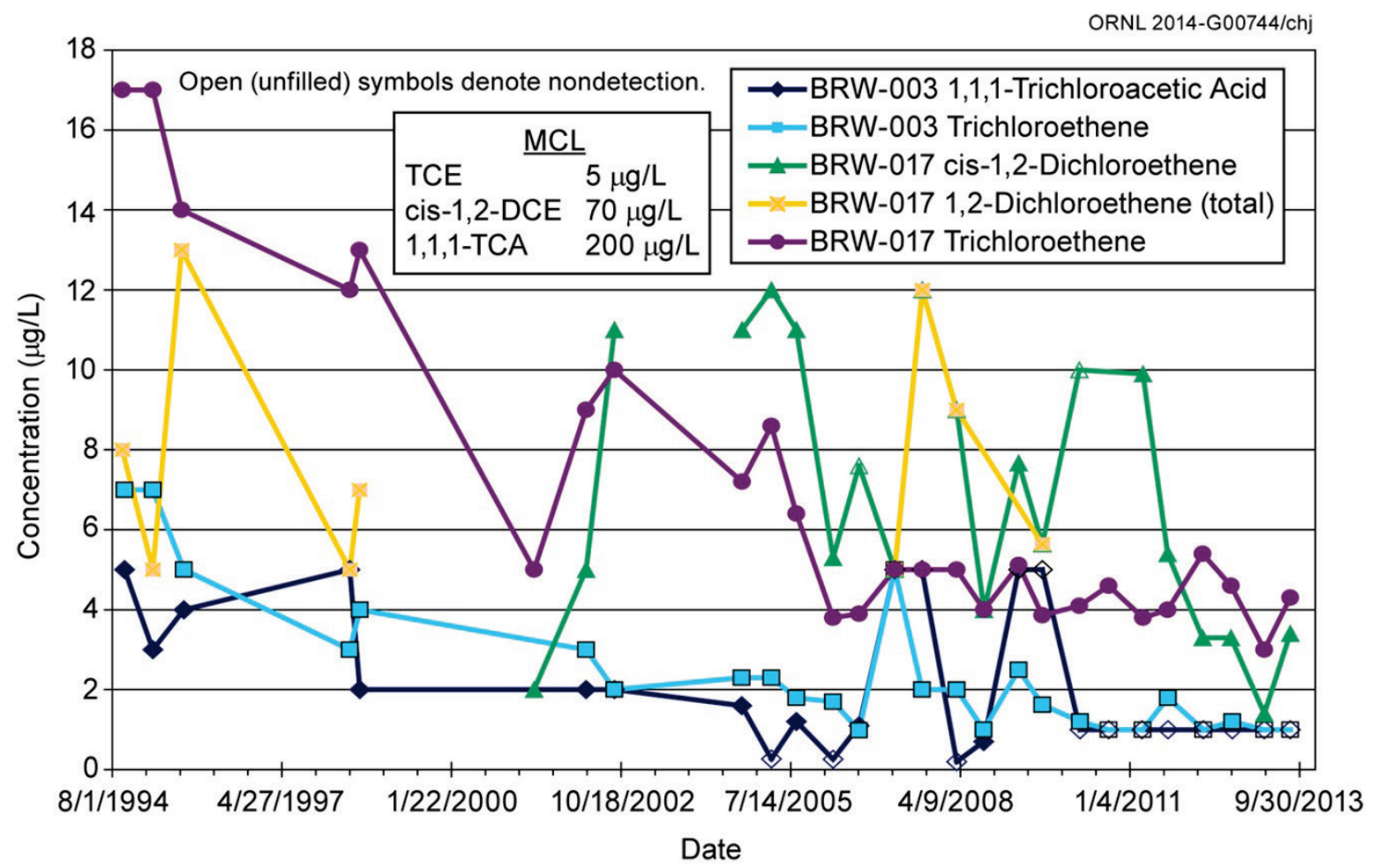

Fig. 3.44. Volatile organic compound concentrations in groundwater at the K-1064 peninsula area. $(B R W=$ bedrock well, $D C E=$ dichloroethene/dichloroethylene, $M C L=$ maximum contaminant level, TCA = trichloroethane, $\mathrm{TCE}=$ trichloroethene/trichloroethylene.)

Groundwater is monitored in four wells (BRW-066, BRW-030, UNW-080, and UNW-043) that lie between the K-31-K-33 area and Poplar Creek, as shown on Fig. 3.43. VOCs are not contaminants of concern (COCs) in this area; however, leaks of recirculated cooling water in the past have left residual subsurface chromium contamination. Figure 3.45 shows the history of chromium detection in wells in the K-31-K-33 area. UNW-043 exhibits the highest residual chromium concentrations of any of the wells in the area. Chromium concentrations in UNW-043 correlate with the turbidity of samples, and acidification of unfiltered samples that contain suspended solids often causes detection of high metals content because the addition of acid preservative releases metals that are adsorbed to the solid particles at the normal groundwater pH. During FY 2006, an investigation was conducted to determine whether groundwater in the vicinity of the K-31 and K-33 buildings contained residual hexavalent chromium from recirculated cooling water leaks. The data indicated the chromium in groundwater near the leak sites was essentially all the less toxic trivalent species. From FY 2008 through FY 2012, field-filtered (i.e., dissolved) and unfiltered samples were collected from UNW-043. Chromium concentrations in the field-filtered samples were consistently much less than the MCL. During FY 2013, both field-filtered and unfiltered samples were collected from BRW-066, UNW-043, and UNW-080. In FY 2013, the chromium concentrations in unfiltered samples from UNW-080 decreased significantly and were nearly the same as concentrations in the filtered sample. Chromium was not detected in the August 2013 filtered samples from UNW-043. Chromium was not detected in any samples from well BRW-066. 


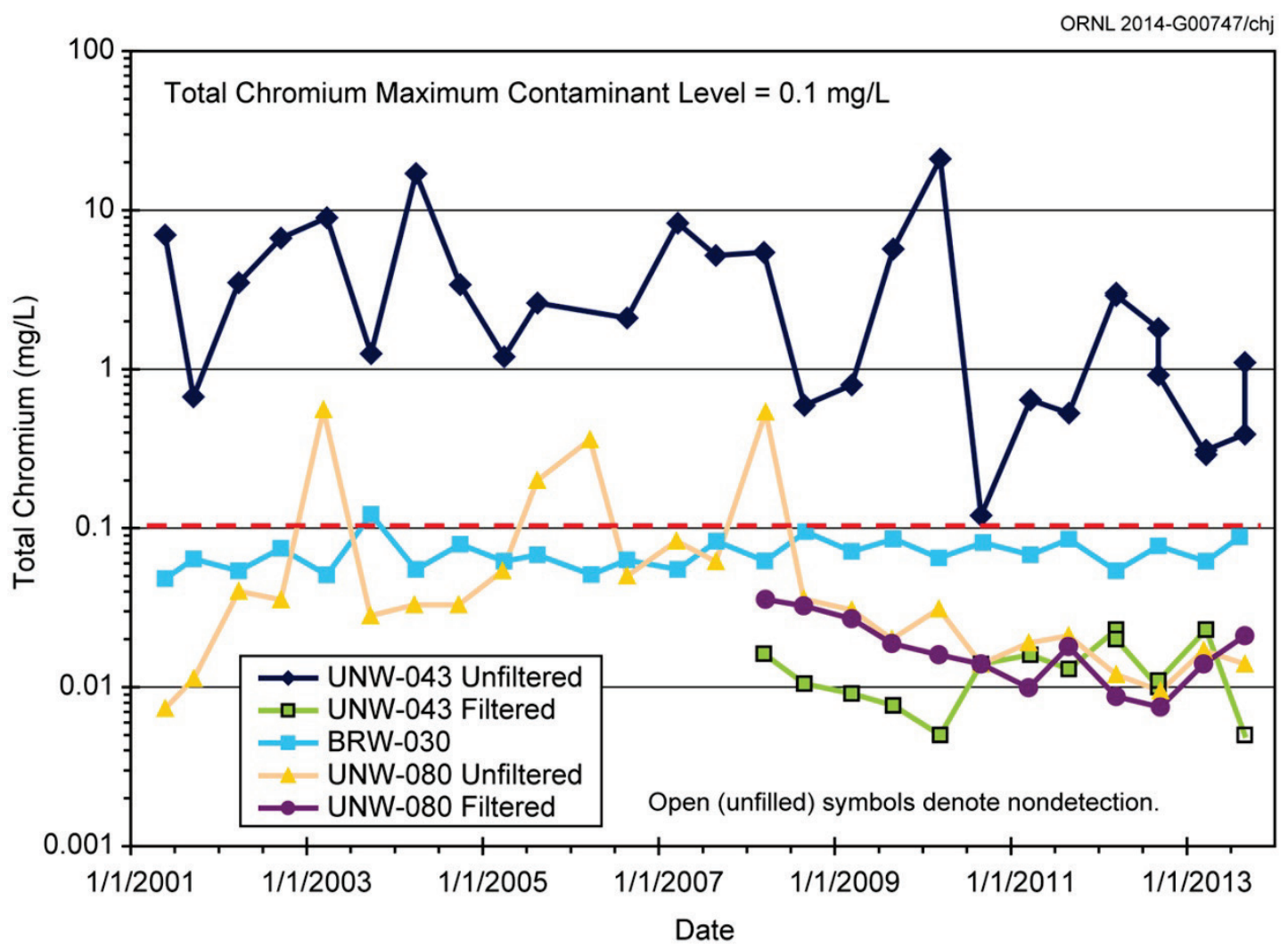

Fig. 3.45. Chromium concentrations in groundwater in the K-31-K-33 area.

(BRW = bedrock well and UNW = unconsolidated well. $)$

Several exit pathway wells are monitored in the K-27-K-29 area, as shown on Fig. 3.43. Figure 3.46 provides concentrations of detected VOCs in wells both north and south of K-27 and K-29 through FY 2013. The source of VOC contamination in BRW-058 is not suspected to be from K-27-K-29 area operations. With the exception of cis-1,2-DCE in well BRW-058, which appears stable to slightly increasing but remains less than its MCL, the VOC concentrations in this area show slowly declining concentrations. At BRW-016, TCE was detected in one of two samples at a concentration of $1 \mu \mathrm{g} / \mathrm{L}$, levels of cis-1,2-DCE are much less than the MCL, and vinyl chloride has not been detected since 2009. TCE levels in well UNW-038 fluctuate between 10 to 20 times the MCL and continue a gradual decreasing trend.

BRW-084 and UNW-108 are exit pathway monitoring locations at the northern edge of the K-1007-P1 holding pond (see Fig. 3.43). These wells were monitored intermittently from 1994 through 1998 and semiannually from FY 2001 through FY 2013. The first detections of VOCs in these wells occurred during FY 2006 with detection of low $(\sim 10 \mu \mathrm{g} / \mathrm{L}$ or less) concentrations of TCE and cis-1,2DCE. The source area for these VOCs is not known. VOCs were not detected in either of these wells during FY 2013. Metals have been detected in the past associated with the presence of high turbidity in the samples. During FY 2013, a single arsenic detection $(5.7 \mu \mathrm{g} / \mathrm{L})$ occurred in a filtered aliquot collected from BRW-084 in August. Cadmium was detected $(<1 \mu \mathrm{g} / \mathrm{L})$ in both the filtered and unfiltered aliquots collected from UNW-108 in August. Aluminum exceeded its secondary MCL in the unfiltered sample from BRW-084 in March and from the unfiltered aliquots from both sample dates at UNW-108. Aluminum was not detectable in any of the filtered aliquots during FY 2013, which indicates turbidity in the samples was the source. Iron exceeded its secondary drinking water standard in one of the unfiltered aliquots from both wells during FY 2013 semiannual sampling events but was not detectable or did not exceed the secondary standard in the field-filtered aliquot. Manganese exceeded its secondary drinking water standard in both the filtered and unfiltered samples from UNW-108 in the fourth quarter sampling 
event. No other primary or secondary MCLs for metals were exceeded in sample aliquots that were fieldfiltered before acid preservation during FY 2013.

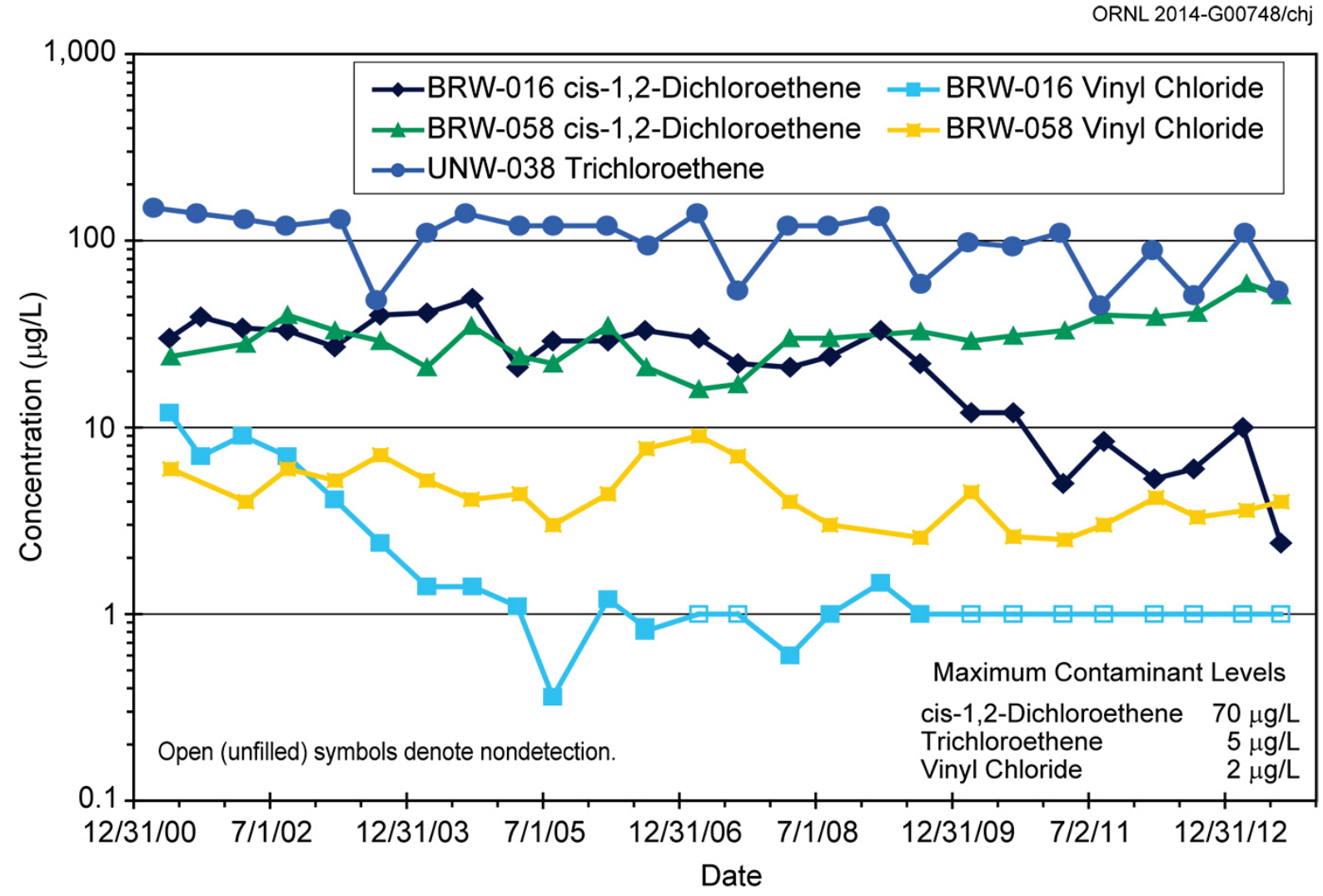

Fig. 3.46. Detected volatile organic compound concentrations in groundwater exit pathway wells near K-27 and K-29. (BRW = bedrock well and UNW = unconsolidated well.)

Exit pathway groundwater in the K-901-A holding pond area (see Fig. 3.43) is monitored by four wells (BRW-035, BRW-068, UNW-066, and UNW-067) and two springs (21-002 and PC-0). Very low concentrations $(<5 \mu \mathrm{g} / \mathrm{L})$ of VOCs are occasionally detected in wells adjacent to the K-901-A holding pond. However, these contaminants are not persistent in groundwater west and south of the pond. No VOCs were detected in the K-901-A holding pond exit pathway wells during FY 2013. Alpha activity in UNW-066 was about $25 \mathrm{pCi} / \mathrm{L}$ in the March 2013 sample but was not detected in the July sample. Beta activity levels were less than the $50 \mathrm{pCi} / \mathrm{L}$ screening level.

TCE is the most significant groundwater contaminant detected in the springs, and the historic TCE concentrations are shown in Fig. 3.47. Spring PC-0 was added to the sampling program in 2004. During the spring through autumn seasons, spring PC-0 is submerged beneath the level of Watts Bar Lake, so this location is accessible for sampling only during winter when the lake level is lowered by TVA. The contaminant source for the PC-0 spring is presumed to be disposed waste at the K-1070-F site. The TCE concentrations in PC-0 have varied between about 9 and $26 \mu \mathrm{g} / \mathrm{L}$ and appear to have decreased from their highest measured value in 2006 to concentrations about 2 times the drinking water standard. At spring 21-002, 1,1,1-TCA, 1,2-DCE, carbon tetrachloride, and TCE are sometimes present at concentrations typically less than $5 \mu \mathrm{g} / \mathrm{L}$. The TCE concentration at spring 21-002 tends to vary between 5 and about $25 \mu \mathrm{g} / \mathrm{L}$, and this variation appears to be related to variability in rainfall, which affects groundwater discharge from the K-1070-A VOC plume. During FY 2013, TCE was detected below its MCL in the March sample and at about twice the MCL in the August sample. Alpha activity was not detected in either sample, and beta activity was present at less than $10 \mathrm{pCi} / \mathrm{L}$. Technetium- 99 was not detected in either sample during FY 2013. 


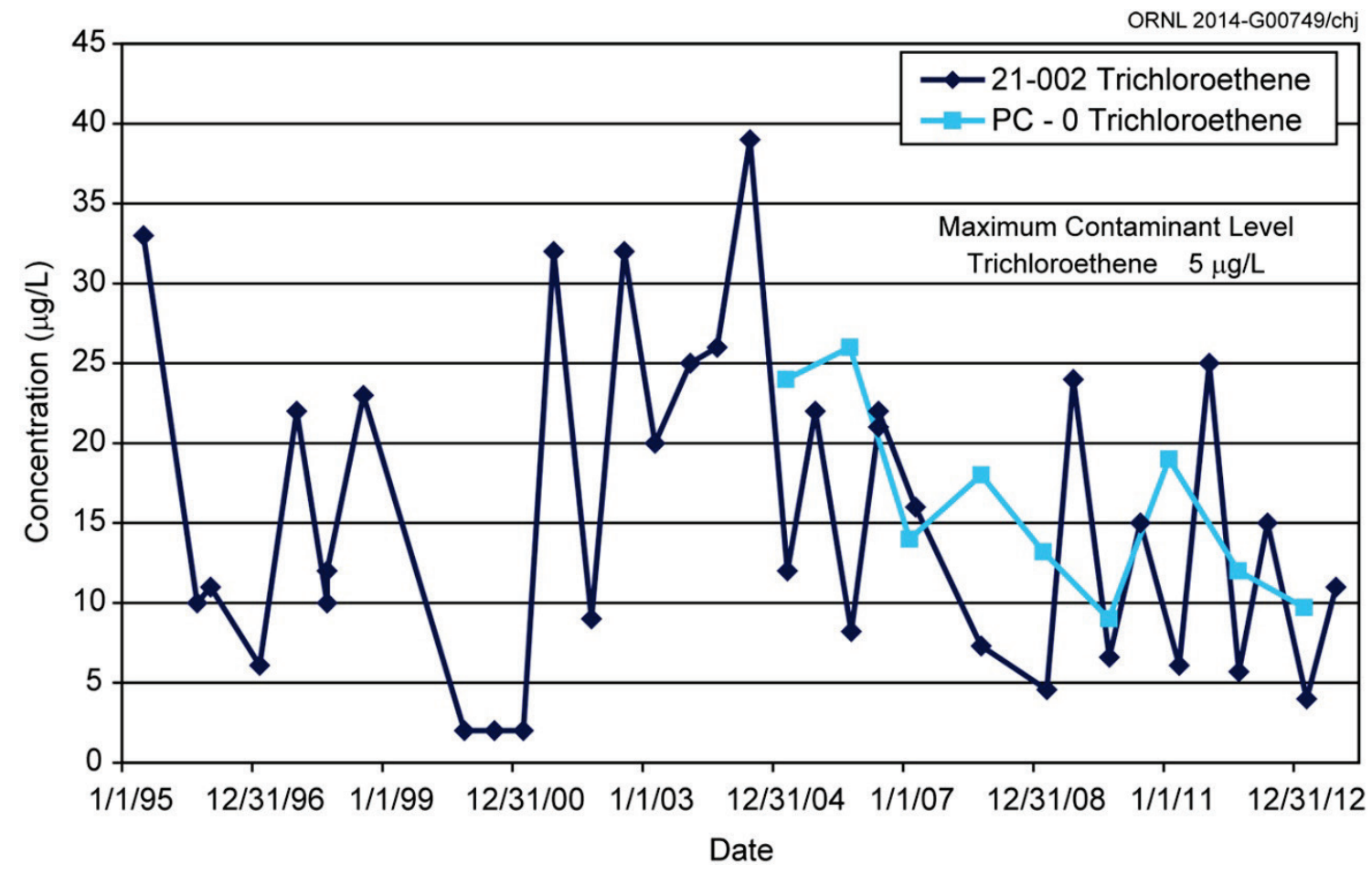

Fig. 3.47. Trichloroethene concentrations in K-901 area springs.

Exit pathway groundwater monitoring is also conducted at the K-770 area where wells UNW-013 and UNW-015 are used to assess radiological groundwater contamination along the Clinch River (see Fig. 3.43). Site access to UNW-015 was restored during FY 2013. Measured alpha and beta activity levels were below MCL levels during FY 2013. Figure 3.48 shows the history of measured alpha and beta activity in this area. Analytical results indicate that the alpha activity is largely attributable to uranium isotopes, and UNW-013 historically contained ${ }^{99} \mathrm{Tc}$, a strong beta-emitting radionuclide responsible for the elevated beta activity in that well. The alpha and beta activity levels in well UNW-015 show a significant decrease since the most recent previous sample collected in 2010. 


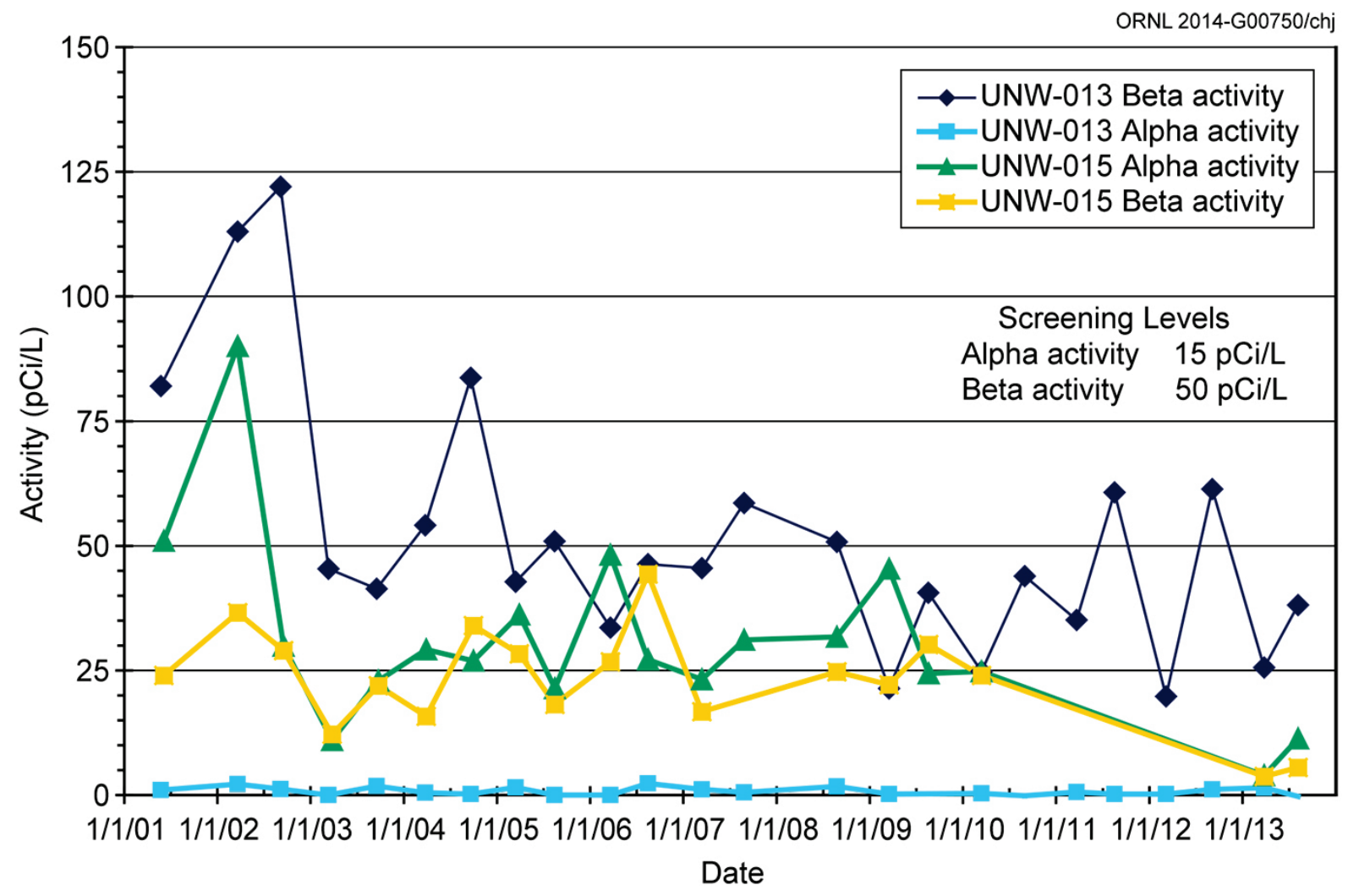

Fig. 3.48. History of measured alpha and beta activity in the K-770 area. (UNW = unconsolidated well.)

\subsubsection{Groundwater Sampling Adjacent to Potential Source Areas}

Additional monitoring of groundwater adjacent to potential sources of groundwater contamination, including the K-1070-C/-D burial ground, was conducted to monitor trends (DOE 2005). Monitoring will continue until a final Zone $2 \mathrm{ROD}$ is approved.

\subsubsection{Groundwater Sampling in the K-1407-B and K-1407-C Ponds Area}

The Remedial Action Report for the K-1407-B Holding Pond and the K-1407-C Retention Basin, Oak Ridge, Tennessee (DOE 1995) proposes semiannual groundwater monitoring for nitrate, metals, and selected radionuclides, including gross alpha and beta activity, ${ }^{99} \mathrm{Tc},{ }^{90} \mathrm{Sr},{ }^{137} \mathrm{Cs},{ }^{230,232} \mathrm{Th}$, and ${ }^{234,238} \mathrm{U}$. However, VOCs are the primary groundwater contaminant in the Mitchell Branch area of ETTP. Remediation target concentrations were not established in the CERCLA decision documents for use in post-remediation monitoring. As recommended by EPA, with concurrence from TDEC, performance monitoring is conducted in wells UNW-003, UNW-009, and the Mitchell Branch weir (K-1700 weir), shown on Fig. 3.49.

The primary groundwater contaminants in the K-1407-B and -C ponds area are VOCs, which are widespread in this portion of ETTP, including contaminant sources upgradient of the ponds. Groundwater samples were collected at UNW-003 and UNW-009 in March and August/September 2013. Monitoring results for FY 2013 at the wells are generally consistent with results from previous years. Although VOC concentrations remain high in UNW-003, located downgradient of the former K-1407-B Pond, the FY 2013 concentrations were somewhat lower than those measured during FY 2012. Significant concentrations of parent compounds PCE $(210$ to $300 \mu \mathrm{g} / \mathrm{L})$ and TCE $(1,800$ to $2,400 \mu \mathrm{g} / \mathrm{L})$ and the degradation products 1,1-DCE $(360$ to $480 \mu \mathrm{g} / \mathrm{L}), 1,1-\mathrm{DCA} \quad(380$ to $590 \mu \mathrm{g} / \mathrm{L})$, cis-1,2-DCE $(1,000$ to $1,700 \mu \mathrm{g} / \mathrm{L})$, and VC $(27$ to $55 \mu \mathrm{g} / \mathrm{L})$ were detected at UNW-003 in FY 2013. The detection of VOCs at concentrations well above $1,000 \mu \mathrm{g} / \mathrm{L}$ and the steady concentrations over recent years suggest 
the possible presence of dense nonaqueous phase liquids (DNAPLs) in the vicinity of UNW-003. The Zone 2 final ROD will address groundwater contamination present in the area of the former ponds.

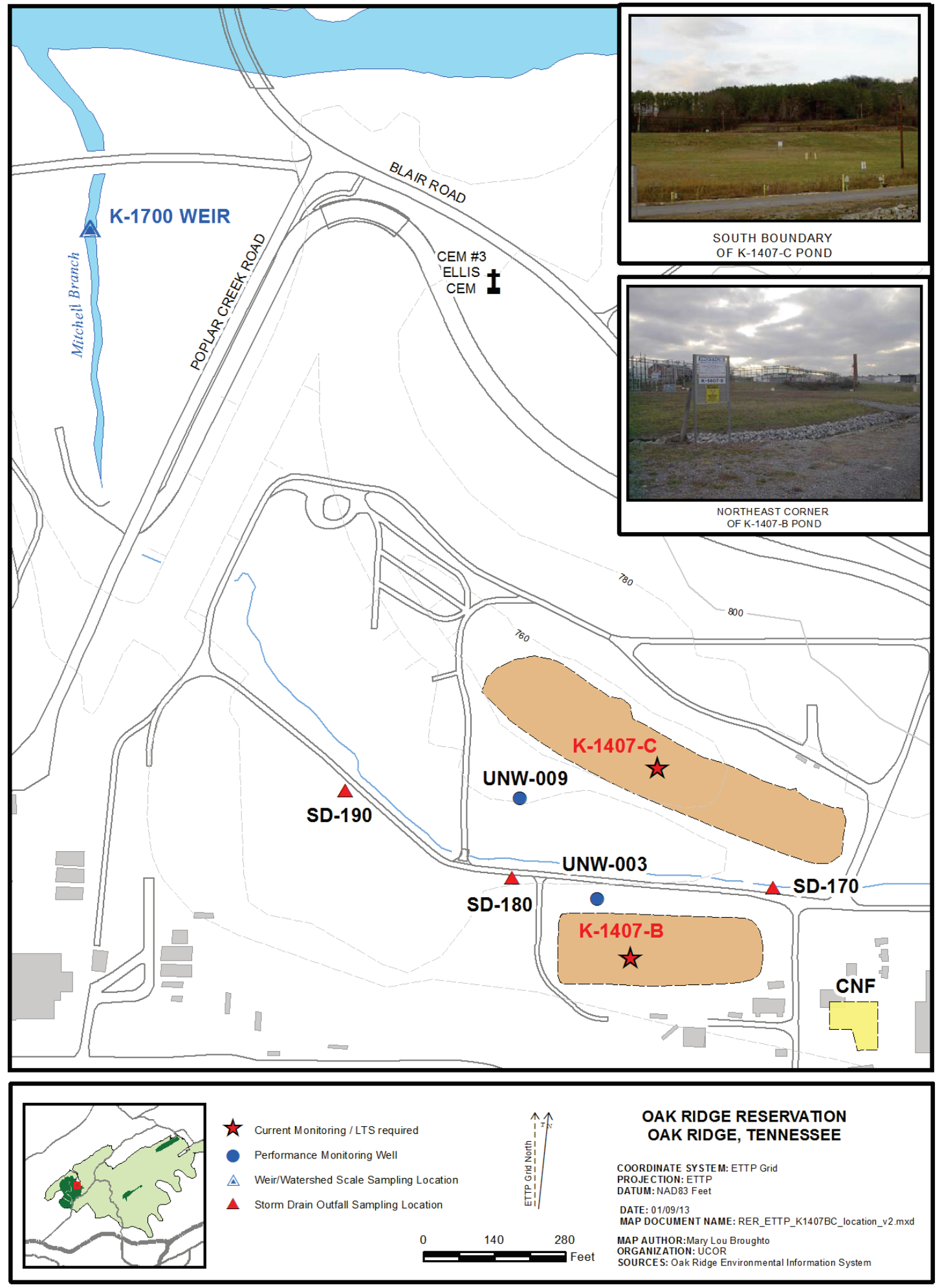

Fig. 3.49. Location of K-1407-B and K-1407-C ponds. (CEM = cemetery, $\mathrm{CNF}=$ Central Neutralization Facility, $\mathrm{SD}=$ storm drain, and UNW $=$ unconsolidated well. 
Gross alpha activity was detected at $4.51 \mathrm{pCi} / \mathrm{L}$ in March and at $5 \mathrm{pCi} / \mathrm{L}$ in August at $\mathrm{UNW}-003$ and was not detected at UNW-009 in either the March or September sampling events. Gross beta activity ranged from 14.4 to $19.1 \mathrm{pCi} / \mathrm{L}$ at UNW-003. Gross beta activity was detected at $5.24 \mathrm{pCi} / \mathrm{L}$ in March and at $4.28 \mathrm{pCi} / \mathrm{L}$ in September at UNW-009. The radionuclide ${ }^{99} \mathrm{Tc}$ was detected at $13.1 \mathrm{pCi} / \mathrm{L}$ in March and at $15.1 \mathrm{pCi} / \mathrm{L}$ in August in UNW-003 and was not detected in either sampling round at UNW-009. Uranium-234 and uranium-238 were not detected at UNW-009 in either sampling round and were not detected in March at UNW-003 but were detected at $4.69 \mathrm{pCi} / \mathrm{L}$ and $1.79 \mathrm{pCi} / \mathrm{L}$ in August. None of the metals having primary drinking water standards exceeded those levels. Iron was elevated above its secondary drinking water standard in both filtered and unfiltered samples from UNW-009 and in only the unfiltered samples from UNW-003. Manganese exceeded its secondary drinking water standard in both filtered and unfiltered aliquots from both wells during both sampling events. The elevated manganese and iron levels are likely caused by chemical reduction in the local groundwater induced by reductive dehalogenation of VOCs.

\subsubsection{Groundwater Sampling Summary}

Groundwater monitoring results in FY 2013 are generally consistent with the results from previous years. VOC concentrations well above $1,000 \mu \mathrm{g} / \mathrm{L}$ and the steady concentrations over recent years suggest the presence of DNAPLs in the vicinity of UNW-003. None of the metals having primary drinking water standards exceeded those values. Some of the iron and manganese concentrations exceeded secondary drinking water standards, possibly the result of chemical reduction induced by reductive dehalogenation of VOCs.

\subsection{Biological Monitoring}

The ETTP BMAP consists of three tasks designed to evaluate the effects of ETTP operations on the local environment, identify areas where abatement measures would be most effective, and test the efficacy of the measures. These tasks are (1) toxicity monitoring of effluent and ambient waters from several locations within Mitchell Branch, (2) bioaccumulation studies, and (3) instream monitoring of biological communities. Figure 3.50 shows the major water bodies at ETTP, and Fig. 3.51 shows the BMAP monitoring locations along Mitchell Branch.

In spring (April-May) and fall (October-November) of 2013, survival and reproduction toxicity tests using the water flea Ceriodaphnia dubia (Fig. 3.52) were conducted at five ambient locations in Mitchell Branch. At the same time, survival and reproduction toxicity tests using $C$. dubia were conducted on effluent from storm water outfalls SD 170 and SD 190. In none of the 2013 tests was toxicity demonstrated (Table 3.36). This continues the trend of the last several tests, where toxicity has been greatly reduced or absent entirely.

The bioaccumulation task includes monitoring of caged clams (Corbicula fluminea) placed at selected locations around ETTP and the collection and analysis of fish from Mitchell Branch and three major ponds on the site. Both clams and fish from uncontaminated off-site locations are also analyzed as points of reference. While historically the primary COC for the bioaccumulation task at ETTP has been PCBs, in recent years mercury has been added to the list of COCs at selected locations.

In 2013, the clams (Fig. 3.53) were allowed to remain in place for 4 weeks and were then analyzed for total PCBs (Table 3.37) and, in a subset of clams, for total mercury and methyl mercury (Table 3.38). In 2013, the greatest concentrations of PCBs were found in the clams from storm water outfall SD 190 and downstream of that location in Mitchell Branch.

Clams from the Mitchell Branch watershed were analyzed for mercury (both total mercury and methyl mercury) in 2013 (Table 3.38). The highest mean total mercury concentrations were found in the clams from the K-1203-10 sump (318.3 ng/g). Clams from the section between K-1700 and storm water outfall SD 190 also had higher levels, with concentrations of total mercury in the caged clam composite samples ranging from a low of $87.7 \mathrm{ng} / \mathrm{g}$ to a high of $210.7 \mathrm{ng} / \mathrm{g}$. At other sites mercury concentrations in clams ranged from at or near reference values to twofold higher $(\sim 25$ to $50 \mathrm{ng} / \mathrm{g})$. 


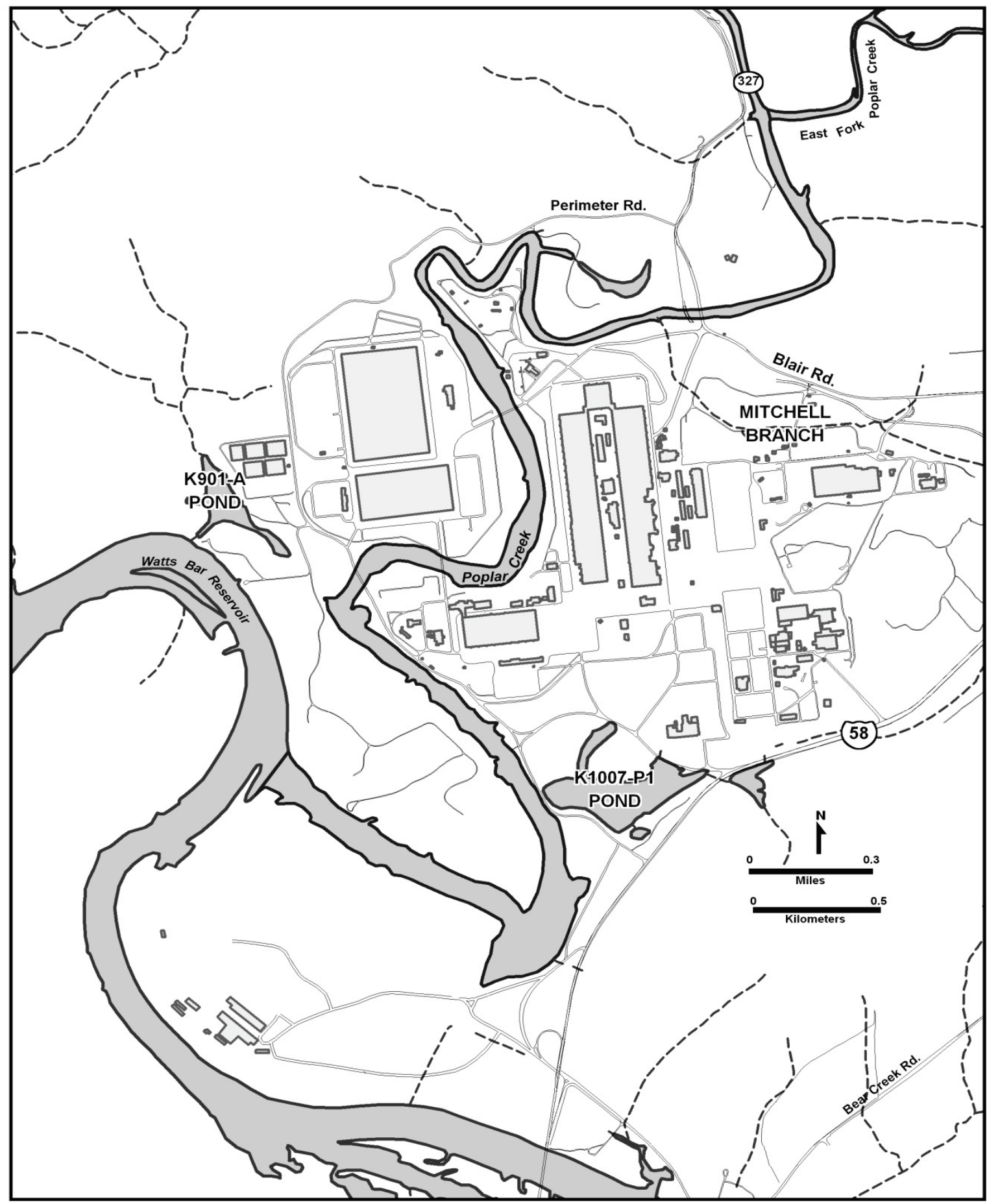

Fig. 3.50. Water bodies at the East Tennessee Technology Park. 


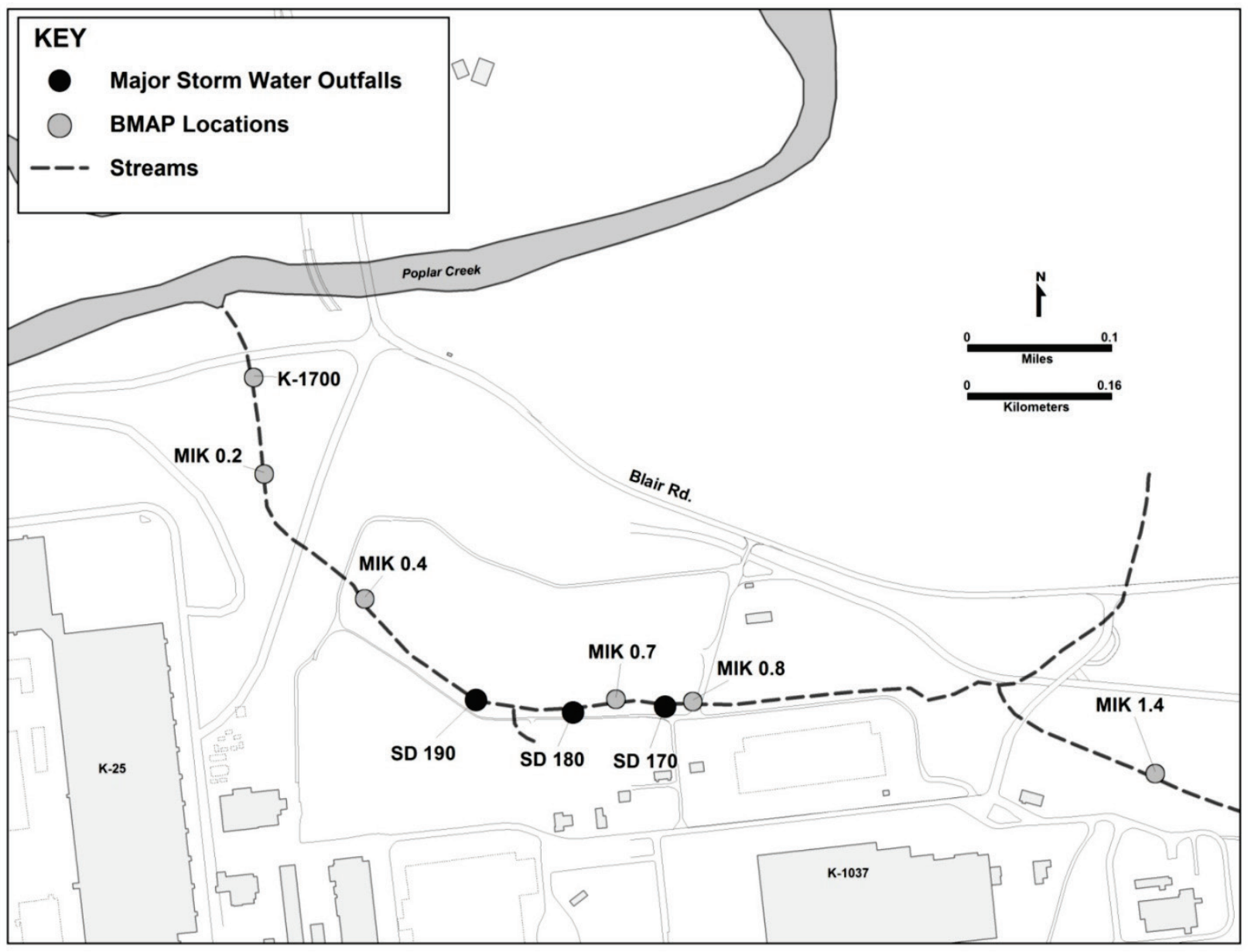

Fig. 3.51. Major storm water outfalls and biological monitoring locations on Mitchell Branch. (BMAP = Biological Monitoring and Abatement Program, MIK = Mitchell Branch kilometer, and $\mathrm{SD}=$ storm drain.)

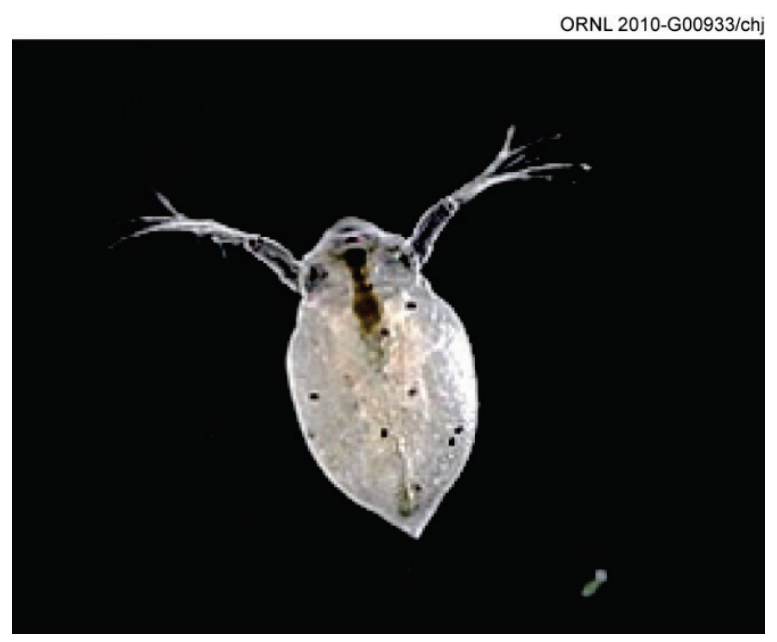

Fig. 3.52. Water flea (Ceriodaphnia dubia). 
Table 3.36. Toxicity test results for Mitchell Branch and associated storm water outfalls, 2013 (no-observed-effects concentrations) ${ }^{a}$

\begin{tabular}{ccccccccc}
\hline Season & Test & $\begin{array}{c}\text { MIK } \\
\mathbf{1 . 4}\end{array}$ & $\begin{array}{c}\text { MIK } \\
\mathbf{0 . 8}\end{array}$ & $\begin{array}{c}\text { SD } \\
\mathbf{1 7 0}\end{array}$ & $\begin{array}{c}\text { MIK } \\
\mathbf{0 . 7}\end{array}$ & $\begin{array}{c}\text { SD } \\
\mathbf{1 9 0}\end{array}$ & $\begin{array}{c}\text { MIK } \\
\mathbf{0 . 4}\end{array}$ & $\begin{array}{c}\text { MIK } \\
\mathbf{0 . 2}\end{array}$ \\
\hline Spring & $\begin{array}{c}\text { Ceriodaphnia dubia } \\
\text { survival (\%) } \\
\text { C. dubia }\end{array}$ & 100 & 100 & 100 & 100 & 100 & 100 & 100 \\
Fall & $\begin{array}{c}\text { reproduction (\%) } \\
\text { C. dubia } \\
\text { survival (\%) } \\
\begin{array}{c}\text { C. dubia } \\
\text { reproduction (\%) }\end{array}\end{array}$ & 100 & 100 & 100 & 100 & 100 & 100 & 100 \\
& 100 & 100 & 100 & 100 & 100 & 100 & 100 \\
\hline
\end{tabular}

${ }^{a}$ Highest tested concentrations of effluent or stream water that had no effect on either survival or reproduction of $C$. dubia in three-brood static renewal tests (EPA test method 1002.0).

Abbreviations

MIK = Mitchell Branch kilometer

$\mathrm{SD}=$ storm drain

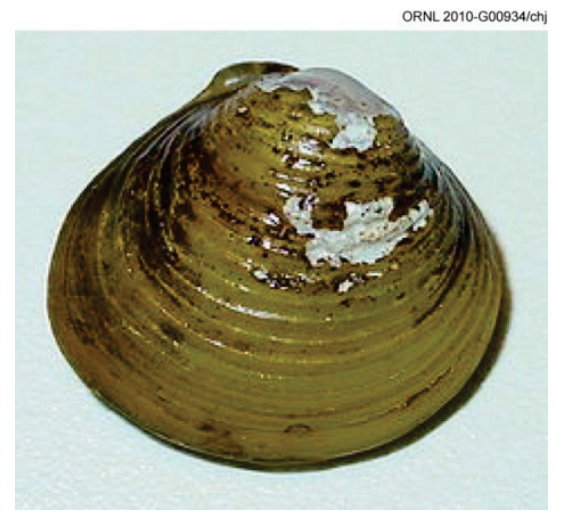

Fig. 3.53. Asiatic clam

(Corbicula fluminea).

Table 3.37. Compiled data for polychlorinated biphenyl concentrations ( $\mu \mathrm{g} / \mathrm{g}$, wet weight) in caged Asiatic clams (Corbicula fluminea), 2009 to 2013

\begin{tabular}{ccccccc}
\hline Site & Basket $^{\boldsymbol{a}}$ & $\mathbf{2 0 0 9}$ & $\mathbf{2 0 1 0}$ & $\mathbf{2 0 1 1}$ & $\mathbf{2 0 1 2}$ & $\mathbf{2 0 1 3}$ \\
\hline \multirow{2}{*}{ MIK 0.8 (above SD 170) } & A & 0.09 & 0.12 & 0.11 & 0.04 & 0.05 \\
SD 170 & B & 0.11 & 0.13 & 0.15 & 0.04 & 0.04 \\
& A & 0.27 & 0.21 & 0.16 & 0.08 & 0.12 \\
MIK 0.7 (below SD 170) & B & 0.25 & 0.28 & 0.16 & 0.15 & 0.13 \\
MIK 0.5 (below SD 180) & A & 0.18 & 0.15 & 0.13 & 0.08 & 0.07 \\
& B & 0.15 & 0.13 & 0.17 & 0.07 & 0.09 \\
& A & 0.25 & 0.15 & 0.13 & $b$ & 0.09
\end{tabular}


Table 3.37. (continued)

\begin{tabular}{|c|c|c|c|c|c|c|}
\hline Site & Basket $^{a}$ & 2009 & 2010 & 2011 & 2012 & 2013 \\
\hline \multirow[t]{2}{*}{ SD 190} & $\mathrm{~A}$ & 2.07 & 1.22 & 2.36 & 0.84 & 2.13 \\
\hline & $\mathrm{B}$ & 1.98 & 1.09 & 1.70 & $b$ & 2.51 \\
\hline \multirow[t]{2}{*}{ MIK 0.4 (below SD 190) } & A & 0.90 & 1.28 & 1.71 & 0.41 & 1.70 \\
\hline & $\mathrm{B}$ & 0.78 & 2.69 & 1.82 & 0.5 & 2.00 \\
\hline \multirow[t]{2}{*}{ SD195 } & A & - & - & - & 0.37 & - \\
\hline & $\mathrm{B}$ & - & - & - & 0.31 & - \\
\hline \multirow[t]{2}{*}{ MIK 0.3} & A & - & 2.93 & 6.74 & 2.52 & 1.80 \\
\hline & $\mathrm{B}$ & - & 3.42 & 4.56 & 2.74 & 2.20 \\
\hline \multirow[t]{2}{*}{ MIK 027} & A & - & - & 4.42 & - & - \\
\hline & $\mathrm{B}$ & - & - & 4.94 & - & - \\
\hline \multirow[t]{2}{*}{ MIK 0.2} & $\mathrm{~A}$ & 2.43 & 2.15 & 5.33 & 0.96 & 2.20 \\
\hline & $\mathrm{B}$ & 2.42 & 2.13 & 4.82 & 1.41 & 2.40 \\
\hline \multirow[t]{2}{*}{ K-1700 } & A & & & & & 2.10 \\
\hline & $\mathrm{B}$ & & & & & 2.30 \\
\hline \multirow[t]{2}{*}{ SD 992} & A & - & 2.93 & - & - & - \\
\hline & B & - & 3.42 & - & - & - \\
\hline \multicolumn{7}{|c|}{ Poplar Creek } \\
\hline \multirow[t]{2}{*}{ K-1203 sump } & A & - & - & - & 0.34 & 0.20 \\
\hline & B & - & - & - & 0.29 & 0.23 \\
\hline \multirow{3}{*}{ SD 100 (upper) } & & $K-100$ & & & & \\
\hline & $\mathrm{A}$ & 0.96 & 0.29 & 2.25 & 1.69 & 0.10 \\
\hline & $\mathrm{B}$ & 0.69 & 0.22 & 1.75 & 1.70 & 0.09 \\
\hline \multirow[t]{2}{*}{ SD 100 (lower) } & A & 1.32 & 0.72 & 5.95 & $b$ & 0.42 \\
\hline & B & 1.72 & 0.80 & 4.50 & 1.92 & 1.35 \\
\hline \multirow[t]{2}{*}{ SD 120} & $\mathrm{~A}$ & 0.34 & 3.06 & 0.75 & 0.11 & 0.28 \\
\hline & B & 0.57 & 1.18 & 0.97 & 0.16 & 0.34 \\
\hline \multirow[t]{2}{*}{ SD 490} & A & 0.40 & 0.37 & 0.39 & 0.19 & 0.18 \\
\hline & B & 0.46 & 0.47 & 0.46 & 0.17 & 0.18 \\
\hline \multirow[t]{2}{*}{ K1007 P1 outfall } & A & 0.91 & - & - & - & 1.29 \\
\hline & $\mathrm{B}$ & 0.85 & - & - & - & 1.30 \\
\hline \multirow[t]{2}{*}{ P1 } & A & 0.86 & 0.99 & 1.38 & 1.48 & - \\
\hline & B & 1.17 & 0.91 & 1.68 & 1.57 & - \\
\hline \multirow{3}{*}{ K-901-A outfall } & \multicolumn{3}{|c|}{ K-901-A Pond } & & & \\
\hline & A & 0.14 & 0.06 & 0.30 & 0.07 & 0.11 \\
\hline & $\mathrm{B}$ & 0.16 & 0.05 & 0.20 & 0.07 & 0.16 \\
\hline \multicolumn{7}{|c|}{ Reference Site } \\
\hline \multirow[t]{2}{*}{ Sewee Creek } & A & 0.02 & 0.01 & 0.00 & 0.01 & 0.004 \\
\hline & $\mathrm{B}$ & 0.02 & 0.01 & 0.01 & 0.003 & 0.002 \\
\hline
\end{tabular}

${ }^{a}$ Sample result is the reported concentration in the composited clam sample from each cage, where A and B denote replicates. Data were extracted from tables within the 2009, 2010, 2011, 2012, and 2013 East Tennessee Technology Park Biological Monitoring and Abatement Program fiscal year reports.

${ }^{b}$ Insufficient numbers of clams survived to provide a suitable sample size for analysis.

$\mathrm{MlK}=$ Mitchell Branch kilometer, $\mathrm{SD}=$ storm drain. 
Table 3.38. Compiled data for mercury concentrations (ng/g, wet weight) in caged Asiatic clams (Corbicula fluminea), 2010 to 2013

\begin{tabular}{|c|c|c|c|c|c|}
\hline Site & Basket $^{a}$ & 2011 & 2012 & $\begin{array}{c}2013 \\
\text { Total Hg }\end{array}$ & $\begin{array}{c}2013 \\
\text { Methyl Hg }\end{array}$ \\
\hline \multicolumn{6}{|c|}{ Mitchell Branch } \\
\hline \multirow[t]{2}{*}{ MIK 0.8 (above SD 170) } & A & 37 & 31.9 & 33.5 & 7.6 \\
\hline & $\mathrm{B}$ & 46.9 & 32.2 & 32.1 & 7.8 \\
\hline \multirow[t]{2}{*}{ SD 170} & A & 67.2 & 88.7 & 34.2 & 3.9 \\
\hline & $\mathrm{B}$ & 80.7 & 62.3 & 38.9 & 5.9 \\
\hline \multirow[t]{2}{*}{ MIK 0.7 (below SD 170) } & $\mathrm{A}$ & 37.7 & 46.2 & 33.5 & 6.5 \\
\hline & $\mathrm{B}$ & 64.8 & 48.8 & 33.3 & 4.8 \\
\hline \multirow[t]{2}{*}{ MIK 0.5 (below SD 180) } & A & 97.2 & 51.4 & 48.7 & 8.9 \\
\hline & $\mathrm{B}$ & 154.8 & $b$ & 49.6 & 8.7 \\
\hline \multirow[t]{2}{*}{ SD 190} & $\mathrm{~A}$ & 109.9 & 127.8 & 187.8 & 4.3 \\
\hline & $\mathrm{B}$ & 80.7 & 270 & 210.7 & 7.9 \\
\hline \multirow[t]{2}{*}{ MIK 0.4 (below SD 190) } & $\mathrm{A}$ & 114 & 85 & 113.1 & 18.2 \\
\hline & $\mathrm{B}$ & 102.3 & 104.8 & 107.1 & 13.3 \\
\hline \multirow[t]{2}{*}{ SD 195} & A & & 88.1 & - & \\
\hline & $\mathrm{B}$ & & 79.5 & - & \\
\hline \multirow[t]{2}{*}{ MIK 0.3} & A & & 311.7 & 116.6 & 12 \\
\hline & $\mathrm{B}$ & & 322.6 & 125.8 & 15.3 \\
\hline \multirow[t]{2}{*}{ MIK 0.2} & A & 166.3 & 115.9 & 100.1 & 13.8 \\
\hline & $\mathrm{B}$ & 187.9 & 136.6 & 105.9 & 18.2 \\
\hline \multirow[t]{2}{*}{$\mathrm{K}-1700$} & A & & & 87.7 & 14.4 \\
\hline & $\mathrm{B}$ & & & 88.3 & 16.7 \\
\hline \multirow{3}{*}{ K-1203-10 sump } & \multicolumn{3}{|c|}{ Poplar Creek } & & \\
\hline & $\mathrm{A}$ & - & 472.3 & 298.8 & 14.0 \\
\hline & $\mathrm{B}$ & - & 336.2 & 337.8 & 10.6 \\
\hline \multicolumn{6}{|c|}{ K-1007-P1 Pond } \\
\hline \multirow[t]{2}{*}{$\mathrm{P} 1$} & $\mathrm{~A}$ & 23 & 25.6 & 19.0 & \\
\hline & $\mathrm{B}$ & 22.6 & 14.5 & 22.4 & \\
\hline \multirow{3}{*}{ K-901-A outfall } & & $K-9$ & & & \\
\hline & A & 33.1 & 17.4 & 18.9 & \\
\hline & $\mathrm{B}$ & 46.4 & 27.6 & 25.8 & \\
\hline \multicolumn{6}{|c|}{ K-1203-10 } \\
\hline \multirow[t]{2}{*}{ SD 05A } & $\mathrm{A}$ & & 472.3 & & \\
\hline & $\mathrm{B}$ & & 336.2 & & \\
\hline \multirow[t]{2}{*}{ SD 992} & A & & & & \\
\hline & $\mathrm{B}$ & & & & \\
\hline \multirow{3}{*}{ Little Sewee Creek } & & Ref & & & \\
\hline & A & $19.6^{\circ}$ & 25.2 & 24.4 & \\
\hline & $\mathrm{B}$ & 27.2 & 19.1 & 26.7 & \\
\hline
\end{tabular}

${ }^{a}$ Sample result is the reported concentration in the composited clam sample from each cage, where A and B denote replicates. Data are extracted from tables within the 2010, 2011, 2012, and 2013 East Tennessee Technology Park Biological Monitoring and Abatement Program fiscal year reports.

${ }^{b}$ Insufficient numbers of clams survived to provide a suitable sample size for analysis.

$\mathrm{MlK}=$ Mitchell Branch kilometer, SD = storm drain.

Bioaccumulation monitoring in the K-1007-P1 pond, K-901-A pond, K-720 slough, and Mitchell Branch involves sampling of fish (Fig 3.54) and analyzing the tissues for PCB concentrations (Table 3.39). Typically, fillets of game fish are used as a monitoring tool to assess human health risks, while whole body 
composites of forage fish are used to assess ecological risks associated with exposure to PCBs. Target species vary from site to site depending upon the ecological conditions and, thus, the available species. The target species for bioaccumulation monitoring in 2013 in the K-1007-P1 pond was bluegill sunfish (Lepomis macrochirus) (Fig. 3.55). In Mitchell Branch, the target species was the redbreast sunfish (Lepomis auritus). In the K-901-A pond and the K-720 slough, the target species were the gizzard shad (Dorosoma cepedianum) and largemouth bass (Micropterus salmoides). As there were not enough largemouth bass, carp (Cyprinus carpio) and smallmouth buffalo (Ictiobus bubalus) were also collected.

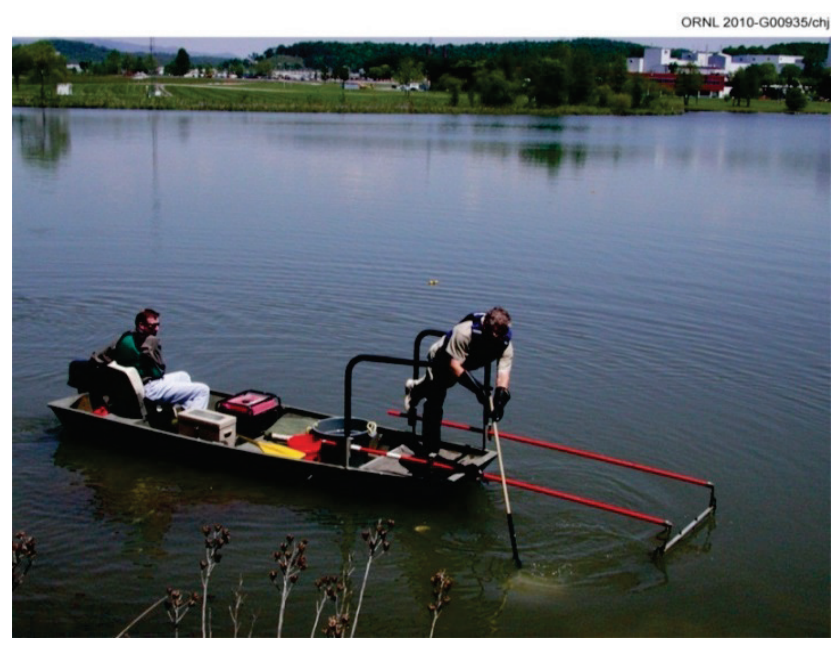

Fig. 3.54. Fish bioaccumulation sampling at $\mathrm{K}-1007-\mathrm{P} 1$ pond.

Table 3.39. Polychlorinated biphenyl levels $(\mathrm{mg} / \mathrm{kg})^{a}$ in fish samples at East Tennessee Technology Park, 2009 to $2013^{b}$

\begin{tabular}{ccccccc}
\hline Site & Fish species & $\mathbf{2 0 0 9}$ & $\mathbf{2 0 1 0}$ & $\mathbf{2 0 1 1}$ & $\mathbf{2 0 1 2}$ & $\mathbf{2 0 1 3}$ \\
\hline Mitchell Branch & Redbreast sunfish & $0.99+0.47$ & $1.17+0.13$ & $1.12+0.21$ & $1.67+0.16$ & $1.29+0.38$ \\
K-901-A pond & Largemouth bass & $0.48+0.12$ & -- & $0.50+0.08$ & $0.72+0.10$ & $1.40+0.19$ \\
K-901-A pond & Common carp & - & $0.71+0.20$ & $2.06+0.25$ & $3.08+0.20$ & $2.94+0.33$ \\
K-901-A pond & Gizzard shad & & & & $4.82+0.38$ & $8.86+0.58$ \\
& & & & & & - \\
K-1007-P1 pond & Largemouth bass & $14.85+5.44$ & $0.30+0.05$ & - & - & - \\
K-1007-P1 pond & Bluegill sunfish & - & $2.13+0.16$ & $1.85+0.31$ & $2.16+0.26$ & $0.70+0.08$ \\
K-1007-P1 pond & $\begin{array}{c}\text { Bluegill sunfish (whole } \\
\text { body composites) }\end{array}$ & & & & $9.25+0.05$ & $4.45+0.25$ \\
Hinds Creek & Redbreast sunfish & $0.0007+$ & $0.09+0.05$ & $0.06+0.001$ & $<0.06$ & $<0.06$ \\
K-720 slough & Largemouth bass & - & - & $0.24+0.02$ & $0.22+0.10$ & $0.14+0.02$ \\
K-720 slough & Smallmouth buffalo & - & - & $0.77+0.19$ & $0.68+0.19$ & $0.44+0.10$ \\
K-720 slough & Common carp & - & - & $0.96+0.21$ & $0.31+0.03$ & $0.45+0.12$ \\
K-720 slough & Gizzard shad (whole & & & & & $0.57+0.04$ \\
\hline
\end{tabular}

${ }^{a}$ Milligrams per kilogram $(\mathrm{mg} / \mathrm{kg})$ are equivalent to micrograms per gram $(\mu / \mathrm{g})$, used in the text.

${ }^{b}$ Data were extracted from tables within the 2009, 2010, 2011, 2012, and 2013 East Tennessee Technology Park Biological Monitoring and Abatement Program fiscal year reports. 


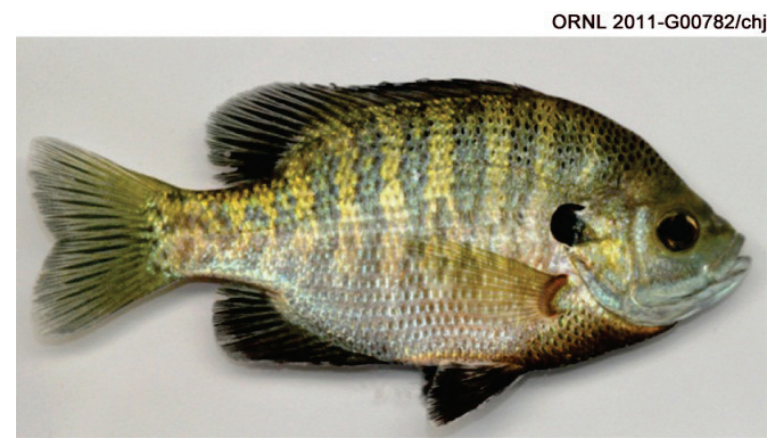

Fig. 3.55. Bluegill sunfish (Lepomis macrochirus).

Whole body composites (six composites of 10 bluegill per composite) and fillets from 20 individual bluegill were analyzed for PCBs to assess the ecological and human health risks associated with PCB contamination in the K-1007-P1 pond. Average PCB levels in whole body composites from the K-1007-P1 pond averaged $4.45 \mu \mathrm{g} / \mathrm{g}$, down from $9.25 \mu \mathrm{g} / \mathrm{g}$ in 2012. Fillets averaged $0.7 \mu \mathrm{g} / \mathrm{g}$ total PCBs, a significant decrease compared to levels seen in $2012(2.16 \mu \mathrm{g} / \mathrm{g})$. Average PCB concentrations in sunfish collected in Mitchell Branch were $1.29 \mu \mathrm{g} / \mathrm{g}$, slightly lower than the levels seen in $2012(1.67 \mu \mathrm{g} / \mathrm{g})$. The concentrations observed in fillets of largemouth bass from the K-901-A pond $(1.4 \mu \mathrm{g} / \mathrm{g})$ and gizzard shad whole body composite samples $(8.86 \mu \mathrm{g} / \mathrm{g})$ saw a significant increase from the concentrations seen in the 2012 monitoring, $0.72 \mu \mathrm{g} / \mathrm{g}$ and $4.82 \mu \mathrm{g} / \mathrm{g}$, respectively. Levels of PCBs in bass from the K-901-A pond have been climbing in recent years and are believed to be linked to the relative abundance of gizzard shad in the pond. Gizzard shad readily bioaccumulate PCBs and are a major food source for bass. Levels of PCBs in bass, gizzard shad, and carp from the K-720 slough $(0.14 \mu \mathrm{g} / \mathrm{g}, 0.57 \mu \mathrm{g} / \mathrm{g}$, and $0.45 \mu \mathrm{g} / \mathrm{g}$, respectively) were considerably lower than for the same species from the K-901-A pond.

In addition to being analyzed for PCBs, the sunfish collected from Mitchell Branch (MIK 0.2) were analyzed for total mercury (Table 3.40). Previous studies have shown that methyl mercury accounts for more than $95 \%$ of the total mercury in fish, so a separate analysis for methyl mercury was not conducted. The EPA's recommended limit for mercury in fish fillets is $0.3 \mu \mathrm{g} / \mathrm{g}$. The mean mercury concentration in fish collected at MIK 0.2 was $0.52 \mu \mathrm{g} / \mathrm{g}$ in 2013, higher than last year. However, mercury concentrations in fish in Mitchell Branch in recent years have averaged about 0.3 to $0.5 \mu \mathrm{g} / \mathrm{g}$ with about $10 \%-20 \%$ variability within the annual collection (Table 3.40). Consequently, it is not certain there has been a significant change in fish mercury concentrations in 2013, and changes in sampling season (from spring to fall) starting in 2012, as well as fish size differences between years, may also be factors affecting mercury levels. Future monitoring efforts are necessary to evaluate whether the recent indication of higher mercury concentrations is a long-term trend.

In April 2013, the benthic macroinvertebrate community at four Mitchell Branch locations (MIKs 0.4, 0.7, 0.8, and 1.4) was sampled using standard quantitative techniques; MIK 1.4 was the reference location. Results of monitoring in 2013 using the ORNL protocols show little change at the three uppermost locations (MIKs 1.4, 0.8, and 0.7). At MIK 0.4, the 2013 study showed an increase in the number of pollution-intolerant species compared to 2012 (Fig. 3.56). This increase followed several years of declining pollution-intolerant species richness and brings the numbers of species back to levels last seen in 2006. However, the number of pollution tolerant species makes up a much larger percentage of the total fauna at MIK 0.4 than at any of the other locations. Otherwise, results at MIK 0.4 generally mirrored those at MIKs 0.7 and 0.8 . In recent years, the benthic macroinvertebrate community at MIK 0.7 and MIK 0.8 has shown no major persistent change in trends of either the mean number of taxa (taxonomic richness of all taxa) or the mean number of pollution-intolerant taxa [i.e., the taxonomic richness of the Ephemeroptera, Plecoptera, and Trichoptera (EPT)]. These results show that the benthic community at MIK 0.4 continues to be negatively impacted while the results for MIKs 0.7 and 0.8 suggest that the macroinvertebrate community at those sites is also impacted but to a lesser degree. 
Table 3.40. Mercury levels $(\mathrm{mg} / \mathrm{kg})^{a}$ in fish fillet and whole body samples at East Tennessee Technology Park, 2009 to $2013^{b}$

\begin{tabular}{|c|c|c|c|c|c|c|}
\hline Site & Fish species & 2009 & 2010 & 2011 & 2012 & 2013 \\
\hline $\begin{array}{l}\text { Mitchell } \\
\text { Branch }\end{array}$ & Redbreast sunfish & $0.49+0.09$ & $0.35+0.059$ & $0.34+0.04$ & $0.37+0.05$ & $0.52+0.09$ \\
\hline $\begin{array}{l}\text { K-901-A } \\
\text { Pond }\end{array}$ & $\begin{array}{l}\text { Gizzard shad (whole } \\
\text { body) }\end{array}$ & & $0.086+0.021$ & & & \\
\hline $\begin{array}{l}\text { K-1007-P1 } \\
\text { Pond }\end{array}$ & Paddlefish (1 sample) & & 0.07 & & & \\
\hline $\begin{array}{l}\text { K-1007-P1 } \\
\text { Pond }\end{array}$ & Bluegill sunfish & & $0.085+0.008$ & & & \\
\hline Hinds Creek & Redbreast sunfish & & $0.08+0.01$ & $0.07+0.01$ & $\begin{array}{c}0.058+ \\
0.005\end{array}$ & $0.07+0.01$ \\
\hline $\begin{array}{l}\text { K-720 } \\
\text { Slough }\end{array}$ & $\begin{array}{l}\text { Gizzard shad (whole } \\
\text { body) }\end{array}$ & & $0.067+0.006$ & & & \\
\hline
\end{tabular}

${ }^{a}$ Milligrams per kilogram $(\mathrm{mg} / \mathrm{kg})$ are equivalent to micrograms per gram $(\mu / \mathrm{g})$, used in the text.

${ }^{b}$ Data are extracted from tables within the 2009, 2010, 2011, 2012, and 2013 East Tennessee Technology Park Biological

Monitoring and Abatement Program fiscal year reports.

Since August 2008, TDEC protocols, which assess both community and habitat characteristics, have also been used at the MIK 0.4, 0.7, and 0.8 monitoring locations. Beginning in August 2009, the use of TDEC protocols was expanded to include MIK 1.4 as well (Fig. 3.57). In 2013, the biotic index (Fig. 3.58) indicated that the community at MIK 0.4 was moderately impaired, the community at MIK 0.7 was slightly impaired, and the communities at MIKs 0.8 and 1.4 were unimpaired. The total number of taxa at all four locations is similar (ranging from 31 to 34), and differences between the sites are within the normal range of fluctuation from year to year. However, the community at MIK 1.4 was richer in pollution-intolerant species (11 species as compared to 5 to 9 species at the other three locations), a situation which has been consistent since the studies were begun in 2008. The habitat assessment (which primarily considers the physical aspects of the stream to determine its suitability to support biological communities) indicated that not all sampling locations along Mitchell Branch met the habitat goals for this region. In 2013, habitat at MIKs 0.7 and 0.8 met the habitat goals while MIKs 0.4 and 1.4 scored as being moderately impaired. However, the habitat score at MIK 1.4 failed to meet the goal by only a small margin, primarily due to the low flow rates, low substrate quality, and erosion of the stream bank at that location. At MIK 0.4, multiple issues influenced the habitat score. Overall, results using TDEC's semiquantitative protocols and ORNL's quantitative protocols since 2008 have been in general agreement that the habitat at MIK 0.4 scores from slightly to severely impaired and that the habitat at MIKs 0.7 and 0.8 scores from moderate impairment to unimpaired. 

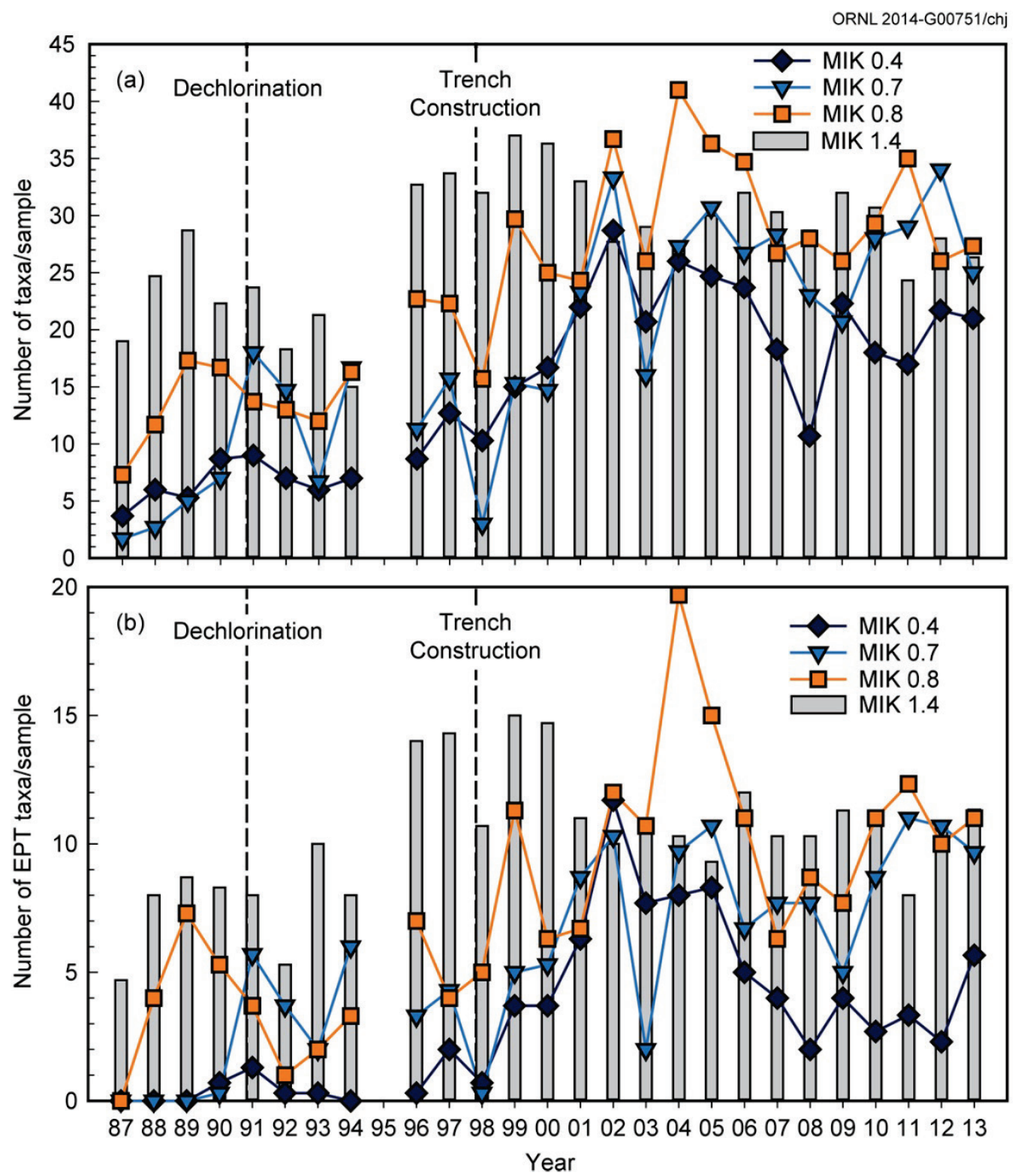

Fig. 3.56. Mean taxonomic richness in Mitchell Branch, 1987-2013: (a) number of all taxa and (b) number of pollution-intolerant Ephemeroptera, Plecoptera, and Trichoptera (mayflies, stoneflies, and caddisflies or EPT) taxa per sample.

Samples were not collected in April 1995, as indicated by the gap in the lines. (MIK $=$ Mitchell Branch kilometer.) 


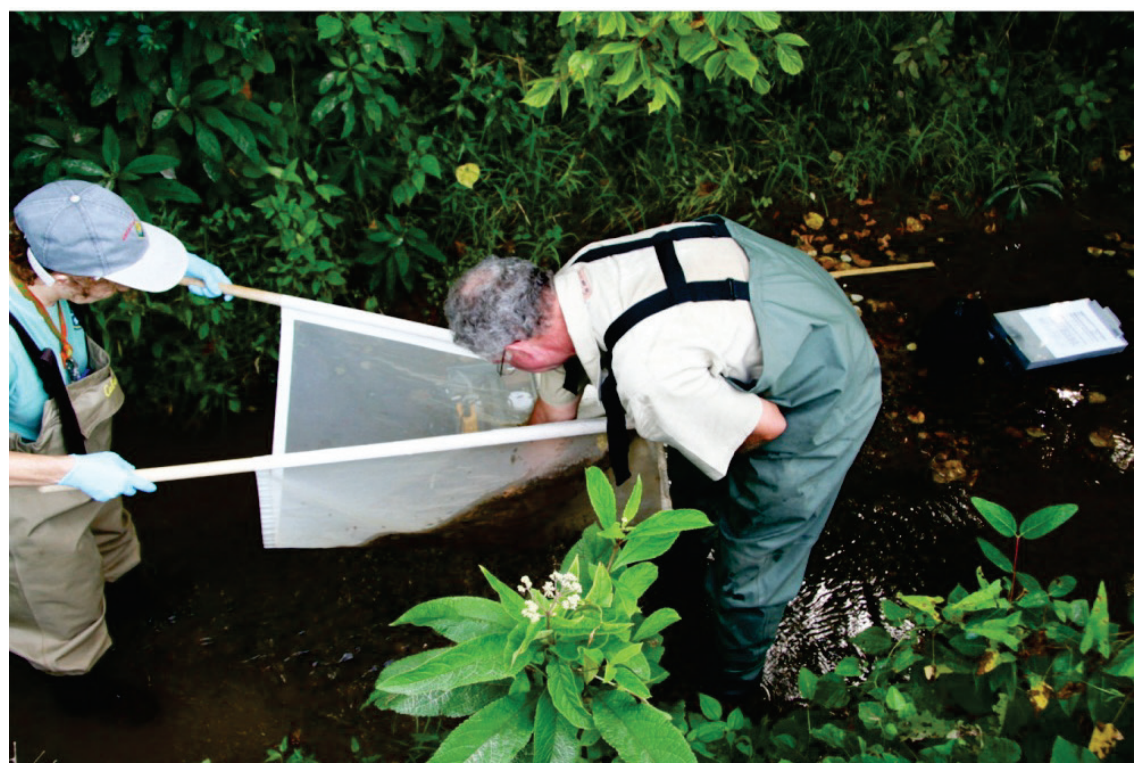

Fig. 3.57. Benthic macroinvertebrate sampling using Tennessee Department of Environment and Conservation protocols.

Fish communities in Mitchell Branch (MIKs 0.4 and 0.7) and at local reference sites were sampled in 2013. Species richness, density, and biomass were examined (Figs. 3.59 and 3.60). Results for 2013 showed only minor changes from 2012. The number of species decreased by one at MIK 0.7 and increased by one at MIK 0.4. All of the species found during the community studies sampling tend to be more tolerant of less than optimal conditions. Both MIK 0.4 and 0.7 had an increase in biomass and density from 2012. Variations in these three parameters are typical of streams that have been severely impacted and are still recovering. While the condition of the fish communities over the last several years has been relatively stable, they have yet to reach conditions typical of less impacted streams in the area, and the stream is still dominated by more tolerant fish species. However, during sampling for the bioaccumulation task at MIK 0.2, five species of fish were collected that have not been collected at the two upper fish community sites in Mitchell Branch. These included the snubnose darter (Etheostoma simoterum), the spotted sucker (Minytrema melanops), and the rock bass (Ambloplites rupestris), all three of which are considered to be pollution sensitive species. This seems to indicate that stream conditions may be able to support additional fish species (at least seasonally) in downstream sections and potentially upstream as well if water quality and habitat conditions improve. 


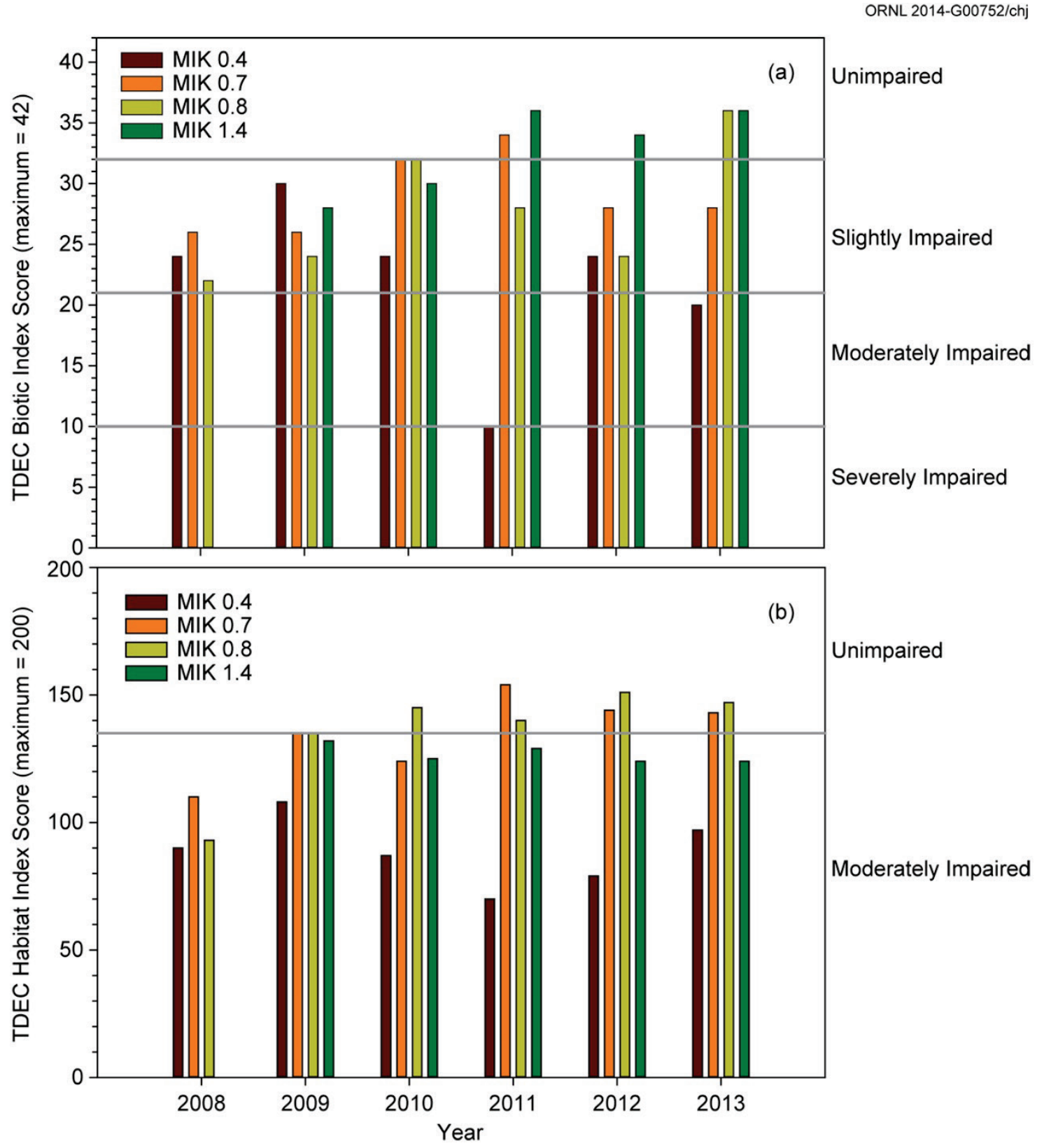

Fig. 3.58. Temporal trends in Tennessee Department of Environment and Conservation (TDEC) Benthic Macroinvertebrate Biotic Index (a) and Stream Habitat Index (b) scores for Mitchell Branch, August 2008 to 2013. Horizontal lines in both graphs show the lower thresholds for narrative index ratings; respective narrative ratings for each threshold are shown on the right side of each graph. (MIK = Mitchell Branch kilometer.) 


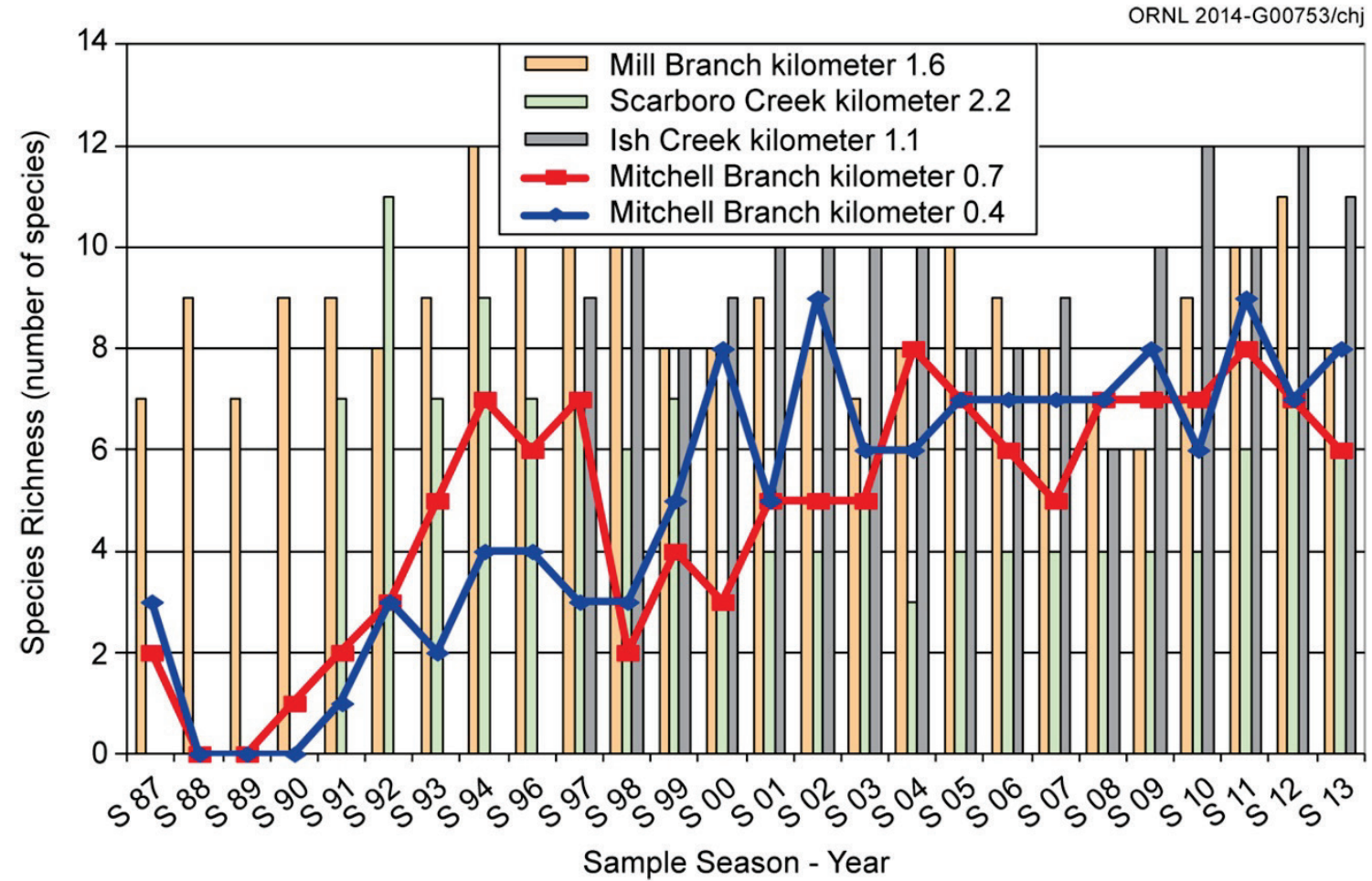

Fig. 3.59. Species richness for fish communities.

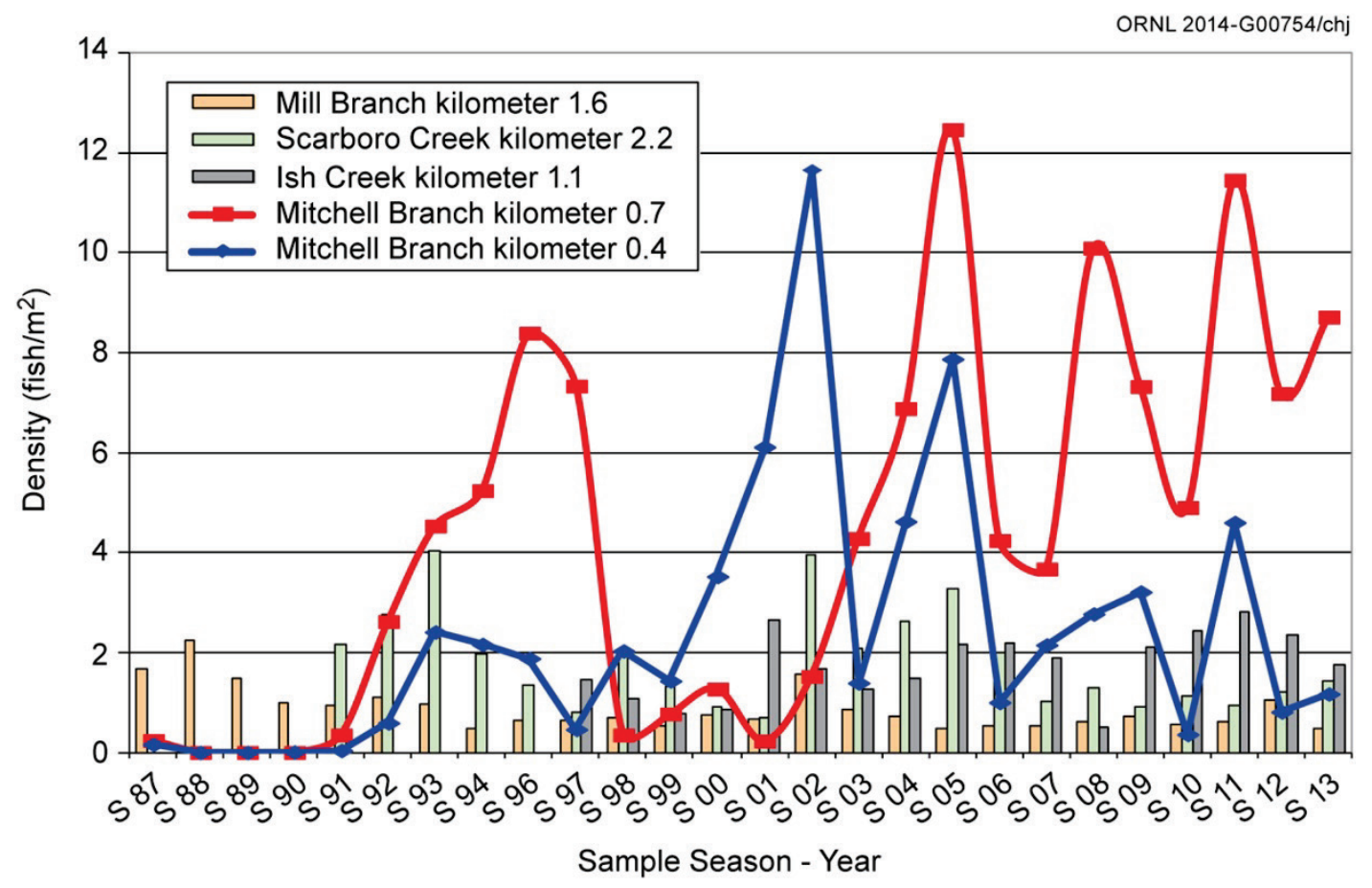

Fig. 3.60. Density for fish communities.

\subsection{Environmental Management and Waste Management Activities}

\subsubsection{Waste Management Activities}

Restoration of the environment, D\&D of facilities, and management of the legacy wastes constitute the major operations at ETTP. 
The TSCA Incinerator located at ETTP was shut down permanently on December 2, 2009, after treating 35.6 million $\mathrm{lb}$ of liquid and solid waste over a 19-year period. The TSCA Incinerator was a oneof-a-kind thermal treatment unit. It played a key role in treating radioactive PCBs and hazardous wastes (mixed wastes) from ORR and other facilities across the DOE complex, thus, facilitating compliance with regulatory and site closure milestones. The certified closure report was submitted to TDEC and EPA in June 2011. Efforts to encapsulate remaining PCB and radioactive contamination, to minimize water management actions, and to reduce the cost of ongoing S\&M continued through 2012. The S\&M program was initiated in 2013 and will be used to manage the facility until its final demolition.

EMWMF, located in Bear Creek Valley west of the Y-12 Complex, is an engineered landfill that accepts waste generated from cleanup activities on ORR. It currently consists of six disposal cells with a total disposal capacity of 2,180,000 $\mathrm{yd}^{3}$. In addition, leachate storage tanks, contact water storage ponds, and contact water storage tanks provide the facility's water management capability. EMWMF accepts low-level radioactive and hazardous wastes that meet specific waste acceptance criteria developed in accordance with agreements with state and federal regulators. Waste types that qualify for disposal include soil, dried sludge and sediment, solidified wastes, stabilized waste, building debris, scrap equipment, and personal protective equipment. During FY 2013, EMWMF operations collected, analyzed, and disposed of about 5.1 million gal of leachate at the ORNL Liquid and Gaseous Waste Operations Facility. An additional 16.7 million gal of contact water was collected, analyzed, and released to the storm water retention basin after it was determined that it met the release criteria. EMWMF received about 7,096 truckloads of waste accounting for about 80,070 tons during FY 2013. Projects that have disposed of waste at EMWMF during the year include the following.

- K-25 Building Demolition Project

- K-33 Building Demolition Project

- Several ORNL demolition projects

EMWMF began operations in 2002 to provide on-site waste disposal capacity from remediation efforts across ORR. Although it has been expanded to its maximum capacity, EMWMF will not be able to handle all of the waste expected to be generated from reservation cleanup activities.

Further expansion at EMWMF is constrained by physical limitations of the site. Therefore, in FY 2010 DOE began evaluating disposal alternatives for future reservation waste cleanup. In September 2012, DOE issued an RI/FS that evaluated the following alternatives.

- No action

- On-site disposal (constructing and operating a new disposal facility on the reservation)

- Off-site disposal (shipping to an off-site facility)

The on-site disposal alternative would provide consolidated disposal of most future-generated CERCLA waste in a newly constructed, engineered facility referred to as the Environmental Management Disposal Facility (EMDF). This alternative would require permanent commitment of land and has the potential to impact environmental resources. EMDF would also be less costly than the off-site disposal alternative and would provide a greater level of certainty that long-term disposal capacity would be available.

The off-site disposal alternative would involve transporting future CERCLA waste for disposal in approved disposal facilities in Nevada and Utah. This alternative would isolate waste more effectively due to the arid climate and the presence of fewer receptors.

In FY 2013, comments received from EPA and TDEC were incorporated into a second draft report that was submitted to regulators on June 20, 2013. A workshop was held in August 2013 to evaluate current and future on-site disposal on ORR.

CNF was a complex of 49 buildings, structures, containment and storage tank facilities, and support trailers. The facility was ETTP's primary wastewater treatment facility and processed both hazardous and nonhazardous waste streams arising from multiple waste treatment facilities and remediation projects. CNF ceased accepting waste in December 2012 in order to begin the decommissioning process. 
Decommissioning activities at CNF included sludge removal and disposal; chemical removal and disposal; material, media, and equipment removal and disposal; oil removal and disposal; equipment rinsing and pressure washing; and characterization and filling of some tanks, basins, containment dikes, and subsurface facilities. The decommissioning process was completed in 2013.

CWTS is a smaller water treatment unit for chromium-contaminated groundwater that sits within the existing CNF footprint. CWTS came online in late 2012 and handles purge water from groundwater monitoring as well as the chromium collection system water. Effluent from CWTS discharges to the Clinch River through an existing CNF discharge line.

At ORNL, about 126 million gal of wastewater was treated and released at the Process Waste Treatment Complex. In addition, the liquid low-level waste evaporator at ORNL treated 218,900 gal of such waste. A total of 2.2 billion $\mathrm{m}^{3}$ of gaseous waste was treated at the ORNL 3039 Stack Facility.

These waste treatment activities supported both EM and Office of Science mission activities in a safe and compliant manner during FY 2013. NNSA at the Y-12 Complex treated more than 116 million gal of contaminated ground/sump water at the Groundwater Treatment Facility, Central Mercury Treatment System, Big Spring Water Treatment System, and East End Volatile Organic Compounds Plume Treatment System.

The Big Spring Water Treatment System treated more than 100 million gal of mercury-contaminated groundwater. The East End Volatile Organic Compounds Plume Treatment System treated more than 11 million gal of VOC-contaminated groundwater. The West End Treatment Facility and the Central Pollution Control Facility at the Y-12 Complex processed more than 826,000 gal of wastewater, primarily in support of NNSA operational activities. The Central Pollution Control Facility processed about 46,000 gal of wastewaters containing oil, chemicals, and radiological materials. The Central Mercury Treatment System treated more than 2 million gal of mercury contaminated sump water from the Alpha 4 building. The Liquid Storage Facility and Groundwater Treatment Facility treated more than 2 million gal of leachate from burial grounds and well purge waters from remediation areas.

In FY 2013, about 36,435 $\mathrm{yd}^{3}$ of industrial wastes and construction/demolition debris was disposed in the landfill. Operation of ORR landfills generated about 1.1 million gal of leachate that was collected, monitored, and discharged to the Y-12 Complex sanitary sewer system, which discharges to the Oak Ridge sewer system under an industrial sewer user permit.

\subsubsection{Environmental Restoration Activities}

ETTP operated as an enrichment facility for four decades during which time many of the buildings became contaminated with radionuclides, heavy metals, and toxic organic compounds. In addition, large quantities of wastes were generated, much of which was stored on the site.

ETTP's Environmental Management Program was created with the goal of demolishing all unnecessary facilities and restoring the site to a usable condition. The safety and health of employees and the public is a constant focus. Cost-effectiveness is also a major consideration in the cleanup operations.

DOE has signed two of three key CERCLA RODs with the State of Tennessee and EPA authorizing environmental restoration of about 890 ha (2,198 acres) of land at ETTP. The area encompasses 567 ha (1,400 acres) outside the main plant security fence (Zone 1) and 324 ha (800 acres) inside the fence within the former plant production area (Zone 2). The main objectives of the two decisions are to protect future industrial workers and the underlying groundwater from contamination that remains in soil, slabs, and subsurface structures. The Zone 1 interim ROD was signed in November 2002 and covers the 567 ha (1,400-acre) area surrounding ETTP outside the main plant perimeter. In FY 2013, EPA and TDEC provided comments on the RI/FS, and an agreement was reached to initiate a Zone 1 final soils ROD and defer Zone 1 surface water and groundwater to a future decision.

The Zone 2 ROD was signed in April 2005 and covers about 324 ha (800 acres) in the main plant area. In FY 2013, remediation of the 13 ha (32-acre) footprint of Building K-33 was completed with the excavation and disposal of the slab and associated soil. EPA and TDEC approved the documents that detail the K-1070-B burial ground cleanup; two subsurface sumps at the TSCA Incinerator were remediated, and several subsurface facilities at CNF were characterized to determine whether remediation would be required before backfill. Based upon the results of the characterization, the facilities were 
backfilled with flowable fill and concrete to eliminate safety hazards and to aid in the management of storm water.

From the time cleanup operations began through FY 2013, 378 facilities have been demolished, 1.88 million $\mathrm{yd}^{3}$ of waste has been removed from the site, and 567 ha $(1,400)$ acres of land have been cleared for unrestricted use. In addition, about 7,000 uranium hexafluoride cylinders were removed from the site.

When ORR was established, a buffer zone was also included between the three major facilities and areas open to the public. This area, about 8,100 ha (20,100 acres) in extent, has little or no process-related history. However, with the listing of ORR on the NPL in 1989, the possibility of contamination had to be investigated. Beginning in 2008, DOE initiated a process to achieve FFA party consensus that the buffer parcels require no further investigation and to modify the FFA appendixes to better represent the known contaminated areas. ORAU was contracted to complete the verification activities (initiated in the late 1990s as a footprint reduction project), including review of historical documents, sampling and analysis, risk analysis, and reporting of study results, with recommendations for no further investigation where appropriate. The first Environmental Baseline Survey Report (EBSR), addressing five parcels around ETTP totaling about 1,863 ha (4,600 acres), was submitted in September 2011, and regulator comments were received in 2012. The second EBSR, addressing 14 parcels of about 6,277 ha (15,500 acres) around ORNL and Y-12, was submitted in September 2012. Based upon these reports, a total of 7,816 ha $(19,300$ acres $)$ could be approved for no further investigation.

\subsubsection{Building K-25 Demolition}

Building K-25 (Fig. 3.61), built during the Manhattan Project, occupied about 16 ha (40 acres) and contained more than 3,000 stages of gaseous diffusion and associated auxiliary equipment. Each stage consisted of a converter, two compressors, two compressor motors, and associated piping. Workers had previously cut through a portion of the east wing to segregate a portion of the building contaminated with ${ }^{99} \mathrm{Tc}$ from the rest of the demolition area. Predemolition activities in that area included characterization, vent, purge, drain, inspection, and foaming of components to stabilize contaminants in place; asbestos removal; and draining of lubricants and coolants. In addition, materials such as uranium-containing monoliths, sodium fluoride traps, and high risk equipment that had been stored in the area had to be removed. In 2013, demolition of the north tower was completed and work began on demolishing the final six units of the east wing. The monoliths and high risk equipment in the east wing were moved from the building to an area where the uranium could be safely removed for disposal. Depending on the nature of the resultant material, debris from the demolition project was sent either to EMWMF for disposal or to the appropriate off-site disposal facility. 


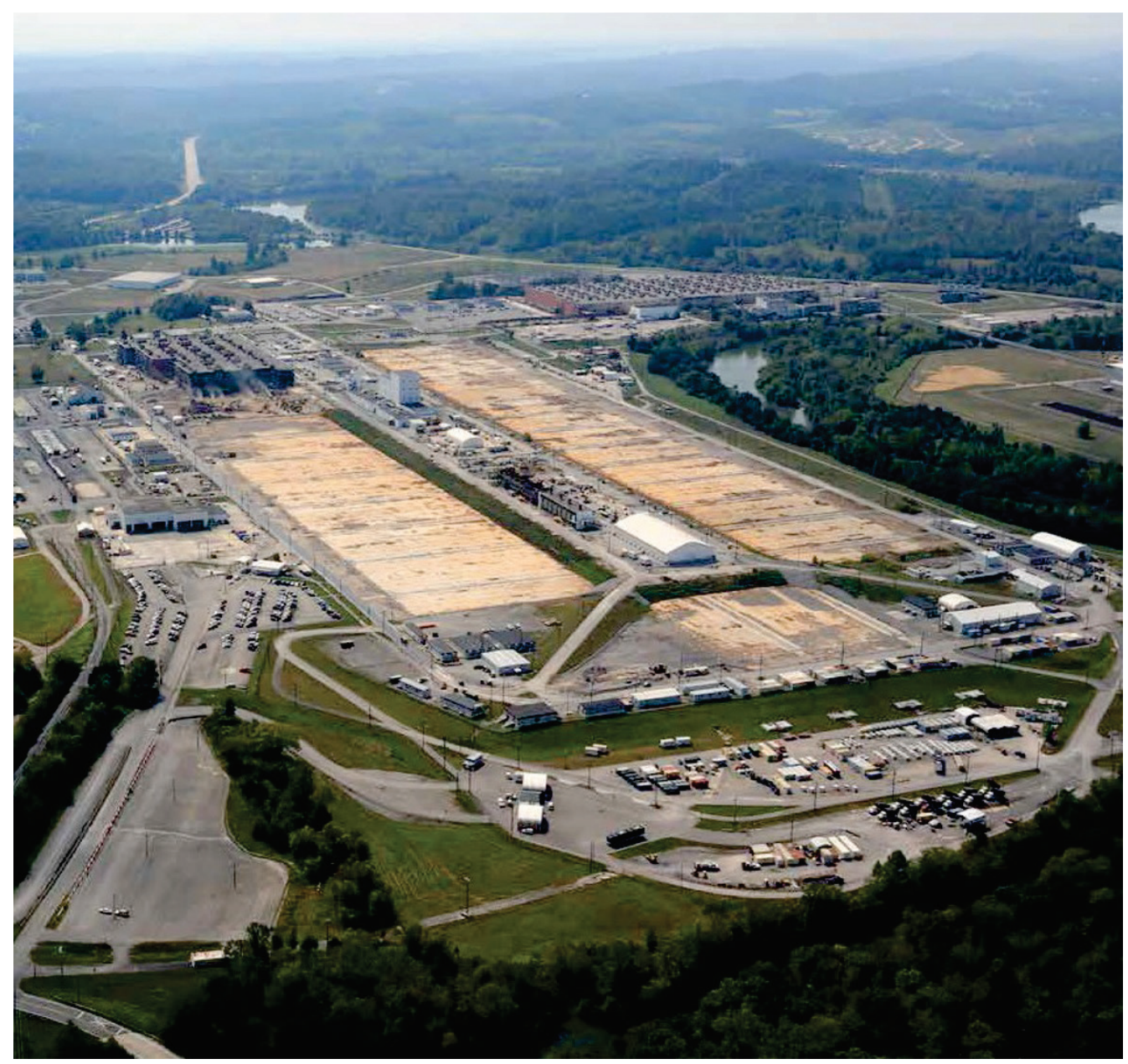

Fig. 3.61. Building K-25 in late 2013.

\subsubsection{Building K-27 Demolition}

Building K-27 was a multistory building that was built as a uranium enrichment process building. The building was about $900 \mathrm{ft}$ long, $400 \mathrm{ft}$ wide, and $58 \mathrm{ft}$ high. In 2013, predemolition work included inventory management; characterization of process equipment; vent, purge, drain, and inspection of process equipment; and the removal of high-hazard sodium fluoride traps. Sodium fluoride traps used sodium fluoride pellets to trap uranium as part of the final uranium removal process. These particular traps still contained uranium materials from when the facility was shut down.

\subsubsection{Building K-33 Remediation Completed}

Building K-33 was a multistory building that was built in 1954 as a uranium enrichment process building. The building covered 13 ha (32 acres) and contained more than 1.4 million $\mathrm{yd}^{3}$ of concrete and steel. The building had been largely decontaminated under an earlier project. Remediation of the building's 13-ha footprint was completed with the removal of the tie lines that connected K-33 with K-31, removal and disposal of the concrete slab and associated soil, and backfilling and seeding of the area.

\subsubsection{Fire Water Tank Demolished}

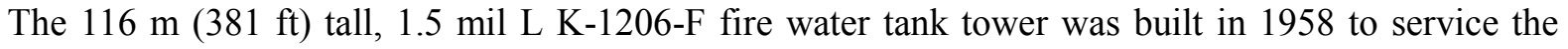
site's fire protection system. In 2013, it was drained, disconnected, and permanently taken out of service. Although it was not originally scheduled to be demolished in 2013, the deteriorating condition of the tank 
led UCOR and DOE to accelerate the schedule for demolition. In August 2013, a controlled explosive demolition was performed, and the resultant debris was shipped for disposal.

\subsubsection{Commemoration of the K-25 Site}

DOE and historic preservation agencies agreed upon commemorative measures that will preserve the Oak Ridge K-25 Site's historic contributions to the World War II Manhattan Project. Planning for the commemorative measures continues. In 2013, a prequalification process for the Professional Site Design Team (PSDT) and museum professional design subcontract was conducted. Nine small business architectural and engineering and museum planning partnering teams competed. The K-25 slab was retained pending results of the slab feasibility study. Bricks from the powerhouse were retained for possible use in the PSDT's wayside exhibits design. The PSDT and museum professional request for proposal for the commemorative facilities was published, and the associated pre-bid meeting and site orientation were conducted.

\subsubsection{Central Neutralization Facility Shutdown Completed}

Shutdown and decommissioning of CNF was completed. CNF ceased accepting waste in December 2012 to begin the decommissioning process. In FY 2013, activities at CNF included sludge removal and disposal; chemical removal and disposal; material, media, and equipment removal and disposal; oil removal and disposal; equipment rinsing and pressure washing; and characterization and filling of tanks, basins, containment dikes, and subsurface facilities. The decommissioning process was completed in FY 2013.

\subsubsection{Soil, Burial Ground, and Exposure Unit Remediation Activities}

The soil at ETTP is to be remediated to a level that protects a future industrial workforce and the underlying groundwater. RODs detailing the selected cleanup methods are in place and address soil, slabs, subsurface structures, and burial grounds for both zones.

Remediation of the soils in Zone 1 was completed in 2011. In 2012, a final RI/FS was prepared to support development of a final Zone 1 ROD. The first draft RI/FS was transmitted to the regulators in March 2012; regulator comments were received in August 2012.

General land use covenants for Zone 2 remained in place during FY 2013 and protected human health and the environment from residual contamination. Short-term restrictions were maintained for government-controlled industrial land use. Signs were maintained to control access, and surveillance patrols conducted as part of routine S\&M inspections were effective in monitoring access by unauthorized personnel. Required mowing was maintained as part of the ETTP S\&M program. Additionally, signs and access controls at the K-1070-C/-D burial ground were inspected annually as part of the ETTP S\&M program.

\subsubsection{Reindustrialization}

The DOE Oak Ridge Reindustrialization Program continued the transformation of ETTP into a private-sector business/industrial park in FY 2013 (Fig. 3.62).

Babcock Services purchased 1 ha $(2.5$ acres) of Parcel ED-10 from CROET and completed construction of a $1,060 \mathrm{~m}^{2}\left(11,400 \mathrm{ft}^{2}\right)$ facility. The facility is used to manage, recover, and refurbish radioactively contaminated components from commercial nuclear power plants and is projected to create more than 100 jobs.

In spring 2013, a $59 \mathrm{~kW}$ photovoltaic solar farm at ETTP was completed. The system consists of seven ground-mounted geo-trackers that rotate to follow the sun. Each tracker holds 30 solar panels and is expected to generate enough electricity to power 15 homes. This project, led by Vis Solis, LLC, required collaboration with TVA, the German Energy Agency, DEGERenergie (Germany's leading solar manufacturer), and CROET. 
The new \$35 million Carbon Fiber Technology Facility (CFTF) at Oak Ridge's Horizon Center began production in FY 2013. This advanced materials facility will allow researchers to develop and demonstrate the commercial viability of low-cost carbon fiber products for several industry sectors. Although carbon fiber has long been considered a desirable lightweight substitute for steel and other materials, its use has been limited due to high production costs. The development of low-cost production methods is expected to create new possibilities for carbon fiber use in a wide array of applications such as building structures, industrial products, and wind turbines.

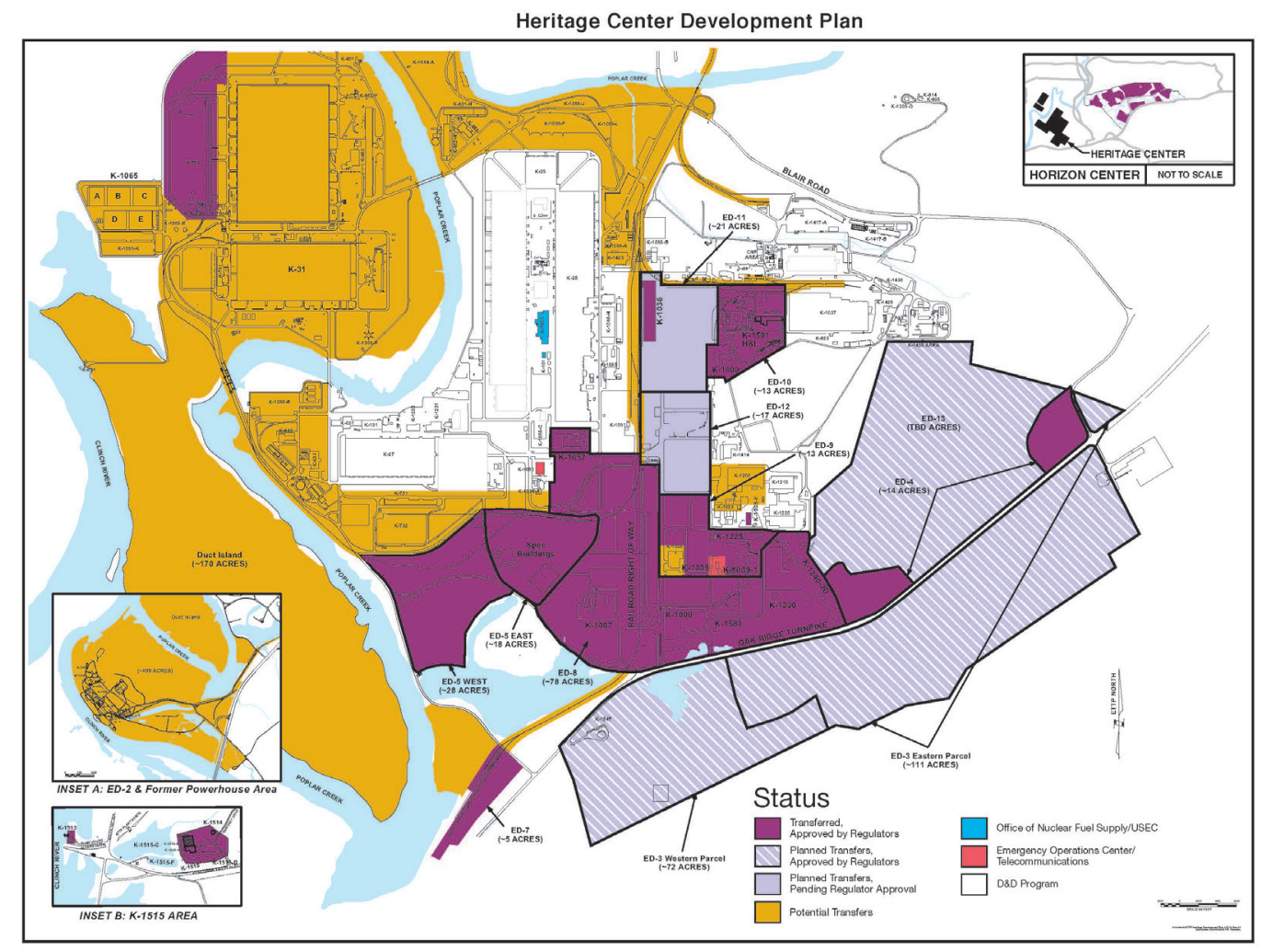

Fig. 3.62. East Tennessee Technology Park reindustrialization status, 2013.

\subsubsection{Biosolids Program}

Under the Biosolids Program, treated municipal sludge (biosolids) from the City of Oak Ridge (the city) publicly owned treatment works (POTW) is applied to six approved sites on ORR as a soil conditioner and fertilizer. UCOR provides oversight for the program (BJC 2006), which operates under a land license agreement between DOE and the city. The city has applied biosolids on ORR since 1983.

\subsubsection{Biosolids Fields on the Oak Ridge Reservation}

The biosolids land application sites are located on ORR in Oak Ridge, Tennessee (Fig. 3.63). Four of the active sites are in the vicinity of Bethel Valley Road, while the remaining active sites, Watson Road 1 and 2, are located on Highway 95 near the Horizon Center. Table 3.41 lists the six application sites and the tons of biosolids applied to each site in CY 2013. 


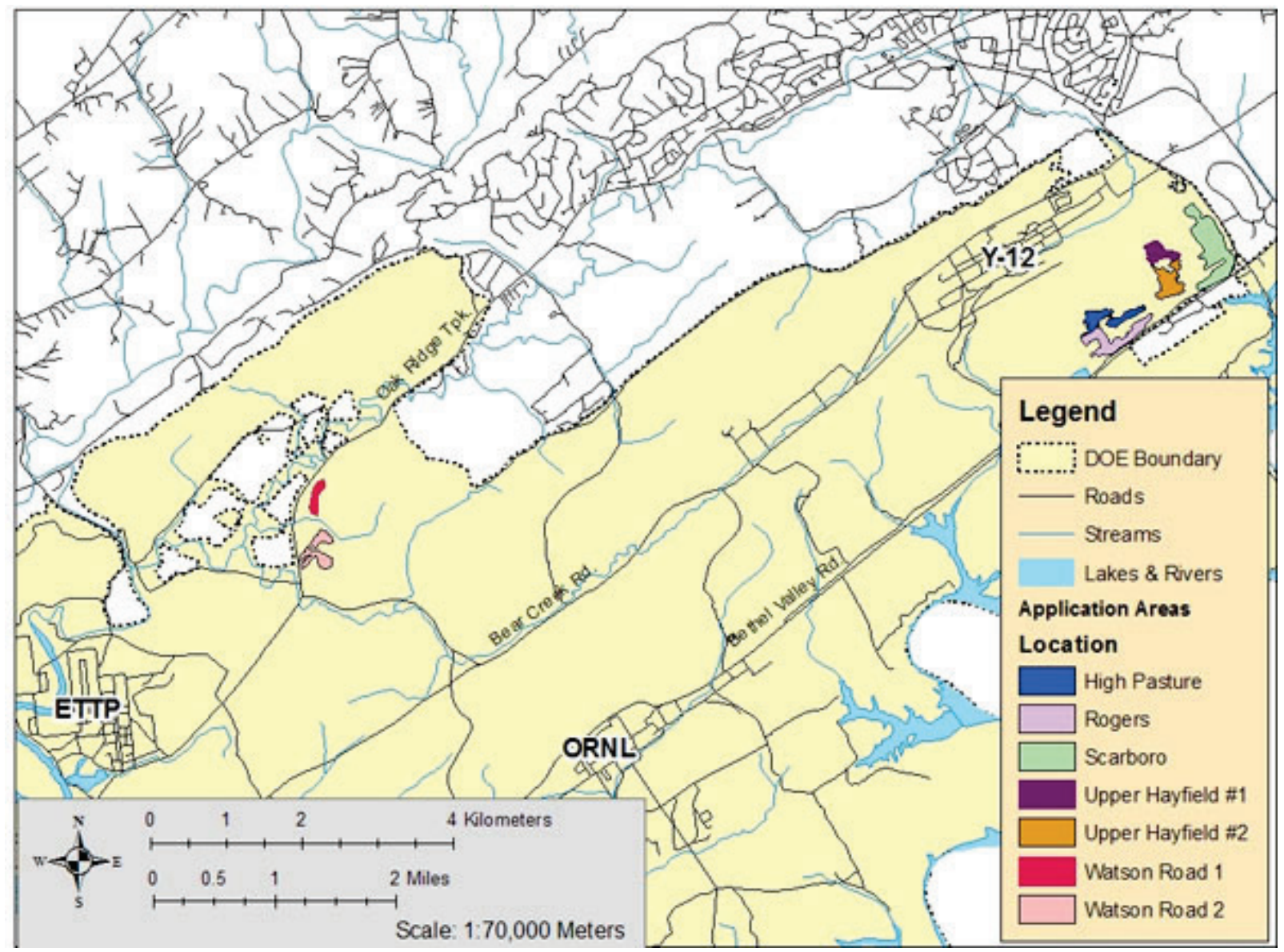

Fig. 3.63. Biosolids application areas on the Oak Ridge Reservation.

Table 3.41. Biosolids applied on the Oak Ridge Reservation in CY 2013 by the City of Oak Ridge (Tons)

\begin{tabular}{cccccc}
\hline \multicolumn{2}{c}{ Bethel Valley } & \multicolumn{2}{c}{ Watson Road } \\
\hline Upper Hayfield & High Pasture & Rogers & Scarboro & Watson Road 1 & Watson Road 2 \\
\hline 41.3 & 50.9 & 19.5 & 6.7 & 0 & 0 \\
\hline
\end{tabular}

\subsubsection{Current Program}

The city POTW near Turtle Park in Oak Ridge, Tennessee, processes about 30 million gal/day of wastewater. The plant receives wastewater from a variety of industrial, commercial, and residential generators in the Anderson County-Roane County area. DOE contributes about $20 \%$ of the influent to the POTW directly from the Y-12 Complex. Currently the Rarity Ridge Sludge is not part of the Biosolids Program; it is disposed to the municipal landfill. All industrial generators are required by Oak Ridge city ordinance 5-09 to obtain an industrial discharge permit from the city, which prescribes discharge limits and monitoring/reporting requirements.

\subsubsection{Current Status}

Under rulemaking effective June 30, 2013, TDEC enacted legislation governing the land application of Class B biosolids in the state of Tennessee under Chapter 0400-40-15 entitled "Biosolids Management." Before this legislation, land application programs in Tennessee operated as selfimplementing, without EPA permit, under the EPA 40 CFR 503 regulations. The city, which currently 
produces Class B biosolids, has completed the required notice of intent and will be grandfathered into the general permit, which is projected for issuance in April 2014 with an effective date of 30 days after issuance. The TDEC regulations include all 40 CFR 503 requirements with the addition of specific agronomic limits and setbacks more protective of surface water and groundwater.

As part of the surveillance program, UCOR successfully completed sampling for the High Pasture site in 2013. Cumulative metal loading is monitored for each site for compliance with limits set in 40 CFR 503. Tables 3.42 through 3.51 present these data for each site and the percentage of the regulatory limit that has been attained for each application area.

The site sampling effort has been eliminated by DOE EM in favor of preapplication monitoring through analysis of the biosolids. UCOR has provided radiological analyses for the biosolids since 2010 . The radiological analyses will continue as a feature of the new preapplication monitoring metric.

Table 3.42. High Pasture Field 1

\begin{tabular}{ccccc}
\hline Heavy metal & $\begin{array}{c}\mathbf{2 0 1 3} \\
\mathbf{( k g / h a )}\end{array}$ & $\begin{array}{c}\text { Cumulative loading } \\
\text { as of 12/13/2013 } \\
\mathbf{( k g / h a )}\end{array}$ & $\begin{array}{c}\text { 40 CFR 503 cumulative } \\
\text { loading limits } \\
\text { (kg/ha) }\end{array}$ & $\begin{array}{c}\text { Percentage of 503 } \\
\text { limits attained }\end{array}$ \\
\hline $\mathrm{As}$ & 0.00 & 0.54 & 41 & 1.3 \\
$\mathrm{Cd}$ & 0.00 & 0.94 & 39 & 2.4 \\
$\mathrm{Cr}$ & 0.00 & 13.22 & $\mathrm{~N} / \mathrm{A}$ & $\mathrm{N} / \mathrm{A}$ \\
$\mathrm{Cu}$ & 0.00 & 91.10 & 1,500 & 6.1 \\
$\mathrm{~Pb}$ & 0.00 & 7.78 & 300 & 2.6 \\
$\mathrm{Hg}$ & 0.00 & 1.16 & 17 & 6.8 \\
$\mathrm{Mo}$ & 0.00 & 1.68 & $\mathrm{~N} / \mathrm{A}$ & $\mathrm{N} / \mathrm{A}$ \\
$\mathrm{Ni}$ & 0.00 & 11.95 & 420 & 2.8 \\
$\mathrm{Se}$ & 0.00 & 2.92 & 100 & 2.9 \\
$\mathrm{Zn}$ & 0.00 & 201.44 & 2,800 & 7.2 \\
\hline
\end{tabular}

Table 3.43. High Pasture Field 2

\begin{tabular}{ccccc}
\hline Heavy metal & $\begin{array}{c}\mathbf{2 0 1 3} \\
\mathbf{( k g / h a )}\end{array}$ & $\begin{array}{c}\text { Cumulative loading } \\
\text { as of 12/13/2013 } \\
\text { (kg/ha) }\end{array}$ & $\begin{array}{c}\text { 40 CFR 503 cumulative } \\
\text { loading limits } \\
\text { (kg/ha) }\end{array}$ & $\begin{array}{c}\text { Percentage of 503 } \\
\text { limits attained }\end{array}$ \\
\hline $\mathrm{As}$ & 0.00 & 0.49 & 41 & 1.2 \\
$\mathrm{Cd}$ & 0.00 & 0.91 & 39 & 2.3 \\
$\mathrm{Cr}$ & 0.00 & 13.12 & $\mathrm{~N} / \mathrm{A}$ & $\mathrm{N} / \mathrm{A}$ \\
$\mathrm{Cu}$ & 0.00 & 90.00 & 1,500 & 6.0 \\
$\mathrm{~Pb}$ & 0.00 & 7.67 & 300 & 2.6 \\
$\mathrm{Hg}$ & 0.00 & 1.15 & 17 & 6.8 \\
$\mathrm{Mo}$ & 0.00 & 1.64 & $\mathrm{~N} / \mathrm{A}$ & $\mathrm{N} / \mathrm{A}$ \\
$\mathrm{Ni}$ & 0.00 & 11.82 & 420 & 2.8 \\
$\mathrm{Se}$ & 0.00 & 2.85 & 100 & 2.9 \\
$\mathrm{Zn}$ & 0.00 & 198.15 & 2,800 & 7.1 \\
\hline
\end{tabular}


Table 3.44. Upper Hay Field 1

\begin{tabular}{ccccc}
\hline Heavy metal & $\begin{array}{c}\mathbf{2 0 1 3} \\
\mathbf{( k g} / \mathbf{h a})\end{array}$ & $\begin{array}{c}\text { Cumulative loading } \\
\text { as of 12/13/2013 } \\
\mathbf{( k g / h a )}\end{array}$ & $\begin{array}{c}\text { 40 CFR 503 cumulative } \\
\text { loading limits } \\
\text { (kg/ha) }\end{array}$ & $\begin{array}{c}\text { Percentage of 503 } \\
\text { limits attained }\end{array}$ \\
\hline $\mathrm{As}$ & 0.00 & 0.26 & 41 & 0.6 \\
$\mathrm{Cd}$ & 0.00 & 0.44 & 39 & 1.1 \\
$\mathrm{Cr}$ & 0.09 & 7.89 & $\mathrm{~N} / \mathrm{A}$ & $\mathrm{N} / \mathrm{A}$ \\
$\mathrm{Cu}$ & 1.93 & 37.96 & 1,500 & 2.5 \\
$\mathrm{~Pb}$ & 0.08 & 5.05 & 300 & 1.7 \\
$\mathrm{Hg}$ & 0.01 & 0.78 & 17 & 4.6 \\
$\mathrm{Mo}$ & 0.02 & 1.22 & $\mathrm{~N} / \mathrm{A}$ & $\mathrm{N} / \mathrm{A}$ \\
$\mathrm{Ni}$ & 0.06 & 3.61 & 420 & 0.9 \\
$\mathrm{Se}$ & 0.04 & 0.53 & 100 & 0.5 \\
$\mathrm{Zn}$ & 2.75 & 108.11 & 2,800 & 3.9 \\
\hline
\end{tabular}

Table 3.45. Upper Hay Field 2

\begin{tabular}{ccccc}
\hline Heavy metal & $\begin{array}{c}\mathbf{2 0 1 3} \\
\mathbf{( k g / h a )}\end{array}$ & $\begin{array}{c}\text { Cumulative loading as } \\
\text { of } \mathbf{1 2 / 1 3 / 2 0 1 3} \\
\mathbf{( k g} / \mathbf{h a})\end{array}$ & $\begin{array}{c}\text { 40 CFR 503 cumulative } \\
\text { loading limits } \\
\text { (kg/ha) }\end{array}$ & $\begin{array}{c}\text { Percentage of 503 } \\
\text { limits attained }\end{array}$ \\
\hline $\mathrm{As}$ & 0.01 & 0.30 & 41 & 0.7 \\
$\mathrm{Cd}$ & 0.00 & 0.51 & 39 & 1.3 \\
$\mathrm{Cr}$ & 0.05 & 8.60 & $\mathrm{~N} / \mathrm{A}$ & $\mathrm{N} / \mathrm{A}$ \\
$\mathrm{Cu}$ & 1.03 & 39.9 & 1,500 & 2.7 \\
$\mathrm{~Pb}$ & 0.04 & 5.22 & 300 & 1.7 \\
$\mathrm{Hg}$ & 0.00 & 0.88 & 17 & 5.2 \\
$\mathrm{Mo}$ & 0.01 & 0.73 & $\mathrm{~N} / \mathrm{A}$ & $\mathrm{N} / \mathrm{A}$ \\
$\mathrm{Ni}$ & 0.03 & 3.27 & 420 & 0.8 \\
$\mathrm{Se}$ & 0.02 & 2.06 & 100 & 2.1 \\
$\mathrm{Zn}$ & 1.45 & 119.72 & 2,800 & 4.3 \\
\hline
\end{tabular}

Table 3.46. Scarboro Field 1

\begin{tabular}{ccccc}
\hline Heavy metal & $\begin{array}{c}\mathbf{2 0 1 3} \\
\mathbf{( k g / h a )}\end{array}$ & $\begin{array}{c}\text { Cumulative loading as } \\
\text { of 12/13/2013 } \\
\mathbf{( k g} / \mathbf{h a})\end{array}$ & $\begin{array}{c}\text { 40 CFR 503 cumulative } \\
\text { loading limits } \\
\text { (kg/ha) }\end{array}$ & $\begin{array}{c}\text { Percentage of 503 } \\
\text { limits attained }\end{array}$ \\
\hline $\mathrm{As}$ & 0.01 & 0.33 & 41 & 0.8 \\
$\mathrm{Cd}$ & 0.00 & 0.54 & 39 & 1.4 \\
$\mathrm{Cr}$ & 0.02 & 8.48 & $\mathrm{~N} / \mathrm{A}$ & $\mathrm{N} / \mathrm{A}$ \\
$\mathrm{Cu}$ & 0.32 & 43.94 & 1,500 & 2.9 \\
$\mathrm{~Pb}$ & 0.01 & 5.02 & 300 & 1.7 \\
$\mathrm{Hg}$ & 0.00 & 0.95 & 17 & 5.6 \\
$\mathrm{Mo}$ & 0.01 & 1.07 & $\mathrm{~N} / \mathrm{A}$ & $\mathrm{N} / \mathrm{A}$ \\
$\mathrm{Ni}$ & 0.01 & 4.64 & 420 & 1.1 \\
$\mathrm{Se}$ & 0.01 & 1.96 & 100 & 2.0 \\
$\mathrm{Zn}$ & 0.46 & 127.06 & 2,800 & 4.5 \\
\hline
\end{tabular}


Table 3.47. Scarboro Field 2

\begin{tabular}{ccccc}
\hline Heavy metal & $\begin{array}{c}\mathbf{2 0 1 3} \\
\mathbf{( k g / h a )}\end{array}$ & $\begin{array}{c}\text { Cumulative loading as } \\
\text { of 12/13/2013 } \\
\text { (kg/ha) }\end{array}$ & $\begin{array}{c}\text { 40 CFR 503 cumulative } \\
\text { loading limits } \\
\text { (kg/ha) }\end{array}$ & $\begin{array}{c}\text { Percentage of 503 } \\
\text { limits attained }\end{array}$ \\
\hline $\mathrm{As}$ & 0.00 & 0.32 & 41 & 0.8 \\
$\mathrm{Cd}$ & 0.00 & 0.54 & 39 & 1.4 \\
$\mathrm{Cr}$ & 0.01 & 8.47 & $\mathrm{~N} / \mathrm{A}$ & $\mathrm{N} / \mathrm{A}$ \\
$\mathrm{Cu}$ & 0.08 & 43.70 & 1,500 & 2.9 \\
$\mathrm{~Pb}$ & 0.00 & 5.01 & 300 & 1.7 \\
$\mathrm{Hg}$ & 0.00 & 0.95 & 17 & 5.6 \\
$\mathrm{Mo}$ & 0.00 & 1.06 & $\mathrm{~N} / \mathrm{A}$ & $\mathrm{N} / \mathrm{A}$ \\
$\mathrm{Ni}$ & 0.01 & 4.64 & 420 & 1.1 \\
$\mathrm{Se}$ & 0.00 & 1.95 & 100 & 2.0 \\
$\mathrm{Zn}$ & 0.11 & 126.71 & 2,800 & 4.5 \\
\hline
\end{tabular}

Table 3.48. Rogers Field 1

\begin{tabular}{ccccc}
\hline Heavy metal & $\begin{array}{c}\mathbf{2 0 1 3} \\
\mathbf{( k g / h a )}\end{array}$ & $\begin{array}{c}\text { Cumulative loading as } \\
\text { of 12/13/2013 } \\
\mathbf{( k g / h a )}\end{array}$ & $\begin{array}{c}\text { 40 CFR 503 cumulative } \\
\text { loading limits } \\
\text { (kg/ha) }\end{array}$ & $\begin{array}{c}\text { Percentage of 503 } \\
\text { limits attained }\end{array}$ \\
\hline $\mathrm{As}$ & 0.00 & 0.45 & 41 & 1.1 \\
$\mathrm{Cd}$ & 0.00 & 1.01 & 39 & 2.6 \\
$\mathrm{Cr}$ & 0.00 & 22.51 & $\mathrm{~N} / \mathrm{A}$ & $\mathrm{N} / \mathrm{A}$ \\
$\mathrm{Cu}$ & 0.00 & 100.59 & 1,500 & 6.7 \\
$\mathrm{~Pb}$ & 0.00 & 13.85 & 300 & 4.6 \\
$\mathrm{Hg}$ & 0.00 & 1.97 & 17 & 11.6 \\
$\mathrm{Mo}$ & 0.00 & 4.28 & $\mathrm{~N} / \mathrm{A}$ & $\mathrm{N} / \mathrm{A}$ \\
$\mathrm{Ni}$ & 0.00 & 10.23 & 420 & 2.4 \\
$\mathrm{Se}$ & 0.00 & 1.31 & 100 & 1.3 \\
$\mathrm{Zn}$ & 0.00 & 249.62 & 2,800 & 8.9 \\
\hline
\end{tabular}

Table 3.49. Rogers Field 2

\begin{tabular}{ccccc}
\hline Heavy metal & $\begin{array}{c}\mathbf{2 0 1 3} \\
\mathbf{( k g} / \mathbf{h a})\end{array}$ & $\begin{array}{c}\text { Cumulative loading as } \\
\text { of } \mathbf{~ 2 / 1 3 / 2 0 1 3} \\
\mathbf{( k g} / \mathbf{h a})\end{array}$ & $\begin{array}{c}\text { 40 CFR 503 cumulative } \\
\text { loading limits } \\
\text { (kg/ha) }\end{array}$ & $\begin{array}{c}\text { Percentage of 503 } \\
\text { limits attained }\end{array}$ \\
\hline $\mathrm{As}$ & 0.00 & 0.47 & 41 & 1.2 \\
$\mathrm{Cd}$ & 0.00 & 1.01 & 39 & 2.6 \\
$\mathrm{Cr}$ & 0.00 & 22.55 & $\mathrm{~N} / \mathrm{A}$ & $\mathrm{N} / \mathrm{A}$ \\
$\mathrm{Cu}$ & 0.00 & 101.25 & 1,500 & 6.7 \\
$\mathrm{~Pb}$ & 0.00 & 13.91 & 300 & 4.6 \\
$\mathrm{Hg}$ & 0.00 & 1.97 & 17 & 11.6 \\
$\mathrm{Mo}$ & 0.00 & 4.29 & $\mathrm{~N} / \mathrm{A}$ & $\mathrm{N} / \mathrm{A}$ \\
$\mathrm{Ni}$ & 0.00 & 10.30 & 420 & 2.5 \\
$\mathrm{Se}$ & 0.00 & 1.35 & 100 & 1.3 \\
$\mathrm{Zn}$ & 0.00 & 251.41 & 2,800 & 9.0 \\
\hline
\end{tabular}


Table 3.50. Watson Road Field 1

\begin{tabular}{ccccc}
\hline Heavy metal & $\begin{array}{c}\mathbf{2 0 1 3} \\
\mathbf{( k g / h a )}\end{array}$ & $\begin{array}{c}\text { Cumulative loading as } \\
\text { of } \mathbf{1 2} / \mathbf{1 3} / \mathbf{2 0 1 3} \\
\mathbf{( k g} / \mathbf{h a})\end{array}$ & $\begin{array}{c}\text { 40 CFR 503 cumulative } \\
\text { loading limits } \\
\text { (kg/ha) }\end{array}$ & $\begin{array}{c}\text { Percentage of 503 } \\
\text { limits attained }\end{array}$ \\
\hline $\mathrm{As}$ & 0.00 & 0.61 & 41 & 1.5 \\
$\mathrm{Cd}$ & 0.00 & 0.82 & 39 & 2.1 \\
$\mathrm{Cr}$ & 0.00 & 13.22 & $\mathrm{~N} / \mathrm{A}$ & $\mathrm{N} / \mathrm{A}$ \\
$\mathrm{Cu}$ & 0.00 & 92.94 & 1,500 & 6.2 \\
$\mathrm{~Pb}$ & 0.00 & 8.97 & 300 & 3.0 \\
$\mathrm{Hg}$ & 0.00 & 1.27 & 17 & 7.4 \\
$\mathrm{Mo}$ & 0.00 & 1.88 & $\mathrm{~N} / \mathrm{A}$ & $\mathrm{N} / \mathrm{A}$ \\
$\mathrm{Ni}$ & 0.00 & 10.93 & 420 & 2.6 \\
$\mathrm{Se}$ & 0.00 & 2.83 & 100 & 2.8 \\
$\mathrm{Zn}$ & 0.00 & 213.10 & 2,800 & 7.6 \\
\hline
\end{tabular}

Table 3.51. Watson Road Field 2

\begin{tabular}{ccccc}
\hline Heavy metal & $\begin{array}{c}\mathbf{2 0 1 3} \\
\text { (kg/ha) }\end{array}$ & $\begin{array}{c}\text { Cumulative loading as } \\
\text { of 12/13/2013 } \\
\text { (kg/ha) }\end{array}$ & $\begin{array}{c}\text { 40 CFR 503 cumulative } \\
\text { loading limits } \\
\text { (kg/ha) }\end{array}$ & $\begin{array}{c}\text { Percentage of 503 } \\
\text { limits attained }\end{array}$ \\
\hline $\mathrm{As}$ & 0.00 & 0.61 & 41 & 1.5 \\
$\mathrm{Cd}$ & 0.00 & 0.82 & 39 & 2.1 \\
$\mathrm{Cr}$ & 0.00 & 13.22 & $\mathrm{~N} / \mathrm{A}$ & $\mathrm{N} / \mathrm{A}$ \\
$\mathrm{Cu}$ & 0.00 & 92.94 & 1,500 & 6.2 \\
$\mathrm{~Pb}$ & 0.00 & 8.97 & 300 & 3.0 \\
$\mathrm{Hg}$ & 0.00 & 1.27 & 17 & 7.4 \\
$\mathrm{Mo}$ & 0.00 & 1.88 & $\mathrm{~N} / \mathrm{A}$ & $\mathrm{N} / \mathrm{A}$ \\
$\mathrm{Ni}$ & 0.00 & 10.93 & 420 & 2.6 \\
$\mathrm{Se}$ & 0.00 & 2.83 & 100 & 2.8 \\
$\mathrm{Zn}$ & 0.00 & 213.10 & 2,800 & 7.6 \\
\hline
\end{tabular}

\subsection{References}

BJC. 2006. Application of Sanitary Biosolids on the Oak Ridge Reservation Program Oversight Plan, Rev. 12. BJC/OR-1217. Bechtel Jacobs, Inc., LLC, Oak Ridge, Tennessee.

CEQ. 2007. Instructions for Implementing Executive Order 13423, "Strengthening Federal Environmental, Energy, and Transportation Management." Council on Environmental Quality, Washington, DC.

DOE. 1990. Radiation Protection of the Public and the Environment, Chapter III, "Derived Concentration Guides for Air and Water." DOE O 5400.5. Approved 2-8-90; Change 2, 1-7-93. US Department of Energy, Washington, DC.

DOE. 1994. Federal Facility Agreement for the Oak Ridge Reservation, http://www.bechteljacobs.com/ pdf/ffa/ffa.pdf. 
DOE. 1995. Remedial Action Report for the K-1407-B Holding Pond and the K-1407-C Retention Basin, Oak Ridge, Tennessee. DOE/OR/01-1371\&D1. US Department of Energy, Office of Environmental Management, Oak Ridge, Tennessee.

DOE. 1996. Environmental Assessment Proposed Changes to the Sanitary Sludge Land Application Program on the Oak Ridge Reservation. DOE/EA-1042. US Department of Energy, Oak Ridge Office, Oak Ridge, Tennessee.

DOE. 2003. Environmental Assessment Proposed Changes to the Sanitary Biosolids Land Application Program on the Oak Ridge Reservation Oak Ridge, Tennessee. DOE/EA-1356. US Department of Energy, Oak Ridge Office, Oak Ridge, Tennessee.

DOE. 2005. Rad-NESHAP Compliance Plan on the Oak Ridge Reservation. DOE/ORO/2196. US Department of Energy, Oak Ridge Office, Oak Ridge, Tennessee.

DOE. 2007. Action Memorandum for the Ponds at the East Tennessee Technology Park, Oak Ridge, Tennessee: K-1007-P Holding Ponds, K-901-A Holding Pond, K-720 Slough, and K-770 Embayment.

DOE. 2008. Removal Action Report for the Reduction of Hexavalent Chromium Releases into Mitchell Branch at the East Tennessee Technology Park, Oak Ridge, Tennessee. DOE.OR/01-2384\&D1.

DOE. 2010. Action Memorandum for the Long-Term Reduction of Hexavalent Chromium Releases into Mitchell Branch at the East Tennessee Technology Park, Oak Ridge, Tennessee. DOE/OR/012448\&D1.

DOE. 2011. Departmental Sustainability. DOE O 436.1. Approved 5-2-11. US Department of Energy, Washington, DC.

DOE. 2011a. Radiation Protection of the Public and the Environment. DOE O 458.1. Approved 2-11-11. US Department of Energy, Washington, D.C.

DOE. 2012. Oak Ridge Reservation Polychlorinated Biphenyl Federal Facilities Compliance Agreement.

DOE. 2013. 2013 Strategic Sustainability Performance Plan, Report to the White House Council on Environmental Quality and Office of Management and Budget. US Department of Energy, Washington, DC.

EO 13423, Strengthening Federal Environmental, Energy, and Transportation Management, January 24, 2007, Fed. Reg. Vol. 72(17).

EO 13514, Federal Leadership in Environmental, Energy, and Economic Performance, October 5, 2009, Fed. Reg. Vol. 74(194).

EPA. 1992. NPDES Storm Water Sampling Guidance Document. US Environmental Protection Agency, EPA 833-B-92-001, Washington, DC.

EPA. 1994. Mercury in Solid or Semisolid Waste (Manual Cold-Vapor Technique). US Environmental Protection Agency, SW-846, Method 7471A, Rev. 1, Washington, DC; available online at http://www.veridianenv.com/docs/SW-846-Methodologies/Methods/7000_Series/7xxx.htm. 
EPA. 2002. Method 1631, Revision E: Mercury in Water by Oxidation, Purge and Trap, and Cold Vapor Atomic Fluorescence Spectrometry. US Environmental Protection Agency, EPA-821-R-02-019, Washington, DC.

EPA. 2002a. Short-Term Methods for Estimating the Chronic Toxicity of Effluents and Receiving Waters to Freshwater Organisms, Fourth Edition, EPA-821-R-02-013. US Environmental Protection Agency, Office of Water, Washington, DC.

EPA. 2005. Method 245.7, Mercury in Water by Cold Vapor Atomic Fluorescence Spectrometry, Rev. 2.0. US Environmental Protection Agency, EPA-821-r-05-001, Washington, DC.

ISO. 2004. Environmental management systems-Requirements with guidance for use. ISO 14001:2004. International Organization for Standardization; available online at http://www.iso.org.

Souza, Peter A., Glyn D. DuVall, and Melisa J. Hart. 2001. Cultural Resource Management Plan, DOE Oak Ridge Reservation, Anderson and Roane Counties, Tennessee. DOE/ORO/2085. US Department of Energy, Washington, DC.

TDEC. 2012. Rules of Tennessee Department of Environment and Conservation, Chapter 0400-4501, Public Water Systems. Tennessee Board of Water Quality, Oil and Gas, Division of Water Resources.

UCOR. 2012. Evaluation of URS |CH2M Oak Ridge LLC Activities and Ranking of Environmental Aspect/Impacts. EMS-2012-002, Rev. 1.

UCOR. 2012a. URS | CH2M Oak Ridge LLC Environmental Management System Implementation Description. EMS-2012-001, Rev. 0.

UCOR. 2012b. Worker Safety and Health Program. PPD-EH-5614. URS | CH2M Oak Ridge LLC, Oak Ridge, Tennessee.

UCOR. 2012c. Environmental Compliance and Protection Program. PPD-EC-1747. URS | CH2M Oak Ridge LLC, Oak Ridge, Tennessee.

UCOR. 2012d. Quality Assurance Program Plan for Compliance with Radionuclide National Emission Standards for Hazardous Air Pollutants. UCOR-4257. URS | CH2M Oak Ridge LLC, Oak Ridge, Tennessee.

UCOR. 2013. Cleanup Progress; Annual Report to the Oak Ridge Community. DOE/ORO-2467. URS | CH2M Oak Ridge LLC, Oak Ridge, Tennessee.

UCOR. 2013a. East Tennessee Technology Park Chromium Water Treatment System Sampling and Analysis Plan. UCOR-4259/R1. URS | CH2M Oak Ridge LLC, Oak Ridge, Tennessee.

UCOR. 2013b. East Tennessee Technology Park Storm Water Pollution Prevention Program Sampling and Analysis Plan. UCOR-4028/R1. URS | CH2M Oak Ridge LLC, Oak Ridge, Tennessee.

UCOR. 2013c. Pollution Prevention and Waste Minimization Program Plan for the East Tennessee Technology Park, Oak Ridge, Tennessee. UCOR-4127/R1. URS | CH2M Oak Ridge LLC, Oak Ridge, Tennessee. 



\section{The Y-12 National Security Complex}

The Y-12 Complex, a premier manufacturing facility operated by B\&W Y-12 for NNSA, plays a vital role in DOE's Nuclear Security Enterprise. While drawing on more than 60 years of manufacturing excellence, the Y-12 Complex helps ensure a safe and reliable US nuclear weapons deterrent.

The complex also retrieves and stores nuclear materials, fuels the nation's naval reactors, and performs complementary work for other government and private-sector entities.

Today's environment requires a Y-12 Complex that has a new level of flexibility and versatility. So while continuing its key role, the $\mathrm{Y}-12$ Complex has evolved to become the resource the nation looks to for support in protecting America's future by developing innovative solutions in manufacturing technologies, prototyping, safeguards and security, technical computing, and environmental stewardship.

Because of differing permit reporting requirements and instrument capabilities, various units of measurement are used in this report. The list of units of measure and conversion factors provided on pages xxvii and xxviii is intended to help readers convert numeric values presented here as needed for specific calculations and comparisons.

\subsection{Description of Site and Operations}

\subsubsection{Mission}

The Y-12 Complex is a one-of-a-kind manufacturing facility that plays an important role in US national security. The roles of the Y-12 Complex include the following:

- receipt, storage, and protection of SNMs;

- quality evaluation/enhanced surveillance of the nation's nuclear weapons stockpile;

- safe and secure storage of nuclear materials;

- dismantlement of weapon secondaries and disposition of weapon components;

- $\quad$ provision of technical support to the NNSA Defense Nuclear Nonproliferation Program;

- removal of vulnerable highly enriched uranium (HEU) worldwide;

- conversion and disposition of HEU for peaceful uses;

- establishment and management of the Nuclear Detection and Sensor Testing Center and the Nuclear Materials Information Program Library;

- provision of nuclear radiological field training and alarm response training;

- provision of fuel for the nation's naval reactors program;

- transfer of technology to private industry;

- maintenance of DOE capabilities; and

- provision of support to DOE, other federal agencies, and other national priorities.

The Y-12 Complex is one of four production facilities in the NNSA Nuclear Security Enterprise. The unique emphasis of the Y-12 Complex is processing and storage of uranium and development of technologies associated with those activities. Decades of precision machining experience make the Y-12 Complex a production facility with capabilities unequaled nationwide.

Located within the city limits of Oak Ridge, the Y-12 Complex covers more than 328 ha (810 acres) in the Bear Creek Valley, stretching $4.0 \mathrm{~km}$ (2.5 miles) in length down the valley and nearly $2.4 \mathrm{~km}$ (1.5 miles) in width across it. NNSA-related facilities located off the Y-12 Complex site but in Oak Ridge include the OST AOEC Secure Transportation Center and Training Facility and an analytical laboratory. 
The laboratory is a leased facility providing a wide range of routine and nonroutine analytical services for environmental and hazardous waste programs of NNSA, DOE, and other customers.

In 2013 the facility was operated by B\&W Y-12, a partnership of the Babcock \& Wilcox Company and Bechtel Corporation, under contract to DOE, of which NNSA is a separately organized agency.

\subsubsection{Transformation}

"Complex Transformation" is NNSA's vision for a smaller, safer, more secure, and less expensive nuclear weapons complex that leverages the scientific and technical capabilities of its workforce and meets national security requirements.

Government-owned facilities and operations are being challenged to become smaller, more efficient, and more responsive to changing national and global challenges. Nowhere in the National Security Enterprise is transformation more evident than at the Y-12 Complex.

Most Y-12 Complex mission-critical facilities are more than 60 years old (Fig. 4.1). To address this situation Y-12 has been consolidating operations, modernizing facilities and infrastructure, and reducing the legacy footprint for more than a decade. These actions are consistent with and supportive of NNSA enterprise transformation planning. Through modernization projects, deferred maintenance reduction, enhanced security measures, technology enhancements, infrastructure reduction, and innovative business practices, the Y-12 Complex is becoming a more responsive, sustainable enterprise as evidenced by the performance achievements presented in this year's ASER.

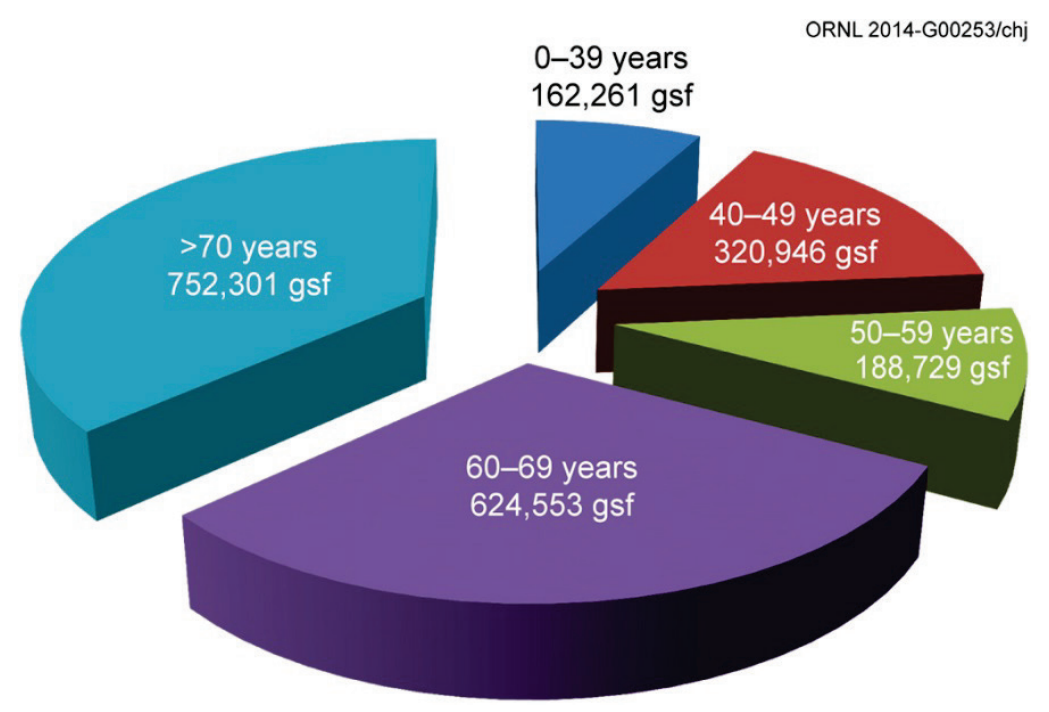

Fig. 4.1. Gross square footage by age of mission-critical facilities at the Y-12 Complex. (gsf = gross square feet.)

Since 2002, Y-12 has demolished more than 1.4 million $\mathrm{ft}^{2}$ of excess facilities. The NNSA Facilities Disposition Program for FY 2014 is under development and will identify and evaluate excess assets, prioritize their disposition, and propose the budget resources required for their disposition. Without a defined program to eliminate excess facilities, the NNSA sites will continue to use limited resources to safely maintain those facilities that no longer have a mission use. The American Recovery and Reinvestment Act (ARRA) funding secured at Y-12 implemented early actions to deactivate and demolish some of these facilities. Results and progress on these projects are detailed in Section 4.8.

UPF (Fig. 4.2) is an integral part of the Y-12 Complex transformation efforts and a key component of the NNSA Uranium Center of Excellence. UPF will be a modern manufacturing facility designed and constructed for health, safety, security, and operations efficiency. Built to today's codes and standards, the facility will leverage new technologies and provide life-cycle cost savings. Planning and design continued through 2013. 


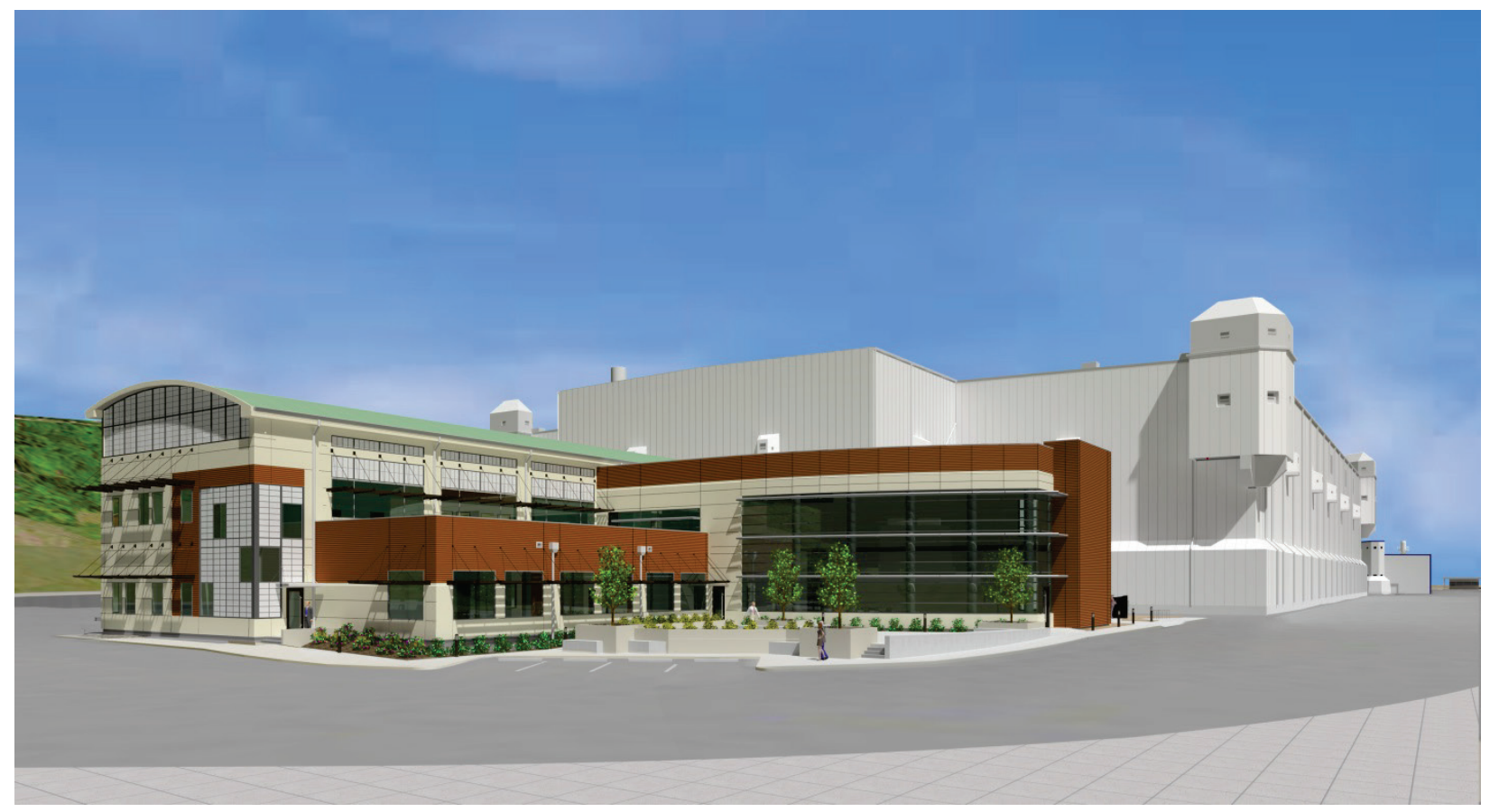

Fig. 4.2. Uranium Processing Facility conceptual image.

\subsection{Environmental Management System}

As part of B\&W Y-12's commitment to environmentally responsible operations, the Y-12 Complex has implemented an EMS based on the rigorous requirements of the globally recognized ISO 14001-2004 (ISO 2004).

DOE O 436.1, Departmental Sustainability, (DOE 2011) provides requirements and responsibilities for managing sustainability within DOE in accordance with EO 13423, its implementing instructions, and EO 13514. The order further requires implementation of an EMS that is either certified to the requirements of ISO 14001:2004 (ISO 2004) by an accredited ISO 14001 registrar or self-declared to be in conformance to the standard in accordance with instructions issued by the Federal Environmental Executive.

The EMS requirements taken from DOE O 436.1 have been incorporated in the Environmental Protection Functional Area of the Y-12 Complex Standards/Requirements Identification Document.

\subsubsection{Integration with Integrated Safety Management System}

ISMS is the DOE umbrella of ES\&H programs and systems that provides the necessary structure for any work activity that could potentially affect the public, a worker, or the environment. B\&W Y-12's ISMS has incorporated the elements of the ISO 14001 EMS in the overall umbrella of ISMS for environmental compliance, pollution prevention, waste minimization, and resource conservation.

\subsubsection{Policy}

The environmental policy of $\mathrm{B} \& \mathrm{~W} \mathrm{Y}-12$ and its commitment to providing sound environmental stewardship practices through the implementation of an EMS have been defined, are endorsed by top management, and have been made available to the public via company-sponsored forums and public documents such as this one. The B\&W Y-12 ES\&H policy is presented in Fig. 4.3.

This policy has been communicated to all employees; incorporated into General Employee Training (GET) for every employee, guest, and contractor; and made available for viewing on the internal Y-12 Complex website. Y-12 Complex personnel are made aware of the commitments stated in the policies and how the commitments relate to Y-12 Complex work activities. 


\section{Y-12 Environment, Safety, and Health Policy}

Policy: As we work to achieve the Y-12 mission and our vision of a modernized Y-12 Complex, we will do so by ensuring the safety and health of every worker, the public, and the environment. Every employee, contractor, and visitor is expected to take personal responsibility for their actions.

- Environmental Policy: We protect the environment, prevent pollution, comply with applicable requirements, and continually improve our environment.

- Safety and Health Policy: The safety and health of our workers and the protection of public health and safety are paramount in all that we do. We maintain a safe work place and plan and conduct our work to ensure hazard prevention and control methods are in place and effective.

In support of this policy, we are committed to:

- Integration of Environment, Safety and Health (ES\&H) into our business processes for w ork planning, budgeting, authorization, execution, and change control in accordance with our Integrated Safety Management System.

- Continuously improving our processes and systems by establishing, tracking, and achieving goals that drive performance excellence.

- Direct, open, and truthful communication of this policy and our ES\&H performance to our employees, contractors, customers, and stakeholders.

- Strive to minimize the impact of our operations on the environment in a safe, compliant, and cost-effective manner using sustainable practices for energy efficiency, fleet management, water consumption, pollution prevention, recycling/reuse, source reduction, resource conservation, and environmentally preferable purchasing.

- Incorporate sustainable design principles into the design and construction of facility upgrades, new facilities, and infrastructure considering life-cycle costs and savings.

- Incorporate the use of engineering controls to reduce or eliminate hazards whenever possible into the design and construction of facility upgrades, new facilities, and infrastructure.

- Strive to provide a clean and efficient workplace free of occupational injuries and illnesses (Target Zero).

- Foster and maintain a work environment of mutual respect and teamwork that encourages free and open expression of ES\&H concerns.

Fig. 4.3. B\&W Y-12 environment, safety, and health policy.

\subsubsection{Planning}

\subsubsection{Environmental Aspects}

Environmental aspects may be thought of as potential environmental hazards associated with a facility operation, maintenance job, or work activity. Aspects and impacts are evaluated to ensure that the significant aspects and potential impacts continue to reflect stakeholder concerns and changes in regulatory requirements. The EMS provides the system to ensure that environmental aspects are systematically identified, monitored, and controlled to mitigate or eliminate potential impacts to the environment.

The FY 2013 analysis identified the following as significant environmental aspects.

- Air Emissions

- GHG Emissions (Scopes 1 and 3)

- Wastewater/Groundwater

- Excess Facilities and Unneeded Materials and Chemicals

- Hazardous or Mixed Wastes

- Radiological Waste

- Universal Waste and Other Recycle Streams
- Surface Water and Storm Water

- Aging Infrastructure and Equipment

- Legacy Contamination and Disturbance

- Storage or Use of Chemicals and Radioactive Materials

- Energy Consumption (Scope 2 GHGs)

- Potable Water Usage

- Raw Materials and Other Natural Resource Procurement/Use 


\subsubsection{Legal and Other Requirements}

To implement the compliance commitments of the ES\&H policy and to meet legal requirements, systems are in place to review changes in federal, state, or local environmental regulations and to communicate those changes to affected staff. The environmental compliance status is documented each year in this report (see Section 4.3).

\subsubsection{Objectives, Targets, and Environmental Action Plans}

$\mathrm{B} \& \mathrm{~W}$ Y-12 continues to respond to change and pursue sustainability initiatives by establishing and maintaining environmental objectives, targets (goals), and action plans. Goals and commitments are established annually; are agreed to by the NNSA Production Office (NPO) and B\&W Y-12; and are consistent with the Y-12 Complex's mission, budget guidance, ES\&H work scope, site incentive plans, and continuous improvement. Targets and action plans are established for broad objectives to pursue improvement in environmental performance in five areas: clean air, energy efficiency, hazardous materials, stewardship of land and water resources, and waste reduction/recycling/buy green. Highlights of the $2013 \mathrm{~B} \& \mathrm{~W}$ Y-12 environmental targets achieved are presented in Section 4.2.6.1.

\subsubsection{Programs}

NNSA has developed and funded several important programs to integrate environmental stewardship into all facets of Y-12 Complex missions. The programs also address the DOE order requirements for protecting various environmental media, reducing pollution, conserving resources, and helping to promote compliance with all applicable environmental regulatory requirements and permits.

\section{Environmental Compliance}

The B\&W Y-12 Environmental Compliance Department (ECD) provides environmental technical support services and oversight for Y-12 Complex line organizations to ensure that site operations are conducted in a manner that is protective of workers, the public, and the environment; in compliance with applicable standards, DOE orders, environmental laws, and regulations; and consistent with B\&W Y-12's environmental policy and site procedures. ECD serves as the B\&W Y-12 interpretive authority for environmental compliance requirements and as the primary point of contact between B\&W Y-12 and external environmental compliance regulatory agencies such as the city of Oak Ridge, TDEC, and EPA. ECD administers compliance programs aligned with the major environmental legislation that affects Y-12 Complex activities. Compliance status and results of monitoring and measurements conducted for these compliance programs are presented in this document.

ECD also maintains and ensures implementation of the Y-12 Complex EMS and spearheads initiatives to proactively address environmental concerns to continually improve environmental performance and go "beyond compliance."

\section{Waste Management}

The B\&W Y-12 waste management programs support the full life cycle of all waste streams within the Y-12 Complex. While ensuring compliance with federal and state regulations, DOE orders, waste acceptance criteria, and Y-12 Complex procedures and policies, the waste management programs provide technical support to generators on waste management, pollution prevention, and recycling issues and waste certification in accordance with DOE orders and NNSS waste acceptance criteria for waste to be shipped to that site for disposition.

\section{Sustainability and Stewardship}

The Sustainability and Stewardship Program has two major missions. The first is to establish and maintain companywide programs and services to support sustainable waste management operations. These sustainable 
operations include pollution prevention and recycling programs, excess materials programs, Generator Services programs, facility destruction and recycling operations, and PrYde. The Y-12 PrYde program incorporates an inspection and rating system related to the cleanliness of facilities, materials, and hazardous/unsafe conditions to help personnel maintain work areas in a clean, safe, environmentally sound, and professional manner.

The second mission is stewardship practices, the programs that manage legacy issues and assist in preventing the development of new problematic issues. Stewardship programs include Clean Sweep and Unneeded Materials and Chemicals (UMC).

Combining these programs under a single umbrella improves overall compliance with EOs, DOE orders, state and federal regulations, and NNSA expectations and eliminates duplication of efforts while providing an overall improved appearance at the Y-12 Complex.

Additionally, the implementation of these programs directly supports EMS objectives and targets to disposition UMC, continually improve recycle programs by adding new recycle streams as applicable, improve sustainable acquisition (i.e., promote the purchase of products made with recycled content and biobased products, including alternative fuels such as E85), meet sustainable design requirements, and adhere to pollution prevention reporting requirements.

\section{Energy Management}

Energy management is an ongoing and comprehensive effort with key strategies to reduce consumption of energy, water, and fuel (electricity, coal, natural gas, and gasoline/diesel). As part of Facility Management and programs in Facilities, Infrastructure, and Services, energy management tracks federally mandated conservation initiatives at the Y-12 Complex and informs personnel about sustainability issues, particularly in relation to energy, water, and fuel conservation and efficiency.

Y-12 energy management and sustainability and stewardship programs support the DOE and NNSA visions for a commitment to energy efficiency and sustainability and achievement of the guiding principles. Specifically, the Y-12 vision is to support the DOE ES\&H policy and SSSP (DOE 2012b) while promoting overall sustainability and reduction of GHG emissions. The mission of the Y-12 Energy Management program is to incorporate energy-efficient technologies sitewide and to position Y-12 to meet NNSA energy requirement needs through 2025 and beyond. Sustainability goals, goal performance, and goal achievement are defined in the site sustainability plan (SSP) issued in December 2013 (B\&W Y-12 2013b).

\subsubsection{Implementation and Operation}

\subsubsection{Roles, Responsibility, and Authority}

The safe, secure, efficient, and environmentally responsible operation of the Y-12 Complex requires the commitment of all personnel. All personnel share the responsibility for successful day-to-day accomplishment of work and the environmentally responsible operation of the Y-12 Complex. Environmental and Waste Management technical support personnel assist the line organizations with identifying and carrying out their environmental responsibilities. Additionally, an Environmental Officer Program is in place to facilitate communication of environmental regulatory requirements and to promote EMS as a tool to drive continual environmental improvement at the Y-12 Complex. Environmental officers coordinate their organizations' efforts to maintain environmental regulatory compliance and promote other proactive improvement activities.

\subsubsection{Communication and Community Involvement}

The Y-12 Complex is committed to keeping the community informed on operations, environmental concerns, safety, and emergency preparedness. The Community Relations Council, composed of 20 members from a cross section of the community, including environmental advocates, neighborhood residents, Y-12 Complex retirees, and business and government leaders, serves to facilitate communication between $\mathrm{B} \& \mathrm{~W} \mathrm{Y}-12$ and the community. The council provides feedback to $\mathrm{B} \& \mathrm{~W} \mathrm{Y}-12$ 
regarding its operations and ways to enhance community and public communications. B\&W Y-12 sponsored the Coal Creek Watershed Foundation, Foothills Land Conservancy, and the University of Tennessee Arboretum in 2013. The following paragraphs describe some of the Y-12 Complex communication and community involvement activities.

As part of the Y-12 Complex America Recycles Day activities, four local charities received \$200 donations from funds raised by the Y-12 Complex employee ABC recycling efforts. Since the ABC recycling program began in 1994, more than $\$ 83,200$ has been donated to various local charities.

Y-12 hosted the TDEC Tennessee Green Star Partnership (TGSP) program East Tennessee Workshop (Fig. 4.4) on August 6, 2013, at the New Hope Center, which is a Leadership in Energy and Environmental Design- (LEED)-certified facility. The purpose of the workshop was to offer guidance on how to advance through the TGSP levels and to promote membership outreach and mentoring in sustainable practices while providing a forum for benchmarking and networking. The TGSP workshop included presentations on the new TGSP program; the Green Globes Program; economy, energy, and the environment; Y-12's sustainability and stewardship initiatives; and various other sustainability topics. The event was hosted at Y-12 as part of our overall goal to promote a more sustainable environment and share various pollution prevention initiatives with other organizations.

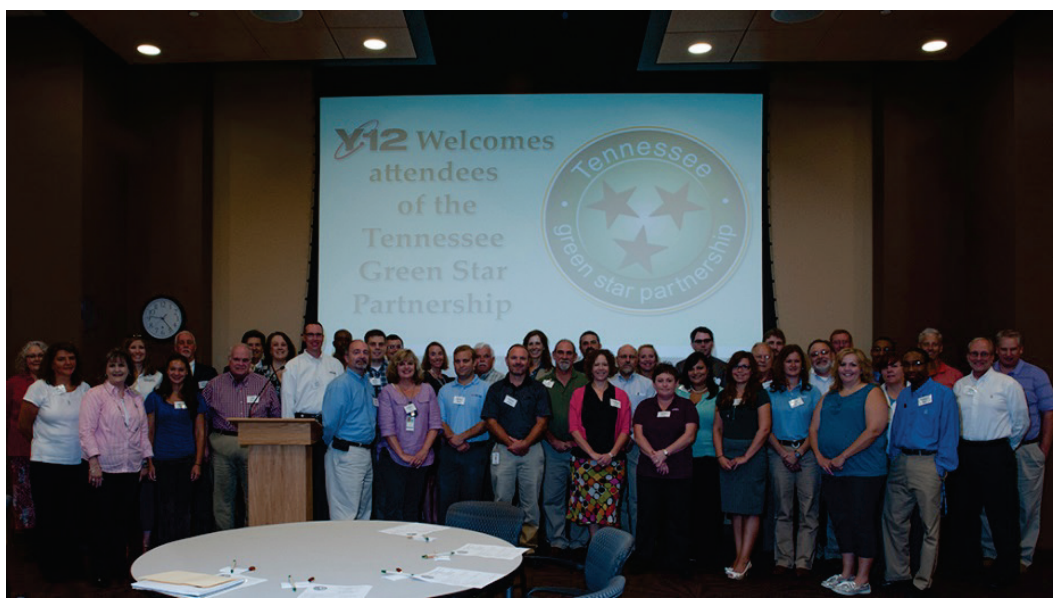

Fig. 4.4. Y-12 hosts the Tennessee Green Star Partnership East Tennessee Workshop. [Source: Scott Fraker, Y-12 photographer.]

On February 21, 2013, the Y-12 Complex hosted the second annual "Introduce a Girl to Engineering" event at the New Hope Visitor Center (Fig. 4.5). The event was dedicated to girls in grades 9 through 12 to encourage them to pursue careers in science, technology, engineering, and mathematics. About 400 girls from 14 area schools attended the event. The event included guest speakers and interactive exhibits, developed by 65 Y-12 women engineers and scientists, and hands-on activities ranging from zinc plating to $\mathrm{T}$-shirt chromatography.

\subsubsection{Emergency Preparedness and Response}

Local, state, and federal emergency response organizations are fully involved in the Y-12 Complex emergency drill and exercise program. The annual drill

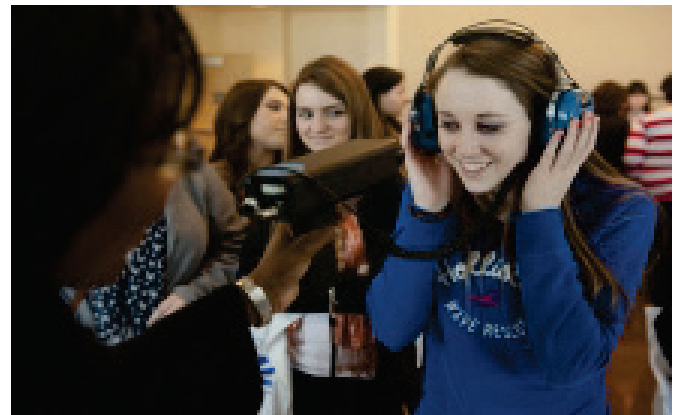

Fig. 4.5. Girls experience hands-on activities at various exhibits during the second "Introduce a Girl to Engineering" day at the Y-12 National Security Complex.

and exercise schedule is coordinated with all organizations to ensure maximum possible participation. At 
a minimum, the Tennessee Emergency Management Agency (TEMA) Duty Office and the DOE headquarters Watch Office participate in all Y-12 Complex emergency response exercises.

The Y-12 Complex conducted two full-participation exercises, one full-scale exercise, one no-notice functional exercise, two severe event tabletop drills, and one off-site field monitoring drill in FY 2013. The drills and exercises focused on topics such as responding to an active shooter event, responding to a nuclear criticality event, and responding to a radiological release event. Additionally, Y-12 was affected and participated in two DOE headquarters Continuity of Government elevations. Eight building evacuation and accountability drills were also conducted.

Y-12 Complex expertise in emergency management continues to be recognized within DOE. Members of the Emergency Management Program Office staff participated in the DOE Emergency Management Issues Special Interest Group Conference held in Chicago, Illinois, in May 2013. The Y-12 Complex staff made presentations, participated in steering committee meetings, and distributed Y-12 Complex Emergency Management Program information to other DOE facility emergency management professionals.

\subsubsection{Checking}

\subsubsection{Monitoring and Measurement}

The Y-12 Complex maintains procedures to monitor overall environmental performance and to monitor and measure key characteristics of its operations and activities that can have a significant environmental impact. Environmental effluent and surveillance monitoring programs are well-established, and the results of the 2013 program activities are reported elsewhere in this document. Progress achieving environmental goals is reported as a monthly metric on the senior management web portal, Performance Track, which consolidates and maintains Y-12 Complex site-level performance measures. Progress is reviewed in periodic meetings with senior management and NPO.

\subsubsection{Environmental Management System Assessments}

To periodically verify that EMS is operating as intended, assessments are conducted as part of the Y-12 Complex internal assessment program. The assessments are designed to ensure that nonconformities with the ISO 14001:2004 standard (ISO 2004) are identified and addressed.

The Environmental Assessment Program comprises several types of assessments, each type serving a distinct but complementary purpose. Assessments range from informal observations of specific activities to rigorous audits of site-level programs.

To self-declare conformance to the ISO 14001:2004 standard in accordance with instructions issued by the Federal Environmental Executive and adhere to DOE O 436.1 (DOE 2011) requirements, EMS must be audited by a qualified party outside of the control or scope of EMS at least every 3 years. To fulfill this requirement, a four-person audit team from the University of Tennessee Center for Industrial Services evaluated the Y-12 EMS April 23-26, 2012. The Y-12 EMS was found to fully conform, and no issues were identified. A final score of 525.5 out of 530.0 or $99.2 \%$ was awarded by the audit team. The next external verification audit is due in April 2015.

\subsubsection{Performance}

The EMS objectives and targets and other plans, initiatives, and successes that work together to accomplish DOE goals and reduce environmental impacts are discussed in this section. The Y-12 Complex used a number of DOE's reporting systems, including the following, to report performance.

- Pollution Prevention Tracking and Reporting System, which collects environmental, sustainable acquisition and product purchases, and best practices data.

- Federal Automotive Statistical Tool (FAST), which collects fleet inventory and fuel use. 
- Consolidated Energy Data Report, which collects additional data on metering requirements, water use, renewable energy generation and purchases, training, and sustainable buildings.

- Site Sustainability Plan Performance Reporting, which collects data on site-identified sustainability projects and supports Energy Independence and Security Act (EISA) Section 432 compliance.

The DOE Office of Health, Safety and Security annual environmental progress reports on implementation of EO 13423, Strengthening Federal Environmental, Energy, and Transportation Management (EO 2007), and the Office of Management and Budget's Environmental Stewardship Scorecard gave the Y-12 Complex an EMS scorecard rating for FY 2013 of green, indicating full implementation of EO 13423 requirements.

\subsubsection{Environmental Management System Objectives and Targets}

At the end of FY 2013 B\&W Y-12 had achieved 6 of 9 targets that had been established the year before. Overall, 38 actions were completed through September. Highlights included the following, with additional details and successes presented in other sections of this report.

- Clean Air-A revised uranium chip cleaning procedure was issued and implemented in the production environment. The procedure reduces solvent use and helps reduce Y-12 Complex fugitive GHG emissions.

- Energy Efficiency-An Energy Savings Performance Contract (ESPC) was awarded in September for projects for improvements to lighting, chilled water, and steam, with implementation scheduled to begin in January 2014. Energy audits were completed for 13 Y-12 buildings. The planned target to provide metering for primary data centers was deleted for this fiscal year because the bids received exceeded the available funding level.

- Hazardous Materials-Projects for legacy material/equipment removal in and around 9201-1 were developed and implemented. A disposition plan for the depleted uranium/zirconium drums was developed and implemented. Shipment was completed in August.

- Land/Water Conservation-A target to relocate flow augmentation in upper EFPC was canceled when the regulators expressed a desire to eliminate the requirement for continued flow addition.

- Reduce/Reuse/Recycle/Buy Green-A target to increase the percentage of recycled toner cartridges purchased was extended into 2014. Use of rechargeable batteries in pagers was evaluated as a means to reduce battery waste.

\subsubsection{Sustainability and Stewardship}

Numerous efforts at the Y-12 Complex have reduced its impact on the environment. Efforts include increased use of environmentally friendly products and processes and reductions in waste and emissions. During the past few years, these efforts have been recognized by our customers, our community, and other stakeholders (see Section 4.2.7). Pollution prevention efforts at the Y-12 Complex have not only benefited the environment but have also resulted in cost efficiencies (Fig. 4.6). 


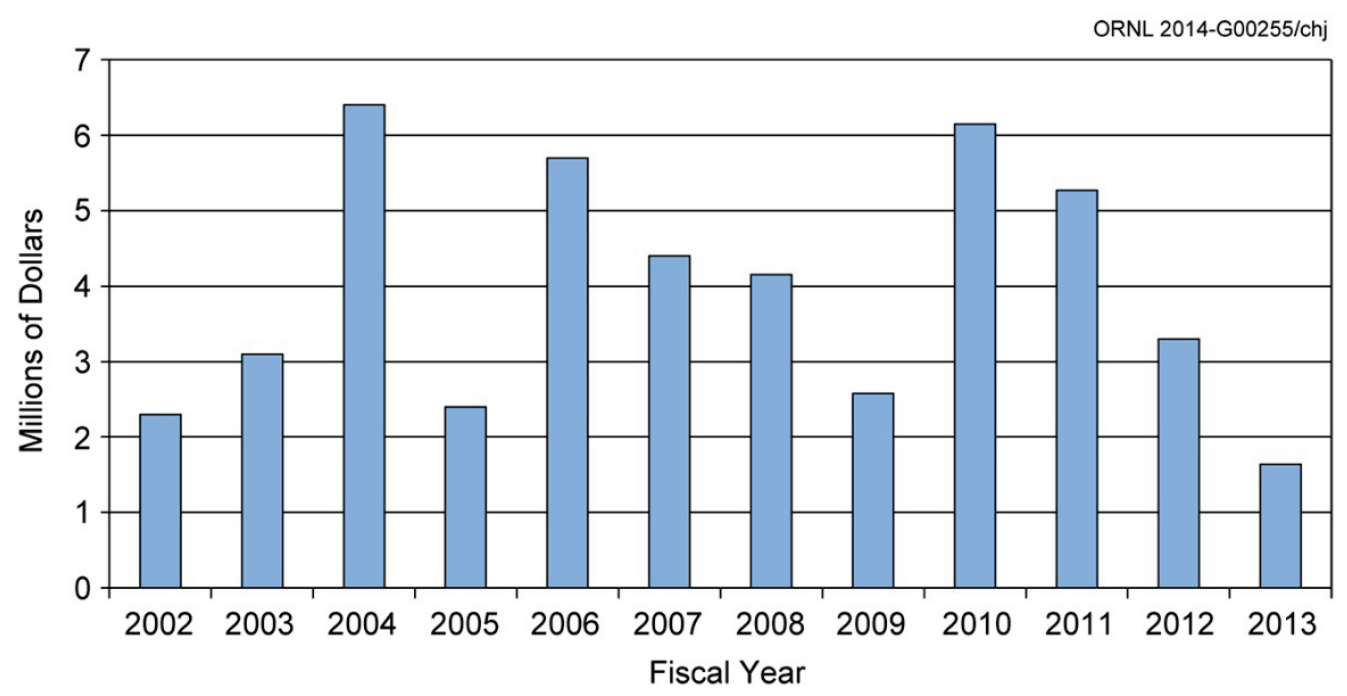

Fig. 4.6. Cost efficiencies from Y-12 Complex pollution prevention activities.

In FY 2013 the Y-12 Complex implemented 88 pollution prevention initiatives (Fig. 4.7), with a reduction of more than 5.5 million $\mathrm{kg}(12.1$ million $\mathrm{lb})$ of waste and cost efficiencies of more than $\$ 1.6$ million. The completed projects include the activities described below.

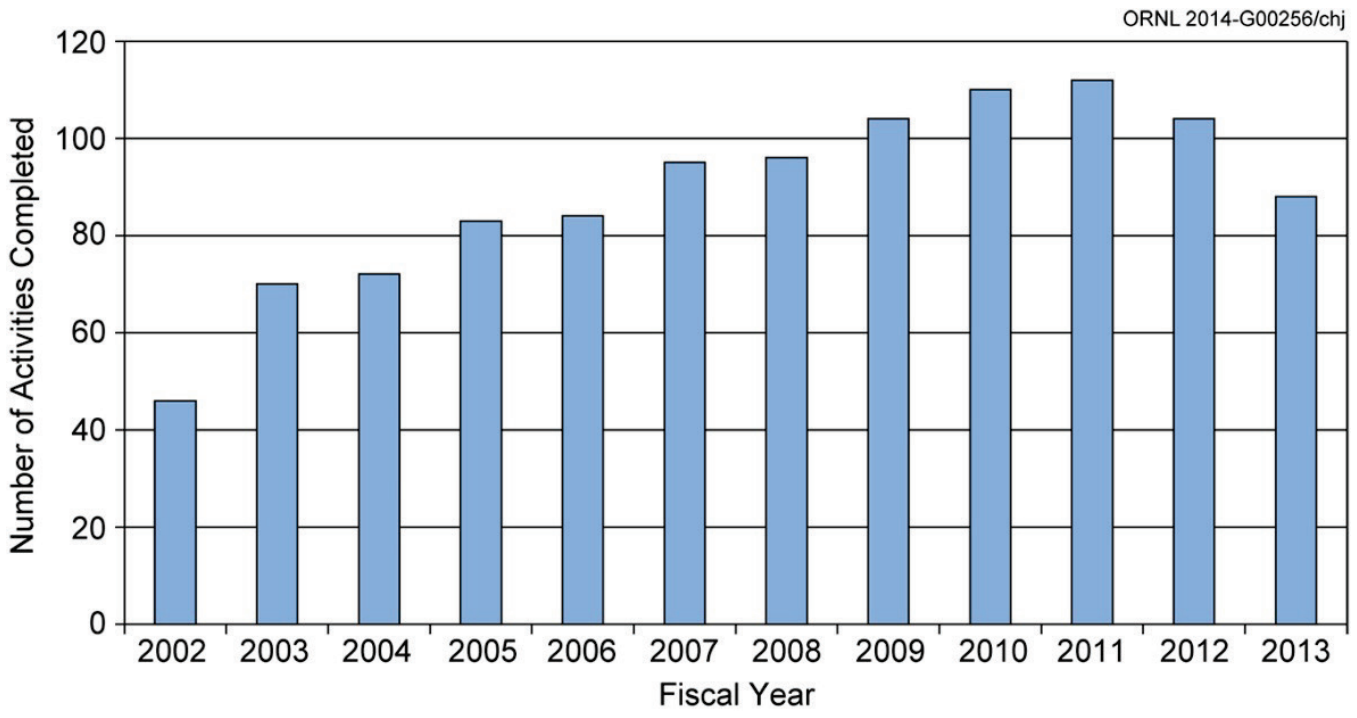

Fig. 4.7. Y-12 Complex pollution prevention initiatives.

Pollution Prevention/Source Reduction. Sustainable initiatives have been embraced across the Y-12 Complex to reduce the impact of pollution on the environment and to increase operational efficiency. Many of the Y-12 Complex's sustainable initiatives have pollution prevention benefits or targets eliminating the source of pollution, including the 2013 activities highlighted in this section.

Sustainable Acquisition-Environmentally Preferable Purchasing. Sustainable products, including recycled-content materials, are procured for use across the Y-12 Complex. In 2013, B\&W Y-12 procured recycled-content materials valued at about $\$ 2.4$ million for use at the site.

Clean Sweep Program. The Clean Sweep Program was developed to improve the environment and support the prevention of pollution through site cleanup efforts. The program provides segregation, staging, and pickup of materials for recycle, excess, and disposal. Clean Sweep "sustain" areas (Fig. 4.8) have been established for the segregation of materials from routine operations and maintenance (O\&M) activities pending disposition. Clean Sweep personnel evaluate surplus materials in the sustain areas to ensure that the 
maximum amount of materials is dispositioned as either excess, recycled, or reused to minimize the total amount of materials disposed of in the landfill. Clean Sweep personnel support the generating organizations by providing a contact for the proper disposition of materials that pose safety hazards, environmental risks, or potential compliance issues or that clutter work areas. In FY 2013, Clean Sweep activities diverted more than $770,000 \mathrm{lb}$ of materials from the sanitary landfill through reuse and recycle.

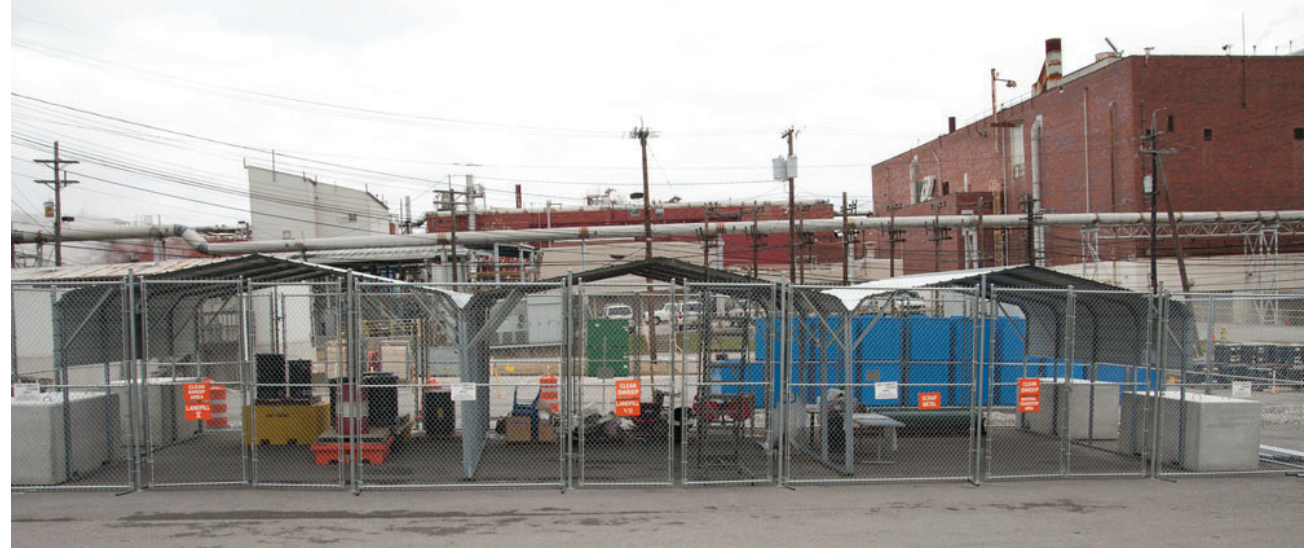

Fig. 4.8. Clean Sweep sustain area at the Y-12 National Security Complex.

Hazardous Chemical Minimization. The Y-12 Complex is committed to reducing the use of toxic and hazardous chemicals and minimizing the volume of hazardous waste generated by site operations. The Generator Services group provides a material disposition management service for waste generators at Y-12 that includes technical support for determining whether materials can be reused, excessed, or recycled rather than declared as waste. Y-12 has also completed various other reduce/reuse initiatives that have reduced the acquisition of hazardous chemicals such as filtering materials so they can be reused and modifying analytical methods to reduce the volume of hazardous reagents used.

Recycling. B\&W Y-12 has a well-established recycling program and continues to identify new material streams and expand the types of materials that can be recycled by finding new markets and outlets for the materials. As shown in Fig. 4.9, more than 1.12 million $\mathrm{kg}(2.27$ million $\mathrm{lb})$ of materials was diverted from landfills and into viable recycle processes during 2013. Currently recycled materials range from office-related materials to operations-related materials such as scrap metal, tires, and batteries. Y-12 adds at least one new recycle

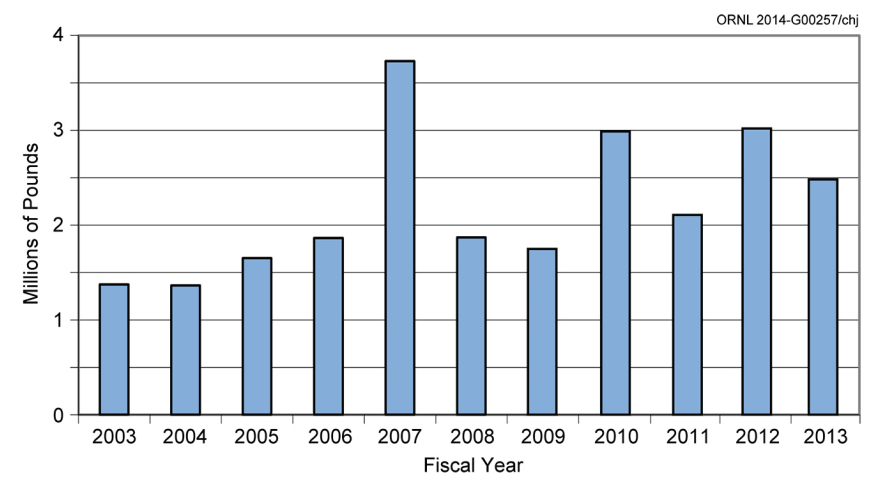

Fig. 4.9. Y-12 Complex recycling results. stream to the Recycle Program each year to continue to increase the waste diversion rate. Plastic water bottle racks and neon lamps were added in FY 2013.

\subsubsection{Energy Management}

The Y-12 Energy Management Program identifies improvements in energy efficiency in facilities, coordinates energy-related efforts across the site, and promotes employee awareness of energy conservation programs and opportunities. The program also includes activities related to the accomplishment of the goals of EO 13423, Strengthening Federal Environmental, Energy, and Transportation Management; EO 13514, Federal Leadership in Environmental, Energy, and Economic Performance; and the DOE Transformational Energy Action Management Initiative. 
The Energy Policy Act of 2005 established a goal of reducing building energy intensity $30 \%$ by 2015 from an FY 2003 baseline. Based on FY 2013 data, energy use at Y-12 is 2,037,495 MBtu. The square footage is 7,383,047; therefore, the FY 2013 estimated energy intensity is 275,969 Btu/gsf, which represents an 8\% reduction from FY 2012 and a 34\% reduction from FY 2003. The site has thus made good progress in implementing energy reduction initiatives, more than meeting the goal a full 2 years ahead of schedule.

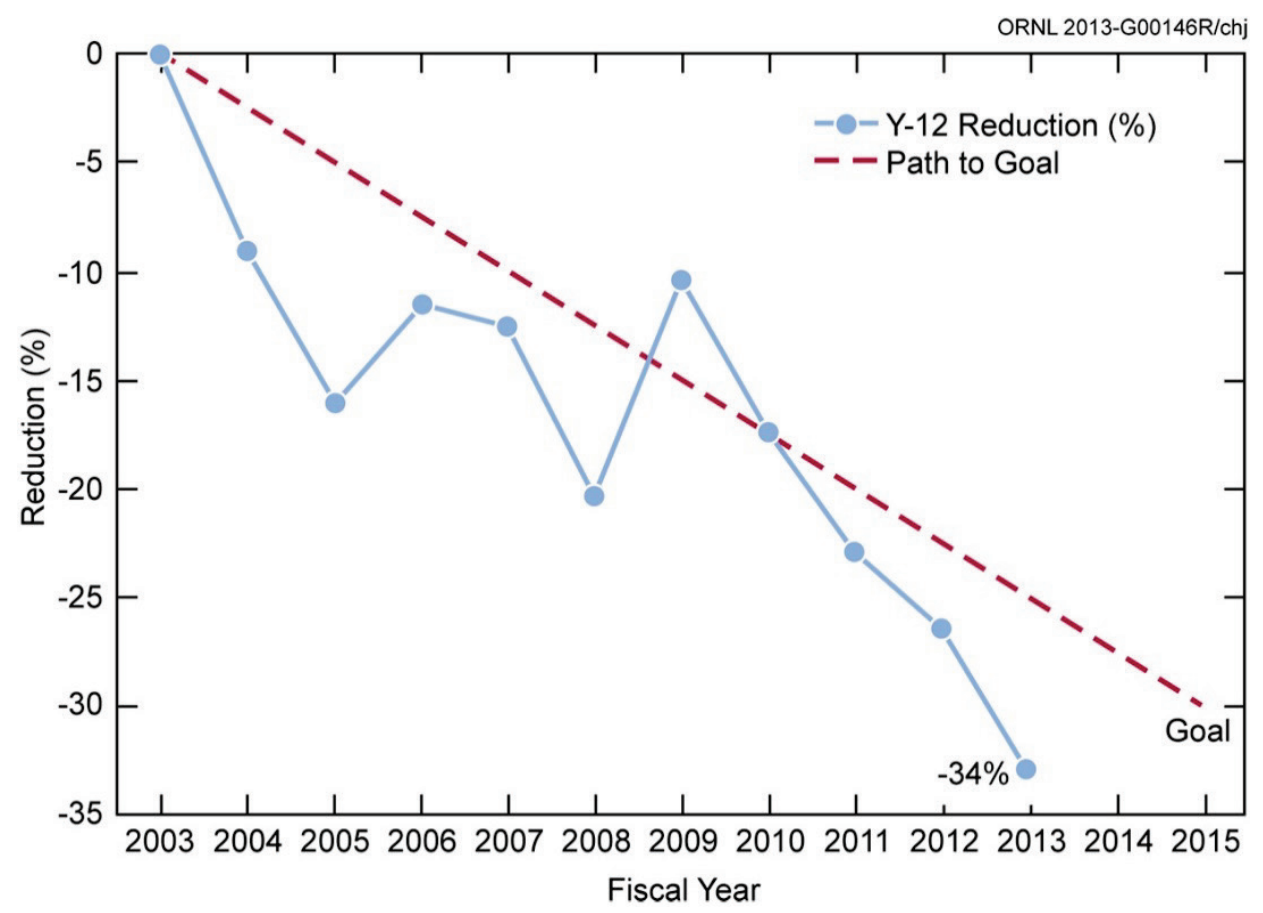

Fig. 4.10. Y-12 has achieved a $34 \%$ reduction in energy intensity compared to the baseline year, 2003.

Significant reductions have been noted with the implementation of the ESPC at Y-12. Delivery order 3 was signed in September with implementation expected to begin in January 2014. This new contract is expected to save 319,894 MBtu per year over the life of the contract.

Specific initiatives that aided in the reduction of electricity consumption at Y-12 during FY 2013 included

- installing light-emitting diode and T-8 fluorescent lighting;

- improving meter readings via the Utilities Management System (UMS) and employee awareness;

- relocating personnel to vacate two facilities; and

- achieving utility efficiencies including reductions in steam pressure, chilled water production, and condensate return.

Additional energy reductions will be required in numerous areas to fully reduce energy use across the plant. Both facility and utilities management are diligently focusing on improvements to achieve the goal. Efforts that are fully incorporated into planning activities for facilities include the following.

- EISA assessments are included in annual reporting.

- Energy conservation measures (ECMs) from both EISA and the ESPC process are included in budgeting reviews.

- Low-cost/no-cost efforts, including component replacements, are incorporated into routine activities.

- EISA assessments and condition assessment surveys (CASs) share resources, including personnel and database support.

- Although the site does not implement a space charge, equivalent metering cost is distributed to facility tenants for awareness. 
During FY 2013, the Security Protective Force, including the Central Training Facility, which is located about 5 miles west of the Y-12 site, was transitioned into the existing management and operating contract at Y-12. The facilities, employees, and fleet vehicles resulting from this change were combined with the Y-12 inventory. The additions to the Facility Information Management System, the Fleet Automotive Statistics Tool, and other data reporting systems have had an impact on previous goal reporting for the site; however, it is not expected that the additions will have a negative impact on the reporting.

As shown in Fig. 4.11, future reductions may be challenging due to a projected increase in the site's energy intensity. Current projections indicate increases may occur once UPF goes online but will again be reduced when an infrastructure reduction program can demolish the remaining facilities in the site transformation plan.

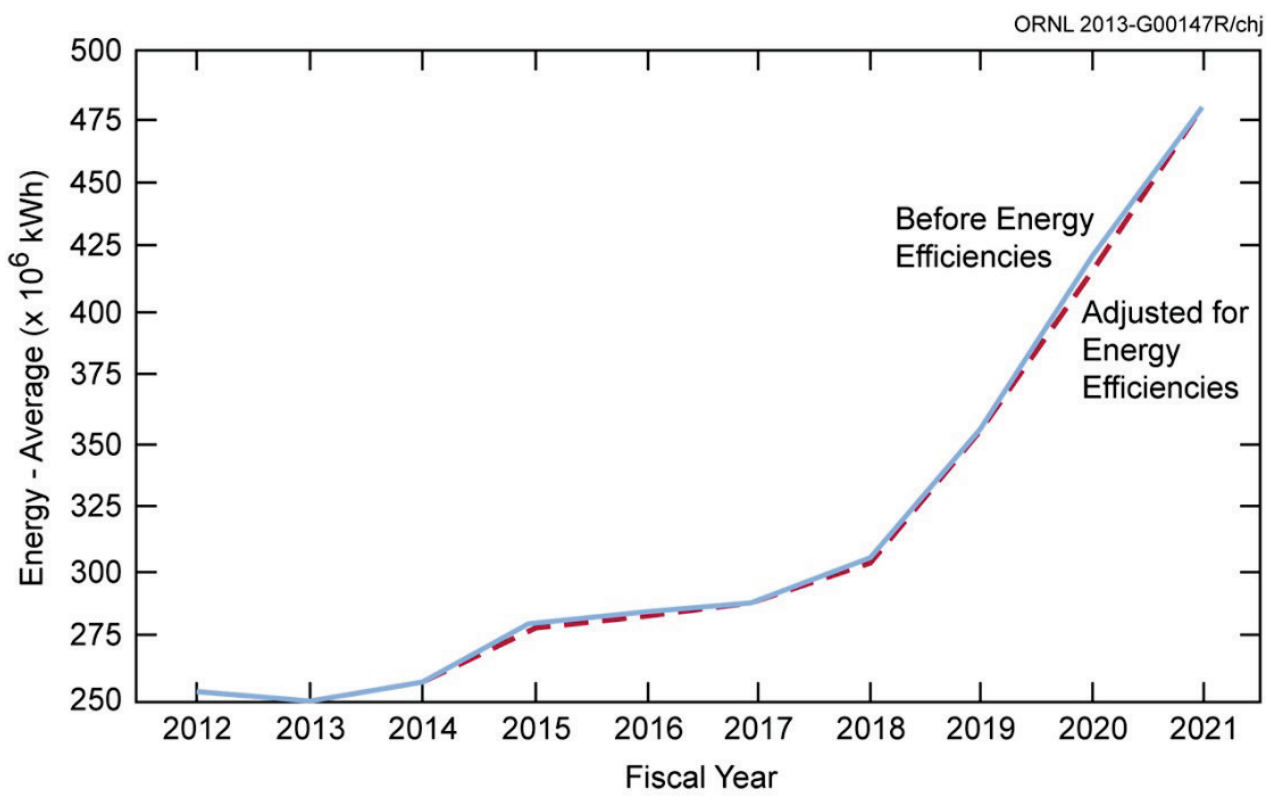

Fig. 4.11. Y-12 Complex electricity load forecast.

\section{Energy Monitoring}

Comprehensive water and energy audits at Y-12 are performed to meet EISA 432. These audits evaluate energy and water use and identify opportunities to reduce use. The audits are performed by an in-house former CAS inspector with energy training. The implementation costs for the ECMs are developed using the Condition Assessment Information System database. Based on the requirement to assess $100 \%$ of the covered facilities at the site, Y-12 successfully completed the first 4-year requirement and began reassessments during FY 2013. The audits are provided to facility and utility management, and ECMs are included in project planning for facilities. ECMs have been prioritized and are implemented as funding is available. Specific examples include heating, ventilating, and air-conditioning (HVAC) replacements and low-flow fixtures. These audits were performed by CAS program staff who are knowledgeable of facility operations and conditions. Additional audits were completed during FY 2013 as part of the ESPC Inspection Grade Audit for delivery order 3.

During FY 2012, Y-12 received funding for meter installations from the Energy Modernization Implementation Program. With this funding, the site was able to install 76 new meters and connect numerous other existing meters to the UMS. This effort has aided the site in developing an energy management system and enabling electronic monthly meter data. During FY 2013 previously installed meters were connected to the UMS.

Minimal funding will be available for dedicated metering during FY 2014. Efforts will continue on establishing communications with the UMS. Metering for high-performance sustainable building (HPSB) candidates is still a concern for the plant. This issue prevents adequate monitoring of energy for the 
required 20\% reduction. It is also impacting required reporting of power usage effectiveness at the plant data centers. Efforts to identify funding to install electric meters for HPSB candidates and for electric, chilled water, and steam metering for the data centers will continue. During FY 2014, Y-12 will coordinate with Oak Ridge Utility District to install facility-specific electric meters at the Central Training Facility. This will enable documentation of energy conservation results and further support the HPSB effort.

The Y-12 Complex began entering facilities into the EPA Portfolio Manager in FY 2011. During FY 2013, metering data continued to be included in the Portfolio Manager, and as new meter data became available, additional information was added. During this fiscal year, many chilled water Btu meters were added. At present, 103 facilities have been entered and are being tracked for compliance. Y-12 enters and tracks data for both covered and noncovered facilities. Data from the Portfolio Manager is shared with NNSA sustainability contacts and is automatically migrated to the CTS for annual reporting in June. Meter data are also entered into Portfolio Manager for benchmarking and reporting purposes.

\section{Energy Savings Performance Contract}

Dedicated funding for energy and water projects is provided via ESPC. ESPC delivery order 2 is in the second period of performance at Y-12; delivery order 3 was awarded in September 2013. Efforts from delivery order 2 have greatly contributed toward both energy reduction and efficiency gains for the projects implemented. Delivery order 3 will be implemented from the first quarter of FY 2014 through the fourth quarter of FY 2016 and is expected to result in an estimated annual energy and water cost savings of $\$ 2,874,696$ and estimated annual energy- and water-related O\&M cost savings of $\$ 2,381,304$. The site will continue to work with NNSA for successful accomplishment of these efforts. ECMs included in ESPC delivery order 3 are listed in Table 4.1.

Table 4.1. Energy conservation measures included in Energy Savings Performance Contract delivery order 3

\begin{tabular}{|c|c|c|c|c|}
\hline $\begin{array}{c}\text { Energy } \\
\text { conservation } \\
\text { measure }^{a, b, c}\end{array}$ & $\begin{array}{c}\text { Conservation } \\
\text { measure name/ } \\
\text { Description }\end{array}$ & $\begin{array}{c}\text { Estimated } \\
\text { annual energy } \\
\text { savings } \\
\text { (MBtu) } \\
\end{array}$ & $\begin{array}{c}\text { Estimated } \\
\text { annual cost } \\
\text { savings }\end{array}$ & Status \\
\hline 1.1 & $\begin{array}{c}\text { Steam } \\
\text { Decentralization } \\
\text { Improvements }\end{array}$ & 152,139 & $\$ 691,816$ & Approved \\
\hline 2.1 & $\begin{array}{l}\text { Chiller Plant } \\
\text { Improvements }\end{array}$ & 36,636 & $\$ 1,274,096$ & Approved \\
\hline 5.1 & $\begin{array}{l}\text { Energy-Efficient } \\
\text { Lighting } \\
\text { Improvements }\end{array}$ & 71,796 & $\$ 2,578,579$ & Approved \\
\hline 7.1 & $\begin{array}{c}\text { Steam } \\
\text { Distribution } \\
\text { System }\end{array}$ & 51,575 & $\$ 241,442$ & Approved \\
\hline 16.1 & $\begin{array}{c}\text { Compressed Air } \\
\text { Plant }\end{array}$ & 7,748 & $\$ 470,067$ & Approved \\
\hline Total & & $\mathbf{3 1 9 , 8 9 4}$ & $\$ 5,256,000$ & \\
\hline
\end{tabular}

\section{Site Sustainability Plan}

The DOE SSPs are an annual reporting requirement intended to comply with the requirements of EOs 13423 and 13514, DOE O 436.1 (DOE 2011), and the DOE SSPP (DOE 2012b). The FY 2014 Y-12 SSP (B\&W Y-12 2013b) serves as a deliverable to fulfill the planning and reporting requirements of the EOs and SSPP. The DOE sustainability goals and Y-12 Complex status and plans for these goals are summarized in Table 4.2. 
Table 4.2. FY 2013 sustainability goals and status

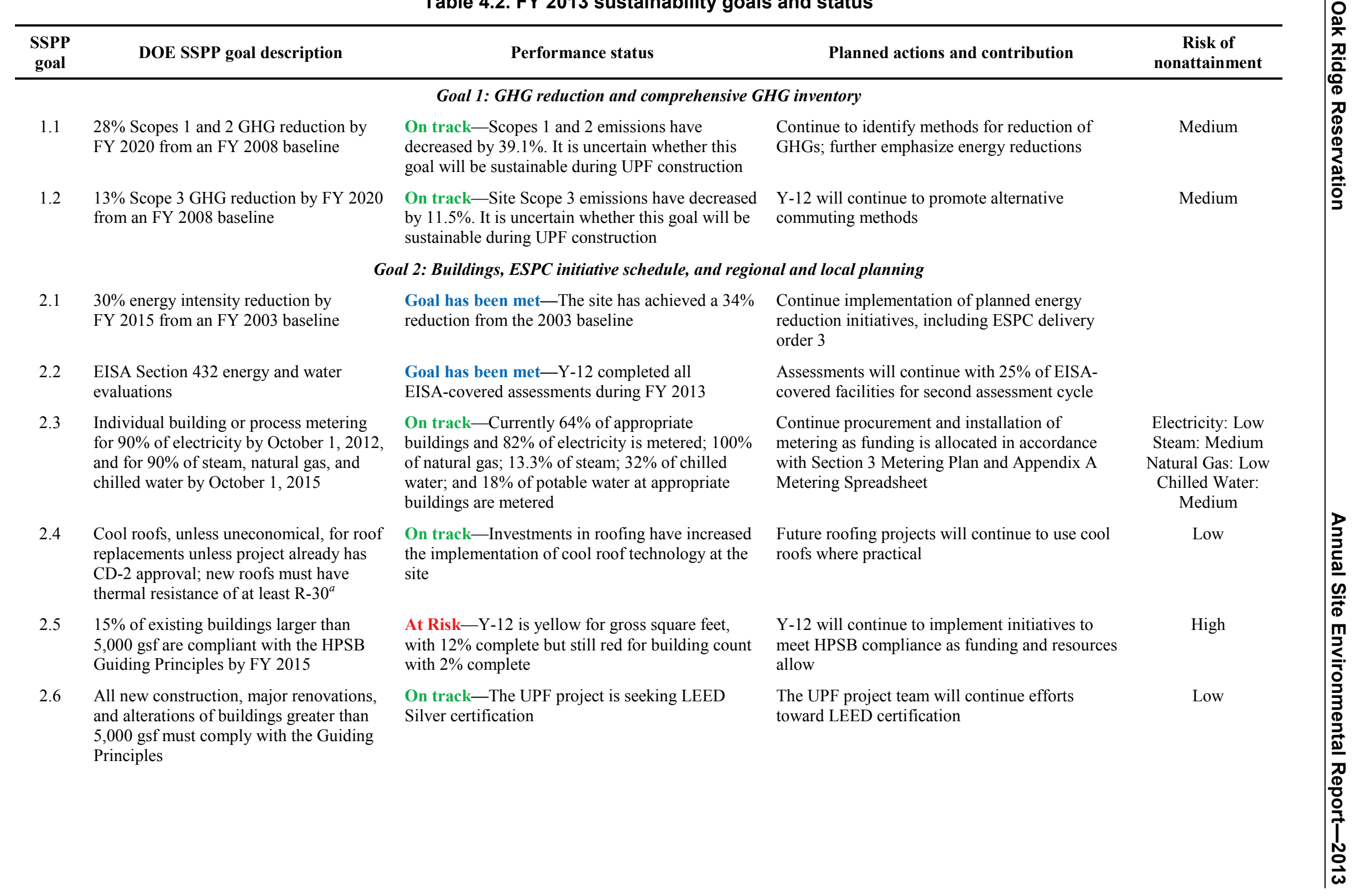


Table 4.2 (continued)

\begin{tabular}{|c|c|c|c|c|}
\hline $\begin{array}{l}\text { SSPP } \\
\text { goal }\end{array}$ & DOE SSPP goal description & Performance status & Planned actions and contribution & $\begin{array}{c}\text { Risk of } \\
\text { nonattainment }\end{array}$ \\
\hline \multicolumn{5}{|c|}{ Goal 3: Fleet management } \\
\hline 3.1 & $\begin{array}{l}10 \% \text { annual increase in fleet alternative } \\
\text { fuel consumption by FY } 2015 \text { relative to } \\
\text { an FY } 2005 \text { baseline }\end{array}$ & $\begin{array}{l}\text { Goal has been met-Y- } 12 \text { has achieved a } 275.5 \% \\
\text { increase in alternative fuel consumption within } \\
7 \text { years }\end{array}$ & $\begin{array}{l}\text { Additional measures are being evaluated for } \\
\text { continued improvement beyond the goal }\end{array}$ & \\
\hline 3.2 & $\begin{array}{l}2 \% \text { annual reduction in fleet petroleum } \\
\text { consumption by FY } 2020 \text { relative to an } \\
\text { FY } 2005 \text { baseline }\end{array}$ & $\begin{array}{l}\text { Goal has been met-Y-12 has achieved the } \\
\text { petroleum reduction goal with a } 55.1 \% \text { reduction } \\
\text { within } 7 \text { years }\end{array}$ & $\begin{array}{l}\text { Additional measures are being evaluated for } \\
\text { continued improvement beyond the goal }\end{array}$ & \\
\hline 3.3 & $\begin{array}{l}100 \% \text { of light-duty vehicle purchases } \\
\text { must consist of AFVs by FY } 2015 \text { and } \\
\text { thereafter }(75 \% \text { FY 2000-2015) }\end{array}$ & $\begin{array}{l}\text { Goal has been met-Y-12 purchases consisted of } \\
98 \% \text { AFVs }\end{array}$ & $\begin{array}{l}\text { Future vehicle purchases will include } \\
\text { consideration for AFVs }\end{array}$ & \\
\hline 3.4 & $\begin{array}{l}\text { Reduce fleet inventory of non-mission- } \\
\text { critical vehicles by } 35 \% \text { by FY } 2013 \\
\text { relative to an FY } 2005 \text { baseline }\end{array}$ & $\begin{array}{l}\text { On Track-NNSA established a } 35 \% \text { reduction } \\
\text { target complexwide }\end{array}$ & $\begin{array}{l}\text { Continue evaluating mission need and use } \\
\text { standards to reassign or remove vehicles from } \\
\text { fleet }\end{array}$ & Low \\
\hline \multicolumn{5}{|c|}{ Goal 4: Water use efficiency and management } \\
\hline 4.1 & $\begin{array}{l}26 \% \text { water intensity reduction by } \\
\text { FY } 2020 \text { from an FY } 2007 \text { baseline }\end{array}$ & $\begin{array}{l}\text { Goal has been met-The site has achieved a } \\
47.1 \% \text { reduction from the baseline }\end{array}$ & $\begin{array}{l}\text { Water conservation measures will continue to be } \\
\text { implemented as practicable in support of the } \\
\text { HPSB initiative }\end{array}$ & \\
\hline 4.2 & $\begin{array}{l}20 \% \text { water consumption reduction for } \\
\text { ILA water by FY } 2020 \text { from an FY } 2010 \\
\text { baseline }\end{array}$ & No ILA use at Y-12 & $\begin{array}{l}\text { All water used at Y-12 is potable water and } \\
\text { included in the potable water category }\end{array}$ & N/A \\
\hline \multicolumn{5}{|c|}{ Goal 5: Pollution prevention and waste reduction } \\
\hline 5.1 & $\begin{array}{l}\text { Divert at least } 50 \% \text { of nonhazardous solid } \\
\text { waste, excluding C\&D debris, by } \\
\text { FY } 2015\end{array}$ & $\begin{array}{l}\text { Goal has been met-More than } 53 \% \text { of } \\
\text { nonhazardous waste diverted from landfill }\end{array}$ & $\begin{array}{l}\text { At least one new recycle material stream is added } \\
\text { to the recycling program each fiscal year to } \\
\text { further increase the diversion rate }\end{array}$ & \\
\hline 5.2 & $\begin{array}{l}\text { Divert at least } 50 \% \text { of C\&D materials and } \\
\text { debris by FY } 2015\end{array}$ & $\begin{array}{l}\text { Goal has been met-More than } 71 \% \text { of C\&D } \\
\text { waste diverted from landfill }\end{array}$ & $\begin{array}{l}\text { Systematic disposition evaluation method will } \\
\text { continue to be used for } C \& D \text { materials to ensure } \\
\text { maximum waste diversion is achieved }\end{array}$ & \\
\hline \multicolumn{5}{|c|}{ Goal 6: Sustainable acquisition } \\
\hline 6.1 & $\begin{array}{l}\text { Procurements meet requirements by } \\
\text { including necessary provisions and } \\
\text { clauses (Sustainable Procurements/ } \\
\text { Biobased Procurements) }\end{array}$ & $\begin{array}{l}\text { Goal has been met-The sustainable acquisition } \\
\text { clause ( } 48 \text { CFR 952.223-78) was incorporated into } \\
\text { Y-12 procurement clauses in FY } 2011 \text {. The terms } \\
\text { and conditions were revised in } 2012 \text { to include } \\
\text { Federal Acquisition Regulation clause } 52.223-15\end{array}$ & $\begin{array}{l}\text { Y-12 will incorporate additional clauses as } \\
\text { requested and will continue to evaluate } \\
\text { sustainable products for use at the site }\end{array}$ & \\
\hline
\end{tabular}


Table 4.2 (continued)

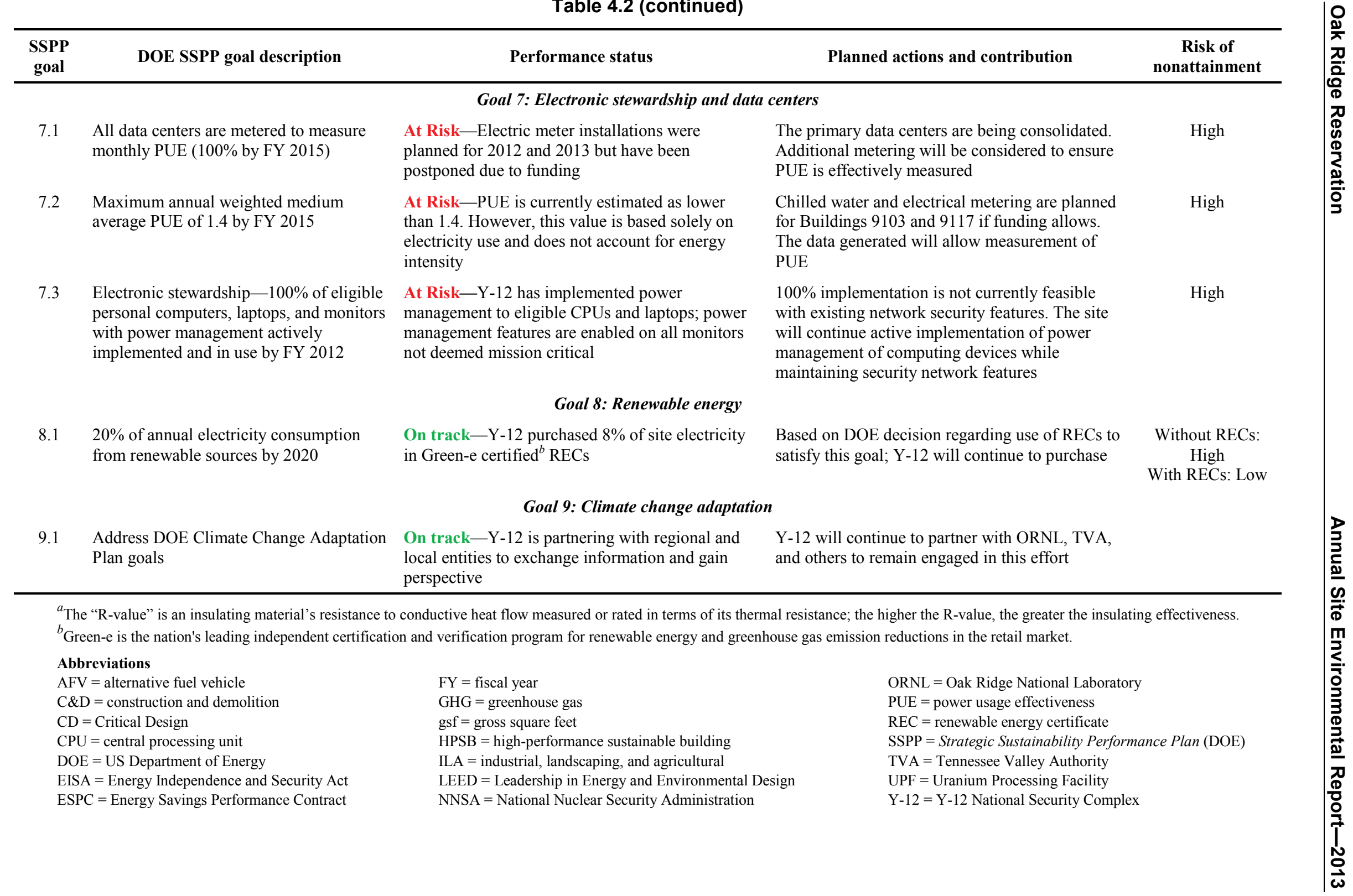




\subsubsection{Water Conservation}

Y-12 is currently exceeding both the 2016 and the 2026 goals for water conservation. By the end of FY 2013, the site had achieved a $47.1 \%$ reduction in potable water use compared to the baseline year, 2007 (Fig. 4.12). During FY 2013, the site noted a reduction of 13.7\% from FY 2012 consumption. Actions that have contributed to the overall reduction in potable water use include the following:

- $\quad$ steam trap repairs and improvements;

- condensate return repairs and reroutes ( 10 million gal/year saved);

- $\quad$ stand-down of Buildings 9201-05, 9204-01, 9204-04, 9204-03, 9201-02, and 9401-03;

- replacement of once-through air handling units ( $~ 5$ million gal /year saved); and

- low-flow fixture installation ( $\sim 660$ thousand gal/year saved).

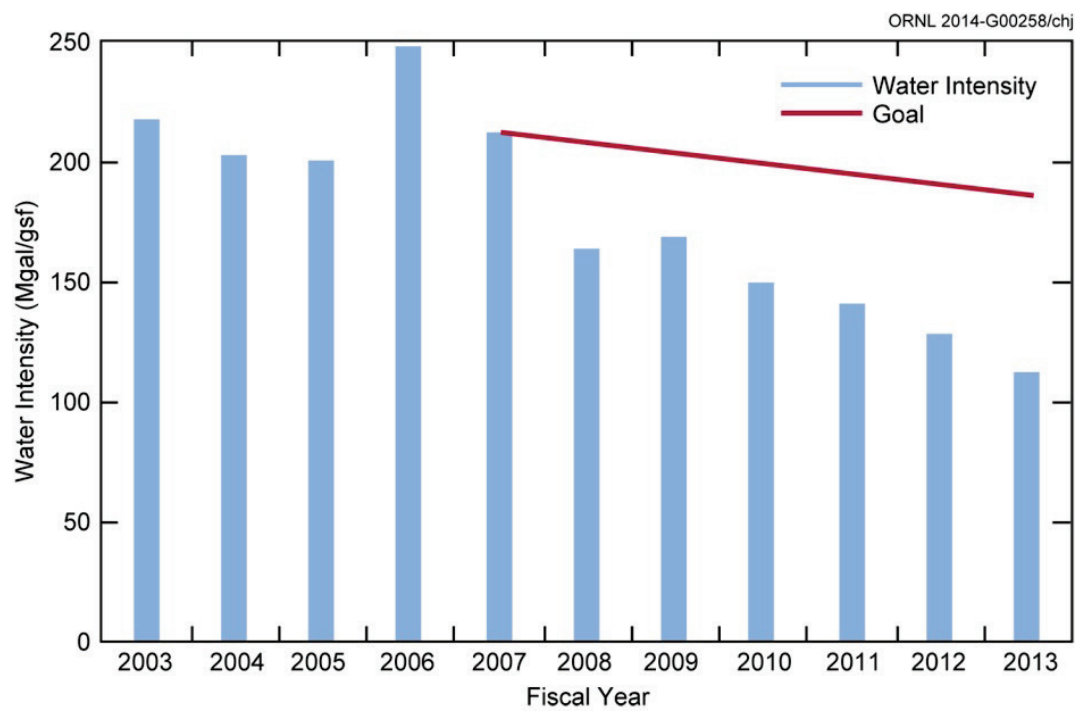

Fig. 4.12. Y-12 Complex water intensity goals. (Mgal = millions of gallons, $g s f=$ gross square foot; red line is the consumption reduction goal.)

Meters are installed on the potable water tanks and on various facilities on the site. A minimal number of meters within the facilities are currently read, and although a verified listing does not exist, Y-12 is working on verifying all locations of water meters. Future metering will include advanced meter installations for all enduring facilities, as applicable, to comply with the 2015 goal. Additionally, new advanced meters will be installed on the potable water tanks because the existing meters are flow meters rather than totalizing meters.

Although Y-12 has made significant progress, future reductions in water consumption can still be achieved through continued improvements within facilities, metering, and replacement of inefficient HVAC units. Continued reductions in water use will be incorporated into ongoing facility repairs and renovations as funding becomes available.

These efforts will include

- upgrading toilets and urinals to low-flow, hands-free units;

- installing flow restrictors on faucets and shower heads;

- repairing condenser loop connections to the cooling towers;

- replacing once-through water-cooled air conditioning systems with air-cooled equivalents;

- installing advanced potable water meters; and

- repairing Building 9212 condensate returns (included in ESPC delivery order 3). 


\subsubsection{Fleet Management}

The Y-12 fleet comprises sedans, light duty trucks/vans, medium duty trucks/vans, and heavy duty trucks. Vehicles range from new to 28 years old with the majority $(90 \%)$ of vehicles between 7 and 24 years old. To achieve the optimum fleet, Fleet Management is coordinating with other departments onsite (e.g., shuttle services) to develop a strategic plan for managing on-site transportation at the Y-12 Complex. Vehicles are used as tools to perform work and support the mission at the Y-12 Complex. Fleet Management is evaluating the current fleet and will focus on efforts to right size the fleet based on mission needs. In addition to the fleet size, petroleum and alternative fuel (E85) use is monitored to ensure EOs are being met. Fleet Management has benchmarked other DOE sites and private industry to allow Y-12 to standardize its fleet and meet federal requirements. Fleet Management goals support EOs associated with petroleum consumption reduction and alternative fuel use.

Y-12 will continue to monitor vehicle use and redistribute or remove vehicles from the fleet as needed. Decisions on replacement vehicle purchases will consider energy use in accordance with sustainable acquisition guidance, and replacement vehicles will be more fuel efficient. Y-12 currently owns and operates four low-speed electric vehicles and a 25-passenger diesel-electric hybrid bus.

As additional guidance becomes available, Y-12 will evaluate the existing fleet to identify further reductions. Additional goals are planned for continued progress in fleet management.

The Y-12 Complex has already surpassed the petroleum reduction goal by achieving a 55.1\% reduction within 7 years. In FY 2013 the Security Protective Force division was added to the fleet, which increased the number of petroleum-dedicated vehicles by 19. In addition, the DOE prime subcontractor was unable to fuel alternative fuel vehicle (AFV) patrol vehicles with E85 due to the extended absence of a mobile fuel truck. These combined factors increased the site's petroleum consumption. However, the site still exceeded the petroleum reduction goal and continues to evaluate opportunities to reduce petroleum consumption. Due to the expanding mission and increase in transformation-related activities on the site, it may be difficult to continue to reduce fuel consumption by $2 \%$ each year and increase nonpetroleum consumption by $10 \%$ annually, but Y-12 continues to progress toward this goal.

The site has also achieved a $275.5 \%$ increase in alternative fuel use from the 2005 baseline. As there is a ready supply of E85 fuel on the site, all AFVs use the fuel $100 \%$ of the time. Data in Table 4.3, pulled from FAST, show the goal will be reached through 2018.

Table 4.3. Summary of petroleum and alternative fuel use over an 8-year period

\begin{tabular}{cccc}
\hline \multicolumn{4}{c}{ Alternative fleet use statistics } \\
\hline $\begin{array}{c}\text { 2005 Baseline } \\
\text { (GGE) }\end{array}$ & $\begin{array}{c}\text { 2013 Data } \\
\text { (GGE) }\end{array}$ & $\begin{array}{c}\text { Increase/Decrease } \\
\text { (\%) }\end{array}$ & $\begin{array}{c}\text { E.O. 13423 } \\
\text { Goal }\end{array}$ \\
\hline 10,700 & 40,177 & +275.5 & $10 \% /$ year increase \\
& Fleet petroleum reduction statistics & \\
\hline $\mathbf{2 0 0 5}$ Baseline & $\mathbf{2 0 1 3 ~ D a t a}$ & Increase/Decrease & E.O. 13423 \\
(GGE) & (GGE) & $\mathbf{( \% )}$ & Goal \\
246,137 & 110,576 & -55.1 & $2 \% /$ year decrease \\
\hline \multicolumn{4}{c}{ GGE $=$ gasoline gallon equivalent }
\end{tabular}

To track the continued success of fuel-saving measures, the fleet manager monitors fuel consumption by both Y-12 Complex and General Services Administration vehicles and maintains monthly reporting metrics. Future fleet management energy savings will be achieved by continued strict monitoring of vehicle use. Increasing the use of alternative fuels and replacing gasoline-fueled vehicles with E85-fueled vehicles will occur as funding permits.

The NNSA fleet reduction goal for FY 2012 and FY 2013 is 35\% for the organization. In FY 2012, Fleet Management removed 100 vehicles from the fleet. Y-12 will maintain a questioning attitude toward vehicle requests in FY 2014. Given the unsustainable state of the current fleet and the existing funding 
constraints, Y-12 Complex Fleet Management is taking a multitiered approach (Fig 4.13) to managing the current fleet while planning for a more sustainable future fleet to meet the mission needs of the site. The ultimate goal is a smaller, more modern, more cost-efficient, and more sustainable fleet.

ORNL 2014-G00259/chj

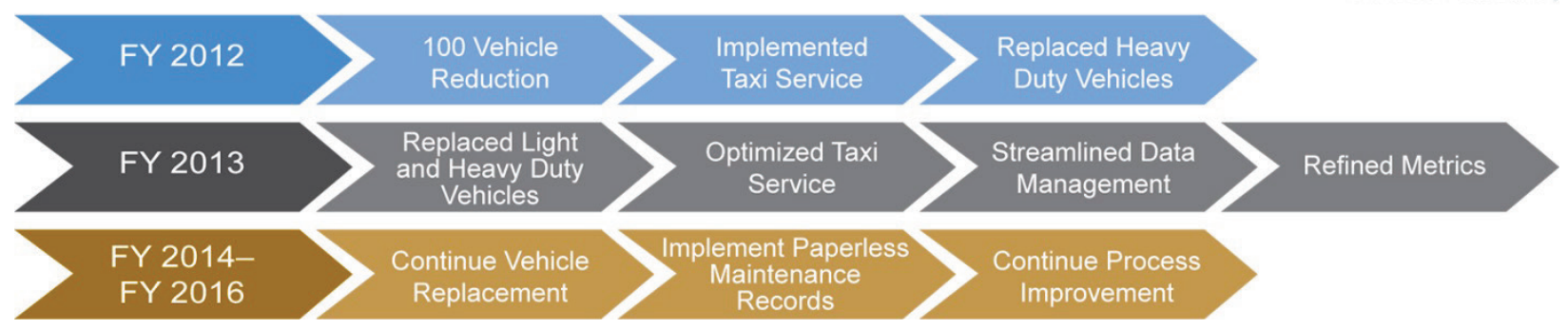

Fig. 4.13. Fleet management roadmap.

\subsubsection{Electronic Stewardship}

Y-12 has implemented a variety of electronic stewardship activities, including server virtualization, virtual desktop infrastructure, procurement of energy-efficient computing equipment, reuse and recycle of computing equipment, replacement of aging computing equipment with more energy-efficient equipment, and reconfiguration of data centers to achieve more energy-efficient operations. More than $98 \%$ of all desktop computers, laptops, monitors, and thin clients purchased or leased during FY 2013 were Electronic Product Environmental Assessment Tool- (EPEAT)-registered products. Y-12's standard desktop configuration specifies the procurement of EPEAT-registered and Energy Star-qualified products.

\subsubsection{Greenhouse Gases}

The Y-12 Complex developed a preliminary GHG inventory in August 2009. The inventory was developed for FY 2008 with an FY 2003 baseline year. Based on the requirements of EO 13514, the baseline year was changed to FY 2008. Table 4.4 provides a summary of Y-12 Complex GHG emissions for FY 2008 and FY 2013.

The Y-12 Complex has reduced Scopes 1 and 2 GHG emissions by 39.1\% since the 2008 baseline year, primarily due to decreased Scope 1 emissions from steam generation, decreased Scope 2 emissions from energy efficiency projects, and HPSB improvements. Scope $3 \mathrm{GHG}$ emissions have been reduced by $11.5 \%$ since the 2008 baseline year. This reduction is due primarily to reductions in business travel and transmission and distribution losses. Employee commuting GHG emissions account for $65 \%$ of the Scope 3 emissions. It will be difficult for the Y-12 Complex to meet the reduction goal for Scope 3 GHG emissions without the addition of public transit to the Oak Ridge area and/or a telecommuting program. To further reduce employee commuting emissions, the Y-12 Complex will continue to encourage use of the Y-12 Complex carpooling and rideshare programs.

Table 4.4. Y-12 National Security Complex greenhouse gas emissions summary

\begin{tabular}{lcc}
\hline \multicolumn{1}{c}{ GHG emission source } & $\begin{array}{c}\text { FY 2008 baseline } \\
\text { (metric ton } \mathrm{CO}_{2} \mathbf{e} / \text { year) }\end{array}$ & $\begin{array}{c}\text { FY 2013 } \\
\text { (metric ton } \mathbf{C O}_{2} \mathbf{e} / \text { year) }\end{array}$ \\
\hline Scope 1 & & \\
Steam (coal, natural gas, fuel oil) & 129,021 & 66,143 \\
Industrial fugitive emissions & 22,542 & 5,579 \\
On-site wastewater treatment & 6.9 & 8.2 \\
Fleet fuels & 1,063 & 665
\end{tabular}


Table 4.4. (continued)

\begin{tabular}{lcc}
\hline \multicolumn{1}{c}{ GHG emission source } & $\begin{array}{c}\text { FY 2008 baseline } \\
\text { (metric ton } \mathbf{C O}_{\mathbf{2}} \mathbf{e} / \text { year) }\end{array}$ & $\begin{array}{c}\text { FY 2013 } \\
\text { (metric ton } \mathbf{C O}_{\mathbf{2}} \mathrm{e} / \text { year) }\end{array}$ \\
\hline Scope 2 & & \\
Renewable energy certificates & & $(13,497)$ \\
Electricity & 184,995 & 146,481 \\
Total Scopes1 and 2 & $\mathbf{3 3 7 , 6 2 7 . 9}$ & $\mathbf{2 0 5 , 3 7 9 . 2}$ \\
Scope 3 & & \\
T\&D losses & $12,185.8$ & $8,723.6$ \\
Off-site municipal wastewater treatment & 25.3 & 26.2 \\
Employee commute & 17,447 & $18,369.6$ \\
Business ground and air travel & 2,251 & 1,123 \\
Total Scope 3 & $\mathbf{3 1 , 9 0 9 . 1}$ & $\mathbf{2 8 , 2 4 2 . 4}$ \\
TOTAL GHG Emissions & $\mathbf{3 6 9 , 5 3 7}$ & $\mathbf{2 3 3 , 6 2 1 . 6}$ \\
\hline
\end{tabular}

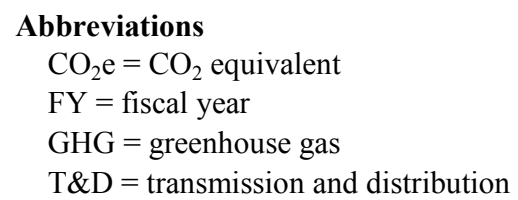

\subsubsection{Storm Water Management and the Energy Independence and Security Act of 2007}

EISA Section 438 requires federal agencies to reduce storm water runoff from development and redevelopment projects to protect water resources. The Y-12 Complex complies with these requirements using a variety of storm water management practices, often referred to as "green infrastructure" or "low impact development" practices. During the last few years several green infrastructure initiatives have been implemented to reduce the size and number of impervious surfaces through the use of sustainable vegetative practices and porous pavements. Among them are the following.

- A new paved area for a training effort included a perimeter installation of number 57 stone to reduce storm water runoff.

- During the site readiness phase of UPF construction, a Faircloth skimmer was installed in Sediment Basin 1 (Fig. 4.14). The Faircloth skimmer surface drain floats on the surface of the sediment basin as it fills and drains, releasing the cleanest water in the basin instead of draining from the bottom as conventional outlets do. The skimmer drains the basin slowly, at a constant rate, over several days to maximize settling.

- A 2012-featured pervious pavement (Fig.4.15) was installed in the parking lot at New Hope Center. Additional efforts during the construction of the lot included removing the excess dirt from the new parking lot and backfilling over rubberized concrete slabs.

In all, about 3.5 acres have been added to the green bank to offset for future projects within the Y-12 Complex. 


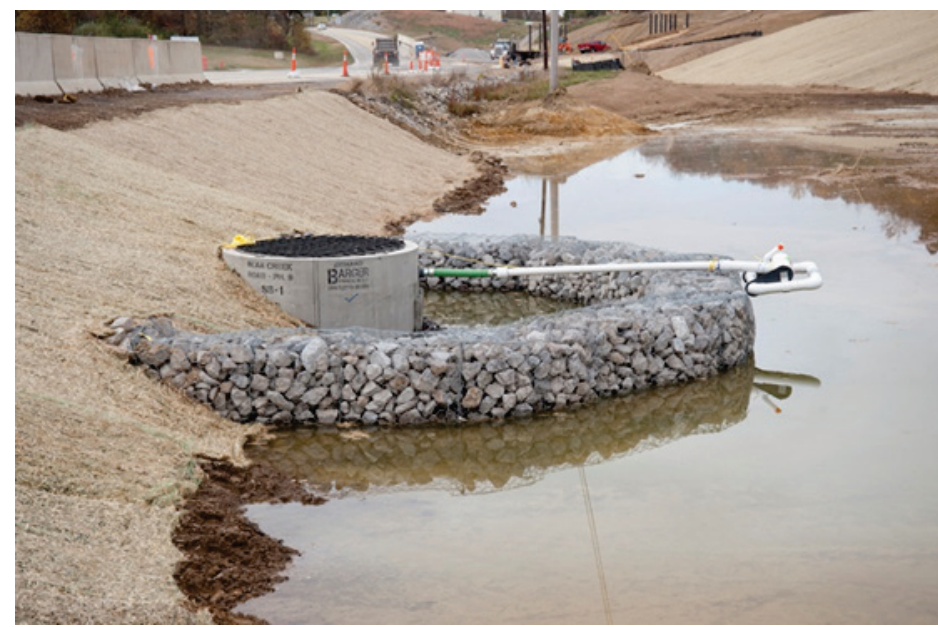

Fig. 4.14. Faircloth skimmer at Sediment Basin 1.

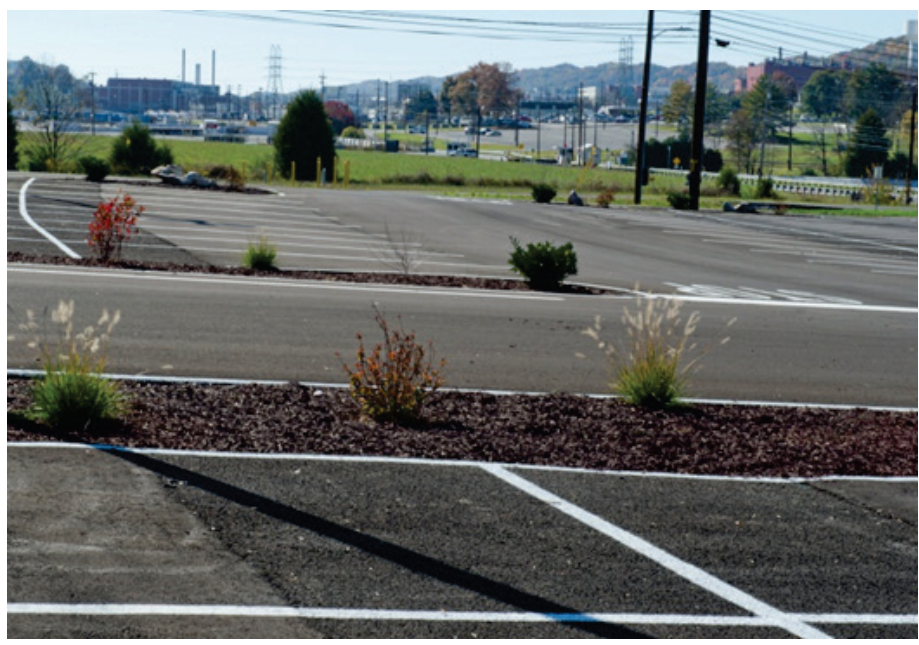

Fig. 4.15. Permeable pavement and native planting contributes to compliance with EISA 438

requirements. [Source: Kathy Fahey, Y-12 Photography.]

\subsubsection{Awards and Recognition}

Since November 2000, the Y-12 Complex commitment to environmentally responsible operations has been recognized with more than 105 external environmental awards from local, state, and national agencies. The awards received in 2013 are summarized below.

DOE Sustainability Award. The "Making Change Happen at Y-12" activity was selected by DOE headquarters to receive a DOE Sustainability Award. DOE Sustainability Awards recognize innovation and/or excellence in pollution prevention and environmental sustainability stewardship efforts within DOE; recipients are selected by an independent panel.

NNSA Awards. In 2013 the Y-12 Complex received four NNSA Pollution Prevention/Sustainability Best in Class Awards and two Environmental Stewardship Award Certificates. This is the 10th consecutive year that the Y-12 Complex has been recognized by NNSA for award-winning activities. These awards recognize innovation and/or excellence in pollution prevention and environmental sustainability stewardship efforts within NNSA and DOE; recipients are selected by an independent panel.

Best Workplaces for Commuters. B\&W Y-12 was recognized as having met the National Standard of Excellence awarded by the Best Workplaces for Commuters. Y-12 was recognized for working a reduced workweek and the use of an on-site taxi service. 


\subsection{Compliance Status}

\subsubsection{Environmental Permits}

Table 4.5 lists environmental permits in force at the Y-12 Complex during 2013. More detailed information can be found in the following sections.

\subsubsection{National Environmental Policy Act/National Historic Preservation Act}

NNSA adheres to NEPA regulations, which require federal agencies to evaluate the effects of proposed major federal activities on the environment. The prescribed evaluation process ensures that the proper level of environmental review is performed before an irreversible commitment of resources is made.

During 2013, environmental evaluations were completed for 52 proposed actions, all of which were determined to be covered by a CX.

The DOE NEPA implementing procedures, 10 CFR 1021, require a 5-year evaluation of the current Y-12 Complex sitewide environmental impact statement (SWEIS). A new SWEIS was prepared to evaluate the new modernization proposals and to update the analyses presented in the original Y-12 Complex SWEIS (issued in November 2001). The final SWEIS was issued February 2011, and the notice of availability was published March 4, 2011. The final SWEIS (DOE 2011a) is available on the Internet at http://www.y12sweis.com.

In accordance with NHPA, NNSA is committed to identifying, preserving, enhancing, and protecting its cultural resources. The compliance activities in 2013 included completing NHPA Section 106 reviews and participating in various outreach projects with local organizations and schools.

Fifty-two proposed projects were evaluated to determine whether any historic properties eligible for inclusion in the NRHP would be adversely impacted. It was determined that none of the 52 projects would have an adverse effect on historic properties eligible for listing in the NRHP and that no further Section 106 documentation was required. The Y-12 Oral History Program continues efforts to conduct oral interviews of current and former employees to document the knowledge and experience of those who worked at the Y-12 Complex during World War II and the Cold War era. The interviews provide information on day-to-day operations of the Y-12 Complex, the use and operation of significant components and machinery, and how technological innovations occurred over time. Some of the information collected from the interviews will be available in various media, including DVDs shown in the Y-12 History Center.

The Y-12 History Center, located in The New Hope Center, continues to be a work in progress. The Y-12 History Center features many historical photographs and artifacts, a history library, and a video viewing area. More interactive and video-based exhibits are planned for the future. The Y-12 History Center is open to the public Monday through Thursday from 8:00 a.m. to 5:00 p.m. and on Fridays by special request. A selection of materials, including documentary DVDs, books, pamphlets, postcards, and fact sheets will continue to be available free to the public.

Outreach activities in 2013 consisted of B\&W Y-12 partnering with the city of Oak Ridge, the Oak Ridge Convention and Visitor's Bureau, and the Arts Council of Oak Ridge, which sponsor the annual Secret City Festival. In June, The Secret City Festival promoted the history of the Manhattan Project by providing information to visitors regarding the History of Y-12 and directions for them to visit the Y-12 History Center.

B\&W Y-12 also partnered with the American Museum of Science and Energy by providing guided public tours of the Y-12 History Center from June through September. Other outreach activities included visiting local schools and conducting presentations on the history of the Y-12 Complex and Oak Ridge. 
Table 4.5. Y-12 National Security Complex environmental permits, 2013

\begin{tabular}{|c|c|c|c|c|c|c|c|}
\hline $\begin{array}{l}\text { Regulatory } \\
\text { driver }\end{array}$ & Title/description & Permit number & Issue date & $\begin{array}{l}\text { Expiration } \\
\text { date }\end{array}$ & Owner & Operator & $\begin{array}{c}\text { Responsible } \\
\text { contractor }\end{array}$ \\
\hline CAA & $\begin{array}{l}\text { Title V Major Source Operating } \\
\text { Permit }\end{array}$ & 562767 & $1 / 8 / 2012$ & $1 / 8 / 2017$ & DOE & DOE & B\&W Y-12 \\
\hline CWA & $\begin{array}{l}\text { Industrial \& Commercial User } \\
\text { Wastewater Discharge (Sanitary } \\
\text { Sewer) Permit }\end{array}$ & $1-91$ & $4 / 1 / 2010$ & $3 / 31 / 2015$ & DOE & DOE & B\&W Y-12 \\
\hline CWA & NPDES Permit & TN0002968 & $10 / 31 / 2011$ & $11 / 30 / 2016$ & DOE & DOE & B\&W Y-12 \\
\hline CWA & $\begin{array}{l}401 \text { Water Quality Certification/ } \\
\text { ARAP Access/Haul Road }\end{array}$ & NRS10.083 & $6 / 10 / 2010$ & $6 / 09 / 2015$ & $\mathrm{~B} \& \mathrm{~W} \mathrm{Y}-12$ & B\&W Y-12 & B\&W Y-12 \\
\hline CWA & Department of Army Permit & 2010-00366 & $9 / 02 / 2010$ & $9 / 02 / 2015$ & $\begin{array}{l}\text { DOE, B\&W } \\
\text { Y-12 }\end{array}$ & B\&W Y-12 & B\&W Y-12 \\
\hline CWA & $\begin{array}{l}\text { General Storm Water Permit Y-12 } \\
\text { Complex ( } 41.7 \text { hectares/103 acres) }\end{array}$ & TNR 134022 & $10 / 27 / 2011$ & $5 / 23 / 2016$ & DOE & B\&W Y-12 & B\&W Y-12 \\
\hline RCRA & $\begin{array}{l}\text { Hazardous Waste Transporter } \\
\text { Permit }\end{array}$ & TN3890090001 & $1 / 17 / 2014$ & $1 / 31 / 2015$ & DOE & DOE & B\&W Y-12 \\
\hline RCRA & $\begin{array}{l}\text { Hazardous Waste Corrective } \\
\text { Action Permit }\end{array}$ & TNHW-121 & $9 / 28 / 2004$ & $9 / 28 / 2014$ & DOE & $\begin{array}{l}\text { DOE, NNSA, and } \\
\text { all ORR } \\
\text { cooperators of } \\
\text { hazardous waste } \\
\text { permits }\end{array}$ & UCOR \\
\hline RCRA & $\begin{array}{l}\text { Hazardous Waste Container } \\
\text { Storage Units }\end{array}$ & TNHW-122 & $8 / 31 / 2005$ & $8 / 31 / 2015$ & DOE & DOE/B\&W Y-12 & $\begin{array}{c}\text { B\&W Y-12/ } \\
\text { Navarro co-operator }\end{array}$ \\
\hline RCRA & $\begin{array}{l}\text { Hazardous Waste Container } \\
\text { Storage and Treatment Units }\end{array}$ & TNHW-127 & $10 / 06 / 2005$ & $10 / 06 / 2015$ & DOE & DOE/B\&W Y-12 & $\begin{array}{l}\text { B\&W Y-12 co- } \\
\text { operator }\end{array}$ \\
\hline RCRA & $\begin{array}{l}\text { RCRA Postclosure Permit for the } \\
\text { Chestnut Ridge Hydrogeologic } \\
\text { Regime }\end{array}$ & TNHW-128 & $9 / 29 / 2006$ & $9 / 29 / 2016$ & DOE & DOE/UCOR & UCOR \\
\hline RCRA & $\begin{array}{l}\text { RCRA Postclosure Permit for the } \\
\text { Bear Creek Hydrogeologic } \\
\text { Regime }\end{array}$ & TNHW-116 & $\begin{array}{c}12 / 10 / 2003 \\
\text { Permit reapplication } \\
\text { submitted to TDEC } \\
\text { on } 1 / 31 / 13\end{array}$ & $12 / 10 / 2013$ & DOE & DOE/UCOR & UCOR \\
\hline
\end{tabular}


Table 4.5. (continued)

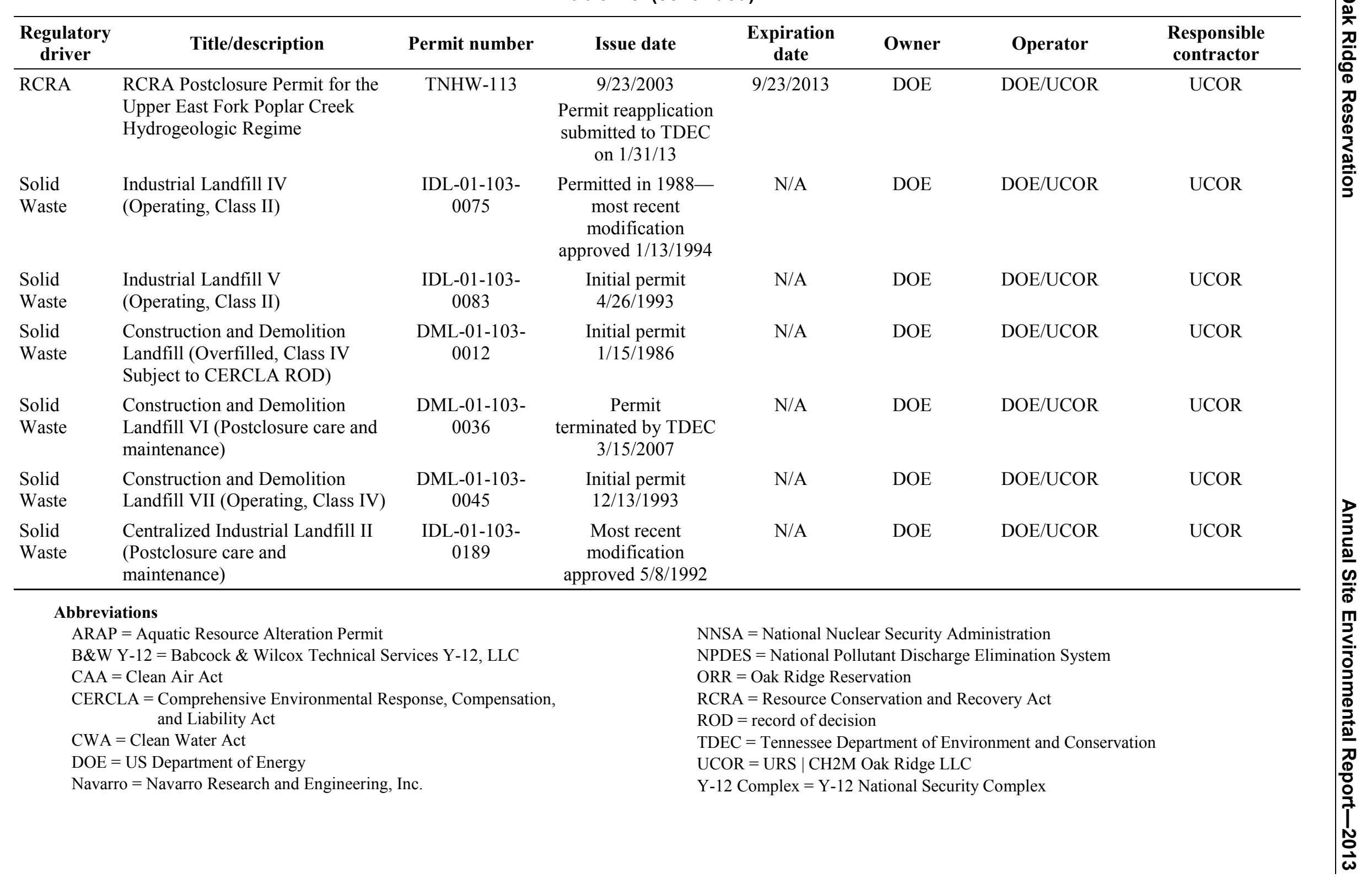




\subsubsection{Clean Air Act Compliance Status}

Permits issued by the State of Tennessee are the primary vehicle used to convey the clean air requirements that are applicable to the Y-12 Complex. New projects are governed by construction permits, and eventually the requirements are incorporated into the sitewide Title $\mathrm{V}$ operating permit. The Y-12 Complex is currently governed by Title V Major Source Operating Permit 562767.

The permit requires annual and semiannual reports. More than 3,000 data points are obtained and reported each year. All reporting requirements were met during CY 2013, and there were no permit violations or exceedances during the report period.

A revision to the Compliance Plan, National Emission Standards for Hazardous Air Pollutants for Airborne Radionuclides on the Oak Ridge Reservation, Oak Ridge, Tennessee (DOE 2013a) was approved by regulatory agencies in April 2013. This revision updates operational contractual responsibilities, facility nomenclature, and tables used to demonstrate compliance with the radionuclide NESHAP.

The TDEC-Knoxville Office, Clean Air Compliance, completed the Y-12 annual Clean Air Compliance inspection on June 19 and 20, 2013. This is the 10th consecutive year in which no noncompliance findings were identified.

Ambient air monitoring, while not specifically required by any permit condition, is conducted at the Y-12 Complex to satisfy DOE order requirements, as a best management practice, and/or to provide evidence of sufficient programmatic control of certain emissions. Ambient air monitoring conducted specifically for the Y-12 Complex (i.e., mercury monitoring) is supplemented by additional monitoring conducted for ORR and by both on-site and off-site monitoring conducted by TDEC.

Section 4.4 provides detailed information on 2013 activities conducted at Y-12 in support of CAA.

\subsubsection{Clean Water Act Compliance Status}

During 2013 the Y-12 Complex continued its excellent record for compliance with the NPDES water discharge permit. Data obtained as part of the NPDES program are provided in a monthly report to TDEC. The percentage of compliance with permit requirements for 2013 was $>99.9 \%$. About 3,100 data points were obtained from sampling required by the NPDES permit; only two noncompliances were reported. The Y-12 NPDES permit in effect during 2013 (TN0002968) was issued on October 31, 2011, and became effective on December 1, 2011. It will expire on November 30, 2016.

The effluent limitations contained in the permit are based on the protection of water quality in the receiving streams. The permit emphasizes biological, toxicological, and radiological monitoring of storm water runoff.

Some of the key requirements and changes incorporated in the current permit are summarized below.

- The current NPDES permit continues to place emphasis on chlorine limitations based on water quality criteria at headwater outfalls 200 and 135 . Outfall 125 is a storm water outfall and no longer requires dechlorination or toxicity testing.

- Whole effluent toxicity testing continues to be required at outfalls 200 and 135.

- The frequency of measurement for flow, $\mathrm{pH}$, and chlorine at the small categorical outfalls has been reduced, and there has been a minor reduction in the number of parameters and measuring frequency at major outfalls.

- NPDES monitoring continues instream at two EFPC locations (station 17 and monitoring location C11).

- Requirements for monitoring and reporting of mercury at station 17 have been increased.

- The Y-12 NPDES permit requires implementation of a radiological monitoring plan for the sampling and reporting of uranium and other isotopes at pertinent locations.

- An annual biological monitoring abatement plan and associated sampling is required. 
- The Y-12 permit requires implementation of an SWPPP, which requires sampling and characterization of storm water.

- Storm water sampling of stream-based sediment at four instream locations and an annual storm water monitoring report are completed each year as required by the SWPPP.

- Requirement to manage the flow of EFPC such that a minimum of 5 million gal/day ( 19 million L/day) is guaranteed by adding raw water from the Clinch River to the headwaters of EFPC.

The permit also included requirements for DOE to perform several activities to reduce the site mercury discharges. Substantial reductions in mercury loading are dependent on DOE successfully completing several cleanup projects previously identified in a CERCLA decision document. In November 2011 DOE filed an appeal to remove the performance of CERCLA actions, most of which were already subject to implementation under the Environmental Management Program under the ORR FAA. See Section 4.8.2 for details of the Mercury Reduction Project to facilitate reduction and lessen mobility of mercury at the Y-12 Complex. Removal of mercury from some storm drain locations has occurred and is noted in Section 4.5.2.

\subsubsection{Safe Drinking Water Act Compliance Status}

The City of Oak Ridge supplies potable water to the Y-12 Complex that meets all federal, state, and local standards for drinking water. The water treatment plant, located north of the Y-12 Complex, is owned and operated by the city of Oak Ridge.

The Tennessee Regulations for Public Water Systems and Drinking Water Quality, Chap.1200-5-1, set limits for biological contaminants and for chemical activities and chemical contaminants. Sampling for total coliform, chlorine residuals, lead, copper, and disinfectant by-product is conducted by the Y-12 Utilities Management Organization.

In 2013 the Y-12 Complex potable water system retained its approved status for potable water with TDEC. All total coliform samples collected during 2013 were analyzed by the State of Tennessee laboratory, and the results were negative. Analytical results for disinfectant by-products (total trihalomethanes and haloacetic acids) for Y-12 Complex water systems were below TDEC and Safe Drinking Water Act (SDWA) limits. The Y-12 Complex potable water system is currently sampled triennially for lead and copper, and the system sampling was last completed in 2011. These results were below TDEC and SDWA limits and met the established requirements.

\subsubsection{Resource Conservation and Recovery Act Compliance Status}

RCRA regulates hazardous wastes that, if mismanaged, could present risks to human health or the environment. The regulations are designed to ensure that hazardous wastes are managed from the point of generation to final disposal. In Tennessee, EPA delegates the RCRA program to TDEC, but EPA retains an oversight role. The Y-12 Complex is considered a large-quantity generator because it may generate more than $1,000 \mathrm{~kg}(2,205 \mathrm{lb})$ of hazardous waste in a month and because it has RCRA permits to store hazardous wastes for up to 1 year before shipping off the site to licensed treatment and disposal facilities. The Y-12 Complex also has a number of satellite accumulation areas (SAAs) and 90-day waste storage areas.

Mixed wastes are materials that are both hazardous (under RCRA guidelines) and radioactive. The Federal Facilities Compliance Act (1992) requires that DOE work with local regulators to develop a site treatment plan to manage mixed waste. Development of the plan has two purposes: to identify available treatment technologies and disposal facilities (federal or commercial) that are able to manage mixed waste produced at federal facilities and to develop a schedule for treating and disposing of the waste streams.

The ORR site treatment plan is updated annually and submitted to TDEC for review. The current plan (TDEC 2012) documents the mixed-waste inventory and describes efforts undertaken to seek new commercial treatment and disposal outlets for various waste streams. NNSA has developed a disposition schedule for the mixed waste in storage and will continue to maintain and update the plan as a reporting 
mechanism as progress is made. The Y-12 Complex has developed new disposition milestones to address its remaining inventory of legacy mixed waste. Disposition milestones for this final inventory are in fiscal years from 2014 through 2018 (see Fig.4.16).

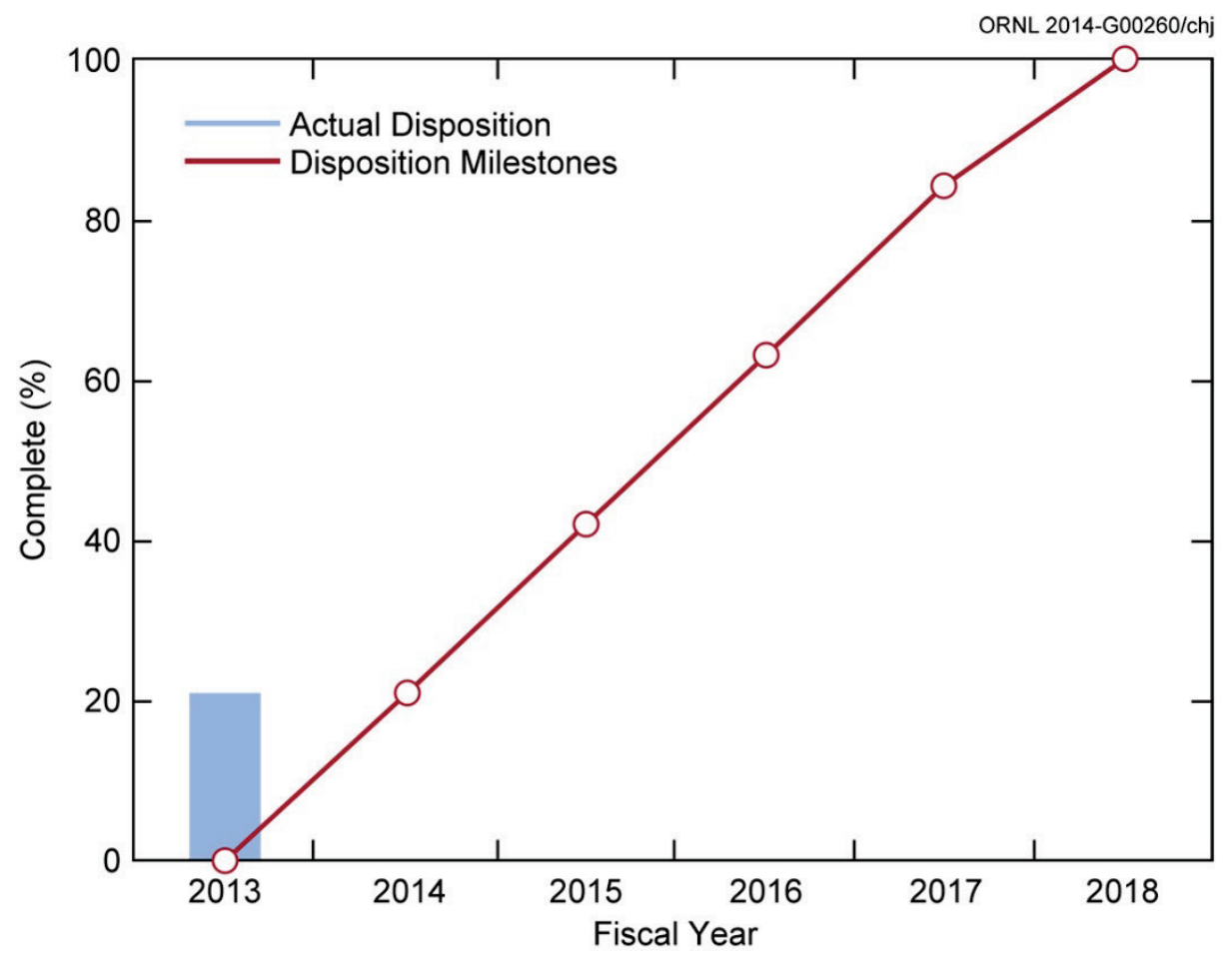

Fig. 4.16. Y-12 National Security Complex path to elimination of inventory of legacy mixed waste as part of the Oak Ridge Reservation site treatment plan.

The quantity of hazardous and mixed wastes generated by the Y-12 Complex decreased in 2013 (Fig. 4.17). Ninety-seven percent of the total hazardous and mixed waste generated in 2013 was generated as contaminated leachate from legacy operations. The Y-12 Complex currently reports waste on 83 active waste streams. The Y-12 Complex is a state-permitted treatment, storage, and disposal facility. Under its permits, the Y-12 Complex received 1,495 kg (3,296 lb) of hazardous and mixed waste from the off-site Union Valley analytical chemistry laboratory in 2013. In addition, 163,596 kg (360,647 lb) of hazardous and mixed waste was shipped to DOE-owned and commercial treatment, storage, and disposal facilities. More than 8 million $\mathrm{kg}$ (18 million $\mathrm{lb})$ of hazardous and mixed wastewater was treated at on-site wastewater treatment facilities.

TDEC conducted a comprehensive inspection of the Y-12 Complex hazardous waste program in November 2013, including permitted storage facilities, SAAs, and 90-day accumulation areas. Three alleged violations were observed during the inspection. The three issues identified were an open satellite waste container, an unlabeled satellite waste container, and unlabeled used oil containers. All issues were immediately corrected and were verified to be corrected by the TDEC inspector. These issues were of an administrative nature, and there was no potential for environmental insult. 


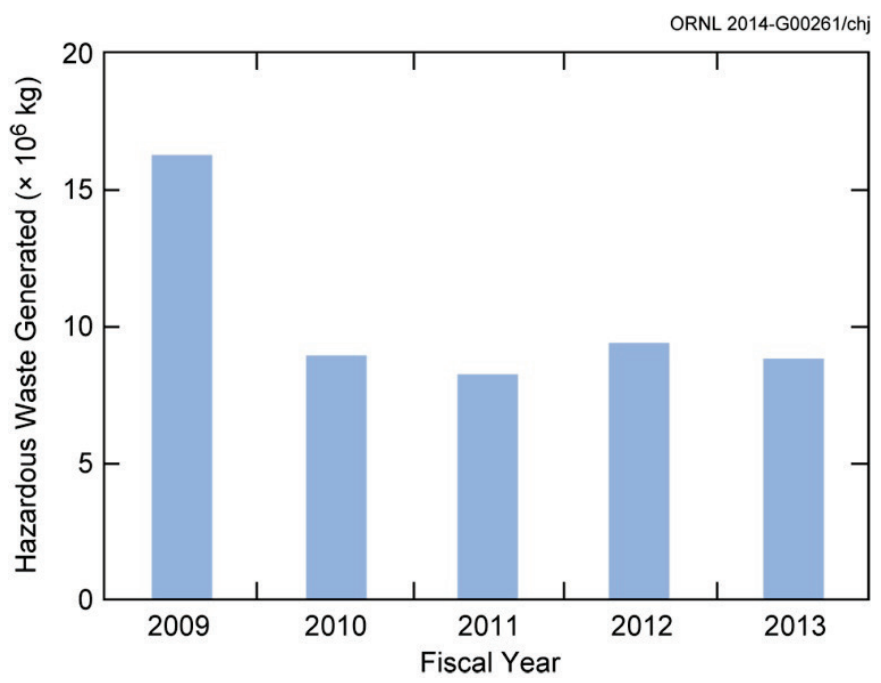

Fig. 4.17. Hazardous waste generation, 2009-2013.

\subsubsection{Resource Conservation and Recovery Act Underground Storage Tanks}

TDEC regulates the active petroleum USTs at the Y-12 Complex. Existing UST systems that are to remain in service at the Y-12 Complex must comply with performance requirements described in TDEC UST regulations (TN 0400-18-01).

Closure and removal of two petroleum USTs at the East End Fuel Station was completed in August 2012. There are no petroleum USTs remaining at Y-12.

\subsubsection{Resource Conservation and Recovery Act Subtitle D Solid Waste}

The ORR landfills operated by the DOE Office of Environmental Management program are located within the boundary of the Y-12 Complex. The facilities include two Class II operating industrial solid waste disposal landfills and one operating Class IV construction demolition landfill. The facilities are permitted by TDEC and accept solid waste from DOE operations on ORR. In addition, one Class IV facility (Spoil Area 1) is overfilled by $8,945 \mathrm{~m}^{3}\left(11,700 \mathrm{yd}^{3}\right)$ and has been the subject of a CERCLA RI/FS. A CERCLA ROD for Spoil Area 1 was signed in 1997. One Class II facility (Landfill II) has been closed and is subject to postclosure care and maintenance. Associated TDEC permit numbers are noted in Table 4.5. Additional information about the operation of these landfills is addressed in Section 4.8.3, "Waste Management."

\subsubsection{Resource Conservation and Recovery Act-Comprehensive Environmental Response, Compensation, and Liability Act Coordination}

The ORR FFA is intended to coordinate the corrective action processes of RCRA required under the Hazardous Waste Corrective Action permit (formerly known as the Hazardous and Solid Waste Amendments permit) with CERCLA response actions.

Three RCRA postclosure permits, one for each of the three hydrogeologic regimes at the Y-12 Complex, have been issued to address the eight major closed waste disposal areas at the Y-12 Complex. Because it falls under the jurisdiction of two postclosure permits, the S-3 pond site is described as having two parts, eastern and former S-3 (Table 4.6). Groundwater corrective actions required under the postclosure permits have been deferred to CERCLA. RCRA groundwater monitoring data were reported to TDEC and EPA in the annual groundwater monitoring report for the Y-12 Complex (UCOR 2013).

Periodic updates of proposed C\&D activities at the Y-12 Complex (including alternative financing projects) have been provided to managers and project personnel from the TDEC DOE Oversight Division and EPA Region 4. A CERCLA screening process is used to identify proposed C\&D projects that warrant CERCLA oversight. The goal is to ensure that modernization efforts do not impact the effectiveness of 
previously completed CERCLA environmental remediation actions and that they do not adversely impact future CERCLA environmental remediation actions.

Table 4.6. Y-12 National Security Complex Resource Conservation and Recovery Act postclosure status for former treatment, storage, and disposal units on the Oak Ridge Reservation

\begin{tabular}{ccc}
\hline Unit & Major components of closure & Major postclosure requirements \\
\hline & Upper East Fork Poplar Creek Hydrogeologic Regime \\
(RCRA Postclosure Permit TNHW-113)
\end{tabular}

New Hope Pond

Engineered cap, upper East Fork Poplar Creek distribution channel

Eastern S-3 ponds groundwater plume

None for groundwater plume, see former S-3 Ponds (S-3 Site) for source area closure
Cap inspection and maintenance. No current groundwater monitoring requirements in lieu of ongoing CERCLA actions in the eastern portion of Y-12 Complex

Postclosure corrective action monitoring. Inspection and maintenance of monitoring network

\section{Chestnut Ridge Hydrogeologic Regime (RCRA Postclosure Permit TNHW-128)}

Chestnut Ridge Engineered cap

security pits

Kerr Hollow

Quarry

Chestnut Ridge

sediment disposal

basin

East Chestnut

Ridge Waste Pile
Waste removal, access controls

Engineered cap

Engineered cap
Cap inspection and maintenance. Postclosure corrective action monitoring. Inspection and maintenance of monitoring network and survey benchmarks

Access controls inspection and maintenance. Postclosure detection monitoring. Inspection and maintenance of monitoring network and survey benchmarks

Cap inspection and maintenance. Postclosure detection monitoring. Inspection and maintenance of monitoring network and survey benchmarks

Cap inspection and maintenance. Postclosure detection monitoring. Inspection and maintenance of monitoring network, leachate collection sump, and survey benchmarks. Management of leachate

\section{Bear Creek Hydrogeologic Regime (RCRA Postclosure Permit TNHW-116)}

Former S-3 ponds (s-3 pond site)

Oil landfarm

Bear Creek Burial Grounds: A-North, A-South, and C-West and the walk-in pits
Neutralization and stabilization of wastes, engineered cap, asphalt cover

Engineered cap

Engineered cap, leachate collection system specific to the burial grounds
Cap inspection and maintenance. Postclosure corrective action monitoring. Inspection and maintenance of monitoring network and survey benchmarks

Cap inspection and maintenance. Postclosure corrective action monitoring. Inspection and maintenance of monitoring network and survey benchmarks

Cap inspection and maintenance. Postclosure corrective action monitoring. Inspection and maintenance of monitoring network and survey benchmarks

\footnotetext{
Abbreviations

CERCLA $=$ Comprehensive Environmental Response, Compensation, and Liability Act

ORR $=$ Oak Ridge Reservation

RCRA $=$ Resource Conservation and Recovery Act

Y-12 Complex = Y-12 National Security Complex
} 


\subsubsection{Toxic Substances Control Act Compliance Status}

The storage, handling, and use of PCBs are regulated under TSCA. Capacitors manufactured before 1970 that are believed to be oil-filled are handled as though they contained PCBs, even when that cannot be verified from manufacturer records. Certain equipment containing PCBs and PCB waste containers must be inventoried and labeled. The inventory is updated by July 1 of each year and was last submitted June 5, 2013.

Given the widespread historical uses of PCBs at the Y-12 Complex and fissionable material requirements that must be met, an agreement between EPA and DOE was negotiated to assist ORR facilities in becoming compliant with TSCA regulations. This agreement, known as the "Oak Ridge Reservation Polychlorinated Biphenyl Federal Facilities Compliance Agreement" (ORR PCB FFCA), which became effective in 1996, provides a forum with which to address PCB compliance issues that are truly unique to these facilities. Y-12 Complex operations involving TSCA-regulated materials were conducted in accordance with TSCA regulations and the ORR PCB FFCA.

The removal of legacy PCB waste, some of which had been stored since 1997, in accordance with the terms of the ORR PCB FFCA, was completed in 2011.

\subsubsection{Emergency Planning and Community Right-to-Know Act Compliance Status}

EPCRA requires that facilities report inventories (i.e., Tier II report sent to state and local emergency responders) and releases (i.e., toxic release inventory report submitted to state and federal environmental agencies) of certain chemicals that exceed specified thresholds. The Y-12 Complex submitted reports in 2013 in accordance with requirements under EPCRA Sections 302, 303, 311, 312, and 313.

The Y-12 Complex had no unplanned releases of extremely hazardous substances as defined by EPCRA in 2013. One Section 311 notification was sent to TEMA and local emergency responders in 2013 because a chemical newly exceeded the reporting threshold. The chemical was not new to Y-12 operations, but it was the first time it had exceeded inventory thresholds. Inventories, locations, and associated hazards of over-threshold hazardous and extremely hazardous chemicals were submitted to TEMA and local emergency responders in the annual Tier II report required by Section 312. Data submittal was through the E-Plan web-based reporting system, as requested by TEMA. Some local emergency responders also accepted data through the E-Plan system, but others still require paper copies of the Tier II reports. Y-12 reported 51 chemicals that were over Section 312 inventory thresholds in 2013.

Y-12 Complex operations are evaluated annually to determine the applicability for submittal of a toxic release inventory report to TEMA and EPA in accordance with EPCRA Section 313 requirements. The amounts of certain chemicals manufactured, processed, or otherwise used are calculated to identify those that exceed reporting thresholds. After threshold determinations are made, releases and off-site transfers are calculated for each chemical that exceeds a threshold. Submittal of the data to TEMA and EPA is made through the TRI-MEweb (Toxics Release Inventory-Made Easy) web-based reporting system operated by EPA. Total 2013 reportable toxic releases to air, water, and land and waste transferred off-site for treatment, disposal, and recycling were 42,454 kg $(92,341 \mathrm{lb})$. Table 4.7 lists the reported chemicals for the Y-12 Complex for 2012 and 2013 and summarizes releases and off-site waste transfers for those chemicals. 
Table 4.7. Emergency Planning and Community Right-to-Know Act

Section 313 toxic chemical release and off-site transfer summary

for the Y-12 National Security Complex, 2012 and 2013

\begin{tabular}{|c|c|c|}
\hline Chemical & Year & $\begin{array}{c}\text { Quantity }^{c} \\
\text { (lb) }\end{array}$ \\
\hline \multirow[t]{2}{*}{ Chromium } & 2012 & 1,447 \\
\hline & 2013 & 9,442 \\
\hline \multirow[t]{2}{*}{ Copper } & 2012 & 9,474 \\
\hline & 2013 & 31,586 \\
\hline \multirow[t]{2}{*}{ Lead compounds } & 2012 & 5,182 \\
\hline & 2013 & 13,313 \\
\hline \multirow[t]{2}{*}{ Manganese } & 2012 & 5,540 \\
\hline & 2013 & $c$ \\
\hline \multirow[t]{2}{*}{ Mercury } & 2012 & 981 \\
\hline & 2013 & 6,973 \\
\hline \multirow[t]{2}{*}{ Methanol } & 2012 & 12,941 \\
\hline & 2013 & 23,233 \\
\hline \multirow[t]{2}{*}{ Nickel } & 2012 & 12,439 \\
\hline & 2013 & 9,047 \\
\hline \multirow[t]{2}{*}{ Total } & 2012 & 48,004 \\
\hline & 2013 & 93,594 \\
\hline
\end{tabular}

${ }^{a}$ Represents total releases to air, land, and water and includes off-site waste transfers. Also includes quantities released to the environment as a result of remedial actions, catastrophic events, or one-time events not associated with production processes.

${ }^{b} 1 \mathrm{lb}=0.4536 \mathrm{~kg}$.

${ }^{c}$ Not reported for the year (i.e., below threshold).

\subsubsection{Spill Prevention, Control, and Countermeasures}

CWA Section 311 regulates the discharge of oils or petroleum products to waters of the United States and requires the development and implementation of spill prevention, control, and countermeasures (SPCC) plans to minimize the potential for oil discharges. The major requirements for SPCC plans are contained in Title 40 CFR Part 112. These regulations require that SPCC plans be reviewed, evaluated, and amended at least once every 5 years, or earlier if significant changes occur. The SPCC rule includes requirements for oil spill prevention, preparedness, and response to prevent oil discharges to navigable waters and adjoining shorelines. The rule requires specific facilities to prepare, amend, and implement SPCC plans.

The Y-12 Complex SPCC plan (B\&W Y-12 2010) was last revised in September 2010 to update general Y-12 Complex spill prevention techniques and changing site infrastructure. This plan presents the SPCC to be implemented by the Y-12 Complex to prevent spills of oil and hazardous constituents and the countermeasures to be invoked should a spill occur. In general, the first response of an individual discovering a spill is to call the plant shift superintendent. Spill response materials and equipment are stored near tanks and drum storage areas and other strategic areas of the Y-12 Complex to facilitate spill response. All Y-12 Complex personnel and subcontractors are required to have initial spill and emergency response training before they can work on the site. This training is received as part of the GET program.

During the 2012-2013 period improvements were made in the way the Y-12 Complex trains employees that handle or manage oil and liquids that contain oil, allowing for updated information and 
improved accountability. A new review of the current Y-12 SPCC plan was begun in late 2013. The review will be completed in 2014, and a revised SPCC plan is scheduled to be issued by early 2015.

\subsubsection{Unplanned Releases}

The Y-12 Complex has procedures for notifying off-site authorities for categorized events at the Y-12 Complex. Off-site notifications are required for specified events according to federal statutes, DOE orders, and TOA. As an example, any observable oil sheen on EFPC and any release impacting surface water must be reported to the EPA National Response Center in addition to other reporting requirements. Spills of CERCLA RQ limits must be reported to the EPA National Response Center, DOE, TEMA, and the Anderson County Local Emergency Planning Committee.

In addition, the Y-12 occurrence reporting program provides timely notification to the DOE community of Y-12 Complex events and site conditions that could adversely affect the public or worker health and safety, the environment, national security, DOE safeguards and security interests, functioning of DOE facilities, or the department's reputation.

Y-12 Complex occurrences are categorized and reported through the Occurrence Reporting and Processing System (ORPS). ORPS provides NNSA and the DOE community with a readily accessible database of information about occurrences at DOE facilities, causes of those occurrences, and corrective actions to prevent recurrence of the events. DOE analyzes aggregate occurrence information for generic implications and operational improvements.

During CY 2013 there were no releases of hazardous substances exceeding an RQ nor were there any observed oil sheens on EFPC. There was a reportable occurrence [NA--YSO-BWXT-Y12SITE-20130011] due to a potable waterline break that occurred on June 8, 2013. Chlorinated water from the point of the break entered the storm drain system and resulted in a fish kill (see Section 4.5.1).

\subsubsection{Audits and Oversight}

A number of federal, state, and local agencies oversee Y-12 Complex activities. In 2013, the Y-12 Complex was inspected by federal, state, or local regulators on four occasions.

As part of the City of Oak Ridge's pretreatment program, city personnel collect samples from the Y-12 monitoring station to conduct compliance monitoring as required by the pretreatment regulations. City personnel also conduct twice yearly compliance inspections. No issues were identified in 2013. It was requested in the August report that Y-12 personnel continue the flow mitigation work already identified and the investigation of new sources of inflow and infiltration.

A TDEC-Knoxville Office Clean Air Compliance auditor completed the Annual Clean Air Compliance inspection on June 19 and 20, 2013, for 19 air emission sources located at the Y-12 Complex. For the 10th consecutive year, no findings were noted.

TDEC conducted a comprehensive inspection of the Y-12 Complex hazardous waste program in November 2013, including permitted storage facilities, SAAs, and 90-day accumulation areas. Three alleged violations were observed during the inspection. The three issues identified were an open satellite waste container, an unlabeled satellite waste container, and unlabeled used oil containers. All issues were immediately corrected and were verified to be corrected by the TDEC inspector. These issues were of an administrative nature, and there was no potential for environmental insult.

Table 4.8 provides a summary of external regulatory audits and reviews for 2013 . 
Table 4.8. Summary of external regulatory audits and reviews, 2013

\begin{tabular}{lclc}
\hline \multicolumn{1}{c}{ Date } & Reviewer & \multicolumn{1}{c}{ Subject } & Issues \\
\hline March 14 & City of Oak Ridge & Semiannual Industrial Pretreatment Compliance & \multirow{2}{*}{ Inspection } \\
June 19-20 & TDEC-Knoxville & Annual CAA Compliance Audit & 0 \\
August 7 & City of Oak Ridge & Semiannual Industrial Pretreatment Compliance & 0 \\
November 4-5 & TDEC & Inspection & 3 \\
\hline
\end{tabular}

Abbreviations

$\mathrm{CAA}=$ Clean Air Act

RCRA $=$ Resource Conservation and Recovery Act

TDEC $=$ Tennessee Department of Environment and Conservation

\subsubsection{Radiological Release of Property}

Clearance of property from the Y-12 Complex is conducted in accordance with approved procedures that comply with DOE O 458.1, Radiation Protection of the Public and the Environment (DOE 2011b). Property consists of real property (i.e., land and structures), personal property, and material and equipment (M\&E). At the Y-12 Complex there are three paths for releasing property to the public based on the potential for radiological contamination:

- $\quad$ survey and release of property potentially contaminated on the surface (using preapproved authorized limits for releasing property),

- evaluation of materials with a potential to be contaminated in volume (volumetric contamination) to ensure no radioactivity has been added, and

- evaluation using process knowledge (surface and volumetric).

These three release paths are discussed below. Table 4.9 summarizes some examples of the quantities of property released in 2013. During FY 2013, Y-12 recycled more than 2.27 million lb of materials off the site for reuse, including but not limited to computers, electronic office equipment, used oil, scrap metal, tires, batteries, lamps, and pallets.

Table 4.9. Summary of materials released in 2013

\begin{tabular}{lc}
\hline \multicolumn{1}{c}{ Category } & Amount released \\
\hline Real property (land and structures) & None \\
Computer Recycle & \\
- towers/laptops & $17,891 \mathrm{lb}$ \\
- mainframe equipment & $5,835 \mathrm{lb}$ \\
- monitors & $11,148 \mathrm{lb}$ \\
- printers and peripherals & $24,674 \mathrm{lb}$ \\
Electronic Office Equipment Recycle & \\
- used office items & \\
- telecommunications equipment & $4,688 \mathrm{lb}$
\end{tabular}


Table 4.9 (continued)

\begin{tabular}{lc}
\hline \multicolumn{1}{c}{ Category } & Amount released \\
\hline Public Sales $^{b}$ & \\
- graphite & $49,756 \mathrm{lb}$ \\
- copper & $20,011 \mathrm{lb}$ \\
- aluminum and stainless steel & $44,960 \mathrm{lb}$ \\
- miscellaneous furniture & $272,473 \mathrm{lb}$ \\
- vehicles & 37 \\
External Transfers $^{c}$ & $404,311 \mathrm{lb}$ \\
\hline
\end{tabular}

${ }^{a}$ Items such as typewriters, telephones, shredders, calculators, laminators. overhead projectors, etc.

${ }^{b}$ Sales during FY 2013.

${ }^{c}$ Vehicles, miscellaneous equipment and materials transferred to various federal, state, and local agencies for reuse during FY 2013.

\section{Property Potentially Contaminated on the Surface}

Property that is potentially contaminated on the surface is subject to a complete survey unless it can be released based on process knowledge or a Multi-Agency Radiation Survey and Site Investigation Manual (MARSSIM)/Multi-Agency Radiation Survey and Assessment of Materials and Equipment Manual (MARSAME) $^{*}$ (NRC 2000 and 2009) survey plan that provides survey instructions along with the technical (process knowledge) justification for the survey plan. The surface contamination limits used at the Y-12 Complex to determine whether M\&E are suitable for release to the public are provided in Table 4.10.

Y-12 uses an administrative limit for total activity of $2,400 \mathrm{dpm} / 100 \mathrm{~cm}^{2}$ for radionuclides in groups 3 and 4. The use of the more restrictive administrative limits ensures that M\&E do not enter into commerce exceeding the 49 CFR 173, Shippers-General Requirements for Shipments and Packagings, definition of "contamination."

\section{Property Potentially Contaminated in Volume (Volumetric Contamination)}

Materials such as activated materials, smelted contaminated metals, liquids, and powders are subject to volumetric contamination (e.g., radioactivity per unit volume or per unit mass) and are treated separately from surface contaminated objects. No authorized volumetric contamination limits have been approved for material released from the Y-12 Complex. Materials that are subject to volumetric contamination are evaluated for release by the following three methods.

1. Unopened, Sealed Containers-Material is still in an original commercial manufacturer's sealed, unopened container. A seal can be a visible manufacturer's seal (i.e., lock tabs, heat shrink) or a manufacturer's seal that cannot be seen (i.e., unbroken fluorescent bulbs, sealed capacitors, etc.), as long as the container remains unopened once received from the manufacturer.

2. Process Knowledge - If it can be determined that there is no likelihood of contamination being able to enter a system then this is documented and used to justify release; then the basis for release is documented. Often this is accompanied by confirmatory surveys.

3. Analytical-The material is sampled and the analytical results are evaluated against measurement method critical levels or background levels from materials that have not been impacted by

\footnotetext{
"The Multi-Agency Radiation Survey and Site Investigation Manual (MARSSIM) provides guidance on how to demonstrate that a site is in compliance with a radiation dose or risk-based regulation, otherwise known as a release criterion. The Multi-Agency Radiation Survey and Assessment of Materials and Equipment manual is a supplement to MARSSIM that provides technical information on approaches for determining proper disposition of materials and equipment.
} 
Y-12 Complex activities. If the results meet defined criteria, then they are documented and the material released.

Table 4.10. DOE O 458.1 preapproved authorized limits ${ }^{a, b}$

\begin{tabular}{|c|c|c|c|}
\hline Radionuclide $^{c}$ & Average $^{d, e}$ & Maximum $^{d, e}$ & Removable $^{f}$ \\
\hline 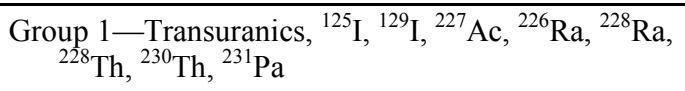 & 100 & 300 & 20 \\
\hline $\begin{array}{l}\text { Group } \\
{ }^{232} \mathrm{U},{ }^{232} \mathrm{Th}\end{array}$ & 1,000 & 3,000 & 200 \\
\hline $\begin{array}{l}\text { Group } 3-\mathrm{U}-\mathrm{Natural},{ }^{235} \mathrm{U},{ }^{238} \mathrm{U} \text {, associated decay } \\
\text { products, alpha emitters }\end{array}$ & 5,000 & 15,000 & 1,000 \\
\hline $\begin{array}{l}\text { Group } 4 \text { - Beta-gamma emitters (radionuclides with d } \\
\text { modes other than alpha emission or spontaneous } \\
\text { fission) except }{ }^{90} \mathrm{Sr} \text { and others noted above }{ }^{g}\end{array}$ & 5,000 & 15,000 & 1,000 \\
\hline Tritium (applicable to surface and subsurface) ${ }^{h}$ & Not applicable & Not applicable & 10,000 \\
\hline
\end{tabular}

${ }^{a}$ The values in this table (except for tritium) apply to radioactive material deposited on but not incorporated into the interior or matrix of the property. No generic concentration guidelines have been approved for release of material that has been contaminated in depth, such as activated material or smelted contaminated metals (e.g., radioactivity per unit volume or per unit mass). Authorized limits for residual radioactive material in volume must be approved separately.

${ }^{b}$ As used in this table, dpm (disintegrations per minute) means the rate of emission by radioactive material as determined by counts per minute measured by an appropriate detector for background, efficiency, and geometric factors associated with the instrumentation.

${ }^{c}$ Where surface contamination by both alpha-emitting and beta-gamma-emitting radionuclides exists, the limits established for alpha-emitting and beta-gamma-emitting radionuclides should apply independently.

${ }^{d}$ Measurements of average contamination should not be averaged over an area of more than $1 \mathrm{~m}^{2}$. Where scanning surveys are not sufficient to detect levels in the table, static counting must be used to measure surface activity. Representative sampling (static counts on the areas) may be used to demonstrate by analyses of the static counting data. The maximum contamination level applies to an area of not more than $100 \mathrm{~cm}^{2}$.

${ }^{e}$ The average and maximum dose rates associated with surface contamination resulting from beta-gamma emitters should not exceed $0.2 \mathrm{millirad}$ per hour $(\mathrm{mrad} / \mathrm{h})$ and $1.0 \mathrm{mrad} / \mathrm{h}$, respectively, at $1 \mathrm{~cm}$.

${ }^{f}$ The amount of removable material per $100 \mathrm{~cm}^{2}$ of surface area should be determined by wiping an area of that size with dry filter or soft absorbent paper, applying moderate pressure, and measuring the amount of radioactive material on the wiping with an appropriate instrument of known efficiency. When removable contamination of objects on surfaces of less than $100 \mathrm{~cm}^{2}$ is determined, the activity per unit area should be based on the actual area, and the entire surface should be wiped. It is not necessary to use wiping techniques to measure removable contamination levels if direct scan surveys indicate the total residual surface contamination levels are within the limits for removable contamination.

${ }^{g}$ This category of radionuclides includes mixed fission products, including the ${ }^{90} \mathrm{Sr}$ that is present in them. It does not apply to ${ }^{90} \mathrm{Sr}$ that has been separated from the other fission products or mixtures where the ${ }^{90} \mathrm{Sr}$ has been enriched.

${ }^{h}$ Measurement should be conducted by a standard smear measurement but using a damp swipe or material that will readily absorb tritium, such as polystyrene foam. Property recently exposed or decontaminated should have measurements (smears) at regular time intervals to prevent a buildup of contamination over time. Because tritium typically penetrates material it contacts, the surface guidelines in group 4 do not apply to tritium. Measurements demonstrating compliance of the removable fraction of tritium on surfaces with this guideline are acceptable to ensure nonremovable fractions and residual tritium in mass will not cause exposures that exceed DOE dose limits and constraints.

\section{Abbreviations}

$\mathrm{N} / \mathrm{A}=$ not applicable

Source: Vázquez 2011.
DOE $=$ US Department of Energy

\section{Process Knowledge}

Process knowledge is used to release property from the Y-12 Complex without monitoring or analytical data and to implement a graded approach (less than $100 \%$ monitoring) for monitoring of some M\&E (MARSAME Classes II and III). A conservative approach (nearly 100\% monitoring) is used to release older $M \& E$ for which a complete and accurate history is difficult to compile and verify (MARSAME Class I). The process knowledge evaluation processes are described in Y-12 Complex procedures. 
The following M\&E are released without monitoring based on process knowledge; this does not preclude conducting verification monitoring, for example, before sale.

- All M\&E from buildings evaluated and designated as "RAD-Free Zones"

- Pallets generated from administrative buildings

- Pallets that are returned to shipping during the same delivery trip

- Lamps from administrative buildings

- M\&E approved for release from Nonradioactive Material Management Areas

- Porta-potties used in nonradiological areas

- Documents, mail, diskettes, compact disks, and other office media; personal M\&E; paper, plastic products, water bottles, ABCs, and toner cartridges; office trash, house-keeping materials, and associated waste; breakroom, cafeteria, and medical wastes; and medical and bioassay samples generated in nonradiological areas

- Subcontractor/vendor/privately owned vehicles, tools, and equipment used in nonradiological areas

- M\&E that are administratively released.

\subsection{Air Quality Program}

Sections of the Y-12 Complex Title V permit 562767 contain requirements that are generally applicable to most industrial sites. Examples include requirements associated with asbestos controls, control of stratospheric ozone-depleting chemicals, control of fugitive emissions, and general administration of the permit. The Title $\mathrm{V}$ permit also contains a section of specific requirements directly applicable to individual sources of air emissions at the Y-12 Complex. Major requirements in that section include the Rad-NESHAPs (40 CFR 61) requirements and the numerous requirements associated with emissions of criteria pollutants and other HAPs (nonradiological). In addition, a number of sources that are exempt from permitting requirements under state rules but subject to listing on the Title V permit application are documented, and information about them is available upon request from the state.

\subsubsection{Construction and Operating Permits}

In 2013 the Y-12 Complex had no construction air permits issued by TDEC. However, one construction permit application and one minor modification permit application were submitted to TDEC for review and approval. The construction permit application for UPF was submitted on July 9, 2013. The minor modification permit application was submitted on May 6, 2013, for emergency/standby engines (see Section 4.4.1.7). Other notable permit notifications or requests included (1) a general notification of change to a permitted emission source to replace two old, obsolete machines with new, similar machines; (2) a request to incorporate the undated NESHAP compliance plan (DOE 2013a) into the Title V operating permit; and (3) submittal of initial notification for the boiler Maximum Achievable Control Technology (MACT) requirements.

Permit administration fees are paid to TDEC annually in support of the Title V program. B\&W Y-12 has chosen to pay the fees based on a combination of actual emissions (steam plant, methanol, solvent 140 VOC) and allowable emissions (balance of plant). In 2013, emissions categorized as actual emissions totaled 40,534 kg (44.68 tons), and emissions calculated by the allowable method totaled $639,966 \mathrm{~kg}$ (705.43 tons). The total emissions fee paid was $\$ 22,504.90$.

Demonstrating compliance with the conditions of air permits is a significant effort at the Y-12 Complex. Key elements of maintaining compliance are maintenance and operation of control devices, monitoring, record keeping, and reporting. High-efficiency particulate air (HEPA) filters and scrubbers are control devices used at the Y-12 Complex. HEPA filters are found throughout the complex, and inplace testing of HEPA filters to verify the integrity of the filters is routinely performed. Scrubbers are operated and maintained in accordance with source-specific procedures. Monitoring consists of tasks such as continuous stack sampling, one-time stack sampling, and monitoring the operation of control devices. Examples of continuous stack sampling are the radiological stack monitoring systems on numerous sources throughout the complex. 
The Y-12 Complex sitewide permit requires annual and semiannual reports. One report is the overall annual ORR Rad-NESHAPs report (DOE 2014), which includes specific information regarding Y-12 Complex radiological emissions; the second is an annual Title V compliance certification report indicating compliance status with all conditions of the permit. The third is a Title V semiannual report which covers a 6-month period for some specific emission sources. It consists of monitoring and recordkeeping requirements for these sources. Table 4.11 gives the actual emissions versus allowable emissions for the Y-12 Complex Steam Plant.

Table 4.11. Actual versus allowable air emissions from the Y-12 Complex Steam Plant, 2013

\begin{tabular}{|c|c|c|c|}
\hline \multirow{2}{*}{ Pollutant } & \multicolumn{2}{|c|}{ Emissions (tons/year) $^{a}$} & \multirow{2}{*}{ Percentage of allowable } \\
\hline & Actual & Allowable & \\
\hline Particulate & 4.5 & 41 & 11.0 \\
\hline Sulfur dioxide & 0.35 & 39 & 0.9 \\
\hline Nitrogen oxides ${ }^{b}$ & 18.3 & 81 & 22.6 \\
\hline $\begin{array}{l}\text { Volatile organic } \\
\text { compounds }^{b}\end{array}$ & 2.9 & 9.4 & 30.9 \\
\hline Carbon monoxide $^{b}$ & 45.4 & 139 & 32.7 \\
\hline
\end{tabular}

NOTE: The emissions are based on fuel usage data for January through December 2013. The emissions also included the fuel used during testing.

${ }^{a} 1$ ton $=907.2 \mathrm{~kg}$.

${ }^{b}$ When there is no applicable standard or enforceable permit condition for a pollutant, the allowable emissions are based on the maximum actual emissions calculation as defined in Tennessee Department of Environment and Conservation Rule 1200-3-26-.02(2)(d)3 (maximum design capacity for 8,760 h/year). Both actual and allowable emissions were calculated based on the latest US Environmental Protection Agency compilation of air pollutant emission factors (EPA 1995 and 1998).
Abbreviations
Y-12 Complex $=$ Y-12 National Security Complex

\subsubsection{Generally Applicable Permit Requirements}

The Y-12 Complex, like many industrial sites, has a number of generally applicable requirements that require management and control. Asbestos, ODSs, and fugitive particulate emissions are notable examples.

\subsection{Control of Asbestos}

The Y-12 Complex has numerous buildings and equipment that contain asbestos-containing materials. The compliance program for management of removal and disposal of asbestos-containing materials includes demolition and renovation notifications to TDEC and inspections, monitoring, and prescribed work practices for abatement and disposal of asbestos materials. There was no reportable release of asbestos in 2013. There were three notifications of asbestos demolition or renovation submitted to TDEC in 2013 for its review and records.

An internal surveillance of the asbestos NESHAP reporting process was conducted on October 28, 2013. The scope of this surveillance was focused on compliance with applicable state and federal environmental regulations, specifically reporting and record-keeping requirements for on-site demolition and renovation activities for buildings. There were no findings or deficiencies identified as a result of this surveillance. 


\subsection{Stratospheric Ozone Protection}

The Y-12 Complex Ozone Depleting Substances (ODS) Phase-Out and Management Plan (B\&W Y-12 2009) provides a complete discussion of requirements and compliance activities at the Y-12 Complex. Past ODSs reduction initiatives began in the early 1980s and focused on elimination of Class I ODS use in refrigerants and solvent cleaning operations. In 2012, the last remaining chiller system at the Y-12 Complex with Class I ODSs was taken out of service. The refrigerant from that system was sent to the Defense Logistics Agency.

Y-12 Complex initiatives have also involved elimination of ODS solvents in cleaning processes. Operations personnel developed and implemented changes in one process which eliminated ODS solvent from that process. Evaluation of ODS reduction opportunities continue for another solvent cleaning operation. Future actions related to this process will be dependent on ongoing efforts to identify a safe and viable replacement chemical or to identify practical and cost-effective modifications to process equipment.

All Class I and Class II substitutions are made in accordance with EPA's Significant New Alternatives Program (SNAP). Y-12 Complex personnel are notified as EPA issues regulations detailing SNAP replacement chemicals which may be applicable to Y-12 Complex operations. To prevent ODSs from coming on-site, procurement documents are written to ensure that no additional equipment or processes using Class I ODSs are brought on-site, and Class II ODS usage is limited wherever possible.

Site procedures are in place for disposition of excess refrigerant or refrigerant-containing equipment. Recovered refrigerant is recycled/reused in equipment in the Y-12 Complex whenever feasible. Refrigerant is recovered from refrigerant-containing equipment before disposal of the equipment. Class I ODSs which cannot be used on-site are first made available to the Defense Logistics Agency. Remaining refrigerants, including Class I and Class II ODSs, are sold to refrigerant reclamation facilities or properly disposed.

\subsection{Fugitive Particulate Emissions}

As modernization and infrastructure reduction efforts increase at the Y-12 Complex, the need also increases for good work practices and controls to minimize fugitive dust emissions from C\&D activities. Y-12 Complex personnel continue to use a mature project planning process to review, recommend, and implement appropriate work practices and controls to minimize fugitive dust emissions. Precautions used to prevent particulate matter from becoming airborne include but are not be limited to (1) use, where possible, of water or chemicals for control of dust in demolition of existing buildings or structures, construction operations, grading of roads, or the clearing of land; (2) application of asphalt, oil, water, or suitable chemicals on dirt roads, material stock piles, and other surfaces that can create airborne dusts; and (3) installation and use of hoods, fans, and fabric filters to enclose and vent the handling of dusty materials.

\subsubsection{National Emission Standards for Hazardous Air Pollutants for Radionuclides}

The release of radiological contaminants, primarily uranium, into the atmosphere at the Y-12 Complex occurs almost exclusively as a result of plant production, maintenance, and waste management activities. The major radionuclide emissions contributing to the dose from the $\mathrm{Y}-12$ Complex are ${ }^{234} \mathrm{U}$, ${ }^{235} \mathrm{U},{ }^{236} \mathrm{U}$, and ${ }^{238} \mathrm{U}$, which are emitted as particulates. The particle size and solubility class of the emissions are determined based on review of the operations and processes served by the exhaust systems to determine the quantity of uranium handled in the operation or process, the physical form of the uranium, and the nature of the operation or process. The four categories of processes or operations that are considered when calculating the total uranium emissions are

- those that exhaust through monitored stacks;

- unmonitored processes for which calculations are performed per Appendix D of 40 CFR 61; 
- processes or operations exhausting through laboratory hoods, also involving Appendix D calculations; and

- emissions from room ventilation exhausts (calculated using radiological control monitoring data from the work area).

Continuous sampling systems are used to monitor emissions from a number of process exhaust stacks at the Y-12 Complex. In addition, a probe-cleaning program is in place, and the results from the probe cleaning at each source are incorporated into the respective emission point source terms. In 2013, 33 process exhaust stacks were continuously monitored, 25 of which were major sources; the remaining 8 were minor sources. The sampling systems on these stacks have been approved by EPA Region 4 .

During 2013, unmonitored uranium emissions at the Y-12 Complex occurred from 33 emission points associated with on-site, unmonitored processes and laboratories operated by B\&W Y-12. Emission estimates for the unmonitored processes and laboratory stacks were made using inventory data with emission factors provided in 40 CFR Part 61, Appendix D. The Y-12 Complex source term includes an estimate of those unmonitored emissions.

The B\&W Y-12 Analytical Chemistry Organization operates out of two main laboratories. One is located on the site in Building 9995 and is included in the discussion above. The other is located in a leased facility on Union Valley Road, about 0.3 miles east of the Y-12 Complex, and is not within the ORR boundary. In 2013, there were no emission points (or sources) in the off-site laboratory facility.

Additionally, estimates from room ventilation systems are considered using radiological control data on airborne radioactivity concentrations in the work areas. Where applicable, exhausts from any area where the monthly concentration average exceeds $10 \%$ of the derived air concentration (DAC) as defined in the ORR radionuclide compliance plan (DOE 2013a) are included in the annual source term. Annual average concentrations and design ventilation rates are used to arrive at the annual emission estimate for those areas. Three emission points from room ventilation exhausts were identified in 2013 where emissions exceeded $10 \%$ of DAC. These emission points feed to monitored stacks, and any radionuclide emissions are accounted for as noted for monitored emission points.

The Y-12 Complex Title V Major Source Operating Permits contain a sitewide, streamlined alternate emission limit for enriched and depleted uranium process emission units. A limit of $907 \mathrm{~kg}(2,000 \mathrm{lb})$ per year of particulate was set for the sources for the purposes of paying fees. The compliance method requires the annual actual mass emission particulate emissions to be generated using the same monitoring methods required for Rad-NESHAPs compliance. An estimated 7.5E-3 Ci $(0.30 \mathrm{~kg})$ of uranium was released into the atmosphere in 2013 as a result of Y-12 Complex process and operational activities (Figs. 4.18 and 4.19).

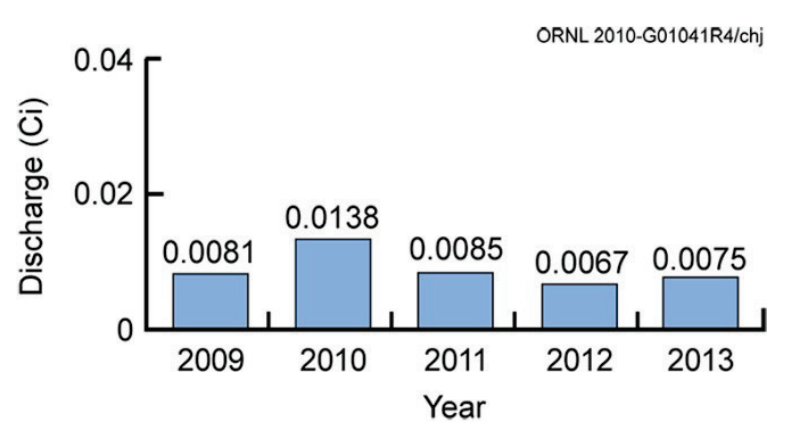

Fig. 4.18. Total curies of uranium discharged from the Y-12 Complex to the atmosphere, 2009-2013.

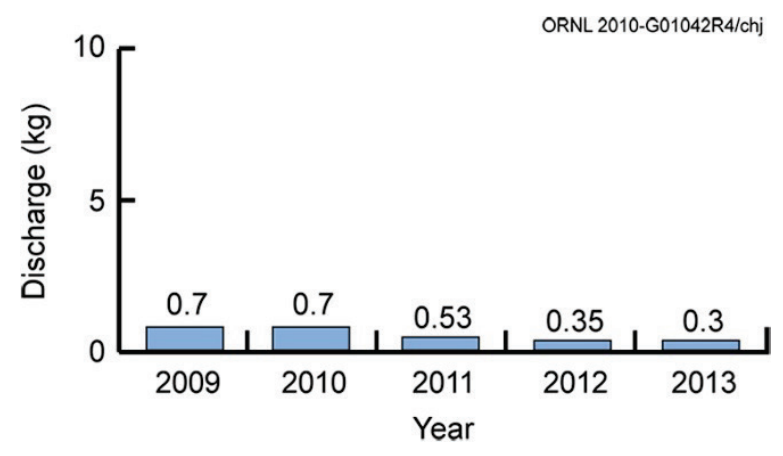

Fig. 4.19. Total kilograms of uranium discharged from the Y-12 Complex to the atmosphere, 2009-2013.

The calculated radiation dose to the maximally exposed off-site individual from airborne radiological release points at the Y-12 Complex during 2013 was 0.1 mrem. This dose is well below the NESHAP 
standard of 10 mrem and is less than $0.04 \%$ of the roughly 300 mrem that the average individual receives from natural sources of radiation. (See Section 7.1.2. for an explanation of how the airborne radionuclide dose was determined.)

\subsubsection{Quality Assurance}

QA activities for the Rad-NESHAPs program are documented in Y-12 National Security Complex Quality Assurance Project Plan for National Emission Standards for Hazardous Air Pollutants (NESHAP) for Radionuclide Emission Measurements (B\&W Y-12 2010a). The plan satisfies the QA requirements in 40 CFR Part 61, Method 114, for ensuring that the radionuclide air emission measurements from the Y-12 Complex are representative to known levels of precision and accuracy and that administrative controls are in place to ensure prompt response when emission measurements indicate an increase over normal radionuclide emissions. The requirements are also referenced in TDEC regulation 1200-3-11-.08. The plan ensures the quality of the Y-12 Complex radionuclide emission measurements data from the continuous samplers, breakthrough monitors, and minor radionuclide release points. It specifies the procedures for management of activities affecting the quality of data. QA objectives for completeness, sensitivity, accuracy, and precision are discussed. Major programmatic elements addressed in the QA plan are the sampling and monitoring program, emissions characterization, analytical program, and minor source emission estimates.

\subsubsection{Source-Specific Criteria Pollutants}

Proper maintenance and operation of a number of control devices (e.g., HEPA filters and scrubbers) are key to controlling emissions of criteria pollutants. The primary source of criteria pollutants at the Y-12 Complex is the steam plant, where natural gas and Number 2 fuel oil were burned in 2013. Information regarding actual vs allowable emissions from the steam plant is provided in Table 4.10.

Particulate emissions from point sources result from many operations throughout the Y-12 Complex. Compliance demonstration is achieved via several activities, including monitoring the operations of control devices, limiting process input materials, and using certified readers to conduct stack-visible emission evaluations.

Use of Solvent 140 and methanol throughout the complex and use of acetonitrile at a single source are primary sources of VOC emissions. Material mass balances and engineering calculations are used to determine annual emissions. The calculated amounts of Solvent 140 and methanol emitted for CY 2013 are $0.882 \mathrm{lb}$ (0.000441 tons) and 19,899 pounds ( 9.95 tons), respectively. The highest calculated amount of acetonitrile emitted to the atmosphere for CY 2013 was 5.686 tons, which was less than the permitted value of 9 tons/year.

\subsubsection{Mandatory Reporting of Greenhouse Gas Emissions under 40 CFR 98}

Title 40 of the Code of Federal Regulations Part 98, Mandatory Greenhouse Gas Reporting, establishes mandatory GHG reporting requirements for owners and operators of certain facilities that directly emit GHGs and for certain fossil fuel suppliers and industrial GHG suppliers. The purpose of the rule is to collect accurate and timely data on GHG emissions that can be used to inform future policy decisions.

The mandatory reporting of GHGs rule requires reporting of annual emissions of carbon dioxide $\left(\mathrm{CO}_{2}\right)$, methane $\left(\mathrm{CH}_{4}\right)$, nitrous oxide $\left(\mathrm{N}_{2} \mathrm{O}\right)$, sulfur hexafluoride $\left(\mathrm{SF}_{6}\right)$, hydrofluorocarbons, perfluorochemicals, and other fluorinated gases (e.g., nitrogen trifluoride and hydrofluorinated ethers). These gases are often expressed in metric tons of $\mathrm{CO}_{2}$ equivalent $\left(\mathrm{CO}_{2} \mathrm{e}\right)$.

The Y-12 Complex is subject only to the Subpart A general provisions and reporting from stationary fuel combustion sources covered in Subpart C, General Stationary Fuel Combustion. Currently the rule does not require control of GHGs; rather, it requires only that sources emitting above the $25,000 \mathrm{CO}_{2} \mathrm{e}$ threshold level monitor and report emissions.

The Y-12 Complex Steam Plant is subjected to this rule. The steam plant consists of four boilers. The maximum heat input capacity of each boiler shall not exceed $99 \mathrm{MM} \mathrm{Btu} / \mathrm{h}$. Natural gas is the primary 
fuel source for these boilers with Number 2 fuel oil as a backup source of fuel. Other limited stationary combustion sources are metal forming operations and production furnaces that use natural gas. In Building 9212, a gas-fired furnace used for drying wet residues and burning solids in a recovery process has a maximum heat input of $700,000 \mathrm{Btu} / \mathrm{h}$. In Building 9215, 10 natural gas torches, each at 300 standard $\mathrm{ft}^{3} / \mathrm{h}$, are used to preheat tooling associated with a forging and forming press. In Building 9204-2, natural gas is used to heat two electrolytic cells. The maximum rated heat input to the burners on each cell is $550,000 \mathrm{Btu} / \mathrm{h}$.

All of the combustion units burning natural gas are served through the fuel supply and distribution system and are reported as combined emissions consistent with the provisions of 40 CFR 98.36(c)(3). The Tier 1 Calculation Method was used to calculate GHGs from the Y-12 Complex. The amount of natural gas supplied to the site, along with the fuel usage logs provides the basic information for calculation of the GHG emissions.

The emission report is submitted electronically in a format specified by the EPA administrator. Each report is signed by a designated representative of the owner or operator, certifying under penalty of law that the report has been prepared in accordance with the requirements of the rule. The total amount of GHGs, subject to the mandatory reporting rule, emitted from the Y-12 Complex is shown in Table 4.12. The decrease in emissions from 2010 to 2013 is associated with the fact that coal is no longer burned since the natural-gas-fired steam plant came online.

Table 4.12. Greenhouse gas emissions from Y-12 Complex stationary fuel combustion sources

\begin{tabular}{cc}
\hline Year & $\begin{array}{c}\text { GHG emissions } \\
\left(\text { metric tons } \mathbf{C O}_{2} \mathbf{e}\right)\end{array}$ \\
\hline 2010 & 97,610 \\
2011 & 70,187 \\
2012 & 63,177 \\
2013 & 61,650 \\
\hline
\end{tabular}

Abbreviations
$\mathrm{CO}_{2 \mathrm{e}}=\mathrm{CO}_{2}$ equivalent
$\mathrm{GHG}=$ greenhouse gas
$\mathrm{Y}-12$ Complex $=$ Y-12 National Security Complex

\subsubsection{Hazardous Air Pollutants (Nonradiological)}

Beryllium emissions from machine shops are regulated under a state-issued permit and are subject to a limit of $10 \mathrm{~g} / 24 \mathrm{~h}$. Compliance is demonstrated through a one-time stack test and through monitoring of control device operations. Hydrogen fluoride is used at one emission source, and emissions are controlled through the use of scrubber systems. The beryllium control devices and the scrubber systems were monitored during 2013 and found to be operating properly.

Methanol is released as fugitive emissions (e.g., pump and valve leaks) as part of the brine/methanol system. Methanol is subject to state air permit requirements; however, due to the nature of its release (fugitive emissions only), there are no specific emission limits or mandated controls. Mercury is a significant legacy contaminant at the Y-12 Complex, and cleanup is being addressed under the environmental remediation program. Like methanol emissions, mercury air emissions from legacy sources are fugitive in nature and therefore are not subject to specific air emission limits or controls. On-site monitoring of mercury is conducted and is discussed under Section 4.4.2, "Ambient Air."

In 2007 EPA vacated a proposed MACT standard that was intended to minimize hazardous air pollution emissions. At that time a case-by-case MACT review was conducted as part of the construction permitting process for the Y-12 Complex replacement steam plant. The new natural-gas-fired steam plant came online on April 20,2010, and coal is no longer combusted. Specific conditions aimed at minimizing HAP emissions from the new steam plant were incorporated into the operating permit issued January 9, 2012 (see Section 4.4.1). In addition, the boiler MACT was revised and reissued on January 31, 2013. 
The new requirements will be incorporated in the Title $\mathrm{V}$ operating air permit no later than January 31 , 2016. This is the date the new steam plant must comply with the new requirements. The new requirements (work practice standards) include conducting annual tune-ups and a one-time energy assessment of the boilers to meet these requirements. There are no numeric emission limit requirements for the steam plant.

Unplanned releases of HAPs are regulated through the Risk Management Planning regulations. Y-12 Complex personnel have determined there are no processes or facilities containing inventories of chemicals in quantities exceeding thresholds specified in rules pursuant to CAA, Title III, Sect.112(r), "Prevention of Accidental Releases." Therefore, the Y-12 Complex is not subject to that rule. Procedures are in place to continually review new processes and/or process changes against the rule thresholds.

\subsubsection{Reciprocating Internal Combustion Engine Standards for New Source Performance Standards and National Emission Standards for Hazardous Air Pollutants}

RICEs are stationary reciprocating internal combustion engines that use reciprocating motion to convert heat energy into mechanical work. A number of stationary emergency use engines (generators) are located throughout the Y-12 Complex. The emergency engines/generators are used to provide power for critical systems in the event of electrical power failures/outages at the Y-12 Complex. Emergency RICEs are defined as stationary RICEs whose operations are limited to emergency situations and require testing and maintenance activities to ensure operation during emergencies. A stationary RICE used for peak shaving is not considered an emergency stationary RICE, although such a RICE may be used for periods of emergency demand response, subject to restriction.

EPA has created multiple national air pollution regulations to reduce air emissions from RICEs. Two types of federal air standards are applicable to RICEs: (1) NSPSs (Title 40 CFR Part 60, Subpart IIII) and (2) NESHAPs (Title 40 CFR Part 63, Subpart ZZZZ). The compression ignition engines/generators located at Y-12 are subject to these rules. EPA is concerned about how RICEs are used and also the emissions generated from these engines in the form of both HAPs and criteria pollutants.

All previous stationary emergency engines/generators were listed in the Y-12 Title V air permit application as "insignificant activities." However, EPA finalized revisions to standards to reduce air pollution from stationary engines that generate electricity and power equipment at sites of major sources of HAPs on January 16, 2013. Regardless of engine size, the rules apply to any existing, new, or reconstructed stationary RICE located at a major source of HAP emissions.

To comply with the rules, the Y-12 Complex prepared a significant permit modification to the Y-12 Major Source (Title V) Operating Air Permit to add numerous stationary, emergency use engines/generators located throughout the Y-12 Complex. The permit application was submitted to TDEC on May 6, 2013, for review and approval. TDEC downgraded the significant modification to a minor modification per EPA's review and request. In a prior, updated permit application for renewal of the Y-12 Major Source (Title V) Operating Air Permit dated March 9, 2011, Y-12 Complex staff identified Title 40 CFR, Part 60, Subpart IIII, Standards of Performance for Stationary Compression Ignition Internal Combustion Engines, as a requirement applicable to the stationary emergency use engines located at the Y-12 Complex. TDEC issued Y-12 a minor permit modification to the Title V air permit on March 3, 2014, for the emergency engines/generators.

\subsubsection{Ambient Air}

To understand the complete picture of ambient air monitoring in and around the Y-12 Complex, data from on- and off-site monitoring conducted specifically for the Y-12 Complex, DOE reservationwide monitoring, and on- and off-site monitoring conducted by EPA and TDEC personnel must be considered.

No federal regulations, state regulations, or DOE orders require ambient air monitoring within the Y-12 Complex boundary; however, on-site ambient air monitoring for mercury and radionuclides is conducted as a best management practice. With the reduction of plant operations and improved emission and administrative controls, levels of measured pollutants have decreased significantly during the past 
several years. In addition, major processes that result in emission of enriched and depleted uranium are equipped with stack samplers that have been reviewed and approved by EPA to meet requirements of the NESHAPs regulations.

\subsubsection{Mercury}

The Y-12 Complex ambient air monitoring program for mercury was established in 1986 as a best management practice. The objectives of the program have been to maintain a database of mercury concentrations in ambient air, to track long-term spatial and temporal trends in ambient mercury vapor, and to demonstrate protection of the environment and human health from releases of mercury to the atmosphere at the Y-12 Complex. Originally four monitoring stations were operated at the Y-12 Complex, including two within WEMA (i.e., the former west end mercury-use area at Y-12). The two atmospheric mercury monitoring stations currently operating at the Y-12 Complex, AAS2 and AAS8, are located near the east and west boundaries of the Y-12 Complex, respectively (Fig. 4.20). Since their establishment in 1986, AAS2 and AAS8 have monitored mercury in ambient air continuously with the exception of short intervals of downtime because of electrical or equipment outages. In addition to the monitoring stations located at the Y-12 Complex, two additional monitoring sites were operated: a reference site (rain gauge 2) was operated on Chestnut Ridge in the Walker Branch Watershed for a 20-month period in 1988 and 1989 to establish a reference concentration and a site was operated at New Hope Pond for a 25-month period from August 1987 to September 1989.

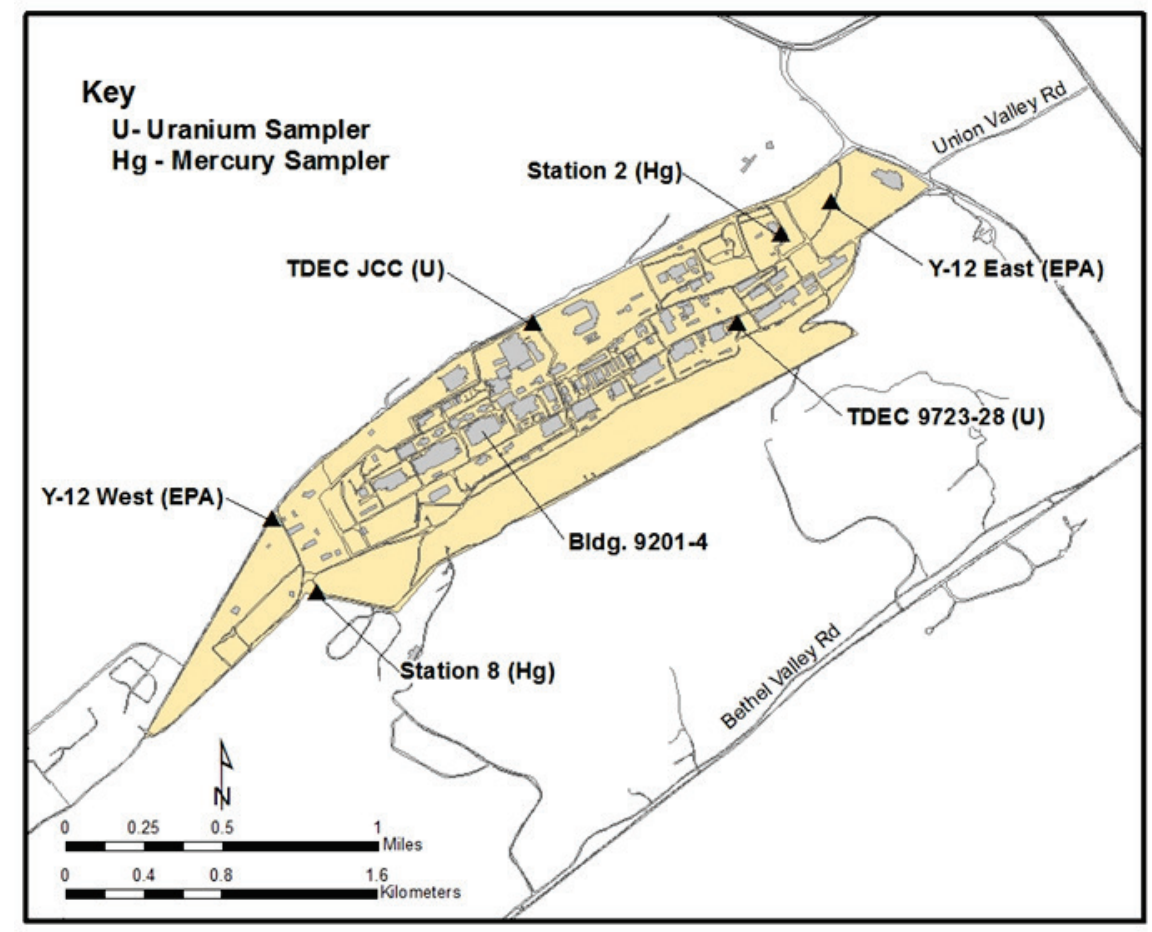

Fig. 4.20. Locations of ambient air monitoring stations at the Y-12 Complex. [EPA = US Environmental Protection Agency (sampler) TDEC $=$ Tennessee Department of Environment and Conservation, and JCC = Jack Case Center.]

To determine mercury concentrations in ambient air, airborne mercury vapor is collected by pulling ambient air through a sampling train consisting of a Teflon filter and an iodinated-charcoal sampling trap. A flow-limiting orifice upstream of the sampling trap restricts airflow through the sampling train to $\sim 1 \mathrm{~L} / \mathrm{min}$. Actual flows are measured weekly with a calibrated Gilmont flowmeter in conjunction with the weekly change-out of the sampling trap. The charcoal in each trap is analyzed for total mercury using 
cold vapor atomic fluorescence spectrometry after acid digestion. The average concentration of mercury vapor in ambient air for each 7-day sampling period is then calculated by dividing the total mercury per trap by the volume of air pulled through the trap during the corresponding 7-day sampling period.

As reported previously, average mercury concentration at the ambient air monitoring sites has declined significantly since the late 1980s. Recent average annual concentrations at the two boundary stations are comparable to concentrations measured in 1988 and 1989 at the Chestnut Ridge reference site (Table 4.13). Average mercury concentration at the AAS2 site for 2013 is $0.0032 \mu \mathrm{g} / \mathrm{m}^{3}(\mathrm{~N}=48)$, comparable to averages measured since 2003. After an increase in average concentration at AAS 8 for the period 2005 through 2007, thought to be possibly due to increased D\&D work on the west end, the average concentration at AAS8 for 2013 was $0.0038 \mu \mathrm{g} / \mathrm{m}^{3}(\mathrm{~N}=48)$, similar to levels reported for 2008 and the early 2000 s.

Table 4.13 summarizes the 2013 mercury results with results from the 1986 through 1988 period included for comparison. Figure 4.21 illustrates temporal trends in mercury concentration for the two active mercury monitoring sites for the period since the inception of the program in 1986 through 2013 [parts (a) and (b)] and seasonal trends at AAS8 from 1994 through 2013 [part (c)]. The dashed line superimposed on the plots in Figs. 4.21(a) and (b) is the EPA reference concentration of $0.3 \mu \mathrm{g} / \mathrm{m}^{3}$ for chronic inhalation exposure. The large increase in mercury concentration at AAS8 observed in the late 1980s [part (b)] was thought to be related to disturbances of mercury-contaminated soils and sediments during the Perimeter Intrusion Detection Assessment System installation and storm drain restoration projects under way at that time within WEMA. In 4.21(c), a monthly moving average has been superimposed over the AAS8 data to highlight seasonal trends in mercury at AAS8 from January 1994 through 2013.

Table 4.13. Summary of data for the $\mathrm{Y}-12$ National Security Complex ambient air monitoring program for mercury for CY 2013

\begin{tabular}{lcccc}
\hline \multirow{2}{*}{ Ambient air monitoring stations } & \multicolumn{3}{c}{ Mercury vapor concentration $\left(\boldsymbol{\mu g} / \mathbf{m}^{\mathbf{3}}\right)$} \\
\cline { 2 - 5 } & $\begin{array}{c}\mathbf{2 0 1 3} \\
\text { Minimum }\end{array}$ & $\begin{array}{c}\mathbf{2 0 1 3} \\
\text { Maximum }\end{array}$ & $\begin{array}{c}\mathbf{2 0 1 3} \\
\text { Average }\end{array}$ & $\begin{array}{c}\mathbf{1 9 8 6 - 1 9 8 8}^{\boldsymbol{a}} \\
\text { Average }^{-}\end{array}$ \\
\hline AAS2 (east end of the Y-12 Complex) & 0.0018 & 0.0060 & 0.0032 & 0.010 \\
AAS8 (west end of the Y-12 Complex) & 0.0017 & 0.0087 & 0.0038 & 0.033 \\
Reference site, rain gauge 2 $\left(1988^{b}\right)$ & N/A & N/A & N/A & 0.006 \\
Reference site, rain gauge 2 $\left(1989^{c}\right)$ & N/A & N/A & N/A & 0.005 \\
\hline
\end{tabular}

${ }^{a}$ Period in late '80s with elevated ambient air mercury levels; shown for comparison.

${ }^{b}$ Data for period from February 9 through December 31, 1988.

${ }^{c}$ Data for period from January 1 through October 31, 1989.

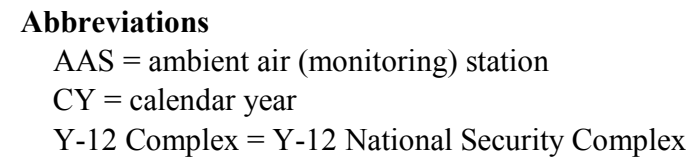


ORNL 2014-G00262/chj
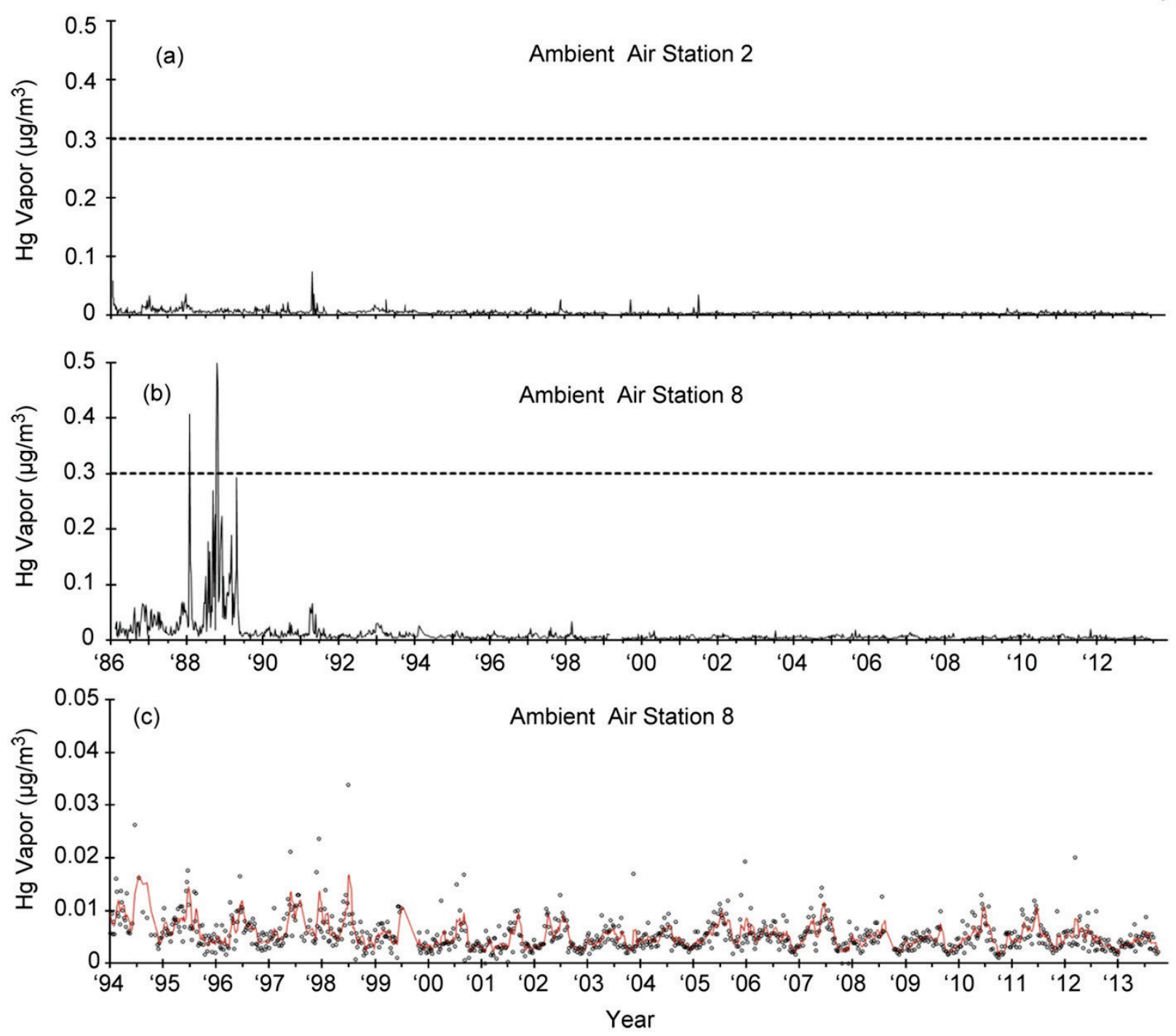

Fig. 4.21. Temporal trends in mercury vapor concentration for the boundary monitoring stations at the Y-12 Complex, July 1986 to January 2013 [(a) and (b)], and for ambient air station 8, January 1994 to January 2013 [(c)]. The dashed lines superimposed on (a) and (b) represent the US Environmental Protection Agency reference concentration of $0.3 \mu \mathrm{g} / \mathrm{m}^{3}$ for chronic inhalation exposure. In (c) (note different concentration scale), a monthly moving average has been superimposed over the data to highlight seasonal trends in mercury at ambient air station 8 from January 1993 to January 2013, with higher concentrations generally measured during the warm weather months.

In conclusion, 2013 average mercury concentrations at the two mercury monitoring sites were comparable to reference levels measured for the Chestnut Ridge reference site in 1988 and 1989. More importantly, measured concentrations continue to be well below current environmental and occupational health standards for inhalation exposure to mercury vapor [i.e., the National Institute for Occupational Safety and Health recommended exposure limit of $50 \mu \mathrm{g} / \mathrm{m}^{3}$, time-weighted average (TWA) for up to a $10 \mathrm{~h}$ workday, $40 \mathrm{~h}$ workweek; the American Conference of Governmental Industrial Hygienists workplace threshold limit value of $25 \mu \mathrm{g} / \mathrm{m}^{3}$ as a TWA for a normal $8 \mathrm{~h}$ workday and $40 \mathrm{~h}$ workweek; and the current EPA reference concentration of $0.3 \mu \mathrm{g} / \mathrm{m}^{3}$ for elemental mercury for a continuous inhalation exposure to the human population without appreciable risk of harmful effects during a lifetime]. 


\subsubsection{Quality Control}

A number of QA/quality control (QC) steps are taken to ensure the quality of the data for the Y-12 Complex mercury in ambient air monitoring program.

An hour meter records the actual operating hours between sample changes. This allows for correction of total flow in the event of power outages during the weekly sampling interval.

The Gilmont correlated flowmeter, used for measuring flows through the sampling train, is purchased annually or, if not new, shipped back to the manufacturer annually for calibration in accordance with standards set by the National Institute of Standards and Technology (NIST).

A minimum of $5 \%$ of the samples in each batch submitted to the analytical laboratory are blank samples. The blank sample traps are submitted "blind" to verify trap blank values and to serve as a field blank for diffusion of mercury vapor into used sample traps during storage before analysis.

To verify the absence of mercury breakthrough, $5 \%$ to $10 \%$ of the field samples have the front (upstream) and back segments of the charcoal sample trap analyzed separately. The absence of mercury above blank values on the back segment confirms the absence of breakthrough.

Chain-of-custody forms track the transfer of sample traps from the field technicians all the way to the analytical laboratory.

A field performance evaluation is conducted annually by the project manager to ensure that proper procedures are followed by the sampling technicians. No issues were identified in the last evaluation conducted, December 12, 2013.

Analytical QA/QC requirements include the following:

- use of prescreened and/or laboratory purified reagents,

- analysis of at least two method blanks per batch,

- analysis of standard reference materials,

- analysis of laboratory duplicates [one per 10 samples; any laboratory duplicates differing by more than $10 \%$ at five or more times the detection limit are to be rerun (third duplicate) to resolve the discrepancy], and

- $\quad$ archiving all primary laboratory records for at least 1 year.

\subsubsection{Ambient Air Monitoring Complementary to the Y-12 Complex Ambient Air Monitoring}

Ambient air monitoring is conducted at multiple locations near ORR to measure radiological and other selected parameters directly in the ambient air. These monitors are operated in accordance with DOE orders. Their locations were selected so that areas of potentially high exposure to the public are monitored continuously for parameters of concern. This monitoring provides direct measurement of airborne concentrations of radionuclides and other HAPs, allows facility personnel to determine the relative level of contaminants at the monitoring locations during an emergency, verifies that the contributions of fugitive and diffuse sources are insignificant, and serves as a check on dose-modeling calculations. As part of the ORR network, an AAS located in the Scarboro Community of Oak Ridge (Station 46) measures off-site impacts of Y-12 Complex operations. This station is located near the theoretical area of maximum public pollutant concentrations as calculated by air-quality modeling. ORR network stations are also located at the east end of the Y-12 Complex (Station 40) and just south of the Country Club Estates neighborhood (Station 37).

In addition to the monitoring described above, the State of Tennessee (TDEC) and EPA perform ambient air monitoring to characterize the region in general and to characterize and monitor DOE operations locally. Specific to Y-12 Complex operations, there are three uranium ambient air monitors within the Y-12 Complex boundary that, since 1999, have been used by TDEC personnel in their environmental monitoring program. Each of the monitors uses $47 \mathrm{~mm}$ borosilicate glass-fiber filters to collect particulates as air is pulled through the units. The monitors control airflow with a pump and rotometer set to average about 2 standard $\mathrm{ft}^{3} /$ min. During 2012, these uranium monitors at stations 4, 5, and 8 were phased out of service, and two additional high volume samplers (Fig. 4.20) are now being 
used by TDEC to provide isotopic uranium monitoring capability. These are located on the east side of the Jack Case Center and on the south side of the Building 9723-28 change house. EPA performs ambient air monitoring on the east end of the plant near the intersection of Scarboro Road and Bear Creek Road and on the west end of the plant near the intersection of Bear Creek Road and Old Bear Creek Road.

In addition, TDEC DOE Oversight Division air quality monitoring includes several other types of monitoring on ORR, for example,

- RADNet air monitoring,

- fugitive radioactive air emission monitoring,

- ambient VOC air monitoring,

- perimeter air monitoring,

- real-time monitoring of gamma radiation,

- ambient gamma radiation monitoring using external dosimetry, and

- $\quad$ program-specific monitoring associated with infrastructure-reduction activities.

Results of these activities are summarized in annual status reports, which are issued by the TDEC DOE Oversight Division.

The State of Tennessee also operates a number of regional monitors to assess ambient concentrations of criteria pollutants such as sulfur dioxide, particulate (various forms), and ozone for comparison against ambient standards. The results are summarized and available through EPA and state reporting mechanisms.

\subsection{Water Quality Program}

\subsubsection{National Pollutant Discharge Elimination System Permit and Compliance Monitoring}

The current Y-12 Complex NPDES permit (TN0002968) requires sampling, analysis, and reporting for about 56 outfalls. Major outfalls are noted in Fig. 4.22. The number is subject to change as outfalls are eliminated or consolidated or if permitted discharges are added. Currently, the Y-12 Complex has outfalls and monitoring points in the following water drainage areas: EFPC, Bear Creek, and several tributaries on the south side of Chestnut Ridge, all of which eventually drain to the Clinch River.

Discharges to surface water allowed under the permit include storm drainage, cooling water, cooling tower blowdown, steam condensate, and treated process wastewaters, including effluents from wastewater treatment facilities. Groundwater inflow into sumps in building basements and infiltration to the storm drain system are also permitted for discharge to the creek. The monitoring data collected by the sampling and analysis of permitted discharges are compared with NPDES limits where applicable for each parameter. Some parameters, defined as "monitor only," have no specified limits.

The water quality of surface streams in the vicinity of the Y-12 Complex is affected by current and legacy operations. Discharges from Y-12 Complex processes flow into EFPC before the water exits the Y-12 Complex. EFPC eventually flows through the city of Oak Ridge to Poplar Creek and into the Clinch River. Bear Creek water quality is affected by area source runoff and groundwater discharges. The NPDES permit requires regular monitoring and storm water characterization in Bear Creek and several of its tributaries. 


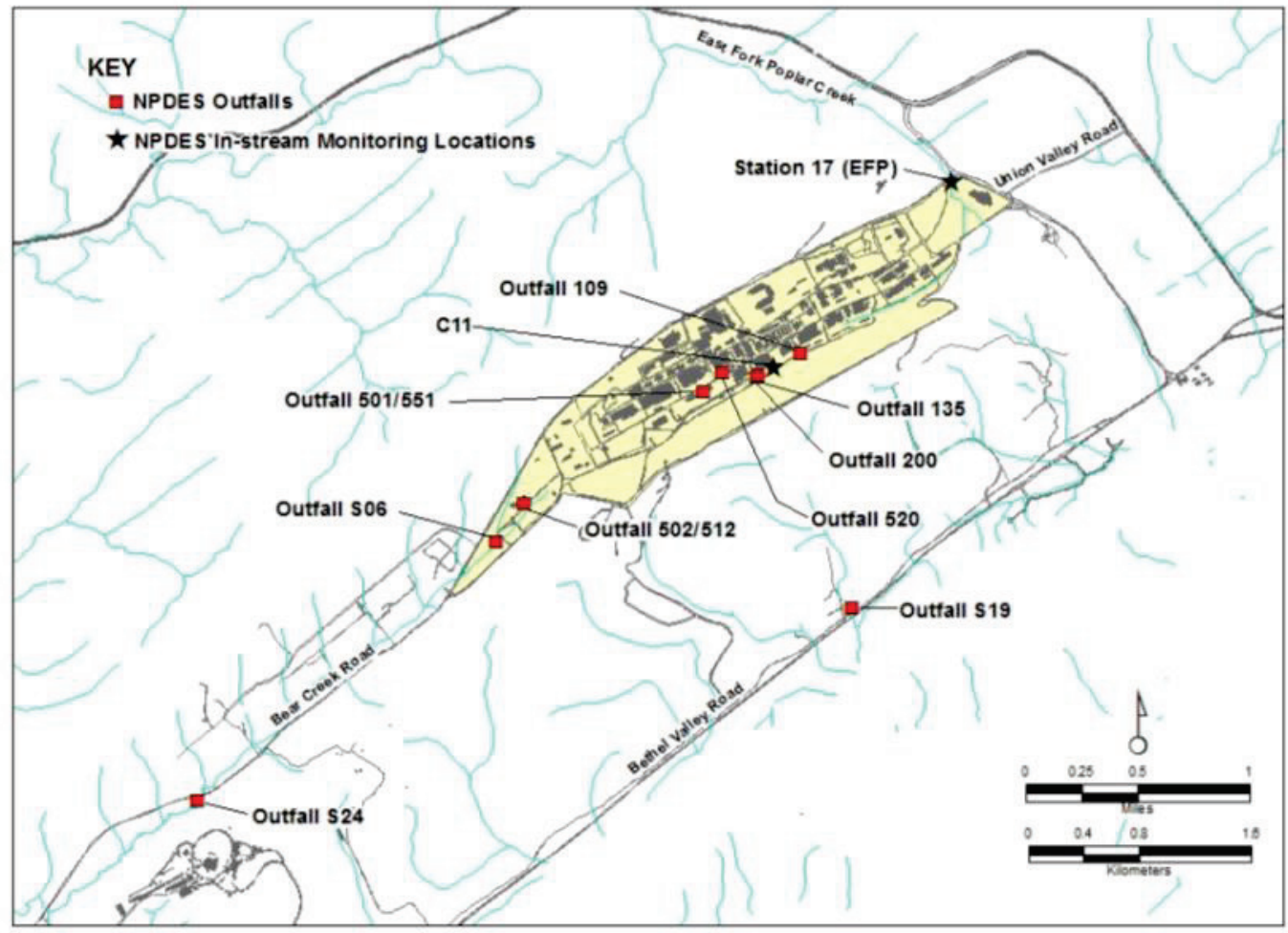

Fig. 4.22. Major Y-12 Complex National Pollutant Discharge Elimination System (NPDES) outfalls and monitoring locations.

Requirements of the NPDES permit for 2013 were satisfied, and monitoring of outfalls and instream locations indicated excellent compliance. Data obtained as part of the NPDES program are provided in a monthly report to TDEC. The percentage of compliance with permit requirements for 2013 was greater than $99.9 \%$.

There was one NPDES permit limit excursion for cadmium (monthly average permit limit $0.001 \mathrm{mg} / \mathrm{L}$ ). Analysis of a composite sample taken October 3, 2013, at the outfall 200 location revealed a value of $0.0174 \mathrm{mg} / \mathrm{L}$, which is below the daily maximum value but above the monthly average value of $0.001 \mathrm{mg} / \mathrm{L}$. The cause of the elevated cadmium value at outfall 200 is not exactly known. A grab sample taken upstream in the storm drain system indicated the presence of cadmium. Cadmium has also been detected in a nearby groundwater well. Composite sampling is planned for this area of the storm drain system, where groundwater data indicate the presence of cadmium.

On the afternoon of November 20, 2013, a reading of $\mathrm{pH} 9.1 \pm 0.24$ was taken from the effluent flow at West End Treatment Facility outfall 502. This value is outside the permitted $\mathrm{pH}$ range established for this facility (6.0 to 9.0 standard units). On discovery of the sample result, West End Treatment Facility operations personnel immediately stopped the discharge. Before discovery of the elevated $\mathrm{pH}$ reading, about 12,153 gal of treated wastewater from a 476,000 gal batch was discharged. The discharge did not result in negative impacts to the water environment or cause any safety consequences. Corrective actions have been implemented to prevent recurrence.

Other events and observations during 2013 include the following.

On June 8, 2013, TEMA personnel were notified at 12:06 p.m. EDT that a water line break at the Y-12 Complex had been isolated and ORNL biologists had been summoned to conduct a fish survey of EFPC. At 2:07 EDT, the Y-12 plant shift superintendent verified with TEMA personnel that a fish kill in EFPC caused by the discharge of potable water from a water line break had occurred. Fisheries biologists from ORNL, working for the Y-12 BMAP, performed a fish survey in upper EFPC on Saturday, June 8, 2013. Biologists walked the stream during a $5 \mathrm{~h}$ period and collected 8,318 dead fish. The stream reach affected was from outfall 21 to Bear Creek Road, a distance of about 1,300 m (4,265 ft). The fish kill was 
consistent with a high volume release of chlorinated water from a line break in the old ORNL biology complex.

The event killed five species of fish, the greatest percentage being small minnows, including stonerollers, striped shiners, and black nose dace. Other fish species present in the stream reach such as sunfish were unaffected.

A letter summarizing this event was provided to the TDEC Knoxville Environmental Field Office on June 12, 2013.

Based on the sequence of response actions, a formal events and causal factors analysis was performed by a team of individuals. The analysis determined that while all responses were performed as expected, the integration of information from two internal alert/alarm systems could be improved. Had the information from the two alerts been combined, the response to the initial water tower level could have more directly pointed to a water line break, thus reducing the duration of the discharge to EFPC.

The event has been thoroughly evaluated to determine casual factors that contributed to the potable water release, and actions taken to address those factors should significantly reduce the likelihood of reoccurrence of a similar event of this magnitude.

Follow-up monitoring of the fish community by BMAP personnel in September 2013 showed a reduction of about $34 \%$ in the fish population when compared to EFPC fish data from recent years. BMAP personnel will continue to do spring and fall monitoring to measure the recovery of the stream and aquatic life. It is estimated that about 2 years of spawning seasons under normal conditions would likely restore the fish community to pre-event conditions

During the period from August 25 through September 3, 2013, instances of discolored water were observed at outfall 200. A contrast in color of water discharging through outfall 200 and receiving stream flow was reported. The incidents did not appear to be related to rain events or the result of manufacturing operations. After investigation of area drainage it was determined that the source was construction dewatering activities at the Bear Creek Road Phase II construction site. Construction in this area is being performed for the UPF Projects Office by a USACE subcontractor.

B\&W Y12 staff met with construction contractors and determined that site dewatering basins as installed were not effective for water filtration. The process was modified to discharge to a grassy slope upgradient of silt fences followed by additional filtering over a second grass area and through a second set of silt fences. This process improved the quality of the discharge water leaving the site and at outfall 200. Following continued discussions with construction personnel additional modifications for filtration were made, including use of a filtering bag. During visits to the site B\&W Y12 Environmental Compliance and NNSA Production Office staff emphasized to the construction contractor that erosion and sediment control practices must be improved and properly maintained.

Dechlorination treatment in the upper reach of EFPC provided excellent control of chlorinated discharges, and toxicity testing results of two outfalls in the upper reach have shown low toxicity. Table 4.14 lists NPDES compliance monitoring requirements with the 2013 record of compliance.

Table 4.14. National Pollutant Discharge Elimination System compliance monitoring requirements and record for the Y-12 Complex, January through December 2013

\begin{tabular}{llcccccc}
\hline \multicolumn{1}{c}{$\begin{array}{c}\text { Discharge } \\
\text { point }\end{array}$} & \multicolumn{1}{c}{$\begin{array}{c}\text { Effluent } \\
\text { parameter }\end{array}$} & $\begin{array}{c}\text { Daily } \\
\text { average } \\
(\mathbf{l b})\end{array}$ & $\begin{array}{c}\text { Daily } \\
\text { maximum } \\
(\mathbf{l b})\end{array}$ & $\begin{array}{c}\text { Monthly } \\
\text { average } \\
(\mathbf{m g} / \mathbf{L})\end{array}$ & $\begin{array}{c}\text { Daily } \\
\text { maximum } \\
(\mathbf{m g} / \mathbf{L})\end{array}$ & $\begin{array}{c}\text { Percentage } \\
\text { of } \\
\text { compliance }\end{array}$ & $\begin{array}{c}\text { Number } \\
\text { of } \\
\text { samples }\end{array}$ \\
\hline $\begin{array}{l}\text { Outfall 501 (Central } \\
\text { Pollution Control) }\end{array}$ & $\mathrm{pH}$, standard units & & & $a$ & 9.0 & $b$ & 0 \\
& & & & & & \\
& Total suspended solids & & & 31.0 & 40.0 & $b$ & 0 \\
& Total toxic organic & & & & 2.13 & $b$ & 0 \\
& Hexane extractables & & & 10 & 15 & $b$ & 0 \\
& Cadmium & 0.16 & 0.4 & 0.07 & 0.15 & $b$ & 0 \\
& Chromium & 1.0 & 1.7 & 0.5 & 1.0 & $b$ & 0 \\
& Copper & 1.2 & 2.0 & 0.5 & 1.0 & $b$ & 0 \\
& Lead & 0.26 & 0.4 & 0.1 & 0.2 & $b$ & 0
\end{tabular}


Table 4.14. (continued)

\begin{tabular}{|c|c|c|c|c|c|c|c|}
\hline $\begin{array}{c}\text { Discharge } \\
\text { point }\end{array}$ & $\begin{array}{l}\text { Effluent } \\
\text { parameter }\end{array}$ & $\begin{array}{c}\text { Daily } \\
\text { average } \\
\text { (lb) }\end{array}$ & $\begin{array}{c}\text { Daily } \\
\text { maximum } \\
(\text { lb) }\end{array}$ & $\begin{array}{c}\text { Monthly } \\
\text { average } \\
(\mathrm{mg} / \mathrm{L})\end{array}$ & $\begin{array}{c}\text { Daily } \\
\text { maximum } \\
(\mathrm{mg} / \mathrm{L})\end{array}$ & $\begin{array}{l}\text { Percentage } \\
\text { of } \\
\text { compliance }\end{array}$ & $\begin{array}{c}\text { Number } \\
\text { of } \\
\text { samples }\end{array}$ \\
\hline & Nickel & 1.4 & 2.4 & 2.38 & 3.98 & $b$ & 0 \\
\hline & Nitrate/Nitrite & & & & 100 & $b$ & 0 \\
\hline & Silver & 0.14 & 0.26 & 0.05 & 0.05 & $b$ & 0 \\
\hline & Zinc & 0.9 & 1.6 & 1.48 & 2.0 & $b$ & 0 \\
\hline & Cyanide & 0.4 & 0.72 & 0.65 & 1.2 & $b$ & 0 \\
\hline & PCB & & & & 0.001 & $b$ & 0 \\
\hline \multirow{14}{*}{$\begin{array}{l}\text { Outfall } 502 \text { (West } \\
\text { End Treatment } \\
\text { Facility) }\end{array}$} & $\mathrm{pH}$, standard units & & & $a$ & 9.0 & 75 & 3 \\
\hline & Total suspended solids & & 31 & & 40 & 100 & 2 \\
\hline & Total toxic organic & & & & 2.13 & 100 & 2 \\
\hline & Hexane extractables & & & 10 & 15 & 100 & 2 \\
\hline & Cadmium & & 0.4 & & 0.15 & 100 & 2 \\
\hline & Chromium & & 1.7 & & 1.0 & 100 & 2 \\
\hline & Copper & & 2.0 & & 1.0 & 100 & 2 \\
\hline & Lead & & 0.4 & & 0.2 & 100 & 2 \\
\hline & Nickel & & 2.4 & & 3.98 & 100 & 2 \\
\hline & Nitrate/Nitrite & & & & 100 & 100 & 2 \\
\hline & Silver & & 0.26 & & 0.05 & 100 & 2 \\
\hline & Zinc & & 0.9 & & 1.48 & 100 & 2 \\
\hline & Cyanide & & 0.72 & & 1.20 & 100 & 2 \\
\hline & PCB & & & & 0.001 & 100 & 2 \\
\hline Outfall 512 & $\mathrm{pH}$, standard units & & & $a$ & 9.0 & 100 & 12 \\
\hline $\begin{array}{l}\text { (Groundwater } \\
\text { Treatment Facility) }\end{array}$ & $\mathrm{PCB}$ & & & & 0.001 & 100 & 1 \\
\hline Outfall 520 & $\mathrm{pH}$, standard units & & & $a$ & 9.0 & 100 & 6 \\
\hline \multirow{6}{*}{$\begin{array}{l}\text { Outfall } 200 \\
\text { (North/South pipes) }\end{array}$} & $\mathrm{pH}$, standard units & & & $a$ & 9.0 & 100 & 53 \\
\hline & Hexane extractables & & & 10 & 15 & 100 & 13 \\
\hline & Cadmium & & & 0.001 & 0.023 & 92 & 13 \\
\hline & $\mathrm{IC}_{25}$ Ceriodaphnia & & & 37\% Minim & & 100 & 1 \\
\hline & $\mathrm{IC}_{25}$ Pimephales & & & 37\% Minim & & 100 & 1 \\
\hline & Total residual chlorine & & & 0.024 & 0.042 & 100 & 12 \\
\hline \multirow[t]{2}{*}{ Outfall 551} & $\mathrm{pH}$, standard units & & & $a$ & 9.0 & 100 & 52 \\
\hline & Mercury & & & 0.002 & 0.004 & 100 & 52 \\
\hline Outfall C11 & $\mathrm{pH}$, standard units & & & $a$ & 9.0 & 100 & 13 \\
\hline \multirow[t]{4}{*}{ Outfall 135} & $\mathrm{pH}$, standard units & & & $a$ & 9.0 & 100 & 12 \\
\hline & $\mathrm{IC}_{25}$ Ceriodaphnia & & & $9 \%$ & & 100 & 1 \\
\hline & & & & Minimum & & & \\
\hline & $\mathrm{IC}_{25}$ Pimephales & & & $\begin{array}{c}9 \% \\
\text { Minimum }\end{array}$ & & 100 & 1 \\
\hline \multirow[t]{2}{*}{ Outfall 109} & $\mathrm{pH}$, standard units & & & $a$ & 9.0 & 100 & 5 \\
\hline & Total residual chlorine & & & 0.010 & 0.017 & 100 & 4 \\
\hline Outfall S19 & $\mathrm{pH}$, standard units & & & $a$ & 9.0 & 100 & 1 \\
\hline Outfall S06 & $\mathrm{pH}$, standard units & & & $a$ & 9.0 & 100 & 3 \\
\hline Outfall S24 & $\mathrm{pH}$, standard units & & & $a$ & 9.0 & 100 & 1 \\
\hline
\end{tabular}


Table 4.14. (continued)

\begin{tabular}{llcccccc}
\hline \multicolumn{1}{c}{$\begin{array}{c}\text { Discharge } \\
\text { point }\end{array}$} & \multicolumn{1}{c}{$\begin{array}{c}\text { Effluent } \\
\text { parameter }\end{array}$} & $\begin{array}{c}\text { Daily } \\
\text { average } \\
(\mathbf{l b})\end{array}$ & $\begin{array}{c}\text { Daily } \\
\text { maximum } \\
(\mathbf{l b})\end{array}$ & $\begin{array}{c}\text { Monthly } \\
\text { average } \\
(\mathbf{m g} / \mathbf{L})\end{array}$ & $\begin{array}{c}\text { Daily } \\
\text { maximum } \\
(\mathbf{m g} / \mathbf{L})\end{array}$ & $\begin{array}{c}\text { Percentage } \\
\text { of } \\
\text { compliance }\end{array}$ & $\begin{array}{c}\text { Number } \\
\text { of } \\
\text { samples }\end{array}$ \\
\hline Outfall EFP & $\mathrm{pH}$, standard units & & & $a$ & 9.0 & 100 & 12 \\
Category I outfalls & $\mathrm{pH}$, standard units & & & $a$ & 9.0 & 100 & 33 \\
Category II outfalls & $\mathrm{pH}$, standard units & & $a$ & 9.0 & 100 & 17 \\
& Total residual chlorine & & & 0.5 & 100 & 16 \\
Category III outfalls & $\mathrm{pH}$ standard units & & & $a$ & 9.0 & 100 & 7 \\
& Total residual chlorine & & & 0.5 & 100 & 6 \\
\hline
\end{tabular}

${ }^{a}$ Not applicable.

${ }^{b}$ No discharge.

Abbreviations

Y-12 Complex = Y-12 National Security Complex

\subsubsection{Mercury Removal from Storm Drain Catch Basins}

The storm drain line on which the catch basins are located flows into EFPC at outfall 200. Mercury tends to collect at those low spots in the drain system following heavy rains. During 2013, spill response and waste services personnel continued to perform work in this area of the Y-12 storm drain system.

During CY 2013, $2.5 \mathrm{~kg}$ (5.5 lb) of mercury was collected from the storm system. See Section 4.8.2 for additional progress of the DOE-EM Mercury Reduction Project.

\subsubsection{Radiological Monitoring Plan and Results}

A radiological monitoring plan is in place at the Y-12 Complex to address compliance with DOE orders and NPDES permit TN0002968. The permit requires the Y-12 Complex to submit results from the radiological monitoring plan quarterly as an addendum to the NPDES discharge monitoring report. There were no discharge limits set by the NPDES permit for radionuclides; the requirement is to monitor and report. The radiological monitoring plan was developed based on an analysis of operational history, expected chemical and physical relationships, and historical monitoring results. Under the existing plan, effluent monitoring is conducted at three types of locations: (1) treatment facilities, (2) other point-source and area-source discharges, and (3) instream locations. Operational history and past monitoring results provide a basis for parameters routinely monitored under the plan (Table 4.15). The current radiological monitoring plan for the Y-12 Complex (B\&W Y-12 2012) was last revised and reissued in January 2012.

Table 4.15. Radiological parameters monitored at the Y-12 Complex, 2013

\begin{tabular}{lll}
\hline \multicolumn{1}{c}{ Parameters } & \multicolumn{1}{c}{ Specific isotopes } & \multicolumn{1}{c}{ Rationale for monitoring } \\
\hline Uranium isotopes & $\begin{array}{l}{ }^{23} \mathrm{U},{ }^{235} \mathrm{U},{ }^{234} \mathrm{U}, \text { total } \mathrm{U}, \\
\text { weight } \%{ }^{235} \mathrm{U}\end{array}$ & $\begin{array}{l}\text { These parameters reflect the major activity, } \\
\text { uranium processing, throughout the history of the } \\
\text { Y-12 Complex and are the dominant detectable } \\
\text { radiological parameters in surface water }\end{array}$ \\
$\begin{array}{ll}\text { Fission and activation } \\
\text { products }\end{array}$ & ${ }^{90} \mathrm{Sr},{ }^{3} \mathrm{H},{ }^{99} \mathrm{Tc},{ }^{137} \mathrm{Cs}$ & $\begin{array}{l}\text { These parameters reflect a minor activity at the } \\
\text { Y-12 Complex, processing recycled uranium from } \\
\text { reactor fuel elements from the early 1960s to the } \\
\text { late 1980s, and will continue to be monitored as } \\
\text { tracers for beta and gamma radionuclides, } \\
\text { although their concentrations in surface water are } \\
\text { low }\end{array}$
\end{tabular}


Table 4.15. (continued)

\begin{tabular}{lll}
\hline \multicolumn{1}{c}{ Parameters } & \multicolumn{1}{c}{ Specific isotopes } & \multicolumn{1}{c}{ Rationale for monitoring } \\
\hline Transuranium isotopes & ${ }^{241} \mathrm{Am},{ }^{237} \mathrm{~Np},{ }^{238} \mathrm{Pu}$, & $\begin{array}{l}\text { These parameters are related to recycle uranium } \\
\text { processing. Monitoring has continued because of } \\
\text { their half-lives and presence in groundwater }\end{array}$ \\
Other isotopes of interest & ${ }^{232} \mathrm{Th},{ }^{230} \mathrm{Th},{ }^{228} \mathrm{Th},{ }^{226} \mathrm{Ra}$, & $\begin{array}{l}\text { These parameters reflect historical thorium } \\
\text { processing and natural radionuclides necessary to } \\
\text { characterize background radioisotopes }\end{array}$ \\
\hline
\end{tabular}

\section{Abbreviations}

Y-12 Complex $=$ Y-12 National Security Complex

Radiological monitoring during storm water events is accomplished as part of the storm water monitoring program. Uranium is monitored at three major EFPC storm water outfalls, two instream monitoring locations and raw water flow, and an outfall on Bear Creek. Results of storm event monitoring during 2013 were reported in the annual storm water report (B\&W Y-12 2013), which was last issued in December 2013. In addition, the monthly 7-day composite sample for radiological parameters taken at Station 17 on EFPC likely includes rain events.

Radiological monitoring plan locations sampled in 2013 are noted on Fig. 4.23. Table 4.16 identifies the monitored locations, the frequency of monitoring, and the sum of the percentages of the derived concentration standards (DCSs) for radionuclides measured in 2013. Radiological data were well below the allowable DCSs.

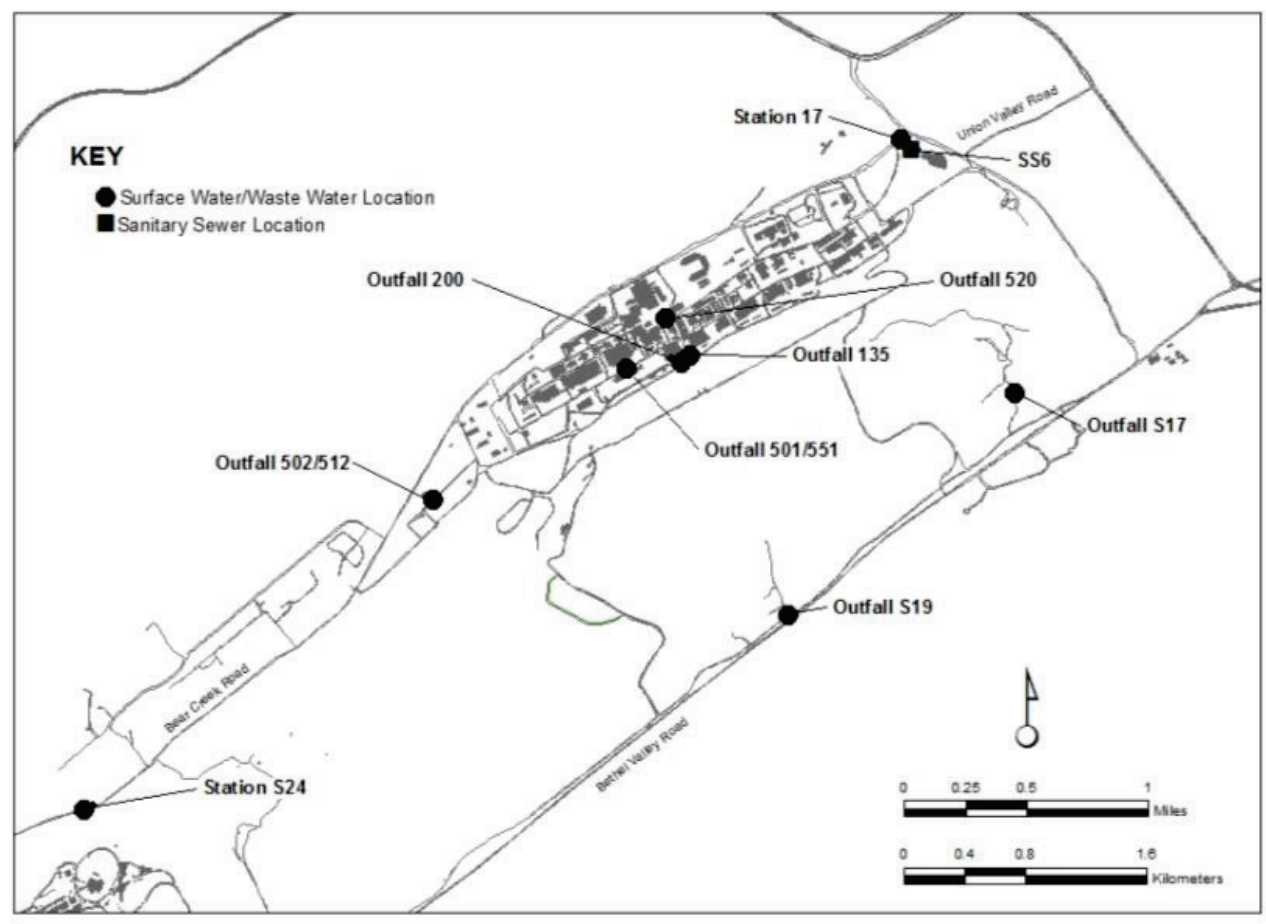

Fig. 4.23. Surface water and sanitary sewer radiological sampling locations at the Y-12 Complex.

In 2013, the total mass of uranium and associated curies released from the Y-12 Complex at the easternmost monitoring station, station 17 on upper EFPC, was $140 \mathrm{~kg}$ or $0.055 \mathrm{Ci}$ (Table 4.17). Figure 4.24 illustrates a 5-year trend of these releases. The total release is calculated by multiplying the average concentration (grams per liter) by the average flow (million gallons per day). Converting units and multiplying 
by 365 days per year yields the calculated discharge. The increase in uranium quantity in 2010 may have been the result of higher rainfall and subsequent movement of sediment and runoff from surfaces such as rooftops.

Table 4.16. Summary of $\mathrm{Y}-12$ Complex radiological monitoring plan sample requirements and 2013 results

\begin{tabular}{|c|c|c|c|}
\hline Location & $\begin{array}{c}\text { Sample } \\
\text { frequency }\end{array}$ & Sample type & $\begin{array}{l}\text { Sum of DCS } \\
\text { percentages }\end{array}$ \\
\hline \multicolumn{4}{|c|}{ Y-12 Complex wastewater treatment facilities } \\
\hline $\begin{array}{l}\text { Central Pollution Control } \\
\text { Facility }\end{array}$ & 1/batch & $\begin{array}{l}\text { Composite during } \\
\text { batch operation }\end{array}$ & No flow \\
\hline West End Treatment Facility & $1 /$ batch & $24 \mathrm{~h}$ composite & 12 \\
\hline $\begin{array}{l}\text { Groundwater Treatment } \\
\text { Facility }\end{array}$ & 4/year & 24 h composite & 4.3 \\
\hline Steam condensate & 1/year & Grab & 0 \\
\hline $\begin{array}{l}\text { Central Mercury Treatment } \\
\text { Facility }\end{array}$ & 4/year & 24 h composite & 4.4 \\
\hline \multicolumn{4}{|c|}{ Other Y-12 Complex point and area source discharges } \\
\hline Outfall 135 & 4/year & $24 \mathrm{~h}$ composite & 3.5 \\
\hline Kerr Hollow Quarry & $1 /$ year & $24 \mathrm{~h}$ composite & 0 \\
\hline Rogers Quarry & 1/year & $24 \mathrm{~h}$ composite & 4.4 \\
\hline \multicolumn{4}{|c|}{ Y-12 Complex instream locations } \\
\hline Outfall S24 & 1/year & 7-day composite & 18 \\
\hline $\begin{array}{l}\text { East Fork Poplar Creek, } \\
\text { complex exit (east) }\end{array}$ & $1 /$ month & 7-day composite & 0.65 \\
\hline North/south pipes & $1 /$ month & $24 \mathrm{~h}$ composite & 7.3 \\
\hline \multicolumn{4}{|c|}{ Y-12 Complex Sanitary Sewer } \\
\hline $\begin{array}{c}\text { East End Sanitary Sewer } \\
\text { Monitoring Station }\end{array}$ & 1/year & 7-day composite & 38 \\
\hline
\end{tabular}

\footnotetext{
Abbreviations

DCS $=$ derived concentration standard

Y-12 Complex = Y-12 National Security Complex
}

Table 4.17. Release of uranium from the $Y-12$ Complex to the off-site environment as a liquid effluent, 2009-2013

\begin{tabular}{lll}
\hline \multirow{2}{*}{ Year } & \multicolumn{2}{c}{ Quantity released } \\
\cline { 2 - 3 } & $\mathbf{C i}^{\boldsymbol{a}}$ & $\mathbf{k g}$ \\
\hline & Station 17 \\
2009 & 0.067 & 187 \\
2010 & 0.075 & 326 \\
2011 & 0.104 & 124 \\
2012 & 0.039 & 121 \\
2013 & 0.055 & 140 \\
\hline
\end{tabular}

${ }^{a} 1 \mathrm{Ci}=3.7 \mathrm{E}+10 \mathrm{~Bq}$.

Abbreviations

Y-12 Complex $=$ Y-12 National Security Complex 


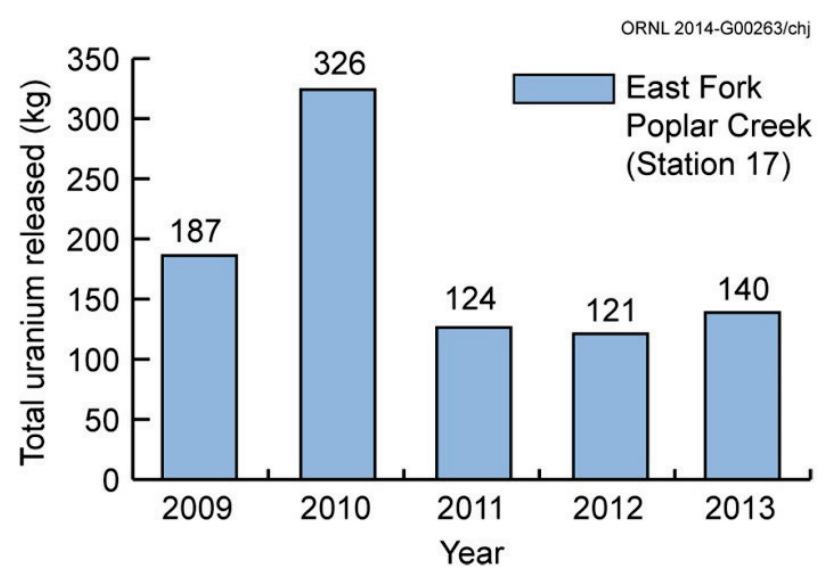

Fig. 4.24. Five-year trend of $\mathrm{Y}-12$ Complex releases of uranium to East Fork Poplar Creek.

The Y-12 Complex is permitted to discharge domestic wastewater to the city of Oak Ridge's publicly owned treatment works. Radiological monitoring of the sanitary sewer system discharge is conducted and reported to the city of Oak Ridge, although there are no city-established radiological limits. Alpha and beta levels are measured weekly, and subsequent uranium analyses are performed if the alpha or beta levels are above prescribed levels. Potential sources of radionuclides discharging to the sanitary sewer have been identified in previous studies at the Y-12 Complex as part of an initiative to meet ALARA goals. Results of radiological monitoring were reported to the city of Oak Ridge in 2013 quarterly monitoring reports.

\subsubsection{Storm Water Pollution Prevention}

The SWPPP at the Y-12 Complex is designed to minimize the discharge of pollutants in storm water runoff. The plan identifies areas that can reasonably be expected to contribute contaminants to surface water bodies via storm water runoff and describes the development and implementation of storm water management controls to reduce or eliminate the discharge of such pollutants. This plan requires (1) characterization of storm water by sampling during storm events, (2) implementation of measures to reduce storm water pollution, (3) facility inspections, and (4) employee training.

The Y-12 SWPPP underwent a significant rewrite in September 2012. This was due to the issuance of a new NPDES permit in November 2011. Significant changes included the elimination of two instream monitoring locations ( $\mathrm{C} 05$ and $\mathrm{C} 08)$ and the removal of the requirement to perform instream base-load sediment sampling. Other requirements remained essentially the same, with the exception of the lowering of a few benchmark values for certain sector outfalls. The NPDES permit defines the primary function of the Y-12 Complex to be a fabricated metal products industry. However, it also requires that storm water monitoring be conducted for three additional sectors: scrap/waste recycling activities; landfill and land application activities; and discharges associated with treatment, storage, and disposal facilities as they are defined in the Tennessee Storm Water Multi Sector General Permit for Industrial Activities (TNR050000). Each sector has prescribed benchmark values and some have defined sector mean values. The "rationale" portion of the NPDES permit for the Y-12 Complex states "These benchmark values were developed by the EPA and the State of Tennessee and are based on data submitted by similar industries for the development of the multi-sector general storm water permit. The benchmark concentrations are target values and should not be construed to represent permit limits."

Storm water sampling was conducted in 2013 during rain events which occurred in March, April, and September. Results were published in the annual storm water report (B\&W Y-12 2013), which was submitted to the TDEC Division of Water Pollution Control in January 2014. Consistent with permit requirements, storm water monitoring is performed each year for sector outfalls, three major outfalls that drain large areas of the Y-12 Complex, raw water flow, and two instream monitoring locations on EFPC (Fig. 4.25). The permit no longer calls for sampling of stream base load sediment that is being transported as a result of the heavy flow. 
In general, the quality of storm water exiting the Y-12 Complex via EFPC continued to improve in 2013. However, there was one unexpected result. The concentration of mercury at outfall 014 was unusually high at $0.00712 \mathrm{mg} / \mathrm{L}$. This was unexpected as this outfall drains an area that has no history of mercury use. Although this outfall is sampled on a rotating basis, it will be resampled in 2014 to determine whether the 2013 result was an outlier or the beginning of an undesirable trend.

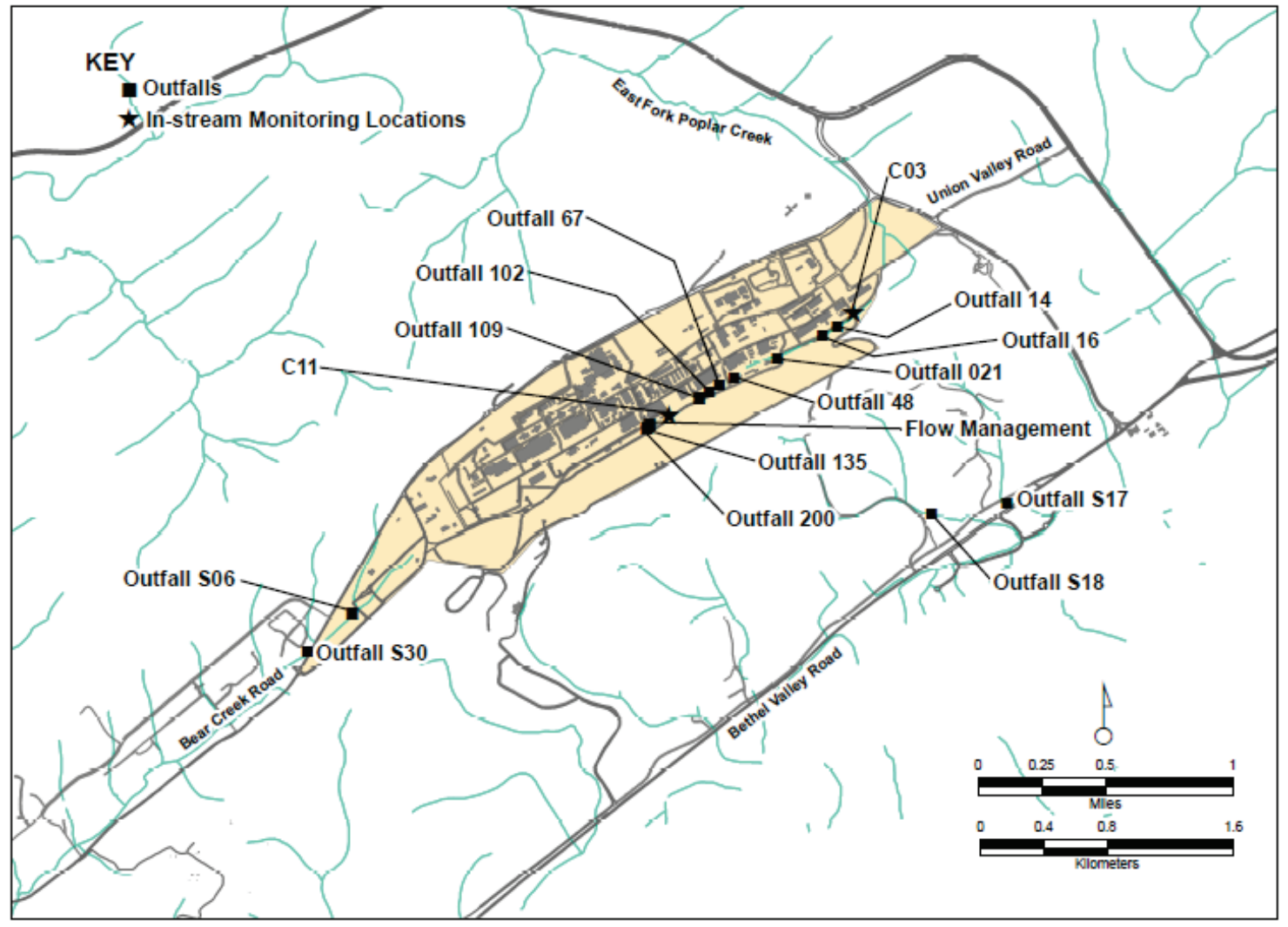

Fig. 4.25. Y-12 Complex storm water monitoring locations.

\subsubsection{Flow Management (or Raw Water)}

Because of concern about maintaining water quality and stable flow in the upper reach of EFPC, the 2006 NPDES permit required the addition of Clinch River water to the headwaters of EFPC (North/South Pipe-outfall 200 area). The addition of Clinch River water to EFPC decreased instream water temperatures by about $5^{\circ} \mathrm{C}$ (from about $26^{\circ} \mathrm{C}$ at the headwaters).

A request to modify the NPDES permit to allow the minimum flow, measured at Station 17, to be reduced to 19 million L/day (5 million gal/day) was made, and on December 30, 2008, TDEC modified the permit. The modified permit requires 19 million L (5 million gal) rather than 26 million L (7 million gal) minimum daily flow as measured at the Station 17 location. In addition to water conservation, this action offers the potential benefit of reducing the transport of mercury from a contaminated section of the streambed.

A new NPDES permit that became effective December 1, 2011, contains a requirement to provide a schedule for the relocation of the addition of raw water to EFPC downstream of its current location to reduce the potential for mercury being suspended by the higher flow due to raw water addition at the headwaters of EFPC. A schedule for relocation of raw water addition to EFPC was submitted to TDEC in accordance with the NPDES permit indicating the raw addition will be relocated and associated water quality studies will be completed in 2015. Subsequently, an engineering report was transmitted to TDEC in December 2012. 
In February 2013, TDEC sent a letter to DOE officials that states, in part, "it is our intent to proceed with the NPDES permit modification to eliminate the requirement for continued flow addition. We have learned that DOE-NNSA plans to proceed with the design and construction of proposed modification to the raw water distribution system in the near future. Thus, we recommend DOE-NNSA reevaluate the proposed construction of these modifications. We will place the proposed permit modification on public notice for benefit of review and comments by all stakeholders." Upon receipt of this letter, the raw water relocation project and the associated water quality study were placed on indefinite hold.

As of the end of 2013, discussions have taken place between NNSA, TDEC, and the Y-12 operating contractor regarding the changes to the NPDES permit. It is expected the proposed permit will be placed on public notice for review and issued in 2014. If this occurs, the flow augmentation to EFPC will be terminated on or before the effective date of the modified permit.

\subsubsection{Y-12 Complex Ambient Surface Water Quality}

To monitor key indicators of water quality, a network of real-time monitors located at three instream locations along upper EFPC is used. The Surface Water Hydrological Information Support System (SWHISS) is available for real-time water quality measurements such as $\mathrm{pH}$, temperature, dissolved oxygen, conductivity, and chlorine. The locations are shown in Fig. 4.26. The primary function of SWHISS is to provide an indication of potential adverse conditions that could be causing an impact on the quality of water in upper EFPC. It is operated as a best management practice.

Additional sampling of springs and tributaries is conducted in accordance with the Y-12 Groundwater Protection Program (GWPP) to monitor trends throughout the three hydrogeologic regimes (see Section 4.6).

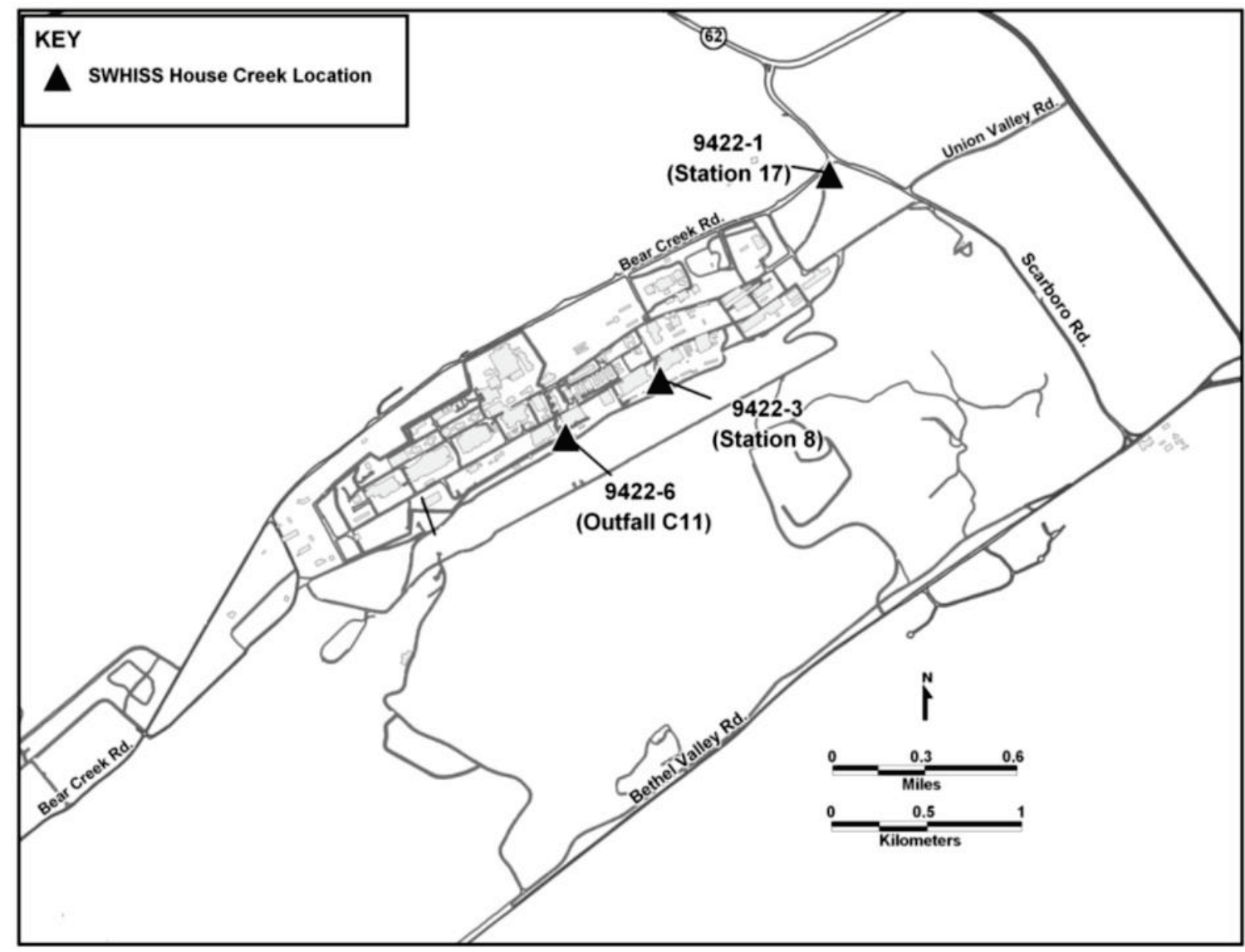

Fig. 4.26. Surface Water Hydrological Information Support System (SWHISS) monitoring locations. 


\subsubsection{Industrial Wastewater Discharge Permit}

The Industrial and Commercial User Wastewater Discharge Permit 1-91 defines requirements for the discharge of wastewaters to the sanitary sewer system as well as prohibitions for certain types of wastewaters. It prescribes requirements for monitoring certain parameters at the East End Sanitary Sewer Monitoring Station. The permit sets limits for most parameters. Samples for gross alpha, gross beta, and uranium are taken in a weekly $24 \mathrm{~h}$ composite sample. The sample is analyzed for uranium if the alpha and beta values exceed certain levels. Other parameters (including metals, oil and grease, solids, and biological oxygen demand) are monitored on a monthly basis. Organic parameters are monitored once per quarter. Results of compliance sampling are reported quarterly. Flow is measured $24 \mathrm{~h} /$ day at the monitoring station.

As part of the City of Oak Ridge's pretreatment program, city personnel also use the east end monitoring station (also known as SS6, see Fig. 4.23) to conduct compliance monitoring as required by the pretreatment regulations. City personnel also conduct twice yearly compliance inspections. Monitoring results during 2013 (Table 4.18) indicate three exceedances of the permit. These were for daily flows in excess of the permit limit that occurred on January 15, January 16, and July 7, 2013.

Table 4.18. Y-12 Complex Discharge Point SS6, Sanitary Sewer Station 6, January through December 2013

(all units are $\mathrm{mg} / \mathrm{L}$ unless noted otherwise)

\begin{tabular}{|c|c|c|c|c|c|}
\hline Effluent parameter & $\begin{array}{c}\text { Number of } \\
\text { samples }\end{array}$ & $\begin{array}{c}\text { Average } \\
\text { value }\end{array}$ & $\begin{array}{l}\text { Daily maximum } \\
\text { (effluent limit) }^{a}\end{array}$ & $\begin{array}{l}\text { Monthly average } \\
\text { (effluent limit) }^{a}\end{array}$ & $\begin{array}{l}\text { Number of } \\
\text { limit } \\
\text { exceedances }\end{array}$ \\
\hline Flow (gal/day) & 365 & 428,674 & $1,400,000$ & $1,400,000$ & 3 \\
\hline $\mathrm{pH}$ (standard units) & 13 & 7.45 & $9 / 6^{b}$ & $9 / 6^{b}$ & 0 \\
\hline $\begin{array}{l}\text { Biochemical oxygen } \\
\text { demand }\end{array}$ & 13 & 66.5 & 300 & 200 & 0 \\
\hline Kjeldahl nitrogen & 13 & 18.3 & 90 & 45 & 0 \\
\hline $\begin{array}{l}\text { Phenols - total } \\
\text { recoverable }\end{array}$ & 13 & $<0.025$ & 0.3 & 0.15 & 0 \\
\hline Oil and grease & 13 & $<6.8$ & 50 & 25 & 0 \\
\hline Suspended solids & 13 & 93.1 & 300 & 200 & 0 \\
\hline Cyanide & 13 & $<0.005$ & 0.062 & 0.041 & 0 \\
\hline Arsenic & 14 & $<0.002$ & 0.025 & 0.010 & 0 \\
\hline Cadmium & 14 & $<0.0002$ & 0.005 & 0.0033 & 0 \\
\hline Chromium & 14 & $<0.002$ & 0.075 & 0.05 & 0 \\
\hline Copper & 14 & 0.032 & 0.21 & 0.14 & 0 \\
\hline Iron & 14 & 0.48 & 30 & 10 & 0 \\
\hline Lead & 14 & $<0.0012$ & 0.074 & 0.049 & 0 \\
\hline Mercury & 13 & 0.002 & 0.035 & 0.023 & 0 \\
\hline Nickel & 14 & $<0.004$ & 0.032 & 0.021 & 0 \\
\hline Silver & 14 & $<0.002$ & 0.10 & 0.05 & 0 \\
\hline Zinc & 14 & 0.1253 & 0.75 & 0.35 & 0 \\
\hline Molybdenum & 14 & 0.0527 & $0.05^{\mathrm{c}}$ & $0.05^{\mathrm{c}}$ & Not Applicable \\
\hline Selenium & 14 & $<0.0044$ & $0.01^{\mathrm{c}}$ & $0.01^{\mathrm{c}}$ & Not Applicable \\
\hline Toluene & 5 & 0.005 & $0.005^{\mathrm{c}}$ & $0.005^{\mathrm{c}}$ & Not Applicable \\
\hline Benzene & 5 & $0.005 \mathrm{U}$ & $0.005^{\mathrm{c}}$ & $0.005^{\mathrm{c}}$ & Not Applicable \\
\hline 111 Trichloroethane & 5 & $0.005 \mathrm{U}$ & $0.005^{\mathrm{c}}$ & $0.005^{\mathrm{c}}$ & Not Applicable \\
\hline Ethylbenzene & 5 & $0.005 \mathrm{U}$ & $0.005^{\mathrm{c}}$ & $0.005^{\mathrm{c}}$ & Not Applicable \\
\hline
\end{tabular}


Table 4.18. (continued)

\begin{tabular}{lccccc}
\hline Effluent parameter & $\begin{array}{c}\text { Number of } \\
\text { samples }\end{array}$ & $\begin{array}{c}\text { Average } \\
\text { value }\end{array}$ & $\begin{array}{c}\text { Daily maximum } \\
\text { (effluent limit) }^{a}\end{array}$ & $\begin{array}{c}\text { Monthly average } \\
\text { (effluent limit) }^{a}\end{array}$ & $\begin{array}{c}\text { Number of } \\
\text { limit } \\
\text { exceedances }\end{array}$ \\
\hline $\begin{array}{l}\text { Carbon } \\
\text { Tetrachloride }\end{array}$ & 5 & $0.005 \mathrm{U}$ & $0.005^{\mathrm{c}}$ & $0.005^{\mathrm{c}}$ & Not Applicable \\
Chloroform & 5 & 0.004 & $0.005^{\mathrm{c}}$ & $0.005^{\mathrm{c}}$ & Not Applicable \\
Tetrachloroethylene & 5 & 0.004 & $0.005^{\mathrm{c}}$ & $0.005^{\mathrm{c}}$ & Not Applicable \\
$\begin{array}{l}\text { Trichloroethene } \\
\text { 1,2 trans }\end{array}$ & 5 & 0.005 & $0.005^{\mathrm{c}}$ & $0.005^{\mathrm{c}}$ & Not Applicable \\
$\begin{array}{l}\text { Dichloroethylene } \\
\text { Methylene Chloride }\end{array}$ & 5 & 0.005 & $0.005^{\mathrm{c}}$ & $0.005^{\mathrm{c}}$ & Not Applicable \\
\hline
\end{tabular}

${ }^{a}$ Industrial and Commercial Users Wastewater Permit limits.

${ }^{b}$ Maximum Value/Minimum Value.

${ }^{\mathrm{c}}$ There is not a permit limit for this parameter. This value is the required detection limit.

Over the last several years, Y-12 Complex personnel have conducted flow monitoring at key locations in the sanitary sewer system during wet and dry weather conditions. This effort has enabled a determination to be made of the general areas of the system most likely to contribute the greatest volume of inflow/infiltration of extraneous water into the lines. Examination of the data led to the conclusion that inflow of surface water was the major contributor, and in November 2009, a plan was developed to conduct smoke tests of the lines to locate specific inflow problems. The testing effort was initiated in 2010 and continued in 2013. In-line flow meters have been installed at various locations within the sanitary sewer system. Results-to-date indicated some areas of the complex where additional smoke testing was needed, and repairs were executed based on these tests. Smoke testing is completed and discussions are taking place to establish funding for future actions. Recommendations include procuring the services of an experienced third party contractor to perform inspections, lining, and possible isolations.

\subsubsection{Quality Assurance/Quality Control}

The Environmental Monitoring Management Information System (EMMIS) is used to manage surface water monitoring data. EMMIS uses standard sample definitions to ensure that samples are taken at the correct location at a specified frequency using the correct sampling protocol.

Field sampling QA encompasses many practices that minimize error and evaluate sampling performance. Some key quality practices include the following:

- use of standard operating procedures for sample collection and analysis;

- use of chain-of-custody and sample identification, customized chain-of-custody documents, and sample labels provided by EMMIS;

- instrument standardization, calibration, and verification;

- sample technician training;

- sample preservation, handling, and decontamination; and

- use of QC samples such as field and trip blanks, duplicates, and equipment rinses.

Surface water data are entered directly by the analytical laboratory into the Laboratory Information Management System (LIMS) on the day of approval. EMMIS routinely accesses LIMS electronically to capture pertinent data. Generally, the system will store the data in the form of concentrations.

A number of electronic data management tools enable automatic flagging of data points and allow for monitoring and trending data over time. Field information on all routine samples taken for surface water monitoring is entered in EMMIS, which also retrieves data nightly from the analytical laboratory. The system then performs numerous checks on the data, including comparisons of the individual results 
against any applicable screening criteria, regulatory thresholds, compliance limits, best management standards, or other water quality indicators, and produces required reports.

\subsubsection{Biomonitoring Program}

In accordance with the requirements of the new 2011 NPDES permit effective December 1, 2011, Part III-E, p. 31, two outfalls that discharge to the headwaters of EFPC (outfalls 200 and 135) were evaluated for toxicity August 8-15, 2013, using fathead minnow larvae and Ceriodaphnia dubia. A third outfall, outfall 125, no longer has sufficient base flows for toxicity to be evaluated. Table 4.19 summarizes the inhibition concentration $\left(\mathrm{IC}_{25}\right)$ results of biomonitoring tests conducted during 2013 at outfalls 200 and 135 . $\mathrm{IC}_{25}$ is the concentration of effluent that causes a $25 \%$ reduction in $C$. dubia survival or reproduction or fathead minnow survival or growth. The lower the value of the $\mathrm{IC}_{25}$, the more toxic the effluent.

Table 4.19. Y-12 Complex Biomonitoring Program summary information for outfalls 200 and 135 in $2013^{a}$

\begin{tabular}{cccc}
\hline Site & Test start date & Species & $\begin{array}{c}\mathbf{I C}_{\mathbf{2 5}}{ }^{\boldsymbol{b}} \\
\mathbf{( \% )}\end{array}$ \\
\hline Outfall 200 & $8 / 08 / 13$ & Ceriodaphnia dubia & 63.7 \\
Outfall 200 & $8 / 08 / 13$ & Fathead minnow & $>100$ \\
Outfall 135 & $8 / 08 / 13$ & Ceriodaphnia dubia & $>36$ \\
Outfall 135 & $8 / 08 / 13$ & Fathead minnow & $>36$ \\
\hline
\end{tabular}

${ }^{a}$ Inhibition concentration $\left(\mathrm{IC}_{25}\right)$ is summarized for the discharge monitoring locations, outfalls 200 and 135.

${ }^{b} \mathrm{IC}_{25}$ as a percentage of full-strength effluent from outfalls 200 and 135 diluted with laboratory control water. $\mathrm{IC}_{25}$ is the concentration that causes a $25 \%$ reduction in Ceriodaphnia dubia survival or reproduction or fathead minnow survival or growth.

\footnotetext{
Abbreviations

Y-12 Complex = Y-12 National Security Complex
}

Effluent from outfall 135 did not reduce fathead minnow survival or growth or Ceriodaphnia survival or reproduction by $25 \%$ or more at any of the tested concentrations. For both species, the $\mathrm{IC}_{25}$ for survival, growth, or reproduction was therefore $>36 \%$ (the highest concentration of effluent tested). Toxicity is demonstrated according to the NPDES permit if the $\mathrm{IC}_{25}$ is less than or equal to the permit limit ( $9 \%$ whole effluent).

Effluent from outfall 200 did not reduce fathead minnow survival or growth by $25 \%$ or more at any of the tested concentrations. Therefore, the fathead minnow $\mathrm{IC}_{25}$ for survival and growth was $>100 \%$ (the highest concentration of effluent tested). Effluent from outfall 200 did not reduce Ceriodaphnia survival by $25 \%$ or more at any of the tested concentrations. However, Ceriodaphnia reproduction was reduced by more than $25 \%$ in both $100 \%$ and $74 \%$ effluent concentrations, with the calculated $\mathrm{IC}_{25}$ for Ceriodaphnia reproduction being $63.7 \%$ effluent. Toxicity is demonstrated according to the NPDES permit if the $\mathrm{IC}_{25}$ is less than or equal to the permit limit (37\% whole effluent).

\subsubsection{Biological Monitoring and Abatement Programs}

The NPDES permit issued for the Y-12 Complex mandates a BMAP with the objective of demonstrating that the effluent limitations established for the facility protect the classified uses of the receiving stream, EFPC. The 2013 BMAP sampling reported here follows the 2011 permit requirements. BMAP, which has been monitoring the ecological health of EFPC since 1985, currently consists of three major tasks that reflect complementary approaches to evaluating the effects of the Y-12 Complex discharges on the aquatic integrity of EFPC. These tasks include (1) bioaccumulation monitoring, 
(2) benthic macroinvertebrate community monitoring, and (3) fish community monitoring. Data collected on contaminant bioaccumulation and the composition and abundance of communities of aquatic organisms provide a direct evaluation of the effectiveness of abatement and remedial measures in improving ecological conditions in the stream.

Monitoring is currently being conducted at five primary EFPC sites although sites may be excluded or added depending on the specific objectives of the various tasks. The primary sampling sites include upper EFPC at EFPC kilometers (EFKs) 24.4 and 23.4 (upstream and downstream of Lake Reality, respectively); EFK 18.7 (also EFK 18.2), located off ORR and below an area of intensive commercial and light industrial development; EFK 13.8, located upstream from the Oak Ridge Wastewater Treatment Facility; and EFK 6.3, located about $1.4 \mathrm{~km}$ downstream of the ORR boundary (Fig. 4.27). Brushy Fork at Brushy Fork kilometer 7.6 is used as a reference stream in two BMAP tasks. Additional sites off ORR are also occasionally used for reference, including Beaver Creek, Bull Run, Cox Creek, Hinds Creek, Paint Rock Creek, and Emory River in the Watts Bar Reservoir (Fig. 4.28).

Significant increases in species richness and diversity in EFPC over the last two decades demonstrate that the overall ecological health of the stream continues to improve. However, the pace of improvement in the upper reach of EFPC near the Y-12 Complex has slowed in recent years, and fish and invertebrate communities continue to be less diverse than the corresponding communities in reference streams.

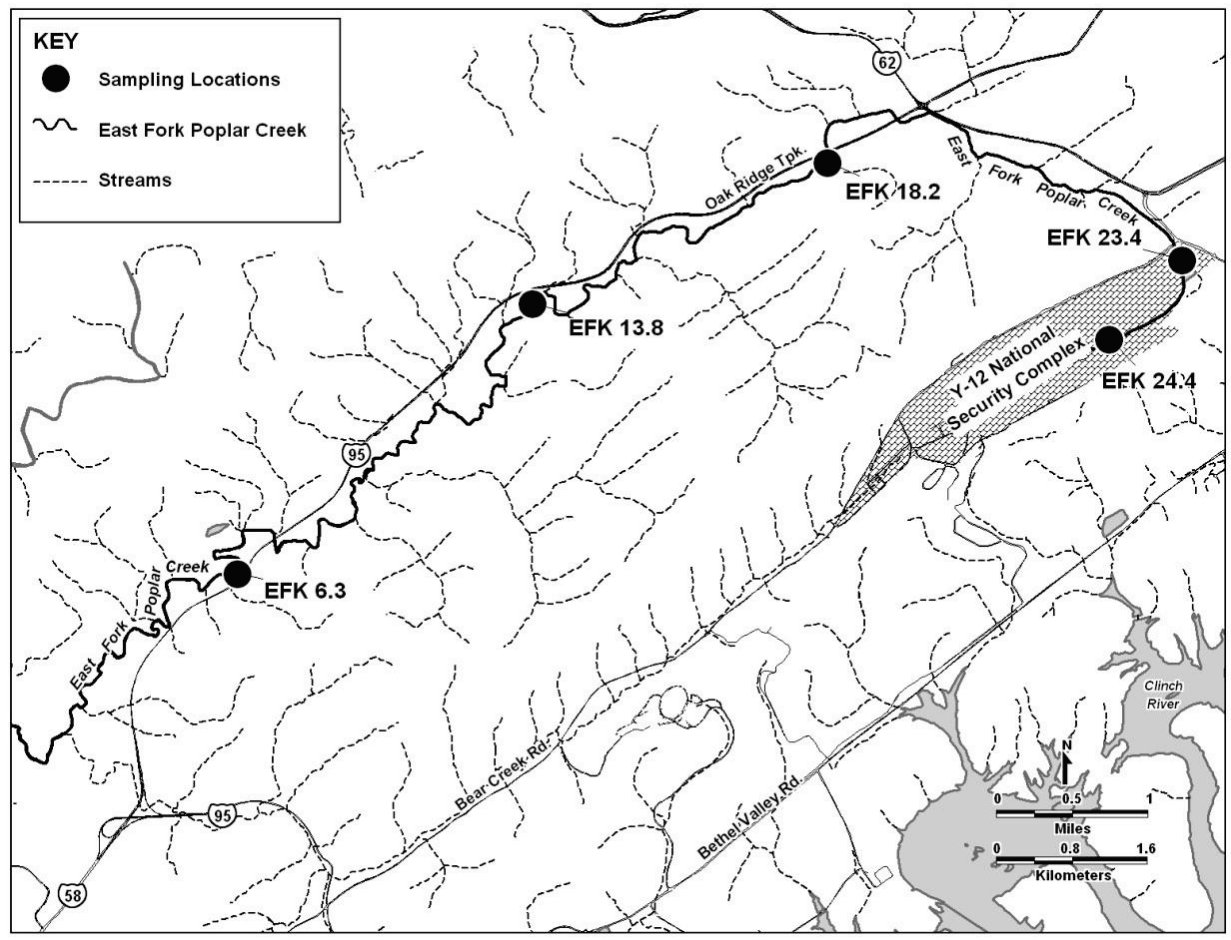

Fig. 4.27. Locations of biological monitoring sites on East Fork Poplar Creek in relation to the Y-12 National Security Complex. (EFK = East Fork Poplar Creek kilometer.) 


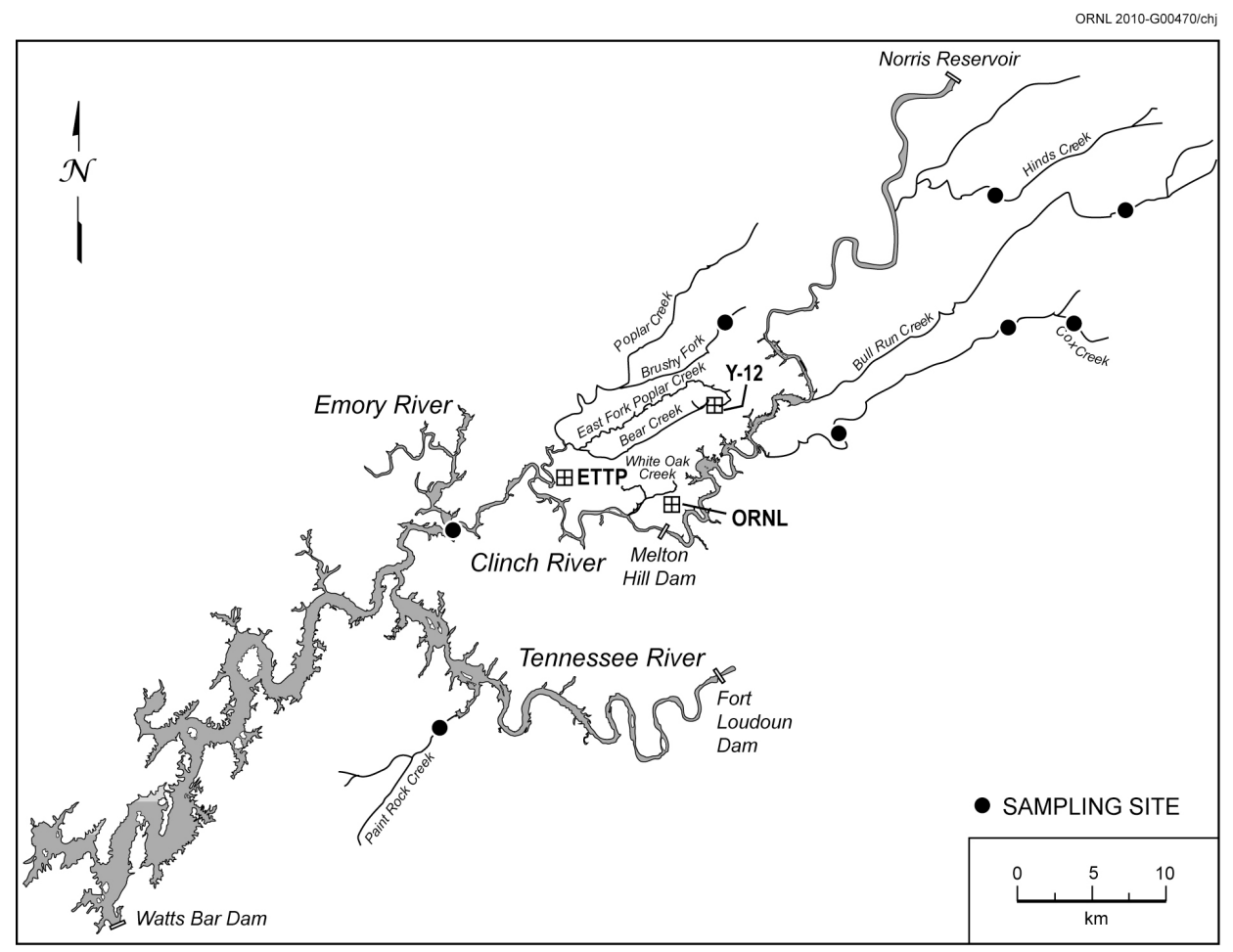

Fig. 4.28. Locations of biological monitoring reference sites in relation to the Y-12 National Security Complex. (ETTP = East Tennessee Technology Park and ORNL = Oak Ridge National Laboratory.)

\subsubsection{Bioaccumulation Studies}

Mercury and PCB levels in fish from EFPC have been historically elevated relative to fish in uncontaminated reference streams. Fish in EFPC are monitored regularly for mercury and PCBs to assess spatial and temporal trends in bioaccumulation associated with ongoing remedial activities and Y-12 Complex operations.

As part of this monitoring effort, redbreast sunfish (Lepomis auritus) and rock bass (Ambloplites rupestris) are collected twice a year from five sites throughout the length of EFPC and are analyzed for tissue concentrations of mercury (twice yearly) and PCBs (annually) (Fig. 4.27). A new sampling site was added in 2013 at EFK 13.0, just downstream of the Oak Ridge Sewage Treatment Plant. Mercury concentrations remained higher in fish from EFPC in 2013 than in fish from reference streams. Elevated mercury concentrations in fish from the upper reach of EFPC indicate that the Y-12 Complex remains a continuing source of mercury to fish in the stream.

Figure 4.29 shows temporal trends for mercury concentrations in water collected from EFK 23.4 (Station 17) and in fish collected just upstream of this monitoring station at EFK 24.4. Waterborne mercury concentrations in the upper reach of EFPC have decreased substantially over the years in response to various RAs, first over the 1990s time period and then again in response to the Big Springs Treatment System in 2006 (Fig. 4.29). Although mercury concentrations in fish over time have not decreased commensurate with mercury levels in water in the lower sections of EFPC, mercury concentrations in fish at the uppermost sampling site (EFK 24.4) decreased steadily in the 1990s, consistent with decreased concentrations in water (Fig. 4.29). Significant fluctuations in aqueous mercury concentrations (thought to be the result of storm drain relining and cleanout) have been seen at EFK 23.4 since 2009. Redbreast collected from the EFK 24.2 sampling site, about 1 kilometer upstream of Station 17, appear to have responded to the recent peak and decline in aqueous mercury concentrations. Mean concentrations at EFK 24.2 increased from $\sim 0.6 \mu \mathrm{g} / \mathrm{g}$ in 2011 to above $1 \mu \mathrm{g} / \mathrm{g}$ in 2012 , and then decreased back down to $\sim 0.6 \mu \mathrm{g} / \mathrm{g}$ in 2013 (Figure 4.29). That this species appears to have responded to changes in water mercury concentrations in the upper reaches of the creek is interesting, given it has not 
responded to decreases in aqueous total mercury concentrations at downstream sites throughout EFPC in the past 20 years. The relationship between aqueous total mercury concentrations and fish tissue concentrations is complex. Aqueous mercury concentrations vary by orders of magnitude throughout the various watersheds across ORR, but fish tissue concentrations tend not to vary greatly (twofold to threefold). Multiple ongoing investigations are being conducted to better understand mercury bioaccumulation dynamics in this creek.

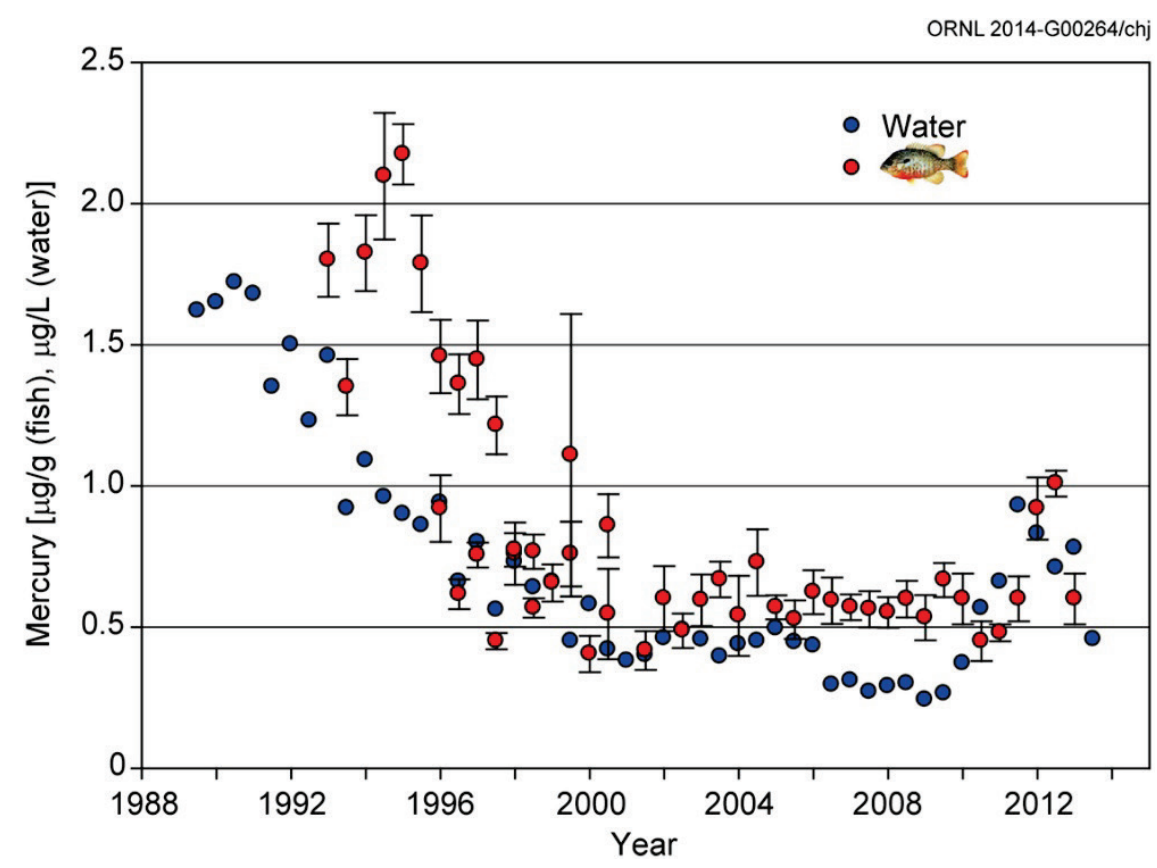

Fig. 4.29. Semiannual average mercury concentration in water from and muscle fillets of redbreast sunfish in East Fork Poplar Creek (EFPC) at EFPC kilometers 23.4 (water) and 24.4 (fish) through 2013.

The mean total PCB concentration in sunfish fillets at EFK 23.4 was $0.25 \mu \mathrm{g} / \mathrm{g}$ in 2013, remaining much lower than the peak levels observed in the mid-1990s (Figure 4.30). Regulatory guidance and human health risk levels have varied widely for $\mathrm{PCBs}$, depending on the regulatory program and the assumptions used in the risk analysis. The Tennessee water quality criteria for individual Aroclors and total PCBs are both $0.00064 \mu \mathrm{g} / \mathrm{L}$ under the recreation designated use classification and are the targets for PCB-focused Total Maximum Daily Loads (TMDLs), including for local reservoirs (Melton Hill, Watts Bar, and Fort Loudon; TDEC 2010a, b, c). In the state of Tennessee, assessments of impairment for water body segments as well as public fishing advisories are based on fish tissue concentrations. Historically, the US Food and Drug Administration threshold limit of $2 \mu \mathrm{g} / \mathrm{g}$ PCBs in fish fillets was used for advisories, and then for many years an approximate range of 0.8 to $1 \mu \mathrm{g} / \mathrm{g}$ was used, depending on the data available and factors such as the fish species and size. The remediation goal for fish fillets at the ETTP K-1007-P1 pond on ORR is $1 \mu \mathrm{g} / \mathrm{g}$ PCBs. Most recently, the water quality criterion has been used to calculate the fish tissue concentration triggering impairment and a TMDL (TDEC 2007); this concentration is $0.02 \mathrm{mg} / \mathrm{kg}$ PCBs in fish fillets (TDEC 2010a, b, and c). The fish PCB concentrations in upper EFPC, about $0.2 \mu \mathrm{g} / \mathrm{g}$ in fish fillets, are well above this concentration. 


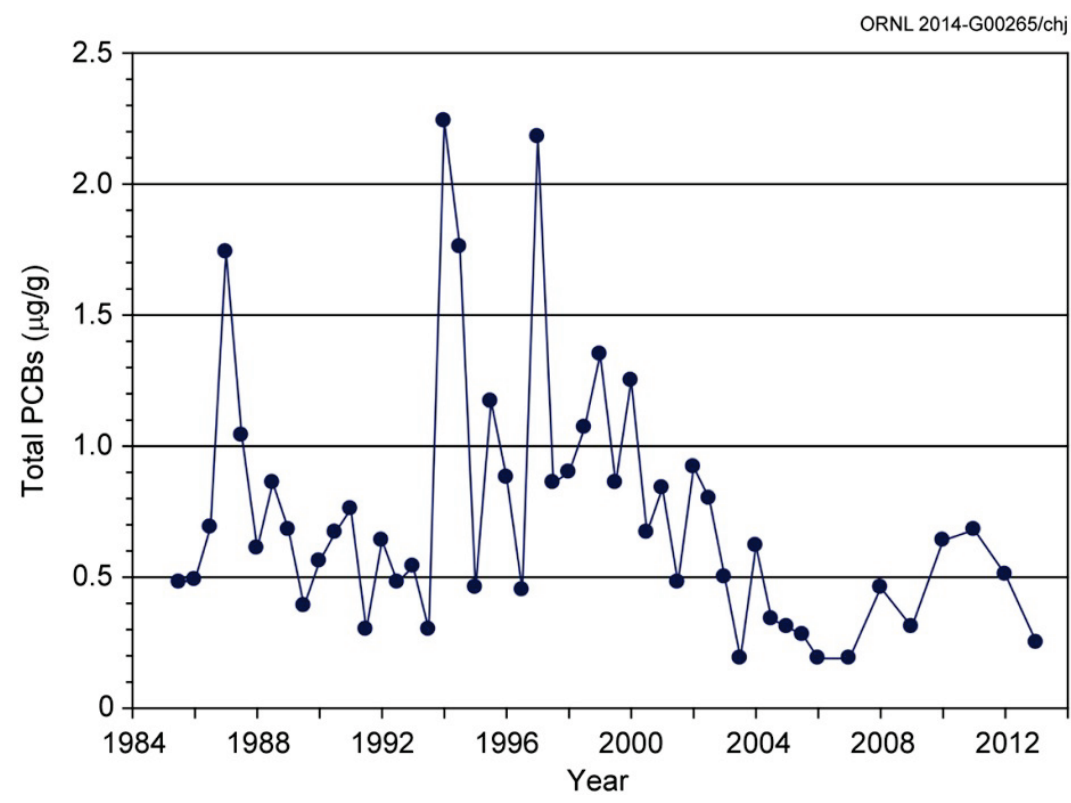

Fig. 4.30. Mean concentrations of polychlorinated biphenyls (PCBs) in rock bass muscle fillets in East Fork Poplar Creek (EFPC) at EFPC kilometer 23.4 through spring 2013.

\subsubsection{Benthic Invertebrate Surveys}

Monitoring of benthic macroinvertebrate communities continued at three sites in EFPC and at two reference streams in the spring of 2013. The number of pollution-intolerant macroinvertebrate taxa continued to be below the $95 \%$ confidence interval for the reference sites in 2013 (Fig. 4.31). This contrasted with EFK 23.4 where the number of pollution-intolerant taxa fell within the $95 \%$ confidence interval for the reference sites for the first time since monitoring began in the 1980s. The number of pollution-intolerant taxa at EFK 13.8 also fell within the 95\% reference confidence interval in 2013. These results show that the macroinvertebrate community at EFK 24.4 remains degraded, and long-term trends suggest that there have been no persistent changes at this site since 1997. Given the extent of annual change that has occurred at EFK 13.8 since monitoring began, results in 2013 mostly likely reflect normal variation. At EFK 23.4, on the other hand, the results appear to suggest that in the years since 2007 as many as two additional pollution-intolerant taxa have generally been present compared with the years prior to 2007. However, some groups of pollution-intolerant taxa (e.g., Plecoptera or stoneflies) remain rare or virtually absent from EFK 23.4 and EFK 13.8, thus suggesting that mildly degraded conditions remain at those sites. 


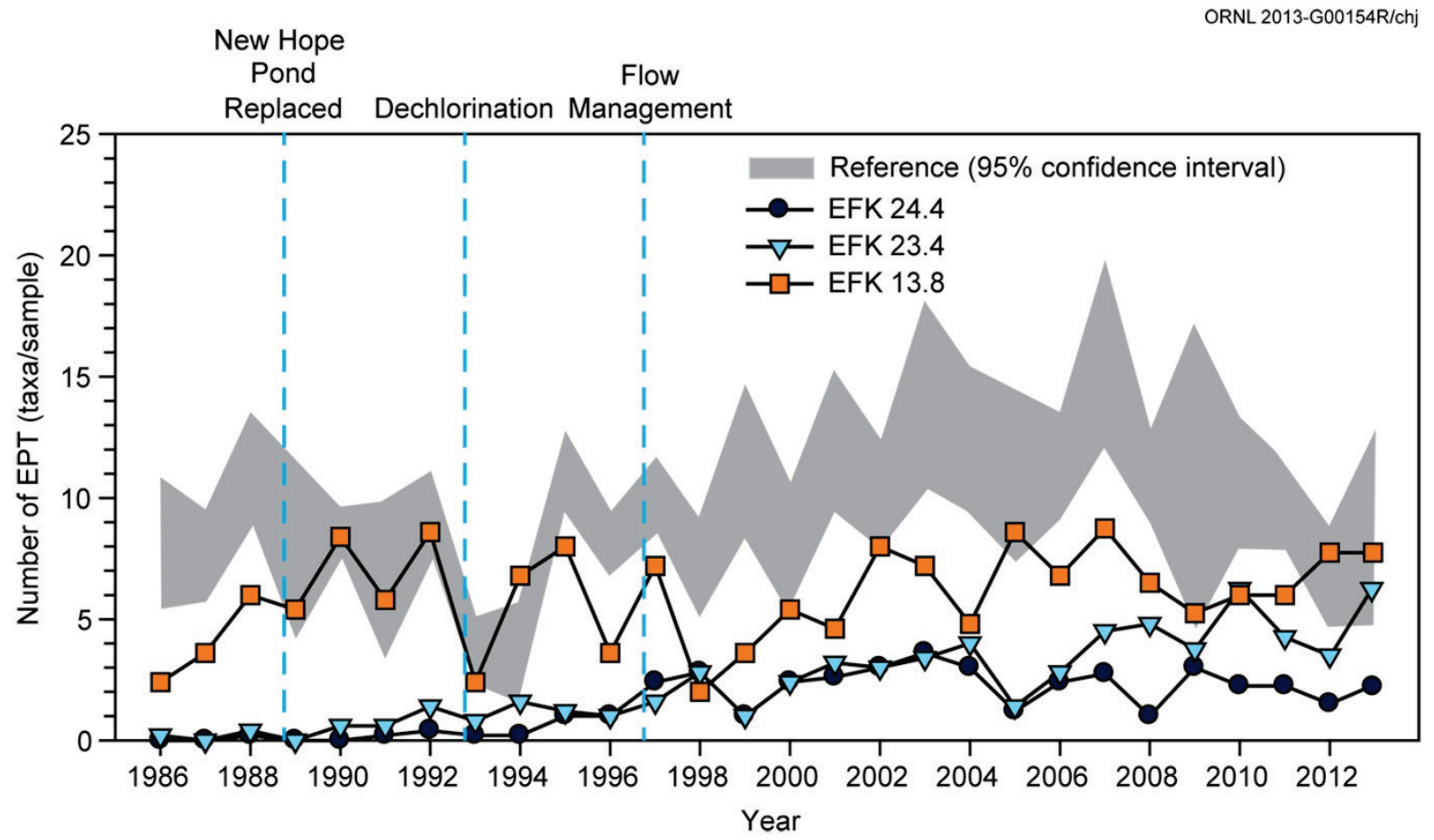

Fig. 4.31. Total taxonomic richness of the Ephemeroptera, Plecoptera, and Trichoptera (EPT) (mean number of EPT taxa/sample) of the benthic macroinvertebrate communities sampled in spring from East Fork Poplar Creek and two nearby reference streams (Brushy Fork and Hinds Creek), 1986-2013. (EFK = East Fork Poplar Creek kilometer.)

\subsubsection{Fish Community Monitoring}

Fish communities were monitored in the spring and fall of 2013 at five sites along EFPC and at a reference stream (Brushy Fork). Over the past two decades, overall species richness, density, biomass, and number of pollution-sensitive fish species have increased at all sampling locations below Lake Reality. The number of sensitive species over time is shown in Fig. 4.32 and dramatically highlights the major improvements in the fish community in the middle to lower sections of EFPC. However, the EFPC fish community continues to lag behind the reference stream community in most important metrics of fish diversity and community structure. This is especially true at the monitoring sites closest to the Y-12 Complex where the sensitive species richness ranges from 0 to $37 \%$ of the reference value.

Fish communities in upper EFPC were impacted by a high volume release of chlorinated water from a water line break in June of 2013. ORNL Environmental Sciences Division personnel, who were called in to investigate, collected more than 8,300 dead fish (see Section 4.5.1). This event was estimated to impact about $19 \%$ of the expected population based on previous fish community data from BMAP locations EFK 23.4 and EFK 24.4. Fall surveys of the fish communities included only the downstream site (EFK 23.4, downstream of Lake Reality); the upstream site within the facility is sampled annually in the spring. A survey of the fish populations at EFK 23.4 in September 2013 yielded 951 individual fish compared to a mean of 1,431 fish for the previous two fall samples, representing a $34 \%$ reduction. Whether the fish kill or other factors are negatively affecting upstream fish populations is currently unknown. Population densities in upper EFPC often fluctuate seasonally; however, fish densities observed in fall 2013 were similar to surveys following a previous fish kill in July 1997, as shown in Fig 4.33. Population densities in upper EFPC will likely recover within a couple of years as was the case in 1997 unless additional events occur. 


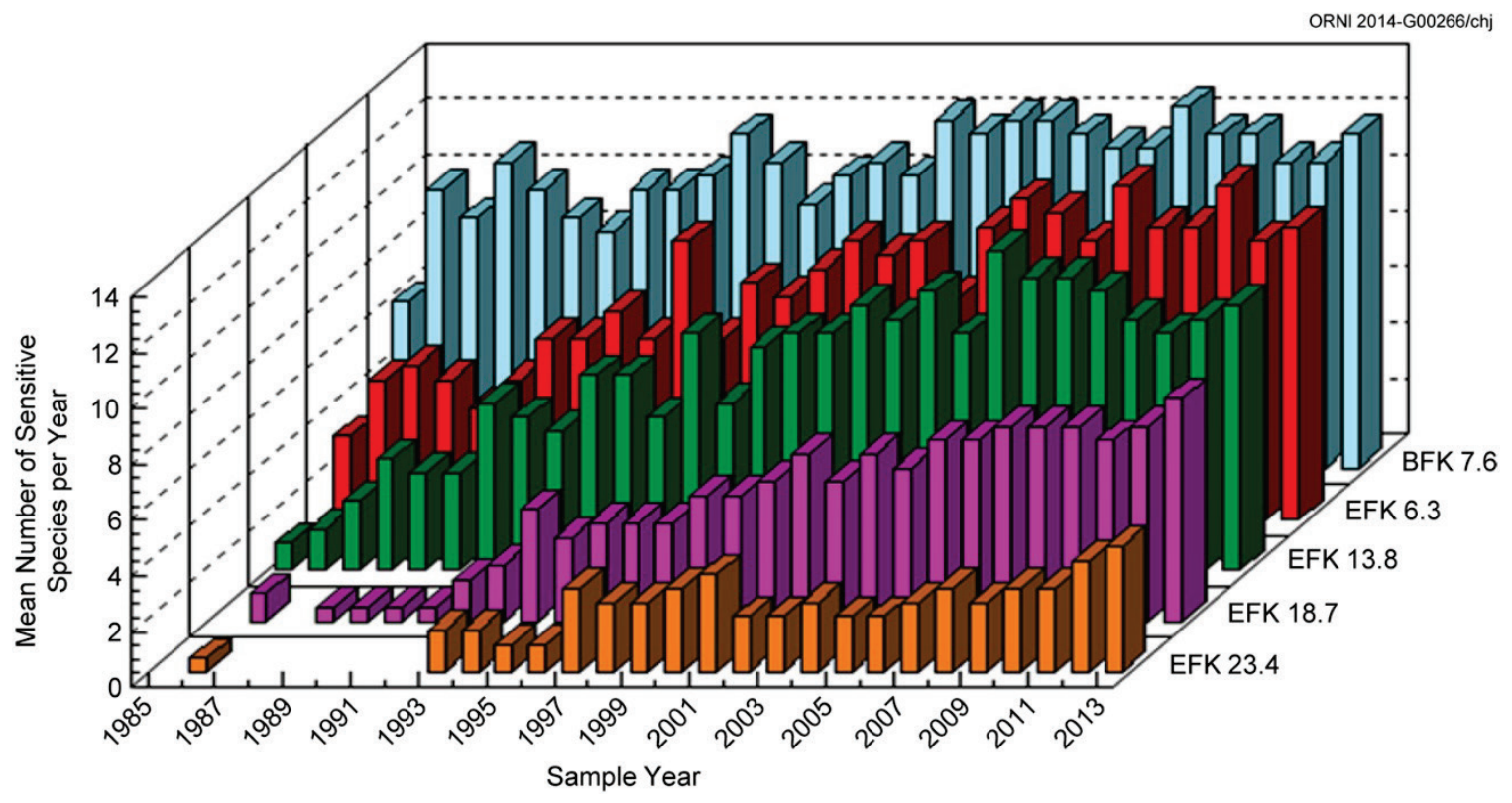

Fig. 4.32. Comparison of mean sensitive species richness (number of species) collected each year from 1985-2013 from four sites in East Fork Poplar Creek and a reference site (Brushy Fork). (EFK = East Fork Poplar Creek kilometer; BFK = Brushy Fork kilometer.)

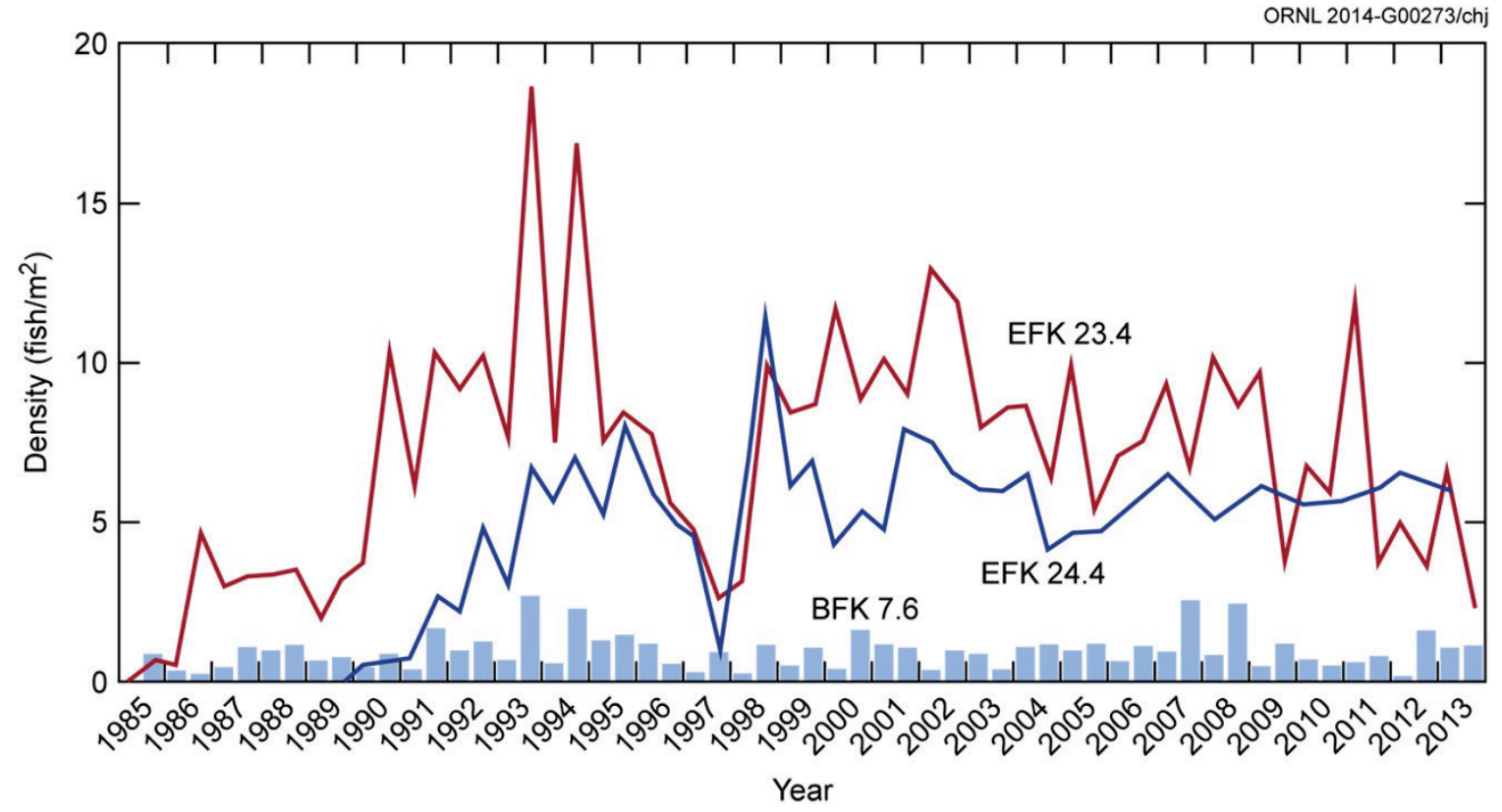

Fig. 4.33. Fish density (number of fish per square meter) for two sites in upper East Fork Poplar Creek and a reference site (Brushy Fork) from 1985-2013. (EFK = East Fork Poplar Creek kilometer; BFK = Brushy Fork kilometer.)

\subsection{Groundwater at the Y-12 Complex}

Groundwater monitoring at the Y-12 Complex is performed to comply with federal and state requirements and to determine what impacts to the environment from legacy and current operations are occurring. More than 150 sites have been identified at the Y-12 Complex that represent known or 
potential sources of contamination to the environment as a result of past operational and waste management practices (DOE 2013b). Monitoring provides information on the nature and extent of contamination of groundwater, which is then used to determine what actions must be taken to protect the worker, public, and environment in compliance with regulations and DOE orders. Figure 4.34 depicts the major facilities or areas for which groundwater monitoring was performed during CY 2013.

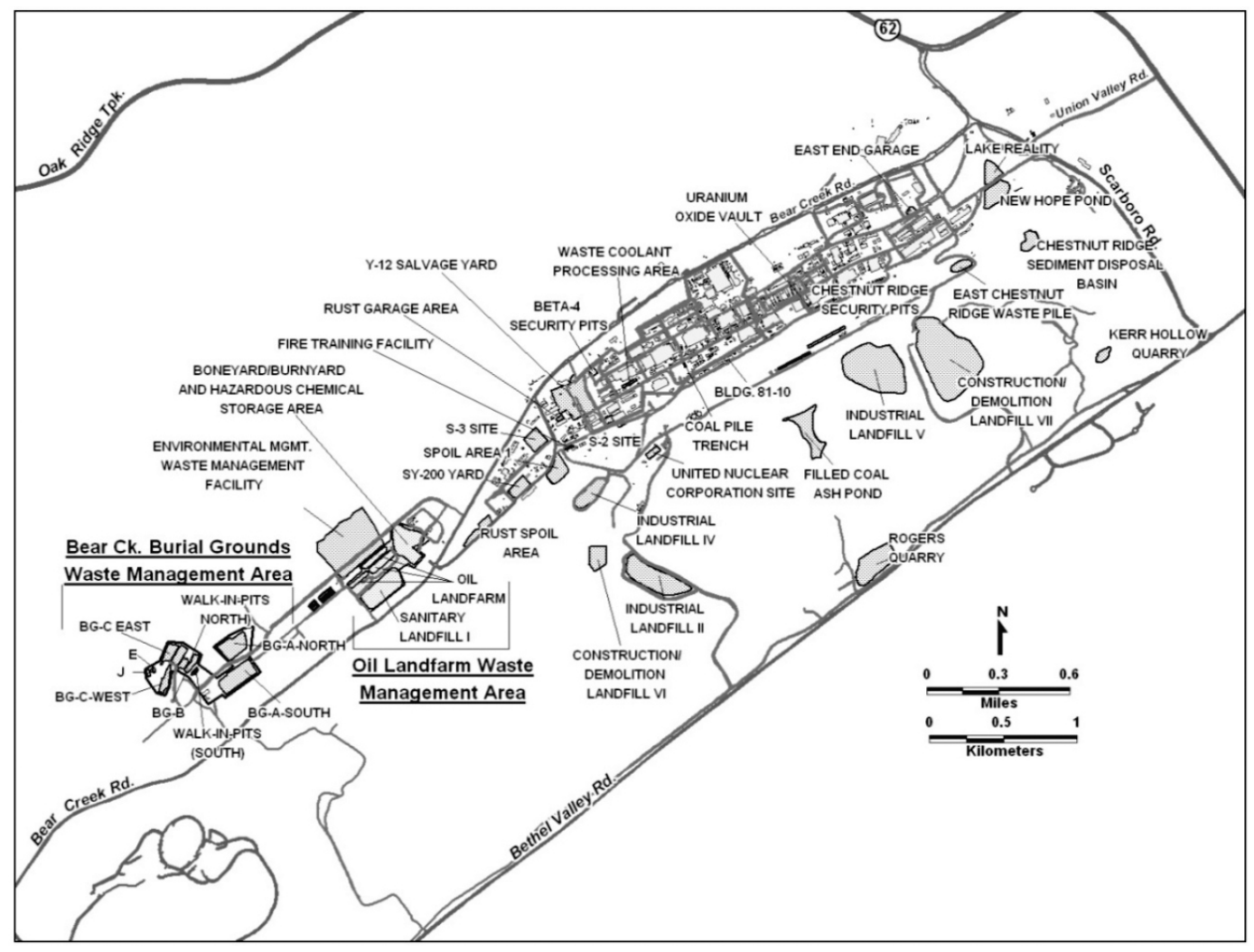

Fig. 4.34. Known or potential contaminant sources for which groundwater monitoring was performed at the Y-12 National Security Complex during CY 2013.

\subsubsection{Hydrogeologic Setting}

The Y-12 Complex is divided into three hydrogeologic regimes (Bear Creek, upper EFPC, and Chestnut Ridge), which are delineated by surface water drainage patterns, topography, and groundwater flow characteristics (Fig. 4.35). Most of the Bear Creek and upper EFPC regimes are underlain by the "shales, siltstones, and sandstones with a subordinate and locally variable amount of carbonate bedrock" mentioned in Section 1.3.5 and hydrostratigraphically referred to as aquitards. Aquitards are rock units that contain water but do not readily yield significant water to pumping wells. However, geologic units that are considered aquitards can often yield water in quantities sufficient for domestic or small farm use (Domenico and Schwartz 1990). The southern portion of the two regimes is underlain by the Maynardville Limestone, which is part of the Knox aquifer. The Chestnut Ridge regime is almost entirely underlain by the Knox aquifer. The southernmost portion near Bethel Valley Road consists of the lowest members of the Chickamauga Group. In general, groundwater flow in the water table interval follows the topography. Shallow groundwater flow in the Bear Creek and upper EFPC regimes is divergent from the topographic and groundwater divide located near the western end of the Y-12 Complex that defines the boundary between the two. In addition, flow converges on the primary surface streams (Bear Creek and upper EFPC) from Pine Ridge and Chestnut Ridge. In the Chestnut Ridge regime, a groundwater divide exists that nearly coincides with the crest of the ridge. Shallow groundwater flow tends to be toward either flank of the ridge, with discharge primarily to surface streams and springs located in Bethel Valley to the south and Bear Creek Valley to the north. 


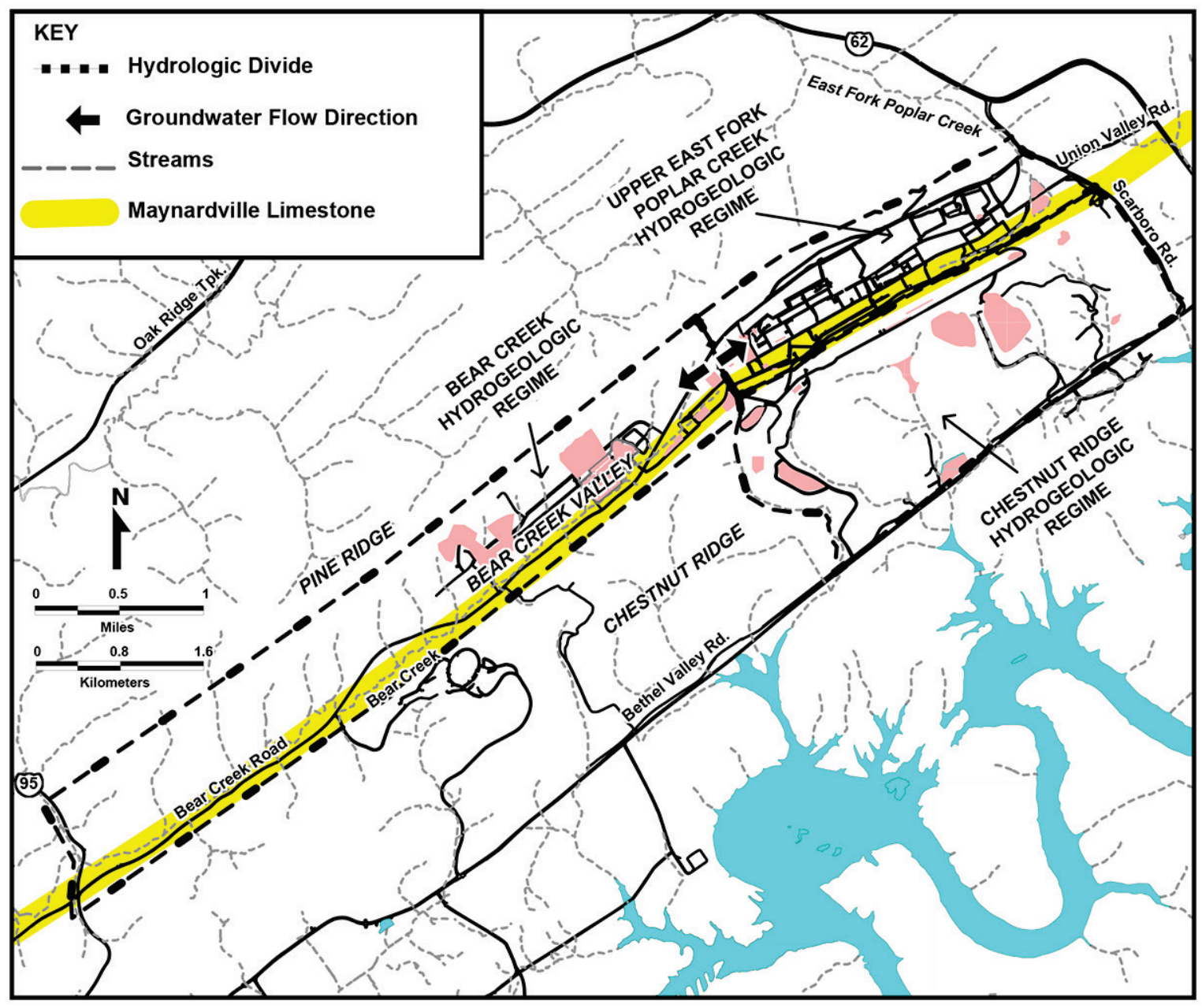

Fig. 4.35. Hydrogeologic regimes at the Y-12 National Security Complex and the position of the Maynardville Limestone in Bear Creek Valley.

In Bear Creek Valley, groundwater in the intermediate and deep intervals moves predominantly through fractures in the aquitard, converging on and then moving through fractures and solution conduits in the Maynardville Limestone (Fig. 4.35). Karst development in the Maynardville Limestone has a significant impact on groundwater flow paths in the water table and intermediate intervals. In general, groundwater flow parallels the valley and geologic strike. Groundwater flow rates in Bear Creek Valley vary widely; they are very slow within the deep interval of the fractured noncarbonate rock (less than $1 \mathrm{ft} /$ year) but can be quite rapid within solution conduits in the Maynardville Limestone (tens to thousands of feet per day). The rate of groundwater flow perpendicular to geologic strike from the aquitard units of the lower Conasauga Group to the Maynardville Limestone is also very slow below the water table interval.

Contaminant migration is primarily advective (contaminants are transported along with flowing groundwater through the pore spaces, fractures, or conduits of the hydrogeologic system). Strike-parallel transport of some contaminants can occur within the aquitard units for significant distances, where they discharge to surface water tributaries or underground utility and storm water distribution systems in industrial areas. Continuous elevated levels of nitrate (a groundwater contaminant from legacy waste disposals) within the fractured bedrock of the aquitards are known to extend east and west from the S-3 site for thousands of feet. VOCs (e.g., petroleum products, coolants, and solvents) at source units over or in the fractured clastic dominated bedrock can remain close to source areas because they tend to adsorb to the bedrock matrix, diffuse into pore spaces within the matrix, and degrade before migrating to exit pathways where more rapid transport occurs for longer distances. However, extensive VOC contamination from multiple sources is observable throughout the groundwater system in both the Bear Creek and upper EFPC regimes. 
Groundwater flow in the Chestnut Ridge regime is through fractures and solution conduits in the Knox Group. Discharge points for intermediate and deep flow are not well known. Groundwater is currently presumed to flow toward Bear Creek Valley to the north and Bethel Valley to the south. Groundwater from intermediate and deep zones may discharge at certain spring locations along the flanks of Chestnut Ridge. Following the crest of the ridge, water table elevations decrease from west to east, demonstrating an overall easterly trend in groundwater flow.

\subsubsection{Well Installation and Plugging and Abandonment Activities}

A number of monitoring devices are routinely used for groundwater data collection at the Y-12 Complex. Monitoring wells are permanent devices used for the collection of groundwater samples; they are installed according to established regulatory and industry standards. Figure 4.36 shows a cross section of a typical groundwater monitoring well. Other devices or techniques (e.g., drive points and direct push installations) are sometimes used to gather groundwater data.

In CY 2013, one well was installed in support of research activities at the Oak Ridge Field Research Center (ORFRC). This well was installed about 4.4 miles $(7 \mathrm{~km})$ west of the S-3 site in the ORFRC background area near the intersection of State Highway 95 and Bear Creek Road. ORFRC was created to provide real-world conditions to investigate the interactions and processes within a contaminated groundwater system to assist in the development of remediation strategies and tools for groundwater cleanup.

One monitoring well was plugged and abandoned during the year. This was not an actively monitored well. It was located near the southeast corner of the Y12 Salvage Yard and was damaged during site cleanup operations.

\subsubsection{Calendar Year 2013 Groundwater Monitoring}

Groundwater monitoring in CY 2013 was performed

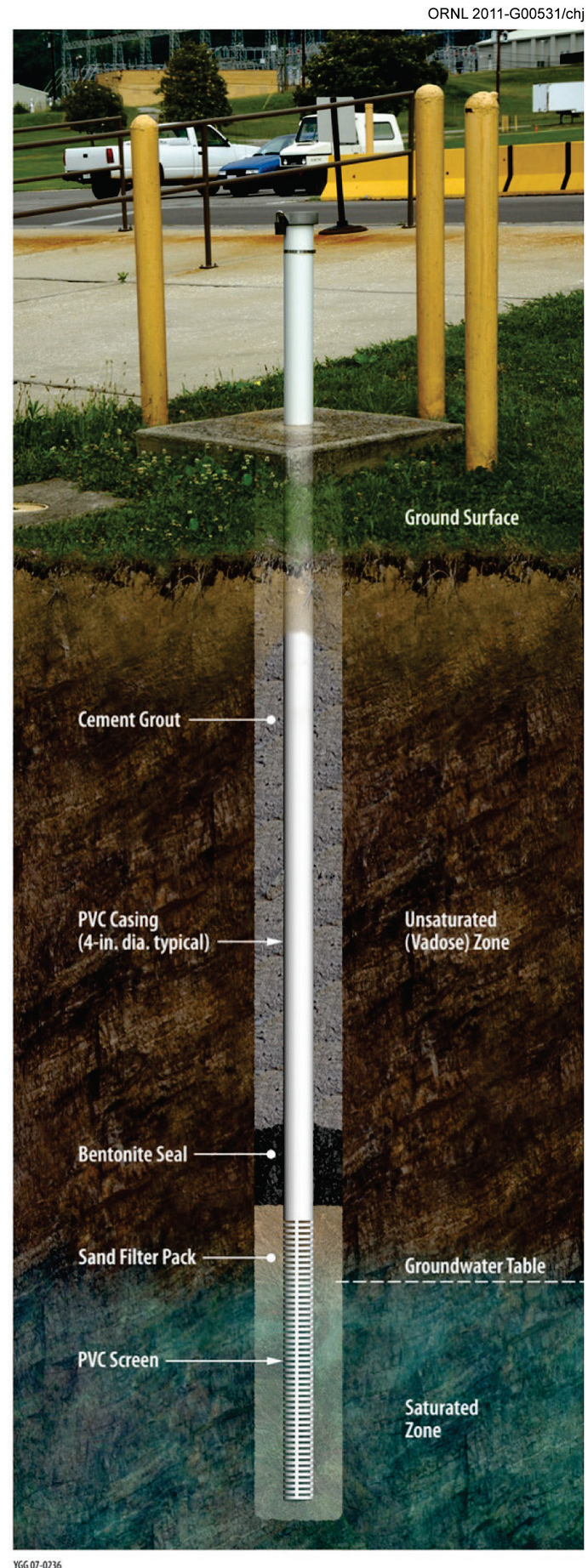

Fig. 4.36. Cross section of a typical groundwater monitoring well. as part of the Y-12 GWPP to comply with DOE orders and regulations, DOE EM programs such as WRRP, and other projects. Compliance requirements were met by monitoring 225 wells and 50 surface water locations and springs (Table 4.20). Figure 4.37 shows the locations of Y-12 Complex perimeter/exit pathway groundwater monitoring stations. 
Table 4.20. Summary groundwater monitoring at the Y-12 National Security Complex, 2013

\begin{tabular}{|c|c|c|c|c|c|}
\hline & \multicolumn{5}{|c|}{ Purpose for which monitoring was performed } \\
\hline & Restoration $^{a}$ & $\begin{array}{c}\text { Waste } \\
\text { management }^{b}\end{array}$ & Surveillance $^{c}$ & Other $^{d}$ & Total \\
\hline Number of active wells & 62 & 34 & 129 & 56 & 281 \\
\hline $\begin{array}{l}\text { Number of other monitoring stations (e.g., } \\
\text { springs, seeps, surface water) }\end{array}$ & 28 & 6 & 16 & 0 & 50 \\
\hline Number of samples taken ${ }^{e}$ & 168 & 150 & 154 & 305 & 777 \\
\hline Number of analyses performed & 8,095 & 20,230 & 12,157 & 2,019 & 42,501 \\
\hline Percentage of analyses that are nondetects & 73.8 & 87.2 & 81.7 & 30.1 & 80.4 \\
\hline \multicolumn{6}{|c|}{ Ranges of results for positive detections, VOCs $(\mu \mathrm{g} / L)^{f}$} \\
\hline Chloroethenes & $1-6,900$ & $0.4-8.46$ & $2-46,000$ & NA & \\
\hline Chloroethanes & $1-380$ & $9.81-59.1$ & $1-1,200$ & NA & \\
\hline Chloromethanes & $1.3-760$ & ND & $2-3,600$ & NA & \\
\hline Petroleum hydrocarbons & $1.1-6,000$ & ND & $1-1,500$ & NA & \\
\hline $\operatorname{Uranium}(\mathrm{mg} / \mathrm{L})$ & $0.0042-0.5$ & $0.0045-0.0195$ & $\begin{array}{c}0.00055- \\
0.988\end{array}$ & $0.255-21.54$ & \\
\hline Nitrates $(\mathrm{mg} / \mathrm{L})$ & $0.011-8,100$ & $0.501-2.14$ & $0.052-9,960$ & $0.326-18,190$ & \\
\hline \multicolumn{6}{|c|}{ Ranges of results for positive detections, radiological parameters $(\mathrm{pCi} / \mathrm{L})^{g}$} \\
\hline Gross alpha activity & $1.34-2,910$ & $0.56-3.34$ & $3.3-190$ & NA & \\
\hline Gross beta activity & $2.38-19,200$ & $3.45-15.1$ & $7.9-8,700$ & NA & \\
\hline
\end{tabular}

${ }^{a}$ Monitoring to comply with CERCLA requirements and with RCRA postclosure detection and corrective action monitoring.

${ }^{b}$ Solid waste landfill detection monitoring and CERCLA landfill detection monitoring.

${ }^{c}$ DOE order surveillance monitoring.

${ }^{d}$ Research-related groundwater monitoring associated with activities of the DOE Oak Ridge Field Research Center.

${ }^{e}$ The number of unfiltered samples, excluding duplicates, determined for unique location/date combinations.

${ }^{f}$ These ranges reflect concentrations of individual contaminants (not summed VOC concentrations):

- $\quad$ chloroethenes - include tetrachloroethene, trichloroethene, 1,2-dichloroethene (cis and trans) 1,1-dichloroethene, and vinyl chloride

- chloroethanes - include 1,1,1-trichloroethane, 1,2-dichloroethane, and 1,1-dichloroethane

- chloromethanes - include carbon tetrachloride, chloroform, and methylene chloride

- $\quad$ petroleum hydrocarbons - include benzene, toluene, ethylbenzene, and xylene

${ }^{g} 1 \mathrm{pCi}=3.7 \times 10^{2} \mathrm{~Bq}$.

\section{Abbreviations}

CERCLA $=$ Comprehensive Environmental Response, Compensation, and Liability Act

$\mathrm{NA}=$ not analyzed

$\mathrm{ND}=$ not detected

RCRA $=$ Resource Conservation and Recovery Act

VOC $=$ volatile organic compound 


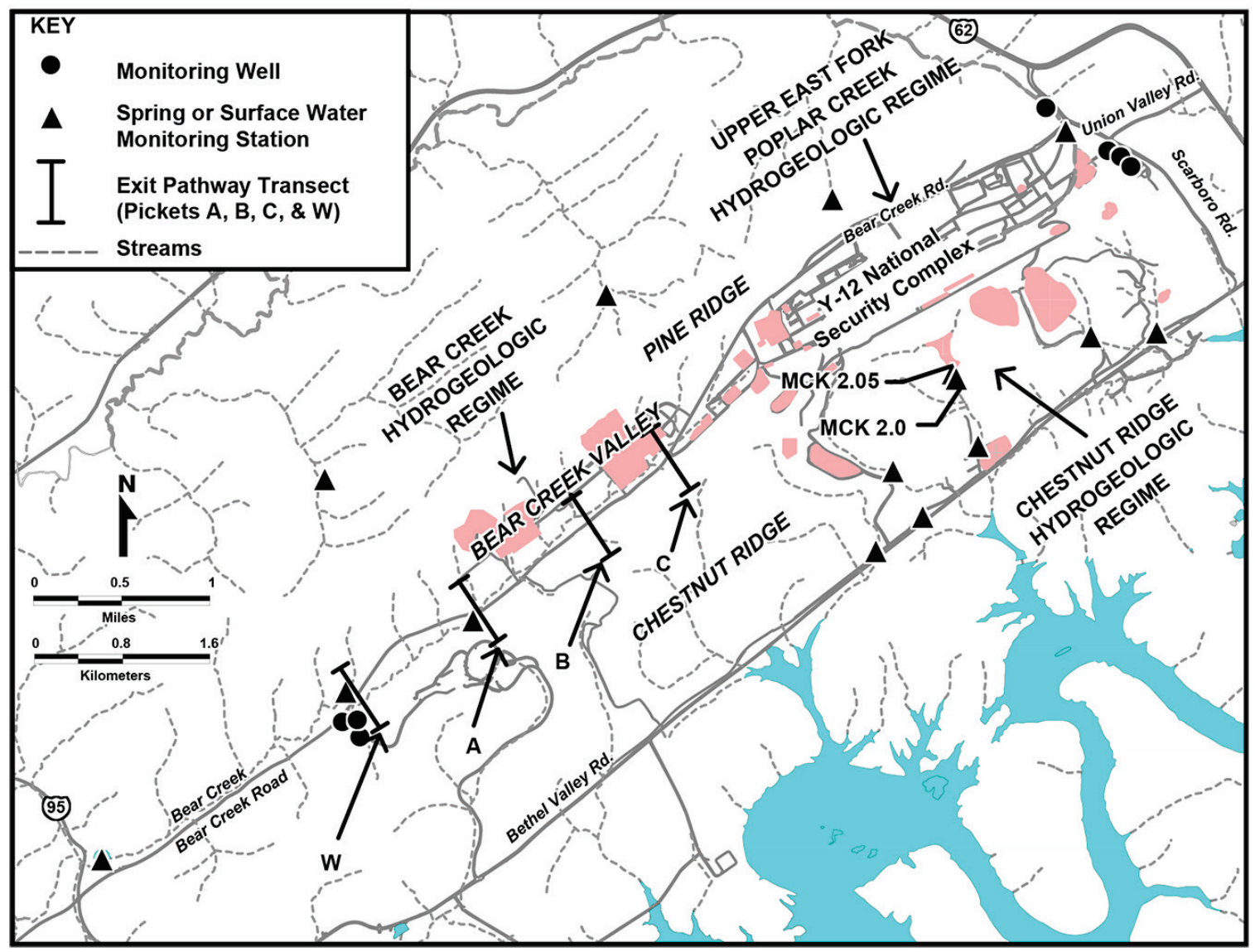

Fig. 4.37. Location of Y-12 National Security Complex perimeter/exit pathway well, spring, and surface water monitoring stations. (MCK = McCoy Branch kilometer.)

Most of the conventional monitoring wells at the Y-12 Complex were sampled using industry standard methods approved by TDEC and EPA (Fig. 4.38). The Y-12 GWPP continued to use passive diffusion bag samplers in 2013 at selected monitoring wells. The passive diffusion bag sampling method is suitable only for monitoring for the presence and concentration of selected VOCs in groundwater. This method involves suspending a polyethylene bag (semipermeable membrane) filled with deionized water at a selected depth within the monitored interval of the well and leaving the passive diffusion bag in place for a prescribed period (at least four weeks). The chemical concentration gradient between the uncontaminated deionized water in the passive diffusion bag and the surrounding contaminated groundwater induces VOCs in the groundwater to diffuse through the bag into the deionized water until equilibrium conditions are achieved. When retrieved, the water in the passive diffusion bag is decanted into VOC sample bottles and analyzed using standard procedures.

Comprehensive water quality results of groundwater monitoring activities at the Y-12 Complex in CY 2013 are presented in Calendar Year 2013 Groundwater Monitoring Report (B\&W Y-12 2014).

Details of monitoring efforts performed specifically for CERCLA baseline and remediation evaluation are published in the FY 2013 and FY 2014 WRRP sampling and analysis plans (UCOR 2012, UCOR 2013) and the annual CERCLA remediation effectiveness reports (DOE 2014a).

Groundwater monitoring compliance reporting to meet RCRA postclosure permit requirements can be found in the annual RCRA groundwater monitoring report (UCOR 2014). 


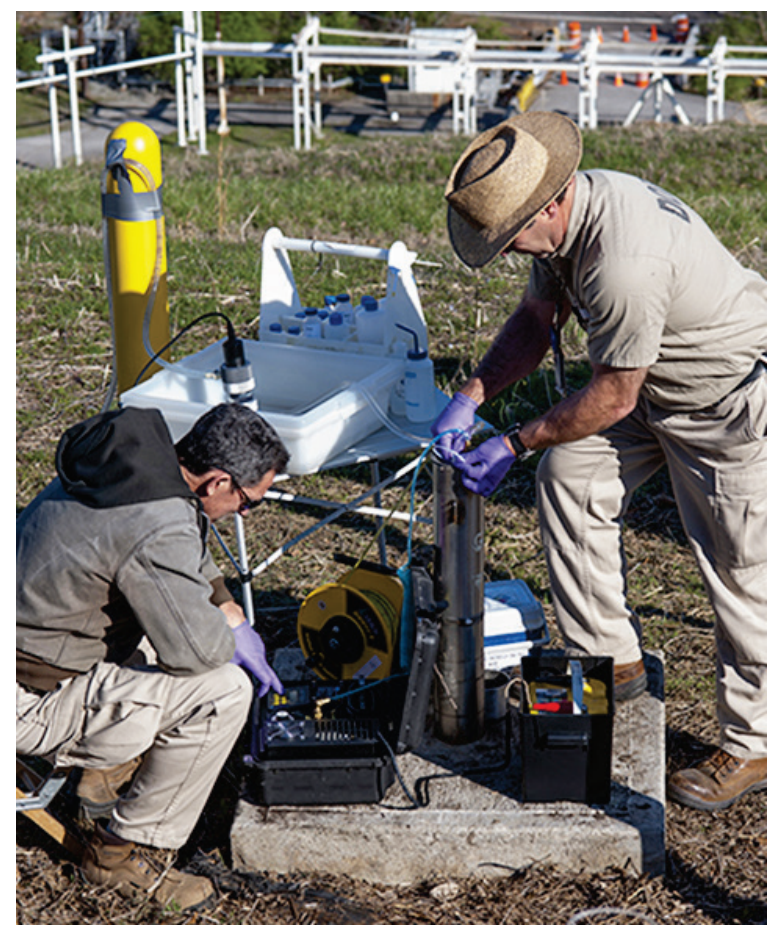

Fig. 4.38. Groundwater monitoring well sampling at the Y-12 National Security Complex. [Source: Kathryn Fahey, Y-12 photographer.]

\subsubsection{Y-12 Complex Groundwater Quality}

Historical monitoring efforts have shown that there are four primary contaminants that have impacted groundwater quality at the Y-12 Complex: nitrate, VOCs, metals, and radionuclides. Of those, VOCs are the most widespread as a result of their common use and disposal at the site. Uranium and ${ }^{99} \mathrm{Tc}$ are the radionuclides of greatest concern. Trace metals (e.g., arsenic, barium, cadmium, chromium, mercury), the least extensive groundwater contaminants, generally occur close to source areas because of their generally high adsorption characteristics. Historical data have shown that plumes from multiple-source units have mixed with one another and that contaminants (other than nitrate and ${ }^{99} \mathrm{Tc}$ ) are not always easily associated with a single source.

\subsubsection{Upper East Fork Poplar Creek Hydrogeologic Regime}

Among the three hydrogeologic regimes underlying the Y-12 Complex, the upper EFPC regime encompasses most of the known and potential sources of surface water and groundwater contamination. A brief description of waste management sites is given in Table 4.21. Chemical constituents from the S-3 site (primarily nitrate and ${ }^{99} \mathrm{Tc}$ ) and VOCs from multiple source areas are observed in the groundwater in the western portion of the upper EFPC regime; groundwater in the eastern portion is predominantly contaminated with VOCs. 
Table 4.21. Description of waste management units and underground storage tanks included in groundwater monitoring activities, upper East Fork Poplar Creek hydrogeologic regime, 2013

\begin{tabular}{|c|c|}
\hline Site & Description \\
\hline New Hope Pond & $\begin{array}{l}\text { Built in } 1963 \text { and closed in 1988. Regulated flow of water in upper East Fork Poplar Creek } \\
\text { before exiting the Y-12 Complex grounds. Sediments include PCBs, mercury, and uranium but } \\
\text { not hazardous according to toxicity characteristic leaching procedure. An oil skimmer basin } \\
\text { was built as part of the pond when constructed. This basin collected oil and floating debris } \\
\text { from upper East Fork Poplar Creek before discharge into the pond. A minor source of uranium } \\
\text { in groundwater, the basin was closed under RCRA in } 1990 \text {. }\end{array}$ \\
\hline
\end{tabular}

Salvage Yard Scrap Metal Storage Area

Salvage Yard Oil/Solvent Drum Storage Area

Salvage Yard Oil Storage Tanks

Salvage Yard Drum Deheader

Building 81-10 Area

Rust Garage Area

Building 9418-3 Uranium Oxide Vault

Fire Training Facility

Beta-4 Security Pits

S-2 Site

Waste Coolant Processing Area

East End Garage

Coal Pile Trench
Used from 1950 to 1999 for scrap metal storage. Some metals contaminated with low levels of uranium. Runoff and infiltration are the principal release mechanisms to groundwater. In 2011 a CERCLA action to characterize and remove the scrap was completed. Soil characterization and analysis performed in 2010 and 2011 determined that this facility is not a significant risk to groundwater.

Operated from 1976 to 1989. Primary wastes included waste oils, solvents, uranium, and beryllium. Closed under RCRA with all drums removed. Leaks and spills represent the primary contamination mechanisms for groundwater. Soil characterization and analysis performed in 2010 and 2011 determined that this facility is not a significant risk to groundwater.

Used from 1978 to 1986. Two tanks used to store PCB-contaminated oils, both within a diked area. Tanks were removed after 1993. Soil characterization and analysis performed in 2010 and 2011 determined that this facility is not a significant risk to groundwater.

Used from 1959 to 1989 . Sump tanks 2063-U, 2328-U, and 2329-U received residual drum contents. Tanks removed in 1989. Sump leakage is a likely release mechanism to groundwater. The facility was demolished and removed and the soils beneath this facility were excavated and replaced with clean fill and gravel to remediate the site in 2011.

Mercury recovery facility operated from 1957 to 1962 . Potential historical releases to soil, groundwater and surface water from leaks and spills of liquid wastes or mercury. The building structure was demolished in 1995.

Former vehicle and equipment maintenance area, including four former petroleum USTs. All tanks were removed by 1990. Petroleum product releases to groundwater are documented.

Originally contained an oil storage tank. Used from 1960 to 1964 to dispose of nonenriched uranium oxide. Leakage from the vault to groundwater is the likely release mechanism.

Used for hands-on firefighting training. Sources of contamination to soil include flammable liquids and chlorinated solvents. Infiltration is the primary release mechanism to groundwater. Used from 1968 to 1972 for disposal of classified materials, scrap metals, and liquid wastes. Site is closed and capped. Primary release mechanism to groundwater is infiltration.

Used from 1945 to 1951. An unlined reservoir received liquid wastes. Infiltration is the primary release mechanism to groundwater.

Used from 1977 to 1985 . Former biodegradation facility used to treat waste coolants from various machining processes. Closed under RCRA in 1988.

Used from 1945 to 1989 as a vehicle fueling station. Five USTs used for petroleum fuel storage were excavated, 1989 to 1993 . Petroleum releases to the groundwater are documented.

Located beneath the current steam plant coal pile. Disposals included solid materials (primarily alloys). Trench leachate is a potential release mechanism to groundwater. In 2011, the coal pile overlying the coal pile trench was removed and the area resurfaced with gravel.

\footnotetext{
Abbreviations

CERCLA = Comprehensive Environmental Response, Compensation, and Liability Act

$\mathrm{PCB}=$ polychlorinated biphenyl

RCRA $=$ Resource Conservation and Recovery Act

UST $=$ underground storage tank

Y-12 Complex $=$ Y-12 National Security Complex
} 


\subsection{Plume Delineation}

Sources of groundwater contaminants monitored during CY 2013 include the S-2 site, the Fire Training Facility, the S-3 site, the Waste Coolant Processing Facility, petroleum UST sites, New Hope Pond, the Beta-4 Security Pits, the salvage yard, and process/production buildings throughout the Y-12 Complex. Although the S-3 site, now closed under RCRA, is located west of the current hydrologic divide that separates the upper EFPC regime from the Bear Creek regime, it has contributed to groundwater contamination in the western part of the upper EFPC regime. As previously mentioned, contaminant plumes in the EFPC regime are elongated in shape as a result of preferential transport of the contaminants parallel to strike (parallel to the valley axis) in both the Knox aquifer and the fractured bedrock of the aquitard units. The plume maps depicted in this section (Figs. 4.39, 4.41, 4.42, and 4.43) have been updated to reflect the average concentrations and radioactivity in groundwater over the last 5 years (CY 2008-2012).

In CY 2013, the Y-12 GWPP evaluated the extent of current groundwater contamination and updated the plume maps for a number of COCs, including the primary contaminants (B\&W Y-12 2013a). Plume maps depicted in previous ASERs were developed from those presented in CERCLA remedial investigations (RIs) that took place in the late 1990s (DOE 1997, 1998). The RI plume maps were determined to be representative of groundwater contamination at Y-12 during the years subsequent to publication and were considered relevant for presentation in the ASERs. The updated maps are based on the more extensive and more recent sampling and analysis results and include data not available for the RIs (e.g., existing or new wells being sampled subsequent to the RI). These results were used to capture current groundwater conditions and in some areas reflect substantially different (higher or lower) contaminant concentrations than the data used during the RIs. These changes are due to improved data availability and/or changes within the hydrogeologic system (i.e., plume migration and/or degradation processes) either related to time and natural processes or as a result of actions taken to mitigate groundwater contamination (e.g., the East End VOC Plume Capture System).

\subsection{Nitrate}

Unlike many groundwater contaminants, nitrate is highly soluble and moves easily with groundwater. Nitrate concentrations in groundwater at the Y-12 Complex exceed the $10 \mathrm{mg} / \mathrm{L}$ drinking water standard in part of the western portion of the upper EFPC regime in the aquitard units (a complete list of national drinking water standards is presented in Appendix C) and in the Maynardville Limestone unit of the Knox aquifer. The two primary sources of nitrate contamination are the S-2 and S-3 sites. The extent of the nitrate plume is essentially defined in the unconsolidated and shallow bedrock zones. In CY 2013, groundwater concentrations of nitrate as high as $8,840 \mathrm{mg} / \mathrm{L}$ (well GW-275) were observed in the shallow bedrock 16.7-19.8 m (55-65 ft) below ground surface) about $396 \mathrm{~m}(1,300 \mathrm{ft})$ east of the S-3 site (Fig. 4.39). These results are consistent with results from previous years. 


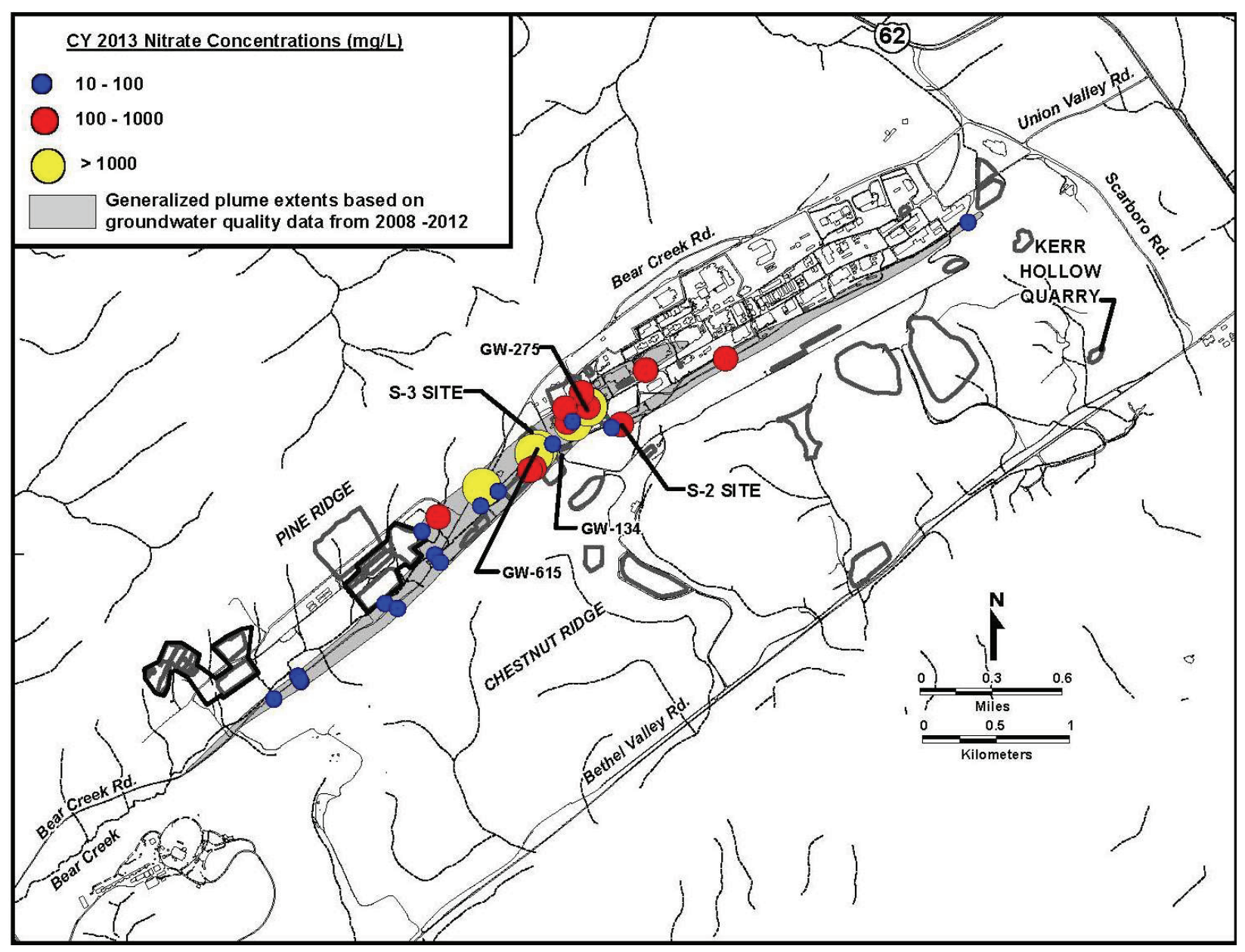

Fig. 4.39. Nitrate observed in groundwater at the Y-12 National Security Complex, 2013.

\subsection{Trace Metals}

Concentrations of barium, beryllium, cadmium, chromium, copper, lead, nickel, thallium, and uranium exceeded drinking water standards during CY 2013 in samples collected from various groundwater monitoring locations downgradient of the S-2 site, the S-3 site, and throughout the complex. Trace metal concentrations above standards tend to occur only adjacent to the source areas due to their low solubility in natural water systems.

Concentrations of uranium exceed the standard $(0.03 \mathrm{mg} / \mathrm{L})$ in a number of source areas (e.g., the S-3 site, the Uranium Oxide Vault, production areas, and the former Oil Skimmer Basin) and contribute to the uranium concentration in upper EFPC.

One trace metal absent from the list of those that exceed drinking water standards in groundwater in CY 2013 is mercury. Due to very low solubility in water and a very high affinity for clay-rich soils and bedrock, such as those on ORR, mercury exhibits little tendency for extensive transport in diffuse groundwater plumes. Additionally, the hydrogeologic complexities of the fracture/conduit flow system underlying the Y-12 Complex make it challenging to delineate the vertical and horizontal extents of any groundwater contamination. Elevated mercury concentrations (above the surveillance monitoring analytical detection limits) in groundwater have been consistently observed only near known source areas (Fig. 4.40). In the past, mercury concentrations above the drinking water standard $(0.002 \mathrm{mg} / \mathrm{L})$ have been observed in groundwater monitoring wells at the identified source areas presented in Fig. 4.40. 


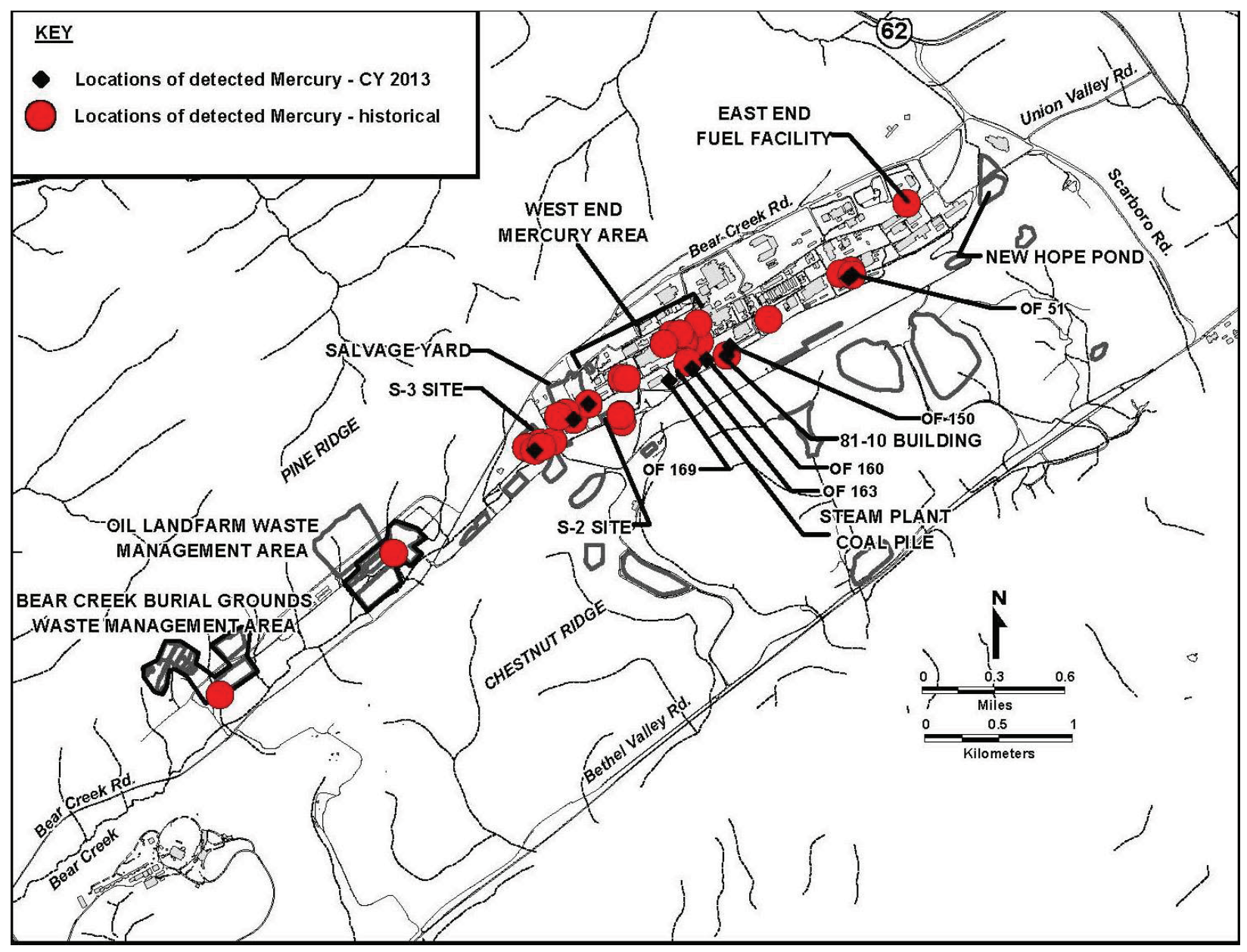

Fig. 4.40. Y-12 groundwater and surface water monitoring stations where mercury has been detected.

Because of past processes and disposal practices, mercury is a legacy contaminant at the Y-12 Complex. It is commonly found in the soils near specific areas where it was used in processes in the 1950 s and 1960s. This metal is a COC in surface waters discharging from these areas. However, the transport mechanisms and connections between process buildings, soil contamination, storm drains, shallow groundwater, buried tributaries, and stream channels are not well understood. When mercury is discharged from the storm drain system into the open creek channel, it is rapidly sequestered by particulate materials, and sediment/particle transport becomes the primary mechanism of mobility. In an attempt to understand the fate and transport of mercury at the Y-12 Complex, researchers have developed a conceptual model integrating known hydrologic, geochemical, and physical data (Peterson et al. 2011).

In tightly fractured shale with high clay content and other noncarbonate bedrock, the natural flow paths are such that significant advective transport of mercury through the groundwater is not likely. This is supported by extensive groundwater surveillance monitoring data. In industrialized areas of the Y-12 Complex where the shallow subsurface has been reworked extensively, some preferential transport along building foundations and underground utilities is apparent as evident from elevated surface water concentrations of mercury. The actual mechanism of transport (e.g., advective, chemically diffusive, colloidal) is uncertain.

Interconnections between the surface water and groundwater systems have been demonstrated by tracer investigations (DOE 2001) and the discharge of elevated concentrations of mercury from a buried spring (i.e., outfall 51) adjacent to EFPC. This discharge is presently captured and treated to remove the mercury at the Big Springs Water Treatment System. Additionally, the regular observation of elemental mercury in storm drains in the western area of the Y-12 Complex has resulted in an increase in monitoring in recent years in several 
storm drain catch basins [e.g., outfall 169, outfall 163, outfall 160, and outfall 150 (Fig. 4.40)] by WRRP. In recent years, storm drain lines in this area have undergone extensive cleaning and lining. In 2012, mercury traps that were developed and fabricated by Y-12 Complex personnel were installed in an attempt to capture and remove as much mercury as possible from the environment. Collection of mercury and sediment from these traps began in CY 2013 (see Section 4.8.2)

\subsection{Volatile Organic Compounds}

Because of the many legacy source areas, VOCs are the most widespread groundwater contaminants in the EFPC regime. Dissolved VOCs in the regime primarily consist of chlorinated and petroleum hydrocarbons. In CY 2013, the highest summed concentration of dissolved chlorinated hydrocarbons $(54,726 \mu \mathrm{g} / \mathrm{L})$ was again found in groundwater at well 55-3B in the western portion of the Y-12 Complex adjacent to manufacturing facilities. The highest dissolved concentration of petroleum hydrocarbons $(16,250 \mu \mathrm{g} / \mathrm{L})$ was obtained from well GW-658 at the closed East End Garage.

These monitoring results generally confirm findings from the previous years of monitoring. A continuous dissolved plume of VOCs in groundwater in the bedrock zone extends eastward from the S-3 site over the entire length of the regime (Fig. 4.41). The primary sources are the Waste Coolant Processing Facility, fuel facilities (Rust Garage and East End Garage), Salvage Yard, and other waste-disposal and production areas throughout the Y-12 Complex. Chloroethene compounds (PCE, TCE, DCE, and vinyl chloride) tend to dominate the volatile organic plume composition in the western and central portions of the Y-12 Complex. However, PCE is almost ubiquitous throughout the extent of the plume, indicating many source areas. Chloromethane compounds (carbon tetrachloride, chloroform, and methylene chloride) are the predominant VOCs in the eastern portion of the Y-12 Complex.

Variability in concentration trends of chlorinated VOCs near source areas is seen within the EFPC regime. As seen in previous years, data from most of the monitoring wells have remained relatively constant (i.e., stable) or have decreased since 1988. Increasing trends have been observed in monitoring wells associated with the Rust Garage, Old Salvage Yard, and S-3 site in the western part of the Y-12 Complex; some legacy sources at production/process facilities in central areas; and the east end VOC plume, indicating that some portions of the plume are still showing activity.

Within the exit pathway (the Maynardville Limestone, underlying EFPC) the general trends are also stable or decreasing, with one exception. One shallow well (GW-605) exhibits an increasing trend in chloroethenes, indicating active transport in this region of the groundwater plume. This well is west and upgradient of the pumping well (GW-845) operated to capture the east end VOC plume before it migrates off ORR into Union Valley. The pumping well may be influencing plume stability causing mobilization in the region of well GW-605. Other than well GW-605, the trends west of New Hope Pond are indicators that the contaminants from source areas are attenuating due to factors such as (1) dilution by surrounding uncontaminated groundwater, (2) dispersion through a complex network of fractures and conduits, (3) degradation by chemical or biological means, or (4) adsorption by surrounding bedrock and soil media. Wells to the southwest to southeast of New Hope Pond are displaying the effects of pumping well GW-845. Wells east of New Hope Pond and north of well GW-845 exhibit stable to increasing trends in VOC concentrations, indicating that little impact or attenuation from the plume capture system is apparent across lithologic units (perpendicular to strike). However, no subsequent downgradient detection of these compounds is apparent, so either migration is limited or some downgradient across-strike influence by the plume capture system is occurring. 


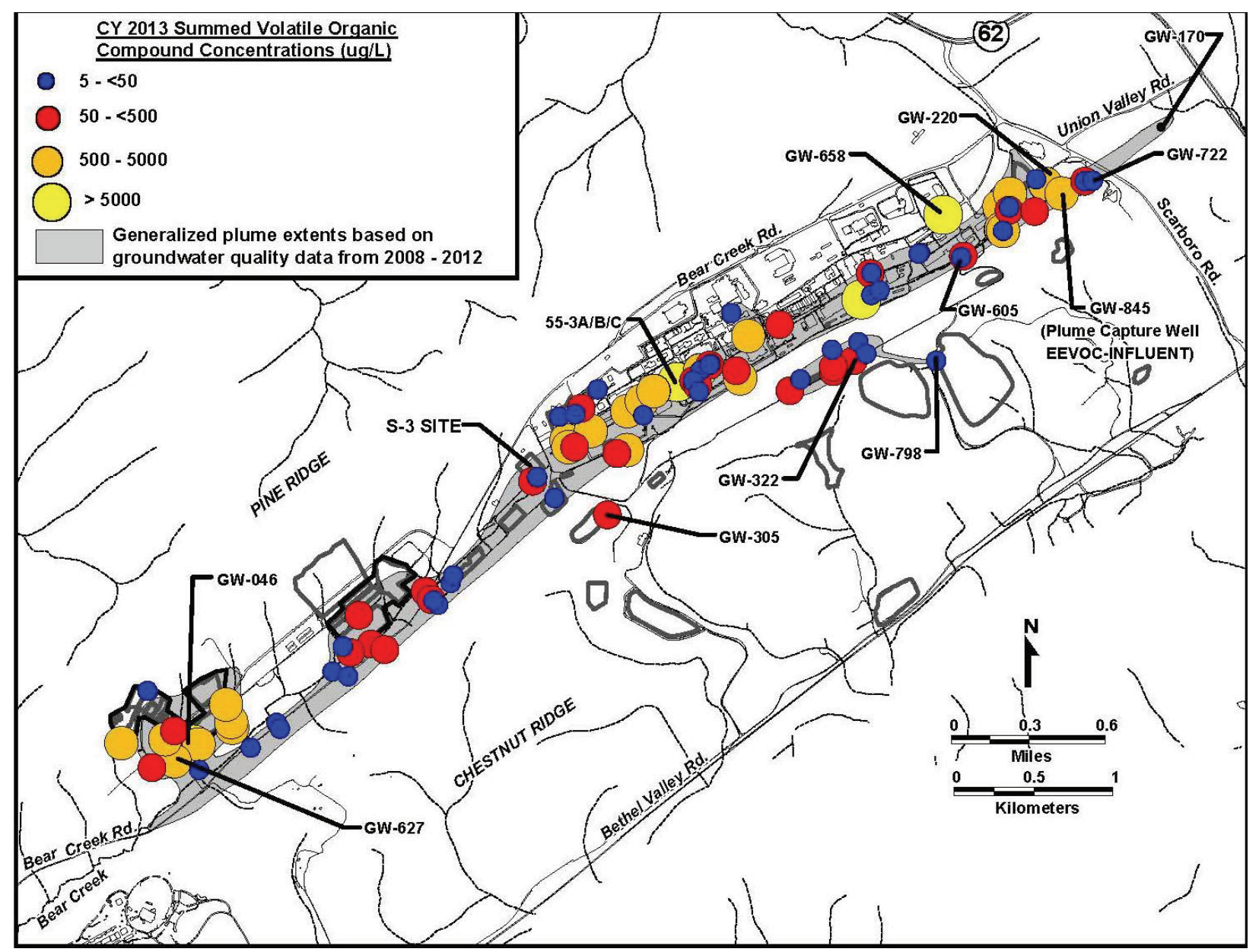

Fig. 4.41. Summed volatile organic compounds observed in groundwater at the $\mathrm{Y}-12$ National Security Complex, 2013.

\subsection{Radionuclides}

The primary alpha-emitting radionuclides found in the EFPC regime during CY 2013 are isotopes of uranium. Historical data show that gross alpha activity consistently exceeds the drinking water standard $(15 \mathrm{pCi} / \mathrm{L})$ and that it is most extensive in groundwater in the unconsolidated zone in the western portion of the Y-12 Complex near source areas such as the S-3 site and the Salvage Yard. The highest gross alpha activity in groundwater $(2,910 \mathrm{pCi} / \mathrm{L})$ in $\mathrm{CY} 2013$ was observed on the west end of the $\mathrm{Y}-12$ Complex in well GW-108, east of the S-3 site (Fig. 4.42).

The primary beta-emitting radionuclides observed in the upper EFPC regime were ${ }^{99} \mathrm{Tc}$ and isotopes of uranium. Elevated gross beta activity in groundwater in the upper EFPC regime shows a pattern similar to that observed for gross alpha activity, where ${ }^{99} \mathrm{Tc}$ is the primary contaminant exceeding the screening level of $50 \mathrm{pCi} / \mathrm{L}$ in groundwater in the western portion of the regime with the source being the S-3 site (Fig. 4.43). The highest gross beta activity in groundwater was observed during CY 2013 from well GW-108 (19,200 pCi/L), east of the S-3 site. 


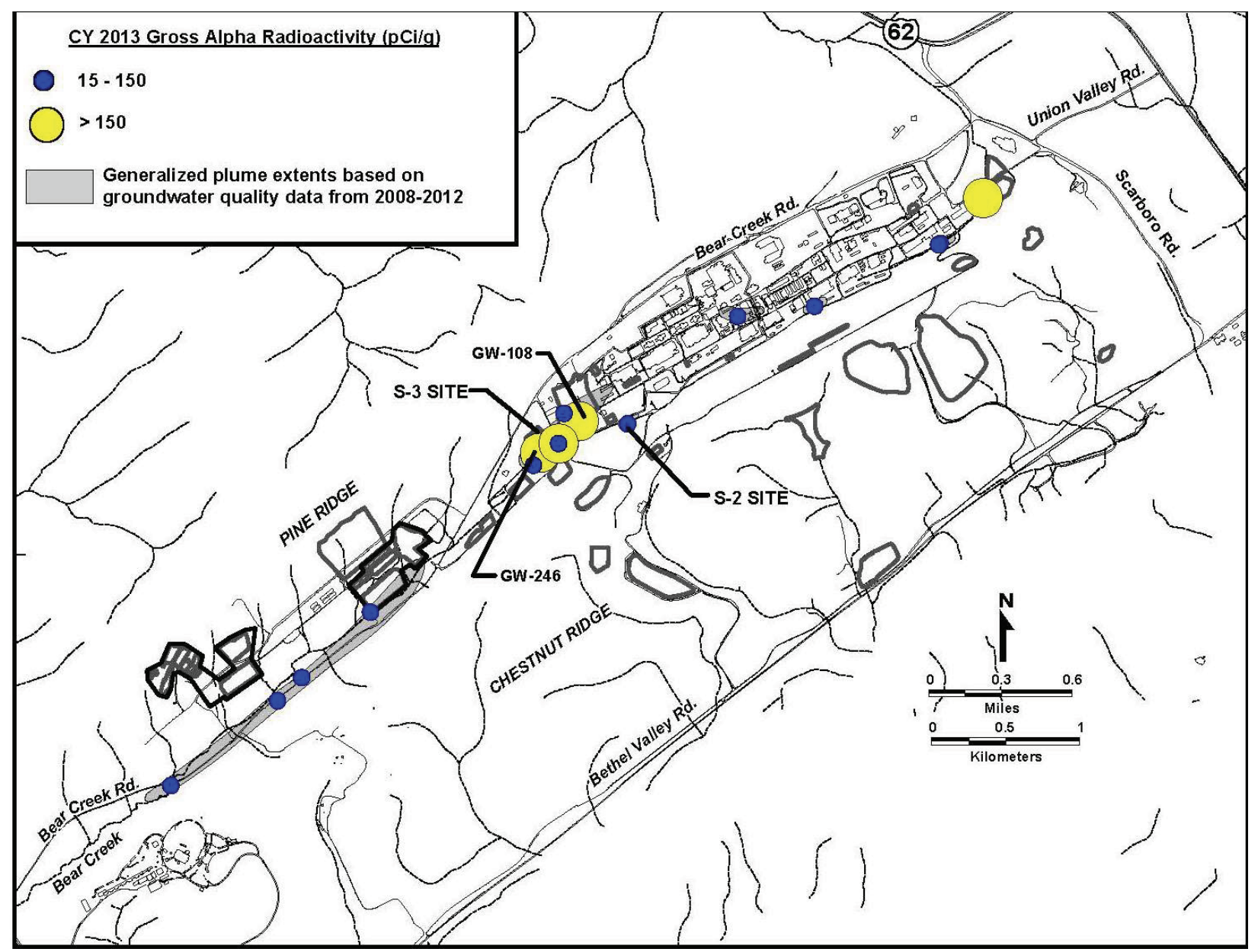

Fig. 4.42. Gross alpha activity observed in groundwater at the $\mathrm{Y}-12$ National Security Complex, 2013. 


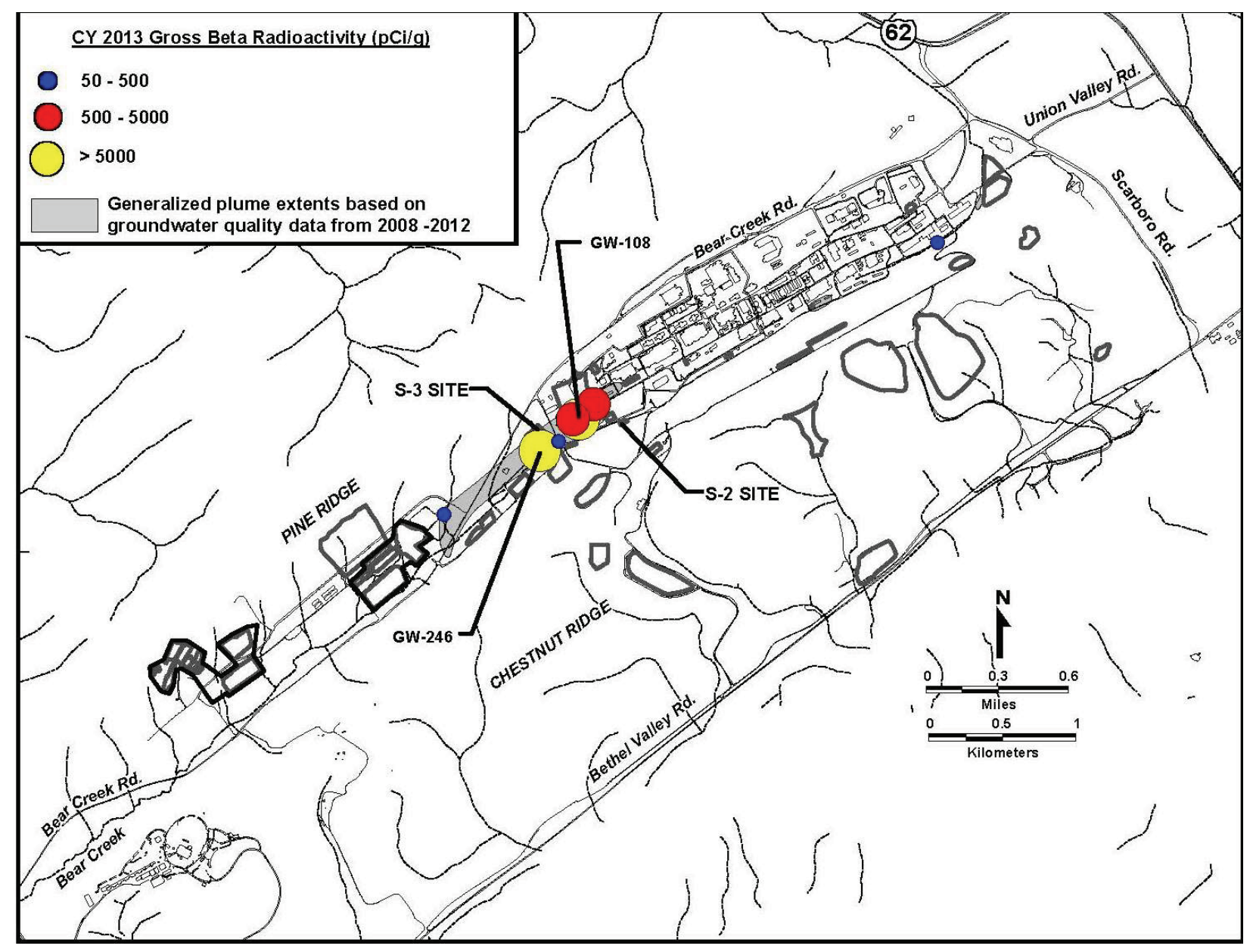

Fig. 4.43. Gross beta activity observed in groundwater at the $\mathrm{Y}-12$ National Security Complex, 2013.

\subsection{Exit Pathway and Perimeter Monitoring}

Data collected to date indicate that VOCs are the primary class of contaminants that are migrating through the exit pathways in the upper EFPC regime. Historically, the compounds have been observed at depths of almost $500 \mathrm{ft}$ in the Maynardville Limestone, the primary exit pathway on the east end of the Y-12 Complex. The deep fractures and solution channels that constitute flow paths within the Maynardville Limestone appear to be well connected, resulting in contaminant migration for substantial distances off ORR into Union Valley to the east of the complex.

In addition to the intermediate-to-deep pathways within the Maynardville Limestone, shallow groundwater within the water table interval of that geologic unit near New Hope Pond, Lake Reality, and upper EFPC are also monitored. Historically, VOCs have been observed near Lake Reality from monitoring wells, a dewatering sump, and the New Hope Pond distribution channel underdrain. In that area, shallow groundwater flows north-northeast through the water table interval east of New Hope Pond and Lake Reality, following the path of the distribution channel for upper EFPC.

During CY 2013, the observed concentrations of VOCs at the New Hope Pond distribution channel underdrain continued to remain low $(22.3 \mu \mathrm{g} / \mathrm{L})$. This may be because the continued operation of the groundwater plume-capture system in well GW-845 southeast of New Hope Pond is effectively reducing the levels of VOCs in the area. The installation of the plume capture system was completed in June 2000. This system pumps groundwater from the intermediate bedrock 48 to $134 \mathrm{~m}$ (157 to $438 \mathrm{ft}$ ) below ground surface to mitigate off-site migration of VOCs. Groundwater is continuously pumped from the Maynardville Limestone at about $95 \mathrm{~L} / \mathrm{min}$ ( $25 \mathrm{gal} / \mathrm{min})$, passes through a treatment system to remove the VOCs, and then discharges to upper EFPC. 
Monitoring wells near well GW-845 continue to show an encouraging response to the pumping activities. The multiport system installed in well GW-722, about $153 \mathrm{~m}(500 \mathrm{ft})$ east and downgradient of well GW-845, permits sampling of vertically discrete zones within the Maynardville Limestone between 27 and $130 \mathrm{~m}$ (87 and $425 \mathrm{ft}$ ) below ground surface (Fig. 4.41). This well has been instrumental in characterizing the vertical extent of the east-end plume of VOCs and is critical in the evaluation of the effectiveness of the plume capture system. Monitoring results from the sampled zones in well GW-722 indicate reductions in VOCs due to groundwater pumping upgradient at well GW-845 (Fig. 4.44). Other wells also show decreases that may be attributable to the plume capture system operation. These indicators demonstrate that operation of the plume capture system is decreasing VOCs upgradient and downgradient of well GW-845, minimizing exposure to the public and the environment.

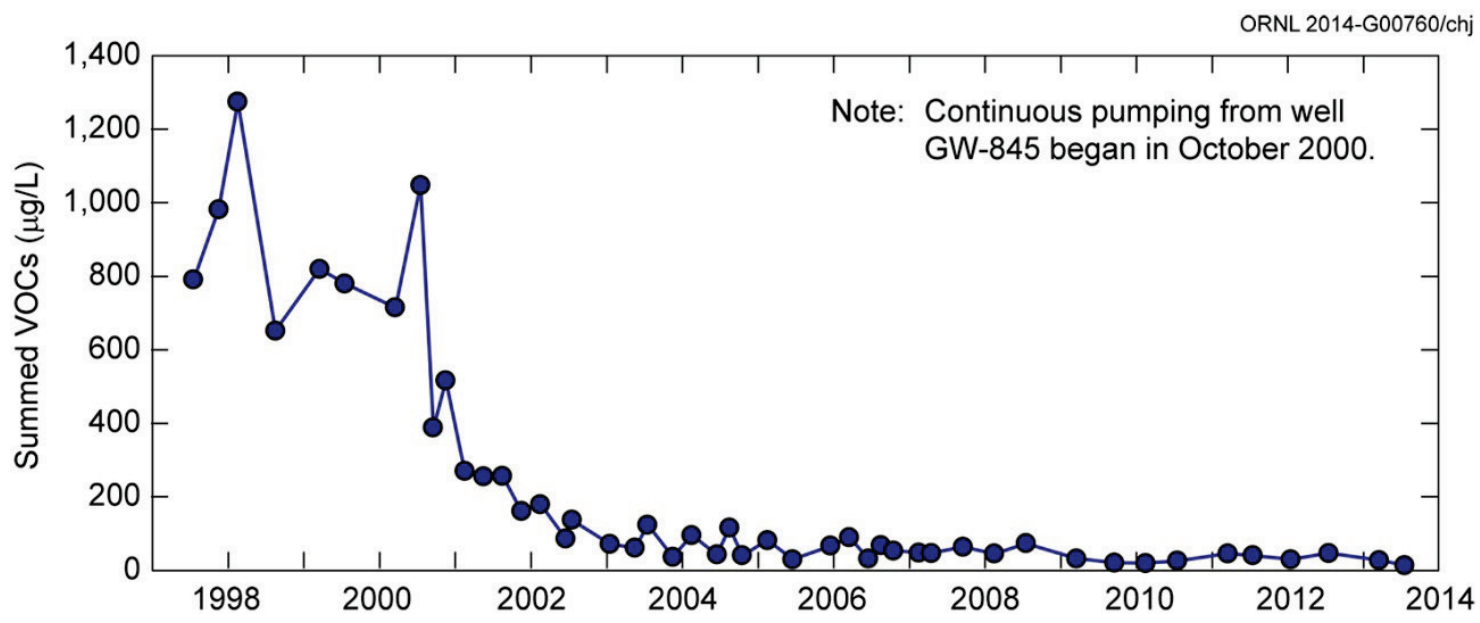

Fig. 4.44. Decreasing summed volatile organic compounds (VOCs) observed in exit pathway well GW-722-17 near the New Hope Pond, 1997-2013.

Upper EFPC flows north from the Y-12 Complex through a large gap in Pine Ridge. Shallow groundwater moves through this exit pathway, and very strong upward vertical flow gradients exist. Continued monitoring of the wells in this pathway gap since about 1990 has shown no indication of any contaminants moving via that exit pathway (Fig. 4.37). Only one shallow well was monitored in CY 2013, and no groundwater contaminants were observed.

Three sampling locations continue to be monitored north and northwest of the Y-12 Complex to evaluate possible contaminant transport from ORR. Those locations are considered unlikely groundwater or surface water contaminant exit pathways; however, monitoring continues to be performed due to previous public concerns regarding potential health impacts from Y-12 Complex operations to nearby residences. One of the stations monitored a tributary that drains the north slope of Pine Ridge on ORR and discharges into the adjacent Scarboro Community. One location monitors an upper reach of Mill Branch, which discharges into the residential areas along Wiltshire Drive. The remaining location monitors Gum Hollow Branch as it discharges from ORR and flows adjacent to the Country Club Estates community. Samples were obtained and analyzed for metals, inorganic parameters, VOCs, and gross alpha and gross beta activities. No results exceeded a drinking water standard nor were there any indications that contaminants were being discharged from ORR into those communities.

\subsection{Union Valley Monitoring}

Groundwater monitoring data obtained during the early 1990s provided the first strong indication that VOCs were being transported off ORR through the deep Maynardville Limestone exit pathway. The upper EFPC RI (DOE 1998) provided a discussion of the nature and extent of the VOCs.

In CY 2013, monitoring of locations in Union Valley continued, showing overall decreasing or very low concentration stable trends (less than drinking water standards) in the individual concentrations of contaminants forming the groundwater contaminant plume in Union Valley. 
Under the terms of an interim ROD, administrative controls such as restrictions on potential future groundwater use have been established and maintained. Additionally, the previously discussed plume capture system (well GW-845) was installed, and operations were initiated to mitigate the migration of groundwater contaminated with VOCs into Union Valley (DOE 2014a).

In July 2006, the Agency for Toxic Substances and Diseases Registry, the principal federal public health agency charged with evaluating the human health effects of exposure to hazardous substances in the environment, published a report in which groundwater contamination across ORR was evaluated (ATSDR 2006). In the report, it was acknowledged that extensive groundwater contamination exists throughout ORR, but the authors concluded that there is no public health hazard from exposure to contaminated groundwater originating on ORR. The Y-12 Complex east end VOC groundwater contaminant plume was acknowledged as the only confirmed off-site contaminant plume migrating across the ORR boundary. The report recognized that the institutional and administrative controls established in the ROD do not provide for reduction in toxicity, mobility, or volume of COCs, but it concluded that the controls are protective of public health to the extent that they limit or prevent community exposure to contaminated groundwater in Union Valley.

\subsubsection{Bear Creek Hydrogeologic Regime}

Located west of the Y-12 Complex in Bear Creek Valley, the Bear Creek regime is bounded to the north by Pine Ridge and to the south by Chestnut Ridge. The regime encompasses the portion of Bear Creek Valley extending from the west end of the Y-12 Complex to State Highway 95. Table 4.22 describes each of the waste management sites within the Bear Creek regime.

Table 4.22. Description of waste management units included in calendar year 2013 groundwater monitoring activities, Bear Creek hydrogeologic regime

\begin{tabular}{ll}
\hline \multicolumn{1}{c}{ Site } & \multicolumn{1}{c}{ Description } \\
\hline S-3 Site & $\begin{array}{l}\text { Four unlined surface impoundments constructed in 1951. Received liquid nitric } \\
\text { acid/uranium-bearing wastes via the nitric acid pipeline until 1983. Other disposals } \\
\text { included }{ }^{99} \text { Tc. Closed and capped under RCRA in 1988. Infiltration was the primary } \\
\text { release mechanism to groundwater. }\end{array}$ \\
& $\begin{array}{l}\text { Operated from } 1973 \text { to 1982. Received waste oils and coolants tainted with metals } \\
\text { and PCBs. Closed and capped under RCRA in 1989. Infiltration was the primary } \\
\text { Oil Landfarm }\end{array}$ \\
& $\begin{array}{l}\text { Used from 1943 to 1970. Unlined shallow trenches used to dispose of construction } \\
\text { debris and to burn magnesium chips and wood. Excavated and restored in 2002-2003 } \\
\text { as part of Boneyard/Burnyard remedial activities. }\end{array}$ \\
Boneyard & Used from 1943 to 1968. Wastes, metal shavings, solvents, oils, and laboratory \\
chemicals were burned in two unlined trenches. Excavated and restored in 2002- \\
2003. \\
Burnyard
\end{tabular}


Table 4.22. (continued)

\begin{tabular}{|c|c|}
\hline Site & Description \\
\hline Sanitary Landfill I & $\begin{array}{l}\text { Used from } 1968 \text { to } 1982 \text {. Nonhazardous industrial landfill. May be a source of certain } \\
\text { contaminants to groundwater. Closed and capped under TDEC requirements in } 1985 \text {. } \\
\text { Evaluation under CERCLA determined that no further action was need. }\end{array}$ \\
\hline $\begin{array}{l}\text { Bear Creek Burial } \\
\text { Grounds A and C } \\
\text { and Walk-In Pits }\end{array}$ & $\begin{array}{l}\text { Burial grounds A and C received waste oils, coolants, beryllium and uranium, various } \\
\text { metallic wastes, and asbestos into unlined trenches and standpipes. Walk-in pits } \\
\text { received chemical wastes, shock-sensitive reagents, and uranium saw fines. Activities } \\
\text { ceased in 1981. Final closure certified for A (1989), C (1993), and the walk-in pits } \\
\text { (1995). Infiltration is the primary release mechanism to groundwater. }\end{array}$ \\
\hline $\begin{array}{l}\text { Bear Creek Burial } \\
\text { Grounds B, D, E, } \\
\text { and J and Oil } \\
\text { Retention Ponds } 1 \\
\text { and } 2\end{array}$ & $\begin{array}{l}\text { Burial grounds B, D, E, and J, unlined trenches, received depleted uranium metal and } \\
\text { oxides and minor amounts of debris and inorganic salts. Ponds } 1 \text { and 2, built in } 1971 \\
\text { and 1972, respectively, captured waste oils seeping into two Bear Creek tributaries. } \\
\text { The ponds were closed and capped under RCRA in 1989. Certification of closure and } \\
\text { capping of Burial grounds B and part of C was granted February } 1995 \text {. }\end{array}$ \\
\hline Rust Spoil Area & $\begin{array}{l}\text { Used from } 1975 \text { to } 1983 \text { for disposal of construction debris but may have included } \\
\text { materials bearing solvents, asbestos, mercury, and uranium. Closed under RCRA in } \\
1984 \text {. Site is a source of VOCs to shallow groundwater according to CERCLA } \\
\text { remedial investigation and current surveillance monitoring. }\end{array}$ \\
\hline Spoil Area I & $\begin{array}{l}\text { Used from } 1980 \text { to } 1988 \text { for disposal of construction debris and other stable, } \\
\text { nonradioactive wastes. Permitted under TDEC solid waste management regulations in } \\
\text { 1986; closure began shortly thereafter. Soil contamination is of primary concern. } \\
\text { CERCLA ROD issued in } 1997 \text {. }\end{array}$ \\
\hline SY-200 Yard & $\begin{array}{l}\text { Used from } 1950 \text { to } 1986 \text { for equipment and materials storage. No documented waste } \\
\text { disposal at the site occurred. Leaks, spills, and soil contamination are concerns. } \\
\text { CERCLA ROD issued in } 1996 .\end{array}$ \\
\hline $\begin{array}{l}\text { Environmental } \\
\text { Management Waste } \\
\text { Management Facility }\end{array}$ & $\begin{array}{l}\text { A CERCLA ROD defines the construction, operation, and closure of this on-site } \\
\text { facility for disposal of radioactive, hazardous, and mixed wastes generated from } \\
\text { CERCLA cleanup projects conducted on ORR and associated sites. The facility began } \\
\text { accepting wastes in } 2002 \text { with full capacity estimated to be reached in FY } 2020 \text {. }\end{array}$ \\
\hline $\begin{array}{l}\text { Abbreviations } \\
\text { CERCLA = Compre } \\
\text { ETTP }=\text { East Tennes } \\
\text { ORNL }=\text { Oak Ridge } \\
\text { PCB }=\text { polychlorinat } \\
\text { RCRA }=\text { Resource C } \\
\text { ROD }=\text { record of dec } \\
\text { TDEC }=\text { Tennessee I } \\
\text { VOC }=\text { volatile orga } \\
\text { Y-12 Complex }=\text { Y- }\end{array}$ & $\begin{array}{l}\text { hensive Environmental Response, Compensation, and Liability Act } \\
\text { see Technology Park } \\
\text { National Laboratory } \\
\text { ed biphenyl } \\
\text { onservation and Recovery Act } \\
\text { ision } \\
\text { Department of Environment and Conservation } \\
\text { hic compound } \\
2 \text { National Security Complex }\end{array}$ \\
\hline
\end{tabular}

\subsection{Plume Delineation}

The primary groundwater contaminants in the Bear Creek regime are nitrate, trace metals, VOCs, and radionuclides. The S-3 Site is a source of all four contaminants. The Bear Creek Burial Grounds and the Oil Landfarm waste management areas are significant sources of uranium and other trace metals and VOCs. High concentrations of chlorinated hydrocarbons and PCBs have been observed as deep as $82 \mathrm{~m}$ (270 ft) below the Bear Creek Burial Grounds (MMES 1990).

Contaminant plume boundaries are essentially defined in the bedrock formations that directly underlie many waste disposal areas in the Bear Creek regime, particularly the Nolichucky Shale. This fractured aquitard unit is positioned north of and adjacent to the exit pathway unit, the Maynardville Limestone. The elongated shape of the contaminant plumes in the Bear Creek regime is the result of preferential 
transport of the contaminants parallel to strike (parallel to the valley axis) in the Maynardville Limestone and the aquitard units.

The plume maps depicted in this section (Figs. 4.39, 4.41, 4.42, and 4.43) have been updated to reflect the average concentrations and radioactivity in groundwater over the last 5 years (CY 2008-2012). See Section 4.6.4.1.1 for more details.

\subsection{Nitrate}

The limits of the nitrate plume probably define the maximum extent of groundwater contamination in the Bear Creek regime. The horizontal extent of the nitrate plume is essentially defined in groundwater in the upper to intermediate bedrock intervals of the aquitard units and Knox aquifer [less than $92 \mathrm{~m} \mathrm{(300 \textrm {ft } )}$ below the ground surface].

Data obtained during CY 2013 indicate that nitrate concentrations in groundwater continue to exceed the drinking water standard in an area that extends west from the source area at the S-3 site. The highest nitrate concentration $(9,960 \mathrm{mg} / \mathrm{L})$ was observed at well $\mathrm{GW}-615$ adjacent to the S-3 site at a depth of

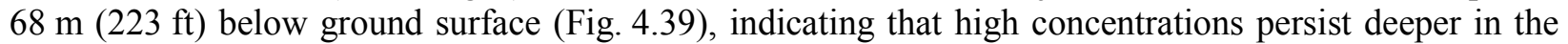
subsurface groundwater system. A multiport monitoring well, GW-134, was sampled in CY 2011 and continues to show elevated concentrations of nitrate $(1,420 \mathrm{mg} / \mathrm{L})$ as deep as $226 \mathrm{~m}(740 \mathrm{ft})$ below ground surface.

\subsection{Trace Metals}

During CY 2013, arsenic, barium, beryllium, cadmium, chromium, lead, manganese, nickel, and uranium were identified from groundwater monitoring as the trace metal contaminants in the Bear Creek regime that exceeded drinking water standards. Historically, elevated concentrations of many of the trace metals were observed at shallow depths near the S-3 site. In the Bear Creek regime, where natural geochemical conditions prevail, the trace metals may occur sporadically and in close association with source areas because conditions are typically not favorable for dissolution and migration. Disposal of acidic liquid wastes at the S-3 site reduced the $\mathrm{pH}$ of the groundwater, which allows the metals to remain in solution longer and migrate further from the source area.

The most prevalent trace metal contaminant observed within the Bear Creek regime is uranium, indicating that geochemical conditions are favorable for its migration. Early characterization indicated that the Boneyard/Burnyard site was the primary source of uranium contamination of surface water and groundwater. Historically, uranium has been observed at concentrations exceeding the drinking water standard of $0.03 \mathrm{mg} / \mathrm{L}$ in shallow monitoring wells, springs, and surface water locations downgradient from all of the waste areas. In 2003, the final RAs at the Boneyard/Burnyard were performed with the objective of removing materials contributing to surface water and groundwater contamination to meet existing ROD goals. About $65,752 \mathrm{~m}^{3}\left(86,000 \mathrm{yd}^{3}\right)$ of waste materials was excavated and placed in the EMWMF (DOE 2007). There were significant decreases in uranium concentration and flux in the surface water tributary immediately downstream of the Boneyard/Burnyard (NT-3), which indicate that the RAs performed from 2002 to 2003 were successful in removing much of a primary source of uranium in Bear Creek Valley. Even though there is an overall decrease in uranium concentrations (Table 4.23), certain areas still present a significant impact to the overall health of Bear Creek.

Additional monitoring has been initiated to attempt to determine uranium inputs to the stream from source areas and the karst groundwater system underlying Bear Creek. Other trace metal contaminants that have been observed in the Bear Creek regime are boron, mercury, selenium, strontium, thallium, and zinc. Concentrations have commonly exceeded background values in groundwater near contaminant source areas. 
Table 4.23. Nitrate and uranium concentrations in Bear Creek

\begin{tabular}{|c|c|c|c|c|c|c|c|}
\hline \multirow{2}{*}{$\begin{array}{c}\text { Bear Creek } \\
\text { Monitoring Station } \\
\text { (distance from S-3 site) }\end{array}$} & \multirow[b]{2}{*}{ Contaminant } & \multicolumn{5}{|c|}{ Average concentration $^{a}(\mathrm{mg} / \mathrm{L})$} & \multirow[b]{2}{*}{$\begin{array}{c}2010 \\
2013\end{array}$} \\
\hline & & $\begin{array}{c}1990 \\
1993\end{array}$ & $\begin{array}{c}1994- \\
1997\end{array}$ & $\begin{array}{c}1998- \\
2001\end{array}$ & $\begin{array}{c}2002- \\
2005\end{array}$ & $\begin{array}{c}2006 \\
2009\end{array}$ & \\
\hline $\mathrm{BCK}^{b}-11.84$ to 11.97 & Nitrate & 119 & 80 & 80 & 79.5 & 33.4 & 47.7 \\
\hline ( $\sim 0.5$ miles downstream) & Uranium & 0.196 & 0.134 & 0.139 & 0.133 & 0.122 & 0.163 \\
\hline BCK-09.20 to 09.47 & Nitrate & 16.4 & 9.6 & 10.6 & 11.3 & 9.1 & 3.9 \\
\hline ( $\sim 2$ miles downstream) & Uranium & 0.091 & 0.094 & 0.171 & 0.092 & 0.067 & 0.049 \\
\hline BCK-04.55 & Nitrate & 4.6 & 3.6 & 2.6 & 2.9 & 1.1 & 0.8 \\
\hline ( $\sim 5$ miles downstream) & Uranium & 0.034 & 0.031 & 0.036 & 0.026 & 0.022 & 0.016 \\
\hline
\end{tabular}

${ }^{a}$ Excludes results that do not meet data quality objectives.

${ }^{b} \mathrm{BCK}=$ Bear Creek kilometer

\subsection{Volatile Organic Compounds}

VOCs are widespread in groundwater in the Bear Creek regime. The primary compounds are PCE, TCE, 1,2-DCE, vinyl chloride, and 1,1-DCA. In most areas, they are dissolved in the groundwater and can occur in bedrock at depths up to $92 \mathrm{~m}(300 \mathrm{ft})$ below ground surface. Groundwater in the fractured bedrock of the aquitard units that contain detectable levels of VOCs occurs within about $305 \mathrm{~m}(1,000 \mathrm{ft})$ of the source areas. The highest concentrations observed in CY 2013 in the Bear Creek regime occurred in the shallow unconsolidated zone at the Bear Creek Burial Ground waste management area, with a maximum summed VOC concentration of $9,526 \mu \mathrm{g} / \mathrm{L}$ in well GW-046 (Fig. 4.41).

High concentrations of VOCs like this and in other near source wells, coupled with increasing trends observed downgradient of the Bear Creek Burial Ground waste management area in the clastic (noncarbonated) dominated fractured bedrock of the aquitard units (Fig. 4.45), indicate that a considerable mass of dense nonaqueous phase organic compounds is still present at a depth below the Bear Creek Burial Grounds, providing a source for dissolved phase migration of VOCs. This migration parallel to the valley axis and toward the exit pathway (Maynardville Limestone) is occurring in both the unconsolidated and bedrock intervals.

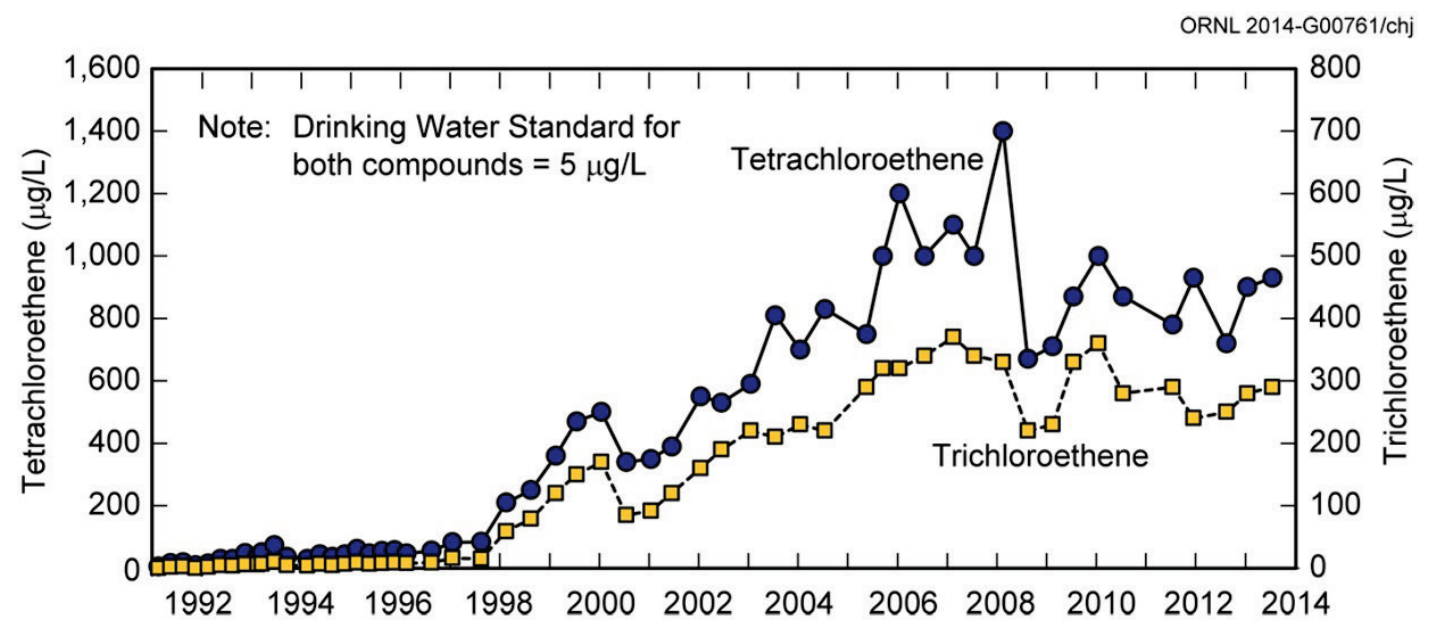

Fig. 4.45. Increasing levels of volatile organic compounds observed in groundwater at well GW-627, west and downgradient of the Bear Creek Burial Grounds, 1991-2013.

Significant transport of VOCs has occurred in the Maynardville Limestone. Data obtained from exit pathway monitoring locations show that in the intermediate groundwater interval, an apparently 
continuous dissolved plume extends at least 2,195 m (7,200 ft) westward from the S-3 site to just south of the Bear Creek Burial Ground waste management area.

\subsection{Radionuclides}

The primary radionuclides identified in the Bear Creek regime are isotopes of uranium and ${ }^{99} \mathrm{Tc}$. Neptunium, americium, radium, strontium, thorium, plutonium, and tritium are secondary and less widespread radionuclides which historically have been observed in groundwater near the S-3 site. Evaluations of the extents of radionuclides in groundwater in the Bear Creek regime during CY 2013 were based primarily on measurements of gross alpha activity and gross beta activity. If the annual average gross alpha activity in groundwater samples from a well exceeded $15 \mathrm{pCi} / \mathrm{L}$ (the drinking water standard for gross alpha activity), then one (or more) of the alpha-emitting radionuclides (e.g., uranium) was assumed to be present at elevated levels in the groundwater monitored by the well. A similar rationale was used for annual average gross beta activity that exceeded $50 \mathrm{pCi} / \mathrm{L}$. Technetium-99, a more volatile radionuclide, is qualitatively screened by gross beta activity analysis and, at certain monitoring locations, is evaluated isotopically.

Groundwater with elevated levels of gross alpha activity occurs near the S-3 site and the Oil Landfarm and Bear Creek Burial Grounds waste management areas. In the bedrock interval, gross alpha activity exceeds $15 \mathrm{pCi} / \mathrm{L}$ in groundwater in the fractured bedrock of the aquitard units only near source areas (Fig. 4.42). Data obtained from exit pathway monitoring stations during CY 2013 show that gross alpha activity in groundwater in the Maynardville Limestone and in the surface waters of Bear Creek exceeds the drinking water standard for over 3,353 m (11,000 ft) west of the S-3 site. The highest gross alpha activity observed in groundwater in CY 2013 was $190 \mathrm{pCi} / \mathrm{L}$ in well GW-246 located adjacent to the $\mathrm{S}-3$ site.

The distribution of gross beta activity in groundwater is similar to that of gross alpha activity. During CY 2013, gross beta activities within the exit pathway groundwater interval and surface water remain below the drinking water standard. Gross beta activity exceeded $50 \mathrm{pCi} / \mathrm{L}$ within the fractured bedrock of the aquitard units $762 \mathrm{~m}(2,500 \mathrm{ft})$ from the S-3 site (Fig. 4.43). The highest gross beta activity in groundwater in the Bear Creek regime in 2013 was $8,700 \mathrm{pCi} / \mathrm{L}$ at well $\mathrm{GW}-246$, located adjacent to the S-3 site.

\subsection{Exit Pathway and Perimeter Monitoring}

Exit pathway monitoring began in 1990 to provide data on the quality of groundwater and surface water exiting the Bear Creek regime. The Maynardville Limestone is the primary exit pathway for groundwater. Bear Creek, which flows across the Maynardville Limestone in much of the Bear Creek regime, is the principal exit pathway for surface water. Various studies have shown that the surface water in Bear Creek, the springs along the valley floor, and the groundwater in the Maynardville Limestone are hydraulically connected. Surveys have been performed that identify gaining (groundwater discharging into surface waters) and losing (surface water discharging into a groundwater system) reaches of Bear Creek. The western exit pathway well transect (Picket W) serves as the perimeter well location for the Bear Creek regime (Fig. 4.37).

Exit pathway monitoring consists of continued monitoring at four well transects (pickets) and selected springs and surface water stations. Groundwater quality data obtained during CY 2013 from the exit pathway monitoring wells indicate that groundwater is contaminated above drinking water standards in the Maynardville Limestone as far west as Picket B, and trends continue to be generally stable to decreasing (Fig. 4.46).

Surface water samples collected during CY 2013 indicate that water in Bear Creek contains many of the compounds found in the groundwater. Nitrate and uranium concentrations exceeding their respective drinking water standards have been observed in surface water west of the burial grounds as far as Picket A. The concentrations in the creek decrease with distance downstream of the waste disposal sites (Table 4.23). 

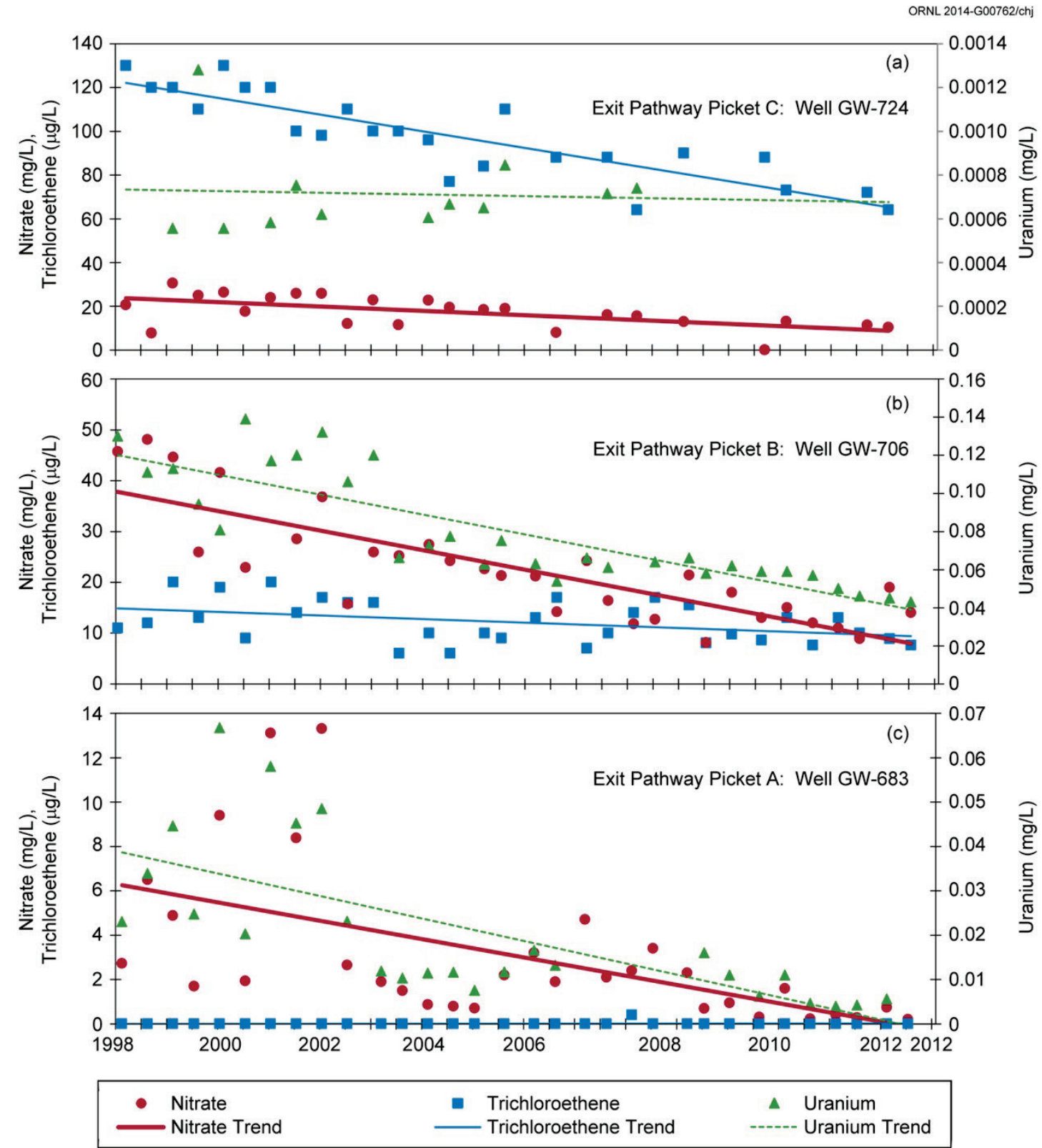

Note: Only nitrate and uranium results above the detection limit are plotted; undetected trichloroethene results are plotted at zero.

Fig. 4.46. CY 2013 concentrations of selected contaminants in exit pathway monitoring wells GW-724 (a), GW-706 (b), and GW-683 (c) in the Bear Creek hydrogeologic regime.

\subsubsection{Chestnut Ridge Hydrogeologic Regime}

The Chestnut Ridge hydrogeologic regime is flanked to the north by Bear Creek Valley and to the south by Bethel Valley Road (Fig. 4.35). The regime encompasses the portion of Chestnut Ridge extending from Scarboro Road, east of the complex, to Dunaway Branch, located just west of Industrial Landfill II.

The Chestnut Ridge Security Pits area is the only documented source of groundwater contamination in the regime. Contamination from the security pits is distinct and does not mingle with plumes from other sources. Table 4.24 summarizes the operational history of waste management units in the regime. 
Table 4.24. Description of waste management units included in groundwater monitoring activities, Chestnut Ridge hydrogeologic regime, 2013

\begin{tabular}{|c|c|}
\hline Site & Description \\
\hline $\begin{array}{l}\text { Chestnut Ridge Sediment } \\
\text { Disposal Basin }\end{array}$ & $\begin{array}{l}\text { Operated from } 1973 \text { to } 1989 \text {. Received soil and sediment from New Hope Pond } \\
\text { and mercury-contaminated soils from the Y-12 Complex. Site was closed under } \\
\text { RCRA in 1989. Not a documented source of groundwater contamination. }\end{array}$ \\
\hline Kerr Hollow Quarry & $\begin{array}{l}\text { Operated from 1940s to } 1988 \text {. Used for the disposal of reactive materials, } \\
\text { compressed gas cylinders, and various debris. RCRA closure (waste removal) } \\
\text { was conducted between } 1990 \text { and } 1993 \text {. Certification of closure with some wastes } \\
\text { remaining in place was approved by TDEC February } 1995 \text {. }\end{array}$ \\
\hline $\begin{array}{l}\text { Chestnut Ridge Security } \\
\text { Pits }\end{array}$ & $\begin{array}{l}\text { Operated from } 1973 \text { to } 1988 \text {. Series of trenches for disposal of classified } \\
\text { materials, liquid wastes, thorium, uranium, heavy metals, and various debris. } \\
\text { Closed under RCRA in 1989. Infiltration is the primary release mechanism to } \\
\text { groundwater. }\end{array}$ \\
\hline $\begin{array}{l}\text { United Nuclear } \\
\quad \text { Corporation Site }\end{array}$ & $\begin{array}{l}\text { Received about } 29,000 \text { drums of cement-fixed sludges and soils demolition } \\
\text { materials and low-level radioactive contaminated soils. CERCLA ROD issued in } \\
1991 \text {. }\end{array}$ \\
\hline Industrial Landfill II & $\begin{array}{l}\text { Operated from 1983-1995. Central sanitary landfill for ORR. Detection } \\
\text { monitoring under postclosure plan has been ongoing since } 1996 .\end{array}$ \\
\hline Industrial Landfill IV & $\begin{array}{l}\text { Opened for operations in 1989. Permitted to receive only nonhazardous industrial } \\
\text { solid wastes. Detection monitoring under TDEC solid-waste-management } \\
\text { regulations has been ongoing since } 1988 \text {. Assessment monitoring began in } 2008 \\
\text { because of consistent exceedance of a TDEC groundwater protection standard. }\end{array}$ \\
\hline Industrial Landfill V & $\begin{array}{l}\text { Initiated operations April 1994. Currently under TDEC solid-waste-management } \\
\text { detection monitoring. }\end{array}$ \\
\hline $\begin{array}{l}\text { Construction/Demolition } \\
\text { Landfill VI }\end{array}$ & $\begin{array}{l}\text { Operated from December } 1993 \text { to November 2003. The postclosure period ended, } \\
\text { and the permit was terminated March } 2007\end{array}$ \\
\hline $\begin{array}{l}\text { Construction/Demolition } \\
\text { Landfill VII }\end{array}$ & $\begin{array}{l}\text { Facility construction completed in December 1994. TDEC granted approval to } \\
\text { operate January } 1995 \text {. Permit-required detection monitoring per TDEC was } \\
\text { temporarily suspended October } 1997 \text { pending closure of construction/demolition } \\
\text { Landfill VI. Reopened and began waste disposal operations in April } 2001 .\end{array}$ \\
\hline Filled Coal Ash Pond & $\begin{array}{l}\text { Site received Y-12 Steam Plant coal ash slurries from } 1955 \text { to 1968. A CERCLA } \\
\text { ROD was issued in 1996. Remedial action complete. }\end{array}$ \\
\hline $\begin{array}{l}\text { East Chestnut Ridge } \\
\text { Waste Pile }\end{array}$ & $\begin{array}{l}\text { Operated from } 1987 \text { to } 1989 \text { to store contaminated soil and spoil material } \\
\text { generated from environmental restoration activities at the Y-12 Complex. Closed } \\
\text { under RCRA in } 2005 \text { and incorporated into RCRA postclosure permit issued by } \\
\text { TDEC in } 2006 .\end{array}$ \\
\hline
\end{tabular}

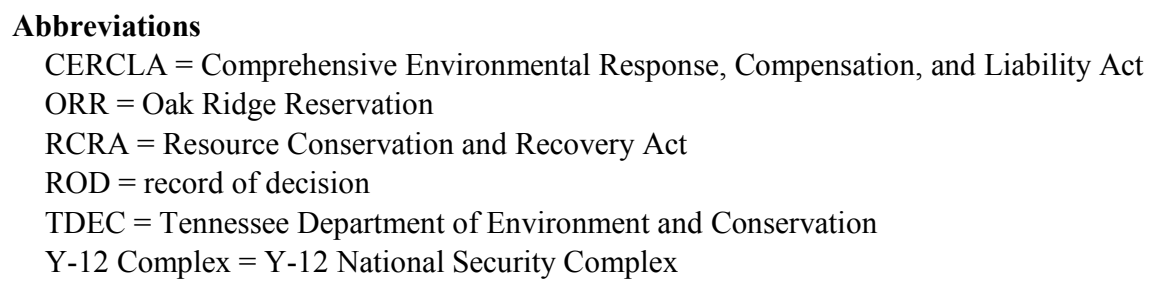

\subsection{Plume Delineation}

Through extensive monitoring of the wells on Chestnut Ridge, the horizontal extent of the VOC plume at the Chestnut Ridge Security Pits seems to be reasonably well defined in the water table and shallow bedrock zones. With two possible exceptions, historical monitoring indicates that the VOC plume from the Chestnut Ridge Security Pits has not migrated very far in any direction $[305 \mathrm{~m}(<1,000 \mathrm{ft})]$. Groundwater quality data obtained during CY 2013 indicate that the western lateral extent of the plume of VOCs at the site has not changed significantly from previous years. The continued observation of VOC contaminants over the past several years at a well about $458 \mathrm{~m}(1,500 \mathrm{ft})$ southeast of the Chestnut Ridge 
Security Pits (well GW-798, Fig. 4.41) shows that some migration of the eastern plume has occurred. Additionally, dye tracer test results and the intermittent detection of very low concentrations of VOCs (similar to those found in wells adjacent to the Chestnut Ridge Security Pits) at a natural spring about $2,745 \mathrm{~m}(9,000 \mathrm{ft})$ to the east and along geologic strike may suggest that Chestnut Ridge Security Pits groundwater contaminants have migrated much further than the monitoring well network indicates.

The plume maps depicted in this section (Figs. 4.39, 4.41, 4.42, and 4.43) have been updated to reflect the average concentrations and radioactivity in groundwater over the last 5 years (CY 2008-2012). See Section 4.6.4.1.1 for more details.

\subsection{Nitrate}

Nitrate concentrations were below the drinking water standard at all monitoring stations in the Chestnut Ridge hydrogeologic regime.

\subsection{Trace Metals}

Elevated concentrations of arsenic were observed in two surface water monitoring locations downstream from the Filled Coal Ash Pond, which is monitored under a CERCLA ROD (DOE 2014a). Under the ROD a constructed wetland area is being used to reduce surface water contamination by effluent from the Filled Coal Ash Pond. During CY 2013, elevated arsenic levels were detected both upgradient [McCoy Branch kilometer (MCK) 2.05] and downgradient (MCK 2.0) of this wetland area (Fig. 4.37). Even though both MCK 2.05 and MCK 2.0 monitoring station concentrations were higher than the drinking water standard for arsenic $(0.01 \mathrm{mg} / \mathrm{L})$, the results were $82 \%$ and $97 \%$ less than the preremediation average concentrations, respectively (DOE 2014a). An exit pathway/perimeter surface water monitoring location about $610 \mathrm{~m}(2,000 \mathrm{ft})$ downstream from the Filled Coal Ash Pond was also sampled during CY 2013 with no detectable arsenic.

\subsection{Volatile Organic Compounds}

In 2013, the highest summed VOC concentration observed in the Chestnut Ridge hydrogeologic regime was at Chestnut Ridge Security Pits well GW-322 (133 $\mu \mathrm{g} / \mathrm{L})$ (Fig. 4.41). Monitoring VOCs in groundwater attributable to the Chestnut Ridge Security Pits has been in progress since 1987. A review of historical data indicates that concentrations of VOCs in groundwater at the site have generally decreased since 1988. However, a stable to very shallow increasing trend in VOCs in groundwater samples from monitoring well GW-798 (Fig. 4.41) to the southeast and downgradient of the Chestnut Ridge Security Pits has been developing since CY 2000. The maximum summed VOC concentration observed at well GW-798 during CY 2013 was $30 \mu \mathrm{g} / \mathrm{L}$. The VOCs detected in well GW-798 continue to be characteristic of the Chestnut Ridge Security Pits plume.

At Industrial Landfill IV, a number of VOCs have been observed since 1992. Monitoring well GW-305, located immediately to the southeast of the facility, has historically displayed concentrations of compounds below applicable drinking water standards, but the concentrations have exhibited a shallow increasing trend. In CY 2013, samples continue to exceed the drinking water standard for 1,1-DCE $(7 \mu \mathrm{g} / \mathrm{L})$. This has resulted in an increased level of monitoring to further evaluate the trend.

\subsection{Radionuclides}

In CY 2013, no gross alpha or gross beta activity above the drinking water standard of $15 \mathrm{pCi} / \mathrm{L}$ and $50 \mathrm{pCi} / \mathrm{L}$, respectively, was observed in any groundwater samples collected in the Chestnut Ridge hydrogeologic regime.

\subsection{Exit Pathway and Perimeter Monitoring}

Contaminant and groundwater flow paths in the karst bedrock underlying the Chestnut Ridge regime have not been well characterized by conventional monitoring techniques. A number of tracer studies have been conducted that show groundwater from Chestnut Ridge discharging into Scarboro Creek and other 
tributaries that feed into Melton Hill Lake. However, no springs or surface streams that represent discharge points for groundwater have been conclusively correlated to a waste management unit or operation at the Y-12 Complex that is a known or potential groundwater contaminant source. Water quality from a spring along Scarboro Creek is monitored quarterly by the TDEC DOE Oversight Office, and trace concentrations of VOCs are intermittently detected. The detected VOCs are suspected to originate from the Chestnut Ridge Security Pits; however, this has not been confirmed.

Monitoring natural groundwater exit pathways is a basic monitoring strategy in a karst regime such as that of Chestnut Ridge. Perimeter springs and surface water tributaries were monitored to determine whether contaminants are exiting the downgradient (southern) side of the regime. Five springs and three surface water monitoring locations were sampled during CY 2013. No contaminants at any of these monitoring stations were detected at levels above drinking water standards.

\subsubsection{Quality Assurance}

All groundwater monitoring is performed under QCs to ensure that representative samples and analytical results are obtained. Because there are a number of organizations responsible for performing groundwater sampling and analysis activities to meet separate requirements, there may be some minor differences in sampling and analysis procedures and methods, but the final results are comparable and therefore useful for all projects and programs. This permits the integrated use of all groundwater quality data obtained at the Y-12 Complex.

A number of QA measures are performed to ensure accurate, consistent, and comparable groundwater results. These measures are described in sampling and analysis plans and include the following.

- Groundwater sampling is performed across the Y-12 Complex using a number of sampling methods and procedures. The predominant method of sampling monitoring wells is by using a low-flow minimum drawdown method. Using this method, a sample is obtained from a discrete depth interval of the monitoring interval (screened or open borehole) without introducing stagnant water from the well casing. Groundwater is pumped from the well at a flow rate low enough to minimize drawdown of the water level in the well; field readings are also taken to ensure that the sample is representative of the groundwater system and not the water column inside the well casing itself. All sampling methods follow industry/regulator-recognized protocols to ensure that consistent and repeatable samples are obtained.

- QCs such as field blank, trip blank, duplicate, and equipment rinsate samples are collected.

- All groundwater samples are controlled under chain of custody from their collection in the field to the analytical laboratory that performs the analyses.

- Laboratory analyses are performed using standard methods and protocols within established holding times.

During 2013 all groundwater monitoring and related analytical activities were performed in accordance with the established protocols.

\subsection{Quality Assurance Program}

It is the intent of B\&W Y-12 that the Y-12 Complex Quality Assurance Program be fully consistent with and supportive of the ISMS program's functions and guiding principles. Management requirement Y60-101PD, Quality Assurance Program Description, details the methods used to carry out work processes safely and securely and in accordance with established procedures. It also describes mechanisms in place to seek continuous improvements by identifying and correcting findings and preventing recurrences.

Many factors can potentially affect the results of environmental data collection activities, including sampling personnel, methods, and procedures; field conditions; sample handling, preservation, and transport; personnel training; analytical methods; data reporting; and record keeping. QA programs are designed to minimize these sources of variability and to control all phases of the monitoring process. 
Field sampling QA encompasses many practices that minimize error and evaluate sampling performance. Some key quality practices include the following:

- use of work control processes and standard operating procedures for sample collection and analysis;

- use of chain-of-custody and sample-identification procedures;

- instrument standardization, calibration, and verification;

- sample technician and laboratory analyst training;

- sample preservation, handling, and decontamination; and

- use of QC samples, such as field and trip blanks, duplicates, and equipment rinses.

Y-12 Environmental Sampling Services performs field sampling, sample preservation and handling, and chain-of-custody and takes field control (QC) samples in accordance with Y-12 Environmental Compliance's internal procedures. Environmental Sampling Services developed a standards and calibration program (SCP) that conforms to International Standard ISO/IEC 17025, General Requirements for Competence of Testing and Calibration Laboratories, and provides a process for uniform standardization, calibration, and verification of measurement and test equipment (M\&TE). The SCP ensures measurements are made using appropriate, documented methods; traceable standards; appropriate M\&TE of known accuracy; trained personnel; and technical best practices.

Analytical results may be affected by a large number of factors inherent to the measurement process. Laboratories that support the Y-12 Complex environmental monitoring programs use internal QA/QC programs to ensure the early detection of problems that may arise from contamination, inadequate calibrations, calculation errors, or improper procedure performance. Internal laboratory QA/QC programs include routine calibrations of counting instruments, yield determinations, frequent use of check sources and background counts, replicate and spiked sample analyses, matrix and reagent blanks, and maintenance of control charts to indicate analytical deficiencies. These activities are supported by the use of standard materials or reference materials (e.g., materials of known composition that are used in the calibration of instruments, methods standardization, spike additions for recovery tests, and other practices). Certified standards traceable to NIST, DOE sources, or EPA are used (when available) for such work.

The Y-12 Analytical Chemistry Organization (ACO) Quality Assurance Plan describes QA program elements that are based on the Y-12 Complex Quality Assurance Program; customer-specific requirements; certification program requirements, International Standard ISO/IEC 17025, General Requirements for Competence of Testing and Calibration Laboratories; federal, state, and local regulations; and waste acceptance criteria. As a government-owned, client-operated laboratory that performs work for DOE, the ACO laboratory operates in accordance with DOE O 414.1D, Quality Assurance. To meet these requirements, the ACO laboratory adheres to the latest edition of Quality Systems for Analytical Services (DOE 2013c), where it applies. The Y-12 ACO was assessed by the DOE Consolidated Audit Program February 26-28, 2013. ACO has received the final report, with three findings, and corrective actions have been completed.

Other internal practices used to ensure that laboratory results are representative of actual conditions include training and managing staff; maintaining adequacy of the laboratory environment; safety; controlling the storage, integrity, and identity of samples; record keeping; maintaining and calibrating instruments; and the using technically validated and properly documented methods.

The Y-12 ACO participated in both Mixed Analyte Performance Evaluation Program studies conducted in 2013 for water, soil, and air filter matrices for metals, organics, and radionuclides. The overall acceptability rating from both studies was greater than $99 \%$.

Verification and validation of environmental data are performed as components of the data collection process, which includes planning, sampling, analysis, and data review. Some level of verification and validation of field and analytical data collected for environmental monitoring and restoration programs is necessary to ensure that data conform to applicable regulatory and contractual requirements. Validation of field and analytical data is a technical review performed to compare data with established quality criteria to ensure that data are adequate for the intended use. The extent of project data verification and validation activities is based on project-specific requirements. 
For routine environmental effluent monitoring and surveillance monitoring, data verification activities may include processes of checking whether (1) data have been accurately transcribed and recorded, (2) appropriate procedures have been followed, (3) electronic and hard-copy data show one-to-one correspondence, and (4) data are consistent with expected trends. Typically, routine data verification actions alone are sufficient to document the validity and accuracy of environmental reports. For restoration projects, routine verification activities are more contractually oriented and include checks for data completeness, consistency, and compliance with a predetermined standard or contract.

Certain projects may require a more thorough technical validation of the data as mandated by the project's data quality objectives. Sampling and analyses conducted as part of an RI to support the CERCLA process may generate data that are needed to evaluate risk to human health and the environment, to document that no further remediation is necessary, or to support a multimillion-dollar construction activity and treatment alternative. In these cases, the data quality objectives of the project may mandate a thorough technical evaluation of the data against rigorous predetermined criteria. The validation process may result in the identification of data that do not meet predetermined QC criteria or in the ultimate rejection of data for their intended use. Typical criteria evaluated in the validation of contract laboratory program data include the percentage of surrogate recoveries, spike recoveries, method blanks, instrument tuning, instrument calibration, continuing calibration verifications, internal standard response, comparison of duplicate samples, and sample holding times.

\subsection{Environmental Management and Waste Management Activities}

\subsubsection{Mercury Remediation Strategy for Y-12, East Fork Poplar Creek}

A draft mercury remediation strategy plan was developed to address cleanup of mercury contamination at Y-12 and in EFPC. The document was submitted to the regulators for review in March 2013. DOE held a workshop with TDEC and EPA in August 2013. Comments on the plan were discussed and the strategic approach refined.

A phased, adaptive management approach is proposed in the plan, which will first address mercury contamination in surface water. A key component is construction of a water treatment facility, the Outfall 200 Mercury Treatment Facility, to provide both current reductions of mercury in the creek and future capacity to treat water during the demolition and remediation of WEMA.

Other actions proposed in the plan will also advance cleanup of mercury at the site and in the creek, including diversion of water sources to avert contact with contaminated soils and sediments. Technology development efforts described in the plan will help support future cleanup on many levels; for example, gaining an understanding of mercury bioaccumulation and movement in the environment can help refine and target methods for remediation, thus reducing cost and time investments.

Mercury source removal — building demolition and soil/sediment remediation — is planned to begin in 2021. Because most of the waste resulting from source remediation actions will be generated after EMWMF reaches full capacity, the plan calls for disposal of the waste in a proposed future landfill.

\subsubsection{Mercury Reduction Project Work Continues}

The Mercury Reduction Project was initiated to facilitate reduction and lower mobility of mercury at Y-12. Subprojects under the Mercury Reduction Project included Five Tanks Remediation, Outfall 200 Conceptual Design, Mercury Recovery Trap Installation, Mercury Soils Treatability Study, and Secondary Pathway Remediation. Field activities on the Mercury Reduction Project began in May 2012 and continued into FY 2013.

\section{Five Tanks Remediation Project}

A tank removal project was initiated in FY 2012 to dispose of five tanks formerly used for mercury-related activities at Y-12. These tanks were removed from service in the 1980s. Characterization was completed along with the necessary documentation needed for disposal of these tanks. 
The tank removal project was completed in FY 2013. Based on characterization results, two tanks were sent to the sanitary landfill at Y-12. Three tanks were transported to Materials and Energy Corporation for residual removal of tank contents and size reduction of the tanks. After size reduction, the tank residuals and debris were disposed. More than $800 \mathrm{lb}$ of mercury was removed and treated. A formal report documenting completion of the project was submitted to EPA and TDEC.

\section{Outfall 200 Mercury Treatment Conceptual Design Project}

An outfall is a discharge point of a waste stream into a body of water. Outfall 200 is the point at which the Y-12 storm drain system discharges to upper EFPC. During FY 2012, a treatability study and a conceptual design project were initiated for a treatment plant to reduce the release of mercury from outfall 200 into upper EFPC. Samples were collected from outfall 200 A6, outfall 169, outfall 163, and outfall 150. Collected samples of storm water effluent and grit from the bottom of the storm sewers were analyzed for constituents of concern and subjected to treatability analysis for removal of suspended solids and mercury. An alternatives analysis was performed for an outfall 200 treatment system.

During FY 2013, the remedial design work plan for the Outfall 200 Mercury Treatment Facility was completed. The work plan described an interim RA to reduce the release of mercury into upper EFPC with a goal of restoring surface waters. The design of the treatment facility was summarized in the conceptual design report for the Outfall 200 Mercury Treatment Facility.

\section{Mercury Recovery Project}

As part of the Mercury Recovery Project, mercury recovery traps were designed and installed at locations upstream of outfalls 150,160,163, and 169. The traps collect elemental mercury and mercury-contaminated sediment, and Y-12 personnel remove that mercury and sediment from the traps and other storm drain locations.

Y-12 began collecting mercury and sediments from these traps in the storm drains in FY 2013. Ongoing collection and disposition of elemental mercury and associated contaminated sediments from the traps in the storm drain system will be summarized in the annual remediation effectiveness report, Remediation Effectiveness Report for the US Department of Energy, Oak Ridge Reservation, Oak Ridge, Tennessee (DOE 2007, 2014), which details the effectiveness of remediation activities.

In FY 2013 a decanting facility was also installed as part of the project to separate mercury from cocollected sediment and water and potentially amalgamate the collected elemental mercury for disposal purposes.

Trapping and removing elemental mercury from the storm drain system will be of benefit by removing some mercury before it reaches the upper EFPC at outfall 200.

\section{Mercury Contaminated Soils Treatability Study}

A treatability study for mercury-contaminated Y-12 soils was started in FY 2012. The treatability study was initiated to define treatment options and available disposal options for Y-12 soils contaminated with mercury.

In FY 2013, the Treatability Study Report for Y-12 Site Mercury Contaminated Soil was prepared, detailing the results of treatability studies and providing treatment and disposal options for the mercury contaminated soils.

\section{Secondary Pathways}

In FY 2013, actions to reduce or eliminate secondary mercury infiltration around Alpha 4 (9201-4) and Alpha 5 (9201-5) and identify and confirm open drains inside Alpha 5 and Beta 4 (9204-4) were completed. These massive facilities were involved with lithium isotope separation activities that used large quantities of elemental mercury. These activities included modifying some roof drains and drainage systems, installing graded impervious surfaces to ensure rainwater runoff is routed to storm drains to 
reduce percolation through mercury-contaminated soils, and investigating potential mercury source points inside the facilities. The actions were documented in a completion report. All waste generated was disposed in FY 2013.

\subsubsection{Waste Management}

\section{CERCLA Waste Disposal}

Much of the waste generated during FY 2013 cleanup activities was disposed at ORR facilities (DOE 2013). EMWMF, located in Bear Creek Valley west of the Y-12 Complex, is an engineered landfill that accepts waste generated from CERCLA response actions and cleanup activities on ORR (low-level, mixed, and classified waste). The Oak Ridge Office of Environmental Management manages the contract with UCOR for operation of EMWMF. See Section 3.8.1 for information about EMWMF.

\section{Solid Waste Disposal}

DOE also operates solid waste disposal facilities called the Oak Ridge Reservation Landfills (ORRLs), which are located near the Y-12 Complex. ORRLs are engineered facilities used for the disposal of sanitary, industrial, construction, and demolition waste.

In FY 2013, about 36,435 $\mathrm{yd}^{3}$ of industrial wastes and construction/demolition debris was disposed in the landfill. Operation of ORRLs generated about 1.1 million gal of leachate that was collected, monitored, and discharged to the Y-12 Complex sanitary sewer system, which discharges to the Oak Ridge sewer system under an industrial sewer user permit.

\subsubsection{Wastewater Treatment}

NNSA at the Y-12 Complex treats wastewater generated from both production activities and environmental cleanup activities. Safe and compliant treatment of 116 million gal of wastewater were provided at various facilities during the year.

The West End Treatment Facility and the Central Pollution Control Facility at the Y-12 Complex processed 826,000 gal of wastewater primarily in support of NNSA operational activities. The Central Pollution Control Facility also downblended more than 45,900 gal of enriched wastewaters using depleted uranium oxides from on the site.

The Big Springs Water Treatment System treated 100 million gal of mercury-contaminated groundwater. The East End Volatile Organic Compounds Treatment System treated 11 million gal of VOC-contaminated groundwater.

The Liquid Storage Facility and Groundwater Treatment Facility treated 2 million gal of leachate from burial grounds and well purge waters from remediation areas.

The Central Mercury Treatment System treated 2 million gal of mercury-contaminated sump waters from the Alpha 4 building.

\subsection{References}

ATSDR. 2006. Public Health Assessment: Evaluation of Potential Exposures to Contaminated OffSite Groundwater from the Oak Ridge Reservation. Agency for Toxic Substances and Diseases Registry. Atlanta, Georgia.

B\&W Y-12. 2009. Y-12 Complex Ozone Depleting Substances (ODS) Phase-Out and Management Plan, Y/TS-1880/R2. Babcock \& Wilcox Technical Services Y-12, LLC, Oak Ridge, Tennessee.

B\&W Y-12. 2010. Spill Prevention, Control, and Countermeasures Plan for the US Department of Energy Y-12 National Security Complex Oak Ridge, Tennessee, Y/SUB/02-001091/5. Babcock \& Wilcox Technical Services Y-12, LLC, Oak Ridge, Tennessee. 
B\&W Y-12. 2010a. Y-12 National Security Complex Quality Assurance Project Plan for National Emission Standards for Hazardous Air Pollutants (NESHAP) for Radionuclide Emission Measurements, Y/TS-874. Babcock \& Wilcox Technical Services Y-12, LLC, Oak Ridge, Tennessee.

B\&W Y-12. 2012. Radiological Monitoring Plan for the Oak Ridge Y-12 National Security Complex: Surface Water, Y/TS-1704/R3. Babcock \& Wilcox Technical Services Y-12, LLC, Oak Ridge, Tennessee.

B\&W Y-12. 2013. Annual Storm Water Report for the Y-12 National Security Complex, Oak Ridge, Tennessee, Y/TS-2035/R7. Babcock \& Wilcox Technical Services Y-12, LLC, Oak Ridge, Tennessee.

B\&W Y-12. 2013a. Y-12 Groundwater Protection Program Extent of the Primary Groundwater Contaminants at the Y-12 National Security Complex. Prepared by Elvado Environmental LLC. Y/SUB/13-08769/3.

B\&W Y-12. 2013b. Y-12 Site Sustainability Plan, Y/IA-451Rev 2. Babcock \& Wilcox Technical Services Y-12, LLC, Oak Ridge, Tennessee.

B\&W Y-12. 2014. Calendar Year 2013 Groundwater Monitoring Report, Y/SUB/14-091569/1. US Department of Energy Y-12 National Security Complex, Oak Ridge, Tennessee.

DOE. 1997. Report on the Remedial Investigation of Bear Creek Valley at the Oak Ridge Y-12 Plant, Oak Ridge, Tennessee, DOE/ORR/01-1455/V1/V6\&D2. US Department of Energy, Washington, D.C.

DOE. 1998. Report on the Remedial Investigation of the Upper East Fork Poplar Creek Characterization Area at the Oak Ridge Y-12 Plant, Oak Ridge, Tennessee, DOE/OR/01-1641/V1V4\&D2. US Department of Energy, Office of Environmental Management, Oak Ridge, Tennessee.

DOE. 2001. Treatability Study Report for Evaluating the Upper East Fork Poplar Creek Hydraulic Connection at the Y-12 National Security Complex, Oak Ridge, Tennessee, DOE/OR/01-1963\&D1. US Department of Energy, Washington, DC.

DOE. 2002. Record of Decision for Phase I Interim Source Control Actions in the Upper East Fork Poplar Creek Characterization Area, Oak Ridge, Tennessee, DOE/OR/01-1951\&D3. US Department of Energy, Office of Environmental Management, Oak Ridge, Tennessee.

DOE. 2007. 2007 Remediation Effectiveness Report for the US Department of Energy, Oak Ridge Reservation, Oak Ridge, Tennessee, Volume 1: Compendium, DOE/OR/01-2337\&D2/V1. US Department of Energy, Washington, DC.

DOE. 2011. Departmental Sustainability, DOE O 436.1. Approved 5-2-11. US Department of Energy, Washington, DC.

DOE. 2011a. Final Site-Wide Environmental Impact Statement for the Y-12 National Security Complex, DOE/EIS-0387. US Department of Energy, National Nuclear Security Administration, Y-12 Site Office, Oak Ridge, Tennessee.

DOE. 2011b. Radiation Protection of the Public and the Environment, DOE O 458.1. Approved February 11, 2011; Change 2 approved June 6, 2011. US Department of Energy, Washington, DC.

DOE. 2012. Opportunities for Energy Savings at Department of Energy Facilities, DOE/IG-0869. US Department of Energy, Washington, DC. 
DOE. 2012a. Explanation of Significant Differences for the Record of Decision for Phase I Interim Source Control Actions in the Upper East Fork Poplar Creek Characterization Area, Oak Ridge, Tennessee, DOE/OR/01-2539\&D2. US Department of Energy, Environmental Restoration Division, Oak Ridge, Tennessee.

DOE. 2012b. 2012 Strategic Sustainability Performance Plan, Report to the White House Council on Environmental Quality. US Department of Energy, Washington, DC.

DOE. 2013. Cleanup Progress; Annual Report to the Oak Ridge Community, DOE/ORO-2467. US Department of Energy, Office of Environmental Management, Oak Ridge, Tennessee. Prepared by URS | CH2M Oak Ridge LLC; available online at http://energy.gov/sites/prod/files/2013/12/f6 /2013CleanupProgress_0.pdf.

DOE. 2013a. Compliance Plan, National Emission Standards for Hazardous Air Pollutants for Airborne Radionuclides on the Oak Ridge Reservation, Oak Ridge, Tennessee, DOE/ORO/2196 Rev.1. US Department of Energy, Washington, DC.

DOE. 2013b. Federal Facility Agreement for the Oak Ridge Reservation, Appendix C, Latest Revision-FFA-PM/13-003, DOE/OR-1014. US Department of Energy, Office of Environmental Management, Oak Ridge, Tennessee.

DOE. 2013c. Quality Systems for Analytical Services, Revision 2.9. US Department of Energy, Washington, DC.

DOE. 2014. Department of Energy Air Emissions Annual Report, Oak Ridge Reservation, Oak Ridge, Tennessee, 40 Code of Federal Regulations (CFR) 61, Subpart H, Calendar Year 2013. US Department of Energy, Washington, DC.

DOE. 2014a. 2014 Remediation Effectiveness Report for the US Department of Energy, Oak Ridge Reservation, Oak Ridge, Tennessee, Data and Evaluation, DOE/OR/01-2640\&D2. US Department of Energy, Washington, DC.

Domenico, P. A., and F. W. Schwartz. 1990. Physical and Chemical Hydrogeology. John Wiley \& Sons, p. 824.

EO 13423, Strengthening Federal Environmental, Energy, and Transportation Management, January 24, 2007, Fed. Reg. Vol. 72(17).

EO 13514, Federal Leadership in Environmental, Energy, and Economic Performance, October 5, 2009, Fed. Reg. Vol. 74(194).

EPA. 1995 and 1998. Compilation of Air Pollutant Emission Factors AP-42, Fifth Edition, Volume 1: Stationary Point and Area Sources. US Environmental Protection Agency, Research Triangle Park, North Carolina January 1995 and September 1998.

ISO. 2004. Environmental management systems-Requirements with guidance for use. ISO 14001:2004. International Organization for Standardization; available online at http://www.iso.org.

MMES. 1990. Report and Preliminary Assessment of the Occurrence of Dense, Nonaqueous Phase Liquids in the Bear Creek Burial Grounds Hazardous Waste Disposal Unit at the Oak Ridge Y-12 Plant, Y/TS-960. Martin Marietta Energy Systems, Inc., Oak Ridge, Tennessee. 
NRC. 2000. Multi-Agency Radiation Survey and Site Investigation Manual (MARSSIM), NUREG-1575, Rev. 1/EPA 402-R-97-016, Rev. 1/DOE/EH-0624, Rev. 1. US Nuclear Regulatory Commission, Environmental Protection Agency, Department of Defense, and Department of Energy, Washington, DC.

NRC. 2009. Multi-Agency Radiation Survey and Assessment of Materials and Equipment Manual (MARSAME), NUREG-1575, Supplement 1/EPA 402-R-09-001/DOE/HS-0004. US Nuclear Regulatory Commission, Environmental Protection Agency, Department of Defense, and Department of Energy, Washington, DC.

Peterson, M., B. Looney, G. Southworth, C. Eddy-Dilek, D. B. Watson, R. H. Ketelle, and M. A. Bogle. 2011. Conceptual Model of Primary Mercury Sources, Transport Pathways, and Flux at the Y-12 Complex and Upper East Fork Poplar Creek, Oak Ridge, Tennessee, ORNL/TM-2011/75. Oak Ridge National Laboratory, Oak Ridge, Tennessee.

TDEC. 2007. State of Tennessee Water Quality Standards, Chapter 1200-4-3, "General Water Quality Criteria," October 2007. Tennessee Department of Environment and Conservation, Division of Water Pollution Control. Approved March 2008. Tennessee Department of Environment and Conservation.

TDEC. 2010a. Proposed Total Maximum Daily Loads (TMDLs) for Polychlorinated Biphenyls (PCBs) and Chlordane in Melton Hill Reservoir: Lower Clinch River Watershed (HUC 06010207), Anderson, Knox, Loudon, and Roane Counties, Tennessee. Tennessee Department of Environment and Conservation, Nashville, Tennessee.

TDEC. 2010b. Proposed Total Maximum Daily Loads (TMDLs) for Polychlorinated Biphenyls (PCBs) and Chlordane in Watts Bar Reservoir: Watts Bar Lake Watershed (HUC 06010201), Lower Clinch River Watershed (HUC 06010207), and Emory River Watershed (HUC 06010208), Loudon, Meigs, Morgan, Rhea, and Roane Counties, Tennessee. Tennessee Department of Environment and Conservation, Nashville, Tennessee.

TDEC. 2010c. Proposed Total Maximum Daily Loads (TMDLs) for Polychlorinated Biphenyls (PCBs) and Chlordane in Fort Loudon Reservoir: Fort Loudon Lake Watershed (HUC 06010201), Blount, Knox, and Loudon Counties, Tennessee. Tennessee Department of Environment and Conservation, Nashville, Tennessee.

TDEC. 2012. Site Treatment Plan for Mixed Wastes on the US Department of Energy Oak Ridge Reservation, TDEC-REV. 17.1. Tennessee Department of Environment and Conservation, Nashville, Tennessee.

UCOR. 2012. URS | CH2M Oak Ridge LLC Sampling and Analysis Plan for the Water Resources Restoration Program for Fiscal Year 2013 Oak Ridge Reservation, Oak Ridge, Tennessee, UCOR-4219. URS | CH2M Oak Ridge LLC, Oak Ridge, Tennessee.

UCOR. 2013. URS | CH2M Oak Ridge LLC Sampling and Analysis Plan for the Water Resources Restoration Program for Fiscal Year 2014 Oak Ridge Reservation, Oak Ridge, Tennessee, UCOR-4457. URS | CH2M Oak Ridge LLC, Oak Ridge, Tennessee.

UCOR. 2014. URS | CH2M Oak Ridge LLC Calendar Year 2013, Resource Conservation and Recovery Act Annual Monitoring Report for the US Department of Energy Y-12 National Security Complex, Oak Ridge, Tennessee, UCOR-4538. URS | CH2M Oak Ridge LLC, Oak Ridge, Tennessee.

Vázquez, Gustavo. 2011. "Clearance of Real and Personal Property Under New DOE Radiation Protection Directive DOE Order 458.1, Radiation Protection of the Public and the Environment." Presented at the56th Annual Meeting of the Health Physics Society, June 26-30, 2011, West Palm Beach, Florida. 



\section{Oak Ridge National Laboratory}

ORNL is the largest science and energy national laboratory in the DOE system. ORNL's scientific programs focus on materials, neutron science, energy, high-performance computing, systems biology, and national security. ORNL partners with the State of Tennessee, universities, and industry to solve challenges in energy, advanced materials, manufacturing, security, and physics. The laboratory's science and technology innovations are translated into applications for economic development and global security. The laboratory is home to several of the world's top supercomputers and is a leading neutron science and nuclear energy research facility that includes SNS and HFIR. ORNL hosts a DOE leadership computing facility, home of the Titan supercomputer; one of DOE's nanoscience centers, the Center for Nanophase Materials Sciences; one of DOE's energy research centers, the BioEnergy Science Center; and the Consortium for Advanced Simulation of Light-Water Reactors, a DOE innovation hub. ORNL operates 10 user facilities that draw thousands of research scientists and visitors each year.

- Building Technologies Research and Integration Center

- CFTF

- Center for Nanophase Materials Sciences

- Center for Structural Molecular Biology

- HFIR

- High Temperature Materials Laboratory

- National Center for Computational Sciences

- National Transportation Research Center (NTRC)

- Shared Research Equipment Collaborative Research Center

- SNS

ORNL is managed by UT-Battelle, LLC, a partnership between the University of Tennessee and Battelle Memorial Institute. During 2013 the ORNL operations of UT-Battelle, WAI, UCOR, Isotek, and SEC Federal Services Corporation (SEC) were conducted in compliance with contractual and regulatory environmental requirements with the exception of five issues identified during a joint EPA-TDEC-RCRA inspection. There were no NOVs or penalties issued by the regulatory agencies.

Because of differing permit reporting requirements and instrument capabilities, various units of measurement are used in this report. The list of units of measure and conversion factors provided on pages xxvii and xxviii is intended to help readers convert numeric values presented here as needed for specific calculations and comparisons.

\subsection{Description of Site, Mission, and Operations}

ORNL, which is managed for DOE by UT-Battelle, LLC, a partnership of the University of Tennessee and Battelle Memorial Institute, lies in the southwest corner of the DOE ORR (Fig. 5.1) and includes facilities in two valleys (Bethel and Melton) and on Chestnut Ridge. ORNL was established in 1943 as part of the secret Manhattan Project to pioneer a method for producing and separating plutonium. During the 1950s and 1960s, and with the creation of DOE in the 1970s, ORNL became an international center for the study of nuclear energy and related research in the physical and life sciences. By the turn of the century, the laboratory supported the nation with a peacetime science and technology mission that was just as important as, but very different from, the work carried out in the days of the Manhattan Project. 


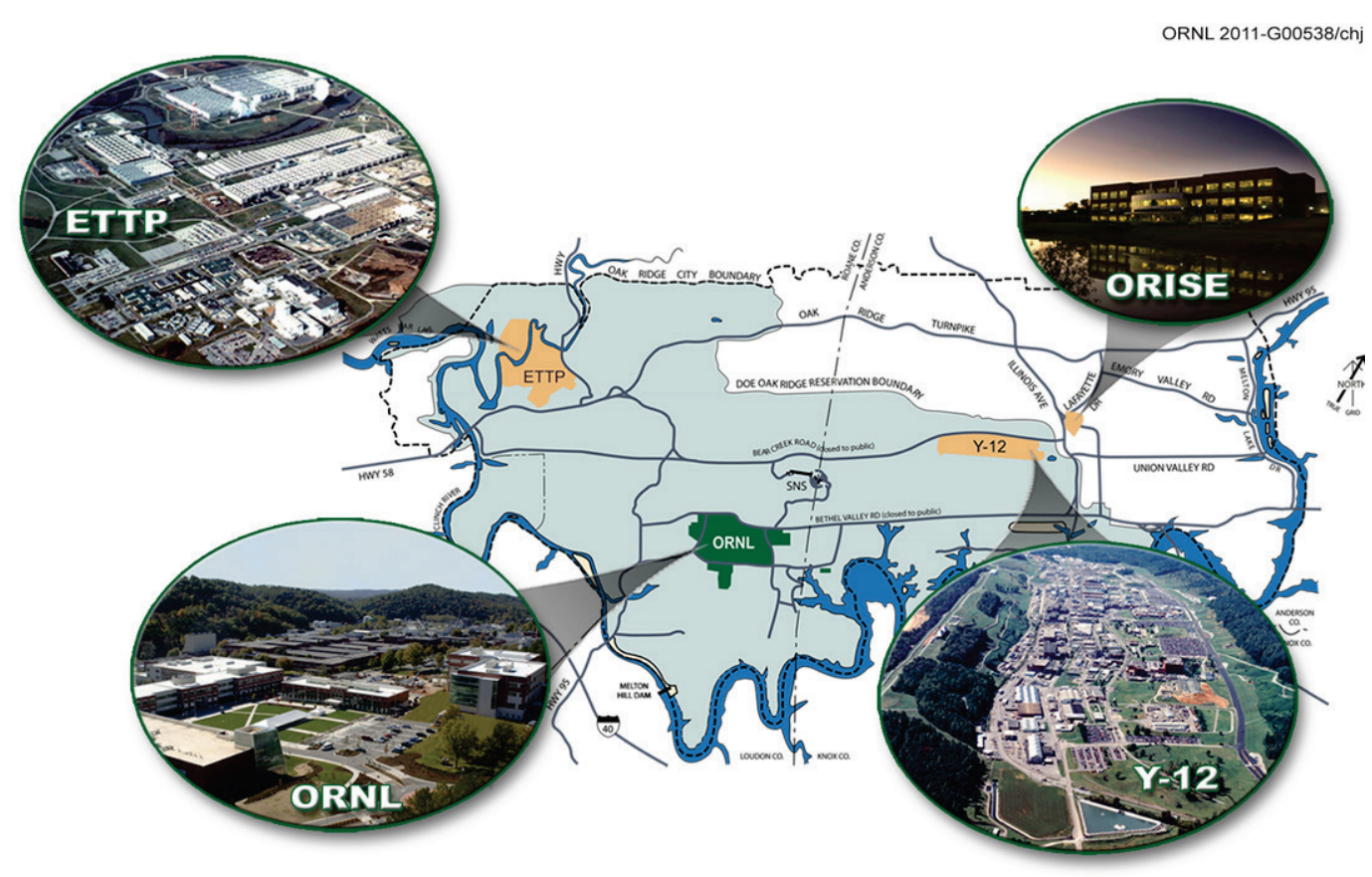

Fig. 5.1. Location of Oak Ridge National Laboratory within the Oak Ridge Reservation and its relationship to other local US Department of Energy facilities.

UT-Battelle also manages several facilities located off the main ORNL campus. These include several buildings and trailers located at the Y-12 Complex, the American Museum of Science and Energy in the city of Oak Ridge, and several other locations around the Oak Ridge vicinity, described below.

NTRC is an alliance among UT-Battelle, the University of Tennessee, DOE, and the Development Corporation of Knox County. NTRC is a two building complex consisting of NTRC1 and NTRC2/Manufacturing Demonstration Facility (MDF). The buildings, co-located on a 2.4 ha (6-acre) site in the Pellissippi Corporate Center, are leased to UT-Battelle and the University of Tennessee separately by Pellissippi Investors LLC. NTRC1, a 7,897 $\mathrm{m}^{2}\left(85,000 \mathrm{ft}^{2}\right)$ building, is the site of activities that span the whole range of transportation research. NTRC2/MDF, a 5,667 $\mathrm{m}^{2}\left(61,000 \mathrm{ft}^{2}\right)$ building, houses the Battery Manufacturing Facility, the country's largest dry, open-access battery manufacturing R\&D center.

CFTF, located in the Horizon Center Business Park in Oak Ridge, is a pilot project to develop ways of making low-cost carbon fiber inexpensively using research from Oak Ridge National Laboratory (Fig. 5.2). Operations at the 3,902 $\mathrm{m}^{2}\left(42,000 \mathrm{ft}^{2}\right)$ CFTF began in March 2013.

TWPC, managed by WAI for DOE, is located on the western boundary of ORNL on about 10.5 ha (26 acres) of land adjacent to the Melton Valley Storage Tanks along State Route 95. TWPC's mission is to receive TRU wastes for processing, treatment, repackaging, and shipment to designated facilities for final disposal. TWPC consists of the waste processing facility, the personnel building, and numerous support buildings and storage areas. TWPC began processing supernatant liquid from the Melton Valley Storage Tanks in 2002, contact-handled (CH) debris waste in December 2005, and remote-handled (RH) debris waste in May 2008. Based on the definition of TRU waste, some waste being managed as TRU is later determined to be low-level waste (LLW) or mixed LLW. 


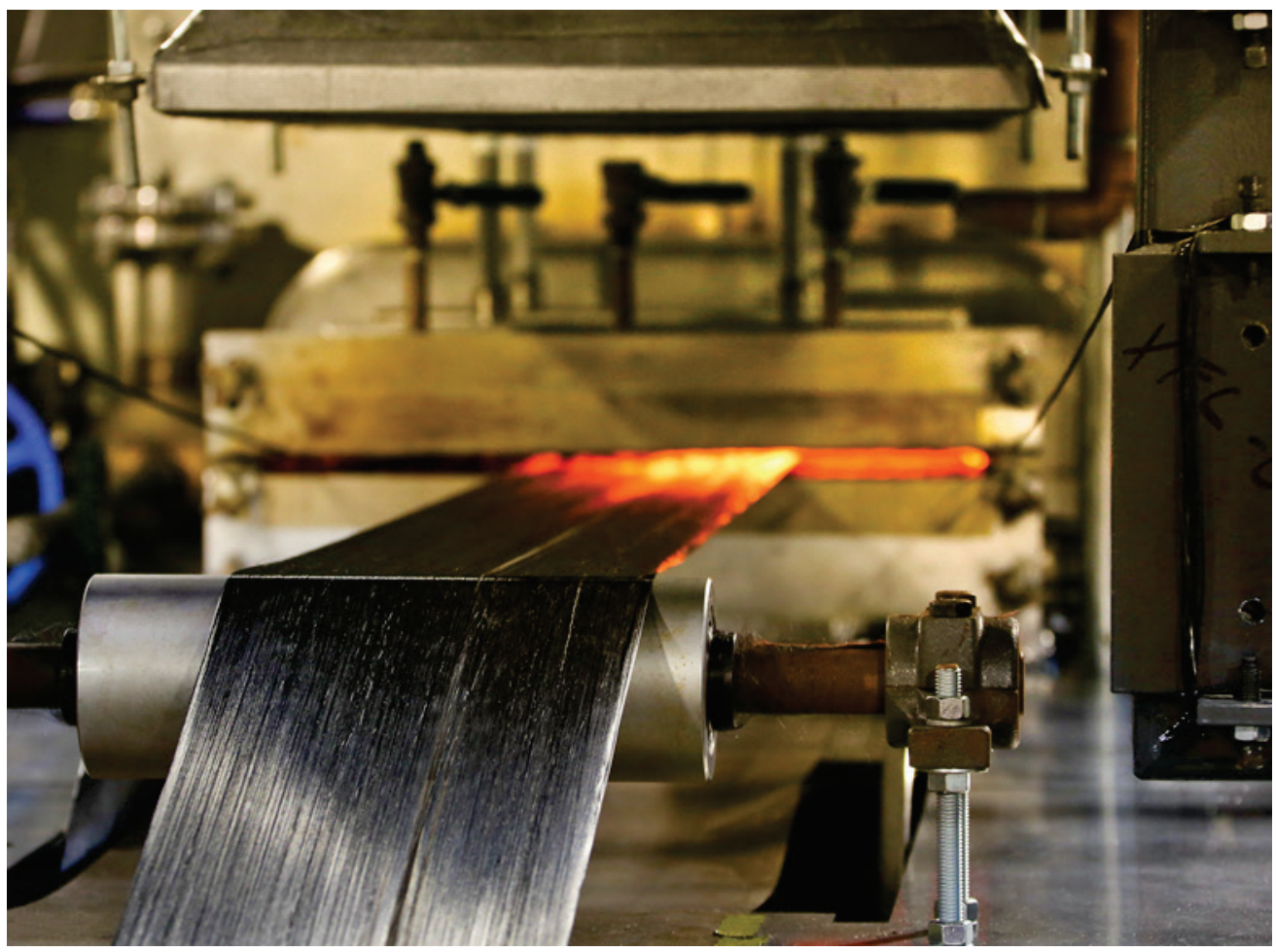

Fig. 5.2. Production of lower cost carbon fiber at the Carbon Fiber Technology Facility.

In March 2007, Isotek assumed responsibility for the Building 3019 Complex at ORNL, where the national repository of ${ }^{233} U$ has been kept since 1962. A letter from the Deputy Secretary of Energy, dated November 24, 2010, directed the conduct of an "alternatives analysis" to determine whether there were more efficient methods available for ${ }^{233} \mathrm{U}$ disposition. In April 2011, the Deputy Secretary of Energy endorsed the recommendations in the final draft ${ }^{233} U$ alternatives analysis phase I report (DOE 2011). The phase I recommendations included the following: (1) proceed with a direct disposition campaign involving the transfer of Zero Power Reactor (ZPR) plate canisters to NNSA for future reuse and disposal at NNSS and (2) conduct a phase II alternatives analysis to determine the best approach for processing the remaining 50\% of the inventory. In December 2011, Isotek initiated transfer of the ZPR plate canisters to the NNSA Critical Safety Program located at the Device Assembly Facility at NNSS. Isotek completed transfer of the ZPR plate canisters in June 2012. In 2013, Isotek continued to plan and prepare for future programmatic transfers and direct disposal of the remaining ${ }^{233} \mathrm{U}$ inventory.

Since 2010 SEC has performed deactivation, demolition, and removal/disposition activities for multiple facilities at ORNL. To accomplish this, SEC was awarded two separate contracts, the Miscellaneous Facilities Decontamination and Decommissioning (D\&D) project, which was completed in 2012, and the Hot Cell project, which included work activities and removal actions regulated by CERCLA.

The main objective of the Hot Cell project was to perform decommissioning of the Building 3026 C/D hot cell complex and legacy material removal from Building 3038 at ORNL. Building $3026 \mathrm{C} / \mathrm{D}$ facilities were to be brought down to their concrete foundation slabs. As a result of budget constraints this project was curtailed in February 2013 when partially completed. It has since been turned over to UCOR to be managed under a surveillance and maintenance agreement.

UT-Battelle performs air and water quality monitoring for CFTF and the Building 3019 complex and water quality monitoring for TWPC. TWPC air monitoring information is included in the ORR RadNESHAPs annual report (DOE 2014). Therefore, the UT-Battelle air and water monitoring discussions in this chapter include results for CFTF, Isotek, and WAI operations at ORNL. 
About 5 ha (12 acres) in the central portion of ORNL has been leased to Halcyon, LLC, a CROET subsidiary, for development into ORSTP. ORSTP provides space for private companies doing research at ORNL, partner universities, start-up companies built around ORNL technologies, and ORNL contractors to conduct business within a short distance of ORNL researchers and DOE user facilities such as SNS, the Center for Nanophase Materials Sciences, and HFIR. Construction of the first ORSTP facility, Pro2Serve's 10,684 $\mathrm{m}^{2}\left(115,000 \mathrm{ft}^{2}\right)$ National Security Engineering Center, was completed in 2009, and the company is now well-established in the building. In addition, the former Building 2033, also leased to Halcyon, LLC, is now known as HCC and continues to attract tenants. The largest tenant in HCC is Roane State Community College, which is offering job training classes on-site in the areas of carbon fiber manufacturing and solar energy technology. Other HCC tenants include several consulting firms and a carbon fiber manufacturer that is partnering with UT-Battelle for materials research. Expansion of ORSTP will continue as more environmental cleanup in ORNL's central campus is completed. EPA has designated ORSTP lessees as collocated workers since they are located on DOE property and are issued security badges to access the facilities.

\subsection{Environmental Management Systems}

An important priority for DOE contractors performing management and operations activities at ORNL is the demonstration of environmental excellence through high-level policies that clearly state expectations for continual improvement, pollution prevention, and compliance with regulations and other requirements.

In accordance with DOE O 436.1, Departmental Sustainability (DOE 2011a), UT-Battelle, WAI, UCOR and Isotek have implemented EMSs, modeled after ISO 14001:2004 (ISO 2004), to measure, manage, and control environmental impacts. An EMS is a continuing cycle of planning, implementing, evaluating, and improving processes and actions undertaken to achieve environmental goals. UT-Battelle's EMS was initially registered to the ISO 14001 standard by a third-party registrar in 2004 and was reregistered in June 2007 and June 2010 by NSF International Strategic Registrations, Ltd (NSF-ISR). No nonconformities were identified during the most recent reregistration audit. Detailed information on the UT-Battelle EMS is provided in Sections 5.2.1 through 5.2.1.7. WAI's EMS for activities at TWPC was registered to the ISO 14001:2004 standard by NSF-ISR in May 2008. NSF-ISR conducted a recertification audit for the WAI EMS program in May 2011, and no nonconformities or issues were identified and several significant practices were noted. Section 5.2.2 describes the WAI EMS and associated implementation activities. In June 2009, DOE conducted an external validation audit and concluded "that Isotek has implemented an Environmental Management System (EMS) that is consistent with the requirements of DOE O 450.1A, Environmental Protection Program" (DOE 2008). In May 2012, DOE conducted another validation audit and issued a memorandum documenting that Isotek's EMS for the U-233 Disposition Project conforms to the ISO 14001:2004 standard.

\subsubsection{UT-Battelle Environmental Management System}

The UT-Battelle EMS is a fully integrated set of environmental management services for UT-Battelle activities and facilities. Services include pollution prevention, waste management, effluent management, regulatory review, reporting, permitting, and other environmental management programs. Through the UT-Battelle Standards-Based Management System (SBMS), EMS establishes environmental policy and translates environmental laws, applicable DOE orders, and other requirements into laboratory-wide subject area documents (procedures and guidelines). SBMS information is based on an evaluation of external requirements (i.e., directives and federal, state, and local laws), corporate policies, and best management practices that have been determined applicable to UT-Battelle operations and processes. Through environmental protection officers, environmental compliance representatives, and waste services representatives, EMS assists the line organizations in identifying and addressing environmental issues in accordance with SBMS requirements. 


\subsubsection{Integration with Integrated Safety Management System}

The UT-Battelle EMS and ISMS are integrated to provide a unified strategy for the management of resources, the control and attenuation of risks, and the establishment and achievement of the organization's ES\&H goals. ISMS and EMS both strive for continual improvement through "plan-docheck-act" cycles. Under ISMS, the term "safety" also encompasses environmental safety and health, including pollution prevention, waste minimization, and resource conservation. Therefore, the guiding principles and core functions in ISMS apply both to the protection of the environment and to safety. Figure 5.3 depicts the relationship between EMS and ISMS.

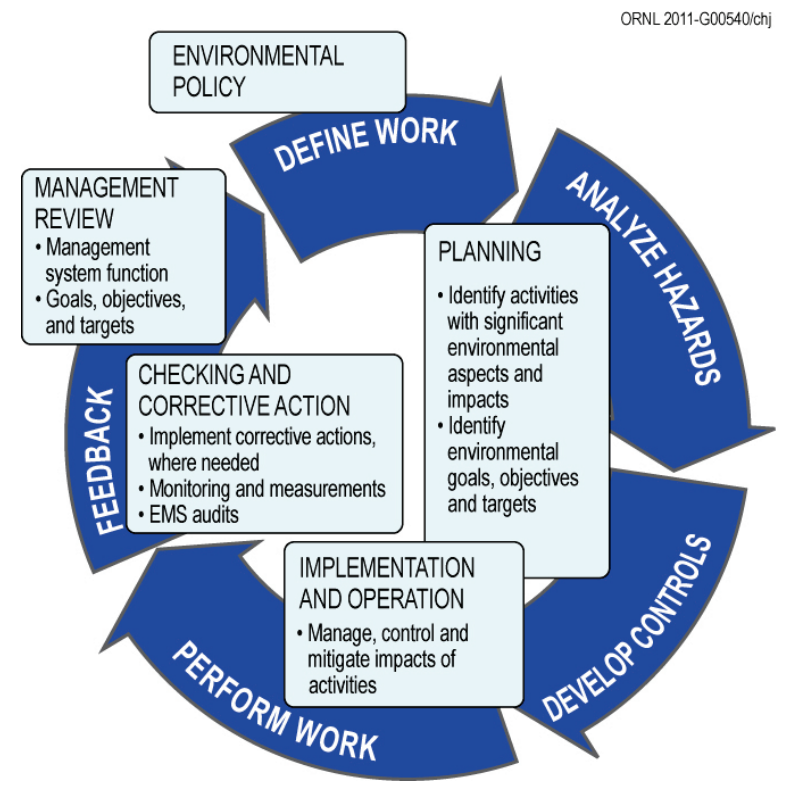

Fig. 5.3. The relationship between the

UT-Battelle Environmental Management System and the Integrated Safety Management System.

The UT-Battelle EMS is consistent with ISMS and includes the following elements:

- environmental policy;

- planning;

- legal and other requirements;

- objectives, targets, and programs;

- implementation and operation;

- resources, roles, responsibility, and authority;

- competence, training, and awareness;

- communication;

- documentation;

- control of documents;

- operational control;

- emergency preparedness and response;

- checking;

- monitoring and measurement;

- evaluation of compliance;

- nonconformity, corrective action, and preventative action;

- control of records;

- internal audit; and

- management review. 


\subsubsection{UT-Battelle Policy for Oak Ridge National Laboratory}

The UT-Battelle environmental policy statements (Fig. 5.4) are part of the UT-Battelle Policy for ORNL, which is the highest level statement of how UT-Battelle conducts business. By clearly stating expectations, the policy provides the framework for setting and reviewing environmental objectives and targets.

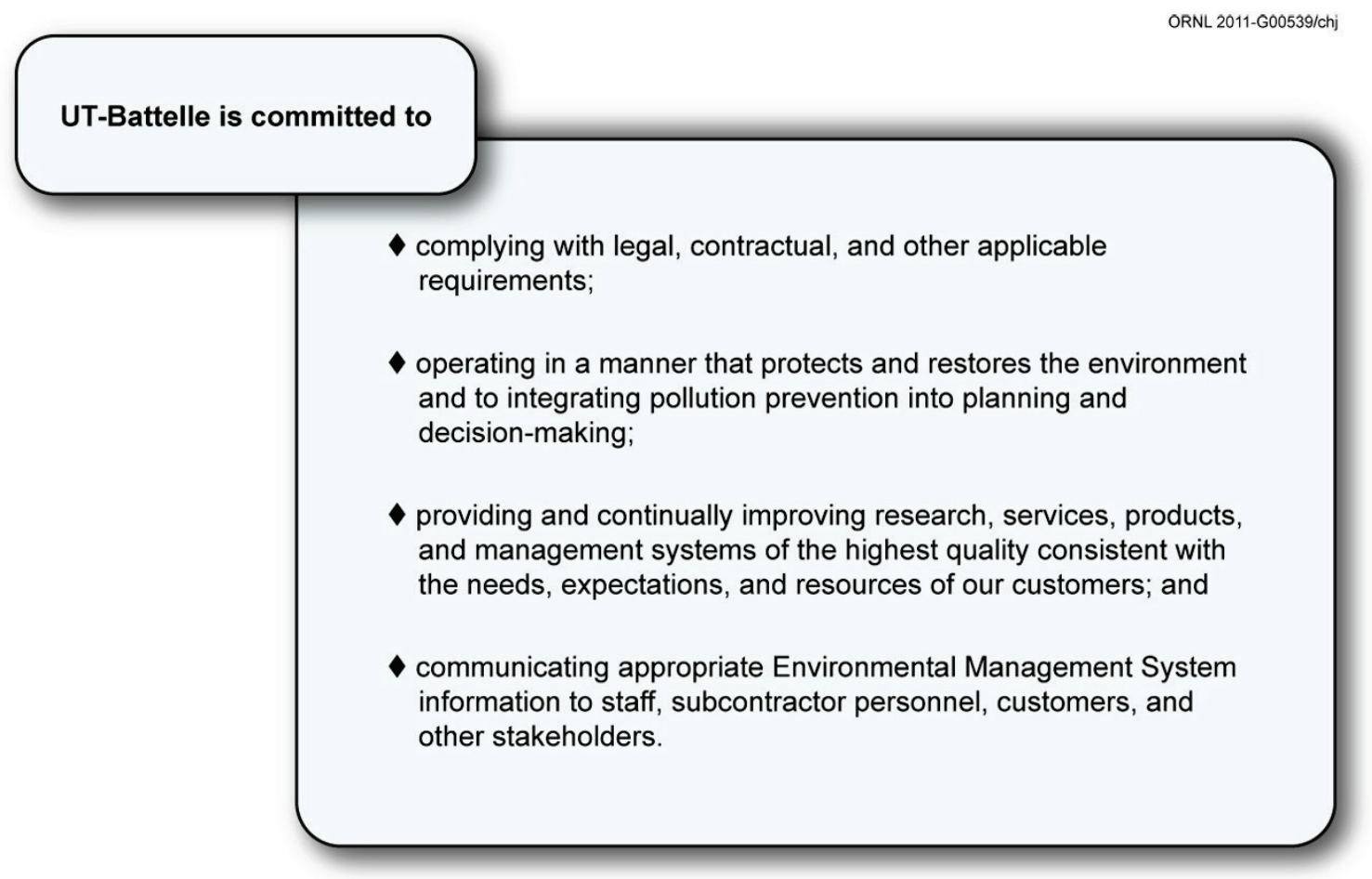

Fig. 5.4. UT-Battelle environmental policy statements.

\subsubsection{Planning}

\subsection{UT-Battelle Environmental Aspects}

Environmental aspects are elements of an organization's activities, products, or services that can interact with the environment. Environmental aspects associated with UT-Battelle activities, products, and services have been identified at both the project and activity level. Activities that are relative to any of these aspects are carefully controlled to minimize or eliminate impacts to the environment. The following aspects have been identified as potentially having significant environmental impacts:

- hazardous waste,

- radioactive waste,

- mixed waste,

- energy use/intensity,

- GHG emissions,

- permitted air emissions,

- regulated liquid discharges, and

- storage or use of chemicals or radioactive materials.

\subsection{UT-Battelle Legal and Other Requirements}

Legal and other requirements that apply to the environmental aspects identified by UT-Battelle include federal, state, and local laws and regulations; environmental permits; applicable DOE orders; UT-Battelle contract clauses; waste acceptance criteria; and voluntary requirements such as 
ISO 14001:2004. UT-Battelle has established procedures to ensure that all applicable requirements are reviewed and that changes and updates are communicated to staff and incorporated into work-planning activities. UT-Battelle's environmental compliance status is discussed in Section 5.3.

\subsection{UT-Battelle Objectives and Targets}

To improve environmental performance, UT-Battelle has established and implemented objectives, targets, and performance indicators for appropriate functions and activities. In all cases, the objectives, targets, and performance indicators are consistent with the UT-Battelle Policy for ORNL and are supportive of the laboratory mission, and where practical, they are measurable. These objectives and targets are entered into a commitment tracking system and tracked to completion.

\subsection{UT-Battelle Programs}

UT-Battelle has established an organizational structure to ensure that environmental stewardship practices are integrated into all facets of UT-Battelle's missions at ORNL. This includes programs led by experts in environmental protection and compliance, energy and resource conservation, pollution prevention, and waste management to ensure that laboratory activities are conducted in accordance with the environmental policy outlined in Fig. 5.4. Information on UT-Battelle's 2013 compliance status, activities, and accomplishments is presented in Section 5.3.

The environmental protection staff provides critical support services in the following areas:

- waste management,

- NEPA compliance,

- air quality compliance,

- water quality compliance,

- US Department of Agriculture (USDA) compliance,

- environmental sampling and data evaluation, and

- CERCLA interface.

The UT-Battelle staff also includes experts who provide critical waste management and disposition support services to research, operations, and support divisions. These include

- waste services representatives who work with waste generators to identify, characterize, package, and certify wastes for disposal;

- the waste-handling team, which performs waste-packing operations and conducts inspections of waste items, areas, and containers;

- the waste and materials disposition team, which coordinates off-site disposition of UT-Battelle's newly generated waste;

- the hazardous material spill response team, which is the first line of response to hazardous materials spills at ORNL and controls and contains such spills until the situation is stabilized; and

- the Environmental Management Program Office (EMPO), which coordinates and directs specific CERCLA decommissioning and demolition work being done on the UT-Battelle site. EMPO activities include developing and implementing interface agreements applicable to multiple contractors, CERCLA applicable or relevant and appropriate requirements, and project work plans.

\subsubsection{UT-Battelle Sustainable Campus Initiative}

The Sustainable Campus Initiative is an ORNL-wide effort that builds upon the laboratory's strength as a premier science and technology organization in integrating energy efficiency, cutting-edge technologies, and operational and business processes to achieve sustainability. The ultimate goal is to achieve benchmark sustainability in campus operation and in the research, development, and deployment of key technologies by 2018.

Figure 5.5 summarizes FY 2013 infrastructure modernization projects. Table 5.1 summarizes FY 2013 performance and planned actions to achieve future sustainability goals. 


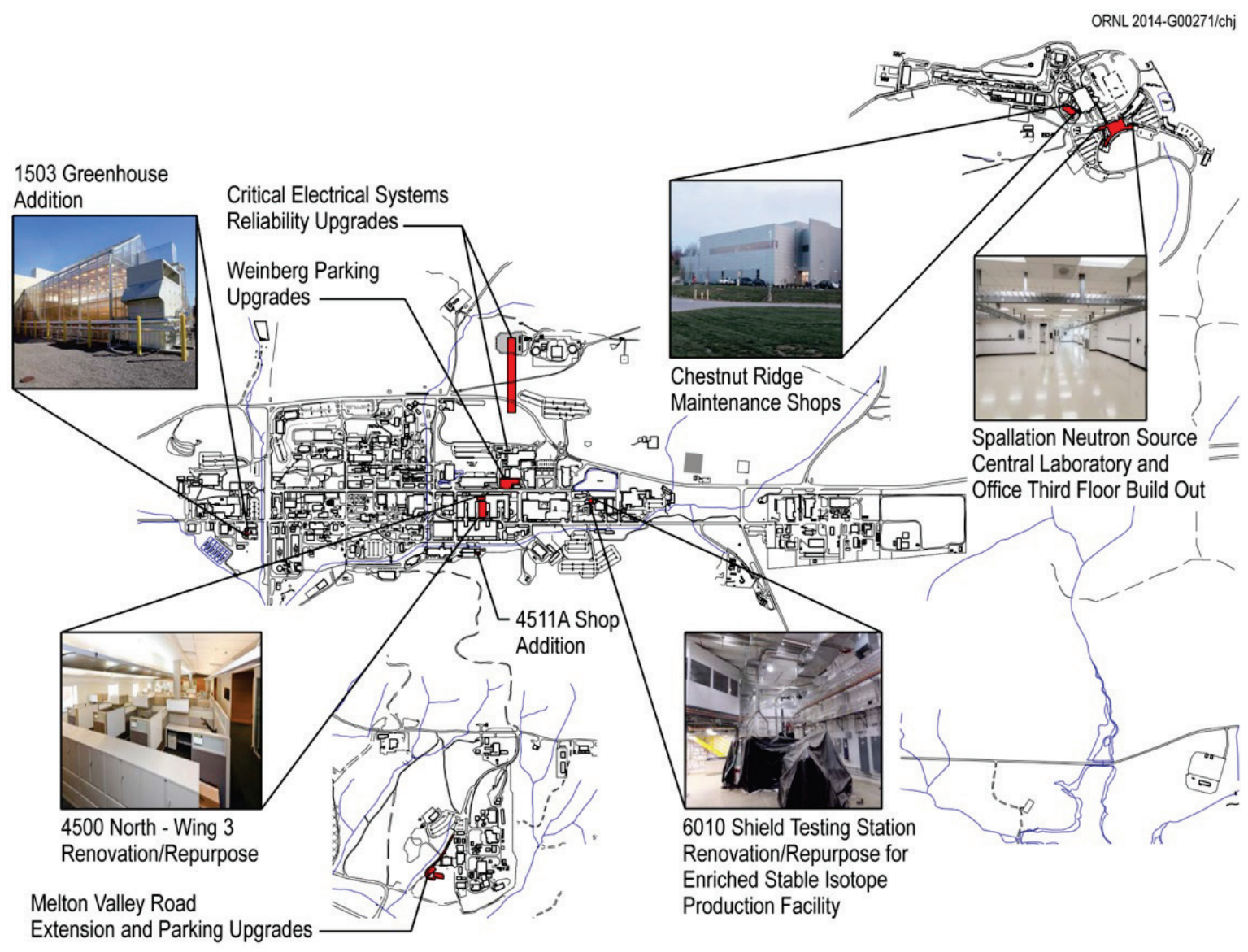

Fig. 5.5. Modernization and facilities revitalization. 
Table 5.1. Summary of UT-Battelle progress toward attainment of DOE sustainability goals, 2013

\begin{tabular}{|c|c|c|c|}
\hline $\begin{array}{l}\text { SC/SSPP/ } \\
\text { OMB Goal }\end{array}$ & DOE Goal & $\begin{array}{l}\text { Performance Status through } \\
\text { FY } 2013\end{array}$ & Planned Actions and Contributions \\
\hline
\end{tabular}

Goal 1: Greenhouse Gas Reduction and Comprehensive Greenhouse Gas Inventory

1.1 28\% Scopes $1 \& 2$ GHG reduction by FY Scope 1- 43,895 metric tons of $\mathrm{CO}_{2} \mathrm{e}$, a decrease of 2020 from a FY 2008 baseline (2013 target: 51\% from FY 2008.

$17 \%$ reduction)

$13 \%$ Scope 3 GHG reduction by FY 2020 from a FY 2008 baseline (2013 target: 4\% reduction)
Scope $-307,660$ metric tons of $\mathrm{CO}_{2} \mathrm{e}$, an increase of $23 \%$ from FY 2008 after allowances for purchased RECs Scopes $1 \& 2$ combined $\sim 351,555$ metric tons of $\mathrm{CO}_{2} \mathrm{e}$, an increase of $4 \%$ from the baseline year of 2008

Scope 3- 42,559 metric tons of $\mathrm{CO}_{2}$ e. Overall Scope 3 emissions have increased by $4 \%$. A $23 \%$ increase in T\&D losses limits overall performance
Scope 1 reductions are expected to exceed the target based on key projects and initiatives planned for the future

Meeting Scope 2 reduction goals is more challenging due to growth in electricity demands for high-energy mission-specific facilities.

Employee engagement programs (i.e., responsible business travel, commuting, and telework programs) continue. However while T\&D losses and purchased electricity will increase, a substation coming online in 2015 will reduce T\&D losses by $\sim 3 \%(\sim 0.75 \mathrm{MW})$ and thus reduce power purchases and Scope $3 \mathrm{GHG}$ emissions

\section{Goal 2: Buildings, Energy Savings Performance Contract Initiative Schedule, and Regional and Local Planning} $30 \%$ energy intensity (Btu/gsf) reduction by FY 2015 from a FY 2003 baseline (2013 target: $24 \%$ )

Each year evaluate a minimum of $25 \%$ of $75 \%$ of facility energy use over a 4 -year cycle per EISA Section 432 Individual buildings metered for $90 \%$ of electricity by October 1, 2012; for $90 \%$ of steam, natural gas, and chilled water by October 1, 2015 (2013 target: 40\%). Data Centers to be metered at $100 \%$ by FY 15 (2013 target: 70\%)

All new roofs must meet cool roof standards and have thermal resistance of at least R-30

$15 \%$ of existing buildings greater than 5,000 gsf to comply with the GPs for HPSBs by FY 2015 (2013 target: 11\%)
UT-Battelle has achieved a reduction of $46.5 \%$ and is on track to exceed the FY 2015 goal (Fig. 5.6). Fig. 5.7 last decade

Over 25\% evaluated during this first year of a second 4 year cycle

As of 2013, metering status of individual buildings was $90.3 \%$ metering for electrical use, $(100 \%$ of data centers).

- $5.5 \%$ steam

- $94.4 \%$ natural gas

- $67.8 \%$ chilled water

UT-Battelle completed one new roofing project in FY 2013 which met all requirements

Six additional existing buildings achieved HPSB status in 2013 for a total of 23, exceeding the DOE goal of 22 HSPBs
Ongoing energy audits will identify future energy conservation projects

Continue pace of $25 \%$ or more through current cycle (end of FY 2016). Use data from prior cycles to conduct focused evaluations

Continued implementation of metering plan will allow progress toward meeting metering goals

New construction and renovation actions will use cool roof technologies

Efforts will continue toward expanding the existing HPSB inventory - planning for two additional buildings in FY 2014 
Table 5.1. (continued)

\begin{tabular}{|c|c|c|c|}
\hline $\begin{array}{l}\text { SC/SSPP/ } \\
\text { OMB Goal }\end{array}$ & DOE Goal & $\begin{array}{l}\text { Performance Status through } \\
\text { FY } 2013 \\
\end{array}$ & Planned Actions and Contributions \\
\hline 2.6 & $\begin{array}{l}\text { All new construction, major renovations, } \\
\text { and alterations of buildings greater than } \\
5,000 \text { gsf must comply with the GPs }\end{array}$ & To date, 16 new facilities have been LEED certified. & $\begin{array}{l}\text { All new construction is specified for LEED Gold. } \\
\text { Two facilities are expected to be in design phase in FY } \\
2014\end{array}$ \\
\hline \multicolumn{4}{|c|}{ Goal 3: Fleet Management } \\
\hline 3.1 & $\begin{array}{l}10 \% \text { annual increase in fleet alternative fuel } \\
\text { consumption by FY } 2015 \text { relative to a FY } \\
2005 \text { baseline ( } 2013 \text { target: } 114 \% \\
\text { cumulative since } 2005)\end{array}$ & $\begin{array}{l}\text { To date alternative fuel use is } 68 \% \text { of total fuel } \\
\text { consumed }\end{array}$ & $\begin{array}{l}\text { Continue to replace older vehicles with AFVs and to } \\
\text { procure electric LSVs }\end{array}$ \\
\hline 3.2 & $\begin{array}{l}2 \% \text { annual reduction in fleet petroleum } \\
\text { consumption by FY } 2020 \text { relative to a FY } \\
2005 \text { baseline ( } 2013 \text { target: } 16 \% \text { cumulative } \\
\text { since 2005). }\end{array}$ & $\begin{array}{l}\text { UT-Battelle has achieved a } 53 \% \text { reduction in fleet } \\
\text { petroleum consumption based on the } 2005 \text { baseline }\end{array}$ & $\begin{array}{l}\text { Continue to replace inefficient vehicles with AFVs and } \\
\text { hybrids and to procure electric LSVs }\end{array}$ \\
\hline 3.3 & $\begin{array}{l}75 \% \text { of light-duty vehicle purchases must } \\
\text { consist of AFVs by FY } 2000 \text { and thereafter }\end{array}$ & $\begin{array}{l}\text { 100\% of the light duty vehicles purchased in FY } 2013 \\
\text { were AFVs }\end{array}$ & $\begin{array}{l}\text { Continue to purchase AFVs as funds are available (Fig. } \\
5.8 \text { ). }\end{array}$ \\
\hline 3.4 & $\begin{array}{l}\text { Reduce fleet inventory of non-mission- } \\
\text { critical vehicles by } 35 \% \text { by FY } 2013 \\
\text { relative to a FY } 2005 \text { baseline }\end{array}$ & UT-Battelle's commitment for this goal has been met & Not applicable \\
\hline \multicolumn{4}{|c|}{ Goal 4: Water Use Efficiency and Management } \\
\hline 4.1 & $\begin{array}{l}26 \% \text { potable water intensity (gal/gsf) } \\
\text { reduction by FY } 2020 \text { from a FY } 2007 \\
\text { baseline (FY } 2013 \text { target: 12\%). }\end{array}$ & $\begin{array}{l}\text { Water use intensity measured } 145 \text { gal/gsf (an 18\% } \\
\text { reduction since 2007) }\end{array}$ & $\begin{array}{l}\text { Future reductions will include eliminating additional } \\
\text { OTC and repairing leaks in the water distribution } \\
\text { system. Fig. } 5.9 \text { shows reductions since } 2007 \text { and } \\
\text { expected progress through } 2020\end{array}$ \\
\hline 4.2 & $\begin{array}{l}20 \% \text { water consumption reduction of ILA } \\
\text { water by FY } 2020 \text { from a FY } 2010 \text { baseline }\end{array}$ & No ILA water is used by UT-Battelle. & Not applicable \\
\hline \multicolumn{4}{|c|}{ Goal 5: Pollution Prevention and Waste Reduction } \\
\hline 5.1 & $\begin{array}{l}\text { Divert at least } 50 \% \text { of nonhazardous solid } \\
\text { waste, excluding construction and } \\
\text { demolition debris, by FY } 2015\end{array}$ & $\begin{array}{l}\text { A 34\% diversion rate was achieved in FY 2013. While } \\
\text { less than the target, this represents a significant } \\
\text { improvement in the past year }\end{array}$ & $\begin{array}{l}\text { Continue initiatives to reduce the amount of material } \\
\text { going to the landfill }\end{array}$ \\
\hline 5.2 & $\begin{array}{l}\text { Divert at least } 50 \% \text { of construction and } \\
\text { demolition materials and debris by FY } 2015\end{array}$ & $\begin{array}{l}\text { UT-Battelle's diversion rate for construction and } \\
\text { demolition debris for FY } 2013 \text { is } 39 \%\end{array}$ & $\begin{array}{l}\text { Continue process improvements to meet or exceed the } \\
\text { goal. Additional focus will be placed on segregation of } \\
\text { waste }\end{array}$ \\
\hline
\end{tabular}




\begin{tabular}{|c|c|c|c|c|c|}
\hline $\begin{array}{l}\text { SC/SSPP/ } \\
\text { OMB Goal }\end{array}$ & \multicolumn{2}{|l|}{ DOE Goal } & \multicolumn{2}{|l|}{$\begin{array}{l}\text { Performance Status through } \\
\text { FY } 2013 \\
\end{array}$} & Planned Actions and Contributions \\
\hline \multicolumn{6}{|c|}{ Goal 6: Sustainable Acquisition } \\
\hline 6.1 & \multicolumn{2}{|c|}{$\begin{array}{l}\text { Procurements meet requirements by } \\
\text { including necessary provisions and clauses } \\
\text { (Sustainable Procurements/Biobased } \\
\text { Procurements) }\end{array}$} & \multicolumn{2}{|c|}{$\begin{array}{l}100 \% \text { of procurement transactions in FY } 2013 \\
\text { (excluding purchase card transactions) contained terms } \\
\text { and conditions that invoke requirements for sustainable } \\
\text { acquisition } \\
\text { Goal 7: Electronic Stewardship and Data Centers }\end{array}$} & $\begin{array}{l}\text { Procurement transactions will continue to include terms } \\
\text { stipulating sustainable acquisition requirement }\end{array}$ \\
\hline 7.1 & \multicolumn{2}{|c|}{$\begin{array}{l}\text { All data centers are metered to measure } \\
\text { monthly PUE by FY } 2015 \text { ( } 2013 \text { target: } \\
80 \%)\end{array}$} & \multicolumn{2}{|c|}{ All existing data center equipment is metered } & $\begin{array}{l}\text { Plans are being developed for adding meters in the } \\
5800 \text { Chiller Plant }\end{array}$ \\
\hline 7.2 & \multicolumn{2}{|c|}{$\begin{array}{l}\text { Maximum annual weighted average PUE of } \\
1.4 \text { by FY } 2015 \text { (2013 target: 1.60). }\end{array}$} & \multicolumn{2}{|c|}{$\begin{array}{l}\text { The calculated PUE value at the end of FY } 2013 \text { was } \\
1.29 \text { for the MRF data center and } 1.26 \text { for the CSB data } \\
\text { center }\end{array}$} & $\begin{array}{l}\text { Automated real-time PUE calculation for all data } \\
\text { centers to be in place in FY 2014. Efforts to provide } \\
\text { monthly and annual PUE calculations will continue }\end{array}$ \\
\hline 7.3 & \multicolumn{2}{|c|}{$\begin{array}{l}\text { Electronic Stewardship- } 100 \% \text { of eligible } \\
\text { equipment with power management } \\
\text { implemented and in use by FY } 2012\end{array}$} & \multicolumn{2}{|c|}{$\begin{array}{l}100 \% \text { of the eligible PCs, laptops, and monitors are } \\
\text { being actively power-managed }\end{array}$} & $\begin{array}{l}\text { Continue to ensure all eligible computing equipment is } \\
\text { power-managed }\end{array}$ \\
\hline \multicolumn{6}{|c|}{ Goal 8: Renewable Energy } \\
\hline 8.1 & \multicolumn{2}{|c|}{$\begin{array}{l}20 \% \text { of annual electricity consumption from } \\
\text { renewable sources by FY } 2020(2013 \\
\text { target: } 7.5 \%)\end{array}$} & \multicolumn{2}{|c|}{$\begin{array}{l}\text { UT-Battelle produced on-site renewable electricity of } \\
\text { less than } 0.024 \% \text { of consumption and purchased a small } \\
\text { amount of green power from TVA. In addition, a } \\
\text { number of local (TVA) and marketplace REC purchases } \\
\text { resulted in a total of } 57,558 \mathrm{MWh} \text { of renewable } \\
\text { attributes, exceeding the } 7.5 \% \text { FY } 2013 \text { goal at } 10.02 \%\end{array}$} & $\begin{array}{l}\text { Annual REC purchases will permit UT-Battelle to meet } \\
\text { the goal until additional cost-effective on-site } \\
\text { generation is implemented }\end{array}$ \\
\hline \multicolumn{6}{|c|}{$\begin{array}{l}\text { Abbreviations } \\
\end{array}$} \\
\hline \multicolumn{2}{|c|}{$\mathrm{AFV}=$ alternative fuel vehicle } & \multicolumn{2}{|c|}{ GPs $=$ guiding principles } & \multicolumn{2}{|c|}{ ORNL $=$ Oak Ridge National Laboratory } \\
\hline \multicolumn{2}{|c|}{ Btu $=$ British thermal unit } & \multicolumn{2}{|c|}{$\mathrm{gsf}=$ gross square feet } & \multicolumn{2}{|c|}{$\mathrm{OTC}=$ once-through-cooling } \\
\hline \multirow{2}{*}{\multicolumn{2}{|c|}{$\begin{array}{l}\mathrm{CO}_{2} \mathrm{e}=\text { carbon dioxide equivalent } \\
\mathrm{CSB}=\text { Computational Science Building }\end{array}$}} & \multirow{2}{*}{\multicolumn{2}{|c|}{ HPSB $=$ High Performance Sustainable Buildings }} & \multicolumn{2}{|c|}{$\mathrm{PC}=$ personal computer } \\
\hline & & \multirow{2}{*}{\multicolumn{2}{|c|}{$\begin{array}{l}\text { ILA = industrial, landscaping, and agricultural } \\
\text { LEED = Leadership in Energy and Environmental Design }\end{array}$}} & \multicolumn{2}{|c|}{ PUE $=$ power usage effectiveness } \\
\hline \multicolumn{2}{|c|}{ DOE = US Department of Energy } & & & \multicolumn{2}{|r|}{$\mathrm{RE}=$ renewable energy } \\
\hline \multicolumn{2}{|c|}{$\mathrm{ECM}=$ energy conservation measure } & \multicolumn{2}{|c|}{ LSV $=$ low-speed vehicle } & \multirow{2}{*}{\multicolumn{2}{|c|}{$\begin{array}{l}\mathrm{REC}=\text { renewable energy credit (also, renewable energy certificate) } \\
\mathrm{SC}=\text { Sustainable Campus }(\mathrm{ORNL})\end{array}$}} \\
\hline \multirow{2}{*}{\multicolumn{2}{|c|}{$\begin{array}{l}\text { EISA }=\text { Energy Independence and Security Act } \\
\text { ESPC }=\text { Energy Savings Performance Contract }\end{array}$}} & \multirow{2}{*}{\multicolumn{2}{|c|}{ MAXLAB = Maximum Energy Efficiency Laboratory }} & & \\
\hline & & & & \multicolumn{2}{|r|}{ SSPP $=$ Strategic Sustainability Performance Plan (DOE) } \\
\hline \multicolumn{2}{|c|}{$\begin{array}{l}\text { FY }=\text { fiscal year } \\
\text { gal }=\text { gallons }\end{array}$} & $\mathrm{MW}=\mathrm{n}$ & negawatt & $\mathrm{T} \& \mathrm{D}=$ & $=$ transmission and distribution \\
\hline gal $=$ gallons & & $\mathrm{MWh}=$ & megawatt-hour & TVA $=$ & $=$ Tennessee Valley Authority \\
\hline $\mathrm{GHG}=$ gree & & $\mathrm{OMB}=$ & Office of Management and Budget & & \\
\hline
\end{tabular}




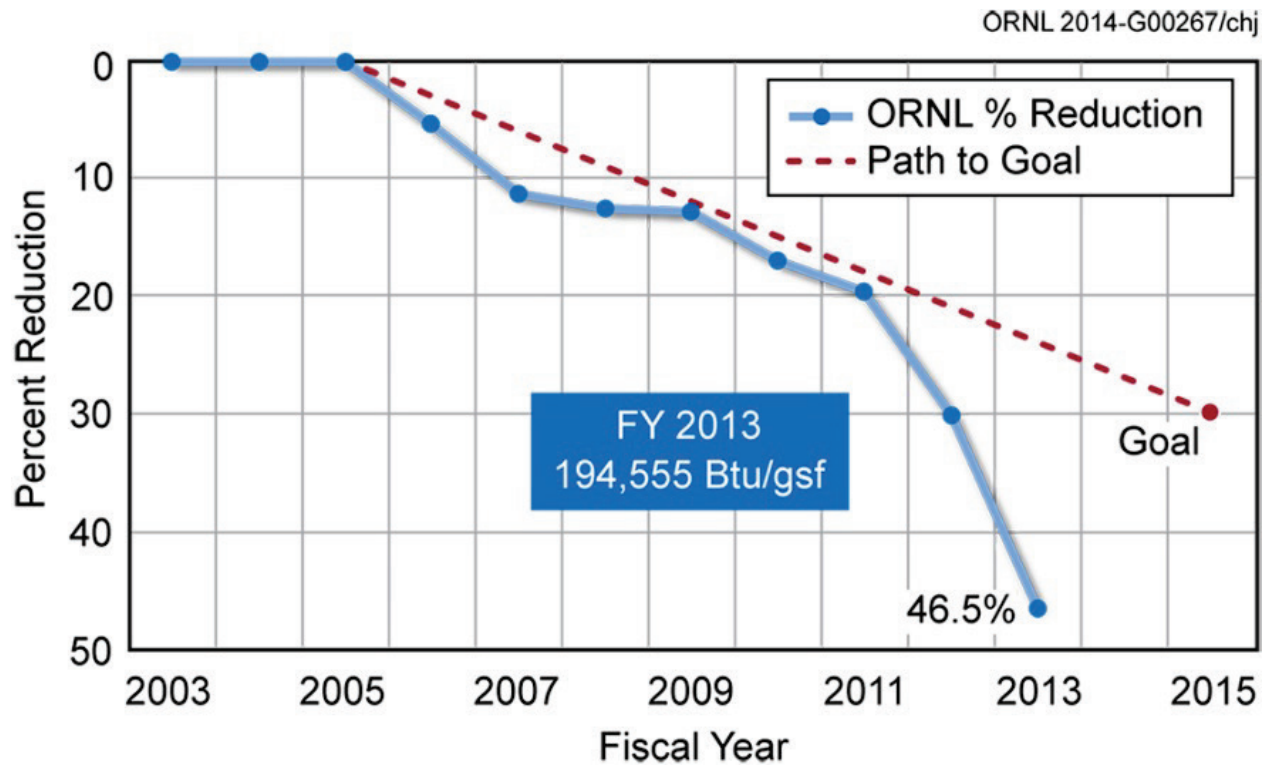

Fig. 5.6. Summary of energy intensity reduction results and progress toward goal ( $30 \%$ reduction), which was met in 2012. (Btu = British thermal unit; gsf = gross square foot.)

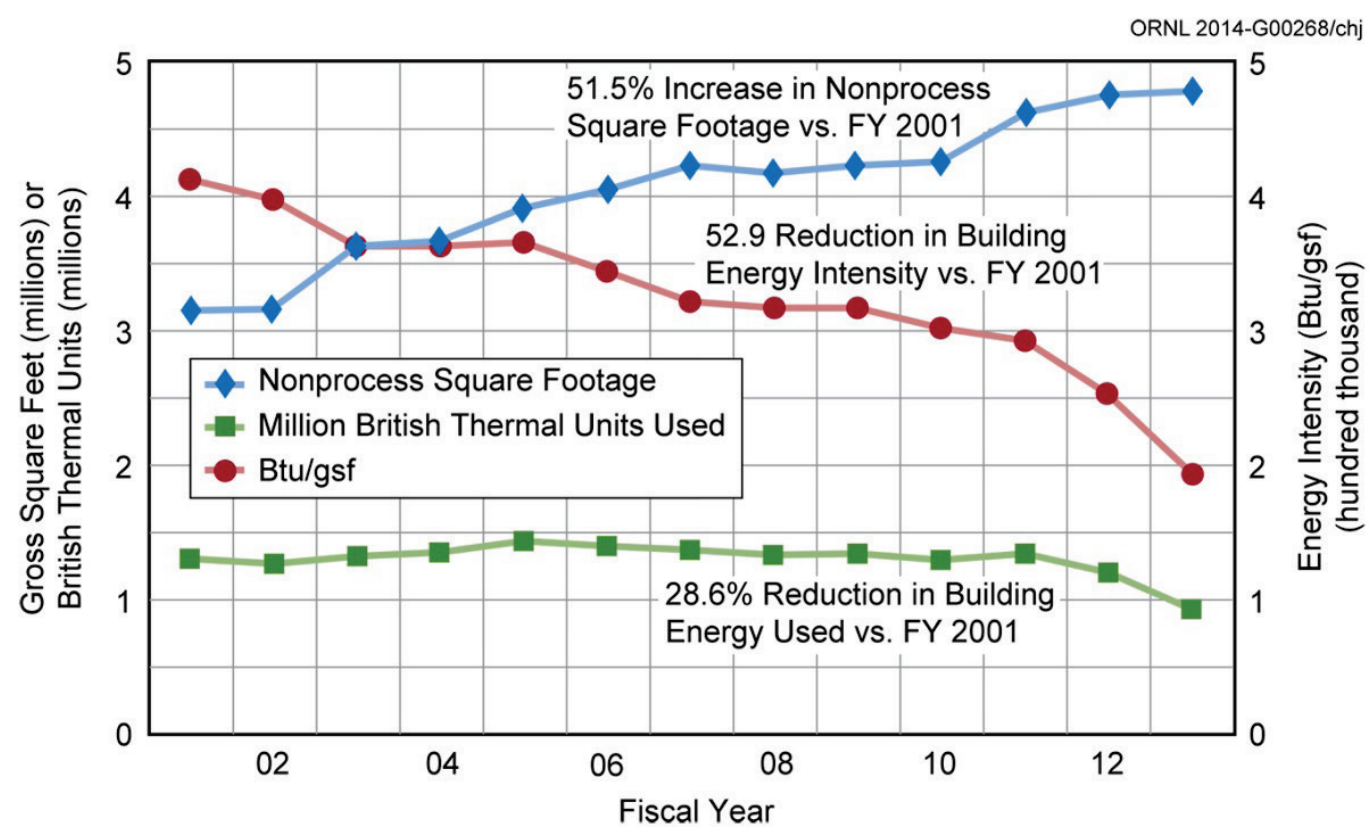

Fig. 5.7. Oak Ridge National Laboratory building energy performance from FY 2001 through FY 2013. 


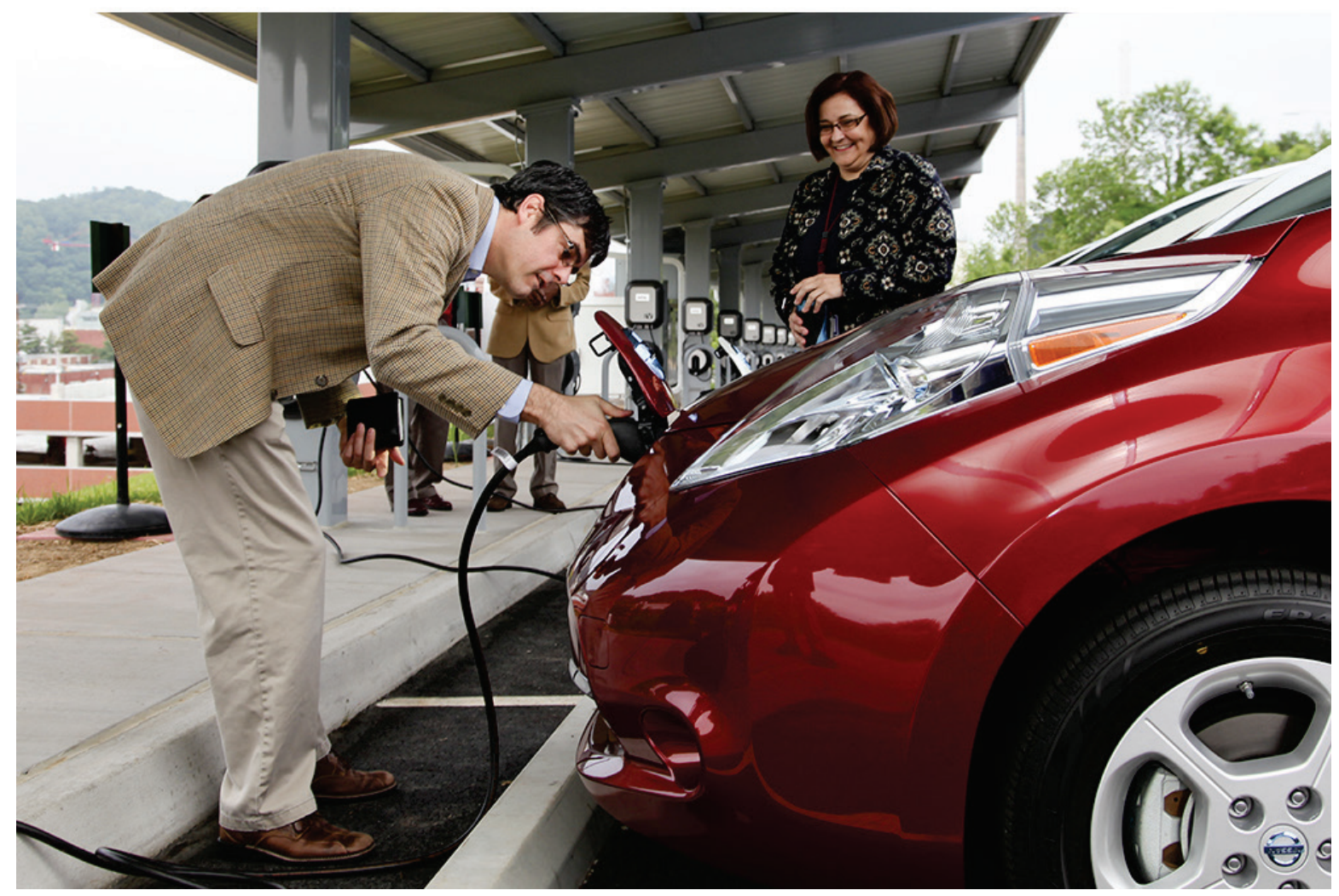

Fig. 5.8. Oak Ridge National Laboratory's solar-assisted electric vehicle charging station.

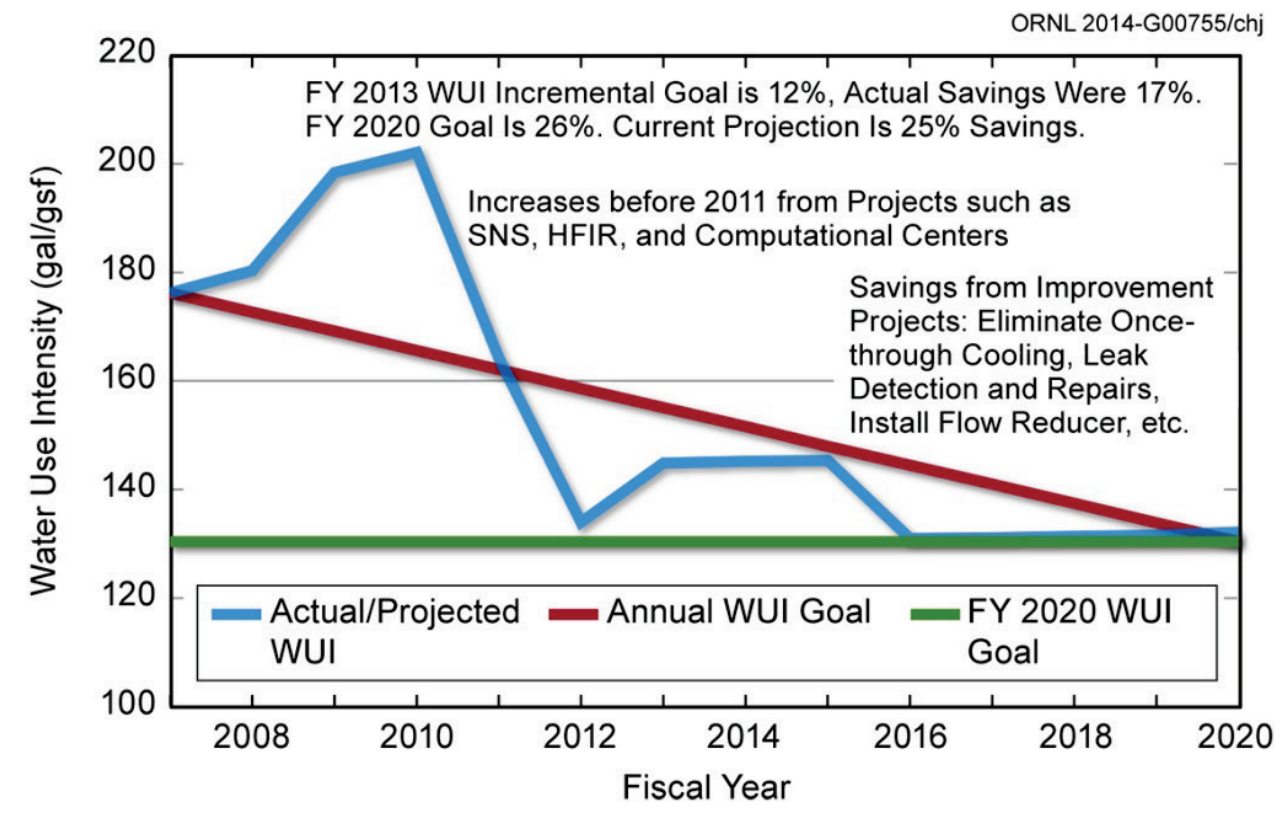

Fig. 5.9. Oak Ridge National Laboratory water use intensity (WUI) FY 2007-FY 2020, including 2020 and incremental DOE goals. 


\subsection{Pollution Prevention and Waste Reduction}

UT-Battelle implemented 42 new pollution prevention projects at ORNL during 2013, eliminating more than 46 million $\mathrm{kg}$ (about 102 million lb) of waste, which included about 11.8 million gal of wastewater. Excluding the wastewater efforts, these projects eliminated about 1.7 million $\mathrm{kg}$ (about 3.7 million $1 \mathrm{~b}$ ) of waste. In total, all of these projects led to cost savings/avoidance of more than $\$ 5.9$ million (including ongoing reuse/recycle projects). In addition to the successful resource conservation and sustainable transportation initiatives discussed previously, source reduction actions such as efforts related to the contracting organization going paperless; resource-efficient supercomputing; and recycling programs for lead, electronics, and C\&D debris were also implemented during 2013 (Fig 5.10). During the year UT-Battelle aggressively supported the recycling program at ORNL with more than 38\% of FY 2013-generated materials being diverted for recycle or beneficial use. Large construction projects incorporated comprehensive project-specific recycling efforts.

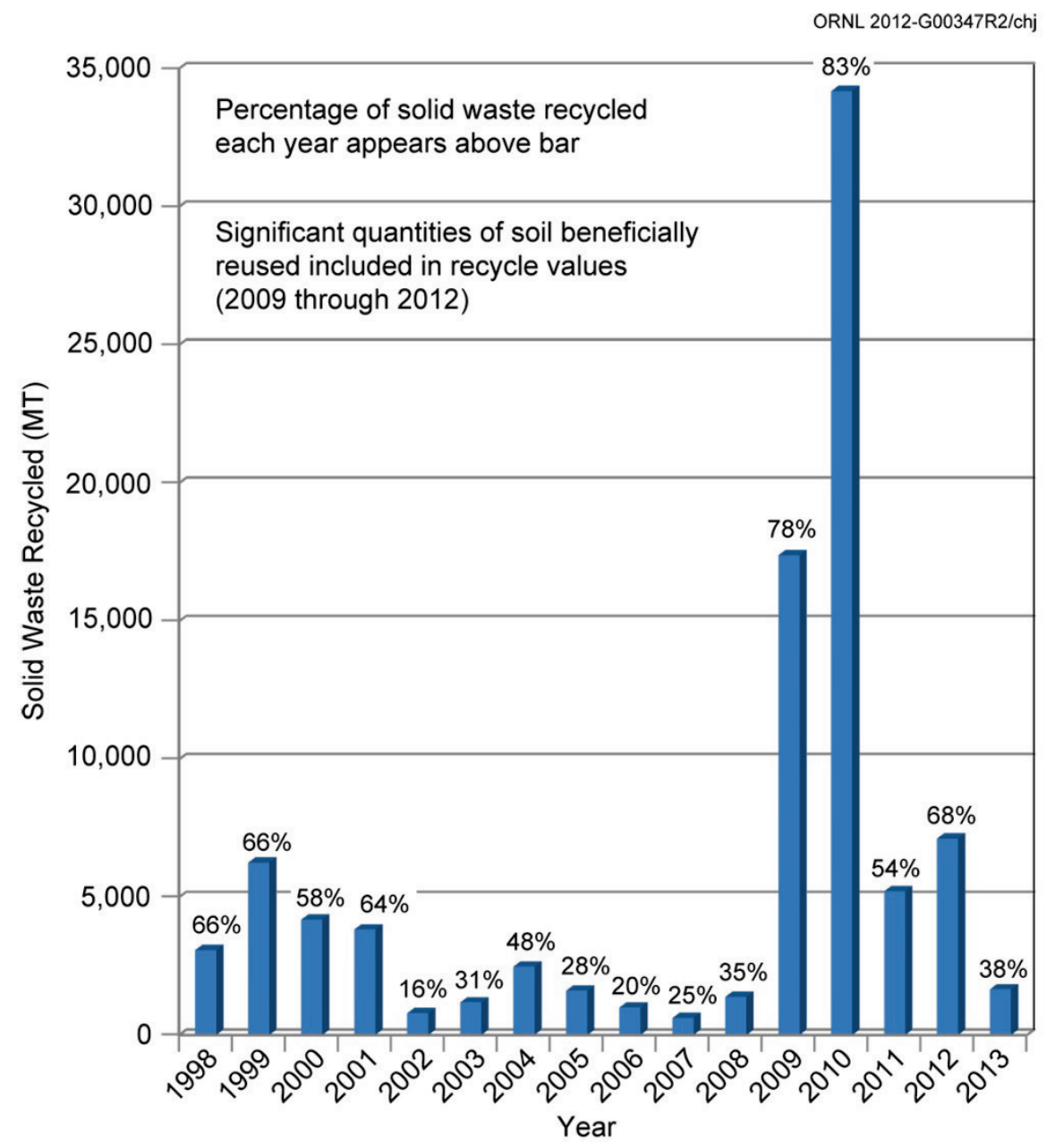

Fig. 5.10. Solid waste recycled at Oak Ridge National Laboratory as a result of recycling programs.

\section{ORNL Site Pollution Prevention/Sustainability Awards}

- Chemical and Materials Sciences Building (CMSB) Award-McCarthy Building Companies, Inc., and UT-Battelle shared a Construction Management Association of America Project Achievement Award for "Buildings, New Construction Project with Constructed Value Less Than \$100 Million." CMSB (Fig. 5.11) cost about $\$ 95$ million and earned a LEED-Gold rating from the U.S. Green Buildings Council. 
- Green Achievers Award-received from GoGreen East Tennessee for participation in the GoGreen.com Business Recognition Program, showcasing the environmental efforts at ORNL and encouraging green business practices throughout the community.

- DOE Vehicle Technologies Office Annual Awardsthree awards received at the 2013 DOE Vehicle Technologies Office Annual Merit Review in recognition of leadership in transitioning reactivity-controlled compression ignition combustion from a single cylinder to a multicylinder engine using biorenewable fuels; exemplary achievements on the Advanced Engine CrossCut Team, U.S. DRIVE Engine Tech Team and 21st

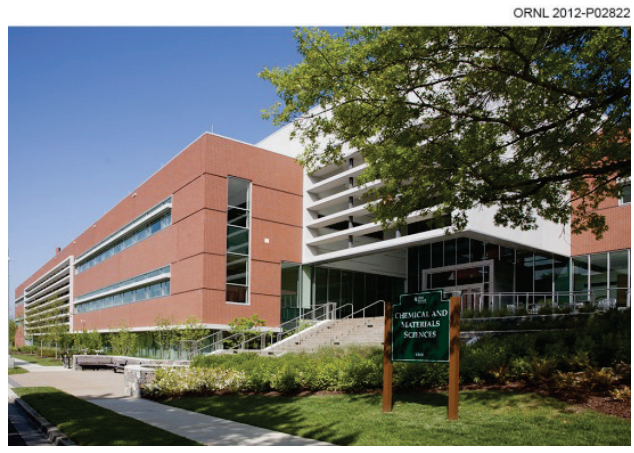

Fig. 5.11. Chemical and Materials Sciences Building. Century Truck; and management of the fueleconomy.gov website.

- 2013 Roane Beautification Award - received from the Roane County Industrial Development Board in recognition of the significant modernization and sustainable campus improvements made at ORNL over the past decade.

- 2013 Federal Energy and Water Management Award-received for UT-Batelle's FY 2012 water resource management efforts that minimized quantity and maximized quality.

- 2013 Tennessee Chamber of Commerce and Industry Air Quality Outstanding Achievement Award (formerly the Air Quality Excellence Award) — received in recognition of the new ORNL Biomass Steam Plant and its impact on air quality.

- 2013 Presidential GreenGov Award - in the "Good Neighbor" category in recognition of recent initiatives with Indian River State College in Florida to create a sustainable campus modeled on the ORNL design and for partnering with the electric vehicles (EVs) charging project in Tennessee to install charging stations across Tennessee.

- 2013 First Place in the Smart Trips Commuter Challenge, Heavyweight Division - awarded based on total number of new participants who signed up for Smart Trips during the challenge, the number of employees who met challenge requirements, and the overall enthusiasm of participants.

- 2013 DOE Sustainability Award - received for championing sustainable pollution prevention efforts at ORNL.

- 2013 DOE Sustainability Award - awarded for the sustainability success of the Biomass Steam Plant at ORNL.

- 2013 Federal Laboratory Consortium (FLC) Excellence in Technology Transfer and 2013 R\&D 100 Awards - received for excellence in technology transfer for the ClimateMaster Trilogy 40 Q-Mode Geothermal Heat Pump, which was developed by ClimateMaster and UT-Battelle through a cooperative $\mathrm{R} \& \mathrm{D}$ agreement. The water-to-air packaged heat pump provides significantly lower energy costs; reduces peak demand for electricity; and provides environmental benefits, especially through reductions in greenhouse gases and pollutants.

- 2013 FLC Excellence in Technology Transfer and 2013 R\&D 100 Awards-awarded to UT-Battelle and Porous Power Technologies LLC for excellence in technology transfer for the SYMMETRIX HPX-F Nanocomposite Separator for Improved Lithium Ion Battery. SYMMETRIX HPX-F reduces lithium ion battery costs and improves safety through the replacement of polymer separators.

- 2013 BuildingGreen Product Award-received by UT-Battelle and the Fraunhofer Institute for Building Physics, IBP, in Germany for the joint development of a family of PC-based modeling tools (called WUFI for "Wärme und Feuchte Instationär") that calculate heat and moisture transfer in multilayer building components. 


\subsection{Storm Water Management and the Energy Independence and Security Act of 2007}

EISA Section 438 stipulates that the sponsor of any development or redevelopment project involving a federal facility with a footprint exceeding $5,000 \mathrm{ft}^{2}$ shall use site planning, design, construction, and maintenance strategies to maintain or restore, to the maximum extent feasible, the predevelopment hydrology of the property. For the purposes of this provision development or redevelopment is defined as "any action that results in the alteration of the landscape during construction of buildings or other infrastructure such as parking lots, roads, etc. (e.g., grading, removal of vegetation, soil compaction) such that the changes affect runoff volumes, rates, temperature, and duration of flow. Examples of projects that would fall under 'redevelopment' include structures or other infrastructure that are being reconstructed or replaced and the landscape is altered. Typical patching or resurfacing of parking lots or other travel areas would not fall under this requirement."

Strategic plans for demolition and renovation of old facilities and construction of new facilities at ORNL incorporate green infrastructure and low impact development (GI/LID) practices to infiltrate, evapotranspire, and/or harvest and use storm water on-site to the maximum extent feasible. GI/LID approaches and technologies have been used to mimic the natural hydrologic cycle processes of infiltration, evapotranspiration, and use. GI/LID practices that have been incorporated at ORNL include the following.

- Trees and tree boxes

- Rain gardens

- Vegetated swales

- Pocket wetlands

- Infiltration planters

- Porous and permeable pavements

- Vegetated median strips

- Reforestation and revegetation

- Protection of riparian buffers and floodplains

- Retention ponds

- Water reuse (e.g., tanks in restrooms to collect water for reuse in irrigation)

At ORNL, a three step approach is used to evaluate and satisfy the requirements of EISA Section 438. Evaluation occurs

1. within the project boundaries. If the necessary volume of runoff cannot be infiltrated or retained onsite, then

2. on land immediately adjacent to the project boundaries. If the necessary volume of runoff cannot be infiltrated or retained on land immediately adjacent to the project boundaries, then

3. within the same valley or ridge area (e.g., within Bethel Valley if the project is within Bethel Valley; within Melton Valley if the project is within Melton Valley).

In addition to the GI/LID practices mentioned above, the projects may remove impervious areas and reestablish pervious areas to allow infiltration or evapotranspiration to occur.

In 2013, EISA requirements were not applicable to any of the construction projects started during the year.

\subsubsection{Emergency Preparedness and Response}

The Emergency Management System supplies the resources and capabilities to provide emergency preparedness services and, in the event of an accident, emergency response services. Emergency preparedness personnel perform hazard surveys and hazard assessments to identify potential emergency situations. Procedures and plans have been developed to prepare for and respond to a wide variety of potential emergency situations. Training is provided to ensure appropriate response and performance during emergency events. Frequent exercises and drills are scheduled to ensure the effective performance of the procedures and plans. An environmental subject matter expert is a member of the emergency 
response team and participates in drills and exercises to ensure that environmental requirements are met and that environmental impacts from the event (and the response) are mitigated.

\subsubsection{Checking}

\subsection{Monitoring and Measurement}

UT-Battelle has developed monitoring and measurement processes for each operation or activity that can have a significant impact on the environment. Several SBMS subject areas include requirements for managers to establish performance objectives, indicators, and targets; conduct performance assessments to collect data and monitor progress; and evaluate the data to identify strengths and weaknesses in performance and areas for improvement.

\subsection{Environmental Management System Assessments}

Several methods are used by UT-Battelle to evaluate compliance with legal and other environmental requirements. Most of the compliance evaluation activities are implemented through EMS or are a part of line-organization assessment activities. Should a nonconformance be identified, the ORNL issues management process requires that any regulatory or management system nonconformance be reviewed for cause and corrective and/or preventive actions developed. These actions are then implemented and tracked to completion.

SBMS requires organizations to perform periodic environmental assessments that cover both legal and other requirements and requires management system owners to conduct annual self-assessments of their systems to ensure the systems are effective and are continually improving.

UT-Battelle also uses the results from numerous external compliance inspections conducted by regulators to verify compliance with requirements. In addition to regulatory compliance assessments, there are internal and external EMS assessments performed annually to ensure the UT-Battelle EMS continues to conform to ISO requirements. In 2013, an internal audit and an external surveillance audit were conducted and verified that EMS continued to conform to ISO 14001:2004. In addition to verifying conformance, these management system assessments also identify continual improvement opportunities.

\subsubsection{Environmental Management System for the Transuranic Waste Processing Center}

The WAI EMS for activities at TWPC was registered to the ISO 14001:2004 Standard by NSF-ISR in May 2008 and is integrated with ISMS to provide a unified strategy for the management of resources, the control and reduction of risks, and the establishment and achievement of the organization's ES\&H goals. EMS and ISMS are incorporated into the Integrated Safety Management System Description (BJC 2009), and a "plan-do-check-act" cycle is used for continual improvement in both. NSF-ISR conducted a recertification audit in May 2011, and no nonconformances or issues were identified and several significant practices were noted.

The WAI EMS incorporates applicable environmental laws, DOE orders, and other requirements (i.e., directives and federal, state, and local laws) through WAI's requirements management document (WAI 2012) and regulatory management plan (WAI 2012a), which dictate how the various requirements are incorporated into subject area documents (procedures and guidelines). EMS assists line organizations in identifying and addressing environmental issues.

Environmental aspects are elements of an organization's activities, products, or services that can interact with the environment. WAI has identified environmental aspects associated with TWPC activities, products, and services at both the project and activity level and has identified waste management activities, air emissions, storm water contamination, pollution prevention, habitat alteration, and energy consumption as potentially having significant environmental impacts. Activities that are relative to any of those aspects are carefully controlled to minimize or eliminate impacts to the environment.

WAI has established and implemented objectives and measurable performance indicators for the targets associated with the identified significant impacts. 
The pollution prevention programs at TWPC involve waste reduction efforts and implementation of sustainable practices that reduce the environmental impacts of the activities conducted at TWPC. The WAI EMS establishes annual goals and targets to reduce the impact of TWPC's environmental aspects.

WAI has a well-established recycling program at TWPC and continues to identify new material-recycling streams and to expand the types of materials included in the program. Currently, recycle streams at TWPC range from office materials such as paper, aluminum cans, plastic drinking bottles, Styrofoam cups, alkaline batteries, and toner cartridges to operations-oriented materials such as scrap metal, cardboard, construction debris, and batteries. WAI has established a "single stream" recycling program that allows the mixing of multiple types of recyclables that increases the population of recyclable items and improves compliance. A construction debris recycling program began in September 2011 and has resulted in about 93 tons being diverted from the landfill to date.

"Environmentally preferable purchasing" is a term used to describe an organization's policy to reduce packaging and to purchase products made with recycled material or biobased materials and other environmentally friendly products. WAI ensures environmentally preferable products are purchased by incorporating the green procurement requirements in WAI procurement procedures.

Several methods are used by WAI to evaluate compliance with legal and other requirements. Most of these compliance evaluation activities are implemented by internal and external environmental and management assessment activities and routine reporting and reviews. WAI also uses the results from numerous external compliance inspections conducted by regulators and contractors to verify compliance with requirements.

\subsection{Compliance Programs and Status}

During 2013 UT-Battelle, UCOR, WAI, Isotek, and SEC operations were conducted in compliance with contractual and regulatory environmental requirements.

There were no NOVs or penalties issued by the regulatory agencies. Table 5.2 presents a summary of environmental audits conducted at ORNL in 2013.

Table 5.2. Summary of regulatory environmental audits, evaluations, inspections, and assessments conducted at Oak Ridge National Laboratory, 2013

\begin{tabular}{lllc}
\hline \multicolumn{1}{c}{ Date } & \multicolumn{1}{c}{ Reviewer } & \multicolumn{1}{c}{ Subject } & Issues \\
\hline February 19 & City of Oak Ridge & CFTF Wastewater Inspection & 0 \\
June 10-11 & TDEC & Annual RCRA Inspection for ORNL & 0 \\
August 6 & Knox County & Annual CAA Inspection for NTRC & 0 \\
August 9 & TDEC & Annual CAA Inspection for ORNL and CFTF & 0 \\
September 26-30 & TDEC & NPDES Compliance Evaluation Inspection & 0 \\
September 30 & City of Oak Ridge & CFTF Wastewater Inspection & 0 \\
October 23 & TDEC & Annual TWPC CAA Inspection & 0 \\
November 4-5 & TDEC & Annual RCRA Inspection of ORNL at Y-12 Facilities & 0 \\
\hline
\end{tabular}

$\mathrm{CAA}=$ Clean Air Act

$\mathrm{CFTF}=$ Carbon Fiber Technology Facility

ORNL $=$ Oak Ridge National Laboratory

NPDES = National Pollutant Discharge Elimination System

NTRC $=$ National Transportation Research Center
Abbreviations

RCRA $=$ Resource Conservation and Recovery Act

$\mathrm{TDEC}=$ Tennessee Department of Environment and Conservation

TWPC $=$ Transuranic Waste Processing Center

Y-12 = Y-12 National Security Complex

No RCRA Subtitle D disposal facilities are operated at ORNL. Industrial solid waste is sent to the Y-12 Complex industrial solid waste disposal landfills. ORNL complies with the requirements by meeting the waste acceptance criteria at the Y-12 facilities.

The following discussions summarize the major environmental programs and activities carried out at ORNL during 2013 and provide an overview of the compliance status for the year.

\subsubsection{Environmental Permits}

Table 5.3 contains a list of environmental permits that were effective in 2013 at ORNL. 
Table 5.3. Oak Ridge National Laboratory environmental permits, 2013

\begin{tabular}{|c|c|c|c|c|c|c|c|}
\hline $\begin{array}{c}\text { Regulatory } \\
\text { driver }\end{array}$ & Permit title/description & $\begin{array}{c}\text { Permit } \\
\text { number }\end{array}$ & $\begin{array}{l}\text { Issue } \\
\text { date }\end{array}$ & $\begin{array}{l}\text { Expiration } \\
\text { date }\end{array}$ & Owner & Operator & $\begin{array}{l}\text { Responsible } \\
\text { contractor }\end{array}$ \\
\hline CAA & Title V Operating Permit, ORNL & 562765 & 08-16-11 & $08-15-16$ & DOE & UT-B & UT-B \\
\hline CAA & Construction Permit, CFTF facility & $965013 \mathrm{P}$ & $03-27-12$ & $11-01-14$ & DOE & UT-B & UT-B \\
\hline CAA & Construction Permit, CFTF emergency generator & $967180 \mathrm{P}$ & $03 / 07 / 14$ & 03-06-15 & DOE & UT-B & UT-B \\
\hline CAA & Operating Permit, NTRC & $0941-05^{a}$ & $10-23-12$ & Annually $^{b}$ & DOE & UT-B & UT-B \\
\hline CAA & Operating Permit, WAI & $063331 \mathrm{P}$ & $03-07-12$ & $03-01-22$ & DOE & WAI & WAI \\
\hline CAA & Title V Operating Permit, ORNL & 562860 & $07-16-10$ & $07-15-15$ & DOE & UCOR & UCOR \\
\hline CAA & Construction Permit, WAI emergency generator & $967178 \mathrm{P}$ & $07-01-13$ & $07-01-14$ & DOE & DOE & WAI \\
\hline CAA & Title V Operating Permit, Isotek & 560898 & 07-27-09 & $07-26-14$ & DOE & Isotek & Isotek \\
\hline CWA & $\begin{array}{l}\text { ORNL NPDES Permit (ORNL sitewide wastewater discharge } \\
\text { permit) }\end{array}$ & TN0002941 & 07-01-08 & $07-30-13$ & DOE & DOE & $\begin{array}{l}\text { UT-B, UCOR, } \\
\text { WAI }\end{array}$ \\
\hline CWA & $\begin{array}{l}\text { Tennessee General (NPDES) Permit TNR10-0000, Storm Water } \\
\text { Discharges from Construction Activities-Spallation Neutron } \\
\text { Source }\end{array}$ & TNR139975 & $10-10-00$ & $05-23-16$ & DOE & DOE & UT-B \\
\hline CWA & $\begin{array}{l}\text { Tennessee General (NPDES) Permit TNR10-0000, Storm Water } \\
\text { Discharges from Construction Activities-ORNL } \\
\text { Modernization of Laboratory Facilities }\end{array}$ & TNR133485 & 05-29-09 & $05-23-16$ & DOE & DOE & UT-B \\
\hline CWA & $\begin{array}{l}\text { Tennessee Storm Water Multi-Sector General Permit for } \\
\text { Industrial Activities for Storm Water Discharges Associated } \\
\text { with Construction Activity (CGP)—0975 Water Reservoir }\end{array}$ & TNR133727 & $07-08-10$ & $05-14-14$ & DOE & DOE & UT-B \\
\hline CWA & $\begin{array}{l}\text { Tennessee General (NPDES) Permit TNR10-0000, Storm Water } \\
\text { Discharges from Construction Activities-ORNL Melton } \\
\text { Valley Access Road and Parking Lot }\end{array}$ & TNR133893 & $08-30-11$ & $05-23-16$ & DOE & DOE & UT-B \\
\hline CWA & $\begin{array}{l}\text { Tennessee General (NPDES) Permit TNR10-0000, Storm Water } \\
\text { Discharges from Construction Activities-Biomass Gasification } \\
\text { System Project }\end{array}$ & TNR133428 & 06-09-10 & $05-23-16$ & DOE & DOE & JCI \\
\hline
\end{tabular}


Table 5.3. (continued)

\begin{tabular}{|c|c|c|c|c|c|c|c|}
\hline $\begin{array}{l}\text { Regulatory } \\
\text { driver }\end{array}$ & Permit title/description & $\begin{array}{l}\text { Permit } \\
\text { number }\end{array}$ & $\begin{array}{l}\text { Issue } \\
\text { date }\end{array}$ & $\begin{array}{l}\text { Expiration } \\
\text { date }\end{array}$ & Owner & Operator & $\begin{array}{l}\text { Responsible } \\
\text { contractor }\end{array}$ \\
\hline CWA & $\begin{array}{l}\text { Tennessee General (NPDES) Permit TNR10-1000, Storm Water } \\
\text { Discharges from Construction Activities-Maximum Energy } \\
\text { Efficiency Building Research Laboratory }\end{array}$ & TNR133932 & $05-24-11$ & $05-23-16$ & DOE & DOE & UT-B \\
\hline CWA & $\begin{array}{l}\text { Industrial and Commercial User Waste Water Discharge Permit } \\
\text { (Carbon Fiber Technology Facility, located near ETTP) }\end{array}$ & $1-12$ & $10-15-12$ & $03-31-15$ & UT-B & UT-B & UT-B \\
\hline CWA & $\begin{array}{l}\text { Tennessee General (NPDES) Permit TNR10-0000, Storm Water } \\
\text { Discharges from Construction Activities-Pro2Serve National } \\
\text { Security Engineering Center }\end{array}$ & & $10-06$ & NA & DOE & DOE & CROET \\
\hline CWA & TN Operating Permit (sewage) & SOP-02056 & $02-01-13$ & $12-31-17$ & DOE & WAI & WAI \\
\hline CWA & $\begin{array}{l}\text { Tennessee General Permit TNR10-0000, Storm Water } \\
\text { Discharges from Construction Activity-Site Expansion Project }\end{array}$ & TNR 133560 & 08-31-09 & NA & DOE & WAI & WAI \\
\hline CWA & $\begin{array}{l}\text { Aquatic Resource Alteration Permit for Temporary Disturbance } \\
\text { to } 0.02 \text { Acres of Wetland at Melton Branch Circle }\end{array}$ & $\begin{array}{l}\text { ARAP } \\
\text { NR1203.123 }\end{array}$ & $09-13-12$ & $09-13-13$ & DOE & UT-B & UT-B \\
\hline RCRA & Hazardous Waste Transporter Permit & TN1890090003 & $12-21-12$ & $01-31-14$ & DOE & DOE & UT-B, UCOR \\
\hline RCRA & Hazardous Waste Corrective Action Permit & TNHW-121 & $09-28-04$ & $09-28-14$ & DOE & DOE/all ${ }^{c}$ & DOE/all \\
\hline RCRA & Hazardous Waste Container Storage and Treatment Units & TNHW-134 & 09-26-08 & $09-26-18$ & DOE & DOE/UT-B & UT-B \\
\hline RCRA & Hazardous Waste Container Storage and Treatment Units & TNHW-145 & 02-03-10 & 02-03-20 & DOE & $\begin{array}{c}\mathrm{DOE} / \\
\mathrm{UCOR} / \mathrm{WAI}\end{array}$ & UCOR/WAI \\
\hline
\end{tabular}

${ }^{a}$ Permit issued by Knox County Department of Air Quality Management.

${ }^{b}$ Continued construction/operation under an expired permit is allowed under air pollution control regulations when timely renewal or construction permit applications are submitted.

${ }^{c} \mathrm{DOE}$ and Oak Ridge Reservation contractors are co-operators of hazardous waste permits.

\section{Abbreviations}

$\mathrm{ARAP}=$ Aquatic Resource Alteration Permit

$\mathrm{CAA}=$ Clean Air Act

CFTF $=$ Carbon Fiber Technology Facility

CGP $=$ Construction General Permit

CROET $=$ Community Reuse Organization of East Tennessee

$\mathrm{CWA}=$ Clean Water Act

DOE $=$ US Department of Energy

ETTP $=$ East Tennessee Technology Park

Isotek $=$ Isotek Systems LLC

NPDES $=$ National Pollutant Discharge Elimination System

NTRC $=$ National Transportation Research Center

ORNL $=$ Oak Ridge National Laboratory

RCRA $=$ Resource Conservation and Recovery Act

UCOR $=$ URS $\mid$ CH2M Hill Oak Ridge LLC

UT-B $=$ UT-Battelle

$\mathrm{WAI}=$ Wastren Advantage, Inc. 


\subsubsection{National Environmental Policy Act/National Historic Preservation Act}

NEPA provides a means to evaluate the potential environmental impact of proposed federal activities and to examine alternatives to those actions. UT-Battelle, WAI, and Isotek maintain compliance with NEPA through the use of site-level procedures and program descriptions that establish effective and responsive communications with program managers and project engineers to establish NEPA as a key consideration in the formative stages of project planning. Table 5.4 summarizes NEPA activities conducted at ORNL during 2013.

Table 5.4. National Environmental Policy Act (NEPA) activities, 2013

\begin{tabular}{|c|c|}
\hline Types of NEPA documentation & $\begin{array}{c}\text { Number of } \\
\text { instances }\end{array}$ \\
\hline \multicolumn{2}{|l|}{ Oak Ridge National Laboratory } \\
\hline Approved under general actions ${ }^{a}$ or generic CX determinations & 45 \\
\hline New generic $\mathrm{CXs}^{\mathrm{b}}$ for research and development & 2 \\
\hline Project-specific $\mathrm{CX}^{\mathrm{b}}$ determinations for demolition activities & 2 \\
\hline \multicolumn{2}{|l|}{ Wastren Advantage, Inc. } \\
\hline Approved under general actions ${ }^{a}$ or generic CX determinations & 0 \\
\hline
\end{tabular}

Abbreviations
$\mathrm{CX}=$ categorical exclusion

During 2013, UT-Battelle and WAI continued to operate under site-level procedures that provide requirements for project reviews and NEPA compliance. These procedures call for a review of each proposed project, activity, or facility to determine the potential for impacts to the environment. To streamline the NEPA review and documentation process, the DOE Oak Ridge Office has approved generic CX determinations that cover proposed bench- and pilot-scale research activities and generic CXs that cover proposed nonresearch activities (e.g., maintenance activities, facilities upgrades, personnel safety enhancements). A CX is one of a category of actions defined in 40 CFR 1508.4 that does not individually or cumulatively have a significant effect on the human environment and for which neither an environmental assessment nor an environmental impact statement is normally required.

UT-Battelle uses SBMS as the delivery system to manage and control work at ORNL. NEPA is an integral part of SBMS, and a UT-Battelle NEPA coordinator works with principal investigators, environmental compliance representatives, and environmental protection officers within each UT-Battelle division to determine appropriate NEPA decisions.

Compliance with NHPA at ORNL is achieved and maintained in conjunction with NEPA compliance. The scope of proposed actions is reviewed in accordance with the ORR cultural resource management plan (Souza et al. 2001).

\subsubsection{Clean Air Act Compliance Status}

CAA, passed in 1970 and amended in 1977 and 1990, forms the basis for the national air pollution control effort. This legislation established comprehensive federal and state regulations to limit air emissions and includes four major regulatory programs: the National Ambient Air Quality Standards, State Implementation Plans, NSPSs, and NESHAPs. Airborne discharges from DOE Oak Ridge facilities, both radioactive and nonradioactive, are subject to regulation by EPA and the TDEC Division of Air Pollution Control. The first sitewide operating air permit was issued in 2004. To demonstrate compliance with the Title V Major Source Operating Permits, more than 1,500 data points are collected and reported 
every year. In addition, $\mathrm{NO}_{\mathrm{X}}$, a criteria pollutant, is monitored continuously at one location; samples are collected continuously from 9 major radionuclide sources and periodically from 15 minor radionuclide sources; and there are numerous other demonstrations of compliance with generally applicable air quality protection requirements (asbestos, stratospheric ozone, etc.). There are also two off-site CAA permits for facilities maintained and operated by UT-Battelle: a minor source operating permit issued by Knox County Air Quality Management for NTRC and a Title V Construction Permit issued by TDEC for CFTF. In summary, there were no UT-Battelle, Isotek, or WAI CAA violations or exceedances in 2013.

Section 5.4 provides detailed information on 2013 activities conducted by UT-Battelle in support of CAA.

\subsubsection{Clean Water Act Compliance Status}

The objective of CWA is to restore, maintain, and protect the integrity of the nation's waters. This act serves as the basis for comprehensive federal and state programs to protect the nation's waters from pollutants. (See Appendix C for water quality reference standards.) One of the strategies developed to achieve the goals of CWA was EPA's establishment of limits on specific pollutants allowed to be discharged to US waters by municipal STPs and industrial facilities. EPA established the NPDES permitting program to regulate compliance with pollutant limitations. The program was designed to protect surface waters by limiting effluent discharges into streams, reservoirs, wetlands, and other surface waters. EPA has delegated authority for implementation and enforcement of the NPDES program to the State of Tennessee.

In 2013, compliance with the ORNL NPDES permit was determined by about 2,300 laboratory analyses and field measurements. The NPDES permit limit compliance rate for all discharge points for 2013 was $100 \%$, with no measurements exceeding numeric NPDES permit limits. However, there were three fish kills at ORNL in 2013. They occurred on July 31, 2013; October 4, 2013; and October 6, 2013. Each was attributed to inadequate dechlorination of cooling water discharges. Mechanical and administrative improvements have been made to guard against future occurrences. Section 5.5 contains detailed information on the monitoring programs and activities carried out in 2013 by UT-Battelle in support of CWA.

\subsubsection{Safe Drinking Water Act Compliance Status}

ORNL's water distribution system is designated as a "nontransient, noncommunity" water system by TDEC's Bureau of Environment Division of Water Supply. TDEC's Bureau of Environment Division of Water Supply rules, Chapter 0400-45-01, Public Water Systems (TDEC 2012), sets limits for biological contaminants and for chemical activities and chemical contaminants. TDEC requires sampling for the following constituents for compliance with state and federal regulations:

- residual chlorine,

- bacterial (total coliform)

- disinfectant by-product (trihalomethanes and haloacetic acids), and

- lead and copper (required once every 3 years)

The city of Oak Ridge supplies potable water to the ORNL water distribution system and meets all regulatory requirements for drinking water. The water treatment plant, located on ORR, north of the Y-12 Complex, is owned and operated by the City of Oak Ridge.

In 2013, sampling results for ORNL's water system residual chlorine levels, bacterial constituents, and disinfectant by-products were all within acceptable limits. Sampling for lead and copper was conducted in 2012 and will not be required again until 2015.

\subsubsection{Resource Conservation and Recovery Act Compliance Status}

The Hazardous Waste Program under RCRA establishes a system for regulating hazardous wastes from the initial point of generation through final disposal. In Tennessee, TDEC has been delegated 
authority by EPA to implement the Hazardous Waste Program; EPA retains an oversight role. In 2013, $\mathrm{DOE}$ and its contractors at ORNL were jointly regulated as a "large-quantity generator of hazardous waste" under EPA ID TN1890090003 because, collectively, they generated more than 1,000 $\mathrm{kg}(2,205 \mathrm{lb})$ of hazardous/mixed wastes in at least 1 calendar month during 2013. Mixed wastes are both hazardous (under RCRA regulations) and radioactive. Hazardous/mixed wastes are accumulated in SAAs, less-than90-day accumulation areas, and are stored and/or treated in RCRA-permitted units. In addition, hazardous/mixed wastes are shipped off-site for treatment and disposal. The RCRA units operate under three permits at ORNL, TNHW-145, TNHW-134, and TNHW-121, as shown in Table 5.5. In 2013, UT-Battelle and UCOR were permitted to transport hazardous wastes under an EPA ID number issued for ORNL activities. After notification to TDEC, UT-Battelle ceased operation in 2013 of a registered ORNL transfer facility for temporary storage (less than 10 days) of hazardous waste transported from off-site locations because the facility was no longer needed.

Reporting is required for hazardous waste activities on 42 active waste streams at ORNL, some of which are mixed wastes. The quantity of hazardous/mixed waste generated at ORNL in 2013 was $1,028,106 \mathrm{~kg}$ (1,133.3 tons). Mixed wastewater accounted for $783,170 \mathrm{~kg}$ (863.3 tons). Excluding the wastewater generation, 2013 hazardous waste generation increased about $14 \%$. The increase is attributed to debris from building cleanout and demolition and TRU waste generation. ORNL generators treated $3,438.5 \mathrm{~kg}$ (3.8 tons) of hazardous/mixed waste by elementary neutralization and silver recovery; and $892 \mathrm{~kg}$ (0.98 tons) of hazardous/mixed waste was received from UT-Battelle generators at the Y-12 Complex-which was stored at ORNL and subsequently shipped to off-site treatment, storage, and disposal facilities for treatment/disposal. The quantity of hazardous/mixed waste treated in RCRA-permitted treatment facilities at ORNL in 2013 was 35,912 $\mathrm{kg}$ (39.6 tons). This includes waste treated by amalgamation, macroencapsulation, size reduction, and stabilization/solidification. In addition, $783,170 \mathrm{~kg}$ (863.3 tons) of mixed waste was treated at an on-site wastewater treatment facility. The amount of hazardous/mixed waste shipped off-site to commercial treatment, storage, and disposal facilities decreased about $7 \%$ to $226,907 \mathrm{~kg}$ (250.1 tons) in 2013 .

In June 2013, TDEC conducted an annual RCRA inspection of ORNL generator areas; battery collection areas; RCRA-permitted treatment, storage, and disposal facilities; and RCRA records. During the June inspection, all activities and records were found to be in compliance with RCRA regulations and the RCRA permits, and no NOVs or penalties were associated with this inspection.

At NTRC DOE and UT-Battelle were regulated as "conditionally exempt small-quantity generators" in 2013 , meaning that less than $100 \mathrm{~kg}(220.5 \mathrm{lb})$ of hazardous waste per month was generated.

No hazardous/mixed wastes were generated, accumulated, or shipped by DOE or UT-Battelle at the DOE Office of Scientific and Technical Information or the 0800 Area in 2013. The 0800 Area is a location on ORR adjacent to ORNL that has been assigned EPA identification number TNR000019760.

In 2013 DOE and UT-Battelle applied for and received an EPA identification number for the 1916-T2 Warehouse in Oak Ridge for hazardous waste generation and shipping activities associated with cleanout of two of the warehouse bays. This facility was classified as a "small quantity generator" in 2013, meaning that between 100 and $1,000 \mathrm{~kg}$ (between 220.5 and 2,205 lb) of hazardous waste was generated during at least one calendar month. This activity is expected to be intermittent.

Table 5.5. Oak Ridge National Laboratory Resource Conservation and Recovery Act operating permits, 2013

\begin{tabular}{ll}
\hline Permit number & \multicolumn{1}{c}{ Storage and treatment units/description } \\
\hline TNHW-134 & \multicolumn{1}{c}{ Oake National Laboratory } \\
& Building 7651 Container Storage Unit \\
& Building 7652 Container Storage Unit \\
& Building 7653 Container Storage Unit \\
& Building 7654 Container Storage Unit \\
& Portable Unit 2 Storage \& Treatment Unit
\end{tabular}


Table 5.5 (continued)

\begin{tabular}{ll}
\hline Permit number & \multicolumn{1}{c}{ Storage and Treatment Units/description } \\
\hline TNHW-145 & Portable Unit 1 Storage Unit \\
Building 7572 Container Storage Unit & Building 7574 Container Storage Unit \\
& Building 7823 Container Storage Unit \\
& Building 7855 Container Storage Unit \\
& Building 7860A Container Storage Unit \\
& Building 7879 Container Storage Unit \\
& Building 7883 Container Storage Unit \\
& Building 7880A TWPC-1 (Contact-Handled Storage Area) Container Storage Unit \\
& TWPC-2 (Second Floor WPB) Container Storage Unit \\
& TWPC-3 (Drum Aging Criteria) Container Storage Unit \\
& TWPC-4 (First Floor WPB) Container Storage Unit \\
& TWPC-5 (Container Storage Area) Container Storage Unit \\
& Building 7880BB TWPC-6 (Contact-Handled Marshaling Building) Container \\
& Storage Unit \\
& Building 7880AA TWPC-7 (Drum-Venting Building) Container Storage Unit \\
& Building 7880QQ TWPC-8 (Multipurpose Building) Container Storage Unit \\
& Macroencapsulation T-1 Treatment Unit \\
& Amalgamation T-2 ${ }^{a}$ Treatment Unit \\
& Solidification/Stabilization T-3 ${ }^{a}$ Treatment Unit \\
& Hot Cell Table T-4 ${ }^{a}$ Treatment Unit \\
& Size Reduction T-5 ${ }^{a}$ Treatment Unit \\
& Groundwater Filtration T-6
\end{tabular}

Oak Ridge Reservation

TNHW-121 Hazardous Waste Corrective Action Permit

${ }^{a}$ Treatment operating units within Building 7880.

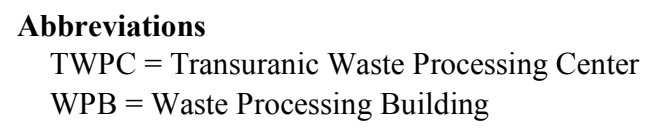

\subsubsection{Oak Ridge National Laboratory RCRA-CERCLA Coordination}

The ORR FFA is intended to coordinate the corrective action processes of RCRA required under the Hazardous and Solid Waste Amendments permit with CERCLA response actions. Annual updates for 2013 for ORNL's Solid Waste Management Units and Areas of Concern were consolidated with updates for ETTP, the Y-12 Complex, and ORR and were reported to TDEC, DOE, and EPA Region 4 in January 2014.

In May 2005, Bechtel Jacobs, Inc., LLC, applied for a RCRA postclosure permit for solid waste storage area (SWSA) 6. In November 2013, TDEC denied issuance of a postclosure permit, following a request from DOE to withdraw the permit application. SWSA 6 is currently being managed under CERCLA.

Periodic updates of proposed C\&D activities and facilities at ORNL have been provided to managers and project personnel from the TDEC DOE Oversight Division and EPA Region 4. A CERCLA screening process is used to identify proposed C\&D projects and facilities that warrant CERCLA oversight. The goal is to ensure that modernization efforts do not impact the effectiveness of previously completed CERCLA environmental remediation actions and do not adversely impact future CERCLA environmental remediation actions.

The UT-Battelle EMPO performs both direct EM work and an integration function for the DOE EMfunded ARRA work at ORNL. Although the completion of EM-related work (i.e., environmental remediation and building decontamination and demolition) is not a UT-Battelle core business function, UT-Battelle has effectively participated in the completion of ARRA-funded cleanup work to accelerate 
ORNL revitalization. Directly performed work included the cleanout of legacy material from Building 4501 Hot Cell D, cleanout of legacy material from Building 2026, removal of the Building 3550 slab and related soil remediation activities and site restoration, removal of roughing and HEPA filters from the 3106 Filter Pit, and grouting the 4556 Filter Pit and the central campus ventilation duct between Building 4501 and the 3039 stack. During 2013, EMPO integrated and supported other DOE contractors in the removal of five radioisotope thermoelectric generators for shipment to NNSS and the stabilization of Building 3038. These activities help reduce the liabilities and risks to current and future ORNL science missions. (For additional information on these activities see Section 5.8.)

\subsubsection{Resource Conservation and Recovery Act Underground Storage Tanks}

USTs containing petroleum and hazardous substances are regulated under RCRA Subtitle I (40 CFR 280). TDEC has been granted authority by EPA to regulate USTs containing petroleum under TDEC Rule 400-18-01; however, hazardous-substance USTs are still regulated by EPA.

ORNL has four USTs registered with TDEC under Facility ID 0-730089. A summary of the USTs follows.

- Two are in service (petroleum) and meet the current UST standards.

- One has been placed into a "temporary closure" status in accordance with the regulations pending permanent closure in the future.

- One is a wastewater treatment tank that is exempt from regulation. An amended notification was filed with TDEC-UST Section explaining that the tank is regulated under CWA Section 402 and is, therefore, excluded from the UST regulations [refer to 40 CFR 280.10(b)]. The "Tank Owner's Authorized Representative or Contact" was also changed to UCOR for this particular UST.

\subsubsection{Comprehensive Environmental Response, Compensation, and Liability Act Compliance Status}

CERCLA, also known as Superfund, was passed in 1980 and was amended in 1986 by SARA. Under CERCLA, a site is investigated and remediated if it poses significant risk to health or the environment. The EPA NPL is a comprehensive list of sites and facilities that have been found to pose a sufficient threat to human health and/or the environment to warrant cleanup under CERCLA.

In 1989, ORR was placed on the EPA NPL. In 1992, the ORR FFA among EPA, TDEC, and DOE became effective and established the framework and schedule for developing, implementing, and monitoring RAs on ORR. The on-site CERCLA EMWMF is operated by UCOR for DOE. Located in Bear Creek Valley, EMWMF is used for disposal of waste resulting from CERCLA cleanup actions on ORR, including ORNL. EMWMF is an engineered landfill that accepts low-level radioactive, hazardous, asbestos, and PCB wastes and combinations of the aforementioned wastes in accordance with specific waste acceptance criteria under an agreement with state and federal regulators.

\subsubsection{Toxic Substances Control Act Compliance Status}

PCB waste generation, transportation, and storage at ORNL are regulated under EPA ID TN1890090003. In 2013, UT-Battelle operated about 26 PCB waste storage areas in generator buildings. When longer term storage was necessary, PCB/radioactive wastes were stored in RCRA-permitted storage buildings at ORNL. Three PCB waste storage areas were operated at UT-Battelle facilities at the Y-12 Complex. The continued use of authorized PCBs in electrical systems and/or equipment (e.g., transformers, capacitors, rectifiers) is regulated at ORNL. The majority of equipment at ORNL that required regulation under TSCA has been disposed of. However, some of the ORNL facilities at the Y-12 Complex continue to use (or store for future reuse) PCB equipment.

Because of the age of many of the ORNL facilities and the varied uses for PCBs in gaskets, grease, building construction, and equipment, DOE self-disclosed unauthorized use of PCBs to EPA in the late 1980s. As a result, DOE and ORNL contractors negotiated a compliance agreement with EPA (see Table 2.1) to address the compliance issues related to these unauthorized uses and to allow for continued 
use pending decontamination or disposal. As a result of that agreement, DOE continues to notify EPA when additional unauthorized uses of PCBs, such as PCBs in paint, adhesives, electrical wiring, or floor tile, are found at ORNL. In 2013, no unauthorized uses of PCBs were discovered.

\title{
5.3.10 Emergency Planning and Community Right-to-Know Act Compliance Status
}

EPCRA and Title III of SARA require that facilities report inventories and releases of certain chemicals that exceed specific release thresholds. The reports are submitted to the local emergency planning committee and the state emergency response commission. Table 5.6 describes the main elements of EPCRA. UT-Battelle complied with these requirements in 2013 through the submittal of reports under EPCRA Sections 302, 303, 311, and 312. These reports reflect information pertinent to all DOE prime contractors and their subcontractors who reported activities at the ORNL site.

ORNL had no releases of extremely hazardous substances, as defined by EPCRA, in 2013.

\section{Table 5.6. Main elements of the Emergency Planning and Community Right-to-Know Act}

\begin{tabular}{ll}
\hline \multicolumn{1}{c}{ Title } & \multicolumn{1}{c}{ Description } \\
\hline $\begin{array}{l}\text { Sections 302 and 303, Planning } \\
\text { Notification }\end{array}$ & $\begin{array}{l}\text { Requires that local planning committee and state emergency response } \\
\text { commission be notified of EPCRA-related planning }\end{array}$ \\
$\begin{array}{l}\text { Section 304, Extremely Hazardous } \\
\text { Substance Release Notification }\end{array}$ & Addresses reporting to state and local authorities of off-site releases \\
$\begin{array}{l}\text { Sections 311-312, Material Safety Data } \\
\text { Sheet/Chemical Inventory }\end{array}$ & $\begin{array}{l}\text { Requires that either material safety data sheets or lists of hazardous } \\
\text { chemicals for which they are required be provided to state and local } \\
\text { authorities for emergency planning. Requires that an inventory of } \\
\text { hazardous chemicals maintained in quantities over thresholds be reported } \\
\text { annually to EPA }\end{array}$
\end{tabular}

Section 313, Toxic Chemical Release Requires that releases of toxic chemicals be reported annually to EPA Reporting

\author{
Abbreviations \\ EPA $=$ US Environmental Protection Agency \\ EPCRA $=$ Emergency Planning and Community Right-to-Know Act
}

\subsubsection{Material Safety Data Sheet/Chemical Inventory (Section 312)}

Inventories, locations, and associated hazards of hazardous and extremely hazardous chemicals were submitted in an annual report to state and local emergency responders as required by the EPCRA Section 312 requirements. In 2013, 19 hazardous or extremely hazardous chemicals were located at ORNL in quantities above EPCRA reporting thresholds.

Private-sector lessees associated with the reindustrialization effort were not included in the 2013 submittals. Under the terms of their leases, lessees must evaluate their own inventories of hazardous and extremely hazardous chemicals and must submit information as required by the regulations.

\subsubsection{Toxic Chemical Release Reporting (EPCRA Section 313)}

DOE submits annual toxic release inventory reports to EPA and TDEC on or before July 1 of each year. The reports cover the previous calendar year and address releases of certain toxic chemicals to air, water, and land and waste management, recycling, and pollution prevention activities. Threshold determinations and reports for each of the ORR facilities are made separately. Operations involving toxic release inventory chemicals were compared with regulatory thresholds to determine which chemicals exceeded the reporting thresholds based on amounts manufactured, processed, or otherwise used at each 
facility. After threshold determinations were made, releases and other waste management activities were calculated for each chemical that exceeded one or more of the thresholds.

\subsubsection{US Department of Agriculture/Tennessee Department of Agriculture}

USDA, through Animal and Plant Health Inspection Services, issues permits for the import, transit, and controlled release of regulated animals, animal products, veterinary biologics, plants, plant products, pests, organisms, soil, and genetically engineered organisms. The Tennessee Department of Agriculture issues agreements and jointly regulates domestic soil. In 2013, UT-Battelle personnel had a combined 39 permits and agreements for the receipt, movement, or controlled release of regulated articles.

\subsubsection{Wetlands}

Activities conducted at ORNL in 2013 in support of wetlands management are discussed below.

Vegetation parameters were measured at the ORNL parking structure wetland (P2) about 2 years after mitigation. Percent cover by species was measured for each plot. Information was also taken on any fauna present at the time of the survey. Third year data obtained for P2 showed excellent overall vegetation coverage, providing good quality habitat. Vegetation growing in the wetland included both planted and volunteer plant species. A good variety of fauna was noted in and around the wetland, including birds, frogs, and insects.

Stream habitat assessments were conducted at both First Creek and White Oak Creek (WOC) reaches using Habitat Assessment Data Sheets found in the Tennessee Mitigation Guidelines. Metrics evaluated at both sites included epifaunal substrate, embeddedness (amount of silt, etc. between rocks), velocity/depth regime, sediment deposition, channel flow, frequency of riffles, bank stability, and vegetative cover. These parameters were measured using rapid bioassessment protocols for use in wadeable streams and rivers (Barbour et al. 1999).

First Creek mitigation activities had already been completed before the first habitat assessment, which was conducted in 2011. The 2013 survey represented the third formal assessment of post-mitigation conditions. Pre-mitigation conditions for First Creek are discussed qualitatively based on information contained in previous reports. The 2013 WOC habitat assessment was based on habitat conditions about 2 years after mitigation.

Riparian zone vegetation surveys were conducted by establishing $10 \mathrm{~m}$ by $5 \mathrm{~m}$ ( $32.8 \mathrm{ft}$ by $16.4 \mathrm{ft})$ plots about $10 \mathrm{~m}(32.8 \mathrm{ft})$ apart (First Creek - east bank, WOC - north and south banks). A total of 11 plots were established at First Creek, and 13 plots were established at WOC. For each plot the following parameters were measured: trees $(\geq 3$ in. diameter at breast height) - measured, shrub stems ( $<3$ in. diameter at breast height) - counted, percent groundcover, percent canopy cover, canopy height, vegetation overhang (in centimeters) for each stream bank.

Fish and benthic community monitoring results were evaluated as an indicator of whether or not the stream sections were functioning as suitable habitat for instream organisms. Benthic macroinvertebrate community data were gathered at First Creek (July 18, 2013) and WOC (July 19, 2013) using an EPA-approved rapid qualitative assessment technique. At each site seven aquatic habitats were identified and sampled for aquatic macroinvertebrates, riffles, leaf packs, woody debris, rocks, root wads, aquatic

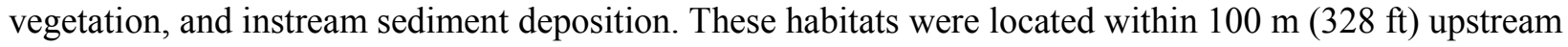
and downstream of the sampling site established along each reach. Habitats missing from the site were not sampled. After all habitats were sampled, a tally of each insect family was completed to determine the number of families represented by EPT. BMAP fish survey data used for evaluation of First Creek were from close proximity to the subject reach. The fish community data used for evaluation of the WOC site were from data taken during routine BMAP surveys within the creek. The fish communities within these reaches were monitored using a multiple pass removal estimate method (Ryon 2011). The sample sites were isolated by block nets, multiple passes were made using backpack or barge electrofishers, and all stunned fish were collected. Fish were identified by species, measured for length and weight, and returned to the site. 
The results of habitat measurements conducted along the First Creek reach in 2013 showed that the creek continued to provide good overall habitat and remained in an unimpaired state. The relatively linear condition of the creek was evidence of past channelization with the development of the area. Relatively narrow riparian zones are a weakness of the site from the perspective of providing good quality habitat. However, riparian zones in this area are restricted by paved and landscaped areas because the creek runs through a developed area. Mitigation plantings on the east side of the creek have improved habitat quality in that area over original habitat conditions that included large mowed turf grass areas and a high number of invasive plant species. The riparian zone on the west side is highly restricted because of the close proximity of landscaped and parking areas associated with a building complex. Cover is maintained to the maximum extent possible in this narrow zone. The presence of invasive plants such as winter creeper in these zones is a potential concern.

The survival rates of east side First Creek riparian plantings have been good thus far. In general, planted vegetation appears to be thriving and very little dead plant growth was noted during the 2013 survey. Dense growths of shrubs previously existing on the site (e.g., silky dogwood, spicebush) provided significant cover along the creek banks, particularly along northern portions of the study area. Overall conditions at the site related to vegetation growth and success remain very good.

A moderately diverse benthic macroinvertebrate population was recorded at the First Creek site in 2013, although somewhat lower than at some reference sites. This included some less tolerant taxa typically found in clear streams. Fish population densities (sampled upstream and downstream of the site) were within or higher than the ranges of densities observed in certain ORR reference streams. The number of fish species at the downstream sampling location was lower than or the same as numbers observed in reference streams. The number of fish species at the upstream sampling location was lower than numbers observed in reference streams.

The fourth year of post-mitigation monitoring for the First Creek site will be conducted in the summer of 2014.

The results of habitat measurements conducted along the WOC reach showed that the creek provided average to good overall habitat in the post-mitigation condition and remained in an unimpaired state. Epifaunal substrate was somewhat lacking in the presence of logs and snags; however, the creek provided numerous riffles, some undercut banks, a variety of particle sizes, and overhanging branches. One velocity/depth regime (fast-deep) was missing from the reach. Channel alteration from past development of the area was evident along some areas of the reach. Vegetative protection at the banks remained good for 2013, with a slight improvement over 2012. Riparian vegetative zone width for 2013 also remained significantly improved over the 2011 pre-mitigation conditions. Plant species diversity remained stable and invasive species presence remained low in the WOC riparian zone for the 2013 survey period. Areas of higher habitat quality were found directly adjacent to the creek, where green ash, black willow, eastern redbud, and silky dogwood were prevalent.

A moderately diverse benthic macroinvertebrate population was recorded at the WOC site in 2013. This included some of the more tolerant taxa found in ORR streams. Fish population densities sampled within the reach were within the ranges of reference streams on ORR. The number of fish species was higher than or the same as reference streams for the October-December 2012 sampling period yet lower than reference streams for the March-May 2013 sampling period.

The third year of post-mitigation monitoring for the WOC site will be conducted in the summer of 2014.

Wetland assessments were conducted for four sites on ORR during 2013 to determine whether jurisdictional wetlands were present in areas adjacent to proposed projects. These included a steam line removal site, a storm damage area, a fence installation site, and a water tower demolition site. These sites were checked to see whether any areas satisfied USACE wetland protocols for soils, hydrology, and vegetation. For two of the sites it was determined that wetlands in the area could be avoided, and no wetlands were found in the other two areas. At two of the sites TDEC Hydrologic Determination Field Data sheets were filled out to determine whether drainages were streams or wet weather conveyances by TDEC guidance. In both instances these drainages were determined to be wet weather conveyances. A riparian zone was also evaluated at one site. 


\subsubsection{Radiological Clearance of Property at Oak Ridge National Laboratory}

\subsubsection{General Property Clearance Processes}

DOE O 458.1, Radiation Protection of the Public and the Environment (DOE 2011b), established standards and requirements for operations of DOE and its contractors with respect to protection of members of the public and the environment against undue risk from radiation. In addition to discharges to the environment, the release of property containing residual radioactive material is a potential contributor to the dose received by the public, and DOE O 458.1 established requirements for clearance of property from DOE control and for public notification of clearance of property.

At ORNL, UT-Battelle uses a graded approach for release of material and equipment for unrestricted public use. Material that may be released to the public has been categorized so that in some cases an administrative release can be accomplished without a radiological survey. Such material originates from nonradiological areas and includes items such as the following:

- documents, mail, diskettes, compact disks, and other office media;

- nonradioactive items or materials received that are immediately (within the same shift) determined to have been misdelivered or damaged;

- personal items or materials;

- $\quad$ paper, plastic products, $\mathrm{ABCs}$, toner cartridges, and other items released for recycling;

- office trash;

- housekeeping materials and associated waste;

- breakroom, cafeteria, and medical wastes;

- medical and bioassay samples; and

- other items with an approved release plan.

Items originating from nonradiological areas within the site's controlled areas not in the listed categories are surveyed before release to the public, or a process knowledge evaluation is conducted to ensure that material has not been exposed to radioactive material or beams of radiation capable of creating radioactive material. In some cases both a radiological survey and a process knowledge evaluation are performed (e.g., a radiological survey is conducted on the outside of the item and a process knowledge form is signed by the custodian for inaccessible surfaces). A similar approach is used for material released to state-permitted landfills on ORR. The only exception is for items that could be internally contaminated; these items are also sampled by laboratory analysis to ensure that landfill permit criteria are met.

When the process knowledge approach is used, the item's custodian is required to sign a statement that specifies the history of the material and confirms that no radioactive material has passed through or contacted the item. This process knowledge certification is more stringent than what is allowed by DOE O 458.1 (DOE 2011b) in that ORNL requires an individual to take personal responsibility and accountability for knowing the complete history of an item before it can be cleared using process knowledge alone. DOE O 458.1 allows use of procedures for evaluating operational records and operating history to make process knowledge release decisions, but UT-Battelle has chosen to continue to require personal certification of the status of an item. This requirement ensures that each individual certifying the item is aware of the significance of this decision and encourages the individual to obtain a survey of the item if he or she is not $100 \%$ confident that the item can be certified as free of contamination.

For large recycling programs or clearance of bulk items with low contamination potential a survey and release plan may be developed to direct the radiological survey process. For such projects, survey and release plans are developed based on guidance from MARSSIM or MARSAME (NRC 2000, 2009). MARSSIM and MARSAME allow for statistically based survey protocols that typically require survey measurements for a representative portion of the items being released. The survey protocols are documented in separate survey and release plans, and the measurements from such surveys are documented in radiological release survey reports.

UT-Battelle continues to use the preapproved authorized limits for surface contamination previously established in Table IV-1 of DOE O 5400.5 and the November 17, 1995, Pelletier memorandum (Pelletier 
1995) for TRU alpha contamination. UT-Battelle also continues to follow the requirements of the scrap metal suspension. No scrap metal directly released from radiological areas is being recycled.

In 2013, UT Battelle cleared more than 17,000 items through the excess items and property sales processes. A summary of items requested for release through these processes (including donations, transfers, landfill, reutilization, and sales) is shown in Table 5.7.

Items advertised for public sale via an auction are also surveyed independently on a random basis by State of Tennessee personnel, giving further assurance that contaminated material and equipment are not being inadvertently released.

Table 5.7. Excess items requested for release and/or recycling, calendar year 2013

\begin{tabular}{|c|c|c|}
\hline & Process knowledge & Radiologically surveyed \\
\hline \multicolumn{3}{|c|}{ Release request totals for calendar year 2013} \\
\hline Computers-for-Learning & 131 & 2 \\
\hline DOE-Donations & 1 & 0 \\
\hline Donations & 933 & 466 \\
\hline LEDP (donations to colleges/universities) & 99 & 0 \\
\hline Other federal agency transfers & 112 & 27 \\
\hline DOE transfers & 283 & 90 \\
\hline Landfill & 0 & 0 \\
\hline Reuse at ORNL & 463 & 101 \\
\hline Sales & 10,468 & 4,268 \\
\hline Totals & 12,490 & 4,954 \\
\hline \multicolumn{3}{|c|}{ Recycling request totals for calendar year 2013} \\
\hline Used oils (gallons) & 7,801 & \\
\hline Scrap metal (nonradiological areas) (tons) & 162.27 & \\
\hline Used tires (each) & 692 & \\
\hline Used auto cores and batteries (pounds) & 28,656 & \\
\hline
\end{tabular}

${ }^{a}$ Less than 2 ppm PCBs.

${ }^{b}$ Greater than $2 \mathrm{ppm}$ and less than $50 \mathrm{ppm}$ PCBs.

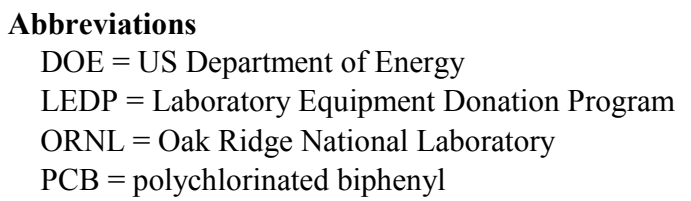

\subsubsection{Authorized Limits Clearance Process for Spallation Neutron Source and High Flux Isotope Reactor Neutron Scattering Experiment Samples}

The SNS and HFIR facilities provide unique neutron scattering experiment capabilities that allow researchers to explore the properties of various materials by exposing samples to well-characterized neutron beams. Because materials exposed to neutrons can become radioactive, a process has been developed to evaluate and clear samples for release to off-site facilities. DOE regulations and orders governing radiological release of material do not specifically cover items that may have radioactivity distributed throughout the volume of the material. To address sample clearance, activity-based limits were established using the authorized limits process defined in DOE O 458.1 and associated guidance. The sample clearance limits are based on an assessment of potential doses against a threshold of $1 \mathrm{mrem} /$ year to an individual and evaluation of other potentially applicable requirements (i.e., US Nuclear Regulatory Commission licensing regulations). Implementation of the clearance limits involves use of unique instrument screening and sample activity prediction methods to provide an efficient and defensible process to release neutron scattering experiment samples to researchers without further DOE control. 
In 2012 the authorized limits process for clearing SNS and HFIR neutron scattering samples was updated and revised to incorporate improvements in the regulatory notification component based on experience gained over about 2 years of implementation.

UT-Battelle initiated an effort to make direct contact with each institution's radiation safety officer (RSO) or health and safety official for the initial authorized limit sample clearance to that institution. The purpose of this approach was to ensure that a responsible official at the institution was informed of and understood the regulatory requirements associated with clearance of samples under the approved authorized limits. This "direct contact" approach proved to be much more effective than the previous approach of relying on use of the official user agreement to ensure that regulatory requirements were understood by the receiving institution. On May 2, 2012, UT-Battelle requested DOE approval of a minor change to the SNS and HFIR sample authorized limits process to replace the user agreement form as the primary regulatory notification tool with initial direct contact with an RSO or other health and safety official at the institution. This change was approved by DOE on May 22, 2012. No changes were made to the sample clearance activity thresholds or to the basic process for evaluating samples for clearance previously approved by DOE.

The approved revised process for notification was continued in 2013 and use of the authorized limits process was increased. In 2013 ORNL cleared 147 samples from neutron scattering experiments using the SNS and HFIR sample authorized limits process.

\subsection{Air Quality Program}

\subsubsection{Construction and Operating Permits}

Permits issued by the State of Tennessee convey the clean air requirements that are applicable to ORNL. New projects are governed by construction permits until converted to operating status. The sitewide Title V Major Source Operating Permits include requirements that are generally applicable to large operations such as a national laboratory (e.g., asbestos and stratospheric ozone), as well as specific requirements directly applicable to individual air emission sources. Source-specific requirements include Rad-NESHAPs (see Section 5.4.3), requirements applicable to sources of ambient air criteria pollutants, and requirements applicable to sources of other HAPs (nonradiological). In September 2011 the State of Tennessee issued Title V Permit 562765 to DOE and UT-Battelle operations at ORNL. In 2013 UTBattelle applied for permit modifications to incorporate source-specific conditions for the operation of the Biomass Gasification System and approval for alternative monitoring procedures for both the Biomass Gasification System and Boiler 6, located at the ORNL Steam Plant. As a result, TDEC issued Significant Modification Number 1 to Permit 562765 to DOE and UT-Battelle in March 2013. In April 2013 UT-Battelle also applied for a modification to Title V Permit 562765 to incorporate 31 emergency-use electrical generators into the permit. The permit modification is anticipated to be issued in early 2014 . DOE and UT-Battelle also maintained a valid minor source operating permit with the Knox County Air Quality Management Division for NTRC facilities located Knox County.

In 2012 UT-Battelle applied for and received construction permit number 965103P for the construction of CFTF, located off-site at the Heritage Center, in Oak Ridge, Tennessee. The initial startup of CFTF occurred in March 2013. In accordance with provisions of the permit an emissions test was performed in July 2013 and confirmed the hydrogen cyanide mass emission rate was $0.0024 \mathrm{lb}$ per hour, far less than the maximum hourly emission rate of $0.05 \mathrm{lb}$ established in the construction permit. The test results were provided to TDEC, and DOE-UT-Battelle will apply for a Title V Major Source Operating Permit for CFTF in 2014. A construction permit was also obtained in 2013 for the CFTF emergency generator. The Title V Operating Permit for the facility and its emergency generator is anticipated to be issued in 2014 or 2015.

DOE-WAI has an operating air permit for one emission source at TWPC. DOE-Isotek has a Title V Major Source Operating permit for the Radiochemical Development Facility (Building 3019 complex). During 2013, no permit limits were exceeded. 


\subsubsection{National Emission Standards for Hazardous Air Pollutants-Asbestos}

Numerous facilities, structures, and facility components and various pieces of equipment at ORNL contain ACM. UT-Battelle's Asbestos Management Program manages the compliance of work activities involving the removal and disposal of ACM, which includes notifications to TDEC for all demolition activities and required renovation activities, approval of asbestos work authorization requests, current use of engineering controls and work practices, inspections, air monitoring, and waste tracking of asbestoscontaminated waste material. No releases of reportable quantities of ACM occurred at ORNL during 2013.

\subsubsection{Oak Ridge National Laboratory Radiological Airborne Effluent Monitoring}

Radioactive airborne discharges at ORNL consist primarily of ventilation air from radioactively contaminated or potentially contaminated areas, vents from tanks and processes, and ventilation for hot cell operations and reactor facilities. (See Appendix E, Table E.1, for a list of radionuclides and associated radioactive half-lives.) The airborne emissions are treated and then filtered with high-efficiency particulate air filters and/or charcoal filters before discharge. Radiological airborne emissions from ORNL consist of solid particulates, adsorbable gases (e.g., iodine), tritium, and nonadsorbable gases (e.g., noble gases).

The major radiological emission point sources for ORNL consist of the following six stacks located in Bethel and Melton Valleys and the SNS Central Exhaust Facility stack located on Chestnut Ridge (Fig. 5.12).

- 2026 Radioactive Materials Analytical Laboratory

- 3020 Radiochemical Development Facility

- 3039 central off-gas and scrubber system, which includes the 3500 and 4500 areas' cell ventilation system, isotope solid-state ventilation system, 3025 area cell ventilation system, 3042 ventilation system, and 3092 central off-gas system

- 7503 Molten Salt Reactor Experiment (MSRE) Facility

- 7880 TWPC

- 7911 Melton Valley complex, which includes HFIR and the Radiochemical Engineering Development Center (REDC)

- 8915 SNS Central Exhaust Facility stack

In 2013 there were 15 minor point/group sources, and emission calculations/estimates were made for each of them. 


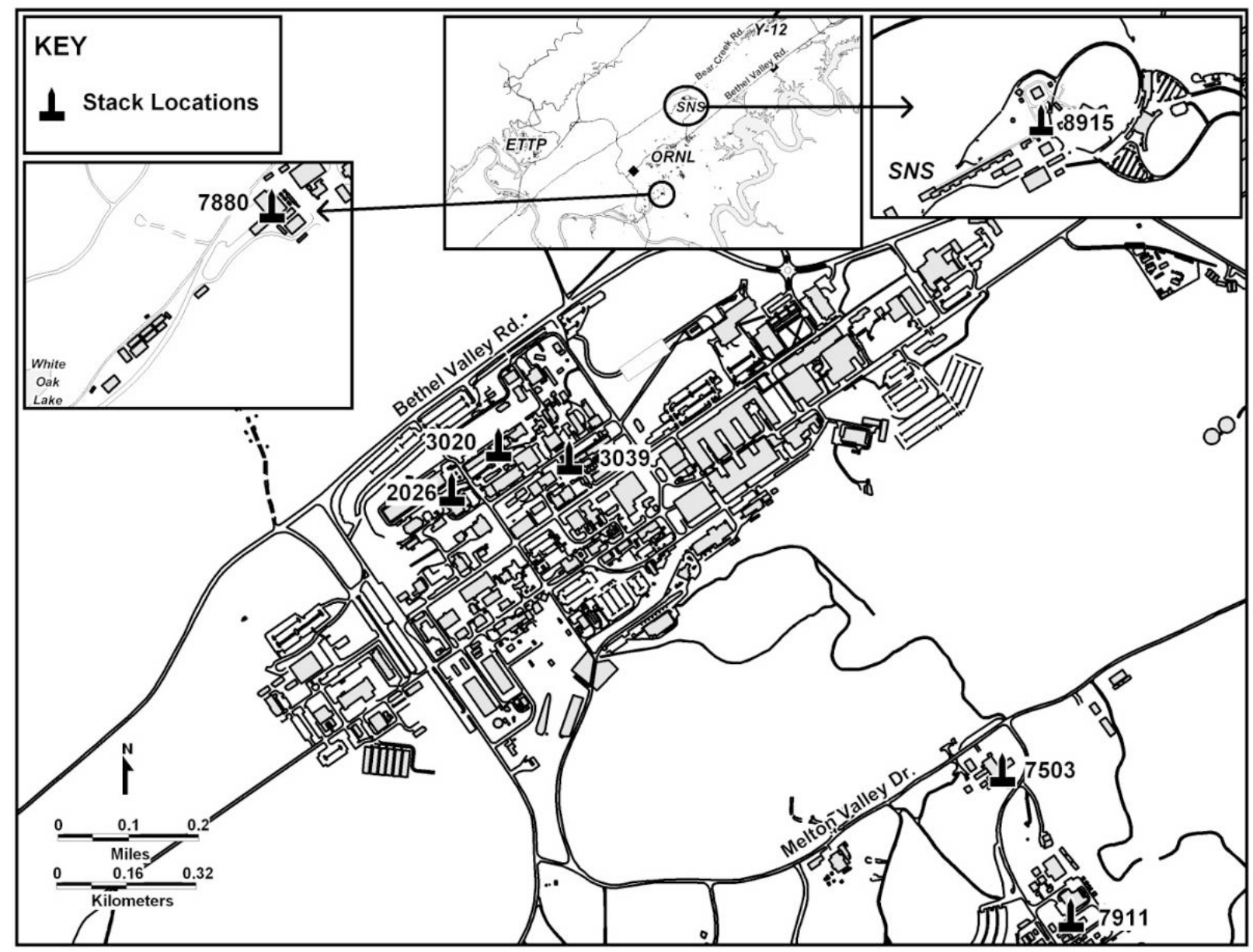

Fig. 5.12. Locations of major radiological emission points at Oak Ridge National Laboratory. (ETTP = East Tennessee Technology Park, ORNL = Oak Ridge National Laboratory, SNS = Spallation Neutron Source)

\subsubsection{Sample Collection and Analytical Procedure}

Four of the major point sources (stacks 2026, 3020, 3039, and 7503) are equipped with in-stack source-sampling systems that comply with criteria in the American National Standards Institute (ANSI) standard ANSI N 13.1-1969 (ANSI 1969). The sampling systems generally consist of a multipoint in-stack sampling probe, a sample transport line, a particulate filter, activated charcoal cartridges, a silica gel cartridge (if required), flow-measurement and totalizing instruments, a sampling pump, and a return line to the stack. The 7911 (Melton Valley complex) and 7880 (TWPC) stacks are equipped with in-stack source-sampling systems that comply with criteria in the ANSI Health Physics Society standard ANSI/HPS N13.1-1999 (ANSI 1999). The 7911 sampling system has the same components as the ANSI 1969 sampling systems but uses a stainless-steel-shrouded probe instead of a multipoint in-stack sampling probe. The sampling system also consists of a high-purity germanium detector with a NOMAD analyzer, which allows continuous isotopic identification and quantification of radioactive noble gases (e.g., ${ }^{41} \mathrm{Ar}$ ) in the effluent stream. The 7880 sampling system consists of a stainless-steel-shrouded probe, an in-line filter-cartridge holder placed at the probe to minimize line losses, a particulate filter, a sample transport line, a rotary vane vacuum pump, and a return line to the stack. The sample probes from both the ANSI 1969 and ANSI 1999 stack sampling systems are removed, inspected, and cleaned annually. The 8915 (SNS Central Exhaust Facility) stack is equipped with an in-stack radiation detector that complies with criteria in ANSI/HPS N13.1-1999. The detector monitors radioactive gases flowing through the exhaust 
stack and provides a continual readout of detected activity using a scintillator probe. The detector is calibrated to correlate with isotopic emissions.

Velocity profiles are performed quarterly following the criteria in EPA Method 2 (EPA 2010) at major and some minor sources. The profiles provide accurate stack flow data for subsequent emission-rate calculations. An annual leak-check program is carried out to verify the integrity of the sample transport system. For the 7880 stack, an annual comparison between the effluent flow rate totalizer and EPA Method 2 is performed. The stack effluent-flow-rate monitoring system response is checked quarterly against the manufacturer's instrument test procedures. The stack sampler rotameter is calibrated at least quarterly in comparison with a secondary (transfer) standard. Only a certified secondary standard is used for all rotameter tests.

In addition to the major sources, ORNL has a number of minor sources that have the potential to emit radionuclides to the atmosphere. A minor source is defined as any ventilation system or component such as a vent, laboratory hood, room exhaust, or stack that does not meet the approved regulatory criteria for a major source but that is located in or vents from a radiological control area as defined by Radiological Support Services of the UT-Battelle Nuclear and Radiological Protection Division. Various methods are used to determine the emissions from the various minor sources. Methods used for minor source-emission calculations comply with EPA criteria. The minor sources are evaluated on a 1- to 5-year basis. Emissions, major and minor, are compiled annually to determine the overall ORNL source term and associated dose.

The charcoal cartridges, particulate filters, and silica-gel traps are collected weekly to biweekly. The use of charcoal cartridges is a standard method for capturing and quantifying radioactive iodine in airborne emissions. Gamma spectrometric analysis of the charcoal samples quantifies the adsorbable gases. Analyses are performed weekly to biweekly. Particulate filters are held for 8 days before a weekly gross alpha and gross beta analysis to minimize the contribution from short-lived isotopes such as ${ }^{220} \mathrm{Rn}$ and its daughter products. At stack 7911, a weekly gamma scan is conducted to better detect short-lived gamma isotopes. The filters are then composited quarterly or semiannually and are analyzed for alpha-, beta-, and gamma-emitting isotopes. At stack 7880, the filters are composited monthly and analyzed for alpha-, beta-, and gamma-emitting isotopes. The sampling system on stack 7880 requires no other type of radionuclide collection media. Compositing provides a better opportunity for quantification of the lowconcentration isotopes. Silica-gel traps are used to capture water vapor that may contain tritium. Analysis is performed weekly to biweekly. At the end of the year, the sample probes for all of the stacks are rinsed, except for 8915 and 7880, and the rinsate is collected and submitted for isotopic analysis identical to that performed on the particulate filters. A probe-cleaning program has been determined unnecessary for 8915 because the sample probe is a scintillator probe used to detect radiation and not to extract a sample of stack exhaust emissions. It is not anticipated that contaminant deposits would collect on the scintillator probe. A probe-cleaning program for 7880 has established that rinse analysis historically showed no detectable contamination. Therefore, the frequency of probe rinse collection and analysis is no more often than every 3 years unless there is an increase in particulate emissions, increase in detectable radionuclides in the sample media, or process modifications.

The data from the charcoal cartridges, silica gel, probe wash, and filter composites are compiled to give the annual emissions for each major source and some minor sources.

\subsubsection{Results}

Annual radioactive airborne emissions for ORNL in 2013 are presented in Table 5.8. All data presented were determined to be statistically different from zero at the $95 \%$ confidence level. Any number not statistically different from zero was not included in the emission calculation. Because measuring a radionuclide requires counting random radioactive emissions from a sample, the same result may not be obtained if the sample is analyzed repeatedly. This deviation is referred to as the "counting uncertainty." Statistical significance at the $95 \%$ confidence level means that there is a $5 \%$ chance that the results could be erroneous. 
Table 5.8. Radiological airborne emissions from all sources at Oak Ridge National Laboratory, $2013^{a}$

\begin{tabular}{|c|c|c|c|c|c|c|c|c|c|c|c|}
\hline \multirow[b]{2}{*}{ Isotope } & \multirow{2}{*}{$\begin{array}{l}\text { Inhalation } \\
\text { form }^{b}\end{array}$} & \multirow{2}{*}{$\begin{array}{l}\text { Chemical } \\
\text { form }\end{array}$} & \multicolumn{9}{|c|}{ Stack } \\
\hline & & & X-2026 & $\mathrm{X}-3020$ & X-3039 & $X-7503$ & X-7880 & X-7911 & X-8915 & $\begin{array}{c}\text { Total minor } \\
\text { source }\end{array}$ & $\begin{array}{c}\text { ORNL } \\
\text { total }\end{array}$ \\
\hline${ }^{225} \mathrm{Ac}$ & M & Unspecified & & & & & & & & $4.75 \mathrm{E}-06$ & $4.75 \mathrm{E}-06$ \\
\hline${ }^{227} \mathrm{Ac}$ & M & Unspecified & & & & & & & & $3.00 \mathrm{E}-09$ & $3.00 \mathrm{E}-09$ \\
\hline${ }^{228} \mathrm{Ac}$ & M & Unspecified & & & & & & & & $1.75 \mathrm{E}-06$ & $1.75 \mathrm{E}-06$ \\
\hline${ }^{110 \mathrm{~m}} \mathrm{Ag}$ & M & Unspecified & & & & & & & & $1.13 \mathrm{E}-09$ & $1.13 \mathrm{E}-09$ \\
\hline${ }^{110 \mathrm{~m}} \mathrm{Ag}$ & $\mathrm{S}$ & Unspecified & & & & & $1.80 \mathrm{E}-06$ & & & & $1.80 \mathrm{E}-06$ \\
\hline${ }^{111} \mathrm{Ag}$ & M & Unspecified & & & & & & & & $1.72 \mathrm{E}-06$ & $1.72 \mathrm{E}-06$ \\
\hline${ }^{241} \mathrm{Am}$ & M & Unspecified & $9.89 \mathrm{E}-07$ & $8.57 \mathrm{E}-07$ & & & & $1.02 \mathrm{E}-07$ & & $2.96 \mathrm{E}-07$ & $2.24 \mathrm{E}-06$ \\
\hline${ }^{241} \mathrm{Am}$ & $\mathrm{F}$ & Unspecified & & & $3.22 \mathrm{E}-07$ & $1.26 \mathrm{E}-08$ & $1.46 \mathrm{E}-06$ & & & $2.79 \mathrm{E}-06$ & $4.59 \mathrm{E}-06$ \\
\hline${ }^{243} \mathrm{Am}$ & M & Unspecified & & & & & & & & $7.46 \mathrm{E}-09$ & $7.46 \mathrm{E}-09$ \\
\hline${ }^{41} \mathrm{Ar}$ & $\mathrm{G}$ & Unspecified & & & & & & $9.31 \mathrm{E}+02$ & $5.41 \mathrm{E}+01$ & & $9.85 \mathrm{E}+02$ \\
\hline${ }^{131} \mathrm{Ba}$ & M & Unspecified & & & & & & & & $4.01 \mathrm{E}-07$ & $4.01 \mathrm{E}-07$ \\
\hline${ }^{139} \mathrm{Ba}$ & M & Unspecified & & & & & & $1.55 \mathrm{E}-01$ & & & $1.55 \mathrm{E}-01$ \\
\hline${ }^{140} \mathrm{Ba}$ & M & Unspecified & & & & & & $3.05 \mathrm{E}-04$ & & $4.03 \mathrm{E}-05$ & $3.45 \mathrm{E}-04$ \\
\hline${ }^{140} \mathrm{Ba}$ & $\mathrm{S}$ & Unspecified & & & & & $3.14 \mathrm{E}-05$ & & & & $3.14 \mathrm{E}-05$ \\
\hline${ }^{7} \mathrm{Be}$ & M & Unspecified & $1.48 \mathrm{E}-07$ & & & & & 7.71E-07 & & 5.29E-06 & $6.21 \mathrm{E}-06$ \\
\hline${ }^{7} \mathrm{Be}$ & $\mathrm{S}$ & Unspecified & & & $7.46 \mathrm{E}-06$ & $1.68 \mathrm{E}-07$ & $1.81 \mathrm{E}-05$ & & & 4.67E-07 & $2.62 \mathrm{E}-05$ \\
\hline${ }^{206} \mathrm{Bi}$ & M & Unspecified & & & & & & & & $2.19 \mathrm{E}-07$ & $2.19 \mathrm{E}-07$ \\
\hline${ }^{207} \mathrm{Bi}$ & M & Unspecified & & & & & & & & $1.00 \mathrm{E}-10$ & $1.00 \mathrm{E}-10$ \\
\hline${ }^{210 \mathrm{~m}} \mathrm{Bi}$ & M & Unspecified & & & & & & & & $3.00 \mathrm{E}-16$ & $3.00 \mathrm{E}-16$ \\
\hline${ }^{211} \mathrm{Bi}$ & M & Unspecified & & & & & & & & $5.55 \mathrm{E}-09$ & $5.55 \mathrm{E}-09$ \\
\hline${ }^{212} \mathrm{Bi}$ & M & Unspecified & & & & & & & & $8.01 \mathrm{E}-08$ & $8.01 \mathrm{E}-08$ \\
\hline${ }^{214} \mathrm{Bi}$ & M & unspecified & & & & & & & & $6.08 \mathrm{E}-07$ & $6.08 \mathrm{E}-07$ \\
\hline${ }^{249} \mathrm{Bk}$ & M & unspecified & & & & & & & & $7.00 \mathrm{E}-11$ & $7.00 \mathrm{E}-11$ \\
\hline${ }^{11} \mathrm{C}$ & $\mathrm{G}$ & dioxide & & & & & & & $5.69 \mathrm{E}+03$ & & $5.69 \mathrm{E}+03$ \\
\hline${ }^{14} \mathrm{C}$ & M & particulate & & & & & & & & $9.55 \mathrm{E}-12$ & $9.55 \mathrm{E}-12$ \\
\hline${ }^{45} \mathrm{Ca}$ & M & unspecified & & & & & & & & $6.20 \mathrm{E}-13$ & $6.20 \mathrm{E}-13$ \\
\hline${ }^{139} \mathrm{Ce}$ & $\mathrm{M}$ & unspecified & & & & & & & & $1.08 \mathrm{E}-08$ & $1.08 \mathrm{E}-08$ \\
\hline
\end{tabular}


Table 5.8. (continued)

\begin{tabular}{|c|c|c|c|c|c|c|c|c|c|c|c|}
\hline \multirow[b]{2}{*}{ Isotope } & \multirow[b]{2}{*}{$\begin{array}{l}\text { Inhalation } \\
\text { form }^{b}\end{array}$} & \multirow[b]{2}{*}{$\begin{array}{l}\text { Chemical } \\
\text { form }\end{array}$} & \multicolumn{9}{|c|}{ Stack } \\
\hline & & & X-2026 & $\mathrm{X}-\mathbf{3 0 2 0}$ & X-3039 & $X-7503$ & X-7880 & X-7911 & X-8915 & $\begin{array}{c}\text { Total minor } \\
\text { source }\end{array}$ & $\begin{array}{c}\text { ORNL } \\
\text { total }\end{array}$ \\
\hline${ }^{141} \mathrm{Ce}$ & $\mathrm{M}$ & unspecified & & & & & & $3.95 \mathrm{E}-07$ & & $2.29 \mathrm{E}-07$ & $6.24 \mathrm{E}-07$ \\
\hline${ }^{144} \mathrm{Ce}$ & M & unspecified & & & & & & & & 3.94E-07 & $3.94 \mathrm{E}-07$ \\
\hline${ }^{249} \mathrm{Cf}$ & M & unspecified & & & & & & & & $2.50 \mathrm{E}-10$ & $2.50 \mathrm{E}-10$ \\
\hline${ }^{252} \mathrm{Cf}^{c}$ & M & unspecified & & & & & & $1.06 \mathrm{E}-09$ & & $2.36 \mathrm{E}-08$ & $2.47 \mathrm{E}-08$ \\
\hline${ }^{242} \mathrm{Cm}$ & M & unspecified & & & & & & & & $1.39 \mathrm{E}-10$ & $1.39 \mathrm{E}-10$ \\
\hline${ }^{243} \mathrm{Cm}$ & $\mathrm{F}$ & unspecified & & & $2.26 \mathrm{E}-08$ & $1.78 \mathrm{E}-10$ & $7.10 \mathrm{E}-07$ & & & $2.49 \mathrm{E}-07$ & $9.82 \mathrm{E}-07$ \\
\hline${ }^{243} \mathrm{Cm}$ & M & unspecified & $5.05 \mathrm{E}-08$ & & & & & & & $5.26 \mathrm{E}-11$ & $5.06 \mathrm{E}-08$ \\
\hline${ }^{244} \mathrm{Cm}$ & $\mathrm{F}$ & unspecified & & & $2.26 \mathrm{E}-08$ & $1.78 \mathrm{E}-10$ & $7.10 \mathrm{E}-07$ & & & $2.49 \mathrm{E}-07$ & $9.82 \mathrm{E}-07$ \\
\hline${ }^{244} \mathrm{Cm}$ & M & unspecified & $5.05 \mathrm{E}-08$ & $3.94 \mathrm{E}-09$ & & & & & & $3.76 \mathrm{E}-06$ & $3.82 \mathrm{E}-06$ \\
\hline${ }^{245} \mathrm{Cm}$ & M & unspecified & & & & & & & & $4.07 \mathrm{E}-10$ & $4.07 \mathrm{E}-10$ \\
\hline${ }^{246} \mathrm{Cm}$ & M & unspecified & & & & & & & & $1.38 \mathrm{E}-12$ & $1.38 \mathrm{E}-12$ \\
\hline${ }^{247} \mathrm{Cm}$ & M & unspecified & & & & & & & & $6.84 \mathrm{E}-14$ & $6.84 \mathrm{E}-14$ \\
\hline${ }^{248} \mathrm{Cm}^{d}$ & M & unspecified & & & & & & & & $1.11 \mathrm{E}-13$ & $1.11 \mathrm{E}-13$ \\
\hline${ }^{57} \mathrm{Co}$ & M & unspecified & & & & & & & & $4.86 \mathrm{E}-07$ & $4.86 \mathrm{E}-07$ \\
\hline${ }^{58} \mathrm{Co}$ & M & unspecified & & & & & & & & 8.30E-09 & $8.30 \mathrm{E}-09$ \\
\hline${ }^{58} \mathrm{Co}$ & $\mathrm{S}$ & unspecified & & & & & & & & $7.33 \mathrm{E}-13$ & $7.33 \mathrm{E}-13$ \\
\hline${ }^{60} \mathrm{Co}$ & M & unspecified & & & & & & & & $3.51 \mathrm{E}-05$ & $3.51 \mathrm{E}-05$ \\
\hline${ }^{60} \mathrm{Co}$ & $\mathrm{S}$ & unspecified & & & $1.53 \mathrm{E}-06$ & & 2.39E-06 & & & $1.20 \mathrm{E}-04$ & $1.24 \mathrm{E}-04$ \\
\hline${ }^{51} \mathrm{Cr}$ & M & unspecified & & & & & & & & $1.26 \mathrm{E}-09$ & $1.26 \mathrm{E}-09$ \\
\hline${ }^{132} \mathrm{Cs}$ & $\mathrm{F}$ & unspecified & & & & & & & & $1.29 \mathrm{E}-07$ & $1.29 \mathrm{E}-07$ \\
\hline${ }^{134} \mathrm{Cs}$ & S & unspecified & & & & & $1.80 \mathrm{E}-06$ & & & $1.63 \mathrm{E}-13$ & $1.80 \mathrm{E}-06$ \\
\hline${ }^{134} \mathrm{Cs}$ & $\mathrm{F}$ & unspecified & & & & & & & & $3.72 \mathrm{E}-07$ & $3.72 \mathrm{E}-07$ \\
\hline${ }^{136} \mathrm{Cs}$ & $\mathrm{F}$ & unspecified & & & & & & & & $1.98 \mathrm{E}-07$ & $1.98 \mathrm{E}-07$ \\
\hline${ }^{137} \mathrm{Cs}$ & $\mathrm{F}$ & unspecified & $8.13 \mathrm{E}-07$ & $2.52 \mathrm{E}-06$ & & & & $4.26 \mathrm{E}-06$ & & $3.50 \mathrm{E}-04$ & $3.57 \mathrm{E}-04$ \\
\hline${ }^{137} \mathrm{Cs}$ & S & unspecified & & & $7.94 \mathrm{E}-05$ & $3.88 \mathrm{E}-08$ & 2.05E-06 & & & $6.10 \mathrm{E}-04$ & $6.91 \mathrm{E}-04$ \\
\hline${ }^{138} \mathrm{Cs}$ & $\mathrm{F}$ & unspecified & & & & & & $5.03 \mathrm{E}+02$ & & & $5.03 \mathrm{E}+02$ \\
\hline${ }^{152} \mathrm{Eu}$ & M & unspecified & & & & & & & & $2.19 \mathrm{E}-07$ & $2.19 \mathrm{E}-07$ \\
\hline
\end{tabular}


Table 5.8. (continued)

\begin{tabular}{|c|c|c|c|c|c|c|c|c|c|c|c|}
\hline \multirow[b]{2}{*}{ Isotope } & \multirow{2}{*}{$\begin{array}{l}\text { Inhalation } \\
\text { form }^{b}\end{array}$} & \multirow{2}{*}{$\begin{array}{l}\text { Chemical } \\
\text { form }\end{array}$} & \multicolumn{9}{|c|}{ Stack } \\
\hline & & & X-2026 & $\mathrm{X}-3020$ & X-3039 & $X-7503$ & $\mathrm{X}-\mathbf{7 8 8 0}$ & X-7911 & X-8915 & $\begin{array}{c}\text { Total minor } \\
\text { source }\end{array}$ & $\begin{array}{c}\text { ORNL } \\
\text { total }\end{array}$ \\
\hline${ }^{154} \mathrm{Eu}$ & $M$ & unspecified & & & & & & & & $2.01 \mathrm{E}-07$ & $2.01 \mathrm{E}-07$ \\
\hline${ }^{155} \mathrm{Eu}$ & M & unspecified & & & & & & & & $4.86 \mathrm{E}-05$ & $4.86 \mathrm{E}-05$ \\
\hline${ }^{55} \mathrm{Fe}$ & M & unspecified & & & & & & & & $1.82 \mathrm{E}-07$ & $1.82 \mathrm{E}-07$ \\
\hline${ }^{59} \mathrm{Fe}$ & M & unspecified & & & & & & & & $3.19 \mathrm{E}-11$ & $3.19 \mathrm{E}-11$ \\
\hline${ }^{153} \mathrm{Gd}$ & M & unspecified & & & & & & & & $6.59 \mathrm{E}-10$ & $6.59 \mathrm{E}-10$ \\
\hline${ }^{3} \mathrm{H}$ & $\mathrm{V}$ & vapor & $1.24 \mathrm{E}-01$ & & $8.07 \mathrm{E}+00$ & $9.94 \mathrm{E}-01$ & & $1.09 \mathrm{E}+02$ & $3.33 \mathrm{E}+02$ & $5.54 \mathrm{E}-01$ & $4.52 \mathrm{E}+02$ \\
\hline${ }^{175} \mathrm{Hf}$ & M & unspecified & & & & & & & & $4.62 \mathrm{E}-10$ & $4.62 \mathrm{E}-10$ \\
\hline${ }^{181} \mathrm{Hf}$ & M & unspecified & & & & & & & & $7.73 \mathrm{E}-10$ & $7.73 \mathrm{E}-10$ \\
\hline${ }^{203} \mathrm{Hg}$ & M & inorganic & & & & & & & & $2.16 \mathrm{E}-07$ & $2.16 \mathrm{E}-07$ \\
\hline${ }^{166 m} \mathrm{Ho}$ & M & unspecified & & & & & & & & $2.00 \mathrm{E}-04$ & $2.00 \mathrm{E}-04$ \\
\hline${ }^{125} \mathrm{I}$ & $\mathrm{F}$ & particulate & & & & & & & & $3.10 \mathrm{E}-07$ & $3.10 \mathrm{E}-07$ \\
\hline${ }^{129} \mathrm{I}$ & $\mathrm{F}$ & particulate & & & & & $1.59 \mathrm{E}-06$ & & & 4.03E-05 & $4.19 \mathrm{E}-05$ \\
\hline${ }^{131} \mathrm{I}$ & $\mathrm{F}$ & particulate & & & $6.40 \mathrm{E}-02$ & & $2.47 \mathrm{E}-05$ & $1.07 \mathrm{E}-01$ & & 4.68E-07 & $1.71 \mathrm{E}-01$ \\
\hline${ }^{132} \mathrm{I}$ & $\mathrm{F}$ & particulate & & & $5.35 \mathrm{E}-04$ & & & $8.63 \mathrm{E}-01$ & & & 8.64E-01 \\
\hline${ }^{133} \mathrm{I}$ & $\mathrm{F}$ & particulate & & & $1.22 \mathrm{E}-04$ & & & $5.53 \mathrm{E}-01$ & & $1.93 \mathrm{E}-06$ & $5.53 \mathrm{E}-01$ \\
\hline${ }^{134} \mathrm{I}$ & $\mathrm{F}$ & particulate & & & & & & $8.29 \mathrm{E}-01$ & & & $8.29 \mathrm{E}-01$ \\
\hline${ }^{135} \mathrm{I}$ & F & particulate & & & & & & $1.89 \mathrm{E}+00$ & & & $1.89 \mathrm{E}+00$ \\
\hline${ }^{114 \mathrm{~m}} \mathrm{In}$ & M & unspecified & & & & & & & & $2.20 \mathrm{E}-08$ & $2.20 \mathrm{E}-08$ \\
\hline${ }^{192} \mathrm{Ir}$ & M & unspecified & & & & & & & & $2.35 \mathrm{E}-07$ & $2.35 \mathrm{E}-07$ \\
\hline${ }^{40} \mathrm{~K}$ & $\mathrm{~S}$ & unspecified & & & & & & & & $4.41 \mathrm{E}-12$ & $4.41 \mathrm{E}-12$ \\
\hline${ }^{40} \mathrm{~K}$ & M & unspecified & & & & & & & & $8.61 \mathrm{E}-06$ & $8.61 \mathrm{E}-06$ \\
\hline${ }^{85} \mathrm{Kr}$ & $\mathrm{G}$ & unspecified & & & & & & $6.46 \mathrm{E}+02$ & & & $6.46 \mathrm{E}+02$ \\
\hline${ }^{85 \mathrm{~m}} \mathrm{Kr}$ & G & unspecified & & & & & & $5.14 \mathrm{E}+00$ & & & $5.14 \mathrm{E}+00$ \\
\hline${ }^{87} \mathrm{Kr}$ & G & unspecified & & & & & & $4.59 \mathrm{E}+01$ & & & $4.59 \mathrm{E}+01$ \\
\hline${ }^{88} \mathrm{Kr}$ & $\mathrm{G}$ & unspecified & & & & & & $4.39 \mathrm{E}+01$ & $4.29 \mathrm{E}+01$ & & $8.68 \mathrm{E}+01$ \\
\hline${ }^{89} \mathrm{Kr}^{e}$ & G & unspecified & & & & & & $2.55 \mathrm{E}+01$ & & & $2.55 \mathrm{E}+01$ \\
\hline${ }^{140} \mathrm{La}$ & M & unspecified & & & & & & $9.11 \mathrm{E}-02$ & & $8.62 \mathrm{E}-08$ & $9.11 \mathrm{E}-02$ \\
\hline
\end{tabular}


Table 5.8. (continued)

\begin{tabular}{|c|c|c|c|c|c|c|c|c|c|c|c|}
\hline \multirow[b]{2}{*}{ Isotope } & \multirow{2}{*}{$\begin{array}{l}\text { Inhalation } \\
\text { form }^{b}\end{array}$} & \multirow{2}{*}{$\begin{array}{l}\text { Chemical } \\
\text { form }\end{array}$} & \multicolumn{9}{|c|}{ Stack } \\
\hline & & & X-2026 & $\mathrm{X}-3020$ & X-3039 & $X-7503$ & X-7880 & X-7911 & X-8915 & $\begin{array}{c}\text { Total minor } \\
\text { source }\end{array}$ & $\begin{array}{c}\text { ORNL } \\
\text { total }\end{array}$ \\
\hline${ }^{140} \mathrm{La}$ & $\mathrm{S}$ & unspecified & & & & & $1.49 \mathrm{E}-05$ & & & & $1.49 \mathrm{E}-05$ \\
\hline${ }^{177} \mathrm{Lu}$ & M & unspecified & & & & & & & & $1.00 \mathrm{E}-08$ & $1.00 \mathrm{E}-08$ \\
\hline${ }^{54} \mathrm{Mn}$ & M & unspecified & & & & & & & & 2.73E-09 & $2.73 \mathrm{E}-09$ \\
\hline${ }^{54} \mathrm{Mn}$ & $\mathrm{S}$ & unspecified & & & & & $1.96 \mathrm{E}-06$ & & & $2.47 \mathrm{E}-13$ & $1.96 \mathrm{E}-06$ \\
\hline${ }^{93} \mathrm{Mo}$ & M & unspecified & & & & & & & & $1.36 \mathrm{E}-11$ & $1.36 \mathrm{E}-11$ \\
\hline${ }^{99} \mathrm{Mo}$ & M & unspecified & & & & & & & & $8.70 \mathrm{E}-07$ & $8.70 \mathrm{E}-07$ \\
\hline${ }^{13} \mathrm{~N}$ & $\mathrm{G}$ & unspecified & & & & & & & $1.25 \mathrm{E}+02$ & & $1.25 \mathrm{E}+02$ \\
\hline${ }^{22} \mathrm{Na}$ & M & unspecified & & & & & & & & $4.93 \mathrm{E}-13$ & $4.93 \mathrm{E}-13$ \\
\hline${ }^{93 \mathrm{~m}} \mathrm{Nb}$ & M & unspecified & & & & & & & & $1.10 \mathrm{E}-09$ & $1.10 \mathrm{E}-09$ \\
\hline${ }^{94} \mathrm{Nb}$ & M & unspecified & & & & & & & & $1.51 \mathrm{E}-10$ & $1.51 \mathrm{E}-10$ \\
\hline${ }^{94} \mathrm{Nb}$ & $\mathrm{S}$ & unspecified & & & & & & & & $5.81 \mathrm{E}-14$ & $5.81 \mathrm{E}-14$ \\
\hline${ }^{95} \mathrm{Nb}$ & M & unspecified & & & & & & & & $1.28 \mathrm{E}-07$ & $1.28 \mathrm{E}-07$ \\
\hline${ }^{147} \mathrm{Nd}$ & M & unspecified & & & & & & & & $1.88 \mathrm{E}-12$ & $1.88 \mathrm{E}-12$ \\
\hline${ }^{59} \mathrm{Ni}$ & M & particulate & & & & & & & & $8.41 \mathrm{E}-13$ & $8.41 \mathrm{E}-13$ \\
\hline${ }^{63} \mathrm{Ni}$ & M & particulate & & & & & & & & $2.06 \mathrm{E}-08$ & $2.06 \mathrm{E}-08$ \\
\hline${ }^{237} \mathrm{~Np}$ & M & unspecified & & & & & & & & $8.45 \mathrm{E}-08$ & $8.45 \mathrm{E}-08$ \\
\hline${ }^{239} \mathrm{~Np}$ & M & unspecified & & & & & & & & 2.54E-09 & $2.54 \mathrm{E}-09$ \\
\hline${ }^{191}$ Os & $\mathrm{S}$ & unspecified & & & $6.54 \mathrm{E}-07$ & & & & & & $6.54 \mathrm{E}-07$ \\
\hline${ }^{191}$ Os & M & unspecified & & & & & & & & $2.72 \mathrm{E}-14$ & $2.72 \mathrm{E}-14$ \\
\hline${ }^{32} \mathrm{P}$ & M & unspecified & & & & & & & & 4.09E-09 & $4.09 \mathrm{E}-09$ \\
\hline${ }^{33} \mathrm{P}$ & M & unspecified & & & & & & & & $1.02 \mathrm{E}-15$ & $1.02 \mathrm{E}-15$ \\
\hline${ }^{230} \mathrm{~Pa}$ & M & unspecified & & & & & & & & $9.51 \mathrm{E}-08$ & $9.51 \mathrm{E}-08$ \\
\hline${ }^{233} \mathrm{~Pa}$ & M & unspecified & & & & & & & & $2.39 \mathrm{E}-07$ & $2.39 \mathrm{E}-07$ \\
\hline${ }^{210} \mathrm{~Pb}$ & M & unspecified & & & & & & & & $2.53 \mathrm{E}-11$ & $2.53 \mathrm{E}-11$ \\
\hline${ }^{211} \mathrm{~Pb}$ & M & unspecified & & & & & & & & 4.03E-08 & $4.03 \mathrm{E}-08$ \\
\hline${ }^{212} \mathrm{~Pb}$ & M & unspecified & 4.72E-01 & 4.79E-01 & & & & $1.37 \mathrm{E}-02$ & & $2.28 \mathrm{E}-06$ & $9.65 \mathrm{E}-01$ \\
\hline${ }^{212} \mathrm{~Pb}$ & $\mathrm{~S}$ & unspecified & & & $9.90 \mathrm{E}-01$ & $1.21 \mathrm{E}-01$ & & & & $2.04 \mathrm{E}-02$ & $1.13 \mathrm{E}+00$ \\
\hline
\end{tabular}


Table 5.8. (continued)

\begin{tabular}{|c|c|c|c|c|c|c|c|c|c|c|c|}
\hline \multirow[b]{2}{*}{ Isotope } & \multirow{2}{*}{$\begin{array}{l}\text { Inhalation } \\
\text { form }^{b}\end{array}$} & \multirow{2}{*}{$\begin{array}{l}\text { Chemical } \\
\text { form }\end{array}$} & \multicolumn{9}{|c|}{ Stack } \\
\hline & & & $X-2026$ & $\mathrm{X}-\mathbf{3 0 2 0}$ & X-3039 & $X-7503$ & X-7880 & X-7911 & X-8915 & $\begin{array}{l}\text { Total minor } \\
\text { source }\end{array}$ & $\begin{array}{c}\text { ORNL } \\
\text { total }\end{array}$ \\
\hline${ }^{214} \mathrm{~Pb}$ & $\mathrm{M}$ & unspecified & & & & & & & & $2.50 \mathrm{E}-13$ & $2.50 \mathrm{E}-13$ \\
\hline${ }^{209} \mathrm{Po}^{f}$ & M & unspecified & & & & & & & & $5.00 \mathrm{E}-11$ & $5.00 \mathrm{E}-11$ \\
\hline${ }^{238} \mathrm{Pu}$ & $\mathrm{F}$ & unspecified & & & $1.35 \mathrm{E}-07$ & 1.13E-09 & $2.00 \mathrm{E}-06$ & & & $1.09 \mathrm{E}-05$ & $1.31 \mathrm{E}-05$ \\
\hline${ }^{238} \mathrm{Pu}$ & M & unspecified & $1.62 \mathrm{E}-08$ & $2.18 \mathrm{E}-06$ & & & & $1.28 \mathrm{E}-07$ & & $2.77 \mathrm{E}-07$ & $2.60 \mathrm{E}-06$ \\
\hline${ }^{239} \mathrm{Pu}$ & M & unspecified & $1.95 \mathrm{E}-07$ & $2.08 \mathrm{E}-06$ & & & & 1.19E-08 & & $1.46 \mathrm{E}-07$ & $2.43 \mathrm{E}-06$ \\
\hline${ }^{239} \mathrm{Pu}$ & $\mathrm{F}$ & unspecified & & & $5.80 \mathrm{E}-07$ & $1.00 \mathrm{E}-09$ & $9.15 \mathrm{E}-07$ & & & $9.97 \mathrm{E}-07$ & $2.49 \mathrm{E}-06$ \\
\hline${ }^{240} \mathrm{Pu}$ & $\mathrm{F}$ & unspecified & & & $5.80 \mathrm{E}-07$ & $1.00 \mathrm{E}-09$ & $9.15 \mathrm{E}-07$ & & & $9.96 \mathrm{E}-07$ & $2.49 \mathrm{E}-06$ \\
\hline${ }^{240} \mathrm{Pu}$ & M & unspecified & $1.95 \mathrm{E}-07$ & & & & & $1.19 \mathrm{E}-08$ & & $3.81 \mathrm{E}-08$ & $2.45 \mathrm{E}-07$ \\
\hline${ }^{241} \mathrm{Pu}$ & $\mathrm{F}$ & unspecified & & & & & & & & $2.57 \mathrm{E}-12$ & $2.57 \mathrm{E}-12$ \\
\hline${ }^{241} \mathrm{Pu}$ & M & unspecified & & & & & & & & $3.19 \mathrm{E}-09$ & $3.19 \mathrm{E}-09$ \\
\hline${ }^{242} \mathrm{Pu}$ & M & unspecified & & & & & & & & 5.04E-09 & $5.04 \mathrm{E}-09$ \\
\hline${ }^{223} \mathrm{Ra}$ & M & unspecified & & & & & & & & $1.73 \mathrm{E}-06$ & $1.73 \mathrm{E}-06$ \\
\hline${ }^{224} \mathrm{Ra}$ & M & unspecified & & & & & & & & $6.78 \mathrm{E}-07$ & $6.78 \mathrm{E}-07$ \\
\hline${ }^{225} \mathrm{Ra}$ & M & unspecified & & & & & & & & 4.12E-07 & $4.12 \mathrm{E}-07$ \\
\hline${ }^{226} \mathrm{Ra}$ & M & unspecified & & & & & & & & $1.60 \mathrm{E}-08$ & $1.60 \mathrm{E}-08$ \\
\hline${ }^{228} \mathrm{Ra}$ & M & unspecified & & & & & & & & $1.92 \mathrm{E}-04$ & $1.92 \mathrm{E}-04$ \\
\hline${ }^{219} \mathrm{Rn}$ & $\mathrm{G}$ & unspecified & & & & & & & & $1.41 \mathrm{E}-08$ & $1.41 \mathrm{E}-08$ \\
\hline${ }^{220} \mathrm{Rn}$ & $\mathrm{G}$ & unspecified & & & & & & & & $8.01 \mathrm{E}-08$ & $8.01 \mathrm{E}-08$ \\
\hline${ }^{103} \mathrm{Ru}$ & M & particulate & & & & & & & & $6.29 \mathrm{E}-07$ & $6.29 \mathrm{E}-07$ \\
\hline${ }^{103} \mathrm{Ru}$ & $\mathrm{S}$ & particulate & & & & & $2.58 \mathrm{E}-06$ & & & & $2.58 \mathrm{E}-06$ \\
\hline${ }^{106} \mathrm{Ru}$ & M & particulate & & & & & & & & $2.96 \mathrm{E}-06$ & $2.96 \mathrm{E}-06$ \\
\hline${ }^{35} \mathrm{~S}$ & M & inorganic & & & & & & & & $5.17 \mathrm{E}-10$ & $5.17 \mathrm{E}-10$ \\
\hline${ }^{120 \mathrm{~m}} \mathrm{Sb}$ & M & unspecified & & & & & & & & $6.97 \mathrm{E}-08$ & $6.97 \mathrm{E}-08$ \\
\hline${ }^{124} \mathrm{Sb}$ & M & unspecified & & & & & & & & 8.24E-08 & $8.24 \mathrm{E}-08$ \\
\hline${ }^{125} \mathrm{Sb}$ & M & unspecified & & & & & & & & $2.29 \mathrm{E}-08$ & $2.29 \mathrm{E}-08$ \\
\hline${ }^{126} \mathrm{Sb}$ & M & unspecified & & & & & & & & $2.51 \mathrm{E}-07$ & $2.51 \mathrm{E}-07$ \\
\hline${ }^{127} \mathrm{Sb}$ & M & unspecified & & & & & & & & 7.03E-07 & 7.03E-07 \\
\hline
\end{tabular}


Table 5.8. (continued)

\begin{tabular}{|c|c|c|c|c|c|c|c|c|c|c|c|}
\hline \multirow[b]{2}{*}{ Isotope } & \multirow{2}{*}{$\begin{array}{l}\text { Inhalation } \\
\text { form }^{b}\end{array}$} & \multirow{2}{*}{$\begin{array}{l}\text { Chemical } \\
\text { form }\end{array}$} & \multicolumn{9}{|c|}{ Stack } \\
\hline & & & X-2026 & $\mathrm{X}-\mathbf{3 0 2 0}$ & X-3039 & $X-7503$ & X-7880 & X-7911 & X-8915 & $\begin{array}{c}\text { Total minor } \\
\text { source }\end{array}$ & $\begin{array}{c}\text { ORNL } \\
\text { total }\end{array}$ \\
\hline${ }^{46} \mathrm{Sc}$ & $\mathrm{M}$ & unspecified & & & & & & & & $6.75 \mathrm{E}-12$ & $6.75 \mathrm{E}-12$ \\
\hline${ }^{75} \mathrm{Se}$ & $\mathrm{S}$ & unspecified & & & $5.42 \mathrm{E}-04$ & & $1.68 \mathrm{E}-06$ & & & & $5.44 \mathrm{E}-04$ \\
\hline${ }^{32} \mathrm{Si}$ & M & unspecified & & & & & & & & $4.10 \mathrm{E}-15$ & $4.10 \mathrm{E}-15$ \\
\hline${ }^{145} \mathrm{Sm}$ & M & unspecified & & & & & & & & $5.82 \mathrm{E}-05$ & $5.82 \mathrm{E}-05$ \\
\hline${ }^{151} \mathrm{Sm}$ & M & unspecified & & & & & & & & $2.00 \mathrm{E}-11$ & $2.00 \mathrm{E}-11$ \\
\hline${ }^{153} \mathrm{Sm}$ & M & unspecified & & & & & & & & $1.01 \mathrm{E}+01$ & $1.01 \mathrm{E}+01$ \\
\hline${ }^{117 \mathrm{~m}} \mathrm{Sn}$ & M & unspecified & & & & & & & & $1.32 \mathrm{E}-07$ & $1.32 \mathrm{E}-07$ \\
\hline${ }^{121 \mathrm{~m}} \mathrm{Sn}$ & M & unspecified & & & & & & & & $1.35 \mathrm{E}-12$ & $1.35 \mathrm{E}-12$ \\
\hline${ }^{125} \mathrm{Sn}$ & M & unspecified & & & & & & & & $2.04 \mathrm{E}-07$ & $2.04 \mathrm{E}-07$ \\
\hline${ }^{89} \mathrm{Sr}$ & M & unspecified & 4.91E-08 & $9.25 \mathrm{E}-07$ & & & & $7.60 \mathrm{E}-06$ & & $8.14 \mathrm{E}-12$ & $8.57 \mathrm{E}-06$ \\
\hline${ }^{89} \mathrm{Sr}$ & $\mathrm{S}$ & unspecified & & & $3.20 \mathrm{E}-05$ & $1.64 \mathrm{E}-07$ & & & & $5.37 \mathrm{E}-05$ & $8.59 \mathrm{E}-05$ \\
\hline${ }^{90} \mathrm{Sr}$ & M & unspecified & 4.91E-08 & $9.25 \mathrm{E}-07$ & & & & 7.60E-06 & & $3.18 \mathrm{E}-04$ & $3.26 \mathrm{E}-04$ \\
\hline${ }^{90} \mathrm{Sr}$ & $\mathrm{S}$ & unspecified & & & $3.20 \mathrm{E}-05$ & $1.64 \mathrm{E}-07$ & $1.08 \mathrm{E}-05$ & & & $5.37 \mathrm{E}-05$ & $9.67 \mathrm{E}-05$ \\
\hline${ }^{182} \mathrm{Ta}$ & M & unspecified & & & & & & & & 4.99E-09 & $4.99 \mathrm{E}-09$ \\
\hline${ }^{99} \mathrm{Tc}$ & M & unspecified & & & & & & & & $5.36 \mathrm{E}-11$ & $5.36 \mathrm{E}-11$ \\
\hline${ }^{99} \mathrm{Tc}$ & $\mathrm{S}$ & unspecified & & & & & $9.60 \mathrm{E}-06$ & & & $1.24 \mathrm{E}-05$ & $2.20 \mathrm{E}-05$ \\
\hline${ }^{125 \mathrm{~m}} \mathrm{Te}$ & M & particulate & & & & & & & & $2.06 \mathrm{E}-12$ & $2.06 \mathrm{E}-12$ \\
\hline${ }^{129 \mathrm{~m}} \mathrm{Te}$ & M & particulate & & & & & & & & $1.21 \mathrm{E}-07$ & $1.21 \mathrm{E}-07$ \\
\hline${ }^{132} \mathrm{Te}$ & M & particulate & & & & & & & & 4.83E-07 & $4.83 \mathrm{E}-07$ \\
\hline${ }^{227} \mathrm{Th}$ & $\mathrm{S}$ & unspecified & & & & & & & & $7.82 \mathrm{E}-07$ & $7.82 \mathrm{E}-07$ \\
\hline${ }^{228} \mathrm{Th}$ & S & unspecified & & $5.17 \mathrm{E}-08$ & $5.53 \mathrm{E}-08$ & $6.46 \mathrm{E}-10$ & & 4.15E-08 & & $1.81 \mathrm{E}-07$ & $3.30 \mathrm{E}-07$ \\
\hline${ }^{229} \mathrm{Th}$ & S & unspecified & & & & & & & & $1.60 \mathrm{E}-13$ & $1.60 \mathrm{E}-13$ \\
\hline${ }^{230} \mathrm{Th}$ & $\mathrm{F}$ & unspecified & & & $9.41 \mathrm{E}-09$ & $1.26 \mathrm{E}-09$ & & & & $1.27 \mathrm{E}-09$ & $1.19 \mathrm{E}-08$ \\
\hline${ }^{230} \mathrm{Th}$ & S & unspecified & $1.37 \mathrm{E}-09$ & $3.01 \mathrm{E}-09$ & & & & $1.99 \mathrm{E}-08$ & & $3.89 \mathrm{E}-09$ & $2.82 \mathrm{E}-08$ \\
\hline${ }^{232} \mathrm{Th}$ & $\mathrm{F}$ & unspecified & & & 7.48E-09 & $1.57 \mathrm{E}-09$ & & & & $8.48 \mathrm{E}-10$ & $9.90 \mathrm{E}-09$ \\
\hline${ }^{232} \mathrm{Th}$ & S & unspecified & $3.80 \mathrm{E}-07$ & 7.29E-07 & & & & $3.53 \mathrm{E}-08$ & & $1.00 \mathrm{E}-03$ & $1.00 \mathrm{E}-03$ \\
\hline${ }^{234} \mathrm{Th}$ & $\mathrm{S}$ & unspecified & & & & & & & & $8.12 \mathrm{E}-06$ & $8.12 \mathrm{E}-06$ \\
\hline
\end{tabular}


Table 5.8. (continued)

\begin{tabular}{|c|c|c|c|c|c|c|c|c|c|c|c|}
\hline \multirow[b]{2}{*}{ Isotope } & \multirow{2}{*}{$\begin{array}{l}\text { Inhalation } \\
\text { form }^{b}\end{array}$} & \multirow{2}{*}{$\begin{array}{l}\text { Chemical } \\
\text { form }\end{array}$} & \multicolumn{9}{|c|}{ Stack } \\
\hline & & & X-2026 & $\mathrm{X}-3020$ & X-3039 & $X-7503$ & X-7880 & X-7911 & X-8915 & $\begin{array}{l}\text { Total minor } \\
\text { source }\end{array}$ & $\begin{array}{c}\text { ORNL } \\
\text { total }\end{array}$ \\
\hline${ }^{208} \mathrm{Tl}$ & $\mathrm{M}$ & unspecified & & & & & & & & $8.01 \mathrm{E}-08$ & $8.01 \mathrm{E}-08$ \\
\hline${ }^{170} \mathrm{Tm}$ & M & unspecified & & & & & & & & $1.20 \mathrm{E}-08$ & $1.20 \mathrm{E}-08$ \\
\hline${ }^{232} \mathrm{U}$ & M & unspecified & & & & & & & & $8.01 \mathrm{E}-08$ & $8.01 \mathrm{E}-08$ \\
\hline${ }^{233} \mathrm{U}$ & M & unspecified & & & & & & $9.70 \mathrm{E}-08$ & & $1.01 \mathrm{E}-09$ & $9.80 \mathrm{E}-08$ \\
\hline${ }^{233} \mathrm{U}$ & $\mathrm{S}$ & unspecified & & & $1.17 \mathrm{E}-07$ & $9.80 \mathrm{E}-09$ & $7.25 \mathrm{E}-07$ & & & $7.66 \mathrm{E}-06$ & $8.51 \mathrm{E}-06$ \\
\hline${ }^{234} \mathrm{U}$ & M & unspecified & $1.39 \mathrm{E}-07$ & 8.04E-07 & & & & $9.70 \mathrm{E}-08$ & & $1.48 \mathrm{E}-05$ & $1.59 \mathrm{E}-05$ \\
\hline${ }^{234} \mathrm{U}$ & $\mathrm{S}$ & unspecified & & & $1.17 \mathrm{E}-07$ & $9.80 \mathrm{E}-09$ & $7.25 \mathrm{E}-07$ & & & 7.67E-06 & $8.52 \mathrm{E}-06$ \\
\hline${ }^{235} \mathrm{U}$ & M & unspecified & $1.91 \mathrm{E}-09$ & $3.56 \mathrm{E}-08$ & & & & $2.06 \mathrm{E}-08$ & & $8.65 \mathrm{E}-05$ & $8.66 \mathrm{E}-05$ \\
\hline${ }^{235} \mathrm{U}$ & $\mathrm{S}$ & unspecified & & & 4.42E-08 & $7.62 \mathrm{E}-10$ & $1.22 \mathrm{E}-06$ & & & $9.47 \mathrm{E}-07$ & $2.21 \mathrm{E}-06$ \\
\hline${ }^{236} \mathrm{U}$ & M & unspecified & & & & & & & & $1.91 \mathrm{E}-08$ & $1.91 \mathrm{E}-08$ \\
\hline${ }^{236} \mathrm{U}$ & $\mathrm{S}$ & unspecified & & & & & & & & $1.20 \mathrm{E}-06$ & $1.20 \mathrm{E}-06$ \\
\hline${ }^{238} \mathrm{U}$ & M & unspecified & 3.63E-09 & 2.19E-08 & & & & $1.71 \mathrm{E}-08$ & & $5.02 \mathrm{E}-03$ & $5.02 \mathrm{E}-03$ \\
\hline${ }^{238} \mathrm{U}$ & $\mathrm{S}$ & unspecified & & & $5.47 \mathrm{E}-08$ & $1.28 \mathrm{E}-09$ & 8.87E-07 & & & $7.82 \mathrm{E}-07$ & $1.73 \mathrm{E}-06$ \\
\hline${ }^{181} \mathrm{~W}$ & M & unspecified & & & & & & & & $3.21 \mathrm{E}-08$ & $3.21 \mathrm{E}-08$ \\
\hline${ }^{185} \mathrm{~W}$ & M & unspecified & & & & & & & & $1.71 \mathrm{E}-07$ & $1.71 \mathrm{E}-07$ \\
\hline${ }^{188} \mathrm{~W}$ & M & unspecified & & & & & & & & $3.50 \mathrm{E}-08$ & $3.50 \mathrm{E}-08$ \\
\hline${ }^{127} \mathrm{Xe}$ & $\mathrm{G}$ & unspecified & & & & & & & $2.76 \mathrm{E}+01$ & & $2.76 \mathrm{E}+01$ \\
\hline${ }^{131 \mathrm{~m}} \mathrm{Xe}$ & G & unspecified & & & & & & $1.39 \mathrm{E}+02$ & & & $1.39 \mathrm{E}+02$ \\
\hline${ }^{133} \mathrm{Xe}$ & G & unspecified & & & & & & $7.80 \mathrm{E}+00$ & & & $7.80 \mathrm{E}+00$ \\
\hline${ }^{133 \mathrm{~m}} \mathrm{Xe}$ & G & unspecified & & & & & & $1.98 \mathrm{E}+01$ & & & $1.98 \mathrm{E}+01$ \\
\hline${ }^{135} \mathrm{Xe}$ & G & unspecified & & & 7.09E-05 & & & $3.23 \mathrm{E}+01$ & & $3.71 \mathrm{E}-06$ & $3.23 \mathrm{E}+01$ \\
\hline${ }^{135 \mathrm{~m}} \mathrm{Xe}$ & G & unspecified & & & & & & $2.22 \mathrm{E}+01$ & & & $2.22 \mathrm{E}+01$ \\
\hline${ }^{137} \mathrm{Xe}^{g}$ & G & unspecified & & & & & & $4.32 \mathrm{E}+01$ & & & $4.32 \mathrm{E}+01$ \\
\hline${ }^{138} \mathrm{Xe}$ & G & unspecified & & & & & & $9.07 \mathrm{E}+01$ & & & $9.07 \mathrm{E}+01$ \\
\hline${ }^{88} \mathrm{Y}$ & M & unspecified & & & & & & & & $9.01 \mathrm{E}-10$ & $9.01 \mathrm{E}-10$ \\
\hline${ }^{88} \mathrm{Y}$ & $\mathrm{F}$ & unspecified & & & & & $2.73 \mathrm{E}-06$ & & & & $2.73 \mathrm{E}-06$ \\
\hline${ }^{91} \mathrm{Y}$ & M & unspecified & & & & & & & & $3.19 \mathrm{E}-12$ & $3.19 \mathrm{E}-12$ \\
\hline
\end{tabular}


Table 5.8. (continued)

\begin{tabular}{|c|c|c|c|c|c|c|c|c|c|c|c|}
\hline \multirow[b]{2}{*}{ Isotope } & \multirow{2}{*}{$\begin{array}{l}\text { Inhalation } \\
\text { form }^{b}\end{array}$} & \multirow{2}{*}{$\begin{array}{l}\text { Chemical } \\
\text { form }\end{array}$} & \multicolumn{9}{|c|}{ Stack } \\
\hline & & & $\mathrm{X}-2026$ & $\mathrm{X}-3020$ & X-3039 & $X-7503$ & $\mathrm{X}-7880$ & X-7911 & X-8915 & $\begin{array}{l}\text { Total minor } \\
\text { source }\end{array}$ & $\begin{array}{c}\text { ORNL } \\
\text { total }\end{array}$ \\
\hline${ }^{175} \mathrm{Yb}$ & $\mathrm{M}$ & unspecified & & & & & & & & $1.00 \mathrm{E}-08$ & $1.00 \mathrm{E}-08$ \\
\hline${ }^{65} \mathrm{Zn}$ & $\mathrm{F}$ & unspecified & & & & & $4.29 \mathrm{E}-06$ & & & & $4.29 \mathrm{E}-06$ \\
\hline${ }^{65} \mathrm{Zn}$ & M & unspecified & & & & & & & & $6.08 \mathrm{E}-09$ & $6.08 \mathrm{E}-09$ \\
\hline${ }^{93} \mathrm{Zr}$ & M & unspecified & & & & & & & & $5.66 \mathrm{E}-13$ & $5.66 \mathrm{E}-13$ \\
\hline${ }^{95} \mathrm{Zr}$ & $\mathrm{M}$ & unspecified & & & & & & & & $7.25 \mathrm{E}-08$ & $7.25 \mathrm{E}-08$ \\
\hline${ }^{95} \mathrm{Zr}$ & $\mathrm{S}$ & unspecified & & & & & $4.22 \mathrm{E}-06$ & & & & $4.22 \mathrm{E}-06$ \\
\hline Totals & & & $5.96 \mathrm{E}-01$ & $4.79 \mathrm{E}-01$ & $9.13 \mathrm{E}+00$ & $1.12 \mathrm{E}+00$ & $1.47 \mathrm{E}-04$ & $2.67 \mathrm{E}+03$ & $6.28 \mathrm{E}+03$ & $1.06 \mathrm{E}+01$ & $8.97 \mathrm{E}+03$ \\
\hline
\end{tabular}

${ }^{a}$ Emissions given in curies $(\mathrm{Ci}) .1 \mathrm{Ci}=3.7 \mathrm{E}+10 \mathrm{~Bq}$.

${ }^{b}$ For particulates, fast $(\mathrm{F})$, moderate $(\mathrm{M})$, or slow $(\mathrm{S})$ refers to the form of the isotope inhaled [associated with the rate of dissolution and level of absorption into the blood (EPA 1999)]. For nonparticulates, (G) or (V) refers to the form in which the isotope was inhaled, gas or vapor, respectively.

${ }^{c}$ Californium-248 surrogate for Californium-252

${ }^{d}$ Curium-245 surrogate for Curium-248

${ }^{e}$ Krypton-88 surrogate for Krypton- 89

${ }^{f}$ Polonium-210 surrogate for Polonium-209

${ }^{g}$ Xenon-135 surrogate for Xenon-137

\section{Abbreviations}

ORNL = Oak Ridge National Laboratory 
Historical trends for ${ }^{3} \mathrm{H}$ (tritium) and ${ }^{131} \mathrm{I}$ are presented in Figs. 5.13 and 5.14. For 2013, tritium emissions totaled about 451.8 Ci (Fig. 5.13), a slight increase from 2012; ${ }^{131}$ I emissions totaled 0.17 Ci (Fig. 5.14), a slight increase but in line with 2012 emissions. The increase in tritium was due to SNS operations and research activities at REDC involving the processing of heavy element targets. For 2013 the major dose contributors to the off-site dose at ORNL were ${ }^{11} \mathrm{C},{ }^{212} \mathrm{~Pb},{ }^{41} \mathrm{Ar},{ }^{138} \mathrm{Cs}$, and ${ }^{232} \mathrm{Th}$, with dose contributions of about $43 \%, 20 \%, 7 \%, 6 \%$, and $5 \%$, respectively. Emissions of ${ }^{11} \mathrm{C}$ result from SNS operations and research activities. Emissions of ${ }^{212} \mathrm{~Pb}$ result from the radiation decay of legacy material stored on the site and contamination areas containing isotopes of ${ }^{228} \mathrm{Th},{ }^{232} \mathrm{Th}$, and ${ }^{232} \mathrm{U}$. Emissions of ${ }^{212} \mathrm{~Pb}$ were from the 2026, 3020, 3039, 7503, 7856, 7935, and 7911 stacks; the STP sludge drier; and the 4000 area laboratory hoods. Emissions of ${ }^{138} \mathrm{Cs}$ were primarily due to research activities at REDC, which exhaust through the 7911 Melton Valley complex stack. Emissions of ${ }^{232} \mathrm{Th}$ come from a number of operations and research activities on the ORNL site. For $2013,{ }^{11} \mathrm{C}$ emissions totaled $5,693 \mathrm{Ci}$, almost double that of $2012 ;{ }^{212} \mathrm{~Pb}$ emissions totaled $2 \mathrm{Ci}$; ${ }^{232} \mathrm{Th}$ emissions totaled $1.00 \mathrm{E}-03 \mathrm{Ci}$; and ${ }^{138} \mathrm{Cs}$ emissions totaled $503 \mathrm{Ci}$ (Fig. 5.15). Emissions of ${ }^{41} \mathrm{Ar}$ totaled $985 \mathrm{Ci}$, which was an increase from 2012.

The calculated radiation dose to the maximally exposed individual (MEI) from all radiological airborne release points at ORR during 2013 was $0.4 \mathrm{mrem}$. The dose contribution to the MEI from all ORNL radiological airborne release points was $97.3 \%$ of the ORR dose. This dose is well below the NESHAPs standard of $10 \mathrm{mrem}$ and is less than $0.1 \%$ of the roughly $300 \mathrm{mrem}$ that the average individual receives from natural sources of radiation. (See Section 7.1.2 for an explanation of how the airborne radionuclide dose was determined.)

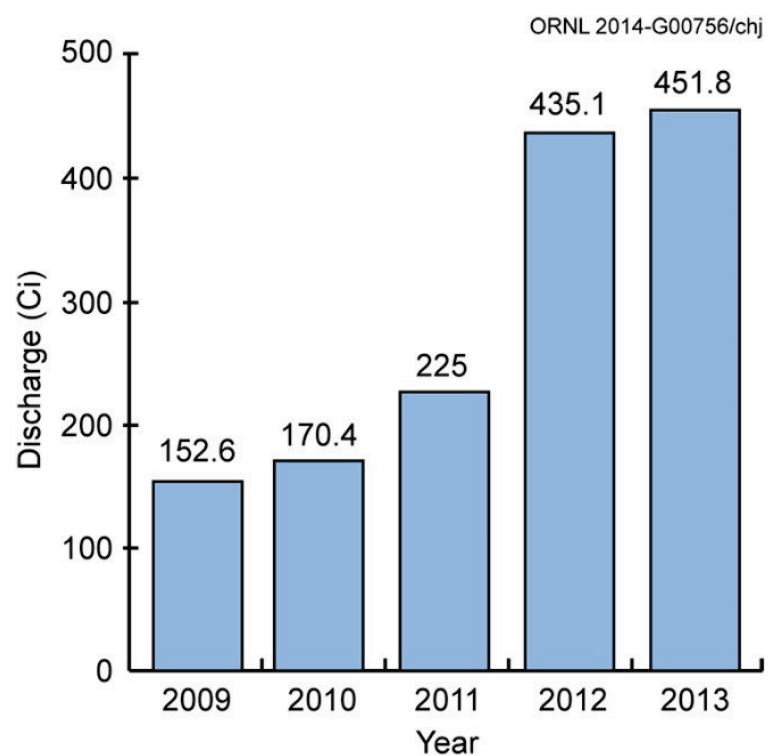

Fig. 5.13. Total curies of tritium discharged from Oak Ridge National Laboratory to the atmosphere, 2009-2013.

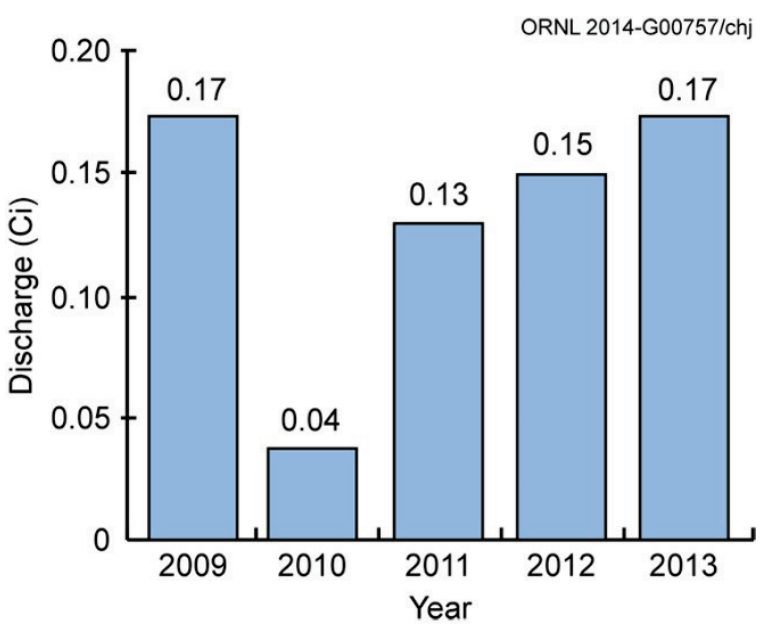

Fig. 5.14. Total curies of ${ }^{131} I$ discharged from Oak Ridge National Laboratory to the atmosphere, 2009-2013. 


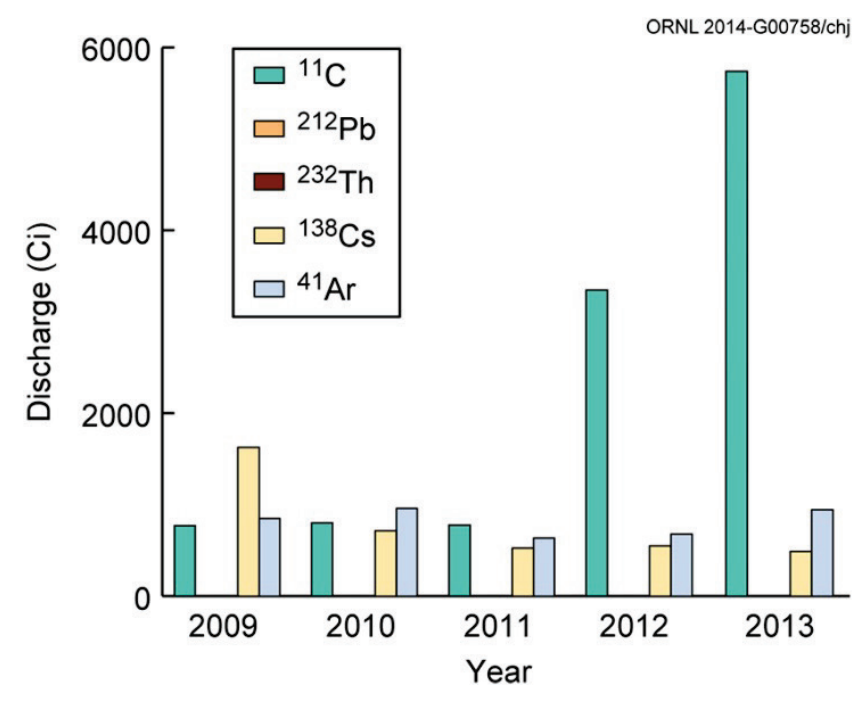

Fig. 5.15. Total discharges of ${ }^{41} \mathrm{Ar},{ }^{11} \mathrm{C},{ }^{138} \mathrm{Cs}$, ${ }^{212} \mathrm{~Pb}$, and ${ }^{232} \mathrm{Th}$ from Oak Ridge National Laboratory to the atmosphere, 2009-2013. (Note: Levels of ${ }^{212} \mathrm{~Pb}$ and ${ }^{232} \mathrm{Th}$ discharged were too low to accurately depict on this figure.)

\subsubsection{Stratospheric Ozone Protection}

As required by the CAA Title VI Amendments of 1990, actions have been implemented to comply with the prohibition against intentionally releasing ODSs during maintenance activities performed on refrigeration equipment. In addition, service requirements for refrigeration systems (including motor vehicle air conditioners), technician certification requirements, and labeling requirements have been implemented. ORNL has implemented a plan to phase out the use of all Class I ODSs. All critical applications of Class I ODSs have been eliminated, replaced, or retrofitted with other materials. Work is progressing as funding becomes available for noncritical applications.

\subsubsection{Ambient Air}

The objectives of the ORNL ambient air monitoring program are to collect samples at site PAM stations located in areas most likely to show impacts of airborne emissions from ORNL and to provide information to support emergency response activities. Four stations, identified as stations 1, 2, 3, and 7, make up the ORNL PAM network (Fig. 5.16). During 2013 sampling was conducted at each station to quantify levels of tritium; uranium; and gross alpha-, beta-, and gamma-emitting radionuclides (Table 5.9).

The sampling system consists of a low-volume air sampler for particulate collection in a $47 \mathrm{~mm}$ glass-fiber filter. The filters are collected biweekly, composited annually, then submitted to the laboratory for analysis. A silica-gel column is used for collection of tritium as tritiated water. These samples are typically collected biweekly or weekly, depending on ambient humidity levels, and composited quarterly for tritium analysis. 


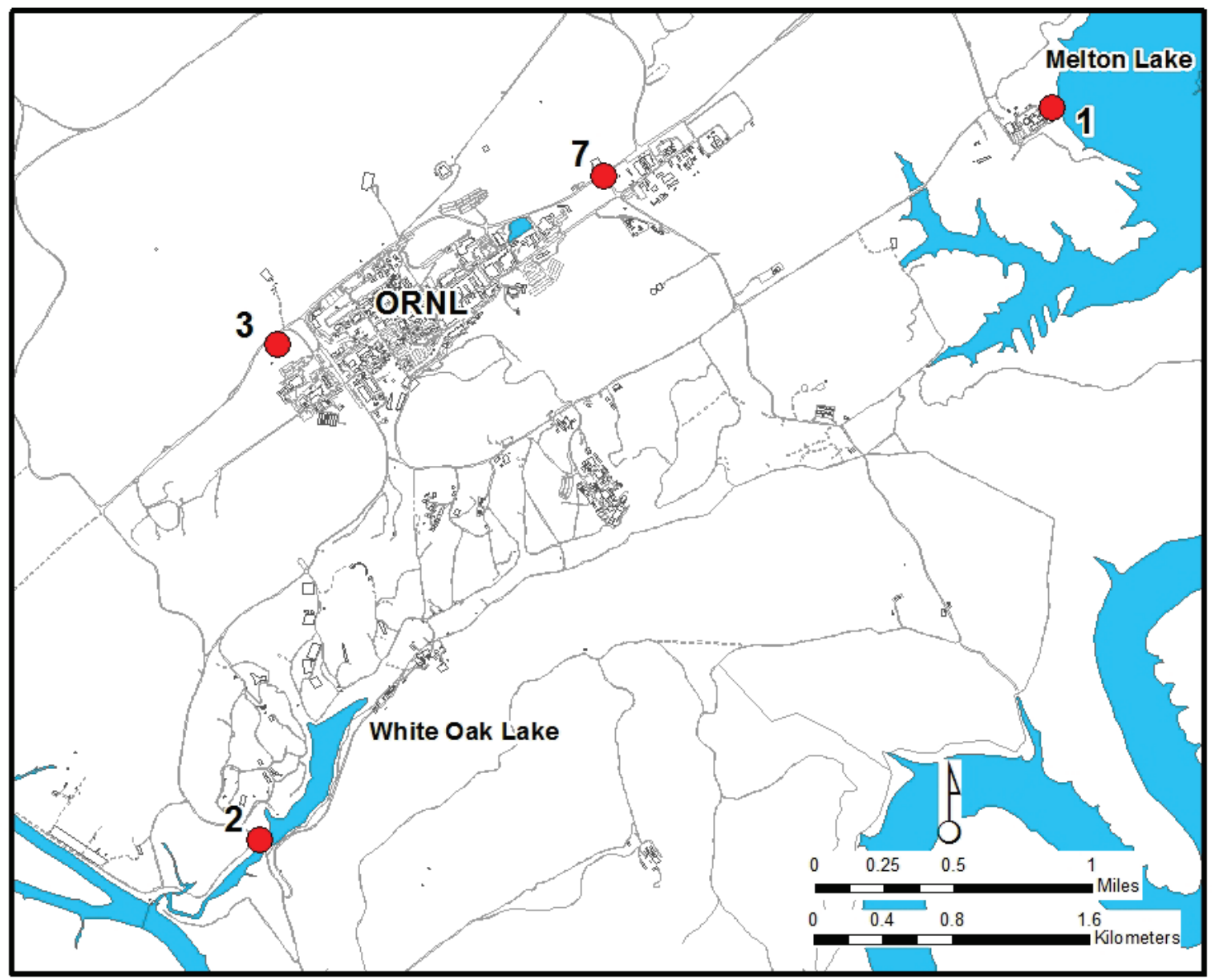

Fig. 5.16. Locations of ambient air monitoring stations at Oak Ridge National Laboratory.

Table 5.9. Radionuclide concentrations $(\mathrm{pCi} / \mathrm{mL})^{a}$ measured at Oak Ridge National Laboratory perimeter air monitoring stations, 2013

\begin{tabular}{lrrrr}
\hline \multirow{2}{*}{ Parameter } & $\begin{array}{c}\text { Number } \\
\text { detected/ } \\
\text { sampled }\end{array}$ & \multicolumn{3}{c}{ Concentration } \\
\cline { 3 - 5 } & & \multicolumn{1}{c}{ Average } & Minimum & Maximum \\
\hline & $4 / 4$ & $2.30 \mathrm{E}-09$ & $1.90 \mathrm{E}-09$ & $3.18 \mathrm{E}-09$ \\
$\mathrm{Alpha}$ & $4 / 4$ & $3.44 \mathrm{E}-08$ & $3.16 \mathrm{E}-08$ & $3.96 \mathrm{E}-08$ \\
${ }^{7} \mathrm{Be}$ & $4 / 4$ & $8.88 \mathrm{E}-09$ & $6.19 \mathrm{E}-09$ & $1.11 \mathrm{E}-08$ \\
$\mathrm{Beta}$ & $1 / 4$ & $5.38 \mathrm{E}-06$ & $-1.6 \mathrm{E}-06$ & $1.13 \mathrm{E}-05$ \\
${ }^{3} \mathrm{H}$ & $0 / 4$ & $-3.65 \mathrm{E}-10$ & $-6.19 \mathrm{E}-10$ & $-3.10 \mathrm{E}-11$ \\
${ }^{40} \mathrm{~K}$ & $4 / 4$ & $4.12 \mathrm{E}-12$ & $2.41 \mathrm{E}-12$ & $7.96 \mathrm{E}-12$ \\
${ }^{234} \mathrm{U}$ & $2 / 4$ & $1.82 \mathrm{E}-13$ & $-1.89 \mathrm{E}-13$ & $3.55 \mathrm{E}-13$ \\
${ }^{235} \mathrm{U}$ & $4 / 4$ & $2.29 \mathrm{E}-12$ & $1.93 \mathrm{E}-12$ & $2.55 \mathrm{E}-12$ \\
${ }^{238} \mathrm{U}$ & $4 / 4$ & $6.60 \mathrm{E}-12$ & $4.15 \mathrm{E}-12$ & $1.06 \mathrm{E}-11$ \\
${ }^{2} \mathrm{Total} \mathrm{U}$ & & & &
\end{tabular}


Table 5.9. (continued)

\begin{tabular}{|c|c|c|c|c|}
\hline \multirow{2}{*}{ Parameter } & \multirow{2}{*}{$\begin{array}{l}\text { Number } \\
\text { detected/ } \\
\text { sampled }\end{array}$} & \multicolumn{3}{|c|}{ Concentration } \\
\hline & & Average & Minimum & Maximum \\
\hline \multicolumn{5}{|c|}{ Station 2} \\
\hline Alpha & $1 / 1$ & $6.63 \mathrm{E}-09$ & $b$ & $b$ \\
\hline${ }^{7} \mathrm{Be}$ & $1 / 1$ & $1.95 \mathrm{E}-08$ & $b$ & $b$ \\
\hline Beta & $1 / 1$ & $1.85 \mathrm{E}-08$ & $b$ & $b$ \\
\hline${ }^{3} \mathrm{H}$ & $0 / 4$ & $2.69 \mathrm{E}-06$ & $1.45 \mathrm{E}-06$ & $3.94 \mathrm{E}-06$ \\
\hline${ }^{40} \mathrm{~K}$ & $0 / 1$ & $5.76 \mathrm{E}-10$ & $b$ & $b$ \\
\hline${ }^{234} \mathrm{U}$ & $1 / 1$ & $5.31 \mathrm{E}-12$ & $b$ & $b$ \\
\hline${ }^{235} \mathrm{U}$ & $1 / 1$ & $8.02 \mathrm{E}-13$ & $b$ & $b$ \\
\hline${ }^{238} \mathrm{U}$ & $1 / 1$ & $2.99 \mathrm{E}-12$ & $b$ & $b$ \\
\hline Total U & $1 / 1$ & $9.09 \mathrm{E}-12$ & $b$ & $b$ \\
\hline \multicolumn{5}{|c|}{ Station 3} \\
\hline Alpha & $1 / 1$ & 5.49E-09 & $b$ & $b$ \\
\hline${ }^{7} \mathrm{Be}$ & $1 / 1$ & $2.08 \mathrm{E}-08$ & $b$ & $b$ \\
\hline Beta & $1 / 1$ & $1.61 \mathrm{E}-08$ & $b$ & $b$ \\
\hline${ }^{3} \mathrm{H}$ & $0 / 4$ & $2.93 \mathrm{E}-06$ & $-8.65 \mathrm{E}-07$ & $6.07 \mathrm{E}-06$ \\
\hline${ }^{40} \mathrm{~K}$ & $0 / 1$ & $-6.96 \mathrm{E}-11$ & $b$ & $b$ \\
\hline${ }^{234} \mathrm{U}$ & $1 / 1$ & $9.59 \mathrm{E}-12$ & $b$ & $b$ \\
\hline${ }^{235} \mathrm{U}$ & $1 / 1$ & $3.70 \mathrm{E}-13$ & $b$ & $b$ \\
\hline${ }^{238} \mathrm{U}$ & $1 / 1$ & $3.07 \mathrm{E}-12$ & $b$ & $b$ \\
\hline Total U & $1 / 1$ & $1.31 \mathrm{E}-11$ & $b$ & $b$ \\
\hline \multicolumn{5}{|c|}{ Station 7} \\
\hline Alpha & $1 / 1$ & $7.56 \mathrm{E}-09$ & $b$ & $b$ \\
\hline${ }^{7} \mathrm{Be}$ & $1 / 1$ & $1.90 \mathrm{E}-08$ & $b$ & $b$ \\
\hline Beta & $1 / 1$ & $1.81 \mathrm{E}-08$ & $b$ & $b$ \\
\hline${ }^{3} \mathrm{H}$ & $2 / 4$ & $1.11 \mathrm{E}-05$ & $-1.67 \mathrm{E}-09$ & $1.88 \mathrm{E}-05$ \\
\hline${ }^{40} \mathrm{~K}$ & $0 / 1$ & $8.71 \mathrm{E}-10$ & $b$ & $b$ \\
\hline${ }^{234} \mathrm{U}$ & $1 / 1$ & $1.35 \mathrm{E}-11$ & $b$ & $b$ \\
\hline${ }^{235} \mathrm{U}$ & $0 / 1$ & $1.85 \mathrm{E}-12$ & $b$ & $b$ \\
\hline${ }^{238} \mathrm{U}$ & $1 / 1$ & $5.97 \mathrm{E}-12$ & $b$ & $b$ \\
\hline Total U & $1 / 1$ & $2.13 \mathrm{E}-11$ & $b$ & $b$ \\
\hline
\end{tabular}

${ }_{1}^{a} \mathrm{pCi}=3.7 \times 10^{-2} \mathrm{~Bq}$.

${ }^{b}$ Not applicable.

\subsubsection{Results}

The ORNL PAM stations are designed to provide data for collectively assessing the specific impact of ORNL operations on local air quality. Sampling data from the ORNL PAM stations (Table 5.9) are compared with DCSs for air established by DOE as guidelines for controlling exposure to members of the public. During 2013, average radionuclide concentrations measured for the ORNL network were less than $1 \%$ of the applicable DCS in all cases.

\subsection{Oak Ridge National Laboratory Water Quality Program}

The NPDES permit issued to DOE for the ORNL site, TN 0002941, was renewed by the State of Tennessee in 2008 and includes requirements for discharging wastewaters from the three ORNL on-site 
wastewater treatment facilities and for the development and implementation of a water quality protection plan (WQPP). The permit calls for WQPP to "establish better linkages between water quality monitoring and detecting and abating water quality and ecological impact." Rather than prescribing rigid monitoring schedules, the ORNL WQPP is flexible, allows an annual assessment of all outfalls, and focuses on significant findings. The WQPP goals are to meet the requirements of the NPDES permit, improve the quality of aquatic resources on the ORNL site, prevent further impacts to aquatic resources from current activities, identify the stressors that contribute to impairment of aquatic resources, use available resources efficiently, and communicate outcomes with decision makers and stakeholders.

The ORNL WQPP was developed by UT-Battelle and approved by TDEC in 2008, and WQPP monitoring was initiated in 2009. WQPP incorporated several control plans that were required under the previous NPDES permit, including a BMAP (ORNL 1986), a chlorine control strategy, an SWPPP (ORNL 2007), a non-storm-water best management practices plan (ORNL 1997), and an NPDES radiological monitoring plan (ORNL 2008). WQPP has been reviewed and revised annually and submitted to TDEC for review and comment.

To prioritize the stressors and/or contaminant sources that may be of greatest concern to water quality and to define conceptual models that would guide any special investigations, the WQPP strategy was defined using EPA's Stressor Identification Guidance Document (EPA 2000). Figure 5.17 summarizes this process. The process involves three major steps for identifying the cause of any impairment:

1. list candidate causes of impairment (based on historical data and a working conceptual model),

2. analyze the evidence (using both case study and outside data), and

3. characterize the causes.

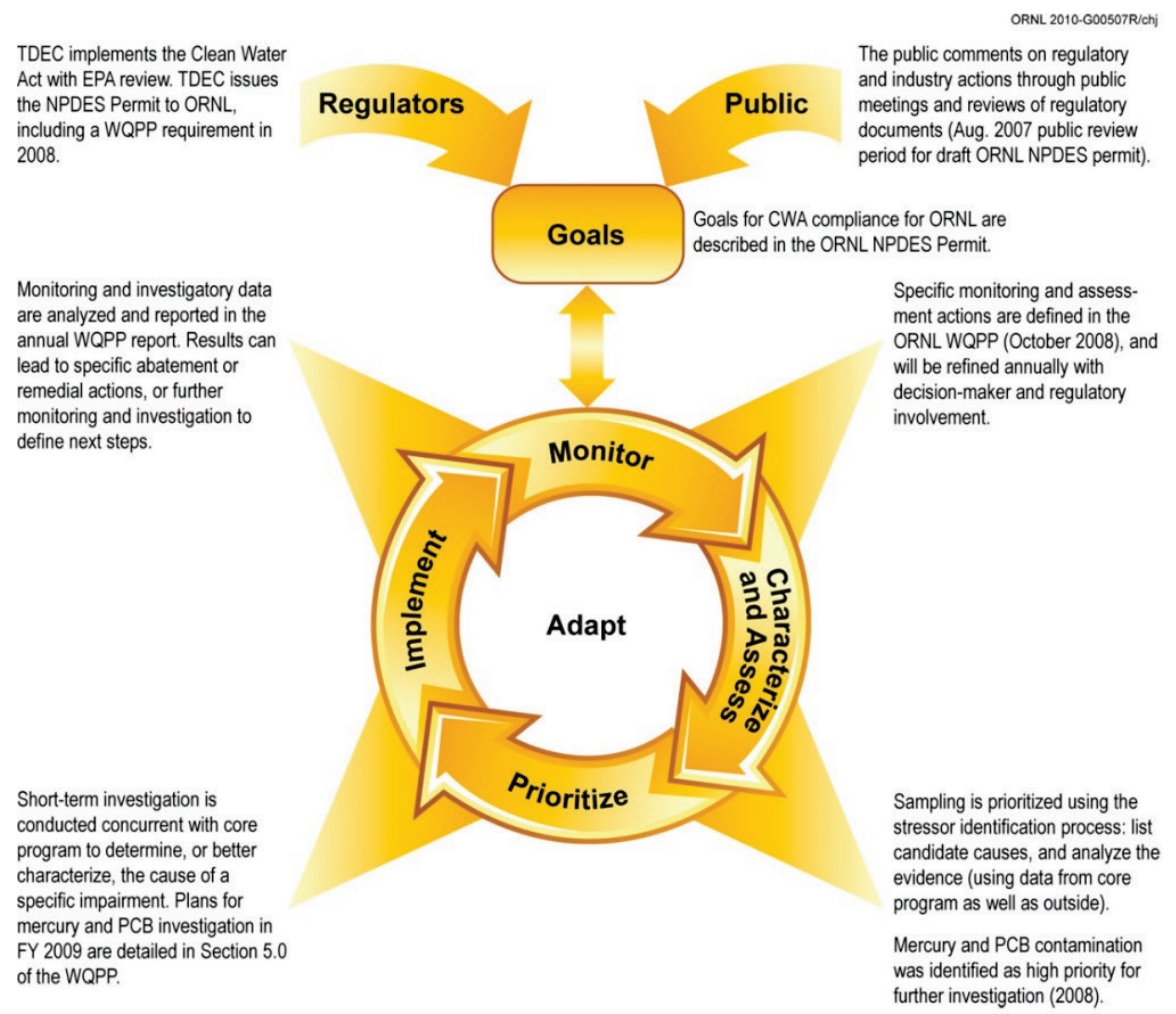

Fig. 5.17. Diagram of the adaptive management framework with step-wise planning specific to the Oak Ridge National Laboratory Water Quality Protection Plan (WQPP). [Adapted from the US Environmental Protection Agency (EPA) stressor guidance document (EPA 2000). Acronyms: CWA = Clean Water Act, NPDES = National Pollutant Discharge Elimination System, ORNL = Oak Ridge National Laboratory, $\mathrm{PCB}=$ polychlorinated biphenyl, TDEC $=$ Tennessee Department of Environment and Conservation.] 
The first two steps of the stressor identification process were initiated in 2009, focusing first on mercury impairment (Fig. 5.18) and then on PCBs because mercury and PCB concentrations in fish from WOC are at or near human health risk thresholds (e.g., EPA AWQC and TDEC fish advisory limits). Some of the major sources of mercury to biota in the WOC watershed are known, providing a good basis from which to define an appropriate conceptual model for mercury contamination in WOC. A list of potential causes of PCB contamination was also developed.

After listing potential causes and analyzing the available evidence on mercury and PCB contamination in the WOC watershed, it was clear that additional investigation was needed to complete the third step of the stressor identification process, "characterizing the cause." Special investigations were designed to identify specific source areas and to revise the conceptual model of the major causes of contamination in the WOC watershed.

At the end of each year, monitoring and investigation data collected under the ORNL WQPP will be analyzed, interpreted, reported, and compared with past results in the WQPP annual report. This information will provide a solid, overall assessment of the status of ORNL's receiving-stream watersheds and the impact of ongoing efforts to protect and restore those watersheds and will guide efforts to improve the water quality in the watershed.

Impairment

ORNL 2010-G00508/chj

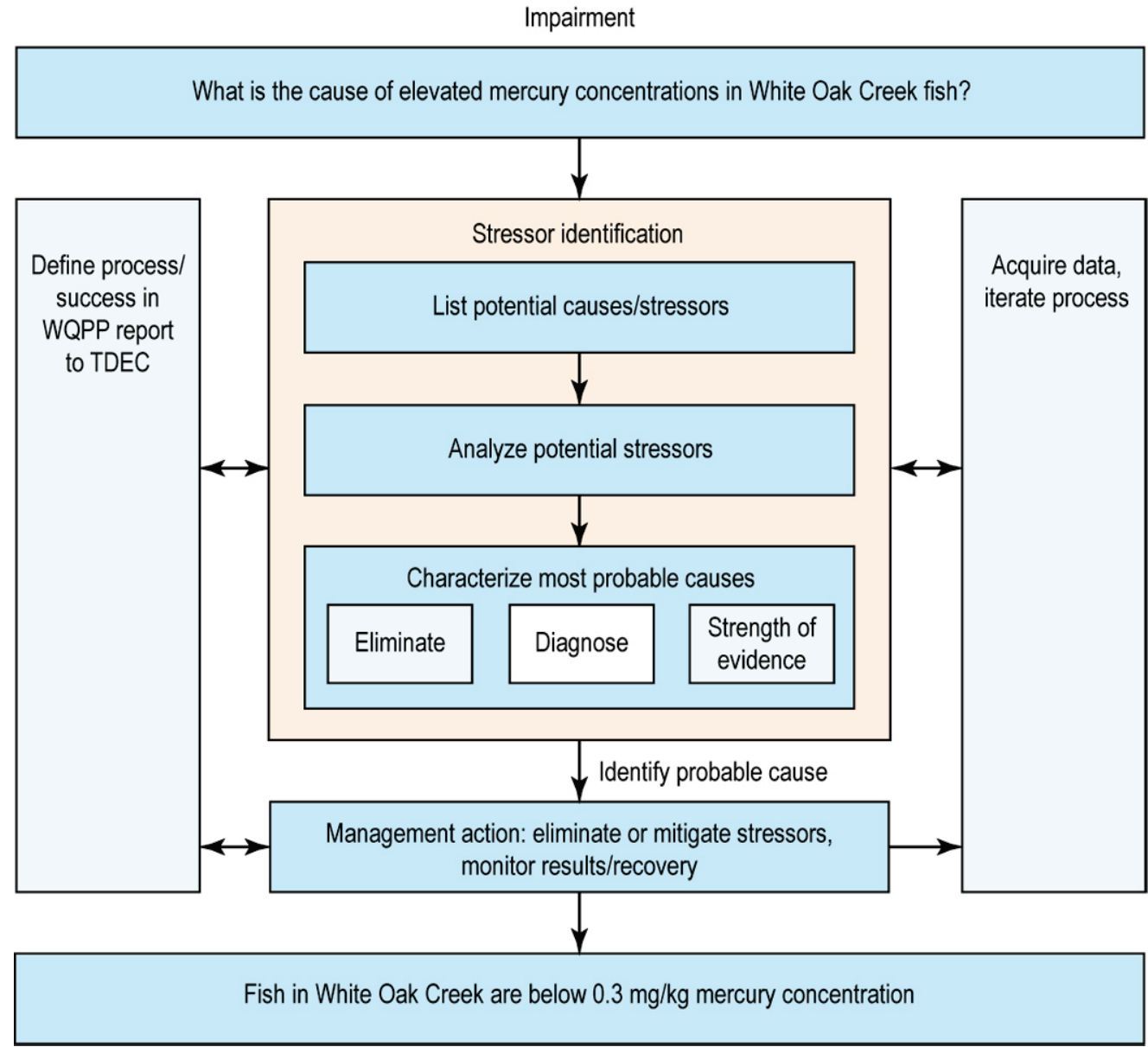

Fig. 5.18. Application of stressor identification guidance to address mercury impairment in the White Oak Creek watershed. [Modified from Figure 1-1 in the US Environmental Protection Agency stressor guidance document (EPA 2000). TDEC = Tennessee Department of Environment and Conservation, WQPP = water quality protection plan.] 


\subsubsection{Treatment Facility Discharges}

Two on-site wastewater treatment systems were operated at ORNL in 2013 to provide appropriate treatment of the various R\&D, operational, and domestic wastewaters generated by site staff and activities. Both were permitted to discharge treated wastewater and were monitored under NPDES permit TN0002941, issued to DOE for the ORNL site by TDEC. These are the ORNL STP (outfall X01) and the ORNL Process Waste Treatment Complex (PWTC; outfall X12). The ORNL NPDES permit requirements include monitoring the two ORNL wastewater treatment facility effluents for conventional, water-quality-based, and radiological constituents and for effluent toxicity, with numeric parameterspecific compliance limits established by TDEC as determined to be necessary.

The results of field measurements and laboratory analyses to assess compliance for the parameters required by the NPDES permit and rates of compliance with numeric limits established in the permit are also provided in Table 5.10. ORNL wastewater treatment facilities achieved $100 \%$ compliance with permit limits and conditions in 2013.

Table 5.10. National Pollutant Discharge Elimination System compliance at Oak Ridge National Laboratory, 2013 (NPDES permit effective August 1, 2008)

\begin{tabular}{|c|c|c|c|c|c|c|c|c|}
\hline \multirow[b]{2}{*}{$\begin{array}{c}\text { Effluent } \\
\text { parameters }\end{array}$} & \multicolumn{5}{|c|}{ Permit limits } & \multicolumn{3}{|c|}{ Permit compliance } \\
\hline & $\begin{array}{l}\text { Monthly } \\
\text { average } \\
\text { (lb/day) }\end{array}$ & $\begin{array}{c}\text { Daily } \\
\text { max. } \\
\text { (lb/day) }\end{array}$ & $\begin{array}{c}\text { Monthly } \\
\text { average } \\
(\mathrm{mg} / \mathrm{L}) \\
\end{array}$ & $\begin{array}{c}\text { Daily } \\
\max . \\
(\mathrm{mg} / \mathrm{L}) \\
\end{array}$ & $\begin{array}{c}\text { Daily } \\
\text { min. } \\
(\mathrm{mg} / \mathrm{L})\end{array}$ & $\begin{array}{c}\begin{array}{c}\text { Number } \\
\text { of } \\
\text { noncompliances }\end{array} \\
\end{array}$ & $\begin{array}{c}\text { Number } \\
\text { of } \\
\text { samples }\end{array}$ & $\begin{array}{c}\begin{array}{c}\text { Percentag } \\
\text { of }\end{array} \\
\text { complianc }\end{array}$ \\
\hline \multicolumn{9}{|c|}{ Outfall 585 (Melton Valley Steam Plant) } \\
\hline $\mathrm{pH}$ (standard units) & & & & 9 & 6 & 0 & 4 & 100 \\
\hline \multicolumn{9}{|c|}{ X01 (ORNL Sewage Treatment Plant) } \\
\hline $\begin{array}{l}\mathrm{LC}_{50} \text { for } \\
\quad \text { Ceriodaphnia }(\%)\end{array}$ & & & & & 69.4 & 0 & 2 & 100 \\
\hline $\begin{array}{l}\mathrm{LC}_{50} \text { for fathead } \\
\text { minnows }(\%)\end{array}$ & & & & & 69.4 & 0 & 2 & 100 \\
\hline $\begin{array}{l}\text { Ammonia, as } \mathrm{N} \\
\text { (summer) }\end{array}$ & 6.26 & 9.39 & 2.5 & 3.75 & & 0 & 26 & 100 \\
\hline $\begin{array}{l}\text { Ammonia, as } \mathrm{N} \\
\text { (winter) }\end{array}$ & 13.14 & 19.78 & 5.25 & 7.9 & & 0 & 27 & 100 \\
\hline $\begin{array}{l}\text { Carbonaceous } \\
\text { biological oxygen } \\
\text { demand }\end{array}$ & 19.2 & 28.8 & 10 & 15 & & 0 & 53 & 100 \\
\hline Dissolved oxygen & & & & & 6 & 0 & 53 & 100 \\
\hline $\begin{array}{l}\text { Escherichia coliform } \\
\quad(\mathrm{col} / 100 \mathrm{~mL})\end{array}$ & & & 941 & 126 & & 0 & 53 & 100 \\
\hline $\begin{array}{l}\mathrm{IC}_{25} \text { for } \\
\quad \text { Ceriodaphnia }(\%)\end{array}$ & & & & & 15.5 & 0 & 2 & 100 \\
\hline $\begin{array}{l}\mathrm{IC}_{25} \text { for fathead } \\
\text { minnows }(\%)\end{array}$ & & & & & 15.5 & 0 & 2 & 100 \\
\hline Oil and grease & 19.2 & 28.8 & 10 & 15 & & 0 & 13 & 100 \\
\hline pH (standard units) & & & & 9 & 6 & 0 & 53 & 100 \\
\hline $\begin{array}{l}\text { Total suspended } \\
\text { solids }\end{array}$ & 57.5 & 86.3 & 30 & 45 & & 0 & 53 & 100 \\
\hline \multicolumn{9}{|c|}{ X12 (Process Waste Treatment Complex) } \\
\hline $\begin{array}{l}\mathrm{LC}_{50} \text { for } \\
\quad \text { Ceriodaphnia }(\%)\end{array}$ & & & & & 100 & 0 & 2 & 100 \\
\hline $\begin{array}{r}\mathrm{LC}_{50} \text { for fathead } \\
\text { minnows }(\%)\end{array}$ & & & & & 100 & 0 & 2 & 100 \\
\hline Arsenic, total & & & 0.007 & 0.014 & & 0 & 6 & 100 \\
\hline Cadmium, total & 1.73 & 4.60 & 0.003 & 0.038 & & 0 & 6 & 100 \\
\hline
\end{tabular}


Table 5.10. (continued)

\begin{tabular}{|c|c|c|c|c|c|c|c|c|}
\hline \multirow[b]{2}{*}{$\begin{array}{c}\text { Effluent } \\
\text { parameters }\end{array}$} & \multicolumn{5}{|c|}{ Permit limits } & \multicolumn{3}{|c|}{ Permit compliance } \\
\hline & $\begin{array}{l}\text { Monthly } \\
\text { average } \\
\text { (lb/day) }\end{array}$ & $\begin{array}{c}\text { Daily } \\
\text { max. } \\
\text { (lb/day) }\end{array}$ & $\begin{array}{c}\text { Monthly } \\
\text { average } \\
(\mathrm{mg} / \mathrm{L})\end{array}$ & $\begin{array}{c}\text { Daily } \\
\max . \\
(\mathrm{mg} / \mathrm{L})\end{array}$ & $\begin{array}{l}\text { Daily } \\
\text { min. } \\
(\mathrm{mg} / \mathrm{L})\end{array}$ & $\begin{array}{c}\text { Number } \\
\text { of } \\
\text { noncompliances }\end{array}$ & $\begin{array}{c}\text { Number } \\
\text { of } \\
\text { samples }\end{array}$ & $\begin{array}{c}\text { Percentage } \\
\text { of } \\
\text { compliance }\end{array}$ \\
\hline Chromium, total & 11.40 & 18.46 & 0.22 & 0.44 & & 0 & 6 & 100 \\
\hline Copper, total & 13.8 & 22.53 & 0.07 & 0.11 & & 0 & 6 & 100 \\
\hline Cyanide, total & 4.33 & 8.00 & 0.008 & 0.046 & & 0 & 2 & 100 \\
\hline Lead, total & 2.87 & 4.60 & 0.028 & 0.69 & & 0 & 6 & 100 \\
\hline $\begin{array}{l}\mathrm{IC}_{25} \text { for Ceriodaphnia } \\
\quad(\%)\end{array}$ & & & & & 30.5 & 0 & 2 & 100 \\
\hline $\begin{array}{l}\mathrm{IC}_{25} \text { for fathead } \\
\text { minnows }(\%)\end{array}$ & & & & & 30.5 & 0 & 2 & 100 \\
\hline Oil and grease & 66.7 & 100 & 10 & 15 & & 0 & 13 & 100 \\
\hline $\mathrm{pH}$ (standard units) & & & & 9.0 & 6.0 & 0 & 53 & 100 \\
\hline Temperature $\left({ }^{\circ} \mathrm{C}\right)$ & & & & 30.5 & & 0 & 53 & 100 \\
\hline \multicolumn{9}{|c|}{ Instream chlorine monitoring points } \\
\hline Total residual oxidant & & & 0.011 & 0.019 & & 0 & 288 & 100 \\
\hline \multicolumn{9}{|c|}{${ }^{a}$ Percentage compliance $=100[($ number of noncompliances/number of samples $) \times 100]}$. \\
\hline $\begin{array}{l}\text { Abbreviations } \\
\qquad \mathrm{LC}_{50}=\text { the concen } \\
\mathrm{IC}_{25}=\text { inhibition } \\
\text { survival, repr } \\
\mathrm{NPDES}=\text { Nation } \\
\text { ORNL }=\text { Oak Rid }\end{array}$ & $\begin{array}{l}\text { tration (as a } \\
\text { concentration } \\
\text { roduction, or } \\
\text { al Pollutant I } \\
\text { ge National }\end{array}$ & $\begin{array}{l}\text { percentage } \\
\mathrm{n} \text {; the conce } \\
\mathrm{r} \text { growth of } \\
\text { Discharge } \mathrm{I} \\
\text { Laboratory }\end{array}$ & $\begin{array}{l}\text { of full-stre } \\
\text { entration as } \\
\text { the test org } \\
\text { Elimination }\end{array}$ & $\begin{array}{l}\text { gth wastev } \\
\text { percentag } \\
\text { iisms. } \\
\text { ystem }\end{array}$ & $\begin{array}{l}\text { ater) that } \\
\text { of full-sti }\end{array}$ & $\begin{array}{l}\text { ills } 50 \% \text { of the test } \mathrm{s} \\
\text { ength wastewater that }\end{array}$ & $\begin{array}{l}\text { pecies in } 48 \\
t \text { caused } 25\end{array}$ & $\begin{array}{l}8 \mathrm{~h} . \\
5 \% \text { reduction in }\end{array}$ \\
\hline
\end{tabular}

Toxicity testing provides an assessment of any harmful effects that could occur from the total combined constituents in discharges from ORNL wastewater treatment facilities. Effluents from STP have been tested for toxicity to aquatic species under the NPDES permit every year since 1986, and effluents from PWTC have been tested since it went into operation in 1990. Test species have been Ceriodaphnia dubia (C. dubia), an aquatic invertebrate, and fathead minnow (Pimephales promelas) larvae. These have been tested using EPA chronic and acute test protocols at frequencies ranging from two to four times per year. Test results have been excellent. PWTC effluent has always been shown to be nontoxic. STP has shown isolated indications of effluent toxicity, none recent, but confirmatory tests conducted as required by the permit have shown that either the result of the routine test was an anomaly or that the condition of toxicity that existed at the time of the routine test was temporary and of short duration.

Toxicity test requirements under the current NPDES permit include testing the ORNL STP and PWTC twice per year each, using two test species. In 2013, toxicity test results for the ORNL wastewater treatment facilities were once again favorable, with no indication of toxicity in any of the tests that were conducted (Table 5.10).

\subsubsection{Residual Bromine and Chlorine Monitoring}

Chlorine is added to drinking water as a disinfectant prior to consumption. Chlorine and bromine are added to cooling system water to prevent bacterial growth in the system. When waters are discharged to streams, residual chlorine and bromine can be toxic to fish and other aquatic life. The ORNL NPDES permit controls the discharge of chlorinated and brominated waters, reported as "total residual oxidant" (TRO), by limiting the TRO mass loading from outfalls and the TRO concentration instream. Outfalls with lower potential to discharge chlorinated water are generally monitored semiannually; outfalls with 
known sources that are dechlorinated are monitored more frequently to ensure operational integrity of the dechlorinator. Instream locations are monitored bimonthly.

NPDES permit outfalls are monitored for TRO to ensure effective operation of cooling towers and dechlorination systems and maintenance of waterlines. When the permit action level of $1.2 \mathrm{~g} / \mathrm{day}$ is exceeded at an outfall, the staff investigates and implements treatment and reduction measures. TRO is also monitored at instream points twice per month to verify that releases are not creating adverse conditions for fish and other aquatic life.

Thirty-two individual outfalls are checked for TRO semiannually, quarterly, monthly, or bimonthly. Flow was detected 261 times. Table 5.11 lists instances in 2013 where outfalls were found to be in excess of the TRO action level. Three outfalls, 265 and 363 on Fifth Creek and 210 on WOC, exceeded the action level during 2013. The sources for outfall 265 have been determined to be aging underground water pipes that are leaking drinking water.

Table 5.11. Outfalls exceeding total residual oxidant action level ${ }^{a}$ in 2013

\begin{tabular}{rrrrrrrr}
\hline $\begin{array}{l}\text { Sample } \\
\text { date }\end{array}$ & Outfall & $\begin{array}{c}\text { TRO } \\
\text { concentration } \\
(\mathbf{m g} / \mathbf{L})\end{array}$ & $\begin{array}{c}\text { Flow } \\
\mathbf{( g p m )}\end{array}$ & $\begin{array}{c}\text { Load } \\
\text { (grams/ } \\
\text { day) }\end{array}$ & $\begin{array}{c}\text { Receiving } \\
\text { stream }\end{array}$ & $\begin{array}{c}\text { Downstream } \\
\text { integration } \\
\text { point }\end{array}$ & $\begin{array}{c}\text { Instream } \\
\text { TRO point }\end{array}$ \\
\hline $2 / 4 / 2013$ & 210 & 2.25 & 60 & 735.75 & White Oak Creek & WCK 3.9 & X22 \\
$4 / 11 / 2013$ & 265 & 0.95 & 25 & 129.44 & Fifth Creek & FFK 0.2 & X19 \\
$4 / 11 / 2013$ & 363 & 0.25 & 6 & 8.18 & Fifth Creek & FFK 0.2 & X19 \\
$10 / 17 / 2013$ & 263 & 0.5 & 18 & 49.05 & Fifth Creek & FFK 0.2 & X19 \\
\hline
\end{tabular}

${ }^{a} 1.2 \mathrm{~g} /$ day
Abbreviations
FFK $=$ Fifth Creek kilometer
TRO $=$ total residual oxidant
WCK $=$ White Oak Creek kilometer

\subsubsection{Cooling Tower Blowdown Whole Effluent Toxicity Monitoring}

As part of the WQPP at ORNL, samples of blowdown from three cooling towers/cooling tower systems $(5600,5807$, and 4510/4521) were tested for whole effluent toxicity (WET) in August and September 2013. This was done in support of the WQPP investigation to identify the causes of biological community impairments in the WOC watershed. That investigation is initially focusing on the reach of WOC that encompasses stream kilometer 3.9 [WOC kilometer (WCK) 3.9]. The towers chosen for WET testing were those thought to have the greatest influence on water quality in that stream reach. The same cooling towers were tested for WET in 2013 as were tested in 2012. Initially plans were to test a different set of towers in 2013, but the decision was made to repeat testing at these locations to evaluate an operational change. Between the 2012 and 2013 test periods a different vendor was selected to oversee chemical maintenance on these cooling towers, which resulted in a change in the brand of chemicals used to maintain the towers.

In WET testing, standard test organisms are exposed to multiple concentrations of effluent under standard test conditions, and the organisms' responses (e.g., survival, reproduction) are measured. The cooling tower blowdown samples evaluated in 2013 were tested with $C$. dubia using a three-brood survival and reproduction test, which is a chronic toxicity test that has been shown to be more sensitive for testing cooling tower blowdown effluents than are acute tests using fathead minnows (Pimephales promelas).

Two of the towers that were tested discharge through outfalls where blowdown is mixed with other effluents before the blowdown reaches the receiving stream, so effluents from those outfalls were also tested concurrently for WET. The outfalls tested were outfall 227, which receives blowdown from the 5600 cooling tower, and outfall 231, which receives blowdown from the 5807 tower. Blowdown from $4510 / 4521$ is discharged through outfall 014 , but is not blended with other wastewaters before discharge; 
therefore, it was not necessary to perform a separate test of outfall 014 effluent. WET test results from 2013 are shown in Table 5.12. It should be noted that samples were collected from the basins under the towers instead of directly from the blowdown lines because of difficulty accessing closed blowdown piping systems for sampling with an automatic water sampler.

Table 5.12. Summary results of chronic Ceriodaphnia dubia toxicity tests of Oak Ridge National Laboratory cooling towers and outfalls conducted during September 2013

\begin{tabular}{|c|c|c|c|}
\hline Location & NOEC $^{a}$ & $\mathrm{IC}_{25}{ }^{b}$ & 96-hour $\mathrm{LC}_{50}{ }^{c}$ \\
\hline Cooling tower $4510 / 4521$ & $75 \%$ & $86 \%$ & $>100 \%$ \\
\hline Cooling tower 5600 & $25 \%$ & $31 \%$ & $44 \%$ \\
\hline Outfall 227 & $25 \%$ & $58 \%$ & $>100 \%$ \\
\hline Cooling tower 5807 & $25 \%$ & $38 \%$ & $>100 \%$ \\
\hline Outfall 231 & $100 \%$ & $100 \%$ & $>100 \%$ \\
\hline
\end{tabular}

${ }^{a} \mathrm{NOEC}=$ No-observed-effect concentration for survival and reproduction

${ }^{b} \mathrm{IC}_{25}=$ Inhibition concentration which would cause a $25 \%$ reduction in mean young per female.

${ }^{c} \mathrm{LC}_{50}=$ Lethal concentration which would cause a $50 \%$ reduction in survival in 96 hours (estimated with this type of chronic test).

The results presented in Table 5.12 indicate that if a population of $C$. dubia was to be continually exposed to a mixture of water composed of roughly $25 \%$ or more of blowdown from these cooling towers (the remaining portion in the mixture being natural stream water for example), a negative effect on C. dubia reproduction could potentially occur. At higher concentrations of blowdown, those approaching $100 \%$ (i.e., full strength/undiluted effluent), survival might also be affected. In the driest summer conditions in WOC, it is possible for concentrations of blowdown in the receiving stream [instream waste concentration (IWC)] at some locations to be as high as $30 \%$ or $40 \%$ on an intermittent basis. However, more work needs to be done to determine whether such impacts (to C. dubia and other organisms) are actually occurring in the stream. As mentioned previously, the WET tests that were performed are chronic tests, which measure impacts to organisms under a continuous exposure scenario lasting several days or longer. In reality, discharges of cooling tower blowdown are intermittent, triggered by a control system that uses measurements of specific conductivity to control opening and closing of the discharge valve. In addition, WET tests done in the past have generally showed that when actual stream water is used as the diluent when making up the various dilutions to be tested (as opposed to the standard degassed mineral water as the diluent), the organisms tend to fare better. The blowdown samples that were tested were prepared with standard diluent.

As mentioned above, two outfalls (227 and 231) receiving these blowdown discharges were tested for WET as well. In similar tests conducted on effluents from the same outfalls in 2012, results indicated that when blowdown sources were mixed with other wastewaters before discharge, the blended effluents were not toxic under test conditions. In 2013, similar results were obtained for outfall 231. Outfall 227, however, tested differently in 2013 compared to 2012. The 2013 results suggest that under some circumstances, after blending with other wastewaters but before mixing with the receiving stream, the effluent from outfall 227 could potentially cause reproductive effects to $C$. dubia. That finding is based on a single test result and has not been confirmed.

In 2013, additional samples of full strength blowdown from the 4510/4521 cooling tower were subjected to some form of treatment (one treatment technology per sample) and were then tested for WET. The treatment technologies used included chelation by addition of ethylenediaminetetraacetic acid (EDTA), particulate removal by filtration, UV light exposure, and activated carbon treatment. The only treatment technology that resulted in lower toxicity in comparison to the untreated sample was chelation with EDTA, which indicated that dissolved metals (at least those that can be removed by EDTA) could be at least partially responsible for the toxicity measured in samples of blowdown from the 4510/4521 tower. This was in contrast to the 2012 results, in which a full strength effluent sample from the same location was treated with EDTA and showed no improvement in toxicity (EDTA was the only treatment 
technology tested in 2012). Though the EDTA-treated sample fared better than the associated untreated sample in 2013 monitoring, the sample still showed some survival and reproductive effects relative to the control (100\% diluent) sample. The investigation is ongoing, but one theory under consideration is that the variable toxicity to $C$. dubia under test conditions may result from nonoxidizing biocide residuals in the blowdown samples, perhaps exacerbated at times by elevated concentrations of dissolved metals.

A change in the nonoxidizing biocide that is used in these cooling towers to control biological growth is being considered, and the alternative product has a potential to result in reduced toxicity of blowdown. If these changes are implemented, plans are to repeat WET testing of these same towers to determine whether the expected improvements in toxicity are achieved. Attempts are also under way to simulate more realistic cooling tower blowdown exposure scenarios for the aquatic organisms inhabiting the reach of WOC that is impacted by these discharges to improve on the interpretation of the WET test results (i.e., the comparison of concentration-based test metrics to more realistic estimations of IWCs).

During the period in which the towers were undergoing WET testing, they were also monitored with grab samples for field parameters (conductivity, dissolved oxygen, $\mathrm{pH}$, and temperature), chemical oxygen demand, total metals, and total suspended solids. Results of that monitoring are shown in Table 5.13.

Table 5.13. Field parameters and results from laboratory analyses of blowdown from Oak Ridge National Laboratory cooling towers

\begin{tabular}{|c|c|c|c|}
\hline \multirow{2}{*}{ Parameter } & \multicolumn{3}{|c|}{ Cooling Tower Sampled } \\
\hline & $4510 / 4521$ & 5600 & $\mathbf{5 8 0 7}$ \\
\hline Conductivity $(\mathrm{mS} / \mathrm{cm})$ & 0.873 & 0.859 & 0.835 \\
\hline Dissolved oxygen $(\mathrm{mg} / \mathrm{L})$ & 7.9 & 10.6 & 10.7 \\
\hline $\mathrm{pH}$ (standard units) & 8.2 & 8.7 & 8.5 \\
\hline Temperature $\left({ }^{\circ} \mathrm{C}\right)$ & 25.2 & 21 & 22.4 \\
\hline Chemical oxygen demand $(\mathrm{mg} / \mathrm{L})$ & 37.7 & 27.4 & 31.4 \\
\hline Total suspended solids (mg/L) & 2 & 15 & 3 \\
\hline $\mathrm{Ag}(\mathrm{mg} / \mathrm{L})$ & $<0.000619$ & $<0.000619$ & $<0.000619$ \\
\hline As (mg/L) & $<0.001$ & 0.00115 & $<0.001$ \\
\hline $\mathrm{Be}(\mathrm{mg} / \mathrm{L})$ & $<0.000686$ & $<0.000686$ & $<0.000686$ \\
\hline $\mathrm{Ca}(\mathrm{mg} / \mathrm{L})$ & 123 & 138 & 124 \\
\hline $\mathrm{Cd}(\mathrm{mg} / \mathrm{L})$ & $<0.000782$ & $<0.000782$ & $<0.000782$ \\
\hline $\mathrm{Cr}(\mathrm{mg} / \mathrm{L})$ & $<0.001$ & $<0.001$ & $<0.001$ \\
\hline $\mathrm{Cu}(\mathrm{mg} / \mathrm{L})$ & 0.00308 & 0.00642 & 0.00836 \\
\hline $\mathrm{Fe}(\mathrm{mg} / \mathrm{L})$ & $<0.0206$ & $<0.0206$ & $<0.0206$ \\
\hline $\mathrm{Mg}(\mathrm{mg} / \mathrm{L})$ & 39 & 43.3 & 37.3 \\
\hline $\mathrm{Mn}(\mathrm{mg} / \mathrm{L})$ & $<0.000953$ & $<0.000953$ & $<0.000953$ \\
\hline Mo (mg/L) & 0.0177 & $<0.000931$ & $<0.000931$ \\
\hline Ni (mg/L) & 0.0028 & 0.00284 & 0.00271 \\
\hline $\mathrm{Pb}(\mathrm{mg} / \mathrm{L})$ & $<0.001$ & $<0.001$ & $<0.001$ \\
\hline $\mathrm{Sb}(\mathrm{mg} / \mathrm{L})$ & 0.00241 & $<0.00081$ & $<0.00081$ \\
\hline $\mathrm{Se}(\mathrm{mg} / \mathrm{L})$ & $<0.0406$ & $<0.0406$ & $<0.0406$ \\
\hline $\mathrm{Zn}(\mathrm{mg} / \mathrm{L})$ & 0.128 & 0.107 & 0.104 \\
\hline
\end{tabular}

${ }^{a}$ Towers 5600 and 5807 sampled August 26, 2013; Tower 4510/4521 sampled September 16, 2013.

\subsubsection{Radiological Monitoring}

At ORNL, monitoring of effluents and instream locations for radioactivity is conducted under the WQPP. Table 5.14 details the monitoring frequencies and target analyses for 2 treatment facility outfalls, 3 instream monitoring locations, and 20 category outfalls (outfalls which are categorized into groups with 
similar effluent characteristics for the purposes of setting monitoring and reporting requirements in the site NPDES permit). Dry-weather discharges from category outfalls are primarily cooling water, groundwater, and condensate. Low levels of radioactivity can be discharged from category outfalls in areas where groundwater contamination exists and where contaminated groundwater enters category outfall collection systems from building and facility sumps, building footer drains, and direct infiltration. In 2013, dry-weather grab samples were collected at 16 of the 20 category outfalls targeted for sampling. Four category outfalls $(203,205,241$, and 284) were not sampled because there was no discharge present during sampling attempts.

Table 5.14. Radiological monitoring conducted under the Oak Ridge National Laboratory Water Quality Protection Plan, 2013

\begin{tabular}{|c|c|c|c|c|c|c|c|}
\hline Location & Frequency & $\begin{array}{c}\text { Gross } \\
\text { alpha/beta }{ }^{a}\end{array}$ & $\begin{array}{c}\text { Total } \\
\text { rad Sr }\end{array}$ & $\begin{array}{c}\text { Tritium } \\
\left({ }^{3} \mathbf{H}\right)\end{array}$ & $\begin{array}{c}\text { Gamma } \\
\text { scan }\end{array}$ & $\begin{array}{l}\text { Isotopic } \\
\text { uranium }\end{array}$ & ${ }^{243 / 244} \mathrm{Cm}$ \\
\hline Outfall 001 & Annual & $\mathrm{X}$ & & & & & \\
\hline Outfall 080 & Monthly & $\mathrm{x}$ & $\mathrm{X}$ & $\mathrm{X}$ & $\mathrm{X}$ & & $\mathrm{X}$ \\
\hline Outfall 081 & Annual & $\mathrm{X}$ & & & & & \\
\hline Outfall 085 & Quarterly & $\mathrm{X}$ & $\mathrm{X}$ & $\mathrm{X}$ & $\mathrm{X}$ & & \\
\hline Outfall $203^{b}$ & Annual & $\mathrm{x}$ & $\mathrm{X}$ & & $\mathrm{x}$ & & \\
\hline Outfall 204 & Semiannual & $\mathrm{X}$ & $\mathrm{x}$ & & $\mathrm{X}$ & & \\
\hline Outfall $205^{b}$ & Annual & $\mathrm{x}$ & & & & & \\
\hline Outfall 207 & Quarterly & $\mathrm{X}$ & & & & & \\
\hline Outfall 211 & Annual & $\mathrm{X}$ & & & & & \\
\hline Outfall 234 & Annual & $\mathrm{X}$ & & & & & \\
\hline Outfall $241^{b}$ & Quarterly & $\mathrm{x}$ & $\mathrm{X}$ & & & $\mathrm{X}$ & \\
\hline Outfall 265 & Annual & $\mathrm{X}$ & & & & & \\
\hline Outfall 281 & Quarterly & $\mathrm{X}$ & & $\mathrm{X}$ & & & \\
\hline Outfall 282 & Quarterly & $\mathrm{x}$ & & & & & \\
\hline Outfall $284^{b}$ & Annual & $\mathrm{x}$ & & & & & \\
\hline Outfall 302 & Monthly & $\mathrm{x}$ & $\mathrm{X}$ & $\mathrm{X}$ & $\mathrm{X}$ & $\mathrm{X}$ & \\
\hline Outfall 304 & Monthly & $\mathrm{X}$ & $\mathrm{X}$ & $\mathrm{X}$ & $\mathrm{X}$ & $\mathrm{X}$ & \\
\hline Outfall 365 & Semiannual & $\mathrm{X}$ & & & & & \\
\hline Outfall 368 & Annual & $\mathrm{X}$ & & & & & \\
\hline Outfall 383 & Annual & $\mathrm{X}$ & & $\mathrm{X}$ & & & \\
\hline STP (X01) & Monthly & $\mathrm{X}$ & $\mathrm{X}$ & $\mathrm{X}$ & $\mathrm{X}$ & & \\
\hline PWTC (X12) & Monthly & $\mathrm{X}$ & $\mathrm{X}$ & $\mathrm{X}$ & $\mathrm{X}$ & $\mathrm{X}$ & \\
\hline Melton Branch 1 (X13) & Monthly & $\mathrm{X}$ & $\mathrm{x}$ & $\mathrm{x}$ & $\mathrm{X}$ & & \\
\hline WOC (X14) & Monthly & $\mathrm{X}$ & $\mathrm{X}$ & $\mathrm{x}$ & $\mathrm{X}$ & & \\
\hline WOD (X15) & Monthly & $\mathrm{X}$ & $\mathrm{X}$ & $\mathrm{X}$ & $\mathrm{X}$ & & \\
\hline
\end{tabular}

${ }^{a}$ Isotopic analyses are performed to identify contributors to gross activities when results exceed screening criteria described in the Water Quality Protection Plan, October 2008.

${ }^{b}$ No sample collected because no discharge present during sampling attempts.

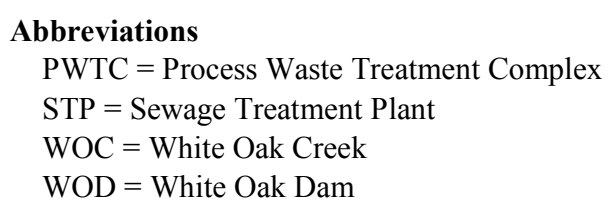

Two ORNL treatment facilities were monitored for radioactivity in 2013: STP (outfall X01) and PWTC (outfall X12). The three instream locations that were monitored were X13 on Melton Branch, X14 on WOC, and X15 at White Oak Dam (WOD) (Fig. 5.19). At each treatment facility and instream 
monitoring location, monthly flow-proportional composite samples were collected using dedicated automatic water samplers.

Radioisotope specific guideline concentration values are published in DOE directives and are used to evaluate discharges of radioactivity from DOE facilities. DCSs were developed for evaluating effluent discharges and are not intended to be applied to instream values, but these comparisons can provide a useful frame of reference. Four percent of the DCS is roughly equivalent to the 4 mrem dose limit on which the EPA radionuclide drinking water standards are based and is a convenient comparison point. It should be noted that although effluents and instream concentrations are compared to DCSs, neither ORNL effluents nor ambient surface waters are direct sources of drinking water. The annual average concentration of at least one radionuclide exceeded $4 \%$ of the relevant DCS concentration in dry-weather discharges from NPDES outfalls 080, 085, 204, 302, 304, X01, and X12 and at instream sampling location X15 (Fig. 5.20).

In 2013 , one outfall had a mean radioactivity concentration greater than $100 \%$ of a DCS. The average concentration of total radioactive strontium $\left({ }^{89,90} \mathrm{Sr}\right.$ ) was $110 \%$ of the DCS for ${ }^{90} \mathrm{Sr}$ (it is reasonable, for an ORNL environmental sample, to assume that ${ }^{89,90} \mathrm{Sr}$ activity is comparable to ${ }^{90} \mathrm{Sr}$ activity due to the relatively short half-life of ${ }^{89} \mathrm{Sr}-50.55$ days). Consequently, concentrations of radioactivity in discharges from that outfall were also greater than DCS levels on a sum-of-fractions (summation of DCS percentages of multiple radiological parameters) basis; the sum-of-fractions was $133 \%$. Concentrations of radioactivity at this outfall were below DCS levels in 2012. The cause of the increased concentrations in 2013 is still under investigation, though the probable cause has already been identified and mitigated by the DOE EM Program. In January 2014, an increase in gross alpha and gross beta activity was detected at a different outfall, NPDES outfall 207. An investigation ensued, and the increase at outfall 207 was suspected to be related to a failed pump in the WC-9 tank farm dry well (which collects contaminated groundwater from a CERCLA soil and groundwater contamination area and routes it for treatment). The storm water collection system for outfall 207 is in close proximity to the tank farm. The pump was repaired shortly after the detection of elevated radioactivity at outfall 207, which resulted in an almost immediate reduction in the concentration of radioactivity in that discharge. Similar to outfall 207, the storm water collection system for outfall 304 traverses multiple soil and groundwater contamination areas, including some groundwater contamination areas in the vicinity of the WC-9 tank farm (infiltration of contaminated groundwater from areas other than WC-9 are thought to be responsible for the baseline levels of radioactivity in outfall 304 discharges). Following the pump repair, outfall monitoring conducted by the DOE EM Program showed that concentrations and fluxes of radioactivity also began to decline at outfall 304, as did the flow rate from the outfall. As of early 2014, both outfalls continue to be monitored, including additional monitoring conducted by the DOE EM Program, to determine whether the mitigation that has already taken place will result in radioactivity concentrations returning to and remaining below DCS levels at both outfalls.

The total annual discharges (or amounts) of radioactivity measured in stream water at WOD, the final monitoring point on WOC before the stream flow leaves ORNL, were calculated from concentration and flow. Results of those calculations for each of the past 5 years are shown in Figs. 5.21 through 5.25. Because discharges of radioactivity are somewhat correlated to stream flow, annual flow volumes measured at the WOD monitoring station are given in Fig. 5.26. Discharges of radioactivity at WOD in 2013 are similar to recent years, particularly when taking into account differences in annual flow volume, and continue to be generally lower than in the years preceding completion of the waste area caps in Melton Valley (substantially complete by 2006). 


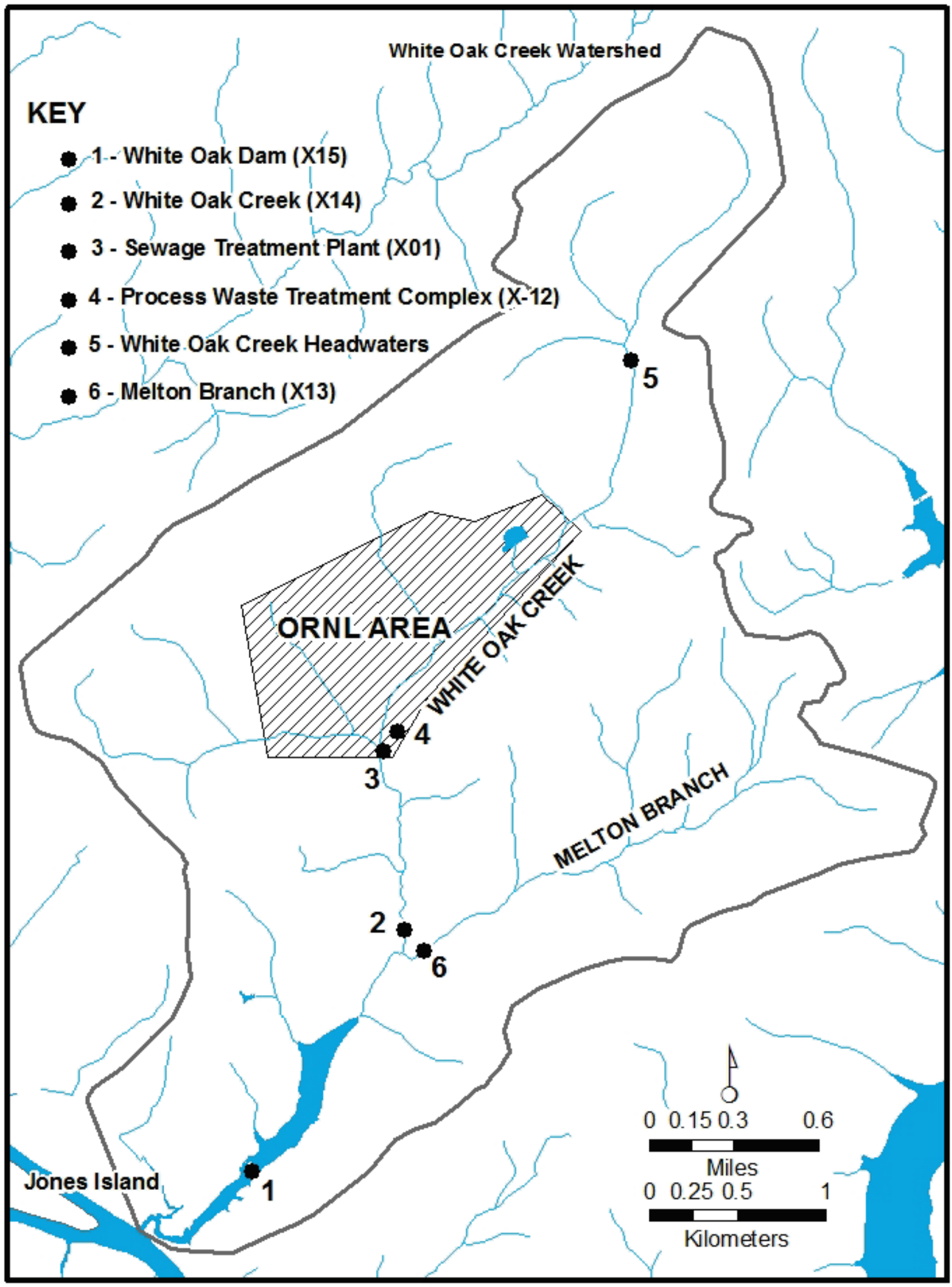

Fig. 5.19. Oak Ridge National Laboratory surface water, National Pollutant Discharge Elimination System, and reference sampling locations. 


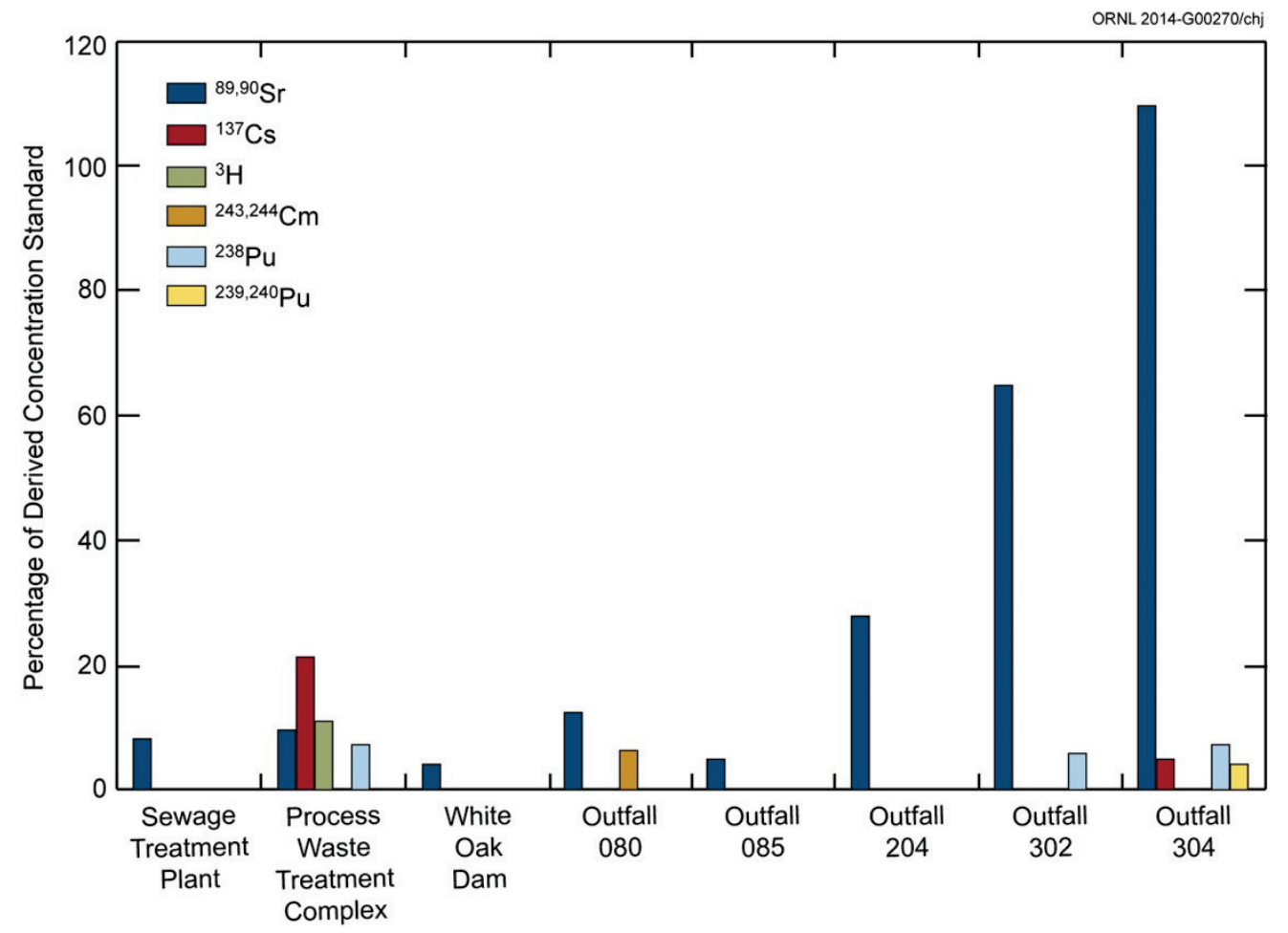

Fig. 5.20. Outfalls at Oak Ridge National Laboratory with average radionuclide concentrations greater than $4 \%$ of the relevant derived concentration standards in 2013.

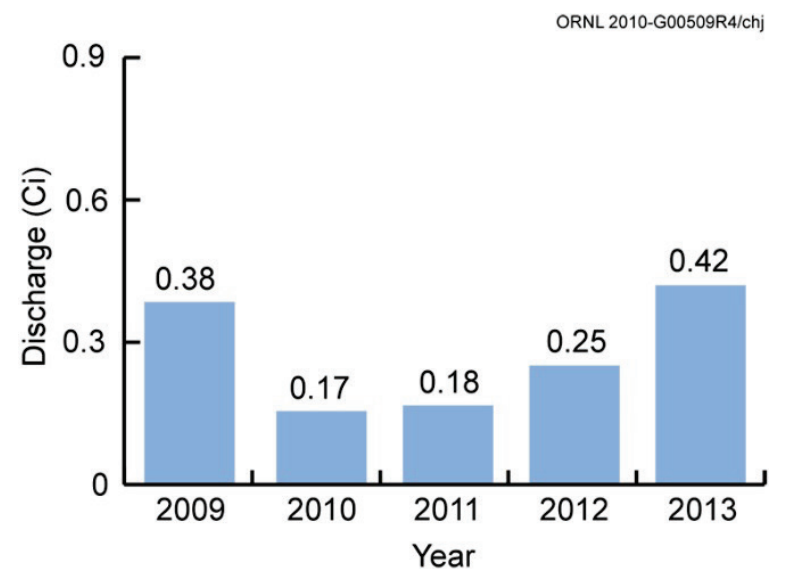

Fig. 5.21. Cesium-137 discharges at White Oak Dam, 2009-2013.

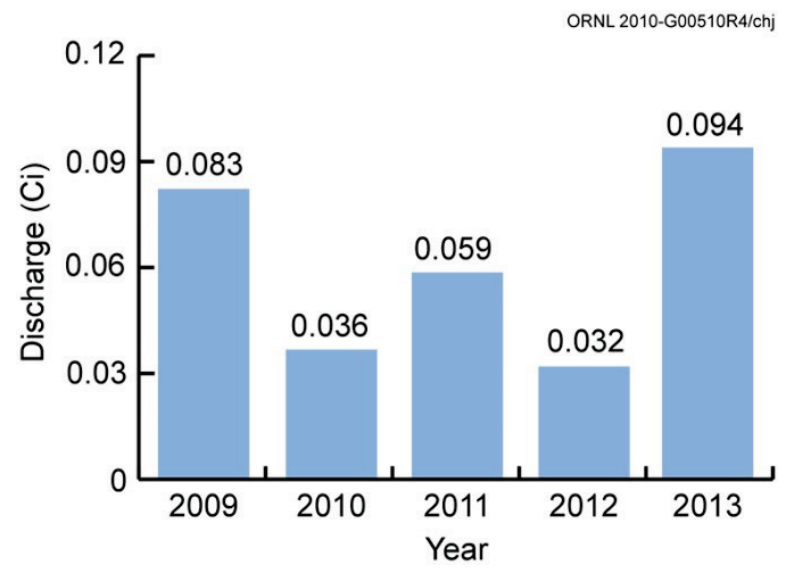

Fig. 5.22. Gross alpha discharges at White Oak Dam, 2009-2013. 


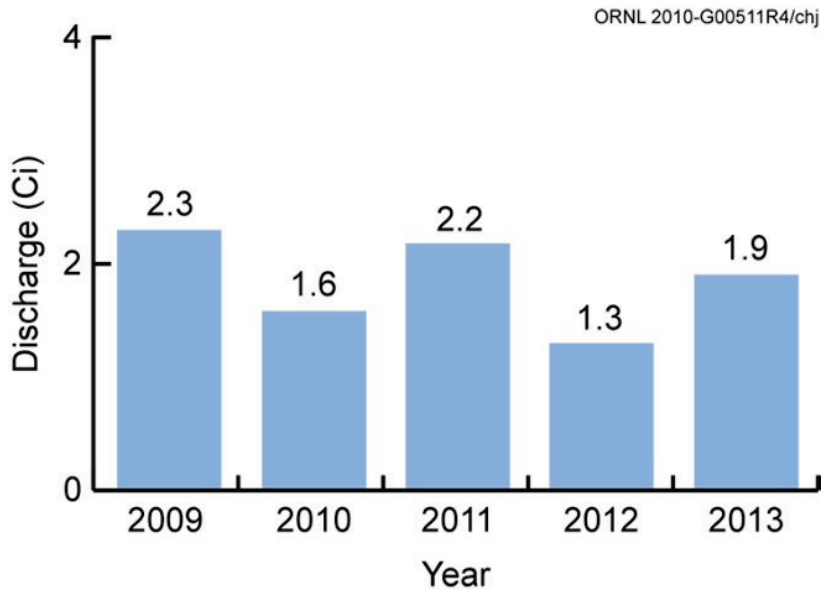

Fig. 5.23. Gross beta discharges at White Oak Dam, 2009-2013.

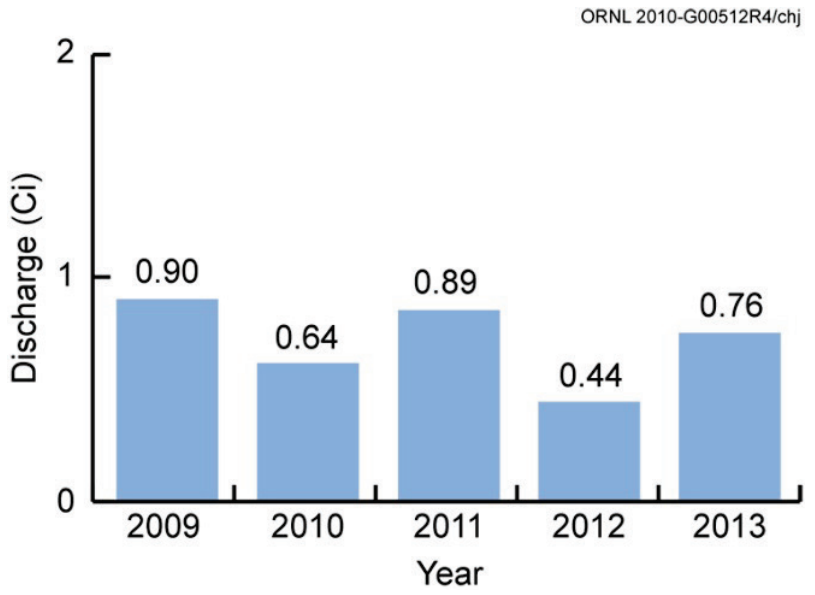

Fig. 5.24. Total radioactive strontium discharges at White Oak Dam, 2009-2013.

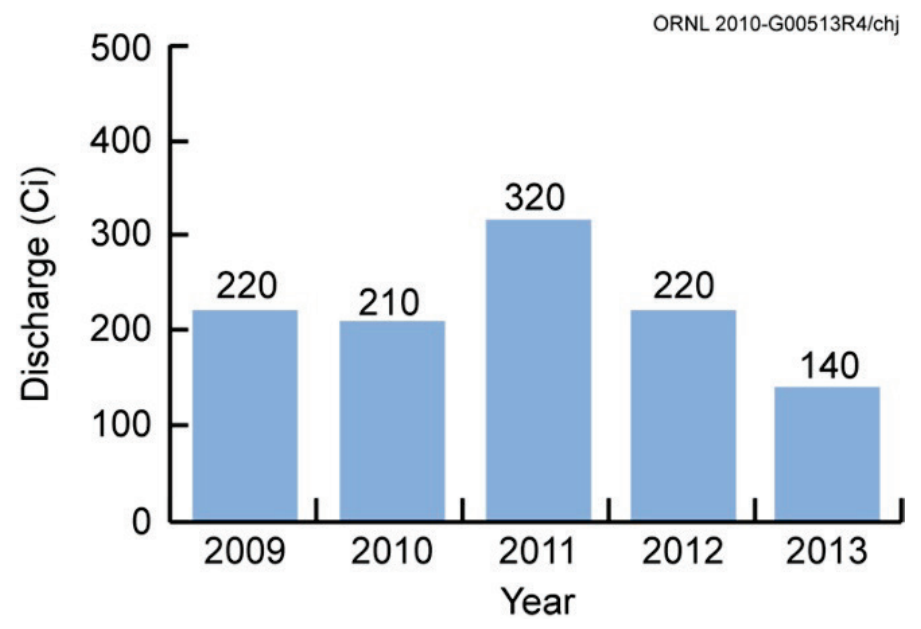

Fig. 5.25. Tritium discharges at White Oak Dam, 2009-2013. 


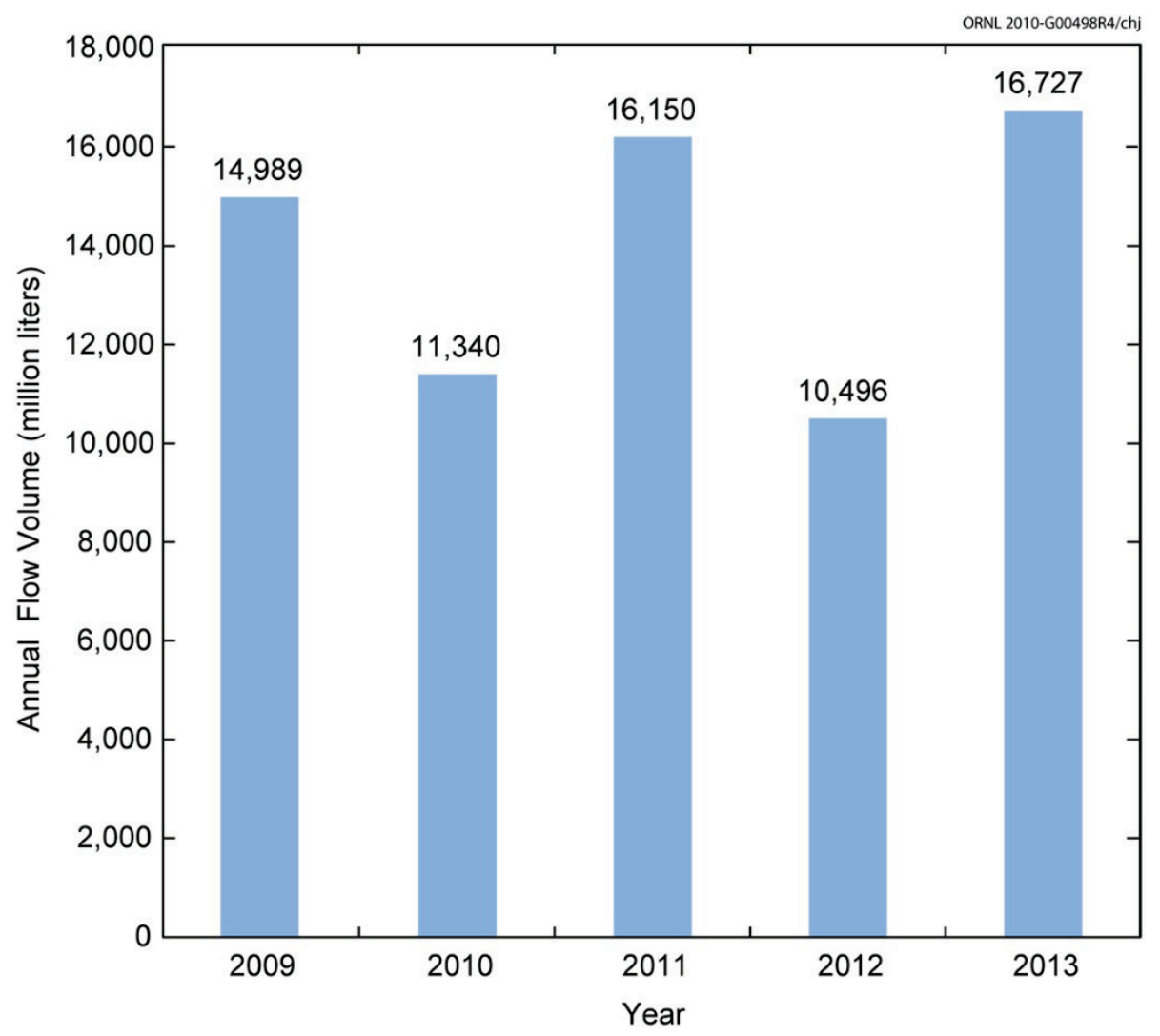

Fig. 5.26. Annual flow volume at White Oak Dam, 2009-2013.

\subsubsection{Mercury in the White Oak Creek Watershed}

Legacy mercury environmental contamination exists at ORNL, largely as a result of spills and releases that occurred in the 1950s during isotope separation pilot-scale work in Buildings 3503, 3592, 4501, and 4505. Because of this, mercury is present in soils and groundwater in and around these four facilities. Buildings 3592 and 3503 were taken down and removed under the CERCLA remedial process in 2011 and 2012, respectively. Mercury is also present in Fifth Creek and WOC surface streams that receive surface runoff and groundwater flow from the area of these buildings.

In the past, process wastewater drains and building sumps from Buildings 4501 and 4505, the facilities where most of the ORNL mercury work was conducted, were routed via underground collectionsystem piping to the ORNL PWTC for treatment to remove constituents, including mercury, before discharge to WOC. Since 2007, three additional groundwater sumps have been redirected to receive treatment for mercury removal, and a mercury pretreatment system was installed on one of these sumps, in Building 4501. These recent actions have significantly diminished the release of legacy mercury contamination from the ORNL site to the WOC watershed (Fig. 5.27).

For the mercury-investigation component of WQPP, data collected during initial monitoring indicates effluent sampling at additional outfalls and instream reaches needs to be incorporated in future WQPP revisions to help prioritize future abatement actions and to delineate mercury sources.

In 2013, monitoring conducted under WQPP included dry-weather sampling at a number of instream points in the WOC watershed upstream, within, and downstream from ORNL and ORNL NPDES outfalls where previous monitoring or site history has shown the potential for effluent mercury. Flow measurements were made for instream and outfall sampling locations. Concentration and flux values were measured and calculated. Selected results of the 2013 monitoring are shown in Fig. 5.28, and complete mercury monitoring results are available in the Oak Ridge Environmental Information System (OREIS). Access to this system can be requested via email (oreis@ettp.doe.gov) or by telephone (865-574-3257). 


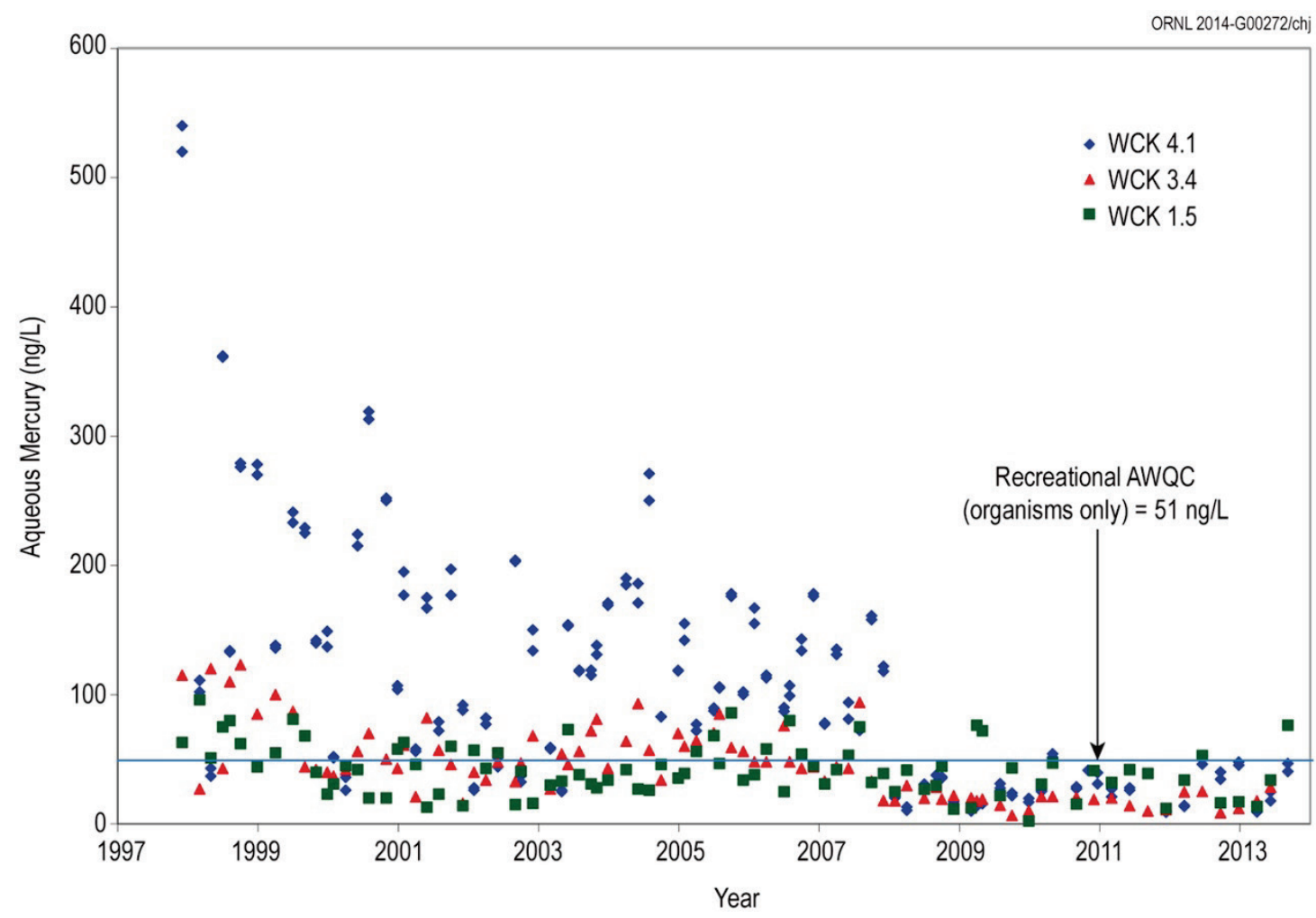

Fig. 5.27. Total aqueous mercury concentrations at sites in White Oak Creek downstream from Oak Ridge National Laboratory, 1998-2013. (AWQC = ambient water quality criterion; WCK $=$ White Oak Creek kilometer.)

Monitoring results for 2013 indicated that Tennessee mercury criteria were largely met at instream locations. As a result of 2011 targeted stream-reach mercury investigations, a storm drain outfall on Fifth Creek, outfall 265, was found to be a more significant source of mercury release than had previously been known. In 2012 this outfall's network of underground piping and catch basins was investigated using a remote video camera. Locations where water was infiltrating the network were discovered. Two sources of water inleakage to the outfall 265 pipe network were identified; both were from leaking underground pipes that supply water to a fire hydrant and associated valve. It is believed that the water in leakage contributes to mobilization of legacy mercury contamination in or near the outfall 265 underground pipe network. Since the water sources were repaired in 2012 and 2013, mercury concentrations in outfall 265 effluent have declined. However, outfall 265 monitoring continues to indicate a mercury presence above background levels. Investigation of additional portions of the outfall 265 drainage network that may be contributing to the mercury flux from that outfall is planned for 2014.

In 2013, WQPP mercury investigative efforts also focused on legacy-mercury-bearing sediment, a sediment-clogged dechlorination unit, and effluent mercury concentrations, all associated with storm water outfall 211. In 2013 the outfall 211 dechlorinator unit was replaced with a system that is less susceptible to clogging by sediment and gravel, and the old dechlorinator and associated piping were removed from the bank of WOC under an ARAP from TDEC. An in-pipe flow-monitoring unit was used to measure effluent flow rates from the outfall 211 pipe under varying conditions (e.g., dry-weather and storm-event) to help build a more complete data record of flow rates from the outfall 211 storm drain network. Plans for 2014 include continuing to investigate sources of supply-water and/or mercury to the outfall 265 drain network; sources of water from buildings within the outfall 211 storm-drain-network drainage area; flow monitoring at various accessible points in the outfall 211 network; and a time-series tracer-dilution study of the mid reach of Fifth Creek. An ongoing mercury-characterization monitoring protocol, which has been maintained at various instream- and outfall-monitoring locations in the WOC watershed since 2009, will be continued in 2014 . 


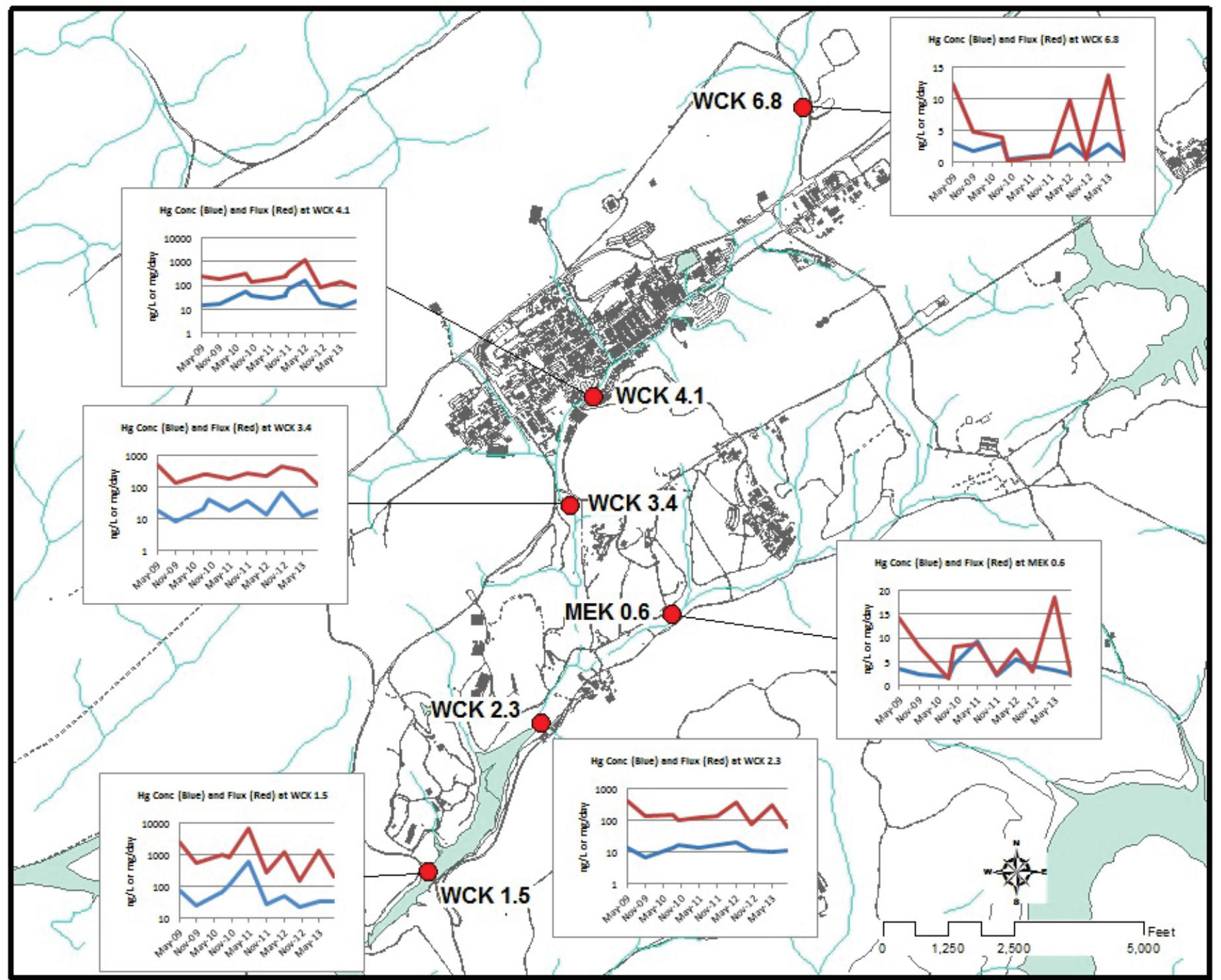




\subsubsection{Storm Water Surveillances and Construction Activities}

Figure 5.29 depicts the location of construction sites that were considered significant in 2013 because of the need to be covered under the general Tennessee NPDES permit for construction activities and/or an ARAP or because they had a footprint greater than 0.405 ha $(1 \mathrm{acre})$. (Construction areas that are part of CERCLA remediation follow substantive requirements of the appropriate water pollution control permits but are not required to obtain official permit coverage). Three of these sites were inspected in 2013 to evaluate overall effectiveness of the best management practices in use. In general, while some short-term impacts to receiving streams were noted, no long-term adverse impacts were observed.

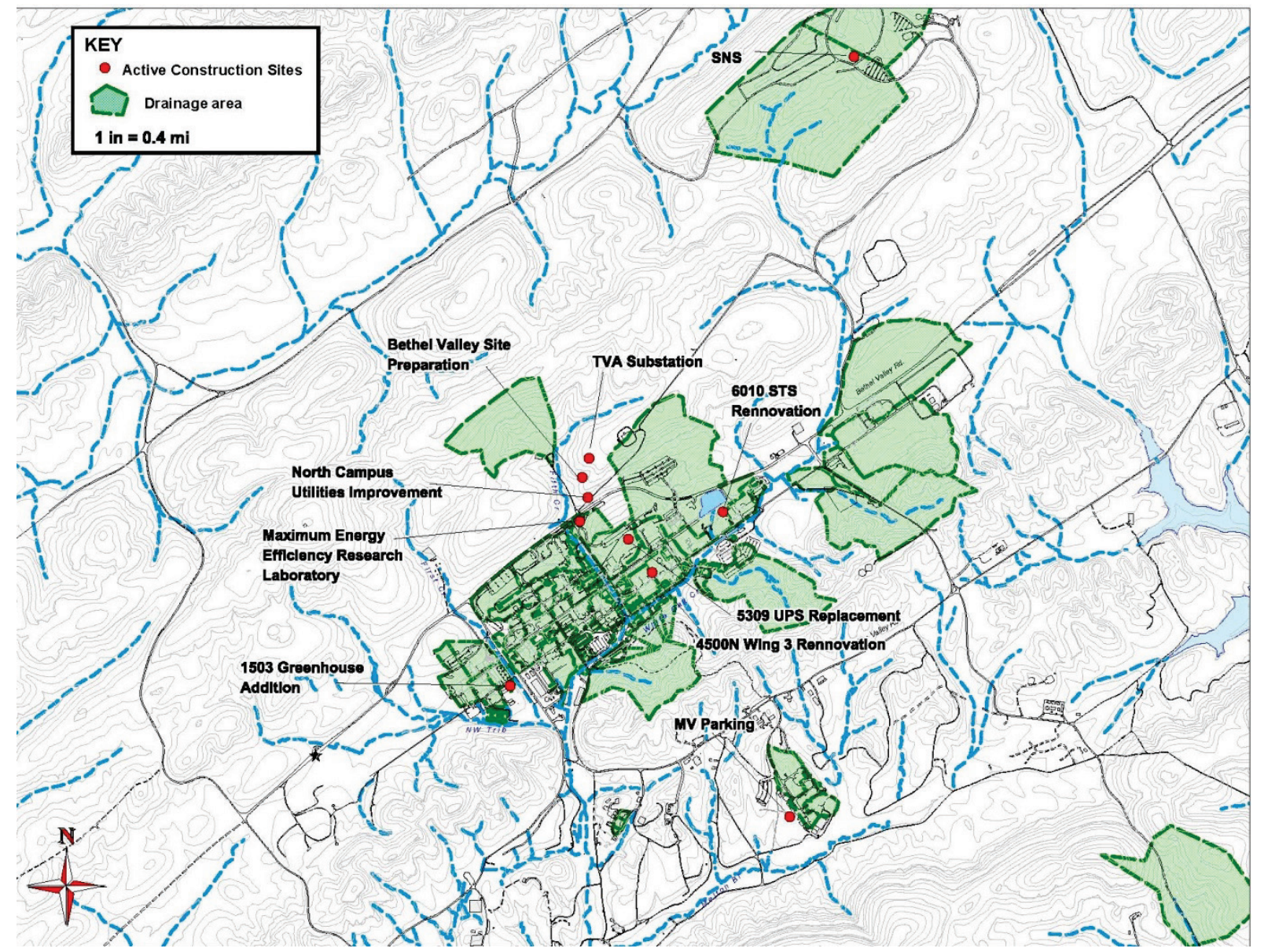

Fig. 5.29. Active construction sites and Oak Ridge National Laboratory Water Quality

Protection Plan monitoring locations, 2013. (MV = Melton Valley, STS = Shield Testing Station, TVA = Tennessee Valley Authority, UPS = uninterruptible power supply.)

Land use within drainage areas is typical of office/industrial settings with surface features including laboratories, support facilities, paved areas, and grassy lawns. Outdoor material storage is most prevalent in the 7000 Area on the east end of the main ORNL facility (where most of the craft and maintenance shops are located), with other smaller outdoor storage areas located throughout the facility in and around loading docks and material delivery areas at laboratory and office buildings. The types of materials stored outside include metal items (sheeting, pipes, and parts); equipment awaiting use, disposal, or repair; construction material; and deicer product.

Some construction activities are performed on third-party-funded construction projects under agreement with other local, state, and federal agencies on the DOE reservation. There are mechanisms in place for ensuring effective storm water controls at these third-party sites, one of which includes staff from UT-Battelle acting as points of contact for communication interface on environmental, spill/emergency response, and other key issues. 


\subsubsection{Biological Monitoring}

\subsubsection{Bioaccumulation Studies}

The bioaccumulation task for BMAP addresses two NPDES permit requirements at ORNL: (1) evaluate whether mercury at the site is contributing to a stream at a level that will impact fish and aquatic life or violate the recreational criteria and (2) monitor the status of PCB contamination in fish tissue in the WOC watershed.

Mercury in Water. In continuation of a monitoring effort initiated in 1997, bimonthly water samples were collected from WOC at four sites in 2013. Stream conditions were selected to be representative of seasonal base-flow conditions (dry weather, clear flow) based on historical results that indicate higher mercury concentrations under these conditions.

The concentration of mercury in WOC upstream from ORNL was less than $5 \mathrm{ng} / \mathrm{L}$ in 2013. Long-term trends in waterborne mercury in the WOC system downstream of ORNL are shown in Fig. 5.27. Waterborne mercury downstream of ORNL declined abruptly in 2008 and remained low through 2013 as a result of rerouting highly contaminated sump water in Building 4501 to PWTC in December 2007. The mean total mercury concentration at WCK 4.1 was $21.8 \pm 14.5 \mathrm{ng} / \mathrm{L}$ in 2013 compared with $108 \pm 33 \mathrm{ng} / \mathrm{L}$ in 2007. The decrease was also apparent but less pronounced at WCK 3.4, with mercury averaging $19.0 \pm 6.8 \mathrm{ng} / \mathrm{L}$ in 2013 versus $49 \pm 23 \mathrm{ng} / \mathrm{L}$ in 2007 . Mercury concentrations at these two sites were significantly lower than levels in 2007. A pretreatment system for the sump water started operation on October 22, 2009, and will remove almost all of the mercury before sending the water to PWTC. This system reduces the mercury concentration in the PWTC influent and effluent. Average aqueous mercury concentration at WOD was $34.11 \pm 29.9 \mathrm{ng} / \mathrm{L}$ in 2013 , a level similar to results reported in recent years.

Bioaccumulation in Fish. In WOC, mercury and PCB concentrations in fish have been at or near human health risk thresholds (e.g., EPA recommended fish-based AWQC, TDEC fish advisory limits). In 2010 , mercury concentrations in redbreast sunfish fillets collected from WOC were below the $0.3 \mu \mathrm{g} / \mathrm{g}$ AWQC for the first time in 10 years, and this decreasing trend has continued through 2013 (Fig. 5.30). Mean fillet concentrations at WCK 3.9 decreased from $0.45 \mu \mathrm{g} / \mathrm{g}$ in 2007 to $0.20 \mu \mathrm{g} / \mathrm{g}$ in 2013 (Fig. 5.30). Because these trends have persisted for several years and because the decreases in fish tissue were more pronounced at upstream sites where the decreases in aqueous mercury concentrations were most evident suggests a causal response. Mercury concentrations in bluegill and largemouth bass collected from WCK 1.5 (White Oak Lake) have been increasing in recent years and remained elevated in 2013. The reason for the increase in the lower end of the WOC watershed is not known, but changes in sediment or mercury methylation rates within the lake could affect bioaccumulation.

Mean PCB concentrations in redbreast sunfish at WCK 3.9 and WCK $2.9(0.46$ and $0.19 \mu \mathrm{g} / \mathrm{g}$, respectively) were comparable to recent years. Mean PCB concentrations in bluegill from WCK 1.5 $(1.15 \mu \mathrm{g} / \mathrm{g})$ increased in 2013 such that concentrations in this species were similar to those seen in largemouth bass and were near typical concentrations that result in a TDEC fish advisory limit (i.e., $\sim 1 \mu \mathrm{g} / \mathrm{g}$ ) (Fig. 5.31). 


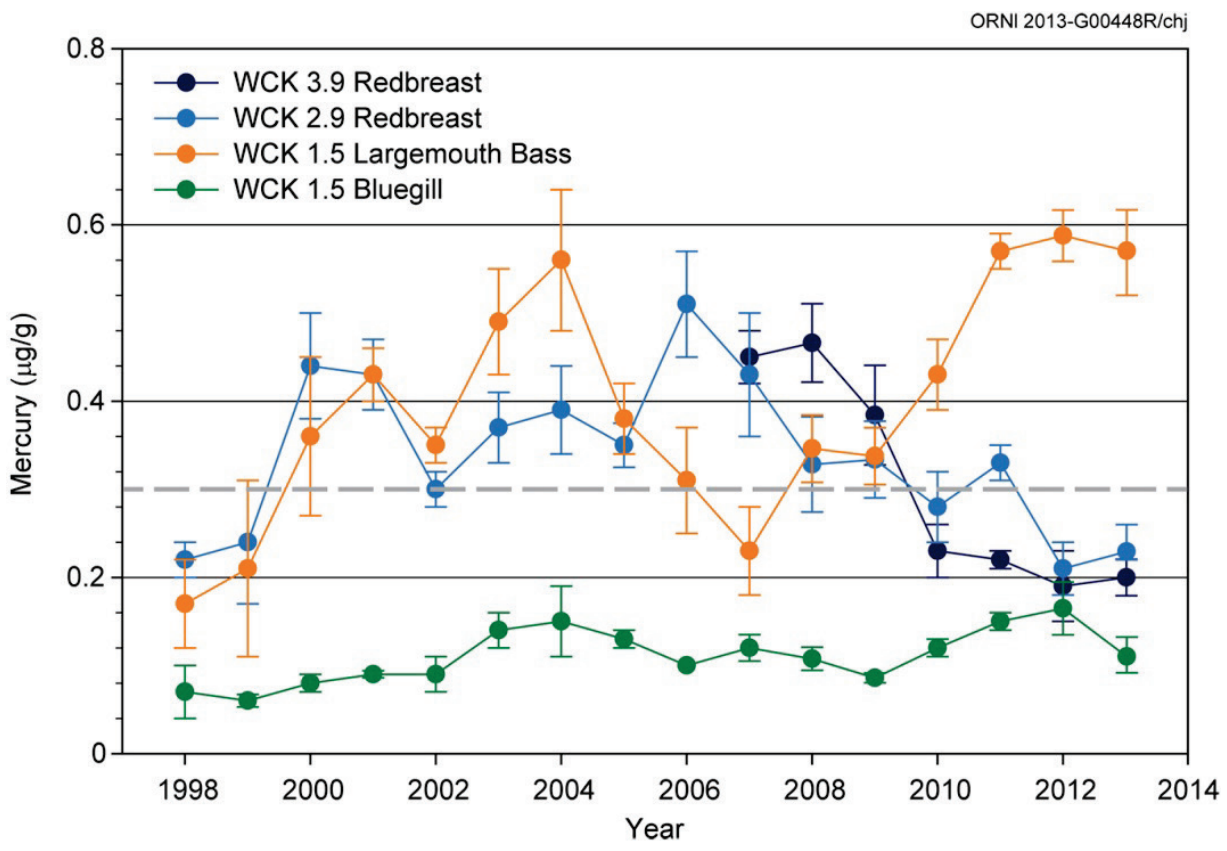

Fig. 5.30. Mean concentrations of mercury ( \pm standard error, $N=6$ ) in muscle tissue of sunfish and bass from White Oak Creek [White Oak Creek kilometers (WCKs) 3.9 and 2.9] and White Oak Lake (WCK 1.5), 1998-2013. [Dashed grey line indicates the US Environmental Protection Agency ambient water quality criterion for mercury $(0.3 \mu \mathrm{g} / \mathrm{g}$ in fish tissue).]

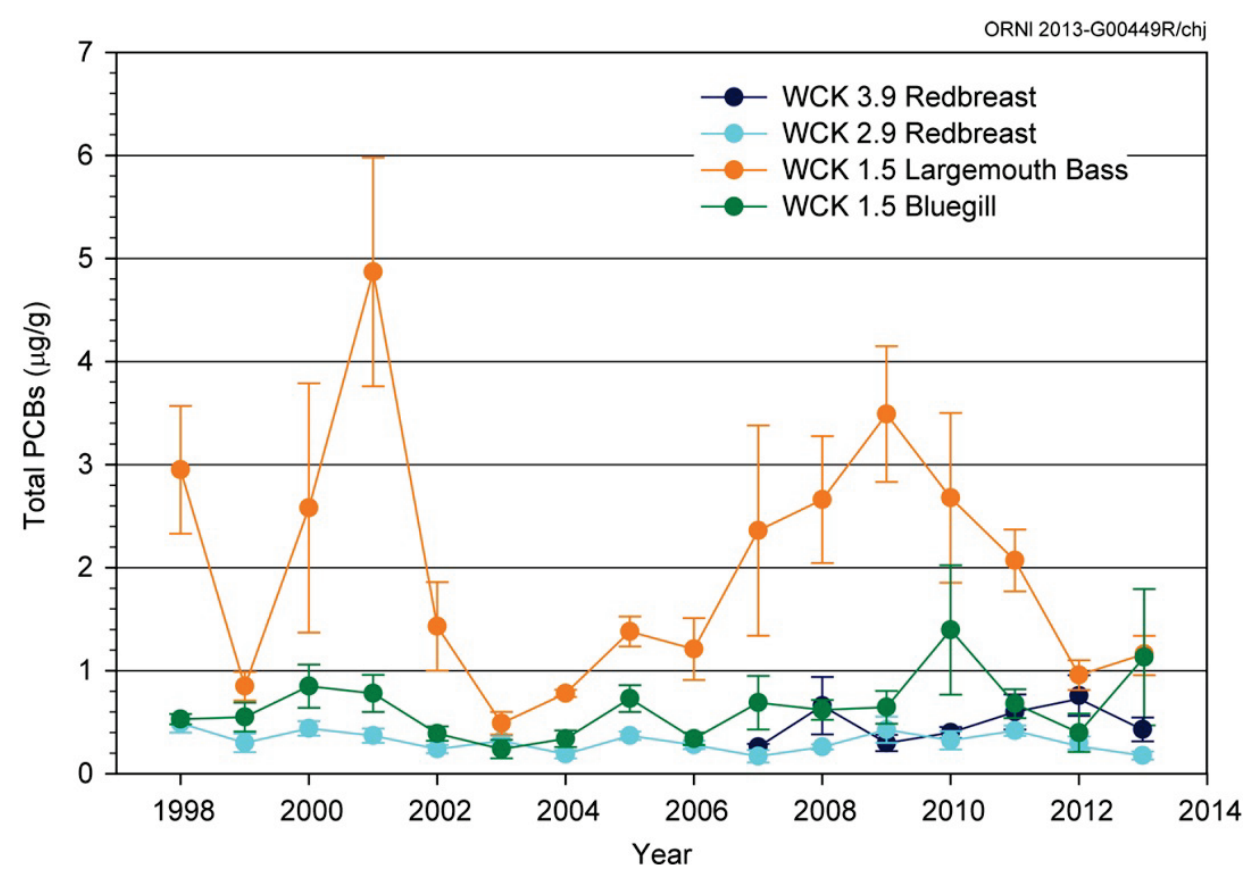

Fig. 5.31. Mean polychlorinated biphenyl (PCB) concentrations ( \pm standard error, $\mathrm{N}=6$ ) in fish fillets collected from the White Oak Creek watershed, 1998-2013. (WCK = White Oak Creek kilometer.) 


\subsubsection{Benthic Macroinvertebrate Communities}

Monitoring of benthic macroinvertebrate communities in WOC, First Creek, and Fifth Creek continued in 2013. Additionally, monitoring of the macroinvertebrate community in lower Melton Branch [Melton Branch kilometer (MEK) 0.6] continued under the EM WRRP. Benthic macroinvertebrate samples are collected once annually following two protocols: protocols developed by ORNL and used since 1986 and TDEC protocols. ORNL protocols provide a continuous long-term data set that allows the most effective means of evaluating and verifying the effectiveness of pollution abatement and RAs taken at ORNL since 1986. These protocols also provide the most effective means of determining the significance of changes in trends relative to historical conditions. TDEC protocols, on the other hand, provide an estimate of the condition of a macroinvertebrate community relative to a state-derived reference condition. The results from both protocols are used to help assess ORNL compliance with current NPDES permit requirements. This report provides a summary of results through 2013 from both sets of protocols.

Compared with the TDEC-derived reference condition, the only site monitored in the WOC watershed that has consistently rated as unimpaired is WCK 6.8, which until construction of SNS had served as the reference site for WOC (Fig. 5.32). Except in 2009 when results with TDEC protocols classified MEK 0.6 as unimpaired and WCK 3.9 as moderately impaired, the invertebrate communities at all other sites in WOC watershed have consistently been classified as slightly impaired.

The benthic macroinvertebrate communities in First Creek, Fifth Creek, and WOC downstream of effluent discharges have recovered significantly since 1987, but community characteristics indicate that ecological impairment remains (Figs. 5.33, 5.34, and 5.35). Relative to reference sites, total taxonomic richness (i.e., the mean number of different species per sample) and richness of the pollution-intolerant taxa (i.e., the mean number of different mayfly, stonefly, and caddisfly species per sample or EPT taxa richness) continue to be lower at these downstream sites. After modest increases in the mid-1990s, metrics at First Creek kilometer (FCK) 0.1 have exhibited no persistent trends in change, thus suggesting that no major changes have since occurred. Trends in metrics at Fifth Creek kilometer (FFK) 0.2 since the mid-1990s suggest that a change in conditions at that site occurred between 2007 and 2008. More recent results, however, suggest that improvements have occurred, and the condition of the invertebrate community is now comparable to what it was before 2008. Metrics values for WCK 2.3 and WCK 3.9 continue to remain notably lower than those for the reference sites, suggesting that no further major changes have occurred at those sites for roughly 10 years.

Macroinvertebrate community metrics for lower Melton Branch (MEK 0.6, Fig. 5.36) suggest that conditions at this site continue to be relatively stable, and taxa richness metrics continue to be similar to reference conditions. However, other macroinvertebrate community metrics (not shown here), such as unusually high total densities of some of the most pollution-tolerant species (e.g., Orthocladiinae midges and aquatic worms) with corresponding lower densities of some of the pollution-intolerant taxa (e.g., mayflies and stoneflies) continue to suggest the presence of elevated concentrations of nutrients (e.g., phosphorus and/or nitrogen). Potential sources of nutrients in lower Melton Branch may be from direct inputs (e.g., effluent discharges or storm water runoff from fertilized land) or indirect inputs (e.g., natural release from freshly disturbed soils or underdeveloped riparian areas). 


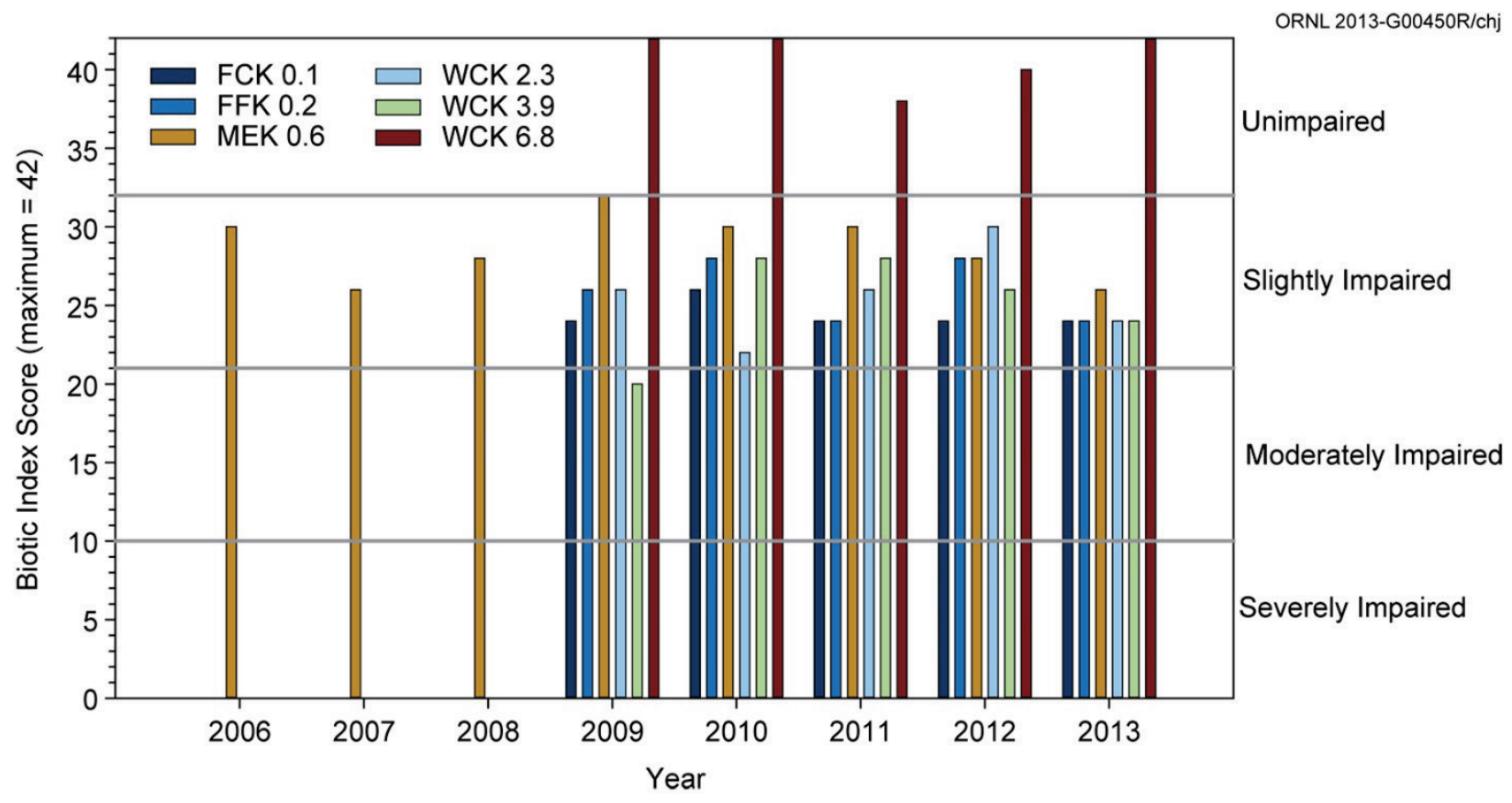

Fig. 5.32. Temporal trends in Tennessee Department of Environment and Conservation Biotic Index Scores for White Oak Creek watershed, August 2006-August 2013. Horizontal lines show the lower thresholds for biotic condition ratings for index scores; respective narrative ratings for each threshold are shown at right of graph. $($ FCK = First Creek kilometer; FFK = Fifth Creek kilometer; MEK = Melton Branch kilometer; WCK $=$ White Oak Creek kilometer.) 

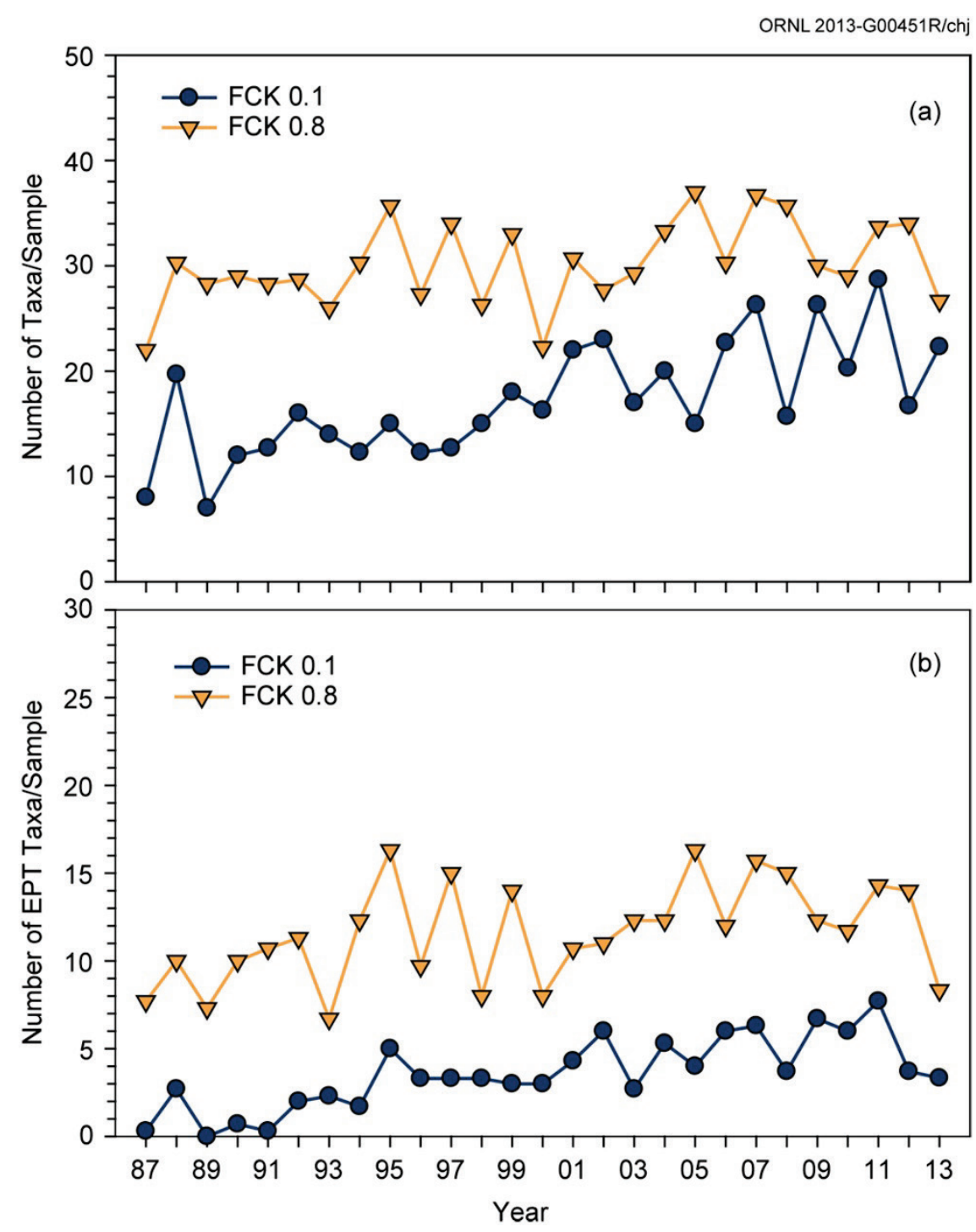

Fig. 5.33. Total taxonomic richness (mean number of all taxa/sample) (a) and taxonomic richness of the pollution intolerant taxa, Ephemeroptera, Plecoptera, and Trichoptera [(EPT); mean number of EPT taxa/sample] (b) of the benthic macroinvertebrate community in First Creek, April sampling periods, 1987-2013. (FCK = First Creek kilometer; FCK 0.8 = reference site.) 

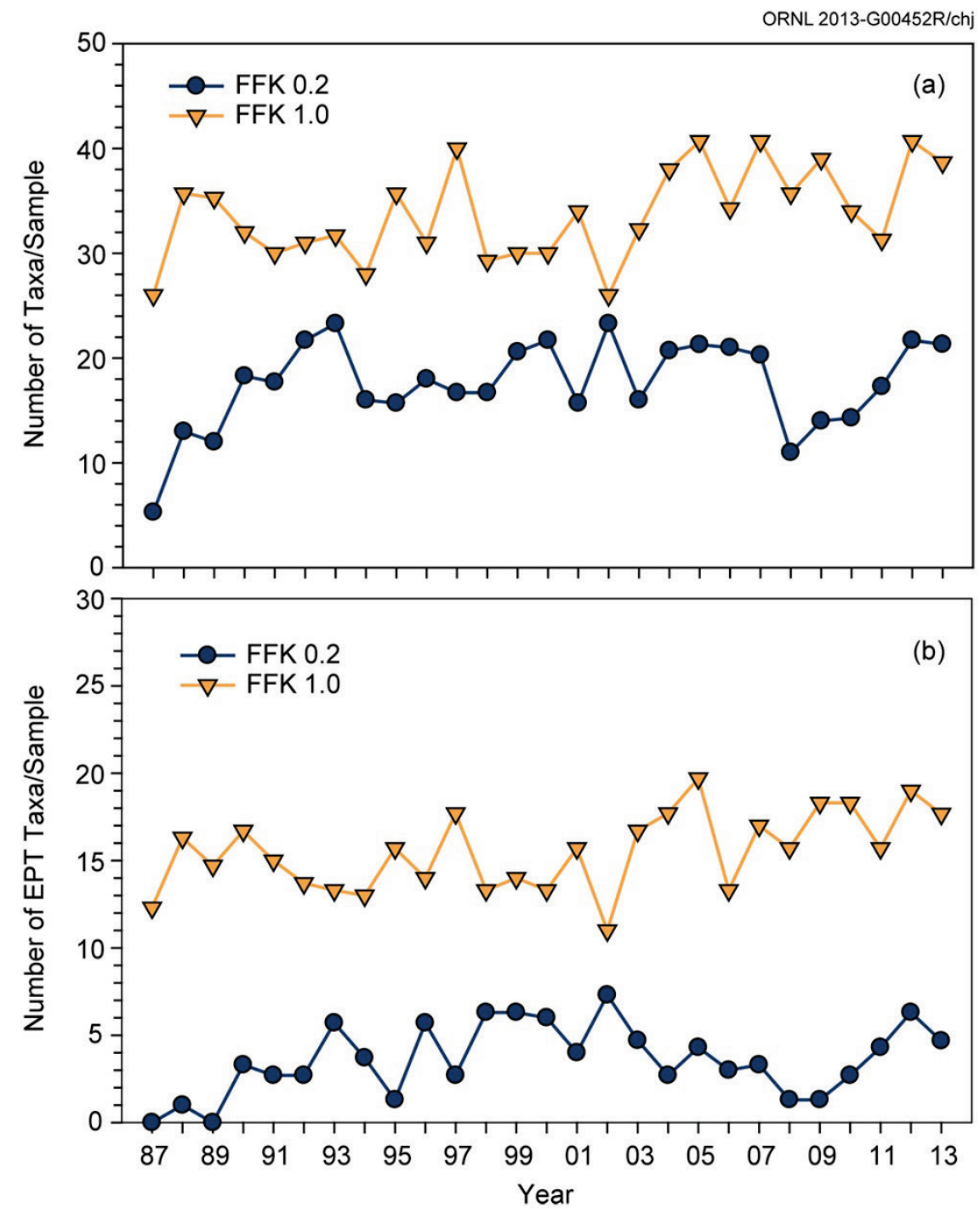

Fig. 5.34. Total taxonomic richness (mean number of all taxa/sample) (a) and taxonomic richness of the pollution intolerant taxa, Ephemeroptera, Plecoptera, and Trichoptera [(EPT); mean number of EPT taxa/sample], (b) of the benthic macroinvertebrate community in Fifth Creek, April sampling periods, 1987-2013. (FFK = Fifth Creek kilometer; FFK 1. 0 = reference site.) 


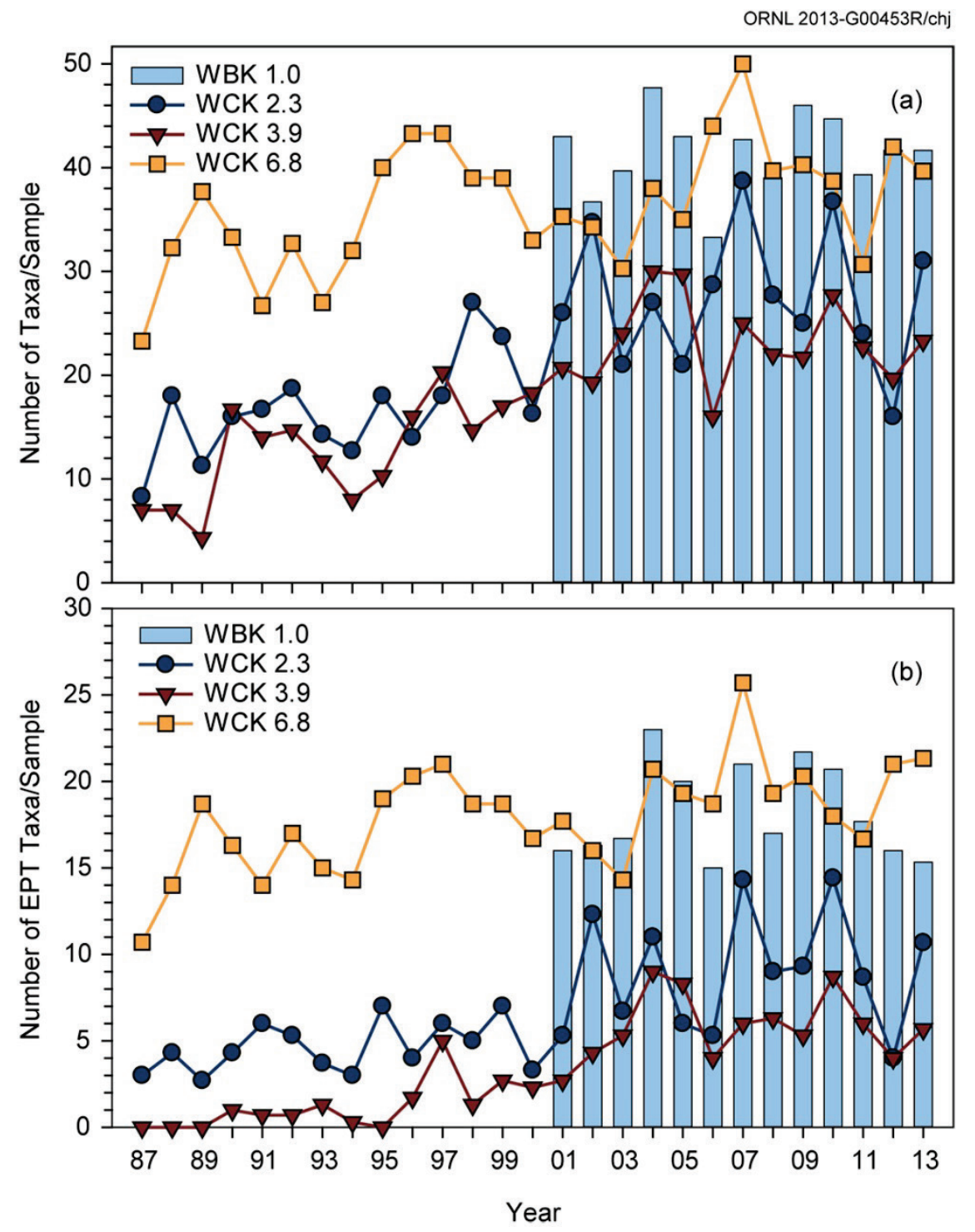

Fig. 5.35. Total taxonomic richness (mean number of all taxa/ sample) (a) and taxonomic richness of the pollution intolerant taxa, Ephemeroptera, Plecoptera, and Trichoptera [(EPT); mean number of EPT taxa/sample], (b) of the benthic macroinvertebrate community in White Oak Creek, April sampling periods, 1987-2013.

(WCK $=$ White Oak Creek kilometer; WBK $=$ Walker Branch kilometer; WBK $1.0=$ reference site.) 

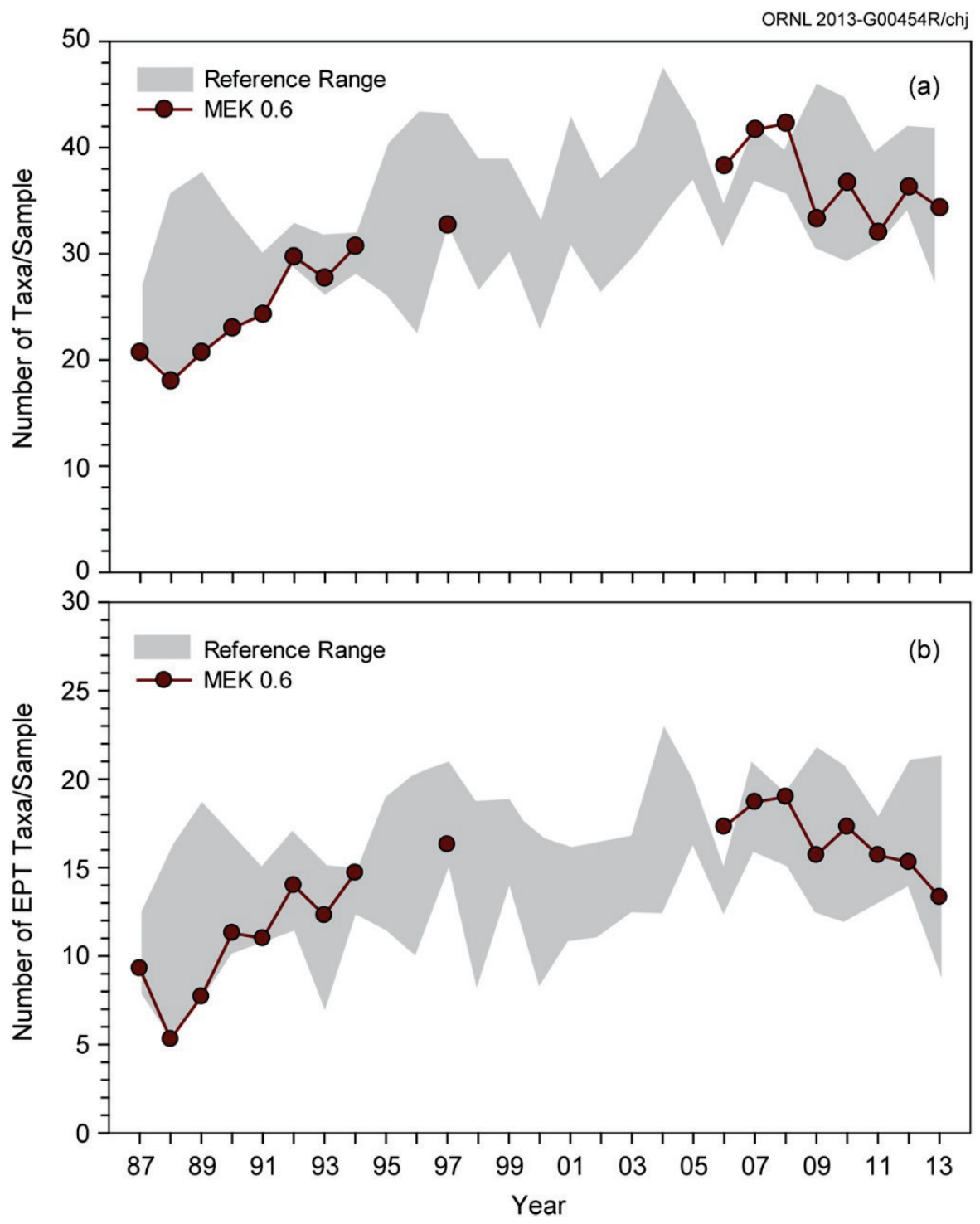

Fig. 5.36. Total taxonomic richness (mean number of all taxa/sample) (a) and taxonomic richness of the pollution intolerant taxa, Ephemeroptera, Plecoptera, and Trichoptera [(EPT); mean number of EPT taxa/sample], (b) of the benthic macroinvertebrate community in lower Melton Branch, April sampling periods, 1987-2013. [MEK = Melton Branch kilometer; reference range $=$ minimum and maximum values for Oak Ridge National Laboratory Biological Monitoring and Abatement Program reference sites on upper Melton Branch (1987-1997), First Creek and Fifth Creek (1987-2013), Walker Branch (2001-2013), and White Oak Creek (1987-2000, 2007-2013).]

\subsubsection{Fish Communities}

Monitoring fish communities in WOC and major tributaries continued in 2013. Fish community surveys were conducted at 11 sites in the WOC watershed in the fall and 10 sites in the spring. Streams located near or within the city of Oak Ridge (Mill Branch and Brushy Fork) were also sampled as reference sites each season.

In WOC, the fish community continued to be degraded in 2013 compared with communities in reference streams, with sites closest to outfalls within the ORNL campus having lower species richness (number of species) (Fig. 5.37), fewer pollution-sensitive species, more pollution-tolerant species, and 
elevated density (number of fish per square meter) compared with similar-sized reference streams. Generally, the fish communities in tributary sites adjacent to and downstream of ORNL outfalls also remained impacted in 2013 relative to reference streams or upstream sites.

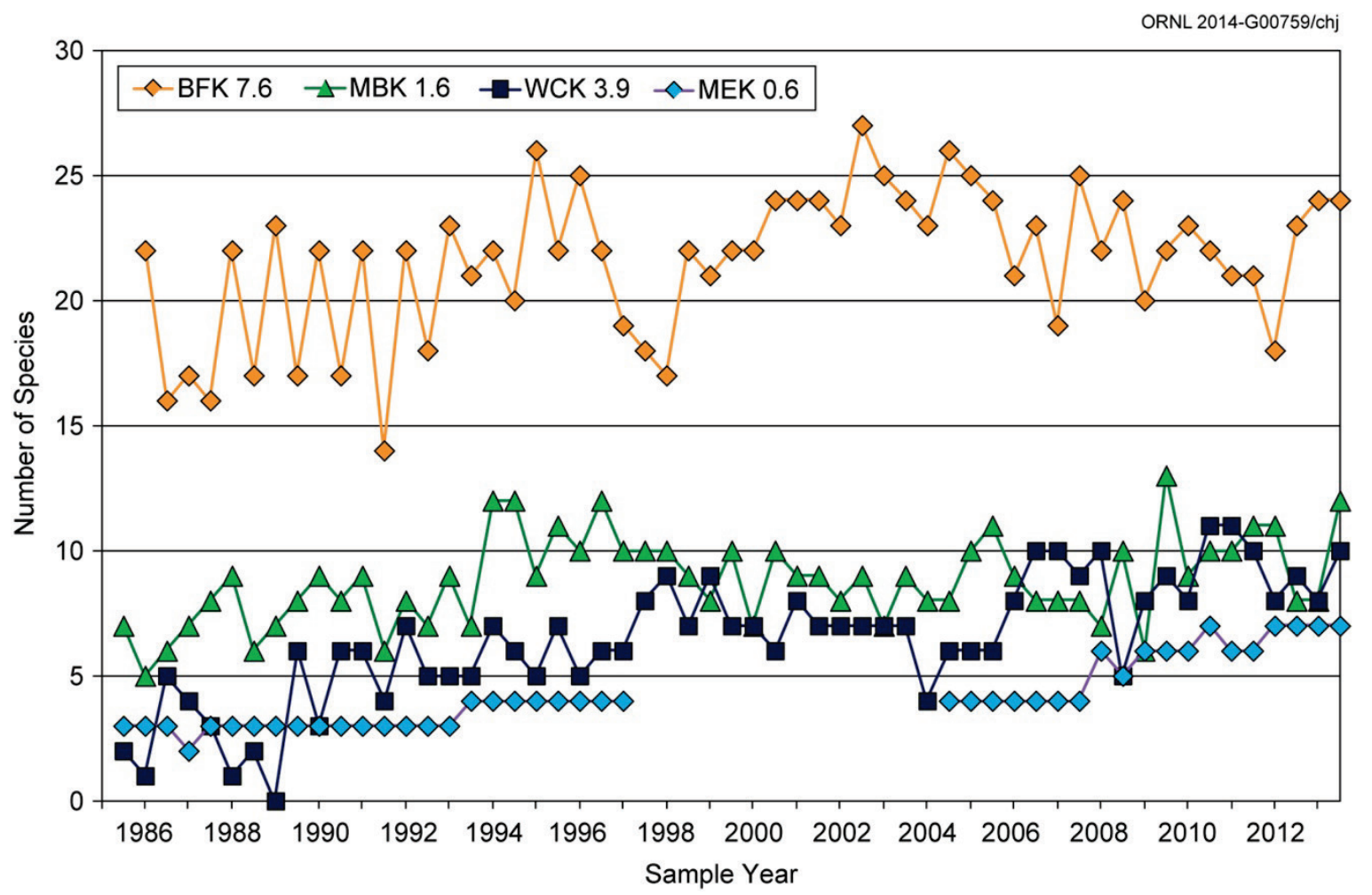

Fig. 5.37. Fish species richness (number of species) in upper White Oak Creek and lower Melton Branch compared with two reference streams (Brushy Fork and Mill Branch). (BFK = Brushy Fork kilometer; MBK = Mill Branch kilometer; MEK = Melton Branch kilometer; and WCK = White Oak Creek kilometer.)

A project to introduce fish species that were not historically found in the WOC watershed but exist in similar systems on ORR was initiated in 2008 by stocking six such native species. Reproduction has been noted for five of the species, and several species have expanded their range downstream from initial introduction sites to establish new reproducing populations. In general, introduced species have had more difficulty establishing populations at upstream sites in both WOC and Melton Branch, and as a result, introductions to supplement the small populations of these fish species are continuing at sites on the main ORNL campus.

\subsubsection{Polychlorinated Biphenyls in the White Oak Creek Watershed}

Past monitoring has shown that while PCBs are present in the watershed, they are not discharged from ORNL outfalls into the WOC watershed at levels detected by standard analytical methods. Largemouth bass collected from White Oak Lake continue to have tissue PCB concentrations higher than those recommended by TDEC and EPA for frequent consumption. While past monitoring efforts were instrumental in establishing a baseline for PCBs, the focus has historically been on relating PCB levels in fish to safe levels for consumption. These studies were not designed to identify specific stream reaches or sources contributing to PCB bioaccumulation.

The mobility of the fish populations used in traditional bioaccumulation monitoring studies precludes the possibility of source identification. Therefore, the source identification task involved the use of semipermeable membrane devices (SPMDs) to assess the chronic, low-level sources of PCBs at critical sites on the reservation. SPMDs are thin plastic sleeves filled with oil in which PCBs are soluble. 
Because SPMDs remain submerged at a given site for 4 weeks and have a high affinity for PCBs, a time-integrated, semiquantitative index of the mean PCB concentration in the water column during the deployment period is provided. SPMDs also have advantages over "snapshot" water concentration analyses. The long deployment period enables distinction between the relative PCB inputs at sites whose aqueous PCB concentrations are below detection limits in water.

In 2013, ORNL's PCB monitoring efforts continued focusing on the First Creek watershed, which has been identified previously as a source of PCBs. SPMDs and clams were deployed in First Creek. SPMDs were deployed in pipe networks for outfalls 250 and 341, which contribute to First Creek (Fig. 5.38). The results are summarized in Table 5.15.

The SPMD deployed at the reference site upstream of the ORNL campus, FCK 0.9, had background levels of PCBs. The PCB concentration for FCK 0.1 was greater than the background levels at FCK 0.9, confirming that the First Creek watershed is a source of PCBs. Inlets 341-3 and 250-3, which collect storm water from the same drainage area, had the highest SPMD accumulations among the inlet samples. The results from the 2013 assessment continue to confirm that the upper parts of the outfalls 250 and 341 pipe networks are of primary interest for legacy PCB sources in the First Creek watershed. The 2013 clam results continue to confirm that sources in the drainage areas served by outfalls 249 and 250 contain PCBs in amounts that are bioaccumulating above background levels.

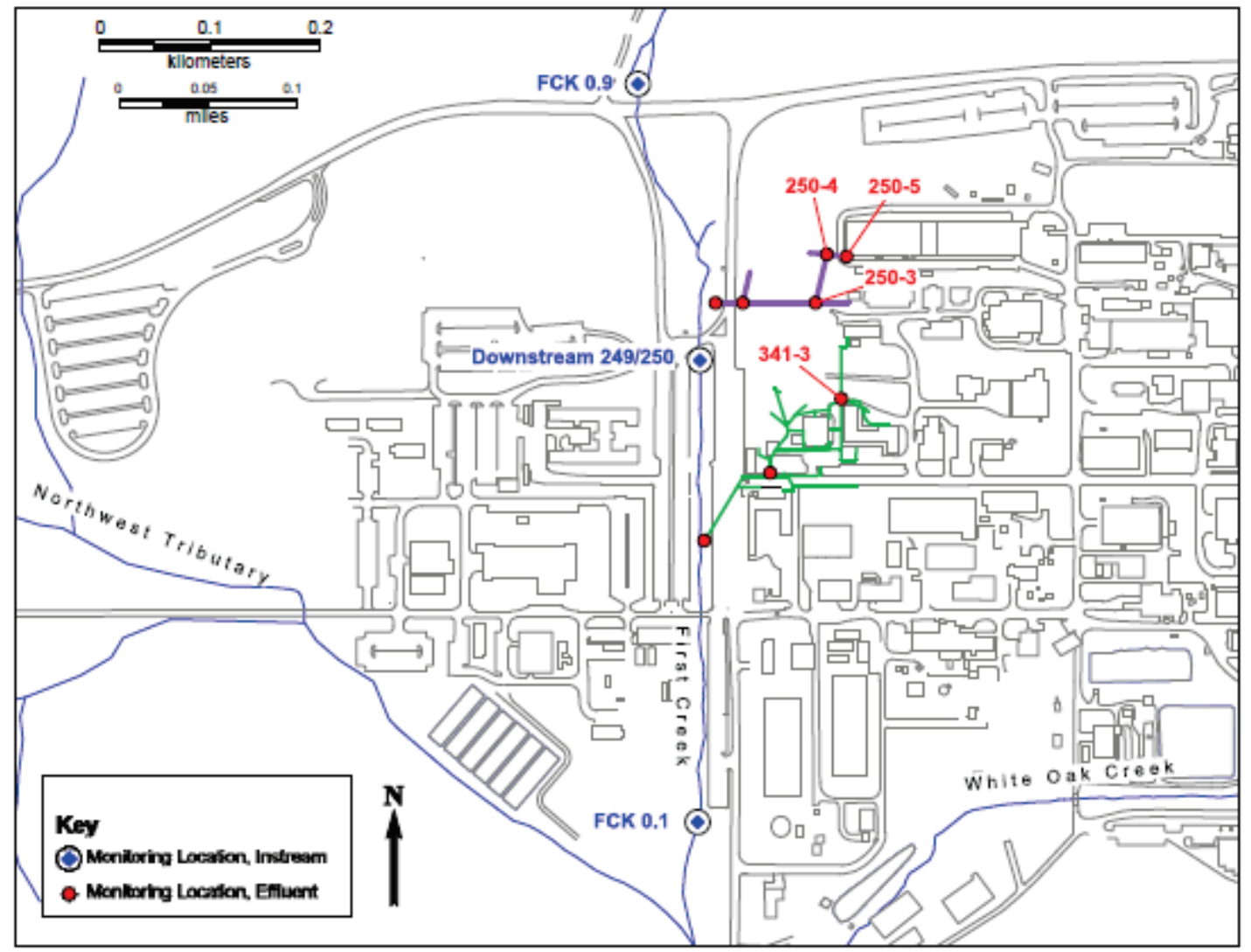

Fig. 5.38. Locations of monitoring points for First Creek source investigation. (FCK = First Creek kilometer) 
Table 5.15. First Creek PCB source assessment, August 2013

[Total PCBs (parts per billion)]

\begin{tabular}{lccc}
\hline \multicolumn{1}{c}{ Sample location } & Location type & SPMD & Clams \\
\hline FCK 0.9 & Reference Site & 101 & 3.05 \\
Catch Basin 250-5 & Inlet & 1,200 & - \\
Manhole 250-4 & Inlet/Outlet & 1,200 & - \\
Manhole 250-3 & Inlet 1 & 6,300 & - \\
Manhole 250-3 & Inlet 2 & 5,100 & - \\
Manhole 250-3 & Inlet 3 & 14,000 & - \\
Manhole 250-3 & Outlet & 12,000 & - \\
Downstream Outfall 249/250 & Instream & 17,000 & 1,350 \\
Manhole 341-3 & Inlet 1 & 26,700 & - \\
Manhole 341-3 & Inlet 2 & 8,100 & - \\
Manhole 341-3 & Inlet 3 & 14,800 & \\
Manhole 341-3 & Outlet & 15,300 & - \\
FCK 0.1 & Instream & 20,200 & 1,895 \\
\hline
\end{tabular}
Abbreviations
FCK First Creek kilometer
$\mathrm{PCB}=$ polychlorinated biphenyl
SPMD semipermeable membrane device

\subsubsection{Oil Pollution Prevention}

CWA Section 311 regulates the discharge of oils or petroleum products to waters of the United States and requires the development and implementation of SPCC plans to minimize the potential for oil discharges. These requirements are provided in 40 CFR 112, Oil Pollution Prevention. Each ORR facility implements a site-specific SPCC plan. NTRC, which is located off ORR, also has an SPCC plan covering the oil inventory at its location. CFTF is also located off ORR; however, this facility was evaluated and a determination made that an SPCC plan was not required. There were no regulatory or permitting actions related to oil pollution prevention at ORNL or NTRC in 2013. An oil handler training program exists to comply with training requirements in 40 CFR 112.

\subsubsection{Surface Water Surveillance Monitoring}

The ORNL surface water monitoring program is conducted in conjunction with the ORR surface water monitoring activities discussed in Section 6.4 to enable assessing the impacts of ongoing DOE operations on the quality of local surface water. The sampling locations (Fig. 5.39) are used to monitor conditions upstream of ORNL main plant waste sources (WCK 6.8); within the ORNL campus (FFK 0.1); and downstream of ORNL discharge points (WCK 1.0).

Sampling frequencies and parameters vary by site and are shown in Table 5.16. Radiological monitoring at the discharge point downstream of ORNL, White Oak Lake at WOD, is conducted monthly under the ORNL WQPP (Section 5.5.4) and, therefore, is not duplicated by this program. Radiological monitoring at the discharge point upstream of ORNL is conducted monthly under the ORNL WQPP (Section 5.5.4) and, therefore, is not duplicated by this program. Total radioactive strontium is monitored quarterly by this surveillance program. 


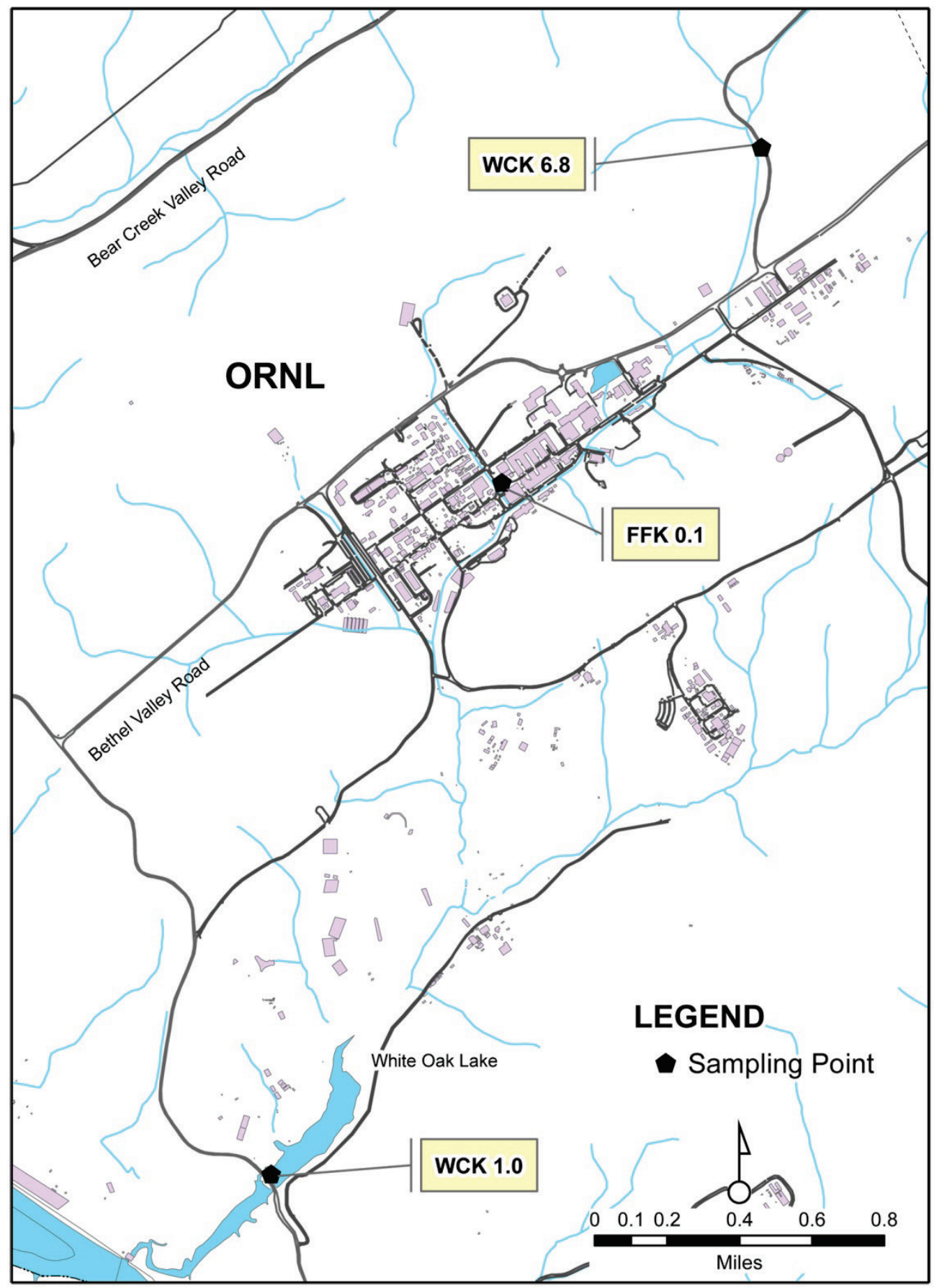

Fig. 5.39. Oak Ridge National Laboratory surface water sampling locations. (FFK = Fifth Creek kilometer; $\mathrm{WCK}=$ White Oak Creek kilometer.)

Samples are collected and analyzed for general water quality parameters and are screened for radioactivity at all locations (either under this program or under WQPP). Samples are further analyzed for specific radionuclides when general screening levels are exceeded. Samples from White Oak Lake at WOD are also checked for VOCs, PCBs, and mercury. WCK 6.8 and WCK 1.0 are classified by the State of Tennessee for freshwater fish and aquatic life. Tennessee WQCs associated with these classifications are used as references where applicable. The Tennessee WQCs do not include criteria for radionuclides. Four percent of the DOE DCS is used for radionuclide comparison because this value is roughly equivalent to the 4 mrem dose limit from ingestion of drinking water on which the EPA radionuclide drinking water standards are based. 
Table 5.16. Oak Ridge National Laboratory surface water sampling locations, frequencies, and parameters, 2013

\begin{tabular}{llll}
\hline \multicolumn{1}{c}{ Location $^{a}$} & \multicolumn{1}{c}{ Description } & Frequency and type & \multicolumn{1}{c}{ Parameters $^{b}$} \\
\hline WCK 1.0 & White Oak Lake at WOD & Quarterly, grab & $\begin{array}{l}\text { Volatiles, mercury, PCBs, field } \\
\text { measurements }\end{array}$ \\
WCK 6.8 & WOC upstream from ORNL & Quarterly, grab & $\begin{array}{l}\text { Total radioactive strontium, field } \\
\text { measurements }\end{array}$ \\
FFK 0.1 & $\begin{array}{l}\text { Fifth Creek just upstream of } \\
\text { WOC (ORNL) }\end{array}$ & $\begin{array}{l}\text { Semiannually, } \\
\text { grab }\end{array}$ & $\begin{array}{l}\text { Gross alpha, gross beta, total } \\
\text { radioactive strontium, gamma scan, } \\
\text { tritium, field measurements }\end{array}$ \\
\hline
\end{tabular}

${ }^{a}$ Locations identify bodies of water and locations on them (e.g., WCK 1.0 is $1 \mathrm{~km}$ upstream from the confluence of White Oak Lake and the Clinch River).

${ }^{b}$ Field measurements consist of dissolved oxygen, $\mathrm{pH}$, and temperature.

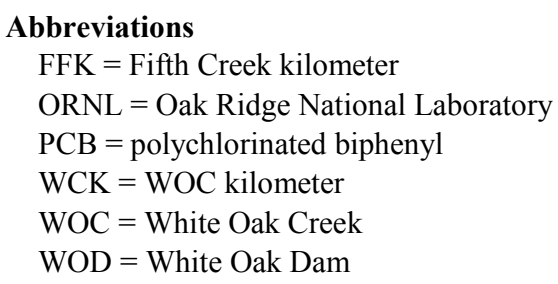

The ORR upstream reference site (CRK 66) may be compared with results from this program as applicable to evaluate potential impacts to area surface water as a result of DOE activities at ORNL (Section 6.4.1). Overall radionuclide results from 2013 surveillance monitoring efforts are consistent with historical data.

Radionuclides were detected at the Fifth Creek location and the WOC location upstream from ORNL; however, none were above $4 \%$ of the DOE DCS. Radionuclide results before WOC empties into the Clinch River (at WOD) are discussed in Section 5.5.4.

Neither mercury nor PCBs were detected during 2013 at WOC at WOD. Other than a couple of PCB detections in 2011 and 2012, PCBs have not been detected since 2001 at WOC at WOD.

\subsubsection{Carbon Fiber Technology Facility Waste Water Monitoring}

Facility and process waste water from activities at CFTF are discharged to the City of Oak Ridge sanitary sewer system under conditions established in City of Oak Ridge Industrial Waste Water Discharge Permit 1-12. Permit limits, parameters, and 2013 compliance status for this permit are summarized in Table 5.17. 
Table 5.17. Industrial and Commercial User Waste Water Discharge Permit compliances at the Oak Ridge National Laboratory Carbon Fiber Technology Facility, 2013

(permit effective October 15, 2012)

\begin{tabular}{|c|c|c|c|c|c|}
\hline \multirow{2}{*}{$\begin{array}{c}\text { Effluent } \\
\text { parameters }\end{array}$} & \multicolumn{2}{|c|}{ Permit limits } & \multicolumn{3}{|c|}{ Permit Compliance } \\
\hline & $\begin{array}{c}\text { Daily max. } \\
(\mathrm{mg} / \mathrm{L})\end{array}$ & $\begin{array}{c}\text { Daily min. } \\
(\mathrm{mg} / \mathrm{L})\end{array}$ & $\begin{array}{c}\text { Number of } \\
\text { noncompliances }\end{array}$ & $\begin{array}{c}\text { Number of } \\
\text { samples }\end{array}$ & $\begin{array}{l}\text { Percentage of } \\
\text { compliance }^{a}\end{array}$ \\
\hline \multicolumn{6}{|c|}{ Outfall 01 (Underground Quench Water Tank) } \\
\hline Cyanide & & 4.2 & 0 & 3 & 100 \\
\hline $\mathrm{pH}$ (standard units) & 9.0 & 6.0 & 0 & 3 & 100 \\
\hline \multicolumn{6}{|c|}{ Outfall 02 (Electrolytic Bath Tank) } \\
\hline $\mathrm{pH}$ (standard units) & 9.0 & 6.0 & 0 & 15 & 100 \\
\hline \multicolumn{6}{|c|}{ Outfall 03 (Sizing Bath Tank) } \\
\hline Copper & & 0.87 & 0 & 4 & 100 \\
\hline Zinc & & 1.24 & 0 & 4 & 100 \\
\hline Total Phenol & & 4.20 & 0 & 4 & 100 \\
\hline $\mathrm{pH}$ (standard units) & 9.0 & 6.0 & 0 & 4 & 100 \\
\hline
\end{tabular}

${ }^{a}$ Percentage compliance $=100[($ number of noncompliances/number of samples $) \times 100]$.

\subsection{Groundwater Monitoring Program}

Groundwater monitoring at ORNL was conducted under two sampling programs in 2013: DOE EM monitoring and DOE Office of Science (OS) surveillance monitoring. The DOE EM groundwater monitoring program was performed by UCOR in 2013. The OS groundwater monitoring surveillance program was conducted by UT-Battelle.

\subsubsection{DOE Office of Environmental Management Groundwater Monitoring}

Monitoring was performed as part of an ongoing comprehensive CERCLA cleanup effort in Bethel and Melton Valleys at ORNL, the two administrative watersheds at the ORNL site. Groundwater monitoring for baseline and trend evaluation in addition to measuring effectiveness of completed CERCLA RAs is conducted as part of WRRP. WRRP is managed by UCOR for the DOE EM Program. The results of CERCLA monitoring for ORR for fiscal year 2013, including monitoring at ORNL, are evaluated and reported in the 2014 remediation effectiveness report (DOE 2014a) as required by the ORR FFA. The monitoring results and remedial effectiveness evaluations for Bethel and Melton Valley are reported in Sections 2 and 3, respectively, in this report.

Following discussions between DOE and TDEC, during 2013 TDEC declined to issue a RCRA PostClosure Permit for SWSA 6. From this point forward, substantively equivalent reporting of groundwater quality in wells at the perimeter of SWSA 6 is to be reported in the annual CERCLA RER.

Groundwater monitoring conducted as part of the EM program at ORNL includes routine sampling and analysis of groundwater in Bethel Valley to measure performance of several RAs and to continue contaminant and groundwater quality trend monitoring. In Melton Valley, where CERCLA RAs were completed in 2006 for the extensive waste management areas, the groundwater monitoring program includes monitoring groundwater levels to evaluate the effectiveness of hydrologic isolation of buried waste units. Additionally, groundwater is sampled and analyzed for a wide range of general chemical and contaminant parameters in 46 wells within the interior portion of the closed waste management area.

In FY 2010 DOE initiated activities on a groundwater treatability study at the Bethel Valley 7000 Services Area VOC plume. This plume contains TCE and its transformation products cis-1,2-DCE and vinyl chloride, all at concentrations greater than EPA primary drinking water standards. The treatability study is a laboratory and field demonstration that microbes inherent to the existing subsurface microbial population can fully degrade the VOCs to nontoxic end products. 
During FY 2013 post-remediation monitoring continued at SWSA 3 following completion of hydrologic isolation of the area by construction of a multilayer cap and upgradient stormflow/shallow groundwater diversion drain. RAs and monitoring were specified in a CERCLA RA work plan that was developed by DOE and was approved by EPA and TDEC before the project was started.

During FY 2013 the EM monitoring program continued sampling and analysis in the off-site groundwater monitoring well array west of the Clinch River adjacent to Melton Valley. In addition to offsite groundwater quality monitoring near Melton Valley, exit pathway groundwater monitoring in Melton Valley is conducted as part of the EM program, including sampling at six multiport monitoring wells in western Melton Valley (wells 4537, 4538, 4539, 4540, 4541, 4542).

\subsubsection{Summary of DOE Office of Environmental Management Groundwater Monitoring}

\subsection{Bethel Valley}

During FY 2011 construction was completed for RAs at two former waste storage sites, SWSA 1 and SWSA 3, which were used for disposal of radioactively contaminated solid wastes between 1944 and 1950. Wastes disposed at SWSA 1 originated from the earliest operations of ORNL while those at SWSA 3 originated from ORNL, Y-12, the K-25 Site (ETTP), and off-site sources. Although most of the disposed waste was solid waste, some containerized liquid wastes were disposed at SWSA 3. Some wastes were encapsulated in concrete after placement in burial trenches while most of the waste was soilcovered. The Bethel Valley ROD (DOE 2002) selected hydrologic isolation using multilayer caps and groundwater diversion trenches as the RA for the waste burial grounds and construction of soil covers over the former contractor's landfill and contaminated soil areas near SWSA 3. The baseline monitoring conducted during FY 2010 included measurement of groundwater levels to obtain baseline data to allow evaluation of post-remediation groundwater-level suppression. Sampling and analysis of groundwater quality and contaminants were also conducted. Post-remediation monitoring was specified for SWSA 3 in the Phased Construction Completion Report for the Bethel Valley Burial Grounds at the Oak Ridge National Laboratory, Oak Ridge, Tennessee (DOE 2012). Required monitoring includes quarterly groundwater-level monitoring in 42 wells with continuous water-level monitoring in 8 wells to confirm cap performance. Groundwater samples are collected semiannually at 13 wells for laboratory analyses to evaluate groundwater contaminant concentration trends. During FY 2013 monitoring results showed that the cap was effective although target groundwater elevations were exceeded at three of eight wells. Comparison of pre-remediation to post-remediation groundwater contaminant concentrations showed that evaluated contaminant levels decreased at four locations, were stable at five locations, and exhibited no trend at three locations.

During FY 2013 the DOE EM Program monitored three groundwater monitoring wells in Bethel Valley to the west of Tennessee Highway 95 to detect and monitor contamination from the SWSA 3 area. These three wells supplement data being collected from a multiport well (4579) near SWSA 3 for exit pathway groundwater monitoring in western Bethel Valley. Groundwater monitoring near SWSA 3, along with the exit pathway, and groundwater monitoring and surface water monitoring at the northwest tributary of WOC and in the headwaters of Raccoon Creek allow integration of data concerning SWSA 3 contaminant releases as presented in the 2014 remediation effectiveness report (DOE 2014a).

Groundwater monitoring continued at the ORNL 7000 Area during FY 2013 to evaluate treatability of the VOC plume at that site. Site characterization testing of the endemic microbial community showed that microbes were present that are capable of fully degrading TCE and its degradation products if sufficient electron donor compounds were present in the subsurface environment. During FY 2011 a mixture of emulsified vegetable oil and a hydrogen releasing compound was injected into four existing monitoring wells in the 7000 area. Monitoring of the stimulation of the endemic microbial community along with concentrations of chlorinated VOCs continued through FY 2013. Results of the monitoring show that the microbial community responded well to the addition of the carbon electron donor, and the VOC concentrations in the treated area have decreased significantly. 
The other principal element of the Bethel Valley ROD (DOE 2002) remedy that requires groundwater monitoring is the containment pumping to control and treat discharges from the ORNL Central Campus core hole 8 plume. The original action for this plume was a CERCLA removal action that was implemented in 1995. The remedy had performed well until the latter portion of FY 2008 when conditions changed and ${ }^{90} \mathrm{Sr}$ and ${ }^{233 / 234} \mathrm{U}$ concentrations in monitoring wells and the groundwater collection system began increasing. Leaking utility waterlines near the source area are suspected to have increased the mass of contaminants feeding the plume. Increased infiltration of plume water into storm drains has allowed increased contaminant flux to First Creek, a tributary of WOC. During FY 2009 the remedy did not meet its performance goal, which is a reduction of ${ }^{90} \mathrm{Sr}$ in WOC. In March $2012 \mathrm{DOE}$ completed refurbishment and enhancement of the groundwater collection system to increase the plume containment effectiveness. During FY 2013 the remedy met its performance goal of reducing ${ }^{90} \mathrm{Sr}$ levels in WOC as measured at the 7500 bridge.

\subsection{Melton Valley}

The Melton Valley ROD (DOE 2000) established goals for a reduction of contaminant levels in surface water, groundwater-level fluctuation reduction goals within hydrologically isolated areas, and minimization of the spread of groundwater contamination. Remedy effectiveness groundwater monitoring in Melton Valley includes groundwater-level monitoring in wells within and adjacent to hydrologically isolated shallow waste burial areas and groundwater quality monitoring in selected wells adjacent to buried waste areas.

Groundwater-level monitoring shows that the hydrologic isolation component of the Melton Valley remedy is effectively minimizing the amount of percolation water contacting buried waste and is reducing contaminated leachate formation. During FY 2013 greater than average annual rainfall occurred for the fifth consecutive year since the remedy was completed in 2006. In a few areas groundwater levels within capped areas continue to respond to groundwater fluctuations imposed from areas outside the caps, but contact of groundwater with buried waste is minimal. Overall the hydrologic isolation systems are performing as designed. During FY 2013 a maintenance action was implemented at the SWSA 4 downgradient collection trench. All 14 groundwater extraction wells in the downgradient trench were redeveloped and faulty pumps were replaced. After this maintenance action the system performance improved as measured by improved groundwater-level suppression in the groundwater collection trench.

Groundwater quality monitoring in the interior of Melton Valley shows that in general groundwater contaminant concentrations are declining or are stable following RAs.

During the past 9 years of groundwater monitoring in the Melton Valley exit pathway, several siterelated contaminants have been detected in groundwater near the Clinch River. Low concentrations of

${ }^{90} \mathrm{Sr}$, tritium, uranium, and VOCs have been detected intermittently in a number of the multizone sampling locations. Groundwater in the exit pathway wells has high alkalinity and sodium and exhibits elevated pH. During FY 2013 an off-site groundwater monitoring well array west of the Clinch River adjacent to Melton Valley was monitored as part of the EM program. Monitoring included groundwaterlevel monitoring to evaluate potential flowpaths near the river and sampling and analysis for a wide array of metals, anions, radionuclides, and VOCs. Groundwater-level monitoring showed that natural head gradient conditions cause groundwater seepage to converge toward the Clinch River from both the DOE (eastern) and off-site (western) sides of the river. During FY 2013 no site-related radionuclides (tritium, ${ }^{90} \mathrm{Sr},{ }^{99} \mathrm{Tc}$ ) or VOCs were detected in the off-site monitoring wells. The only site-related radionuclide detected in the DOE on-site exit pathway wells near the Clinch River was ${ }^{90} \mathrm{Sr}$, which was detected in one multiport well sampling location at an activity level less than half the derived drinking water limit equivalent level. Monitoring results are summarized in the 2014 remediation effectiveness report (DOE 2014a).

\subsubsection{DOE Office of Science Groundwater Monitoring}

DOE O 458.1 (DOE 2011b) is the primary requirement for a sitewide groundwater protection program at ORNL. As part of the groundwater protection program, and to be consistent with UT-Battelle 
management objectives, groundwater surveillance monitoring was performed to monitor ORNL groundwater exit pathways and UT-Battelle facilities ("active sites") potentially posing a risk to groundwater resources at ORNL. Results of the DOE OS groundwater surveillance monitoring program are reported in the following sections.

Exit pathway and active-sites groundwater surveillance monitoring points sampled during 2013 included seep/spring and surface-water monitoring locations in addition to groundwater surveillance monitoring wells. Seep/spring and surface-water monitoring locations were used in the absence of monitoring wells located in appropriate groundwater discharge areas.

Groundwater monitoring performed under the exit pathway groundwater surveillance and active-sites monitoring programs is not regulated by federal or state regulations. Consequently, no permit or standards exist for evaluating sampling results. To provide a basis for evaluating analytical results and for assessment of groundwater quality at locations monitored by UT-Battelle for OS, federal drinking water standards and Tennessee WQCs for domestic water supplies (TDEC 2012) were used as reference standards in the following discussions. Four percent of the DCSs established by DOE O 458.1 were used if no federal or state standards had been established for a particular radionuclide. Although drinking water standards and DOE DCSs are used for comparative purposes, it is important to note that no members of the public consume groundwater from ORNL wells, nor do any groundwater wells furnish drinking water to personnel at ORNL.

Results of OS monitoring of groundwater exit pathway discharge areas for radiological and metal contaminants were generally consistent with results reported in past ASERs. One organic compound was detected in samples collected from two WOC discharge area sampling locations. Based on the results of the 2013 monitoring effort, there is no indication that current OS operations are significantly impacting groundwater at ORNL.

\subsubsection{Exit Pathway Monitoring}

During 2013, exit pathway groundwater surveillance monitoring was performed in accordance with the exit pathway sampling and analysis plan (SAP) (Bonine 2012). Groundwater exit pathways at ORNL include areas from watersheds or subwatersheds where groundwater discharges to the Clinch RiverMelton Hill Reservoir to the west, south, and east of the ORNL main campus. The exit pathway monitoring points were chosen based on hydrologic features, screened interval depths (for wells), and locations relative to discharge areas proximate to DOE facilities operated by, or under the control of, UT-Battelle. The groundwater exit pathways at ORNL include four discharge zones identified by a data quality objectives process. One of the original exit pathway zones was split into two zones for geographic expediency. The Southern Discharge Area Exit Pathway was carved from the East End Discharge Area Exit Pathway.

The five zones are as follows:

- the WOC Discharge Area Exit Pathway,

- the 7000-Bearden Creek Watershed Discharge Area Exit Pathway,

- the East End Discharge Area Exit Pathway,

- the Northwestern Discharge Area Exit Pathway, and

- the Southern Discharge Area Exit Pathway.

Figure 5.40 shows the locations of the exit pathway monitoring points sampled in 2013. 


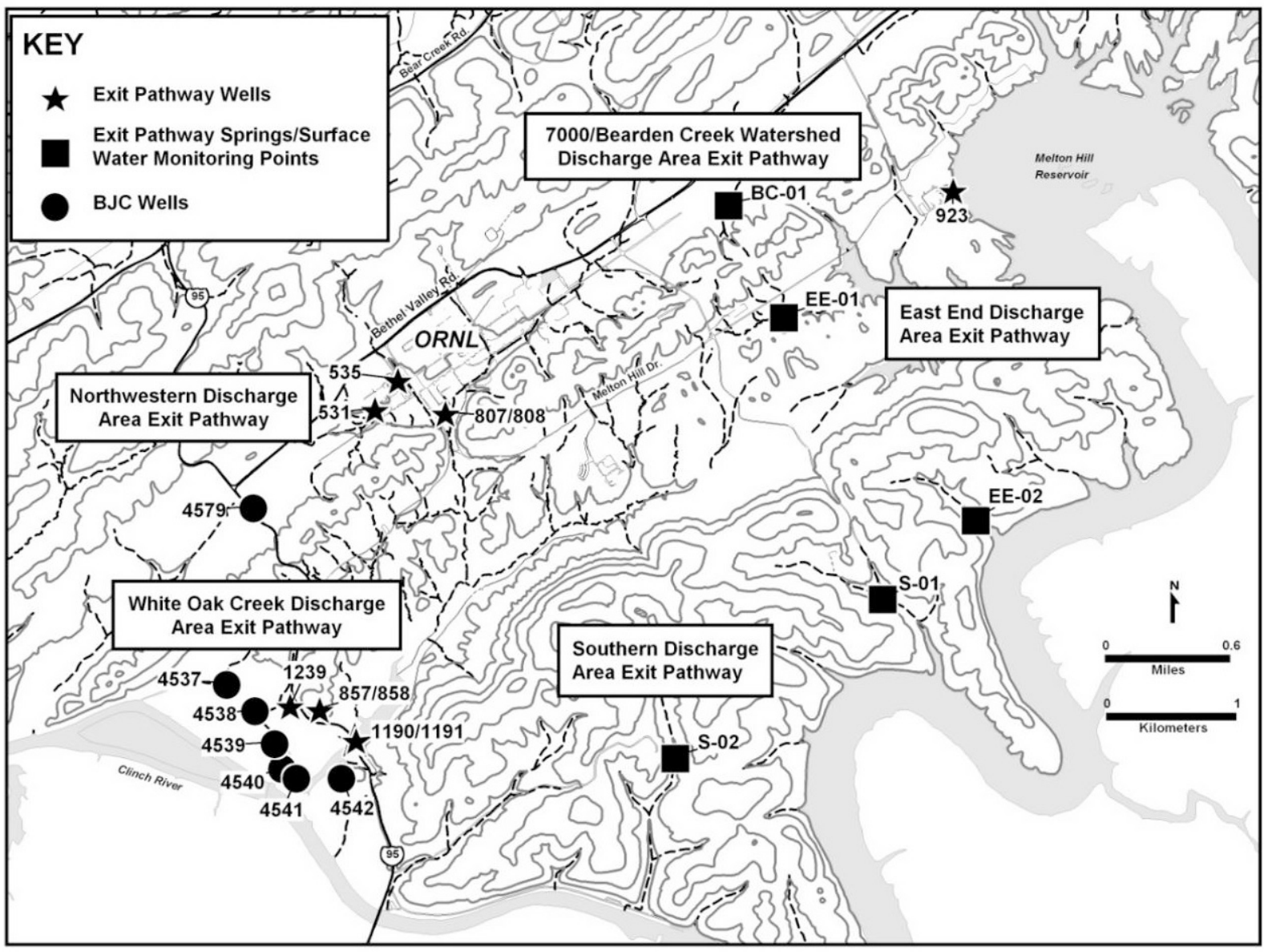

Fig. 5.40. UT-Battelle exit pathway groundwater monitoring locations at Oak Ridge National Laboratory, 2013. (BJC = Bechtel Jacobs, Inc., LLC.)

The efficacy of the exit pathway monitoring program was reviewed in late 2011. As a result, the groundwater monitoring program was modified through an optimization approach that included frequency analysis of parameters and their concentrations based on an exhaustive review of historical groundwater sampling data. The modification resulted in a 10-year staggered groundwater monitoring schedule and analytical suite selection. This approach was initiated in 2012. The groundwater monitoring program implemented in 2013 is outlined in Table 5.18.

Unfiltered samples were collected from the exit pathway groundwater surveillance monitoring points in 2013. The organic suite was composed of VOCs and semivolatile organic compounds (SVOCs); the metallic suite included metals (e.g., aluminum, iron, lead, mercury); and the radionuclide suite was composed of gross alpha/gross beta activity, gamma emitters, total radioactive strontium, and tritium. Under the monitoring strategy outlined in the exit pathway SAP, samples were collected semiannually during the wet (April) and dry (August and September) seasons. 
Table 5.18. Scheduled 2013 exit pathway groundwater monitoring

\begin{tabular}{|c|c|c|c|}
\hline Discharge area & Monitoring point & Wet season & Dry season \\
\hline \multirow{5}{*}{ White Oak Creek } & 857 & Radiological & Radiological \\
\hline & 858 & Radiological & Radiological \\
\hline & 1190 & $\begin{array}{c}\text { Radiological, organic, and } \\
\text { metals }\end{array}$ & $\begin{array}{c}\text { Radiological, organic, and } \\
\text { metals }\end{array}$ \\
\hline & 1191 & $\begin{array}{l}\text { Radiological, organic, and } \\
\text { metals }\end{array}$ & $\begin{array}{c}\text { Radiological, organic, and } \\
\text { metals }\end{array}$ \\
\hline & 1239 & Radiological & $\begin{array}{c}\text { Radiological, organic, and } \\
\text { metals }\end{array}$ \\
\hline \multirow{4}{*}{ Northwestern } & 531 & Radiological & $\begin{array}{l}\text { Radiological, organic, and } \\
\text { metals }\end{array}$ \\
\hline & 535 & Radiological & Radiological \\
\hline & 807 & Radiological & Radiological \\
\hline & 808 & Radiological & $\begin{array}{c}\text { Radiological, organic, and } \\
\text { metals }\end{array}$ \\
\hline \multirow[t]{2}{*}{ 7000-Bearden Creek } & BC-01 & Radiological & Radiological \\
\hline & 923 & Radiological & $\begin{array}{l}\text { Radiological, organic, and } \\
\text { metals }\end{array}$ \\
\hline \multirow[t]{2}{*}{ East End } & EE-01 & Radiological & Radiological \\
\hline & EE-02 & Radiological & $\begin{array}{l}\text { Radiological, organic, and } \\
\text { metals }\end{array}$ \\
\hline \multirow{2}{*}{ Southern } & S-01 & Radiological & Radiological \\
\hline & $\mathrm{S}-02$ & Radiological & Radiological \\
\hline
\end{tabular}

\subsection{Exit Pathway Monitoring Results}

Statistical trend analyses were performed on 2013 exit pathway monitoring data sets containing data exceeding reference standards. The bases used for the trend analyses were the historical data collected from the late 1980s through 2013. Trend analyses were not performed on data sets where minimum detection limits exceeded reference standards (i.e., the SVOCs atrazine, benzo(a)pyrene, hexachlorobenzene, and pentachlorophenol) and were not performed on parameters for which there are no reference standards or where data densities were insufficient. Parameters that exhibited statistically significant ( $80 \%$ to $99 \%$ confidence levels) upward or downward trends are reported. Trend analysis results are summarized in Table 5.19.

Samples were not collected at S-01 during the dry season due to a lack of water flow at that location. Samples were collected at all other monitoring points during both the wet and dry seasons. Monitoring results are available in OREIS. Access to this system can be requested via email (oreis@ettp.doe.gov) or by telephone (865-574-3257).

Table 5.20 provides a summary of radiological parameters detected in samples collected from exit pathway monitoring points during 2013. Table 5.21 summarizes organics parameters detected in samples collected from exit pathway monitoring points. Given that metal parameters are ubiquitously detected in exit pathway groundwater monitoring points, they are not likewise summarized. 
Table 5.19. 2013 exit pathway groundwater monitoring-results of trend analyses for parameters exceeding reference standards

\begin{tabular}{cccc}
\hline Discharge area & Monitoring point & Parameter & $\begin{array}{c}\text { Statistically } \\
\text { significant trend }\end{array}$ \\
\hline White Oak Creek & 1190 & Iron & Downward \\
& & Manganese & Downward \\
& 1191 & Tritium & Downward \\
& Iron & Downward \\
& Manganese & Upward \\
& & Gross beta & Downward \\
& & Total radioactive strontium & None \\
& & Tritium & Downward \\
Northwestern & Iron & None \\
Eastern & EE-02 & Aluminum & None \\
& & Iron & None \\
& & Manganese & None \\
& \multirow{2}{*}{923} & Iron & None \\
& & Manganese & None \\
\hline
\end{tabular}

Table 5.20. 2013 exit pathway groundwater monitoring results—detected radiological parameters $^{a}$

\begin{tabular}{|c|c|c|c|c|}
\hline Discharge area & Monitoring point & Radiological parameter & Wet season & Dry season \\
\hline \multirow[t]{15}{*}{ White Oak Creek } & 857 & Bismuth-214 & 27 & 31 \\
\hline & & Lead-214 & 35 & 40 \\
\hline & & Tritium & 230 & 190 \\
\hline & 1190 & Gross beta & 2.6 & 3.1 \\
\hline & & Bismuth-214 & 42 & 15 \\
\hline & & Lead-214 & 36 & 18 \\
\hline & & Thallium-208 & $b$ & 2.8 \\
\hline & & Tritium & 21,000 & 21,000 \\
\hline & 1191 & Gross beta & 350 & 310 \\
\hline & & Bismuth-214 & $b$ & 13 \\
\hline & & Lead-214 & 18 & 14 \\
\hline & & Potassium- 40 & 44 & $b$ \\
\hline & & Total radioactive strontium & 150 & 130 \\
\hline & & Tritium & 30,000 & 21,000 \\
\hline & 1239 & Gross beta & 2.3 & $b$ \\
\hline \multirow[t]{9}{*}{ Northwestern } & 531 & Bismuth-214 & $b$ & 1,100 \\
\hline & & Lead-214 & $b$ & 1,400 \\
\hline & 535 & Gross alpha & 3.8 & $b$ \\
\hline & & Bismuth-214 & $b$ & 11 \\
\hline & & Lead-214 & $b$ & 13 \\
\hline & & Tritium & 380 & 270 \\
\hline & 807 & Gross beta & 4.6 & 4.4 \\
\hline & & Bismuth-214 & $b$ & 58 \\
\hline & & Lead-214 & $b$ & 56 \\
\hline
\end{tabular}


Table 5.20. (continued)

\begin{tabular}{lcccc}
\hline Discharge area & Monitoring point & Radiological parameter & Wet season & Dry season \\
\hline \multirow{4}{*}{808} & Tritium & 570 & 480 \\
& & Gross beta & 4.2 & 3.9 \\
& BC-01 & Potassium-40 & $b$ & 26 \\
7000-Bearden Creek & Bismuth-214 & 16 & 9.4 \\
East End & EE-01 & Gross beta & $b$ & 2.8 \\
& \multirow{2}{*}{ EE-02 } & Bismuth-214 & $b$ & 11 \\
& & Bismuth-214 & 420 & 25 \\
& & Lead-212 & $b$ & 4.6 \\
& \multirow{4}{*}{923} & Lead-214 & $b$ & 25 \\
& & Gross beta & 4 & 3.7 \\
& & Bismuth-214 & 11 & 5.8 \\
& S-01 & Lead-214 & 10 & $b$ \\
& S-02 & Bismuth-214 & 66 & $c$ \\
& & Gross beta & $b$ & 3.3 \\
& & Bismuth-214 & 18 & 8.9 \\
\hline
\end{tabular}

${ }^{a}$ Units: $\mathrm{pCi} / \mathrm{L}$.

${ }^{b}$ Not detected.

${ }^{c}$ Not sampled due to lack of water flow.

Table 5.21. 2013 exit pathway groundwater monitoring results-detected organic parameters $^{a}$

\begin{tabular}{lcccc}
\hline \multicolumn{1}{c}{ Discharge area } & $\begin{array}{c}\text { Monitoring } \\
\text { point }\end{array}$ & Organic parameter & Wet season & Dry season \\
\hline White Oak Creek & $1190 / 1191$ & $\begin{array}{c}\text { Bis(2-ethyhexyl) } \\
\text { phthalate }\end{array}$ & $27 / 100$ & $b$ \\
\hline
\end{tabular}

${ }^{a}$ Units $-\mu \mathrm{g} / \mathrm{L}$.

${ }^{b}$ Not detected.

Radiological and metal contaminant concentrations observed in groundwater exit pathway discharge areas were generally consistent with observations reported in past ASERs. Tritium, total radioactive strontium, and gross beta activity were the only radiological contaminants exceeding reference standards at any of the discharge areas, and as in past years, these three contaminants were observed at the WOC discharge area in 2013 (in wells 1190 and 1191). Statistical trend analyses show that the concentration trends for these parameters continue downward. The downward trend in radiological contaminants in the WOC discharge area is very likely attributable to the continued EM remediation effort in Melton Valley. No other radiological contaminants exceed reference standards at other discharge areas. Metals were detected in groundwater monitoring locations in all of the exit pathway discharge areas. Only three metals (iron, manganese, and aluminum) were detected at concentrations exceeding reference standards. These metals are commonly found in groundwater at ORNL. One SVOC, bis(2-ethyhexyl) phthalate, was detected in samples collected from Wells 1190 and 1191 in the WOC discharge area. Based on the results of the 2013 monitoring effort, there is no indication that current OS operations are significantly impacting groundwater at ORNL. 


\subsubsection{Active Sites Monitoring}

\subsection{Active Sites Monitoring-High Flux Isotope Reactor}

Groundwater monitoring conducted by the Research Reactors Division ceased in 2007 based on declining tritium concentrations observed since the repair of the subsurface leak site discovered in late 2000. Since then, outfall pipelines intercepting groundwater have been monitored for tritium routinely under the ORNL NPDES permit. (See Section 5.5.4 for a discussion of results.)

\subsection{Active Sites Monitoring-Spallation Neutron Source}

Active sites groundwater surveillance monitoring was performed in 2013 at the SNS site. The site was monitored based on the potential for adverse impact on groundwater resources at ORNL should a release occur. Monitoring at the SNS site was performed in 2013 under the SNS operational monitoring plan (OMP) (Bonine et al. 2007). Operational monitoring was initiated at the initiation of SNS operations following a 2-year (2004-2006) baseline monitoring program and will continue throughout the duration of SNS operations.

The SNS site is located atop Chestnut Ridge, northeast of the main ORNL facilities. The site slopes to the north and south, and small stream valleys, populated by springs and seeps, lie on the ridge flanks. Surface water drainage from the site flows into Bear Creek to the north and WOC to the south.

The SNS site is a hydrologic recharge area underlain by geologic formations that form karst geologic features. Groundwater flow directions at the site are based on the generally observed tendency for groundwater to flow parallel to geologic strike (parallel to the orientation of the rock beds) and via karst conduits that break out at the surface in springs and seeps located down gradient of the SNS site. A sizable fraction of infiltrating precipitation (groundwater recharge) flows to springs and seeps via the karst conduits.

SNS operations have the potential for introducing radioactivity (via neutron activation) in the shielding berm surrounding the SNS linac, accumulator ring, and/or beam transport lines. A principal concern is the potential for water infiltrating the berm soils to transport radionuclide contamination generated by neutron activation to saturated groundwater zones. The ability to accurately model the fate and transport of neutron activation products generated by beam interactions with the engineered soil berm is complicated by multiple uncertainties resulting from a variety of factors, including hydraulic conductivity differences in earth materials found at depth, the distribution of water-bearing zones, the fate and transport characteristics of neutron activation products produced, diffusion and advection, and the presence of karst geomorphic features found on the SNS site. These uncertainties led to the initiation of the groundwater surveillance monitoring program at the SNS site. Objectives of the groundwater monitoring program outlined by the OMP include the following: (1) maintain compliance with applicable DOE contract requirements and environmental quality standards and (2) provide uninterrupted monitoring of the SNS site.

A total of seven seeps/springs and surface water sampling points (seeps/springs S-1, S-2, S-3, S-4, S-5, and SP-1 and surface-water point SW-1) were routinely monitored as analogues to, and in lieu of, groundwater monitoring wells. Locations were chosen based on hydrogeological factors and proximity to the beam line. Figure 5.41 shows the locations of the specific monitoring points sampled during 2013.

In November 2011 the SNS historical tritium data set underwent review and analysis to determine whether sampling could be optimized. The influence of flow condition on the proportion of tritium "detects" and "nondetects" in water samples collected at SNS from April 2004 through September 2011 was examined. In addition, the effect of seasonality on the proportion of detects and nondetects was examined for the same data set. The results of the analysis indicated that the proportion of detects to nondetects is not related to flow conditions or seasonality. Consequently, neither flow condition nor season affects the proportion of tritium detects to nondetects. This implies that samples can be collected during any flow condition and season with the expectation that no statistical difference in the proportion of tritium detects to nondetects exists. The results of this statistical analysis of the April 2004-September 2011 data set are the basis for the modified OMP monitoring scheme implemented in 2013.

Taking a conservative approach, samples were collected from each monitoring point on a quarterly basis in 2013, allowing the opportunity for wet and dry season monitoring. All sampling performed in 
2013 was performed in conjunction with rainfall events, with samples being collected during rising or falling (recession) limb flow conditions (see Fig. 5.42). Table 5.22 shows the sampling and parameter schedule followed in 2013.

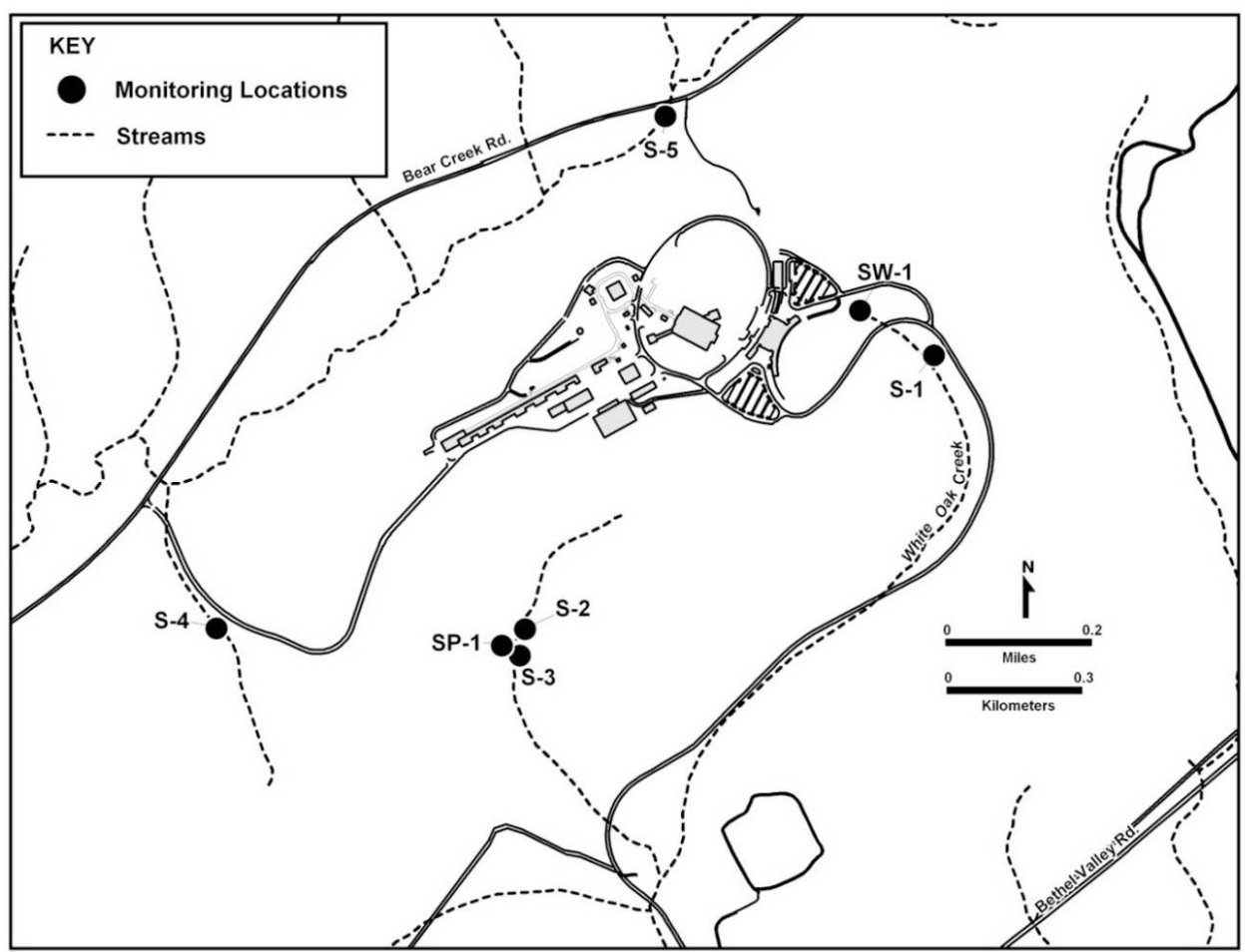

Fig. 5.41. Groundwater monitoring locations at the Spallation Neutron Source, 2013.

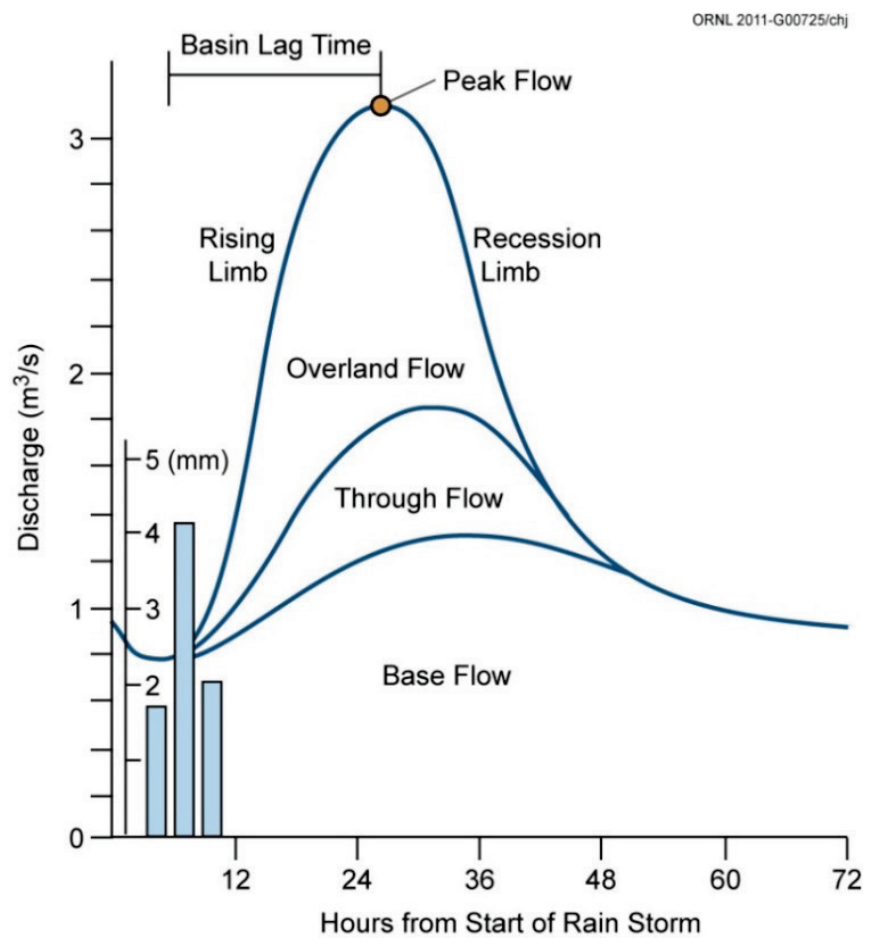

Fig. 5.42. Simple hydrograph of spring discharge vs. time after initiation of rainfall. 
Table 5.22. 2013 Spallation Neutron Source monitoring program schedule

\begin{tabular}{|c|c|c|c|c|}
\hline Monitoring location & $\begin{array}{c}\text { Quarter 1 } \\
\text { January-March } \\
\end{array}$ & $\begin{array}{c}\text { Quarter } 2 \\
\text { April-June } \\
\end{array}$ & $\begin{array}{c}\text { Quarter 3 } \\
\text { July-September }\end{array}$ & $\begin{array}{c}\text { Quarter } 4 \\
\text { October-December } \\
\end{array}$ \\
\hline SW-1 & $\begin{array}{l}\text { Tritium and expanded } \\
\text { suite }^{a}\end{array}$ & Tritium & Tritium & Tritium \\
\hline S-1 & $\begin{array}{l}\text { Tritium and expanded } \\
\text { suite }\end{array}$ & Tritium & Tritium & Tritium \\
\hline S-2 & Tritium & $\begin{array}{l}\text { Tritium and expanded } \\
\text { suite }\end{array}$ & Tritium & Tritium \\
\hline S-3 & Tritium & $\begin{array}{l}\text { Tritium and expanded } \\
\text { suite }\end{array}$ & Tritium & Tritium \\
\hline S-4 & Tritium & Tritium & $\begin{array}{l}\text { Tritium and expanded } \\
\text { suite }\end{array}$ & Tritium \\
\hline S-5 & Tritium & Tritium & $\begin{array}{l}\text { Tritium and expanded } \\
\text { suite }\end{array}$ & Tritium \\
\hline SP-1 & Tritium & Tritium & Tritium & $\begin{array}{l}\text { Tritium and expanded } \\
\text { suite }\end{array}$ \\
\hline
\end{tabular}

${ }^{a}$ The expanded suite includes gross alpha and gross beta and gamma emitters.

\section{Spallation Neutron Source Site Results}

In 2013 sampling at the SNS site occurred during February (quarter 1), June (quarter 2), September (quarter 3), and November (quarter 4). Low concentrations of tritium were detected numerous times during 2013. Table 5.23 provides a summary of the locations and sampling events for tritium detections observed during 2013. The reference standard for tritium was not exceeded at any SNS monitoring location in 2013.

Table 5.23. Spallation Neutron Source groundwater monitoring results-tritium detections in 2013

\begin{tabular}{cc}
\hline Monitoring point & Detected in \\
\hline S-1 & 1st quarter \\
S-2 & 1st, 2nd, and 4th quarters \\
S-3 & Not detected \\
S-4 & Not detected \\
S-5 & Not detected \\
SP-1 & Not detected \\
SW-1 & 1st, 2nd, 3rd,and 4th quarters \\
\hline
\end{tabular}

Table 5.24 provides a summary of the locations and sampling events for other radionuclide detections observed in 2013. 
Table 5.24. Spallation Neutron Source groundwater monitoring results-other radionuclide detections in 2013

\begin{tabular}{cccccccc}
\hline $\begin{array}{c}\text { Monitoring } \\
\text { Location }\end{array}$ & $\begin{array}{c}\text { Gross } \\
\text { alpha }\end{array}$ & Gross beta & ${ }^{2 \mathbf{1 1}} \mathbf{B i}$ & ${ }^{\mathbf{2 1 4}} \mathbf{P b}$ & ${ }^{137} \mathbf{C s}$ & ${ }^{233,234} \mathbf{U}$ & ${ }^{238} \mathbf{U}$ \\
S-1 & ND & ND & ND & 1st quarter & ND & ND & ND \\
S-2 & ND & ND & ND & 2nd quarter & ND & ND & ND \\
S-3 & ND & 2nd quarter & 2nd quarter & ND & 2nd quarter & ND & ND \\
S-4 & ND & ND & 3rd quarter & 3rd quarter & ND & ND & ND \\
S-5 & 3rd quarter & 3rd quarter & 3rd quarter & 3rd quarter & ND & 3rd quarter & 3rd quarter \\
SP-1 & ND & ND & ND & ND & ND & ND & ND \\
SW-1 & ND & ND & 1st quarter & 1st quarter & ND & ND & ND \\
\hline
\end{tabular}

$\mathrm{ND}=$ not detected in sample.

The only radionuclide exceeding its reference standard during 2013 was gross alpha activity $(18.9 \mathrm{pCi} / \mathrm{L})$ at $\mathrm{S}-5$ in the third quarter. The reference standard for gross alpha activity is $15 \mathrm{pCi} / \mathrm{L}$. Cesium-137 was detected at a low concentration in a sample collected from S-3 during the second quarter. The origin of the ${ }^{137} \mathrm{Cs}$ is unknown. Gross activity and uranium detected in S-5 during the third quarter likely originated in the S-3 ponds located upgradient of the SNS site. S-5 is in hydrologic communication with the S-3 pond plume via karst features.

\subsection{Quality Assurance Program}

UT-Battelle implements the requirements of DOE O 414.1D, Quality Assurance, (DOE 2011c) for all programs, projects, and activities and 10 CFR 830 Subpart A, Quality Assurance Requirements, for nuclear facilities, radiological areas, and programs and activities that have the potential to impact nuclear or radiological safety. ORNL has adopted ISO 9001:2008 as the laboratory consensus standard and has been registered to the standard by a third party registrar. Adoption of ISO 9001:2008 provides the level of rigor and flexibility necessary for the wide range of activities UT-Battelle conducts at ORNL. Additional QA requirements or guidance documents are used on a project- or process-specific basis based on potential risk factors and customer requirements. The application of QA/QC programs specifically focused on environmental monitoring activities on ORR is essential for generating data of known and defensible quality. Each aspect of an environmental monitoring program from sample collection to data management and record keeping must address and meet applicable quality standards. The activities associated with administration, sampling, data management, and reporting for ORNL environmental programs are performed by the UT-Battelle Environmental Protection and Waste Services Division (EP\&WSD).

UT-Battelle uses SBMS to provide a systematic approach for integrating QA, environmental, and safety considerations into every aspect of ORNL environmental monitoring. SBMS is a web-based system that provides a single point of access to all the requirements necessary for staff to safely and effectively perform work. SBMS translates laws, orders, directives, policies, and best-management practices into laboratory-wide subject areas and procedures.

\subsubsection{Work/Project Planning and Control}

UT-Battelle's work/project planning and control directives establish the processes and requirements for executing work activities at ORNL. All environmental sampling tasks are performed following the four steps required in the work control subject areas:

- define scope of work;

- $\quad$ perform work planning - analyze hazards and define controls; 
- execute work; and

- provide feedback.

In addition, EP\&WSD has approved project-specific standard operating procedures for all activities controlled and maintained through the Integrated Document Management System (IDMS).

Environmental sampling standard operating procedures developed for UT-Battelle environmental sampling programs provide detailed instructions on maintaining chain of custody, sample identification, sample collection and handling, sample preservation, equipment decontamination, and collection of quality control samples such as field and trip blanks, duplicates, and equipment rinses.

\subsubsection{Personnel Training and Qualifications}

The UT-Battelle Training and Qualification Management System provides employees and nonemployee staff of UT-Battelle with the knowledge and skills necessary to perform their jobs safely, effectively, and efficiently with minimal supervision. This capability is accomplished by establishing site-level procedures and guidance for training program implementation with an infrastructure of supporting systems, services, and processes.

Likewise, the WAI Training and Qualification program provides employees with the knowledge and skills necessary to perform their jobs safely, effectively, and efficiently with minimal supervision. This capability is accomplished by establishing site-level procedures and guidance for training program implementation with an infrastructure of supporting systems, services, and processes.

\subsubsection{Equipment and Instrumentation}

\subsubsection{Calibration}

The UT-Battelle Quality Management System includes subject area directives that require all UT-Battelle staff to use equipment of known accuracy based on appropriate calibration requirements that are traceable to an authority standard. UT-Battelle Facilities and Operations Instrumentation and Control Technical Support tracks all equipment used in the environmental monitoring programs conducted by UT-Battelle for the ORNL site and ORR through a maintenance recall program to ensure that equipment is functioning properly and within defined tolerance ranges. The determination of calibration schedules and frequencies is based on a graded approach at the activity planning level. EP\&WSD environmental monitoring programs follow rigorous calibration schedules to eliminate gross drift and the need for data adjustments. Instrument tolerances, functions, ranges, and calibration frequencies are established based on manufacturer specifications, program requirements, actual operating environment and conditions, and budget considerations.

In addition, continuous monitors used for CAA compliance monitoring at specific ORNL boilers are subjected to rigorous quality assurance protocols as specified by EPA methods. A relative accuracy test audit (RATA) is performed annually to certify the Predictive Emissions Monitoring System (PEMS) for nitrogen oxides and oxygen. The purpose of RATA is to provide a rigorous QA assessment in accordance with EPA 40 CFR, Performance Specification 16. Three out of four quarters a relative accuracy audit is performed on PEMS using a second, calibrated system to verify the accuracy of the on-stack system. A calibration error opacity audit is performed quarterly on continuous opacity monitoring systems. This audit is performed at low-, mid-, and high-ranges. Automated zero and span checks are performed daily. The results of these QA tests are provided to TDEC quarterly and annually as applicable.

\subsubsection{Standardization}

The UT-Battelle IDMS provides the necessary functionality and controls to ensure controlled documents are managed, distributed, revised, and maintained in accordance with ORNL document control requirements. EP\&WSD sampling procedures are maintained in IDMS and include requirements and instructions for the proper standardization and use of monitoring equipment. Requirements include the use of traceable standards and measurements; performance of routine, before-use equipment 
standardizations; and actions to follow when standardization steps do not produce required values. Standard operating procedures for sampling also include instructions for designating nonconforming instruments as "out-of-service" and initiating requests for maintenance.

\subsubsection{Visual Inspection, Housekeeping, and Grounds Maintenance}

EP\&WSD environmental sampling personnel conduct routine visual inspections of all sampling instrumentation and sampling locations. These inspections identify and address any safety, grounds keeping, general maintenance, and housekeeping issues or needs.

\subsubsection{Assessment}

Independent audits, surveillance, and internal management assessments are performed to verify that requirements have been accurately specified and activities that have been performed conform to expectations and requirements. External assessments are scheduled based on requests from auditing agencies. Table 2.1 presents a list of environmental audits and assessments performed at ORNL in 2013 and information on the number of findings identified, if any. EP\&WSD also conducts internal management assessments of UT-Battelle environmental monitoring procedural compliance, safety performance, and work planning and control. Surveillance results, recommendations, and completion of corrective actions, if required, are also documented and tracked in the ORNL Assessment and Commitment Tracking System.

WAI and Isotek perform independent audits, surveillances, and internal management assessments to verify that requirements have been accurately specified and activities that have been performed conform to expectations and requirements. Corrective actions, if required, are documented and tracked in the WAI Issues Management Database and the Isotek Assessment and Commitment Tracking System, respectively.

\subsubsection{Analytical Quality Assurance}

The contract laboratories that perform analyses of environmental samples from the UT-Battelle environmental monitoring programs at ORNL and on ORR are required to have documented QA/QC programs, trained and qualified staff, appropriately maintained equipment and facilities, and applicable certifications. Several laboratories are contracted under basic ordering agreements to perform analytical work to characterize UT-Battelle environmental samples. As applicable, these laboratories participate in accreditation, certification, and performance evaluation programs, including the National Environmental Laboratory Accreditation Program, Mixed Analyte Performance Evaluation Program, Discharge Monitoring Report Quality Assurance Study, and DOE Environmental Management Consolidated Audit Program. Any issues of concern identified through accreditation/certification programs or performance evaluation testing are addressed with analytical laboratories and considered when determinations are made on data integrity.

A statement of work for each project specifies any additional QA/QC requirements and includes detailed information on data deliverables, turnaround times, and required methods and detection limits. Blank and duplicate samples are routinely submitted along with ORR environmental samples to provide an additional check on analytical laboratory performance.

\subsubsection{Data Management and Reporting}

Management of data collected by UT-Battelle in conjunction with ORR and ORNL environmental surveillance programs and with CWA activities at ORNL is accomplished using the Environmental Surveillance System (ESS), a web interface data management tool. A software QA plan for ESS has been developed to document ESS user access rules; verification and validation methods; configuration and change management rules; release history; software registration information; and the employed methods, standards, practices, and tools.

Field measurements and sample information are entered into ESS, and an independent verification is performed on all records to ensure accurate data entry. Sample results and associated information are 
loaded into ESS from electronic files provided by analytical laboratories. An automated screening is performed to ensure that all required analyses were performed, appropriate analytical methods were used, holding times were met, and specified detection levels were achieved.

Following the screening, a series of checks is performed to determine whether results are consistent with expected outcomes and historical data. QC sample results (i.e., blanks and duplicates) are reviewed to check for potential sample contamination and to confirm repeatability of analytical methods within required limits. More in-depth investigations are conducted to explain results that are questionable or problematic.

ORNL radiological airborne effluent monitoring data are managed using the Rad-NESHAPs Inventory Web Application and the Rad NESHAPs Source Data Application. Field measurements and analytical data inputs along with emission calculations results are independently verified.

\subsubsection{Records Management}

The UT-Battelle Records Management System provides the requirements for managing all UT-Battelle records. Requirements include creating and identifying record material; scheduling, protecting, and record storage in office areas and the UT-Battelle Inactive Records Center; and destroying records.

WAI and Isotek maintain all records specific to their projects at ORNL, and associated records management programs include the requirements for creating and identifying record material, protecting and storing records in applicable areas, and destroying records.

\subsection{Environmental Management and Waste Management Activities at Oak Ridge National Laboratory}

ORNL is becoming one of the world's most modern campuses for scientific discovery in materials and chemical sciences, nuclear science, energy research, and super-computing. However, in the midst of all this modern infrastructure are large contaminated areas - the legacy of past operations and waste disposal practices. The DOE EM Program has divided ORNL into two major cleanup areas: Bethel Valley and Melton Valley. The Bethel Valley area includes reactors and the principal research facilities, and Melton Valley includes reactors and waste management areas. The following sections summarize some of the 2013 EM activities undertaken at ORNL. More detailed information is available in the 2013 cleanup progress report (DOE 2013).

\subsubsection{Hot Cells Facility Downgraded and Maintained in Surveillance and Maintenance Mode}

The 3026 hot cells facility (Fig. 5.43) has been downgraded from a Hazard Category 3 nuclear facility to a radiological facility. Three of the facility's five hot cells were previously demolished. However, due to unanticipated conditions, the remaining hot cells were downgraded and placed into surveillance and maintenance. In FY 2013 a report documenting the work completed and work remaining was submitted to EPA and TDEC.

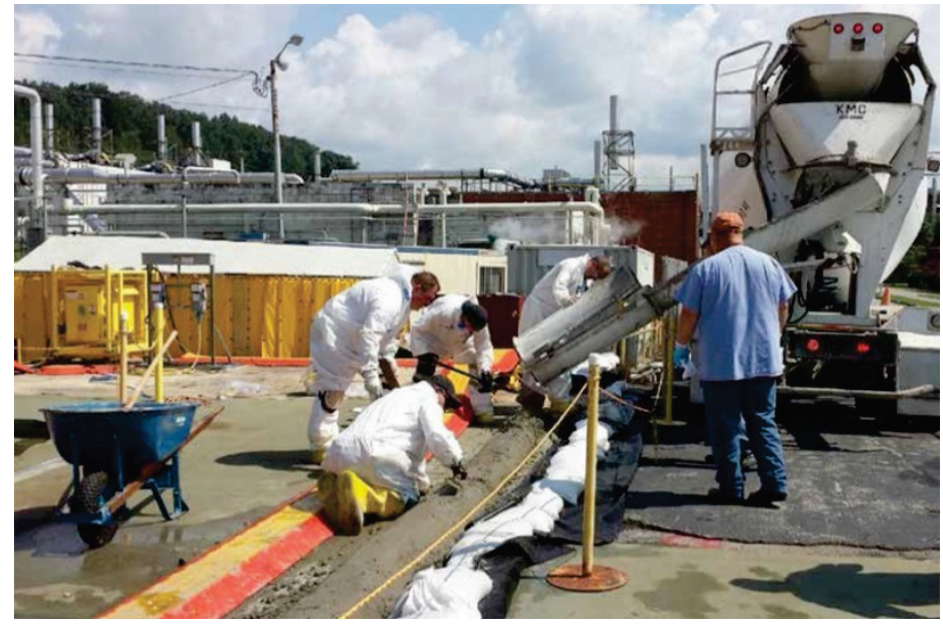

Fig. 5.43. A concrete berm being poured as part of the 3026 stabilization activities. 


\subsubsection{Bethel Valley Groundwater Monitoring}

Groundwater monitoring in the Bethel Valley 7000 Area continued in FY 2013. The 7000 Area includes the maintenance facilities on the east end of ORNL. A treatability study was initiated earlier to determine the feasibility of using bacteria to eliminate TCE in groundwater.

\subsubsection{Off-Site Groundwater Monitoring}

Groundwater monitoring was conducted in FY 2013 in off-site wells adjacent to Melton Valley to determine whether any contaminant migration off the reservation was occurring. Signature human-made contaminants that have been detected in groundwater near former Melton Valley waste disposal areas on DOE property include the radionuclides tritium, ${ }^{90} \mathrm{Sr}$, and ${ }^{99} \mathrm{Tc}$ and chlorinated organic compounds and related degradation products. None of these contaminants were detected in off-site groundwater.

\subsubsection{Upgrade of 4500 Area Gaseous Waste System}

The objective of the 4500 Area gaseous waste system upgrades project (Fig 5.44) was to deactivate one of the five cell ventilation system branches and remove several facilities from the central hot off-gas system.

The ventilation system branches and off-gas system are part of the central gaseous waste system at ORNL that vents through the 3039 stack. The project plans include providing localized ventilation systems to the 4501, 4505, $4500 \mathrm{~N}$, and 4507 facilities; stabilizing the hot cells in Building 4507; cleaning out filter pits 3106 and 4556; and stabilizing hundreds of feet of deactivated underground ductwork.

Demolition, removal of existing equipment, and fabrication and installation of the replacement ventilation system for the 4501,4505 , and $4500 \mathrm{~N}$ facilities were completed in January of 2013. In September of 2013, characterization and stabilization of the underground ductwork and cleanout of the 3106 and 4556 filter pits were completed.

\subsubsection{Excavation of Building 3550 Slab}

In 2013, the Building 3550 slab, located on Central Avenue at ORNL, was excavated, along with $2 \mathrm{ft}$ of

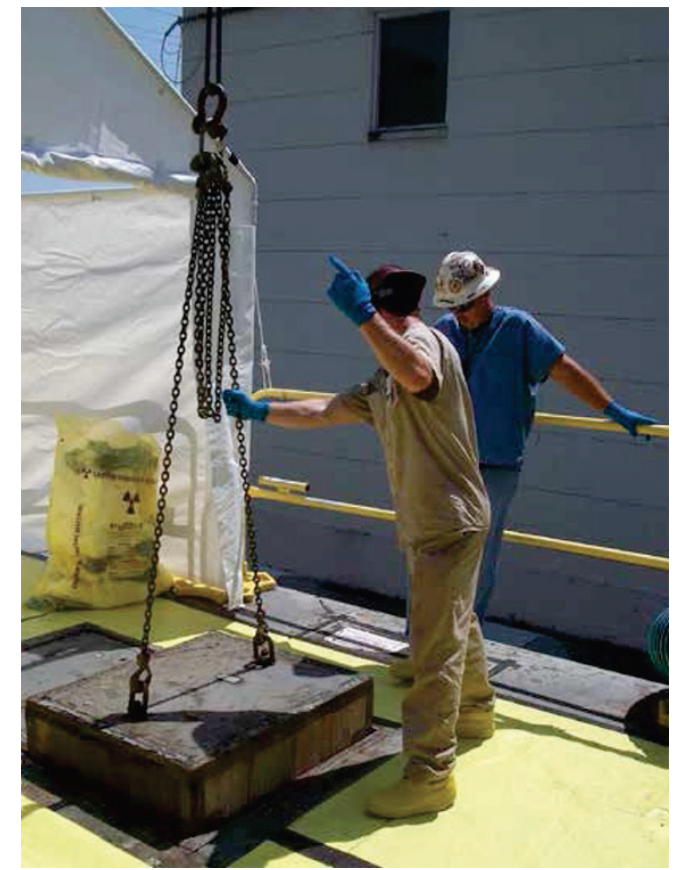

Fig. 5.44. HEPA shield plug being removed from a filter pit. contaminated soil. A completion report was submitted to EPA and TDEC.

\subsubsection{Uranium-233 Project}

A significant inventory of ${ }^{233} \mathrm{U}$ is stored in ORNL's Building 3019A. The ${ }^{233} \mathrm{U}$ project was initiated to address safeguards and security requirements, eliminate safety and nuclear criticality concerns, and safely dispose of this material. At the end of FY 2013 preparations necessary for shipment and disposal of stored material from a 1980s project were complete, but shipment of the material had not been initiated pending resolution of issues on disposal with the State of Nevada.

Conceptual plans for processing and disposing of the ${ }^{233} U$ inventory were initiated in 2013 , but follow-on design activities in FY 2014 will be contingent on budget availability. 


\subsubsection{Building 3038 Waste Removal and Stabilization}

Building 3038, a $722 \mathrm{~m}^{2}\left(7,773 \mathrm{ft}^{2}\right)$ nuclear facility in ORNL's Central Campus area, was used for packaging, inspecting, and shipping activities for radioisotopes until 1994. In FY 2013, in preparation for building demolition, all waste was removed from the building, stabilization activities were completed, the local ventilation system was restarted, air monitoring equipment was placed online, and a report documenting completion was submitted to EPA and TDEC.

\subsubsection{Molten Salt Reactor Experiment Flush and Fuel Salt Removal}

The MSRE Facility, a graphite-moderated, liquid-fueled reactor, operated from 1965 through 1969. Since shutdown, several studies and removal actions have been performed to address contaminated fuel and flush salts in the facility. In 1998, a ROD for an interim action to remove fuel and flush salts was approved.

In FY 2013, comments on the MSRE Remediation Strategy Plan were received from EPA and TDEC, and a revised plan was prepared and submitted.

Also in FY 2013, additional waste from defueling performed in 2006 was identified. An inventory of the waste was completed, and a waste disposition plan was prepared and submitted to EPA and TDEC.

\subsubsection{Oak Ridge National Laboratory Waste Management}

\subsubsection{Oak Ridge National Laboratory Wastewater Treatment}

At ORNL, DOE EM operates PWTC and the Liquid Low-Level Waste Treatment Facility. In 2013 462 million L (122 million gal) of wastewater was treated and released at PWTC. In addition, the liquid LLW evaporator at ORNL treated 793,044 L (209,500 gal) of waste. The waste treatment activities of these facilities support both DOE EM and DOE OS mission activities, ensuring that wastewaters from activities associated with projects of both offices are managed in a safe and compliant manner.

\subsubsection{Oak Ridge National Laboratory Newly Generated Waste Management}

ORNL is the largest, most diverse DOE OS laboratory in the DOE complex. Although much effort is expended to prevent pollution and eliminate waste generation, some waste streams are generated as a byproduct of performing research and operational activities and must be managed to ensure that the environment is protected from associated hazards. UT-Battelle, as the prime contractor for the management of ORNL, is responsible for management of most of the wastes generated from $R \& D$ activities and wastes generated from operation of the R\&D facilities. TRU wastes and waste streams that can be treated by on-site liquid and/or gaseous waste treatment facilities operated by EM are treated via these systems. Other R\&D waste streams are generally packaged by UT-Battelle in appropriate shipping containers for off-site transport to commercial waste processing facilities. In CY 2013, ORNL performed 73 waste shipments to off-site hazardous/radiological/mixed waste treatment and/or disposal vendors with no shipment rejections or violations.

\subsubsection{Transuranic Waste Processing Center}

TRU waste-processing activities carried out for DOE in 2013 by WAI addressed $\mathrm{CH}$ solids/debris and RH solids/debris and involved processing, treating, repackaging, and off-site transportation and disposal at NNSS, WIPP, and other approved off-site facilities. Planning for treating RH sludge continued this year.

During CY 2013, $104.2 \mathrm{~m}^{3}\left(136.3 \mathrm{yd}^{3}\right)$ of $\mathrm{CH}$ waste and $97.5 \mathrm{~m}^{3}\left(127.5 \mathrm{yd}^{3}\right)$ of $\mathrm{RH}$ waste were processed. In CY 2013, $86.7 \mathrm{~m}^{3}\left(113.4 \mathrm{yd}^{3}\right)$ of $\mathrm{CH}$ waste and $53.2 \mathrm{~m}^{3}\left(69.6 \mathrm{yd}^{3}\right)$ of $\mathrm{RH}$ waste were shipped off-site. 


\subsubsection{SEC Federal Services Corporation Waste}

In 2013 SEC shipped $79.46 \mathrm{~m}^{3}\left(103.93 \mathrm{yd}^{3}\right)$ of material from the Hot Cells Project. This included waste from Building 3026 and Building 3038.

\subsection{References}

ANSI. 1969. Guide to Sampling Airborne Radioactive Materials in Nuclear Facilities. ANSI N13.11969R. American National Standards Institute, Washington, DC.

ANSI. 1999. Sampling and Monitoring Releases of Airborne Radioactive Substances from the Stacks and Ducts of Nuclear Facilities. ANSI/HPS N13.1-1999. American National Standards Institute, Health Physics Society, New York, New York.

Barbour, Michael T., et al. 1999. Rapid Bioassessment Protocols for Use in Streams and Wadeable Rivers: Periphyton, Benthic Macroinvertebrates, and Fish, 2d ed. EPA 841-B-99-002, US Environmental Protection Agency, Office of Water, Washington, DC.

Bonine, T. M., R. H. Ketelle, and S. M. Trotter. 2007. Operational Groundwater Monitoring Plan for the Spallation Neutron Source Site. SNS 102040000-ES0001-R01, ORNL/TM-2004/118. Oak Ridge National Laboratory, Oak Ridge, Tennessee.

Bonine, T. M. 2012. UT-Battelle Sampling and Analysis Plan for Surveillance Monitoring of Exit Pathway Groundwater at Oak Ridge National Laboratory. Oak Ridge National Laboratory, Oak Ridge, Tennessee.

BJC. 2009. Integrated Safety Management System Description, BJC-GM-1400/R12. Bechtel Jacobs, Inc., LLC, Oak Ridge, Tennessee.

DOE. 2000. Record of Decision for Interim Actions for the Melton Valley Watershed at the Oak Ridge National Laboratory, Oak Ridge, Tennessee, DOE/OR/01-1826\&D3. US Department of Energy, Washington, DC.

DOE. 2002. Record of Decision for Interim Actions in Bethel Valley Watershed, Oak Ridge, Tennessee, DOE/OR/01-1862\&D4.

DOE. 2008. Environmental Protection Program, DOE O 450.1A. Approved 6-4-08. US Department of Energy, Washington, DC.

DOE. 2011. Final Draft U-233 Alternatives Analysis, Phase I Report: Screening of Alternative Disposition Approaches. US Department of Energy, Washington, DC.

DOE. 2011a. Departmental Sustainability, DOE O 436.1. Approved 5-2-11. US Department of Energy, Washington, DC.

DOE. 2011b. Radiation Protection of the Public and the Environment, DOE O 458.1, Approved February 11, 2011; Change 2 approved June 6, 2011. US Department of Energy, Washington, DC.

DOE. 2011c. Quality Assurance, DOE O 414.1D, Approved April 25, 2011. US Department of Energy, Washington, DC.

DOE. 2012. Phased Construction Completion Report for the Bethel Valley Burial Grounds at the Oak Ridge National Laboratory, Oak Ridge, Tennessee. DOE/OR/01-2533\&D2. Prepared by the Water 
Resources Restoration Program, URS | CH2M Oak Ridge, LLC. US Department of Energy, Oak Ridge, Tennessee.

DOE. 2013. Cleanup Progress; Annual Report to the Oak Ridge Community, DOE/ORO-2467. US Department of Energy, Office of Environmental Management, Oak Ridge, Tennessee. Prepared by URS | CH2M Oak Ridge LLC; available online at http://energy.gov/sites/prod/files/2013/12/f6 /2013CleanupProgress_0.pdf.

DOE. 2014. Department of Energy Air Emissions Annual Report, Oak Ridge Reservation, Oak Ridge, Tennessee, 40 Code of Federal Regulations (CFR) 61, Subpart H, Calendar Year 2013. US Department of Energy, Washington, DC.

DOE. 2014a. 2014 Remediation Effectiveness Report for the U.S. Department of Energy Oak Ridge Reservation, Oak Ridge, Tennessee; Data and Evaluations. DOE/OR/01-2640\&D1. US Department of Energy, Oak Ridge, Tennessee. Prepared by the URS | CH2M Oak Ridge LLC Water Resources Restoration Program.

EPA 1999. Cancer Risk Coefficients for Environmental Exposure to Radionuclides, Federal Guidance Report 13, EPA 402-R-99-001. US Environmental Protection Agency, Washington, DC.

EPA. 2000. Stressor Identification Guidance Document. EPA-822-B-00-025. US Environmental Protection Agency, Office of Water, Washington, DC.

EPA. 2010. 40 CFR Part 60, Appendix A-1, Method 2 "Method 2-Determination of Stack Gas Velocity and Volumetric Flow Rate (Type S Pitot Tube)."

ISO. 2004. Environmental Management Systems-Requirements with Guidance for Use. ISO 14001:2004. International Organization for Standardization. http://www.iso.org.

NRC. 2000. Multi-Agency Radiation Survey and Site Investigation Manual (MARSSIM), NUREG-1575, Rev. 1/EPA 402-R-97-016, Rev. 1/DOE/EH-0624, Rev. 1. US Nuclear Regulatory Commission, Environmental Protection Agency, Department of Defense, and Department of Energy, Washington, DC.

NRC. 2009. Multi-Agency Radiation Survey and Assessment of Materials and Equipment Manual (MARSAME), NUREG-1575, Supplement 1/EPA 402-R-09-001/DOE/HS-0004. US Nuclear Regulatory Commission, Environmental Protection Agency, Department of Defense, and Department of Energy, Washington, DC.

ORNL. 1986. Biological Monitoring and Abatement Program (BMAP). ORNL/TM-10370.

ORNL. 1997. Non-Storm Water Best Management Practices Plan.

ORNL. 2007. Storm Water Pollution Prevention Plan.

ORNL. 2008. Oak Ridge National Laboratory NPDES Water Quality Protection Plan, October (unpublished).

Pelletier, Raymond F. 1995. Application of DOE 5400.5 Requirements for Release and Control of Property Containing Residual Radioactive Material, correspondence to distribution. US Department of Energy, Office of Environmental Policy and Assistance, Washington, DC. (Note: An abbreviated version minus some of the attachments appears on the web at http://www.hss.doe.gov/sesa/environment/guidance/aea/release.pdf.) 
Ryon, M. G. 2011. "Recovery of fish communities in a warm water stream following pollution abatement," Environmental Management, 47(6), 1096-1111.

Souza, Peter A., Glyn D. DuVall, and Melisa J. Hart. 2001. Cultural Resource Management Plan, DOE Oak Ridge Reservation, Anderson and Roane Counties, Tennessee. DOE/ORO/2085. US Department of Energy, Washington, DC.

TDEC. 2012. Tennessee Regulations for Public Water Systems and Drinking Water Quality, Chap. 040045-01. Tennessee Department of Environment and Conservation, Bureau of Environment, Division of Water Supply (http://www.state.tn.us/sos/rules/0400/0400-45/0400-45-01.20121030.pdf).

WAI. 2012. Wastren Advantage Incorporated Contract Requirements Document for Contract DEEM0000323, Section J, Attachment C, Baseline List of Required Compliance Documents, Revision 14 (original contract date: April 27, 2010). Oak Ridge National Laboratory, Oak Ridge, Tennessee.

WAI. 2012a. Wastren Advantage Incorporated Regulatory Management Plan, Revision 5, CM-A-EN-005. Oak Ridge National Laboratory, Oak Ridge, Tennessee. 



\section{Oak Ridge Reservation Environmental Monitoring Program}

In addition to environmental monitoring conducted at the three major Oak Ridge DOE installations, reservationwide environmental monitoring is performed to measure radiological and nonradiological parameters directly in environmental media adjacent to the facilities. Data from the ORR-wide environmental monitoring program are analyzed to assess the environmental impact of DOE operations on the entire reservation and the surrounding area. Dose assessment information based on data from this program is presented in Chapter 7 .

Because of differing permit reporting requirements and instrument capabilities, various units of measurement are used in this report. The list of units of measure and conversion factors provided on pages xxvii and xxviii is intended to help readers convert numeric values presented herein as needed for specific calculations and comparisons.

\subsection{Meteorological Monitoring}

Nine meteorological towers provide data on meteorological conditions and on the transport and diffusion qualities of the atmosphere on the ORR. Data collected at the towers are used in routine dispersion modeling to predict impacts from facility operations and as input to emergency-response atmospheric models, which are used for simulated and potential accidental releases from a facility. Data from the towers are also used to support various research and engineering projects.

\subsubsection{Description}

The nine meteorological towers on ORR are described in Table 6.1 and depicted in Fig. 6.1. In this document, the individual ORR-managed towers are designated by "MT" followed by a numeral; however, other commonly used names for the sites are provided in Table 6.1. Meteorological data are collected at different levels above the ground $(2,10,15,30,33,60$, and $100 \mathrm{~m})$ to assess the vertical structure of the atmosphere, particularly with respect to wind shear and stability. Stable boundary layers and significant wind shear zones (associated with the local ridge-and-valley terrain as well as the Great Valley of Eastern Tennessee; see Appendix B) can significantly affect the movement of a plume after a facility release (Bowen et al. 2000). Data are collected at the $10 \mathrm{~m}$ level at all towers except MT3, MT9, and MT11, where data are collected at $15 \mathrm{~m}$ or $25 \mathrm{~m}$. Additionally, data are collected at selected towers at the 30,33 , 60 , and $100 \mathrm{~m}$ levels. At each measurement level, temperature, wind speed, and wind direction are measured. Atmospheric stability (a measure of vertical mixing properties of the atmosphere) is measured at most towers; however, measurements involving vertical temperature profiles limit accurate determination of nighttime stability to those towers that are $60 \mathrm{~m}$ or higher. Barometric pressure is measured at one or more of the towers at each ORR plant (MT1, MT2, MT7, and MT9). Precipitation is measured at MT6 and MT9 at the Y-12 Complex, at MT1 and MT7 at ETTP, and at MT2 and MT4 at ORNL. Solar radiation is measured at MT6 and MT9 at the Y-12 Complex, at MT1 and MT7 at ETTP, and at MT2 at ORNL. Data are collected at 1 second intervals and averaged for 1, 15, and $60 \mathrm{~min}$ intervals. Calibrations of the instruments are managed by UT-Battelle and B\&W Y-12 and were performed every 3 to 6 months by an independent auditor (Shaw Environmental).

In addition to the meteorological towers, sonic detection and ranging (SODAR) devices have been installed at the east end of the Y-12 Complex and at tower MT2 at ORNL. These devices use acoustic waves to estimate wind direction, wind speed, and turbulence at altitudes higher than the reach of meteorological towers (100-600 m above ground level). Although SODAR measurements are slightly less accurate than measurements made on the towers, SODAR devices provide useful information regarding stability, upper 
air winds, and mixing depth. Mixing depth represents the thickness of the air layer adjacent to the ground over which an emitted or entrained inert nonbuoyant tracer would be mixed by turbulence within $1 \mathrm{~h}$ or less.

Table 6.1. Oak Ridge Reservation meteorological towers

\begin{tabular}{|c|c|c|c|c|}
\hline Tower & $\begin{array}{c}\text { Alternate } \\
\text { tower names }\end{array}$ & $\begin{array}{l}\text { Location } \\
\text { (lat., long.) }\end{array}$ & $\begin{array}{l}\text { Altitude } \\
\text { (m MSL) }\end{array}$ & $\begin{array}{c}\text { Measurement } \\
\text { heights } \\
\text { (m) }\end{array}$ \\
\hline \multicolumn{5}{|c|}{ ETTP } \\
\hline MT1 & “K,” 1208 & $35.93317 \mathrm{~N},-84.38833 \mathrm{~W}$ & 253 & 10,60 \\
\hline MT7 & “L,” 1209 & $\begin{array}{c}35.92522 \mathrm{~N},-84.39414 \mathrm{~W} \\
\text { ORNL }\end{array}$ & 233 & 10,30 \\
\hline MT2 & “C," 1057 & $35.92559 \mathrm{~N},-84.32379 \mathrm{~W}$ & 261 & $10,30,100$ \\
\hline MT3 & "B," 6555 & $35.93273 \mathrm{~N},-84.30254 \mathrm{~W}$ & 256 & 15,30 \\
\hline MT4 & “A,” 7571 & $35.92185 \mathrm{~N},-84.30470 \mathrm{~W}$ & 263 & 10,30 \\
\hline MT10 & "M," 208A & $35.90947 \mathrm{~N},-84.38796 \mathrm{~W}$ & 237 & 10 \\
\hline \multicolumn{5}{|c|}{ Y-12 Complex } \\
\hline MT6 & "W," West & $35.98058 \mathrm{~N},-84.27358 \mathrm{~W}$ & 326 & $2,10,30,60$ \\
\hline МТ9 & “Y,” PSS Tower & $35.98745 \mathrm{~N},-84.25363 \mathrm{~W}$ & 290 & $2,15,33$ \\
\hline MT11 & "S," South Tower & $35.98190 \mathrm{~N},-84.25504 \mathrm{~W}$ & 352 & 25 \\
\hline
\end{tabular}

\footnotetext{
Abbreviations

ETTP $=$ East Tennessee Technology Park

$\mathrm{MSL}=$ mean sea level

ORNL $=$ Oak Ridge National Laboratory

PSS $=$ Park Shift Superintendent

Y-12 Complex = Y-12 National Security Complex
}

Data are collected in real time for $1 \mathrm{~min}, 15 \mathrm{~min}$, and hourly average intervals for emergencyresponse purposes, including dispersion modeling at the ORNL and Y-12 Complex Emergency Operations Centers.

Annual dose estimates are calculated from the archived hourly data. Data quality is checked continuously against predetermined data constraints, and out-of-range parameters are marked invalid and are excluded from compliance modeling. Quality assurance records of missing and erroneous data are routinely kept for the nine DOE-managed towers. 


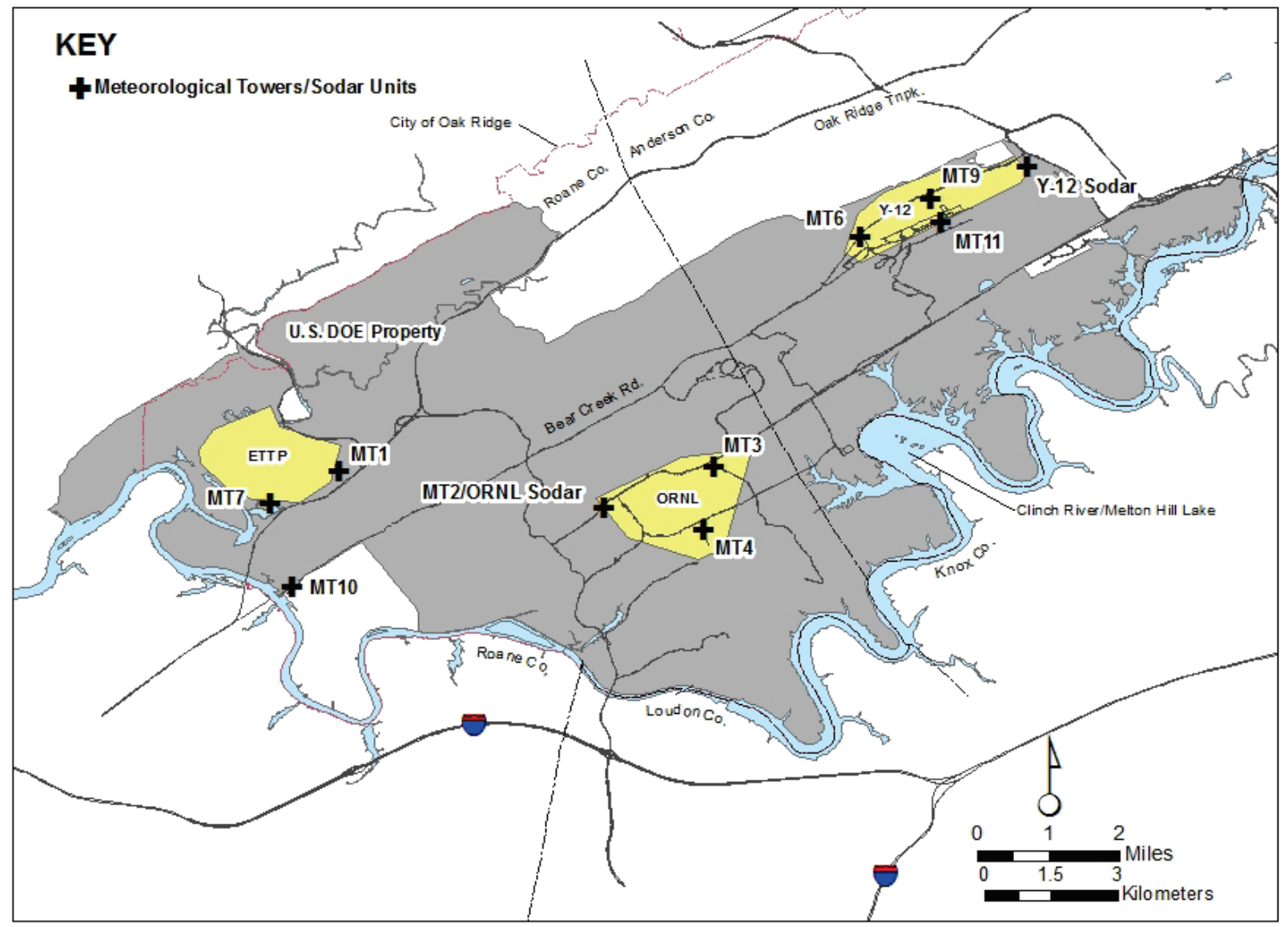

Fig. 6.1. The Oak Ridge Reservation meteorological monitoring network, including SODARs (sonic detection and ranging wind profilers).

\subsubsection{Meteorological Impacts on Modeling Results}

Prevailing winds are generally up-valley from the southwest and west-southwest or down-valley from the northeast and east-northeast, a pattern that typically results from channeling effects produced by the ridges flanking the ORR sites. Winds in the valleys tend to follow the ridge axes, limiting cross-ridge flow within local valley bottoms. These conditions dominate over most of ORR, but less so at ETTP, which is located in a less constrained open valley bottom, resulting in greater flow variation.

On ORR, low-speed winds dominate near the valley surfaces, largely because of the decelerating influence of nearby ridges and mountains. Wind acceleration sometimes is observed at ridge-top level, particularly when flow is not parallel to the ridges (see Appendix B).

The atmosphere over ORR is often dominated by stable conditions at night and for a few hours after sunrise. These conditions, when coupled with low wind speeds and channeling effects in the valleys, result in poor dilution of pollutants emitted from the facilities. However, high roughness values (caused by terrain and obstructions such as trees and buildings) partially mitigate these factors through increased turbulence processes (atmospheric mixing). These features are captured in data input to dispersion models and are reflected in modeling studies conducted for each facility.

Precipitation data from tower MT2 are used in stream-flow modeling and in certain research efforts. The data indicate the variability of regional precipitation: the high winter rainfall resulting from frontal systems and the uneven, but occasionally intense, summer rainfall associated with thunderstorms. The total precipitation in Oak Ridge (townsite) during 2013 (1,712 $\mathrm{mm}$ or $67.37 \mathrm{in}$.) was $32 \%$ above the longterm average of 1,294 $\mathrm{mm}$ (50.91 in.), yielding a 32\% surplus for the 30 year period from 1981 to 2010.

The average data recovery rates (a measure of acceptable data) across locations used for modeling during 2013 were greater than 97\% for ORNL sites (towers MT2, MT3, MT4, and MT10); however, there 
were problems with a few sensors at tower MT2. Because of structural problems, tower MT2 is being replaced and has been deemed unsafe for climbing. Therefore, some sensors at the 30 and $100 \mathrm{~m}$ levels could not be reached for repair during 2013, and the recovery rate for $100 \mathrm{~m}$ temperature data was less than 15\% (acceptable substitution values were available from tower MT1 and other ambient meteorological data). Similarly, the wind monitor speed threshold at tower MT2 was anomalously high at $30 \mathrm{~m}$, resulting in a minimum quarterly data recovery of $78.0 \%$ (82.0\% for the year). All other tower MT2 instrument recoveries were well above $90 \%$ for both quarterly and annual values. Tower MT2 was scheduled for replacement in early 2014.

Quarterly data recovery from ETTP during 2013 ranged from 96.8 to 100\% (towers MT1 and MT7) and ranged from 99.2 to $100.0 \%$ on an annual basis. Y-12 sites (towers MT6, MT9, and MT11) had recovery rates ranging from 98.7 to $100 \%$ during 2013 .

\subsection{External Gamma Radiation Monitoring}

\subsubsection{Data Collection and Analysis}

External gamma measurements (exposure rates) are recorded weekly at six AASs from resident external gross gamma monitors (Fig. 6.2). Each consists of a dual-range, high-pressure ion chamber sensor and digital electronic count-rate meter and a totalizer. Totalizing consists of multiplying the count rate by the time of exposure to obtain total exposure.

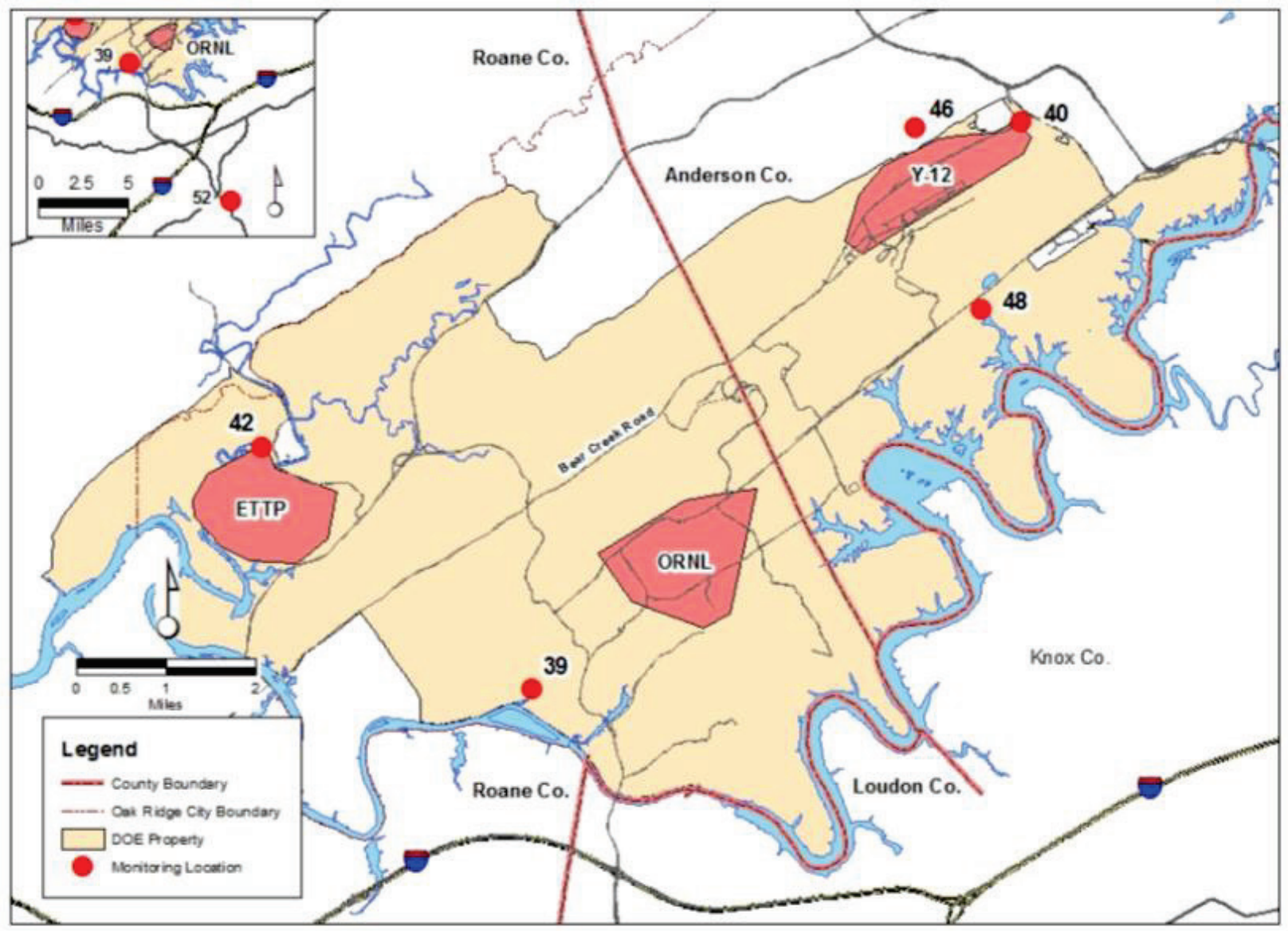

Fig. 6.2. External gamma radiation monitoring locations on the Oak Ridge Reservation. 


\subsubsection{Results}

Table 6.2 summarizes the data collected at each station during the year. The mean observed exposure rate for the reservation network for 2013 was $8.2 \mu \mathrm{R} / \mathrm{h}$, and the average at the reference location was $6.8 \mu \mathrm{R} / \mathrm{h}$. Exposure rates from background sources in Tennessee range from 2.9 to $11 \mu \mathrm{R} / \mathrm{h}$.

Table 6.2. External gamma (exposure rate) averages for the Oak Ridge Reservation, 2013

\begin{tabular}{ccccc}
\hline \multirow{2}{*}{$\begin{array}{c}\text { Monitoring } \\
\text { location }\end{array}$} & $\begin{array}{c}\text { Number of } \\
\text { data values } \\
\text { collected }\end{array}$ & \multicolumn{3}{c}{ Measurement $(\boldsymbol{\mu R} / \mathbf{h})^{\boldsymbol{a}}$} \\
\cline { 3 - 5 } & 52 & 8.7 & 9.7 & 9.1 \\
\hline 39 & 52 & 7.6 & 8.8 & 8.0 \\
40 & 52 & 6.4 & 8.6 & 7.6 \\
42 & 52 & 8.2 & 9.4 & 8.7 \\
46 & 52 & 6.7 & 8.5 & 7.5 \\
48 & 52 & 6.6 & 7.5 & 6.8 \\
52 & &
\end{tabular}

${ }^{a}$ To convert microroentgens per hour $(\mu \mathrm{R} / \mathrm{h})$ to milliroentgens per year, multiply by 8.760 .

\subsection{Ambient Air Monitoring}

In addition to exhaust stack monitoring conducted at the DOE Oak Ridge installations, ambient air monitoring is performed to measure radiological parameters directly in the ambient air adjacent to the facilities (Fig. 6.3). Ambient air monitoring provides a means to verify that contributions of fugitive and diffuse sources are insignificant, serves as a check on dose-modeling calculations, and would allow determination of contaminant levels at monitoring locations in the event of an emergency.

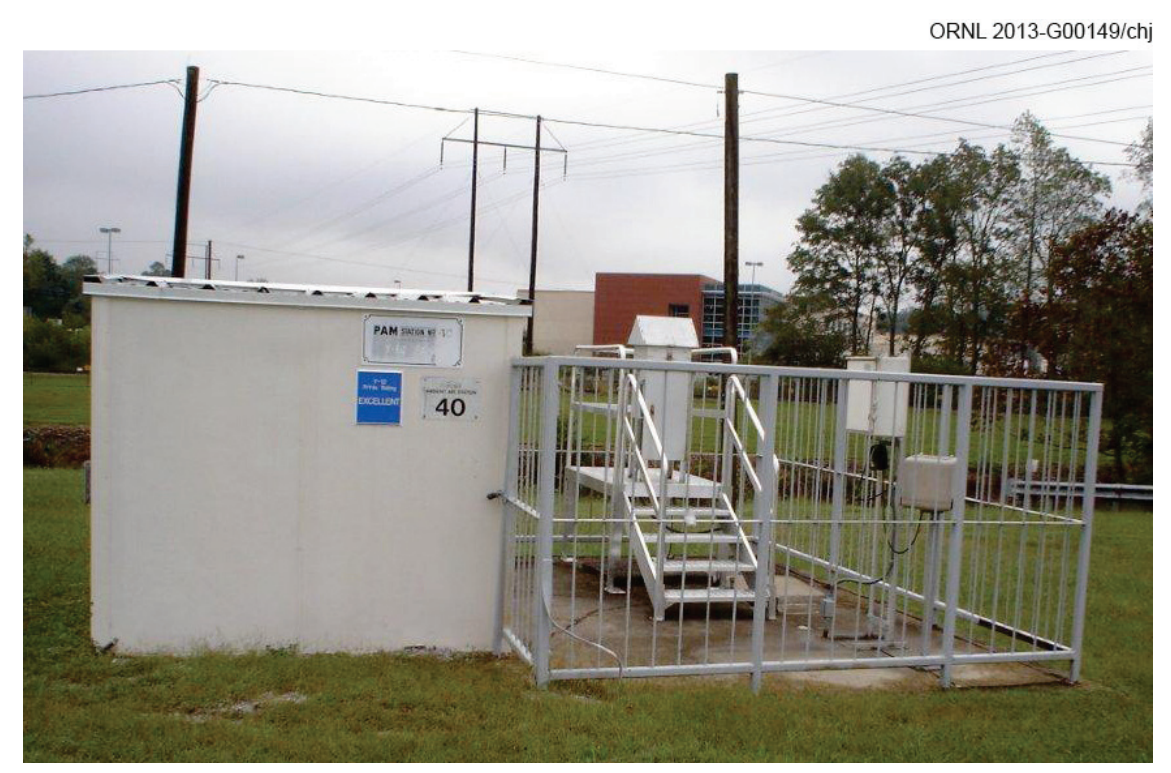

Fig. 6.3. Oak Ridge Reservation ambient air station.

Ambient air monitoring conducted by individual site programs is discussed in Chapters $3-5$. The ORR ambient air monitoring program complements these individual site programs and permits the impacts of ORR operations to be assessed on an integrated basis. This program is discussed in detail in the following sections. 


\subsubsection{Oak Ridge Reservation Ambient Air Monitoring}

The objectives of the ORR ambient air monitoring program are to perform surveillance of airborne radionuclides at the reservation perimeter and to collect reference data from a location not affected by activities on ORR. The ORR perimeter air monitoring network includes stations 35, 37, 38, 39, 40, 42, 46, and 48 (Fig. 6.4). Reference samples are collected from Station 52 (Fort Loudoun Dam). Sampling was conducted at each ORR station during 2013 to quantify levels of alpha-, beta-, and gamma-emitting radionuclides.

Atmospheric dispersion modeling was used to select appropriate sampling locations. The locations selected are those likely to be affected most by releases from the Oak Ridge facilities. Therefore, in the event of a release, no residence or business in the vicinity of ORR should receive a radiation dose greater than doses calculated at the sampled locations.

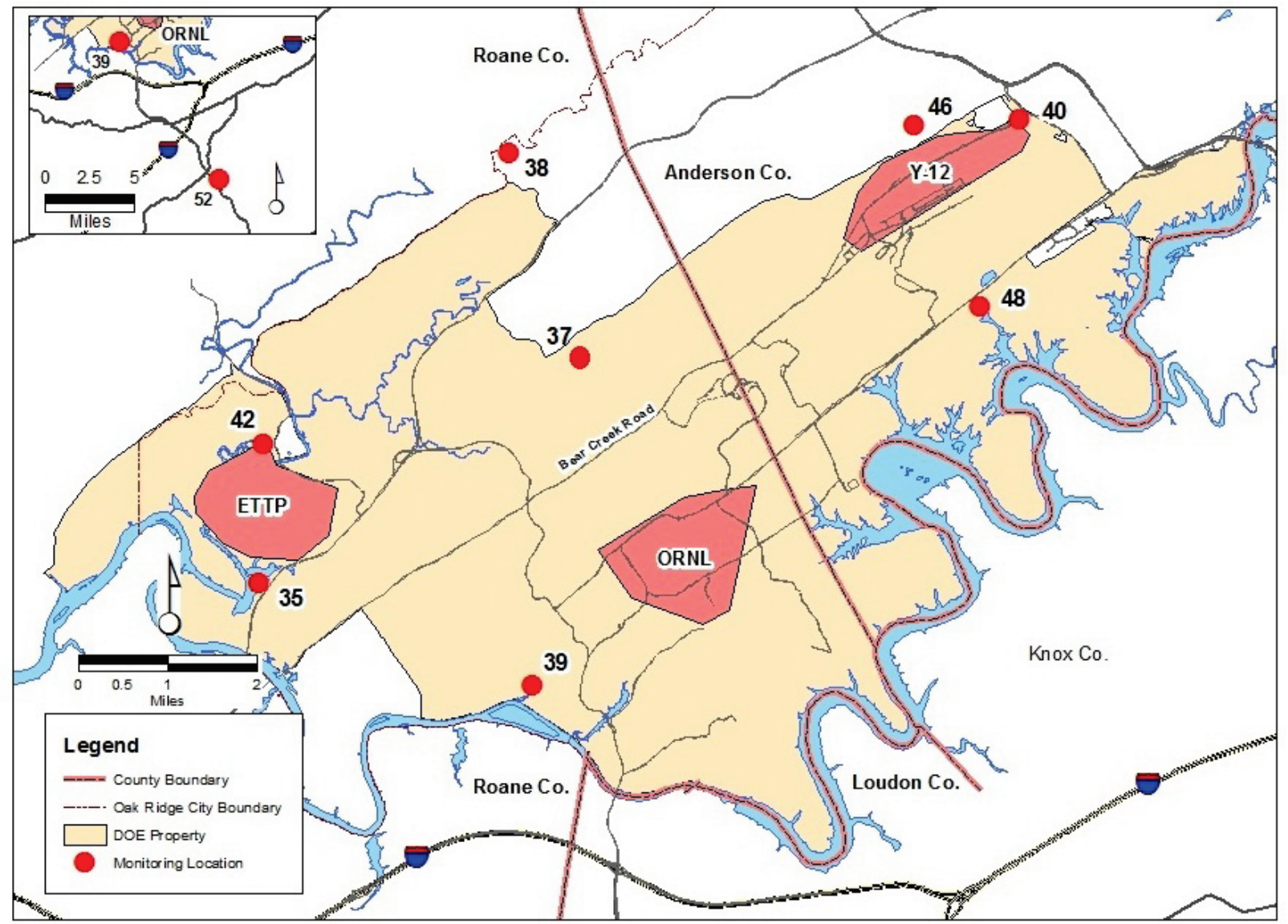

Fig. 6.4. Locations of Oak Ridge Reservation perimeter air monitoring stations.

The sampling system consists of two separate instruments. Particulates are captured by high-volume air samples equipped with glass-fiber filters. The filters are collected weekly, composited quarterly, and then submitted to an analytical laboratory to quantify gross alpha and beta activity and to determine the concentrations of specific isotopes of interest on ORR. The second system is designed to collect tritiated water vapor. The sampler consists of a prefilter followed by an adsorbent trap that contains indicating silica gel. The samples are collected weekly or biweekly, composited quarterly, and then submitted to an analytical laboratory for tritium analysis.

\subsubsection{Results}

Data from the ORR AASs are analyzed to assess the impact of DOE operations on the local air quality. Each measured radionuclide concentration (Table 6.3) is compared with DCSs for air established 
by DOE as guidelines for controlling exposure to members of the public. All radionuclide concentrations measured at the ORR AASs during 2013 were less than 1\% of applicable DCSs, indicating that activities on the reservation are not adversely affecting local air quality.

Table 6.3. Average radionuclide concentrations at Oak Ridge Reservation perimeter air monitoring stations, 2013

\begin{tabular}{|c|c|c|c|c|}
\hline \multirow{2}{*}{ Parameter } & \multirow{2}{*}{$\mathbf{N}$ detected/N total } & \multicolumn{3}{|c|}{ Concentration (pCi/mL) } \\
\hline & & Average & Minimum & Maximum \\
\hline \multicolumn{5}{|c|}{ Station 35} \\
\hline${ }^{7} \mathrm{Be}$ & $4 / 4$ & $2.68 \mathrm{E}-08$ & $2.51 \mathrm{E}-08$ & 2.87E-08 \\
\hline${ }^{40} \mathrm{~K}$ & $1 / 4$ & $1.84 \mathrm{E}-10$ & $-5.00 \mathrm{E}-10$ & 1.47E-09 \\
\hline${ }^{3} \mathrm{H}$ & $1 / 4$ & $3.17 \mathrm{E}-06$ & $2.20 \mathrm{E}-07$ & $9.76 \mathrm{E}-06$ \\
\hline${ }^{234} \mathrm{U}$ & $4 / 4$ & $1.70 \mathrm{E}-11$ & $3.29 \mathrm{E}-12$ & $3.41 \mathrm{E}-11$ \\
\hline${ }^{235} \mathrm{U}$ & $3 / 4$ & $9.49 \mathrm{E}-13$ & $2.11 \mathrm{E}-13$ & $2.14 \mathrm{E}-12$ \\
\hline${ }^{238} \mathrm{U}$ & $4 / 4$ & $4.14 \mathrm{E}-12$ & $1.48 \mathrm{E}-12$ & $7.45 \mathrm{E}-12$ \\
\hline \multicolumn{5}{|c|}{ Station 37} \\
\hline${ }^{7} \mathrm{Be}$ & $4 / 4$ & 2.16E-08 & $1.43 \mathrm{E}-08$ & $2.57 \mathrm{E}-08$ \\
\hline${ }^{40} \mathrm{~K}$ & $0 / 4$ & $-6.94 \mathrm{E}-11$ & $-3.04 \mathrm{E}-10$ & $2.12 \mathrm{E}-10$ \\
\hline${ }^{3} \mathrm{H}$ & $0 / 4$ & $2.88 \mathrm{E}-06$ & $3.30 \mathrm{E}-07$ & $6.12 \mathrm{E}-06$ \\
\hline${ }^{234} \mathrm{U}$ & $4 / 4$ & $3.75 \mathrm{E}-12$ & $1.37 \mathrm{E}-12$ & $8.61 \mathrm{E}-12$ \\
\hline${ }^{235} \mathrm{U}$ & $1 / 4$ & $3.86 \mathrm{E}-13$ & $1.81 \mathrm{E}-13$ & $6.67 \mathrm{E}-13$ \\
\hline${ }^{238} \mathrm{U}$ & $4 / 4$ & $1.34 \mathrm{E}-12$ & $9.49 \mathrm{E}-13$ & $1.87 \mathrm{E}-12$ \\
\hline \multicolumn{5}{|c|}{ Station 38} \\
\hline${ }^{7} \mathrm{Be}$ & $4 / 4$ & 2.74E-08 & $2.24 \mathrm{E}-08$ & $3.05 \mathrm{E}-08$ \\
\hline${ }^{40} \mathrm{~K}$ & $0 / 4$ & 2.13E-10 & $2.42 \mathrm{E}-11$ & $4.38 \mathrm{E}-10$ \\
\hline${ }^{3} \mathrm{H}$ & $0 / 4$ & $2.33 \mathrm{E}-06$ & $-4.35 \mathrm{E}-07$ & 8.87E-06 \\
\hline${ }^{234} \mathrm{U}$ & $4 / 4$ & $3.46 \mathrm{E}-12$ & $1.44 \mathrm{E}-12$ & 7.97E-12 \\
\hline${ }^{235} \mathrm{U}$ & $1 / 4$ & $2.65 \mathrm{E}-13$ & $4.98 \mathrm{E}-14$ & $4.92 \mathrm{E}-13$ \\
\hline${ }^{238} \mathrm{U}$ & $4 / 4$ & $1.95 \mathrm{E}-12$ & $1.35 \mathrm{E}-12$ & $2.83 \mathrm{E}-12$ \\
\hline \multicolumn{5}{|c|}{ Station 39} \\
\hline${ }^{7} \mathrm{Be}$ & $4 / 4$ & 2.43E-08 & $2.40 \mathrm{E}-08$ & $2.46 \mathrm{E}-08$ \\
\hline${ }^{40} \mathrm{~K}$ & $0 / 4$ & $8.75 \mathrm{E}-11$ & $-1.82 \mathrm{E}-10$ & $2.99 \mathrm{E}-10$ \\
\hline${ }^{3} \mathrm{H}$ & $0 / 4$ & $4.02 \mathrm{E}-06$ & $4.73 \mathrm{E}-07$ & $9.24 \mathrm{E}-06$ \\
\hline${ }^{234} \mathrm{U}$ & $4 / 4$ & $2.51 \mathrm{E}-12$ & $1.19 \mathrm{E}-12$ & $3.23 \mathrm{E}-12$ \\
\hline${ }^{235} \mathrm{U}$ & $1 / 4$ & $2.64 \mathrm{E}-13$ & $1.61 \mathrm{E}-13$ & $3.66 \mathrm{E}-13$ \\
\hline${ }^{238} \mathrm{U}$ & $4 / 4$ & $1.30 \mathrm{E}-12$ & $1.05 \mathrm{E}-12$ & $1.66 \mathrm{E}-12$ \\
\hline \multicolumn{5}{|c|}{ Station 40} \\
\hline${ }^{7} \mathrm{Be}$ & $4 / 4$ & 3.08E-08 & $2.90 \mathrm{E}-08$ & $3.34 \mathrm{E}-08$ \\
\hline${ }^{40} \mathrm{~K}$ & $0 / 4$ & $-2.85 \mathrm{E}-11$ & $-3.46 \mathrm{E}-10$ & $2.87 \mathrm{E}-10$ \\
\hline${ }^{3} \mathrm{H}$ & $0 / 4$ & $3.26 \mathrm{E}-06$ & 4.53E-08 & $5.55 \mathrm{E}-06$ \\
\hline${ }^{234} \mathrm{U}$ & $4 / 4$ & $7.98 \mathrm{E}-12$ & $4.31 \mathrm{E}-12$ & $1.12 \mathrm{E}-11$ \\
\hline${ }^{235} \mathrm{U}$ & $2 / 4$ & $5.48 \mathrm{E}-13$ & $2.31 \mathrm{E}-13$ & $1.00 \mathrm{E}-12$ \\
\hline${ }^{238} \mathrm{U}$ & $4 / 4$ & $2.78 \mathrm{E}-12$ & $2.16 \mathrm{E}-12$ & $3.57 \mathrm{E}-12$ \\
\hline
\end{tabular}


Table 6.3. (continued)

\begin{tabular}{|c|c|c|c|c|}
\hline \multirow{2}{*}{ Parameter } & \multirow{2}{*}{$\mathbf{N}$ detected/N total } & \multicolumn{3}{|c|}{ Concentration (pCi/mL) } \\
\hline & & Average & Minimum & Maximum \\
\hline \multicolumn{5}{|c|}{ Station 42} \\
\hline${ }^{7} \mathrm{Be}$ & $4 / 4$ & 2.89E-08 & 2.62E-08 & $3.35 \mathrm{E}-08$ \\
\hline${ }^{40} \mathrm{~K}$ & $0 / 4$ & $-2.13 \mathrm{E}-10$ & $-4.21 \mathrm{E}-10$ & $1.12 \mathrm{E}-10$ \\
\hline${ }^{3} \mathrm{H}$ & $0 / 4$ & 4.20E-06 & $-5.27 \mathrm{E}-07$ & $6.41 \mathrm{E}-06$ \\
\hline${ }^{234} \mathrm{U}$ & $4 / 4$ & $1.01 \mathrm{E}-11$ & $4.71 \mathrm{E}-12$ & $2.00 \mathrm{E}-11$ \\
\hline${ }^{235} \mathrm{U}$ & $3 / 4$ & $6.05 \mathrm{E}-13$ & $4.31 \mathrm{E}-13$ & $1.06 \mathrm{E}-12$ \\
\hline${ }^{238} \mathrm{U}$ & $4 / 4$ & $2.57 \mathrm{E}-12$ & $1.26 \mathrm{E}-12$ & $3.94 \mathrm{E}-12$ \\
\hline \multicolumn{5}{|c|}{ Station 46} \\
\hline${ }^{7} \mathrm{Be}$ & $4 / 4$ & $2.46 \mathrm{E}-08$ & $1.99 \mathrm{E}-08$ & $3.01 \mathrm{E}-08$ \\
\hline${ }^{40} \mathrm{~K}$ & $0 / 4$ & $-1.06 \mathrm{E}-10$ & $-3.57 \mathrm{E}-10$ & $1.92 \mathrm{E}-10$ \\
\hline${ }^{3} \mathrm{H}$ & $1 / 4$ & $9.88 \mathrm{E}-06$ & $3.06 \mathrm{E}-07$ & $2.95 \mathrm{E}-05$ \\
\hline${ }^{234} \mathrm{U}$ & $4 / 4$ & $5.17 \mathrm{E}-12$ & $3.41 \mathrm{E}-12$ & $7.87 \mathrm{E}-12$ \\
\hline${ }^{235} \mathrm{U}$ & $0 / 4$ & $3.44 \mathrm{E}-13$ & $1.49 \mathrm{E}-13$ & $5.65 \mathrm{E}-13$ \\
\hline${ }^{238} \mathrm{U}$ & $4 / 4$ & $2.12 \mathrm{E}-12$ & $1.64 \mathrm{E}-12$ & $2.86 \mathrm{E}-12$ \\
\hline \multicolumn{5}{|c|}{ Station 48} \\
\hline${ }^{7} \mathrm{Be}$ & $4 / 4$ & $2.85 \mathrm{E}-08$ & $2.55 \mathrm{E}-08$ & $3.38 \mathrm{E}-08$ \\
\hline${ }^{40} \mathrm{~K}$ & $0 / 4$ & $-9.34 \mathrm{E}-11$ & $-4.02 \mathrm{E}-10$ & $1.84 \mathrm{E}-10$ \\
\hline${ }^{3} \mathrm{H}$ & $0 / 4$ & $4.01 \mathrm{E}-06$ & $-6.11 \mathrm{E}-07$ & 7.39E-06 \\
\hline${ }^{234} \mathrm{U}$ & $4 / 4$ & 3.32E-12 & $1.43 \mathrm{E}-12$ & $5.93 \mathrm{E}-12$ \\
\hline${ }^{235} \mathrm{U}$ & $0 / 4$ & $2.43 \mathrm{E}-13$ & $1.56 \mathrm{E}-13$ & $3.07 \mathrm{E}-13$ \\
\hline${ }^{238} \mathrm{U}$ & $4 / 4$ & $1.99 \mathrm{E}-12$ & $1.58 \mathrm{E}-12$ & $2.43 \mathrm{E}-12$ \\
\hline \multicolumn{5}{|c|}{ Station 52} \\
\hline${ }^{7} \mathrm{Be}$ & $4 / 4$ & 2.79E-08 & $2.15 \mathrm{E}-08$ & $3.78 \mathrm{E}-08$ \\
\hline${ }^{40} \mathrm{~K}$ & $0 / 4$ & $-1.92 \mathrm{E}-10$ & $-6.39 \mathrm{E}-10$ & $1.24 \mathrm{E}-10$ \\
\hline${ }^{3} \mathrm{H}$ & $1 / 4$ & 4.19E-06 & $-1.56 \mathrm{E}-06$ & $1.57 \mathrm{E}-05$ \\
\hline${ }^{234} \mathrm{U}$ & $4 / 4$ & $1.98 \mathrm{E}-12$ & $1.63 \mathrm{E}-12$ & $2.20 \mathrm{E}-12$ \\
\hline${ }^{235} \mathrm{U}$ & $0 / 4$ & $1.30 \mathrm{E}-13$ & 0 & $2.97 \mathrm{E}-13$ \\
\hline${ }^{238} \mathrm{U}$ & $4 / 4$ & $1.49 \mathrm{E}-12$ & $1.30 \mathrm{E}-12$ & $1.78 \mathrm{E}-12$ \\
\hline
\end{tabular}

\subsection{Surface Water Monitoring}

\subsubsection{Oak Ridge Reservation Surface Water Monitoring}

The ORR surface water monitoring program consists of sample collection and analysis from five locations on the Clinch River, including public water intakes (Fig. 6.5). This program is conducted in conjunction with site-specific surface water monitoring activities to enable an assessment of the impacts of past and current DOE operations on the quality of local surface water. 


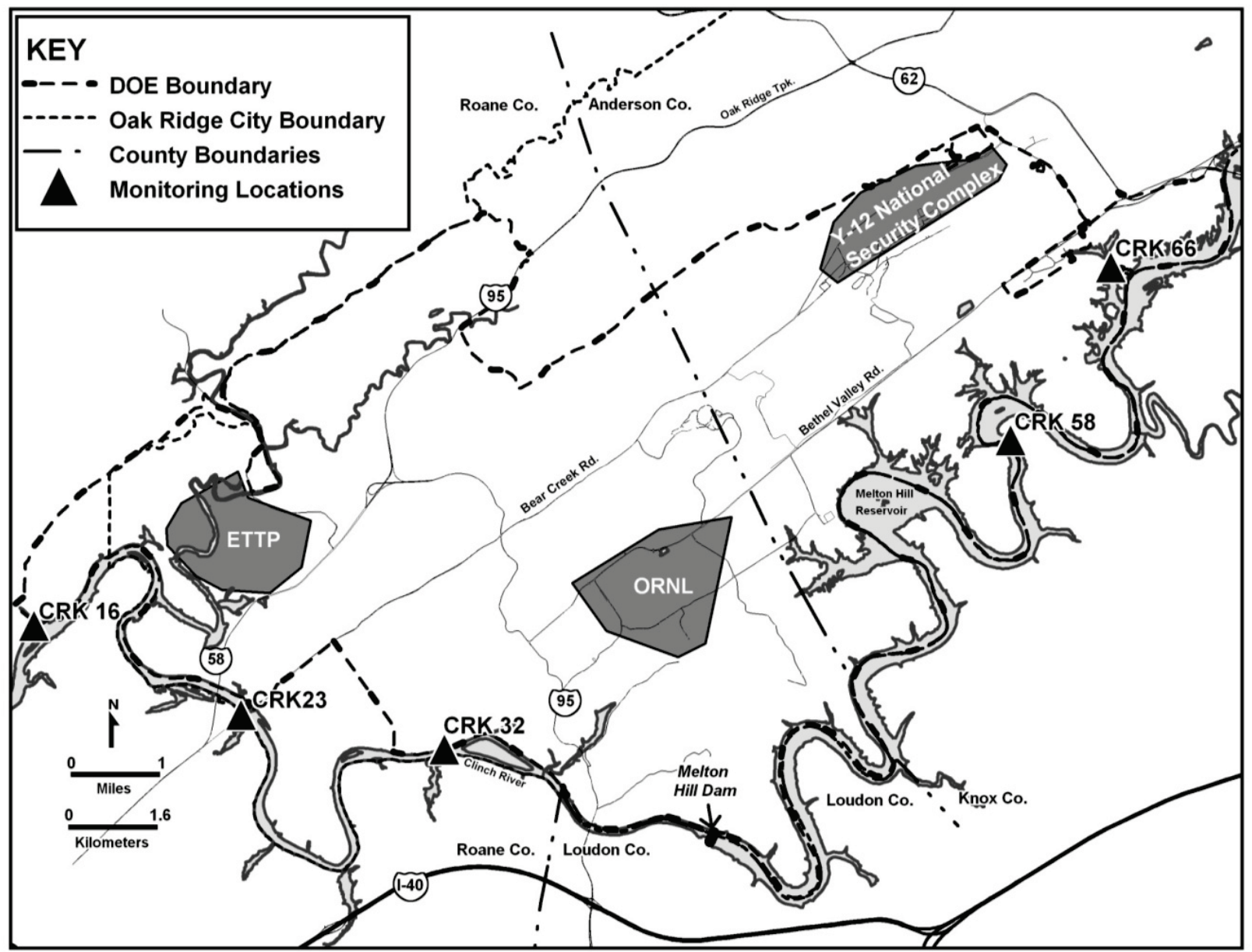

Fig. 6.5. Oak Ridge Reservation surface water surveillance sampling locations.

Grab samples are collected quarterly at all five locations and are analyzed for general water quality parameters, screened for radioactivity, and analyzed for mercury and specific radionuclides when appropriate. Table 6.4 lists the specific locations and associated sampling frequencies and parameters.

The sampling locations are classified by the State of Tennessee for recreation and domestic use. Tennessee WQCs associated with these classifications are used as references where applicable (TDEC 2008). The Tennessee WQCs do not include criteria for radionuclides. Four percent of the DOE DCS is used for radionuclide comparison because this value is roughly equivalent to the 4 mrem dose limit from ingestion of drinking water on which the EPA radionuclide drinking water standards are based.

Table 6.4. Oak Ridge Reservation surface water sampling locations, frequencies, and parameters, 2013

\begin{tabular}{|c|c|c|c|}
\hline Location $^{a}$ & Description & Frequency & Parameters \\
\hline CRK 16 & $\begin{array}{l}\text { Clinch River downstream from all } \\
\text { DOE ORR inputs }\end{array}$ & Quarterly & $\begin{array}{l}\text { Mercury, gross alpha, gross beta, gamma scan, } \\
{ }^{3} \mathrm{H} \text {, field measurements }{ }^{b}\end{array}$ \\
\hline CRK 23 & Water supply intake for ETTP & Quarterly & $\begin{array}{l}\text { Mercury, gross alpha, gross beta, gamma scan, } \\
{ }^{3} \mathrm{H} \text {, field measurements }{ }^{b}\end{array}$ \\
\hline CRK 32 & $\begin{array}{l}\text { Clinch River downstream from } \\
\text { ORNL }\end{array}$ & Quarterly & $\begin{array}{l}\text { Gross alpha, gross beta, gamma scan, total } \\
\text { radioactive strontium, }{ }^{3} \mathrm{H} \text {, field measurements }\end{array}$ \\
\hline
\end{tabular}


Table 6.4. (continued)

\begin{tabular}{clll}
\hline Location $^{a}$ & \multicolumn{1}{c}{ Description } & Frequency & \multicolumn{1}{c}{ Parameters } \\
\hline CRK 58 & $\begin{array}{l}\text { Water supply intake for Knox } \\
\text { County }\end{array}$ & Quarterly & $\begin{array}{l}\text { Gross alpha, gross beta, gamma scan, }{ }^{3} \mathrm{H}, \text { field } \\
\text { measurements }\end{array}$ \\
CRK 66 & $\begin{array}{l}\text { Melton Hill Reservoir above city } \\
\text { of Oak Ridge water intake }\end{array}$ & Quarterly & $\begin{array}{l}\text { Mercury, gross alpha, gross beta, gamma scan, } \\
\text { total radioactive strontium, }{ }^{3} \mathrm{H}, \text { field } \\
\text { measurements }\end{array}$ \\
\hline
\end{tabular}

${ }^{a}$ Locations indicate the water body and distances upstream of the confluence of the Clinch and Tennessee Rivers (e.g., CRK 16 is $16 \mathrm{~km}$ upstream from the confluence of the Clinch River with the Tennessee River, Watts Bar Reservoir).

${ }^{b}$ Field measurements consist of dissolved oxygen, $\mathrm{pH}$, and temperature.

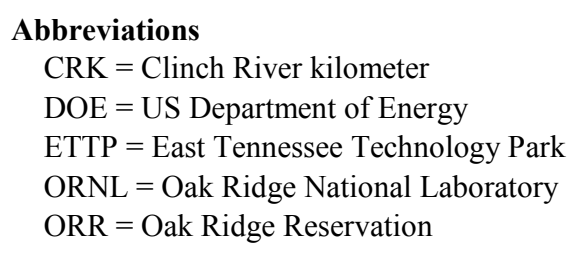

\subsubsection{Results}

A comparison of 2013 sampling results for surface water collected upstream of DOE inputs with surface water collected downstream of DOE inputs shows no statistically significant difference for any of the radionuclides. None of the radionuclides at any location were detected above $4 \%$ of the respective DCS or the 4 mrem dose limit, which is the MCL for beta and photon emitters in community drinking water systems (40 CFR 141.66, Maximum Contaminant Levels for Radionuclides). There were no mercury detections above MCLs at any of the three designated sampling locations.

\subsection{Food}

Vegetation samples are collected from areas that could be affected by activities on the reservation. The samples are analyzed to evaluate the potential radiation doses to people who consume local food crops. Food crop monitoring data are also used to monitor trends in environmental contamination and possible long-term accumulation of radionuclides.

\subsubsection{Vegetables}

Tomatoes, lettuce, and turnips were purchased from farms near ORR. The locations were chosen based on availability and on the likelihood of their being affected by routine releases from the Oak Ridge facilities.

\subsubsection{Results}

Samples were analyzed for gross alpha, gross beta, gamma emitters, and uranium isotopes. No gamma-emitting radionuclides were detected above the minimum detectable activity (MDA), with the exception of the naturally occurring radionuclides ${ }^{7} \mathrm{Be}$ and ${ }^{40} \mathrm{~K}$. Concentrations of radionuclides detected above MDA are shown in Table 6.5. 
Table 6.5. Concentrations of radionuclides detected in vegetables, $2013(\mathrm{pCi} / \mathrm{kg})^{a}$

\begin{tabular}{|c|c|c|c|c|c|c|c|}
\hline Location & $\begin{array}{l}\text { Gross } \\
\text { alpha }\end{array}$ & $\begin{array}{l}\text { Gross } \\
\text { beta }\end{array}$ & ${ }^{7} \mathbf{B e}$ & ${ }^{40} \mathrm{~K}$ & ${ }^{234} \mathbf{U}$ & ${ }^{235} \mathbf{U}$ & ${ }^{238} \mathbf{U}$ \\
\hline \multicolumn{8}{|c|}{ Lettuce } \\
\hline $\begin{array}{l}\text { East of Y-12 Complex } \\
\text { (Claxton vicinity) }\end{array}$ & $b$ & 0.00286 & $b$ & 0.00358 & 0.00000611 & 0.00000492 & $b$ \\
\hline West of ETTP & $b$ & 0.00338 & $b$ & 0.00359 & $b$ & $b$ & $b$ \\
\hline North of Y-12 Complex & $b$ & 0.00473 & $b$ & 0.00695 & 0.00000522 & $b$ & 0.00000424 \\
\hline South of ORNL & $b$ & 0.0031 & $b$ & 0.00457 & $b$ & $b$ & 0.00000377 \\
\hline $\begin{array}{l}\text { Southwest of ORNL, } \\
\text { Lenoir City }\end{array}$ & $b$ & 0.00352 & $b$ & 0.00361 & $b$ & $b$ & $b$ \\
\hline $\begin{array}{l}\text { Reference location, } \\
\text { Maryville }\end{array}$ & $b$ & 0.00334 & $b$ & 0.00526 & $b$ & $b$ & $b$ \\
\hline \multicolumn{8}{|c|}{ Tomatoes } \\
\hline $\begin{array}{l}\text { East of Y-12 Complex } \\
\text { (Claxton vicinity) }\end{array}$ & $b$ & 0.00131 & $b$ & 0.00248 & $b$ & 0.000000836 & $b$ \\
\hline West of ETTP & $b$ & 0.000988 & $b$ & 0.00209 & $b$ & $b$ & $b$ \\
\hline North of Y-12 Complex & $b$ & 0.00112 & $b$ & 0.00272 & $b$ & $b$ & $b$ \\
\hline South of ORNL & $b$ & 0.000994 & $b$ & 0.00256 & 0.00000268 & $b$ & $b$ \\
\hline $\begin{array}{l}\text { Southwest of ORNL, } \\
\text { Lenoir City }\end{array}$ & $b$ & 0.000418 & $b$ & $b$ & $b$ & $b$ & $b$ \\
\hline $\begin{array}{l}\text { Reference location, } \\
\text { Maryville }\end{array}$ & $b$ & 0.000606 & $b$ & $b$ & $b$ & $b$ & $b$ \\
\hline \multicolumn{8}{|c|}{ Turnips } \\
\hline $\begin{array}{l}\text { East of Y-12 Complex } \\
\text { (Claxton vicinity) }\end{array}$ & $b$ & 0.0022 & $b$ & 0.00308 & $b$ & $b$ & $b$ \\
\hline West of ETTP & $b$ & 0.00105 & $b$ & 0.00215 & $b$ & $b$ & $b$ \\
\hline North of Y-12 Complex & $b$ & 0.00226 & $b$ & 0.00515 & $b$ & 0.00000111 & $b$ \\
\hline South of ORNL & $b$ & 0.00251 & $b$ & 0.00362 & $b$ & $b$ & $b$ \\
\hline $\begin{array}{l}\text { Southwest of ORNL, } \\
\text { Lenoir City }\end{array}$ & 0.0000359 & 0.00164 & $b$ & 0.00302 & $b$ & $b$ & $b$ \\
\hline $\begin{array}{l}\text { Reference location, } \\
\text { Maryville }\end{array}$ & $b$ & 0.0015 & $b$ & 0.00221 & $b$ & $b$ & $b$ \\
\hline
\end{tabular}

${ }^{a}$ Detected radionuclides are those at or above minimum detectable activity. $1 \mathrm{pCi}=3.7 \times 10^{-2} \mathrm{~Bq}$.

${ }^{b}$ Value was not above minimum detectable activity.

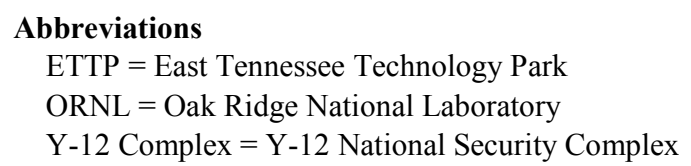

\subsubsection{Milk}

Radionuclides can be transferred from the environment to people via such food chains as the grasscow-milk pathway. Milk is a potentially significant source to humans of some radionuclides deposited from airborne emissions because of the relatively large surface area on which a cow can graze daily, the rapid transfer of milk from producer to consumer, and the importance of milk in the diet.

Information from county extension offices in counties where milk production could be impacted by activities on ORR is reviewed periodically to identify local dairy operations that could provide milk samples for this program.

The 2014 milk sampling program consisted of grab samples collected every other month from a dairy in Claxton and one reference location in Maryville (Fig. 6.6). Milk samples are analyzed for gamma 
emitters and for total radioactive strontium $\left({ }^{89} \mathrm{Sr}+{ }^{90} \mathrm{Sr}\right)$ by chemical separation and low-background beta counting. Liquid scintillation is used to analyze for tritium.

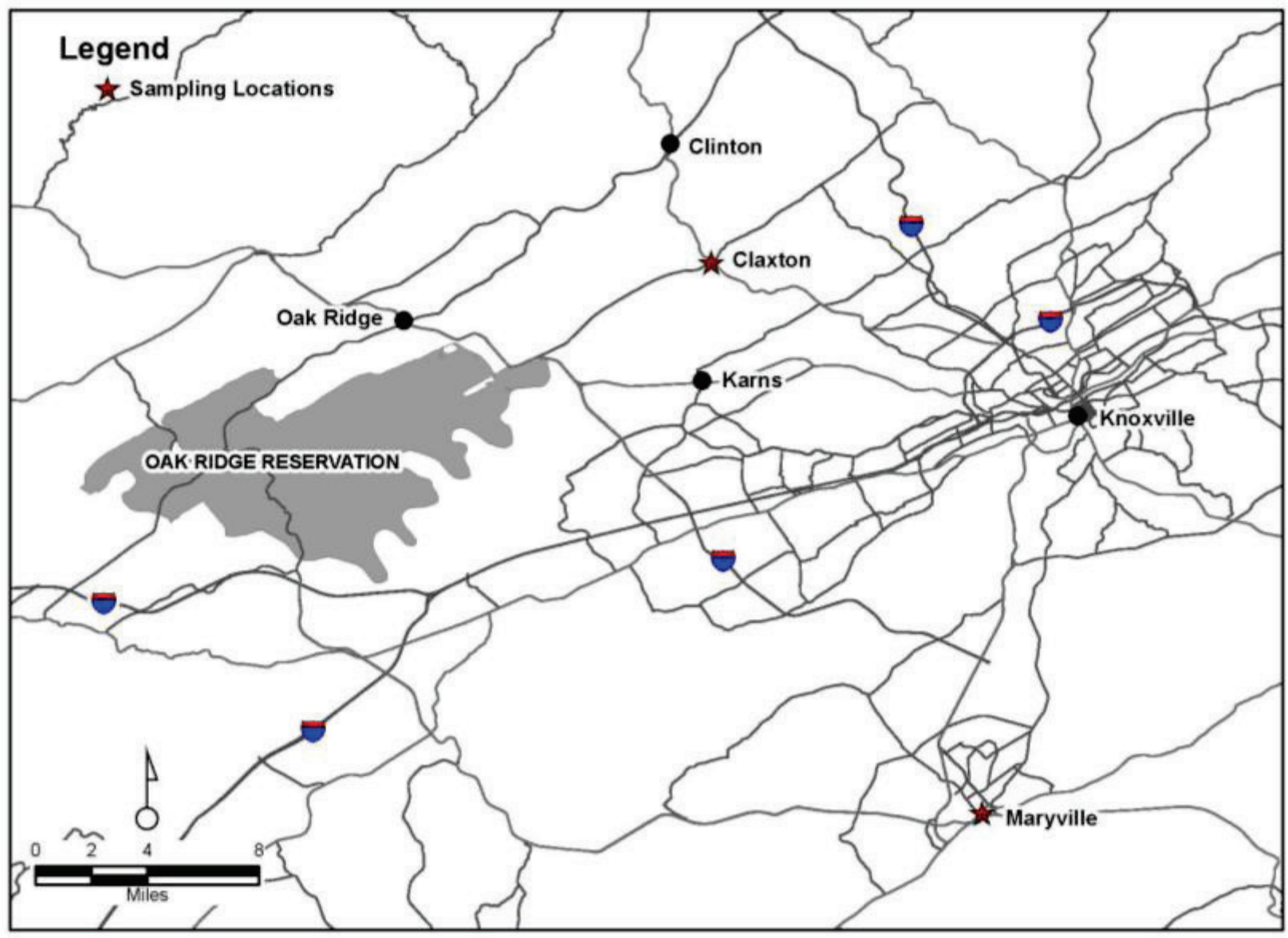

Fig. 6.6. Milk sampling locations in the vicinity of the Oak Ridge Reservation.

\subsubsection{Results}

Concentrations of radionuclides detected above MDA in milk are presented in Table 6.6. Potassium-40 was detected at both locations for each sampling event and total radioactive strontium was detected twice at each location. Comparing results for milk collected from the Claxton dairy with those for milk collected from the reference location dairy shows no statistical difference for any of the radionuclides.

Table 6.6. Concentrations of radionuclides detected in raw milk, 2013

\begin{tabular}{|c|c|c|c|c|c|}
\hline \multirow{2}{*}{ Analysis } & \multirow{2}{*}{$\begin{array}{l}\text { Number detected/ } \\
\text { total number }\end{array}$} & \multicolumn{3}{|c|}{ Detected concentration $(\mathrm{pCi} / \mathrm{L})^{a}$} & \multirow{2}{*}{$\begin{array}{c}\text { Standard } \\
\text { error of mean }\end{array}$} \\
\hline & & Max & Min & Avg & \\
\hline \multicolumn{6}{|c|}{ Claxton } \\
\hline${ }^{40} \mathrm{~K}$ & $6 / 6$ & $1,300^{b}$ & $1,100^{b}$ & $1,200^{b}$ & 30 \\
\hline Total rad Sr & $2 / 6$ & $5.0^{b}$ & 0.17 & $1.7^{b}$ & 0.79 \\
\hline \multicolumn{6}{|c|}{ Reference location } \\
\hline${ }^{40} \mathrm{~K}$ & $6 / 6$ & $1,400^{b}$ & $1,100^{b}$ & $1,300^{b}$ & 71 \\
\hline Total rad Sr & $2 / 6$ & $4.4^{b}$ & 0.16 & $1.9^{b}$ & 0.76 \\
\hline
\end{tabular}

${ }^{a}$ Detected radionuclides are those above minimum detectable activity. $1 \mathrm{pCi}=3.7 \times 10^{12} \mathrm{~Bq}$.

${ }^{b}$ Individual and average concentrations significantly greater than zero at the $95 \%$ confidence level. 


\subsection{Fish}

Members of the public could be exposed to contaminants originating from DOE ORR activities through consumption of fish caught in area waters. This potential exposure pathway is monitored annually by collecting fish from three locations on the Clinch River and analyzing edible flesh for specific contaminants. The locations are as follows (Fig. 6.7):

- Clinch River upstream from all DOE ORR inputs [Clinch River kilometer (CRK) 70],

- Clinch River downstream from ORNL (CRK 32), and

- Clinch River downstream from all DOE ORR inputs (CRK 16).

Sunfish (Lepomis macrochirus, L. auritus, and Ambloplites rupestris) and catfish (Ictalurus punctatus) are collected from each of the three locations to represent both top-feeding and bottomfeeding-predator species. In 2013, a composite sample of each of these species at each location was analyzed for selected metals, PCBs, tritium, gross alpha, gross beta, gamma-emitting radionuclides, and total radioactive strontium. To accurately estimate exposure levels to consumers, only edible portions of the fish were submitted for analysis.

It should be noted that TDEC issues advisories on consumption of certain fish species (http://www.tn.gov/environment/water/docs/wpc/advisories.pdf) caught in specified Tennessee waters. These advisories apply to fish that could contain potentially hazardous contaminants. A "do not consume" advisory has been issued by TDEC for catfish in the Melton Hill Reservoir in its entirety, not just in those areas that could be impacted by ORR activities, because of PCB contamination. Similarly, a precautionary advisory for catfish in the Clinch River arm of Watts Bar Reservoir has been issued because of PCB contamination (TDEC 2008).

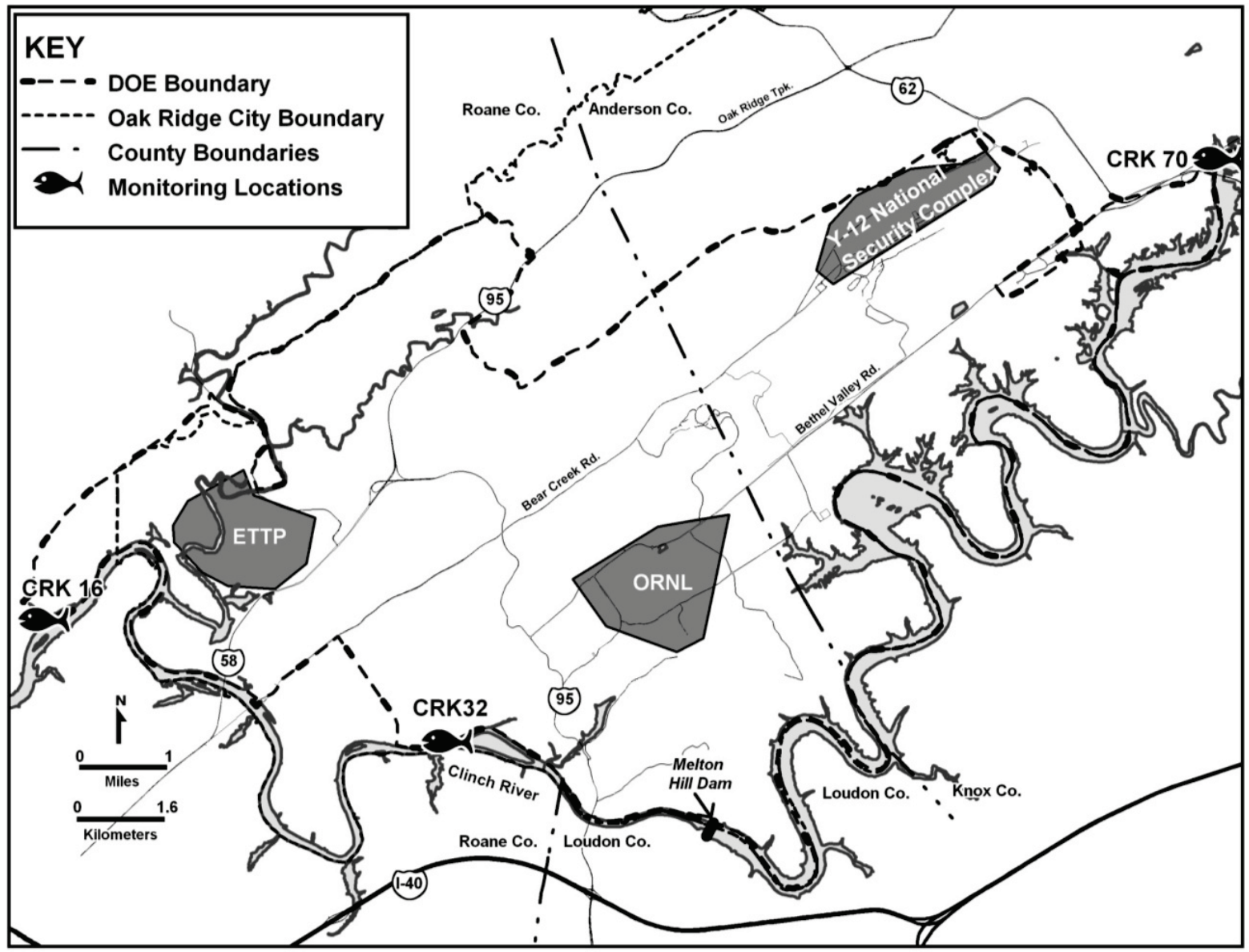

Fig. 6.7. Fish sampling locations for the Oak Ridge Reservation Surveillance Program. 


\subsubsection{Results}

PCBs, specifically Aroclor-1260, and mercury were detected in both sunfish and catfish at all three locations in 2013; Aroclor-1254 was detected in sunfish at CRK 32. These results are consistent with the TDEC advisories discussed above. Detected PCBs, mercury, and radionuclides are shown in Table 6.7.

Radiological analyses for fish tissues sampled in 2013 showed no statistical differences (at the 95\% confidence level) between the upstream and downstream locations, indicating that DOE activities on ORR are not significant contributors to the public radiological dose from fish consumption.

Table 6.7. Tissue concentrations in catfish and sunfish for mercury, detected PCBs, and detected radionuclides, 2013 ${ }^{a}$

\begin{tabular}{lcc}
\hline \multicolumn{1}{c}{ Parameter } & Catfish $^{\boldsymbol{b}}$ & Sunfish $^{\boldsymbol{b}}$ \\
\hline \multicolumn{2}{c}{ Clinch River downstream from } & all DOE ORR inputs (CRK 16) \\
Metals $(\mathrm{mg} / \mathrm{kg})$ & 0.17 & 0.058 \\
$\mathrm{Hg}$ & & \\
Pesticides and PCBs $(\mu \mathrm{g} / \mathrm{kg})$ & 430 & 26 \\
$\quad \mathrm{PCB}-1260$ & & \\
Radionuclides $(\mathrm{pCi} / \mathrm{g})^{b}$ & $2.6 \mathrm{c}$ & $1.6 \mathrm{c}$ \\
${ }^{B}{ }^{40} \mathrm{~K}$ activity & $2.6 \mathrm{c}$ & $2.7 \mathrm{c}$ \\
${ }^{90} \mathrm{Sr}$ & -0.018 & $0.014 \mathrm{c}$
\end{tabular}

Clinch River downstream from ORNL (CRK 32)

Metals $(\mathrm{mg} / \mathrm{kg})$

$\mathrm{Hg}$

0.082

Pesticides and PCBs $(\mu \mathrm{g} / \mathrm{kg})$

PCB-1254

PCB-1260 450

150

Radionuclides $(\mathrm{pCi} / \mathrm{g})^{b}$

$\begin{array}{lll}\text { Beta activity } & 2.0 \mathrm{c} & 1.9 \mathrm{c} \\ { }^{40} \mathrm{~K} & 3.5 \mathrm{c} & 3.8 \mathrm{c} \\ { }^{90} \mathrm{Sr} & 0.0028 & 0.085 \mathrm{c}\end{array}$

Clinch River (Solway Bridge) upstream from all DOE ORR inputs (CRK 70) Metals $(\mathrm{mg} / \mathrm{kg})$

$\mathrm{Hg}$

0.075

0.042

Pesticides and PCBs $(\mu \mathrm{g} / \mathrm{kg})$

PCB-1260 310 28

Radionuclides $(\mathrm{pCi} / \mathrm{g})^{b}$

Beta activity

${ }^{40} \mathrm{~K}$

$2.2 \mathrm{c}$

$1.9 \mathrm{c}$

$2.4 \mathrm{c}$

$2.9 \mathrm{c}$

${ }^{a}$ Only parameters that were detected for at least one species are listed in the table. The sampling and analysis plan contains a complete list of analyses performed.

${ }^{b}$ Radiological results are reported after background activity has been subtracted. Negative values are reported when background activity exceeds sample activity.

${ }^{c}$ Radionuclide concentrations were significantly greater than zero. Detected radionuclides are at or above the minimum detectable activity.

${ }^{d}$ Result is below method detection limit.

Abbreviations

$\mathrm{CRK}=$ Clinch River kilometer

DOE $=$ US Department of Energy

ORNL $=$ Oak Ridge National Laboratory
ORR $=$ Oak Ridge Reservation

$\mathrm{PCB}=$ polychlorinated biphenyl 


\subsection{White-Tailed Deer}

Two deer hunts took place on ORR during the final quarter of 2013. ORNL staff, Tennessee Wildlife Resources Agency (TWRA) personnel, and student members of the Wildlife Society (University of Tennessee chapter) performed most of the necessary operations at the checking station.

Shotgun/muzzleloader and archery hunts took place November 9-10 and December 14-15. About 450 shotgun/muzzleloader-permitted hunters and 675 archery-permitted hunters participated per weekend. Areas adjacent to the Tower Shielding facility, Park City Road and Chestnut Ridge, and Poplar Creek Road were opened for an archery-only hunt on the two weekends. The year's total harvest was 188 deer. From the total deer harvest, $108(57.4 \%)$ were bucks, and $80(42.6 \%)$ were does. The heaviest buck had nine antler points and weighed $183 \mathrm{lb}$. The greatest number of antler points found on one buck was 10 . The heaviest doe weighed $111 \mathrm{lb}$.

Since 1985, 11,821 deer have been harvested. Of these, only 205 (1.7\%) have been retained because of potential radiological contamination. The heaviest buck was $218 \mathrm{lb}$ (harvested in 1998); the average weight is $85.9 \mathrm{lb}$. The oldest deer harvested was 12 years old; the average age is 2.0 years. For more information, see the ORR hunt information website (http://www.ornl.gov/sci/rmal/huntinfo.htm).

\subsubsection{Results}

The wildlife administrative release limits associated with deer, turkey, and geese harvested on ORR are conservative and were established based on ALARA principles to ensure that doses to consumers of wildlife harvested on the reservation are managed and controlled to levels well below regulatory dose thresholds. The ALARA concept is not a dose limit but rather a philosophy that has the objective of maintaining exposures to workers, members of the public, and the environment below regulatory limits. The administrative release limit of $5 \mathrm{pCi} / \mathrm{g}$ for ${ }^{137} \mathrm{Cs}$ is based on the assumption that one person consumes all of the meat from a maximum-weight deer, goose, or turkey. This limit ensures that members of the public who harvest wildlife on the reservation will not receive significant radionuclide doses from this consumption pathway. Similarly, the gross beta count administrative limit of 2.5 times background is near the detection limit for field measurements.

Of the 188 deer harvested on ORR during the 2013 hunts, one $(0.5 \%)$ was retained for exceeding the administrative release limits [1.5 times the background for beta activity in bone $(\sim 20 \mathrm{pCi} / \mathrm{g})$ or $5 \mathrm{pCi} / \mathrm{g}$ of ${ }^{137} \mathrm{Cs}$ in edible tissue]. The retained deer exceeded the limit for beta-particle activity in bone.

\subsection{Fowl}

\subsubsection{Waterfowl Surveys-Canada Geese}

The consumption of Canada geese is a potential pathway for exposure of members of the public to radionuclides released from ORR operations because open hunts for Canada geese take place each year on ORR and in counties adjacent to the reservation. To determine concentrations of gamma-emitting radionuclides accumulated by waterfowl that feed and live on ORR, Canada geese are rounded up each summer for noninvasive gross radiological surveys.

\subsubsection{Results}

During the 2013 roundup, 70 geese were subjected to live whole-body gamma scans. The geese were collected from ORNL (13), Pumphouse Road (10), Y-12 (3), and Melton Hill Dam (44). None exceeded the administrative release limits.

The $5 \mathrm{pCi} / \mathrm{g}$ administrative release limit for ${ }^{137} \mathrm{Cs}$ discussed for deer is also applied to geese. This limit assumes that one person consumes all of the meat from a maximum-weight goose. The administrative limits were established to keep doses ALARA and to provide consistent standards for releasing harvested wildlife 


\subsubsection{Turkey Monitoring}

Two wild turkey hunts managed by DOE and TWRA were held on the reservation (April 13-14 and April 20-21, 2013). Hunting was open for both shotguns and archery. Thirty-nine turkeys were harvested, of which $4(10.3 \%)$ were juveniles and $35(89.7 \%)$ were adults. The average turkey weight was about $18.5 \mathrm{lb}$, with the largest weighing $23.3 \mathrm{lb}$. The longest beard was $11.5 \mathrm{in}$., and the average was $9.4 \mathrm{in}$. The longest spur was $1.5 \mathrm{in}$., and the average was $0.8 \mathrm{in}$.

\subsubsection{Results}

In 2013, none of the 39 turkeys harvested exceeded the administrative release limits established for radiological contamination. Since 1997, 756 turkeys have been harvested. Of these, only three $(0.4 \%)$ have been retained because of potential radiological contamination. For additional information, see http://www.ornl.gov/rmal/huntinfo.htm.

The $5 \mathrm{pCi} / \mathrm{g}$ administrative release limit for ${ }^{137} \mathrm{Cs}$ that is applied to deer and geese is also applied to turkey. This limit assumes that one person consumes all of the meat from a maximum-weight turkey. The administrative limits were established to keep doses ALARA and to provide consistent standards for releasing harvested wildlife.

\subsection{Quality Assurance}

The activities associated with administration, sampling, data management, and reporting for the ORR environmental surveillance programs are performed by UT-Battelle EP\&WSD. Project scope is established by a task team whose members represent DOE, UT-Battelle, B\&W Y-12, and UCOR. UT-Battelle integrates quality assurance, environmental, and safety considerations into every aspect of ORR environmental monitoring. (See Section 5.7 for a discussion of UT-Battelle quality assurance program elements for environmental monitoring and surveillance activities.)

\subsection{References}

Bowen, B. M., J. A. Baars, and G. L. Stone. 2000. "Nocturnal wind shear and its potential impact on pollutant transport." Journal of Applied Meteorology 39(3), 437-45.

TDEC. 2008. The Status of Water Quality in Tennessee. 305b Report. Tennessee Department of Environment and Conservation, Division of Water Pollution Control, Nashville, Tennessee. April. 


\section{Dose}

Activities on ORR have the potential to release small quantities of radionuclides and hazardous chemicals to the environment. These releases could expose members of the public to low concentrations of radionuclides or chemicals. Monitoring of materials released from the reservation and environmental monitoring and surveillance on and around the reservation provide data used to show that doses from released radionuclides and chemicals are in compliance with the law.

A hypothetical maximally exposed individual could have received in 2013 an ED of about 0.4 mrem from radionuclides emitted to the atmosphere from all ORR sources; this is well below the NESHAPs standard of 10 mrem for protection of the public.

A worst-case analysis of exposures to waterborne radionuclides for all pathways combined gives a maximum possible individual ED of about $2 \mathrm{mrem}$. This dose is based on a person eating $27 \mathrm{~kg} /$ year (60 lb/year) of the most contaminated fish accessible, drinking $930 \mathrm{~L} /$ year (246 gal/year) of the most contaminated drinking water, and using the shoreline near the most contaminated stretch of water for $60 \mathrm{~h} /$ year.

In addition, if a hypothetical person consumed one deer, one turkey, and two geese (containing the maximum ${ }^{137} \mathrm{Cs}$ concentration and maximum weights), that person could have received an ED of about 2 mrem. This calculation is conducted to provide an estimated upperbound ED from consuming wildlife harvested from ORR.

Therefore, the annual dose to a maximally exposed individual from all these potential exposure pathways combined was estimated to be about $5 \mathrm{mrem}$. There are no known significant doses from discharges of radioactive constituents from ORR other than those reported. DOE O 458.1, Radiation Protection of the Public and the Environment (DOE 2011), limits the ED that an individual may receive from all exposure pathways from all radionuclides released from ORR during 1 year to no more than 100 mrem. The 2013 maximum ED was about $5 \%$ of the limit given in DOE O 458.1 .

The potential doses to aquatic and terrestrial biota from contaminated soil and water were evaluated using a graded approach. Results of the screening calculations indicate that contaminants released from ORR site activities do not have an adverse impact on plants or animal populations.

\subsection{Radiation Dose}

Small quantities of radionuclides were released to the environment from operations at ORR facilities during 2013. Those releases were described, characterized, and quantified in previous chapters of this report. This chapter presents estimates of potential radiation doses to the public from the releases. The dose estimates were obtained using monitored and estimated release data, environmental monitoring and surveillance data, estimated exposure conditions that tend to maximize the calculated doses, and environmental transport and dosimetry codes that also tend to overestimate the calculated doses. Thus, the presented doses are likely overestimates of the doses received by actual people in the ORR vicinity.

\subsubsection{Terminology}

Exposures to radiation from nuclides located outside the body are called external exposures; exposures to radiation from nuclides deposited inside the body are called internal exposures. This distinction is important because external exposures occur only when a person is near or in a radionuclidecontaining medium, whereas internal exposures continue as long as the radionuclides remain inside a person. Also, external exposures may result in uniform irradiation of the entire body, including all organs, while internal exposures usually result in nonuniform irradiation of the body and organs. When taken into 
the body, most radionuclides deposit preferentially in specific organs or tissues and thus do not irradiate the body uniformly.

A number of the specialized terms and units used to characterize exposures to ionizing radiation are defined in Appendix E. "Effective dose" or "ED" is an important term to understand. ED is a risk-based equivalent dose that can be used to estimate health effects or risks to exposed persons. It is a weighted sum of dose equivalents to specified organs and is expressed in rems or sieverts $(1 \mathrm{rem}=0.01 \mathrm{~Sv})$.

One rem of ED, regardless of radiation type or method of delivery, has the same total radiological (in this case, also biological) risk effect. Because the doses being considered here are very small, EDs are expressed in millirem (mrem), which is one one-thousandth of a rem. (See Appendix E, Sections E.5.6 through E.5.10, for a comparison and description of various dose levels.)

\subsubsection{Methods of Evaluation}

\subsubsection{Airborne Radionuclides}

The radiological consequences of radionuclides released to the atmosphere from ORR operations during 2013 were characterized by calculating, for each major facility and for the entire ORR, EDs to maximally exposed on- and off-site members of the public, and to the entire population residing within $80 \mathrm{~km}$ (50 miles) of the ORR center. The dose calculations were made with the CAP-88PC Version 3 software program (CAP-88) developed under EPA sponsorship to demonstrate compliance with 40 CFR 61, Subpart H, which governs the emissions of radionuclides other than radon from DOE facilities. CAP-88 implements a steady-state Gaussian plume atmospheric dispersion model to calculate concentrations of radionuclides in the air and on the ground and uses food-chain models to calculate radionuclide concentrations in foodstuffs (vegetables, meat, and milk) and subsequent intakes by humans.

CAP-88 PC Version 3 calculates EDs using radionuclide-specific dose coefficients (ED per unit intake) from Federal Guidance Report 13 (EPA 1999). The dose coefficients were calculated by use of the methods in Publication 72 of the International Commission on Radiological Protection (ICRP 1996). These coefficients are weighted sums of equivalent doses to 12 specified tissues or organs plus a remainder term that accounts for the rest of the tissues and organs in the body.

A total of 38 emission points on ORR, each of which includes one or more individual sources, were modeled during 2013. The total includes 3 (two combined) points at the Y-12 Complex, 29 points at ORNL, and 5 points at ETTP. Table 7.1 lists the emission-point parameter values and receptor locations used in the dose calculations.

Meteorological data used in the calculations for 2013 were in the form of joint frequency distributions of wind direction, wind speed class, and atmospheric stability category. (See Table 7.2 for a summary of tower locations used to model the various sources.) During 2013, rainfall, as averaged over the five rain gauges located on ORR, was $176.4 \mathrm{~cm}\left(69.4 \mathrm{in}\right.$.). The average air temperature was $13.9^{\circ} \mathrm{C}\left(57.0^{\circ} \mathrm{F}\right)$, and the average mixing-layer height for ETTP and ORNL was $639.1 \mathrm{~m}(2,097 \mathrm{ft})$ and for Y-12 was $601.4 \mathrm{~m}$ $(1,973 \mathrm{ft})$. The mixing height is the depth of the atmosphere adjacent to the surface within which air is mixed.

For occupants of residences, the dose calculations assume that the occupant remained at home during the entire year and obtained food according to the rural pattern defined in the NESHAPs background documents (EPA 1989). This pattern specifies that $70 \%$ of the vegetables and produce, $44.2 \%$ of the meat, and $39.9 \%$ of the milk consumed are produced in the local area (e.g., a home garden). The remaining portion of each food is assumed to be produced within $80 \mathrm{~km}$ (50 miles) of ORR. The same assumptions are used for occupants of businesses, but the resulting doses are divided by 2 to compensate for the fact that businesses are occupied for less than half a year and less than half of a worker's food intake occurs at work. For collective ED estimates, production of beef, milk, and crops within $80 \mathrm{~km}$ (50 miles) of ORR was calculated using the production rates provided with CAP-88 PC Version 3. 
Table 7.1. Emission point parameters and receptor locations used in the dose calculations

\begin{tabular}{|c|c|c|c|c|c|c|c|}
\hline \multirow{2}{*}{ Source ID } & \multirow{2}{*}{$\begin{array}{l}\text { Stack } \\
\text { height } \\
\text { (m) }\end{array}$} & \multirow{2}{*}{$\begin{array}{c}\text { Stack } \\
\text { diameter } \\
(\mathbf{m})\end{array}$} & \multirow{2}{*}{$\begin{array}{c}\text { Effective } \\
\text { exit gas } \\
\text { velocity } \\
(\mathrm{m} / \mathrm{s})\end{array}$} & \multicolumn{4}{|c|}{$\begin{array}{c}\text { Distance }(\mathrm{m}) \text { and direction to } \\
\text { the maximally exposed } \\
\text { individual }^{a}\end{array}$} \\
\hline & & & & \multicolumn{2}{|c|}{$\begin{array}{c}\text { Plant } \\
\text { maximum }\end{array}$} & \multicolumn{2}{|c|}{$\begin{array}{c}\text { Oak Ridge } \\
\text { Reservation } \\
\text { maximum }\end{array}$} \\
\hline \multicolumn{8}{|c|}{ Oak Ridge National Laboratory } \\
\hline X-2000 Lab Hoods & 15 & 0.5 & 0 & 4770 & SW & 4770 & SW \\
\hline X-3000 Lab Hoods & 15 & 0.5 & 0 & 5100 & SW & 5100 & SW \\
\hline X-4000 Lab Hoods & 15 & 0.5 & 0 & 5270 & SW & 5270 & SW \\
\hline X-6000 Lab Hoods & 15 & 0.5 & 0 & 5850 & SW & 5850 & SW \\
\hline X-7000 Lab Hoods & 15 & 0.5 & 0 & 5290 & WSW & 5290 & WSW \\
\hline $\mathrm{X}-2026$ & 22.9 & 1.05 & 8.76 & 4820 & SW & 4820 & SW \\
\hline X-2099 & 3.66 & 0.178 & 21.9 & 4810 & SW & 4810 & SW \\
\hline $\mathrm{X}-3018$ & 61 & 4.11 & 0.17 & 5050 & SW & 5050 & SW \\
\hline $\mathrm{X}-3020$ & 61 & 1.22 & 16.47 & 4970 & SW & 4970 & SW \\
\hline X-3026 D Pad & 2.438 & 0.203 & 29.11 & 4990 & SW & 4990 & SW \\
\hline $\mathrm{X}-3039$ & 76.2 & 2.44 & 8.53 & 5060 & SW & 5060 & SW \\
\hline $\mathrm{X}-3544$ & 9.53 & 0.279 & 23.8 & 4810 & SW & 4810 & SW \\
\hline X-3608 Air Stripper & 10.97 & 2.44 & 0.57 & 4930 & SW & 4930 & SW \\
\hline X-3608 Filter Press & 8.99 & 0.36 & 9.27 & $\mathrm{NA}^{a}$ & & $\mathrm{NA}^{a}$ & \\
\hline $\mathrm{X}-5505 \mathrm{M}$ & 11 & 0.305 & 4.06 & $\mathrm{NA}^{a}$ & & $\mathrm{NA}^{a}$ & \\
\hline $\mathrm{X}-5505 \mathrm{NS}$ & 11 & 0.96 & 0 & 5550 & SW & 5550 & SW \\
\hline$X-7503$ & 30.5 & 0.91 & 12.65 & 5330 & SW & 5330 & SW \\
\hline X-7830 Group & 4.6 & 0.248 & 9.06 & 3920 & WSW & 3920 & WSW \\
\hline X-7856-CIP & 18.29 & 0.483 & 10.87 & 3970 & WSW & 3970 & WSW \\
\hline $\mathrm{X}-7877$ & 13.9 & 0.406 & 13.56 & 3890 & WSW & 3890 & WSW \\
\hline $\mathrm{X}-7880$ & 27.7 & 1.52 & 14.94 & 3970 & WSW & 3970 & WSW \\
\hline $\mathrm{X}-7911$ & 76.2 & 1.52 & 13.4 & 5240 & WSW & 5240 & WSW \\
\hline 7935 Building Stack & 18.29 & 0.6096 & 0 & $\mathrm{NA}^{a}$ & & $\mathrm{NA}^{a}$ & \\
\hline 7935 Glove Box & 9.14 & 0.254 & 0 & $\mathrm{NA}^{a}$ & & $\mathrm{NA}^{a}$ & \\
\hline$X-7966$ & 6.096 & 0.292 & 10.9 & 5330 & SW & 5330 & SW \\
\hline $\mathrm{X}-8915$ & 24.38 & 1.219 & 6.93 & 8070 & SW & 8070 & SW \\
\hline X-Decon Areas & 15 & 0.5 & 0 & 5310 & SW & 5310 & SW \\
\hline X-STP & 7.6 & 0.203 & 10.21 & 4590 & SW & 4590 & SW \\
\hline \multicolumn{8}{|c|}{ East Tennessee Technology Park } \\
\hline K-1200 South Bay & 28 & 0.81 & 13.7 & 1930 & WNW & 5050 & SE \\
\hline K-1407-U CNF & 7.16 & 1.22 & 0.625 & 1770 & W & 5700 & SSE \\
\hline K-1407-AL CWTS & 2.74 & 0.15 & 0 & 1770 & W & 5710 & SSE \\
\hline K-2500-H-B & 8.23 & 0.61 & 12.9 & 970 & WSW & 6350 & SE \\
\hline $\mathrm{K}-2500-\mathrm{H}-\mathrm{C}$ & 8.23 & 0.61 & 12.9 & 960 & WSW & 6330 & SE \\
\hline K-2527-BR & 2.0 & 0.3 & 0 & 850 & W & 6280 & $\mathrm{SE}$ \\
\hline
\end{tabular}


Table 7.1. (continued)

\begin{tabular}{|c|c|c|c|c|c|c|c|}
\hline \multirow{2}{*}{ Source ID } & \multirow{2}{*}{$\begin{array}{l}\text { Stack } \\
\text { height } \\
\text { (m) }\end{array}$} & \multirow{2}{*}{$\begin{array}{l}\text { Stack } \\
\text { diameter } \\
(\mathbf{m})\end{array}$} & \multirow{2}{*}{$\begin{array}{c}\text { Effective } \\
\text { exit gas } \\
\text { velocity } \\
(\mathrm{m} / \mathrm{s})\end{array}$} & \multicolumn{4}{|c|}{$\begin{array}{c}\text { Distance }(\mathrm{m}) \text { and direction to } \\
\text { the maximally exposed } \\
\text { individual }^{a}\end{array}$} \\
\hline & & & & \multicolumn{2}{|c|}{$\begin{array}{c}\text { Plant } \\
\text { maximum }\end{array}$} & \multicolumn{2}{|c|}{$\begin{array}{c}\text { Oak Ridge } \\
\text { Reservation } \\
\text { maximum }\end{array}$} \\
\hline \multicolumn{8}{|c|}{ Y-12 National Security Complex } \\
\hline Y-Monitored & 20 & 0.5 & 0 & 2270 & $\mathrm{NE}$ & 13,340 & SW \\
\hline $\begin{array}{l}\text { Y-Unmonitored } \\
\text { Processes }\end{array}$ & 20 & 0.5 & 0 & 2270 & $\mathrm{NE}$ & 13,340 & SW \\
\hline $\begin{array}{l}\text { Y-Unmonitored Lab } \\
\text { Hoods }\end{array}$ & 20 & 0.5 & 0 & 2270 & NE & 13,340 & SW \\
\hline
\end{tabular}

Note: Exit gas temperatures are "ambient air" unless noted otherwise.

${ }^{a}$ NA: Effective doses were calculated to be zero; therefore, distance and direction to maximally exposed individuals could not be determined.

Table 7.2. Meteorological towers and heights used to model atmospheric dispersion from source emissions

\begin{tabular}{lcl}
\hline \multicolumn{1}{c}{ Tower } & $\begin{array}{c}\text { Height } \\
(\mathbf{m})\end{array}$ & \multicolumn{1}{c}{ Source } \\
\hline MT6 (West Y-12) & $30^{a}$ & Y-12 National Security Complex \\
& 60 & $\begin{array}{l}\text { Spallation Neutron Source (ORNL) } \\
\text { El12 sources }\end{array}$ \\
& 10 & K-1407-U, K-1407-AL CWTS, K-2500-H- B, C, and K-2527-BR \\
MT7 (K1209) & 30 & K-1200 South Bay \\
& 10 & Oak Ridge National Laboratory \\
& 30 & X-7830, X-7966, X-7935 Glove Box \\
MT4 (Tow A) & & Hoods \\
& 15 & X-6000 Lab Hoods, X-5505 \\
MT3 (Tow B) & 10 & X-2099, X-3026 D, X-3544, X-3608 FP, X-3608 AS, STP \\
MT2 (Tow C) & 30 & X-2026, X-Decon Hoods, X-2000, X-3000, and X-4000 Lab Hoods \\
& 100 & X-3018, X-3020, and X-3039 \\
\hline
\end{tabular}

${ }^{a}$ Wind speeds adjusted to match conditions at a height of $30 \mathrm{~m}$.

\subsection{Results}

Calculated EDs from radionuclides emitted to the atmosphere from ORR are listed in Table 7.3 (maximum individual) and Table 7.4 (collective). The hypothetical maximally exposed individual for ORR was located about 13,340 m southwest of the main Y-12 Complex release point, about 5,240 m west-southwest of the 7911 stack at ORNL, and about 5,700 m south-southeast of the K-1407-U CNF at ETTP. This individual could have received an ED of about $0.4 \mathrm{mrem}$, which is well below the NESHAPs standard of $10 \mathrm{mrem}$ and is about $0.1 \%$ of the roughly $300 \mathrm{mrem}$ that the average individual receives from natural sources of radiation. Based on the 2010 population census data, the calculated collective ED to the entire population within $80 \mathrm{~km}$ (50 miles) of ORR (about 1,172,530 persons) was about 
35.3 person-rem, which is about $0.01 \%$ of the 363,484 person-rem that this population received from natural sources of radiation (based on an individual dose of about $300 \mathrm{mrem} /$ year).

Table 7.3. Calculated radiation doses to maximally exposed off-site individuals from airborne releases, 2013

\begin{tabular}{lcc}
\hline \multirow{2}{*}{ Plant } & \multicolumn{2}{c}{ Effective dose, mrem (mSv) } \\
\cline { 2 - 3 } & At plant max & At Oak Ridge Reservation max \\
\hline Oak Ridge National Laboratory & $0.37(0.0037)^{a}$ & $0.37(0.0037)$ \\
East Tennessee Technology Park & $0.008(0.00008)^{b}$ & $4 \mathrm{E}-4(4 \mathrm{E}-6)$ \\
Y-12 National Security Complex & $0.1(0.001)^{c}$ & $0.01(0.0001)$ \\
Entire Oak Ridge Reservation & $d$ & $0.4(0.004)^{e}$ \\
\hline
\end{tabular}

${ }^{a}$ The maximally exposed individual was located 5,070 m SW of X-3039 and 5,240 m WSW of X-7911.

${ }^{b}$ The maximally exposed individual was located $450 \mathrm{~m} \mathrm{~W}$ of K-1407-U CNF.

${ }^{c}$ The maximally exposed individual was located 2,270 $\mathrm{m}$ NE of the Y-12 National Security Complex release point.

${ }^{d}$ Not applicable.

${ }^{e}$ The maximally exposed individual for the entire ORR is also the ORNL maximally exposed individual.

Table 7.4. Calculated collective effective doses from airborne releases, 2013

\begin{tabular}{lcc}
\hline \multicolumn{1}{c}{ Plant } & \multicolumn{2}{c}{ Collective effective dose $^{\boldsymbol{a}}$} \\
\cline { 2 - 3 } & Person-rem & Person-Sv $^{1}$ \\
\hline Oak Ridge National Laboratory & 34.1 & 0.341 \\
East Tennessee Technology Park & 0.02 & $2.0 \mathrm{E}-4$ \\
Y-12 National Security Complex & 1.2 & 0.012 \\
Entire Oak Ridge Reservation & 35.3 & 0.35 \\
\hline
\end{tabular}

${ }^{a}$ Collective effective dose to the $1,172,530$ persons residing within $80 \mathrm{~km}$ (50 miles) of Oak Ridge Reservation (based on 2010 census data).

The maximally exposed individual for the Y-12 Complex was located at a residence about 2,270 m (1.4 miles) northeast of the main Y-12 Complex release point. This individual could have received an ED of about 0.1 mrem from Y-12 emissions. Inhalation and ingestion of uranium radioisotopes (i.e., ${ }^{233} \mathrm{U}$, ${ }^{234} \mathrm{U},{ }^{235} \mathrm{U},{ }^{236} \mathrm{U}$, and $\left.{ }^{238} \mathrm{U}\right)$ accounted for about $98 \%$ and technicium-99 $\left({ }^{99} \mathrm{Tc}\right)$ accounted for about $1.5 \%$ of the dose (Fig. 7.1). The contribution of Y-12 Complex emissions to the 50-year committed collective ED to the population residing within $80 \mathrm{~km}$ (50 miles) of ORR was calculated to be about 1.2 person-rem, which is about $3.4 \%$ of the collective ED for ORR. 


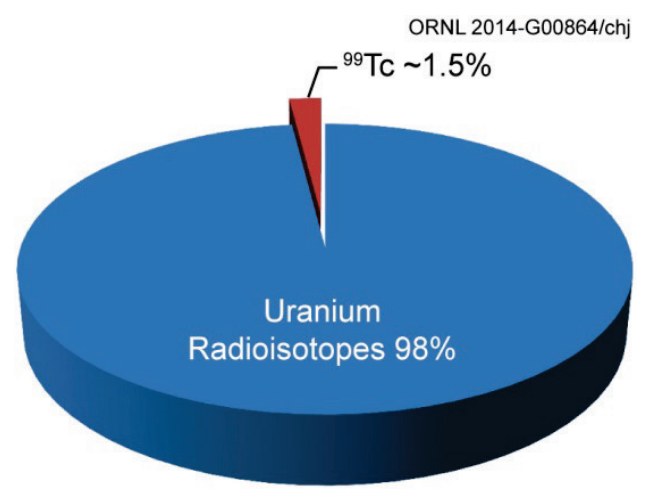

Fig. 7.1. Nuclides contributing to the effective dose at the Y-12 National Security Complex.

The maximally exposed individual for ORNL was located at a residence about 5,060 m (3.2 miles) southwest of the 3039 stack and 5,240 m (3.3 miles) west-southwest of the 7911 stack. This individual could have received an ED of about 0.37 mrem from ORNL emissions. Radionuclides contributing 5\% or more to the dose include ${ }^{11} \mathrm{C}(43 \%),{ }^{212} \mathrm{~Pb}(20 \%),{ }^{41} \mathrm{Ar}(7 \%),{ }^{138} \mathrm{Cs}(6 \%)$, and ${ }^{232} \mathrm{Th}(5 \%)$ (Fig. 7.2). The contribution of ORNL emissions to the collective ED to the population residing within $80 \mathrm{~km}$ (50 miles) of ORR was calculated to be about 34.1 person-rem, about $97 \%$ of the collective ED for ORR.

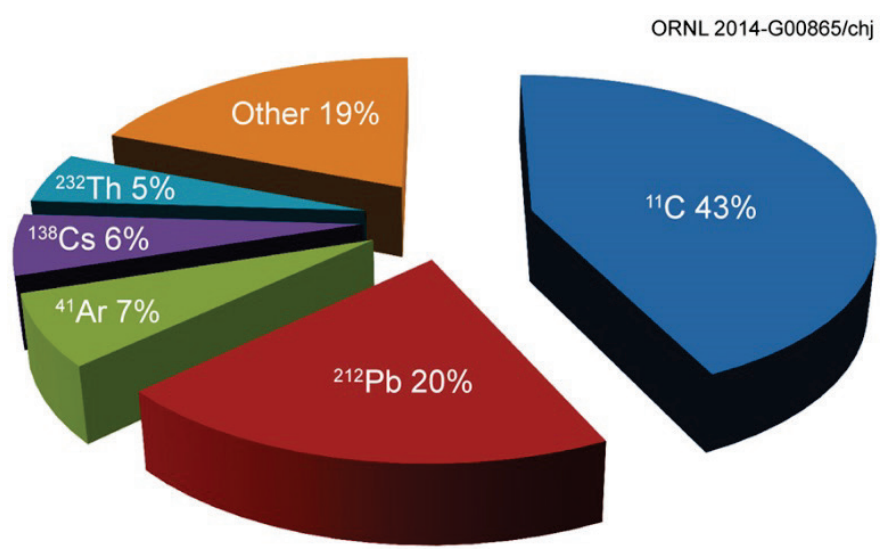

Fig. 7.2. Nuclides contributing to effective dose at Oak Ridge National Laboratory.

The maximally exposed individual for ETTP was located at a business about 1,770 $\mathrm{m}$ (1.1 miles) west of the K-1407-U CNF. The ED received by this individual was calculated to be about $0.008 \mathrm{mrem}$. About $87 \%$ of the dose is from uranium radioisotopes $\left({ }^{234} \mathrm{U},{ }^{235} \mathrm{U},{ }^{236} \mathrm{U}\right.$, and $\left.{ }^{238} \mathrm{U}\right)$ and $13 \%$ of the dose is from

${ }^{99} \mathrm{Tc}$ (Fig. 7.3). The contribution of ETTP emissions to the collective ED to the population residing within $80 \mathrm{~km}$ (50 miles) of ORR was calculated to be about 0.02 person-rem, or about $0.05 \%$ of the collective ED for the reservation. 


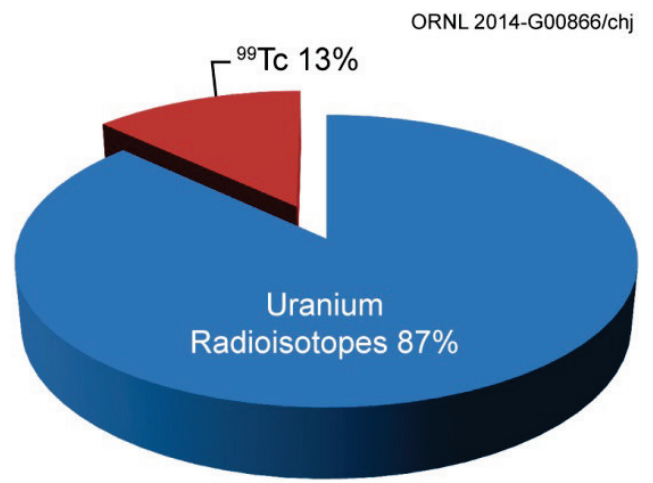

Fig. 7.3. Nuclides contributing to effective dose at East Tennessee Technology Park.

The reasonableness of the estimated doses can be inferred by comparing EDs calculated at the ORR PAM stations from measured air concentrations of radionuclides, excluding naturally occurring ${ }^{7} \mathrm{Be}$ and ${ }^{40} \mathrm{~K}$, with air concentrations calculated using CAP-88PC Version 3 and emissions data (Table 7.5). Based on measured air concentrations, hypothetical individuals assumed to reside at the PAM stations could have received EDs between 0.01 and $0.05 \mathrm{mrem} / \mathrm{year}$. Based on calculated air concentrations using CAP-88PC Version 3, the above individuals could have received EDs between 0.06 and 0.4 mrem/year. As shown in Table 7.5, EDs calculated using CAP-88PC Version 3 and emissions data tend to be higher than or equivalent to EDs calculated using measured air concentrations.

Table 7.5. Hypothetical effective doses from living at the Oak Ridge Reservation and the East Tennessee Technology Park ambient-air monitoring stations, 2013

\begin{tabular}{|c|c|c|c|c|}
\hline \multirow{3}{*}{ Station } & \multicolumn{4}{|c|}{$\begin{array}{c}\text { Calculated effective doses } \\
\end{array}$} \\
\hline & \multicolumn{2}{|c|}{ Using air monitor data } & \multicolumn{2}{|c|}{ Using CAP-88 ${ }^{a}$ and emission data } \\
\hline & mrem/year & mSv/year & mrem/year & mSv/year \\
\hline 35 & 0.02 & 0.0002 & 0.2 & 0.002 \\
\hline 37 & 0.01 & 0.0001 & 0.2 & 0.002 \\
\hline 38 & 0.01 & 0.0001 & 0.06 & 0.0006 \\
\hline 39 & 0.02 & 0.0002 & 0.3 & 0.003 \\
\hline 40 & 0.02 & 0.0002 & 0.3 & 0.003 \\
\hline 42 & 0.02 & 0.0002 & 0.1 & 0.001 \\
\hline 46 & 0.05 & 0.0005 & 0.3 & 0.003 \\
\hline 48 & 0.02 & 0.0002 & 0.4 & 0.004 \\
\hline 52 & 0.02 & 0.0002 & 0.03 & 0.0003 \\
\hline K2 & 0.09 & 0.0009 & 0.1 & 0.001 \\
\hline K6 & 0.1 & 0.001 & 0.08 & 0.0008 \\
\hline K11 & 0.3 & 0.003 & 0.09 & 0.0009 \\
\hline
\end{tabular}

${ }^{a}$ CAP-88PC Version 3 software, developed under US Environmental Protection Agency sponsorship to demonstrate compliance with 40 CFR 61, Subpart H.

Station 52, located remotely from the ORR, gives an indication of potential EDs from background sources. Based on measured air concentrations, the ED was estimated to be $0.02 \mathrm{mrem} /$ year (the isotopes ${ }^{7} \mathrm{Be}$ and ${ }^{40} \mathrm{~K}$ also were not included in the background air monitoring station calculation), whereas the estimated ED based on calculated air concentrations using CAP-88PC Version 3 was estimated to be $0.03 \mathrm{mrem} /$ year. It should be noted that measured air concentrations of ${ }^{7} \mathrm{Be}$ were similar at the PAM stations and at the background air monitoring station. 
Of particular interest is a comparison of EDs calculated using measured air concentrations of radionuclides at PAM stations located near the maximally exposed individuals for each plant and EDs calculated for those individuals using CAP-88PC Version 3 calculated air concentrations and emissions data. PAM station 46 is located near the maximally exposed individual for the Y-12 Complex. The ED calculated with measured air concentrations was $0.05 \mathrm{mrem} / \mathrm{year}$, which is less than the ED of $0.3 \mathrm{mrem} /$ year estimated using CAP-88PC Version 3 calculated air concentrations and emissions data. This year the maximally exposed individual location for ORR/ORNL was located off-site near the PAM station 39 air monitoring location; the ED calculated with measured air concentrations was $0.02 \mathrm{mrem} / \mathrm{year}$, which was considerably less than the $0.3 \mathrm{mrem} / \mathrm{year}$ calculated using CAP-88PC Version 3 and emissions data.

In 2013, activities associated with the demolition of the K-25 gaseous diffusion building were conducted. These activities resulted in fugitive emissions that are not included in the dose estimates based on point source emissions. The K11 Air Monitoring Station is located near the ETTP maximally exposed individual (at a business); the ED calculated using measured air concentrations was about $0.3 \mathrm{mrem} / \mathrm{year}$, which was greater than the estimated dose from point source emissions. The dose result for K11 of 0.3 mrem was the highest at any of the ambient air sampling locations. This would be consistent with the potential impact of fugitive emissions on the onsite K11 air monitoring location during the demolition of the K-25 gaseous diffusion building directly upwind of K11. Additionally, isotopic details show that the most significant dose contributor at this sampling location was from ${ }^{99} \mathrm{Tc}$, which provided about $92 \%$ of the 0.3 mrem dose. This corresponds to the sections of the K-25 building demolished during this reporting period that contain the highest levels of ${ }^{99} \mathrm{Tc}$ contamination. However, based on monitoring results, K2 and K6 ambient air monitors were also impacted by the fugitive emissions. Data show that all measurements are well below the 10 mrem annual dose limit, with the K11 result being only about 3\% of the standard.

\subsubsection{Waterborne Radionuclides}

Radionuclides discharged to surface waters from ORR enter the Tennessee River system by way of the Clinch River (see Section 1.3.4 for the surface water setting of ORR). Discharges from the Y-12 Complex enter the Clinch River via Bear Creek and EFPC, both of which enter Poplar Creek before it enters the Clinch River, and by discharges from Rogers Quarry into McCoy Branch and then into Melton Hill Lake. Discharges from ORNL enter the Clinch River via WOC and enter Melton Hill Lake via some small drainage creeks. Discharges from ETTP enter the Clinch River either directly or via Poplar Creek. This section discusses the potential radiological impacts of these discharges to persons who drink water; eat fish; and swim, boat, and use the shoreline at various locations along the Clinch and Tennessee Rivers.

For assessment purposes, surface waters potentially affected by ORR are divided into seven segments: (1) Melton Hill Lake above all possible ORR inputs, (2) Melton Hill Lake, (3) Upper Clinch River (from Melton Hill Dam to confluence with Poplar Creek), (4) Lower Clinch River (from confluence with Poplar Creek to confluence with the Tennessee River), (5) Upper Watts Bar Lake (from near the confluence of the Clinch and Tennessee rivers to below Kingston), (6) the lower system (the remainder of Watts Bar Lake and Chickamauga Lake to Chattanooga), and (7) Poplar Creek (including the confluence of EFPC).

Two methods are used to estimate potential radiation doses to the public. The first method uses radionuclide concentrations in the medium of interest (i.e., in water and fish) determined by laboratory analyses of water and fish samples (see Sections 6.4 and 6.6). The second method calculates possible radionuclide concentrations in water and fish from measured radionuclide discharges and known or estimated stream flows. In both methods, reported concentrations of radionuclides were used if the reported value was statistically significant. The advantage of the first method is the use of radionuclide concentrations measured in water and fish; disadvantages are the inclusion of naturally occurring radionuclides (e.g., ${ }^{40} \mathrm{~K}$, uranium and its progeny, thorium and its progeny, and unidentified alpha and beta activities), the possible inclusion of radionuclides discharged from sources not part of ORR, and the possibility that some radionuclides of ORR origin might be present in quantities too low to be measured. The advantages of the second method are that most radionuclides discharged from ORR will be quantified 
and that naturally occurring radionuclides may not be considered or may be accounted for separately; the disadvantage is the use of models to estimate the concentrations of the radionuclides in water and fish. Both methods use the same models (Hamby 1991) to estimate radionuclide concentrations in media and at locations other than those that are sampled (e.g., downstream). However, combining the two methods allows the potential radiation doses to be bounded. The EDs estimated by both methods, in each of the surface water segments, are provided in Appendix E.

\subsection{Drinking Water Consumption}

\section{Surface Water}

Several water treatment plants that draw water from the Clinch and Tennessee river systems could be affected by discharges from ORR. No in-plant radionuclide concentration data are available for these plants; all of the dose estimates given below likely are high because they are based on radionuclide concentrations in water before it enters a processing plant. Based on a nationwide food consumption survey (EPA 2011) and weighted based on the combined population of Anderson, Knox, Loudon, and Roane counties, the drinking water consumption rate for the maximally exposed individual is $930 \mathrm{~L} /$ year $(246 \mathrm{gal} /$ year) and the drinking water consumption rate for the average person is $330 \mathrm{~L} /$ year $(87$ gal/year). The average drinking water consumption rate is used to estimate the collective ED. At all locations in 2013, estimated maximum EDs to a person drinking water were calculated using both measured radionuclide concentrations in and measured radionuclide discharges to off-site surface water, excluding naturally occurring radionuclides such as ${ }^{40} \mathrm{~K}$.

Upper Melton Hill Lake above all possible ORR inputs. Based on samples from Melton Hill Lake above possible ORR inputs [at Clinch River kilometer (CRK) 66], a maximally exposed individual drinking water at this location could have received an ED of about 0.04 mrem. The collective ED to the 41,495 persons who drink water from the city of Oak Ridge water plant would also be 0.6 person-rem. The doses are attributable to the detection of ${ }^{137} \mathrm{Cs}$ in one of four water samples taken at CRK 66, which is above ORR inputs. This detection of ${ }^{137} \mathrm{Cs}$ dominated doses at CRK 66 and at all downstream locations.

Melton Hill Lake. The only water treatment plant located on Melton Hill Lake that could be affected by discharges from ORR is a Knox County plant. This plant is located near surface water sampling location CRK 58. A maximally exposed individual could have received an ED of about $0.04 \mathrm{mrem}$; the collective dose to the 62,157 persons who drink water from this plant could have been 0.9 person-rem.

Upper Clinch River. The ETTP (Gallaher) water plant draws water from the Clinch River near CRK 23. For assessment purposes, it is assumed that workers obtain half their annual water [ $465 \mathrm{~L}$ (123 gal)] intake at work. Such a worker could have received an ED of about 0.08 mrem; the collective dose to the 1,318 workers who drink water from this plant could have been about 0.04 person-rem.

Lower Clinch River. There are no known drinking water intakes in this river segment (from the confluence of Poplar Creek to the confluence of the Tennessee River).

Upper Watts Bar Lake. The Kingston and Rockwood municipal water plants draw water from the Tennessee River not very far from its confluence with the Clinch River. A maximally exposed individual could have received an ED of about $0.01 \mathrm{mrem}$; the collective dose to the 28,534 persons who drink water from these plants could have been about 0.1 person-rem.

Lower system. Several water treatment plants are located on tributaries of Watts Bar Lake and Chickamauga Lake. Persons drinking water from these plants could not have received EDs greater than the 0.01 mrem calculated for drinking Kingston and Rockwood water. The collective dose to the 298,614 persons who drink water within the lower system could have been about 1.1 person-rem.

Poplar Creek/Lower East Fork Poplar Creek. No drinking water intakes are located on Poplar Creek or lower EFPC. 


\section{Groundwater}

In 2004, six groundwater monitoring wells were installed in the western end of Melton Valley as sentinel wells to detect site-related contaminants that might seep toward the Clinch River. In FY 2010, off-site monitoring was initiated west of the Clinch River across from the Melton Valley waste management areas. This action was taken in response to detection of site-related contaminants in some of the on-site sentinel well monitoring zones in FY 2007 through FY 2009. Sampling of the off-site wells occurred semiannually during FY 2012 and FY 2013. Analysis for alpha-emitting radionuclides in Melton Valley and off-site groundwater has detected low levels of uranium. Strontium-90 was not detected in any of the off-site monitoring wells during FY 2012 or FY 2013. Technetium-99 was not detected in any of the on-site sentinel wells or in the off-site monitoring wells during FY 2012 or FY2 0213. Currently no water is consumed from these groundwater wells. A revised sampling was agreed upon in FY 2013 by DOE, EPA, and TDEC (DOE 2014).

\subsection{Fish Consumption}

Fishing is quite common on the Clinch and Tennessee river systems. Based on a nationwide food consumption survey (EPA 2011) and weighted based on the combined population of Anderson, Knox, Loudon, and Roane counties, it was assumed that avid fish consumers would have eaten $27 \mathrm{~kg}(60 \mathrm{lb})$ of fish during 2013. For the average person used for collective dose calculations, it was assumed that $11 \mathrm{~kg}$ $(24 \mathrm{lb})$ of fish was consumed in 2013. The estimated maximum ED will be based on either the first method, measured radionuclide concentrations in fish, or by the second method, which calculates possible radionuclide concentrations in fish from measured radionuclide discharges and known or estimated stream flows. The EDs estimated by both methods, in each of the surface water segments, are provided in Appendix E. The number of individuals who could have eaten fish is based on lake creel surveys conducted annually by TWRA. The 2012 Melton Hill, Watts Bar, and Chickamauga creel surveys are used to estimate the numbers of individuals who harvested fish from these water bodies.

Upper Melton Hill Lake Above All Possible ORR Inputs. For reference purposes, a hypothetical avid fish consumer who ate fish caught at CRK 66, which is above all possible ORR inputs, could have received an ED of about $0.5 \mathrm{mrem}$. This dose was estimated because of detection of ${ }^{137} \mathrm{Cs}$ in surface water collected at CRK 66, which affected estimated doses downstream of this location. The collective ED to the 28 persons who could have eaten such fish was about $5 \times 10^{-3}$ person-mrem.

Melton Hill Lake. An avid fish consumer who ate fish from Melton Hill Lake could have received an ED of about 0.5 mrem. The collective ED to the 248 persons who could have eaten such fish could be about 0.05 person-rem.

Upper Clinch River. An avid fish consumer who ate fish from the upper Clinch River could have received an ED of about $1.5 \mathrm{mrem}$. This dose was estimated from a composite fish sample collected near CRK 32 and ${ }^{137} \mathrm{Cs}$ was the primary dose contributor. The collective ED to the 140 persons who could have eaten such fish could have been about 0.09 person-rem.

Lower Clinch River. An avid fish consumer who ate fish from the lower Clinch River (CRK 16) could have received an ED of about $0.5 \mathrm{mrem}$. The collective ED to the 327 persons who could have eaten such fish could have been about 0.06 person-rem.

Upper Watts Bar Lake. An avid fish consumer who ate fish from upper Watts Bar Lake could have received an ED of about 0.08 mrem. The collective ED to the 934 persons who could have eaten such fish could be about 0.03 person-rem.

Lower System. An avid fish consumer who ate fish from the lower system could have received an ED of about 0.07 mrem. The collective ED to the 40,811 persons who could have eaten such fish could have been about 1.0 person-rem. Poplar Creek/Lower East Fork Poplar Creek. An avid fish consumer who ate fish from lower EFPC above its confluence with Poplar Creek could have received an ED of about $0.6 \mathrm{mrem}$. Assuming that 100 people could have eaten fish from lower EFPC and 100 from Poplar Creek, the collective ED could have been about 0.03 person-rem. 


\subsection{Other Uses}

Other uses of ORR area waterways include swimming or wading, boating, and use of the shoreline. A highly exposed "other user" was assumed to swim or wade for $30 \mathrm{~h} /$ year, boat for $63 \mathrm{~h} /$ year, and use the shoreline for $60 \mathrm{~h} /$ year. The average individual, who is used for collective dose estimates, was assumed to swim or wade for $10 \mathrm{~h} /$ year, boat for $21 \mathrm{~h} /$ year, and use the shoreline for $20 \mathrm{~h} /$ year. Measured and calculated concentrations of radionuclides in water and the LADTAP XL code (Hamby 1991) were used to estimate potential EDs from these activities. At all locations in 2013, the estimated maximally exposed individual EDs were based on measured off-site surface water radionuclide concentrations and excluded naturally occurring radionuclides such as ${ }^{40} \mathrm{~K}$.

The number of individuals who could have been other users is different for each section of water because the data sources differ. For Watts Bar parts (upper Clinch River through lower Watts Bar), the assumption for other users is five times the number of people who harvest fish. For Chickamauga and Melton Hill, the number for other users is based on surveys conducted by TVA.

Upper Melton Hill Lake Above All Possible ORR Inputs. A hypothetical maximally exposed other user of upper Melton Hill Lake above possible ORR inputs (CRK 66) could have received an ED of about $0.09 \mathrm{mrem}$. This dose was estimated due to detection of ${ }^{137} \mathrm{Cs}$ in surface water collected at CRK 66, which affected estimated doses downstream of this location. The collective ED to the 10,412 other users could have been 0.3 person-rem.

Melton Hill Lake. An individual other user of Melton Hill Lake could have received an ED of about 0.09 mrem. The collective ED to the 24,294 other users could have been about 0.6 person-rem.

Upper Clinch River. An individual other user of the upper Clinch River could have received an ED of about 0.06 mrem. The collective ED to the 966 other users could have been about 0.02 person-rem.

Lower Clinch River. An individual other user of the lower Clinch River could have received an ED of about $0.06 \mathrm{mrem}$. The collective ED to the 2,263 other users could have been about 0.05 person-rem.

Upper Watts Bar Lake. An individual other user of upper Watts Bar Lake could have received an ED of about 0.02 mrem. The collective ED to the 6,444 other users could have been about 0.03 person-rem.

Lower system. An individual other user of the lower system could have received an ED of about 0.01 mrem. The collective ED to the 289,063 other users could have been about 0.7 person-rem.

Poplar Creek/Lower East Fork Poplar Creek. An individual other user of Lower East Fork Poplar Creek, above its confluence with Poplar Creek, could have received an ED of about $0.01 \mathrm{mrem}$. The collective ED to the 200 other users of Poplar Creek and Lower East Fork Poplar Creek could have been about $5 \times 10^{-4}$ person-rem.

\subsection{Summary}

Table 7.6 is a summary of potential EDs from identified waterborne radionuclides around ORR. Adding worst-case EDs for all pathways in a water-body segment gives a maximum individual ED of about 2 mrem to a person obtaining his or her full annual complement of fish from, and participating in other water uses on, Lower East Fork Poplar Creek. The maximum collective ED to the $80 \mathrm{~km}$ (50-mile) population could be as high as 6 person-rem. These are small percentages of individual and collective doses attributable to natural background radiation, about $0.7 \%$ of the average individual background dose of roughly $300 \mathrm{mrem} / \mathrm{year}$ and $0.002 \%$ of the 363,484 person-rem that this population received from natural sources of radiation.

Table 7.6. Summary of annual maximum individual (mrem) and collective (person-rem) effective doses (EDs) from waterborne radionuclides, $2013^{a, b}$

\begin{tabular}{lcccc}
\hline & Drinking water & Eating fish & Other uses & Total \\
\hline \multicolumn{4}{c}{ Upstream of all Oak Ridge Reservation discharge locations } \\
(CRK 66, City of Oak Ridge Water Plant) \\
Individual ED & 0.04 & 0.5 & 0.9 & 0.6 \\
Collective ED & 0.6 & 0.005 & 0.3 & 0.9
\end{tabular}


Table 7.6. (continued)

\begin{tabular}{|c|c|c|c|c|}
\hline & Drinking water & Eating fish & Other uses & Total $^{c}$ \\
\hline \multicolumn{5}{|c|}{ Melton Hill Lake (CRK 58, Knox County Water Plant) } \\
\hline Individual ED & 0.04 & 0.5 & 0.09 & 0.6 \\
\hline Collective ED & 0.9 & 0.05 & 0.6 & 1.5 \\
\hline \multicolumn{5}{|c|}{ Upper Clinch River (CRK 23, Gallaher Water Plant, CRK 32) } \\
\hline Individual ED & 0.08 & 1.5 & 0.06 & 1.7 \\
\hline Collective ED & 0.04 & 0.09 & 0.02 & 0.2 \\
\hline \multicolumn{5}{|c|}{ Lower Clinch River (CRK 16) } \\
\hline Individual ED & $\mathrm{NA}^{d}$ & 0.5 & 0.06 & 0.5 \\
\hline Collective ED & $\mathrm{NA}^{d}$ & 0.06 & 0.05 & 0.1 \\
\hline \multicolumn{5}{|c|}{ Upper Watts Bar Lake, Kingston Municipal Water Plant } \\
\hline Individual ED & 0.01 & 0.08 & 0.02 & 0.1 \\
\hline Collective ED & 0.1 & 0.03 & 0.03 & 0.2 \\
\hline \multicolumn{5}{|c|}{ Lower system (Lower Watts Bar Lake and Chickamauga Lake) } \\
\hline Individual ED & 0.01 & 0.07 & 0.01 & 0.1 \\
\hline Collective ED & 1.1 & 1.0 & 0.7 & 2.8 \\
\hline \multicolumn{5}{|c|}{ Lower East Fork Poplar Creek and Poplar Creek } \\
\hline Individual ED & $\mathrm{NA}^{d}$ & 0.6 & 0.01 & 0.6 \\
\hline Collective ED & $\mathrm{NA}^{d}$ & 0.03 & 0.0005 & 0.03 \\
\hline
\end{tabular}

${ }^{a} 1 \mathrm{mrem}=0.01 \mathrm{mSv}$.

${ }^{b}$ Doses based on measured radionuclide concentrations in water or estimated from measured discharges and known or estimated stream flows.

${ }^{c}$ Total doses and apparent sums over individual pathway doses may differ because of rounding.

${ }^{d}$ Not at or near drinking water supply locations.

Abbreviation: $\mathrm{CRK}=$ Clinch River kilometer.

\subsubsection{Radionuclides in Other Environmental Media}

The CAP-88 computer codes are used to calculate radiation doses from ingestion of meat, milk, and vegetables that contain radionuclides released to the atmosphere. These doses are included in the dose calculations for airborne radionuclides. However, some environmental media, including milk and vegetables, are sampled as part of the surveillance program. The following dose estimates are based on environmental sampling results and may include contributions from radionuclides occurring in the natural environment, released from ORR, or both.

\subsection{Milk}

During 2013, milk samples were collected from a nearby dairy, and milk samples were composited from several reference locations. Based on a nationwide food consumption survey (EPA 2011), a hypothetical person (weighted based on the combined population of Anderson, Knox, Loudon, and Roane counties) who drank milk was assumed to have consumed a maximum of about $256 \mathrm{~L}$ (68 gal) of milk annually. Significant concentrations of ${ }^{40} \mathrm{~K}$ were detected in all samples, and radioactive strontium was detected in two out of six samples from both the nearby dairy and the composite of several reference locations. Potential EDs attributable to ${ }^{40} \mathrm{~K}$ at both "locations" were about $10 \mathrm{mrem} / \mathrm{year}$. The doses due to strontium at the nearby dairy and the composite reference locations were estimated to be about $0.2 \mathrm{mrem}$. This dose is higher than estimated in 2012 in part because of the higher consumption rate but also due to analytical results. 


\subsection{Food Crops}

The food-crop sampling program is described in Section 6.5. Samples of tomatoes, lettuce, and turnips were obtained from six gardens, five local and one distant. These vegetables represent fruitbearing, leafy, and root vegetables. All radionuclides detected in the food crops are found in the natural environment and in commercial fertilizers, and all but ${ }^{7} \mathrm{Be}$ and ${ }^{40} \mathrm{~K}$ also are emitted from ORR. Dose estimates are based on hypothetical consumption rates of vegetables that contain statistically significant amounts of detected radionuclides that could have come from ORR. Based on a nationwide food consumption survey (EPA 2011), a hypothetical home gardener (weighted based on the combined population of Anderson, Knox, Loudon, and Roane counties) was assumed to have eaten a maximum of about $72 \mathrm{~kg}(158 \mathrm{lb})$ of homegrown tomatoes, $15 \mathrm{~kg}(33 \mathrm{lb})$ of homegrown lettuce, and $89 \mathrm{~kg}(195 \mathrm{lb})$ of homegrown turnips. The hypothetical gardener could have received a 50-year committed ED of between 0.005 and $0.1 \mathrm{mrem}$, depending on garden location. Of this total, between 0 and 0.07 mrem could have come from eating tomatoes, between 0.004 and $0.03 \mathrm{mrem}$ from eating lettuce, and between 0 and $0.04 \mathrm{mrem}$ from eating turnips. The highest dose to a gardener could have been about $0.1 \mathrm{mrem}$ from consuming all three types of homegrown vegetables. A person eating food from the distant (background) garden also could have received a committed ED of 0.1 mrem from consumption of all three vegetables.

An example of a naturally occurring and fertilizer-introduced radionuclide is ${ }^{40} \mathrm{~K}$, which is specifically identified in the samples and accounts for most of the beta activity found in them. The presence of ${ }^{40} \mathrm{~K}$ in the samples adds, on average, about $14 \mathrm{mrem}$ to the hypothetical home gardener's ED. In 2013, each gardener was asked about water sources and fertilizers used. One gardener used commercial fertilizers and irrigated via Melton Hill Lake, and the other five reported that they did not use fertilizers and did not irrigate. It is believed ${ }^{40} \mathrm{~K}$ and most of the excess unidentified alpha activities are due to naturally occurring or fertilizer-introduced radionuclides, not radionuclides discharged from ORR.

\subsection{White-Tailed Deer}

TWRA conducted two 2-day deer hunts during 2013 on the Oak Ridge Wildlife Management Area, which is part of ORR (see Section 6.7). During the hunts, 188 deer were harvested and were brought to the TWRA checking station. At the station, a bone sample and a tissue sample were taken from each deer; these samples were field counted for radioactivity to ensure that the deer met wildlife release criteria (less than $20 \mathrm{pCi} / \mathrm{g}$ of beta-particle activity in bone or $5 \mathrm{pCi} / \mathrm{g}$ of ${ }^{137} \mathrm{Cs}$ in edible tissue). One deer exceeded the limit for beta-particle activity in bone and was retained. The remaining 187 deer were released to the hunters.

The average ${ }^{137} \mathrm{Cs}$ concentration in tissue of the 187 released deer, as determined by field counting, was $0.54 \mathrm{pCi} / \mathrm{g}$; the maximum ${ }^{137} \mathrm{Cs}$ concentration in a released deer was $0.93 \mathrm{pCi} / \mathrm{g}$. Most of the ${ }^{137} \mathrm{Cs}$ concentrations were less than minimum detectable levels. Of the released deer, the average weight was about $35 \mathrm{~kg}(78 \mathrm{lb})$ and the maximum weight was $83 \mathrm{~kg}(183 \mathrm{lb})$. The EDs attributed to field-measured ${ }^{137} \mathrm{Cs}$ concentrations and actual field weights of the released deer ranged from about 0.004 to $1.2 \mathrm{mrem}$, with an average of $0.5 \mathrm{mrem}$.

Potential doses attributed to deer that might have moved off ORR and been harvested elsewhere were also evaluated. In this scenario, an individual who consumed one hypothetical average-weight $35 \mathrm{~kg}$ (78 lb) deer (assuming 55\% field weight is edible meat) containing the 2013 average field-measured concentration of ${ }^{137} \mathrm{Cs}(0.5 \mathrm{pCi} / \mathrm{g})$ could have received an ED of about $0.5 \mathrm{mrem}$. The maximum fieldmeasured ${ }^{137} \mathrm{Cs}$ concentration was $0.93 \mathrm{pCi} / \mathrm{g}$, and the maximum deer weight was $83 \mathrm{~kg}(183 \mathrm{lb})$. A hunter who consumed a hypothetical deer of maximum weight and ${ }^{137} \mathrm{Cs}$ content could have received an ED of about 2 mrem.

Tissue samples collected in 2013 from 13 deer (12 released and 1 retained) were subjected to laboratory analysis. Requested radioisotopic analyses included ${ }^{137} \mathrm{Cs},{ }^{90} \mathrm{Sr}$, and ${ }^{40} \mathrm{~K}$ radionuclides. Comparison of the field results to analytical ${ }^{137} \mathrm{Cs}$ concentrations found that the field concentrations were all greater than the analytical results and all were less than the administrative limit of $5 \mathrm{pCi} / \mathrm{g}$. Using analytically measured ${ }^{137} \mathrm{Cs}(0.034 \mathrm{pCi} / \mathrm{g}$ to $0.13 \mathrm{pCi} / \mathrm{g})$ and ${ }^{90} \mathrm{Sr}(0.003 \mathrm{pCi} / \mathrm{g}$ to $0.27 \mathrm{pCi} / \mathrm{g})$ and excluding ${ }^{40} \mathrm{~K}$ (a naturally occurring radionuclide) and actual deer weights, the estimated doses for the 
13 deer (both retained and released) ranged between 0.05 and $1.5 \mathrm{mrem}$. When present at MDA levels, the primary contributor to dose was ${ }^{90} \mathrm{Sr}$; however, a number of results were at less than detection.

The maximum ED to an individual consuming venison from two deer was also evaluated. About 16 hunters each harvested two deer from ORR. Based on ${ }^{137} \mathrm{Cs}$ concentrations determined by field counting and actual field weight, the ED range to a hunter who consumed two or more harvested deer was estimated to be between 0.5 and $1.4 \mathrm{mrem}$. Also evaluated were maximum EDs if more than two deer were harvested by one household; in 2013 there was one household comprising three hunters that harvested four deer. If assumed that only one individual consumed all of the venison from the four deer, the estimated dose was $1.3 \mathrm{mrem}$.

The collective ED from eating all the harvested venison from ORR with a 2013 average field-derived ${ }^{137} \mathrm{Cs}$ concentration of $0.54 \mathrm{pCi} / \mathrm{g}$ and an average weight of $35 \mathrm{~kg}(78 \mathrm{lb})$ is estimated to be about 0.1 person-rem.

\subsection{Canada Geese}

During the 2013 goose roundup, 37 geese were weighed and subjected to whole-body gamma scans. The geese were field counted for radioactivity to ensure that they met wildlife release criteria $(<5 \mathrm{pCi} / \mathrm{g}$ of

${ }^{137} \mathrm{Cs}$ in tissue). The average ${ }^{137} \mathrm{Cs}$ concentration was $0.2 \mathrm{pCi} / \mathrm{g}$, with a maximum ${ }^{137} \mathrm{Cs}$ concentration in the released geese of $0.5 \mathrm{pCi} / \mathrm{g}$. Most of the ${ }^{137} \mathrm{Cs}$ concentrations were below MDA levels. The average weight of the geese screened during the roundup was about $3.8 \mathrm{~kg}(8.4 \mathrm{lb})$, and the maximum weight was about $5.4 \mathrm{~kg}(11.9 \mathrm{lb})$.

The EDs attributed to field-measured ${ }^{137} \mathrm{Cs}$ concentrations and actual field weights of the geese ranged from 0 to $0.05 \mathrm{mrem}$. However, for bounding purposes, if a person consumed a released goose with an average weight of $3.8 \mathrm{~kg}(8.3 \mathrm{lb})$ and an average ${ }^{137} \mathrm{Cs}$ concentration of $0.2 \mathrm{pCi} / \mathrm{g}$, the estimated ED would be about $0.02 \mathrm{mrem}$. It is assumed that about half the weight of a Canada goose is edible. The maximum estimated ED to an individual who consumed a hypothetical released goose with the maximum ${ }^{137} \mathrm{Cs}$ concentration of $0.5 \mathrm{pCi} / \mathrm{g}$ and the maximum weight of $5.4 \mathrm{~kg}(11.9 \mathrm{lb})$ was about $0.07 \mathrm{mrem}$.

It is possible that a person could eat more than one goose that spent time on ORR. The average seasonal goose bag per active hunter from Tennessee in the Mississippi Flyway has ranged from 1.9 to 3.0 geese per hunting season between 1999 and 2010 (TWRA 2010). If one person consumed two hypothetical geese of maximum weight with the highest measured concentration of ${ }^{137} \mathrm{Cs}$, that person could have received an ED of about 0.1 mrem.

Between 2000 and 2009, 22 geese tissue samples were analyzed. An evaluation of potential doses was made based on laboratory-determined concentrations of the following radionuclides: ${ }^{40} \mathrm{~K},{ }^{137} \mathrm{Cs},{ }^{90} \mathrm{Sr}$, thorium $\left({ }^{228} \mathrm{Th},{ }^{230} \mathrm{Th},{ }^{232} \mathrm{Th}\right)$, uranium $\left({ }^{233 / 234} \mathrm{U},{ }^{235} \mathrm{U},{ }^{238} \mathrm{U}\right)$, and transuranics $\left({ }^{241} \mathrm{Am},{ }^{243 / 244} \mathrm{Cm},{ }^{238} \mathrm{Pu}\right.$, ${ }^{239 / 240} \mathrm{Pu}$ ). The total dose, less the contribution of ${ }^{40} \mathrm{~K}$, ranged from 0.01 to $0.5 \mathrm{mrem}$, with an average of 0.2 mrem (EP\&WSD 2010).

\subsection{Eastern Wild Turkey}

Participating hunters are allowed to harvest one turkey from the reservation in a given season unless a harvested turkey is retained, in which case, the hunter is allowed to hunt for another turkey. Two wild turkey hunts took place on the reservation in 2013: April 13-14 and April 20-21. In addition, one turkey harvested offsite was brought in to the checking station on December 15. Forty birds were harvested, and none were retained. The average ${ }^{137} \mathrm{Cs}$ concentration measured in the released turkeys was $0.11 \mathrm{pCi} / \mathrm{g}$, and the maximum ${ }^{137} \mathrm{Cs}$ concentration was $0.15 \mathrm{pCi} / \mathrm{g}$. The average weight of the turkeys released was about $8.4 \mathrm{~kg}(18.5 \mathrm{lb})$. The maximum turkey weight was about $10.6 \mathrm{~kg}(23.3 \mathrm{lb})$.

The EDs attributed to the field-measured ${ }^{137} \mathrm{Cs}$ concentrations and the actual field weights of the released turkeys ranged from about 0.02 to $0.03 \mathrm{mrem}$ with an average dose of $0.02 \mathrm{mrem}$. Potential doses were also evaluated for turkeys that might have moved off ORR and were then harvested elsewhere. In this scenario, if a person consumed a wild turkey with an average weight of $8.4 \mathrm{~kg}(18.5 \mathrm{lb})$ and an average ${ }^{137} \mathrm{Cs}$ concentration of $0.11 \mathrm{pCi} / \mathrm{g}$, the estimated ED would be about $0.02 \mathrm{mrem}$. The maximum estimated ED to an individual who consumed a hypothetical released turkey with the maximum ${ }^{137} \mathrm{Cs}$ concentration of 
$0.15 \mathrm{pCi} / \mathrm{g}$ and the maximum weight of $10.6 \mathrm{~kg}(23.3 \mathrm{lb})$ was about $0.04 \mathrm{mrem}$. It is assumed that approximately half the weight of a wild turkey is edible. No tissue samples were analyzed in 2013.

The collective ED from consuming all the harvested wild turkey meat (40 birds) with an average field-derived ${ }^{137} \mathrm{Cs}$ concentration of $0.11 \mathrm{pCi} / \mathrm{g}$ and average weight of $8.4 \mathrm{~kg}(18.5 \mathrm{lb})$ is estimated to be about 0.0009 person-rem.

Earlier evaluations of doses based on laboratory-determined concentrations of radionuclides included ${ }^{40} \mathrm{~K},{ }^{137} \mathrm{Cs},{ }^{90} \mathrm{Sr},{ }^{230} \mathrm{Th},{ }^{3} \mathrm{H},{ }^{234} \mathrm{U},{ }^{235} \mathrm{U},{ }^{238} \mathrm{U}$, and transuranics $\left({ }^{241} \mathrm{Am},{ }^{244} \mathrm{Cm},{ }^{237} \mathrm{~Np},{ }^{239} \mathrm{Pu}\right)$. The total dose, less the contribution of ${ }^{40} \mathrm{~K}$, ranged from 0.06 to 0.2 mrem (EP\&WSD 2010).

\subsection{Direct Radiation}

External exposure rates due to background sources in the state of Tennessee average about $6.4 \mu \mathrm{R} / \mathrm{h}$ and range from 2.9 to $11 \mu \mathrm{R} / \mathrm{h}$ (Myrick 1981). These exposure rates correspond to ED rates between 18 and $69 \mathrm{mrem} /$ year, with an average of $40 \mathrm{mrem} /$ year.

External radiation exposure rates are measured at numerous locations on and off ORR. Exposure rates measured at five PAM stations around ORR during 2013 averaged about $8.2 \mu \mathrm{R} / \mathrm{h}$ and ranged from 6.45 to $9.7 \mu \mathrm{R} / \mathrm{h}$. These exposure rates correspond to an average ED rate of about $51 \mathrm{mrem} / \mathrm{year}$ and a range of 40 to $60 \mathrm{mrem} / \mathrm{year}$. At the remote PAM station, the exposure rate averaged $6.8 \mu \mathrm{R} / \mathrm{h}$ (about $43 \mathrm{mrem} /$ year) and ranged from 6.6 to $7.5 \mu \mathrm{R} / \mathrm{h}$ (41 to $47 \mathrm{mrem} /$ year). All measured exposure rates at or near the ORR boundaries fall within the range of statewide background levels.

\subsubsection{Current-Year Summary}

A summary of the maximum EDs to individuals by pathway of exposure is given in Table 7.7. In the unlikely event that any person was irradiated by all of those sources and pathways for the duration of 2013, that person could have received a total ED of about $5 \mathrm{mrem}$. Of that total, $0.4 \mathrm{mrem}$ would have come from airborne emissions and $2.2 \mathrm{mrem}$ from waterborne emissions $(0.08 \mathrm{mrem}$ from drinking water, 2 mrem from consuming fish along the upper Clinch River and 0.09 mrem from other water uses along Melton Hill Lake), and no appreciable dose above background from external radiation. There are no known significant doses from discharges of radioactive constituents from ORR other than those reported.

The dose of $5 \mathrm{mrem}$ is about $2 \%$ of the annual dose (roughly $300 \mathrm{mrem}$ ) from background radiation. The ED of 5 mrem includes the person who received the highest EDs from eating wildlife harvested on ORR. If the maximally exposed individual did not consume wildlife harvested from ORR, the estimated dose would be about 3 mrem.

DOE O 458.1 limits the ED that an individual may receive from all exposure pathways from all radionuclides released from ORR during 1 year to no more than 100 mrem. The 2013 maximum ED should not have exceeded about 5 mrem, or about $5 \%$ of the limit given in DOE O 458.1. (For further information, see Sections E.5.6 through E.5.10 in Appendix E, which summarize dose levels associated with a wide range of activities.)

The total collective ED to the population living within an $80 \mathrm{~km}(50$-mile) radius of ORR was estimated to be about 41 person-rem. This dose is about $0.01 \%$ of the 363,484 person-rem that this population received from natural sources during 2013. 
Table 7.7. Summary of maximum estimated effective doses to an adult by exposure pathway

\begin{tabular}{|c|c|c|c|c|c|c|c|}
\hline \multirow[t]{2}{*}{ Pathway } & \multicolumn{2}{|c|}{$\begin{array}{c}\text { Dose to } \\
\text { maximally } \\
\text { exposed } \\
\text { individual }\end{array}$} & \multirow{2}{*}{$\begin{array}{l}\text { Percentage } \\
\text { of DOE } \\
\text { mrem/year } \\
\text { limit } \\
(\%)\end{array}$} & \multicolumn{2}{|c|}{$\begin{array}{c}\text { Estimated } \\
\text { population dose }\end{array}$} & \multirow[t]{2}{*}{$\begin{array}{c}\text { Population } \\
\text { within } 80 \text { km }\end{array}$} & \multirow{2}{*}{$\begin{array}{c}\text { Estimated } \\
\text { background } \\
\text { radiation } \\
\text { population dos } \\
\text { (person-rem) }\end{array}$} \\
\hline & mrem & $\mathbf{m S v}$ & & $\begin{array}{c}\text { person- } \\
\text { rem }\end{array}$ & $\begin{array}{c}\text { person- } \\
\text { Sv }\end{array}$ & & \\
\hline \multicolumn{8}{|c|}{ Airborne effluents: } \\
\hline All pathways & 0.4 & 0.004 & 0.4 & 35.3 & 0.35 & $1,172,530^{b}$ & \\
\hline \multicolumn{8}{|c|}{ Liquid effluents: } \\
\hline Drinking water & 0.08 & 0.0008 & 0.08 & 2.8 & 0.028 & $432,118^{c}$ & \\
\hline Eating fish & 2 & 0.02 & 2 & 1.3 & 0.013 & $42,688^{d}$ & \\
\hline Other activities & 0.09 & 0.0009 & 0.09 & 1.6 & 0.016 & $33642^{d}$ & \\
\hline \multicolumn{8}{|c|}{ Other Pathways: } \\
\hline Eating deer & $2^{e}$ & 0.02 & 2 & 0.1 & 0.001 & 188 & \\
\hline Eating geese & $0.1^{f}$ & 0.001 & 0.1 & $g$ & $g$ & & \\
\hline Eating turkey & $0.08^{h}$ & 0.0008 & 0.08 & 0.0009 & 0.000009 & 40 & \\
\hline Direct radiation & $\mathrm{NA}^{i}$ & NA & & & & & \\
\hline All pathways & 5 & 0.005 & 5 & 41 & 0.41 & $1,172,530$ & 363,484 \\
\hline
\end{tabular}

${ }^{a}$ Estimated background population dose is based on the roughly $300 \mathrm{mrem} /$ year individual dose and the population within $80 \mathrm{~km}$ (50 miles) of the Oak Ridge Reservation.

${ }^{b}$ Population based on 2010 census data.

${ }^{c}$ Population estimates based on community and non-community drinking water supply data from the Tennessee Department of Environment and Conservation, Division of Water.

${ }^{d}$ Population estimates based on population within $80 \mathrm{~km}$ (50 miles) and fraction of fish harvested from Melton Hill, Watts Bar, and Chickamauga reservoirs. Melton Hill and Chickamauga recreational use information was obtained from the Tennessee Valley Authority (Stephens et al. 2006 and Stephens et al. 2007).

${ }^{e}$ From consuming one hypothetical worst-case deer, a combination of the heaviest deer harvested and the highest measured concentrations of ${ }^{137} \mathrm{Cs}$ in released deer on ORR; population dose based on number of hunters that harvested deer.

${ }^{f}$ From consuming two hypothetical worst-case geese, each a combination of the heaviest goose harvested and the highest measured concentrations of ${ }^{137} \mathrm{Cs}$ in released geese.

${ }^{g}$ Population doses were not estimated for the consumption of geese because no geese were brought to the checking station during the goose hunt.

${ }^{h}$ From consuming one hypothetical worst-case turkey, a combination of the heaviest turkey harvested and the highest measured concentrations of ${ }^{137} \mathrm{Cs}$ in released turkey. The population dose is based on the number of hunters who harvested turkey.

${ }^{i}$ Direct radiation dose estimates were conducted, although exposure rates near the Clinch River were near background levels. In addition, direct radiation monitoring is no longer conducted for locations that were formerly the $\mathrm{UF}_{6}$ cylinder storage yards and the K-770 Scrap Yard. Direct dose measurements have been taken and have confirmed that there is no longer a source of potential dose to the public above the background levels.

\subsubsection{Five-Year Trends}

EDs associated with selected exposure pathways for the years 2009 to 2013 are given in Table 7.8. In 2013, an increase in the dose from fish consumption was observed as compared to earlier years. This increase in dose was because of a composite fish sample collected near CRK 32 in which ${ }^{137}$ Cs was the primary dose contributor. Recent measurements along the Clinch River indicate doses near background levels. Doses from consumption of wildlife have been similar the last 5 years. 
Table 7.8. Trends in effective dose $(\mathrm{mrem})^{a}$ for selected pathways

\begin{tabular}{|c|c|c|c|c|c|}
\hline Pathway & 2009 & 2010 & 2011 & 2012 & 2013 \\
\hline Air pathway (all routes) & 0.3 & 0.4 & 0.3 & 0.3 & 0.4 \\
\hline \multicolumn{6}{|l|}{ Surface water pathway } \\
\hline Fish consumption (Clinch River) & 1.2 & 0.3 & 0.3 & 0.08 & 1.5 \\
\hline Drinking water (Kingston) & 0.03 & 0.03 & 0.02 & 0.02 & 0.01 \\
\hline \multicolumn{6}{|l|}{ Direct radiation pathway } \\
\hline Clinch River & $0.4^{b}$ & $\mathrm{NA}^{b}$ & $\mathrm{NA}^{b}$ & $\mathrm{NA}^{b}$ & $\mathrm{NA}^{b}$ \\
\hline \multicolumn{6}{|l|}{ Wildlife } \\
\hline Deer & 3 & 2 & 2 & 2 & 2 \\
\hline Geese & 0.1 & 0.2 & 0.1 & 0.1 & 0.1 \\
\hline Turkey & 0.04 & 0.05 & 0.1 & 0.06 & 0.08 \\
\hline
\end{tabular}

\subsubsection{Potential Contributions from Non-DOE Sources}

DOE O 458.1 requires that if the DOE-related annual dose is greater than $25 \mathrm{mrem}$, the dose to members of the public must include major non-DOE sources of exposure as well as doses from DOErelated sources. In 2013, the DOE-related source doses were considerably below the 25 mrem criteria. However, DOE requested information from non-DOE facilities pertaining to potential radiation doses to members of the public. There are several non-DOE facilities on or near ORR that could contribute radiation doses to the public. These facilities submit annual reports to demonstrate compliance with NESHAPs regulations and the terms of their operating licenses. Twelve facilities responded to the DOE request. Five facilities, using either CAP88PC or the COMPLY screening tool for evaluating radiation exposure from atmospheric releases of radionuclides, reported annual doses from airborne emissions ranging from $3.4 \times 10^{-4}$ mrem to $0.31 \mathrm{mrem}$; one facility reported $<10$ mrem (COMPLY, level 1). NonDOE facility doses from water discharges ranged from zero emissions to sewer discharges less than the sum of ratios. Doses from direct radiation ranged from none to an annual dose rate of 35.6 mrem from direct radiation exposure measurements outside a facility to an annual dose of 58 mrem based on area monitors location within one of the facilities. Therefore, doses from air and water emissions and external radiation from both non-DOE and DOE sources should be less than the DOE O 458.1 requirement of 100 mrem.

\subsubsection{Doses to Aquatic and Terrestrial Biota}

\subsubsection{Aquatic Biota}

DOE O 458.1 sets an absorbed dose rate limit of $1 \mathrm{rad} /$ day to native aquatic organisms from exposure to radioactive material in liquid wastes discharged to natural waterways (see Appendix E for definitions of absorbed dose and rad). To demonstrate compliance with this limit, the aquatic organism assessment was conducted using the RESRAD-Biota code (1.5), a companion tool for implementing the DOE technical standard, A Graded Approach for Evaluating Radiation Doses to Aquatic and Terrestrial Biota (DOE 2002). The code serves as DOE's biota dose evaluation tool and uses the screening [i.e., biota concentration guides (BCGs)] and analysis methods in the technical standard. The BCG is the limiting concentration of a radionuclide in sediment or water that would not cause dose limits for protection of aquatic biota populations to be exceeded.

The intent of the graded approach is to protect populations of aquatic organisms from the effects of exposure to anthropogenic ionizing radiation. Certain organisms are more sensitive to ionizing radiation than others. Therefore, it is generally assumed that protecting the more-sensitive organisms will 
adequately protect other less-sensitive organisms. Depending on the radionuclide, either aquatic organisms (e.g., crustaceans) or riparian organisms (e.g., raccoons) may be considered to be the more sensitive and are typically the limiting organisms for the general screening phase of the graded approach for aquatic organisms.

At ORNL, doses to aquatic organisms are based on surface water concentrations at the following 10 different instream sampling locations.

- $\quad$ Melton Branch (MEK 0.2)

- White Oak Creek (WCK 1.0, WCK 2.6, and WCK 3.4 )

- First Creek

- $\quad$ Fifth Creek

- Northwest Tributary

- $\quad$ Clinch River (CRK 23, CRK 32, and CRK 66)

All locations, except MEK 0.2 and WCK1.0 and WCK 2.6, passed the general screening phase (comparison of maximum radionuclide water concentrations to default BCGs). Both MEK 0.2 and WCK 2.6 passed when comparing average radionuclide water concentrations to default BCGs. For WCK 1.0, average concentrations were used, and the default bioaccumulation factors for both ${ }^{137} \mathrm{Cs}$ and ${ }^{90} \mathrm{Sr}$ were adjusted to reflect on-site bioaccumulation of these radionuclides in fish. Riparian organisms are the limiting receptor for both ${ }^{137} \mathrm{Cs}$ and ${ }^{90} \mathrm{Sr}$ in surface water; however, the best available bioaccumulation data for WOC are for fish. Because fish are consumed by riparian organisms (e.g., raccoons), adjustment of the fish bioaccumulation factor modified the bioaccumulation of both ${ }^{90} \mathrm{Sr}$ and ${ }^{137} \mathrm{Cs}$ in riparian organisms. This resulted in absorbed dose rates to aquatic organisms below the DOE aquatic dose limit of $1 \mathrm{rad} /$ day at all six sampling locations.

At the Y-12 Complex, doses to aquatic organisms were estimated from surface water concentrations at the following four different instream sampling locations.

- Surface Water Hydrological Information Support System Station 9422-1 (also known as station 17)

- Discharge Point S24, Bear Creek at Bear Creek kilometer 9.4

- Discharge Point S17 (unnamed tributary to the Clinch River)

- Discharge Point S19 (Rogers Quarry)

All locations, except Station 9422-1, passed the general screening phase (maximum water concentrations and default parameters for BCGs). Station 9422-1 passed, when comparing average radionuclide water concentrations to default BCGs. This resulted in absorbed dose rates to aquatic organisms below the DOE aquatic dose limit of $1 \mathrm{rad} /$ day at all four Y-12 Complex locations.

At ETTP, doses to aquatic organisms were estimated from surface water concentrations at the following 13 different instream sampling locations.

- $\quad$ Mitchell Branch at K1700; MIKs 0.45, 0.59, 0.71, 0.82, and 1.4 (upstream location)

- Poplar Creek at K-716 (downstream)

- K1007-B and K-1710 (upstream location)

- K-702A and K901-A (downstream of ETTP operations)

- Clinch River (CRK 16 and CRK 23)

All of these locations passed the initial general screening (using maximum concentrations and default parameters for BCGs). This resulted in absorbed dose rates to aquatic organisms below the DOE aquatic dose limit of $1 \mathrm{rad} /$ day at all 13 sampling locations.

\subsubsection{Terrestrial Biota}

To evaluate impacts on biota, in accordance with requirements in DOE O 458.1, a terrestrial organism assessment was conducted. An absorbed dose rate of $0.1 \mathrm{rad} /$ day is recommended as the limit for terrestrial animal exposure to radioactive material in soils. As for aquatic and riparian biota, certain terrestrial organisms are more sensitive to ionizing radiation than others, and it is generally 
assumed that protecting the more sensitive organisms will adequately protect other less-sensitive organisms. Soil sampling for terrestrial dose assessment was initiated in 2007. This biota sampling strategy was developed by taking into account guidance provided in A Graded Approach for Evaluating Radiation Doses to Aquatic and Terrestrial Biota (DOE 2002) and existing radiological information on the concentrations and distribution of radiological contaminants on ORR. The soil sampling focused on unremediated areas, such as floodplains and some upland areas. Floodplains are often downstream of contaminant source areas and are dynamic systems where soils are eroding in some places and being deposited in others. Soil sampling locations are identified as follows.

- WOC floodplain and upland location

- Bear Creek Valley floodplain

- Mitchell Branch floodplain

- Two background locations: Gum Hollow and near Bearden Creek

With the exception of samples collected on the WOC floodplain (collected on the confluence of Melton Branch and WOC and collected on the WOC floodplain upstream from White Oak Dam), samples taken at all other soil sampling locations passed either the initial-level screening (comparison of maximum radionuclide soil concentrations to default BCGs) or second-level screening, for which BCG default parameters and average soil concentrations were used. Cesium-137 is the primary dose contributor in the soil samples collected on the WOC floodplain. Radiological risk to wildlife associated with ${ }^{137} \mathrm{Cs}$ on the WOC floodplain is known and will be addressed in future CERCLA records of decisions.

Biota sampling in the WOC floodplain was conducted in 2009. White-footed mice (Peromyscus leucopus), deer mice (Peromyscus maniculatus), and hispid cotton rats (Sigmodon hispidus) were selected for sampling because they live and forage in these areas, are food for other mammals, and have relatively small home ranges. The biota sampling locations were at the confluence of Melton Branch and WOC and in the floodplain upstream of White Oak Lake. In addition, biota samples were collected at a background location (Gum Hollow). The maximum radionuclide tissue concentrations and maximum soil radionuclide concentrations for each sample location were used to estimate the terrestrial dose. The tissue concentrations were used to estimate the internal dose. To evaluate the external dose, the soil concentrations previously collected were also included in the dose assessment. The external dose was the primary contributor to the total dose. For WOC, ${ }^{137} \mathrm{Cs}$ was the major contributor to the total dose (0.023 rad/day), with ${ }^{90} \mathrm{Sr}$ and ${ }^{40} \mathrm{~K}$ as secondary contributors $\left(7.0 \times 10^{-4}\right.$ and $5.97 \times 10^{-4} \mathrm{rad} /$ day, respectively). For Melton Branch, ${ }^{137} \mathrm{Cs}$ was the major contributor to dose $(0.009 \mathrm{rad} /$ day $)$, with ${ }^{90} \mathrm{Sr}$ and ${ }^{40} \mathrm{~K}$ as secondary contributors $\left(8.2 \times 10^{-4}\right.$ and $7.8 \times 10^{-4} \mathrm{rad} /$ day, respectively). For the background location, Gum Hollow, ${ }^{40} \mathrm{~K}$ was the major contributor to dose $\left(7.4 \times 10^{-4} \mathrm{rad} /\right.$ day $)$, with ${ }^{238} \mathrm{U}$ as the secondary dose contributor $\left(3.5 \times 10^{-4} \mathrm{rad} /\right.$ day $)$. Based on measured concentrations in soil and tissue, the absorbed doses to the terrestrial organisms collected along the confluence of Melton Branch and WOC and in the floodplain upstream of White Oak Lake were less than $0.1 \mathrm{rad} /$ day.

Based on the low level exposure rates found in the terrestrial organisms during the 2009 sampling, the sampling period has been changed from annual to periodic. The next evaluation of exposure to terrestrial organisms would be within the next 5 years or if an abnormal event occurs that could have adverse impacts on terrestrial organisms.

\subsection{Chemical Dose}

\subsubsection{Drinking Water Consumption}

\section{Surface Water}

To evaluate the drinking water pathway, hazard quotients (HQs) were estimated downstream of ORNL and downstream of ORR discharge points (Table 7.9). The HQ is a ratio that compares the estimated exposure dose or intake to the reference dose. (See Appendix F for a detailed description of the chemical dose methodology.) Based on a nationwide food consumption survey (EPA 2011) and weighted 
based on the combined population of Anderson, Knox, Loudon, and Roane counties, it was assumed that the drinking water consumption rate for the maximally exposed individual is $930 \mathrm{~L} /$ year ( 246 gal/year). This is the same drinking water consumption rate used in the estimation of the maximum exposed radiological dose from consumption of drinking water. Chemical analytes were measured in surface water samples collected at CRK 23 and CRK 16. CRK 23 is located near the water intake for ETTP; CRK 16 is located downstream of all DOE discharge points. As shown in Table 7.9, HQs were less than 1 for detected chemical analytes for which there are reference doses or maximum contaminant levels.

Acceptable risk levels for carcinogens typically range in magnitude from $10^{-4}$ to $10^{-6}$. A risk value slightly greater than or equal to $10^{-5}$ was calculated for the intake of arsenic in water collected at both locations.

Table 7.9. Chemical hazard quotients and estimated risks for drinking water, 2013

\begin{tabular}{|c|c|c|}
\hline \multirow{2}{*}{ Chemical } & \multicolumn{2}{|c|}{ Hazard quotient } \\
\hline & CRK 23 ${ }^{a}$ & CRK $16^{b}$ \\
\hline Antimony & 0.009 & \\
\hline Arsenic & & 0.07 \\
\hline Barium & 0.004 & 0.005 \\
\hline Boron & 0.005 & 0.005 \\
\hline Lead & & 0.07 \\
\hline Manganese & 0.006 & 0.01 \\
\hline Mercury & 0.0001 & 0.001 \\
\hline Nickel & & 0.004 \\
\hline Selenium & & 0.004 \\
\hline Silver & & 0.0003 \\
\hline Uranium & 0.002 & 0.004 \\
\hline Vanadium & 0.001 & 0.002 \\
\hline Zinc & & 0.001 \\
\hline \multicolumn{3}{|c|}{ Risk for carcinogens } \\
\hline Arsenic & $4 \times 10^{-5}$ & $1 \times 10^{-5}$ \\
\hline
\end{tabular}

\section{Groundwater}

As mentioned in Section 7.1.2.2.1, a series of off-site monitoring wells was installed across the Clinch River from ORNL west of the Melton Valley waste management areas in 2010. Sampling of the off-site wells occurred semiannually during FY 2012 and FY 2013, and results were compared to EPA maximum contaminant levels (DOE 2014). A trend evaluation of monitoring data from two off-site monitoring wells (2012 through 2013) indicates that fluoride and barium concentrations were increasing, antimony levels were decreasing, and arsenic concentrations were stable (DOE 2014). Reviews of shallow groundwater monitoring data near the Melton Valley waste disposal areas do not show fluoride plumes emanating from the buried waste. Fluoride has natural and potential human-made sources in Melton Valley. Barium is a common constituent of geologic brines (DOE 2013). VOCs have not been detected in off-site wells since September 2010 (DOE 2014). Currently, no water is consumed from these off-site groundwater wells. 


\subsubsection{Fish Consumption}

Chemicals in water can be accumulated by aquatic organisms that may be consumed by humans. To evaluate the potential health effects from the fish consumption pathway, HQs were estimated for the consumption of noncarcinogens, and risk values were estimated for the consumption of carcinogens detected in sunfish and catfish collected both upstream and downstream of the ORR discharge points. Based on a nationwide food consumption survey (EPA 2011) and weighted based on the combined population of Anderson, Knox, Loudon, and Roane counties, it was assumed that avid fish consumers would have eaten $27 \mathrm{~kg}(60 \mathrm{lb})$ of fish during 2013. This fish consumption rate of $74 \mathrm{~g} /$ day $(27 \mathrm{~kg} / \mathrm{year})$ is assumed for both the noncarcinogenic and carcinogenic pollutants. This is the same fish consumption rate used in the estimation of the radiological dose from consumption of fish. (See Appendix $F$ for a detailed description of the chemical dose methodology.)

As shown in Table 7.10, for consumption of sunfish and catfish, HQ values of less than 1 were calculated for all detected analytes except for Arsenic, Aroclor-1254, and Aroclor-1260 (which are PCBs, also referred to as PCB-1254 and PCB-1260). An HQ greater than 1 for Arsenic and Aroclor-1254 was estimated for sunfish at CRK 32. An HQ greater than 1 for Aroclor-1260 was estimated in sunfish and catfish at all three locations (CRKs 16, 32, and 70). It is not known why the Aroclor-1254 and Aroclor1260 concentration in the fish composite sample from CRK 32 was elevated compared to composted fish collected at other locations or why it was greater than observed in previous years.

For carcinogens, risk values at or greater than $10^{-5}$ were calculated for the intake of arsenic and Aroclor-1254 in sunfish collected at CRK 32. Aroclor-1260 was found in sunfish and catfish collected at all three locations. TDEC has issued a fish advisory that states that catfish should not be consumed from Melton Hill Reservoir (in its entirety) because of PCB contamination and has issued a precautionary fish consumption advisory for catfish in the Clinch River arm of Watts Bar Reservoir (TWRA 2012). The risk values for Aroclor-1260 for catfish at CRK 32 and CRK 16 were roughly an order of magnitude greater for catfish as compared to those estimated in 2012.

Table 7.10. Chemical hazard quotients and estimated risks for carcinogens in fish, $2013^{a}$

\begin{tabular}{|c|c|c|c|c|c|c|}
\hline \multirow{2}{*}{ Carcinogen } & \multicolumn{3}{|c|}{ Sunfish } & \multicolumn{3}{|c|}{ Catfish } \\
\hline & CRK 70 $^{b}$ & CRK 32 ${ }^{c}$ & CRK 16 $^{d}$ & CRK 70 $^{b}$ & CRK 32 ${ }^{c}$ & CRK 16 ${ }^{d}$ \\
\hline \multicolumn{7}{|c|}{ Hazard quotient for metals } \\
\hline Antimony & 0.5 & 0.3 & 0.5 & & 0.4 & 0.3 \\
\hline Arsenic & 0.6 & 1 & 0.8 & & & \\
\hline Barium & 0.004 & 0.004 & 0.008 & & & 0.0003 \\
\hline Beryllium & 0.006 & 0.006 & 0.006 & & & \\
\hline Cadmium & & & 0.04 & & & \\
\hline Chromium & 0.04 & 0.05 & 0.07 & 0.01 & 0.01 & 0.01 \\
\hline Copper & 0.007 & 0.01 & 0.01 & 0.005 & 0.005 & 0.01 \\
\hline Lead & 0.3 & 0.4 & 0.5 & 0.3 & 0.4 & 0.3 \\
\hline Manganese & 0.02 & 0.04 & 0.05 & 0.005 & 0.001 & 0.003 \\
\hline Mercury & 0.1 & 0.3 & 0.2 & 0.3 & 0.4 & 0.6 \\
\hline Nickel & 0.004 & 0.004 & 0.006 & & 0.002 & \\
\hline Selenium & 0.3 & 0.3 & 0.3 & 0.3 & 0.3 & 0.3 \\
\hline Strontium & 0.009 & 0.008 & 0.02 & 0.0002 & 0.0003 & 0.0003 \\
\hline Thallium & 0.1 & 0.1 & 0.2 & 0.06 & 0.07 & 0.2 \\
\hline Uranium & 0.003 & 0.0003 & 0.0007 & 0.001 & 0.004 & 0.01 \\
\hline Zinc & 0.05 & 0.05 & 0.06 & 0.02 & 0.02 & 0.03 \\
\hline
\end{tabular}


Table 7.10. (continued)

\begin{tabular}{|c|c|c|c|c|c|c|}
\hline \multirow{2}{*}{ Carcinogen } & \multicolumn{3}{|c|}{ Sunfish } & \multicolumn{3}{|c|}{ Catfish } \\
\hline & CRK 70 $^{b}$ & CRK 32 ${ }^{c}$ & CRK 16 $^{d}$ & CRK 70 $^{b}$ & CRK 32 ${ }^{c}$ & CRK 16 $^{d}$ \\
\hline \multicolumn{7}{|c|}{ Hazard quotient for pesticides and Aroclors } \\
\hline Aroclor-1254 & & 10 & & & & \\
\hline Aroclor-1260 & 1 & 8 & 1 & 16 & 23 & 22 \\
\hline \multicolumn{7}{|c|}{ Risks for carcinogens } \\
\hline Arsenic & $1 \mathrm{E}-4$ & $2 \mathrm{E}-4$ & $2 \mathrm{E}-4$ & & & \\
\hline Aroclor-1254 & & $2 \mathrm{E}-4$ & & & & \\
\hline Aroclor-1260 & $2 \mathrm{E}-5$ & $1 \mathrm{E}-4$ & $2 \mathrm{E}-5$ & $3 E-4$ & $4 \mathrm{E}-4$ & $4 \mathrm{E}-4$ \\
\hline PCBs (mixed) ${ }^{e}$ & $2 \mathrm{E}-5$ & $3 E-4$ & $2 \mathrm{E}-5$ & $3 E-4$ & $4 \mathrm{E}-4$ & $4 \mathrm{E}-4$ \\
\hline \multicolumn{7}{|c|}{$\begin{array}{l}{ }^{a} \text { The symbol "<" indicates that the value for a parameter was not quantifiable at the analytical detection limit, } \\
d \text { a blank space indicates that the parameter was undetected. } \\
\text { b Melton Hill Reservoir, above the city of Oak Ridge Water Plant. }\end{array}$} \\
\hline $\begin{array}{c}\text { Abbreviation } \\
\text { CRK }=\text { Clin }\end{array}$ & er kilomete & & & & & \\
\hline
\end{tabular}

\subsection{References}

DOE. 2002. DOE Standard: A Graded Approach for Evaluating Radiation Doses to Aquatic and Terrestrial Biota. DOE-STD-1153-2002. US Department of Energy, Washington, DC.

DOE. 2011. Radiation Protection of the Public and the Environment, DOE O 458.1. Approved 2-11-2011 (Admin. Chg. 3 dated 1-15-2013). US Department of Energy, Washington, DC.

DOE. 2014. 2014 Remediation Effectiveness Report for the U.S. Department of Energy Oak Ridge Reservation, Oak Ridge, Tennessee, Data and Evaluations. DOE/OR/01-2640\&D1, March 2014.

EP\&WSD. 2010. Radiological Monitoring and Dose Report for Selected Wildlife Populations Oak Ridge Reservation. EPWSD-EPS-TP-01. Oak Ridge National Laboratory, Environmental Protection and Waste Services Division, Oak Ridge, Tennessee.

Hamby, D. M. 1991. "LADTAP XL: An Improved Electronic Spreadsheet Version of LADTAP II." DE93003179. Westinghouse Savannah River Company, Aiken, South Carolina.

Myrick, T. E., et al. 1981. State Background Radiation Levels: Results of Measurements Taken during 1975-1979. ORNL/TM-7343. Oak Ridge National Laboratory, Oak Ridge, Tennessee.

Stephens, B., et al. 2006. Recreation Use on Norris Reservoir. October. Human Dimensions Research Lab, University of Tennessee Agriculture Institute.

Stephens, B., et al. 2007. Recreation Use on Chickamauga Reservoir. December. Human Dimensions Research Lab, University of Tennessee Agriculture Institute.

TWRA. 2010. Tennessee Waterfowl Report 2010-2011, Tennessee Wildlife Resources Agency Technical Report No. 11-XX, 2011 (accessed http://www.tn.gov/twra/pdfs/waterfowlreport1011.pdf).

TWRA. 2012. TWRA Region 4-Reservoir Fisheries Management Program, "Fish Consumption Advisory," updated August, 2012. http://www.tnfish.org/ContaminantsInFishAdvisories_TWRA/ FishFleshConsumptionAdvisories_TWRA.htm. 
Appendix A. Glossary 



\section{Appendix A. Glossary}

accuracy-The closeness of the result of a measurement to the true value of the quantity.

aliquot - The quantity of a sample being used for analysis.

alkalinity - The capacity of an aqueous solution to neutralize an acid. Alkalinity measurements are important in determining the sensitivity of a body of water to acid inputs such as acidic pollution from rainfall or wastewater.

alpha particle - A positively charged particle emitted from the nucleus of an atom; it has the same charge and mass as that of a helium nucleus (two protons and two neutrons).

ambient air-The surrounding atmosphere as it exists around people, plants, and structures.

analyte - A constituent or parameter that is being analyzed.

analytical detection limit-The lowest reasonably accurate concentration of an analyte that can be detected; this value varies depending on the method, instrument, and dilution used.

anion-A negatively charged ion.

aquifer-A saturated, permeable geologic unit that can transmit significant quantities of water under ordinary hydraulic gradients.

aquitard-A geologic unit that inhibits the flow of water.

beta particle - A negatively charged particle emitted from the nucleus of an atom. It has a mass and charge equal to those of an electron.

biota-The animal and plant life of a particular region considered as a total ecological entity.

blank-A control sample that is identical, in principle, to the sample of interest, except that the substance being analyzed is absent. In such cases, the measured value or signal for the substance being analyzed is believed to be a result of artifacts. Under certain circumstances, that value may be subtracted from the measured value to give a net result reflecting the amount of the substance in the sample. The US Environmental Protection Agency (EPA) does not permit the subtraction of blank results in EPAregulated analyses.

calibration-Determination of variance from a standard of accuracy of a measuring instrument to ascertain necessary correction factors.

CERCLA-reportable release - $A$ release to the environment that exceeds reportable quantities as defined by the Comprehensive Environmental Response, Compensation, and Liability Act (CERCLA).

chemical oxygen demand-Indicates the quantity of oxidizable materials present in water and varies with water composition, concentrations of reagent, temperature, period of contact, and other factors.

closure - Specifically, closure of a hazardous waste management facility under Resource Conservation and Recovery Act (RCRA) requirements. 
compliance - Fulfillment of applicable requirements of a plan or schedule ordered or approved by government authority.

concentration - The amount of a substance contained in a unit volume or mass of a sample.

conductivity-A measure of water's capacity to convey an electric current. This property is related to the total concentration of the ionized substances in water and the temperature at which the measurement is made.

confluence-The point at which two or more streams meet; the point where a tributary joins the main stream.

contamination-Deposition of unwanted material on the surfaces of structures, areas, objects, or personnel.

cosmic radiation - Ionizing radiation with very high energies, originating outside the earth's atmosphere. Cosmic radiation is one source contributing to natural background radiation.

count - A measure of the radiation from an object or device; the signal that announces an ionization event within a counter.

curie (Ci) - A unit of radioactivity. One curie is defined as $3.7 \times 10^{10}$ (37 billion) disintegrations per second. Several fractions and multiples of the curie are commonly used:

kilocurie (kCi) $-10^{3} \mathrm{Ci}$, one thousand curies; $3.7 \times 10^{13}$ disintegrations per second.

millicurie $(\mathbf{m C i})-10^{-3} \mathrm{Ci}$, one-thousandth of a curie; $3.7 \times 10^{7}$ disintegrations per second.

microcurie $(\mu \mathrm{Ci})-10^{-6} \mathrm{Ci}$, one-millionth of a curie; $3.7 \times 10^{4}$ disintegrations per second.

picocurie (pCi) $-10^{-12} \mathrm{Ci}$, one-trillionth of a curie; 0.037 disintegrations per second.

daughter-A nuclide formed by the radioactive decay of a parent nuclide.

decay, radioactive - The spontaneous transformation of one radionuclide into a different radioactive or nonradioactive nuclide, or into a different energy state of the same radionuclide.

dense nonaqueous phase liquid (DNAPL) - The liquid phase of chlorinated organic solvents. These liquids are denser than water and include commonly used industrial compounds such as tetrachloroethene and trichloroethene.

derived concentration guide (DCG) - The concentration of a radionuclide in air or water that, under conditions of continuous exposure for 1 year by one exposure mode (i.e., ingestion of water, submersion in air, or inhalation), would result in either an effective dose equivalent of $0.1 \mathrm{rem}(1 \mathrm{mSv})$ or a dose equivalent of $5 \mathrm{rem}(50 \mathrm{mSv})$ to any tissue, including skin and lens of the eye. The guides for radionuclides in air and water are given in DOE O 5400.5.

derived concentration standard (DCS) - Quantities used in the design and conduct of radiological environmental protection programs at US Department of Energy facilities and sites. These quantities represent the concentration of a given radionuclide in either water or air that results in a member of the public receiving a $1 \mathrm{mSv}$ (100 mrem) effective dose following continuous exposure for 1 year for each of the following pathways: ingestion of water, submersion in air, and inhalation. 
disintegration, nuclear - A spontaneous nuclear transformation (radioactivity) characterized by the emission of energy and/or mass from the nucleus of an atom.

dissolved oxygen - A measurement of the amount of gaseous oxygen in an aqueous solution. Adequate dissolved oxygen is necessary for good water quality.

dose - A general term for absorbed dose, equivalent dose, effective dose, committed equivalent dose, committed effective dose, or total effective dose.

absorbed dose-The average energy imparted by ionizing radiation to the matter in a volume element per unit mass of irradiated material. The absorbed dose is expressed in units of rad (or gray) $(1 \mathrm{rad}=0.01$ gray).

collective dose/collective effective dose-The sum of the total effective dose to all persons in a specified population received in a specified period of time. It can be approximated by the sum of the average effective dose for a given subgroup $\mathrm{i}$, and $\mathrm{Ni}$ is the number of individuals in this subgroup. Collective dose is expressed in units of person-rem (or person-sievert).

committed effective dose - The sum of the products of the committed organ or tissue equivalent doses and the appropriate tissue weighting factors in the years following the intake of a radionuclide into the body. The commitment period is taken to be 50 years for adults. Committed effective dose is expressed in units of rem (or sievert).

committed equivalent dose (HT,50) - The equivalent dose calculated to be received by a tissue or organ over a 50 -year period after the intake of a radionuclide into the body. It does not include contributions from radiation sources external to the body. Committed equivalent dose is expressed in units of rems (or sieverts).

effective dose (E or ED) - The summation of the products of the equivalent dose (HT) received by specified tissues or organs of the body and the appropriate tissue weighting factor (wT). It includes the dose from radiation sources internal and/or external to the body. The effective dose is expressed in units of rems (or sieverts).

equivalent dose (HT) - The product of average absorbed dose (DT,R) in rad (or gray) in a tissue or organ $(\mathrm{T})$ and a radiation (R) weighting factor (wR).

total effective dose (TED) - Sum of the effective dose (for external exposures) and the committed effective dose.

dosimetry-Measurement and calculation of radiation doses from exposure to ionizing radiation.

drinking water standard (DWS) - Federal primary drinking water standards, both proposed and final, as set forth by the US Environmental Protection Agency.

duplicate samples - Two or more samples collected simultaneously into separate containers.

effluent - A liquid or gaseous waste discharge to the environment.

effluent monitoring - The collection and analysis of samples or measurements of liquid and gaseous effluents for purposes of characterizing and quantifying the release of contaminants, assessing radiation exposures of members of the public, and demonstrating compliance with applicable standards. 
energy intensity-Energy consumption per square foot of building space, including industrial or laboratory facilities [EO 13514, Section 19(f)].

Environmental Management - A US Department of Energy program that directs the assessment and cleanup of its sites (remediation) and facilities contaminated with waste as a result of nuclear-related activities.

exposure (radiation) - The incidence of radiation on living or inanimate material by accident or intent. Background exposure is the exposure to natural background ionizing radiation. Occupational exposure is the exposure to ionizing radiation that takes place during a person's working hours. Population exposure is the exposure to the total number of persons who inhabit an area.

external radiation - Exposure to ionizing radiation when the radiation source is located outside the body.

flux -A flow or discharge of a substance (in units of mass, radioactivity, etc.) per unit of time.

gamma ray-High-energy, short-wavelength electromagnetic radiation emitted from the nucleus of an excited atom. Gamma rays are identical to x-rays except for the source of the emission.

gamma spectrometry-A system consisting of a detector, associated electronics, and a multichannel analyzer that is used to analyze samples for gamma-emitting radionuclides.

grab sample - A sample collected instantaneously with a glass or plastic bottle placed below the water surface to collect surface water samples (also called dip samples).

greenhouse gas (GHG) - Gas that traps heat in the atmosphere. The four major greenhouses gases are carbon dioxide, methane, nitrous oxide, and fluorinated gases.

groundwater-The water located beneath the earth's surface in soil pore spaces and in the fractures of rock formations.

hardness - Water hardness is caused by polyvalent metallic ions dissolved in water. In fresh water, these are mainly calcium and magnesium, although other metals such as iron, strontium, and manganese may contribute to hardness.

hectare-A metric unit of area equal to 10,000 square meters or 2.47 acres.

hydrogeology — Hydrologic aspects of site geology.

hydrology-The science dealing with the properties, distribution, and circulation of natural water systems.

internal radiation - Internal radiation occurs when radionuclides enter the body by ingestion of foods, milk, and water, and by inhalation. Radon is the major contributor to the annual dose equivalent for internal radionuclides.

ion-An atom or compound that carries an electrical charge.

irradiation-Exposure to radiation.

isotopes-Forms of an element having the same number of protons in their nuclei but differing in the number of neutrons. 
Leadership in Energy and Environmental Design (LEED) - A suite of rating systems for the design, construction, operation, and maintenance of green buildings, homes, and neighborhoods. LEED is intended to help building owners and operators find and implement ways to be environmentally responsible and resource-efficient.

maximally exposed individual (MEI) - A hypothetical individual who, because of proximity, activities, or living habits, could potentially receive the maximum possible dose of radiation from a given event or process.

microbes-Microscopic organisms.

migration - The transfer or movement of a material through the air, soil, or groundwater.

millirem (mrem) - The dose equivalent that is one one-thousandth of a rem.

milliroentgen $(\mathbf{m R})$ - A measure of x-ray or gamma radiation. The unit is one-thousandth of a roentgen.

minimum detectable activity (MDA) - The smallest activity of a radionuclide that can be distinguished in a sample by a given measurement system at a preselected counting time and at a given confidence level.

monitoring - A process whereby the quantity and quality of factors that can affect the environment and/or human health are measured periodically to regulate and control potential impacts.

natural radiation-Radiation arising from cosmic and other naturally occurring radionuclide sources (such as radon) present in the environment.

nuclide - An atom specified by its atomic weight, atomic number, and energy state. A radionuclide is a radioactive nuclide.

outfall-The point of conveyance (e.g., drain or pipe) of wastewater or other effluents into a ditch, pond, or river.

ozone - A gas made up of three oxygen atoms that occurs both in earth's upper atmosphere and at ground level. Ozone can be "good" or "bad" for human health and the environment, depending on its location in the atmosphere. Ozone acts as a protective layer high above the earth, but it can be harmful to breathe.

parts per billion (ppb) - A unit measure of concentration equivalent to the weight/volume ratio expressed as micrograms per liter or nanograms per milliliter.

parts per million (ppm) - A unit measure of concentration equivalent to the weight/volume ratio expressed as milligrams per liter.

person-rem-Collective dose to a population group. For example, a dose of 1 rem to 10 individuals results in a collective dose of 10 person-rem.

pH-A measure of the hydrogen ion concentration in an aqueous solution. Acidic solutions have a $\mathrm{pH}$ from 0 through 6 , basic solutions have a $\mathrm{pH}>7$, and neutral solutions have a $\mathrm{pH}=7$.

precision-The degree to which repeated measurements under unchanged conditions show the same results (also called reproducibility or repeatability). 
quality assurance (QA) - Any action in environmental monitoring to ensure the reliability of monitoring and measurement data.

quality control (QC) - The routine application of procedures within environmental monitoring to obtain the required standards of performance in monitoring and measurement processes.

rad-The unit of absorbed dose deposited in a volume of material.

radioactivity - The spontaneous emission of radiation, generally alpha or beta particles or gamma rays, from the nucleus of an unstable isotope.

radioisotopes - Radioactive isotopes.

radionuclide - An unstable nuclide capable of spontaneous transformation into other nuclides by changing its nuclear configuration or energy level. This transformation is accompanied by the emission of photons or particles.

reclamation - Recovery of wasteland, desert, etc., by ditching, filling, draining, or planting.

reference material-A material or substance with one or more properties that is sufficiently well established and used to calibrate an apparatus, to assess a measurement method, or to assign values to materials.

release - Any discharge to the environment. "Environment" is broadly defined as any water, land, or ambient air.

rem-The unit of dose equivalent (absorbed dose in rads $\times$ the radiation quality factor). Dose equivalent is frequently reported in units of millirem (mrem), which is one one-thousandth of a rem.

remediation-The correction of a problem. On the Oak Ridge Reservation remediation efforts focus on the safe cleanup of the environmental legacy resulting from research activities and weapons production over the past 5 decades.

remedial investigation/feasibility study (RI/FS) - An in-depth study designed to gather data needed to determine the nature and extent of contamination at a Superfund site; establish site cleanup criteria; identify preliminary alternatives for remedial action; and support technical and cost analyses of alternatives. The remedial investigation is usually done with the feasibility study. Together they are usually referred to as the "RI/FS."

roentgen - A unit of radiation exposure equal to the quantity of ionizing radiation that will produce one electrostatic unit of electricity in one cubic centimeter of dry air at $0^{\circ} \mathrm{C}$ and standard atmospheric pressure. One roentgen equals $2.58 \times 10^{-4}$ coulombs per kilogram of air. [Note: A coulomb is a unit of electric charge - the SI (International System of Units) unit of electric charge equal to the amount of charge transported by a current of one ampere in one second.]

self-absorption-Absorption of radiation by the sample itself, preventing detection by the counting instrument.

sensitivity - The capability of a methodology or an instrument to discriminate among samples with differing concentrations or containing varying amounts of analyte.

settleable solids - Material settling out of suspension within a defined period. 
settling basin - A temporary holding basin (excavation) that receives wastewater, which is subsequently discharged.

sievert (Sv) - The SI (International System of Units) unit of dose equivalent, $1 \mathrm{~Sv}=100 \mathrm{rem}$.

spike - The addition of a known amount of reference material containing the analyte of interest to a blank sample.

spiked sample — A sample to which a known amount of some substance has been added.

stable — Not radioactive or not easily decomposed or otherwise modified chemically.

stack-A vertical pipe or flue designed to exhaust airborne gases and suspended particulate matter.

standard deviation-An indication of the dispersion of a set of results around their average.

standard reference material (SRM) - A reference material distributed and certified by the National Institute of Standards and Technology.

statistical significance testing-A procedure for decision making and data evaluation based on mathematical probability that provides a consistent, scientific methodology for collecting, analyzing, and presenting data. Statistical significance testing reflects the mathematical likelihood of certain outcomes but says nothing about its environmental significance.

storm water runoff-Surface streams that appear after precipitation.

stratospheric ozone - The stratosphere or "good" ozone layer extends upward from about 6 to 30 miles above the earth's surface and protects the earth from the sun's harmful ultraviolet rays.

substrate - The substance, base, surface, or medium in which an organism lives and grows.

Superfund-The Superfund Amendments and Reauthorization Act amended the Comprehensive Environmental Response, Compensation, and Liability Act (CERCLA) in 1986. CERCLA, the federal government's program to clean up the nation's uncontrolled hazardous waste, is now commonly known as Superfund.

surface water-All water on the surface of the earth, as distinguished from groundwater.

terrestrial radiation-Ionizing radiation emitted from radioactive materials, primarily potassium-40, thorium, and uranium, in the earth's soils. Terrestrial radiation contributes to natural background radiation.

total activity - The total number of atoms of a radioactive substance that decay per unit of time.

total dissolved solids-Dissolved solids and total dissolved solids are terms generally associated with freshwater systems; they consist of inorganic salts, small amounts of organic matter, and dissolved materials.

transect-A line across an area being studied. The line is composed of points where specific measurements or samples are taken.

transmissive zone-A zone of sediments sufficiently porous and permeable to allow the flow of groundwater through the zone. 
transuranic (or transuranium) - Of or relating to elements with higher atomic weights than uranium; all 13 known transuranic elements are radioactive and are produced artificially.

transuranic waste - Solid radioactive waste containing primarily alpha-emitting elements heavier than uranium.

trip blank-A sample container of deionized water that is transported to a sampling location, treated as a sample, and sent to the laboratory for analysis; trip blanks are used to check for contamination resulting from transport, shipping, and site conditions.

turbidity - A measure of the concentration of sediment or suspended particles in solution.

unconsolidated zone - Soil zone located above the water table.

volatile organic compounds - Organic chemicals that have a high vapor pressure at ordinary conditions. They include both human and naturally occurring chemical compounds and are used in many industrial processes. Common examples include trichloroethane, tetrachloroethene, and trichloroethene.

watershed-The region draining into a river, river system, or body of water.

wetlands - Lowland areas, such as a marshes or swamps, inundated or saturated by surface water or groundwater sufficiently to support aquatic vegetation or plants adapted for life in saturated soils.

wind rose - A diagram in which statistical information concerning direction and speed of the wind at a location is summarized. 


\section{Appendix B. Climate Overview of the Oak Ridge Area}





\section{Appendix B. Climate Overview of the Oak Ridge Area}

\section{B.1 Regional Climate}

The climate of the Oak Ridge area and its surroundings may be broadly classified as humid subtropical. The term "humid" indicates that the region receives an overall surplus of precipitation compared to the level of evapotranspiration that is normally experienced throughout the year. The "subtropical" designation indicates that the region experiences a wide range of seasonal temperatures. Such areas are typified by significant differences in temperature between summer and winter.

Oak Ridge winters are characterized by synoptic weather systems that produce significant precipitation events every 3 to 5 days. These wet periods are occasionally followed by arctic air outbreaks. Although snow and ice are not associated with many of these systems, occasional snowfall does occur. Winter cloud cover tends to be enhanced by the regional terrain (due to cold air wedging and moisture trapping).

Severe thunderstorms are most frequent during spring but can occur at any time of the year. The Cumberland Mountains and Cumberland Plateau often inhibit the intensity of severe systems that traverse the region, due to the downward momentum created as the storms move off higher terrain into the Great Valley. Summers are characterized by very warm, humid conditions. Occasional frontal systems may produce organized lines of thunderstorms (and rare damaging tornados). More frequently, however, summer precipitation results from "air mass" thundershowers that form as a consequence of daytime heating, rising humid air, and local terrain features. Although adequate precipitation usually occurs during the fall, the months of August through October represent the driest period of the year. The occurrence of precipitation during the fall tends to be less cyclical than for other seasons but is occasionally enhanced by decaying tropical cyclones moving north from the Gulf of Mexico. During November, winter-type cyclones again begin to dominate the weather and may continue until April or May.

Decadal-scale climate change has recently affected the East Tennessee region. Most of these changes appear to be related to the hemispheric effects caused by the frequency and phase of the El NiñoSouthern Oscillation (ENSO), the Pacific Decadal Oscillation (PDO), and the Atlantic Multidecadal Oscillation (AMO). The ENSO and PDO patterns, with cycles of 3 to 7 years and about 40 years, respectively, affect Pacific Ocean sea surface temperatures. The AMO, with a cycle of 30-70 years, affects Atlantic sea surface temperature. All of these patterns collectively modulate regional temperature and precipitation trends in eastern Tennessee. The AMO shifted from a cold to a warm sea surface temperature phase (mid-1990s) and could continue in its present state for another decade or so. The PDO entered a cool sea surface temperature phase around 2000. Also, the ENSO pattern has more frequently brought about warmer Eastern Pacific sea surface temperatures during the 1990s, though this effect has reversed somewhat during the 2000s. Additionally, some evidence exists that human-induced climate change may be producing some effects (via an assembly of first-order influences such as well-mixed greenhouse gases, land cover change, carbon soot, and aerosols). Solar influences on the jet stream, via changes to the stratospheric temperature gradient with respect to the 11-year solar cycle, also play a role in inter-annual climate variability (Ineson et al. 2011). Largely due to the effects of the AMO and ENSO, the Oak Ridge climate warmed about $1.1^{\circ} \mathrm{C}$ from the 1980 s to the $1990 \mathrm{~s}$ but has stabilized just above the $1990 \mathrm{~s}$ values during the $2000 \mathrm{~s}$ (a further warming of $0.2^{\circ} \mathrm{C}$ was observed). The recent warming appears to have lengthened the growing season [i.e., the period with temperatures above $0^{\circ} \mathrm{C}\left(32^{\circ} \mathrm{F}\right)$ ] by about 2 to 3 weeks over the last 30 years. In addition, a warming of minimum temperature has been noted over the last 30 years, this latter effect being presumably related to changes in the interaction of the surface boundary layer with greenhouse gases and/or aerosol concentration changes. Temperature averages for individual years can vary, as noted by the more than $1^{\circ} \mathrm{C}$ contrast between $2012\left(15.9^{\circ} \mathrm{C}\right.$ average $)$ and $2013\left(14.8^{\circ} \mathrm{C}\right.$ average). 


\section{B.2 Winds}

Five major terrain-related wind regimes regularly affect the Great Valley of eastern Tennessee: pressure-driven channeling, downward-momentum transport or vertically coupled flow, forced channeling, along-valley and mountain-valley thermal circulations, and down sloping. Pressure-driven channeling and vertically coupled flow affect winds on scales comparable to those of the Great Valley (hundreds of kilometers). Forced channeling occurs on similar scales but is also quite important at small spatial scales, such as those characterizing the ridge-and-valley terrain on the Oak Ridge Reservation (ORR) (Birdwell 2011). Along-valley and mountain-valley circulations are thermally driven and occur within a large range of spatial scales. Thermally driven flows are more prevalent under conditions of clear skies and low humidity.

Forced channeling is defined as the direct deflection of wind by terrain. This form of channeling necessitates some degree of vertical motion transfer, implying that the mechanism is less pronounced during strong temperature-inversion conditions. Although forced channeling may result from interactions between large valleys and mountain ranges (such as the Great Valley and the surrounding mountains), the mechanism is especially important in narrow, small valleys such as those on ORR (Kossman and Sturman 2002).

Forced channeling within the Central Great Valley represents the most dominant large-scale wind mechanism, influencing 50\%-60\% of all winds observed in the area. For up-valley flow cases, these winds are frequently associated with large wind shifts when they initiate or terminate $\left(45^{\circ}-90^{\circ}\right)$. At small scales, ridge-and-valley terrain usually produces forced-channeled local flow ( $>90 \%$ of cases). Most forced-channeled winds prefer weak-to-moderate synoptic pressure gradients of less than $0.010 \mathrm{mb} / \mathrm{km}$ (Birdwell 2011).

Large-scale forced channeling occurs regularly within the Great Valley when northwest to north winds (perpendicular to the axis of the central Great Valley) coincide with vertically coupled flow. The phenomenon sometimes results in a split-flow pattern (winds southwest of Knoxville moving downvalley and those east of Knoxville moving up-valley). The causes of such a flow pattern may include the shape characteristics of the Great Valley (Kossman and Sturman 2002) but also may be associated with the specific location of the Cumberland and Smoky Mountains relative to upper level wind flow (Eckman 1998). The convex shape of the Great Valley with respect to a northwest wind flow may lead to a divergent wind flow pattern in the Knoxville area. This results in downward air motion. Additionally, horizontal flow is reduced by the windward mountain range (Cumberland Mountains), which increases buoyancy and Coriolis effects (also known as Froude and Rossby ratios). Consequently, the leeward mountain range (Smoky Mountains) becomes more effective at blocking or redirecting the winds.

Vertically coupled winds tend to occur when the atmosphere is unstably or neutrally buoyant. When a strong horizontal wind component is present, as in conditions behind a winter cold front or during strong cold air advection, winds tend to override the terrain, flowing roughly in the same direction as the winds aloft. This phenomenon is a consequence of the horizontal transport and momentum aloft being transferred to the surface. However, Coriolis effects may turn the winds by up to $40^{\circ}$ to the left (Birdwell 1996).

In the Central Valley, vertically coupled winds dominate about $25 \%$ to $35 \%$ of the time; however, most such winds are turned toward an up-valley or down-valley direction when small-scale ridge-andvalley terrain is present. Wintertime vertically coupled flow is typically dominated by strong large-scale pressure forces, whereas the summertime cases tend to be more associated with deep mixing depths $(>500 \mathrm{~m})$. Most vertically coupled flows are associated with major wind shifts $\left(90^{\circ}-135^{\circ}\right)$ when such flow patterns begin or terminate (Birdwell 2011).

Pressure-driven channeling, in essence, is the redirection of synoptically induced wind flow through a valley channel. The direction of wind flow through the valley is determined by the pressure gradient superimposed on a valley axis (Whiteman 2000). The process is affected by Coriolis forces, a leftward deflection of winds in the Northern Hemisphere. Eckman (1998) suggested that pressure-driven channeling plays a significant role in the Great Valley. Winds driven purely by such a process shift from up-valley to down-valley flow or conversely as large-scale pressure systems induce flow shifts across the

axis of the Great Valley. Since the processes involved in pressure-driven flow primarily affect the 
horizontal motion of air, the presence of a temperature inversion enhances this pattern significantly. Weak vertical air motion and momentum associated with such inversions allow different layers of air to slide over each other (Monti et al. 2002).

Within the Central Great Valley, especially ORR, winds dominated by down-valley pressure-driven channeling range in frequency from $2 \%$ to $10 \%$, with the lowest values in summer and the highest in winter. Up-valley pressure-driven channeling usually does not dominate winds in the Central Great Valley, but co-occurs with forced-channeled winds $50 \%$ of the time. Winds dominated by pressure driven channeling often result in large wind shifts $\left(90^{\circ}-180^{\circ}\right)$ before and after the occurrence of the wind pattern. These wind shifts occur about twice as frequently within and near ORR when compared to other parts of the Great Valley (Birdwell 2011). Most pressure-driven channeled winds occurred in association with moderate synoptic pressure gradients $(0.006-0.016 \mathrm{mb} / \mathrm{km})$.

Thermally driven winds are common in areas of significant complex terrain. These winds occur as a result of pressure and temperature differences caused by varied surface-air energy exchange at similar altitudes along a valley's axis, sidewalls, and/or slopes. Thermal flows operate most effectively when synoptic winds are light and when thermal differences are exacerbated by clear skies and low humidity (Whiteman 2000). Ridge-and-valley terrain may be responsible for enhancing or inhibiting such flow, depending on ambient weather conditions. Large-scale thermally driven wind frequency varies from $2 \%$ to $20 \%$ with respect to season in the Central Great Valley. Frequencies are highest during summer and fall when intense surface heating and/or low humidity help drive flow patterns (Birdwell 2011).

Annual wind roses have been compiled for 2013 for each of the nine DOE-managed ORR meteorological towers (towers MT1, MT2, MT3, MT4, MT6, MT7, MT9, MT10, and MT11). These, along with other annual wind rose data may be viewed online at http://web.ornl.gov/adm/fo/lp/orrm /page 7.htm. The wind roses represent large-scale trends and should be used with caution for estimates involving short-term variations.

A wind rose depicts the typical distribution of wind speed and direction for a given location. The winds are represented in terms of the direction from which they originate. The rays emanating from the center correspond to points of the compass. The length of each ray is related to the frequency at which winds blow from the given direction. The concentric circles represent increasing frequencies from the center outward, given in percentages. Precipitation wind roses display similar information except that wind speed frequencies are replaced with data associated with the rate of hourly precipitation. Likewise, wind direction stability and wind direction mixing height roses replace wind speeds with data on stability class and mixing height respectively. Wind direction peak gust roses reflect the frequency of peak 1-second wind gusts for various wind directions. All of these roses can be found at http://web.ornl.gov/adm/fo/lp/orrm/page $7 . h t m$.

\section{B.3 Temperature and Precipitation}

Temperature and precipitation normals (1981-2010) and extremes (1948-2013) and their durations for the city of Oak Ridge are summarized in Table B.1. Decadal temperature and precipitation averages for the four decades of the 1970s to 2000s are provided in Table B.2. Hourly freeze data (1985-2013) are given in Table B.3.

\section{B.3.1 Recent Climate Change with Respect to Temperature and Precipitation}

Table B.2 presents a decadal analysis of temperature patterns for the decades of the 1970 s to 2000 s. In general, temperatures in Oak Ridge rose until the 1990s but have leveled off during the 2000s. Based on these average decadal temperatures, temperatures have risen $1.4^{\circ} \mathrm{C}$ between the decades of the $1970 \mathrm{~s}$ and the $2000 \mathrm{~s}$ from $13.8^{\circ} \mathrm{F}$ to $15.2^{\circ} \mathrm{C}\left(56.8^{\circ} \mathrm{F}\right.$ to $\left.59.3^{\circ} \mathrm{F}\right)$. More detailed analysis reveals that these temperature increases have been neither linear nor equal throughout the months or seasons.

January and February average temperatures have seen increases of $2.1^{\circ} \mathrm{C}$ and $1.9^{\circ} \mathrm{C}$, respectively. This significant increase is probably dominated by the effects of the AMO, though this climate response may include both natural and anthropogenic effects. The Arctic has seen the largest increase in temperatures of anywhere in the Northern Hemisphere over the last 30 years. 
Table B.1. Climate normals (1981-2010) and extremes (1948-2013) for City of Oak Ridge, Tennessee (townsite), with 2013 comparisons

\begin{tabular}{|c|c|c|c|c|c|c|c|c|c|c|c|c|c|}
\hline Monthly variables & January & February & March & April & May & June & July & August & September & October & November & December & Annual \\
\hline \multicolumn{14}{|c|}{ Temperature, ${ }^{\circ} \mathrm{C}\left({ }^{\circ} \mathrm{F}\right)$} \\
\hline 30-Year Average Max & $8.1(46.6)$ & $11.1(51.9)$ & $16.3(61.4)$ & $21.4(70.6)$ & $25.7(78.3)$ & $29.8(85.7)$ & $31.3(88.4)$ & $31.1(88.0)$ & $27.6(81.7)$ & $21.7(71.1)$ & $15.3(59.6)$ & $9.8(49.6)$ & $20.8(69.5)$ \\
\hline 2013 Average Max & $10.1(50.1)$ & $10.8(51.4)$ & $11.9(53.5)$ & $21.6(70.9)$ & $25.4(77.7)$ & $29.7(85.4)$ & $29.2(84.6)$ & $29.7(85.5)$ & $27.9(82.2)$ & $22.0(71.6)$ & $14.3(57.8)$ & $10.6(51.1)$ & $20.3(68.5)$ \\
\hline 66-Year Record Max & $25(77)$ & $26(79)$ & $30(86)$ & $33(92)$ & $35(95)$ & $41(105)$ & $41(105)$ & $39(103)$ & $39(102)$ & $32(90)$ & $28(83)$ & $26(78)$ & $41(105)$ \\
\hline 30-Year Average Min & $-1.7(28.9)$ & $-0.2(31.7)$ & $4.1(39.3)$ & $8.3(46.9)$ & $12.9(55.2)$ & $18.1(64.5)$ & $20.3(68.6)$ & $19.6(67.2)$ & $15.4(59.7)$ & $8.9(48.0)$ & $3.5(38.3)$ & $-0.5(31.1)$ & $9.1(48.4)$ \\
\hline 2013 Average Min & $1.1(34.0)$ & $0.5(32.9)$ & $1.7(35.0)$ & $7.9(46.3)$ & $12.9(55.3)$ & $18.8(65.9)$ & $19.9(67.8)$ & $19.8(67.7)$ & $16.3(61.3)$ & $10.3(50.6)$ & $2.2(36.0)$ & $0.9(33.7)$ & $9.4(48.9)$ \\
\hline 66-Year Record Min & $-27(-17)$ & $-25(-13)$ & $-17(1)$ & $-7(20)$ & $-1(30)$ & $4(39)$ & $9(49)$ & $10(50)$ & $1(33)$ & $-6(21)$ & $-16(3)$ & $-22(-7)$ & $-27(-17)$ \\
\hline 30-Year Average & $3.2(37.7)$ & $5.4(41.8)$ & $10.2(50.4)$ & $14.9(58.8)$ & $19.3(66.8)$ & $23.9(75.1)$ & $25.8(78.5)$ & $25.3(77.6)$ & $21.5(70.7)$ & $15.3(59.5)$ & $9.4(48.9)$ & $4.6(40.3)$ & $14.9(58.9)$ \\
\hline 2013 Average & $5.6(42.0)$ & $5.7(42.2)$ & $6.8(44.2)$ & $14.8(58.6)$ & $19.2(66.5)$ & $24.2(75.6)$ & $24.6(76.2)$ & $24.8(76.6)$ & $22.1(71.8)$ & $16.2(61.1)$ & $8.3(46.9)$ & $5.7(42.3)$ & $14.8(58.7)$ \\
\hline $\begin{array}{l}2013 \text { Departure from } \\
\text { Average }\end{array}$ & $2.4(4.3)$ & $0.2(0.4)$ & $-3.4(-6.2)$ & $-0.1(-0.2)$ & $-0.2(-0.3)$ & $0.3(0.5)$ & $-1.3(-2.3)$ & $-0.6(-1.0)$ & $0.6(1.1)$ & $0.9(1.6)$ & $-1.1(-2.0)$ & $1.1(2.0)$ & $-0.1(-0.2)$ \\
\hline \multicolumn{14}{|c|}{ 30-year average heating degree days, ${ }^{\circ} \mathrm{C}\left({ }^{\circ} \mathrm{F}\right)^{a}$} \\
\hline & $383(689)$ & $303(546)$ & $96(172)$ & $79(142)$ & $6(11)$ & $3(5)$ & 0 & 0 & $11(19)$ & $126(227)$ & 297 (534) & $322(580)$ & $1625(2925)$ \\
\hline \multicolumn{14}{|c|}{ 30-year average cooling degree days, ${ }^{\circ} \mathrm{C}\left({ }^{\circ} \mathrm{F}\right)^{a}$} \\
\hline & 0 & 0 & $24(44)$ & $26(46)$ & $127(229)$ & $189(341)$ & $289(520)$ & $200(360)$ & 104 (188) & $6(10)$ & 0 & 0 & $966(1738)$ \\
\hline \multicolumn{14}{|c|}{ Precipitation, mm (in.) } \\
\hline 30-Year Average & $115.4(4.54)$ & $116.1(4.57)$ & $128.6(5.06)$ & $106.2(4.18)$ & $109.0(4.29)$ & $108.7(4.28)$ & $133.9(5.27)$ & $70.1(2.76)$ & $93.8(3.69)$ & $74.2(2.92)$ & $114.1(4.49)$ & $123.5(4.86)$ & $1294(50.91)$ \\
\hline 2013 Totals & $267.0(10.51)$ & $58.9(2.32)$ & $145.3(5.72)$ & $161.8(6.37)$ & $135.4(5.33)$ & $201.2(7.92)$ & $204.3(8.04)$ & $117.1(4.61)$ & $85.9(3.38)$ & $18.3(0.72)$ & $112.0(4.41)$ & $204.3(8.04)$ & $1711.7(67.37)$ \\
\hline $\begin{array}{l}2013 \text { Departure from } \\
\text { Average }\end{array}$ & $151.7(5.97)$ & $-57.2(-2.25)$ & $16.8(0.66)$ & $55.6(2.19)$ & $26.4(1.04)$ & $92.5(3.64)$ & $70.4(2.77)$ & $47.0(1.85)$ & $-7.9(-0.31)$ & $-55.9(-2.20)$ & $-2.0(-0.08)$ & $80.8(3.18)$ & $\begin{array}{l}+418.2 \\
(+16.46)\end{array}$ \\
\hline 66-Year Max Monthly & $337.2(13.27)$ & $324.7(12.78)$ & $311.0(12.24)$ & $356.5(14.03)$ & $271.9(10.70)$ & $283.0(11.14)$ & $489.6(19.27)$ & $265.8(10.46)$ & $257.4(10.14)$ & $176.6(6.95)$ & $310.5(12.22)$ & $321.2(12.64)$ & $1939(76.33)$ \\
\hline 66-Year Max 24-hr & $108.0(4.25)$ & $131.6(5.18)$ & $120.4(4.74)$ & $158.5(6.24)$ & $112.0(4.41)$ & $94.0(3.70)$ & $124.8(4.91)$ & $190.1(7.48)$ & $160.1(6.30)$ & $67.6(2.66)$ & $130.1(5.12)$ & $130.1(5.12)$ & $190.1(7.48)$ \\
\hline 66-Year Min Monthly & $23.6(0.93)$ & $21.3(0.84)$ & $54.1(2.13)$ & $46.2(1.82)$ & $20.3(0.80)$ & $13.5(0.53)$ & $31.3(1.23)$ & $13.7(0.54)$ & Trace & Trace & $34.8(1.37)$ & $17.0(0.67)$ & $911.4(35.87)$ \\
\hline \multicolumn{14}{|c|}{ Snowfall, cm (in.) } \\
\hline 30-Year Average & $7.4(2.9)$ & $6.6(2.6)$ & $2.5(1.0)$ & $7.6(0.3)$ & 0 & 0 & 0 & 0 & 0 & 0 & Trace & $4.1(1.6)$ & $21.3(8.4)$ \\
\hline 2013 Totals & $7.6(0.3)$ & $45.7(1.8)$ & $27.9(1.1)$ & 0 & 0 & 0 & 0 & 0 & 0 & 0 & $12.7(0.5)$ & Trace & $94.0(3.7)$ \\
\hline 66-Year Max Monthly & $24.4(9.6)$ & $43.7(17.2)$ & $53.4(21.0)$ & $15.0(5.9)$ & Trace & 0 & 0 & 0 & 0 & Trace & $16.5(6.5)$ & $53.4(21.0)$ & $105.2(41.4)$ \\
\hline 66-Year Max 24-hr & $21.1(8.3)$ & $28.7(11.3)$ & $30.5(12.0)$ & $13.7(5.4)$ & Trace & 0 & 0 & 0 & 0 & Trace & $16.5(6.5)$ & $30.5(12.0)$ & $30.5(12.0)$ \\
\hline \multicolumn{14}{|c|}{ Days w/temp } \\
\hline 30 -Year $\operatorname{Max} \geq 32^{\circ} \mathrm{C}$ & 0 & 0 & 0 & 0.1 & 0.3 & 5.9 & 11.3 & 10.4 & 2.9 & 0 & 0 & 0 & 30.9 \\
\hline $2012 \mathrm{Max} \geq 32^{\circ} \mathrm{C}$ & 0 & 0 & 0 & 0 & 0 & 1 & 7 & 4 & 4 & 0 & 0 & 0 & 16 \\
\hline 30 -Year Min $\leq 0^{\circ} \mathrm{C}$ & 20.8 & 15.0 & 6.5 & 1.3 & 0 & 0 & 0 & 0 & 0 & 1.5 & 8.2 & 17.7 & 71.0 \\
\hline $2012 \mathrm{Min} \leq 0^{\circ} \mathrm{C}$ & 16 & 11 & 16 & 0 & 0 & 0 & 0 & 0 & 0 & 2 & 11 & 16 & 72 \\
\hline 30 -Year Max $\leq{ }^{\circ} \mathrm{C}$ & 2.8 & 0.5 & 0 & 0 & 0 & 0 & 0 & 0 & 0 & 0 & 0 & 0.8 & 4.1 \\
\hline $2012 \mathrm{Max} \leq 0^{\circ} \mathrm{C}$ & 0 & 0 & 0 & 0 & 0 & 0 & 0 & 0 & 0 & 0 & 0 & 0 & 0 \\
\hline \multicolumn{14}{|c|}{ Days w/precipitation } \\
\hline 30 -Year Avg $\geq 0.01$ in. & 10.9 & 10.1 & 11.2 & 10.4 & 11.9 & 10.8 & 13.0 & 8.9 & 8.4 & 8.3 & 9.3 & 11.3 & 124.5 \\
\hline 2012 Days $\geq 0.01$ in. & 14 & 13 & 12 & 9 & 15 & 13 & 15 & 14 & 5 & 6 & 9 & 13 & 138 \\
\hline $30-$ Year Avg $\geq 1.00$ in. & 1.4 & 1.1 & 1.2 & 0.9 & 1.4 & 0.8 & 1.5 & 0.5 & 1.3 & 0.7 & 1.5 & 1.4 & 13.7 \\
\hline 2012 Days $\geq 1.00$ in. & 5 & 0 & 3 & 4 & 2 & 3 & 2 & 1 & 1 & 0 & 1 & 3 & 25 \\
\hline
\end{tabular}


Table B.2. Decadal climate change (1970-2013) for City of Oak Ridge, Tennessee, with 2013 comparisons

\begin{tabular}{|c|c|c|c|c|c|c|c|c|c|c|c|c|c|}
\hline Monthly variables & January & February & March & April & May & June & July & August & September & October & November & December & Annual \\
\hline \multicolumn{14}{|c|}{ Temperature, ${ }^{\circ} \mathrm{C}\left({ }^{\circ} \mathrm{F}\right)$} \\
\hline 1970-1979 Avg Max & $6.6(43.8)$ & $9.7(49.5)$ & $15.6(60.1)$ & $21.4(70.6)$ & $24.8(76.7)$ & $28.5(83.3)$ & $30.0(85.9)$ & $29.7(85.5)$ & $26.8(80.2)$ & $20.8(69.4)$ & $14.5(58.2)$ & $10.0(49.9)$ & $19.9(67.8)$ \\
\hline 1980-1989 Avg Max & $6.9(44.4)$ & $10.2(50.3)$ & $15.9(60.7)$ & $21.0(69.8)$ & $25.6(78.1)$ & $29.8(85.7)$ & $31.6(88.8)$ & $30.7(87.3)$ & $27.1(80.8)$ & $21.3(70.3)$ & $15.6(60.2)$ & $8.6(47.5)$ & $20.3(68.6)$ \\
\hline 1990-1999 Avg Max & $9.4(48.8)$ & $12.3(54.1)$ & $16.2(61.2)$ & $21.9(71.3)$ & $26.2(79.1)$ & $29.7(85.5)$ & $32.1(89.8)$ & $31.4(88.6)$ & $28.4(83.2)$ & $22.6(72.8)$ & $15.2(59.4)$ & $10.4(50.8)$ & $21.3(70.4)$ \\
\hline 2000-2009 Avg Max & $8.8(47.9)$ & $11.2(52.1)$ & $17.0(62.7)$ & $21.4(70.6)$ & $25.8(78.4)$ & $29.8(85.6)$ & $30.8(87.5)$ & $31.4(88.5)$ & $27.6(81.8)$ & $21.8(71.2)$ & $15.9(60.6)$ & $9.8(49.6)$ & $21.0(69.7)$ \\
\hline 2010-2013 Avg Max & $8.4(47.1)$ & $10.7(51.3)$ & $16.4(61.5)$ & $23.2(73.8)$ & $26.7(80.1)$ & $31.0(87.8)$ & $31.9(89.5)$ & $31.5(88.7)$ & $27.7(81.8)$ & $21.5(70.7)$ & $15.4(59.8)$ & $9.9(49.8)$ & $21.2(70.2)$ \\
\hline 1980 s vs. $2010 \mathrm{~s}$ & $1.5(2.7)$ & $0.6(1.0)$ & $0.4(0.8)$ & $2.2(4.0)$ & $1.1(2.0)$ & $1.2(2.1)$ & $0.4(0.7)$ & $0.8(1.4)$ & $0.6(1.0)$ & $0.2(0.4)$ & $-0.2(-0.4)$ & $1.3(2.3)$ & $0.4(0.9)$ \\
\hline 2000 s vs. 2010 s & $-0.4(-0.8)$ & $-0.4(-0.8)$ & $-0.7(-1.2)$ & $1.8(3.2)$ & $0.9(1.7)$ & $1.2(2.2)$ & $1.1(2.0)$ & $0.1(0.2)$ & $0.0(0.0)$ & $-0.3(-0.5)$ & $-0.4(-0.8)$ & $0.1(0.2)$ & $0.2(0.3)$ \\
\hline 2013 Avg Max & $10.1(50.1)$ & $10.8(51.4)$ & $11.9(53.5)$ & $21.6(70.9)$ & $25.4(77.7)$ & $29.7(85.4)$ & $29.2(84.6)$ & $29.7(85.5)$ & $27.9(82.2)$ & $22.0(71.6)$ & $14.3(57.8)$ & $10.6(51.1)$ & $20.3(68.6)$ \\
\hline 1970-1979 Avg Min & $-3.4(25.8)$ & $-2.4(27.6)$ & $3.0(37.4)$ & $6.7(44.1)$ & $11.6(52.8)$ & $15.7(60.2)$ & $18.3(64.9)$ & $18.1(64.6)$ & $15.5(59.9)$ & $7.5(45.5)$ & $2.6(36.8)$ & $-0.8(30.5)$ & $7.7(45.8)$ \\
\hline 1980-1989 Avg Min & $-4.1(24.7)$ & $-2.1(28.3)$ & $1.7(35.0)$ & $6.0(42.9)$ & $11.4(52.4)$ & $16.2(61.2)$ & $19.0(66.2)$ & $18.4(65.1)$ & $14.4(57.9)$ & $7.5(45.4)$ & $3.1(37.5)$ & $-2.3(27.8)$ & $7.4(45.3)$ \\
\hline 1990-1999 Avg Min & $-0.9(30.3)$ & $0.0(32.0)$ & $2.9(37.1)$ & $7.2(45.0)$ & $12.5(54.5)$ & $17.2(63.0)$ & $20.0(67.9)$ & $18.9(66.1)$ & $15.1(59.2)$ & $8.2(46.8)$ & $2.2(36.0)$ & $0.1(32.2)$ & $8.6(47.6)$ \\
\hline 2000-2009 Avg Min & $-1.4(29.5)$ & $0.0(32.0)$ & $4.4(39.9)$ & $8.6(47.5)$ & $13.6(56.4)$ & $18.0(64.3)$ & $20.0(67.9)$ & $20.0(68.0)$ & $16.1(61.0)$ & $9.5(49.0)$ & $3.9(39.0)$ & $-0.4(31.4)$ & $9.4(48.9)$ \\
\hline 2010-2013 Avg Min & $-1.1(30.1)$ & $0.3(32.5)$ & $5.0(41.0)$ & $9.1(48.4)$ & $14.5(58.1)$ & $19.1(66.4)$ & $21.3(70.4)$ & $20.0(68.0)$ & $15.7(60.3)$ & $8.7(47.7)$ & $2.6(37.7)$ & $0.3(32.5)$ & $9.749 .4)$ \\
\hline 1980 s vs. 2010 s & $3.0(5.4)$ & $2.3(4.2)$ & $3.3(6.0)$ & $3.1(5.5)$ & $3.2(5.7)$ & $2.9(5.2)$ & $2.3(4.2)$ & $1.6(2.9)$ & $1.3(2.4)$ & $1.3(2.3)$ & $-0.4(-0.8)$ & $2.6(4.7)$ & $2.3(4.2)$ \\
\hline 2000 s vs. 2010 s & $0.3(0.6)$ & $0.3(0.5)$ & $0.6(1.1)$ & $0.5(0.9)$ & $0.9(1.7)$ & $1.2(2.1)$ & $1.4(2.5)$ & $0.0(0.0)$ & $-0.4(-0.7)$ & $-0.7(-1.3)$ & $-1.3(-2.3)$ & $0.6(1.1)$ & $0.3(0.6)$ \\
\hline 2013 Avg Min & $1.1(34.0)$ & $0.5(32.9)$ & $1.7(35.0)$ & $7.9(46.3)$ & $12.9(55.3)$ & $18.8(65.9)$ & $19.9(67.8)$ & $19.8(67.7)$ & $16.3(61.3)$ & $10.3(50.6)$ & $2.2(36.0)$ & $0.9(33.7)$ & $9.4(49.0)$ \\
\hline 1970-1979 Avg & $1.6(34.9)$ & $3.7(38.6)$ & $9.3(48.8)$ & $14.1(57.4)$ & $18.1(64.7)$ & $22.1(71.8)$ & $24.1(75.4)$ & $23.9(75.0)$ & $21.1(70.0)$ & $14.2(57.5)$ & $8.6(47.5)$ & $4.6(40.3)$ & $13.8(56.8)$ \\
\hline 1980-1989 Avg & $1.4(34.6)$ & $4.1(39.3)$ & $8.8(47.9)$ & $13.5(56.4)$ & $18.5(65.3)$ & $23.0(73.4)$ & $25.3(77.5)$ & $24.6(76.2)$ & $20.8(69.4)$ & $14.4(57.9)$ & $9.4(48.8)$ & $3.1(37.7)$ & $13.9(57.0)$ \\
\hline 1990-1999 Avg & $4.2(39.6)$ & $6.2(43.1)$ & $9.6(49.2)$ & $14.5(58.2)$ & $19.4(66.8)$ & $23.5(74.3)$ & $26.0(78.9)$ & $25.2(77.4)$ & $21.9(71.4)$ & $15.5(59.8)$ & $8.8(47.8)$ & $5.3(41.5)$ & $15.0(59.0)$ \\
\hline 2000-2009 Avg & $3.7(38.7)$ & $5.6(42.1)$ & $10.7(51.3)$ & $15.3(59.6)$ & $19.7(67.5)$ & $23.9(75.1)$ & $25.4(77.7)$ & $25.7(78.3)$ & $21.9(71.4)$ & $15.6(60.1)$ & $9.9(49.8)$ & $4.7(40.5)$ & $15.2(59.3)$ \\
\hline 2010-2013 Avg & $3.7(38.6)$ & $5.5(41.9)$ & $10.9(51.7)$ & $16.2(61.1)$ & $20.7(69.2)$ & $25.1(77.1)$ & $26.7(80.0)$ & $25.7(78.3)$ & $21.7(71.1)$ & $15.1(59.2)$ & $9.1(48.3)$ & $5.1(41.2)$ & $15.4(59.8)$ \\
\hline 1980 s vs. 2010 s & $2.2(4.0)$ & $1.4(2.6)$ & $2.1(3.8)$ & $2.6(4.7)$ & $2.2(3.9)$ & $2.1(3.7)$ & $1.4(2.5)$ & $1.2(2.1)$ & $0.9(1.7)$ & $0.7(1.3)$ & $-0.3(-0.5)$ & $1.9(3.5)$ & $1.5(2.7)$ \\
\hline 2000 s vs. 2010 s & $-0.1(-0.1)$ & $-0.1(-0.2)$ & $0.2(0.4)$ & $0.8(1.5)$ & $0.9(1.7)$ & $1.1(2.0)$ & $1.3(2.3)$ & $0.0(0.0)$ & $-0.2(-0.3)$ & $-0.5(-0.9)$ & $-0.8(-1.5)$ & $0.4(0.7)$ & $0.3(0.6)$ \\
\hline 2013 Avg & $5.6(42.0)$ & $5.7(42.2)$ & $6.8(44.2)$ & $14.8(58.6)$ & $19.2(66.5)$ & $24.2(75.6)$ & $24.6(76.2)$ & $24.8(76.6)$ & $22.1(71.8)$ & $16.2(61.1)$ & $8.3(46.9)$ & $5.7(42.3)$ & $14.8(58.6)$ \\
\hline \multicolumn{14}{|c|}{ Precipitation, mm (in.) } \\
\hline 1970-1979 Avg & $143.4(5.65)$ & $94.6(3.72)$ & $169.4(6.67)$ & $118.3(4.66)$ & $149.8(5.89)$ & $120.5(4.74)$ & $130.4(5.13)$ & $109.8(4.32)$ & $107.2(4.22)$ & $99.8(3.93)$ & $129.6(5.10)$ & $145.3(5.72)$ & $1516.4(59.68)$ \\
\hline 1980-1989 Avg & $100.4(3.95)$ & $109.1(4.29)$ & $112.6(4.43)$ & $88.8(3.49)$ & $110.6(4.35)$ & $84.1(3.31)$ & $120.4(4.74)$ & $82.6(3.25)$ & $108.9(4.29)$ & $79.8(3.14)$ & $128.0(5.04)$ & $107.6(4.23)$ & $1236.2(48.66)$ \\
\hline 1990-1999 Avg & $141.4(5.57)$ & $136.5(5.37)$ & $149.0(5.86)$ & $126.3(4.97)$ & $113.4(4.47)$ & $110.0(4.33)$ & $134.8(5.31)$ & $83.6(3.29)$ & $71.9(2.83)$ & $67.3(2.65)$ & $109.8(4.32)$ & $161.0(6.34)$ & $1429.4(56.26)$ \\
\hline 2000-2009 Avg & $116.9(4.60)$ & $121.8(4.80)$ & $115.6(4.55)$ & $125.0(4.92)$ & $117.8(4.64)$ & $95.2(3.75)$ & $138.9(5.47)$ & $78.4(3.09)$ & $108.8(4.28)$ & $74.0(2.91)$ & $121.4(4.78)$ & $124.4(4.90)$ & $1333.4(52.48)$ \\
\hline 2010-2013 Avg & $183.4(7.22)$ & $97.8(3.85)$ & $136.7(5.38)$ & $136.9(5.39)$ & $104.2(4.10)$ & $125.0(4.92)$ & $156.5(6.16)$ & $71.1(2.80)$ & $163.9(6.45)$ & $68.6(2.70)$ & $151.9(5.98)$ & $137.2(5.40)$ & $1513.6(59.57)$ \\
\hline 1980 s vs. $2010 \mathrm{~s}$ & $83.1(3.27)$ & $-11.2(-0.44)$ & $24.1(0.95)$ & $48.3(1.90)$ & $-6.4(-0.25)$ & $40.9(1.61)$ & $36.1(1.42)$ & $-11.4(-0.45)$ & $54.9(2.16)$ & $-11.2(-0.44)$ & $23.9(0.94)$ & $29.7(1.17)$ & $274.9(10.82)$ \\
\hline 2000 s vs. 2010 s & $66.6(2.62)$ & $-24.1(-0.95)$ & $21.1(0.83)$ & $11.9(0.47)$ & $-13.7(-0.54)$ & $29.7(1.17)$ & $17.5(0.69)$ & $-7.4(-0.29)$ & $55.1(2.17)$ & $-5.3(-0.21)$ & $30.5(1.20)$ & $12.7(0.50)$ & $182.2(7.17)$ \\
\hline 2013 Totals & $267.0(10.51)$ & $58.9(2.32)$ & $145.3(5.72)$ & $161.8(6.37)$ & $135.4(5.33)$ & $201.2(7.92)$ & $204.3(8.04)$ & $117.1(4.61)$ & $85.9(3.38)$ & $18.3(0.72)$ & $112.0(4.41)$ & $204.3(8.04)$ & $1711.7(67.37)$ \\
\hline \multicolumn{14}{|c|}{ Snowfall, cm (in.) } \\
\hline 1970-1979 Avg & $11.1(4.4)$ & $12.5(4.9)$ & $4.2(1.7)$ & $0.2(0.1)$ & 0 & 0 & 0 & 0 & 0 & 0 & $0.5(0.2)$ & $4.4(1.8)$ & $35.1(13.8)$ \\
\hline 1980-1989 Avg & $11.3(4.5)$ & $8.8(3.5)$ & $2.2(0.9)$ & $2.2(0.9)$ & 0 & 0 & 0 & 0 & 0 & 0 & 0 & $7.5(3.0)$ & $32.8(12.9)$ \\
\hline 1990-1999 Avg & $6.8(2.7)$ & $7.8(3.1)$ & $8.1(3.2)$ & Trace & 0 & 0 & 0 & 0 & 0 & 0 & $0.3(0.1)$ & $3.1(1.2)$ & $10.9(4.3)$ \\
\hline 2000-2009 Avg & $2.1(0.8)$ & $4.5(1.8)$ & Trace & Trace & 0 & 0 & 0 & 0 & 0 & 0 & Trace & $1.7(0.7)$ & $8.3(3.3)$ \\
\hline 2010-2013 Avg & $6.1(2.4)$ & $3.8(1.5)$ & $0.8(0.3)$ & $0.0(0.0)$ & 0 & 0 & 0 & 0 & 0 & 0 & $0.5(0.2)$ & $2.3(0.9)$ & $13.5(5.3)$ \\
\hline 1980 s vs. 2010 s & $-5.2(-2.1)$ & $-5.0(-2.0)$ & $-1.4(-0.6)$ & $-2.2(-0.9)$ & 0 & 0 & 0 & 0 & 0 & 0 & $0.5(0.2)$ & $-5.2(-2.1)$ & $-19.3(-7.6)$ \\
\hline 2000 s vs. 2010 s & $4.0(1.6)$ & $-0.7(-0.3)$ & $0.8(0.3)$ & $0.0(0.0)$ & 0 & 0 & 0 & 0 & 0 & 0 & $0.5(0.2)$ & $0.6(0.2)$ & $5.2(2.0)$ \\
\hline 2013 Totals & $0.8(0.3)$ & $4.6(1.8)$ & $2.8(1.1)$ & 0 & 0 & 0 & 0 & 0 & 0 & 0 & $1.2(0.5)$ & $0.0(0.0$ & $9.4(3.7)$ \\
\hline
\end{tabular}


Table B.3. Hourly subfreezing temperature data for Oak Ridge, Tennessee, January 1985-March 2014

(Hours at or below $0,-5,-10$, and $-15^{\circ} \mathrm{C}^{a}$ )

\begin{tabular}{|c|c|c|c|c|c|c|c|c|c|c|c|c|c|c|c|c|c|c|c|c|c|c|c|c|c|c|c|c|}
\hline \multirow{2}{*}{ Year } & \multicolumn{4}{|c|}{ January } & \multicolumn{4}{|c|}{ February } & \multicolumn{3}{|c|}{ March } & \multicolumn{2}{|c|}{ April } & \multicolumn{2}{|c|}{ May } & \multicolumn{2}{|c|}{ October } & \multicolumn{3}{|c|}{ November } & \multicolumn{4}{|c|}{ December } & \multicolumn{4}{|c|}{ Annual } \\
\hline & $\leq 0$ & $<-5$ & $<-10$ & $<-15$ & $\leq 0$ & $<-5$ & $<-10$ & $<-15$ & $\leq 0$ & $<-5$ & $<-10$ & $\leq 0$ & $<-5$ & $\leq 0$ & $<-5$ & $\leq 0$ & $<-5$ & $\leq 0$ & $<-5$ & $<-10$ & $\leq 0$ & $<-5$ & $<-10$ & $<-15$ & $\leq 0$ & $<-5$ & $<-10$ & $<-15$ \\
\hline 1985 & 467 & 195 & 103 & 39 & 331 & 127 & 26 & 0 & 105 & 6 & 0 & 43 & 3 & 0 & 0 & 0 & 0 & 22 & 0 & 0 & 431 & 201 & 66 & 2 & 1399 & 532 & 195 & 41 \\
\hline 1986 & 308 & 125 & 38 & 10 & 161 & 29 & 3 & 0 & 124 & 28 & 0 & 17 & 0 & 0 & 0 & 0 & 0 & 32 & 10 & 0 & 232 & 34 & 0 & 0 & 874 & 226 & 41 & 10 \\
\hline 1987 & 302 & 53 & 7 & 0 & 111 & 19 & 3 & 0 & 95 & 0 & 0 & 55 & 4 & 0 & 0 & 36 & 0 & 103 & 18 & 0 & 151 & 16 & 0 & 0 & 853 & 110 & 10 & 0 \\
\hline 1988 & 385 & 182 & 43 & 0 & 294 & 102 & 19 & 0 & 97 & 9 & 0 & 6 & 0 & 0 & 0 & 45 & 0 & 62 & 3 & 0 & 301 & 55 & 0 & 0 & 1190 & 351 & 62 & 0 \\
\hline 1989 & 163 & 27 & 0 & 0 & 190 & 66 & 10 & 0 & 35 & 0 & 0 & 18 & 0 & 3 & 0 & 7 & 0 & 125 & 14 & 0 & 421 & 188 & 71 & 30 & 962 & 295 & 81 & 30 \\
\hline 1990 & 142 & 13 & 0 & 0 & 115 & 5 & 0 & 0 & 35 & 0 & 0 & 35 & 0 & 0 & 0 & 19 & 0 & 62 & 1 & 0 & 172 & 43 & 5 & 0 & 580 & 62 & 5 & 0 \\
\hline 1991 & 186 & 44 & 0 & 0 & 158 & 47 & 15 & 0 & 49 & 0 & 0 & 0 & 0 & 0 & 0 & 4 & 0 & 148 & 16 & 0 & 192 & 38 & 0 & 0 & 737 & 145 & 15 & 0 \\
\hline 1992 & 230 & 65 & 8 & 0 & 116 & 22 & 0 & 0 & 116 & 4 & 0 & 27 & 2 & 0 & 0 & 7 & 0 & 100 & 0 & 0 & 166 & 9 & 0 & 0 & 762 & 102 & 8 & 0 \\
\hline 1993 & 125 & 11 & 0 & 0 & 245 & 47 & 8 & 0 & 124 & 32 & 9 & 3 & 0 & 0 & 0 & 0 & 0 & 152 & 2 & 0 & 223 & 44 & 0 & 0 & 872 & 136 & 17 & 0 \\
\hline 1994 & 337 & 191 & 85 & 26 & 196 & 46 & 3 & 0 & 66 & 0 & 0 & 18 & 0 & 0 & 0 & 0 & 0 & 53 & 1 & 0 & 142 & 0 & 0 & 0 & 812 & 238 & 88 & 26 \\
\hline 1995 & 240 & 45 & 6 & 0 & 217 & 84 & 18 & 0 & 37 & 0 & 0 & 0 & 0 & 0 & 0 & 0 & 0 & 142 & 3 & 0 & 288 & 84 & 10 & 0 & 924 & 216 & 34 & 0 \\
\hline 1996 & 301 & 91 & 0 & 0 & 225 & 110 & 62 & 27 & 182 & 49 & 6 & 23 & 0 & 0 & 0 & 3 & 0 & 101 & 0 & 0 & 194 & 40 & 4 & 0 & 1029 & 290 & 72 & 27 \\
\hline 1997 & 254 & 101 & 24 & 0 & 67 & 0 & 0 & 0 & 25 & 0 & 0 & 6 & 0 & 0 & 0 & 6 & 0 & 96 & 10 & 0 & 232 & 14 & 0 & 0 & 686 & 125 & 24 & 0 \\
\hline 1998 & 97 & 10 & 7 & 0 & 25 & 0 & 0 & 0 & 74 & 20 & 0 & 0 & 0 & 0 & 0 & 0 & 0 & 38 & 0 & 0 & 132 & 4 & 0 & 0 & 366 & 34 & 7 & 0 \\
\hline 1999 & 181 & 68 & 0 & 0 & 113 & 14 & 0 & 0 & 62 & 0 & 0 & 0 & 0 & 0 & 0 & 4 & 0 & 41 & 0 & 0 & 177 & 23 & 0 & 0 & 578 & 105 & 0 & 0 \\
\hline 2000 & 273 & 62 & 5 & 0 & 127 & 30 & 0 & 0 & 18 & 0 & 0 & 8 & 0 & 0 & 0 & 11 & 0 & 94 & 11 & 0 & 345 & 124 & 7 & 0 & 876 & 227 & 12 & 0 \\
\hline 2001 & 281 & 60 & 5 & 0 & 79 & 9 & 0 & 0 & 53 & 0 & 0 & 2 & 0 & 0 & 0 & 18 & 0 & 28 & 0 & 0 & 137 & 35 & 0 & 0 & 598 & 104 & 5 & 0 \\
\hline 2002 & 185 & 28 & 0 & 0 & 121 & 16 & 0 & 0 & 91 & 17 & 0 & 2 & 0 & 0 & 0 & 0 & 0 & 41 & 0 & 0 & 82 & 6 & 0 & 0 & 522 & 67 & 0 & 0 \\
\hline 2003 & 345 & 123 & 26 & 0 & 117 & 12 & 0 & 0 & 19 & 0 & 0 & 0 & 0 & 0 & 0 & 0 & 0 & 37 & 0 & 0 & 102 & 9 & 0 & 0 & 620 & 144 & 26 & 0 \\
\hline 2004 & 285 & 50 & 2 & 0 & 76 & 0 & 0 & 0 & 18 & 0 & 0 & 0 & 0 & 0 & 0 & 0 & 0 & 9 & 0 & 0 & 247 & 41 & 4 & 0 & 635 & 91 & 6 & 0 \\
\hline 2005 & 151 & 65 & 6 & 0 & 52 & 1 & 0 & 0 & 81 & 1 & 0 & 0 & 0 & 0 & 0 & 1 & 0 & 55 & 0 & 0 & 176 & 28 & 0 & 0 & 516 & 95 & 6 & 0 \\
\hline 2006 & 70 & 0 & 0 & 0 & 169 & 19 & 0 & 0 & 44 & 0 & 0 & 0 & 0 & 0 & 0 & 15 & 0 & 37 & 0 & 0 & 126 & 41 & 1 & 0 & 461 & 60 & 1 & 0 \\
\hline 2007 & 189 & 30 & 5 & 0 & 283 & 70 & 0 & 0 & 29 & 0 & 0 & 32 & 0 & 0 & 0 & 0 & 0 & 60 & 0 & 0 & 83 & 8 & 0 & 0 & 673 & 111 & 5 & 0 \\
\hline 2008 & 242 & 86 & 11 & 0 & 114 & 7 & 0 & 0 & 69 & 6 & 0 & 0 & 0 & 0 & 0 & 15 & 0 & 89 & 18 & 0 & 157 & 34 & 5 & 0 & 686 & 151 & 16 & 0 \\
\hline 2009 & 238 & 93 & 29 & 0 & 178 & 64 & 5 & 0 & 55 & 15 & 0 & 5 & 0 & 0 & 0 & 0 & 0 & 8 & 0 & 0 & 178 & 22 & 0 & 0 & 662 & 194 & 34 & 0 \\
\hline 2010 & 384 & 181 & 14 & 0 & 289 & 32 & 0 & 0 & 40 & 2 & 0 & 0 & 0 & 0 & 0 & 0 & 0 & 46 & 0 & 0 & 364 & 109 & 11 & 0 & 1123 & 324 & 25 & 0 \\
\hline 2011 & 300 & 61 & 0 & 0 & 108 & 14 & 0 & 0 & 2 & 0 & 0 & 0 & 0 & 0 & 0 & 5 & 0 & 29 & 0 & 0 & 91 & 0 & 0 & 0 & 535 & 75 & 0 & 0 \\
\hline 2012 & 169 & 27 & 0 & 0 & 78 & 19 & 0 & 0 & 9 & 0 & 0 & 1 & 0 & 0 & 0 & 0 & 0 & 46 & 0 & 0 & 76 & 0 & 0 & 0 & 379 & 46 & 0 & 0 \\
\hline 2013 & 245 & 49 & 0 & 0 & 120 & 12 & 0 & 0 & 95 & 7 & 0 & 0 & 0 & 0 & 0 & 11 & 0 & 121 & 0 & 0 & 173 & 6 & 0 & 0 & 765 & 74 & 0 & 0 \\
\hline 2014 & 371 & 208 & 76 & 12 & 109 & 5 & 0 & 0 & 45 & 0 & 0 & & & & & & & & & & & & & & $525^{b}$ & $213^{b}$ & $76^{b}$ & $12^{b}$ \\
\hline Avg. & 248 & 78 & 17 & 3 & 153 & 34 & 6 & 1 & 63 & 7 & 1 & 10 & 0 & 0 & 0 & 7 & 0 & 68 & 4 & 0 & 200 & 43 & 6 & 1 & 740 & 165 & 29 & 5 \\
\hline
\end{tabular}


During the months of January and February, much of the air entering eastern Tennessee comes from the Arctic. As a result, Oak Ridge temperatures have warmed more dramatically during these months. Spring temperatures (March-April) have risen by about $1.4^{\circ} \mathrm{C}$. Summer and fall temperatures have exhibited lesser temperature rises of $1.1^{\circ} \mathrm{C}$ and $0.9^{\circ} \mathrm{C}\left(2.5^{\circ} \mathrm{F}\right)$, respectively. September and December temperatures changed little $\left(0.0^{\circ} \mathrm{C}\right.$ and $+0.1^{\circ} \mathrm{C}$ respectively). Most of these changes were driven by significant increases in minimum daily temperatures, a change likely resulting from the redistribution of heat in the boundary layer resulting from increased presence of greenhouse gases and aerosols near the surface. More greenhouse gases and aerosols act to weaken the strength of nighttime surface temperature inversions. Overall, annual minimum temperatures seem to have increased more dramatically $\left(1.7^{\circ} \mathrm{C}\right)$ than maximum temperatures $\left(1.1^{\circ} \mathrm{C}\right)$. For the most recent full decade (2000s), August average temperatures were slightly warmer than those of July. During the 2010s so far, winter temperatures seem to have declined slightly from the 1990s and 2000s.

Decadal precipitation averages suggest some important changes in precipitation patterns in Oak Ridge over the period of the 1970s to 2000s. Although overall precipitation has remained within a window of about 48 to $60 \mathrm{in}$. annually, there have been some recent decadal shifts in the patterns of rainfall on a monthly or seasonal scale. In particular, precipitation has tended to increase during midwinter but decrease during late winter and late spring. Fall and early winter (September through December) have also been characterized by a slight drying (see Table B.2). Overall, annual precipitation during the 2000s is consistent with the 30 year average [around $132 \mathrm{~cm}(52 \mathrm{in}$.$) ]. The year 2007$ was the driest year on record in Oak Ridge ( $91.1 \mathrm{~cm}$ or $35.87 \mathrm{in}$.), which represented the core of a 4 year period of belowaverage precipitation (2005-2008). However, the most recent calendar year of 2013 yielded precipitation totals around $32 \%$ above the 30 year mean, with a total of 67.37 inches $(1,711.2 \mathrm{~mm})$. These statistics encompass the period from 1948 to 2013.

The previously discussed increase in winter temperatures has affected monthly and annual snowfall amounts until recently. During the 1970s and 1980s, snowfall averaged about 25.4-28 cm (10-11 in.) annually in Oak Ridge. However, during the most recent full decade (2000s), snowfall has averaged only $6.6 \mathrm{~cm}$ (2.6 in). This decrease seems to have occurred largely since the mid-1990s. The slight cooling of winter temperatures in the 2010s thus far has reversed the decrease in snowfall slightly, with annual averages of 3.6 inches $(9.1 \mathrm{~cm})$ for January 2010 through March 2014. Concurrently with the overall decrease in snowfall, the annual number of hours of subfreezing weather has generally declined since the 1980s (Table B.3). However, the number of subfreezing hours during $2010(1,123)$ was the highest recorded since 1988, and January 2014 was the coldest January since 1985 with 371 subfreezing hours.

Select wind roses for the ORR towers that show wind direction for hours with precipitation have been compiled for 2013 and may be reviewed at: http://web.ornl.gov/adm/fo/lp/orrm/page7.htm.

Hourly values of subfreezing temperatures in Oak Ridge are presented in Table B.3 for January 1985 to March 2014. During the middle-to-late 1980s, a typical year experienced about $900-1,000 \mathrm{~h}$ of subfreezing temperatures. In recent years, the value has fallen to about 500-700 h, though higher values have occurred recently (2010 at 1,123 hours). Other statistics on winter precipitation may be found at http://web.ornl.gov/adm/fo/lp/orrm/page7.htm.

\section{B.4 Moisture}

ORR's humid environment results in frequent saturation of the surface layer, especially at night. Average annual humidity at Oak Ridge National Laboratory (ORNL) is 73.5\% (1998-2013). In terms of absolute humidity $\left(\mathrm{g} / \mathrm{m}^{3}\right)$, the average annual humidity for ORR is $10.24 \mathrm{~g} / \mathrm{m}^{3}$. This value varies greatly throughout the annual cycle, ranging from a monthly minimum of about $4.9 \mathrm{~g} / \mathrm{m}^{3}$ during winter to a maximum of about $17.2 \mathrm{~g} / \mathrm{m}^{3}$. These data are summarized for absolute and relative humidity and dew point at: http://web.ornl.gov/adm/fo/lp/orrm/page5.htm. 


\section{B.5 Severe Weather}

On average, thunderstorms and associated lightning occur in the Oak Ridge area at a rate of 50 days/year, with a monthly maximum near 11 occurring in July. About 40 of these thunderstorm days occur during a 6 month period from April through September, with most of the remainder spread throughout the fall and winter. Monthly and annual average numbers of thunderstorm days for ORNL and Knoxville McGhee-Tyson Airport, respectively, during 2001-2013 can be viewed at: http://web.ornl.gov/adm/fo/lp/orrm/page5.htm. The highest number of thunderstorm days at ORNL was observed during 2012 (65) and the lowest during 2007 (34).

Hailstorms are infrequent on ORR but typically occur in association with severe thunderstorms. The phenomenon usually occurs as a result of high altitude thunderstorm updrafts, which propel water droplets above the freezing level. Some hail events have been known to occur in association with nonthunder rain showers in association with low freezing levels (particularly during winter or spring). Most hailstorm occurrences (77\%) do not result in hailstones larger than $2 \mathrm{~cm}$. For the 1961-1990 period, about six hail events were documented (having hailstones larger than about $2 \mathrm{~cm}$ ) to have occurred at locations within $40 \mathrm{~km}$ (25 miles) of ORNL. Virtually all of these events occurred during the summer and fall seasons. During the 2011 significant tornado outbreak in East Tennessee, large hail greater than $2 \mathrm{~cm}$ was observed in Farragut, Tennessee, about $15 \mathrm{~km}$ (9 miles) southeast of ORNL.

Although greater tornado frequencies occur in Middle and West Tennessee, East Tennessee experiences infrequent tornado outbreaks ( 3 to 6 years on average). Tornado indices from the National Weather Service in Morristown show that since 1950, three tornadoes have been documented within $10 \mathrm{~km}$ (6 miles) of ORNL, represented by two F0 (Fujita Scale) tornadoes and one F3 tornado. A moderately strong F3 tornado occurred in February 1993 and moved through Bear Creek Valley near the Y-12 National Security Complex with winds damaging the roofs of several buildings along Union Valley Road. To date, the February 1993 tornado has been the only documented tornado to occur within ORR.

An additional eight tornadoes have been documented since 1950 at distances within $20 \mathrm{~km}$ (12 miles) of ORNL, ranging in intensity from F0/EF0 (Enhanced Fujita Scale) to F2/EF2 in intensity. The most recent of these were three EF0-EF1 tornadoes that occurred during the April 27, 2011, tornado outbreak. These tornadoes affected eastern Roane County to the south and the Edgemoor Road area to the northeast of ORR. Another 10 tornadoes, ranging from F0/EF0 to F3/EF3 in intensity, have occurred within $35 \mathrm{~km}$ (22 miles) of ORNL since 1950. Most of these occurred to the east and south of ORR in Knox and Roane Counties; however, a few of these occurred in the Lake City and Norris areas. Tornado statistics relevant to ORR are provided for Anderson, Knox, Loudon, and Roane Counties at: http://web.ornl.gov/adm /fo/lp/orrm/page5.htm.

The annual probability that a tornado will strike any location in a grid square may be estimated by multiplying the number of tornadoes per year per square kilometer (in that particular grid square) by the path area of a tornado. The result of such a calculation is seen to be greatly affected by the assumption of the size of the path area of a tornado. In total, about 21 tornadoes have been documented within $35 \mathrm{~km}$ (22 miles) of ORNL since 1950. This represents a surface area of $3,848 \mathrm{~km}^{2}\left(1,485 \mathrm{miles}^{2}\right)$ and yields a probability of 0.005 tornadoes per square kilometer per 50 -year period.

\section{B.6 Stability}

The local ridge-and-valley terrain plays a role in the development of stable surface air under certain conditions and influences the dynamics of air flow. Although ridge-and-valley terrain creates identifiable patterns of association during unstable conditions as well, strong vertical mixing and momentum tend to reduce these effects. "Stability" describes the tendency of the atmosphere to mix (especially vertically) or overturn. Consequently, dispersion parameters are influenced by the stability characteristics of the atmosphere. Stability classes range from "A" (very unstable) to "G" (very stable), with "D" being a neutral state.

The suppression of vertical motions during stable conditions increases the effect of local terrain on air motion. Conversely, stable conditions isolate wind flows within the ridge-and-valley terrain from the effects of more distant terrain features and from winds aloft. These effects are particularly significant with 
respect to mountain waves. Deep stable layers of air tend to reduce the vertical space available for oscillating vertical air motions caused by local mountain ranges (Smith et al. 2002). This effect on mountain wave formation may be important with regard to the impact that the nearby Cumberland Mountains may have on local air flow.

A second factor that may decouple large-scale wind flow effects from local ones (and thus produce stable surface layers) occurs with overcast sky conditions. Clouds overlying the Great Valley may warm due to direct insolation on the cloud tops. Warming may also occur within the clouds as latent energy, which is released due to the condensation of moisture. Surface air underlying the clouds may remain relatively cool as the layer remains cut off from direct exposure to the sun. Consequently, the vertical temperature gradient associated with the air mass becomes more stable (Lewellen and Lewellen 2002). Long wave cooling of fog decks has also been observed to help modify stability in the surface layer (Whiteman et al. 2001).

Stable boundary layers typically form as a result of radiational cooling processes near the ground (Van De Weil et al. 2002); however, they are also influenced by the mechanical energy supplied by horizontal wind motion, which is in turn influenced by the synoptic-scale "weather"-related pressure gradient. Ridge-and-valley terrain may have significant ability to block such winds and their associated mechanical energy (Carlson and Stull 1986). Consequently, radiational cooling at the surface is enhanced since there is less wind energy available to remove chilled air.

Stable boundary layers also exhibit intermittent turbulence, which has been associated with a number of the above factors. The process results from "give-and-take" between the effects of friction and radiational cooling. As a stable surface layer intensifies via a radiation cooling process, it tends to decouple from air aloft, thereby reducing the effects of surface friction. The upper air layer responds with an acceleration in wind speed. Increased wind speed aloft results in an increase in mechanical turbulence and wind shear at the boundary with the stable surface layer. Eventually, the turbulence works into the surface layer and weakens it. As the inversion weakens, friction again increases, reducing winds aloft. The reduced wind speeds aloft allow enhanced radiation cooling at the surface, which reintensifies the inversion and allows the process to start again. Van De Weil et al. (2002) have shown that cyclical temperature oscillations up to $4^{\circ} \mathrm{C}\left(7^{\circ} \mathrm{F}\right)$ may result from these processes. Since these intermittent processes are driven primarily by large-scale horizontal wind flow and radiational cooling of the surface, ridge-and-valley terrain significantly affect these oscillations.

Wind roses for stability and mixing depth have been compiled for all of the ORR tower sites for 2013. These may be viewed at: http:/web.ornl.gov/adm/fo/lp/orrm/page $7 . h t m$. The wind roses in general reveal that both unstable conditions and/or deep mixing depths are associated with less channeling of winds, while stable conditions and/or shallow mixing depths tend to promote channeled flow. Associated mixing height tables can be accessed at: http://web.ornl.gov/adm/fo/lp/orrm/page5.htm. 


\section{B.7 References}

Birdwell, K. R. 1996. "A Climatology of Winds over a Ridge and Valley Terrain within the Great Valley of Eastern Tennessee." Master's Thesis, Department of Geosciences, Murray State University, Murray, Kentucky.

Birdwell, K. R. 2011. "Wind Regimes in Complex Terrain of the Great Valley of Eastern Tennessee." Doctoral Dissertation, Department of Geography, University of Tennessee, Knoxville, Tennessee.Carlson, M. A., and R. B. Stull. 1986. "Subsidence in the Nocturnal Boundary Layer." Journal of Climate and Applied Meteorology 25, 1088-99.

Eckman, R. M. 1998. "Observations and Numerical Simulations of Winds within a Broad Forested Valley." Journal of Applied Meteorology 37, 206-19.

Ineson, S., A. A. Scaife, J. R. Knight, J. C. Manners, N. J. Dunstone, L. J. Grey, and J. D. Haigh. 2011. "Solar forcing of winter climate variability in the Northern Hemisphere." Nature Geoscience 4, 753757.

Kossman, M., and A. P. Sturman. 2002. "Pressure Driven Channeling Effects in Bent Valleys." Journal of Applied Meteorology 42, 151-58.

Lewellen, D. C., and W. S. Lewellen. 2002. "Entrainment and decoupling relations for cloudy boundary layers." Journal of the Atmospheric Sciences 59, 2966-2986.

Monti, P., H. J. S. Fernando, M. Princevac, W. C. Chan, T. A. Kowalewski, and E. R. Pardyjak. 2002. "Observations of Flow and Turbulence in the Nocturnal Boundary Layer over a Slope." Journal of the Atmospheric Sciences 59, 2513-34.

Smith, R. B., S. Skubis, J. D. Doyle, A. S. Broad, C. Kiemle, and H. Volkert. 2002. "Mountain waves over Mount Blanc: Influence of a stagnant boundary layer." Journal of the Atmospheric Sciences 59, 2073-2092.

Van De Weil, B. J. H., A. F. Moene, R. J. Ronda, H. A. R. De Bruin, and A. A. M. Holtslag. 2002. "Intermittent Turbulence and Oscillations in the Stable Boundary Layer over Land. Part II: A System Dynamics Approach.” Journal of the Atmospheric Sciences 59, 2567-81.

Whiteman, C. D. 2000. Mountain Meteorology: Fundamentals and Applications. Oxford University Press, New York.

Whiteman, C. D., S. Zhong, W. J. Shaw, J. M. Hubbe, and X. Bian. 2001. "Cold Pools in the Columbia River Basin." Weather and Forecasting 16, 432-47. 


\section{Appendix C. Reference Standards and Data for Water}





\section{Appendix C. Reference Standards and Data for Water}

Table C.1. Reference standards for radionuclides in water

\begin{tabular}{|c|c|c|c|}
\hline Parameter $^{a}$ & $\begin{array}{l}\text { National primary drinking } \\
\text { water standard }^{b}\end{array}$ & $4 \%$ of $\mathrm{DCS}^{c}$ & $\mathrm{DCS}^{d}$ \\
\hline${ }^{241} \mathrm{Am}$ & & 6.8 & 170 \\
\hline${ }^{214} \mathrm{Bi}$ & & 10,400 & 260,000 \\
\hline${ }^{109} \mathrm{Cd}$ & & 640 & 16,000 \\
\hline${ }^{143} \mathrm{Ce}$ & & 1,040 & 26,000 \\
\hline${ }^{60} \mathrm{Co}$ & & 288 & 7,200 \\
\hline${ }^{51} \mathrm{Cr}$ & & 31,600 & 790,000 \\
\hline${ }^{137} \mathrm{Cs}$ & & 120 & 3,000 \\
\hline${ }^{155} \mathrm{Eu}$ & & 3480 & 87,000 \\
\hline Gross alpha $^{e}$ & 15 & & \\
\hline Gross beta (mrem/year) & 4 & & \\
\hline${ }^{3} \mathrm{H}$ & $20,000^{f}$ & 76,000 & $1,900,000$ \\
\hline${ }^{131} \mathrm{I}$ & & 52 & 1,300 \\
\hline${ }^{40} \mathrm{~K}$ & & 192 & 4,800 \\
\hline${ }^{237} \mathrm{~Np}$ & & 12.8 & 320 \\
\hline${ }^{234 m} \mathrm{~Pa}$ & & 2,840 & 71,000 \\
\hline${ }^{238} \mathrm{Pu}$ & & 6 & 150 \\
\hline${ }^{239 / 240} \mathrm{Pu}$ & & 5.6 & 140 \\
\hline${ }^{226} \mathrm{Ra}$ & $5^{g}$ & 3.5 & 87 \\
\hline${ }^{228} \mathrm{Ra}$ & $5^{g}$ & 1 & 25 \\
\hline${ }^{106} \mathrm{Ru}$ & & 164 & 4,100 \\
\hline${ }^{90} \mathrm{Sr}$ & $8^{f}$ & 44 & 1,100 \\
\hline${ }^{99} \mathrm{Tc}$ & & 1,760 & 44,000 \\
\hline${ }^{228} \mathrm{Th}$ & & 13.6 & 340 \\
\hline${ }^{230} \mathrm{Th}$ & & 6.4 & 160 \\
\hline${ }^{232} \mathrm{Th}$ & & 5.6 & 140 \\
\hline${ }^{234} \mathrm{Th}$ & & 336 & 8,400 \\
\hline Thorium, natural & & 5.6 & 140 \\
\hline${ }^{234} \mathrm{U}$ & & 27.2 & 680 \\
\hline${ }^{235} \mathrm{U}$ & & 28.8 & 720 \\
\hline${ }^{236} \mathrm{U}$ & & 28.8 & 720 \\
\hline${ }^{238} \mathrm{U}$ & & 30 & 750 \\
\hline Uranium, natural & & 30 & 750 \\
\hline Uranium, total ${ }^{h}(\mu \mathrm{g} / \mathrm{L})$ & 30 & 27.2 & 680 \\
\hline
\end{tabular}


Table C.1. (continued)

${ }^{a}$ Only the radionuclides included in the Oak Ridge Reservation monitoring programs are listed. Unless labeled otherwise, units are $\mathrm{pCi} / \mathrm{L}$.

${ }^{b} 40$ CFR Part 141, National Primary Drinking Water Regulations, Subparts B and G. The drinking water standards are presented strictly for reference purposes and have regulatory applicability only for public water supplies.

${ }^{c}$ Four percent of the derived concentration standard represents the DOE criterion of 4 mrem effective dose equivalent from ingestion of drinking water.

${ }^{d}$ DOE. "Derived Concentration Technical Standard, DOE-STD-1196-2011, April 2011."

${ }^{e}$ Excludes radon and uranium.

${ }^{f}$ These values are not maximum contaminant levels but are concentrations that result in the effective dose equivalent of the maximum contaminant level for gross beta emissions, which is $4 \mathrm{mrem} /$ year.

${ }^{g}$ Applies to combined ${ }^{226} \mathrm{Ra}$ and ${ }^{228} \mathrm{Ra}$.

${ }^{h}$ Minimum of uranium isotopes.

Table C.2. TDEC and EPA nonradiological water quality standards and criteria ( $\mu \mathrm{g} / \mathrm{L})$

\begin{tabular}{|c|c|c|c|c|}
\hline \multirow[t]{2}{*}{ Chemical } & \multirow{2}{*}{$\begin{array}{l}\text { TDEC and EPA Drinking } \\
\text { Water Standards }\end{array}$} & \multicolumn{2}{|c|}{$\begin{array}{c}\text { TDEC Fish and Aquatic } \\
\text { Life Criteria }\end{array}$} & \multirow{2}{*}{$\begin{array}{c}\text { TDEC recreation criteria } \\
\text { water }+ \text { organisms, } \\
\text { organisms only }^{b}\end{array}$} \\
\hline & & Maximum & Continuous & \\
\hline Acenaphthene & & & & 670,990 \\
\hline Acrolein & & & & 6,9 \\
\hline Acrylonitrile (c) & & & & $0.51,2.5$ \\
\hline Alachlor & $2(\mathrm{E} 1, \mathrm{~T})$ & & & \\
\hline Aldrin (c) & & 3.0 & - & $0.00049,0.00050$ \\
\hline Aluminum & $50-200(\mathrm{E} 2)$ & & & \\
\hline Anthracene & & & & $8300,40,000$ \\
\hline Antimony & $6(\mathrm{E} 1, \mathrm{~T})$ & & & $5.6,640$ \\
\hline Arsenic (c) & $10(\mathrm{E} 1, \mathrm{~T})$ & & & $10.0,10.0$ \\
\hline $\operatorname{Arsenic}_{(\mathrm{III})}^{c}$ & & $340^{c}$ & $150^{c}$ & \\
\hline Asbestos & $\begin{array}{l}7 \text { million fibers/L (MFL) } \\
\text { (E1) }\end{array}$ & & & \\
\hline Atrazine & $3(\mathrm{E} 1, \mathrm{~T})$ & & & \\
\hline Barium & $2000(\mathrm{E} 1, \mathrm{~T})$ & & & \\
\hline Benzene (c) & $5(\mathrm{E} 1, \mathrm{~T})$ & & & 22,510 \\
\hline Benzidine (c) & & & & $0.00086,0.0020$ \\
\hline Benzo(a)anthracene (c) & & & & $0.038,0.18$ \\
\hline Benzo(a)pyrene (c) & $0.2(\mathrm{E} 1, \mathrm{~T})$ & & & $0.038,0.18$ \\
\hline Benzo(b)fluoranthene (c) & & & & $0.038,0.18$ \\
\hline Benzo(k)fluoranthene (c) & & & & $0.038,0.18$ \\
\hline Beryllium & $4(\mathrm{E} 1, \mathrm{~T})$ & & & \\
\hline a-BHC (c) & & & & $0.026,0.049$ \\
\hline b-BHC (c) & & & & $0.091,0.17$ \\
\hline g-BHC (Lindane) & $0.2(\mathrm{E} 1, \mathrm{~T})$ & 0.95 & - & $0.98,1.8$ \\
\hline Bis(2-chloroethyl)ether (c) & & & & $0.30,5.3$ \\
\hline Bis(2-chloro-isopropyl)ether & & & & $1400,65,000$ \\
\hline Bis(2-ethylhexyl)phthalate (c) & & & & 12,22 \\
\hline Bromate & $10(\mathrm{E} 1)$ & & & \\
\hline Bromoform (c) & & & & 43,1400 \\
\hline Butylbenzyl phthalate & & & & 1500,1900 \\
\hline Cadmium & $5(\mathrm{E} 1, \mathrm{~T})$ & $2.0^{d}$ & $0.25^{d}$ & \\
\hline Carbofuran & $40(\mathrm{E} 1, \mathrm{~T})$ & & & \\
\hline
\end{tabular}


Table C.2. (continued)

\begin{tabular}{|c|c|c|c|c|}
\hline \multirow[t]{2}{*}{ Chemical } & \multirow{2}{*}{$\begin{array}{l}\text { TDEC and EPA Drinking } \\
\text { Water Standards }{ }^{a}\end{array}$} & \multicolumn{2}{|c|}{$\begin{array}{c}\text { TDEC Fish and Aquatic } \\
\text { Life Criteria }\end{array}$} & \multirow{2}{*}{$\begin{array}{c}\text { TDEC recreation criteria } \\
\text { water + organisms, } \\
\text { organisms only }^{b}\end{array}$} \\
\hline & & Maximum & Continuous & \\
\hline Carbon tetrachloride (c) & $5(\mathrm{E} 1, \mathrm{~T})$ & & & $2.3,16$ \\
\hline Chlordane (c) & $2(\mathrm{E} 1, \mathrm{~T})$ & 2.4 & 0.0043 & $0.0080,0.0081$ \\
\hline Chloride & $250,000(\mathrm{E} 2)$ & & & \\
\hline Chlorine (TRC) & $4000(\mathrm{E} 1)$ & 19 & 11 & \\
\hline Chlorite & $1000(\mathrm{E} 1)$ & & & \\
\hline Chlorobenzene & $100(\mathrm{E} 1, \mathrm{~T})$ & & & 130,1600 \\
\hline Chlorodibromomethane (c) & & & & $4.0,130$ \\
\hline Chloroform (c) & & & & 57,4700 \\
\hline 2-Chloronaphthalene & & & & 1000,1600 \\
\hline 2-Chlorophenol & & & & 81,150 \\
\hline Chromium (total) & $100(\mathrm{E} 1, \mathrm{~T})$ & & & \\
\hline Chromium(III) & & $570^{d}$ & $74^{d}$ & \\
\hline Chromium(VI) ${ }^{c}$ & & $16^{c}$ & $11^{c}$ & \\
\hline Chrysene (c) & & & & $0.038,0.18$ \\
\hline Coliforms & $\begin{array}{c}630 / 100 \mathrm{~mL}, \text { E. coli, } \\
\text { geometric mean }(\mathrm{T}) ; \\
\text { no more than } 5 \% \text { of samples } \\
\text { per month can be positive for } \\
\text { total coliforms }(\mathrm{E} 1)\end{array}$ & $\begin{array}{l}\text { 2880/100 } \\
\text { mL, E. coli } \\
\text { (single } \\
\text { sample) }\end{array}$ & $\begin{array}{l}\text { 630/100 mL, } \\
\text { E. coli } \\
\text { (geometric } \\
\text { mean) }\end{array}$ & $\begin{array}{c}\text { 126/100 mL, geometric } \\
\text { mean, } E \text {. coli } \\
\text { 487, maximum } \\
\text { lakes/reservoirs, } E \text {. coli } \\
\text { 941, maximum, other water } \\
\text { bodies, } E \text {. coli }\end{array}$ \\
\hline Color & 15 color units $(\mathrm{E} 2)$ & & & \\
\hline Copper & $\begin{array}{c}1000 \text { (E2) } \\
1300 \text { (E1 “Action Level”) }\end{array}$ & $13^{d}$ & $9.0^{d}$ & \\
\hline Cyanide (as free cyanide) & $200(\mathrm{E} 1, \mathrm{~T})$ & 22 & 5.2 & 140,140 \\
\hline $\begin{array}{l}\text { 2,4-D (Dichlorophennoxyacetic } \\
\text { acid) }\end{array}$ & $70(\mathrm{E} 1, \mathrm{~T})$ & & & \\
\hline $4,4^{\prime}-\mathrm{DDT}(\mathrm{c})$ & & 1.1 & 0.001 & $0.0022,0.0022$ \\
\hline 4,4'-DDE (c) & & & & $0.0022,0.0022$ \\
\hline 4,4'-DDD (c) & & & & $0.0031,0.0031$ \\
\hline Dalapon & $200(\mathrm{E} 1, \mathrm{~T})$ & & & \\
\hline Demeton & & & 0.1 & \\
\hline Diazinon & & 0.1 & 0.1 & \\
\hline Dibenz(a,h)anthracene (c) & & & & $0.038,0.18$ \\
\hline $\begin{array}{l}\text { 1,2-dibromo-3-chloropropane } \\
\text { (DBCP) }\end{array}$ & $0.2(\mathrm{E} 1, \mathrm{~T})$ & & & \\
\hline 1,2-Dichlorobenzene (ortho-) & $600(\mathrm{E} 1, \mathrm{~T})$ & & & 420,1300 \\
\hline 1,3-Dichlorobenzene (meta-) & & & & 320,960 \\
\hline 1,4-Dichlorobenzene (para-) & $75(\mathrm{E} 1, \mathrm{~T})$ & & & 63,190 \\
\hline 3,3-Dichlorobenzidine (c) & & & & $0.21,0.28$ \\
\hline Dichlorobromomethane (c) & & & & $5.5,170$ \\
\hline 1,2-Dichloroethane (c) & $5(\mathrm{E} 1, \mathrm{~T})$ & & & $3.8,370$ \\
\hline 1,1-Dichloroethylene & $7(\mathrm{E} 1, \mathrm{~T})$ & & & 330,7100 \\
\hline Cis-1,2-Dichloroethylene & $70(\mathrm{E} 1, \mathrm{~T})$ & & & \\
\hline trans 1,2-Dichloroethylene & $100(\mathrm{E} 1, \mathrm{~T})$ & & & $140,10,000$ \\
\hline Dichloromethane & $5(\mathrm{E} 1, \mathrm{~T})$ & & & \\
\hline 2,4-Dichlorophenol & & & & 77,290 \\
\hline 1,2-Dichloropropane (c) & $5(\mathrm{E} 1, \mathrm{~T})$ & & & $5.0,150$ \\
\hline 1,3-Dichloropropene (c) & & & & $3.4,210$ \\
\hline Dieldrin $(\mathrm{c})$ & & 0.24 & 0.056 & $0.00052,0.00054$ \\
\hline Diethyl phthalate & & & & $17,000,44,000$ \\
\hline
\end{tabular}


Table C.2. (continued)

\begin{tabular}{|c|c|c|c|c|}
\hline \multirow[t]{2}{*}{ Chemical } & \multirow{2}{*}{$\begin{array}{l}\text { TDEC and EPA Drinking } \\
\text { Water Standards }{ }^{a}\end{array}$} & \multicolumn{2}{|c|}{$\begin{array}{c}\text { TDEC Fish and Aquatic } \\
\text { Life Criteria }\end{array}$} & \multirow{2}{*}{$\begin{array}{c}\text { TDEC recreation criteria } \\
\text { water + organisms, } \\
\text { organisms only }^{b}\end{array}$} \\
\hline & & Maximum & Continuous & \\
\hline Di (2-ethylhexyl) adipate & $400(\mathrm{E} 1, \mathrm{~T})$ & & & \\
\hline Di (2-ethylhexyl) phthalate & $6(\mathrm{E} 1, \mathrm{~T})$ & & & \\
\hline Dinoseb & $7(\mathrm{E} 1, \mathrm{~T})$ & & & \\
\hline Dimethyl phthalate & & & & $270,000,1,100,000$ \\
\hline 2,4-Dimethylphenol & & & & 380,850 \\
\hline Di-n-butyl phthalate & & & & 2000,4500 \\
\hline 2,4-Dinitrophenol & & & & 69,5300 \\
\hline 2,4-Dinitrotoluene (c) & & & & $1.1,34$ \\
\hline Dioxin $(2,3,7,8$-TCDD) (c) & 3 E-5 $(\mathrm{E} 1, \mathrm{~T})$ & & & $0.000001,0.000001$ \\
\hline Diquat & $20(\mathrm{E} 1, \mathrm{~T})$ & & & \\
\hline 1,2-Diphenylhydrazine (c) & & & & $0.36,2.0$ \\
\hline a-Endosulfan & & 0.22 & 0.056 & 62,89 \\
\hline b-Endosulfan & & 0.22 & 0.056 & 62,89 \\
\hline Endosulfan sulfate & & & & 62,89 \\
\hline Endothall & $100(\mathrm{E} 1, \mathrm{~T})$ & & & \\
\hline Endrin & $2(\mathrm{E} 1, \mathrm{~T})$ & 0.086 & 0.036 & $0.059,0.06$ \\
\hline Endrin aldehyde & & & & $0.29,0.30$ \\
\hline Ethylbenzene & $700(\mathrm{E} 1, \mathrm{~T})$ & & & 530,2100 \\
\hline Ethylene dibromide & $0.05(\mathrm{E} 1, \mathrm{~T})$ & & & \\
\hline Fluoranthene & & & & 130,140 \\
\hline Fluorene & & & & 1100,5300 \\
\hline Fluoride & $\begin{array}{l}2000(\mathrm{E} 2) \\
4000(\mathrm{E} 1)\end{array}$ & & & \\
\hline Foaming agents & $500(\mathrm{E} 2)$ & & & \\
\hline Glyphosate & $700(\mathrm{E} 1, \mathrm{~T})$ & & & \\
\hline Guthion & & & 0.01 & \\
\hline Haloacetic acids (five) & $60(\mathrm{E} 1)$ & & & \\
\hline Heptachlor (c) & $0.4(\mathrm{E} 1, \mathrm{~T})$ & 0.52 & 0.0038 & $0.00079,0.00079$ \\
\hline Heptachlor epoxide (c) & $0.2(\mathrm{E} 1, \mathrm{~T})$ & 0.52 & 0.0038 & $0.00039,0.00039$ \\
\hline Hexachlorobenzene (c) & $1(\mathrm{E} 1, \mathrm{~T})$ & & & $0.0028,0.0029$ \\
\hline Hexachlorobutadiene (c) & & & & $4.4,180$ \\
\hline Hexachlorocyclopentadiene & $50(\mathrm{E} 1, \mathrm{~T})$ & & & 40,1100 \\
\hline Hexachloroethane (c) & & & & 14,33 \\
\hline Ideno(1,2,3-cd)pyrene (c) & & & & $0.038,0.18$ \\
\hline Iron & 300 (E2) & & & \\
\hline Isophorone (c) & & & & 350,9600 \\
\hline Lead & $\begin{array}{c}5(\mathrm{~T}) \\
15 \text { (E1 "Action Level”) }\end{array}$ & $65^{d}$ & $2.5^{d}$ & \\
\hline Malathion & & & 0.1 & \\
\hline Manganese & $50(\mathrm{E} 2)$ & & & \\
\hline Mercury (inorganic) ${ }^{c}$ & $2(\mathrm{E} 1, \mathrm{~T})$ & $1.4^{c}$ & $0.77^{c}$ & $0.05,0.051$ \\
\hline Methoxychlor & & & 0.03 & \\
\hline Methyl bromide & & & & 47,1500 \\
\hline 2-Methyl-4,6-dinitrophenol & & & & 13,280 \\
\hline $\begin{array}{l}\text { Methylene chloride } \\
\text { (Dichloromethane) (c) }\end{array}$ & & & & 46,5900 \\
\hline Mirex & & & 0.001 & \\
\hline Nickel & $100(\mathrm{~T})$ & $470^{d}$ & $52^{d}$ & 610,4600 \\
\hline Nitrate as $\mathrm{N}$ & $10,000(\mathrm{E} 1)$ & & & \\
\hline Nitrite as $\mathrm{N}$ & $1000(\mathrm{E} 1, \mathrm{~T})$ & & & \\
\hline
\end{tabular}


Table C.2. (continued)

\begin{tabular}{|c|c|c|c|c|}
\hline \multirow[t]{2}{*}{ Chemical } & \multirow{2}{*}{$\begin{array}{l}\text { TDEC and EPA Drinking } \\
\text { Water Standards }{ }^{a}\end{array}$} & \multicolumn{2}{|c|}{$\begin{array}{c}\text { TDEC Fish and Aquatic } \\
\text { Life Criteria }\end{array}$} & \multirow{2}{*}{$\begin{array}{c}\text { TDEC recreation criteria } \\
\text { water }+ \text { organisms, } \\
\text { organisms only }^{b}\end{array}$} \\
\hline & & Maximum & Continuous & \\
\hline Nitrobenzene & & & & 17,690 \\
\hline N-Nitrosodimethylamine (c) & & & & $0.0069,30$ \\
\hline $\begin{array}{l}\text { N-Nitrosodi-n-propylamine } \\
\text { (c) }\end{array}$ & & & & $0.05,5.1$ \\
\hline N-Nitrosodiphenylamine (c) & & & & 33,60 \\
\hline Nonylphenol & & 28.0 & 6.6 & \\
\hline Odor & $\begin{array}{l}3 \text { threshold odor number } \\
\text { (E2) }\end{array}$ & & & \\
\hline Oxamyl (Vydate) & $200(\mathrm{E} 1, \mathrm{~T})$ & & & \\
\hline Parathion & & 0.065 & 0.013 & \\
\hline Pentachlorophenol (c) & $1(\mathrm{E} 1, \mathrm{~T})$ & $19^{e}$ & $15^{e}$ & $2.7,30$ \\
\hline $\mathrm{pH}$ & $\begin{array}{l}6.5 \text { to } 8.5 \text { units (E2) } \\
6.0 \text { to } 9.0 \text { units (T) }\end{array}$ & & $\begin{array}{l}6.0 \text { to } 9.0 \\
\text { units, wade- } \\
\text { able streams } \\
6.5 \text { to } 9.0 \\
\text { units, larger } \\
\text { rivers, lakes, } \\
\text { etc }\end{array}$ & 6.0 to 9.0 units \\
\hline Phenol & & & & $10,000,860,000$ \\
\hline PCBs, total (c) & $0.5(\mathrm{E} 1, \mathrm{~T})$ & - & 0.014 & $0.00064,0.00064$ \\
\hline Pyrene & & & & 830,4000 \\
\hline Selenium & $50(\mathrm{E} 1, \mathrm{~T})$ & 20 & 5 & \\
\hline Silver & $100(\mathrm{E} 2)$ & $3.2^{d}$ & - & \\
\hline Simazine & $4(\mathrm{E} 1, \mathrm{~T})$ & & & \\
\hline Styrene & $100(\mathrm{E} 1, \mathrm{~T})$ & & & \\
\hline Sulfate & $250,000(\mathrm{E} 2)$ & & & \\
\hline 1,1,2,2-Tetrachloroethane (c) & & & & $1.7,40$ \\
\hline Tetrachloroethylene (c) & $5(\mathrm{E} 1, \mathrm{~T})$ & & & $6.9,33$ \\
\hline Thallium & $2(\mathrm{E} 1, \mathrm{~T})$ & & & $0.24,0.47$ \\
\hline Toluene & $1000(\mathrm{E} 1, \mathrm{~T})$ & & & $1300,15,000$ \\
\hline Total dissolved solids & $500,000(\mathrm{E} 2)$ & & & \\
\hline Total trihalomethanes & $80(\mathrm{E} 1)$ & & & \\
\hline Toxaphene (c) & $3(\mathrm{E} 1, \mathrm{~T})$ & 0.73 & 0.0002 & $0.0028,0.0028$ \\
\hline 2,4,5-TP (Silvex) & $50(\mathrm{E} 1, \mathrm{~T})$ & & & \\
\hline Tributyltin (TBT) & & 0.46 & 0.072 & \\
\hline 1,2,4-Trichlorobenzene & $70(\mathrm{E} 1, \mathrm{~T})$ & & & 35,70 \\
\hline 1,1,1-Trichloroethane & $200(\mathrm{E} 1, \mathrm{~T})$ & & & \\
\hline 1,1,2-Trichloroethane (c) & $5(\mathrm{E} 1, \mathrm{~T})$ & & & $5.9,160$ \\
\hline Trichloroethylene (c) & $5(\mathrm{E} 1, \mathrm{~T})$ & & & 25,300 \\
\hline 2,4,6-Trichlorophenol (c) & & & & 14,24 \\
\hline Vinyl chloride (c) & $2(\mathrm{E} 1, \mathrm{~T})$ & & & $0.25,24$ \\
\hline Xylenes (total) & $10,000(\mathrm{E} 1, \mathrm{~T})$ & & & \\
\hline Zinc & $5000(\mathrm{E} 2)$ & $120^{d}$ & $120^{d}$ & \\
\hline
\end{tabular}


Table C.2. (continued)

\begin{tabular}{|c|c|c|c|c|}
\hline \multirow[t]{2}{*}{ Chemical } & \multirow{2}{*}{$\begin{array}{l}\text { TDEC and EPA Drinking } \\
\text { Water Standards }{ }^{a}\end{array}$} & \multicolumn{2}{|c|}{$\begin{array}{c}\text { TDEC Fish and Aquatic } \\
\text { Life Criteria } \\
\end{array}$} & \multirow{2}{*}{$\begin{array}{c}\text { TDEC recreation criteria } \\
\text { water }+ \text { organisms, } \\
\text { organisms only }^{b}\end{array}$} \\
\hline & & Maximum & Continuous & \\
\hline
\end{tabular}

${ }^{a}$ E1 = EPA Primary Drinking Water Standards; E2 = EPA Secondary Drinking Water Standards; T = TDEC domestic water supply criteria.

${ }^{b}$ For each parameter, the first recreational criterion is for "water and organisms" and is applicable on the Oak Ridge Reservation (ORR) only to the Clinch River because the Clinch is the only stream on ORR that is classified for both domestic water supply and for recreation. The second criterion is for "organisms only" and is applicable to the other streams on ORR. TDEC uses a $10^{-5}$ risk level for recreational criteria for all carcinogenic pollutants (designated with "(c)" under "Chemical" column). Recreational criteria for noncarcinogenic chemicals are set using a $10^{-6}$ risk level. (Note: All federal recreational criteria are set at a $10^{-6}$ risk level.)

${ }^{c}$ Criteria are expressed as dissolved.

${ }^{d}$ Criteria are expressed as dissolved and are a function of total hardness $(\mathrm{mg} / \mathrm{L})$. Criteria displayed correspond to a total hardness of $100 \mathrm{mg} / \mathrm{L}$.

${ }^{e}$ Criteria are expressed as a function of $\mathrm{pH}$; values shown correspond to a $\mathrm{pH}$ of 7.8 .
Abbreviations
TDEC $=$ Tennessee Department of Environment and Conservation
EPA $=$ US Environmental Protection Agency 


\section{Appendix D. National Pollutant Discharge Elimination System Noncompliance Summaries for 2013}





\section{Appendix D. National Pollutant Discharge Elimination System Noncompliance Summaries for 2013}

\section{D.1 Y-12 National Security Complex}

\section{A. National Pollutant Discharge Elimination System Permit}

There was one National Pollutant Discharge Elimination System (NPDES) permit limit excursion for cadmium (monthly average permit limit of $0.001 \mathrm{mg} / \mathrm{L}$ ). Analysis of a composite sample taken on October 3, 2013, at the outfall 200 location revealed a value of $0.0174 \mathrm{mg} / \mathrm{L}$, which is below the daily maximum value but above the monthly average value of $0.001 \mathrm{mg} / \mathrm{L}$. The exact cause of the elevated cadmium value at outfall 200 is not known. A grab sample taken upstream in the storm drain system indicated the presence of cadmium, which also has been detected in a nearby groundwater well. Composite sampling in the storm drain system is planned for the area of the storm drain where groundwater data indicate the presence of cadmium.

On the afternoon of November 20, 2013, a reading of $\mathrm{pH} 9.1 \pm 0.24$ was taken from the effluent flow at the West End Treatment Facility (WETF) outfall 502. This value is outside the permitted pH range of 6.0 to 9.0 standard units established for this facility. On discovery of the sample result, WETF Operations personnel immediately stopped the discharge. Before discovery of the elevated $\mathrm{pH}$ reading, approximately 12,153 gal of treated wastewater were discharged from a 476,000-gal batch. The discharge did not result in negative impacts to the water environment or cause any safety consequences. Corrective actions have been implemented to prevent a recurrence.

A potable waterline break occurred on June 8, 2013. Chlorinated water from the point of the break entered the storm drain system and resulted in a fish kill. Fisheries biologists from Oak Ridge National Laboratory (ORNL), working for the Y-12 Biological Monitoring and Abatement Program (BMAP), performed a fish survey in upper East Fork Poplar Creek (EFPC) on June 8, 2013. Biologists walked the stream during a 5-hour period and collected 8,318 dead fish. The affected stream reach was from outfall 21 to Bear Creek Road, a distance of approximately 1,300 m. The fish kill was consistent with a high volume release of chlorinated water from the line break in the old ORNL biology complex.

The event killed five species of fish, the greatest percentage being small minnows (stonerollers, striped shiners, and black nose dace). Other fish species present in the stream reach, such as sunfish, were unaffected.

Follow-up monitoring of the fish community by BMAP personnel in September 2013 showed approximately a $34 \%$ reduction in the fish population when compared with EFPC fish data from recent years. BMAP personnel will continue spring and fall monitoring to measure the recovery of the stream and aquatic life. It is estimated that about two years of spawning seasons under normal conditions will likely restore the fish community to pre-event conditions

\section{B. Industrial and Commercial User Wastewater Discharge Permit}

Monitoring results during 2013 indicate three exceedances of the permit. These were for daily flows in excess of the permit limit (1.4 Mgd) that occurred on January 15 (1.66 Mgd), January 16 (1.5 Mgd), and July 7 (1.646 Mgd).

Progress continued through 2013 in identifying and correcting sources of stormwater inflow. In-line flow meters have been installed and additional smoke testing conducted at various locations within the sanitary sewer system. Needed repairs were executed based on these tests. Smoke testing is completed, and discussions are taking place to establish funding for future actions. Recommendations include procuring the services of an experienced third-party contractor to perform inspections, lining, and possible isolations. 


\section{D.2 East Tennessee Technology Park}

In 2013, compliance with East Tennessee Technology Park (ETTP) NPDES stormwater permit TN0002950 was determined by 143 laboratory analyses and 125 field measurements and flow estimates. The NPDES permit compliance rate for all discharge points for 2013 was $100 \%$.

In 2013, compliance with the ETTP NPDES permit for industrial wastewater from the Central Neutralization Facility (CNF) was determined by 224 laboratory analyses and 694 field measurements. The CNF NPDES permit compliance rate for 2013 was $100 \%$ with no noncompliances. CNF ceased all discharges in 2013, and the permit was allowed to expire on December 31, 2013.

\section{D.3 Oak Ridge National Laboratory}

Three incidents resulting in aquatic mortality in White Oak Creek watershed streams occurred in 2013. The first incident occurred in July 2013, when it was discovered that inadequately dechlorinated discharges were coming from two outfalls, both of which were equipped with dechlorinator units. An investigation resulted in the finding that both dechlorinator units had a similar malfunction consisting of a blocked tablet feeder tube. Twenty dead fish and two dead crayfish were observed downstream of these two outfalls. Repairs were quickly made so that the dechlorinator units resumed proper operation later that same day. Checks of all other operating dechlorinator units were made by ORNL staff to evaluate them for similar vulnerabilities, and preventive maintenance was performed where needed.

The second incident occurred in early October 2013, when a dechlorinator system that was temporarily being used to supply once-through cooling water to a cooling tower/heat exchanger system malfunctioned and resulted in a chlorinated water discharge through an outfall to Melton Branch. Forty-six dead fish and 28 dead salamanders were discovered downstream of the outfall pipe. The cooling water supply was shut off, and dechlorinator tablets were placed at the outfall to amend the discharge. Corrective actions included a revision of operating procedures, including additional safeguards to ensure that environmental aspects of temporary cooling water discharges are adequately addressed before temporary discharges are initiated.

The third incident also occurred in October 2013, when a dechlorinator pump in an ORNL building failed. Upon discovery of the failure, dechlorination tablets were placed in the outfall pipe that drained into White Oak Creek, and pump repairs were initiated and completed. Five dead minnows were found downstream of this outfall pipe. Corrective actions included replacement of the pump power and emergency power supply and the completion of regular maintenance of these components. In addition, manual checks were implemented during every 12-hour shift. 
Appendix E. Radiation 



\section{Appendix E. Radiation}

This appendix presents basic facts about radiation. The information is intended to be a basis for understanding the potential doses associated with releases of radionuclides from the Oak Ridge Reservation (ORR), not as a comprehensive discussion of radiation and its effects on the environment and biological systems.

Radiation comes from natural and human-made sources. People are exposed to naturally occurring radiation constantly. For example, cosmic radiation; radon in air; potassium in food and water; and uranium, thorium, and radium in the earth's crust are all sources of radiation. The following discussion describes important aspects of radiation, including atoms and isotopes; types, sources, and pathways of radiation; radiation measurement; and dose information.

\section{E.1 Atoms and Isotopes}

All matter is made up of atoms. An atom is "a unit of matter consisting of a single nucleus surrounded by a number of electrons equal to the number of protons in the nucleus" (Alter 1986). The number of protons in the nucleus determines an element's atomic number or chemical identity. With the exception of hydrogen, the nucleus of each type of atom also contains at least one neutron. Unlike protons, the neutrons may vary in number among atoms of the same element. The number of neutrons and protons determines the atomic weight. Atoms of the same element that have different numbers of neutrons are called isotopes. In other words, isotopes have the same chemical properties but different atomic weights (Fig. E.1).
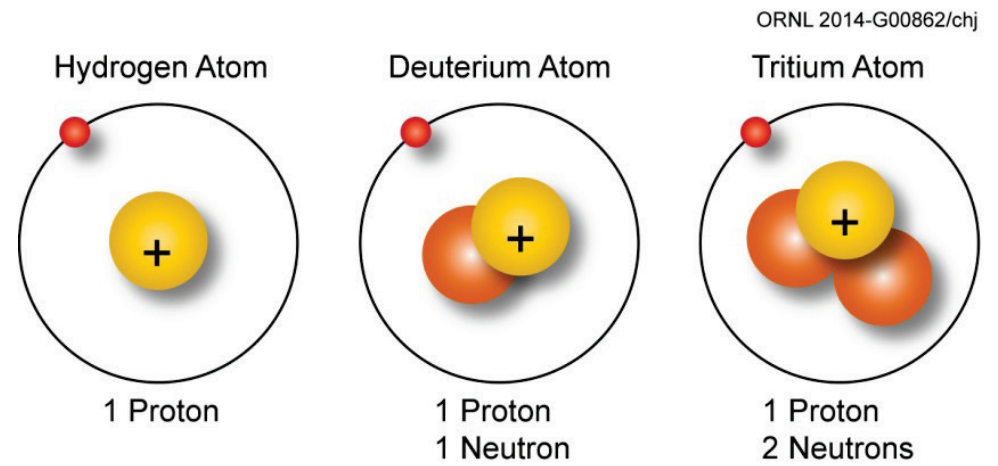

Fig. E.1. The hydrogen atom and its isotopes.

For example, the element uranium has 92 protons. All isotopes of uranium, therefore, have 92 protons. However, each uranium isotope has a different number of neutrons:

- uranium-238 has 92 protons and 146 neutrons,

- uranium-235 has 92 protons and 143 neutrons, and

- uranium-234 has 92 protons and 142 neutrons.

Some isotopes are stable, or nonradioactive; some are radioactive. Radioactive isotopes are called "radionuclides" or "radioisotopes." In an attempt to become stable, radionuclides "throw away," or emit, rays or particles. This emission of rays and particles is known as radioactive decay. Each radioisotope has a "radioactive half-life," which is the average time required for half of a specified number of atoms to decay. Half-lives can be very short (fractions of a second) or very long (millions of years), depending on the isotope (Table E.1). 
Table E.1. Selected radionuclide half-lives

\begin{tabular}{|c|c|c|c|c|c|}
\hline Radionuclide & Symbol & Half-life & Radionuclide & Symbol & Half-life \\
\hline Americium-241 & ${ }^{241} \mathrm{Am}$ & 432.2 years & Plutonium-238 & ${ }^{238} \mathrm{Pu}$ & 87.75 years \\
\hline Americium-243 & ${ }^{243} \mathrm{Am}$ & $7.38 \mathrm{E}+3$ years & Plutonium-239 & ${ }^{239} \mathrm{Pu}$ & $2.41 \mathrm{E}+4$ years \\
\hline Antimony-125 & ${ }^{125} \mathrm{Sb}$ & 2.77 years & Plutonium-240 & ${ }^{240} \mathrm{Pu}$ & $6.569 \mathrm{E}+3$ years \\
\hline Argon-41 & ${ }^{41} \mathrm{Ar}$ & $1.827 \mathrm{~h}$ & Potassium-40 & ${ }^{40} \mathrm{~K}$ & $1.2777 \mathrm{E}+9$ years \\
\hline Beryllium-7 & ${ }^{7} \mathrm{Be}$ & 53.44 days & Promethium-147 & ${ }^{147} \mathrm{Pm}$ & 2.6234 years \\
\hline Californium-252 & ${ }^{252} \mathrm{Cf}$ & 2.639 years & Protactinium-234m & ${ }^{234 m} \mathrm{~Pa}$ & $1.17 \mathrm{~min}$ \\
\hline Carbon-11 & ${ }^{11} \mathrm{C}$ & $20.48 \mathrm{~min}$ & Radium-226 & ${ }^{226} \mathrm{Ra}$ & $1.6 \mathrm{E}+3$ years \\
\hline Carbon-14 & ${ }^{14} \mathrm{C}$ & $5.730 \mathrm{E}+3$ years & Radium-228 & ${ }^{228} \mathrm{Ra}$ & 5.75 years \\
\hline Cerium-141 & ${ }^{141} \mathrm{Ce}$ & 32.50 days & Ruthenium-103 & ${ }^{103} \mathrm{Ru}$ & 39.35 days \\
\hline Cerium-144 & ${ }^{144} \mathrm{Ce}$ & 284.3 days & Ruthenium-106 & ${ }^{106} \mathrm{Ru}$ & 368.2 days \\
\hline Cesium-134 & ${ }^{134} \mathrm{Cs}$ & 2.062 years & Strontium-89 & ${ }^{89} \mathrm{Sr}$ & 50.55 days \\
\hline Cesium-137 & ${ }^{137} \mathrm{Cs}$ & 30.17 years & Strontium-90 & ${ }^{90} \mathrm{Sr}$ & 28.6 years \\
\hline Cesium-138 & ${ }^{138} \mathrm{Cs}$ & $32.2 \mathrm{~min}$ & Technetium-99 & ${ }^{99} \mathrm{Tc}$ & $2.13 \mathrm{E}+5$ years \\
\hline Cobalt-58 & ${ }^{58} \mathrm{Co}$ & 70.80 days & Thorium-228 & ${ }^{228} \mathrm{Th}$ & 1.9132 years \\
\hline Cobalt- 60 & ${ }^{60} \mathrm{Co}$ & 5.271 years & Thorium-230 & ${ }^{230} \mathrm{Th}$ & $7.54 \mathrm{E}+4$ years \\
\hline Curium-242 & ${ }^{242} \mathrm{Cm}$ & 163.2 days & Thorium-232 & ${ }^{232} \mathrm{Th}$ & $1.405 \mathrm{E}+10$ years \\
\hline Curium-244 & ${ }^{244} \mathrm{Cm}$ & 18.11 years & Thorium-234 & ${ }^{234} \mathrm{Th}$ & $2.41 \mathrm{E}+1$ day \\
\hline Iodine-129 & ${ }^{129} \mathrm{I}$ & $157 \mathrm{E}+7$ years & Tritium & ${ }^{3} \mathrm{H}$ & 12.28 years \\
\hline Iodine-131 & ${ }^{131} \mathrm{I}$ & 8.04 days & Uranium-234 & ${ }^{234} \mathrm{U}$ & $2.445 \mathrm{E}+5$ years \\
\hline Krypton-85 & ${ }^{85} \mathrm{Kr}$ & 10.72 years & Uranium-235 & ${ }^{235} \mathrm{U}$ & $7.038 \mathrm{E}+8$ years \\
\hline Krypton- 88 & ${ }^{88} \mathrm{Kr}$ & $2.84 \mathrm{~h}$ & Uranium-236 & ${ }^{236} \mathrm{U}$ & $2.3415 \mathrm{E}+7$ years \\
\hline Lead-212 & ${ }^{212} \mathrm{~Pb}$ & $10.643 \mathrm{~min}$ & Uranium-238 & ${ }^{238} \mathrm{U}$ & $4.468 \mathrm{E}+9$ years \\
\hline Manganese-54 & ${ }^{54} \mathrm{Mn}$ & 312.7 days & Xenon-133 & ${ }^{133} \mathrm{Xe}$ & $5.245 \mathrm{E}+9$ years \\
\hline Neptunium-237 & ${ }^{237} \mathrm{~Np}$ & $2.14 \mathrm{E}+6$ days & Xenon-135 & ${ }^{135} \mathrm{Xe}$ & $9.11 \mathrm{~h}$ \\
\hline Niobium-95 & ${ }^{95} \mathrm{Nb}$ & 35.06 days & Yttrium-90 & ${ }^{90} \mathrm{Y}$ & $64.1 \mathrm{~h}$ \\
\hline Osmium-185 & ${ }^{185} \mathrm{Os}$ & 93.6 days & Zirconium-95 & ${ }^{95} \mathrm{Zr}$ & 64.02 days \\
\hline Polonium-210 & ${ }^{210} \mathrm{Po}$ & 138.378 days & & & \\
\hline
\end{tabular}

Source: DOE 1989. Radioactive Decay Data Tables: A Handbook of Decay Data for Application to Radioactive Dosimetry and Radiological Assessments, DOE/TIC-11026.

\section{E.2 Radiation}

Radiation, or radiant energy, is energy in the form of waves or particles moving through space. Visible light, heat, radio waves, and alpha particles are examples of radiation. When people feel warmth from sunlight, they are actually absorbing the radiant energy emitted by the sun.

Electromagnetic radiation is radiation in the form of electromagnetic waves. Examples include gamma rays, ultraviolet light, and radio waves. Particulate radiation is radiation in the form of particles. Examples include alpha and beta particles. Radiation also is characterized as ionizing or nonionizing because of the way in which it interacts with matter.

\section{E.2.1 lonizing Radiation}

Normally, an atom has an equal number of protons and electrons; however, atoms can lose or gain electrons in a process known as ionization. Some forms of radiation (called ionizing radiation) can ionize atoms by "knocking" electrons off atoms. Examples of ionizing radiation include alpha, beta, and gamma radiation.

Ionizing radiation is capable of changing the chemical state of matter and subsequently causing biological damage. By this mechanism, it is potentially harmful to human health. 


\section{E.2.2 Nonionizing Radiation}

Nonionizing radiation is described as a series of energy waves composed of oscillating electric and magnetic fields traveling at the speed of light. Nonionizing radiation includes the spectrum of ultraviolet (UV), visible light, infrared (IR), microwave, radio frequency (RF), and extremely low frequency. Lasers commonly operate in the UV, visible, and IR frequencies. Microwave radiation is absorbed near the skin, while RF radiation may be absorbed throughout the body. At high enough intensities, both will damage tissue through heating. Excessive visible radiation can damage the eyes and skin (Department of Labor, OSHA Safety and Health Topics online). However, in the discussion that follows, the term "radiation" is used to describe ionizing radiation.

\section{E.3 Sources of Radiation}

Radiation is everywhere. Most occurs naturally; a small percentage is human made. Naturally occurring radiation is known as background radiation.

\section{E.3.1 Background Radiation}

Many materials are naturally radioactive. In fact, this naturally occurring radiation is the major source of radiation in the environment. Although people have little control over the amount of background radiation to which they are exposed, this exposure must be put into perspective. Background radiation remains relatively constant over time and is present in the environment today much as it was hundreds of years ago. Sources of background radiation include uranium in the earth, radon in the air, and potassium in food. Background radiation is categorized as cosmic, terrestrial, or internal, depending on its origin.

\section{E.3.1.1 Cosmic Radiation}

Energetically charged particles from outer space continuously hit the earth's atmosphere. These particles and the secondary particles and photons they create are called cosmic radiation. Because the atmosphere provides some shielding against cosmic radiation, the intensity of this radiation increases with altitude above sea level. For example, a person in Denver is exposed to more cosmic radiation than the amount to which a person in New Orleans is exposed.

\section{E.3.1.2 Terrestrial Radiation}

Terrestrial radiation refers to radiation emitted from radioactive materials in the earth's rocks, soils, and minerals. Radon ( $\mathrm{Rn}$ ), radon progeny (the relatively short-lived decay products from the decay of the radon isotope $\left.{ }^{222} \mathrm{Rn}\right)$, potassium $\left({ }^{40} \mathrm{~K}\right)$, isotopes of thorium $(\mathrm{Th})$, and isotopes of uranium $(\mathrm{U})$ are the elements responsible for most terrestrial radiation.

\section{E.3.1.3 Internal Radiation}

Radionuclides in the environment enter the body with the air people breathe and the foods they eat. They also can enter through an open wound. Natural radionuclides that can be inhaled and ingested include isotopes of uranium and its progeny, especially radon $\left({ }^{222} \mathrm{Rn}\right)$ and its progeny, thoron $\left({ }^{220} \mathrm{Rn}\right)$ and its progeny, potassium $\left({ }^{40} \mathrm{~K}\right)$, rubidium $\left({ }^{87} \mathrm{Rb}\right)$, and carbon $\left({ }^{14} \mathrm{C}\right)$. Radionuclides contained in the body are dominated by ${ }^{40} \mathrm{~K}$ and polonium $\left({ }^{210} \mathrm{Po}\right)$; others include ${ }^{87} \mathrm{Rb}$ and ${ }^{14} \mathrm{C}$ (NCRP 1987).

\section{E.3.2 Human-Made Radiation}

In addition to background radiation, there are human-made sources of radiation to which most people are exposed. Examples include consumer products, medical sources, fallout from atmospheric atomic bomb tests, and industrial by-products. No atmospheric testing of atomic weapons has occurred since 1980 (NCRP 1987). 


\section{E.3.2.1 Consumer Products}

Some consumer products are sources of radiation. The radiation in these products, such as smoke detectors, radioluminous products (e.g., self-illuminating exit signs in commercial buildings), and airport $\mathrm{x}$-ray baggage inspection systems, is essential to the performance of the device. In other products, such as tobacco products and building materials, the radiation occurs incidentally to the product's function (NCRP 1987, NCRP 2009).

\section{E.3.2.2 Medical Sources}

Radiation is an important tool of diagnostic medicine and treatment, which are the main sources of exposure to the public from human-made radiation. Exposure is deliberate and directly beneficial to the patients exposed. In general, medical exposures from diagnostic or therapeutic x-rays result from beams directed to specific areas of the body. Thus, not all body organs are irradiated uniformly. Nuclear medicine examinations and treatments involve the internal administration of radioactive compounds, or radiopharmaceuticals, by injection, inhalation, consumption, or insertion. Even then, radionuclides are not distributed uniformly throughout the body. Radiation and radioactive materials also are used in the preparation of medical instruments, including the sterilization of heat-sensitive products such as plastic heart valves.

\section{E.3.2.3 Other Sources}

Other sources of radiation include emissions of radioactive materials from nuclear facilities such as uranium mines, fuel-processing plants, and nuclear power plants; transportation of radioactive materials; and emissions from mineral-extraction facilities.

\section{E.4 Pathways of Radionuclides}

People can be exposed to radionuclides in the environment through a number of routes (Fig. E.2). Potential routes for internal and/or external exposure are referred to as pathways. For example, radionuclides in the air could fall on grass in a pasture. The grass then could be eaten by cows, and the radionuclides deposited on the grass would show up in the cow's milk. People drinking the milk would be exposed to this radiation. People could also inhale the airborne radionuclides. Similarly, radionuclides in water could be ingested by fish, and people eating the fish would then ingest the radionuclides in the fish tissue. People swimming in the water also would be exposed.

\section{E.5 Measuring Radiation}

To determine the possible effects of radiation on the health of the environment and people, the radiation must be measured. More precisely, its potential to cause damage must be ascertained.

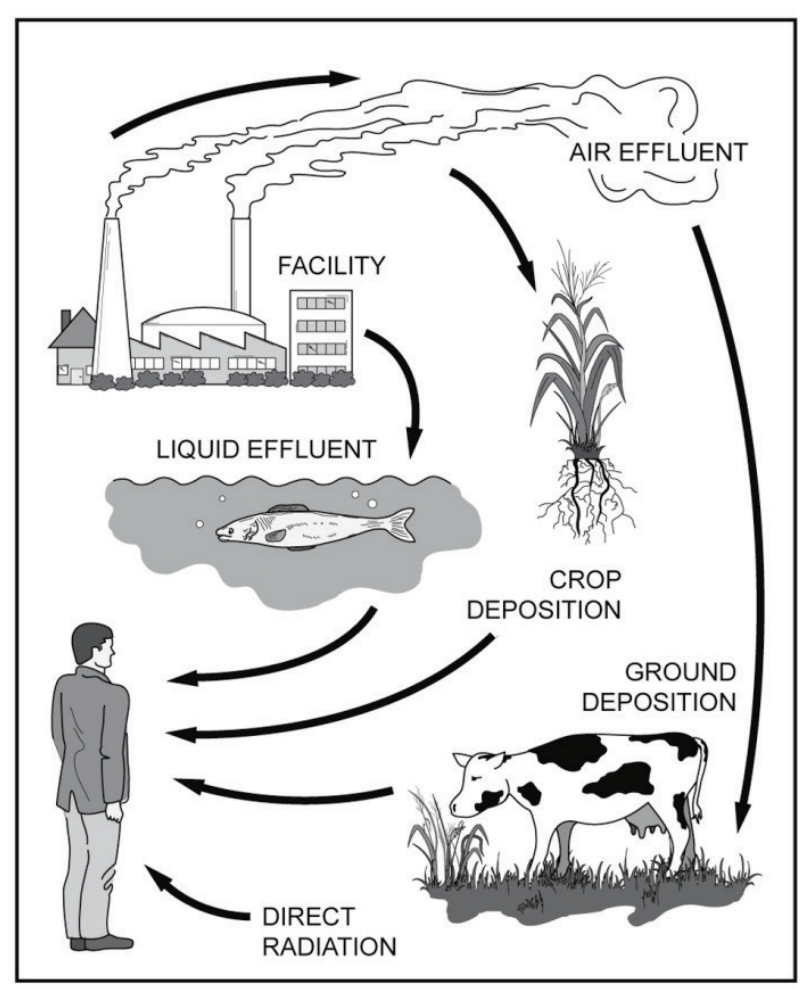

Fig. E.2. Examples of radiation pathways. 


\section{E.5.1 Activity}

When we measure the amount of radiation in the environment, we actually are measuring the rate of radioactive decay or activity. The rate of decay varies widely among the various radioisotopes. For that reason, $1 \mathrm{~g}$ of a radioactive substance may contain the same amount of activity as several tons of another material. This activity is expressed in a unit of measure known as a curie (Ci). More specifically, $1 \mathrm{Ci}$ equals $3.7 \times 10^{10}(37,000,000,000)$ atomic disintegrations per second $(\mathrm{dps})$. In the International System of Units, 1 dps equals 1 becquerel $(\mathrm{Bq})$.

\section{E.5.2 Absorbed Dose}

The total amount of energy absorbed per unit mass of the exposed material because of exposure to radiation is expressed in a unit of measure known as a rad. The effect of the absorbed energy (the biological damage that occurs) is important, not the actual amount. In the International System of Units, 100 rad equals 1 gray (Gy).

\section{E.5.3 Effective Dose}

The measure of potential biological damage to the body caused by exposure to and subsequent absorption of radiation is expressed in a unit of measure known as a rem. For radiation protection purposes, 1 rem of any type of radiation has the same total damaging effect. Because a rem represents a fairly large equivalent dose, it is usually expressed as millirem (mrem), which is 1/1000 of a rem. In the International System of Units, 1 sievert (Sv) equals $100 \mathrm{rem}$; 1 millisievert (mSv) equals $100 \mathrm{mrem}$. The effective dose (ED) is the weighted sum of equivalent dose over specified tissues or organs. The ED is based on tissue-weighting factors for 12 specific tissues or organs plus a weight factor for the remainder organs and tissues. In addition, the ED is based on the latest lung model, gastrointestinal absorption fractions, and biokinetic models used for selected elements. Specific types of EDs are defined as follows:

- committed ED - the weighted sum of the committed ED in specified tissues in the human body during the 50-year period following intake; and

- collective ED - the product of the mean ED for a population and the number of persons in the population.

\section{E.5.4 Dose Determination}

Determining dose is an involved process in which complex mathematical equations based on several factors, including the type of radiation, rate of exposure, weather conditions, and typical diet, are used. Basically, radioactive decay, or activity, generates radiant energy. People absorb some of the energy to which they are exposed. The effect of this absorbed energy is responsible for an individual's dose. Whether radiation is natural or human-made, it has the same effect on people.

Many terms are used to report dose. The terms take several factors into account, including the amount of radiation absorbed, the organ absorbing the radiation, and the effect of the radiation over a 50-year period. The term "dose" in this report means the committed ED, which is the ED that will be received during a specified time (50 years) from radionuclides taken into the body in the current year, and the ED due to exposure during the year to penetrating radiation from sources external to the body.

\section{E.5.5 Dose Coefficient}

A dose coefficient is defined as the ED received from exposure to a unit quantity of a radionuclide by way of a specific exposure pathway. There are two types of dose coefficients. One type gives the committed ED (rem) resulting from intake (by inhalation and ingestion) of a unit activity $(1.0 \mu \mathrm{Ci})$ of a radionuclide. The second gives the ED rate (millirem per year) per unit activity $(1.0 \mu \mathrm{Ci})$ of a radionuclide in a unit (cubic or square centimeters) of an environmental compartment (air volume or ground surface). In 2011 the Department of Energy replaced DOE O 5400.5 with DOE O 458.1. As part of this revision, dose coefficients were derived for a hypothetical Reference Person. The Reference 
Person is an aggregate of individuals in the US population (DOE 2011). The Reference Person effective dose coefficients are used for the ingestion pathway. For the airborne pathway, dose coefficients from Federal Guidance Report 13 were used, since these dose coefficients are used in the EPA-approved model CAP88PC, version 3 (EPA 1999).

\section{E.5.6 Comparison of Dose Levels}

Figure E. 3 gives the 2006 percent contributions of various sources of exposure to total collective dose for the US population. As shown, the major sources are radon and thoron (37\%), computed tomography (24\%), and nuclear medicine (12\%) (NCRP 2009). Consumer, occupational, and industrial sources contribute about $2 \%$ to the total US collective dose. This information is intended to help the reader become familiar with a range of doses that various individuals may receive.

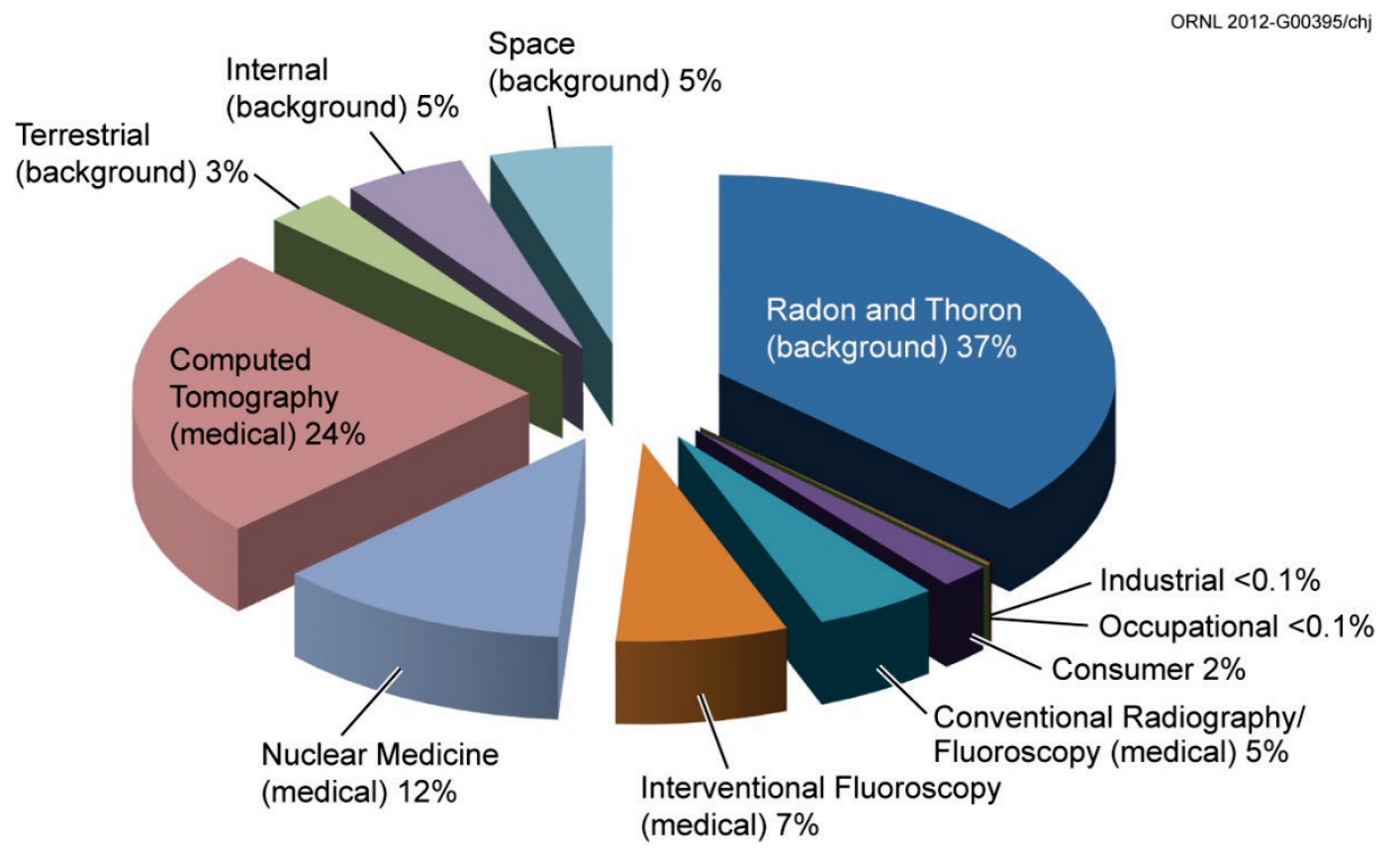

Fig. E.3. All exposure categories for collective effective dose for 2006 (NCRP 2009).

\section{E.5.7 Doses from Background Radiation}

The primary sources of background radiation are cosmic radiation, terrestrial radiation, radon and thoron and their decay products, and other sources of internal radiation.

\section{Dose from Cosmic Radiation}

The average annual effective dose to people in the United States from cosmic radiation is about $33 \mathrm{mrem}(0.33 \mathrm{mSv}$ ) (NCRP 2009). Effective dose rates from cosmic radiation depend on geomagnetic latitude and elevation above sea level.

\section{Dose from Terrestrial Radiation}

The average annual dose in the United States from terrestrial gamma radiation is about 26 mrem $(0.26 \mathrm{mSv})$ but varies geographically across the country (NCRP 2009). Typical reported values are about $23 \mathrm{mrem}(0.23 \mathrm{mSv})$ on the Atlantic and Gulf coastal plains, about $90 \mathrm{mrem}(0.9 \mathrm{mSv})$ on the Colorado Plateau, and about $46 \mathrm{mrem}(0.46 \mathrm{mSv})$ elsewhere (EPA, 2014). 


\section{Dose from Radon and Thoron and Decay Products}

The major contributors to the annual effective dose from background radiation sources are radon and thoron and their short-lived decay products. As shown in Fig. E.3, 37\% of the dose from all exposure categories is from radon, thoron, and their decay products, which contribute an average dose of about $228 \mathrm{mrem}(2.28 \mathrm{mSv})$ per year (NCRP 2009). A small fraction of radon, an inert gas, is retained in the body; however, the dose to the lungs comes from the short-lived radon decay products. Radon levels vary widely across the United States. Elevated levels are most commonly found in the Appalachians, the upper Midwest, and the Rocky Mountain states (NCRP 2009).

\section{Doses from Other Sources of Internal Radiation}

Other sources of internal radiation include ${ }^{40} \mathrm{~K},{ }^{232} \mathrm{Th}$, and ${ }^{238} \mathrm{U}$ series. The primary source of ${ }^{40} \mathrm{~K}$ in body tissues is food, primarily fruits and vegetables. The sources of radionuclides from ${ }^{232} \mathrm{Th}$ and ${ }^{238} \mathrm{U}$ series are food and water (NCRP 2009) The average dose from these internal radionuclides is about $29 \mathrm{mrem}(0.29 \mathrm{mSv})$ per year. This dose is attributed predominantly to ${ }^{40} \mathrm{~K}$, the naturally occurring radioactive isotope of potassium.

\section{E.5.8 Dose from Consumer Products and Activities}

The US average annual dose to an individual from consumer products and activities is about 13 mrem $(0.13 \mathrm{mSv})$, ranging between 0.1 and $40 \mathrm{mrem}(0.001$ and $0.4 \mathrm{mSv})$. Cigarette smoking accounts for about $35 \%$ of this dose. Other important sources are building materials $(27 \%)$, commercial air travel $(26 \%)$, mining and agriculture $(6 \%)$, miscellaneous consumer-oriented products $(3 \%)$, combustion of fossil fuels $(2 \%)$, highway and road construction materials $(0.6 \%)$, and glass and ceramics $(<0.003 \%)$. Television and video, sewage sludge and ash, and self-illuminating signs all contribute negligible doses (NCRP 2009).

\section{E.5.9 Dose from Medical Sources}

Nuclear medicine examinations, which involve internal administration of radiopharmaceuticals, generally account for the largest portion of dose from human-made sources. However, the radionuclides used for specific tests are not distributed uniformly throughout the body. In these cases, the concept of ED, which relates the significance of exposures of organs or body parts to the effect on the entire body, is useful in making comparisons. The average annual ED from medical examinations is roughly $300 \mathrm{mrem}(3 \mathrm{mSv})$, including $147 \mathrm{mrem}(1.47 \mathrm{mSv})$ from computed tomography scans, 77 mrem $(0.77 \mathrm{mSv})$ from nuclear medicine procedures, $43 \mathrm{mrem}(0.43 \mathrm{mSv})$ from interventional fluoroscopy, and $33 \mathrm{mrem}(0.33 \mathrm{mSv})$ from conventional radiography and fluoroscopy (NCRP 2009). Not everyone receives such exams each year.

\section{E.5.10 Doses from Other Sources}

A few additional sources of radiation contribute minor doses to individuals in the United States. The dose to the general public from nuclear fuel cycle facilities, such as uranium mines, mills, fuel-processing plants, nuclear power plants, and transportation routes, has been estimated at less than $1 \mathrm{mrem}(0.01 \mathrm{mSv})$ per year (NCRP 1987).

Small doses to individuals occur because of radioactive fallout from atmospheric atomic bomb tests, emissions of radioactive materials from nuclear facilities, emissions from certain mineral extraction facilities, and transportation of radioactive materials. The combination of these sources contributes less than $1 \mathrm{mrem}(0.01 \mathrm{mSv})$ per year to an individual's average dose (NCRP 1987).

\section{E.6 Water Pathway Dose Method}

People can be exposed to radionuclides in the environment through a number of routes (Fig. E.2). Potential routes for internal and/or external exposure are referred to as exposure pathways. Several such 
pathways exist for exposures of humans to radionuclides in water. People may directly ingest (drink) the water. They may eat fish that contain radionuclides taken in from the water where the fish were caught. Also, people may swim in or boat on the water or use a shoreline that has absorbed radionuclides from the water. The following sections discuss the methods used to calculate potential radiological impacts to persons who drink water; eat fish; and swim, boat, and use the shoreline at various locations along the Clinch and Tennessee Rivers. The results of these calculations are summarized in Section 7.1.2.2.

Radionuclides discharged to surface waters from ORR enter the Tennessee River system by way of the Clinch River and various feeder streams (see Section 1.3.4 for the surface water setting of ORR). Discharges from the Y-12 National Security Complex enter the Clinch River via Bear Creek and East Fork Poplar Creek (both of which enter Poplar Creek before it enters the Clinch River) and by discharges from Rogers Quarry into McCoy Branch and then into Melton Hill Lake. Discharges from Oak Ridge National Laboratory enter the Clinch River via White Oak Creek and Melton Hill Lake via some small drainage creeks. Discharges from East Tennessee Technology Park enter the Clinch River either directly or via Poplar Creek. For convenience, and to correspond to water sampling locations, surface waters around and below ORR are divided into seven segments (called water bodies in this appendix):

- Melton Hill Lake above all possible ORR inputs,

- Melton Hill Lake,

- Upper Clinch River (from Melton Hill Dam to confluence with Poplar Creek),

- Lower Clinch River (from confluence with Poplar Creek to confluence with the Tennessee River),

- Upper Watts Bar Lake (from around the confluence with the Clinch River to below Kingston),

- Lower system (remainder of Watts Bar Lake and Chicamauga Lake), and

- Poplar Creek, including the confluence of East Fork Poplar Creek.

Because East Fork Poplar Creek is posted against water use, dose estimates for such uses are not reported.

Two methods, determined by the type of data, are used to estimate potential radiation doses to the public. The first method uses radionuclide concentrations in the medium of interest (i.e., water and fish) that were determined by laboratory analyses of actual water and fish samples (see Sections 6.4 and 6.6). The second method estimates radionuclide concentrations in water and fish that were calculated from measured radionuclide discharges and known or estimated stream flows.

The advantage of the first method is the use of radionuclide concentrations actually measured in water and fish. Disadvantages of the first method are the inclusion of naturally occurring radionuclides, especially in gross alpha- and beta-activity measurements; the possibility that some radionuclides of ORR origin might be present in quantities too low to be measured; and the possibility that the presence of some radionuclides might be misstated (e.g., present in a quantity below the detection limit). The advantages of the second method are that most radionuclides discharged from ORR will be quantified and that naturally occurring radionuclides will not be considered or will be accounted for separately; the disadvantage is the lack of complete river, discharge, and stream flow data. Both methods use models to estimate the concentrations of the radionuclides in water and fish, except at locations (water bodies) where actual measurements are made. Using the two methods should allow the potential radiation doses to be bounded.

For some water bodies, radionuclide concentrations are measured directly. These water body concentrations are then used to calculate concentrations in fish and the shoreline. Concentrations in the water body downstream of the measured water body are obtained by multiplying the measured water body concentrations by the ratio of the measured water body flow (liters per year) to the downstream water body flow (liters per year). In essence, the concentrations in the upstream water body are diluted by any additional water input to the downstream water body. This dilution calculation continues for all other downstream water bodies. Note that the dilution from upper Watts Bar Lake to the lower system (lower Watts Bar Lake) is considered negligible.

For other water bodies, data are available on the activities of radionuclides discharged to a water body. These data may be in the form of (1) total activities discharged per year (curies per year) or (2) activities per unit volume of water (curies per liter) plus the total volume of water discharged per year (liters per year). Radionuclide concentrations in the receiving water body are calculated simply by 
dividing the measured discharge activities (curies per year) by the total annual flow of the receiving water body (liters per year). The process for calculating concentrations in downstream water bodies is the same as that described in the previous paragraph. The discharge flow rate is usually negligible with respect to the receiving water body flow rate.

\section{E.6.1 Drinking Water}

Several water treatment plants along the Clinch and Tennessee river systems could be affected by discharges from ORR, but data on radiological constituents in the treated water are not available. Therefore, the dose estimates given below are based on concentrations of radionuclides in water before it undergoes treatment and are most likely overestimates. Most water treatment plants use flocculation/sedimentation processes. The flocculant process produces a precipitate that helps to remove solids and also adsorbs dissolved metals. Many radionuclides would be adsorbed by the solids. However, the fraction removed depends on the radionuclide and initial concentration. For purposes of assessment, it was assumed that maximally exposed individuals drink $930 \mathrm{~L} /$ year of water and that the average person drinks $330 \mathrm{~L} /$ year.

Table E.2 is a summary of potential EDs from identified waterborne radionuclides around ORR and shows the variation in dose based on method used to estimate dose.

\section{E.6.2 Eating Fish}

Fishing is quite common on the Clinch and Tennessee river systems. For purposes of assessment, it was assumed that avid fish consumers eat $27 \mathrm{~kg} /$ year of fish and that the average person consumes $11 \mathrm{~kg} /$ year. EDs were calculated from measured radionuclide contents in fish (see Section 6.6), measured concentrations of radionuclides in water, and calculated concentrations in water.

Fish samples are collected from Melton Hill Lake above all ORR inputs [Clinch River kilometer (CRK) 70], from the upper part of the Clinch River (CRK 32), and from the Clinch River below all ORR inputs (CRK 16). Table E.2 is a summary of estimated EDs from consumption of fish and shows the variation in dose based on method used to estimate dose.

\section{E.6.3 Other Uses}

Other uses of the ORR area waterways include swimming or wading, boating, and use of the shoreline. A highly exposed "other user" was assumed to swim or wade for $30 \mathrm{~h} / \mathrm{year}$, boat for $63 \mathrm{~h} / \mathrm{year}$, and use the shoreline for $60 \mathrm{~h} /$ year. Average "other users" were assumed to swim or wade for $10 \mathrm{~h} / \mathrm{year}$, boat for $21 \mathrm{~h} /$ year, and use the shoreline for $20 \mathrm{~h} /$ year. Measured and calculated concentrations of radionuclides in water and LADTAP XL were used to estimate potential EDs from these activities. When compared with EDs from drinking water and eating fish from the same waters, the EDs from these other uses are relatively small. Table E. 2 summarizes EDs from other uses of ORR area waterways and shows the variation in dose based on the method used to estimate dose. 
Table E.2. Summary of annual maximum individual effective dose equivalents from waterborne radionuclides (mrem) ${ }^{a}$

\begin{tabular}{|c|c|c|c|c|}
\hline $\begin{array}{l}\text { Type of } \\
\text { sample }\end{array}$ & Drinking water & $\begin{array}{l}\text { Eating } \\
\text { fish }\end{array}$ & Other uses & $\begin{array}{l}\text { Total of } \\
\text { highest }\end{array}$ \\
\hline \multicolumn{5}{|c|}{ Melton Hill Lake above ORR inputs, CRK 66} \\
\hline $\operatorname{Fish}^{b}$ & \multicolumn{3}{|c|}{0.0008} & 0.0008 \\
\hline Water $^{c}$ & 0.04 & 0.5 & 0.09 & 0.6 \\
\hline Maximum & 0.04 & 0.5 & 0.09 & 0.6 \\
\hline \multicolumn{5}{|c|}{ Melton Hill Lake, CRK 58} \\
\hline Water $^{c}$ & 0.04 & 0.5 & 0.09 & 0.6 \\
\hline Discharge $^{d}$ & $3 \mathrm{E}-09$ & $3 \mathrm{E}-09$ & $2 \mathrm{E}-12$ & $6 \mathrm{E}-09$ \\
\hline Maximum & 0.04 & 0.5 & 0.09 & 0.6 \\
\hline \multicolumn{5}{|c|}{ Upper Clinch River, CRK 23, Gallaher Water Plant, CRK 32} \\
\hline Fish $^{b}$ & & 1.5 & & 1.5 \\
\hline Water $^{c}$ & 0.08 & 0.5 & 0.06 & 0.6 \\
\hline Discharge $^{d}$ & 2E-06 & $7 \mathrm{E}-6$ & $8 \mathrm{E}-07$ & $1 \mathrm{E}-05$ \\
\hline Maximum & 0.08 & 1.5 & 0.06 & 1.7 \\
\hline \multicolumn{5}{|c|}{ Lower Clinch River, CRK 16} \\
\hline Fish $^{b}$ & & 0.04 & & 0.04 \\
\hline Water $^{c}$ & $\mathrm{NA}^{e}$ & 0.5 & 0.06 & 0.5 \\
\hline Discharge $^{d}$ & $\mathrm{NA}^{e}$ & 7E-06 & $8 \mathrm{E}-07$ & $8 \mathrm{E}-06$ \\
\hline Maximum & $\mathrm{NA}^{e}$ & 0.5 & 0.06 & 0.5 \\
\hline \multicolumn{5}{|c|}{ Upper Watts Bar Lake, Kingston Municipal Water Plant } \\
\hline Water $^{c}$ & 0.01 & 0.08 & 0.02 & 0.1 \\
\hline Discharge $^{d}$ & $5 \mathrm{E}-07$ & $1 \mathrm{E}-06$ & $2 \mathrm{E}-07$ & 2E-06 \\
\hline Maximum & 0.01 & 0.08 & 0.02 & 0.1 \\
\hline \multicolumn{5}{|c|}{ Lower system (lower Watts Bar Lake and Chickamauga Lake) } \\
\hline Water $^{c}$ & 0.01 & 0.07 & 0.01 & 0.09 \\
\hline Discharge $^{d}$ & $4 \mathrm{E}-07$ & $1 \mathrm{E}-06$ & $2 \mathrm{E}-07$ & $2 \mathrm{E}-06$ \\
\hline Maximum & 0.01 & 0.07 & 0.01 & 0.1 \\
\hline \multicolumn{5}{|c|}{ Lower East Fork Poplar Creek and Poplar Creek } \\
\hline Water $^{c}$ & $\mathrm{NA}^{e}$ & 0.6 & 0.003 & 0.6 \\
\hline Discharge $^{d}$ & $\mathrm{NA}^{e}$ & 0.3 & 0.01 & 0.3 \\
\hline Maximum & $\mathrm{NA}^{e}$ & 0.6 & 0.003 & 0.6 \\
\hline \multicolumn{5}{|c|}{$\begin{array}{l}\text { Note: } \mathrm{CRK}=\text { Clinch River kilometer; ORR = Oak Ridge Reservation. } \\
{ }^{a} 1 \mathrm{mrem}=0.01 \mathrm{mSv} \text {. } \\
\text { b } \\
{ }^{c} \text { Doses based on measured radionuclide concentrations in fish tissue. } \\
{ }^{c} \text { Doses based on measured radionuclide concentrations in water. } \\
d^{d} \text { Doses based on measured discharges of radionuclides from on-site outfalls. } \\
{ }^{e} \text { Not at drinking water supply locations. }\end{array}$} \\
\hline
\end{tabular}




\section{E.7 References}

Alter, H. 1986. A Glossary of Terms in Nuclear Science and Technology. American Nuclear Society, La Grange Park, Illinois.

Department of Energy (DOE). 1989. Radioactive Decay Data Tables: A Handbook of Decay Data for Application to Radioactive Dosimetry and Radiological Assessments. DOE/TIC-11026. US Department of Energy, Washington, DC.

Department of Energy (DOE), 2011. DOE Standard Derived Concentration Technical Standard. DOESTD-1196-2011, April. US Department of Energy, Washington, DC.

Department of Labor. OSHA Safety and Health Topics. http://www.osha.gov/SLTC /radiation_nonionizing/; last accessed June 2013.

Environmental Protection Agency (EPA). 1999. Cancer Risk Coefficients for Environmental Exposure to Radionuclide: Updates and Supplements. Federal Guidance Report 13, updated 2002. http://www.epa.gov/rpdweb00/federal/techdocs.html\#report13.

Environmental Protection Agency (EPA). 2014. Calculate Your Radiation Dose. http://www.epa.gov/rpdweb00/understand/calculate.html.

National Council on Radiation Protection and Measurements (NCRP). 1987. Ionizing Radiation Exposure of the Population of the United States. NCRP Report No. 93. National Council on Radiation Protection and Measurements, Washington, DC.

National Council on Radiation Protection and Measurements (NCRP). 2009. Ionizing Radiation Exposure of the Population of the United States. NCRP Report No. 160, National Council on Radiation Protection and Measurements, Bethesda, Maryland. 

Appendix F. Chemicals 



\section{Appendix F. Chemicals}

This appendix presents basic facts about chemicals. The information is intended to be a basis for understanding the dose or relative toxicity assessment associated with possible releases from the Oak Ridge Reservation (ORR), not a comprehensive discussion of chemicals and their effects on the environment and biological systems.

\section{F.1 Perspective on Chemicals}

The lives of modern humans have been improved greatly by the development of chemicals such as pharmaceuticals, building materials, housewares, pesticides, and industrial chemicals. Use of chemicals allows us to increase food production, cure diseases, build more efficient houses, and send people to the moon. At the same time, we must be cautious to ensure that our own existence is not endangered by uncontrolled and overexpanded use of chemicals (Chan et al. 1982).

Just as all humans are exposed to radiation in the normal daily routine, humans are also exposed to chemicals. Some potentially hazardous chemicals exist in the natural environment. In many areas of the country, soils contain naturally elevated concentrations of metals such as selenium, arsenic, or molybdenum, which may be hazardous to humans or animals. Even some of the foods we eat contain natural toxins. Aflatoxin is a known toxin found in peanuts, and cyanide is found in apple seeds. However, exposures to many more hazardous chemicals result from the direct or indirect actions of humans. Building materials used for the construction of homes may contain chemicals such as formaldehyde (in some insulation materials), asbestos (formerly used in insulations and ceiling tiles), and lead (formerly used in paints and gasoline). Some chemicals are present as a result of application of pesticides and fertilizers to soil. Other chemicals may have been transported long distances through the atmosphere from industrial sources before being deposited on soil or water.

\section{F.2 Pathways of Chemicals from Oak Ridge Reservation to the Public}

"Pathway" refers to the route or way in which a person can come in contact with a chemical substance. Chemicals released to the air may remain suspended for long periods, or they may be deposited rapidly on plants, soil, and water. Chemicals also may be released as liquid wastes called effluents, which can enter streams and rivers.

People are exposed to chemicals by inhalation (breathing air), ingestion (eating exposed plants and animals or drinking water), or direct contact (touching the soil or swimming in water). For example, fish that live in a river that receives effluents may take in some of the chemicals present. People eating the fish would then be exposed to the chemical. Less likely would be exposure by directly drinking from the river.

The public is not normally exposed to chemicals on ORR because access to the reservation is limited. However, chemicals released because of ORR operations can move through the environment to off-site locations, resulting in potential exposure to the public.

\section{F.3 Definitions}

\section{F.3.1 Toxicity}

Chemicals have varying types of effects. Chemical health effects are divided into two broad categories: adverse or systemic effects (noncarcinogens) and cancer (carcinogens). Sometimes a chemical can have both noncarcinogenic and carcinogenic effects. The toxic effect can be acute (short-term severe health effect) or chronic (longer-term persistent health effect). Toxicity is often evident in a shorter length of time than the carcinogenic effect. The potential health effects of noncarcinogens range from skin irritation to fatality. Carcinogens cause or increase the incidence of malignant neoplasms or cancers. 
Toxicity refers to an adverse effect of a chemical on human health. Every day we ingest chemicals in food, water, and sometimes medications. Even chemicals generally considered toxic are usually nontoxic or harmless below a certain concentration.

Concentration limits or advisories are set by government agencies for some chemicals that are known or thought to have adverse effects on human health. These concentration limits can be used to calculate chemical doses that would not harm even individuals who are particularly sensitive to the chemical.

\section{F.3.2 Dose Terms for Noncarcinogens}

\section{F.3.2.1 Reference Dose}

A reference dose (RfD) is an estimate of a daily exposure level for the human population, including sensitive subpopulations. These reference doses are likely to be without appreciable risk of deleterious effects during a lifetime. Units are expressed as milligrams of chemical per kilogram of an adult's body weight per day ( $\mathrm{mg} / \mathrm{kg}$-day). These values are given in Table F.1.

Values for reference doses are derived from doses of chemicals that result in no adverse effect or the lowest dose that showed an adverse effect on humans or laboratory animals. Uncertainty factors are typically used in deriving reference doses. Uncertainty adjustments may be made if animal toxicity data are extrapolated to humans to account for human sensitivity, extrapolated from subchronic to chronic noobserved-adverse-effect levels, extrapolated from lowest-observed-adverse-effect levels to no-observedadverse-effect levels, and to account for database deficiencies. The use of uncertainty factors in deriving reference doses is thought to protect the sensitive human populations. The US Environmental Protection Agency (EPA) maintains the Integrated Risk Information System (IRIS) database, which contains verified reference doses and up-to-date health risk and EPA regulatory information for numerous chemicals.

\section{F.3.2.2 Primary Maximum Contaminant Levels}

For chemicals for which reference doses are not available in IRIS, national primary drinking water maximum contaminant levels, expressed in milligrams of chemical per liter of drinking water, are converted to reference dose values by multiplying by $2 \mathrm{~L}$ (the average daily adult water intake) and dividing by $70 \mathrm{~kg}$ (the reference adult body weight). The result is a "derived" reference dose expressed in milligrams per kilogram per day (mg/kg-day). These values are given in Table F.1.

\section{F.3.3 Dose Term for Carcinogens}

\section{F.3.3.1 Slope Factor}

A slope factor is a plausible upper-bound estimate of the probability of a response per unit intake of a chemical during a lifetime. The slope factor is used to estimate an upper-bound probability of an individual developing cancer as a result of a lifetime exposure to a particular level of a potential carcinogen. Units are expressed as risk per dose (mg/kg-day). These values are given in Table F.1.

The slope factor converts the estimated daily intake averaged over a lifetime exposure to the incremental risk of an individual developing cancer. Because it is unknown for most chemicals whether a threshold (a dose below which no adverse effect occurs) exists for carcinogens, units for carcinogens are set in terms of risk factors. Acceptable risk levels for carcinogens range from $10^{-4}$ (risk of developing cancer over a human lifetime of 1 in 10,000 ) to $10^{-6}$ (risk of developing cancer over a human lifetime is 1 in 1,000,000). In other words, a certain chemical concentration in food or water could cause a risk of one additional cancer for every $10,000\left(10^{-4}\right)$ to $1,000,000\left(10^{-6}\right)$ exposed persons, respectively. 
Table F.1. Chemical reference doses and slope factors used in drinking water and fish intake analysis

\begin{tabular}{|c|c|c|c|c|c|}
\hline Chemical & Factor & Reference $^{a}$ & Chemical & Factor & $\underset{a}{\text { Reference }}$ \\
\hline \multirow[t]{2}{*}{ Arsenic } & $3.0 \mathrm{E}-04$ & RfD & Thallium & $5.7 \mathrm{E}-05$ & $b, c$ \\
\hline & $1.5 \mathrm{E}+00$ & $\mathrm{SF}$ & Uranium $^{d}$ & $3.0 \mathrm{E}-03$ & RfD \\
\hline Barium & $2.0 \mathrm{E}-01$ & RfD & Vanadium $^{e}$ & $9.0 \mathrm{E}-03$ & RfD \\
\hline Beryllium & $2.0 \mathrm{E}-03$ & RfD & Zinc & $3.0 \mathrm{E}-01$ & RfD \\
\hline Boron & $2.0 \mathrm{E}-01$ & RfD & & & \\
\hline Cadmium & $5.0 \mathrm{E}-04$ & RfD & Aroclor-1260 & $2.0 \mathrm{E}-05$ & $\operatorname{RfD}^{f}$ \\
\hline Chromium VI & $3.0 \mathrm{E}-03$ & RfD & Benzene & 4.0E-03 & RfD \\
\hline Lead & $1.4 \mathrm{E}-04$ & $b, g$ & & $1.5 \mathrm{E}-02$ & $\mathrm{SF}^{h}$ \\
\hline Manganese & $1.4 \mathrm{E}-01$ & RfD & Chloroform & $1.0 \mathrm{E}-02$ & RfD \\
\hline Mercury & $3.0 \mathrm{E}-04$ & $\operatorname{RfD}^{i}$ & PCBs (mixed) & $2.0 \mathrm{E}+00$ & $\mathrm{SF}^{j}$ \\
\hline Molybdenum & $5.0 \mathrm{E}-03$ & RfD & Toluene & $8.0 \mathrm{E}-02$ & RfD \\
\hline Nickel $^{d}$ & $2.0 \mathrm{E}-02$ & RfD & & & \\
\hline
\end{tabular}

${ }^{a} \mathrm{RfD}$ : reference dose (mg/kg-day); SF: slope factor (risk per mg/kg-day). Values obtained from US Environmental Protection Agency (EPA), IRIS.

${ }^{b}$ The water quality criteria (WQCs) are given in units of micrograms per liter. To convert the concentration to an RfD (mg/kg-day), each was divided by 1,000 (to convert to milligrams per liter), multiplied by the consumption rate $(2 \mathrm{~L} /$ day), and divided by the mass of a reference man, $70 \mathrm{~kg}$.

${ }^{c}$ This value is based on the 2008 Tennessee WQC (TDEC 2008) for thallium for domestic water supplies, which reflects the maximum contaminant level value $(2 \mu \mathrm{g} / \mathrm{L})$.

${ }^{d}$ Soluble salts.

${ }^{e}$ As vanadium pentoxide.

${ }^{f}$ The RfD for Aroclor-1254 is used for Aroclor-1260.

${ }^{g}$ This value is based on the 2008 Tennessee WQC (TDEC 2008) for lead for domestic water supplies, which reflects the maximum contaminant level value $(5 \mu \mathrm{g} / \mathrm{L})$.

${ }^{h}$ This value is the lower end of a range provided for the oral slope factor for benzene, $1.5 \mathrm{E}-02$ to $5.5 \mathrm{E}-02$.

${ }^{i}$ An EPA-approved oral chronic RfD, SF, or other guideline for elemental mercury in water or aquatic organisms is not available. Most guidelines refer to "recoverable" or inorganic mercury. RfD values exist for several inorganic mercury salts. The EPA oral RfD for soluble mercuric chloride $\left(\mathrm{HgCl}_{2}\right)$ is $3.0 \mathrm{E}-04 \mathrm{mg} / \mathrm{kg} / \mathrm{day}$.

${ }^{j}$ The cancer potency of PCB mixtures is determined using a three-tiered approach. This value is the upper bound slope factor for the High Risk and Persistence Tier. 


\section{F.4 Measuring Chemicals}

Environmental samples are collected in areas surrounding ORR and are analyzed for those chemical constituents most likely to be released from ORR. Typically, chemical concentrations in liquids are expressed in terms of milligrams or micrograms of chemical per liter of water; concentrations in solids (soil and fish tissue) are expressed in terms of milligrams or micrograms of chemical per gram or kilogram of sample material.

The instruments used to measure chemical concentrations are sensitive; however, there are limits below which they cannot detect chemicals of interest. Concentrations detected below the reported analytical detection limits of the instruments are recorded by the laboratory as estimated values, which have a greater uncertainty than those concentrations detected above the detection limits of the instruments. Health effect calculations that use these estimated values are indicated by the less-than symbol $(<)$, which indicates that the value for a parameter was not quantifiable at the analytical detection limit.

\section{F.5 Risk Assessment Methodology}

\section{F.5.1 Exposure Assessment}

To evaluate an individual's exposure by way of a specific exposure pathway, the intake amount of the chemical must be determined. For example, chemical exposure by drinking water and eating fish from the Clinch River is assessed in the following way. Clinch River surface water and fish samples are analyzed to estimate chemical contaminant concentrations. It is assumed that individuals drink $2.55 \mathrm{~L}$ ( $0.7 \mathrm{gal})$ of water per day directly from the river, which amounts to $930 \mathrm{~L}(246 \mathrm{gal})$ per year, and that they eat $0.07 \mathrm{~kg}$ (roughly $0.2 \mathrm{lb}$ ) of fish per day from the river $(27 \mathrm{~kg}$ or $60 \mathrm{lb}$ per year). Estimated daily intakes or estimated doses to the public are calculated by multiplying measured (statistically significant) concentrations in water by $2.55 \mathrm{~L}$, or those in fish by $0.07 \mathrm{~kg}$. This intake is first multiplied by the exposure duration (30 years) and exposure frequency (350 days/year), and then divided by an averaging time (30 years for noncarcinogens and 70 years for carcinogens). These assumptions are conservative, and in many cases, they result in higher estimated intakes and doses than an individual would actually receive.

\section{F.5.2 Dose Estimate}

When the contaminant oral daily intake via exposure pathways has been estimated, the dose is determined. For chemicals, the dose to humans is measured as milligrams per kilogram-day (mg/kg-day). In this case, the "kilogram" refers to the body weight of an adult. When a chemical dose is calculated, the length of time an individual is exposed to a certain concentration is important. To assess off-site doses, it is assumed that the exposure duration occurs over 30 years. Such exposures are called "chronic" in contrast to short-term exposures, which are called "acute."

\section{F.5.3 Calculation Method}

Current risk assessment methodologies use the term "hazard quotient" to evaluate noncarcinogenic health effects. Because intakes are calculated in milligrams per kilogram per day in the hazard quotient methodology, they are expressed in terms of dose. Hazard quotient values of less than 1 indicate an unlikely potential for adverse health effects, whereas hazard quotient values greater than 1 indicate a concern for adverse health effects or the need for further study.

To evaluate carcinogenic risk, slope factors are used instead of reference doses. 
To estimate the risk of inducing cancers from ingestion of water and fish, the estimated dose or intake ( $I$ ) is multiplied by the slope factor (risk per $\mathrm{mg} / \mathrm{kg}$-day). As mentioned earlier, acceptable risk levels for carcinogens range from $10^{-4}$ (risk of developing cancer over a human lifetime of 1 in 10,000) to $10^{-6}$ (risk of developing cancer over a human lifetime is 1 in 1,000,000). The tilde $(\sim)$ indicates that estimated values were used in estimating the average concentrations of a chemical.

\section{F.6 References}

Chan, P. K., G. P. O’Hara, and A. W. Hayes. 1982. "Principles and Methods for Acute and Subchronic Toxicity." Principles and Methods of Toxicology. Raven Press, New York.

TDEC. 2008. "General Water Quality Criteria." Chapter 1200-4-3 in Rules of Tennessee Department of Environment and Conservation, Tennessee Water Quality Control Board, Division of Water Pollution Control. June. 



\section{Disclaimer}

This report was prepared as an account of work sponsored by an agency of the United States Government. Neither the United States; UT-Battelle, LLC; B\&W Technical Services Y-12 L.L.C.; URS | CH2M Oak Ridge LLC; nor any agency thereof, nor any of their employees, makes any warranty, express or implied, or assumes any legal liability or responsibility for the accuracy, completeness, or usefulness of any information, apparatus, product, or process disclosed, or represents that its use would not infringe privately owned rights. Reference herein to any specific commercial product, process, or service by trade name, trademark, manufacturer, or otherwise, does not necessarily constitute or imply its endorsement, recommendation, or favoring by the United States Government or any agency thereof. The views and opinions of authors expressed herein do not necessarily state or reflect those of the United States Government or any agency thereof. The sampling and monitoring results reported herein are not a comprehensive report of all sampling and analysis performed. 
ORR ASER 2013 


\section{Disclaimer}

This report was prepared as an account of work sponsored by an agency of the United States Government. Neither the United States; UT-Battelle, LLC; B\&W Technical Services Y-12 L.L.C.; URS | CH2M Oak Ridge LLC; nor any agency thereof, nor any of their employees, makes any warranty, express or implied, or assumes any legal liability or responsibility for the accuracy, completeness, or usefulness of any information, apparatus, product, or process disclosed, or represents that its use would not infringe privately owned rights. Reference herein to any specific commercial product, process, or service by trade name, trademark, manufacturer, or otherwise, does not necessarily constitute or imply its endorsement, recommendation, or favoring by the United States Government or any agency thereof. The views and opinions of authors expressed herein do not necessarily state or reflect those of the United States Government or any agency thereof. The sampling and monitoring results reported herein are not a comprehensive report of all sampling and analysis performed. 
ORR ASER 2013 